\title{
DE LA PARTITURA
}

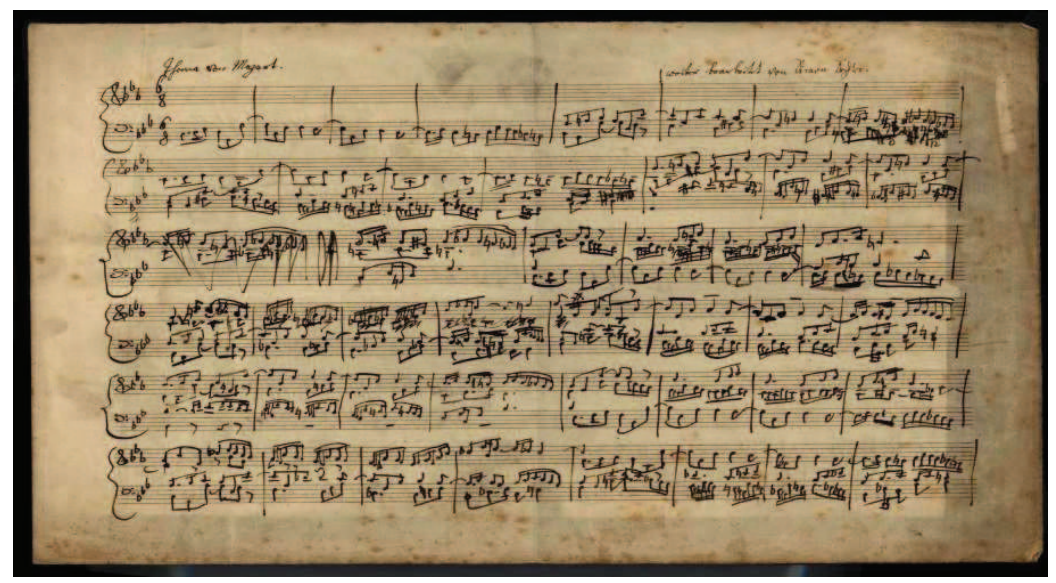

A LA PANTALla,

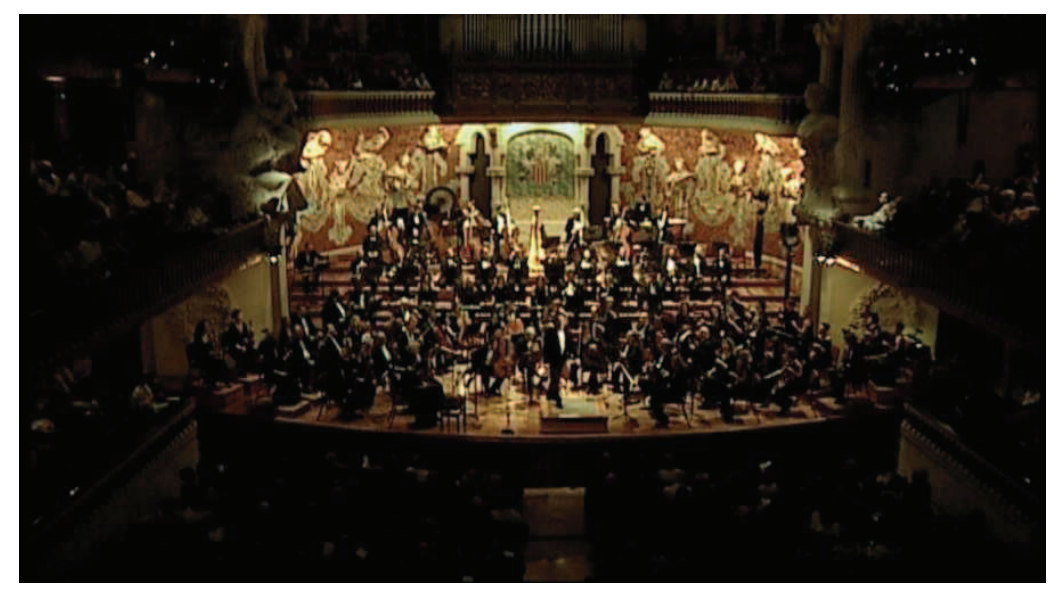

PLANO Y CONTRAPLANO

DE UNA MISMA REALIDAD

\author{
Marta Millà Bruch
}

Noviembre, 2017

Universidad de Salamanca, USAL

Facultad de Geografía e Historia

Directora de tesis: Dra. Matilde Olarte Martínez 
- Figura A. Partitura Mozart Title. Thema von Mozart, weiter bearbeitet von Simon Sechter, 9 Nov. 1858. Contributor Names Sechter, Simon, 1788-1867. Created / Published 1858, monographic [Fotografía]. https://www.loc.gov/item/molden.3355/

- Figura B. Millà, M. (2016). Palau de la Música. [Fotografía]. 


\section{ÍNDICE}

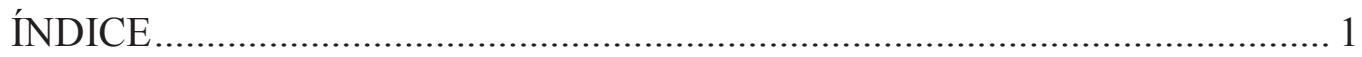

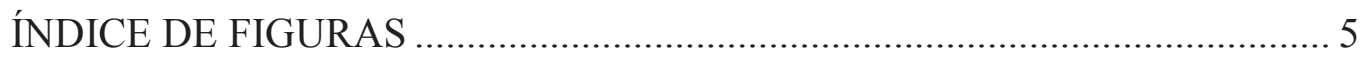

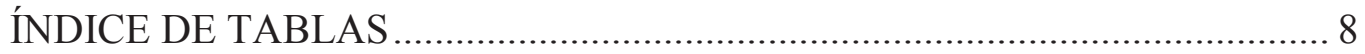

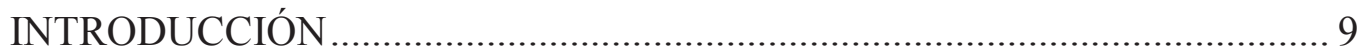

- Elección del tema y estado de la cuestión................................................... 9

- Objetivos generales y específicos ...................................................... 11

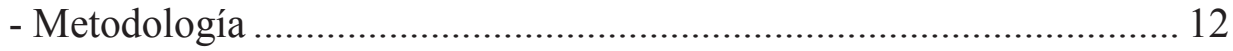

PARTE I: TÁCTICA Y ESTRATEGIA …………………………………....... 15

Capítulo 1: Marco teórico: Música e imagen ......................................................... 17

1.1. Tres géneros de narrativa audiovisual musical: videoclip,

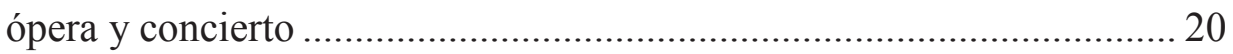

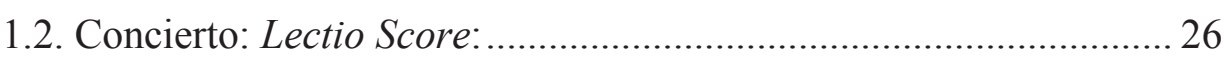

a) Guía de orquesta para jóvenes, de Benjamin Britten............. 27

b) Adagio para cuerdas, de Samuel Barber ................................. 33

1.3. El lenguaje audiovisual en los conciertos: táctica, estrategia

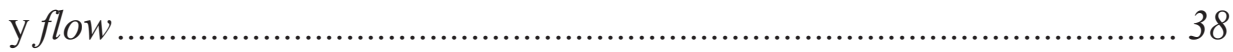

1.4. Elementos de la narratividad; planos y ritmo ……………………..... 43

1.5. Elementos de la narratividad: sonido e iluminación ........................... 64

1.6. Elementos de la narratividad: gestualidad del músico ...................... 67

PARTE II: DOS CONCEPTOS DE FILMACIÓN …………………………..... 75

Capítulo 2: Concepto de filmación para la emisión de conciertos en

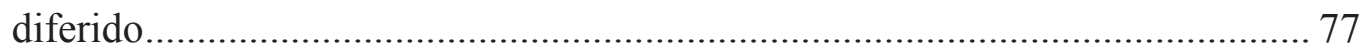

2.1. La partitura como discurso narrativo................................................ 80

a) Narrador ......................................................................... 80

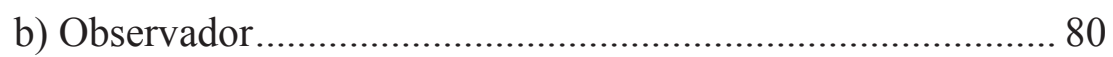

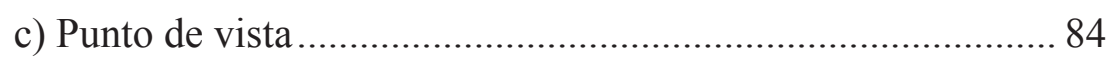

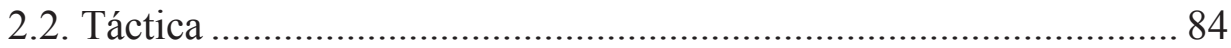

a) Concierto filmado en directo con una única grabación .......... 85

b) Concierto filmado en directo, con más de una

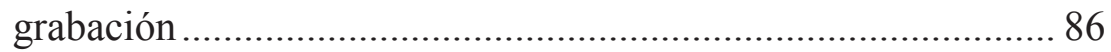

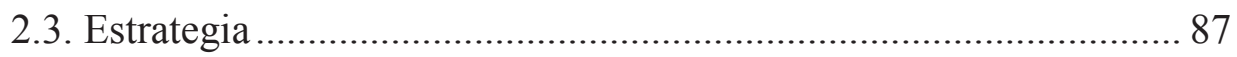

2.4. Ejemplo de filmación con emisión en diferido: Eroica ................... 89 


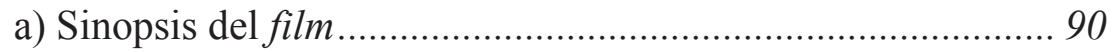

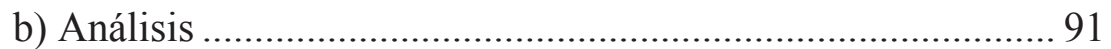

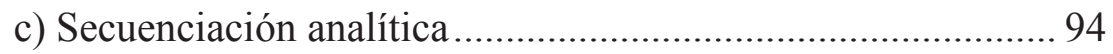

d) Cuarenta y cinco vertiginosos segundos............................ 160

e) Elementos finales ........................................................... 162

Capítulo 3: Concepto de filmación para la emisión de conciertos en

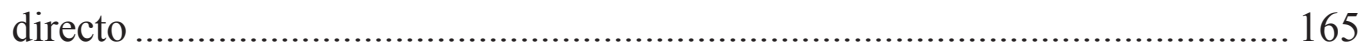

3.1. La partitura como discurso narrativo............................................ 167

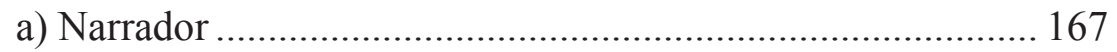

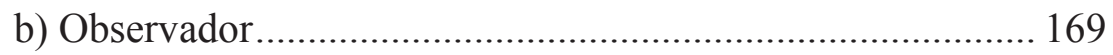

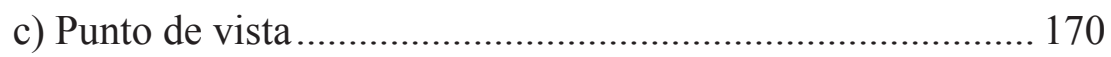

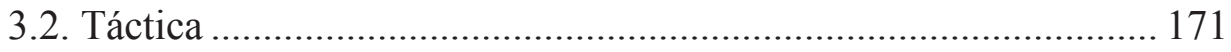

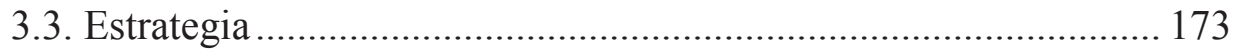

3.4. Ejemplo de filmación con emisión en directo: El vals del

Danubio Azul, Concierto de Año Nuevo desde Viena ......................... 174

a) Vals Danubio Azul, concierto Año Nuevo 1987 .................. 175

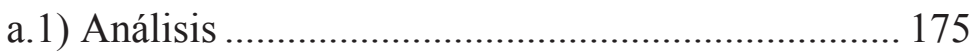

a.2) Estrategia: Secuenciación analítica...................... 176

a.3) Comentarios sobre realización.............................. 185

a.4) Elementos finales............................................. 187

b) Vals Danubio Azul, concierto Año Nuevo 2011.................. 189

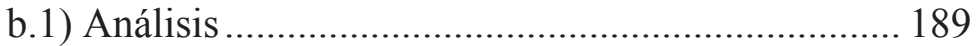

b.2) Táctica .................................................................. 190

b.3) Estrategia: Secuenciación analítica ..................... 195

b.4) Comentarios sobre la realización.......................... 201

b.5) Elementos finales............................................... 202

c) Vals Danubio Azul, concierto Año Nuevo 2013 .................. 203

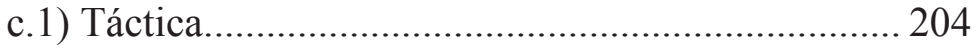

c.2) Estrategia: Secuenciación analítica...................... 207

c.3) Comentarios sobre la realización........................... 220

c.4) Elementos finales................................................ 221

d) Vals Danubio Azul, concierto Año Nuevo 2016.................. 222

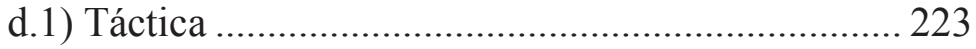

d.2) Estrategia: Secuenciación analítica ...................... 229 
d.3) Comentarios sobre la realización.

d.4) Elementos finales y estudio comparativo.

3.5. Coda.

PARTE III: Estudio empírico músico audiovisual

Capítulo 4: Percepción del plano y contraplano a través de fragmentos de conciertos filmados.

4.1. Enfoque, objetivos y diseño metodológico 255

4.2. Resultados obtenidos: Cuestionarios personales 264

a) Cuestionario personal 1 265

b) Cuestionario personal 2 270

4.3. Resultados obtenidos: Cuestionarios sobre los ejemplos de realización auiovisual-musical 277

a) Adagio para cuerdas, Samuel Barber 277

b) Vuelo del moscardón, Rimsky-Korsakov 285

c) Seis Bagatelas, Giorg Ligeti ..... 290

d) Danubio Azul, Johann Strauss 298

4.4. Cuestionario comparativo de las cuatro filmaciones. 306

4.5. Cuestionario sobre el didacticismo de las filmaciones 314

4.6. Comentarios sobre preguntas no respondidas 317

4.7. Epílogo 320

CONCLUSIONES 323

BIBLIOGRAFÍA 327

WEBGRAFÍA 329

LISTADO DE FIGURAS. 331

APÉNDICE I: Partituras analizadas para este trabajo 339

APÉNDICE II: Fuentes orales en diferido y en directo: personas entrevistadas. Transcripción de las entrevistas

APÉNDICE III: Resultado de las encuestas

APÉNDICE IV: Audio de las entrevistas originales 
De la partitura a la pantalla: plano y contraplano de una misma realidad - 4 


\section{ÍNDICE DE FIGURAS}

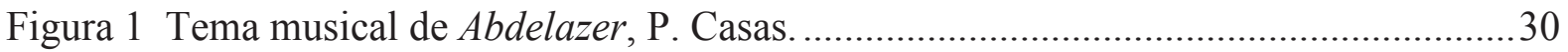

Figura 2 Tema musical de la Fuga (Henry Purcell), P. Casas. .................................................30

Figura 3. Elementos que intervienen en la preproducción de una filmación, M. Millà...........38

Figura 4 Posiciones de cámara posibles en el Palau de la Música Catalana, Barcelona. ........39

Figura 5 Posiciones de cámara ya seleccionadas en el Palau de la Música Catalana,

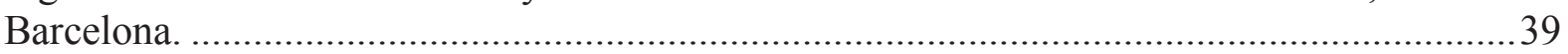

Figura 6 Posiciones de cámara ya seleccionadas en el Gran Teatre del Liceu de Barcelona. .40

Figura 7 Soportes y modos de anclaje de las cámaras en la Philharmonie de Berlín.............41

Figura 8 Soportes y modos de anclaje de las cámaras en la Philharmonie de Berlín ..............41

Figura 9 Gran plano general de situación exterior "OBC a la platja". M, Millà. ...................45

Figura 10 Gran plano general Philharmonie, Berlín. M, Millà.............................................46

Figura 11 Plano General de Escena, Palau de la Música de Barcelona. M, Millà...................46

Figura 12 Contraplano General de Orquesta, Palau de la Música de Barcelona. M. Millà....47

Figura 13 El Liceu, de Ramon Casas. J. Fernández...............................................................48

Figura 14 L'Orchestre de l'Opéra, de Edgar Degas. Wikimedia Commons..........................48

Figura 15 Plano conjunto de violas, L'Auditori, Barcelona (OBC). M. Millà. ........................49

Figura 16 Plano de Conjunto Viento madera y metal, L'Auditori, Barcelona (OBC). M, Millà.

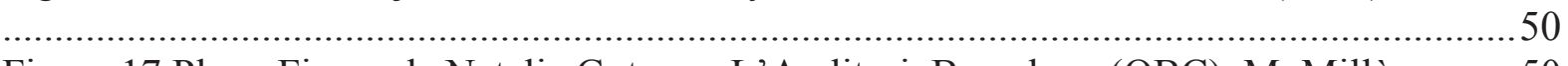

Figura 17 Plano Figura de Natalia Gutman, L'Auditori, Barcelona (OBC). M, Millà.............50

Figura 18 Plano Americano de Pablo Pérez, director de orquesta .........................................51

Figura 19 Plano Medio violinista, L'Auditori, Barcelona (OBC). M, Millà............................52

Figura 20 Primer plano de clarinetista, L'Auditori, Barcelona (OBC). M, Millà. ...................53

Figura 21. Plano corto de timbales, L'Auditori, Barcelona (OBC). M, Millà..........................53

Figura 22 Plano corto de Violista, L'Auditori, Barcelona (OBC). M, Millà............................53

Figura 23 Plano detalle de contrabajo (arqueo), L'Auditori, Barcelona (OBC). M, Millà. ....54

Figura 24 Plano detalle de violín (pizzicato). M, Millà. ........................................................54

Figura 25 Plano detalle de timbales, L'Auditori, Barcelona (OBC). M, Millà. .......................55

Figura 26 Plano detalle de violín (digitación). M, Millà. .....................................................55

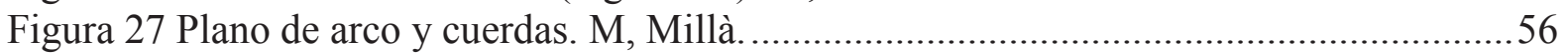

Figura 28 Plano americano del director a través de violín. M, Millà. ......................................56

Figura 29 Plano en escorzo de violín con partitura desenfocada. M, Millà..............................56

Figura 30 Contraplano frontal y contraplano lateral izquierdo. M, Millà. .............................57

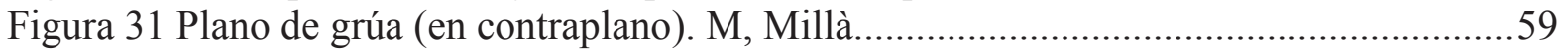

Figura 32 Plano realizado con cámara GoPro. M, Millà..........................................................60

Figura 33 Contraplano lateral de la Budapest Festival Orchestra (Palau de la Música

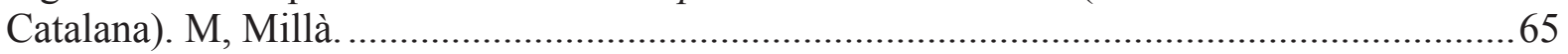

Figura 34 Plano lateral de escena, Orfeó Català (Palau de la Música Catalana). M, Millà.....65

Figura 35 Plano lateral de escena, Budapest Festival Orchestra (Royal Concertgebouw

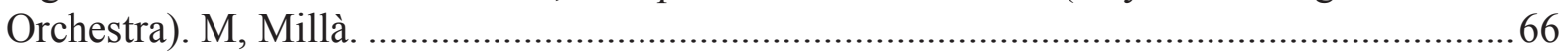

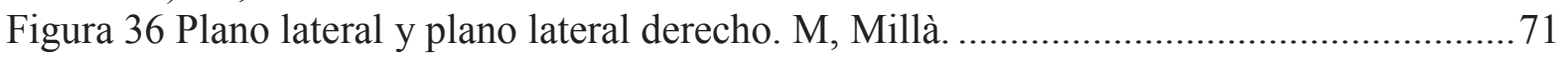

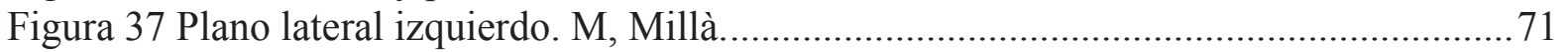

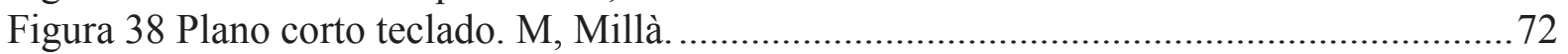

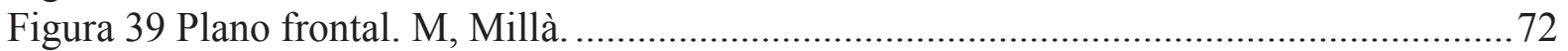

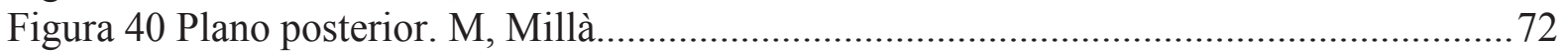

Figura 41 Elementos semióticos en la comunicación audiovisual y musical. M. Millà..........83 
Figura 42 Posiciones de cámara para el concierto Casa Nostra, Casa Vostra en el Palau Sant

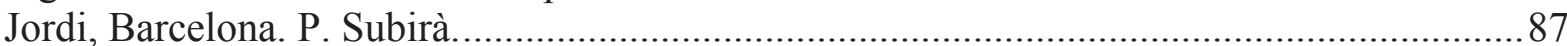
Figura 43 Fotograma de la Película Eroica. M. Millà............................................................89

Figura 44 Travelling circular de la cámara, realizando el seguimiento a Beethoven. M.

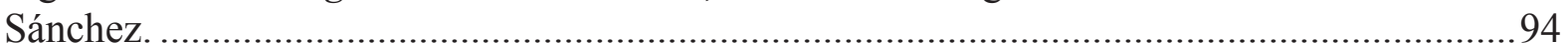

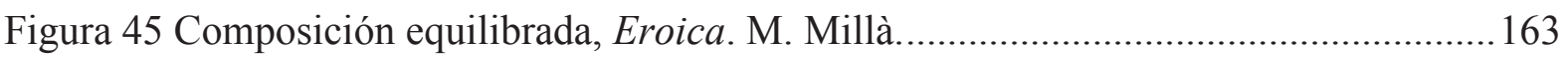

Figura 46 Composición angulada y con desequilibrio, Eroica. M. Millà................................ 163

Figura 47 Exterior de la sala de conciertos Musikverein de Viena. Framepool.....................174

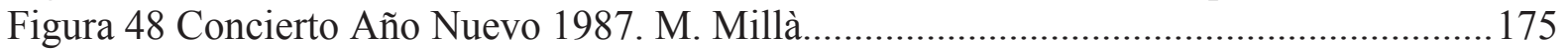

Figura 49 Plano de cámaras realización del concierto de Año Nuevo Enero 2011. R. Penzel

Figura 50 Cámaras 1 y 2 (Escenario lateral izquierda). R. Penzel. ......................................191

Figura 51 Cámara 3 (interior escenario). R. Penzel.............................................................. 192

Figura 52 Cámara 5 (Plano general frontal). R. Penzel. ..................................................... 192

Figura 53 Cámara 6 (Lateral derecho, sobre platea). R. Penzel. ........................................... 192

Figura 54 Cámara 7 (Lateral derecho, sobre escenario). R. Penzel....................................... 192

Figura 55 Cámara 8 (Lateral derecho, dentro escenario/ Contraplano). R. Penzel. ...............193

Figura 56 Cámara 9 (Plano cenital con raíl y con control remoto). R. Penzel. ......................193

Figura 57 Cámara 11 (Lateral izquierdo en el interior de escenario). R. Penzel.................... 193

Figura 58 Minicámara en el interior de escenario. R. Penzel. ...............................................193

Figura 59 Cámara 13 (Lateral izquierdo, plano general). R. Penzel...................................... 194

Figura 60 Cámara 14 (Contraplano general desde el primer piso). R. Penzel........................ 194

Figura 61 Cámara 14 (a) (al lado del director). R. Penzel. ..................................................... 194

Figura 62 Cámaras 15, 16 y 17 (En el hall, para la realización del Ballet). R. Penzel.........194

Figura 63 Karina Fibich y Brian Large en el control de realización de la Unidad móvil. E.

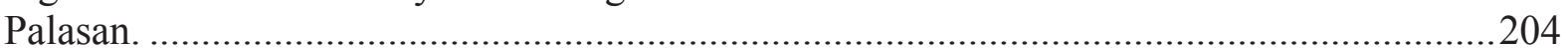

Figura 64 Plano de cámaras para la realización del concierto de Año Nuevo de enero de 2013.

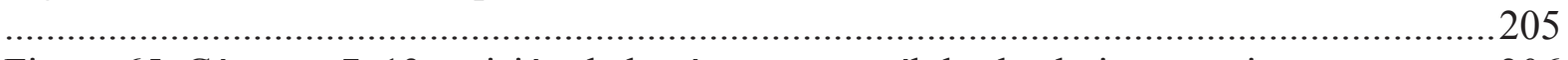

Figura 65 Cámaras 7, 13 y visión de la cámara con raíl desde el piso superior. ..................206

Figura 66 Cámaras 5, 6 y visión de la cámara con raíl contrapicada....................................206

Figura 67 Unidad móvil- TV Skyline Ü8- para el concierto de Año Nuevo de Enero 2016.224

Figura 68 Plano de cámaras para la realización del concierto de Año Nuevo de enero de 2016

Figura 69 Cámara 2 (lateral izquierdo escenario)

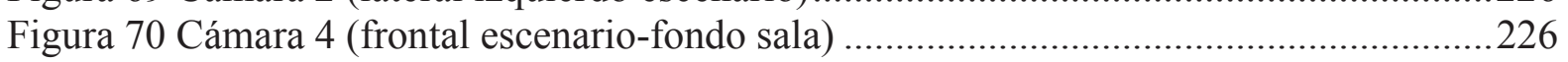

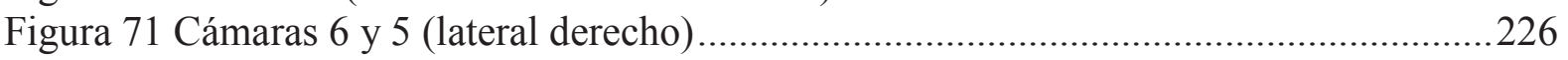

Figura 72 Cámara 6 (indicaciones al cámara en una Tablet, script) ...................................227

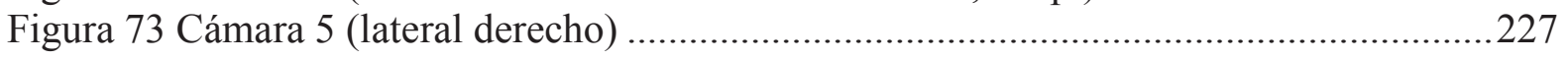

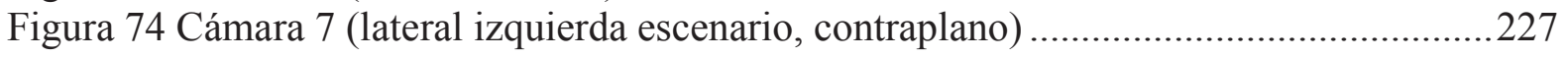

Figura 75. Cámara 7 (lateral izquierda escenario, vista del contraplano)............................227

Figura 76 Cámara 8 (centro escenario, contraplano sala y director) ....................................228

Figura 77 Cámara 9 (lateral derecho escenario, contraplano sala y director).......................228

Figura 78 Cámara 14 (plano frontal, con raíl y control remoto)..........................................228

Figura 79 Controles remotos de cámaras fuera de la sala Musikverein. ..............................228

Figura 80 Fotograma extraído del DVD André Rieu At Schönbrunn, Vienna.......................245

Figura 81 Sexo de las personas que respondieron la encuesta, M. Millà. ...........................265

Figura 82 Edad de las mujeres que respondieron la encuesta, M. Millà. ............................266

Figura 83. Edad de los hombres que respondieron la encuesta, M. Millà. ...........................266

Figura 84 Personas encuestadas con estudios musicales, M. Millà......................................268

Figura 85 Nivel académico de estudios musicales, M. Millà..............................................269 


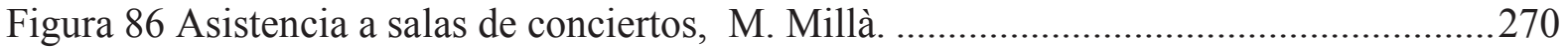

Figura 87 Frecuencia de asistencia a los conciertos, M. Millà..........................................271

Figura 88 Hábito de consumo audiovisual de conciertos, M. Millà. ...................................275

Figura 89. Porcentaje de personas que no consumen audiovisualmente y asisten o no a

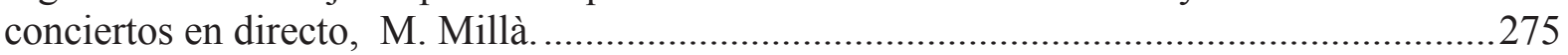

Figura 90 Porcentaje de medios audiovisuales empleados para ver conciertos, M. Millà. ...276

Figura 91 Conocimiento de autor y obra (Adagio, Samuel Barber), M. Millà......................278

Figura 92 Porcentaje de personas que conocen la obra y poseen estudios musicales, M. Millà.

Figura 93 Percepción de coherencia entre música e imagen (Adagio, Samuel Barber ) M.

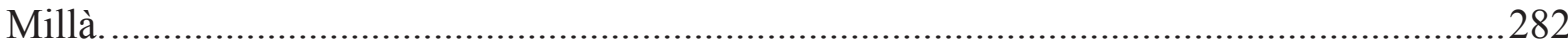

Figura 94 Conocimiento de autor y obra (Vuelo del moscardón, Rimsky-Korsakov),M. Millà.

Figura 95 Percepción de coherencia entre música e imagen (Vuelo del moscardón, Rimsky-

Korsakov), M. Millà. ...........................................................................................................28

Figura 96 Conocimiento de autor y obra (Bagatela, Georg Ligeti), M. Millà. ......................291

Figura 97 Percepción de coherencia entre música e imagen (Bagatela, Georg Ligeti), M.

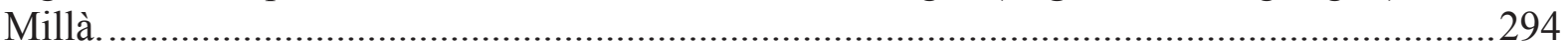

Figura 98 Conocimiento de autor y obra (Vals Danubio Azul, Johann Strauss), M. Millà. ..298

Figura 99 Percepción de coherencia entre música e imagen (Vals Danubio Azul, Johann

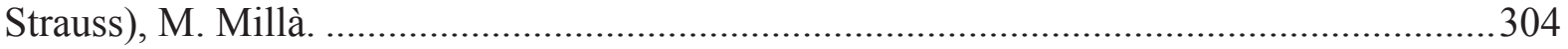

Figura 100 Obra más atrayente en su formato audiovisual, M. Millà. ................................307

Figura 101 Obra menos más atrayente en su formato audiovisual, M. Millà........................308

Figura 102 Interpretación de coherencia según edad. Adagio de Samuel Barber, M. Millà.311

Figura 103 Interpretación de coherencia según edad. Vuelo del moscardón de Rimsky-

Korsakov, M. Millà........................................................................................................ 312

Figura 104 Interpretación de coherencia según edad. Bagatela de Georg Ligeti, M. Millà. 312

Figura 105 Interpretación de coherencia según edad. Vals Danubio Azul de Johann Strauss,

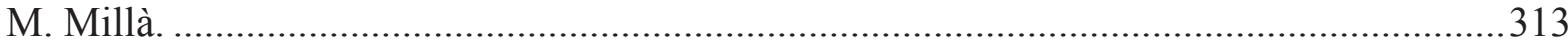

Figura 106 Valoración del didacticismo del formato audiovisual a través de los cuatro

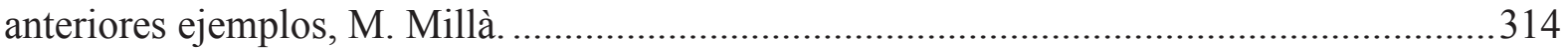

Figura 107 Relación entre el conocimiento de la obra y las preguntas no respondidas (Adagio,

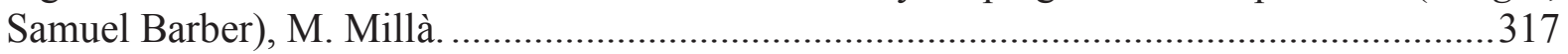

Figura 108 Relación entre el conocimiento de la obra y las preguntas no respondidas (Vuelo

del moscardón, Rimsky-Korsakov), M. Millà................................................................... 318

Figura 109 Relación entre el conocimiento de la obra y las preguntas no respondidas

(Bagatela, Georg Ligeti), M. Millà...................................................................................... 318

Figura 110. Relación entre el conocimiento de la obra y las preguntas no respondidas (Vals

Danubio Azul, Johann Strauss), M. Millà. 


\section{INDICE DE TABLAS}

- Tabla 1. Millà, M. (2017). Instrumentos musicales en la Guía de de orquesta para jóvenes, Benjamin Britten.

- Tabla 2. Millà, M. (2017). Tabla comparativa de los aspectos de realización en cuatro versiones del Danubio Azul 


\section{INTRODUCCIÓN}

\section{Elección del tema y estado de la cuestión}

Dos son las razones que me han llevado a realizar esta tesis doctoral: mi interdisciplinariedad por lo que respecta a la formación académica y mi profesionalidad desde los medios de comunicación; en concreto, desde los servicios artísticos y de realización a los que estoy comprometida y entregada desde que inicié mi trayectoria profesional en el mundo de la imagen y el sonido en Televisió de Catalunya.

Parto de dos mundos académicos a partir de los cuales he sostenido la base de mi investigación: la lingüística y la música. n definitiva, la comunicación por partida doble. Por un lado, todo lo que nos ofrece la semiótica como disciplina lingüística y, por otro, la música como medio a través del cual podemos describir, expresar o narrar.

Gracias a mi trabajo en el departamento de Realización desde el año 2000, he tenido la oportunidad de poner en práctica el objeto de estudio utilizando las mejores herramientas disponibles en la empresa audiovisual donde trabajo. Además, he podido contar con el consejo y opinión de expertos en realización de otros países, como han sido Robert Gummlich (realizador del Digital Concert Hall de la Berliner Philharmoniker) y Michael Beyer (director freelance de escena y televisión y pianista); así como, músicos especializados en la visualización de la música desde la composición aplicada, como es el caso de José Nieto, o desde el campo de la gestualización y la interpretación, como, Albert Nieto. Ambos los he escogido por sus escritos sobre la música expresiva y estructural y por su interés en aplicar pedagógicamente sus ideas creativas.

Será objeto de mi estudio ver cómo inmortalizamos a través de los diferentes medios audiovisuales técnicos y artísticos la narración audiovisual que el compositor quiso que viviéramos como experiencia (en principio, sólo auditiva). A menudo, por no decir siempre, dada la programación de nuestros auditorios, con frecuencia centrada en repertorio anterior al siglo $\mathrm{XX}$, no podemos contar con que el compositor contextualice su obra, sino que tenemos la experiencia de otro intermediario: el director de orquesta. Así, que será labor del realizador hacer de puente entre la partitura como texto musical y el espectador-oyente, pasando por el intérprete-director musical. 
En la actualidad, existen escasos estudios e investigaciones acerca de la manera de proceder en este campo artístico (como expondré más tarde) y, por ello, quiero comparar, investigar y sistematizar diferentes maneras de proceder. Ver qué caminos se han seguido y cuáles son las líneas de trabajo emprendidas para que la historia audiovisual, a través de las herramientas semióticas que nos ofrece la disciplina lingüística, dé un paso más en el ya adentrado siglo XXI.

La cita que viene a continuación quiere demostrar qué supone la música dentro del mundo de la comunicación a partir del libro de John Eliot Gardiner:

"Las personas suelen quejarse de que la música es demasiado ambigua", escribió Mendelssohn en 1842. Todo el mundo entiende las palabras, por supuesto, pero los oyentes no saben qué es lo que deberían pensar cuando oyen música. A mí me pasa exactamente lo contrario, y no sólo en relación con toda una parrafada, sino también con las palabras concretas. También ellas me parecen tan ambiguas, tan fácilmente malinterpretadas en comparación con la música genuina, que llena el alma con miles de cosas mejores que las palabras. Los pensamientos que se me expresan por medio de la música que amo no son demasiado indefinidos para plasmarse con palabras sino, por el contrario, demasiado definidos. Se trata de una afirmación sorprendente (...) La relación de la música con el lenguaje es tan compleja como la del lenguaje con el pensamiento. El lenguaje puede elucidar, pero también puede estrangular la sensibilidad en el proceso de transmisión. La música, por otro lado, cuando se interpreta, permite que el canal del pensamiento transmitido y la sensibilidad fluyan con total libertad" (Eliot Gardiner, John (2015). La música en el castillo del cielo (pp.647-648). Barcelona: Galaxia Gutenberg.)

Los libros de ensayo en los que me voy a basar para establecer los elementos de análisis para mi objeto de estudio proceden del campo académico de la semiótica general ya que se adaptaban mejor a esta investigación. Un primer libro es el de J.L. Austin (1962), Cómo hacer cosas con palabras (Barcelona: Paidós), que me ha proporcionado metafóricamente “cómo hacer cosas con imágenes". Un segundo libro es el publicado por la Universitat Oberta de Catalunya de Paolo Bertetti (2012), La Historia audiovisual. Las teorías y herramientas semióticas (Barcelona: UOC), que es el marco teórico que he aplicado en esta tesis doctoral. Para el estudio de la percepción en el espectador, he utilizado la primera parte, "Líneas generales de una teoría e historia de la experiencia estética" del manual clásico de H.R. Jauss basado en la hermenéutica literaria, Experiencia estética y hermenéutica literaria: Ensayos en el campo de la experiencia estética (Madrid: Taurus), que he aplicado al análisis de la 
poiesis o aspecto productivo de la experiencia estética, de la aiesthesis o aspecto receptivo de dicha experiencia y de la catarsis o función comunicativa.

En cuanto a la metodología de las fuentes orales, para utilizar las herramientas del trabajo de campo, de la entrevista y la encuesta, me he basado dos manuales. Por una parte, el libro de Rubén López-Cano y Úrsula San Cristóbal Opazo (2014), Investigación artística en música (Barcelona: ESMUC), que fundamenta académicamente las investigaciones artísticas, tal como apuntaba W. J- T. Michell (2001) en "Mostrando el ver". Por otra parte, el libro de Loraine Blaxter, Christina Hughes y Malcolm Tight (2002), Cómo se hace una investigación (Barcelona: Gedisa), concretiza las distintas metodologías y los métodos de investigación a través de encuestas, entrevistas, cuestionarios para la recolección de datos y la organización de los mismos.

También he consultado las publicaciones de Philip Tagg y Anahid Kasabian, que aportan un enfoque unidireccional en cuanto a la percepción del receptor y a su interpretación, más que a todos los elementos semióticos en conjunto que se interrelacionan junto con el director musical, el realizador y el compositor, actantes del proceso.

Para terminar, ha sido de gran ayuda tanto el manual de José Nieto (1996), Música para la imagen: la influencia secreta (Madrid: SGAE) como el libro de Vicente J. Ruiz Antón (2016), José Nieto. Un encuentro imprescindible (Salamanca: Amarú).

\section{Objetivos generales y específicos}

Los objetivos de mi investigación los puedo dividir en generales y específicos.

Dentro de los objetivos generales se encuentra el estudiar la música como sujeto y como objeto: Un nuevo planteamiento de "gramática artística" hacia una prospección de la labor narrativa y creadora de la investigación artístico-musical a través del mundo de la imagen.

Otro objetivo general es analizar la música como finalidad audiovisual a partir de la realización de conciertos de música clásica para llegar al espectador a través de la pantalla. 
Un tercer objetivo general es establecer la diferencia entre táctica y estrategia de los elementos técnicos y artísticos que confluyen para caminar hacia nuevos retos de aproximación a la expresión audiovisual de la música.

En cuanto a los objetivos específicos, se pueden concretar en:

- Analizar por medio de las fuentes orales en un universo a explorar cómo influye la herencia cultural en la cultura visual.

- Comprobar si hay disonancias entre los nuevos estudios visuales (cine, televisión o videoarte entre otras formas) y las áreas disciplinarias tradicionales dedicadas a la percepción (estética visual) o historia del arte (estudio histórico), a través del análisis de las encuestas de los trabajos de campo.

- Visualizar e interpretar el grado de experimentación que existe en la creación audiovisual a partir de la grabación de un concierto para que el espectador no sea un ente pasivo.

- Profundizar en el papel que juega el discurso musical dentro de la "gramática audiovisual": discernir si se trata sólo de una estética audiovisual o existe un discurso narrativo con finalidad hermenéutica.

- Valorar el uso de los avances tecnológicos para transmitir una partitura original en pleno siglo XXI.

- Identificar los elementos característicos del lenguaje musical compartidos con el lenguaje audiovisual a partir de la semiología.

- Estudiar la relación entre los elementos y el espacio para comprobar si a través de los elementos connotativos un concierto se convierte en un evento sociocultural.

- Estudiar y justificar las figuras del director musical y del realizador utilizando las entrevistas y las encuestas como fuentes orales, para comprobar si existe genialidad o hay una rutina basada en la normativa académica.

\section{Metodología}

Mi deseo y necesidad de investigar en este campo audiovisual, como ya he indicado, surge a partir de la ausencia de análisis y estudios que he detectado acerca del tema de la 
recepción musical en proyectos audiovisuales. Por eso, los estudios generales con los que asiento y delimito mi investigación son, principalmente, los dedicados a la semiótica del discurso y del texto

Junto a ello y, debido a que mi intención de labor investigadora surge de mis años de profesión y de mi profundo interés y continuas reflexiones acerca de los "usos" de la música en los medios audiovisuales, mis métodos o estrategias metodológicas son los siguientes:

Primero, una investigación documental basada en las fuentes bibliográficas ya señaladas.

Segundo, el método cualitativo del trabajo de campo con los siguientes elementos:

- Observación participante y cuaderno de campo. Debido a mi profesión, fundamentaré mi investigación, no sólo en la observación, sino en "una observación participante" o "etnografía audiovisual". Acercar la "Investigación académica" a la "Investigación artística" a través de la asistencia a un proceso de elaboración creativa. Eso es, preparación y asistencia a la retransmisión o filmación de cada concierto escogido, con la posterior postproducción.

- Encuestas estructuradas, a través de un cuestionario realizado con el universo a explorar escogido y la consecuente recogida y análisis de datos.

- Entrevistas personales a profesionales implicados en procesos audiovisuales y musicales.

- Estudio de partituras llevadas a la pantalla: confrontación entre el "texto musical" y el "texto audiovisual"

- Recopilación y análisis de fotografías y planos de los auditorios en los que se realiza la grabación o la retransmisión del concierto para el estudio táctico y estratégico.

- Todo el trabajo está elaborado según las Normas APA 6 edición. 
De la partitura a la pantalla: plano y contraplano de una misma realidad - 14 
PARTE I: TÁCTICA Y ESTRATEGIA 
De la partitura a la pantalla: plano y contraplano de una misma realidad - 16 
Capítulo 1: Marco teórico: Música e imagen 
De la partitura a la pantalla: plano y contraplano de una misma realidad - 18 
Llama la atención que la semiótica, la teoría del signo y del símbolo, y sobre todo la gramatología- con su encomiable interés centrado en la escritura, y en su cortejo de huellas, de marcas y de inscripciones-no hayan reparado apenas en un acontecimiento fundador de historia y de memoria. Algo muy relevante en la World History. Un evento con incidencia en la historia de la humanidad: el nacimiento de la escritura musical (Trías, 2010:33)

Empiezo el primer capítulo con este fragmento del libro "La imaginación sonora" de Eugenio Trías para poder vincular nuestro pasado semiótico: el nacimiento de la escritura musical, con nuestro presente: la ya desarrollada escritura audiovisual en diferentes disciplinas. He podido comprobar que lo mismo que llamó la atención al eminente filósofo ya fallecido -la falta de una semiótica de la escritura musical- está pasando también en la actualidad: la falta de una semiótica audiovisual. Existe una extensa bibliografía acerca del lenguaje fílmico y sus géneros, pero, casi son inexistentes los estudios que atañen a un análisis textual y semiológico y a su proceso de significación más allá del lenguaje cinematográfico. Cualquier signo no debe ser tomado como individual, sino como significado dentro de un texto o contexto. Por ello, no se trata de analizar aquello que dice o significa una creación audiovisual, sino aquellas estrategias que son usadas para narrar o expresar su contenido o intención. Y, cuando hablo de contenido, me refiero a cualquier producto audiovisual: documental, serie televisiva o soap opera, entretenimiento, reportaje, videoclip o concierto de música, objetivo de mi investigación.

Si nos fijamos, en el texto del filósofo, aparece la expresión: "Un evento con incidencia en la historia de la humanidad”. Quiero subrayar, precisamente este adjetivo: Incidental. El significado esencial que nos aporta es que describe algo que no deja indiferente, que no es normal y que ocurre de manera repentina. Aquí es donde quiero ir. ¿Qué necesita una música para ser incidental? Cada día escuchamos muchas músicas en los medios audiovisuales. Todas ellas son músicas que inciden en unas imágenes. Pero, para mí, lo importante no es qué música está sonando en ese momento sino a qué imagen, plano o secuencia acompaña, qué nos quiere explicar acerca de la imagen o qué nos expresa. En definitiva, qué uso de la música se está haciendo para que aquello no incida sólo en la imagen, sino en un "hipertexto comunicativo" más allá de la obra audiovisual en sí. Nos podemos preguntar: ¿En qué incide, en mí, ese uso musical?

Antes de profundizar en dicha incidencia, quiero establecer una diferenciación entre los usos y orígenes de cualquier audiovisual musical. De esta manera, veremos que sería una 
labor exhaustiva fundamentar mi investigación desde múltiples formas artísticas debido a la distinta esencia de ellas. "De la partitura a la pantalla" quiere significar aquella partitura de concierto que excluye cualquier otro tipo de expresión musical que pueda incluir voz, lo que entendemos por música clásica instrumental.

\section{1- Tres géneros de narrativa audiovisual musical: videoclip, ópera y concierto.}

Previamente al desarrollo de la táctica y estrategia narrativa, quiero analizar y destacar no sólo las principales características de cada uno de estos géneros, sino, también aquellas que, aun pasando desapercibidas o suponiendo, desde una visión superficial, cierta nimiedad, son de elevada importancia para evidenciar que cada uno de dichos géneros, a pesar de nacer a partir de un mismo código semiótico como es la escritura musical, sigue una evolución y se gesta de manera distinta en cuanto a lenguaje audiovisual se refiere. Me parece interesante aportar dichas diferenciaciones para evidenciar la realización de los conciertos de música clásica como un género audiovisual con lenguaje y entidad propia.

Antes de entrar en las especificaciones de cada uno de los géneros, quiero analizar el concepto conocido como débrayage. A diferencia de eventos semióticos como la fotografía, cuya esencia es lo estático, tal como nos advierte Bertetti, podemos corroborar que:

(...) lo audiovisual se caracteriza por la presencia de una demora inevitable entre el tiempo de producción y el de la recepción (o si se prefiere, para anticipar una terminología que aprenderemos a conocer, un débrayage entre el "aquí y ahora" del sujeto enunciante y aquello del sujeto enunciatario (...) Este retraso puede ser esencialmente del espacio (como en el caso de una emisión de televisión en directo); o por naturaleza, el espacio esencialmente temporal (como en el cine y en general en los registros audiovisuales). (Bertetti, 2015:20).

Me gustaría añadir a estas palabras o precisar su contenido respecto a mi estudio a través de una observación: referente a la filmación de conciertos u otros géneros audiovisuales, 
también existe un débrayage en cuanto al tiempo, no solo en cuanto al espacio. En el análisis de los siguientes géneros audiovisuales lo podemos comprobar ${ }^{1}$.

a) Videoclip ${ }^{2}$

- Nace, ya, en la era del audiovisual. Por lo tanto, su única fuente de emisión es la pantalla. Me refiero aquí a pantalla, porque, como todos sabemos muy bien, ya la televisión ha dejado de ser la "hija única" en los hábitos de consumo audiovisual de las familias. Es posible, en una misma familia, que un miembro mire un informativo en la televisión, otro mire algún capítulo de una serie por Internet desde el ordenador y, otro, esté viendo, a la vez, cualquier otro género audiovisual desde su tableta.

- Parte, preferentemente, de una canción y, a partir de ella se insertan las imágenes. Al contrario de lo que supone, en general, la música incidental dentro de un género audiovisual, en el que, primero se graban las imágenes $\mathrm{y}$, en paralelo o posteriormente, el compositor o ambientador musical adapta la música. La manera de trabajar el videoclip presupone una creación muy distinta: "tenemos la música...vamos a crear las imágenes".

- Como siempre, el apartado económico tiene mucho que ver en la creación del videoclip, así que, normalmente, el presupuesto para la elaboración de un videoclip suele ser elevado debido a la repercusión que el productor puede tener tras una campaña de marketing arriesgada; aunque, la canción o disco promocionado no sea de un nivel artístico marcado por la exigencia de cierto nivel cultural.

- $\quad$ El hecho de haber nacido para las pantallas y para campañas publicitarias hace que cualquier recurso audiovisual sea válido, tanto técnico como estético: colorimetría, ritmo rápido, montajes acelerados o ralentizados, múltiples cambios de plano, corta duración de los planos, distintas texturas, uso de infografía, paso de la diégesis a la extradiégesis con facilidad, entre muchos otros recursos.

\footnotetext{
${ }^{1}$ Existen otros tipos de géneros audivisuales musicales: documentales, biopics sobre compositores o músicos, retransmisión de conciertos Pop-Rock u otros géneros o estilos musicales; en cuanto a esta investigación, he querido centrarme en estos tres por ser los que reúnen las características más diferenciadas y extensibles a los géneros mencionados. A partir de los tres, podemos explicar cualquier género musical en cuanto a "audiovisualización" se refiere.

${ }^{2}$ La tesis doctoral de Eduardo Viñuela es un interesante estudio sobre el mundo del videoclip entre los años 1980 y 1995 en España. Lo hace desde el campo de la musicología y, en su publicación, podemos ver todos los elementos significativos de esta forma músico-audiovisual.

Viñuela, E. (2009). El videoclip en España (1980-1995): gesto audiovisual, discurso y mercado. Madrid: Edidiones del ICCMU.
} 
- Débrayage, según terminología de Paolo Bertetti. Es decir, entre la grabación y su emisión pasa un tiempo. Es el trabajo conocido como postproducción. No sólo existe débrayage temporal sino espacial respecto al consumidor. Es uno de los factores a tener en cuenta ante la grabación de un audiovisual musical.

- Otro aspecto importante es el factor "sincronía". Se puede realizar un videoclip sin necesidad de que haya ningún momento sincrónico entre imagen y sonido y no sorprenderá a nadie.

En resumen, como diría Michel Chion (1993):

Se sirve de una base musical que reina sobre el conjunto, con la única limitación de sembrar aquí y allá unos puntos de sincronización, con la intención de unir la imagen y la música de manera flexible, lo que permite a la imagen pasearse a su gusto por el tiempo y el espacio. (p. 156-158)

Un ejemplo ilustrativo de estas características mencionadas lo podemos ver en el siguiente videoclip de un grupo adolescente gallego de música Rock :

\section{Ejemplo 13:}

With my hands, de Furious Monkey House

\section{https://www.youtube.com/watch?v=DwFYbsGsZIU}

En este anterior ejemplo, podemos comprobar cómo no existen más de 10" de sincronía vocal. Siguiendo el análisis del minutaje del videoclip, la sincronía vocal (lip sync) ${ }^{4}$ aparece entre los segundos siguientes:

$$
48 "-50 "
$$

$53 "-55 "$

1'55'-1'57'"

\footnotetext{
3 Todos los ejemplos de vídeos están en Youtube

${ }^{4}$ Lip-synchronization o Lip-sync; es decir, sincronización en el doblaje de cantantes o actores y actrices. Sin embargo, en este punto dedicado a la ópera no me refiero al hecho de "tener labiales" o no como puede ocurrir en el género videoclip, sino que se trata de un error técnico que no permite hacer llegar la sincronización que se debe respetar en una retransmisión o filmación del género ópera.
} 
2'03'-2'06"

2'59'-3'

A pesar de los pocos segundos de sincronía no se interpreta como un error de edición o de playback.

El uso de imágenes ralentizadas es permanente en todo el videoclip, así como el uso de flashes blancos como elemento conector de imágenes de corta duración dando lugar a un editaje rápido y acelerado al final del videoclip. Todo este proceso no es posible en una retransmisión en directo, sino que precisa de una minuciosa labor de postproducción ya pensada de antemano. Los ralentizados deben ser grabados con cámaras especiales que, en el momento de la filmación, registran a velocidad muy superior a lo normal, para después, ya en la sala de edición, aplicar aplicar la disminución de velocidad y conseguir el efecto deseado. Así pues, el uso de recursos tecnológicos y electrónicos es muy adecuado para este tipo de creación audiovisual.

b) Ópera

- Evidentemente, género anterior a la era audiovisual; sin embargo, todas las composiciones eran músicas incidentales para un texto a interpretar.

- $\quad$ Lorenzo Da Ponte (1749-1838), libretista del compositor Wolfgang Amadeus Mozart en tres de sus principales óperas: Las bodas de Fígaro, Cosi fan tutte y Don Giovanni, es un buen ejemplo de ello. La realización audiovisual depende de un texto interpretado por cantantes. Así pues, no podemos escapar a ciertos momentos de clímax en la interpretación de los mismos. En muchos momentos donde la vocalización exige su mayor rigurosidad musical, se muestran los primeros planos de los cantantes. La realidad debe ser mostrada y, en este caso, parece que cuanto más nos acercan al cantante, más credibilidad nos transmite en cuanto a su profesionalidad y talento.

- La posibilidad de usar distintos recursos, depende del débrayage: si la ópera se retransmite en directo, existirán unas posibilidades distintas a las que podemos usar cuando la ópera es en diferido y la emisión posterior.

- Los primeros planos de los cantantes tienen que ser tratados con el máximo rigor: iluminación, maquillaje, peluquería o caracterización; así como el uso de los efectos especiales. 
- Importancia evidente de la sincronía. Los receptores no perdonarían la falta de sincronía entre imagen (voz) y sonido (música). Es lo que denominamos en argot profesional "tener labiales" 5 . Un profesional puede llegar a detectar un frame de falta de sincronía; y, a veces, se convierte en una pesadilla de difícil arreglo cuando se detecta este fallo en una grabación.

- La complejidad ante una dirección audiovisual de una ópera, evidentemente, necesitaría una investigación "personalizada" para desarrollar y analizar cada uno de sus pasos creativos y artísticos en lo que respecta a música, letra o libretto, atrezzo, y demás elementos artísticos antes de subir el telón y empezar la filmación.

En el siguiente ejemplo de la ópera La mujer sin sombra del compositor austríaco Richard Strauss podemos comprobar cómo fue resuelta la "sombra". El realizador, Toni Janés de Televisió de Catalunya, pensó en usar medios infográficos y electrónicos para que el resultado final fuese creativo e inteligible a partir del contenido textual de la ópera.

\section{Ejemplo 2:}

La mujer sin sombra, Richard Strauss

\section{https://www.youtube.com/watch?v=zLPRBZ4gPzc}

c) Conciertos de música clásica ${ }^{6}$

- $\quad$ Anterior a la era audiovisual; sin embargo, su potencial cualitativo, el hecho de poder llegar a muchos públicos y su función como archivo cultural y patrimonial en cada país, ha provocado el nacimiento o la especialización en departamentos de empresas dedicadas a su filmación o retransmisión en directo: BBC, Opus Arte, Cadena ARTE, Medici (París), Digital Concert Hall (Berlín). Así, de no poder asistir a diferentes auditorios para escuchar conciertos debido a diversas causas como la falta de tiempo y a la economía, entre otras, existe la solución de poder verlo gracias a las filmaciones para emisión por televisión, para DVD o retransmitidas en directo por streamming, vía web.

\footnotetext{
${ }^{5}$ Ver nota al pie 4.

${ }^{6}$ Me refiero, específicamente, a los conciertos de música clásica por lo que supone de distinto concepto de realización o dirección audiovisual frente a un concierto de Pop-Rock.
} 
- Es importante resaltar que, tampoco es necesaria la televisión, cualquier pantalla nos es válida para poder disfrutar de un concierto. Tiene un interés especial cuando no existe el débrayage de tiempo, aunque sí el de espacio; es decir, cuando estamos ante una interpretación en directo desde cualquier sala de conciertos del mundo y lo vemos desde las salas de cine escogidas para la ocasión. Es obvio que la vivencia en directo no es la misma que la que supone estar en la sala de conciertos, pero, realmente, se puede comprobar cómo el público de la sala de cine reacciona aplaudiendo como si los intérpretes pudiesen percibir dichas reacciones.

- También en estos conciertos es de suma importancia la sincronía. Ver pulsar un pizzicato en un violín o arquear un contrabajo y que el sonido llegue tarde o se anticipe es como desafinar, pero "audiovisualmente".

- Afrontar una dirección o realización de un concierto supone no depender de un "texto" escrito como en la ópera; por ello, resulta mucho más complejo decidir qué hacemos llegar a los espectadores. De repente, la mirada del profesional se convierte en la mirada del espectador. Existen muchas decisiones a tomar y, es por ello, por lo que es de vital importancia saber qué vamos a mostrar: los espectadores oirán todo, pero verán aquello que nosotros queramos.

En este caso se "manipula" la voluntariedad de la vista, e, incluso, del oído. Es muy distinto sonorizar un concierto cuando se retransmite únicamente por radio que sonorizar el mismo cuando existe una apuesta de emisión televisiva. Es decir, si en un pasaje musical decidimos enseñar en imagen el arpa, es normal que en la sala de sonido se refuerce la pista de sonido que corresponde a este instrumento o se realice una mezcla de sonido orquestal de tal manera que, antinaturalmente, quizás, tengamos que reforzar aquellos instrumentos que aparecen en pantalla puesto que los tenemos en primer plano. De aquí, la gran labor que entre realizador y técnico de sonido llevan a cabo para encontrar aquel punto en que imagen y música crean un entramado que debe substraer al espectador.

Para terminar este capítulo, un recuerdo también para el sabio semiótico Umberto Eco. En la entrevista ${ }^{7}$ realizada en México, en el Instituto Italiano de Cultura, por Lauretta

\footnotetext{
${ }^{7}$ Entrevista realizada a Umberto Eco In Memoriam (20 de febrero del 2016): https://www.youtube.com/watch?v=iEw7PCIB0r8
} 
Belsasso para la Radio de la Universidad UNAM (Universidad Nacional Autónoma de México), Eco dice lo siguiente:

El pueblo cree que lo que se ve en la pantalla es la realidad, no sabe que es el resultado de una selección. Si la audiencia aprende a manejar la cámara, aprende que la realidad proporcionada por la cámara es una realidad seleccionada. La educación para la televisión es un problema del nuevo alfabetismo (Entrevista In Memoriam, 7'15'-7'48').

En mi trabajo de investigación -capítulo 4- a partir de la encuesta realizada a cien personas sobre cómo perciben la realización, he podido comprobar que, más que un problema (y sin desmerecer las palabras del gran maestro de la semiótica), el hecho de aprender a leer el lenguaje audiovisual se nos convierte en un reto. Después del análisis, constato que ya es mayoritario el conocimiento de que "alguien" ha hecho una selección de la realidad antes de llevar a la pantalla aquello que vemos. Es decir, no es ya analfabetismo audiovisual pensar que lo que vemos no es la realidad, sino una realidad seleccionada, sin embargo, quizás sí se trata de alfabetizar un nuevo componente: no es tan importante lo que vemos sino lo que nos quiere decir o significar aquella imagen o secuencia de imágenes escogidas. Para ello, paso al siguiente punto. Y, esto, es dar un paso más.

\section{2- Concierto: Lectio Score}

Tomando como eje del análisis la realización de los conciertos de música clásica, no sólo en el mundo televisivo, sino también en cualquier retransmisión o emisión de conciertos- por Internet, por ejemplo-, el realizador debe partir de una narrativa básica, pero comprometida también y, fundamentalmente, con aquello que quiere significar y que quiere transmitir de la música compuesta e interpretada.

Para demostrar cómo existen distintas maneras de significación a pesar de partir de un lenguaje narrativo común, la partitura, he analizado dos obras a partir de métodos estratégicos prioritarios.

Una estrategia prioritaria es la lectura atenta (es a este trabajo previo al que le llamo aquí lectio score) de cada una de las partituras que van a "traducirse" en la pantalla. Y, no 
solamente, este estudio en profundidad es uno de los aspectos más importantes, sino también un acercamiento al compositor, a su época e, incluso, al momento personal en que escribió dicha obra, sin dejar de obviar las anotaciones pertinentes que encontramos escritas por él mismo en la partitura, como es el caso de las dos obras que analizo a continuación.

La primera obra tiene su origen en una composición que nació como música incidental para una obra de teatro: Abdelazer o La venganza del moro, de Henry Purcell. La obra literaria fue escrita por Aphra Behn, escritora inglesa del siglo XVII.

La segunda obra analizada es el Adagio del compositor Samuel Barber.

\section{a. Guía de orquesta para jóvenes, de Benjamin Britten}

Lo que quiero remarcar de la composición de Purcell como música incidental, no es la obra en sí, sino, cómo se convirtió en una guía de orquesta a través de las variaciones que el compositor inglés Benjamin Britten (1913-1976), trescientos años más tarde, compuso sobre el "Rondó" que forma parte de la pieza musical del compositor barroco. La obra de Britten, escrita hacia 1946, nació como encargo del Ministerio de Cultura inglés para ilustrar la música de la película Los instrumentos de música. De esta manera se convertía en música incidental desde su doble función: acompañar una obra de teatro y hacerse visible desde las pantallas.

Esta partitura nos puede ayudar a entender cómo llevar, podríamos decir, de manera literal, la partitura a la pantalla. Como he dicho, estamos ante una obra que nació como música incidental y, al mismo tiempo, fue escogida para convertirse en un "audiovisual didáctico"; además de ser un homenaje al barroco compositor inglés, Henry Purcell.

Antes del análisis minucioso del paso de la partitura a la pantalla a partir de esta obra, quiero destacar cómo, según cita de Bertetti (2015), Maria Pia Pozzato, en su libro Semiotica del testo, nos propone tres funciones perceptivas desde el punto de vista del observador. Pablo Bertetti, profesor y semiólogo de la Universidad de Siena, amplía dichas funciones a una cuarta:

1. Función perceptiva, que instaura un punto de vista óptico-perspectivo.

2. Función evaluativa, con un punto de vista entendido como opinión, inversión de valor, orientación del juicio. 
3. Función cognitiva, donde el punto de vista consiste en una "distribución del conocimiento a través del texto" (Pozzato, 2001:88).

4. Se puede añadir una función tímica-pasional (emocional), relativa a las emociones y a los estados propios del actante observador. (Bertetti, 2015:126)

Quiero detenerme, antes de seguir, en el concepto "actante" que encontramos en la cuarta función. El lingüista y semiólogo A. J. Greimas (1979) afirma: “el término personaje fue gradualmente reemplazado por dos conceptos más estrictamente definidos en semióticade actante y actor" (p. 252).

Así pues, se trata de un concepto que, en semiótica, reemplazó el término "personaje", dándole una categoría de entidad abstracta y diferenciándolo del concepto de "actor", como entidad específica. En el caso que nos ocupa, el actante observador es la persona que lleva a cabo la acción y, en este trabajo de investigación, se convierte, como veremos, en un agente fundamental.

Benjamin Britten nos propone dos funciones, según terminología y teoría de Maria Pia Pozzato en su libro Semántica del testo: la función perceptiva y la función cognitiva. Desde la primera nos ofrece un punto de vista objetivo: "suena este instrumento musical y os lo muestro"; a partir de la segunda función, nos conduce a un conocimiento del Texto a través de la "semántica musical": cómo vamos interrelacionando cada plano y construyendo el “fraseo o escritura audiovisual". Pero, y creo que esta tercera función es la que nos interesa aquí, existe la función emocional, la que ha tenido a bien en añadir Paolo Bertetti. Con esta función se refiere a las emociones de la persona observadora; en nuestro caso, el "actanteespectador multipantalla".

Todo lo que de expresividad, narración, poesía, descripción o comunicación tiene una partitura, debe ser transmitido al "actante observador". Se trata de ver, saber o cognoscere y emocionar.

Así pues, de igual manera que existe una música incidental sobre las imágenes, existe una "manera incidental" de realizar una grabación de un concierto; esto es, de hacer llegar el contenido de una partitura al espectador a través de la realización audiovisual. De aquí, el título de mi labor investigadora: "De la partitura a la pantalla: plano y contraplano de una misma realidad". 
A continuación el primer ejemplo de Lectio Score. Presento un análisis de Guía de orquesta para jóvenes de Benjamin Britten en el que veremos cómo se desarrollan dos de las tres funciones principales, la perceptiva y la cognitiva.

\section{Ejemplo 3:}

Abdelazer, de Henry Purcell/Guía de orquesta para jóvenes, de Benjamin Britten:

\section{https://www.youtube.com/watch?v=3HhTMJ2bek0}

En este ejemplo, podemos constatar una realización desde una función perceptiva. La partitura misma nos indica qué enseñar o mostrar en pantalla. El objetivo didáctico nos conduce a una realización, diríamos, "simple y llana...", con poca significación simbólica o emocional. Es una lección músico-audiovisual. Comparado a un texto escrito, podríamos estar ante un "manual de instrucciones", no en vano, el título de la obra música está encabezado por la palabra "Guía".

La instrumentación la muestro en la siguiente tabla:

Tabla 1. Instrumentación Guía de orquesta para jóvenes, Benjamin Britten.

\begin{tabular}{|c|c|c|c|}
\hline Viento Madera & Viento Metal & Percusión & Cuerda \\
\hline 2 Flautas 1 Piccolo & 4 Trompas en Fa & Timbales & Violines I y II \\
\hline 2 Oboes & 2 Trompetas en Do & 3 Percusionistas: & Violas \\
\hline 2 Clarinetes en Si b y La & 3 Trombones & \multirow{2}{*}{$\begin{array}{l}\text { Tambor bajo, platillos, } \\
\text { pandereta. Triángulo, caja } \\
\text { china, caja, xilófono, } \\
\text { castañuelas, gong y látigo }\end{array}$} & Violoncelos \\
\hline 2 Fagotes & Tuba & & Contrabajos \\
\hline \multicolumn{4}{|c|}{ Arpa } \\
\hline
\end{tabular}

Nota. Tabla con el desglose de instrumentos por familias orquestales, de M. Millà, 2017. 
El tema musical de Purcell que interpretan las diferentes familias instrumentales es el siguiente:

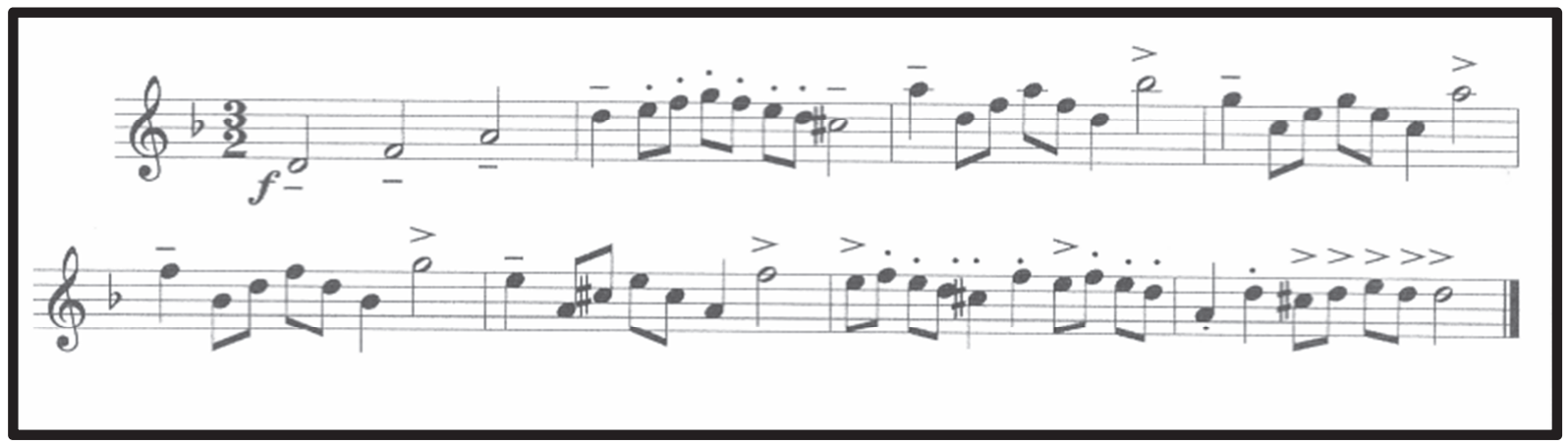

Figura 1 Tema musical de Abdelazer, P. Casas.

Escrito en la tonalidad de Re menor, el tema se desarrolla a partir del arpegio del acorde de tónica, medio habitual en la construcción temática de la música que abarca, sobretodo, el período conocido como "de la práctica común” (del barroco al impresionismo). Sobresale la progresión también llamada Fortspinnung, c3-4-5-6, típica de la música del alto barroco.

A continuación, el tema de la fuga llevado a cabo por el compositor Benjamin Britten:

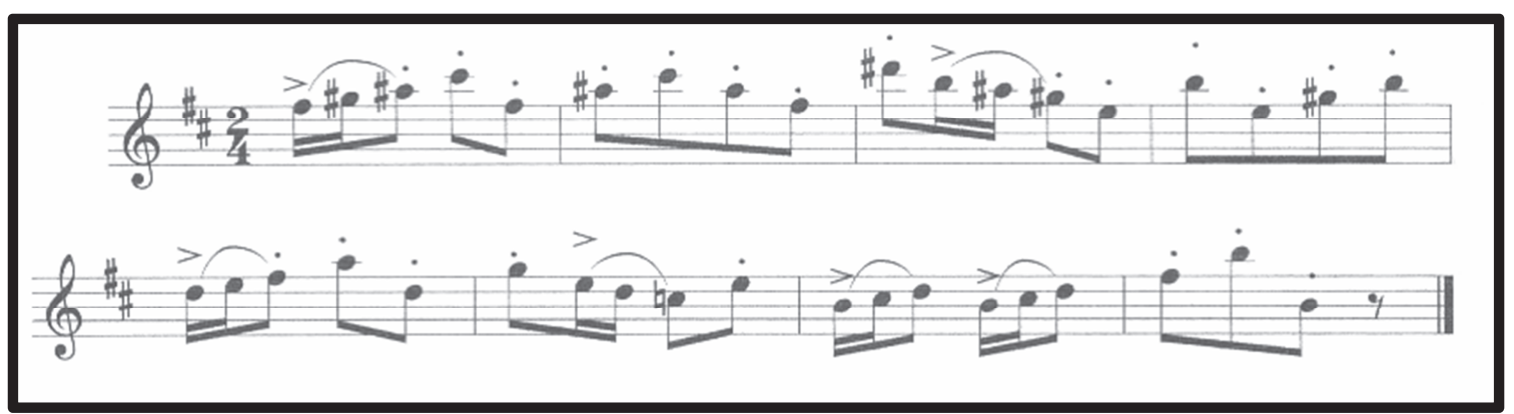

Figura 2 Tema musical de la Fuga (Henry Purcell), P. Casas.

Este tema está construido sobre una relación de fundamentales de $5^{\mathrm{a}}$ descendente, desde donde sobresale el tritono Fa\#M-Do M. Su construcción sigue procedimientos similares al tema de Purcell, aunque añadiendo por parte de Britten, cambios en la dirección de los pequeños motivos que componen la frase.

Para poder seguir el análisis que hago de la realización, adjunto la partitura en el Apéndice $\mathrm{I}^{8}$. Respecto a la versión filmada, corresponde a la que se llevó a cabo en la Ópera de Sidney el año 2011 y todos los tiempos son extraídos de esta versión. Se trata de la

\footnotetext{
${ }^{8}$ La realización audiovisual se puede ver a través del link indicado en la página 16.
} 
Youtube Symphony Orchestra dirigida por Michael Tilson Thomas, Youtube Symphony Artistic Advisor.

La partitura se divide tres secciones:

1. Primera sección: presentación de los instrumentos

00:10- Tutti- La orquesta al completo presenta el tema (cc.1-16).

00:34- Viento-madera- La familia instrumental de viento-madera sigue con el tema (cc.17-26).

00:57- Viento-metal- Sigue con el tema la familia viento-metal (cc.27-37).

01:15- Cuerda- Toda la familia instrumental interpreta el tema mediante arqueo y pulsación; se añade el arpa a mitad de frase (cc.38-46).

01:36- Percusión- Después de la interpretación de los instrumentos de cuerda, recoge el tema la percusión, para terminar con el tutti orquestal final (cc.47-53).

01:56- Tutti para final de la sección (cc.54-62).

2. Segunda sección: trece variaciones a través de cada uno de los instrumentos

02:13- Flauta y piccolo (cc.63-98)- Acompañan el tema los violines, el arpa y el triángulo.

02:46- Oboes (cc.99-106)- Acompañan la familia de cuerda y los timbales.

03:40- Clarinetes (cc.107-123)- Acompañados por el pizzicato de cuerda y el instrumento más grave de la sección de metal: la tuba.

04:20- Fagots (cc. 124-148)- Acompañados por la cuerda y la caja como percusión. 
05:07- Violines I-II (cc. 149-172)- Interpretan el tema acompañados por los instrumentos de metal y, como instrumento percutivo, el bombo.

05:40- Violas (cc. 173-192)- Acompañadas por toda la familia instrumental de viento: madera y metal.

06:39- Violoncelos (cc. 193-215)- Acompañados por las violas, clarinetes y arpa.

07:42- Contrabajos (cc. 216-266)- Siguen la melodía, acompañados por la pandereta y viento madera.

08:45- Arpa (cc. 267-281)-acompañada en el tema por la cuerda al completo y dos instrumentos de percusión: gong y platillos.

09:36- Trompas (cc. 282-297)- Arpa, timbales y toda la cuerda son los instrumentos que acompañan la melodía de las trompas.

10:21- Trompetas (cc. 298-338)- Acompañadas por la cuerda y la caja.

10:53- Trombones y tuba (cc. 339-366)- Los instrumentos de metal graves van acompañados por los instrumentos de viento madera, trompas y contrabajos.

12:06- Percusión (cc. 367-435)- Para finalizar esta segunda sección de instrumentos solistas que interpretan el tema, aparece la percusión acompañada de la cuerda al completo, antes de entrar en la fuga final, precedida por el xilófono (13’40”)

\section{Tercera sección: Fuga- (13:52/cc.436 hasta el final)}

En esta forma musical, los instrumentos se van sumando en el mismo orden que en las anteriores Variaciones hasta llegar a la interpretación del tema principal con los instrumentos de metal (15'48”) mediante un tempo mucho más lento y majestuoso, el cual nos conduce al acelerando final para concluir la obra. 
Como podemos comprobar a través de la evolución cronológica de las imágenes, se trata de una realización que plasma literalmente aquello que nos va indicando la partitura; en algún momento nos ofrece un plano de situación desde el exterior en que podemos ver la Ópera de Sidney, así como planos generales para ver la situación de la orquesta y la ópera desde el interior. También podemos seguir algunas partes de los instrumentos de la orquesta que van haciendo de contrapunto de la melodía principal. Todo ello enriquece la realización, pero, se hace evidente la literalidad de la "puesta en pantalla": la imagen sigue la melodía o tema principal.

A continuación, un segundo ejemplo que nos muestra otra posibilidad de realización.

\section{b. Adagio para cuerdas, de Samuel Barber, op.11}

Quizás conocida por ser usada como música incidental en varias películas, entre ellas: $E l$ hombre elefante (1980), Platoon (1986) y Amélie (2003); incluso también se ha realizado alguna que otra versión trance ${ }^{9}$ como la de William Orbit o la de Tiësto. Esta composición ha sido interpretada en muchísimas ocasiones y grabada, para ser vista y escuchada, en muchas otras. La versión que propongo analizar aquí es la interpretada por la OBC en L'Auditori de Barcelona en el año 2006. El director es Víctor Pablo Pérez, su titular en aquel momento, y la versión para televisión fue realizada por la cadena Medici.

Voy a analizar tres momentos de la grabación junto con la partitura ${ }^{10}$.

Ejemplos 4-5-6: Adagio para cuerdas, de Samuel Barber, op.11

1. Primera parte o inicio (Ejemplo 4)

https://www.youtube.com/edit?o=U\&video $\mathrm{id}=$ mm11Xwo5UEY

00:00- Director (cc.1-4)

00:36- Violas (cc. 4-8)

01:06- Director (c.8)

\footnotetext{
${ }^{9}$ Se trata de un subgénero de la música electrónica nacido a principios de 1990.

${ }^{10}$ En el Apéndice I-Partituras, se puede seguir la explicación descriptiva de los compases
} 
01:10- Violoncelos (cc. 8-10)

01:24- Director (cc. 10-13)

01:42- Violas (cc. 13-15)- fraseo musical dividido en dos planos distintos.

02:00- 02:31- Director (cc. 15-19)

Este inicio se caracteriza por:

- Movimientos muy lentos y suaves efectuados por la cámara .

- Continuos pasos por el director antes de ir a cada instrumento.

- Planos cortos o muy cortos. Muestra el director en plano americano. El resto de planos son detalles de instrumentos o planos muy cortos de músicos.

- Cambios de plano por corte.

- Imágenes enfocadas y amplia profundidad de campo.

- Podemos observar en la partitura cómo la línea melódica principal es interpretada por determinados instrumentos; sin embargo, las imágenes siguen otros "caminos" narrativos. Partitura e imagen bifurcan la narratividad a partir de la selección audiovisual del realizador.

2. Segunda parte o clímax (Ejemplo 5)

https://www.youtube.com/watch?v=6o_O4mUcFyo

00:00- Violoncelos (cc. 43-45)

00:19- Director desde dos puntos de vista (cc. 45-47)

00:30- Violines (cc. 47-49)

00:43- Director (c. 49)

00:48- Concertino (Clímax, cc. 50-52)

00:58- Encadenado a director de 7"' (cc. 52-55)

01:30- Encadenado a Violín de 12” (cc. 56-59) 
02:00- encadenado a Violas de 9" (cc. 59-60)

En esta parte central donde se encuentra el clímax de la obra, es importante subrayar un cambio en la realización. Se dan tres características:

- El momento culminante se ataca con un plano corto del concertino (y de algún violín más que entra en plano).

- Una vez alcanzado el clímax del adagio, pasamos a una realización donde los cambios de plano se dan a través de largos encadenados en los que la imagen se confunde. 11

- Continúa existiendo divergencia entre el seguimiento melódico y los planos de instrumentos que configuran esta narratividad musical.

3. Tercera parte o final (Ejemplo 6)

https://www.youtube.com/watch?v=hCgXToXi4Ds

00:00- Plano detalle de violonchelo y arco (cc. 63-64)

Encadenado o transición entre imágenes de 13” de duración.

00:20- Plano corto de violista, entre encadenados largos de imagen (cc. 64-65)

Encadenado o transición de 10" entre imágenes.

00:37-01:03- Plano detalle de las manos del director, panorámica vertical ascendente junto con obertura del plano hasta llegar a plano americano del director (cc. 66-68)

Otro avance más en el planteamiento de la realización:

- Movimientos extremadamente suaves y lentos. Las figuras de redonda ligadas hasta el final son traducidas en imagen a través de dichos movimientos.

\footnotetext{
${ }^{11}$ En el capítulo 4, dedicado al cuestionario, veremos cómo algunas de las personas encuestadas perciben esta decisión artística como un error técnico.
} 
- Encadenados de imágenes largos (vemos encadenados de 13", e incluso más)

- Planos muy cortos de instrumentos. Pasamos del plano detalle del violoncelo, al plano de viola y, para terminar, plano detalle de las manos del director para ir abriendo el zoom hasta descubrir el plano general.

A través de estos tres momentos, podemos comprobar una evolución en el concepto de realización. Si en la obra anterior, en el ejemplo de Benjamin Britten, se proponía una literalidad en cuanto a la realización, en esta se nos propone ir algunos pasos más allá. En las dos existe un estudio y profundización de la partitura, pero, es cierto que, en la segunda se aborda una realización más metafórica, incluso tratando de enseñar aquello que el espectador que está en la sala de conciertos no ve.

No se trata de emitir juicios, pero quizás se puede discutir si hay un exceso de imagen del director o no, qué aportan los encadenados tan prolongados o, porqué, si el ritmo o tempo, es el mismo durante toda la pieza musical, el realizador decide, a partir del clímax tratar la imagen con encadenados e imágenes superpuestas. Quizás sólo hay un motivo, durante la primera parte queda "dicho todo" y, a partir de la segunda parte, es cuestión de aportar una estética que enriquezca el producto final. De todas maneras, creo que debe quedar claro que hay una intencionalidad detrás de esta realización y a eso me refiero cuando hablamos de la tercera función: la función emotiva y simbólica.

Para concluir, démonos cuenta que, si en la Guía de orquesta para jóvenes, la melodía es seguida "caligráficamente"; en el Adagio para cuerdas de Samuel Barber, la imagen se escapa de la melodía en muchos momentos de la realización. Pero, está claro que en las dos realizaciones hay dos cuestiones importantes:

- Estudio y conocimiento de la partitura y la obra en cuestión.

- Clara finalidad o un "para qué" pensado y razonado, una significación sobre el objetivo audiovisual a conseguir para que llegue al espectador de manera inteligible.

Quiero introducir aquí un concepto conocido como dumbing down: se trata del hecho de simplificar, estandarizar o o empobrecer intelectualmente para hacer más comprensible la cultura. Oliver MacFarlane $^{12}$ (2008) propuso este término ante el temor que la realización de

\footnotetext{
${ }^{12}$ Oliver McFarlane, realizador de la BBC.
} 
los BBC Proms, conocido festival británico, incurriera en este "error" cuando no era su objetivo.

I hope I have given a sense of how artistic vision of the Director of the Proms festival is realised into exciting and involving television through technological innovation, production and editorial ambition and expertise. There also voices off who accuse Tv of “dumbing down" but I hope I have shown that we have not (p. 464) ${ }^{13}$.

(Espero que les haya ofrecido cómo la visión artística del Director del Festival Proms se ha convertido en una emocionante y complicada retransmisión televisiva a través de la innovación tecnológica, la producción y la ambiciosa y experta editorial. Existen, también, voces que acusan la televisión de dumbing down pero espero demostrar que no es así $)^{14}$.

Es un riesgo que podemos correr y, por ello veo fundamental la Lectio Score; es decir, la lectura atenta de la partitura y su análisis antes de trabajar la realización propiamente dicha. En primer lugar, porque enriquece el objetivo audiovisual en sí y, en segundo lugar, para no caer en el dumbing down dentro de una disciplina artística a la que puede tener fácil acceso dicho fenómeno debido a la proliferación de técnicas y tecnologías disponibles. Así pues, no se puede establecer una relación directa entre innovación tecnológica y dumbing down, ya que el producto final bien puede llegar a un nivel satisfactorio de excelencia si los avances tecnológicos no son usados únicamente a nivel estético sin más, sino con una finalidad que profundice en el contenido y contribuya a su inteligibilidad.

A modo conclusivo, en la figura 3, podemos ver qué elementos configuran la preproducción:

\footnotetext{
${ }^{13}$ MacFarlane, O. (Mayo de 2008). TV master class. Libro de actos. En 2 n Congrés Internacional de Música a Catalunya. Simposio llevado a cabo en el congreso Consell Català de la Música, Universidad Barcelona.

${ }^{14}$ Traducción realizada por Finn McLafferty, profesor de inglés (TVC)
} 


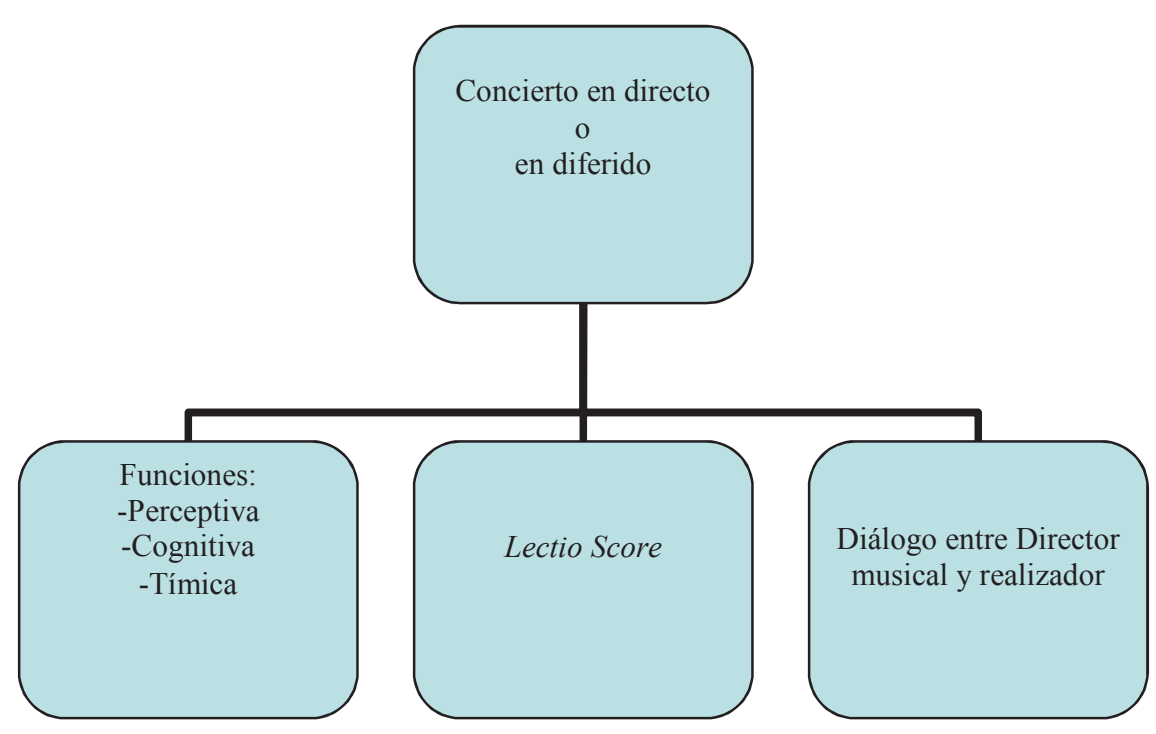

Figura 3. Elementos que intervienen en la preproducción de una filmación, M. Millà.

\section{3- El lenguaje audiovisual en los conciertos: táctica, estrategia y flow}

Una vez analizada la funcionalidad de cada audiovisual a través de dos ejemplos muy distintos entre sí, y antes de presentar los distintos elementos que conducen y enriquecen la narratividad en la realización de un concierto, quiero diferenciar dos conceptos clave: táctica y estrategia. A lo largo de los distintos capítulos, iré profundizando en dichos conceptos porque creo que son fundamentales en este trabajo de investigación como metodología a seguir.

El concepto "táctica" representa aquello que es estático, un posicionamiento. Con este concepto me refiero a la colocación de las cámaras, evidentemente distinta según sea el espacio en que tendrá lugar la filmación, según el tipo de producción -no es lo mismo un quinteto que una gran orquesta sinfónica- y, también, según se trate de una filmación con postproducción o de una retransmisión en directo.

Referente a la primera posibilidad ${ }^{15}$, el espacio, muestro a continuación, distintos planos de que ejemplifican distintas posibilidades de posiciones de cámaras:

\footnotetext{
${ }^{15}$ Dedico un análisis más exhaustivo a los dos tipos de filmación-en directo o en diferido- en los capítulos 2 y 3 de mi trabajo de investigación.
} 


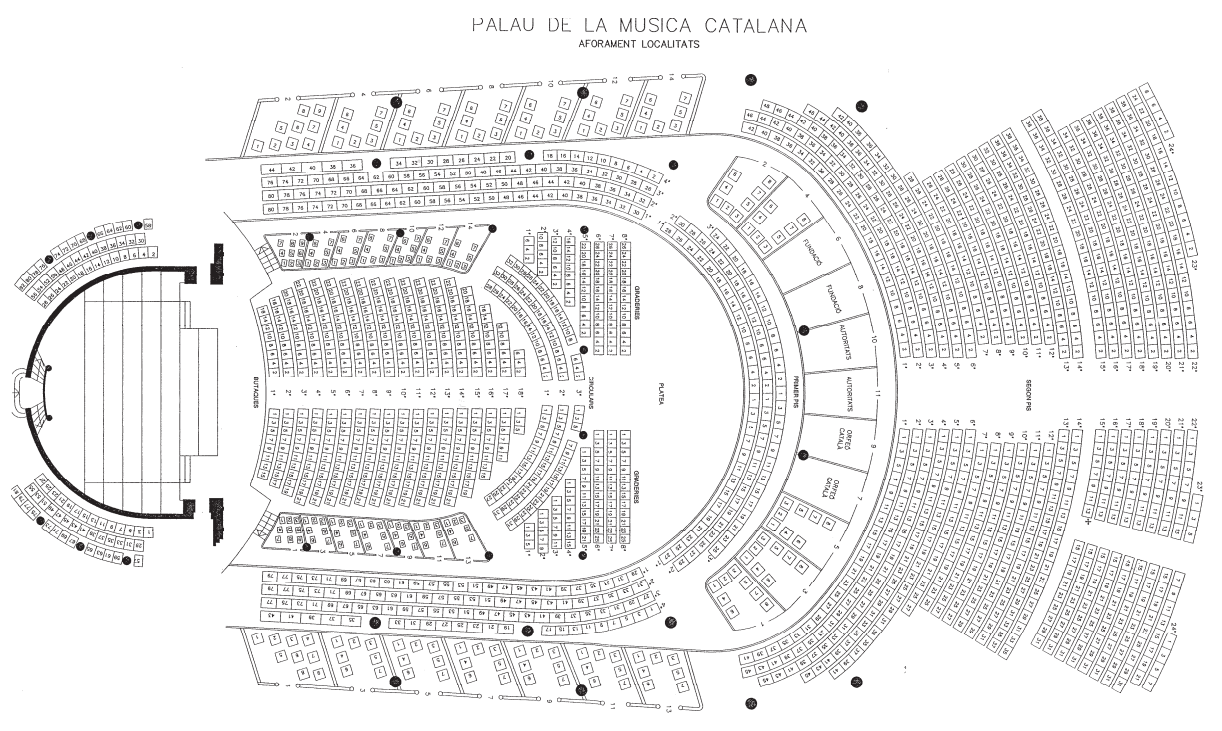

Figura 4 Posiciones de cámara posibles en el Palau de la Música Catalana, Barcelona.

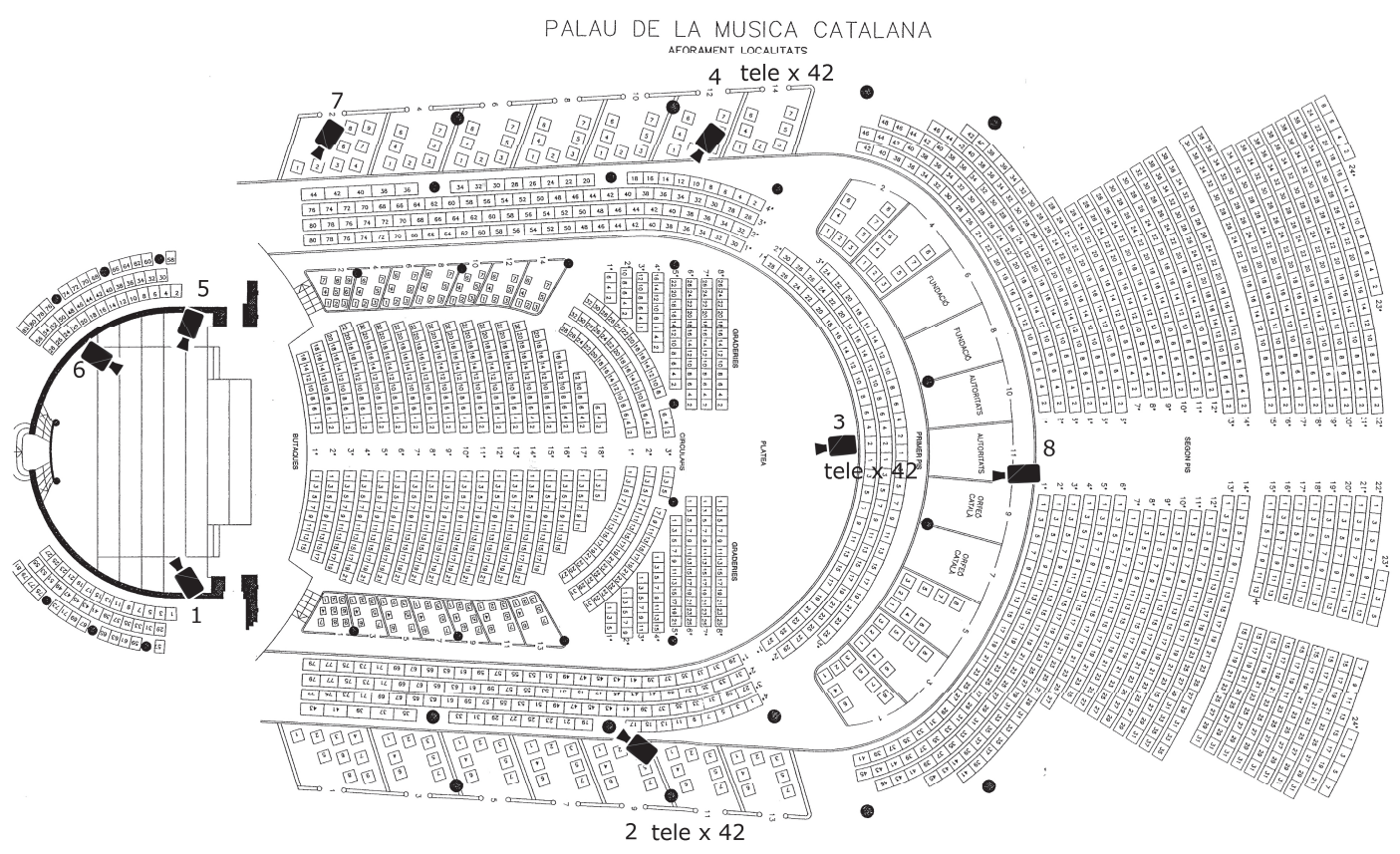

Figura 5 Posiciones de cámara ya seleccionadas en el Palau de la Música Catalana, Barcelona. 


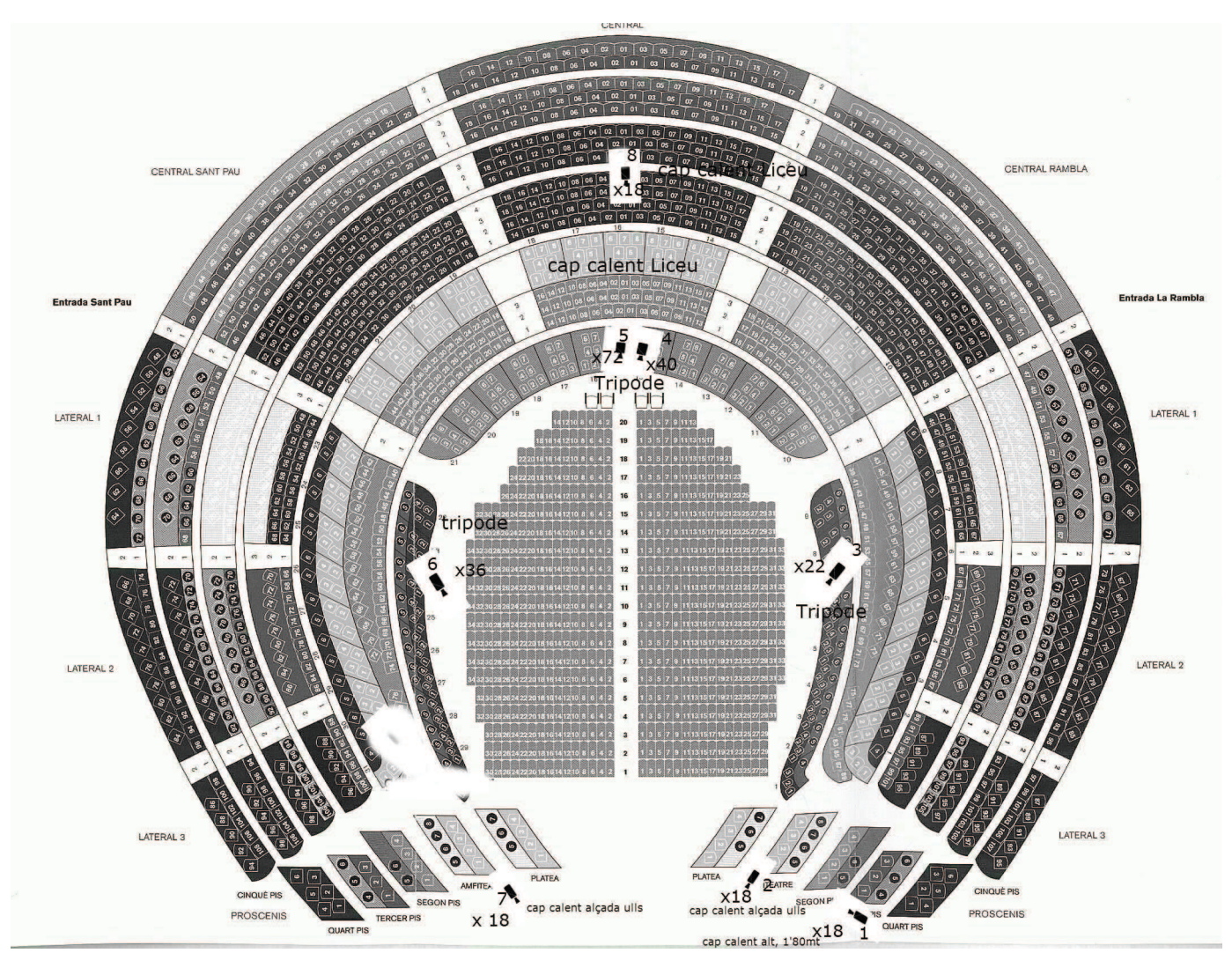

Figura 6 Posiciones de cámara ya seleccionadas en el Gran Teatre del Liceu de Barcelona.

En la Figura 4, aparecen todas las posiciones de cámara posibles en la sala del Palau de la Música Catalana de Barcelona. El realizador tiene la libertad de poder situar más cámaras en otras zonas de la sala que no sean los anclajes previstos donde poder sostenerlas; por ejemplo, en platea frontal. Podemos comprobar dicha colocación de cámaras en la Figura 5. En este plano, a cada cámara le corresponde un número que será el que se le asignará desde la Unidad Móvil. También se especifica qué tipo de óptica se usará en la producción; por ejemplo, en este caso, hay tres teleobjetivos (x42) para poder llegar a dar desde estas tres cámaras los planos más cortos de la orquesta.

La Figura 6 corresponde al plano de la sala del Gran Teatre del Liceu de Barcelona. Como en el plano anterior, están las cámaras ya numeradas; en este caso ocho cámaras con sus respectivas ópticas. Para llegar a un acuerdo con los profesionales de cada una de las salas se realiza lo que se conoce, profesionalmente hablando, como "localización". Es decir, el equipo que se encargará de la realización se traslada a la sala de conciertos días antes y pacta las situaciones de las cámaras puesto que, a veces, es complicado y supone una dificultad añadida situar cámaras en según qué espacios. 
Quiero mostrar qué sistema tienen en el Digital Concert Hall de la Philharmonie de Berlín para que los planos sean adecuados según sea la colocación de los instrumentistas para cada concierto. A continuación, tres fotografías (Figuras 7 y 8) para ver cómo son los anclajes usados:

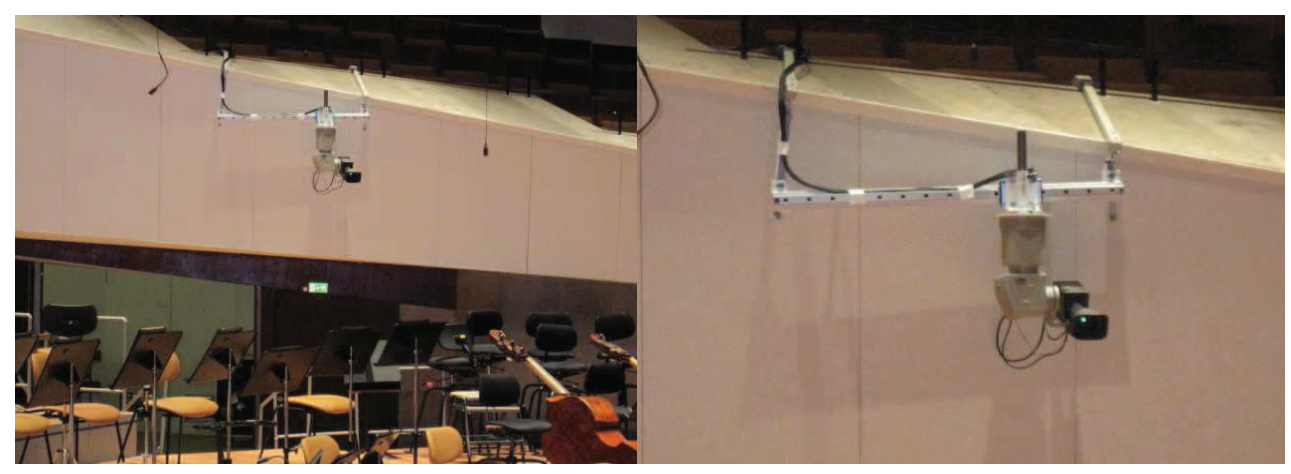

Figura 7 Soportes y modos de anclaje de las cámaras en la Philharmonie de Berlín.

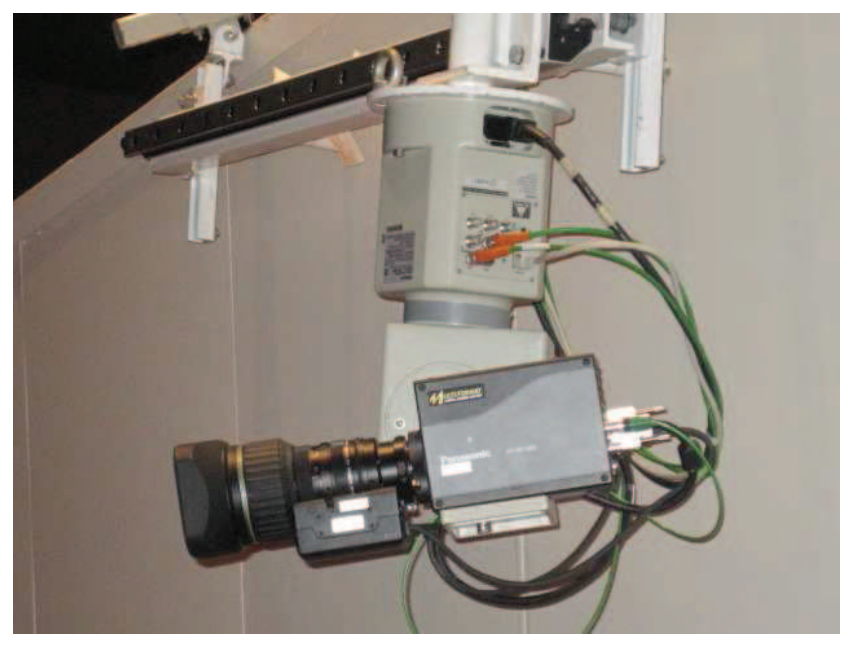

Figura 8 Soportes y modos de anclaje de las cámaras en la Philharmonie de Berlín

En las Figuras 7 y 8, se ve exactamente cómo el anclaje de la cámara puede variar en algunos centímetros. Es simple, pero ciertamente, puede depender de un centímetro el tipo de plano que se puede obtener de cada músico. Una diferencia de $10 \mathrm{~cm}$. puede hacer variar completamente la composición de un plano y quedarse con la visión ciega del instrumento musical que quiere mostrarse en pantalla. 
Así pues, y tal como afirma Oliver MacFarlane (2008), los realizadores no sólo tienen que conocer la música y estudiar la partitura de la pieza que se va a "retratar", sino tener un plano de situación de cada uno de los músicos de la orquesta en el día del concierto.

For a director apart from getting to know the music and studying the score the most important thing is to get a reliable plan of the orchestral layout. Conductors often don't understand how important this is and are prone to change the layout at will, even on the day of a concert but this is potentially detrimental to the achieving the best results in a live Tv broadcast. Having got an orchestral plan a director will aim to position his cameras in the most advantageous positions to give the best coverage of the music (p. 463).

(Para un director ${ }^{16}$, además de conocer la música y estudiar la partitura, lo más importante es disponer de un plano fiable de la disposición de la orquesta. Los directores de orquesta, a menudo, no entienden cuán importante es esto y son propensos a cambiar dicha disposición, incluso el mismo día del concierto; pero, esto es en detrimento a alcanzar los mejores resultados para la retransmisión. Si el director dispone de un plano de la orquesta, podrá disponer de las cámaras en las situaciones más ventajosas y así poder realizar la mejor cobertura de la música ${ }^{17}$.

A partir de estas palabras, parece obvio tener en cuenta otro elemento en la filmación de conciertos: la predisposición y el diálogo con el director de orquesta. Se trata de un paso importante si se quiere conseguir que el espectador vea el concierto de manera que cuando termine pueda afirmar que no sólo ha podido verlo, sino que ha participado de aquello que, en directo, en muchas ocasiones tampoco se "ve ni se percibe". Es decir, la libertad de la percepción visual que tenemos como humanos, la toma de decisiones continuas, son suplidas por momentos visuales y sonoros que no podemos tener desde las localidades de los auditorios. Planos cortos de instrumentos, expresividad de los músicos, expresividad del director, gran plano general de toda la sala, entre otras muchas opciones, permiten a los espectadores contemplar un mundo audiovisual impensable desde la sala.

Es importante valorar la creatividad de los cámaras en el momento preciso y su profesionalidad puesto que dan origen a imágenes y posibilidades de creación de planos que

\footnotetext{
${ }^{16}$ En anglosajón, el director audiovisual se corresponde con el réalisateur francés. En España, se ha tomado la etimología francófona: realizador.

${ }^{17}$ Traducción realizada por Finn McLafferty, profesor de inglés (TVC).
} 
hacen que se conviertan en aliados imprescindibles. Las combinaciones creativas se multiplican cuando entran en juego otros elementos en la narratividad del conjunto audiovisual. Para ello, paso ahora a hablar del segundo concepto de este capítulo.

La estrategia complementa la táctica, pero aporta un significado nuevo: se trata de un concepto dinamizador. Incluye todos aquellos movimientos individuales de cámara para dar el mejor plano en cada momento; así como la "comunicación" con el resto de cámaras para ir elaborando la narrativa audiovisual pensada para cada concierto en concreto. Es decir, los cambios de plano de una cámara a otra, así como los diversos tipos de unión entre ellos, el ritmo interior de cada plano, el ritmo durante una secuencia de cambios de plano...todo ello genera la función dinamizadora de la estrategia. Se trata de un concepto complejo y, es por ello, que en los siguientes capítulos lo desarrollaré en profundidad y a partir del proceso analítico de dos ejemplos: conciertos en diferido y conciertos en directo.

Del diálogo entre táctica y estrategia nace el flow en cada concierto. Es difícil encontrar respuesta a qué es primero, si la táctica o la estrategia, dependerá de cada ocasión. Se puede vislumbrar una estrategia para un concierto y, a partir de aquí, establecer la táctica o situación de cámaras. Pero, también es posible partir de una colocación fija de cámaras y, a partir de ella, establecer la estrategia. Táctica y estrategia, al final, confluirán el flow entendido como el proceso de ir "navegando" por la filmación a través de los planos atrapando al espectador en el fluir de los planos, en la personal experiencia estética de la producción audiovisual.

Para ello, es muy importante tener en cuenta el punto que viene a continuación dedicado a los elementos de la narratividad. El proceso, en realidad, acaba de empezar.

\section{4- Elementos de la narratividad: planos y ritmo}

Llegados a este punto, podemos afirmar que se ha terminado el proceso de preproducción; es decir, todas aquellas decisiones previas a la filmación. A partir de ahora, nos encontramos en la producción propiamente dicha: el momento de la filmación.

Existen muchos elementos para llevar a cabo la narratividad en la realización de un concierto. Algunos, como la gestualidad del músico, dentro de la vertiente artística, o la microfonía, por lo que respecta a una de las partes técnicas. Creo que todo confluye para bien 
de una realización que quiera alcanzar los tres objetivos nombrados al principio: perceptivo, cognitivo y emotivo. Pero, en este primer apartado dedicado a los elementos narrativos quiero centrarme en dos de ellos: el plano y el ritmo.

\section{a. El plano}

"El cine es en realidad una forma de comunicación con los espectadores, que se beben las películas como se beben la música (...) porque les permiten adentrarse en el reino del sentimiento de las ideas" (Rabiger, 2001:87).

En el inicio del capítulo, ante los dos ejemplos musicales, hemos visto cómo podemos pasar de una filmación literal a una filmación cuya función sea tímico-emocional; es decir, que no sólo cumpla con una función más o menos didáctica sino que tenga relación con las emociones, recuerdos o los estados del mismo actante desde su pasado y hasta su presente. La cita que acabo de transcribir acerca de la dirección de los documentales, también nos adentra en esta función y, resulta curioso que, Michael Rabiger, exponga esta teoría de la comunicación en su trabajo antes de adentrarse en el lenguaje del plano, lejos de los convencionalismos establecidos. Expongo a continuación otra cita suya en la que describe, no sólo desde la afirmación, sino desde la negación, de qué hablamos cuando tratamos el concepto "plano":

Un plano es una imagen encuadrada y grabada por alguien que piensa que esa imagen tiene significado propio. Si visiona copiones, que son las grabaciones recién salidas de la cámara, intentará dilucidar lo que pensaban, lo que sentían o lo que buscaban el operador de cámara y el director. No sólo se trata de lo que se ve en una determinada toma, sino también de lo que se excluye de ella. El plano de un hombre que mira fuera de pantalla, cuando excluye lo que el hombre ve, da una enorme importancia a lo que le hace sentir y pasa por alto el objeto de su observación. (Rabiger, 2001:88)

Es decir, encuadrar un plano no es tarea fácil cuando se persigue una función o una significación más allá de lo que se ve.

Existen todos los tipos de planos que uno puede llegar a crear, pero los convencionalismos en la disciplina audiovisual han llevado a clasificarlos en unos estándares. En mi primer curso de armonía, se nos prohibieron las quintas y octavas sucesivas. Mi 
sorpresa fue cuando, al seguir mis estudios con otros profesores, se me desmontó dicha teoría igual que un castillo de naipes...Digo esto porque creo que el mundo audiovisual no está lejos de esta anécdota. Existen unos convencionalismos y teorías que, a medida que uno busca un lenguaje propio a partir de la partitura, pueden saltarse y enriquecer el producto final.

Dicho esto, y sabiendo que cada realizador puede llegar hasta donde su capacidad creativa le lleve, basaré este apartado en la descripción y presentación de aquellos planos que sirven como punto de partida de la narración y/o escritura audiovisual.

Existen tres grandes tipos de planos: de situación, descriptivos o metafóricos. El valor del plano es lo que define su tamaño. El encuadre es lo que definirá finalmente el valor de cada plano. A continuación presento los diversos tipos de plano con los que nos podemos encontrar:

a.1- Planos de situación:

- Plano exterior de situación

Plano que nos muestra el lugar de la grabación. Nos sitúan "geográficamente" ${ }^{18}$. Son planos, principalmente, descriptivos y nos muestran si se trata de una iglesia, una sala de conciertos, un museo u otros escenarios preparados para acoger conciertos.

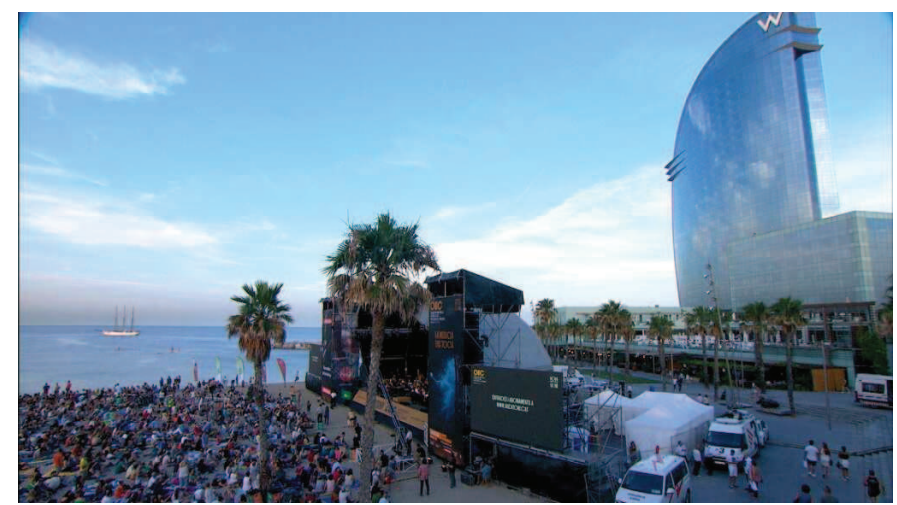

Figura 9 Gran plano general de situación exterior “OBC a la platja”. M, Millà.

\footnotetext{
${ }^{18}$ He señalado este plano en el ejemplo 3- Guía de orquesta, de Benjamin Britten- desde la Ópera de Sidney.
} 
- $\quad$ Gran Plano General (GPG) ${ }^{19}$

Plano muy abierto (interior o exterior) en el que no apreciamos detalles de la orquesta, pero sí vemos la ubicación de los músicos y su relación con el público. Pueden ser cenitales -desde el techo de la sala, visión aérea-, frontales o desde el escenario.

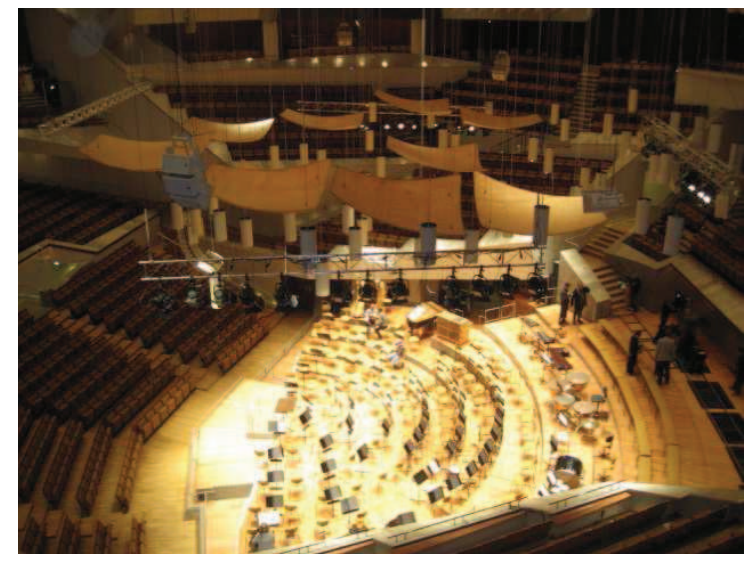

Figura 10 Gran plano general Philharmonie, Berlín. M, Millà.

- $\quad$ Plano General de Escena (PG de escena)

Plano abierto ajustado a la boca de escenario. Sigue siendo un plano descriptivo en el que el punto de vista del espectador se acerca más a la orquesta.

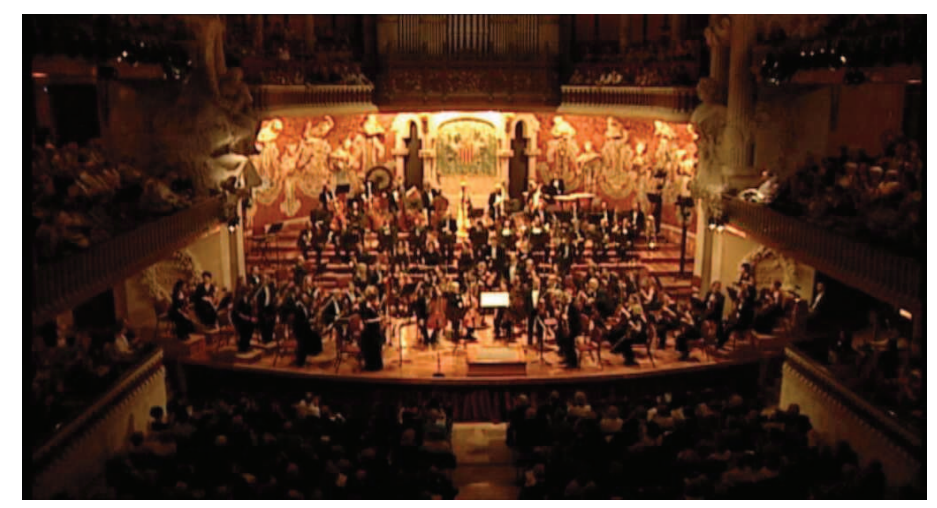

Figura 11 Plano General de Escena, Palau de la Música de Barcelona. M, Millà.

\footnotetext{
${ }^{19}$ Al lado de cada tipo de plano, transcribo las abreviaturas usadas comúnmente en la profesión.
} 
- $\quad$ Plano General de Orquesta (PG de orquesta)

Plano general de toda la orquesta. Puede ser tomado desde cualquier punto de vista. En el siguiente caso, el plano es desde la parte trasera del escenario. Este plano se conoce como contraplano, puesto que el tiro de la cámara es desde el lado opuesto a la parte frontal del escenario.

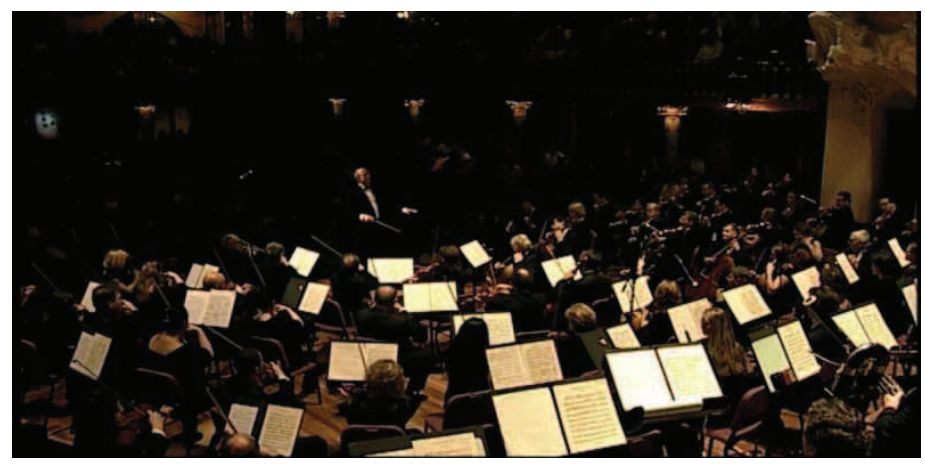

Figura 12 Contraplano General de Orquesta, Palau de la Música de Barcelona. M. Millà

\section{a.2- Planos Descriptivos:}

Llorenç Soler (1998), gran realizador de documentales, no sólo define muy bien qué significa "plano"20: "si el encuadre es margen, el encuadre es imagen" (p. 83); sino que compara muy bien y distingue dos maneras de proceder en el momento de crear un plano o un cuadro, su fundamento está en la esencia de la construcción del mismo:

El plano tiende a seleccionar los contenidos de la realidad, a aislarlos (...) Sin embargo, el pintor opera de un modo totalmente distinto al del operador de la cámara. Ante él se presenta la superficie en blanco de la tela o del papel, con su proporción y sus límites dados. (...) El pintor llena de imágenes visuales el espacio plástico sobre el que actúa con plena libertad, forzando perspectivas y composiciones, si ello fuera preciso. Allí donde el pintor añade, allí donde actúa por sumas, el operador de cámara lo hace por eliminaciones. El pintor incluye. Éste, excluye. (Soler, 1998, p.83)

\footnotetext{
${ }^{20}$ Llorenç Soler contempla la definición de plano del mismo modo que Michael Rubiger. Ambos tienen claro que se trata de una sustracción de contenidos y que debe tenerse en consideración aquello que no se ve en el encuadre de la cámara, pero está. El llamado fuera de campo.
} 
En los dos cuadros siguientes (Figuras 13 y 14), podemos comprobar cómo dos pintores distintos han decidido rellenar los lienzos dentro de una misma temática, la asistencia a un acto cultural (ópera y concierto).

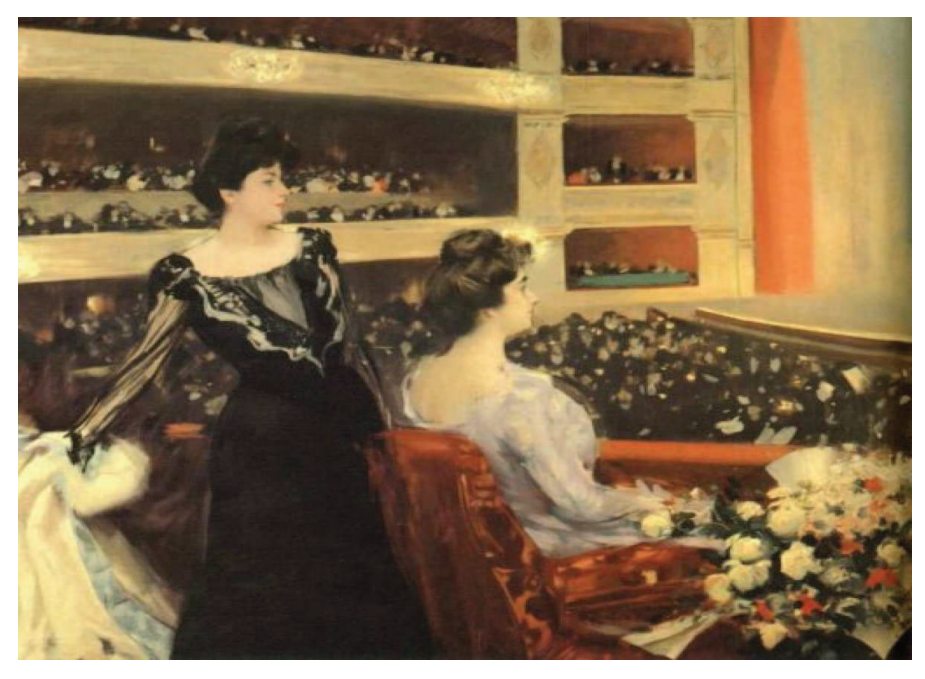

Figura 13 El Liceu, de Ramon Casas. J. Fernández.

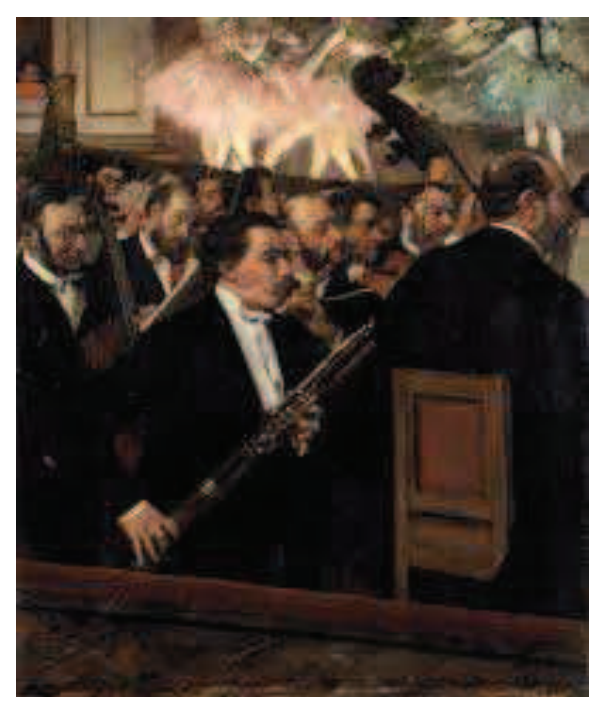

Figura 14 L'Orchestre de l'Opéra, de Edgar Degas. Wikimedia Commons.

En el cuadro del pintor Ramon Casas, observamos que se trata del escenario lo que queda fuera de campo; en el cuadro de Edgar Degas, al contrario, es el público lo que no vemos. Pero, según planteamiento de Llorenç Soler, no son selecciones de la realidad, sino una suma de elementos que los pintores han decidido reflejar en sus lienzos. 
En la siguiente explicación de planos descriptivos, entenderemos lo que nos quiere decir el mismo Soler cuando habla de planos como selección de una realidad por parte del operador de cámara o del realizador. Los planos descriptivos, contrariamente a los planos generales que tratan de situarnos y, por ello, intentan recoger toda la realidad posible, son una selección dentro de este plano general. Nos explican con más detalle aquello que el realizador quiere comunicar. Existen diversos tipos de planos descriptivos, cada uno con su valor o tamaño. La variación, según tamaño gradual descendente sería: plano de conjunto, plano figura, plano americano, plano medio y primer plano. Dejo para después el plano detalle porque su funcionalidad es otra que la mera descripción.

- $\quad$ Plano de Conjunto (instrumental, en este caso)

Más descriptivo que el plano general, puesto que nos aporta mayor información:

- Qué familia de instrumentos musicales son: violas (Figura 15) y violines (Figura 16)

- Disposición de la orquesta

- Situación del director deducida por la dirección de la mirada de los instrumentistas

- Interrelación entre los intérpretes: unísono, solista, pregunta-respuesta.

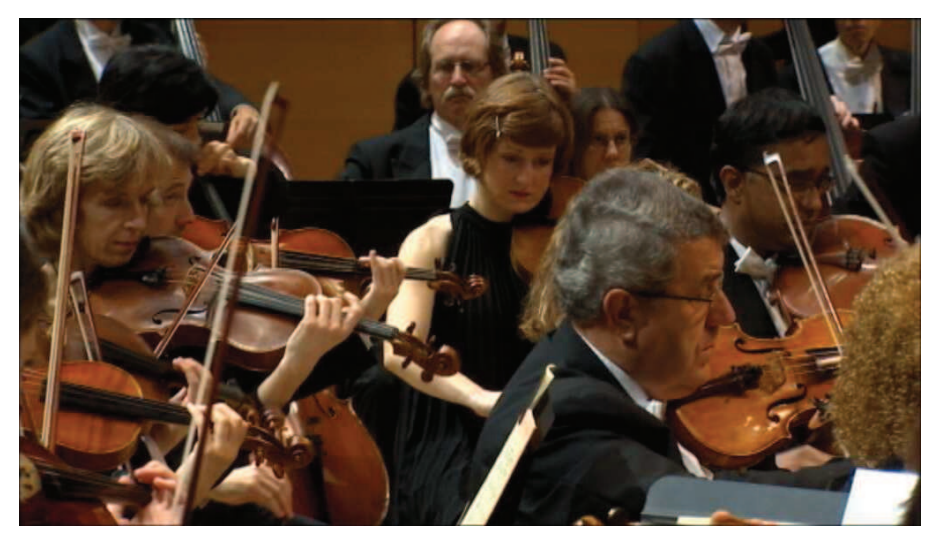

Figura 15 Plano conjunto de violas, L’Auditori, Barcelona (OBC). M. Millà. 


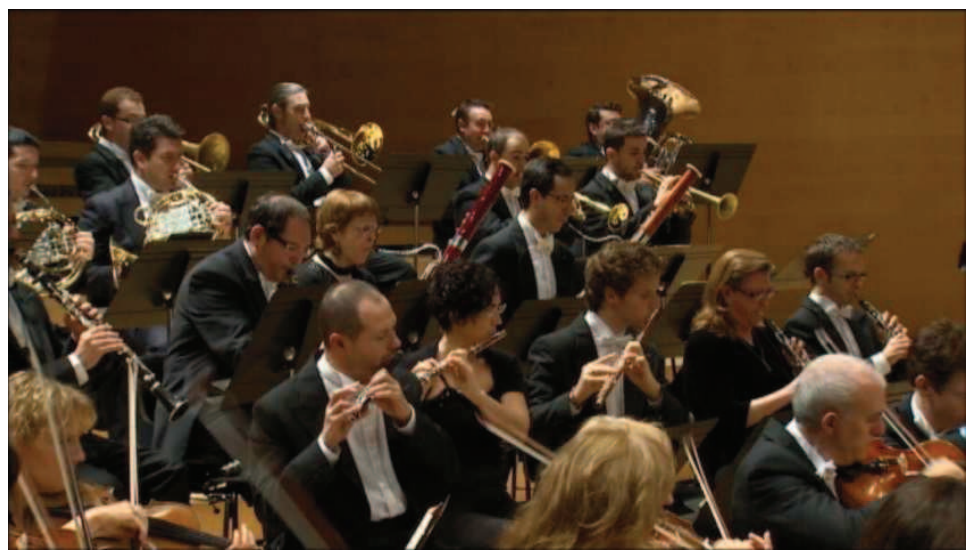

Figura 16 Plano de Conjunto Viento madera y metal, L'Auditori, Barcelona (OBC). M, Millà.

- $\quad$ Plano Figura (PF)

Plano que toma como referencia la figura humana completa. En el caso de los integrantes de una orquesta, cualquier plano figura se convierte por obligación en plano americano o plano medio - planos descritos en el punto siguiente-. A excepción de cuando se trata de un concierto con solista o formaciones de música de cámara, a quienes se puede mostrar con plano figura puesto que no quedan escondidos tras los atriles u otros músicos. Abrir a plano figura un instrumentista implica en muchas ocasiones convertirlo en plano de conjunto.

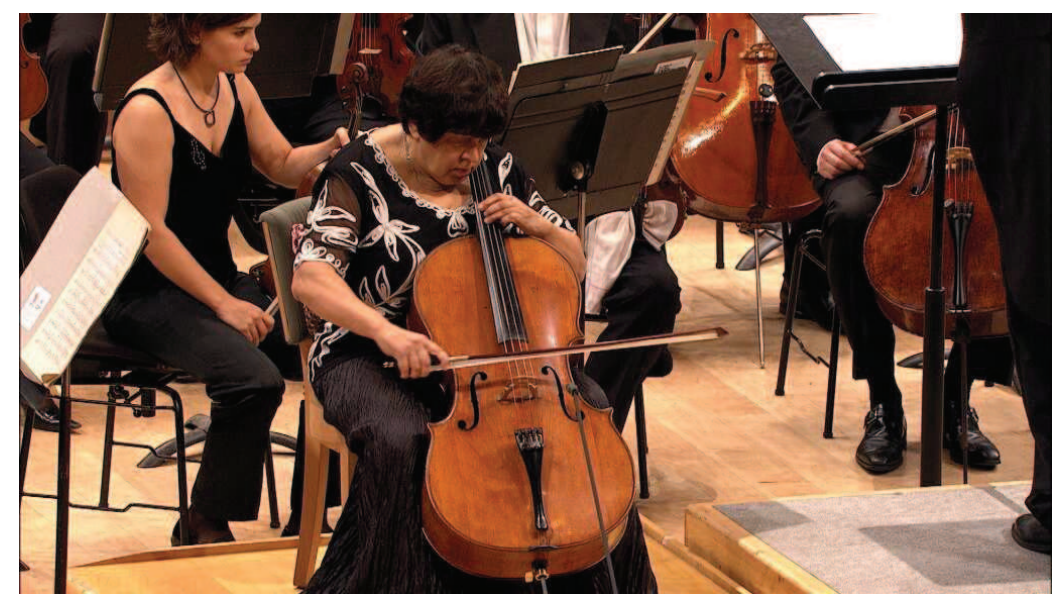

Figura 17 Plano Figura de Natalia Gutman, L'Auditori, Barcelona (OBC). M, Millà. 
- $\quad$ Plano Americano (PA)

Plano que corta la persona desde la parte inferior de las piernas sin que se vean ya las rodillas.

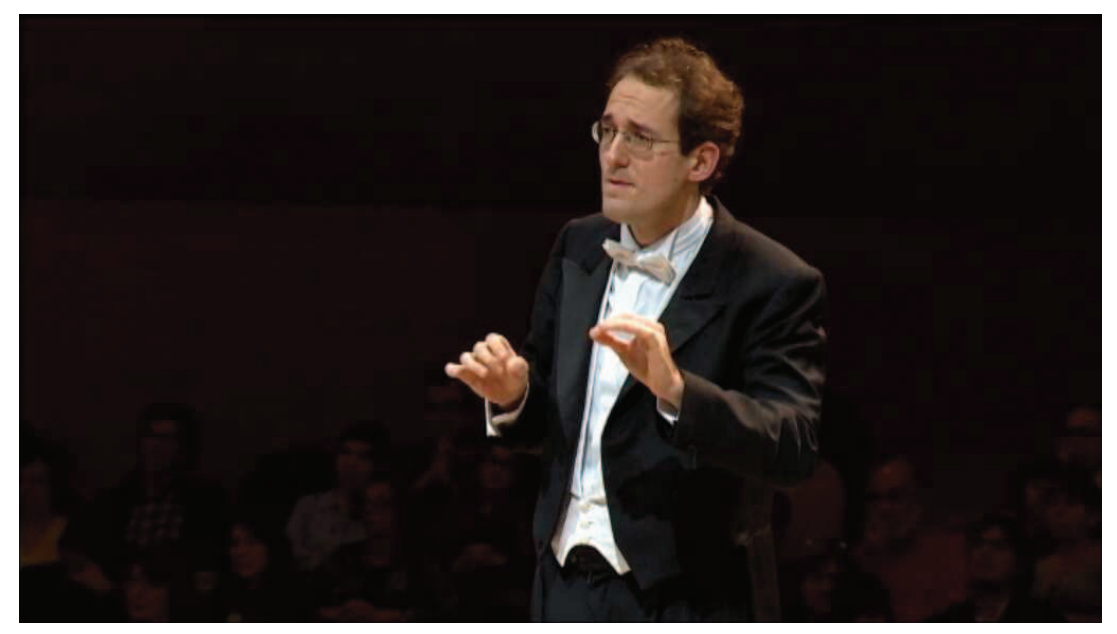

Figura 18 Plano Americano de Pablo Pérez, director de orquesta

\section{a.3- Planos Expresivos:}

Son aquellos planos cuya función va más allá de la mera descripción. A través de ellos nos llega la expresión o la emoción de lo que ocurre en aquel momento. Cuanto más cerrado es el plano, más intencionalidad expresiva y emocional.

\section{- $\quad$ Plano Medio (PM)}

Como ha quedado explicado en la imagen del plano figura, en los planos de los integrantes de la orquesta, algún plano medio puede interpretarse como plano figura. Si se abre más el plano, entran otros músicos en plano y se pierde la focalización hacia el músico pertinente. Así pues, lo más natural es que cuando la intención esté en un músico concreto, nos quedemos en plano medio. A través de este plano medio, se consigue transmitir la expresividad de un músico y el lenguaje corporal y gestual del mismo. Estamos en el tipo de plano cuya funcionalidad puede ser tanto descriptiva como expresiva. Es decir, ya a atraviesa la frontera de aquello que nos llega más emocionalmente. Soler (1998) dice: "El rostro humano es un 
continuo generador de gestos, expresiones, matices, de todo aquello que trasluce sentimientos, pasiones, estados de ánimo" (p. 90).

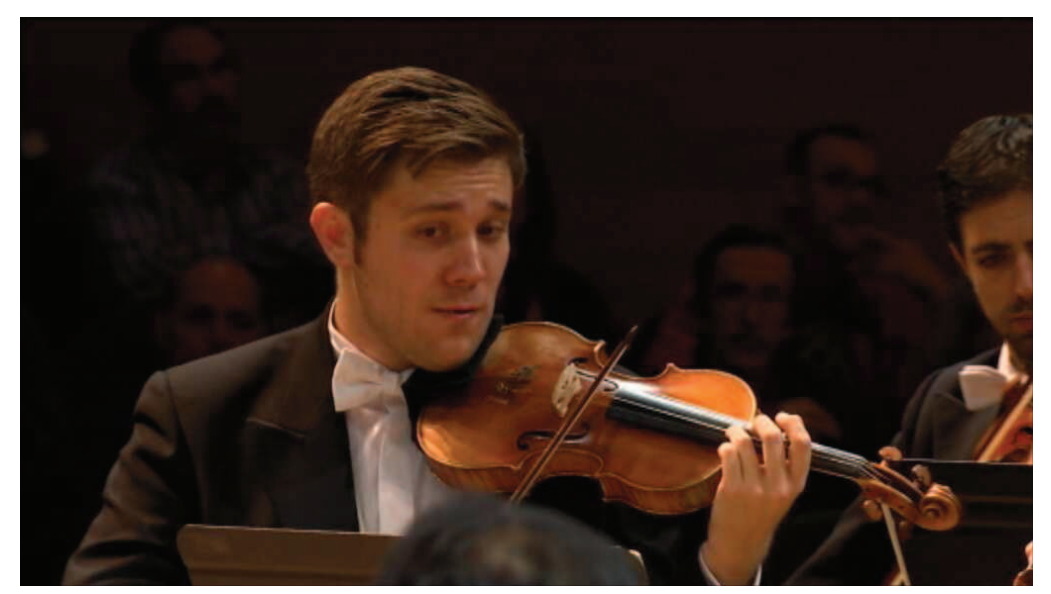

Figura 19 Plano Medio violinista, L'Auditori, Barcelona (OBC). M, Millà.

- $\quad$ Primer Plano (PP)

Los primeros planos, o planos cortos, son aquellos que comunican una mayor expresividad y transmiten el lenguaje corporal de manera acentuada debido a la proximidad. Son planos alejados del público -normalmente, los espectadores que están en la sala no llegan a tener una visión tan próxima del instrumentista- y, es a través de este tipo de plano que se nos ofrece la interioridad del "cuerpo orquestal". Pueden ser primeros planos de los músicos, o bien, de los instrumentos. Es interesante hacer notar que si se trata de primeros planos de instrumentos, la realización se convierte en un buen recurso educativo puesto que muestra la ejecución del intérprete muy de cerca ${ }^{21}$.

\footnotetext{
${ }^{21}$ Así nos lo hace constar el compositor José Nieto en la entrevista que está en el Apéndice II
} 


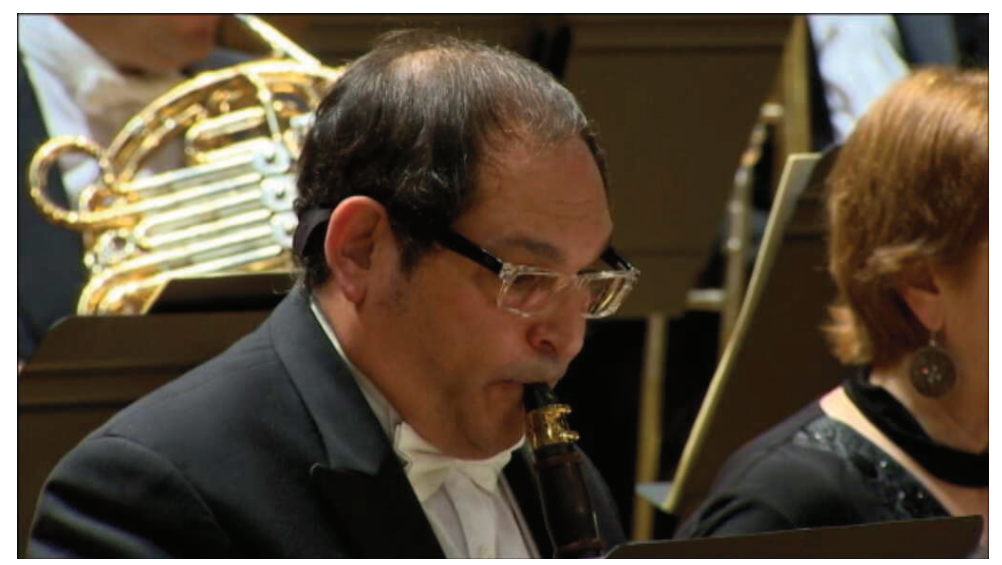

Figura 20 Primer plano de clarinetista, L'Auditori, Barcelona (OBC). M, Millà.

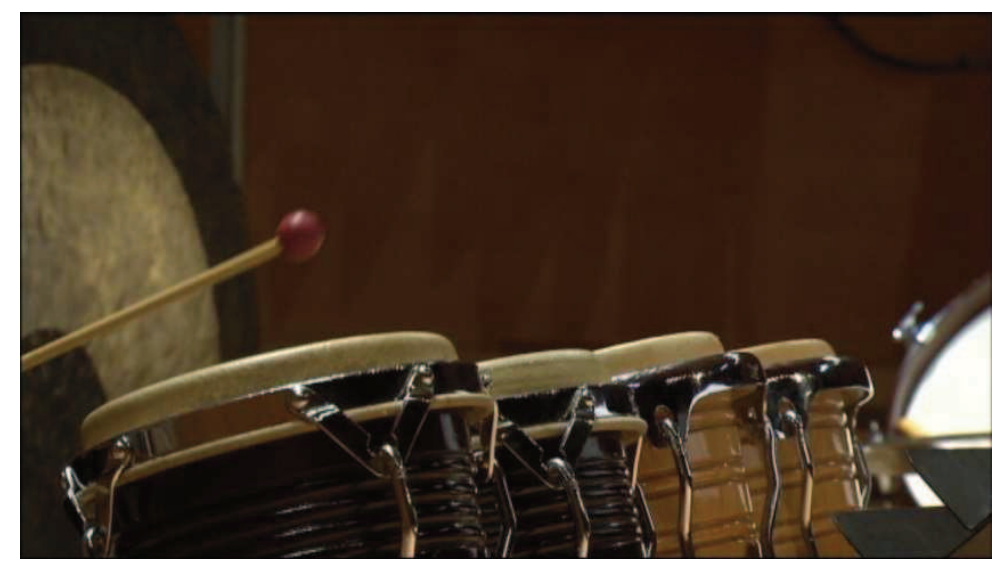

Figura 21. Plano corto de timbales, L'Auditori, Barcelona ( $\mathrm{OBC})$. M, Millà.

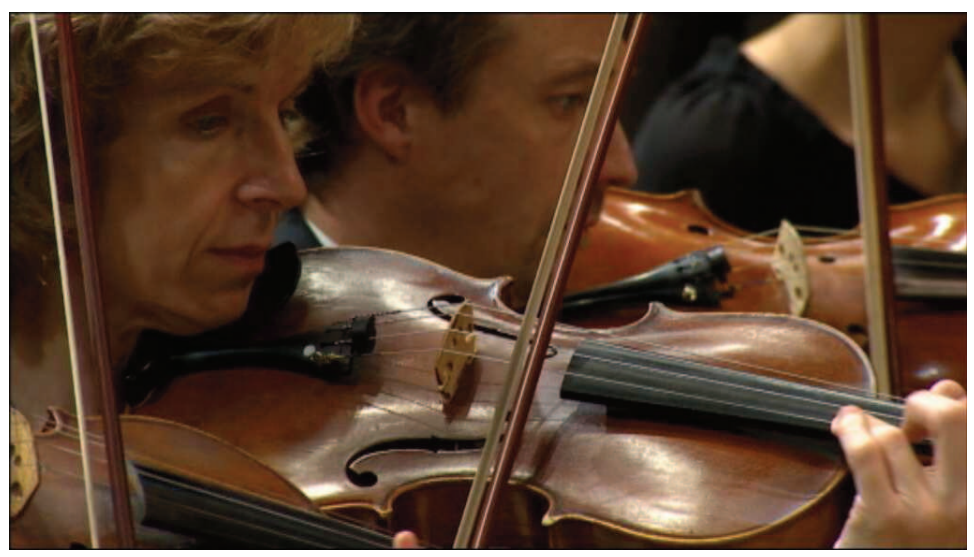

Figura 22 Plano corto de Violista, L'Auditori, Barcelona (OBC). M, Millà. 
- $\quad$ Plano Detalle

Los planos detalle, habitualmente de los dedos del músico en ejecución, son usados no sólo como planos expresivos sino como planos que enriquecen la estética visual: pizzicati, arqueos, trémolos, dificultad de ejecución, digitaciones aceleradas en arpegios o escalas, virtuosismo. algunos directores prefieren no usar un primer plano demasiado cerrado al rostro del músico ya que lo que puede ganarse en expresividad, se pierde en estética: embocaduras demasiado cercanas, por ejemplo, y sin posibilidad de ver el instrumento al completo en la imagen. Algunos ejemplos en las figuras siguientes:

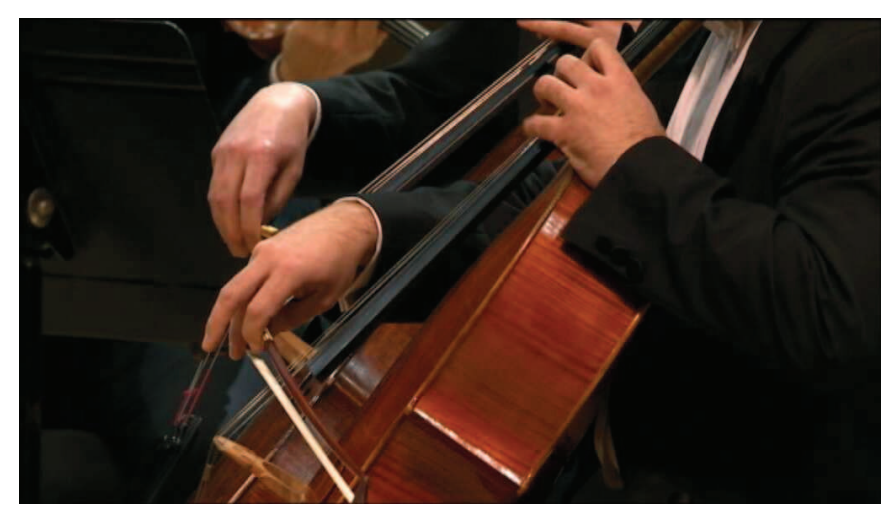

Figura 23 Plano detalle de contrabajo (arqueo), L'Auditori, Barcelona (OBC). M, Millà.

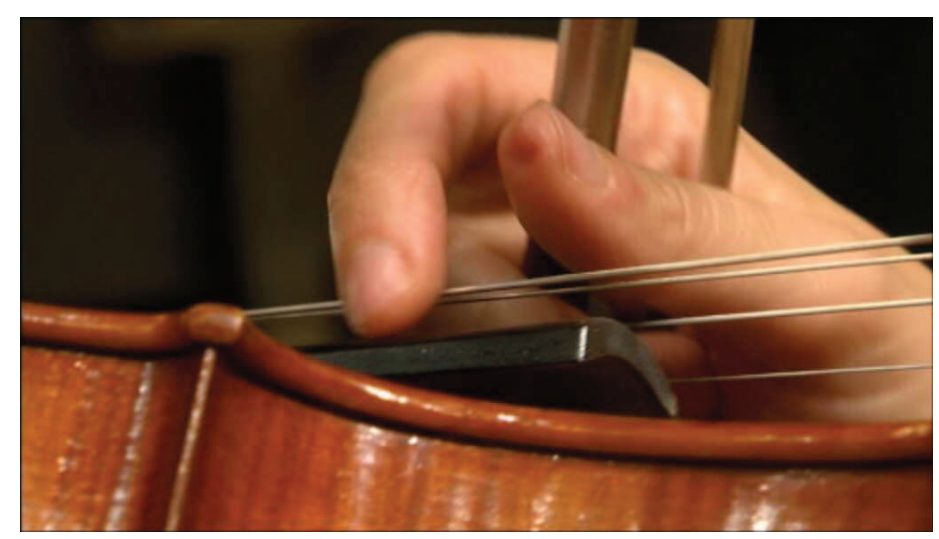

Figura 24 Plano detalle de violín (pizzicato). M, Millà. 


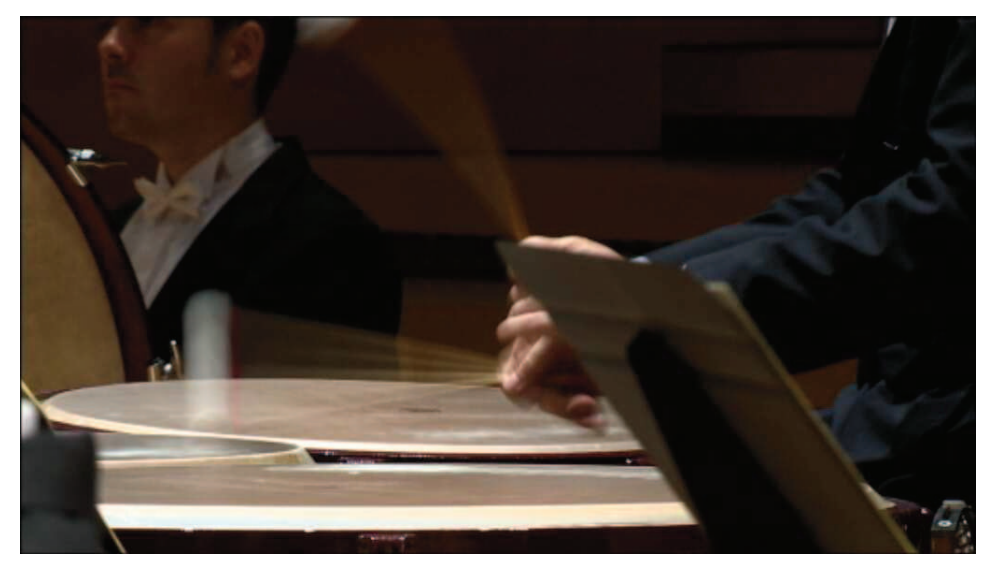

Figura 25 Plano detalle de timbales, L'Auditori, Barcelona (OBC). M, Millà.

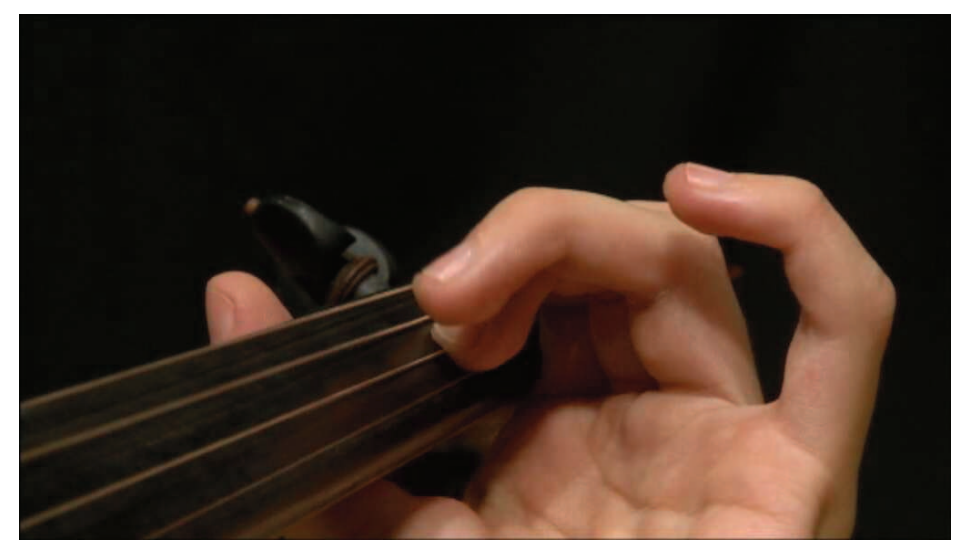

Figura 26 Plano detalle de violín (digitación). M, Millà.

\section{a.4- Planos Metafóricos o estéticos:}

En el extremo opuesto al gran plano general que nos sirve de situación y de relación espacial entre orquesta y público, existen aquellos planos metafóricos o estéticos que enriquecen el resultado final. Son planos de los que, generalmente, conviene no excederse para no huir de la narrativa audiovisual y desconcertar continuamente al espectador. Son puntos de vista que no acostumbran a tenerse desde el patio de butacas y que aportan mucha riqueza en el resultado global de la realización. 


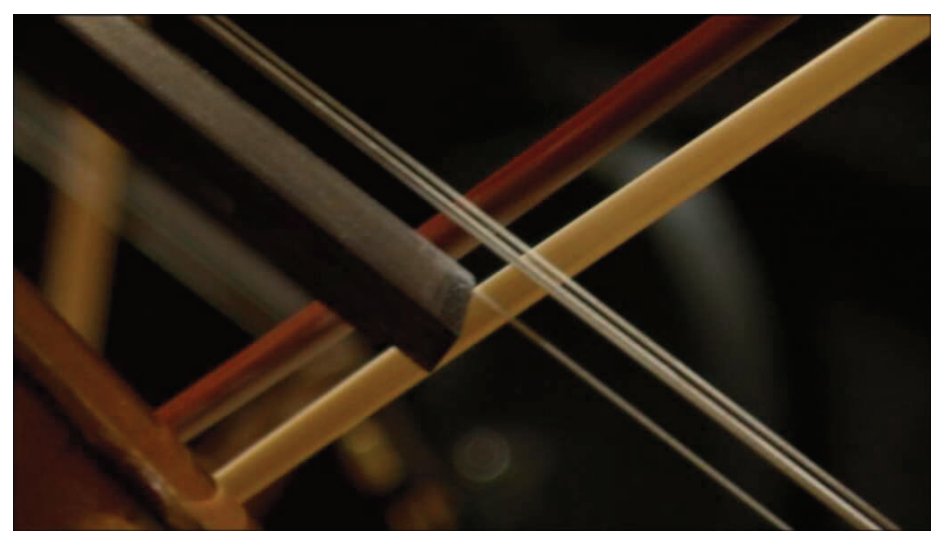

Figura 27 Plano de arco y cuerdas. M, Millà.

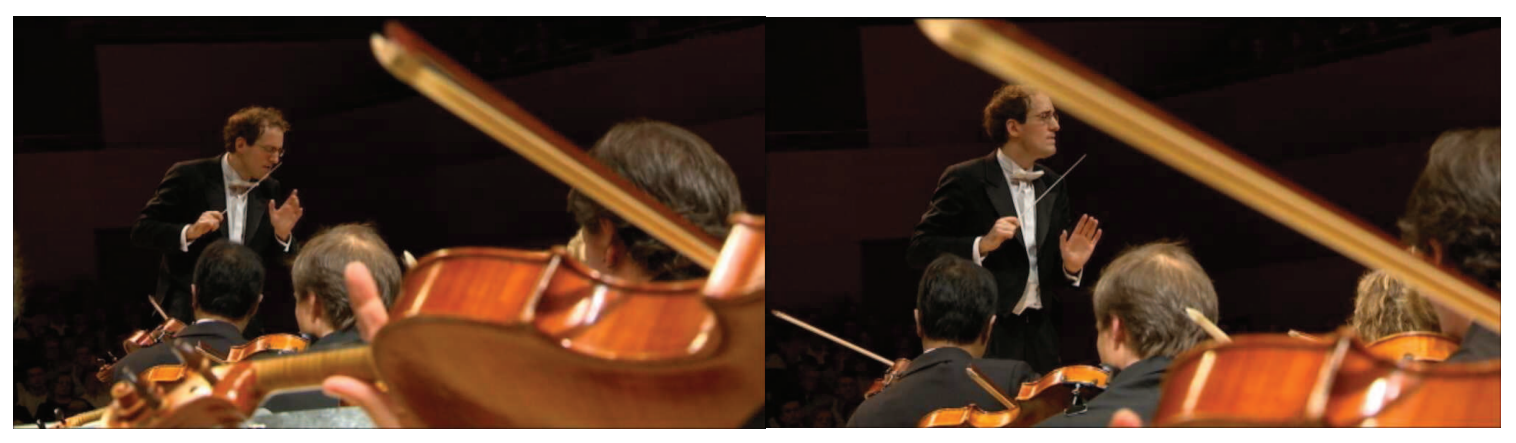

Figura 28 Plano americano del director a través de violín. M, Millà.

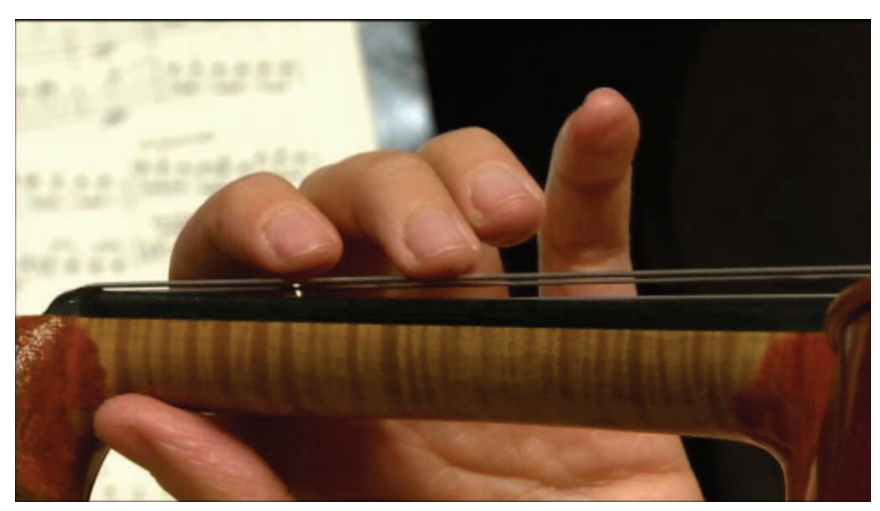

Figura 29 Plano en escorzo de violín con partitura desenfocada. M, Millà.

En la figura 28, podemos ver un tipo de plano que nos permite ver el director de manera frontal, es el llamado contraplano ${ }^{22}$. Gracias a este plano, el espectador puede ver las expresiones del director y su comunicación con la orquesta a través de su mirada y su gestualidad tanto física como facial; dicha visión es imposible tenerla desde la sala de conciertos, a no ser que estemos en una sala que permita tener cierto número de localidades tras la orquesta o que tenga forma circular.

${ }^{22}$ Ya lo hemos visto en la Figura 12, como plano general. Aquí me refiero a un uso más estético del mismo. 


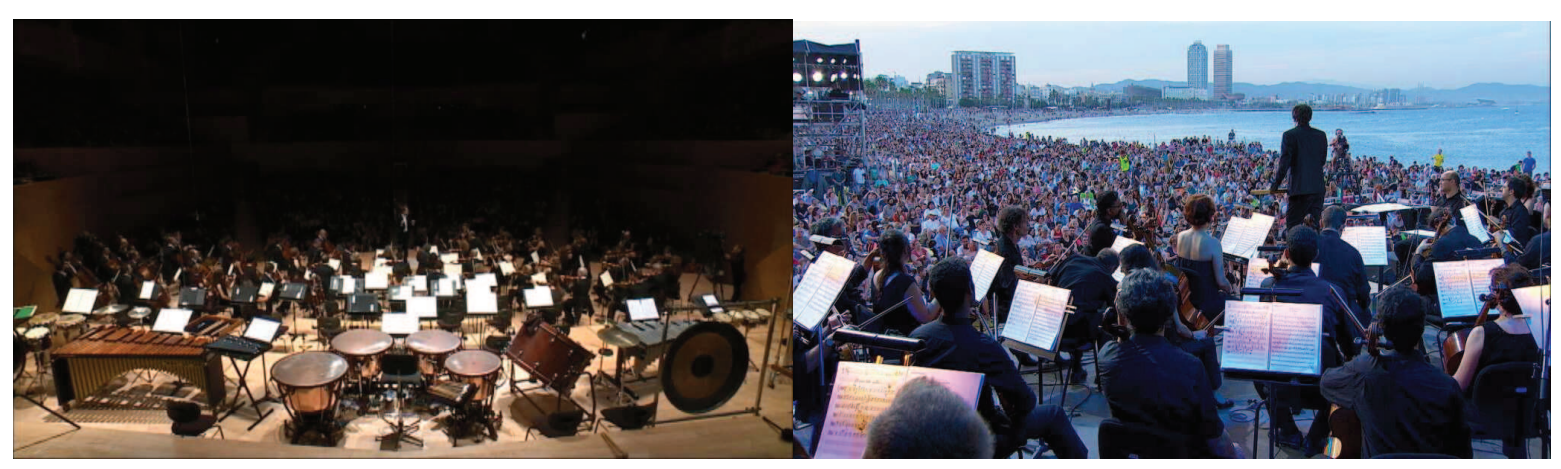

Figura 30 Contraplano frontal y contraplano lateral izquierdo. M, Millà.

A través de los diversos tipos de planos queda demostrada la multiplicidad de opciones que, a cada segundo, puede modificar el tipo de realización generada. Ciertamente, y a pesar de los "planos-base" que aparecen en todo tipo de manuales audiovisuales, existen tantos planos como miradas pueden percibir la realidad.

El lenguaje del plano, sin embargo, no termina aquí puesto que no sólo es importante el tipo de plano, lo que conocemos como valor de plano, sino su angulación y el movimiento, no del contenido interior sino el que provoca el movimiento de la cámara y que es exterior. Referente a la angulación, es un elemento muy importante en cuanto a decisión tomada por el realizador ya que a través de él puede transmitir y comunicar al público qué tipo de música y de interpretación queremos hacer llegar al público. Mientras vemos en la figura 19 un plano figura del violinista que transmite estabilidad, serenidad, podemos apreciar en la figura 28 una angulación atrevida, en diagonal, que denota cierta inestabilidad y movimiento.

Existen diversas angulaciones, pero las principales y que tienen una lectura muy distinta son:

- Plano picado: plano cuya visión es desde arriba del objeto o persona encuadrado.

- Plano contrapicado: plano cuya visión es desde abajo del objeto o persona encuadrado.

- Plano cenital: plano totalmente vertical (desde el techo de la sala de conciertos)

Referente al movimiento externo, pasamos al siguiente punto de estudio. 
a.5- Planos en movimiento:

El análisis del valor de los planos que he realizado en los anteriores apartados junto con sus ejemplos sirve, bien para planos estáticos, bien para planos en movimiento. Y, es el realizador quien determinada cuándo y en qué momento debe moverse el plano y cómo lo debe ejecutar. Las posibilidades son infinitas y evidentemente, durante el movimiento se puede mantener el mismo valor de plano o se puede modificar el mismo. Nuevamente, Soler (1998) nos lo expone de manera concisa y clara: "La posibilidad de movimiento de la cámara marca con su sello específico el estilo narrativo empleado, imprimiéndole un carácter y una personalidad determinados" (p. 103).

Así pues, las posibilidades narrativas se multiplican exponencialmente ya que los movimientos de cámara combinados con la composición y la angulación de los planos ofrecen infinidad de recursos visuales para la narración.

- Zoom

Tipo de movimiento que consiste en alejar o acercar aquello que queremos enfocar como polo de atracción visual. Puede ser un zoom in, el cual consiste en ir cerrando el plano a la velocidad deseada hasta llegar a la imagen objeto de nuestra atención. El movimiento contrario se denomina zoom out. Consiste en partir de un plano cerrado e ir abriendo para obtener más información.

- Panorámica vertical u horizontal

El eje de la cámara está estático y la cámara se mueve entre ambos lados o verticalmente. La panorámica va descubriendo la realidad según un objetivo narrativo; por ejemplo, partir de un plano de director y llegar, a través de una panorámica lateral derecha a la sección de cuerda. Como ejemplo vertical existe el plano que hemos visto en muchos conciertos: empieza en el techo de la sala y va descendiendo hasta mostrar la orquesta.

\section{- $\quad$ Travelling}

Se trata de un movimiento de panorámica pero con desplazamiento de la cámara a través de raíles u otros soportes mecánicos. El travelling ayuda a entrar en 
la escena al espectador; sin embargo, no es un recurso muy empleado en conciertos filmados en directo porque resulta una mecánica muy invasiva física y auditivamente.

- Grúa

Con eje vertical y horizontal, la grúa es muy eficaz cuando se trata de lo que se entiende por "volar" y dar planos de toda la orquesta. Es un tipo de plano en movimiento que da una perspectiva especial y enriquece la realización general del concierto.

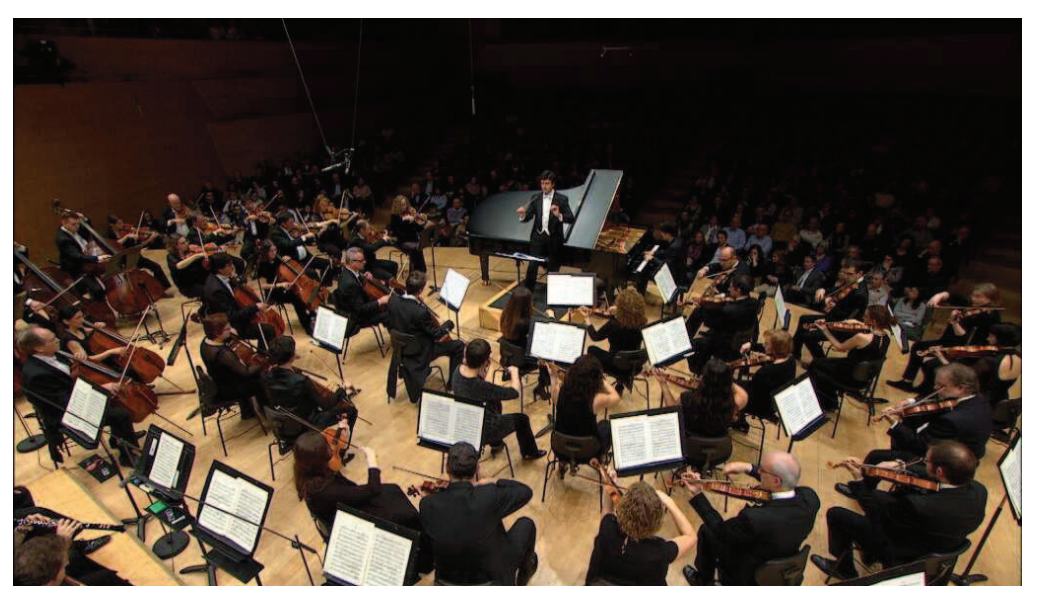

Figura 31 Plano de grúa (en contraplano). M, Millà.

a.6- Tipos de planos según el tipo de cámara:

\section{- $\quad$ Steadycam}

Este tipo de cámara lleva un estabilizador junto con un soporte vertical y va unida al torso del operador de cámara. Permite una realización subjetiva, es decir, como si el punto de vista de la imagen fuera el espectador. Es una visión de lo que sucede directa y muy real. No es posible usar este tipo de cámara en los conciertos en directo debido a que el operador necesita desplazarse por el escenario y, quizás, entre músicos. Es por este motivo que suele usarse en conciertos que permiten más de una filmación y, alguna, sin público. Existe, en caso de ser así, un presupuesto añadido ya que el realizador debe usar para finalizar la filmación salas de 
postproducción y un operador de imagen que pueda realizar las ediciones pertinentes.

\section{- $\quad$ Gopro}

Modelo de cámara muy pequeño que no necesita operador. Es muy resistente y acostumbra a usarse en filmación de deportes ya que el plano puede ser subjetivo; es decir, se ve la misma imagen que la persona que está en acción. Otro tipo de plano usado es el plano fijo; por ejemplo el plano de un teclado de piano o de una marimba. Esto facilita la producción audiovisual ya que se necesita un operador de cámara menos y el realizador siempre tiene el plano del instrumento musical escogido a punto. Sin embargo, hay que comentar que su luminosidad no es la misma que el resto de cámaras y es por ello que también se acostumbra a incluir sus planos en la postproducción, para poder igualarla con el resto de cámaras.

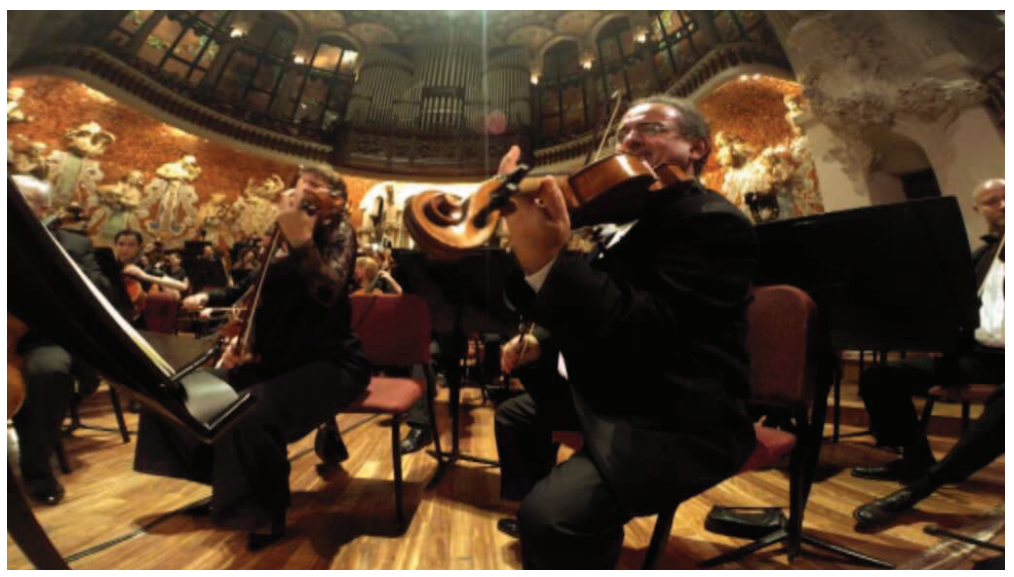

Figura 32 Plano realizado con cámara GoPro. M, Millà.

\section{- Cámara en mano}

Este modo de filmar es llamado así por el modo de llevar el operador la cámara: sin ningún tipo de soporte. Su uso implica una realización ágil, de proximidad y rápida. Acostumbra a usarse en reportajes, aunque es posible también en conciertos de música clásica. Para ello, es importante saber en qué momentos debe entrar la cámara en escena puesto que su resultado será más óptimo y no se excederá en el cansancio físico del operador. 
Una vez vistas todas las posibilidades de planos $^{23}$, podemos afirmar que el hecho de abordar una filmación es un asunto en el que la decisión personal del realizador juega un papel importante; sin embargo, debo añadir aquí el papel que también juega el operador de cámara, puesto que con su visión, puede acabar de completar una buena filmación:

Se identifica el lenguaje de la cámara con el lenguaje de la mirada; la cámara puede actuar de modo inquisitorial, preciso, profundo, o bien de un modo totalmente epidérmico. (...) Puede mirar y puede, realmente, ver. (...) El modo de escritura con la cámara determina un tipo muy preciso de relato visual, un estilo, un modo de ver, de sentir, que se identifica absolutamente con las intenciones y los sentimientos de quien la maneja. (...) Un estilo $u$ otro de caligrafía audiovisual responderá a exigencias muy precisas (Soler, 1998: 115).

b. El ritmo

El ritmo es uno de los elementos primordiales en el momento de la realización.

Cada plano tiene un movimiento interno; músicos, director, público. Debido a este movimiento interior de cada uno de los planos y a su valor -es decir, el tamaño del plano-, la duración de cada uno de ellos puede ser mayor o menor. Así, el signo cinético audiovisual tiene múltiples visualizaciones llevadas a cabo desde muy diversas variantes: desde la filmación de un plano fijo con movimiento interno hasta la edición de planos muy cortos a ritmo acelerado. Precisamente, uno de los medios resolutivos para conseguir el ritmo adecuado es la concatenación de planos: cada cuánto tiempo se supone que hay que cambiar de plano y cómo debe hacerse el encadenado. José Nieto nos habla de ello muy explícitamente en la entrevista realizada para esta investigación ${ }^{24}$ y es que cualquier profesional del medio sabe perfectamente que este es un punto esencial.

\footnotetext{
${ }^{23}$ Existen otras posibilidades, pero estas son las más frecuentes y, además, quiero añadir que el mundo de la tecnología en el ámbito audiovisual evoluciona tan rápidamente que cada día surgen más posibilidades de creación y estética visual para cualquier filmación que se lleve a cabo.

${ }^{24}$ Ver "Apéndice II. Entrevistas"
} 
Debe decidirse de antemano qué ritmo queremos transmitir. En el análisis del Adagio para cuerdas de Samuel Barber realizado en el apartado dedicado a la Lectio Score, hemos podido ver una primera parte con los pasos de un plano a otro por corte y, una segunda parte, después del clímax de la composición, en que los encadenados largos son los que caracterizan la pieza hasta llegar al final.

En término "académicos", los encadenados suelen utilizarse en pasajes lento y melódicos, mientras que los pasajes con ritmo suelen trasladarse a la pantalla con pasos entre plano por corte y duración corta de los planos. Según mi parecer y desde el visionado de numerosos conciertos, he podido comprobar que el ritmo musical no es lo mismo que el ritmo audiovisual y que, en ello, influye la literalidad caligráfica de la partitura llevada a la pantalla.

Si se sigue este tópico, el ritmo lento musical (como un Adagio, por ejemplo) traducido en imagen en movimiento igual de lento, puede llegar a obtener como resultado una narración sin el flow del que hablaba anteriormente y que el espectador pierda el interés en lo que está viendo. Al contrario, pasaría lo mismo con un ritmo musical rápido. Encontrar el equilibrio entre estos dos ritmos -musical y audiovisual- es el medio que propongo como persistencia del flow narrativo-musical.

Como ejemplo, no hace falta seguir el ritmo acelerado de El vuelo del Moscardón a través de la rapidez de transiciones de un plano a otro para transmitir ese movimiento. Simplemente, con un plano secuencia de todos los instrumentos que van interpretando dicha aceleración de unas notas seguidas de otras, podemos transmitir el ritmo "frenético" que Rimsky-Korsakov dejó en la partitura simulando el vuelo. Dentro del plano tenemos todo el ritmo necesario...la composición nos lo da hecho.

Así, el ritmo depende de la "vida" y movimiento interior de cada plano, de la duración de cada plano y del paso de un plano a otro en el momento adecuado. Dicha labor es mucho más difícil de lo que, aparentemente, se supone. Conseguir el ritmo audiovisual, que no musical, de cada obra es uno de los retos que cada realizador tiene ante una grabación o retransmisión en directo. 
Para ejemplificar el ritmo, propongo la filmación de dos piezas musicales $\operatorname{cortas}^{25}$ : El vuelo del moscardón, de Rimsky-Korsakov y Mambo, de Leonard Bernstein. Se trata de dos obras grabadas de manera muy distinta a una retransmisión en directo. En este caso, se grababan varios pases, en concreto tres (excepto, cuando la pieza era más compleja). Se disponía de seis cámaras y tres tipos de soporte:

- Una cámara en una grúa,

- Tres cámaras usadas con trípode estático, "cámara-mano" o con vías para realizar panorámicas con desplazamiento y

- Dos cámaras Gopro $^{26}$ para detalles de ciertos instrumentos como la percusión o arpa.

El procedimiento fue "diseccionar" previamente la partitura por capas instrumentales. Así pues, en la primera toma se grabaron tres secciones de instrumentos; en la segunda, otras tres secciones distintas o, se repetía alguna sección anterior, pero con cambios en los valores de los planos-más cerrados, principalmente- y, en la tercera, otros nuevos planos, generalmente, los solos orquestales o momentos visuales que interesaban por alguna característica especial que pudiera enriquecer la filmación: glissandos, pizzicati, miradas o gestos del director, entre otros. De esta manera, se obtenían como resultado dieciocho planos -en ocasiones, hasta veinticuatro- para cada momento de la filmación. Evidentemente, una realización así conlleva un trabajo de sincronización y de elección importante, por lo que el trabajo final de edición se convierte en una tarea lenta y laboriosa. El resultado final lo podemos ver en los enlaces de los siguientes dos ejemplos:

\section{Ejemplo7:}

El vuelo del moscardón, de Rimsky-Korsakov ${ }^{27}$

https://www.youtube.com/watch?v=WTHT8aR1MKI

\footnotetext{
${ }^{25}$ Se trata de una propuesta conjunta entre TVC (Televisió de Catalunya) y L'Auditori de Barcelona para grabar minipiezas conocidas de música clásica en formato videoclip. La idea se extrajo de un programa de la cadena europea ARTE. Por ello, el concepto de realización es muy distinto al que se sigue en una retransmisión en directo.

${ }^{26}$ Tipo de cámara explicado en el apartado a.6

${ }^{27}$ Se trata de uno de los ejemplos planteados en la encuesta del capítulo 4.
} 
Ejemplo 8:

Mambo, de Leonard Bernstein.

https://www.youtube.com/watch?v=Zm-ofiUDtRg

Retomo lo dicho al principio, no es lo mismo una retransmisión donde el débrayage no existe puesto que la realización es simultánea con el concierto (ya sea por Internet o por televisión como los BBC Proms), que una producción de un concierto con débrayage, o que una grabación cuya finalidad es un producto similar a un videoclip. El juego de ritmos variará en cada uno de ellos y los riesgos que se pueden correr en el último no son los mismos que los que uno puede correr en una retransmisión en directo.

\section{5- Elementos de la narratividad: sonido e iluminación}

Iluminación y sonido son dos factores que influyen de manera directa en el resultado final, no sólo a nivel técnico, sino a nivel estético. Quizás el registro sonoro, a pesar de la dificultad que entraña, pasa más desapercibido que una correcta iluminación. Pero con los avances tecnológicos de captura del sonido, cada vez podemos ser más críticos en este aspecto técnico. Uno de los factores relevantes en la época actual es darnos cuenta de cómo somos tan poco exigentes en el día a día de la escucha de archivos sonoros. Escuchamos a través de auriculares de dudosa calidad, a través del teléfono móvil, de ordenadores sin altavoces adecuados. Cada vez más, nuestro oído está bajando sus índices de calidad sonora, sin embargo, si esto ocurriera con la imagen, nuestro nivel de tolerancia sería bajísimo puesto que no soportaríamos ver imágenes de mala calidad o poca resolución. Por otro lado, la tecnología de hoy en día, permite escuchar estéreos, Dolby Surround o mezclas 5.1 entre otros sistemas de escucha. Así pues, es esencial que exista un control de calidad para que todos los elementos narrativos fluyan en la filmación.

a. El sonido

Sin entrar en disquisiciones técnicas, los mejores y más experimentados técnicos de sonido son los que graban el audio de un concierto con los menos micrófonos posibles. Menos es más. Hay que tener en cuenta que no es lo mismo grabar sonido para una 
retransmisión para la radio que para la televisión, el cine o cualquier tipo de formato en imagen. En el momento en que se muestra en plano un instrumento específico "hay que oírlo, escucharlo", sino, se desvía la atención de aquel oyente que, por ejemplo, ve una arpa en primer término y no la oye; o bien, ve el pizzicato de un violoncelo y tampoco lo escucha. Por ello, la grabación por sectores, llamado multipistas ${ }^{28}$, es tan importante. En el momento de la mezcla de sonido se potencia cada momento aquello que, por partitura e imagen, el realizador y el técnico de sonido han pactado previamente. Se entra en un terreno que podríamos calificar de "antiético" o poco respetuoso con lo que la partitura quizás transmite. ¿Realmente se está respetando lo que el compositor quiso que sonara en cada momento? La interpretación es libre y ahí, precisamente, entra en juego aquella que cada director de orquesta quiere transmitir fielmente al espectador.

b. La iluminación

Empiezo este apartado con tres ejemplos:

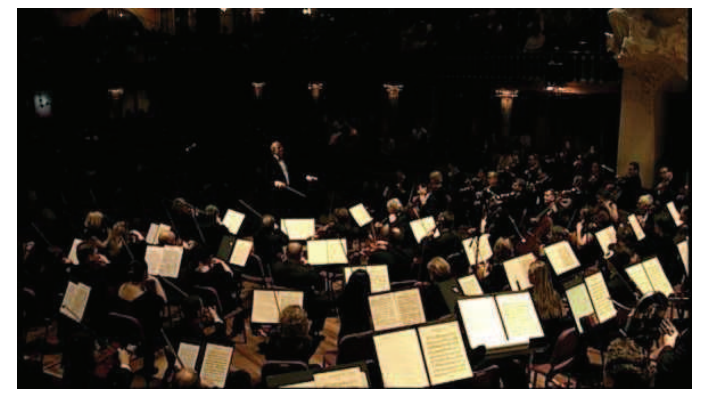

Figura 33 Contraplano lateral de la Budapest Festival Orchestra (Palau de la Música Catalana). M, Millà.

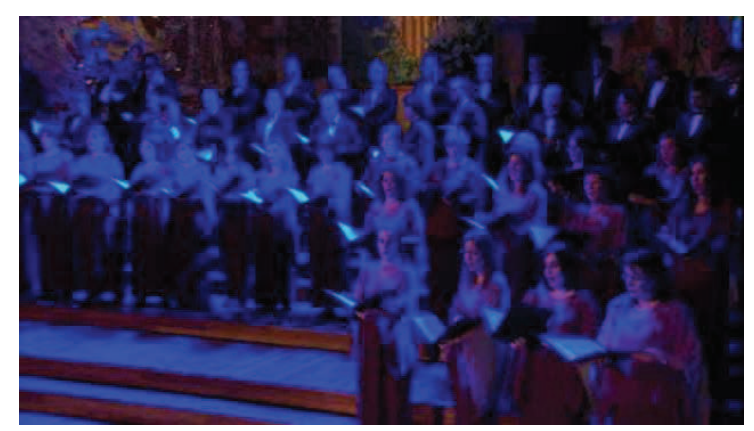

Figura 34 Plano lateral de escena, Orfeó Català (Palau de la Música Catalana). M, Millà.

\footnotetext{
${ }^{28}$ En cada pista de sonido se graba una sección de instrumentos o un solista en concreto.
} 


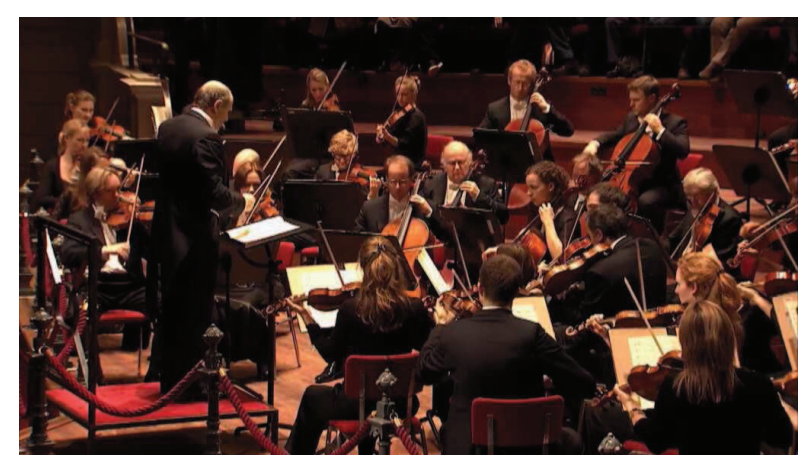

Figura 35 Plano lateral de escena, Budapest Festival Orchestra (Royal Concertgebouw Orchestra). M, Millà.

A través de estos tres ejemplos podemos apreciar cómo lo técnico incide directamente en lo artístico.

En el primer ejemplo (figura 33), estamos ante una iluminación no adecuada para un proyecto audiovisual. Lo que el ojo percibe directamente, no es lo que percibe la cámara. Por ello, siempre debemos partir de una mayor iluminación de la que nos ofrece la realidad del escenario. A veces es un cambio sutil, pero suficiente para conseguir la calidad requerida. Si no existe un diálogo previo, puede ser motivo de discusión por parte de los músicos y del director.

En el segundo ejemplo (figura 34), tenemos un tipo de iluminación apreciablemente azul intenso. En el intento de "colorear" un concierto para darle un aire estético distinto, podemos encontrarnos con sorpresas desagradables. En un concierto de Pop-Rock, quizás no sorprendería, pero en el mundo de la música clásica, algunos atrevimientos no controlados son, francamente, contraproducentes.

En el tercer ejemplo (figura 35), vemos una iluminación correcta del concierto. La corrección en su elaboración y la calidez de la misma, hace que nos podamos centrar en lo importante: en la música.

Cualquier elemento externo que nos haga despistar o distraer del principal objetivo, obviamente, debe ser estudiado y tratado previamente. Por ello, las condiciones de la retransmisión o de la grabación deben ser lo más óptimas posibles. La responsabilidad del realizador, como vemos, alcanza todas las áreas cuya implicación pueden conducir hacia un resultado final óptimo o no. 


\section{6- Elementos de la narratividad: gestualidad del músico}

Es fundamental para un director que los músicos se muestren dispuestos a colaborar en una filmación del concierto que van a interpretar y, en el cual, ellos mismos van a ser sujetos protagonistas. La comunicación entre el realizador, el director musical y los músicos debe ser lo más fluida posible puesto que, siempre, existirán peticiones de mínimos cambios de posición, cambio de altura de los atriles, alertas de cámaras que puede ser que se interpongan entre músicos o grúas en movimiento. Sin embargo, no siempre los factores externos a los músicos son los que acompañan una buena realización; sino, que la comunicación entre la orquesta y el espectador también depende de otro aspecto, tal como nos advierte el pianista Albert Nieto (2015):

Hay que reconocer que la radio ha permitido dar a conocer un amplio repertorio que de otro modo no hubiera sido posible difundir; e incluso; ha propiciado nuevos aficionados a la música. Pero por todo lo dicho anteriormente, es obvio que se establece una diferencia trascendental entre una escucha solamente auditiva (ya sea fonográfica o radiofónica) y una escucha visual (ya sea en directo o en vídeo). Y en este segundo tipo de escucha, para que el "milagro" de la comunicación se produzca, es de vital importancia que el cuerpo del intérprete se muestre flexible, susceptible de moverse libremente a los dictados de su estado emocional, puesto que si se situara ante el instrumento como si fuese de piedra, emanaría una música igualmente rígida. En cambio, liberado de todas las posibles ataduras, se convierte en un transmisor del sinfín de estados de ánimo que puede contener una obra. (...) En definitiva, si el intérprete es espontáneo y vive la música de manera que sus gestos vayan en sintonía con el carácter que él ha concebido, no hay duda de que el espectador podrá captar mejor diversos estados de ánimo, pues se habrá potenciado el canal de comunicación, el flujo de las emociones y sensaciones que se establece entre el intérprete y el público. (p. 11)

Creo que estamos ante un nuevo factor generador de una narrativa que puede traspasar la pantalla y llegar al espectador de manera que todo el trabajo del realizador se vea potenciado por el trabajo del músico. A este factor, Albert Nieto le llama "el gesto expresivo del 
músico". En la entrevista realizada a Albert Nieto ${ }^{29}$, precisamente quise indagar en lo que de novedad emerge de esta observación de los músicos. También demostraré en el capítulo 4 cómo muchas de las personas encuestadas se han visto atraídas por la interpretación de una de las Bagatelas de Ligeti, no tanto por la música, sino por la especial gestualidad y, yo añadiría, coreografía del quinteto.

Ya Delalande (como se cita en Nieto, 2016) diferenciaba entre el gesto productor del sonido - evidentemente de una gran importancia por lo que significa la proyección sonora- y el gesto comunicativo o de interacción. Albert deja claro al inicio de su libro sobre la gestualidad que trata sobre el gesto musical-comunicativo. Así, Nieto (2016) afirma: "Mi estudio se dirige al gesto como complemento natural de la comunicación expresiva instrumental; al gesto corporal y facial completamente integrado con el carácter musical que el intérprete quiere transmitir" (p. 20).

Si el gesto comunicativo del músico, no sólo como gestor de sonido sino como gestor músico-comunicativo, ayuda a que la convergencia entre la música escrita en cualquier momento histórico y el intérprete vaya más allá de las pantallas llegando a cada uno de los espectadores, se convierte en un elemento narrativo más a tener en cuenta. Es difícil que el realizador pueda llegar a influir en este trabajo gestual; pero, quizás sí, es posible transmitir una mayor sensibilización hacia los músicos en este aspecto en el momento de iniciar una producción audiovisual para conseguir que esta se convierta en un acto comunicativo:

Mientras que el movimiento se refiere al cambio de un cuerpo que transcurre en el tiempo, y una acción a una serie de movimientos, el gesto implica la transmisión de un significado, un sentimiento o una intención, es decir, implica un acto de comunicación. (Nieto, 2016:20)

Expongo a continuación los puntos principales extraídos de la entrevista a Albert Nieto. Veo interesante destacarlos por lo que de novedoso me aporta en mi investigación:

- $\quad$ Son dos los actantes principales en cuanto al gesto expresivo: el músico y el espectador. Pero, cabe matizar el papel del espectador en cuanto a que se trata de una cuestión perceptiva subjetiva. Más bien, como nos describe Albert Nieto, se trata de una intuición perceptiva y de una experiencia.

${ }^{29}$ Ver “Apéndice.II Entrevistas". 
- La línea que separa la comunicación expresiva de una gestualidad exagerada, casi teatral, es muy sutil. Hay quien valora dicho tipo de ejecución y hay quien no. El hecho es dejarse de prejuicios e intentar disfrutar de lo que nos ofrecen ciertos intérpretes, como Lang Lang, a través de su ejecución.

- Hubo una época en que la expresividad era añadida a posteriori; este tipo de estudio-primero las notas y luego todo lo referente al fraseo, pedal, expresión...provocaba un exceso de gestualidad. ${ }^{30}$

- El músico siempre debe sentir esta necesidad de comunicación expresivocorporal, independientemente de si se trata de una filmación o no. De todos modos, es muy positivo para la percepción del espectador potenciar dicha comunicación a través de coreografías o a través del uso de medios técnicos; fundamentalmente, cuando hablamos de conciertos grabados y no en directo, donde el proceso de realización implica una estrategia distinta a la utilizada cuando el concierto puede pasar por procesos de postproducción tecnológica.

- $\quad$ El hecho de sentir la necesidad expresiva en un concierto depende de cada músico, pero, en la grabación de conciertos grabados, esta comunicación es esencial. El director de orquesta es uno de los actantes principales para ayudar a ello. Muchos músicos puede que vengan de una formación más "restrictiva" en este aspecto y el director es una pieza clave para lograr esta comunicación expresiva.

- Cada vez es más frecuente que cuartetos y quintetos interpreten obras de pie para facilitar esta mayor gestualidad.

- Otro actante que se está incorporando a la ejecución de las obras es el director de escena o director de actores. De esta manera existe un trabajo en cuanto a la actitud escénica de los músicos.

- Es importante el lugar donde se realiza el concierto tanto por lo significativo que pueda ser y la implicación emocional de los músicos con el mismo. Por ejemplo: Iglesia de Leipzig (donde Bach fue organista) o la Iglesia Protestante de la misma ciudad, donde precisamente Johann Sebastian Bach compuso la colección de las Suites francesas.

- Albert Nieto llama "espíritu del directo" a aquellos momentos en que se ve al espectador con una atención intensa, una vivencia especial. Uno de estos es el instante en

\footnotetext{
${ }^{30}$ Albert Nieto indica aquí la acertada lectura de un cuento de Mario Benedetti donde expresa muy bien lo afirmado en este punto. Se trata de La expresión, dentro de la publicación La muerte y otras sorpresas.
} 
que el espectador espera silenciosamente para aplaudir el final de la ejecución. Existen filmaciones que recogen este especial momento; sin embargo, hay realizadores que no lo respetan. Es totalmente "lícito" salir del intérprete e ir a alguna persona del público que se muestre extasiada en ese momento por la interpretación.

- No sólo se trata de recoger el carácter de una obra en una filmación, también hay que dar su importancia a elementos del discurso musical, como por ejemplo:

- la vivencia de los silencios,

- poner en evidencia los ritmos sincopados o los puntos culminantes,

- ser sensible a los enlaces entre los movimientos de las obras.

- Los planos más valorados desde el punto de vista gestual por Albert Nieto son los siguientes (y no tienen por qué coincidir con los planos que, en determinado momento, escogería el realizador):

- Planos frontales que dejen ver la expresividad del músico, tanto facial como corporal. $^{31}$

- Si se trata de un conjunto instrumental o una orquesta, el intérprete escogido por el realizador debería tener la mirada hacia sus compañeros o hacia el director, no hacia la partitura. Así, se potencia también el diálogo musical. ${ }^{32}$

- Mostrar cada una de las intervenciones de los intérpretes. Así como enseñar la "vivencia de espera", es decir, la espera del solista que está inmerso absolutamente en la música.

Creo que estas interesantes conclusiones extraídas de lo que nos aporta Albert Nieto desde su estudio del gesto en el acto comunicativo-musical no deben ser tomadas en vano. Como afirma José García del Busto en el prólogo de su libro, Nieto (2016):

A la hora de observar y estudiar el momento mágico del concierto, esa convergencia en el tiempo de música escrita por un compositor -en un ayer

\footnotetext{
${ }^{31}$ Por ejemplo, Xavier Garasa, como realizador, opina que los planos frontales no son estéticos y así lo explicita en la entrevista que se puede consultar en el Apéndice II: Entrevistas.

${ }^{32}$ Me gustaría añadir aquí, desde el punto de vista audiovisual, que las miradas y la concentración hacia el instrumento, también tienen su interés narrativo-visual.
} 
próximo o remoto- y a la que aquí y ahora da vida un intérprete para que la podamos percibir, aprehender y disfrutar los oyentes, no cabe obviar que el concierto lleva consigo una dimensión de espectáculo, de celebración que es fundamentalmente auditiva, pero también visual. (p. 10)

Como ejemplo de espectáculo visual, un poco de historia: es en el siglo XVIII cuando el pianista Jan Ladislav Lussek decide dejar de tocar de espaldas al público y gira el piano $45^{\circ}$. De esta manera, el pianista se sitúa de perfil al público. Aún mantenemos actualmente esta colocación; sin embargo, para ver de manera óptima la interpretación, nos sigue resultando complicado puesto que dicha visión sólo es posible desde pocas localidades y el precio económico no es asumible para muchos bolsillos. De ahí que una grabación que nos pueda permitir la visión en $360^{\circ}$ del pianista y su ejecución (ver figuras 36, 37, 38, 39 y 40), hoy en día sea una de las muchas razones por las que la disciplina artística musical y el fenómeno audiovisual salen mutuamente enriquecidos.

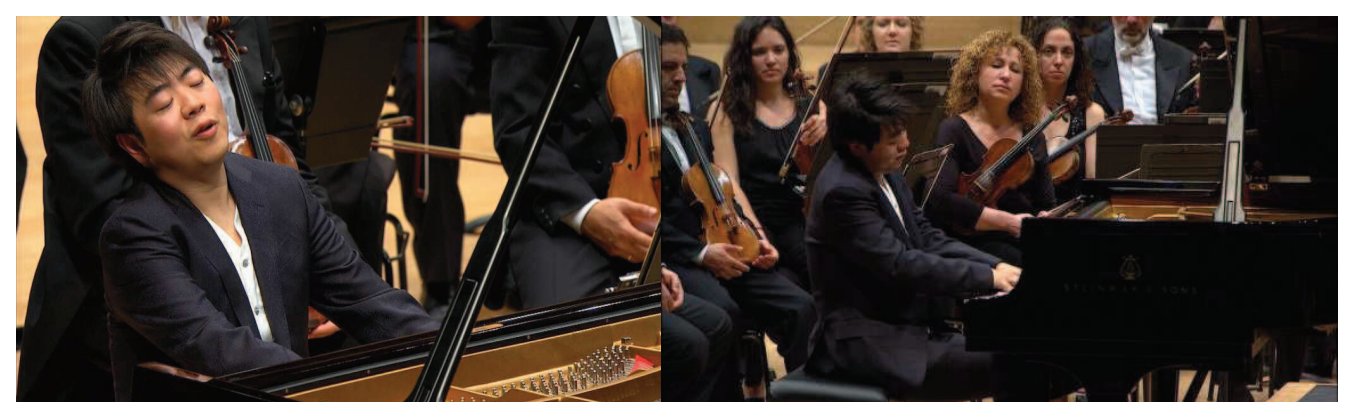

Figura 36 Plano lateral y plano lateral derecho. M, Millà.

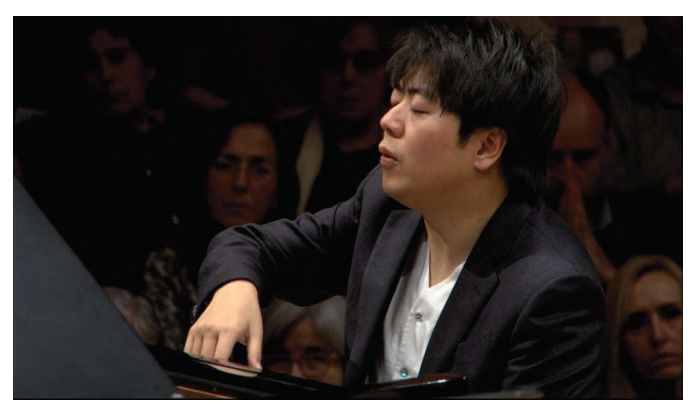

Figura 37 Plano lateral izquierdo. M, Millà. 


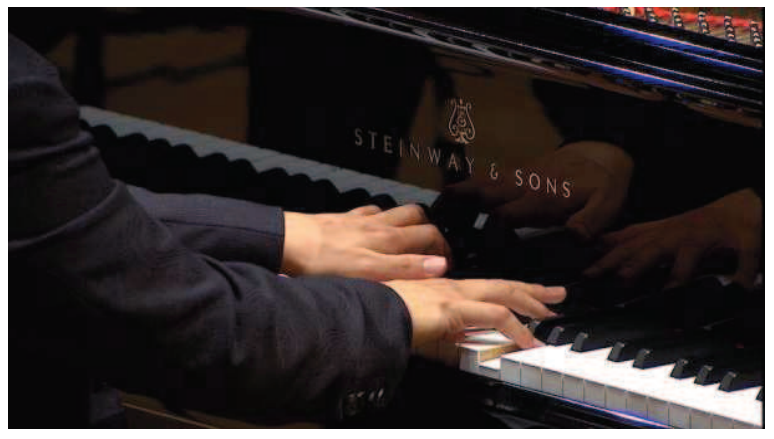

Figura 38 Plano corto teclado. M, Millà.

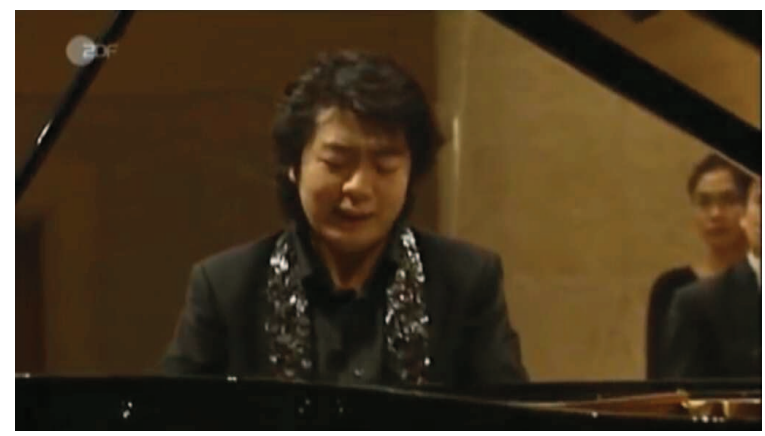

Figura 39 Plano frontal. M, Millà.

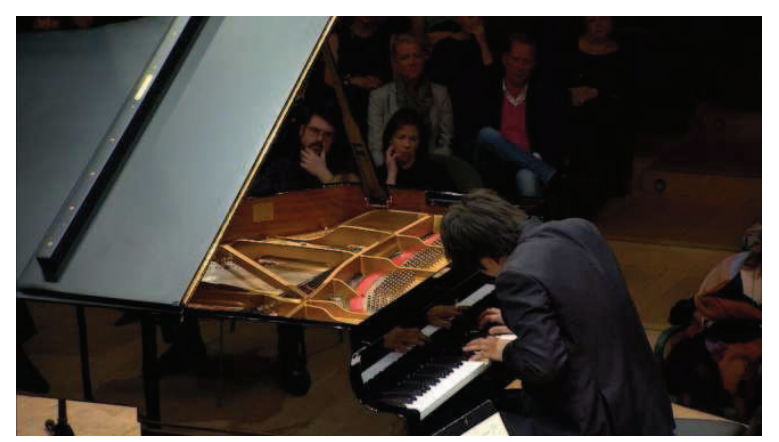

Figura 40 Plano posterior. M, Millà.

Por este motivo y por el que sugiere la cita siguiente con la que deseo cerrar este primer capítulo, sugiero una investigación a fondo para explorar el universo que existe tras las pantallas y que tiene su origen en una partitura simplemente escrita.

Ara Malikian (según cita Nieto, 2016) afirma:

La música clásica se ha ido quedando atrás al confiar excesivamente en la propia solvencia de las obras, y sin contar con apoyos visuales que refuercen la audición en un concierto...En su pretensión de no depender de lo visual, de 
librarse de cualquier acompañamiento extramusical ha ido quedándose atrás respecto del pop y rock. En los conciertos de pop y de rock el elemento visual es muy importante: se trata de un espectáculo audiovisual. Tal vez tendríamos que fijarnos un poco más en estos tipos de música para atraer la atención de nuevos oyentes. Ayudarnos del color, la escenografía o el movimiento para hacerlo más emocionante e interesar a más gente (...) (p. 46) ${ }^{33}$.

${ }^{33}$ Entrevista a Ara Malikian. Diverdi n²01, marzo de 2011 
De la partitura a la pantalla: plano y contraplano de una misma realidad - 74 
De la partitura a la pantalla: plano y contraplano de una misma realidad - 75

PARTE II: DOS CONCEPTOS DE FILMACIÓN 
De la partitura a la pantalla: plano y contraplano de una misma realidad - 76 
Capítulo 2: Concepto de filmación para la emisión de conciertos en diferido 
De la partitura a la pantalla: plano y contraplano de una misma realidad- 78 


\section{Introducción}

La metodología seguida para la filmación de conciertos que van a ser emitidos en diferido es, naturalmente, muy distinta, ya desde el momento de la planificación, de la metodología para conciertos que van a ser retransmitidos en directo a múltiples plataformas. Sin embargo, la gestación de aquello que no fue concebido para la pantalla, pero que tiene que llegar a ella sea en diferido o en directo y, a través de ella, a cuantos más posibles espectadores de cualquier tipo de clase social, edad, formación académica y ocupación laboral implica una gran dosis de minucioso trabajo en lo que se refiere al múltiple y complejo mundo de la imagen; sin dejar de lado una lectio score que ayude a dar a cada uno de estos trabajos su huella, no solo digital, sino dactilar.

¿A qué me refiero con ello? Con huella digital (del latín, digitus) me estoy refiriendo a aquella huella que algo o alguien deja en internet, o en cualquier dispositivo digital; evidentemente, es personal, pero pasa por una filtración implícita o explícita desde muchos aspectos, desde los más personales -educación, formación, incluso carácter y temperamentoa los estrictamente sociales -clase social, cultural o, incluso, la salud, entre muchos otros condicionantes que van configurando la personalidad de cada uno. Por otro lado, con huella dactilar (del griego, dactylus) me refiero a aquello más intrínseco de la persona, aquello que la caracteriza y la hace única sin pasar por "espacios” intermedios.

Así pues, la lectio score supondría un estudio profundo de aquella partitura que queremos filmar, sabiendo que es el material que nos llega directamente escrito del compositor. La construcción de cada una de las frases y la narración musical completa, con un inicio y un final musical firmado por un compositor que ha entregado su tiempo y esfuerzo a ello, tiene que verse, de alguna manera, "recompensada", años, décadas o siglos después, con una huella digital que tenga como substrato un estudio de la época, de la personalidad del compositor, de la forma musical así como de otros elementos que, durante la preparación de la obra que va a ser filmada, se van a tener en cuenta.

Pero, ¿cómo pasar de la huella dactilar a la huella digital en un concierto filmado para ser editado y emitido posteriormente? Paso a detallar los aspectos que también serán analizados en el capítulo dedicado a las transmisiones en directo. 


\section{1- La partitura como discurso narrativo.}

a) Narrador

El primer elemento a tener en cuenta es la figura del narrador. Se trata de un acontecimiento musical, un único acontecimiento musical, que es interpretado por varios sujetos y percibido por, posiblemente y según las circunstancias, por millones de espectadores. El principal narrador es el compositor; su huella táctil está clara y puede que dicho compositor sea el director de orquesta que interpreta su partitura ${ }^{34}$ o no. Actualmente, se dan pocas programaciones en las salas de conciertos en que se dé el caso de que el mismo compositor dirija su obra. Quizás esté en la sala e incluso, durante los ensayos haya dado sus pertinentes consideraciones, pero no es habitual verlo dirigiendo con su batuta. En este caso, es importante considerar que la asistencia a los ensayos y la escucha de las indicaciones del compositor por parte del director artístico de la filmación pueden originar nuevas ideas en su camino hacia la pantalla.

Otro narrador, evidentemente, es el director de orquesta cuando no es el mismo compositor. Juega un papel muy importante en la manera de interpretar el discurso narrativo de la partitura, de la composición. Es él quien conduce la orquesta a niveles de lectura y de interpretación que, aunque sutiles, se impregnan ya de una huella hacia lo digital que no se puede dejar escapar.

Un tercer narrador, es, no sólo la orquesta, sino cada uno de los músicos que compone dicha orquesta, conjunto instrumental, dúo o, incluso, el solista que se enfrenta a su personal interpretación de aquello que, minutos antes, es algo que no "existe".

\section{b) Observador}

Diría que, entre el narrador y el observador está la pieza humana clave en mi investigación: el director artístico encargado de filmar la "partitura", la música que tiene que llegar al espectador. Como bisagra entre el papel y la pantalla, el director o realizador es un puro observador, pero su ojo sólo enseñará aquello a lo que su percepción le ha conducido hasta el momento. De ahí el momento tan importante que supone una preparación del material del que dispone para enseñar. Su ojo discrimina...y no puede discriminar aquello que

\footnotetext{
${ }^{34}$ Como en el ejemplo de la película Eroica en que Ludwig Van Beethoven es compositor y director de orquesta.
} 
no ha visto. Por ello es importante tener en cuenta la opinión positiva o negativa que respecto a este asunto, en la encuesta realizada en mi trabajo de campo, afirman varias personas:

“Que la filmación dé su "versión”.

"La realizacion audiovisual de un concierto en vivo puede llegar a condicionar nuestra atención, impresión, interés y hasta opinión sobre las obras. Según nos planteemos una obra musical, cambia nuestra percepción".

"Como "público", no me gusta escuchar y ver música con un filtro e interpretación de un realizador. La obra ya se interpreta por los músicos y el intérprete, si además tiene que pasar por el filtro del realizador, me quita todo el placer como oyente. Sólo puedo consumir lo que me dan, y eso no me gusta".

Es importante que, al discriminar, el realizador no camine con pasos restringidos que omitan la riqueza que pueda llegar al espectador.

Y, ya que he introducido la figura del espectador, aquí está el último observador: el realizador convierte su propio punto de vista en el punto de vista del espectador y, esto, puede gustar o no, tal como hemos visto en los encuestados.

Claro que, precedente a eso y, como anécdota explicada en su entrevista ${ }^{35}$, tomo el comentario del compositor José Nieto. Ya de por sí, según el poder adquisitivo, el espectador que asiste a la sala de conciertos para ver y escuchar el concierto en directo, puede tener un maravilloso plano general desde las alturas o unos excelentes primeros planos desde las butacas de platea; es decir, la condición económica influye en el punto de vista del espectador. Él mismo admite que, de joven disfrutaba del plano general y, cuando tuvo mayor poder adquisitivo, pudo disfrutar del seguimiento de la interpretación de los músicos. Bromas aparte, quiero considerar cuán importante es saber mucho para discriminar razonablemente, de manera que el producto audiovisual final sea de calidad a pesar de saber todos que siempre echaremos en falta aquel plano que uno hubiera deseado ver. Pero, habrá qué ver cómo tratar cada plano para que, aquél que no hemos visto, sea suplido por una imagen que transporte el espectador a apreciar la realización como algo excepcional que no da el directo, el aquí y ahora.

${ }^{35}$ Ver Apéndice II-Entrevistas 
En este punto, la diferencia entre el observador principal -a partir de ahora, realizador o director $^{36}$ - y el espectador (observador secundario) es que el primero está presente espacial y temporalmente en el momento de la interpretación del concierto; mientras que el segundo, vive un claro evento semiótico con débrayage. Será él quien decida no sólo cuándo y dónde ver el concierto, sino desde qué tipo de soporte audiovisual: pantalla de televisión, teléfono móvil, ordenador, entre otras plataformas disponibles hasta el momento. Es cierto que este aspecto cambia cuando se trata de una transmisión en directo: el débrayage sólo es espacial, no temporal. Sin embargo, el realizador sigue "gozando" de la disposición privilegiada para decidir qué enseñar en cada segundo musical. En el anterior párrafo, cuando me refiero a espectador con la definición "observador secundario", no pretendo restar importancia al espectador, no es cualitativo el adjetivo sino que en la cadena semiótica del discurso lo entiendo como el "sujeto paciente" a quien llega la realización en su versión final. A pesar, de que, a partir de que el evento llega a sus pupilas, la percepción se vuelve todo lo activa que uno quiera ${ }^{37}$ y se convertirá en sujeto activo.

En el momento en que el director pasa de ser observador a narrador, nos encontramos con un elemento nuevo: el punto de vista.

Antes de pasar a este importante elemento dentro de la elaboración audiovisual, quiero detenerme en el diagrama siguiente (Figura 41).

Este grafico circular muestra los elementos semióticos que forman parte de la comunicación dentro de la elaboración de una narrativa audiovisual y musical. Lo que quiero dejar manifiesto es el movimiento cíclico entre los diferentes elementos: desde que empieza, hasta finalizar la producción audiovisual que lleva a término cada proyecto, estos elementos no deben dejar de estar en la mente y el imaginario, principalmente, del realizador, como agente de enlace entre la partitura y la pantalla.

\footnotetext{
${ }^{36}$ Con "director", me refiero al director audiovisual o realizador; cuando me refiera al director de orquesta, lo especificaré (nota de la autora)

${ }^{37}$ La disciplina de la Psicoacústica bien sabe de ello; depende de la predisposición y de cómo estemos en el momento de escuchar el concierto, la percepción será muy distinta. Pero, este sería otro tema, interesante sin lugar a dudas, pero que nos desviaría en exceso del camino.
} 


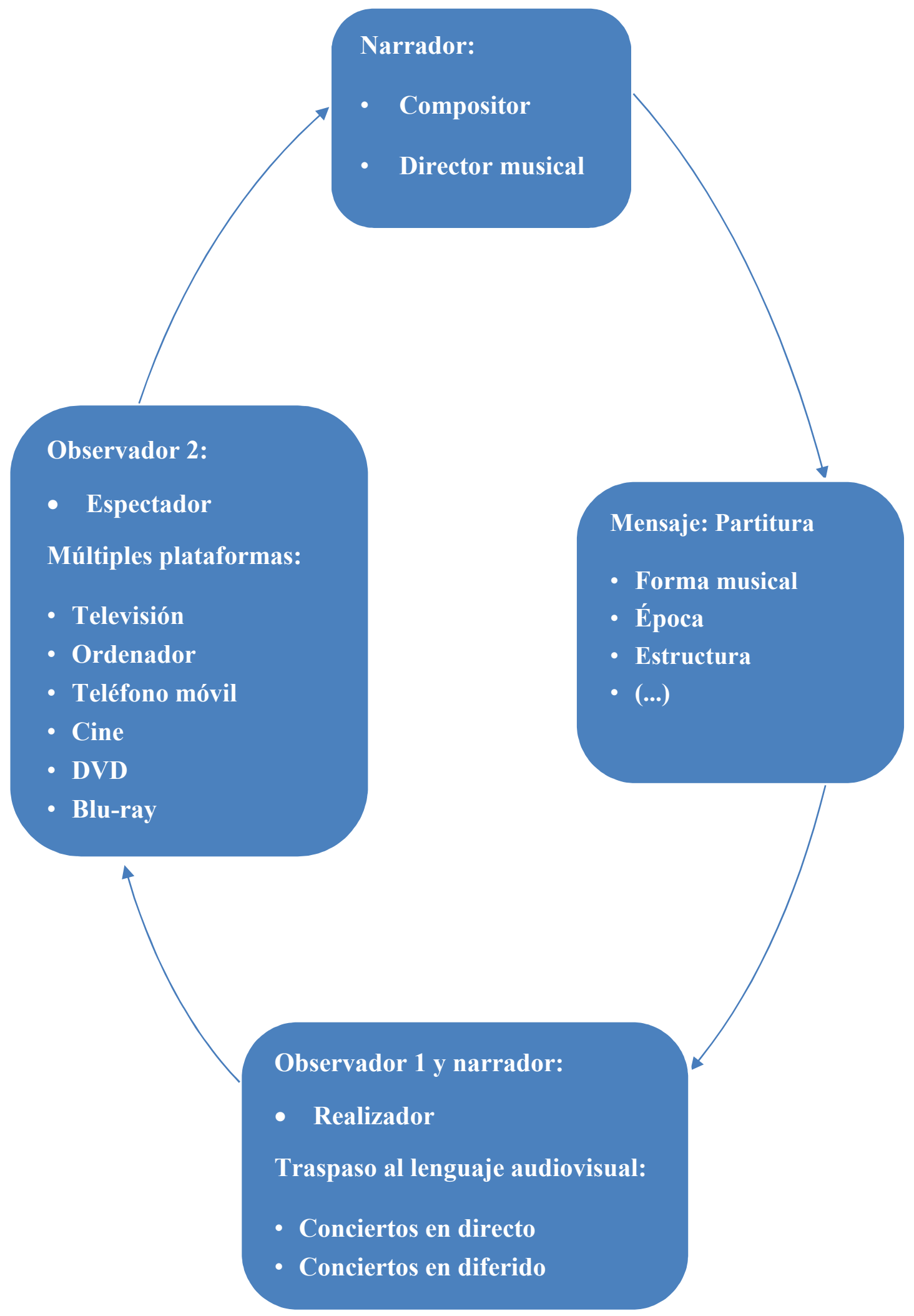

Figura 41 Elementos semióticos en la comunicación audiovisual y musical. M. Millà. 


\section{c) Punto de vista}

El observador es quien decide el punto de vista de cada uno de sus eventos musicales. Siguiendo el símil literario, puede ser omnisciente, externo, impersonal o personal. Para establecer estos puntos de vista, hace uso de las técnicas disponibles y, en concreto, el elemento tecnológico principal que usa para llegar al punto de vista que cree mejor es la cámara. La óptica de cada cámara será el ojo que el director quiere en ese momento. Sin embargo, una cosa es el "punto de vista" general y, otro, cada uno de los puntos de vista que engloban la concepción global que se quiere lograr y, para ello, cada cámara dará su punto de vista que enlazado, como plano, al siguiente plano, conseguirá la sintaxis del texto que lleva al discurso narrativo final.

Después de analizar las encuestas, la herramienta utilizada en esta investigación y que ya he citado en la introducción del presente trabajo, queda claro el hecho de que cuanto más omnisciente es el punto de vista, más impersonal y menos llega al espectador de manera emocional. Es decir, se mantiene alejada de aquello que transmite. Sin embargo, es el tipo de realización que valora el espectador como lo que llamaríamos “un trabajo bien hecho". En el momento en que el realizador se convierte en un narrador personal, sin los excesos de un ego artístico que haga prevalecer lo artístico del plano antes que la propia narratividad musical, el placer de una percepción con un equilibrio entre estético y formativo, es cuando ese evento musical se convierte en un archivo para la posteridad, con dosis equilibrada de la personalidad del autor, pero que transmite la música en su esencia narrativa.

\section{2- Táctica}

La táctica, como ya he descrito en el primer capítulo y como seguiré profundizando en ella en el siguiente capítulo, viene definida por el lugar que ocupan las cámaras en un plano. Cuando se trata de un concierto que se filma en directo, pero se emite a posteriori, la táctica es muy distinta de la que se emplea en una retransmisión en directo. Así mismo, en el caso que nos concierne, el de la filmación para emitir en otro momento, se pueden dar dos circunstancias: 
a) Concierto filmado en directo, con una única grabación.

En este caso, se acostumbran a grabar las cámaras de manera independiente, a pesar de que se ya se lleve a cabo una primera realización "en directo". Este método ofrece posibilidades de cambio de planos en la sala de postproducción por diferentes motivos:

- $\quad$ Error: un plano en el que no tocaba el instrumento, falta de foco en la imagen, movimiento involuntario de la cámara, retraso o adelanto al "pinchar" ${ }^{38}$ la cámara que tocaba en ese momento, no tener preparado el plano necesario, entre otros errores posibles.

- Imposibilidad de llegar en directo a un plano por el ritmo que lleva la música o por el ritmo que el director ha previsto para la realización en ese momento.

- $\quad$ Posibilidad de retoque con dispositivos informáticos de la luz, el color $\mathrm{u}$ otros elementos susceptibles de ser mejorados o adaptados a un tipo de realización particular: pantallas partidas, ralentizados, acelerados, luminancia, corrector de color, blur (desenfoques), entre otros miles de efectos disponibles.

En realidad, cuando se plantea este tipo de realización, en la planificación ya se previene una serie de planos que se dejará para poner en la sala de edición. Cada realizador dispone su propio método, pero estos planos acostumbran a ser los de los instrumentos de percusión dada su sincronización puntual. Es una dificultad añadida, en medio de un directo, "pinchar" en el momento exacto la cámara que tiene los timbales, el gong, el triángulo o cualquier golpe percusivo. También acostumbran a ser planos que se dejan para la sala de edición posterior, aquellos planos que se suponen secundarios en la textura musical: pizzicati de los instrumentos de cuerda, contrapunto en las melodías, respuestas dentro de los diálogos entre instrumentos; es decir, en un diálogo flauta-oboe, por ejemplo, se graba el oboe, mientras en directo tienes la flauta y/o el conjunto flautaoboe. De esta manera, cuando se llega a la sala de edición, se añade el oboe donde interesa por discurso narrativo-musical. Es una manera de no estar pendiente de tantos elementos en el directo y poder enriquecer el concierto en la postproducción, antes de la emisión.

\footnotetext{
${ }^{38}$ En el argot audiovisual, "pinchar" se usa como sinónimo de "pulsar". Es decir, pulsar el botón -en la mesa de mezcla de vídeo- de la cámara que tiene el plano en ese preciso momento.
} 
Respecto a los retoques informáticos de la imagen en postproducción, es importante saber que, tal como he dicho más arriba, si el director tiene un planteamiento general de la obra y ha pensado en un estilo personalizado de la misma, es en el momento de plantear la táctica del directo cuando se tendrán en cuenta los elementos que se añadirán después, en el momento de la postproducción.

b) Concierto filmado en directo, con más de una grabación.

Se trata de un concierto filmado, pero con algún pase del mismo sólo para cámaras; es el ejemplo del concierto filmado que analizo dentro de este capítulo. Cabe decir que se trata de un ejemplo llevado al extremo puesto que se trata de una película histórica filmada por la BCC y, por tanto, con unos elementos extras a cualquier filmación "simple" de un concierto 39 . En casos no tan complejos, se trata de la filmación en varios días. Un ejemplo podría ser, una filmación sin pausa con público y, por supuesto, con la grabación de las cámaras llamadas de recurso. Son cámaras que dan los planos que luego se insertarán en el edición y que en el directo no está previsto pinchar. Una segunda filmación del concierto sin público para disponer las cámaras a conveniencia sin molestar las personas que han pagado por ver un buen concierto; es decir, los puntos de vista se multiplican y el enriquecimiento de la filmación es evidente. En las encuestas, se constata cómo los espectadores valoran los distintos puntos de vista de los instrumentos y los músicos. Se trata, por poner un ejemplo que ocurre con frecuencia, de cámaras con travelling delante del escenario y que, obviamente, impiden la visión a los espectadores sentados en la platea de la sala y que pueden molestar con el ruido de su maquinaria. Y, una tercera y última grabación por secuencias y sin público que permite invadir el escenario con cámaras y aportar aquellas imágenes más cercanas que enriquecen la visión del concierto ${ }^{40}$.

Evidentemente, esta metodología de filmación supone una previsión económica que no toda empresa está dispuesta a pagar; sin embargo, es la que puede dar resultados óptimos en el resultado final.

\footnotetext{
${ }^{39}$ Elementos como el vestuario de época, así como los instrumentos musicales y el atrezzo nos indican que estamos ante algo más que una filmación musical.

${ }^{40}$ Se trata de un ejemplo de cronograma de filmación, está claro que una filmación puede constar de todos los días y medios de los cuales un producción pueda disponer económicamente.
} 


\section{3- Estrategia}

Entro de lleno en lo que supone la realización en sí misma: el dinamismo. Es este dinamismo el que convierte una fotografía en imagen en movimiento, en vídeo. La táctica es la disposición de las cámaras a partir de la localización previa que el equipo ha realizado días o meses antes de una producción. Se trata de un concepto estático, tal y como he mostrado en el primer capítulo a través de planos y como se puede ver en la siguiente figura:

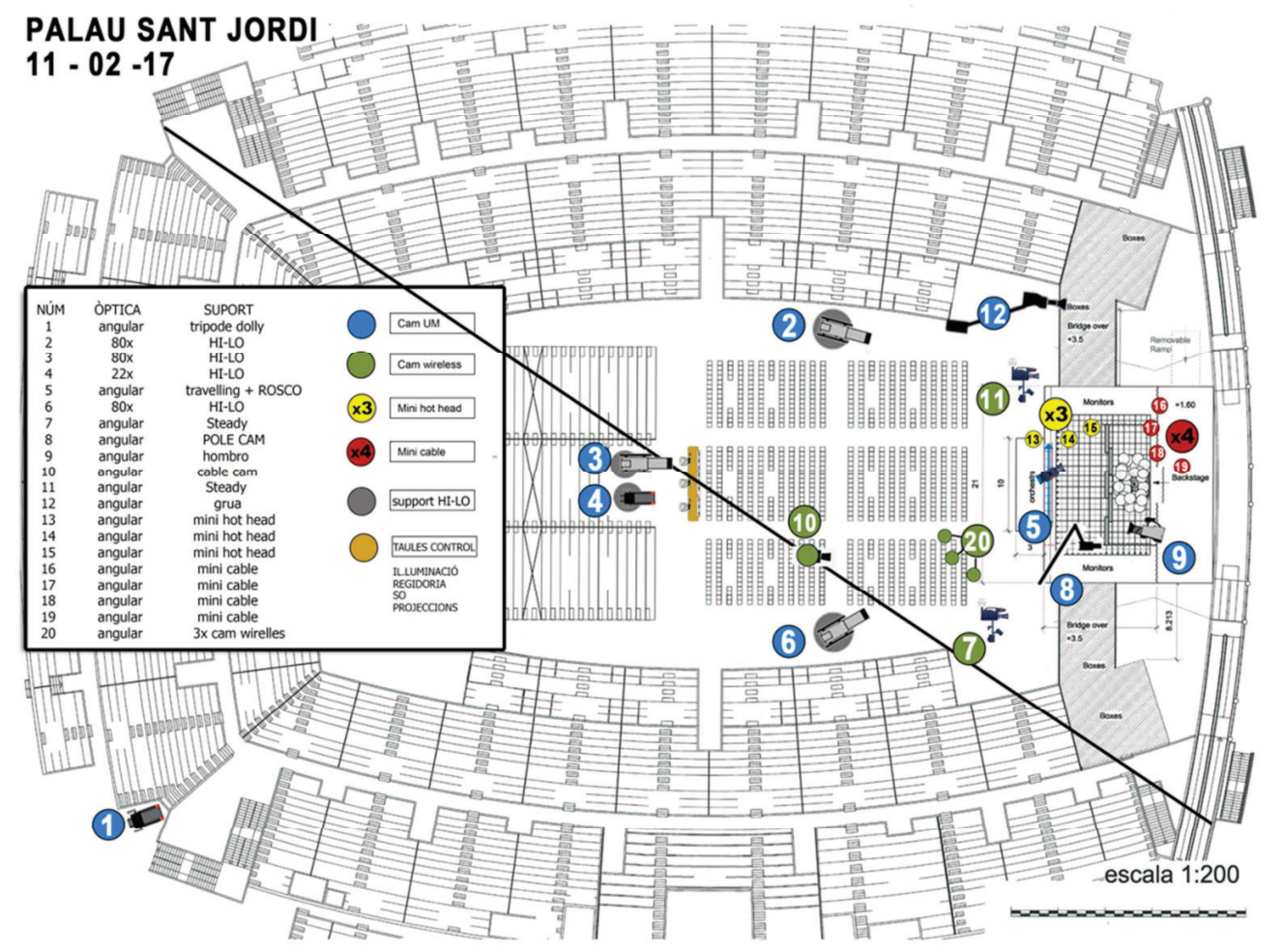

Figura 42 Posiciones de cámara para el concierto Casa Nostra, Casa Vostra en el Palau Sant Jordi, Barcelona. P. Subirà.

Sin embargo, es a partir de la táctica, definida y puesta sobre plano, que empieza la estrategia: movimiento de cada cámara y movimiento entre planos. Si la música es ritmo; realización, también es ritmo. Lo dificultoso es entrar en el ritmo que marca la música para que la realización fluya de manera natural. Es decir, se trata de seguir, no la partitura, sino el espíritu de la música. José Nieto, en la entrevista realizada para esta investigación, lo explica de la siguiente manera:

El montaje tiene que tener pulso musical, el montaje tiene que respirar musicalmente y que tiene que haber...eso, fluidez y ¿cómo se consigue eso? Pues con una relación "musical" entre el movimiento que hay en los planos, y los cortes de los planos. Cuando la 
relación entre el movimiento y el corte tiene musicalidad entonces el montaje respira y el montaje fluye y les pongo unos ejemplos muy sorprendentes de montajes hechos de esta manera en los cuales, cuando los ves, se capta el pulso del montaje y resulta que tú le añades una música que no está pensada para eso, pero que tiene ese pulso y, sorprendentemente, funciona. Entonces, yo creo que cuando retransmitís es al revés: el pulso ya está, es el de la música y entonces los cambios, los cortes de plano y cómo paso de uno a otro tiene que tener respiración musical. Por ejemplo, si estás en un adagio, cuidado con los planos por corte; porque los planos por corte te van a dar algo que no está en el espíritu de la música, dureza. Y si haces coincidir un cambio de plano sincrónico... muy sincrónico con un ataque de orquesta entonces, la brusquedad, la dureza está garantizada. La fluidez se produce precisamente cuando la música no está matemáticamente sincronizada, que no se perciba la sincronía. Tiene que estar, yo prefiero utilizar en clase el término, articulada. Entonces, el grado de articulación puede ser sincronía dura, cuando quieres retransmitir algo con sensación de violencia y cuando no, la sincronía tiene que no ser perceptible. El espectador no se tiene que dar cuenta que estás siguiendo (...) (Entrevista a José Nieto, Hotel Liceu, 9 de octubre del $2016)^{41}$.

Es a esta fluidez a lo que tiene que tender el trabajo del director. Aun así, resulta curioso mirar cualquier filmación de conciertos en los inicios del vídeo. Veremos cómo, a pesar de que la música es la misma, con el paso de los años, nos hemos acostumbrado a un ritmo mucho más acelerado y vertiginoso en cuanto al cambio de las imágenes. Nuestra percepción se ha adaptado a un ritmo distinto en cuanto al cambio de las imágenes. A veces, en directo, intentar seguir un ritmo así es imposible puesto que cuando se indica una orden, el plano requerido ya ha pasado; es por ello que, en la sala de edición una de las apuestas principales es buscar, más que el ritmo, el tempo de aquella obra musical en simbiosis con las imágenes. La fluidez que nos describe el compositor José Nieto es la esencia en la realización de cualquier evento musical.

Dicha estrategia se consigue a través de los elementos técnicos que inducen al movimiento y que ya hemos visto en otro capítulo. No los volveré a nombrar aquí, pero sí quiero dejar claro que en un concierto filmado para ser editado posteriormente hay que pensar en cómo va a ser la estrategia de cada una de las secuencias. No se trata del movimiento por el movimiento, sino del movimiento para dar un sentido al fluir de cada pasaje musical, sea

\footnotetext{
${ }^{41}$ Ver Apéndice II-Entrevistas
} 
lento, rápido o acelerado. El plano que tiene movimiento interior -zoom in, zoom out, zoom retro, zoom avance, travelling, panorámica, y otros- tiene que "saberse entender" con el plano siguiente. Todo es discurso y, tras un plano viene otro, y otro, y otro... movimiento cadencial que no debe ser truncado por exceso de protagonismo del realizador ni por defecto de preparación audiovisual "músico-fílmica".

En el caso de la estrategia, nos encontramos con la sintaxis del audiovisual, la construcción de secuencias que conforman un todo. Así pues, la estrategia es un concepto dinámico. Pretende englobar la táctica, los movimientos de cada una de las cámaras y los movimientos que van pasando entre ellas como si de un balón se tratara para acceder al concepto que define el concierto que se va a filmar.

\section{4- Ejemplo de filmación con emisión en diferido: Eroica}

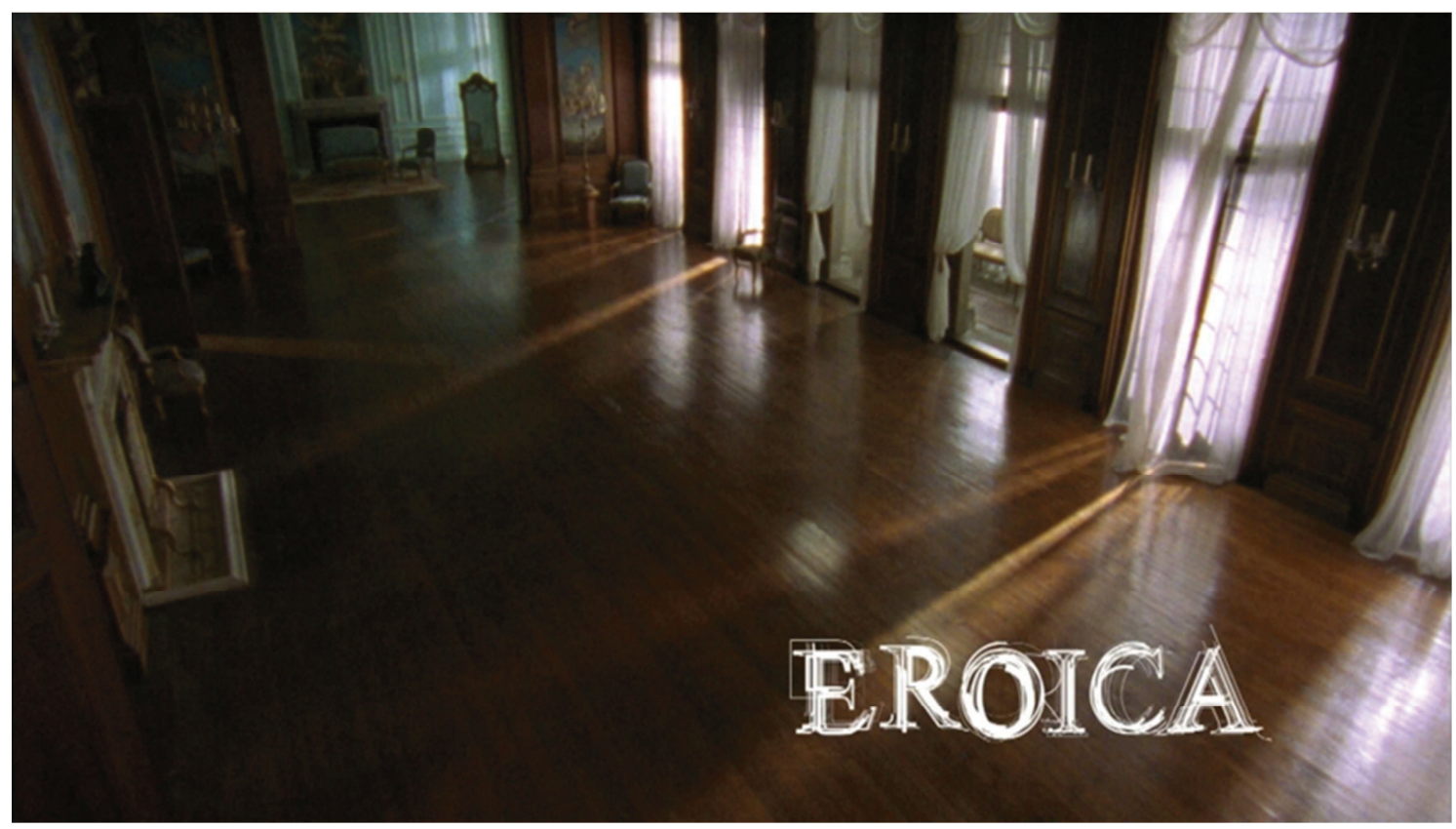

Figura 43 Fotograma de la Película Eroica. M. Millà.

He tomado esta filmación de la British Broadcasting Corporation (BBC) como caso de emisión en diferido llevado hasta el extremo por lo que de distinto tiene en cuanto a su forma; su análisis, sin profundizar en los elementos de vestuario, atrezzo y ambientación, puede 
aportar a la investigación todos los datos necesarios para ver cómo el lenguaje de los planos nos transporta a una concepción distinta en cada tiempo musical según lo que pretende, desde el guión, el mismo director.

Datos:

\section{SINFONÍA N.3 EN MI bemol MAYOR, "HEROICA"}

Director: Simon Cellan Jones

Director musical: Sir John Eliot Gardiner

Interpretación: "L'orchestre revolutionnaire et romantique"

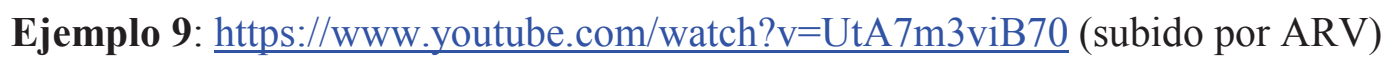

a) Sinopsis del film

El director Simon Cellan traduce en imágenes un guión centrado en la primera interpretación de la Sinfonía Heroica el 9 de junio de de 1804 en una de las salas del Palacio del príncipe Franz Lobkowitz. Además de seguir la narración audiovisual de esta partitura, aparecen dos tramas emocionales paralelas:

- la declaración de amor por parte de Ludwig Van Beethoven a la viuda Josephine Von Deym,

- la escucha atenta de la interpretación de la sinfonía por parte de Franz Joseph Haydn.

Beethoven no consigue el matrimonio con esta viuda perteneciente a la nobleza, a pesar de haberle manifestado la voluntad de convertirse en marido suyo y de que ella le corresponde a dicho sentimiento, porque este paso supondría, para ella, perder a sus hijos y la renuncia al título nobiliario. Por otro lado, Haydn, absorto por lo que acaba de escuchar, describe la sinfonía como novedosa, a pesar de ser larga y estruendosa, porque, tal como expresa Haydn, el alma de Beethoven se ha puesto en el centro de la música y, ahí, radica la novedad. La frase final de Franz Joseph Haydn lo resume: "todo es diferente desde hoy". 
La composición de esta sinfonía estaba dedicada a Napoleón Bonaparte, pero, cuando Beethoven conoce por parte de su discípulo Reis que éste se ha autoproclamado Emperador, decide retirar el título y cambiarlo puesto que siente traicionada su confianza en él. Así, el título final queda como: Sinfonía Heroica, compuesta para festejar el recuerdo de un gran hombre.

Simon Cellan traduce todos estos elementos emocionales en miradas, principalmente durante la interpretación del cuarto tiempo: Finale- (Allegro molto). Aunque, es a lo largo de todo el film que los primeros planos de los protagonistas se convierten en conductores de un guión "no hablado", es al cuarto tiempo al que dedico mi análisis fílmico en profundidad por lo que supone de novedad dentro de este ámbito académico. Pero, antes, realizo un análisis de cada uno de los tiempos para ver cómo todo confluye y explosiona en los vertiginosos 4 minutos finales del film. $^{42}$

b) Análisis

Se inicia la película con una prueba acústica. Entra un personaje, el primer violín, en la sala donde se estrenará la Sinfonía Heroica y comprueba su sonido: quizás la reverberación, el eco y el "color" que toma el sonido en dicha sala. Es el mismo plano picado que recupera en varias ocasiones Simon Cellan para mostrar la perspectiva al espectador.

A continuación, otro personaje, nos pone en situación: advierte al violinista que los músicos deben ir vestidos como corresponde.

Sólo con estos dos momentos ya entramos en dos cuestiones absolutamente centrales y actuales cuando hablamos de la filmación de un concierto: la técnica y la estética.

También el compositor se viste con lo mejor; le pide a su discípulo Ries que le diga dónde está su mejor camisa. El vestuario es de gran importancia y debería convertirse en una parte importante dentro de la estética de la realización tal como

\footnotetext{
${ }^{42}$ No trato de explicar el film en profundidad en cuanto a "guión literario", sino cómo se van tejiendo emocionalmente las tramas a través del análisis audiovisual. Es por ello que, principalmente, analizo las partes de la orquesta, es decir, los diferentes tiempos musicales.
} 
hemos visto en el apartado dedicado a los servicios artísticos. En este caso, el vestuario es de época, y su importancia para contextualizar el momento histórico es evidente.

De camino al palacio del príncipe Lobkovitz, donde se interpretará la sinfonía, inicialmente, llamada Buonaparte, Beethoven muestra su confianza en el futuro emperador. Es importante este fragmento de la película para, al final, ser conscientes del dramatismo hacia el que se dirige el final de la Sinfonía.

Poco a poco van llegando los músicos intérpretes cargando con sus instrumentos y se van situando en la sala, así como también el conde de Dietrichstein. El primer violín o concertino Wranitsky es presentado al conde.

Cuando en el minuto 6:43 los criados hablan de poder escuchar la música, nos presentan la finalidad de la música: para bailar o rezar. No saben que lo que les espera es un vivencia estética totalmente distinta. Poco a poco lo iremos viendo en sus expresiones. Simon Cellan no se reprime en el uso de primeros planos para hacer llegar al espectador los sentimientos que se producen en la sala, todos conducidos estratégicamente a través de la música.

A partir de ahora, pasado el preámbulo, empieza, con el sonido del diapasón, la afinación de cada uno de los instrumentos. Cabe destacar que se trata de instrumentos originales, con afinación en La $432 \mathrm{Khz}$.

La primera música que suena en el film es interpretada por la orquesta y dirigida por su concertino. Aunque al principio escuchamos la música y vemos primeros planos de los príncipes y el conde, es al cabo de 30" que podemos ver la orquesta interpretando este primer tiempo. Se trata de música diegética; es decir, la música que oímos está interpretada en el film directamente por una orquesta. Aunque, es necesario remarcar la importancia del trato "no diegético" que en ciertos momentos, principalmente dramáticos, recibe la música. Lo mostraré más adelante.

En el minuto 8:45, la imagen sale fuera de campo. La música es tratada acústicamente para que el espectador entienda que salimos de la sala. De esta manera, el director corrobora que se trata de música diegética, puesto que si no lo fuera, 
continuaría sonando con toda su calidad acústica. En el minuto 9:12, volvemos a entrar en la sala y recuperamos el sonido de la orquesta.

Cabe destacar cómo dignifica Beethoven el trabajo de los músicos cuando hace que el intérprete de trompa suba por la escalera principal y no por la de atrás. Un simple gesto físico, pero que va mucho más allá en cuanto a los estereotipos sociales de la época.

Es en el momento del diálogo con el conde de Dietrichstein cuando entra un tercer elemento importante: Beethoven no pertenece a un alto rango social. Él mismo se define como "cerebroteniente", y no terrateniente, provocando una situación desconcertante en quienes están en la conversación.

Beethoven busca a la condesa; pero ésta, no ha llegado todavía. Todo son preámbulos para advertir al espectador que las relaciones entre todos los personajes irán desarrollándose y serán importantes en el devenir de la música.

Cuando entra la doncella en la sala mira el criado; es ahí cuando empieza la "narración de las miradas".

Otros diálogos importantes son los que tratan, no el amor, sino el significado de la música. Uno de ellos es el dialogo entre la princesa y el discípulo de Beethoven, Ries. Es el momento en que se insinúa ya la esencia de la sinfonía. La princesa pregunta: “¿crees que puede la música existir independientemente de la política, señor Ries?"

Minutos antes de la interpretación del primer tiempo, empiezan las murmuraciones sobre la composición. Ante ellas, el silencio de Beethoven se impone para dar paso al ataque del primer acorde.

Se inicia, así pues, con un travelling circular que llega hasta Beethoven, momento en que hace parar la orquesta (14:35- 15:24). Los adjetivos que recibe la interpretación por parte de los allí presentes son: "descompensada", "innecesariamente violenta", "difícil de leer", "diabólica". Contrariamente a semejantes calificativos, destaca la inocencia de la esposa del príncipe. A ella, le parece moderna $\mathrm{y}$, realmente, durante toda su interpretación, a través de sus 
expresiones, se ve cómo penetra en la música disfrutando de ella. Todo ello se expresa con el movimiento circular iniciado en Beethoven, pasando por todos los instrumentos y terminando con el zoom in que aterriza en la expresión del compositor.

\section{Beethoven}

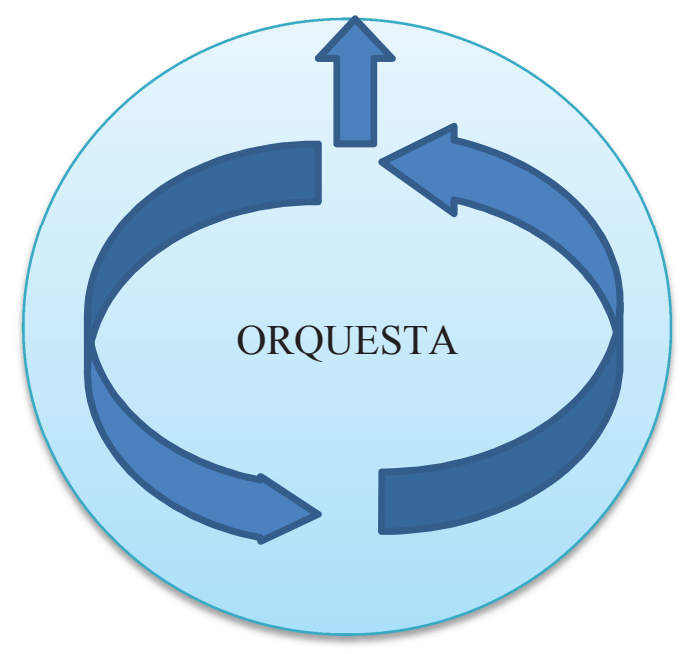

Figura 44 Travelling circular de la cámara, realizando el seguimiento a Beethoven. M. Sánchez.

A partir de este momento, se inicia la filmación de la interpretación de la sinfonía tal como se trataría un concierto.

c) Secuenciación analítica ${ }^{43}$

A continuación, expongo el análisis de cada uno de los planos durante el primer tiempo. Las cinco columnas incluyen las siguientes informaciones ${ }^{44}$ :

1. Número de plano.

2. El time code o código de tiempo ${ }^{45}$ en el que empieza el plano siguiente expresado en horas-minutos-segundos y, en algún tiempo musical en que una fracción de tiempo menor es importante, también señalaré los frames.

\footnotetext{
${ }^{43}$ Ver la partitura analizada y trabajada en el Apéndice I

${ }^{44}$ En cada uno de los tiempos de la sinfonía, el análisis por columnas tendrá la misma composición.

${ }^{45}$ El Time Code o código de tiempo pertenece a la versión de Youtube del año 2003 cuyo link he añadido en los datos indicados en el punto cuatro del capítulo.
} 
3. Tipo de transición entre planos consecutivos: por corte ( C ) o por encadenado ( E).

4. Descripción del contenido del plano, de su valor y del movimiento interno que tiene. Indicaré con abreviaturas el tipo de plano. Dichas abreviaturas a parecen explicadas en el primer capítulo. Sin embargo, prefiero recordarlas nuevamente:

- GPG- Gran plano general

- PG- Plano general

- PF- Plano de figura

- PA- Plano americano

- PP- Primer plano

Existen otros muchos tipos o valores de plano los cuales quedan especificados con una descripción.

5. Imagen de un frame congelado. Quiero recordar que un frame corresponde a un fotograma de película o de vídeo. En cine, cada segundo está dividido en 25 frames. Hago constar que, dada la cantidad de fotogramas empleados, no los he tratado como figuras dentro de la investigación, sino como elementos que participan del cuerpo del texto; es por ello que, no los hago constar en el listado de figuras. 


\section{Primer Tiempo: Allegro con brio}

\begin{tabular}{|c|c|c|c|c|}
\hline Núm. & Time Code & Cambio & Descripción del plano & Frame congelado \\
\hline 1 & $17: 00: 00$ & $\mathrm{E}$ & $\begin{array}{l}\text { Zoom in a } \\
\text { Beethoven }\end{array}$ & \\
\hline 2 & $17: 34: 12$ & $\mathrm{E}$ & $\begin{array}{l}\text { Plano medio, } \\
\text { miradas entre el } \\
\text { conde y el príncipe }\end{array}$ & \\
\hline 3 & 17:37:07 & E & $\begin{array}{l}\text { Contrapicado } \\
\text { plano figura } \\
\text { violoncelos }\end{array}$ & \\
\hline 4 & $17: 39: 15$ & $\mathrm{C}$ & $\begin{array}{l}\text { Primer plano } \\
\text { violín }\end{array}$ & \\
\hline 5 & $17: 41: 05$ & E & $\begin{array}{c}\text { Travelling } \\
\text { circular trompetas }\end{array}$ & \\
\hline 6 & $17: 45: 04$ & $\mathrm{C}$ & $\begin{array}{l}\text { PP del discípulo } \\
\text { Ries }\end{array}$ & \\
\hline 7 & $17: 47: 14$ & $\mathrm{E}$ & $\begin{array}{l}\text { Travelling } \\
\text { circular violín }\end{array}$ & \\
\hline
\end{tabular}


De la partitura a la pantalla: plano y contraplano de una misma realidad - 97

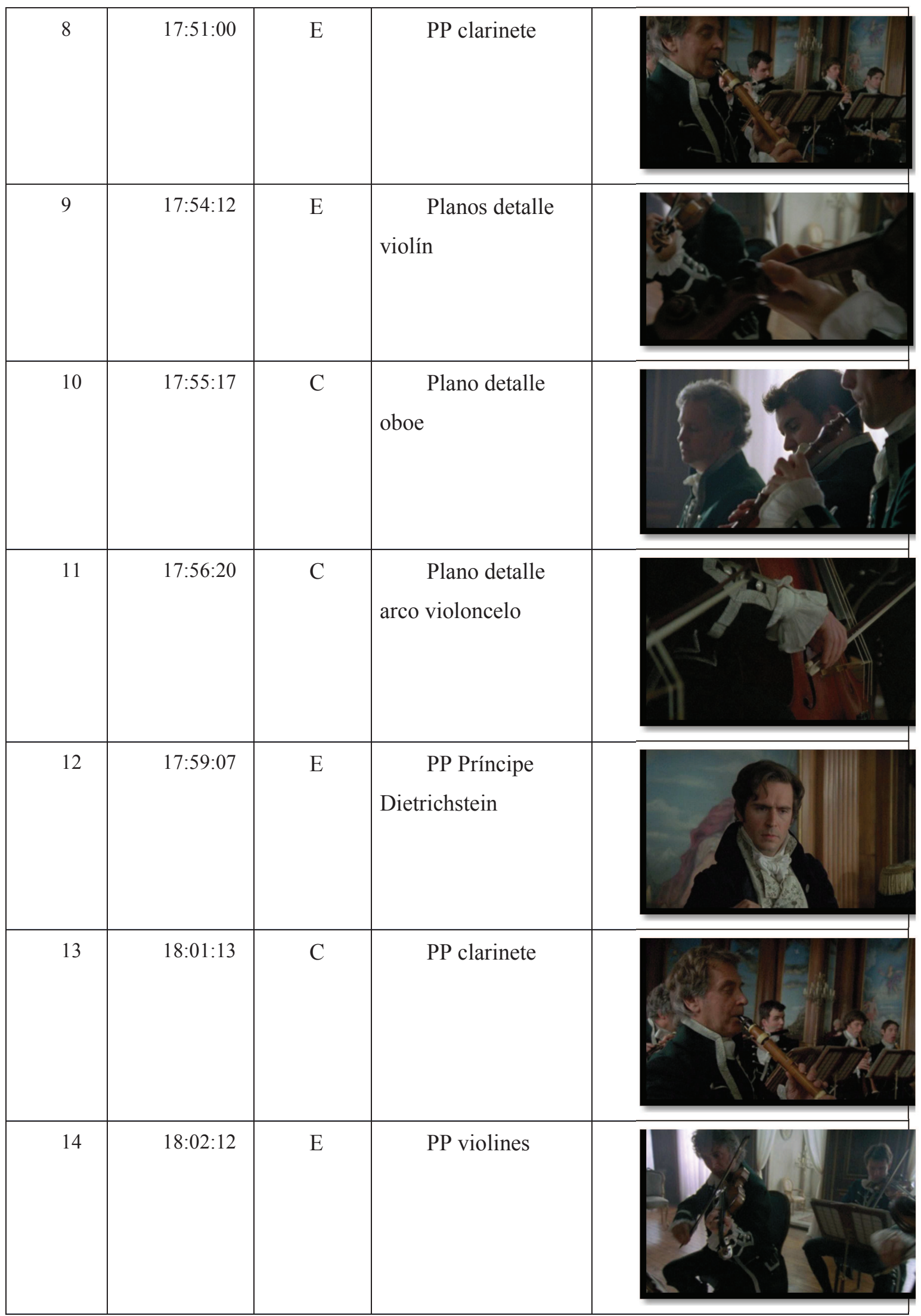


De la partitura a la pantalla: plano y contraplano de una misma realidad-98

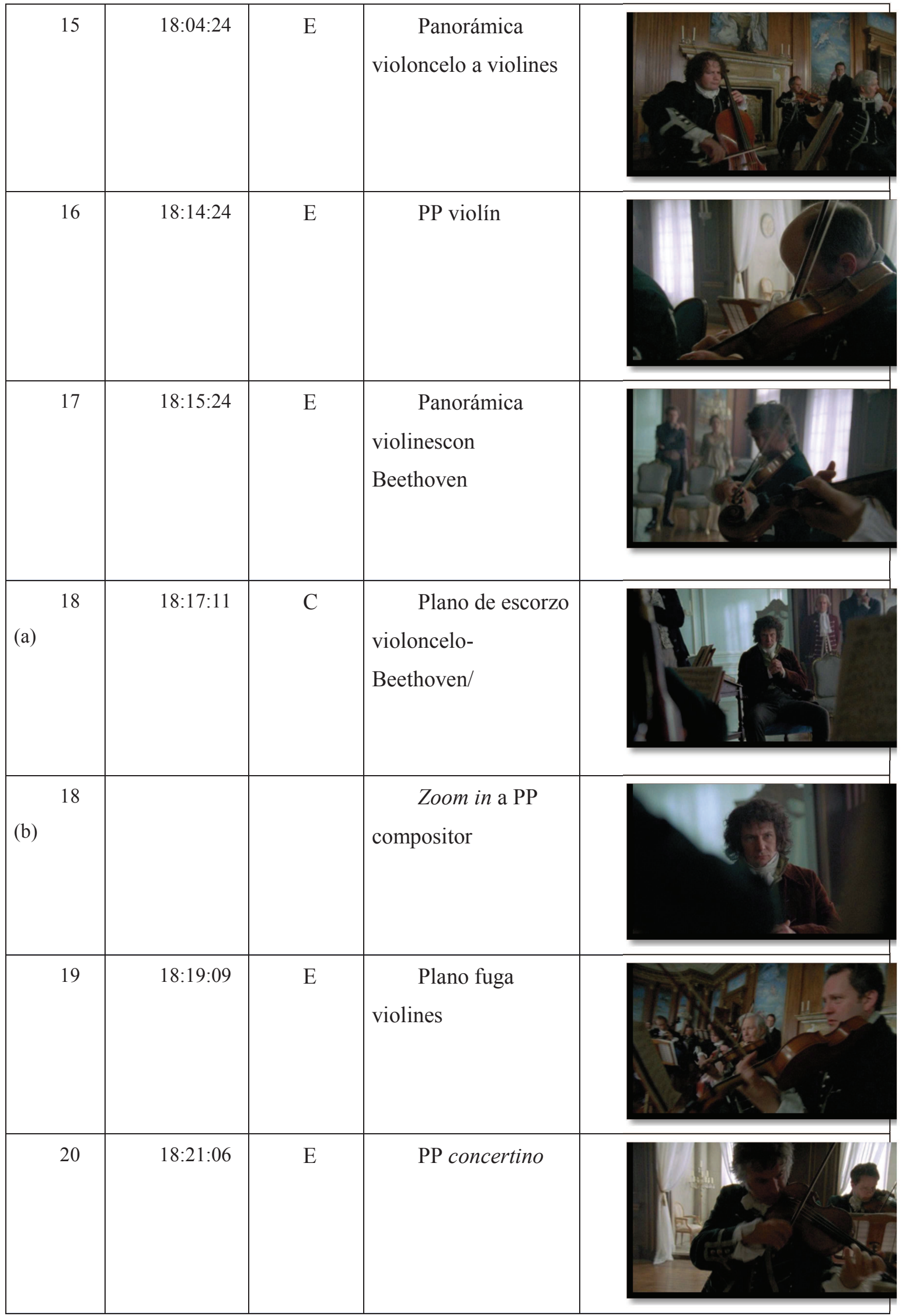


De la partitura a la pantalla: plano y contraplano de una misma realidad - 99

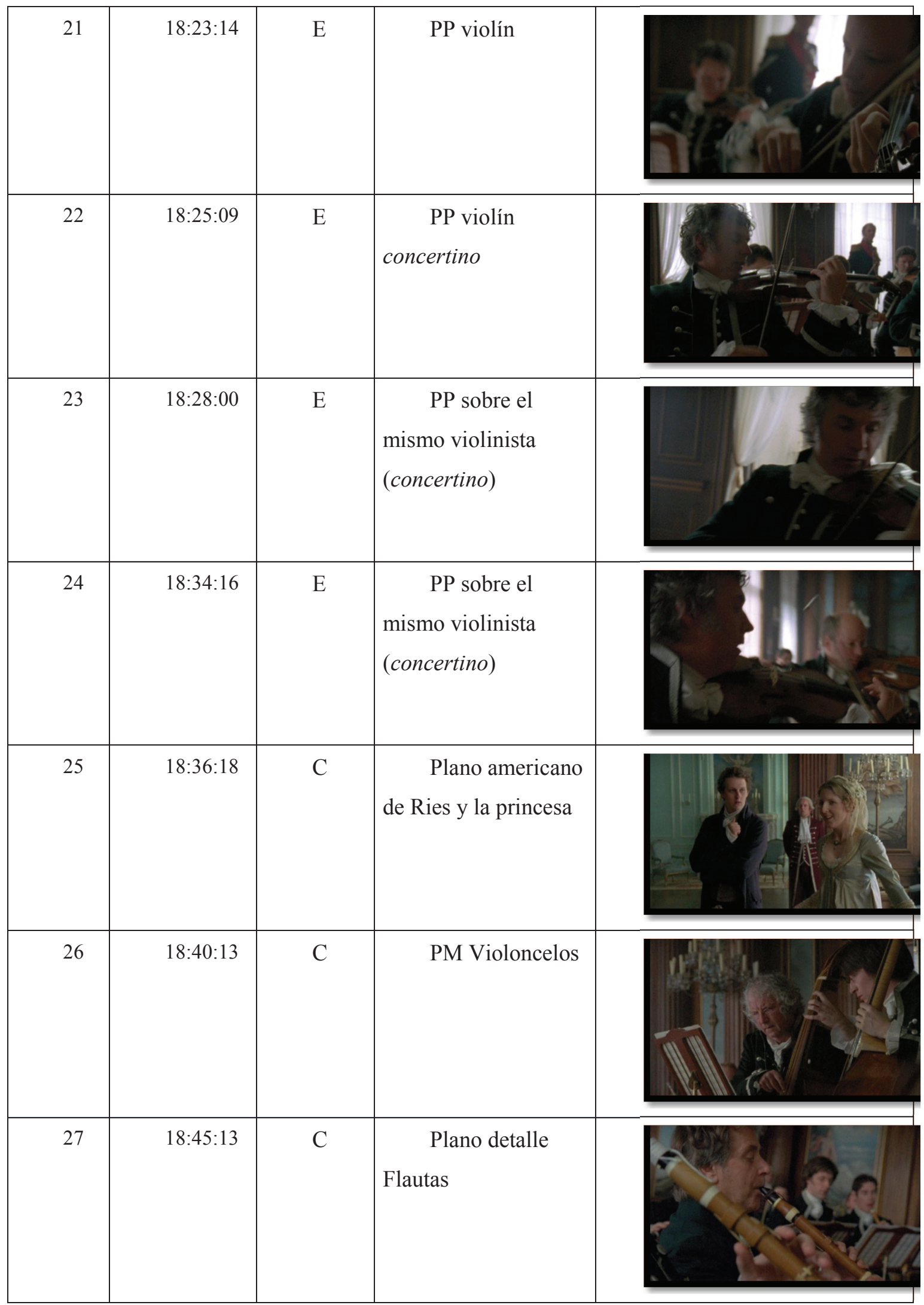




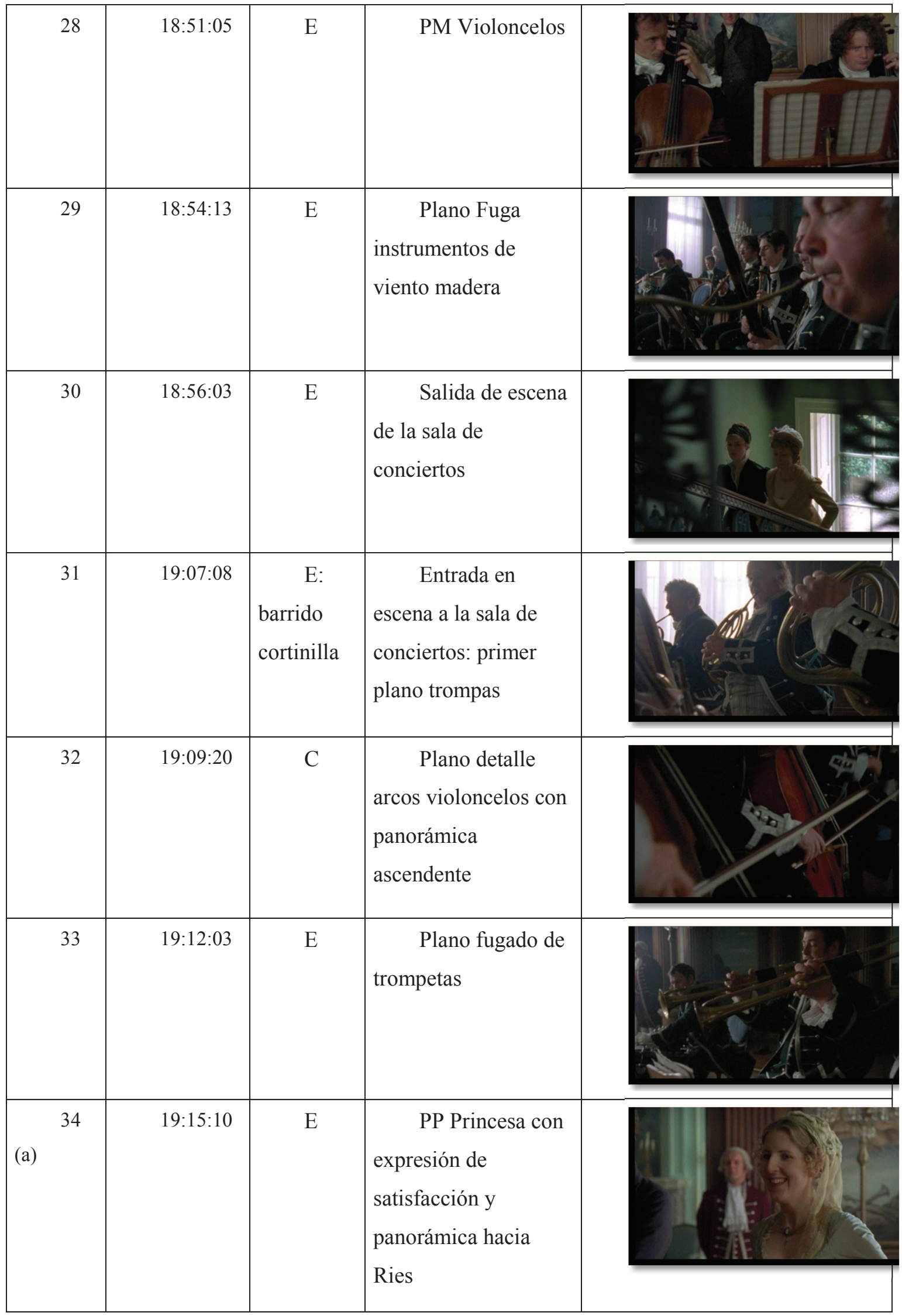




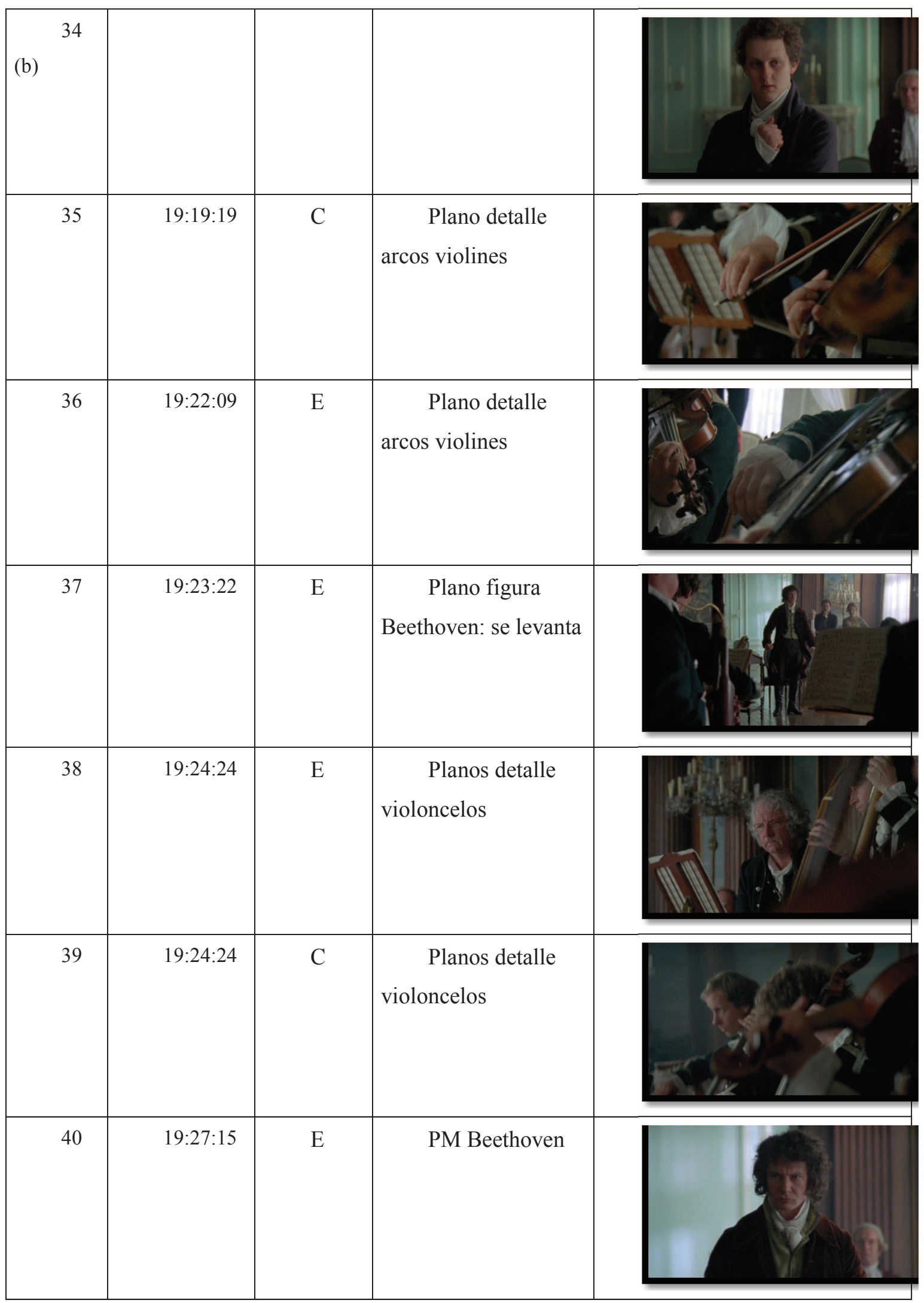


De la partitura a la pantalla: plano y contraplano de una misma realidad - 102

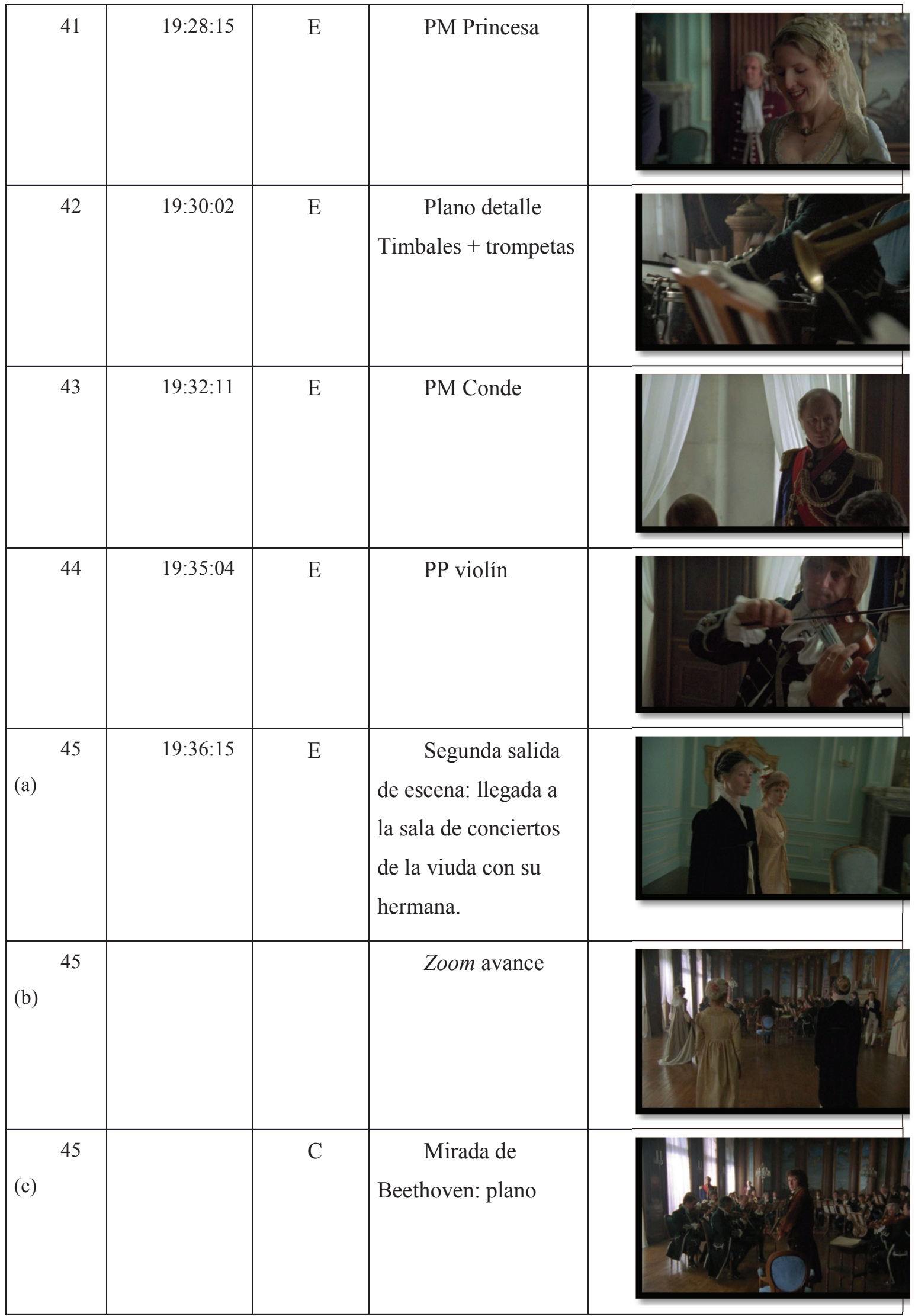


De la partitura a la pantalla: plano y contraplano de una misma realidad - 103

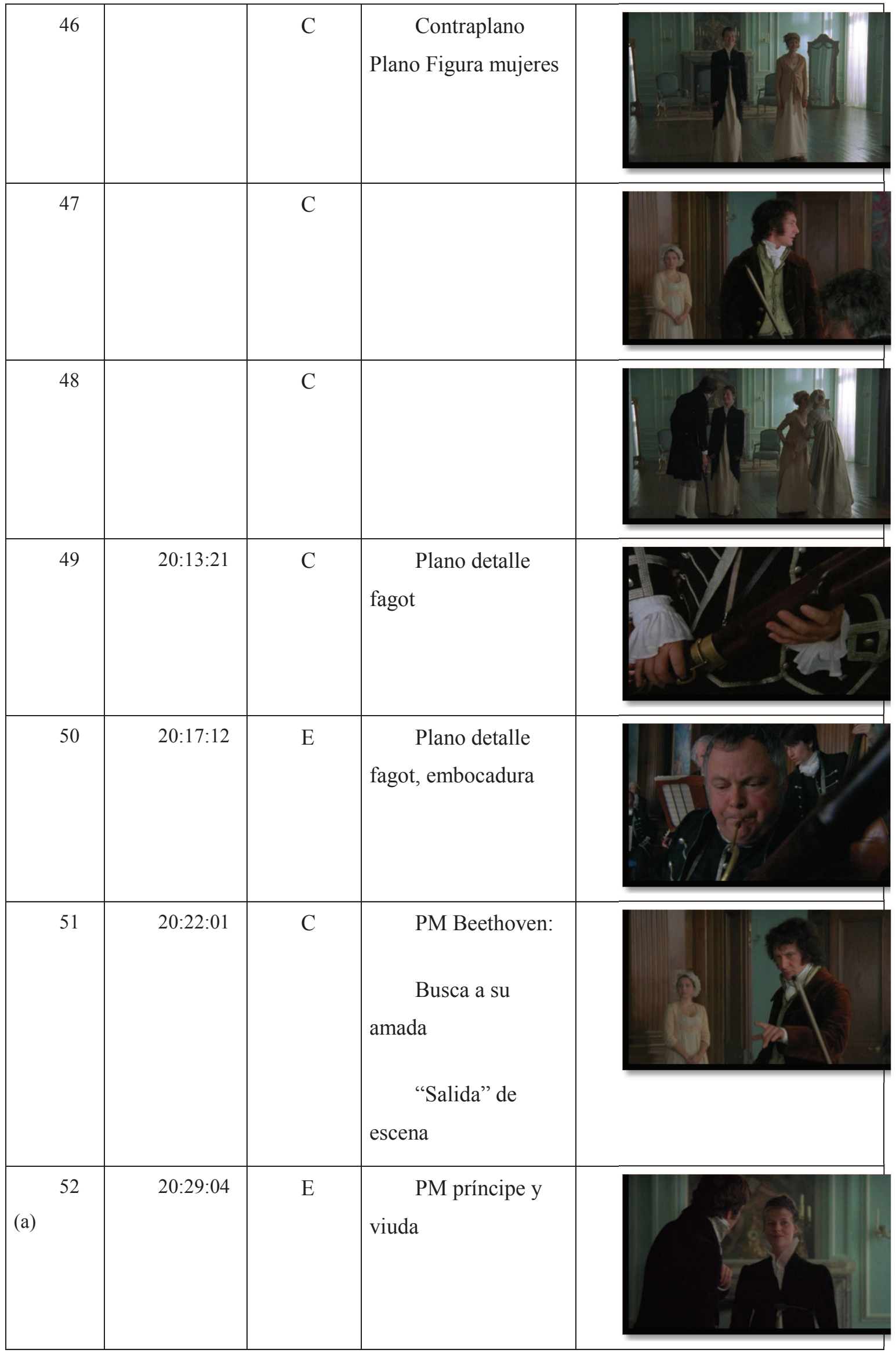




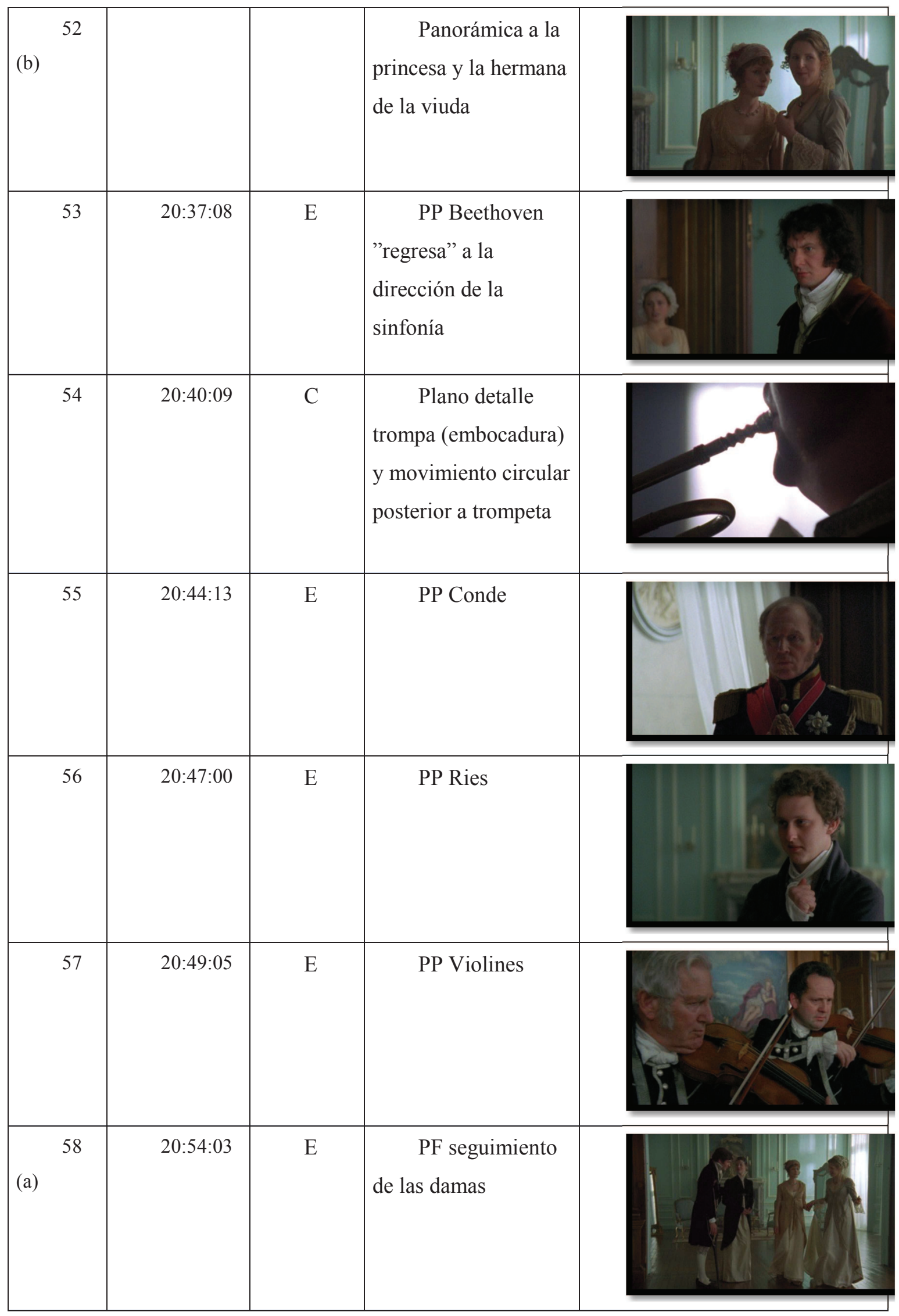




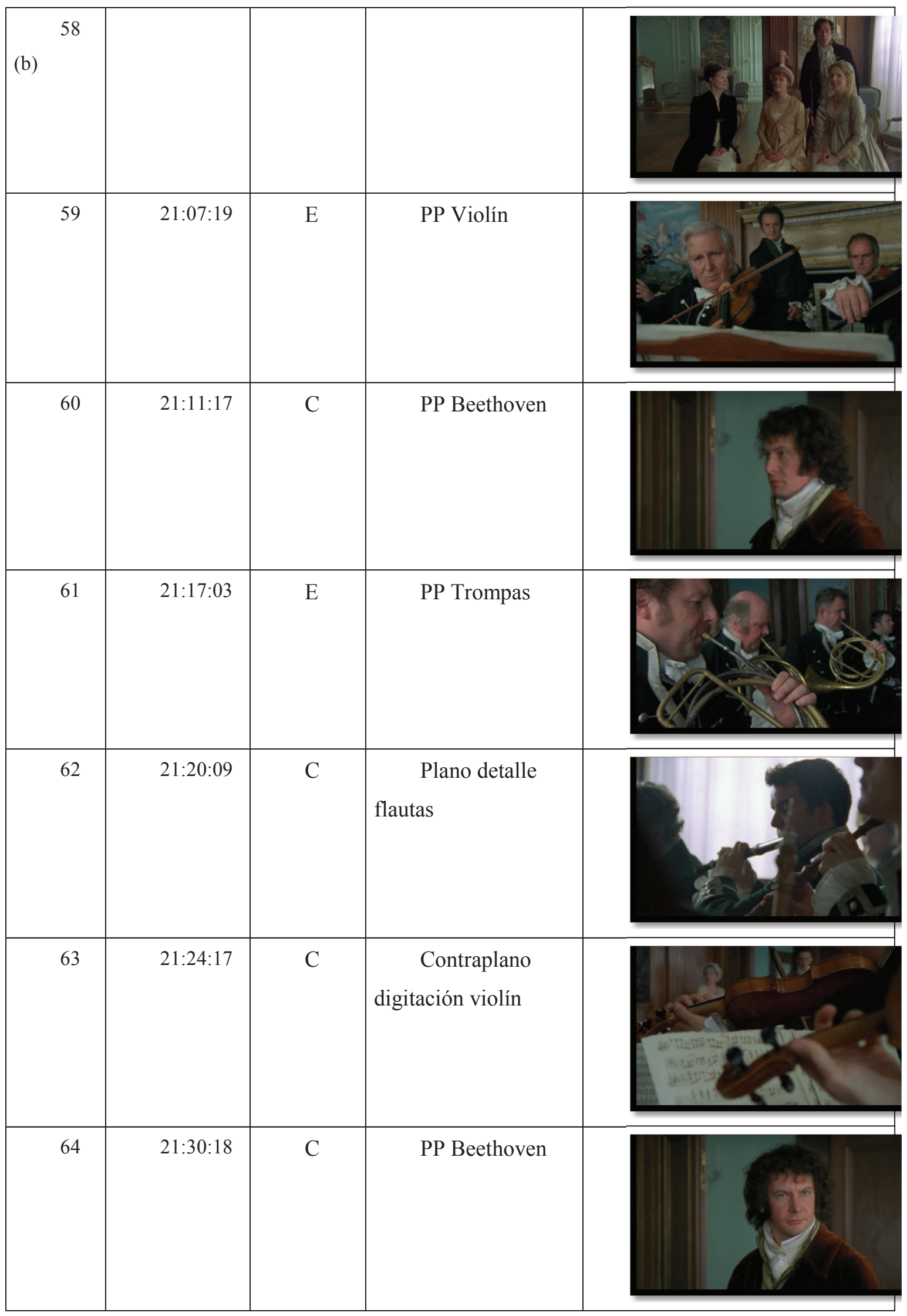




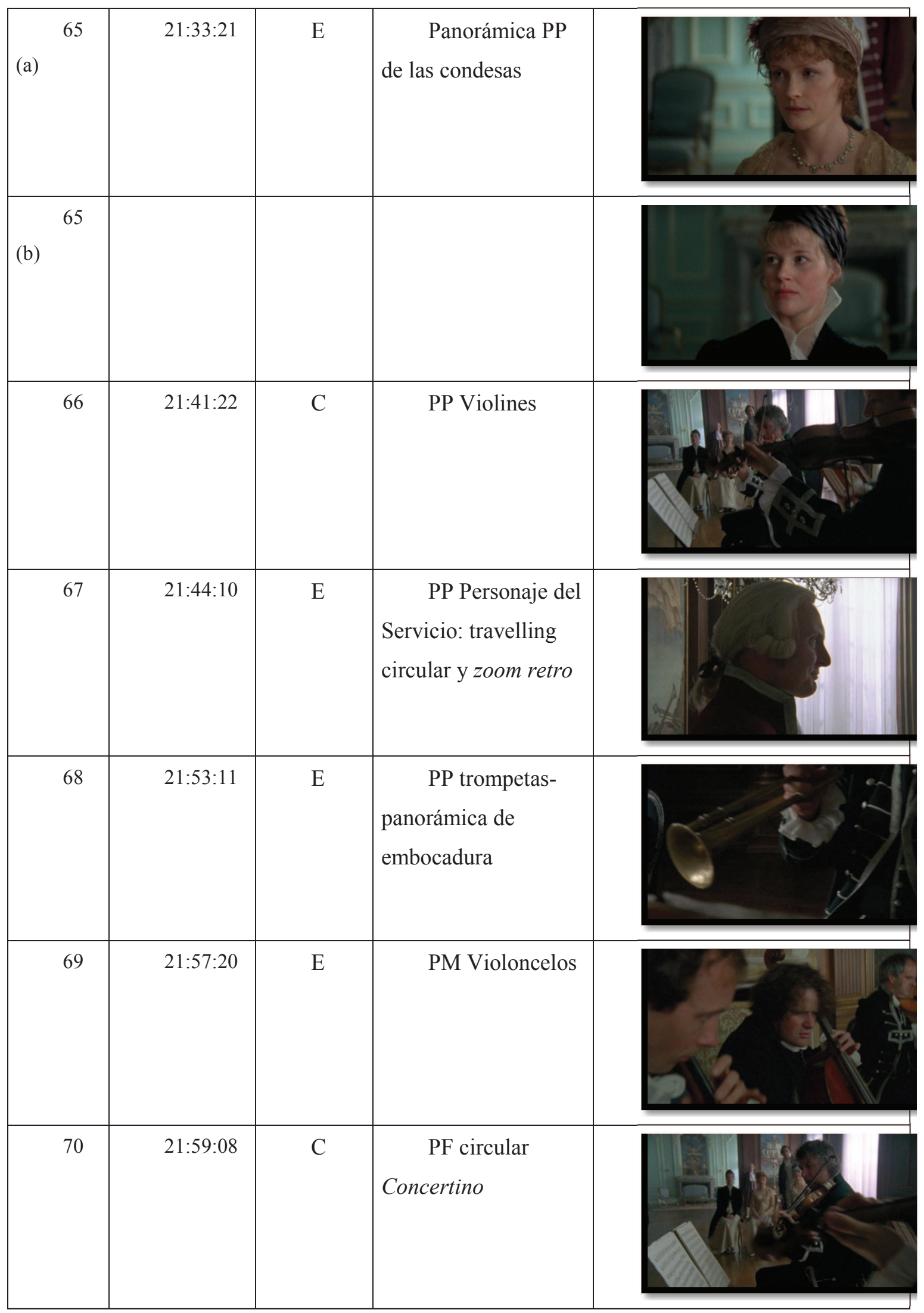


De la partitura a la pantalla: plano y contraplano de una misma realidad - 107

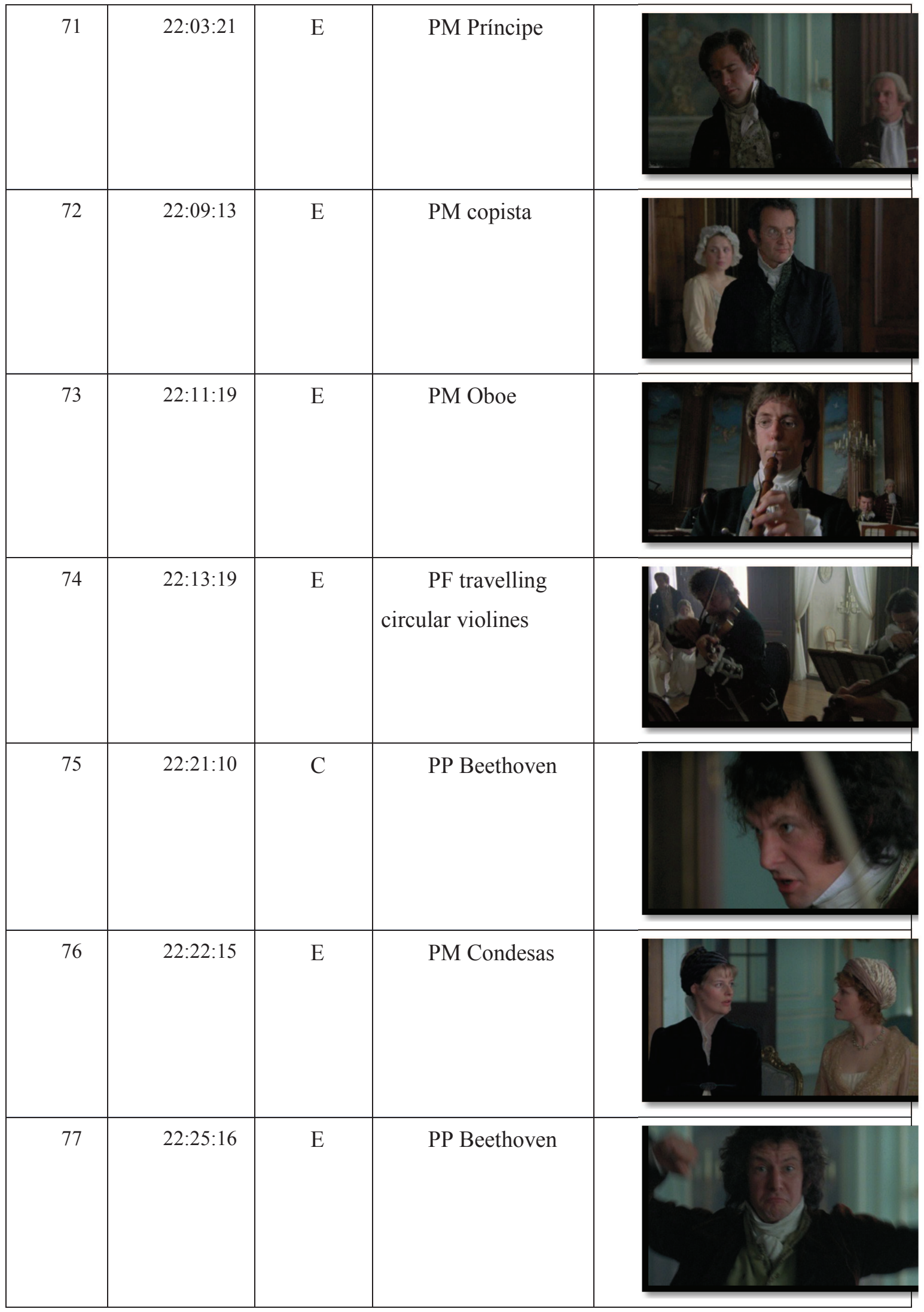




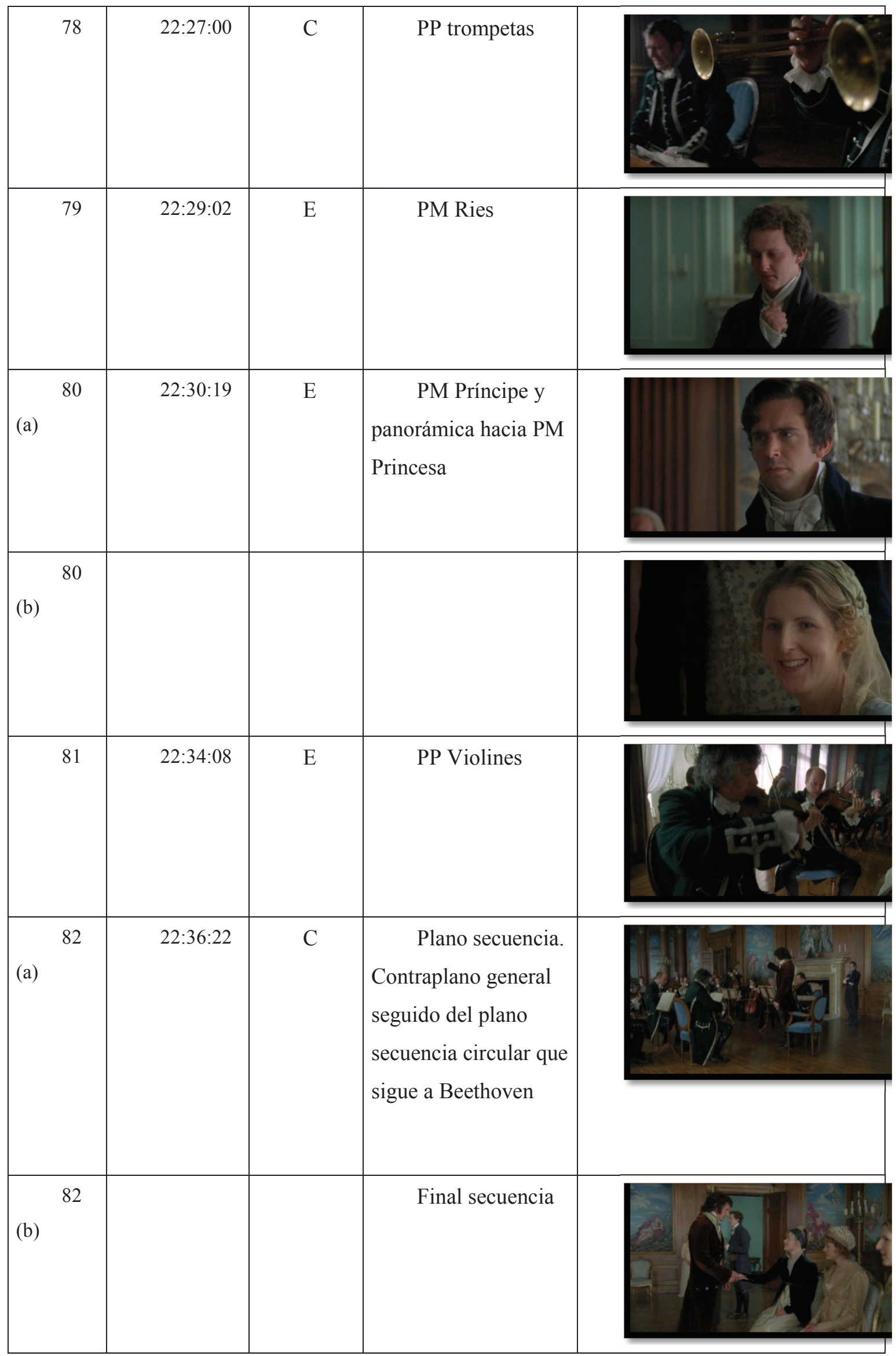


De la partitura a la pantalla: plano y contraplano de una misma realidad - 109

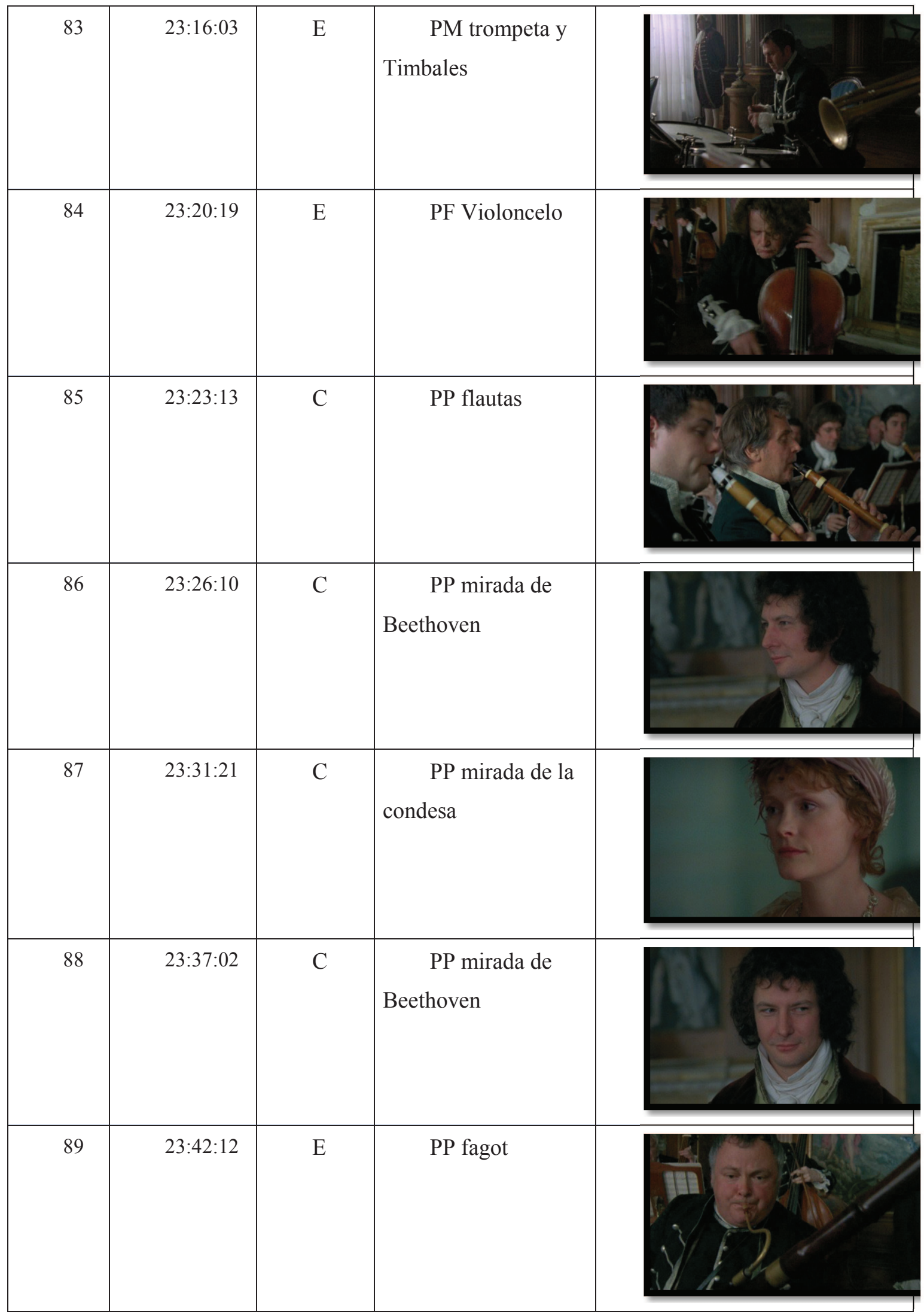




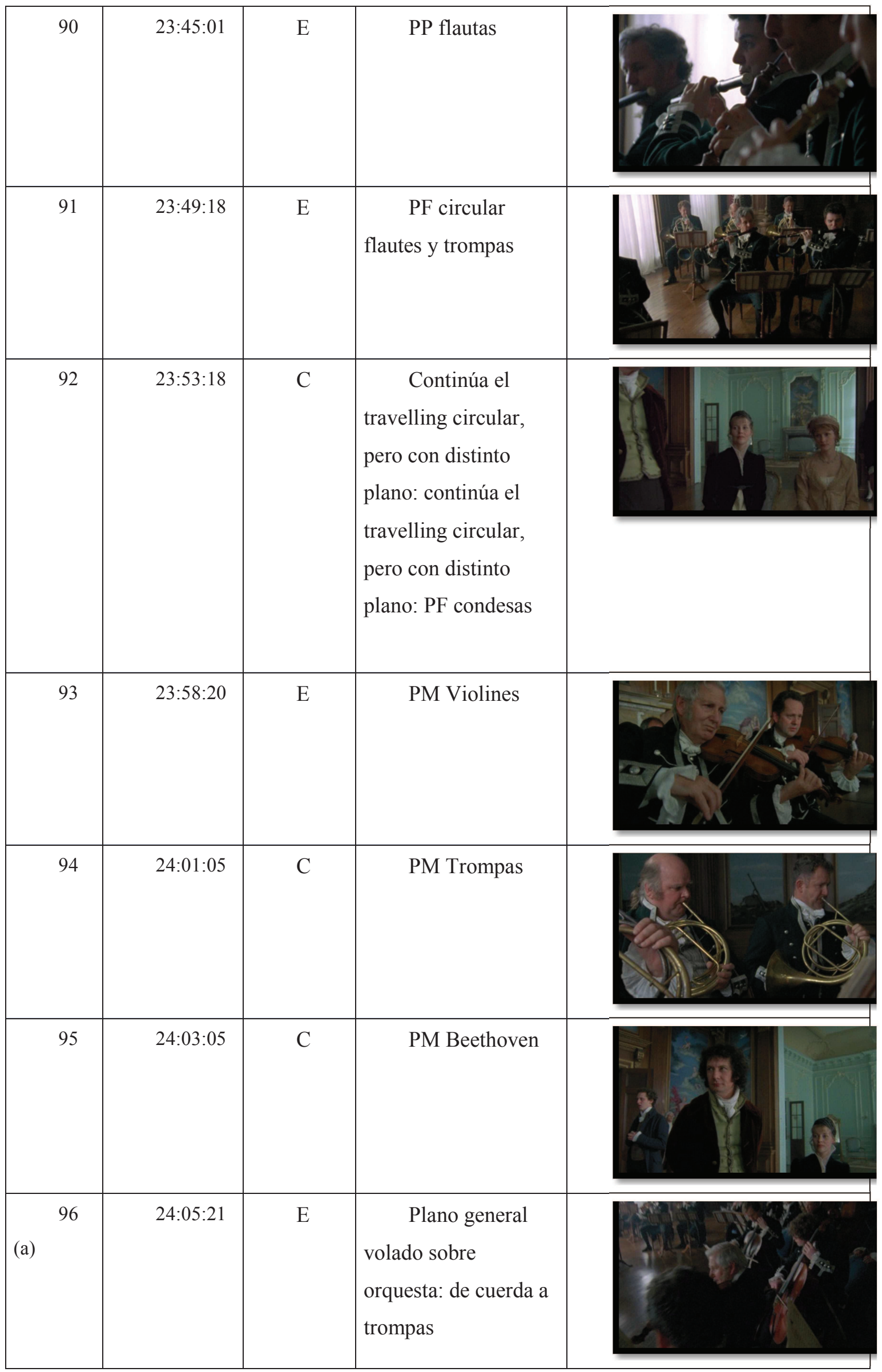


De la partitura a la pantalla: plano y contraplano de una misma realidad - 111

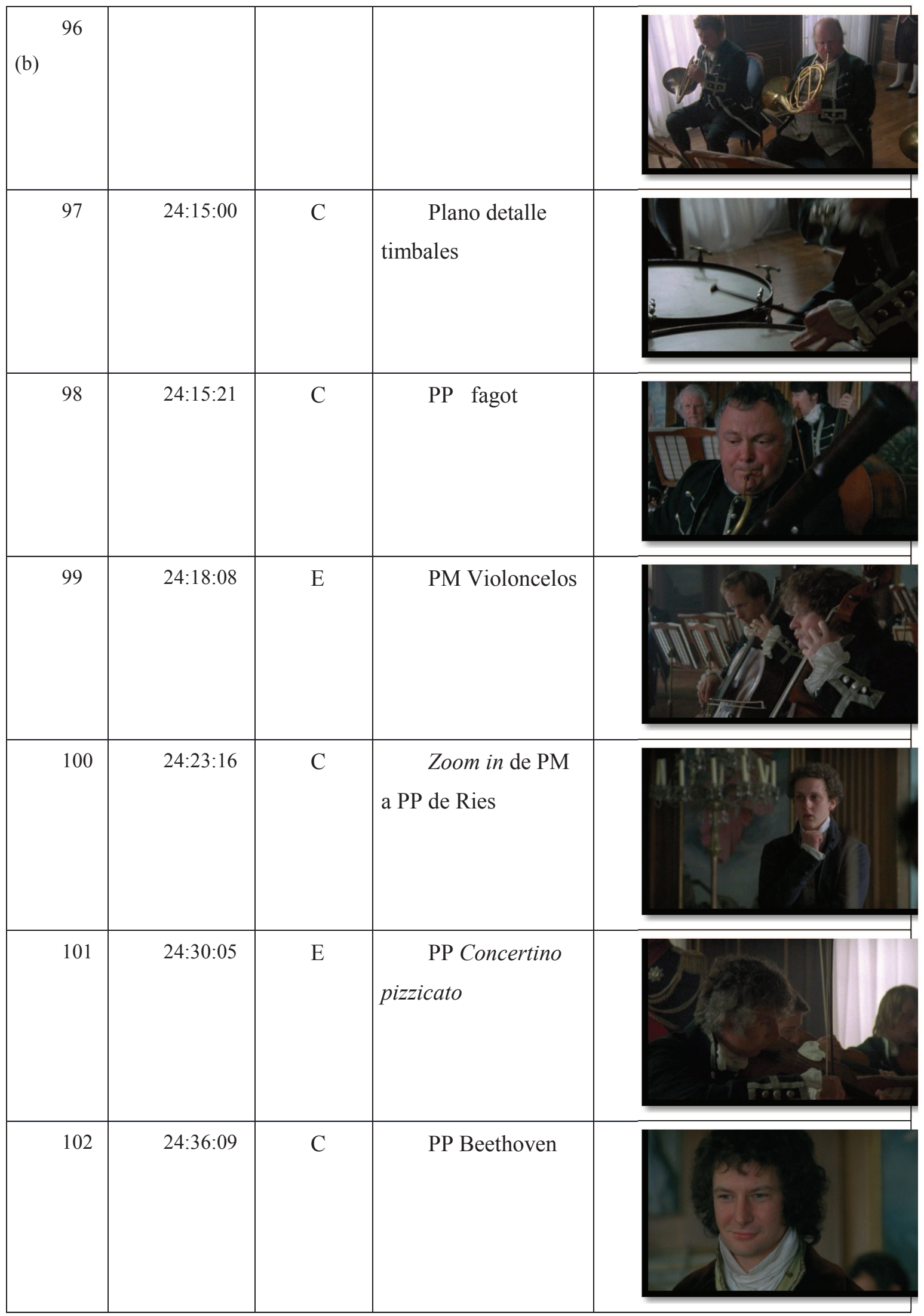


De la partitura a la pantalla: plano y contraplano de una misma realidad - 112

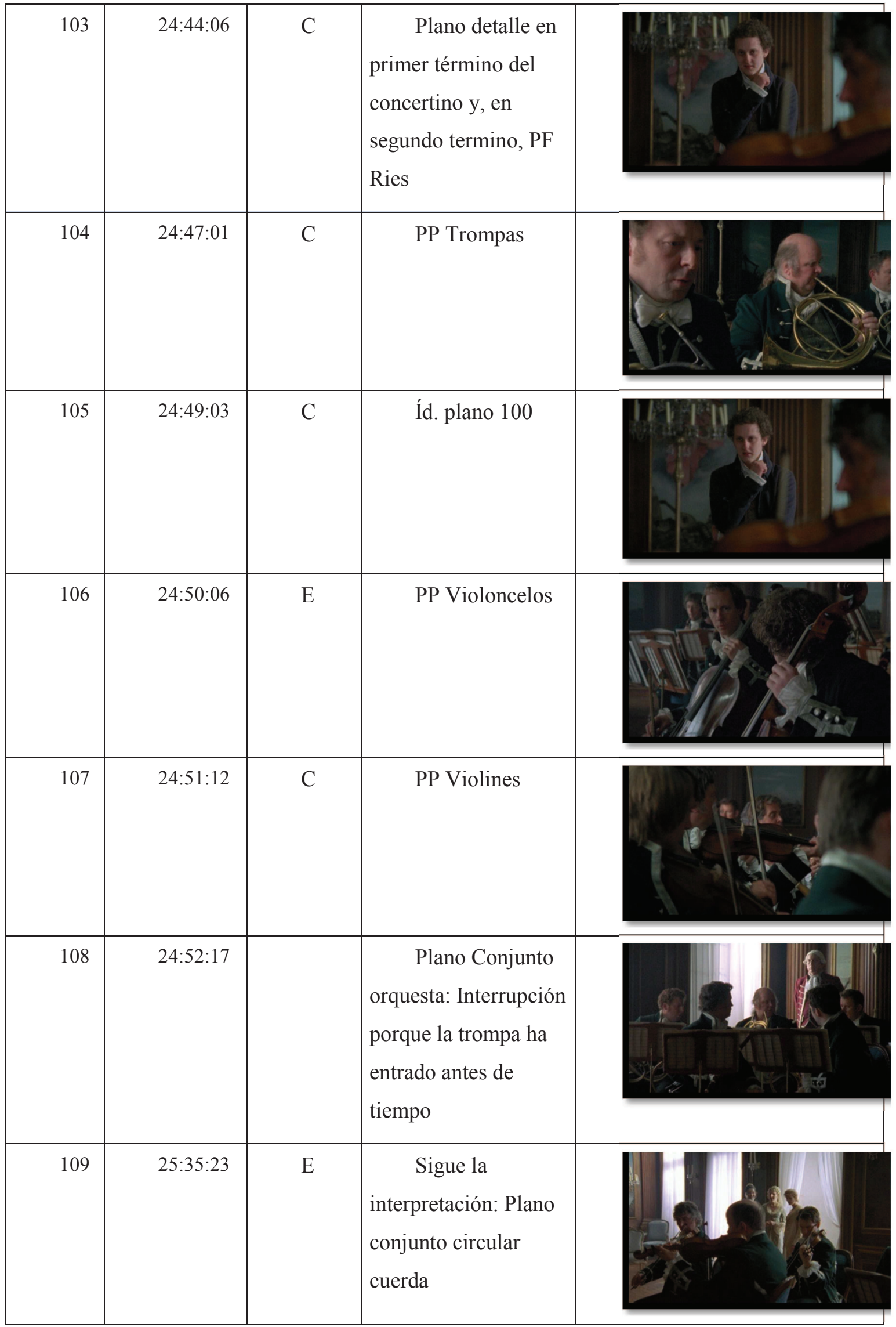


De la partitura a la pantalla: plano y contraplano de una misma realidad - 113

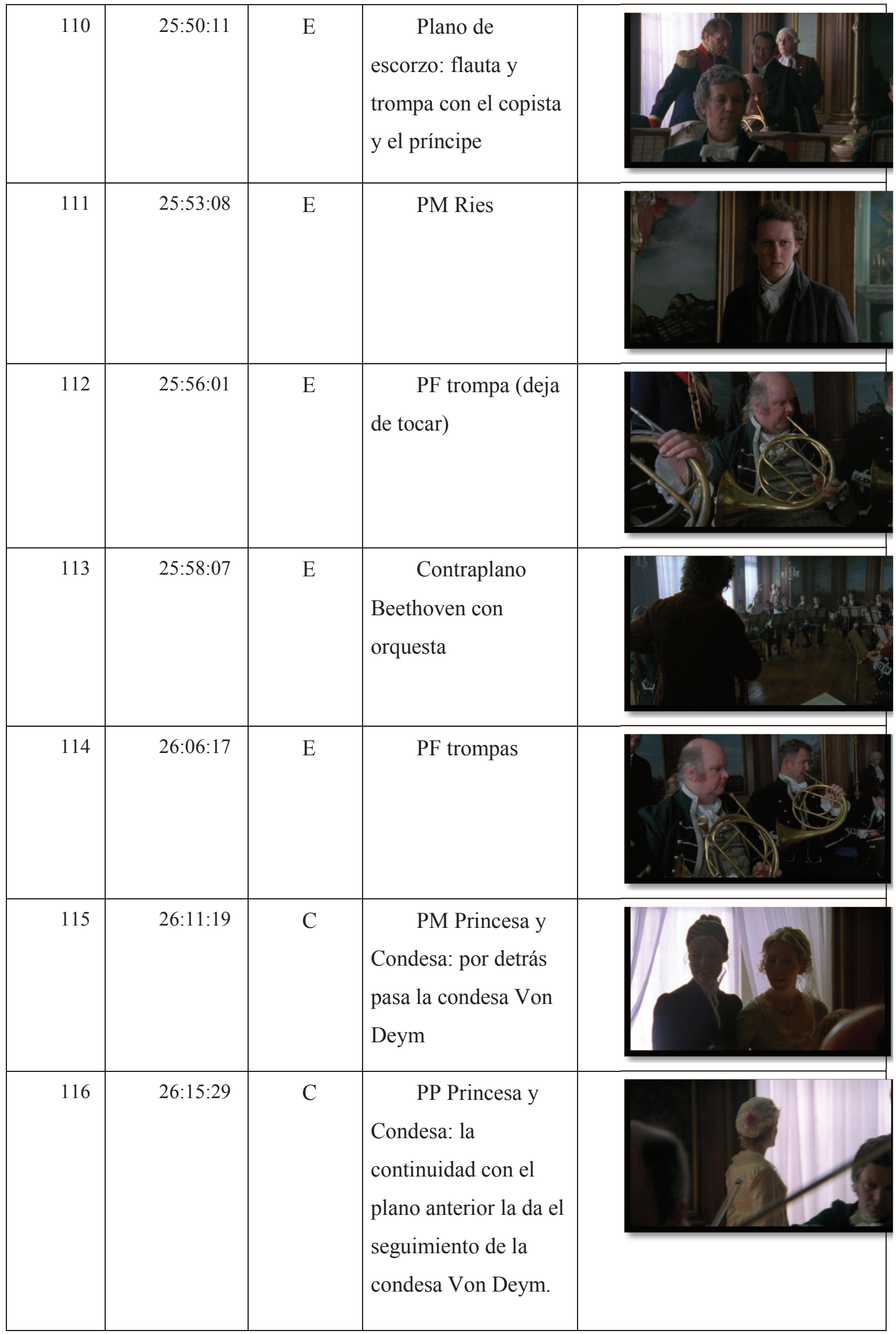


De la partitura a la pantalla: plano y contraplano de una misma realidad - 114

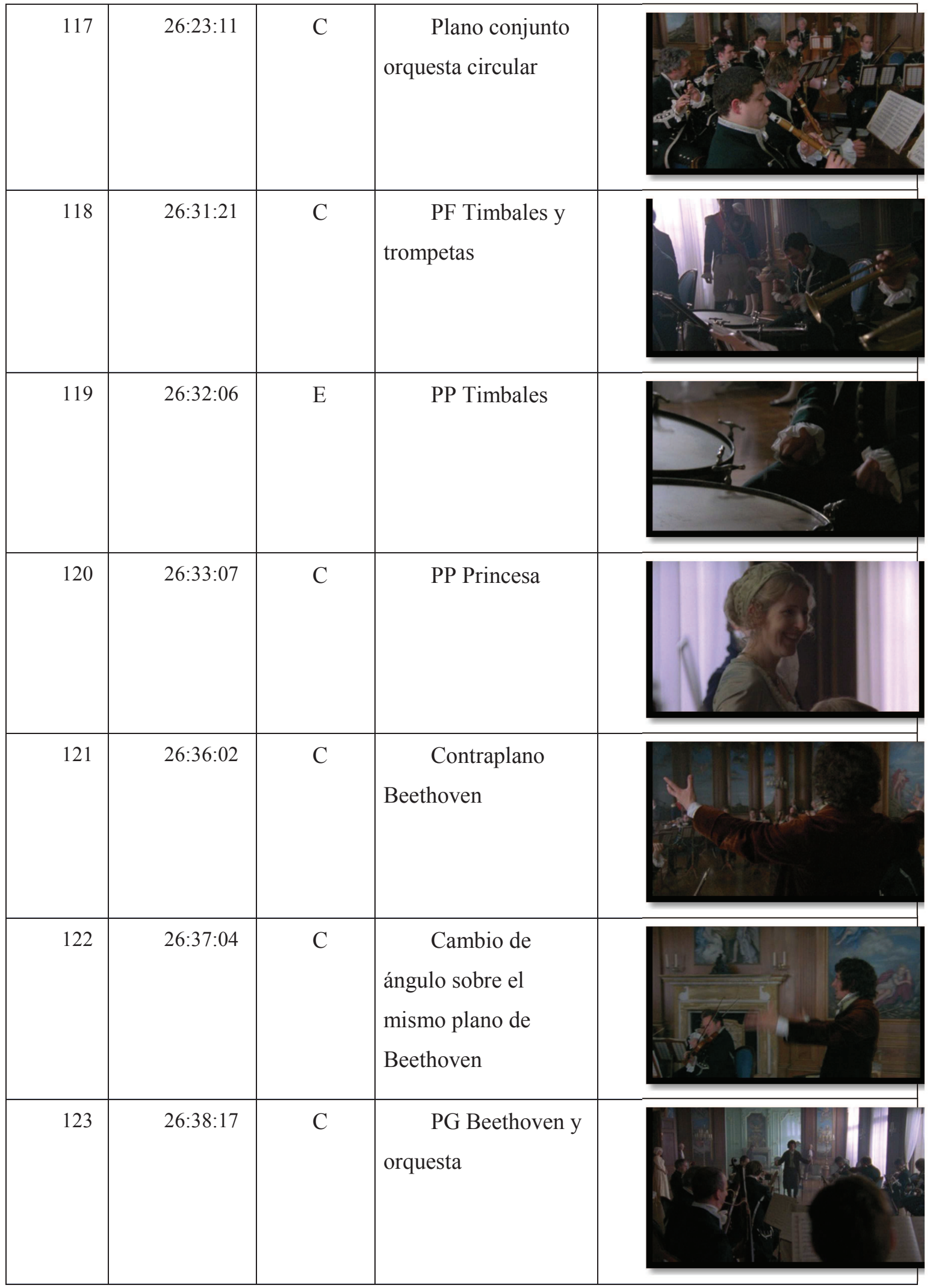


De la partitura a la pantalla: plano y contraplano de una misma realidad - 115

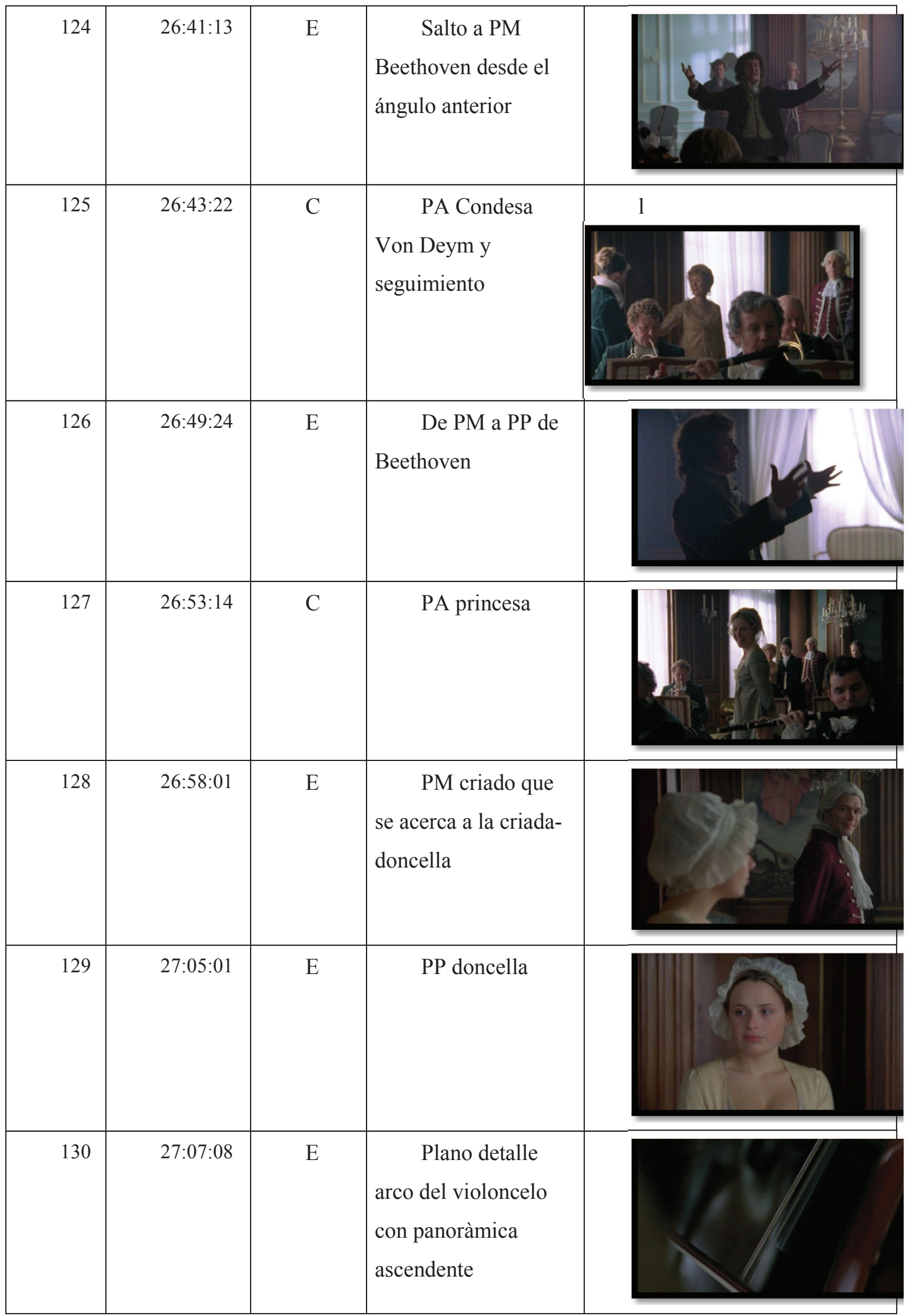


De la partitura a la pantalla: plano y contraplano de una misma realidad - 116

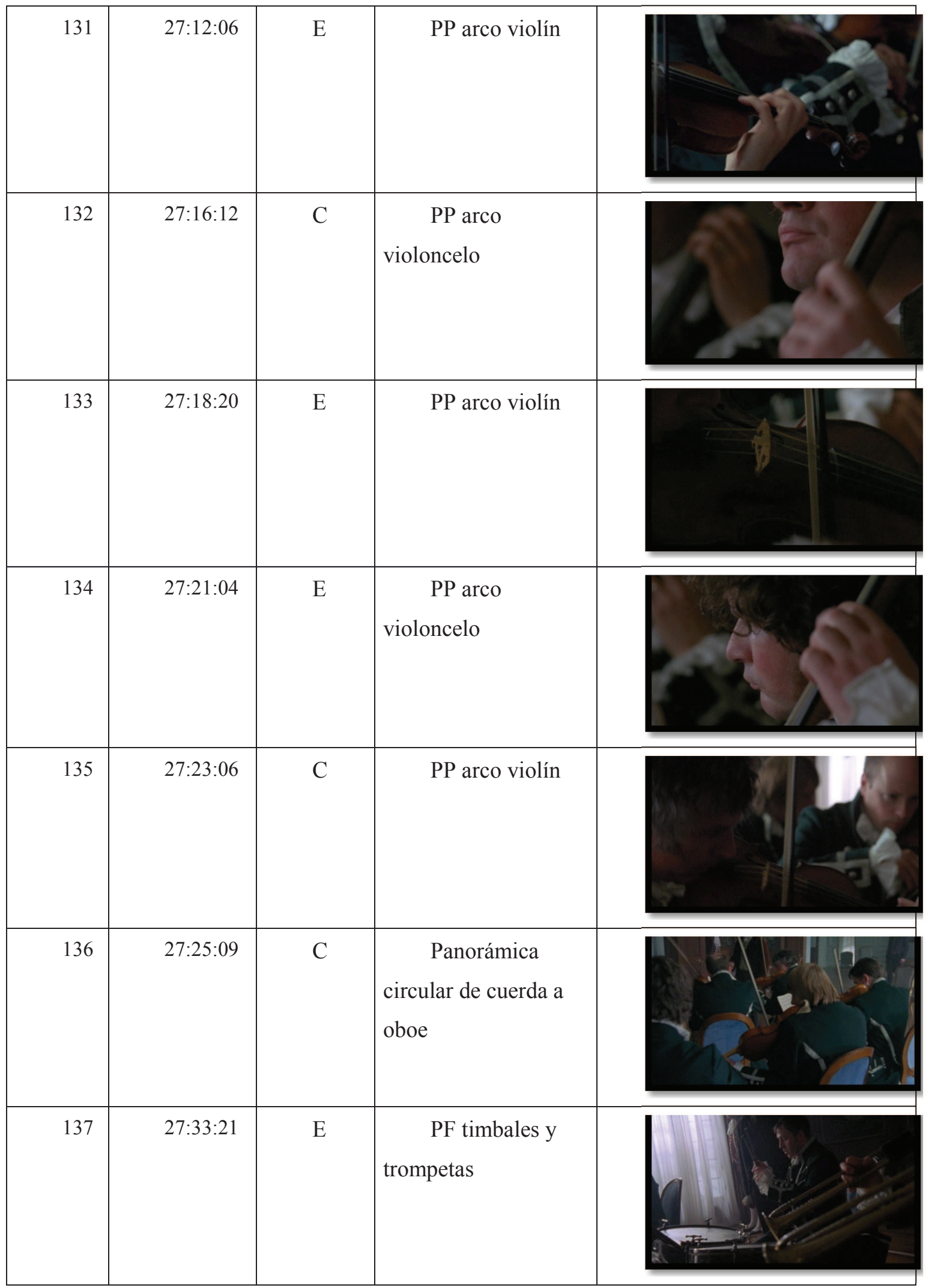


De la partitura a la pantalla: plano y contraplano de una misma realidad - 117

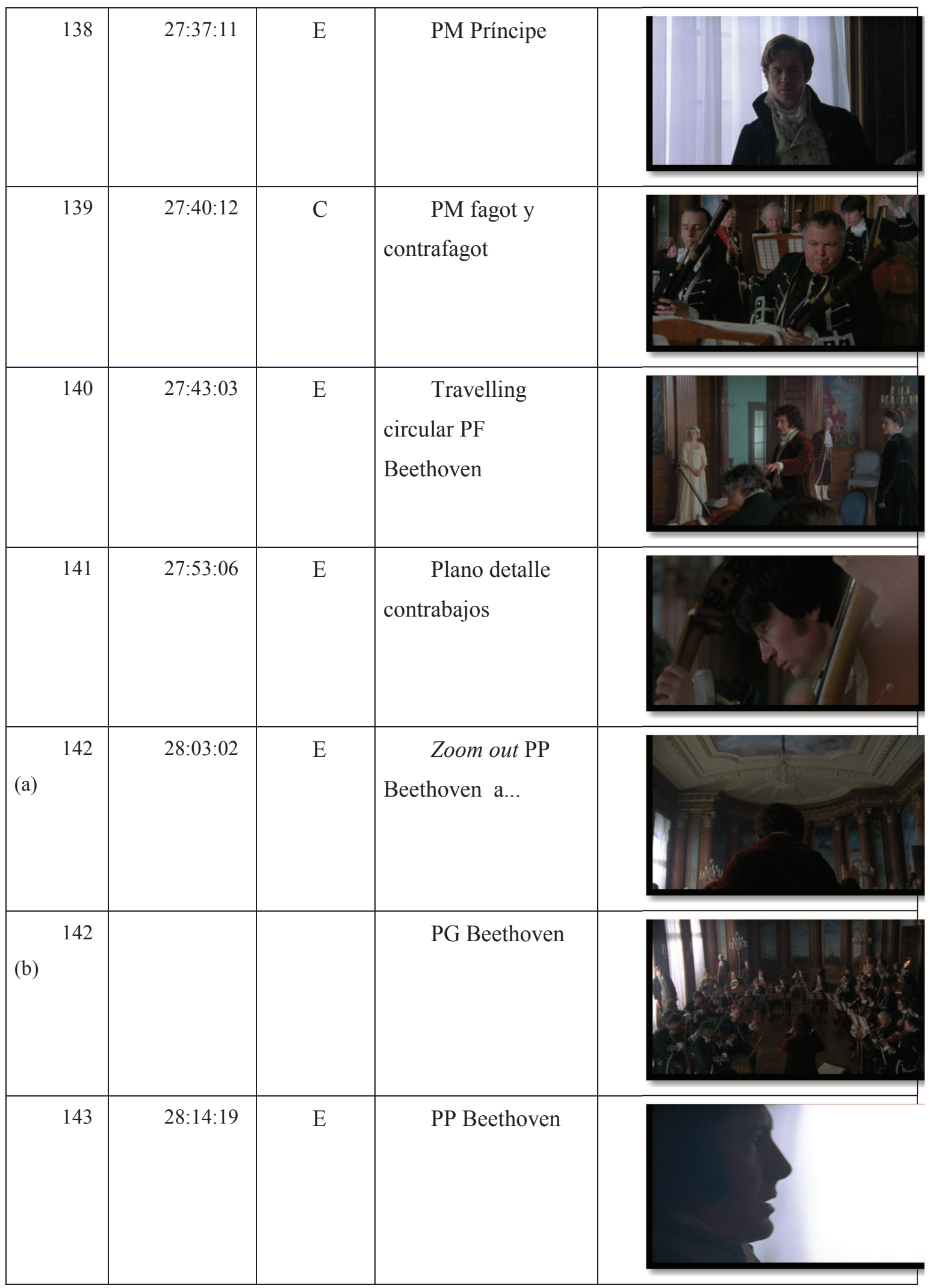


De la partitura a la pantalla: plano y contraplano de una misma realidad - 118

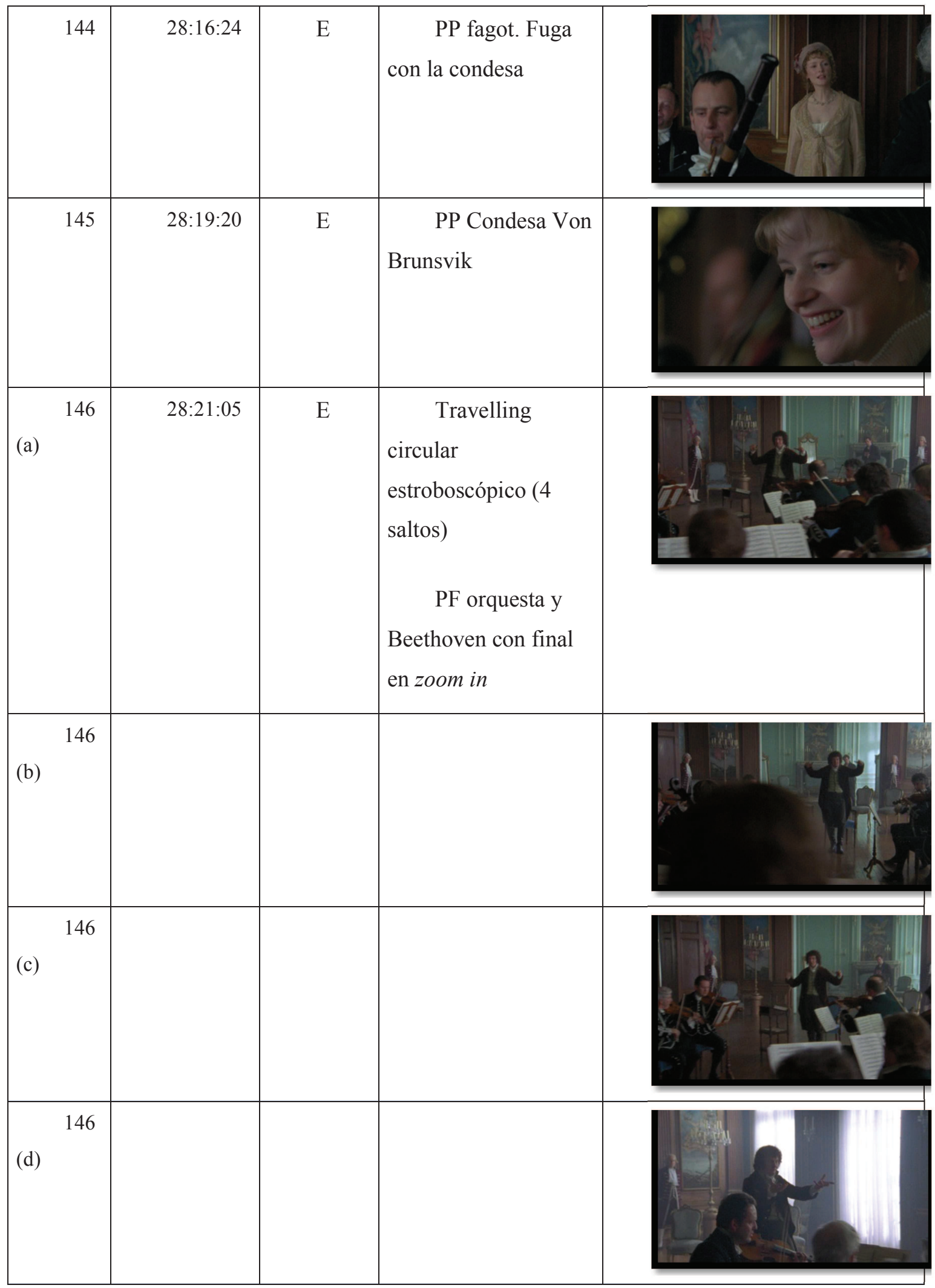


De la partitura a la pantalla: plano y contraplano de una misma realidad - 119

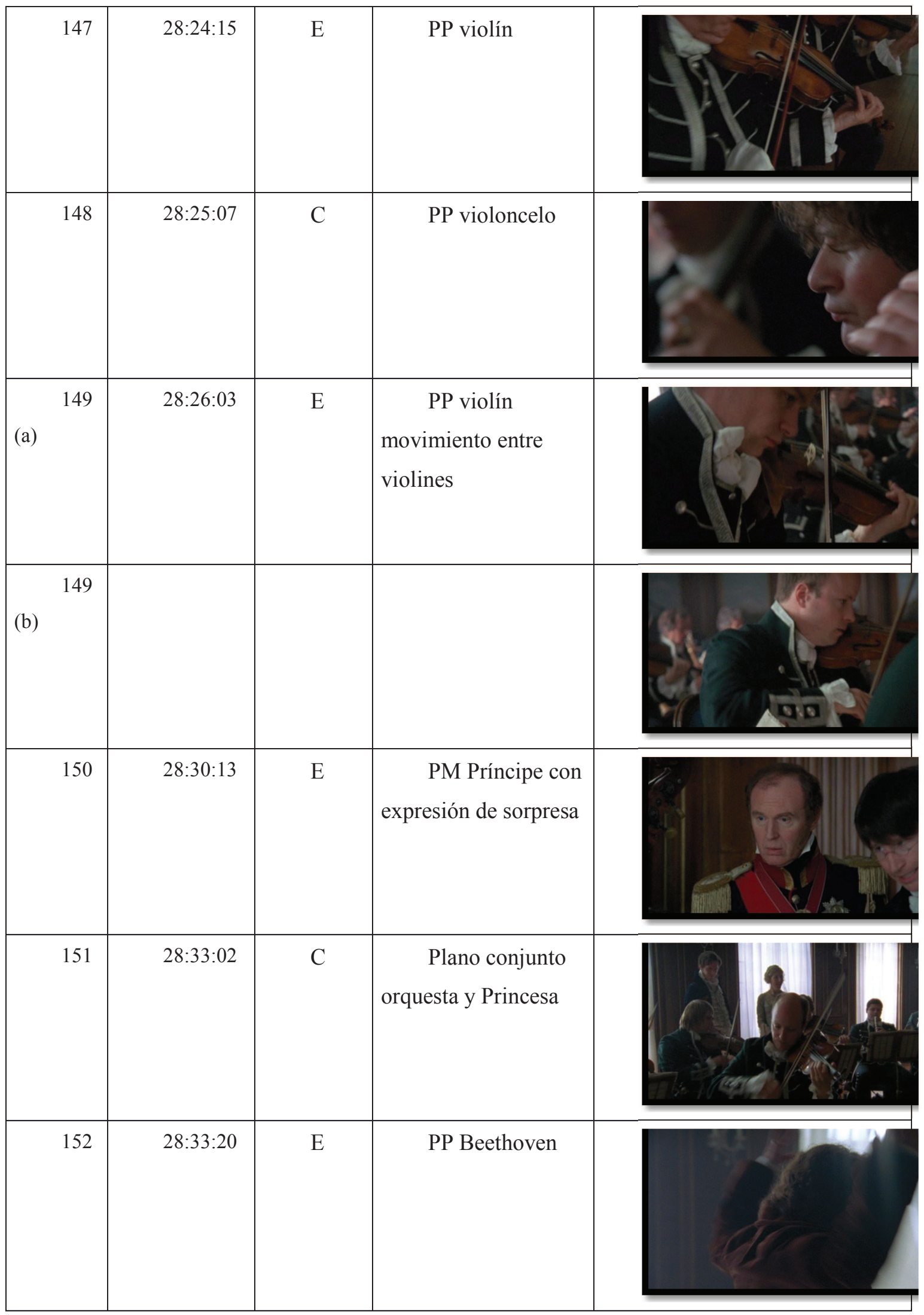


De la partitura a la pantalla: plano y contraplano de una misma realidad - 120

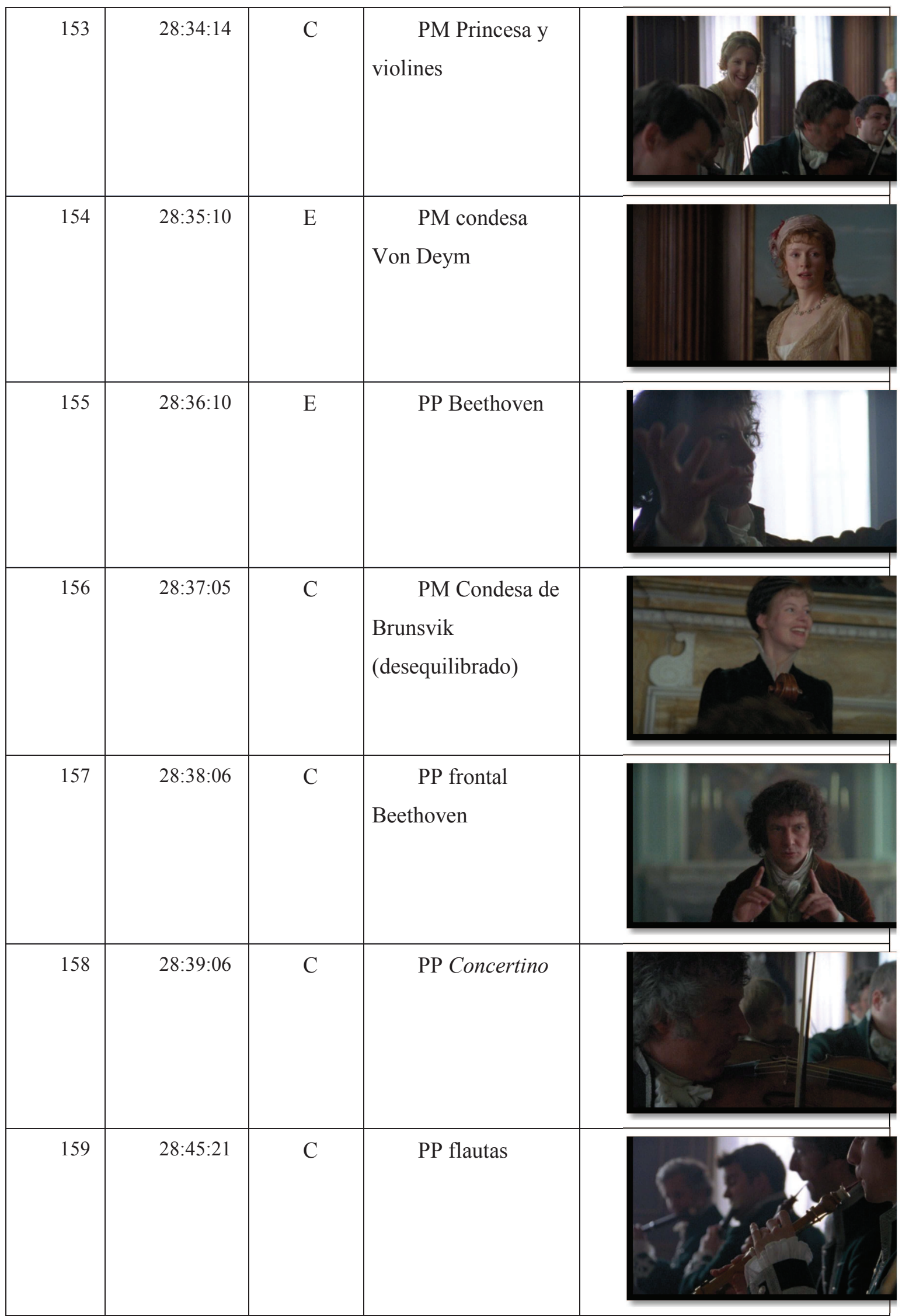


De la partitura a la pantalla: plano y contraplano de una misma realidad - 121

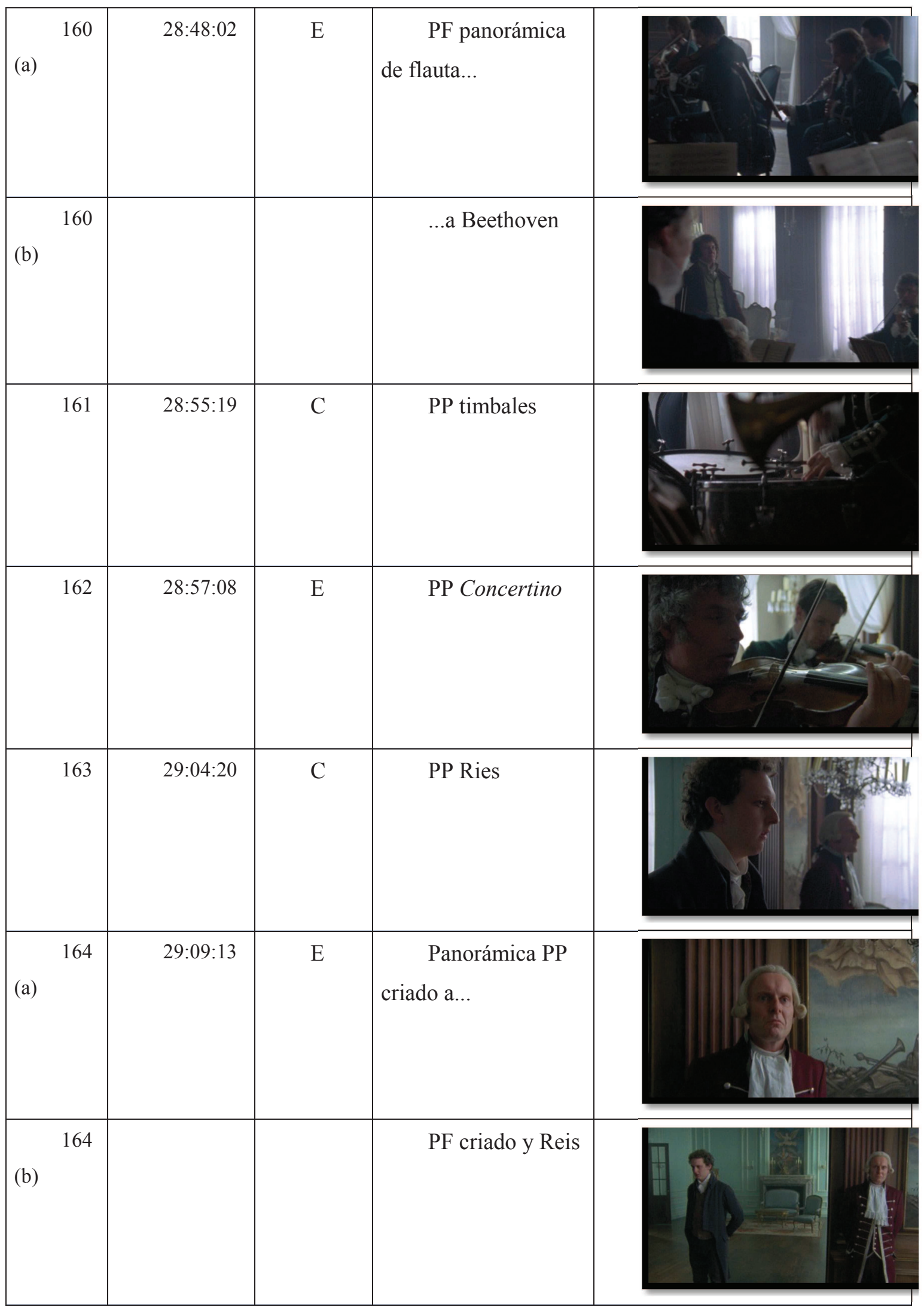


De la partitura a la pantalla: plano y contraplano de una misma realidad - 122

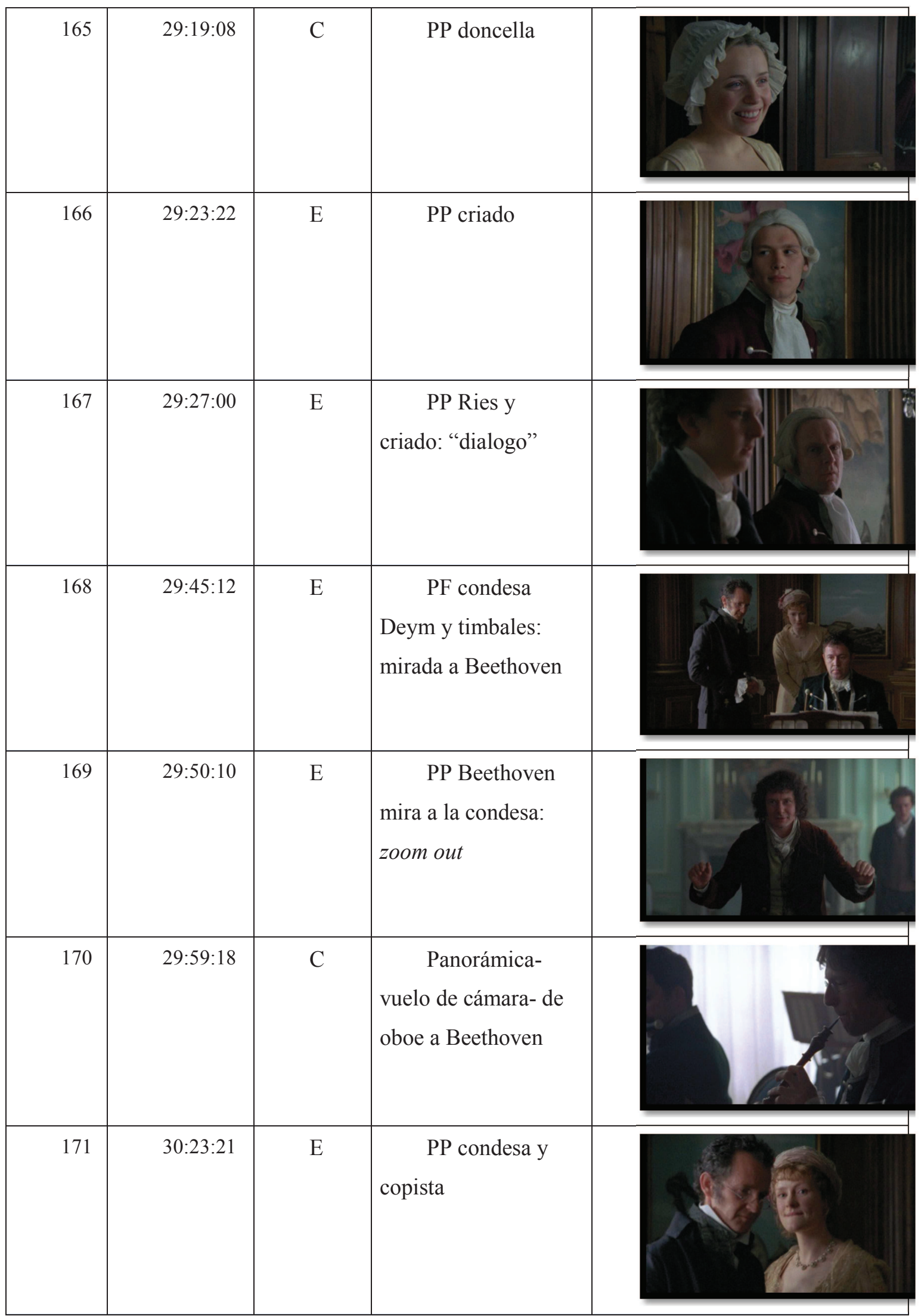


De la partitura a la pantalla: plano y contraplano de una misma realidad - 123

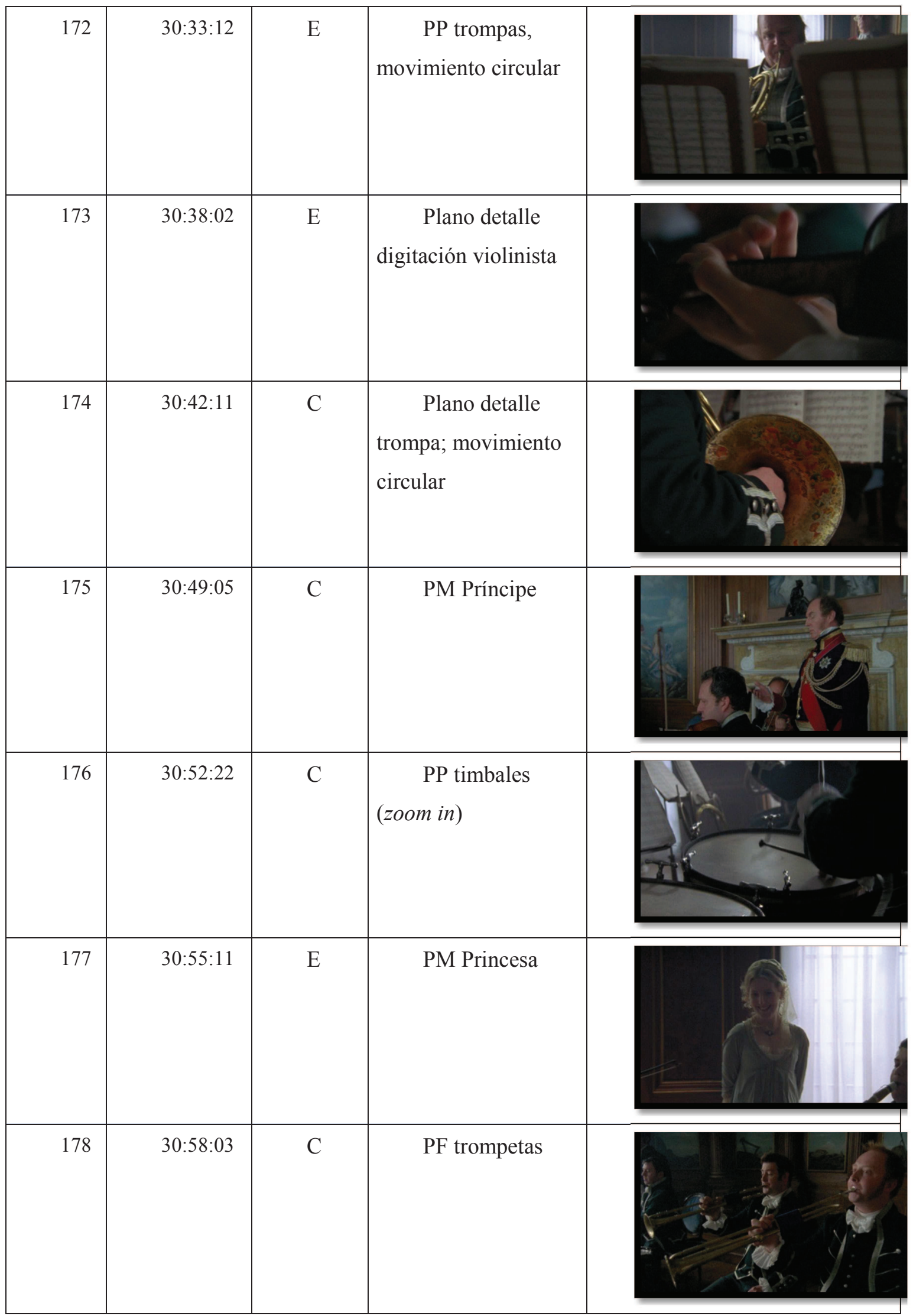


De la partitura a la pantalla: plano y contraplano de una misma realidad - 124

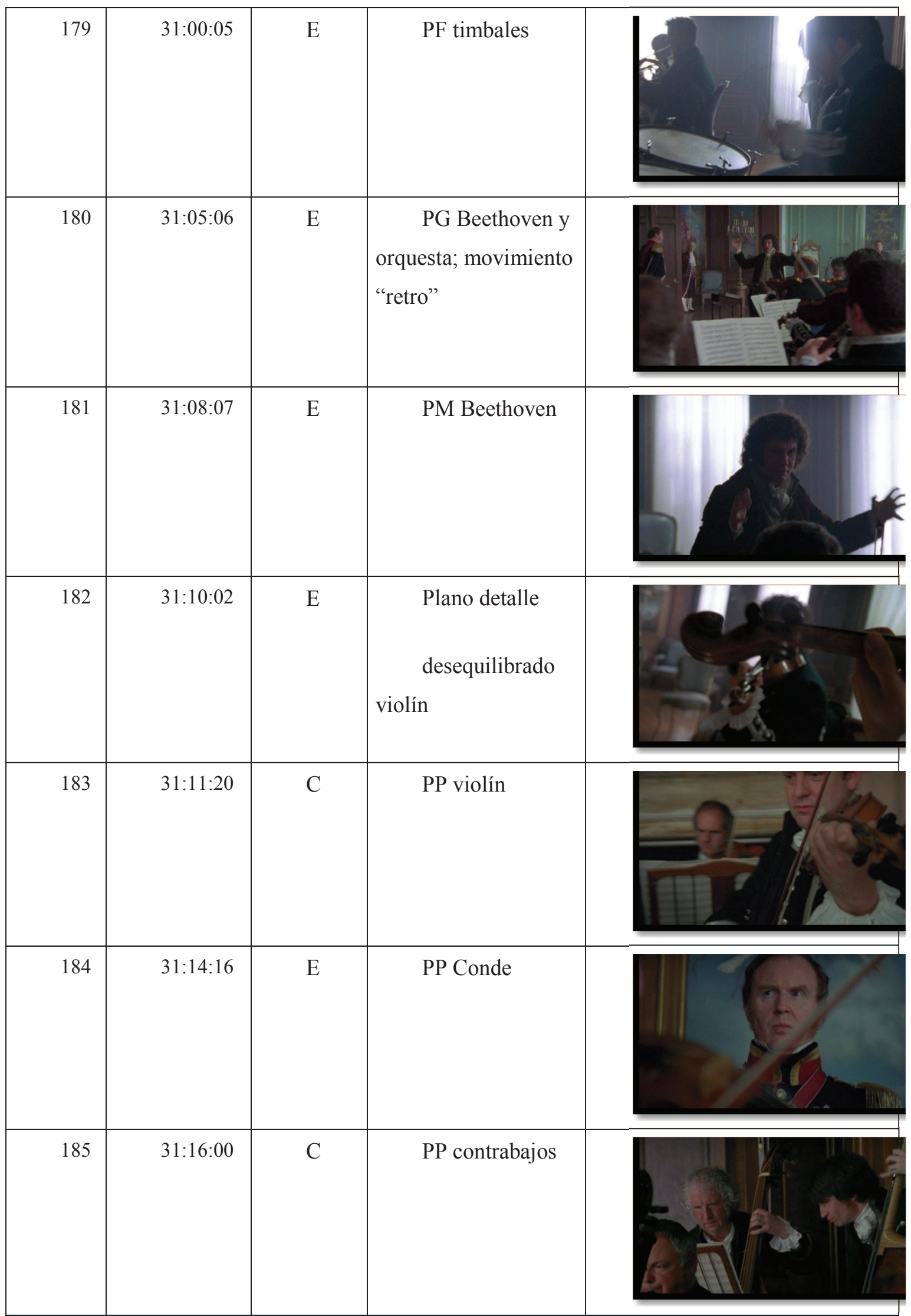


De la partitura a la pantalla: plano y contraplano de una misma realidad - 125

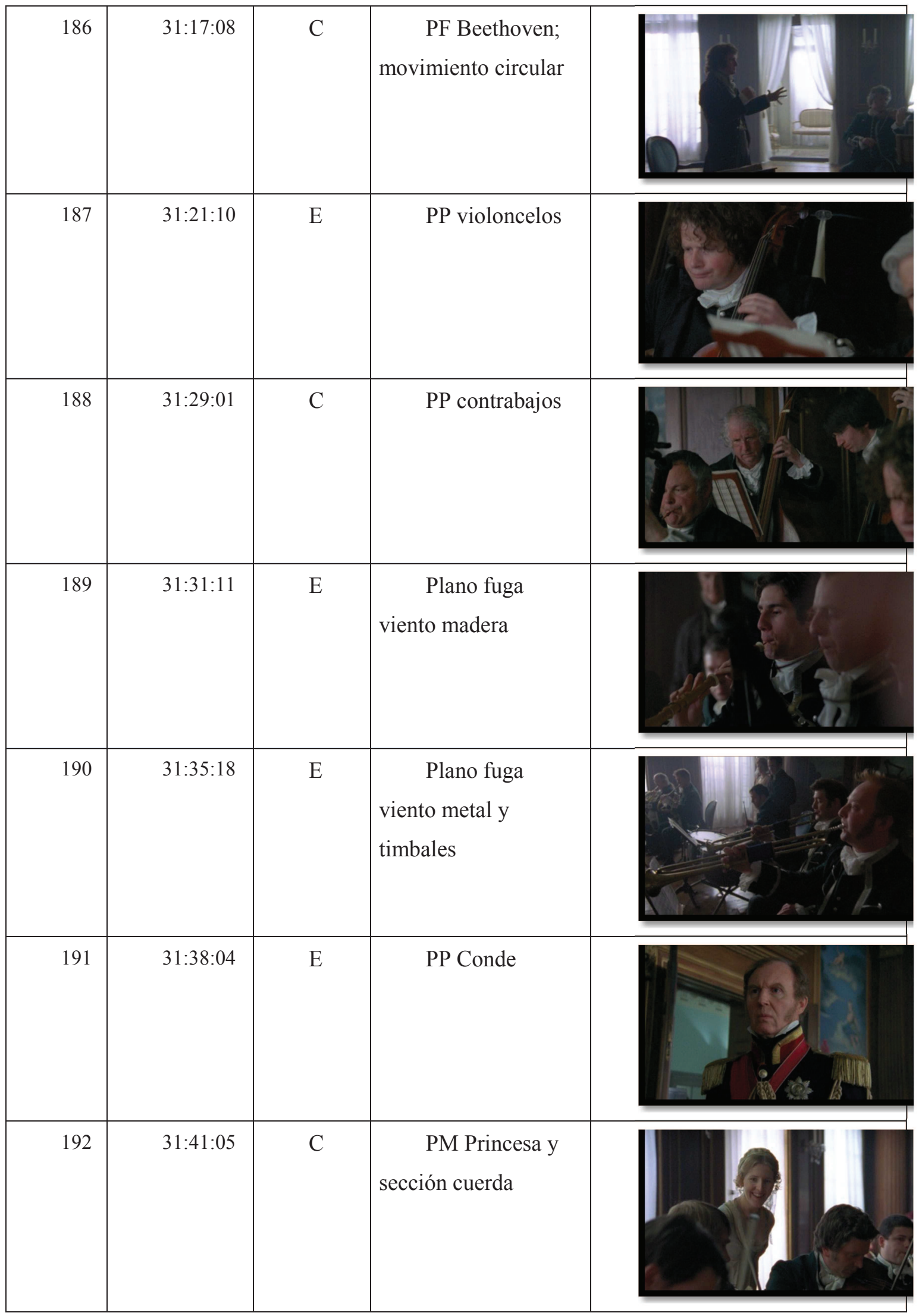




\begin{tabular}{|l|l|l|l|}
\hline 193 & $31: 43: 23$ & $\begin{array}{l}\text { PP Contrabajos } \\
\text { y Condesa de } \\
\text { Brunsvik }\end{array}$ & \\
\hline
\end{tabular}

Un promedio de setenta planos no nos enseñan sólo los músicos sino los personajes que han asistido al concierto. Todos los planos que nos muestran dichos personajes son primeros planos. Y, es que es este valor de plano el que muestra y refleja mejor los sentimientos y/o emociones. La condesa de Brunsvik y la princesa (planos 34 y 145) expresan su entusiasmo por la música. El conde, al contrario, expresa su contrariedad hacia ella (plano 191). El resto de los personajes no solo escuchan la música, sino que se dejan llevar por sus sentimientos, como los criados (165-166) o la condesa de Deym (154). En el único personaje que vemos expresadas las intensas emociones de manera dual -por la música y por sus sentimientos- es en Beethoven. El director traslada estos sentimientos al espectador a través de unos movimientos de cámara con eje que envuelven a Beethoven (travelling circular) y otros en los que la óptica se va cerrando sobre él (zoom in). Incluso en algunos momentos se combinan los dos movimientos.

Por lo que respecta a los planos de orquesta, en este primer tiempo abundan los planos figura de secciones instrumentales: violines, violoncelos, madera o viento. También son interesantes dos planos de instrumentos: trompa y concertino. La importancia que da Beethoven a las trompas y la importancia que tiene en sí mismo el concertino se proyecta en estos planos figura de un único instrumentista. Sólo en aquellos momentos en los que la música sube de intensidad o, más bien, de dramatismo, el director opta por planos muy detalle y de poca duración y esto no se da hasta bien entrado el primer movimiento, desde el plano 130 (plano muy detalle del arco del violoncelo) hasta el plano 135 (plano detalle del arco del violín); de hecho hasta bien pasada la mitad del tiempo musical no empiezan a combinarse primeros planos de personajes con primeros planos de instrumentos con más alta frecuencia. Se acrecienta de esta manera la densidad del hilo narrativo-emocional.

Quiero destacar la introducción de un elemento "antidogmático" por lo que se refiere al uso de la angulación de los planos o la regla de los ejes. Se recomienda que el salto de una 
angulación a otra sea lo suficientemente amplia para que el plano sea distinto y no suceda lo que los profesionales describen como un "salto" en la imagen. Lo habitual, si se quiere mantener el mismo eje óptico, es decir la orientación del personaje respecto el espectador o la pantalla, es cambiar el valor del plano sin variar la angulación. Sin embargo, mantener el mismo valor de plano pero con distinto eje óptico, si la distancia entre los dos ejes no es suficiente, provoca dicho salto y transgrede las normas habituales de montaje. En algunos momentos de este primer tiempo, estos saltos son usados como elementos de edición para transmitir sentimientos más profundos de tensión. Se trata de fuerzas visuales que potencian la percepción de dicha tensión y dramatismo. Son ejemplos de ello los tres planos seguidos del concertino en los números 22-23-24. ¿El salto de un plano al siguiente sobre el mismo instrumentista, en primer plano y desde un cambio de eje mínimo podría no considerarse lícito en cualquier retransmisión? Aquí queda justificado por motivos narrativos $\mathrm{y}$, seguramente, al espectador no le parece extraño. Pero, probablemente, estaría expuesto a crítica en una retransmisión en directo por considerarse un error sintáctico en la unión de los planos. Hacia el final de este primer tiempo, en la secuencia de planos 146 (a-b-c-d), podemos apreciar el mismo uso de este efecto audiovisual en Beethoven, aunque esta vez con un añadido, al salto de eje óptico se le añade un movimiento circular de travelling. Este fenómeno es antinatural y es por ello que tiene detractores en su uso; pero, debemos admitir que, al ser antinatural puesto que nuestro ojo tiene visión consecutiva y no "estroboscópica", le añade un valor emocional.

Terminado el primer tiempo, los músicos quedan exhaustos y las expresiones de estupefacción, sorpresa, alegría o entusiasmo por lo que acaban de oir pasan por los primeros planos de los protagonistas.

Como última observación de este primer tiempo, quiero destacar el elevado número de panorámicas y zoom in/out que describen el paso de un plano a otro, dilatando la realización en catorce momentos. Planos secuencia que duran entre dos y catorce segundos y contrastan con lo que analizaremos en el cuarto y último tiempo. Es por ello que, a pesar de ir introduciéndonos en todo un juego de emociones y sentimientos, la realización mantiene cierto equilibrio y reserva nuevos métodos estratégicos para más adelante. 


\section{Segundo tiempo: Adagio}

Estamos ante el núcleo del film de Simon Cellan. Es en este segundo tiempo cuando muchos de los planos nos muestran los sentimientos que despierta la música de Beethoven. A pesar de que, al terminar su interpretación, es calificada de:

- ser una masa informe, sin estructura; no responder a lo que se espera de una sinfonía.

- ser una "mera disposición de ruidos"

- ser una "acumulación de ideas colosales"

- "estar llena de discordia"

- "le falta redondeo"

Y el príncipe la define como:

- "es difícil"

En el aspecto emocional, este segundo movimiento penetra en cada uno de los personajes y uno de ellos la describe como: "commovedora" y "con momentos sublimes".

Beethoven, ante la calificación de "difícil”, responde que es positiva porque la dificultad es buena, bella y acerca a la verdad. Es decir, estética en estado puro.

Y la princesa añade: conmovedor, francés, audaz, nuevo.

En el minuto 53:25, llegamos a uno de los núcleos en cuanto a la relación Beethovencondesa von Deym. Ella misma le define su música como:

-Fuerte, belicosa, con transiciones muy abruptas. Afirma que le sugiere turbulencia, le asusta y ella quiere paz... nada peor le podía haber dicho a Beethoven.

Veamos a través del lenguaje audiovisual todos estos sentimientos. 
De la partitura a la pantalla: plano y contraplano de una misma realidad - 129

\begin{tabular}{|c|c|c|c|c|}
\hline Núm. & Time Code & Cambio & Descripción del plano & Frame congelado \\
\hline 1 & $33: 27: 01$ & $\mathrm{E}$ & PP Concertino & \\
\hline 2 & $33: 31: 09$ & $\mathrm{C}$ & $\begin{array}{l}\text { Zoom in de PG } \\
\text { orquesta a PG violines } \\
\text { primeros }\end{array}$ & \\
\hline 3 & $34: 03: 02$ & $\mathrm{E}$ & PP oboe & \\
\hline 4 & $34: 11: 02$ & $\mathrm{E}$ & $\begin{array}{l}\quad \text { PP arco y mano } \\
\text { violoncelo. Panorámica de } \\
\text { arco a... }\end{array}$ & \\
\hline (b) 4 & & & $\begin{array}{l}\text {...digitación de } \\
\text { violoncelo }\end{array}$ & \\
\hline 5 & $34: 20: 04$ & $\mathrm{C}$ & $\begin{array}{l}\text { PP oboe. Zoom out } \\
\text { a... }\end{array}$ & \\
\hline (b) & & & $\begin{array}{l}\text {... fuga de viento } \\
\text { madera }\end{array}$ & \\
\hline
\end{tabular}


De la partitura a la pantalla: plano y contraplano de una misma realidad - 130

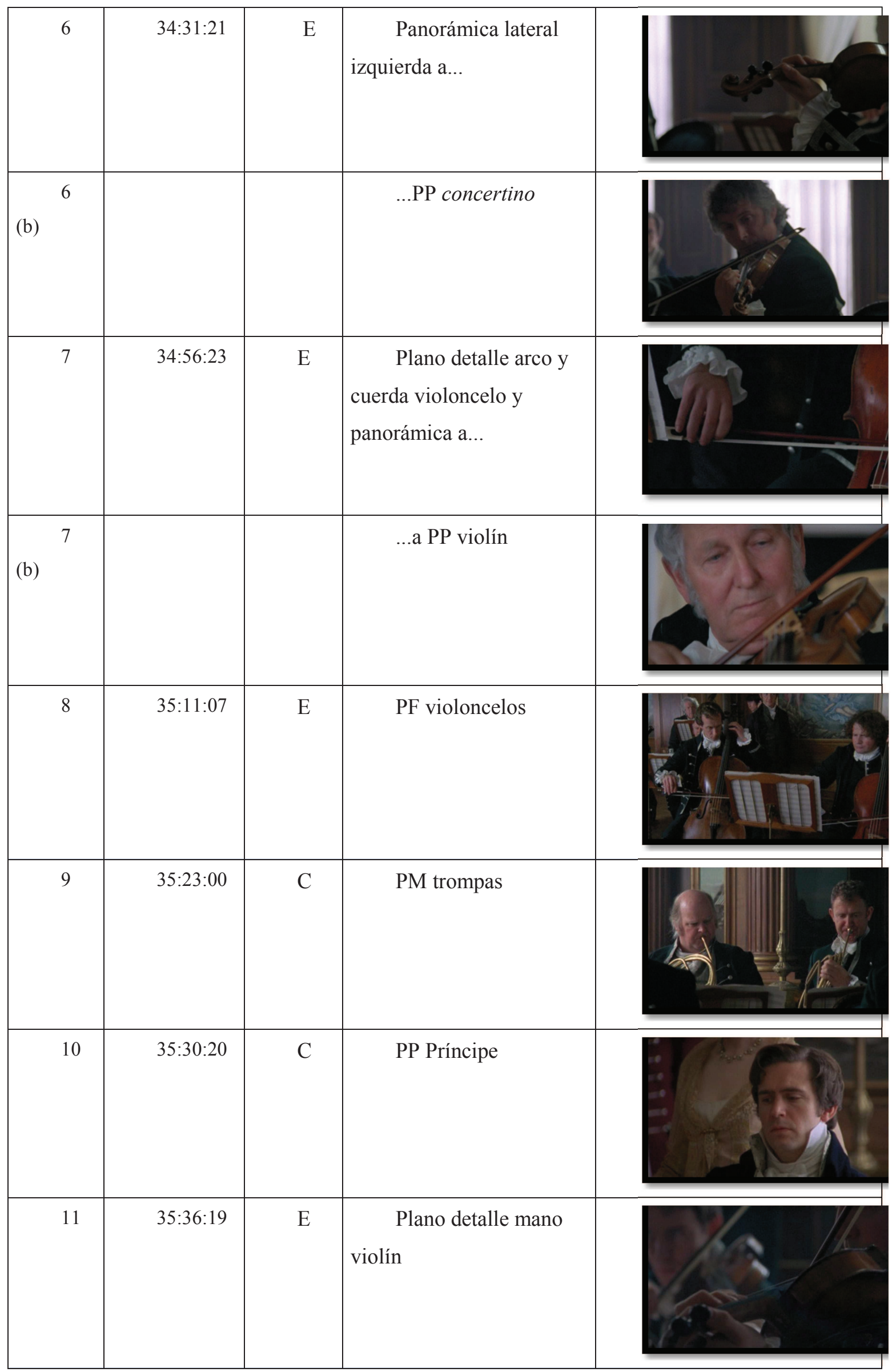


De la partitura a la pantalla: plano y contraplano de una misma realidad - 131

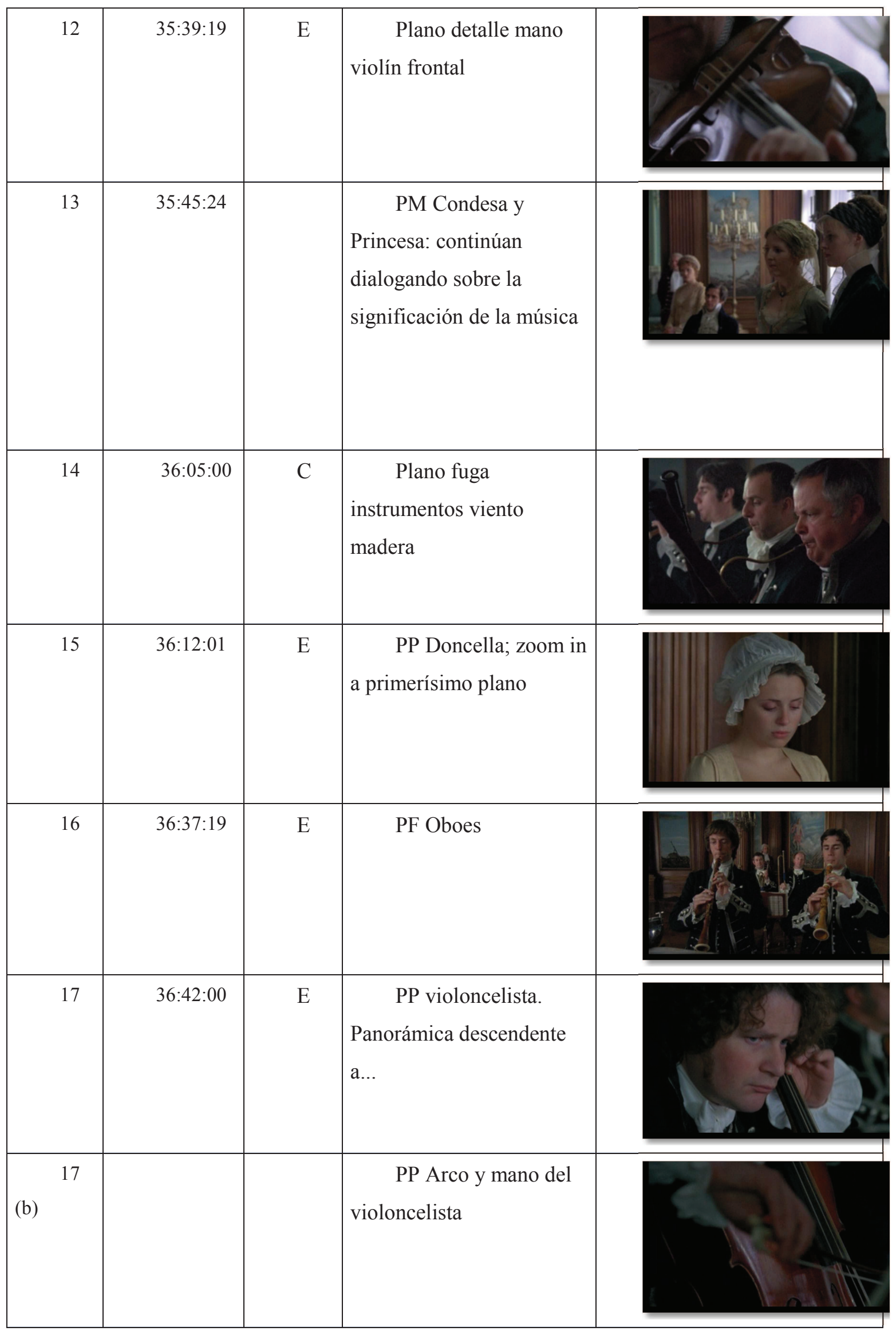


De la partitura a la pantalla: plano y contraplano de una misma realidad - 132

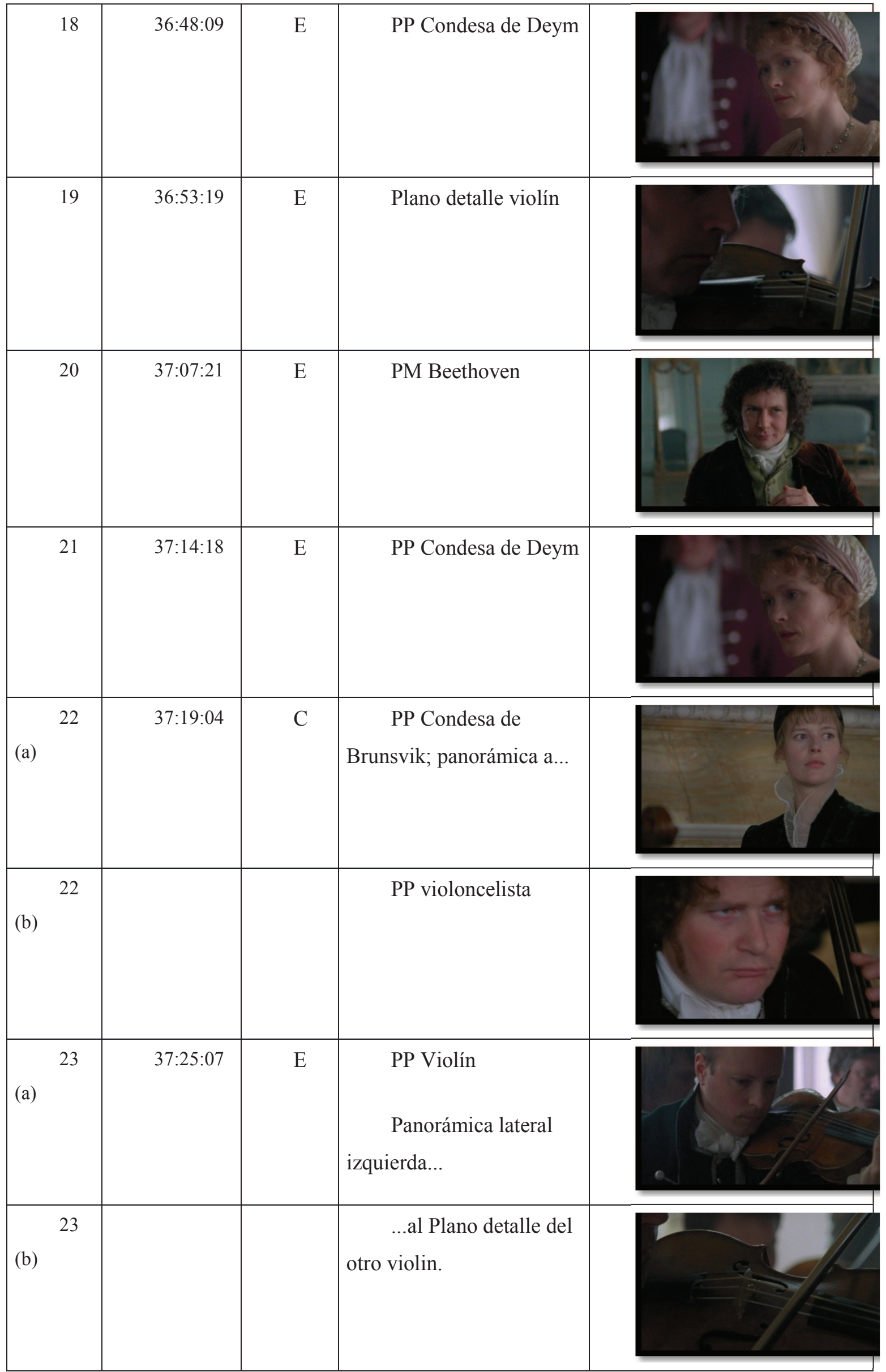


De la partitura a la pantalla: plano y contraplano de una misma realidad - 133

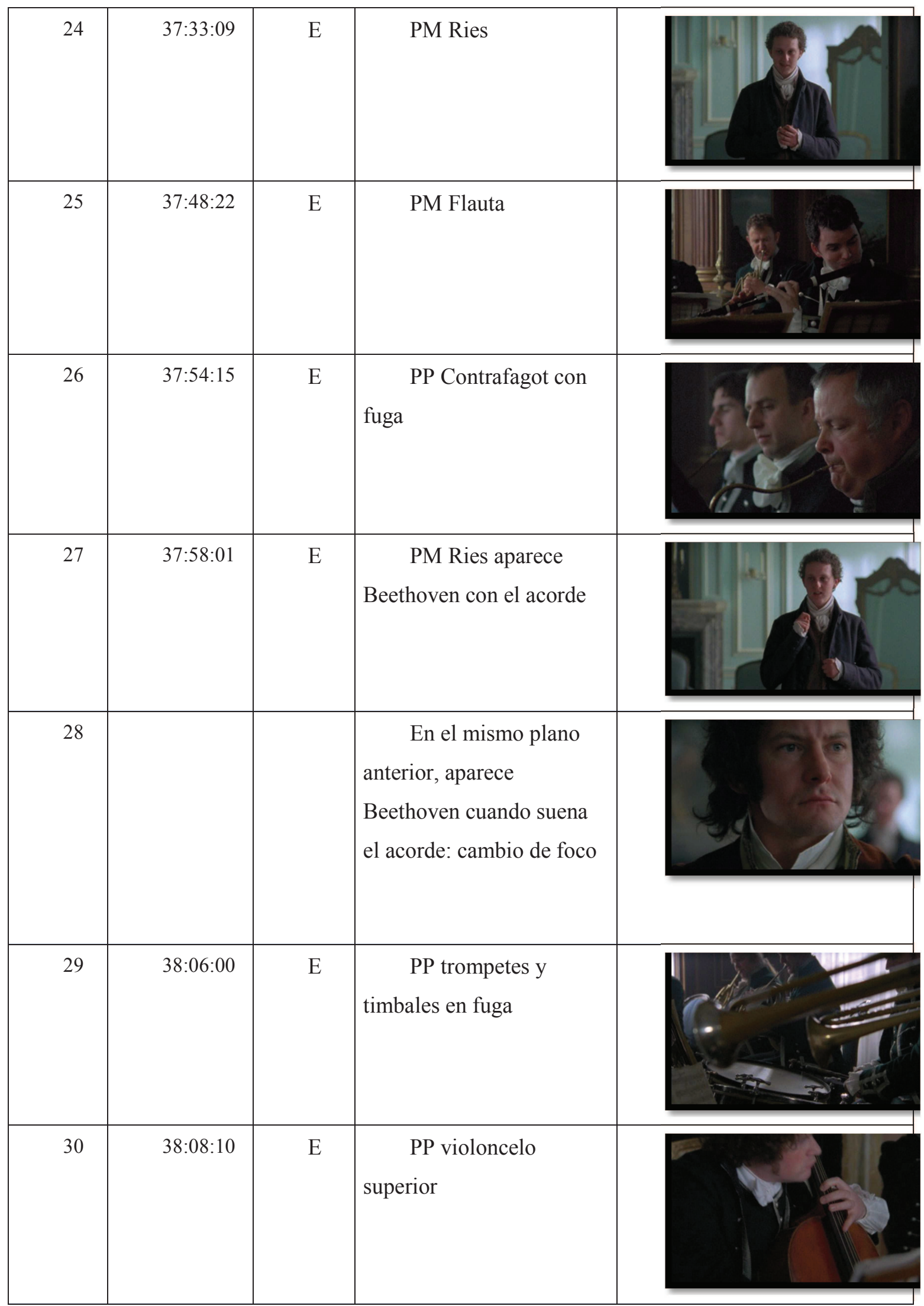


De la partitura a la pantalla: plano y contraplano de una misma realidad - 134

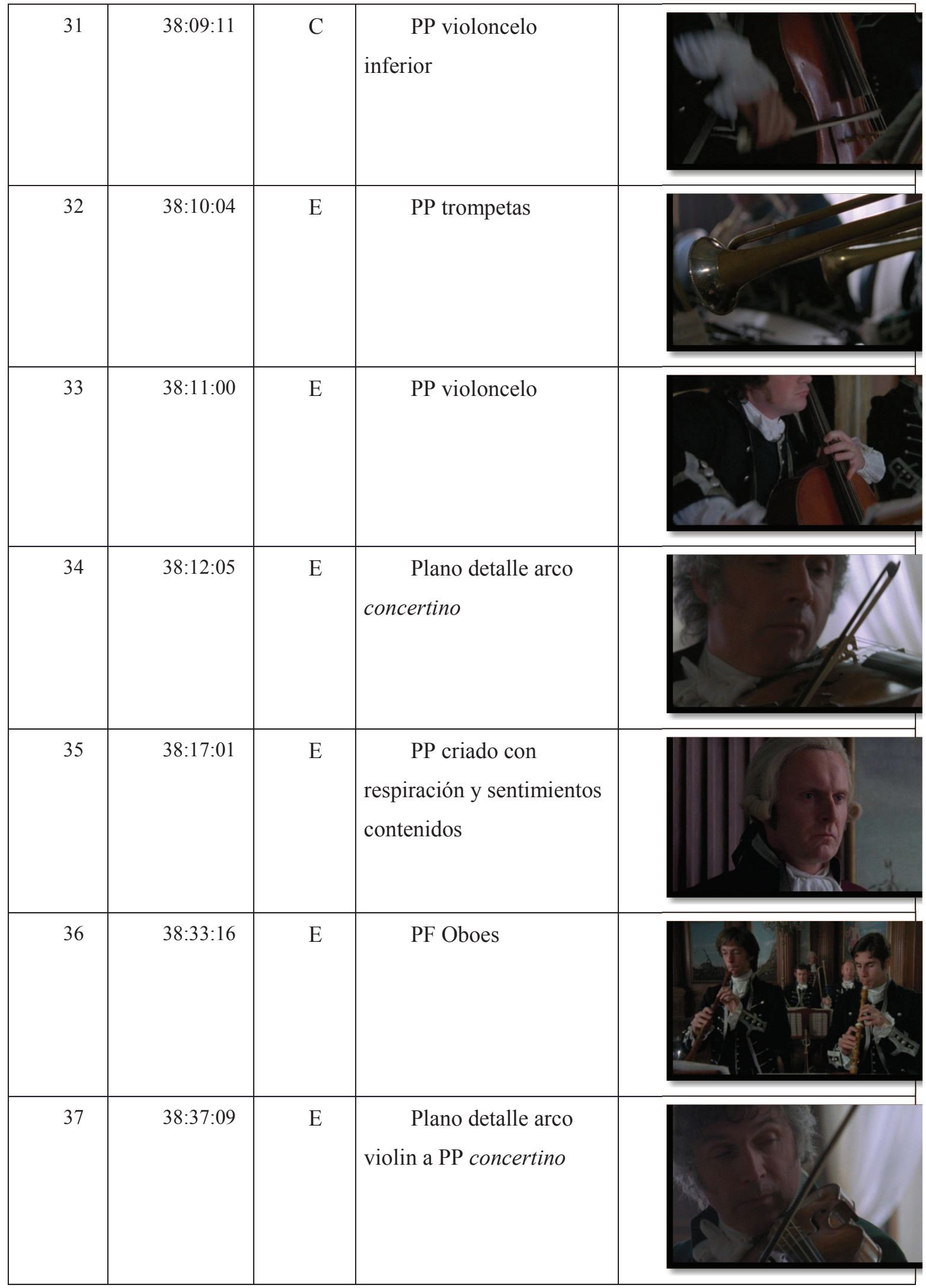


De la partitura a la pantalla: plano y contraplano de una misma realidad - 135

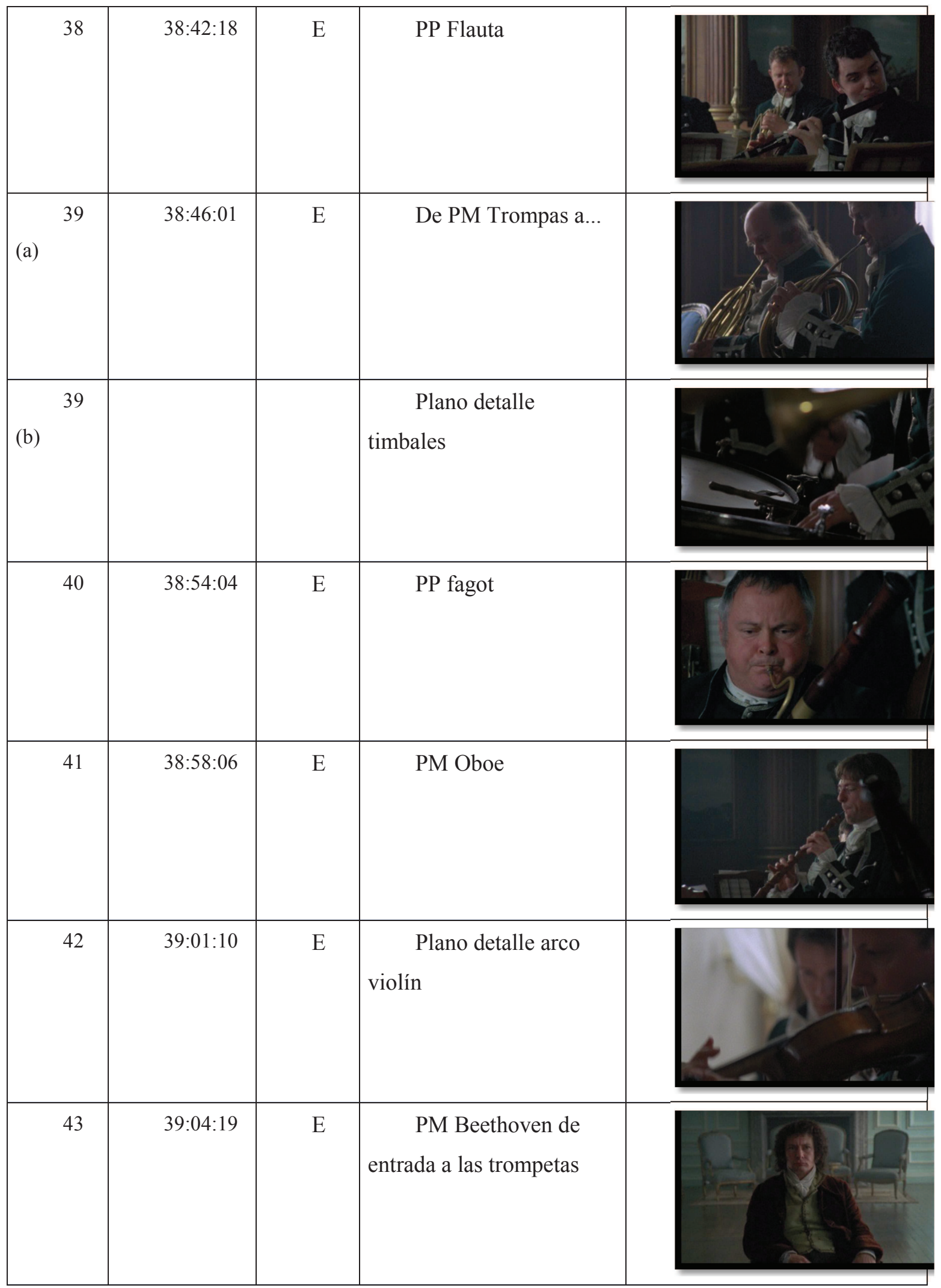


De la partitura a la pantalla: plano y contraplano de una misma realidad - 136

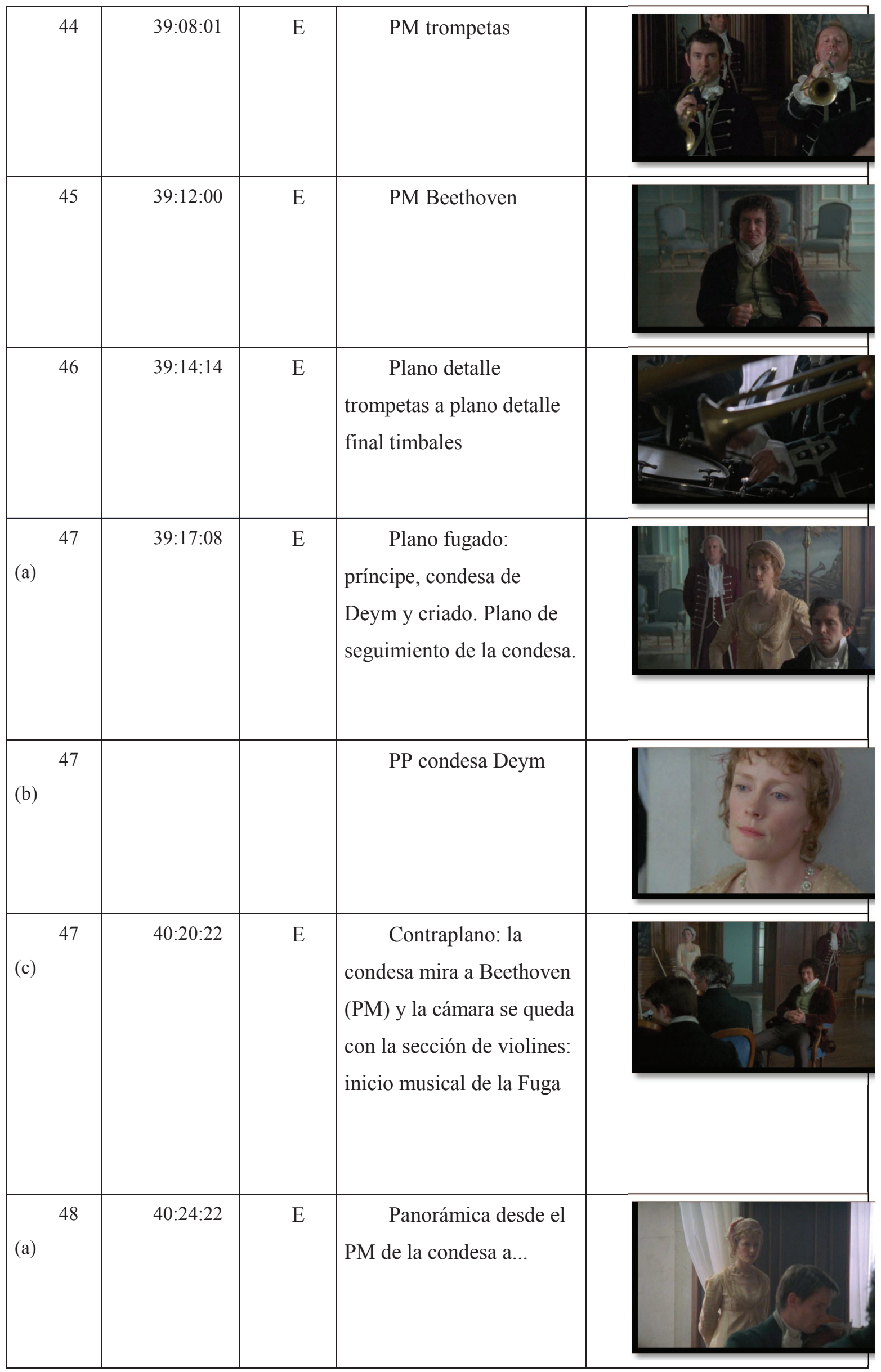


De la partitura a la pantalla: plano y contraplano de una misma realidad - 137

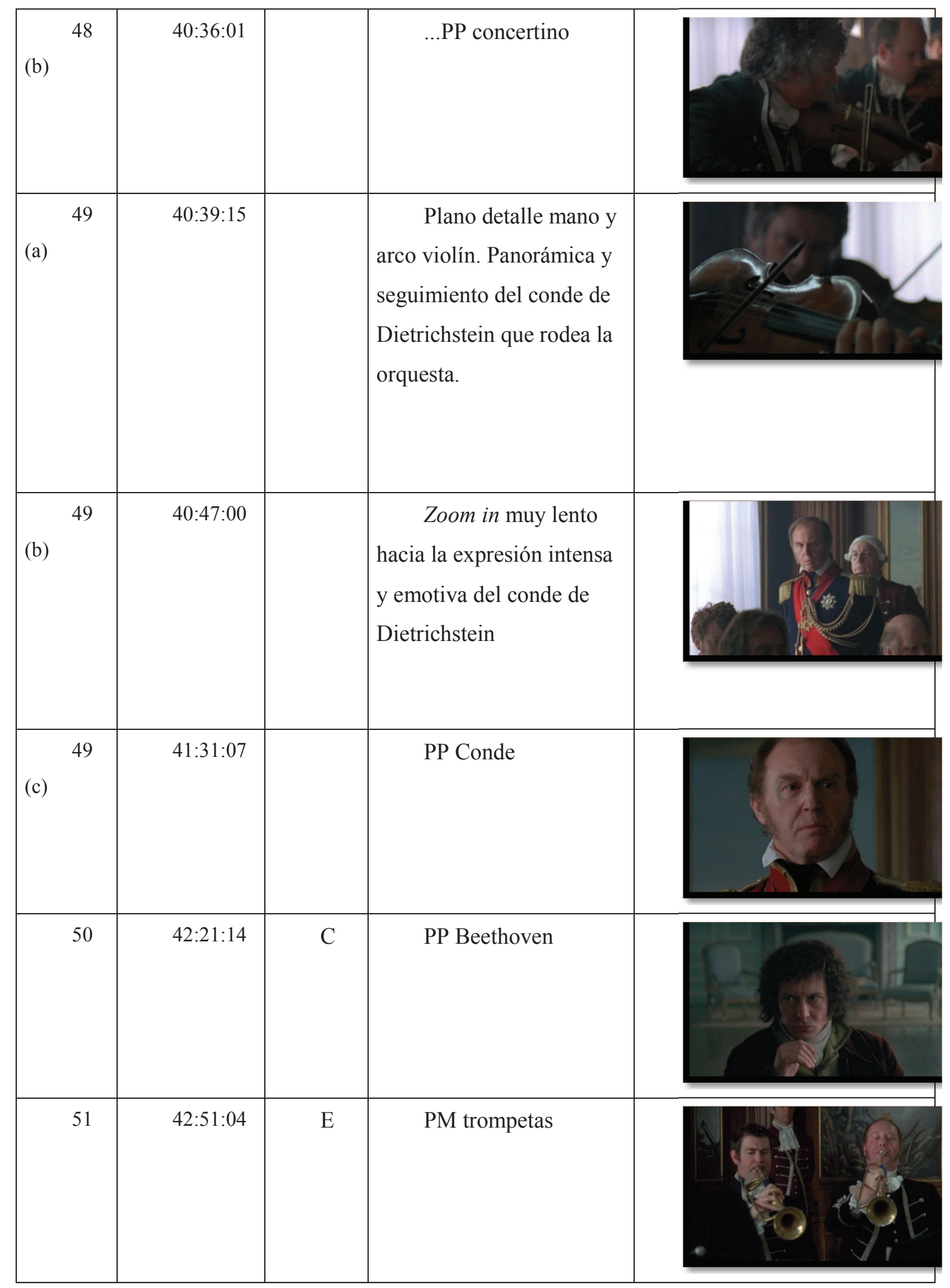




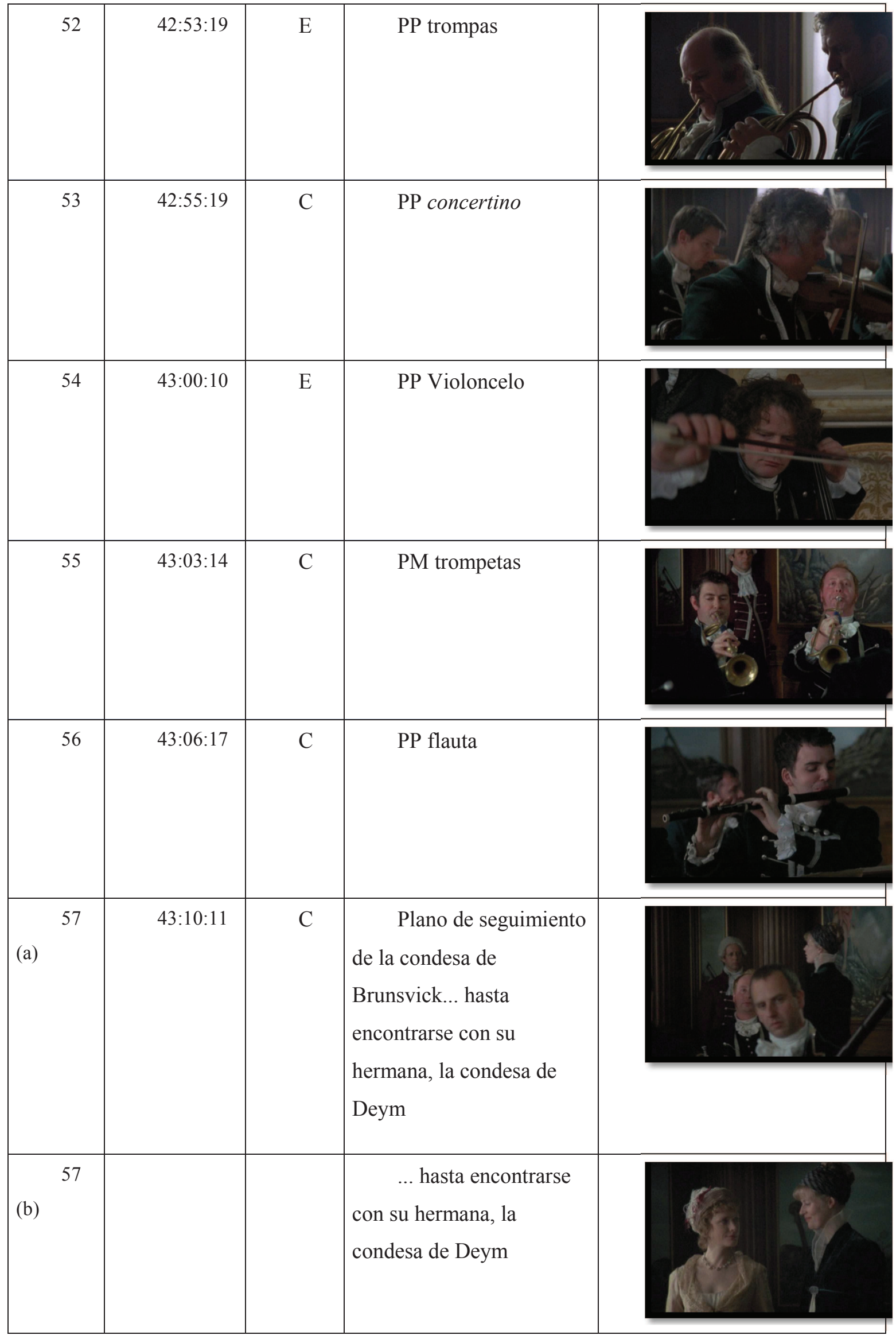


De la partitura a la pantalla: plano y contraplano de una misma realidad - 139

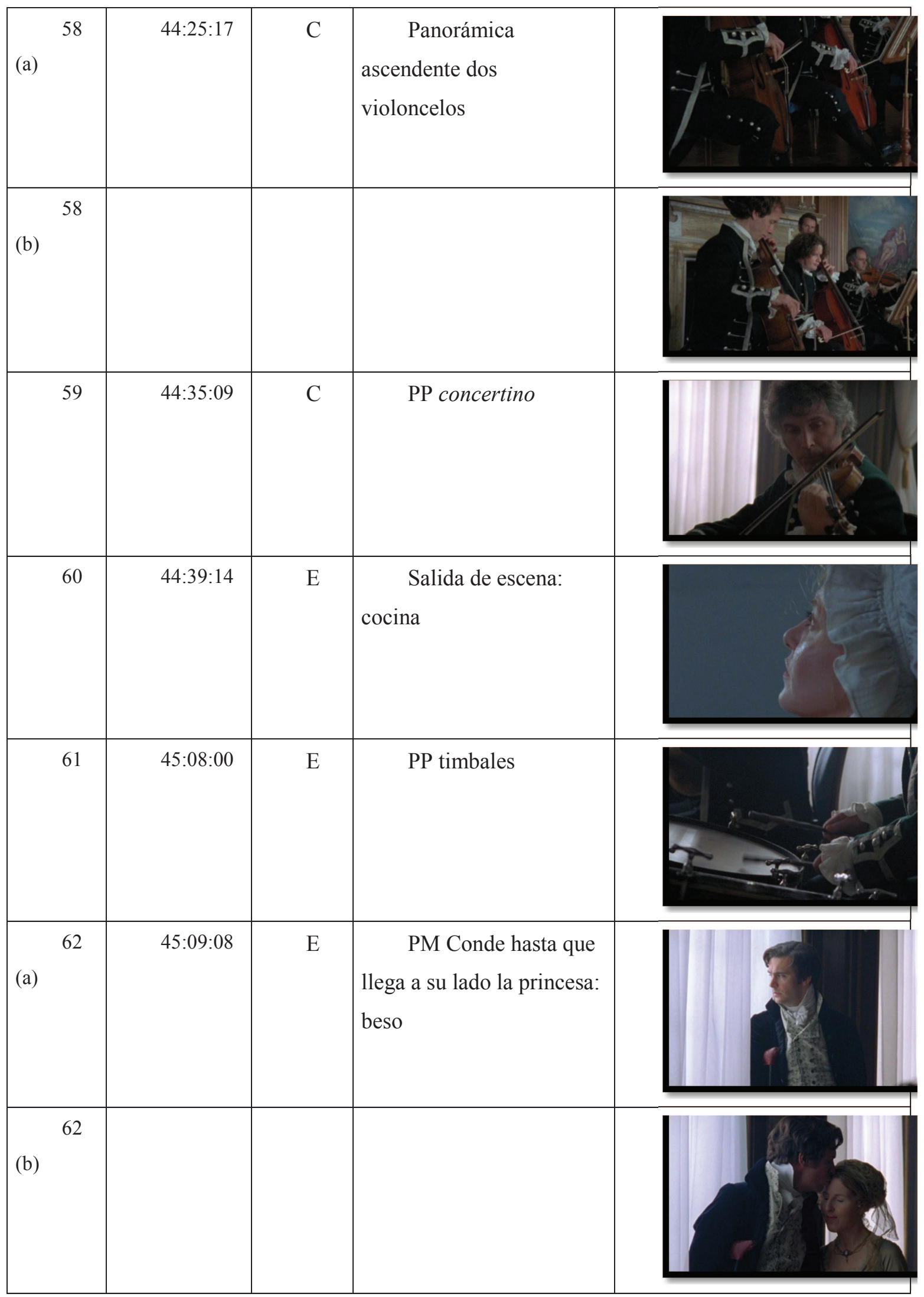


De la partitura a la pantalla: plano y contraplano de una misma realidad - 140

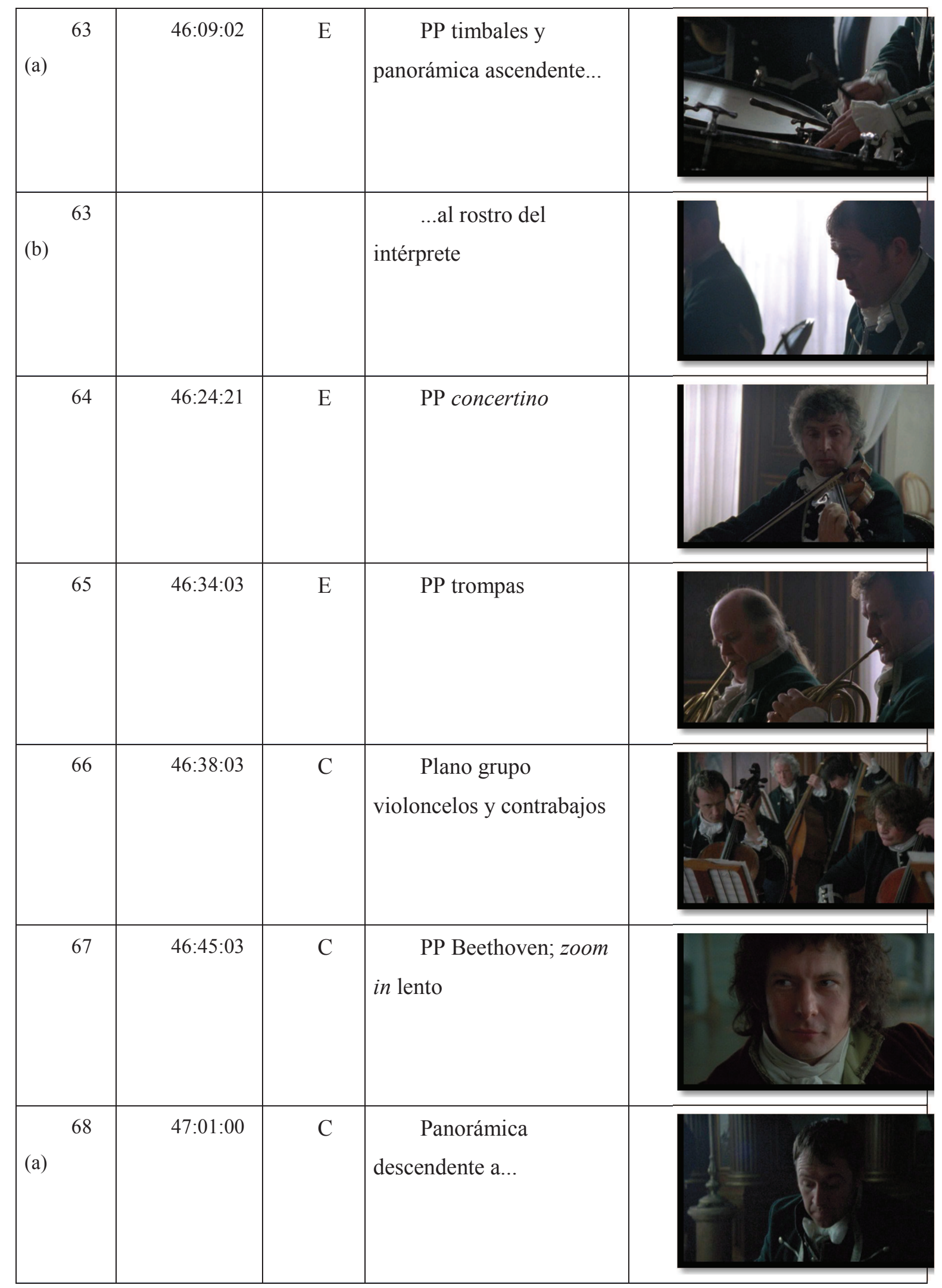


De la partitura a la pantalla: plano y contraplano de una misma realidad - 141

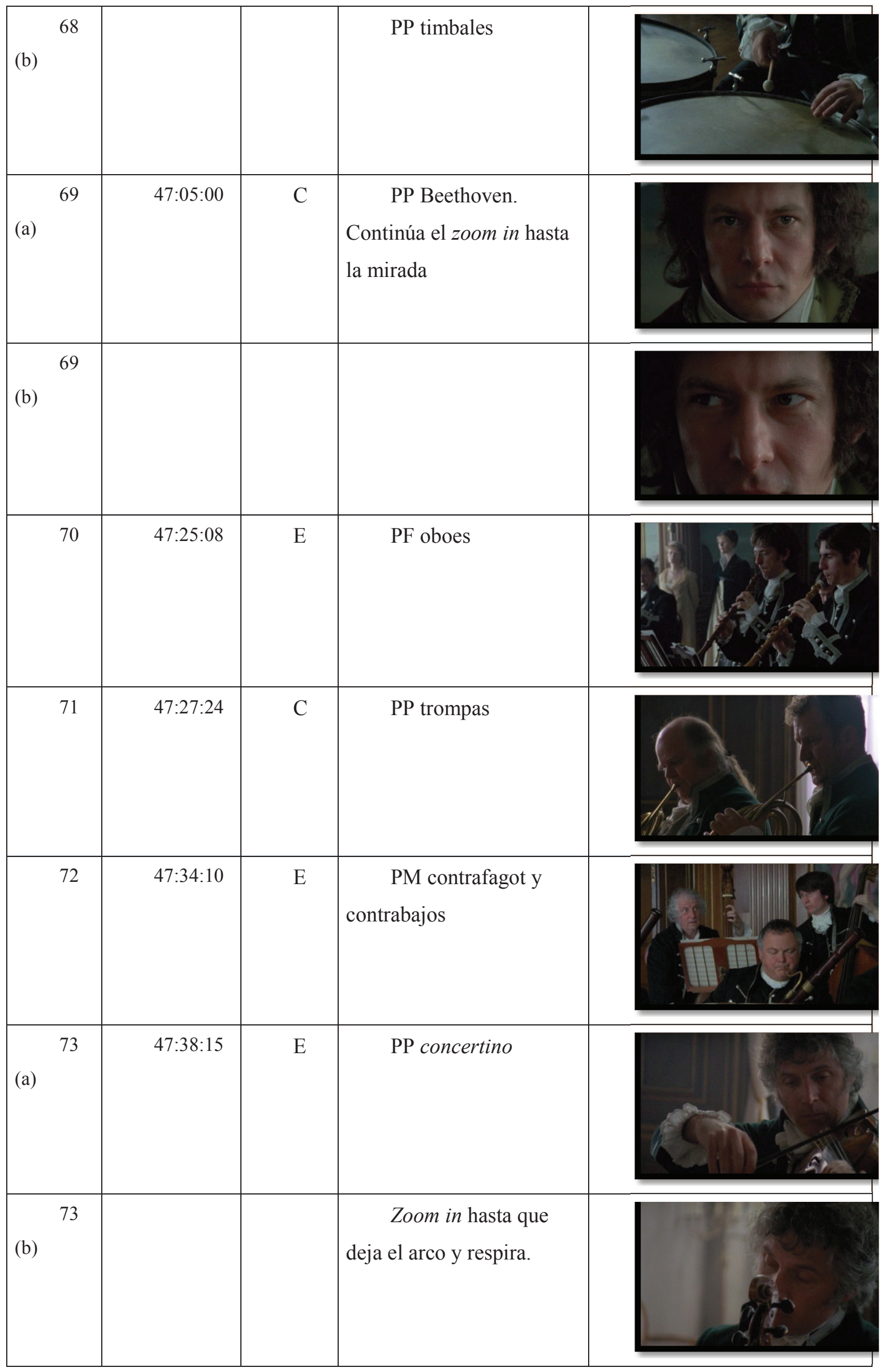




\begin{tabular}{|l|l|l|l|l|}
\hline 74 & $47: 52: 00$ & & $\begin{array}{c}\text { PP Beethoven: final } \\
\text { segundo tiempo }\end{array}$ \\
\hline
\end{tabular}

Casi la mitad de los planos en este segundo tiempo (29 planos de un total de 74) contienen información de los personajes y no muestran los músicos. Siempre, o casi siempre, primeros planos que permiten deducir qué sentimientos hay detrás de cada rostro. Es por ello que, junto a este adagio, nos adentramos en la narración que discurre paralela a la ejecución musical.

Las características de la filmación en este segundo tiempo son:

1. Planos largos- muchos de los planos tienen duraciones de más de diez segundos.

2. Planos con movimientos internos lentos: zoom in/out y panorámicas.

3. Transiciones entre planos por encadenados.

4. Mayor número de planos de orquesta como planos figura de conjunto: flauta y oboe, trompas, violoncelos, fagots y trompetas.

5. Aparece algún plano detalle de instrumento de corta duración en el momento central del movimiento: del plano 30 al plano 35.

Así pues, dichas características subrayan el hecho de que estamos ante un movimiento lento, denso y con una fuerza interior que llega al espectador.

Principalmente, cabe destacar dos momentos. El primero llega en el minuto 40:20:22 del film. Es el mismo momento en que empieza la fuga. Tal densidad musical acompaña una panorámica que sigue el conde de Dietrichstein. Son 52 segundos sin pausa, muy lentos, al final de los cuales, un zoom in de 8 segundos cierra el plano en la expresión entre airada y desconcertada del conde. En este momento acaba la fuga. Después del fuera de campo en la cocina en que la música toma un papel de música no diegética sin serlo y de empática en cuanto a su expresión emocional, llega el segundo momento importante: el beso entre los príncipes (45'08”). Se ha visto durante el transcurso de la narración que no se trata de una buena relación; sin embargo, es en este momento cuando se resuelve dicho estado emocional 
entre ambos. El plano es estático y en él se puede ver un príncipe pensativo. Entra en plano la princesa y llega el clímax, después de un largo minuto. Finalmente, el último plano intenso. Se trata del largo zoom in hacia los ojos de Beethoven que transmite una fuerza expresiva elocuente (46'45").

En este segundo tiempo de emociones densas y contenidas, la percepción de haber traído en primer término, a través de las imágenes, aquello que la partitura "esconde" parece que se ha hecho realidad. Como dice Piero Polidoro (2016):

Llevar a un primer plano la dimensión opaca de la representación significa atraer nuestra atención sobre la pintura, sobre su técnica y sobre su lenguaje; se convierte, entonces, en un presupuesto necesario para cada reflexión interna al cuadro, sobre la misma pintura; es decir, para cada discurso metapictórico (p.75)

Si cambiamos la disciplina artística "pintura" por la "música", está claro que existe este lenguaje metamusical que lleva a un primer plano la "dimensión opaca" o quizás mejor, la dimensión latente en cada composición musical. Se trata de la huella dactilar convertida en huella "multidigital".

\section{Tercer tiempo: Scherzo}

Este tercer tiempo se inicia en el minuto 59:11:00 con un fuera de escena hasta el minuto 01:00:53:15. Tiene función de música no diegética hasta que Beethoven entra en la sala.

Narrativamente, desde el guión del film, Ludwig Van Beethoven pide a la condesa salir de la sala antes de empezar el Scherzo. Mientras están en conversación, empieza la interpretación de la orquesta; de esta manera, a pesar de que el espectador sabe que es la orquesta la que está tocando, la sensación es que se trata de música no diegética; principalmente, se percibe como música no diegética y empática la que suena durante los 10 segundos antes de entrar el compositor a dirigir nuevamente. Previo a la entrada de las trompas, escuchamos una escala descendente a través de las cuerdas que termina con unas notas del contrabajo. Este elemento musical descendente coincide con el pensamiento y el control de las emociones de la condesa de Deym, puesto que le acaba de comunicar a 
Beethoven que no puede casarse con él, a pesar de que le ama, por su condición plebeya. Ella perdería su título y a sus hijos. La mirada introspectiva es simultánea al descenso musical. Tras la afinación de la orquesta y el primer minuto y medio, el compositor entra en la sala y regresamos a la visualización de los intérpretes. El elemento importante, sin embargo, no es la orquesta sino los sentimientos de Beethoven. Lo vemos a través de los planos que el director Simon Cellan ha realizado:

Se trata de saltos de plano continuos sobre el músico desde casi la misma angulación para terminar con un travelling circular que se va cerrando, sobre él, opresivamente hasta llegar a su grito para la entrada de las trompas. Planos desequilibrados, con cambios rápidos $\mathrm{y}$, todos ellos, sobre el mismo personaje provocando una percepción de fuerza visual por parte del espectador que le conduce a la intensidad y tensión emocional que desborda en ese momento a Beethoven. Su grito, simultáneo al barrido fugaz de la cámara hasta el plano del primer trompista, nos adentra, nuevamente, en la orquesta.

A partir de aquí, el lenguaje audio-musical reemprende planos que siguen la melodía de la partitura. Una vez mostrados algunos de ellos, empieza un nuevo concepto de realización, más pausado para percibir bien las emociones y sentimientos tras cada rostro a través de primeros planos de las expresiones de cada uno de los asistentes, a su vez, intercaladas entre los primeros planos de los instrumentos.

Expresión de satisfacción y gozo por parte de la princesa, el desconcierto de Thérèse, la abrumación del conde, el dolor de la condesa de Deym y la sorpresa del príncipe. En este momento, una nueva salida de escena para ver cómo llega a la sala el compositor Franz Joseph Haydn, compositor y amigo de Beethoven. Oímos la música ecualizada, puesto que es cómo la oye desde su situación en escena el mismo Haydn, desde la escalera que conduce a la sala. La llegada de este músico es ciertamente importante porque, al acabar, después de su atenta escucha, sentencia con una frase la música de Beethoven. Más adelante me referiré a ella.

Así pues, la duración del tercer tiempo de esta sonata Heroica divide la narración fílmica en dos partes: el diálogo, importante y central diálogo, entre la condesa y Beethoven y la llegada de Haydn a la sala de conciertos. Así que, la realización de lo que supone la orquestación de la partitura queda en segundo plano. Sin embargo, sólo con estos cinco 
minutos, podemos leer en los rostros de los personajes qué acontece emocionalmente en cada uno de ellos a través de la música.

El resumen audiovisual para entender estos minutos quedan ilustrados en los siguientes planos:

Fotogramas del diálogo con la condesa de Deym
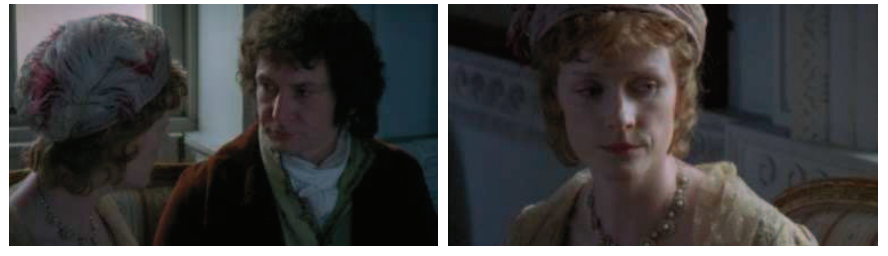

Secuencia de planos en la entrada de Beethoven a la sala
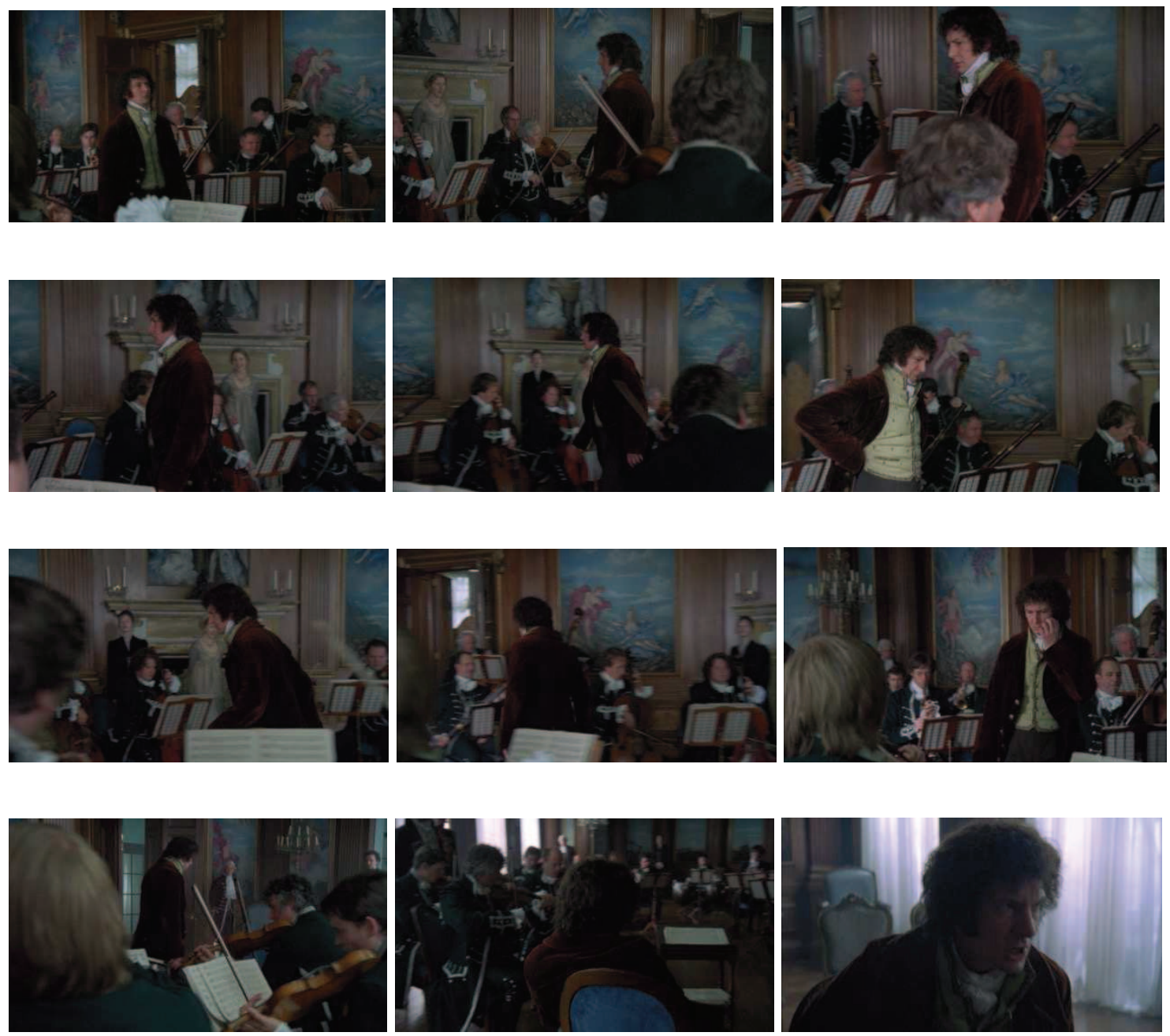
Primer plano del compositor Franz Joseph Haydn

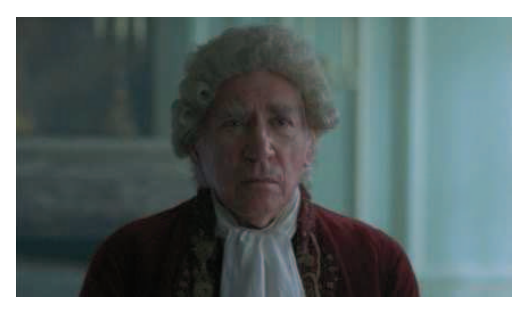

Cuando termina, y antes de iniciar el cuarto tiempo, los comentarios siguen siendo negativos respecto a la forma:

El conde afirma: "No se esfuerza por alcanzar la perfección normal; es puro estruendo y gruñidos"; Haydn replica que él sólo quiere alcanzar el equilibrio entre las emociones y el intelecto, la clave de lo cual es la moderación. Como hemos podido comprobar, la única que se muestra entusiasta y aprueba la música de Beethoven es la princesa. Es ella quien convence a su esposo, el príncipe, para que pueda remunerar el trabajo de Beethoven. De esta manera, el ensayo sigue con el Finale.

\section{Cuarto tiempo: Finale.}

Así empieza el cuarto tiempo: Beethoven contesta a Haydn que el tema de esta sinfonía es "heroísmo". Veamos cómo se resuelve audiovisualmente.

Tras casi siete minutos de planos de orquesta y diferentes expresiones de los presentes en la sala, incluida la expresión de satisfacción del príncipe que, hasta el momento no habíamos visto, y tras una entrada de los hijos de la condesa importunando con sus voces y corridas por la sala, llegamos a un primer plano que se va abriendo con la expresión atónita de Haydn. Este espléndido plano por lo que tiene de empático con la música, no sólo por el sonido amplio de las trompas que enfatiza el zoom out del primer plano de Haydn, sino porque funciona como un punto y aparte para la secuencia final.

Es en este momento cuando el director lleva la narración musical fuera de la sala dando un salto, no sólo en el espacio, sino en el tiempo; pasa a un futuro no lejano que representa el 
momento en que Beethoven y discípulo se van a cenar después del ensayo. A partir de aquí, la narración de los hechos ya evoluciona sin parar hasta el final.

El film de Simon Cellan discurre, a partir de ahora, a través de una edición de montaje en paralelo. Antes de llegar al desglose de los planos filmados y editados para el final de la secuencia, quiero detenerme en este gran momento que nos conduce ya al final de la película.

Este tiempo final empieza con planos de la orquesta durante el ensayo ante Haydn y, evidentemente, con planos llenos de fuerza de Ludwig Van Beethoven mientras dirige la sinfonía. La bifurcación de caminos empieza con el seguimiento narrativo, diríamos, textual o del guión, de la película. Mientras la orquesta sigue tocando, los personajes van entrando y el director nos expone, a través de un gran uso de la dirección de las miradas, la relación que existe entre cada uno de los personajes. El cruce de miradas se lleva a cabo con gran maestría $\mathrm{y}$, de hecho, no es necesario ningún diálogo hablado para que el espectador entienda lo que sucede en la sala donde se desarrolla el ensayo.

Así pues, en un primer momento, coinciden simultáneamente cinco elementos narrativos:

- Narración musical, seguimiento de la partitura.

- Narración literaria del guión

- Divertimento de algunos personajes al escuchar la música

- Comunicación emocional: Haydn

- Comunicación músico-emotiva: Beethoven (miradas entre él y la viuda Josephine Von Deym)

En la segunda parte de la filmación, salimos de escenario y de tiempo, sin embargo, la música interpretada continúa en "presente”. Esto ocurre en el compás 350, después del acorde de séptima, cuando empieza el Poco Andante en el compás siguiente. Así pues, discurren en paralelo tres momentos:

- Interpretación de la sinfonía en la sala del Palacio (cc. 1-349; cc. 382-390; cc. $433-475)$

- Flash Forward, hechos que ocurren una vez finalizada dicha interpretación: 
1. Beethoven y su discípulo Ries de camino a la taberna y cena (cc. 350366; cc. 390-403; cc. 408-432)

2. Comentarios de Haydn acerca de la Sinfonía (cc. 366-382)

3. Salida de la sala de toda la familia e invitados (cc. 404-408)

Así, el orden de situaciones, mientras la música suena tanto diegéticamente como no, sería el siguiente:

a) Interpretación de la sinfonía en la sala. Música diegética: cc. 1-349

b) Flash Forward- Beethoven y Ries de camino a la taberna, espacio exterior: cc. $350-366$

c) Flash Forward- Intervención final de Haydn: cc. 366-382

d) Interpretación de la sinfonía en la sala. Música diegética: cc. 382-390

e) Flash Forward-Beethoven y Ries en la taberna: cc.390-403

f) Salida de la sala de toda la familia e invitados: cc. 404-408

g) Flash Forward- Beethoven y Ries en la taberna: cc. 408-432

h) Interpretación de la sinfonía en la sala: cc. 433-475

- $\quad \mathrm{Y}$, en tercer lugar y para terminar, el plato fuerte: los últimos intensos minutos de la película que ocurren cuando Ries comunica a Beethoven que "han nombrado" emperador a Napoleón Bonaparte. A partir de este momento, terminan las palabras y, sólo a través del lenguaje fílmico de los planos, se suceden uno tras otro los planos narrativos hasta concluir con la desaparición del compositor por la puerta de entrada al salón, mediante un "largo" plano secuencia. Plano secuencia largo percibido después de una realización a través de planos cortos que no pasan de 1 segundo la mayoría de ellos. De esta manera, los 45 " de sucesión de planos acelerados contrastan con los siguientes 45" segundos de silencio con planos estáticos, interrumpidos sólo por un "Gracias" expresado por Beethoven antes de abandonar la sala. 
DESGLOSE DE PLANOS EN LA SECUENCIA FINAL (presto)

\begin{tabular}{|c|c|c|c|c|}
\hline Núm. & Time Code & Cambio & Descripción del plano & Frame congelado \\
\hline 1 & 01:20:45:00 & E & $\begin{array}{l}\quad \text { Zoom in Plano } \\
\text { picado de orquesta en el } \\
\text { ensayo }\end{array}$ & \\
\hline 2 & 01:20:49:01 & $\mathrm{E}$ & $\begin{array}{l}\text { Plano detalle } \\
\text { trompa }\end{array}$ & \\
\hline 3 & 01:20:50:12 & (1fr.) & $\begin{array}{l}\text { Plano sobre la } \\
\text { misma trompa }\end{array}$ & \\
\hline 4 & $01: 20: 50: 24$ & (1fr.) & $\begin{array}{l}\text { Plano sobre la } \\
\text { misma trompa; distinto } \\
\text { ángulo. }\end{array}$ & \\
\hline 5 & 01:20:51:18 & (1fr.) & $\begin{array}{l}\text { Embocadura de la } \\
\text { trompa }\end{array}$ & \\
\hline 6 & 01:20:52:04 & (1fr.) & Plano detalle & \\
\hline 7 & $01: 20: 52: 22$ & (1fr.) & $\begin{array}{l}\text { Plano sobre trompa } \\
\text { (íd. Plano 3) }\end{array}$ & \\
\hline 8 & 01:20:53:08 & (1fr.) & $\begin{array}{l}\text { Violoncelo: plano } \\
\text { detalle mano con arco }\end{array}$ & \\
\hline
\end{tabular}


De la partitura a la pantalla: plano y contraplano de una misma realidad - 150

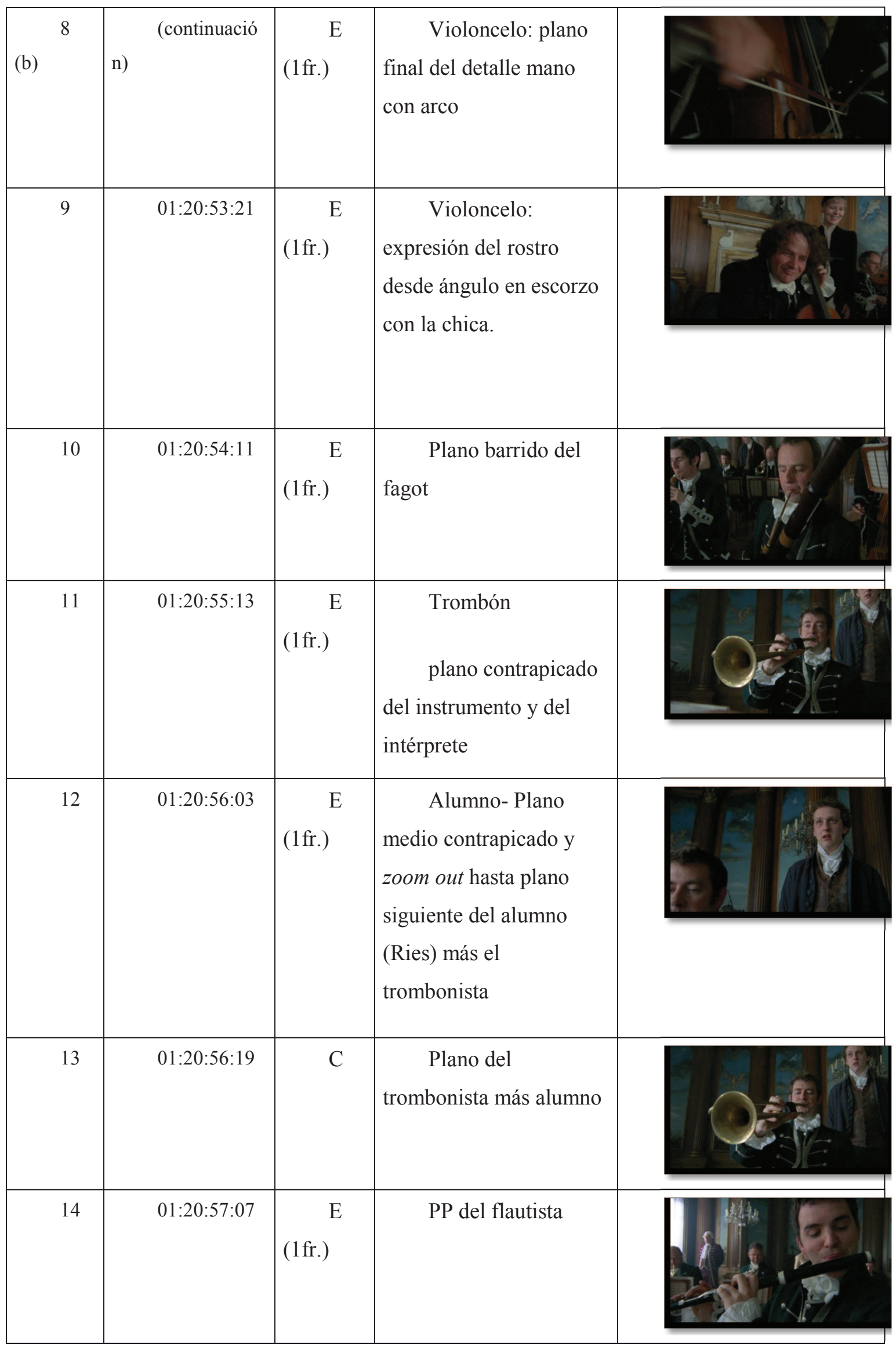


De la partitura a la pantalla: plano y contraplano de una misma realidad - 151

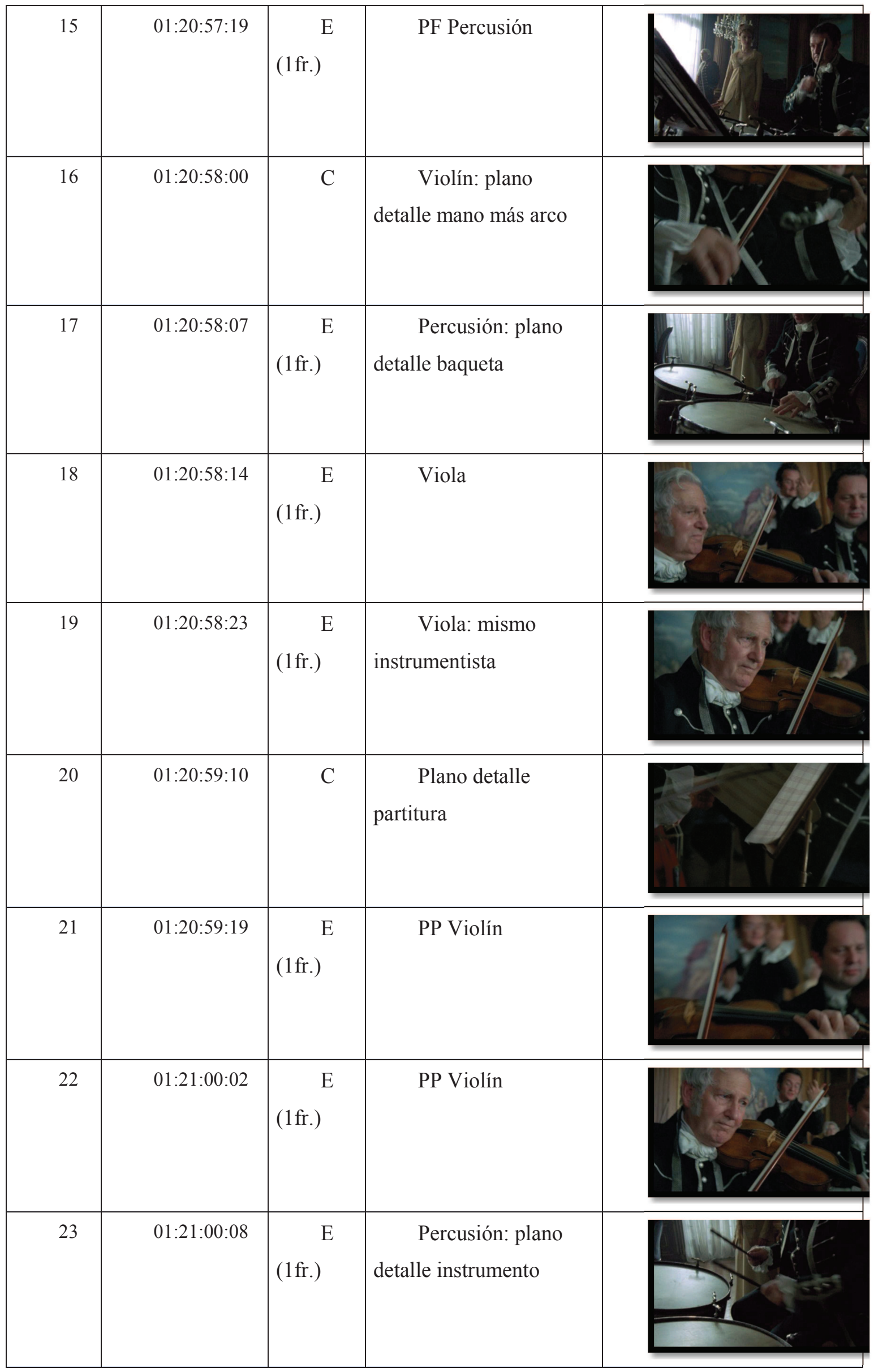


De la partitura a la pantalla: plano y contraplano de una misma realidad - 152

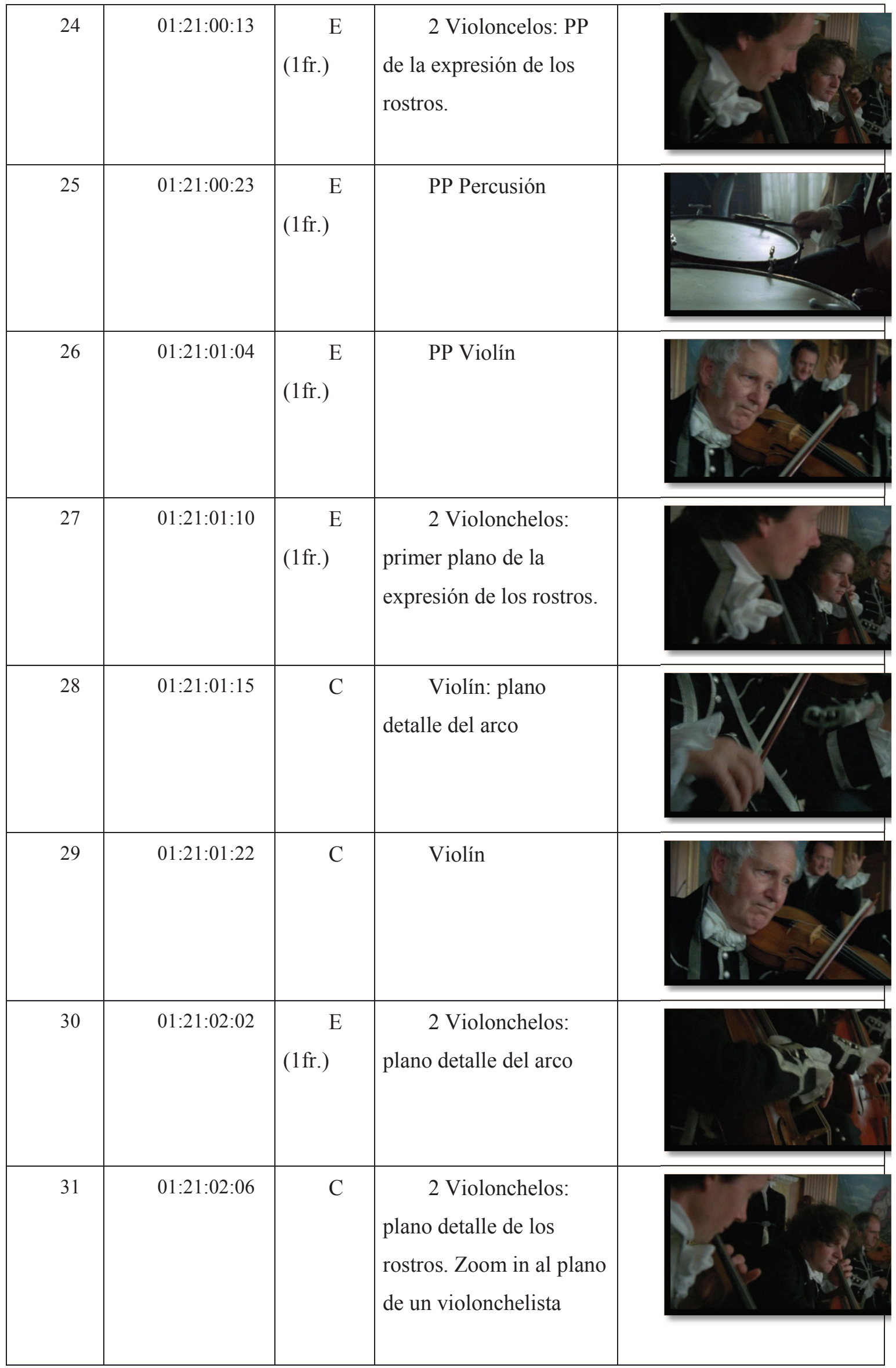


De la partitura a la pantalla: plano y contraplano de una misma realidad - 153

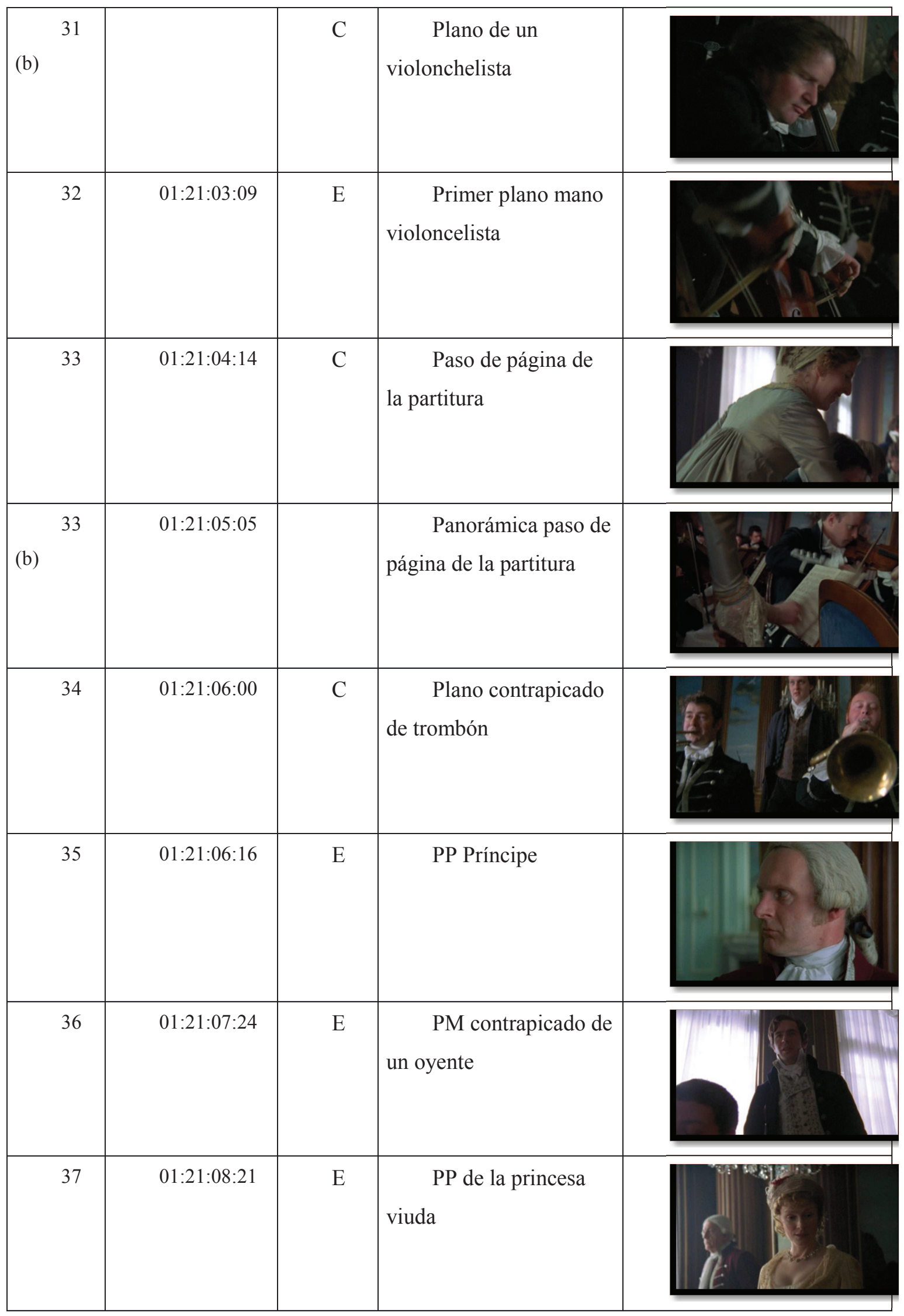


De la partitura a la pantalla: plano y contraplano de una misma realidad - 154

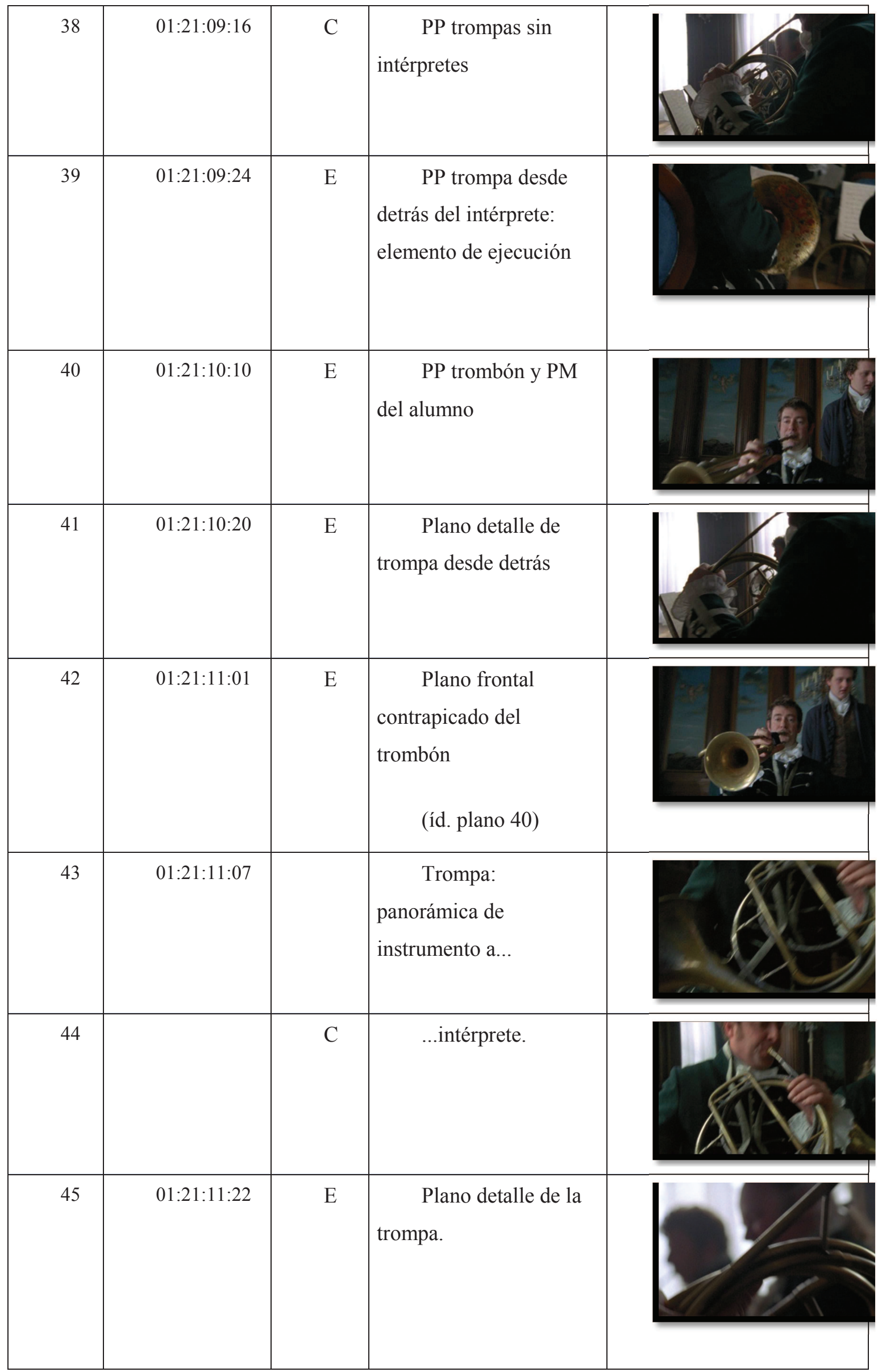


De la partitura a la pantalla: plano y contraplano de una misma realidad - 155

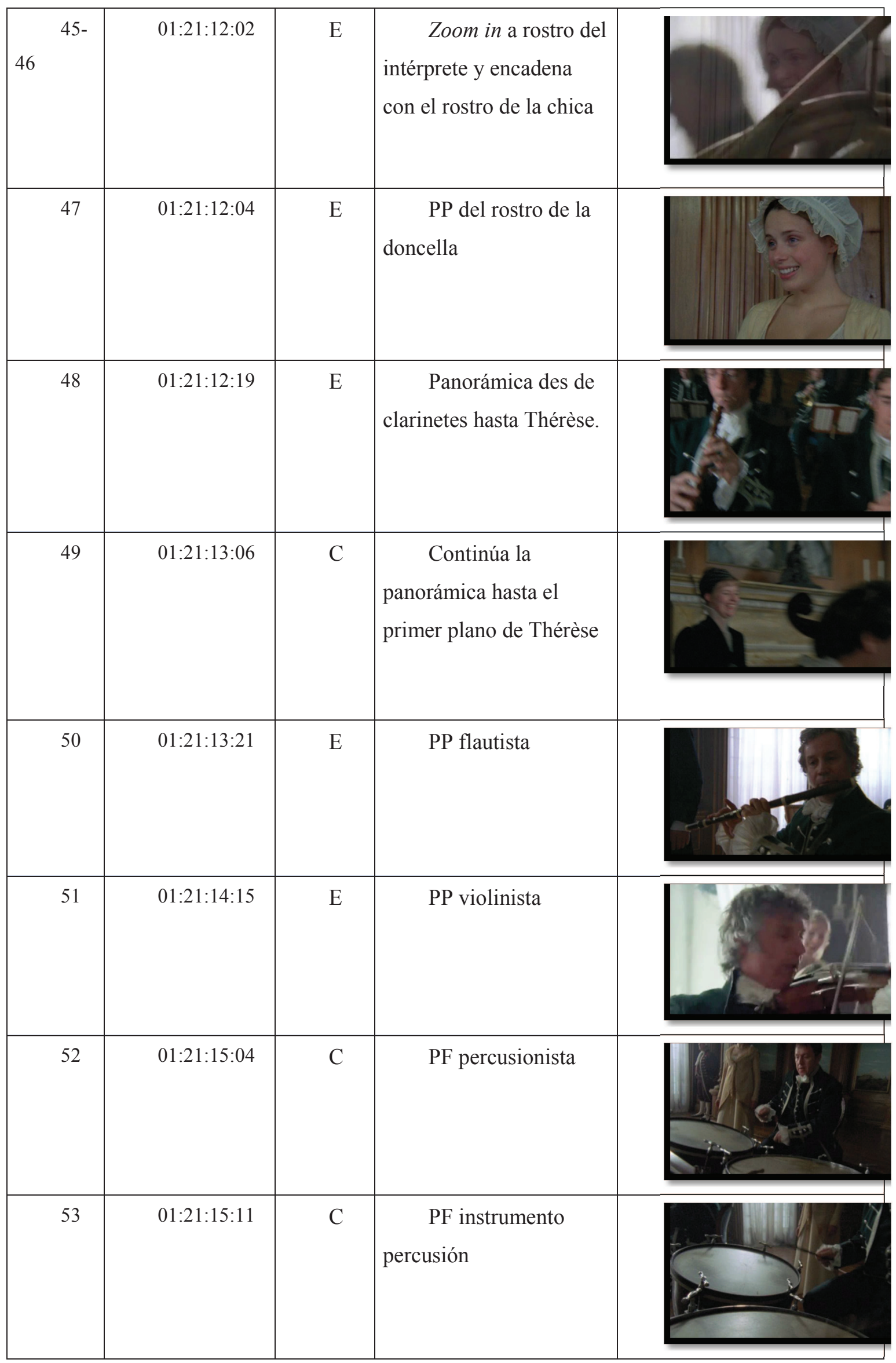


De la partitura a la pantalla: plano y contraplano de una misma realidad - 156

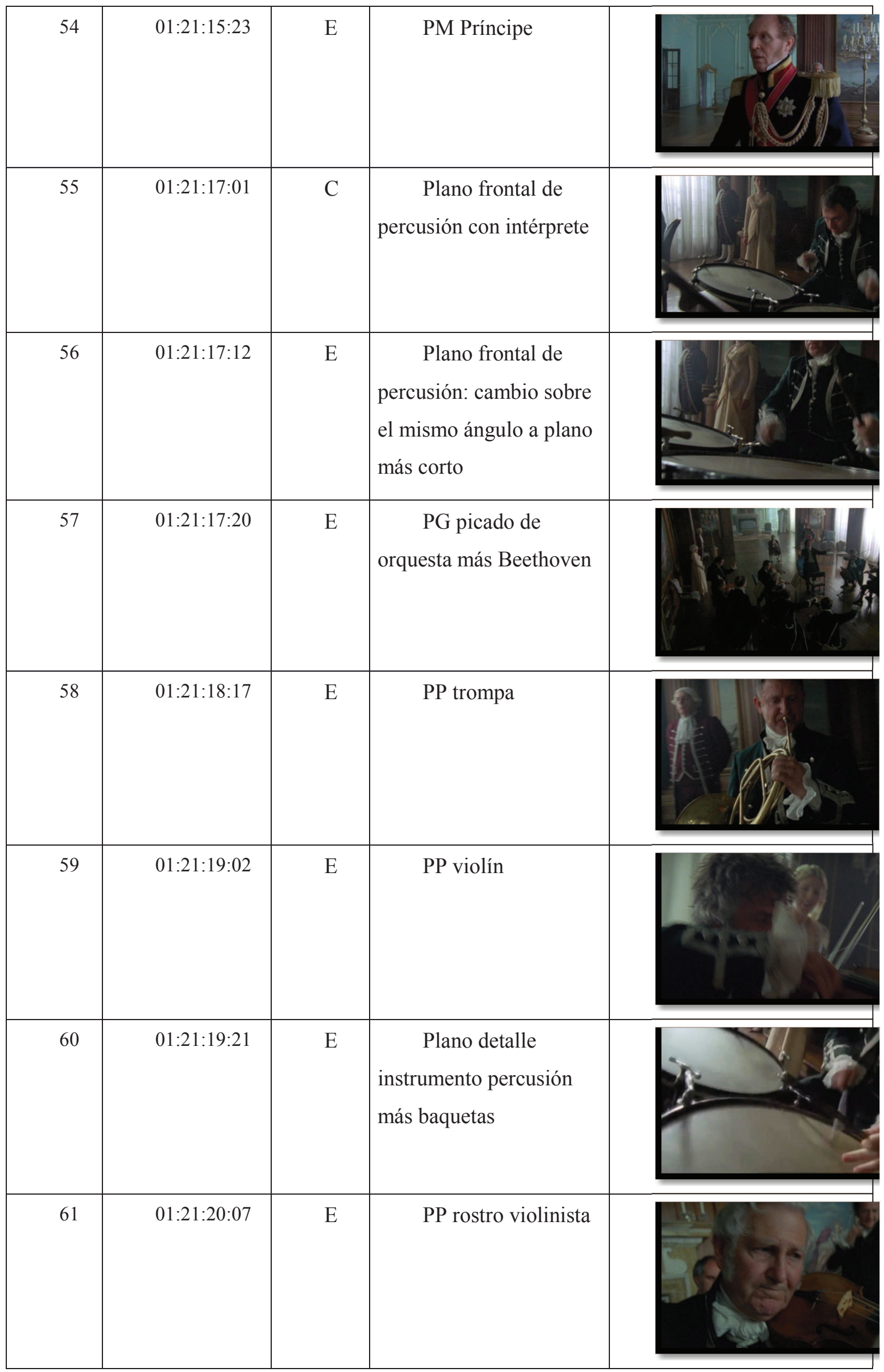


De la partitura a la pantalla: plano y contraplano de una misma realidad - 157

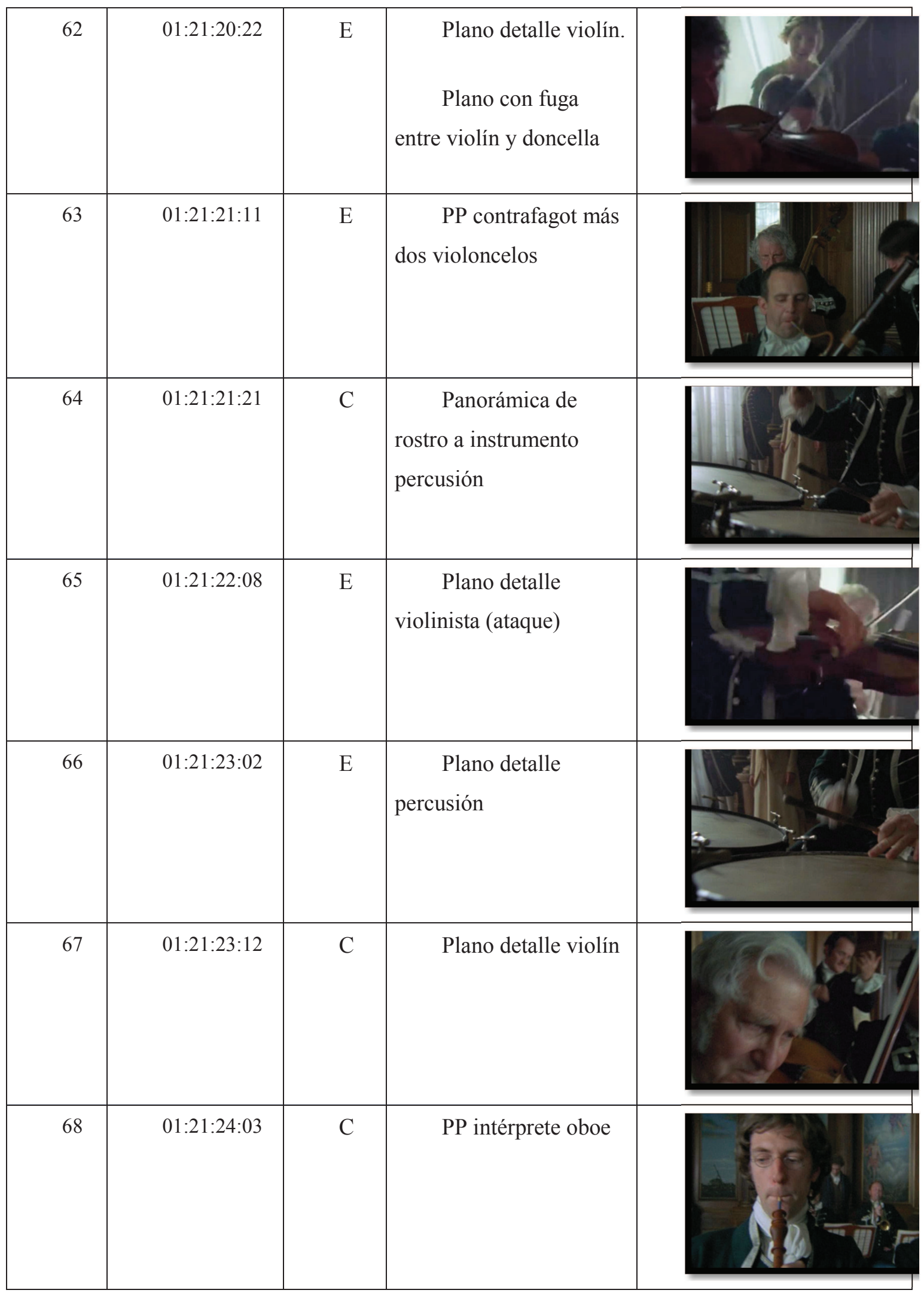


De la partitura a la pantalla: plano y contraplano de una misma realidad - 158

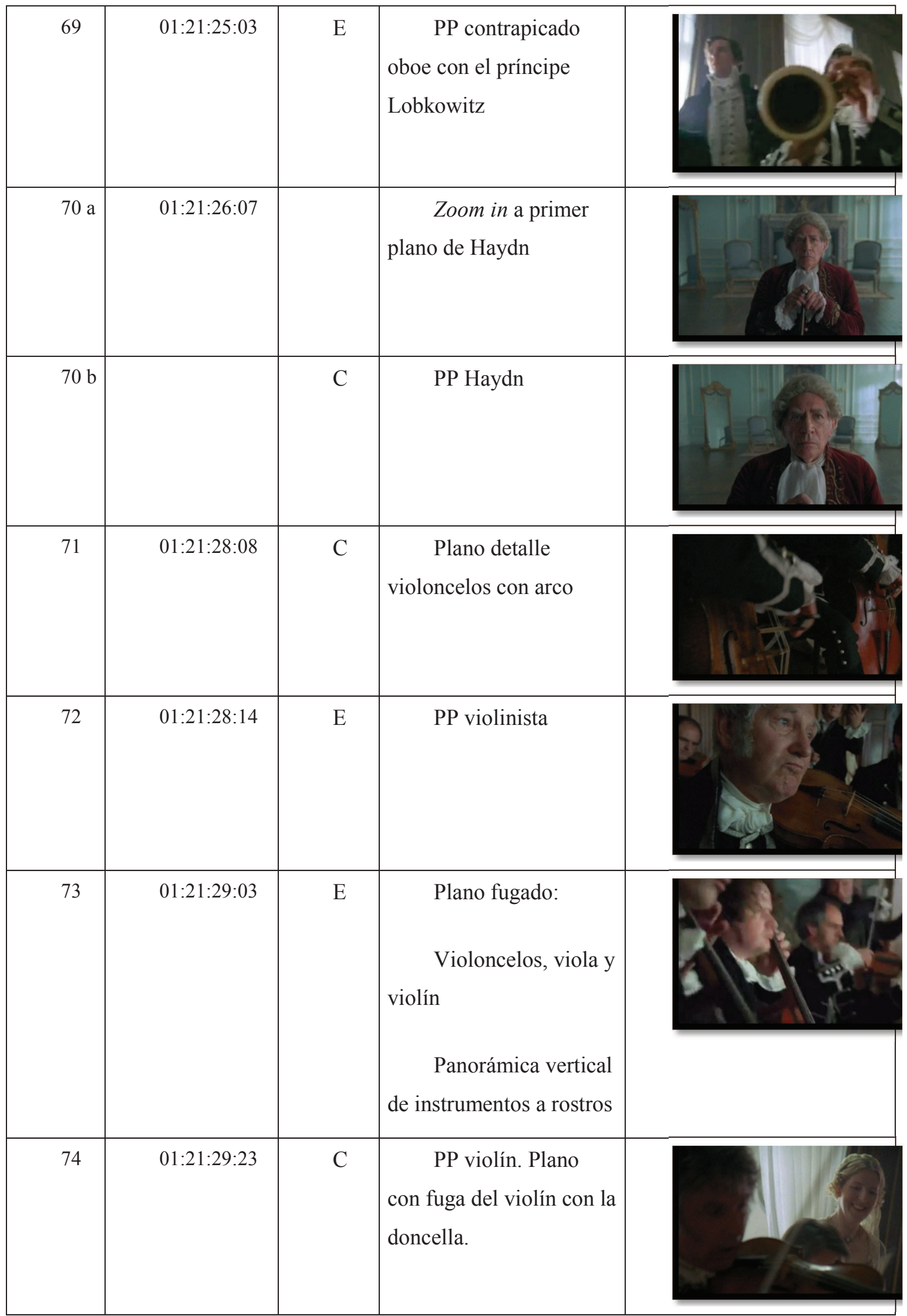


De la partitura a la pantalla: plano y contraplano de una misma realidad - 159

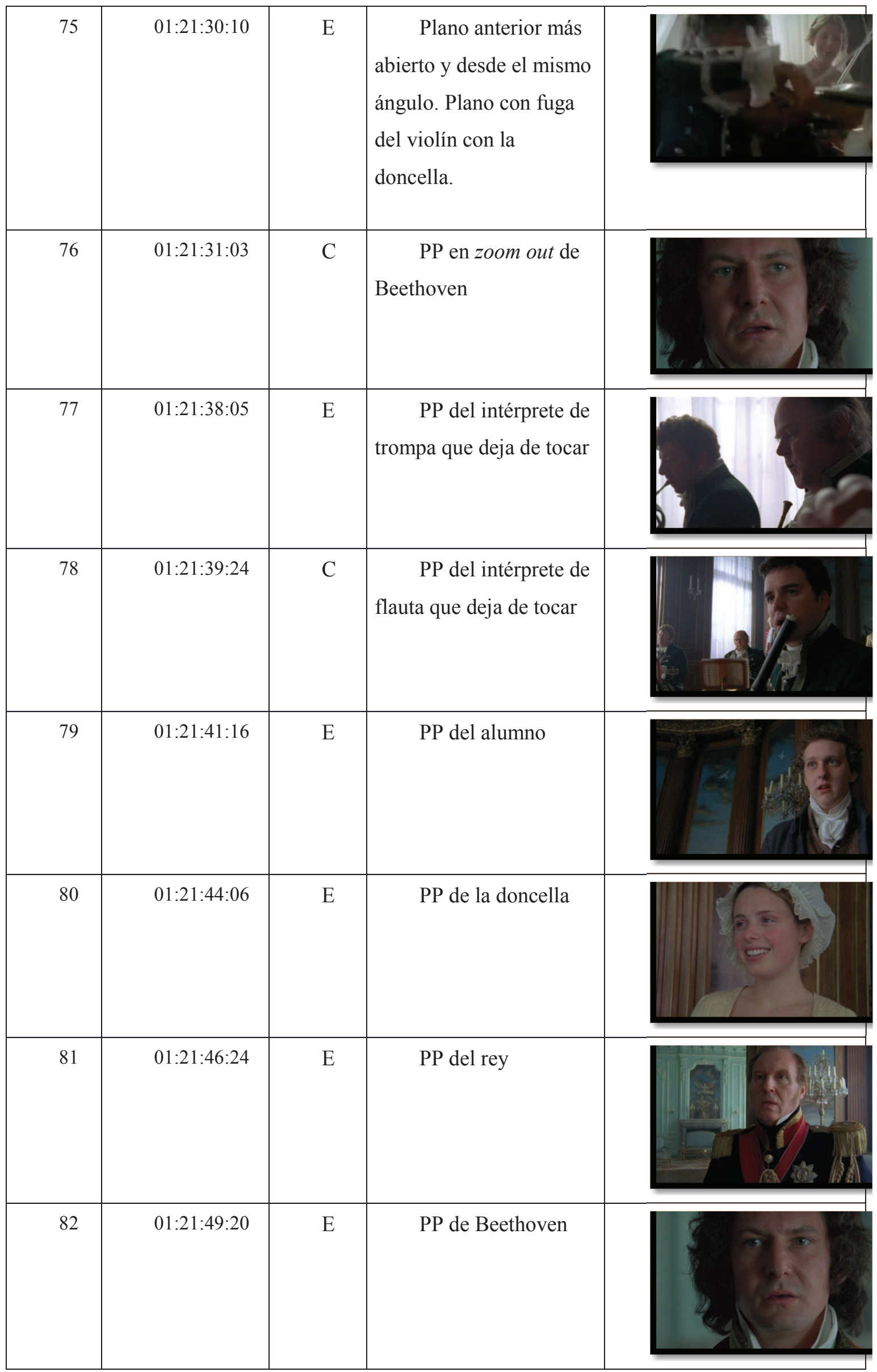




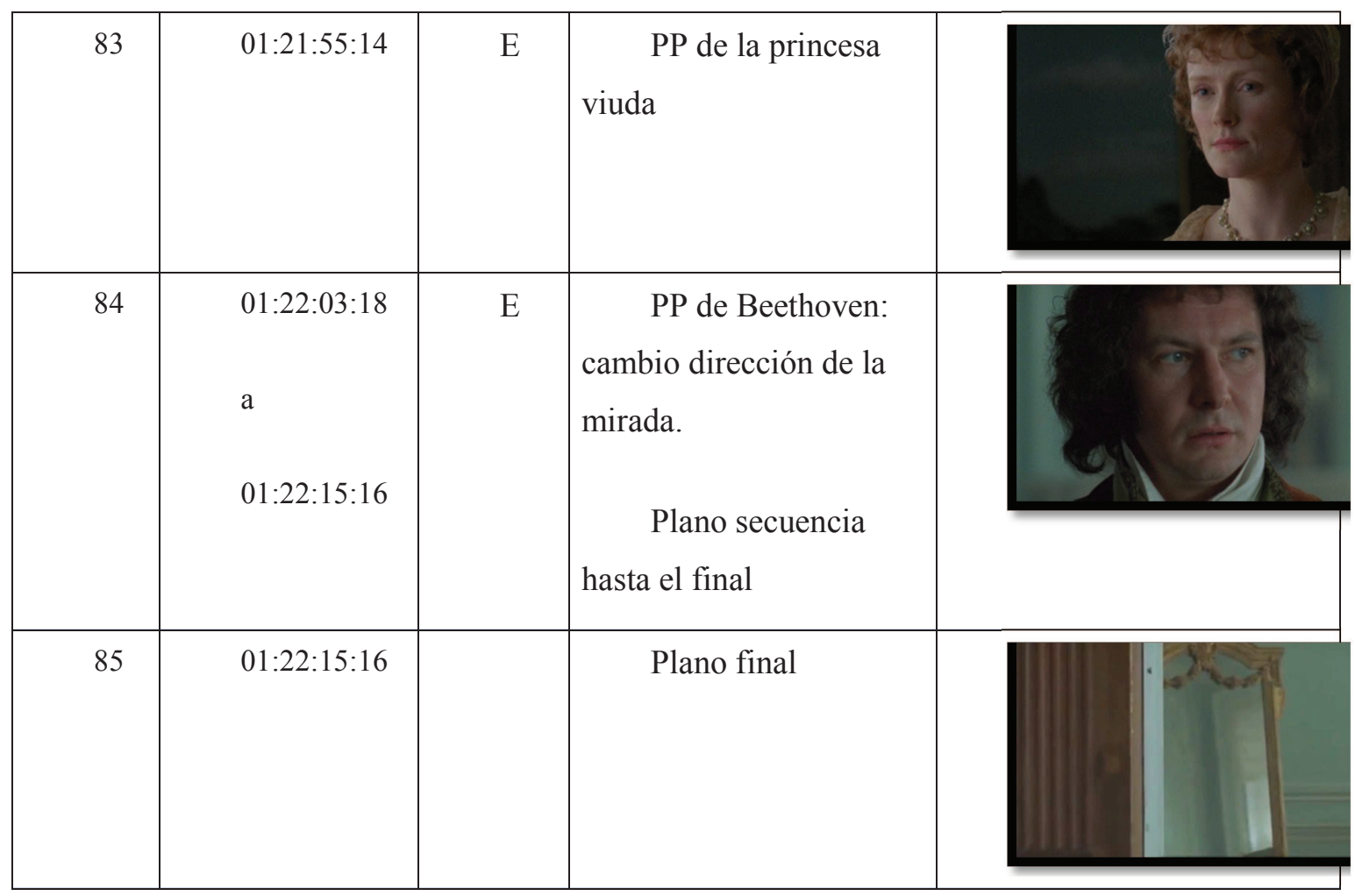

d) Cuarenta y cinco vertiginosos segundos

En el desglose plano a plano y de manera sintética se puede apreciar una gran mayoría de planos que se suceden rápidamente uno tres otro y que se caracterizan por un dinamismo interno. Lo analizo más detalladamente a continuación. ${ }^{46}$

- 76 planos durante 45" segundos. Podemos comprobar, así pues, el ritmo vertiginoso de realización en este final de la sinfonía.

- 71 planos tienen una duración de menos de un segundo. Sólo los planos 1, 10, 31, 54, 68, 69 y 70 duran más de un segundo. El primer plano dura más segundos porque responde a la lectura de un plano general de la orquesta y es la manera de situar en el entorno al espectador. La razón de que otros planos duren más de un segundo es porque la cámara hace un movimiento de barrido o una panorámica dentro del mismo plano.

\footnotetext{
${ }^{46}$ Ya en el primer tiempo quedan comentados estos elementos no aceptados desde las primeras normas audiovisuales. En estos últimos cuatro segundos es cuando constatamos un uso importante de estos recursos llevados al límite.
} 
- La transición entre planos es principalmente por encadenado de un frame, excepto en algunas ocasiones que es por corte. Este tipo de transiciones rápidas modelan el dinamismo sintáctico de la realización.

- Todos los planos son dinámicos; bien porque el instrumentista se mueve, bien porque la cámara realiza pequeños o bruscos movimientos.

- La composición del plano acostumbra a ser desequilibrada. Es decir, con más peso en un lado del plano que en otro. Por ejemplo, se puede apreciar en los fotogramas 40, 49 o 69. Esto da sensación de dinamismo.

- Las angulaciones de los planos también son muy extremas en algún momento; sin embargo, la composición de cada plano no pierde su valor.

- Existen saltos entre planos académicamente "ilícitos" si se tratara de una realización de un concierto; sin embargo, dado el dramatismo de este momento final, parece que el espectador lo asume y percibe con una lectura audiovisual totalmente lógica. Por ejemplo, el paso del plano segundo al plano tercero. Es un salto sobre el mismo instrumento, la trompa, en plano detalle pero sin continuidad: no cambia el valor del plano ni la angulación; son casi el mismo plano y, sin embargo, queda perfectamente integrado en la realización narrativo-musical. Lo mismo ocurre con los bombos entre los planos 55-56. Saltar entre planos similares acostumbra a percibirse como un defecto, sin embargo, nuevamente, queda integrado. Y, por último, entre los planos 75 y 76, pasa lo mismo. El segundo plano no es mucho más abierto que el primero y, sin embargo, el ojo acepta este salto de valor de plano.

Y para acabar, cuarenta y cinco silenciosos segundos.

Secuencia final, de silencio absoluto excepto el "Gracias" de Beethoven, todos los planos exceden la duración de un segundo. Es importante remarcar los tres planos de más duración:

1. Planos 76 y 82 del compositor

2. Plano 83, viuda Josephine Von Deym

3. Plano 84, plano secuencia final de Beethoven 
- Planos más estáticos $\mathrm{y}$, todos ellos, son primeros planos de distintos personajes: dos instrumentistas, el discípulo, la doncella, el rey y, cómo no, los dos protagonistas: Beethoven y Josephine.

- $\quad$ El último plano es el más largo: plano secuencia de Beethoven que va desde su mirada a Josephine, el cambio de dirección de dicha mirada y la posterior salida de escena del protagonista.

e) Elementos finales

El semiólogo italiano Piero Polidoro trata tres conceptos a tener en cuenta: la pregnancia, las categorias eidéticas y el equilibrio visual. Desde estos tres elementos semióticos, la percepción de los planos desequilibrados y con angulaciones forzadas colabora en la transmisión de las emociones de cada uno de los personajes y en su interacción.

- Pregnancia- Se trata de la "buena forma":

Una buena forma es una forma particularmente sencilla, regular, simétrica y, por lo tanto, estable. (...) Las buenas formas serían por lo tanto configuraciones particularmente estables, puntos de referencia en relación a los cuales las otras configuraciones pueden ser consideradas como desviaciones (Polidoro, 2016: 94-95)

Es en el juego de contrastes entre planos que captamos el concepto de pregnancia: formas sencillas y regulares en el interior de los planos frente a momentos que se alejan de estos planos con una composición más atrevida. Lo vemos en los dos siguientes fotogramas: 


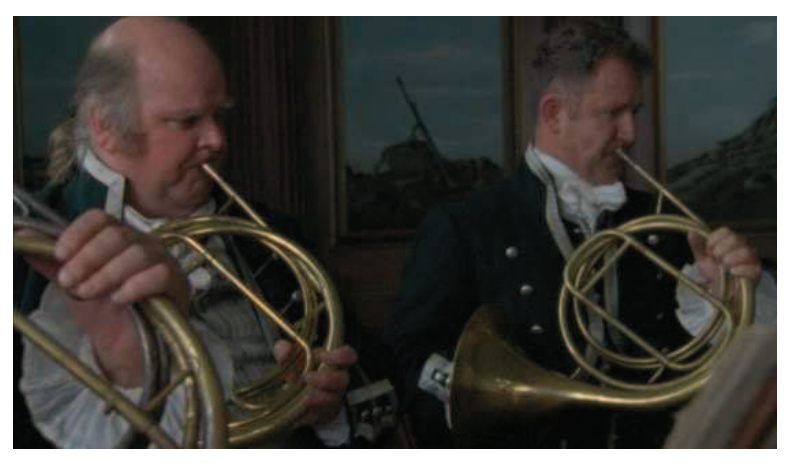

Figura 45 Composición equilibrada, Eroica. M. Millà.

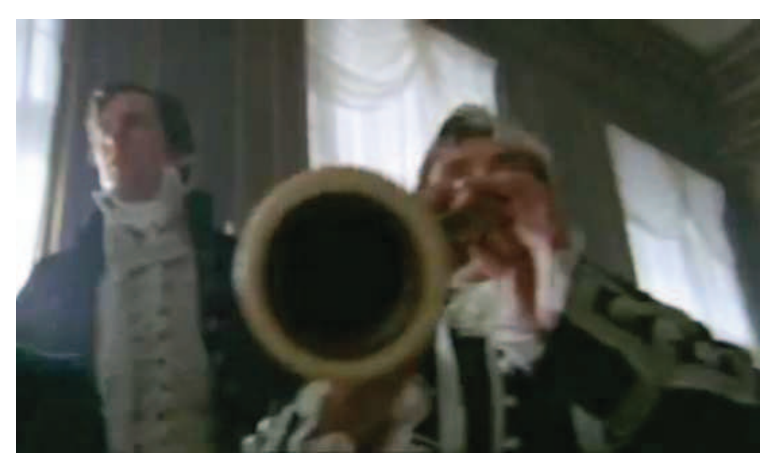

Figura 46 Composición angulada y con desequilibrio, Eroica. M. Millà.

- Categorías eidéticas:

Son las propiedades del trazo de una línea: rectilínea, curvilínea, segmentada entre otros.

Estas categorías se perciben a través de la composición interna del plano líneas diagonales o verticales- y a través del movimiento de la cámara - travellings circulares, barridos horizontales o verticales, entre otros movimientos-. La combinación de ambos elementos audiovisuales provocan la percepción de los distintos ritmos. Ya hemos podido comprobar cuán distinta es la solución encontrada por el director en la filmación del pausado segundo tiempo frente a la solución de los cuarenta y cinco vertiginosos segundos del cuarto tiempo.

- Equilibrio visual: 
Este equilibrio se percibe a través de los vectores, la dirección de los cuales hace que un plano se perciba como más o menos dinámico. Hablamos de más o menos equilibrio a partir de unes connotaciones culturales. Pero, es a partir de este substrato cultural que percibimos cada plano con un lenguaje propio.

Durante toda la filmación del concierto se perciben planos equilibrados, con un eje vertical u horizontal evidentes, y planos desequilibrados que inducen a una percepción mucho más dinámica de la narración, con un añadido que es la interpretación emocional o dramática de la misma.

La suma de todos elementos ayudan al director a una realización cinematográfica de la narración narrativo-musical.

Sin embargo, cuando José Nieto nos habla de una realización cinematográfica, excluye aquellos planos que sólo enseñan una mano que interpreta, una embocadura en el caso de los instrumentos de viento, planos muy de detalle...entonces, ¿cuál sería el valor cinematográfíco de Eroica ya que hemos comprobado un elevado uso de este tipo de planos?

¿Cuándo podemos traspasar estos límites que nos alejan de la cinematografía de la que nos habla José Nieto?

Creo que el valor que tiene cruzar la frontera de estos convencionalismos está en el hecho de que se trata de una filmación cuyo producto final es una película y su trasfondo o intención está más allá de lo puramente musical. Sin embargo, y como mostraré en los capítulos posteriores, la narrativa audiovisual de los espectadores ha evolucionado de tal manera que, incorporar dichos recursos más avanzados en cuanto a lectura audiovisual, convierte determinadas filmaciones en producciones interesantes que implican más al espectador. A modo conclusivo, creo que ambas acepciones del concepto de "cinematografía musical" no son antagónicas sino perfectamente conjugables: una, desde un contexto puramente estético-visual y, otra, desde un concepto implícito de aquello que en la partitura subyace. El encuentro de ambas no hace más que permitirme seguir el camino en dicha investigación. 
Capítulo 3: Concepto de filmación para la emisión de conciertos en directo 
De la partitura a la pantalla: plano y contraplano de una misma realidad - 166 


\section{Introducción}

Una vez analizada, en el capítulo anterior, la manera de proceder para la filmación de un concierto grabado, ahora voy a profundizar en el concierto, quizás, más visto a través de televisión, a nivel mundial: dicen que un billón de personas ven, año tres año, la realización en vivo y en directo del tradicional concierto de Año Nuevo. Dicho evento musical es retransmitido el día 1 de enero a las 11.00 hrs, aproximadamente, desde la sala Dorada del Musikverein de Viena (Austria). Sin duda, una de las cunas de la música clásica europea. A ella acuden, por sorteo (aunque también, cada vez más, viajes organizados proporcionan una entrada segura) a lo que, más que un concierto, podríamos llamar: evento cultural del año.

A pesar de estar ante este evento cultural de primer orden, y que ello implicará unas características a tener en cuenta en el momento de la retransmisión, la tarea principal del director sigue siendo la misma: llevar a la pantalla aquello que existe en la partitura previamente. Es muy importante no perder de vista este dato ya que lo que verán en sus televisores los espectadores que están a miles de kilómetros de dicha capital austríaca, no deja de ser lo que otros están viendo desde la misma sala y, esto es, un concierto. Han sido muchos otros aspectos los que lo han convertido en algo que va mucho más allá y que analizaré en otro apartado de este mismo capítulo; pero, la esencia es la misma que la que lleva a Simon Cellan a captar la Sinfonía Heroica: música escrita, interpretada y llevada a la pantalla.

Cuando en el anterior capítulo diferenciaba entre huella dactilar y huella digital, aquí ocurre lo mismo; sin embargo el paso de una huella a otra, ante un directo, implica una metodología totalmente distinta. Los motivos los iré señalando y analizando uno por uno.

\subsection{La partitura como discurso narrativo}

\section{a) Narrador}

Con cada uno de los compositores elegidos, estamos ante una de las principales figuras que participan en el Concierto de Año Nuevo. Siempre es importante el narrador, pero, en este caso en concreto, su importancia es básica, ¿por qué? Pues porque no se entendería un Concierto de Año Nuevo en el que se interpretaran obras de compositores ajenos a la historia de la música clásica europea que se aleje de unos estándares habituales, principalmente los 
compositores que integran la familia Strauss: Johann Strauss - padre e hijo-, Josef Strauss y Eduard Strauss. Es sabido que, en su momento, Johann Strauss fue juzgado como un compositor de segunda fila, sin embargo, con el paso del tiempo se ha hecho un buen lugar en la historia musical europea. Así pues, si, algún año alguien se atreviera a programar una pieza musical de Mompou o Debussy, por nombrar algunos compositores, seguramente las críticas serían abundantes por lo que de tradicional tiene este concierto en cuanto a la elección de sus "narradores".

Otro narrador es el director de orquesta. El primer director que asumió la tarea de dirigir este concierto fue Clemens Krauss, austríaco. Acometió dicha labor en trece ocasiones: el primer año, 1939, y hasta el año 1954. Sólo en dos años intermedios cedió la batuta a otro director austríaco: Josef Kripps (1946 y 1947). A continuación, veinticinco años seguidos (1955-1979) en los que la dirección fue asumida por el, también, austríaco Bill Boskovsky. Y, a partir de aquí, un primer cambio de rumbo en la tradición de la dirección musical del concierto. De repente, aparece un estadounidense en la dirección del concierto del día 1 de enero de 1980: Lorin Maazel. Lo hace durante seis años y, es en el año 1987, cuando, nuevamente, se decide romper con la tradición más absoluta y que cada año dirija un maestro distinto de fama internacional. El primero en ser invitado es Herbert von Karajan ${ }^{47}$. Posteriormente, han pasado muchos directores de muy diversas nacionalidades ${ }^{48} \mathrm{y}$, evidentemente, cada "narrador-director musical" aporta su personalidad al concierto. El factor sorpresa para saber qué director será el que dirigirá la orquesta el año siguiente es uno de elementos que juegan a favor de que este concierto se convierta en un evento de relevancia mundial $\mathrm{y}$, sobretodo, en materia importante a tener en cuenta para aquellos críticos musicales de cada uno de los países a los cuales llega la señal internacional para poder ver el concierto o escucharlo, puesto que también se transmite a numerosas radios de todo el mundo.

Como tercer narrador: la orquesta. Si la tradición se rompe con el nombramiento anual de director musical, la orquesta es siempre la misma: la Orquesta Filarmónica de Viena. Es evidente, ni la sala de conciertos ni la orquesta pueden ser cambiados puesto que se trata del "narrador legítimo" y la ubicación original para este concierto. Es este concierto, en esta sala

\footnotetext{
47 Analizaré audiovisualmente la realización llevada a cabo ese año (1987) en el apartado dedicado al Vals Danubio Azul

${ }^{48}$ Daniel Barenboim, Seiji Ozawa, Claudio Abbado, Riccardo Muti, Zubin Mehta, entre otros. El último, Gustavo Dudamel (2017).
} 
y con esta orquesta, lo que convierte este evento musical en el evento socio-cultural, me atrevería a decir, de mayor raigambre a nivel mundial. Existen otros, pero, no mueven un equipo audiovisual con una logística de tanto nivel para llegar a nivel internacional y que tenga un público potencial de un billón de espectadores gracias a la retransmisión en directo que llega a 90 países diferentes. Desde el año 1959, el primer año en retransmitirse a través de la Österreichischer Rundfunk (cadena televisiva austríaca), se han ido añadiendo diferentes países de todo el mundo para recibir la señal en directo del concierto que abre las puertas a cada año nuevo.

Así pues, los tres narradores ya están muy definidos por lo que respecta a la retransmisión de este concierto. El "juego" entre los tres es lo que dará la calidad musical a tan prestigioso, al mismo tiempo que popular, concierto de Año Nuevo. Tal y como afirma la orquesta, no se trata sólo de hacer llegar la música de este tipo de género a los espectadores, sino que, como embajadores de Austria, felicitar, a través de ella, el nuevo año.

\section{b) Observador}

Llegamos a la pieza clave en este proceso entre lo que es la "huella dactilar" y la "huella digital": el observador. En este caso el director o realizador se convierte en un observador de excepción. Cualquier profesional dedicado al broadcast ${ }^{49}$ sabe que llegar a dirigir este concierto supone muchas cualidades a tener en cuenta; pero, una, principalmente: me refiero a saber dirigir un gran equipo humano en el que, en el momento del directo, cada uno sepa qué tiene que hacer, cómo lo tiene que ejecutar y, sobretodo, ayudar a una exigente atención en cada momento para que el engranaje sea perfecto o, prácticamente, perfecto.

Es decir, estamos ante un observador, no sólo de aquello que tiene que traspasar a la pantalla, sino del equipo que tiene delante. $\mathrm{Si}$ en un concierto con posterior edición y montaje, se tiene que llevar a cabo una planificación exhaustiva en cuanto a todo el equipo técnico y artístico; en el caso de un concierto que se emite en directo, la planificación debe llevarse a cabo de manera que el grado de error que se pueda cometer debe quedar en cero, o casi cero, posibilidades. Para ello, la preproducción de un concierto de este tipo debe desarrollar una táctica y una estrategia que no deje nada para la improvisación.

\footnotetext{
${ }^{49}$ Retransmisión en directo de eventos culturales, musicales, deportivos, entre otros.
} 
Cada vez más, el espectador entiende de lenguaje audiovisual y acostumbra a ser crítico con lo que ve. En este concierto, son muchos los espectadores que "examinan", de alguna manera, el director que está decidiendo por ellos lo que hay que ver en cada momento. Así que la figura del realizador en este concierto es una pieza clave: él será los ojos de billones de espectadores. Este es un difícil cometido por partida doble. No sólo por el hecho de que este producto va a entrar en un elevado número de hogares, sino porque el concierto siempre es en el mismo espacio y, además, algunas de las obras acostumbran a repetirse, con lo cual, el director debe estudiar de qué manera afronta la originalidad en la realización para no sucumbir, año tras año, en lo evidente de cada partitura. Así que cada director, intentará timbrar su sello personal a sabiendas que, también críticos de todo el mundo, se atreven ya a juzgar planos, ritmo y demás cuestiones audivisuales.

En la realización del Concierto de Año Nuevo, el débrayage entre el concierto y los espectadores de televisión sólo es de espacio ${ }^{50}$. Este dato es un valor añadido. Puesto que, actualmente, sólo eventos de este tipo son seguidos por millones de personas si se les ofrece en directo al mismo tiempo en que sucede el evento; estoy casi segura que, en caso de pasarse el concierto el mismo día por la noche, el nivel de las audiencias descendería notablemente. Poderlo ver en directo es lo que le convierte en el concierto más visto a nivel mundial. ${ }^{51}$

La tensión que suponen todos estos elementos presuponen un director que sea un buen líder: artístico, técnico y humano.

Así pues, a pesar de la simultaneidad en el tiempo, el realizador hace ya tiempo que ha estado viendo y analizando el concierto. En el momento de la retransmisión tiene muy claro qué es aquello que verá definitivamente el espectador. Su planteamiento lo ha decidido hace tiempo y la táctica y la estrategia ya están en escena. Sólo una buena preproducción y preparación del contenido puede ayudar en caso de que, en plena retransmisión surja algún problema técnico o artístico.

c) Punto de vista

De igual modo que en las grabaciones para conciertos que tendrán una edición posterior, el punto de vista se refiere a dos niveles:

\footnotetext{
${ }^{50}$ A no ser que no lo vean en directo y lo hagan posteriormente a través de la web, Youtube o en DVD.

${ }^{51}$ Dejo de lado los visionados a través de Internet y del DVD que se produce casi al mismo tiempo que el concierto (al día siguiente ya es posible comprarlo) que aumentan considerablemente los niveles de audiencia.
} 
- el punto de vista desde el concepto audiovisual concebido por el director a partir de la partitura que tiene que trasladar a los espectadores. Se trata de un punto de vista subjetivo y sugerente; con una significación subyacente que los espectadores no aprecian directamente pero que influye en la percepción estética global de la obra.

- el punto de vista desde cada una de las cámaras y sus ópticas. Se trata de un punto de vista concreto que llevará al punto de vista global.

De este modo, un punto de vista desde una cámara que ofrece planos picados o $\operatorname{contrapicados}^{52}$, sugerirá un punto de vista global al cual quiere llegar el director. Esta manera de realizar da un sentido semiótico a la partitura y hace que la percepción de la música llegue al espectador de manera que, el mismo, no espera. Mostraré algún ejemplo de ello en el análisis del Danubio Azul que se retransmite desde Viena el primer día del año.

\subsection{Táctica}

El director debe ser un buen profesional en el momento de proyectar la táctica encima de un plano. Taktiké techné, según el griego antiguo, supone ser una persona táctica; una persona que domina el arte de la ordenación o la colocación. Así pues, la táctica o colocación de cámaras en un concierto es aquella manera de proceder por parte del director que le hace reflexionar y tomar una inteligente decisión para que el producto audiovisual en cuestión no salga mermado en calidad y desarrollo narrativo, sino, todo lo contrario, bien explicado y enriquecido.

En el caso de mi investigación, es indiferente si se trata de un concierto en directo o en diferido, la táctica debe disponerse según cada una de las variantes metodológicas. Es cierto que, en directo, el riesgo a correr debe ser mínimo; sin embargo, ante una futura postproducción, el número de cámaras y su posición, puede ser mayor y más variado. Aún así, la diferencia principal está en el paso siguiente: el momento de pensar en la estrategia. Sea en directo o en diferido, se necesitan los puntos de vista básicos para ver toda la orquesta:

- Gran plano general- plano de toda la sala de conciertos o lugar donde se realice

- Plano general- plano ajustado a toda la orquesta

- Planos laterales- planos que muestran el lateral izquierdo o derecho de la orquesta

${ }^{52}$ Véase el ejemplo del concierto realizado por Karina Fibich. 
Estos tres tipos de planos son planos descriptivos. A partir de aquí- y tal como hemos visto en el primer capítulo- las distintas posiciones y número de cámaras serán decisión del director. Son las cámaras que, a través de planos más cortos y de detalle u otros planos estudiados de antemano por el director, enriquecen el lenguaje audiovisual.

Como no existe el débrayage temporal con el espectador, el director debe tener presente que tiene que enseñar todo aquello que, en directo, pero desde la distancia física, los espectadores quieren ver. Además, cuenta con la sala de edición para resolver errores; así que debe tener muy claro aquellos momentos a los que puede llegar y a los que no; por ejemplo, cualquier golpe percutivo de timbales, triángulo, gong u otros instrumentos que tienen un momento de ejecución corto, pero significativo y enriquecedor, debe asegurarse ya que, cualquier retraso o adelanto es un error sin posibilidad de solución puesto que el siguiente compás sigue sin ningún tipo de contemplación. En el caso de los conciertos en diferido, este tipo de planos se asegura con una cámara grabada como recurso $\mathrm{y}$, en caso de no llegar a tiempo, siempre queda la solución en la fase de postproducción. En este caso, la labor del equipo de realización y la indicación por parte del realizador del momento preciso deben rozar la perfección. Esto supone un trabajo de concentración, segundo tras segundo, que no se puede perder. Otros errores en las cámaras pueden provocar un cambio de timón en instantes precisos. Entre estos errores o problemas que pueden surgir están:

- Falta de foco en el plano.

- Plano no preparado para lo que se tiene previsto en un momento dado.

- Enfoque que no llega a tiempo a aquello que queremos porque el cámara aún está en movimiento buscando el plano pedido.

- Falta de comunicación entre el cámara y el equipo de realización por motivos técnicos

- Falta de encendido del avisador de la cámara que está en ese momento pinchada en directo ("tally"), con lo cual, el cámara no sabe si en ese momento puede moverse o cambiar de plano.

Evidentemente, pueden suceder muchos otros inconvenientes, es por ello que enfrentarse a una realización multicámara en directo supone un gran trabajo previo lleno de disciplina, concentración y, por encima de todo, un buen trabajo de equipo. 
De todos modos, los cámaras, después de varios ensayos y reuniones, llegan al directo con un listado preparado según el cual ya saben qué plano deben $\operatorname{preparar}^{53} \mathrm{y}$ de cuánto tiempo cuentan para ello. Nada es dejado, pues, al azar.

\subsection{Estrategia}

Aquí es donde el director se juega el todo en una realización en directo y, aquí está la diferencia fundamental con la realización en diferido. Strategia significa, en griego, el plan que una persona decide llevar a cabo para alcanzar su propósito. Así, en este caso, el director, como estratega de la realización, debe tener en cuenta todos los factores que intervienen en dicho evento músico-audiovisual. La espontaneidad y la poca o nula planificación pueden llevar al caos en momentos en que la orquesta avanza sin tregua y es imprescindible saber dónde se está en cada momento.

En el planteamiento deben entrar otros elementos a tener en cuenta:

- El ritmo o, mejor, tempo debe seguir, consecuentemente, la música: no caer en la lentitud debido a una mala previsión de planos; ni intentar seguir un ritmo vertiginoso que vaya contra la música y pierda el pulso que hace que una realización en directo fluya como si de un instrumento más de la orquesta se tratara.

- Riqueza de planos para que el espectador no pueda prever el plano que vendrá a continuación.

- Movimiento de cada plano con una intención planificada: panorámicas, travellings o zoom in/out.

- Paso de un plano a otro por encadenado o por corte, según el planteamiento de cada obra.

- Saber que no existe posibilidad de repetición y pasar al plano siguiente sin pensar en aquello que se había preparado y no ha podido ser. De no ser así, la concatenación de errores puede seguir hasta el final.

Así pues, la implicación en un directo para dar un óptimo resultado debe venir de tiempo atrás. Es por ello que, en el siguiente apartado, analizo cuatro tipos de realización del Danubio Azul. Todos sabemos que si hay algún concierto retransmitido para televisión que esté bien preparado y producido, este es, precisamente, el Concierto de Año Nuevo.

\footnotetext{
${ }^{53}$ En el caso de realizadores europeos que preparan minuciosamente su trabajo audiovisual.
} 


\subsection{Ejemplo de retransmisión en directo: El Danubio azul}

\section{Concierto de Año Nuevo desde Viena}

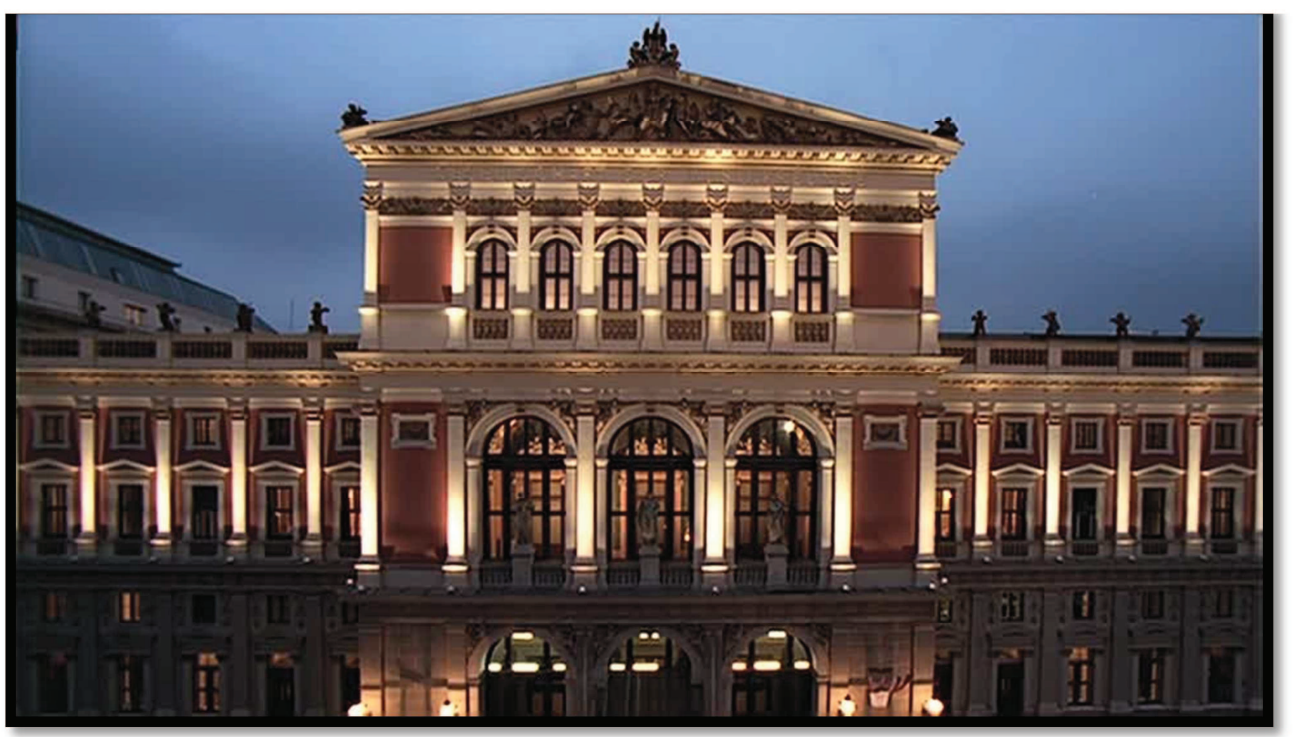

Figura 47 Exterior de la sala de conciertos Musikverein de Viena. Framepool.

He escogido cuatro versiones diferentes de esta composición para poder analizar cuatro maneras distintas de ejecutar una realización audiovisual a partir de una misma partitura. A continuación expongo los datos de las cuatro versiones con una diferencia de 29 años entre ellas; lo suficiente, también, para ver el proceso evolutivo, no sólo en lo artístico, sino en lo técnico. El trabajo de análisis de las partituras se puede consultar en el Apéndice I.

Obra: Vals Danubio Azul (An der schönen blauen Donau, op. 314)

Compositor y año: Johann Strauss (hijo), 1866

\section{Directores musicales:}

Año 1987: Herbert Von Karajan

Año 2011: Franz Welser-Möst

Año 2013: Franz Welser-Möst

Año 2016: Mariss Jansons

\section{Directores audiovisuales:}

Año 1987: Humprey Burton https://www.youtube.com/watch?v=tfRT8T7VX2U

Año 2011: Brian Large https://www.youtube.com/watch?v=tEDxGTLAUsQ

Año 2013: Karina Fibich

https://www.youtube.com/watch?v=1Sm730vHSGM\&feature=youtu.be 
Año 2016: Michael Beyer https:/www.youtube.com/watch?v=S fk5aoEfl4 Interpretación: "Orquesta Filarmónica de Viena"

\section{a) Vals Danubio Azul, Concierto Año Nuevo, 1987}

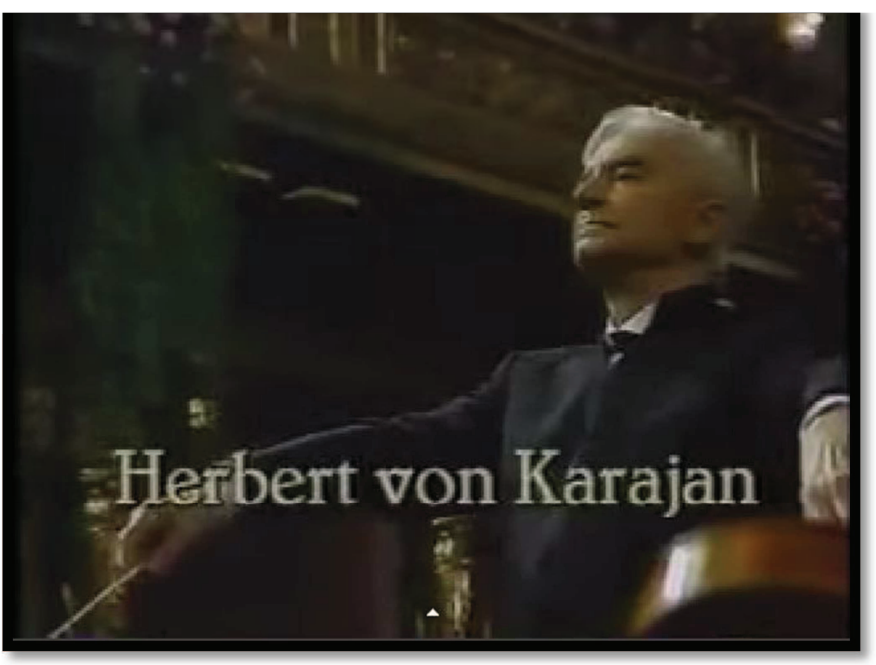

Figura 48 Concierto Año Nuevo 1987. M. Millà.

\section{Director musical:}

Herbert Von Karajan

\section{Director audiovisual:}

Humprey Burton

Ejemplo 10: https://www.youtube.com/watch?v=tfRT8T7VX2U (subido por M. Millà)

\section{a.1) Análisis}

1987 fue el primer año en que se decidió apostar por directores de orquesta que tuvieran cierta relación con la Orquesta Filarmónica de Viena y, supuestamente, reconocidos internacionalmente. Este año, Herbert Von Karajan fue el encargado de dirigir el concierto. Muchas críticas han valorado dicho concierto como uno de los mejores de la historia de dicha retransmisión. El realizador o director (Bildregie, tal como sale en alemán en los créditos ${ }^{54}$ del concierto) fue Humprey Burton. No es un

\footnotetext{
${ }^{54}$ Los créditos son todos los nombres que salen en pantalla, en forma de listado, al final de una retransmisión. Es decir, el listado de nombres que han hecho posible técnica y artísticamente la retransmisión.
} 
nombre conocido y, sin embargo, resulta ser una persona de gran prestigio y reconocida en el ámbito de la cadena BBC. Fue jefe de "Music and Arts" en dicha cadena y un gran productor, presentador y director (broadcaster) de conciertos. Así que, no pusieron en manos de un desconocido la dirección audiovisual del concierto en ese año, sino que la responsabilidad recayó en un director ampliamente conocido dentro de la música clásica y los medios audiovisuales.

Dos características que imprimen carácter actualmente en la retransmisión de este concierto, aún no existían en aquel momento:

- Al inicio de la retransmisión no aparece en pantalla total el nombre del director Humpfrey Burton; sólo aparece el nombre del director musical, en este caso, el gran maestro Herbert Von Karajan.

- $\quad$ El momento inicial del Vals del Danubio Azul, el trémolo de los violines, no es interrumpido para dar paso a la felicitación del nuevo año que acaba de empezar. Es decir, la entrada falsa a la que, hoy en día, ya estamos acostumbrados y cuyo público en la sala Musikverein ya espera, aún no estaba instaurada como "convención anual" dentro del concierto.

Destaco estos dos elementos porque creo que son importantes respecto a la importancia social que este concierto tiene. El primer elemento introduce la significación y el valor que, actualmente, se da al realizador del evento. En muchas críticas de periódicos se trata el tipo de realización e, incluso, días antes ya se comenta quién será el encargado de llevar a cabo la retransmisión. En cuanto al segundo elemento, es curioso ver cómo se van creando convenciones sociales, por lo cual, el realizador debe estar prevenido para enseñar a todo el mundo la "broma" que los espectadores esperan. Es decir, es evidente que, aparte de enseñar musicalmente aquello que sucede, la realización debe significar especialmente aquellos elementos sociales que el concierto refuerza año tras año.

\section{a.2) Estrategia: Secuenciación analítica}

No todos los años se lleva a cabo una realización que combine orquesta y ballet en el Vals del Danubio Azul. En el caso del año 1987 se decidió por dicha combinación de 
artes. A continuación, expongo el análisis de cada uno de los planos en la realización de dicha composición musical. Las seis columnas incluyen las siguientes informaciones ${ }^{55}$ :

1. Número de plano.

2. El time code o código de tiempo en el que empieza el plano siguiente expresado en horas-minutos-segundos y, en algún tiempo musical en que una fracción de tiempo menor es importante, también señalaré los frames $^{56}$

3. Tipo de transición entre planos consecutivos: por corte ( C ) o por encadenado ( E).

4. Descripción del contenido del plano, de su valor y del movimiento interno que tiene.

5. Movimiento interior del plano.

6. Imagen de un frame congelado.

\footnotetext{
${ }^{55}$ He seguido el mismo método de análisis de planos de los conciertos en diferido; aunque, en el caso de los cuatro videoclips de este capítulo, he preferido añadir una columna más con la información del movimiento interior de los planos para poder realizar una comparación más exhaustiva entre ellos.

${ }^{56}$ Añado la misma observación que en el anterior capítulo respecto los fotogramas de la película Eroica; no los incluyo dentro del listado de figuras puesto que todos son fotogramas extraídos de los videoclips de cada concierto.
} 
De la partitura a la pantalla: plano y contraplano de una misma realidad - 178

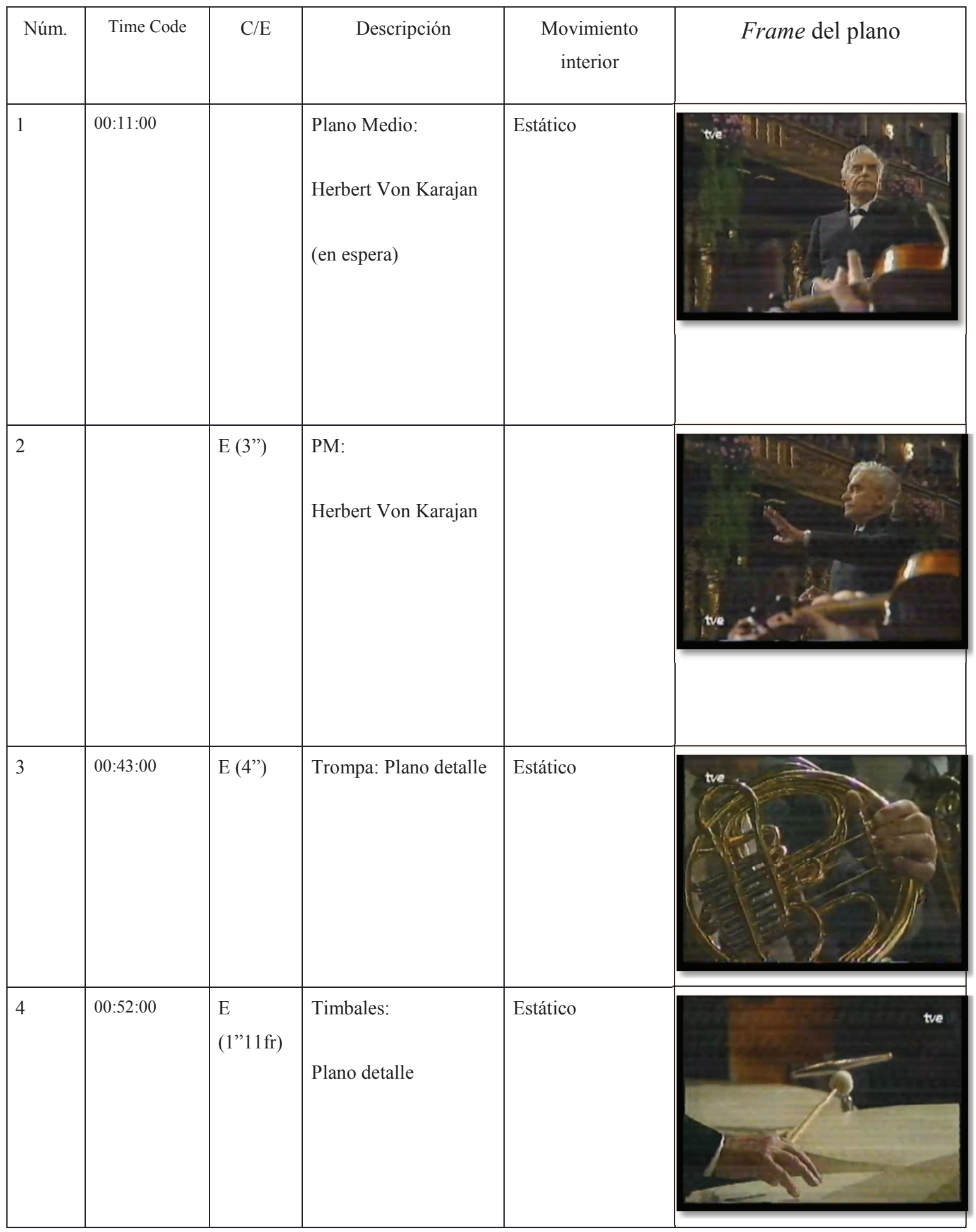


De la partitura a la pantalla: plano y contraplano de una misma realidad - 179

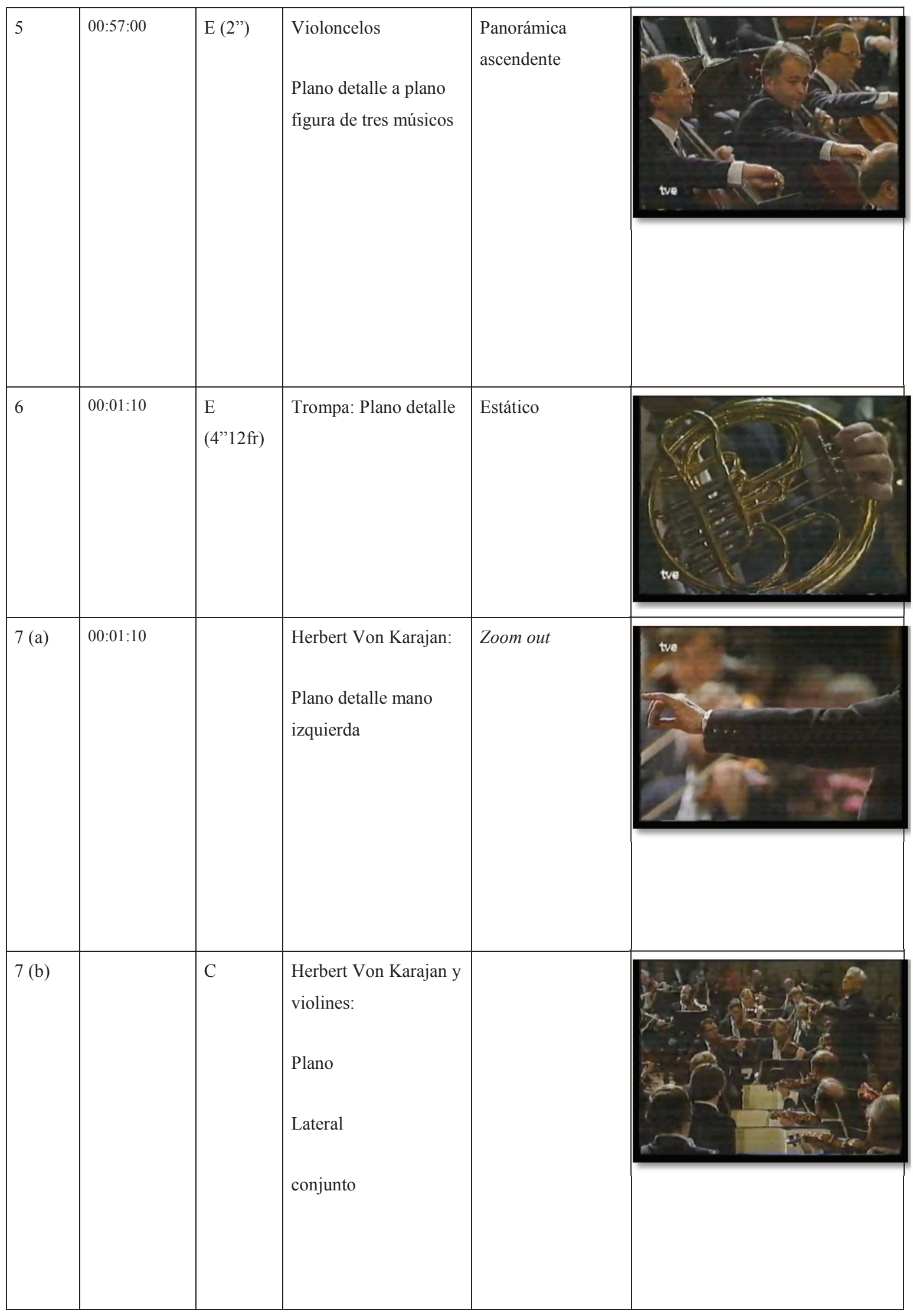


De la partitura a la pantalla: plano y contraplano de una misma realidad - 180

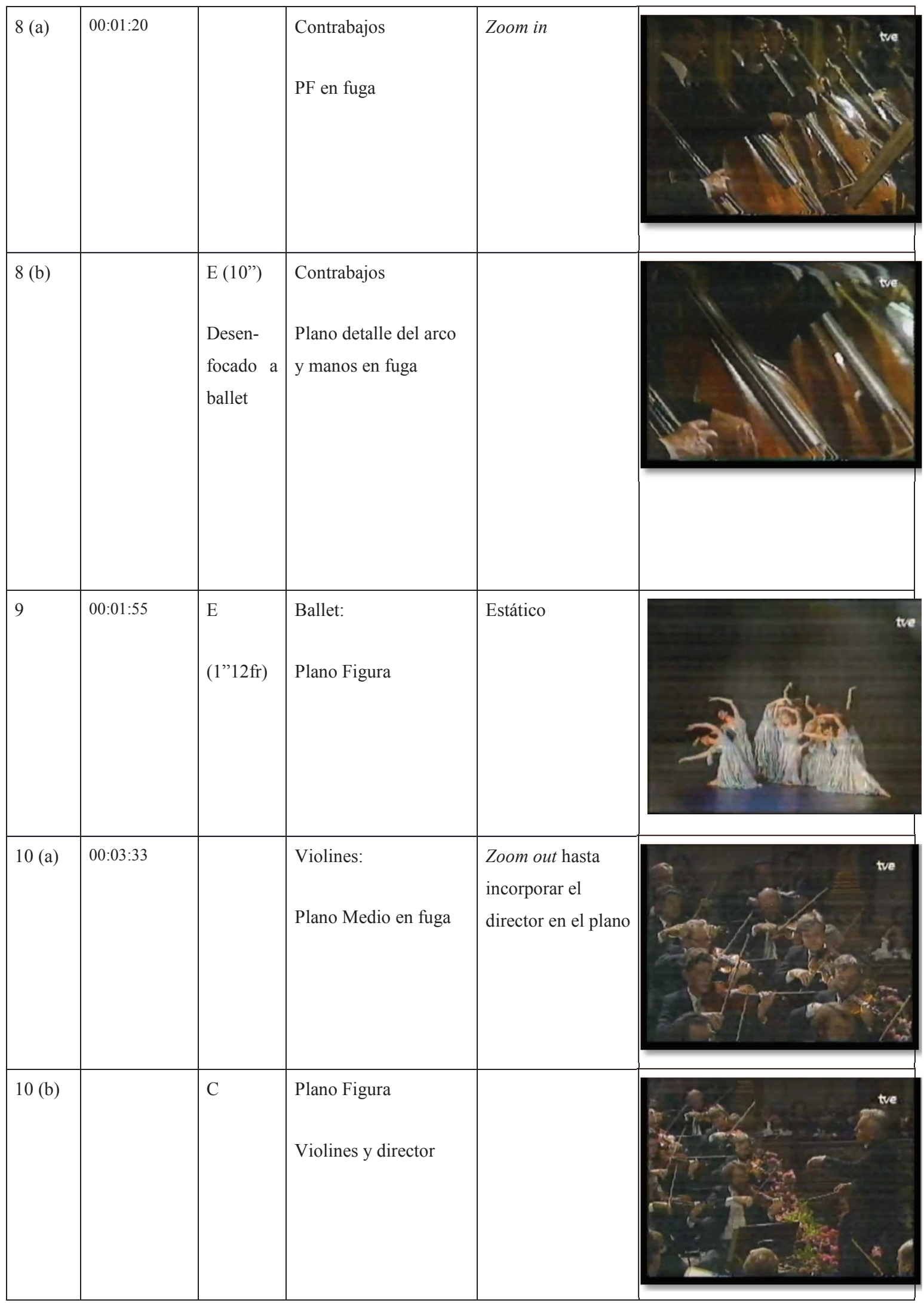


De la partitura a la pantalla: plano y contraplano de una misma realidad - 181

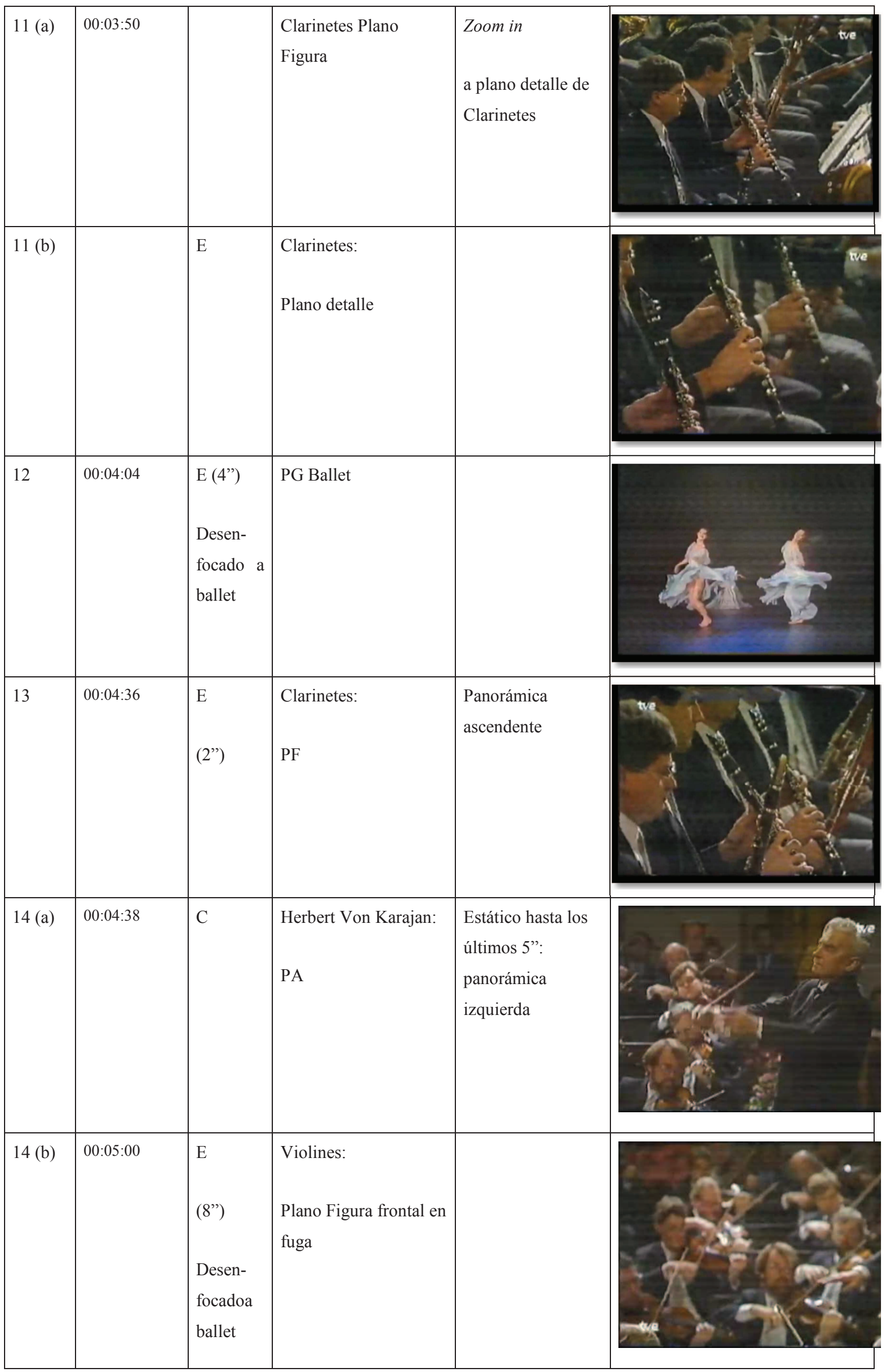


De la partitura a la pantalla: plano y contraplano de una misma realidad-182

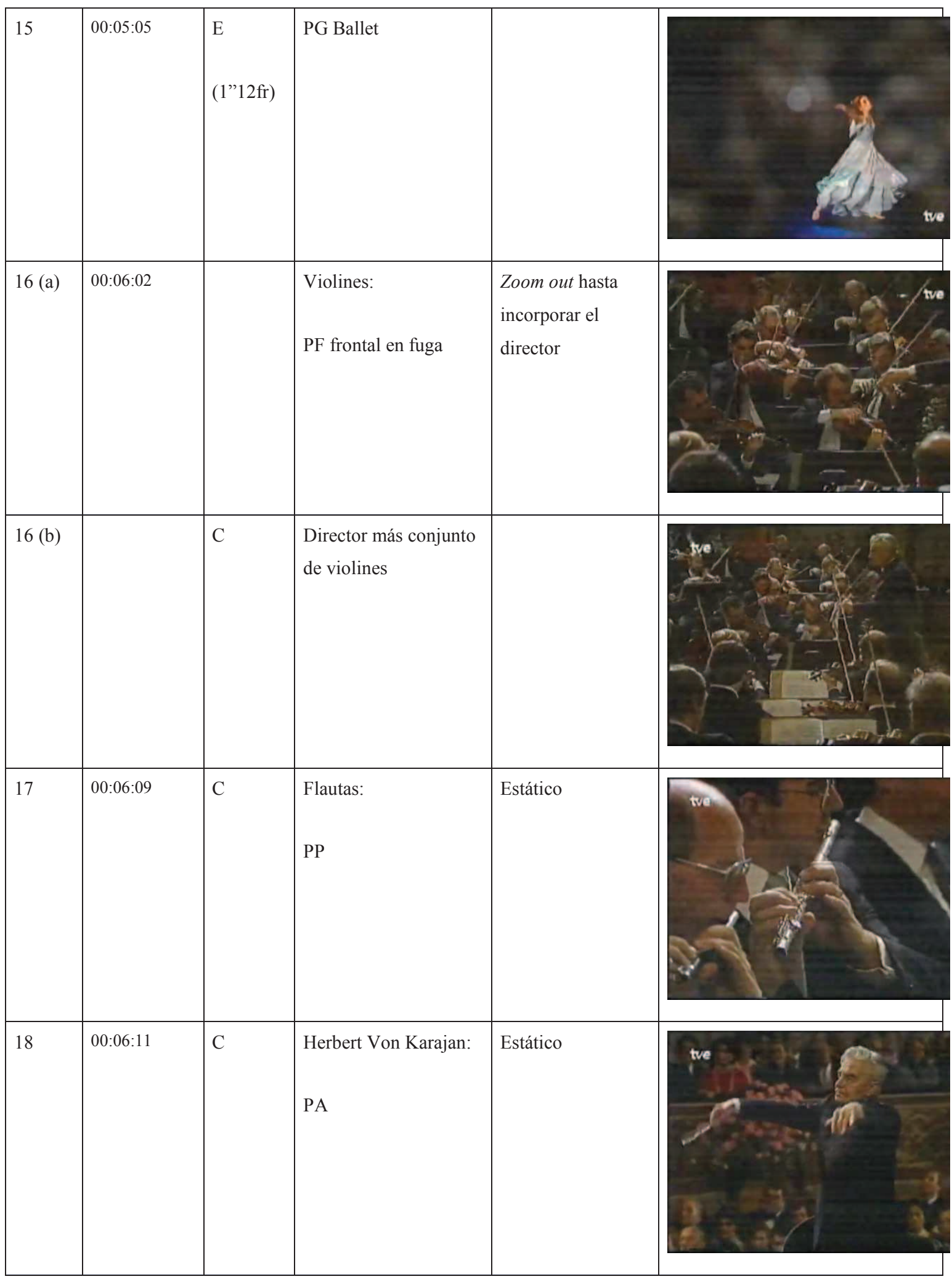


De la partitura a la pantalla: plano y contraplano de una misma realidad-183

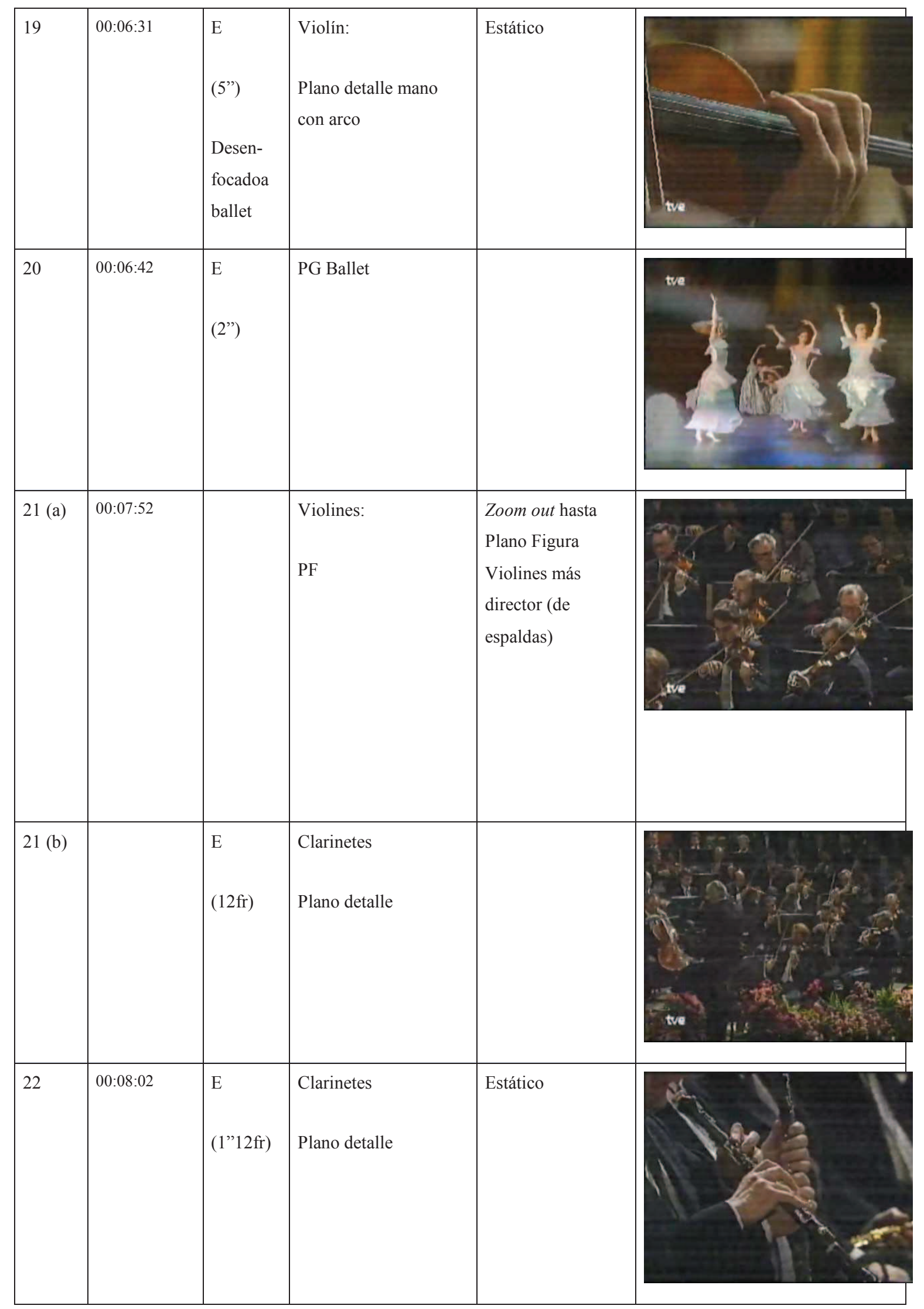


De la partitura a la pantalla: plano y contraplano de una misma realidad - 184

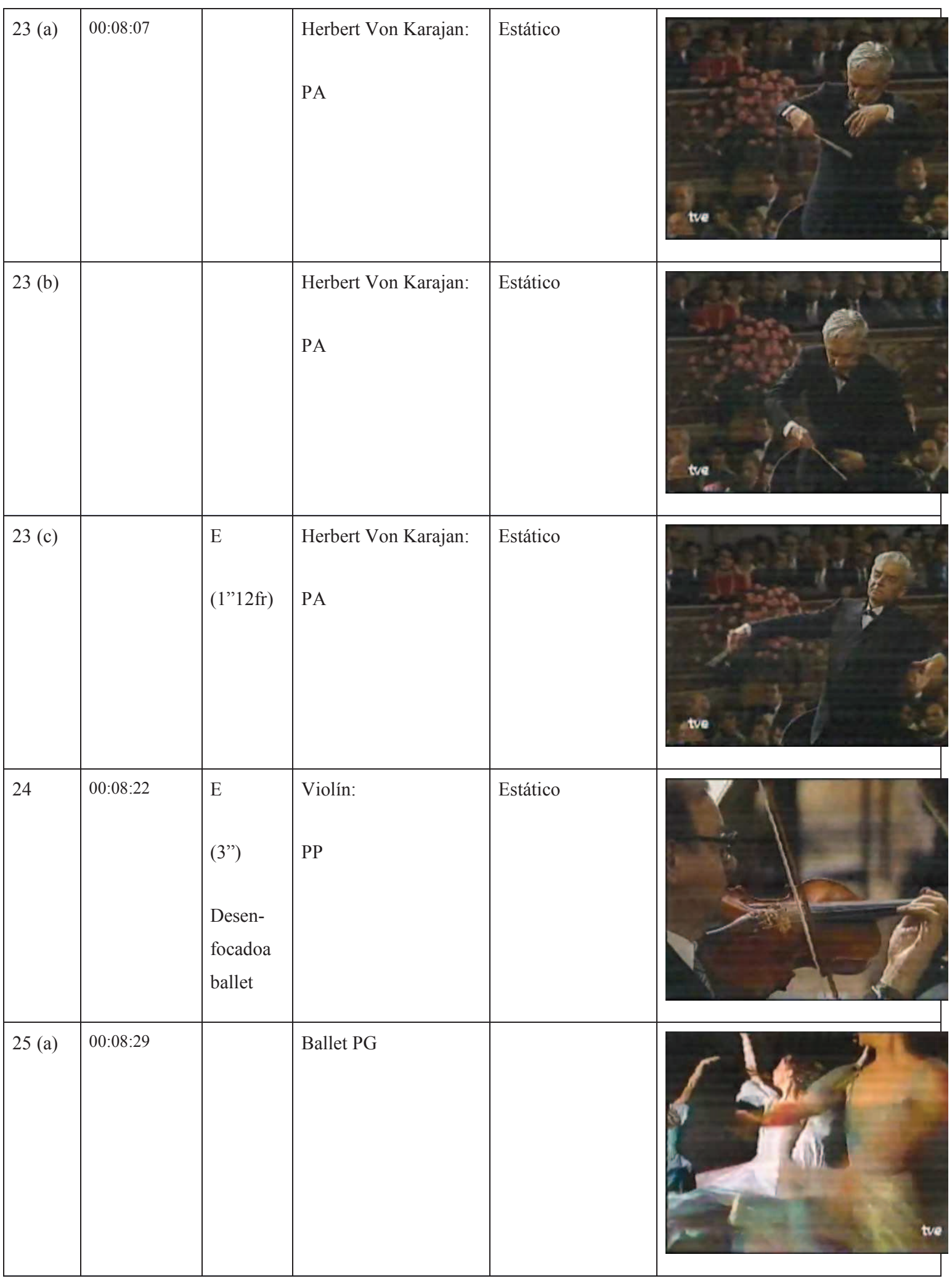




\begin{tabular}{|c|c|c|c|c|c|}
\hline 25 (b) & & $\begin{array}{l}\text { E } \\
(4 ” 12 \mathrm{fr})\end{array}$ & Ballet PG & & twe \\
\hline 26 & 00:10:04 & & $\begin{array}{l}\text { Concertino: } \\
\text { PM }\end{array}$ & $\begin{array}{l}\text { Zoom out a } \\
\text { Orquesta }\end{array}$ & \\
\hline 27 & 00:10:25 & & Final & \begin{tabular}{|l} 
Plano General \\
Lateral Orquesta, \\
director y público
\end{tabular} & \\
\hline
\end{tabular}

a.3) Comentarios sobre la realización

La realización empieza con un plano medio del maestro director Herbert Von Karajan muy largo y estático. Me refiero al estatismo en cuanto al movimiento de cámara, puesto que aquí, la intención del realizador es clara: enseñar la rica y "compleja" gestualidad del director. En un largo plano nos adentra en esta conocida composición de Johann Strauss. No creo que sea exagerado emplear la palabra "ensimismado" para adjetivar lo que produce tal gestualidad, no se trata sólo de elegantes gestos, sino significativos para que los músicos saquen el sonido de cada instrumento.

Mientras la mano derecha sostiene la batuta, es la mano izquierda la que, a través de sus gestos, se comunica con cada músico. 
A continuación, planos detalle de instrumentos. Es importante remarcar el hecho de que no vemos ningún músico hasta que ha pasado un minuto de la realización: los primeros instrumentistas que vemos son los violoncelistas.

El siguiente plano (núm. 6), aunque pueda parecer estático, está planificado al detalle: vemos cómo entra la mano de un intérprete de trompa en mitad del plano mientras otro ya está tocando el instrumento y cómo se mantiene la nota de las trompas. De esta manera, tratándose, en principio, de un plano estático, aporta un movimiento interno que ayuda a la concatenación sintáctica de la partitura.

Tras un largo encadenado, vemos un plano detalle del gesto del director. Este plano se abre lentamente hasta llegar a un plano general de la sección de violines junto con Herbert Von Karajan. El hecho de mantener este plano durante largo tiempo también es intencionado. Quizás otro realizador habría pasado por varios planos, pero mantener esta introducción en planos largos hasta que llegan las notas del tema del vals del Danubio Azul, parece una decisión acertada. Sin uno darse cuenta, va adentrándose en la música de una manera visualmente pausada que atrapa al espectador a pesar de conocerse la obra debido a su popularidad.

En este momento, la edición del plano final de "conjunto de violines más director" al plano siguiente, el plano figura de los contrabajos, es por corte. El realizador muestra un plano abierto de contrabajos que se va cerrando para llegar a un plano detalle. La situación milimétricamente estudiada de cada uno de los contrabajistas está planificada previamente (planos $8 \mathrm{a}$ y $8 \mathrm{~b}$ ). La estética audiovisual de dicho plano es evidente y no deja lugar a dudas que la situación táctica de las cámaras está elaborada de antemano.

A partir de aquí, llegan casi dos minutos de ballet. El comentario de estas imágenes lo dejo para el momento de las conclusiones del análisis genérico. Sólo quiero precisar tres indicaciones:

- En el momento final de la introducción y el inicio del tema del vals del Danubio Azul, pasamos a las imágenes externas del ballet.

- Todo el movimiento de las secuencias del ballet es interno, de las bailarinas. Se trata de una cámara fija que encuadra el ballet como si de un cuadro plástico se tratara, sólo que en él, el baile es lo que mantiene el interés del espectador. 
- En la sala, los asistentes no ven estas imágenes, sino que siguen viendo la interpretación de la orquesta. Así que, sólo los que siguen esta retransmisión desde sus casas pueden disfrutar de la realización del ballet.

Tras el paso por las imágenes del ballet, quiero destacar un corto paso por los clarinetistas, tan sólo cinco segundos, para mostrar de nuevo al director en un plano estético lleno de su gestualidad. Tras la corta panorámica izquierda hacia los violines... de nuevo, el ballet o danza. En este caso, se potencia el efecto de encadenado y se mantiene durante un largo espacio de tiempo la imagen de la bailarina con los músicos desenfocados.

Desde este momento y hasta el final, la realización repite las mismas estrategias. Largos pasos por el ballet y el director y algún plano de los instrumentos, incluido algún plano detalle. Sin embargo, quiero resaltar los últimos compases finales: el maestro Herbert Von Karajan deja de dirigir a los músicos y hace que terminen solos la pieza musical. En el último plano, cuando los músicos ya están terminando, el realizador muestra ya una panorámica hacia el público.

A continuación, un análisis de los elementos más importantes.

\section{a.4) Elementos finales}

Se trata de una interpretación considerada de las mejores en la historia del concierto de Año Nuevo; no se podía esperar menos del gran maestro Von Karajan. Por lo que concierne a la realización, destacaría tres elementos:

- Realización de ritmo pausado reflejo de largos planos estáticos del director o con movimientos de cámara lentos y largos encadenados entre los mismos. Me queda la duda de si, actualmente, alguien se atrevería con una realización de este tipo.

- Vemos en pantalla durante muchos minutos el director Herbert Von Karajan. Puede que sea una de las directrices ordenadas al realizador por dos motivos: por ser uno de los grandes maestros dentro de la dirección de orquesta y por ser el primer director de orquesta fuera del habitual. Como he dicho anteriormente, 
fue el primer año en que se decidió que cada concierto de Año Nuevo tuviera un director distinto con una vinculación especial a la orquesta.

- Variedad de planos de instrumentos. Distintos valores de plano:

$\checkmark \quad$ Primeros planos: Trompa, clarinete, contrabajo, violín, timbales.

$\checkmark \quad$ Planos conjunto de secciones instrumentales: madera, violines, violas, contrabajos.

$\checkmark$ Contrasta con esta variedad de secciones, el único plano de trompa por lo que respecta a la sección de metal. Principalmente, es la sección de cuerda la que vemos desde diferentes ángulos

$\checkmark$ Se dan tres tipos de plano del director:

- Planos americanos largos de duración y estáticos,

- Planos con panorámica para abrir del director a orquesta o de orquesta a director

- Planos desde el director con un zoom out que abre a la sección de violines.

Cambio de escenario, saliendo de la sala Musikverein para la actuación de un ballet en un escenario. Se trata de una coreografía neoclásica: el vals no es bailado por pareja bailarín-bailarina, no llevan tutú y van descalzas. Así que rompe los esquemas de lo que los espectadores esperan al oír el vals. Hay que añadir que no se trata de una realización que se base en una narración audiovisual sino que es un plano general fijo en el que, durante todo el tiempo, vemos las bailarinas, con sus solos y sus coreografías conjuntas. $\mathrm{Y}$, cabe destacar, cómo fluye el baile mientras van saliendo y entrando en plano. Su movimiento es el que nos ofrece primeros planos o planos generales. Las bailarinas vienen y van.

- Se trata de una realización austera -plano de cámara fijo- acompañada por unos elementos escenográficos que la apoyan: escenario negro con escasa iluminación que contrasta con el blanco del vestuario de las bailarinas.

- Referente a los cambios de plano, se trata de largos encadenados para dar paso a las escenas de danza y planos por corte cada vez que se va a planos detalle de instrumentos. 
De hecho, todas las secuencias de danza permanecen con un desenfoque del plano de la orquesta.

- La sensación de movimiento continuo es debida a la larga duración de la realización del ballet con las bailarinas en continuo movimiento y creación de cuadros escénicos.

- Para terminar, un análisis del tiempo de los planos nos ofrece la conclusión que de los diez minutos quince segundos (10’15”) que dura el vals, dos minutos cuarenta y tres segundos ( 2 ’43”) están dedicados al director y cinco minutos y cincuenta y dos segundos (5'52”) al escenario de la danza; así, pues, para enseñar la orquesta sólo queda un minuto y diez segundos (1'40”). Es un dato a tener en cuenta para los análisis de las posteriores realizaciones.

Todos estos elementos analizados conducen a la conclusión de que se trata de una realización que fluye en su lentitud y que te adentra en la obra como espectador desde el principio hasta el fin.

\section{b) Vals Danubio Azul, Concierto Año Nuevo, 2011}

\section{Director musical:}

Franz Welser Möst

\section{Director audiovisual:}

Brian Large

\section{Ejemplo 11: https://www.youtube.com/watch?v=tEDxGTLAUsQ}

(Subido a Youtube por "heymystuff")

\section{b.1) Análisis}

No deja de resultar curioso que cuando alguien nombra Brian Large resulta que es conocido como el realizador del concierto de Año Nuevo desde Viena; a pesar, de tener en sus espaldas una gran cantidad de eventos musicales realizados.

Incluso los profanos en la materia saben, a menudo, de quién se trata. 
Brian Large estudio en la Royal Academia of Music y se doctoró en música y filosofia. Fue director del departamento de Música y filmación en la BBC durante quince años, desde el año 1965 hasta el año 1980. Es decir, que su proyección musical y audiovisual no deja lugar a dudas. En su haber cuenta con un gran número de óperas filmadas, así como conciertos. Y, precisamente, fue el gran número de conciertos de Año Nuevo lo que le llevó a la fama.

En el año 2011, fue el encargado de la realización del concierto. Ese año, el director musical fue un austríaco Franz Welser-Möst. No estamos ante un maestro con la fama de Herbert Von Karajan, así que el análisis audiovisual de la realización puede resultar un tanto diferente puesto que, seguramente, los planos largos del director que hemos apreciado en el anterior análisis, aquí no tendrán la intencionalidad pretendida.

A finales de los 80, evidentemente no existía la tecnología que en 2011 ya se había desarrollado. Si entonces las cámaras empleadas eran $\mathrm{HD}$ y $\mathrm{SD}^{57}$, en este año, toda la tecnología ya era de alta definición (HD). Así que Brian Large contó con quince cámaras Sony HD-1500 y una cámara Sony HDC-P1, además de sonido Dolby Surround 5.1. Es decir, contó con una tecnología puntera en esa época. Tres cámaras remotas y una railcam, la cámara que se desliza sobre un raíl anclado de extremo a extremo del techo y que da el espectacular plano cenital de sala. También, dentro de la orquesta están situadas dos minicámaras. Y, en esta realización en concreto, el director dispone de tres cámaras más Sony HDC-1500 para la realización de las imágenes del ballet en el hall. Así pues, dispone de un total de dieciocho cámaras y treinta y tres micrófonos para que dicha realización del evento ofrezca un alto nivel no sólo en cuanto a calidad técnica sino artística.

\section{b.2) Táctica}

Österreichischer Rundfunk (ORF), la radio y televisión públicas austríacas ${ }^{58}$ han dado su permiso para publicar el plano de cámaras que muestro a continuación. En él podemos ver la táctica diseñada por Brian Large.

\footnotetext{
${ }^{57} \mathrm{HD}$, tecnologia en alta resolución y SD, tecnologia en baja resolución. Actualmente, se trabaja ya en unidades móviles con una resolución de $4 \mathrm{~K}$.

${ }^{58}$ Todas las ilustraciones del concierto del año 2011 pertenecen a: http://www.live-production.tv/news/cultural-events/orf-and-sivision-are-ready-broadcast-newyear $\%$ E2\%80\%99s-concert-2011.html
} 


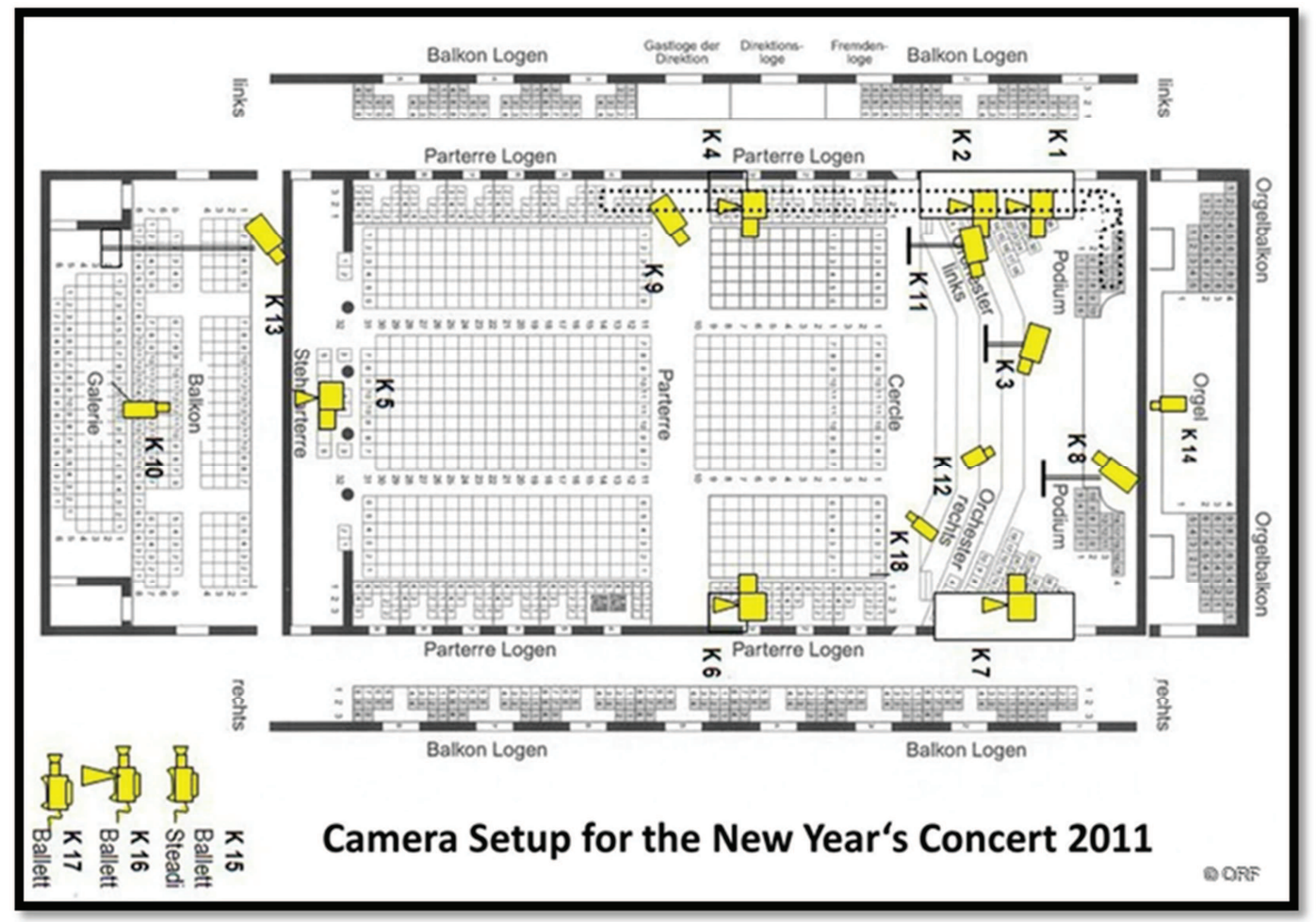

Figura 49 Plano de cámaras realización del concierto de Año Nuevo Enero 2011. R. Penzel

A continuación, las fotografías que nos muestran su colocación en sala ${ }^{59}$ :

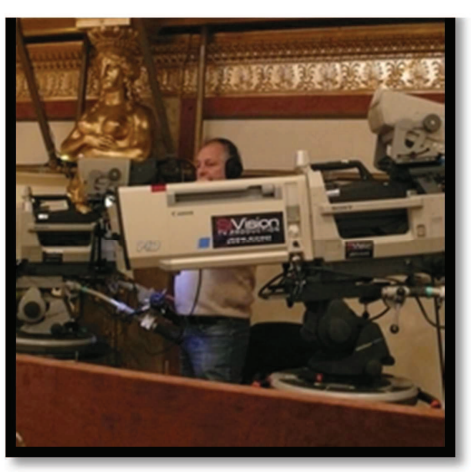

Figura 50 Cámaras 1 y 2 (Escenario lateral izquierda). R. Penzel.

\footnotetext{
${ }^{59}$ Enumero las cámaras con números arábigos para su mejor identificación en el plano y por su uso normalizado dentro de la profesión.
} 


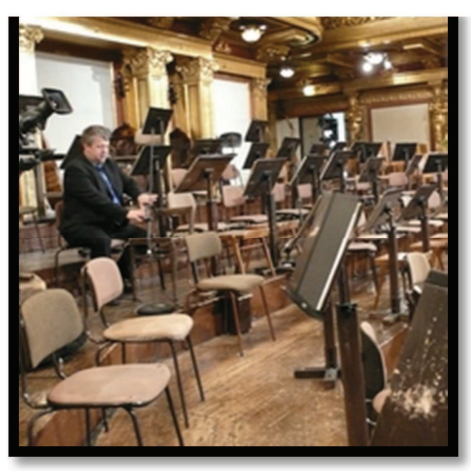

Figura 51 Cámara 3 (interior escenario). R. Penzel.

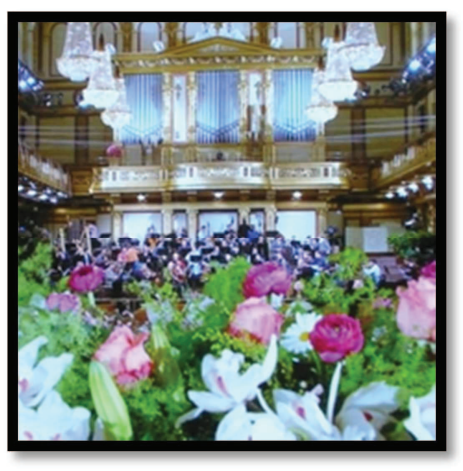

Figura 52 Cámara 5 (Plano general frontal). R. Penzel.

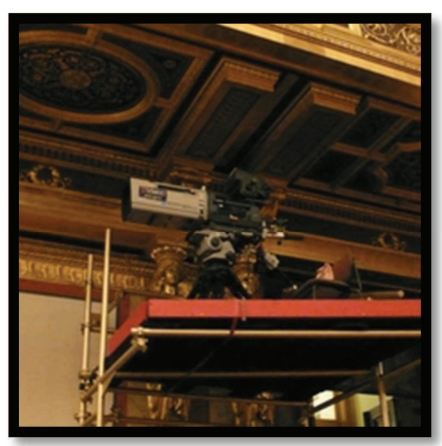

Figura 53 Cámara 6 (Lateral derecho, sobre platea). R. Penzel.

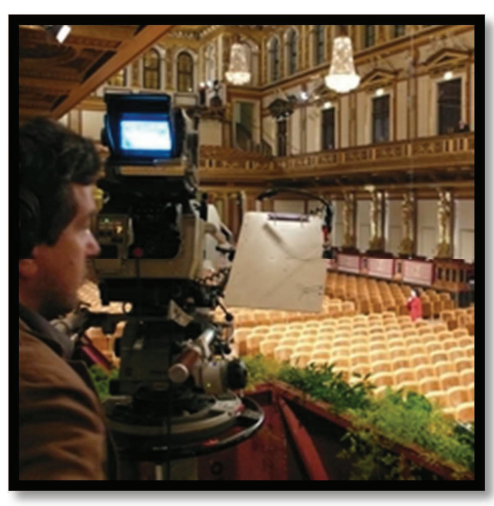

Figura 54 Cámara 7 (Lateral derecho, sobre escenario). R. Penzel. 


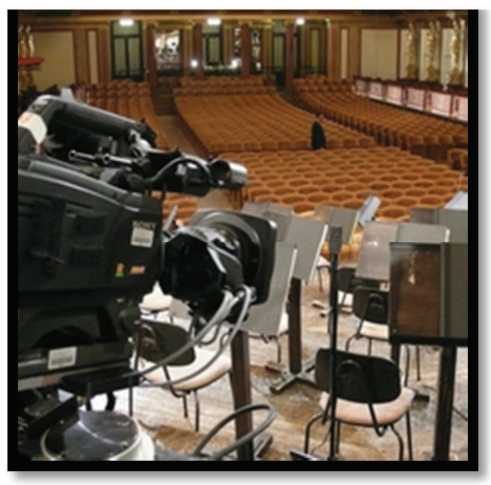

Figura 55 Cámara 8 (Lateral derecho, dentro escenario/ Contraplano). R. Penzel.

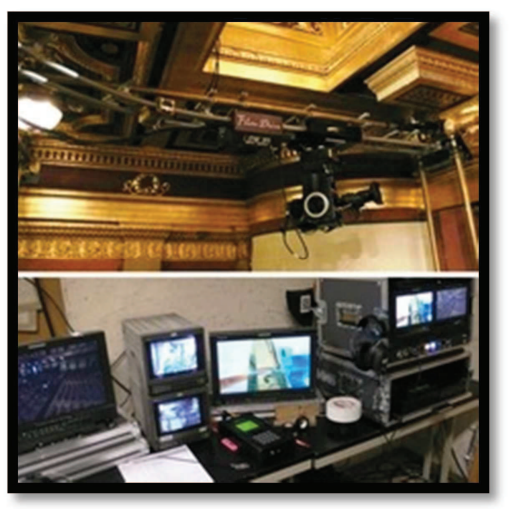

Figura 56 Cámara 9 (Plano cenital con raíl y con control remoto). R. Penzel.

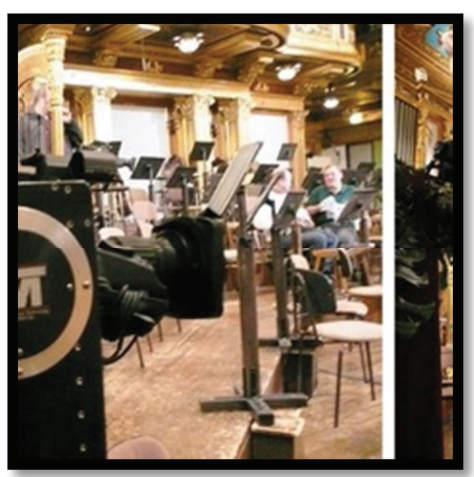

Figura 57 Cámara 11 (Lateral izquierdo en el interior de escenario). R. Penzel.
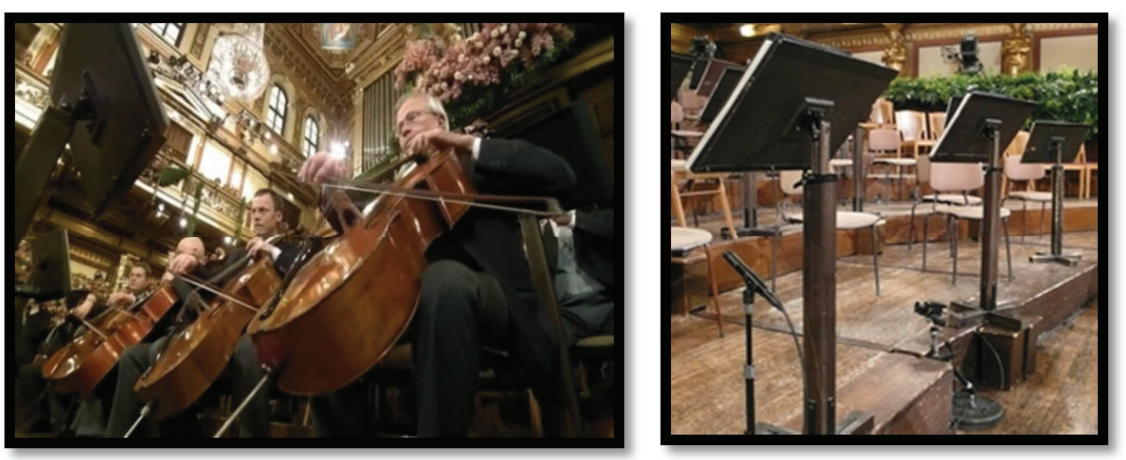

Figura 58 Minicámara en el interior de escenario. R. Penzel. 


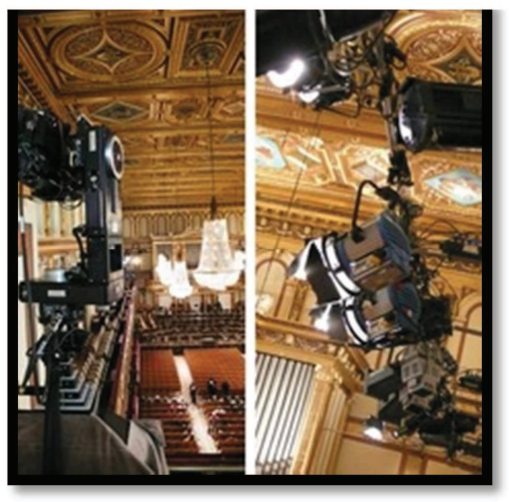

Figura 59 Cámara 13 (Lateral izquierdo, plano general). R. Penzel.

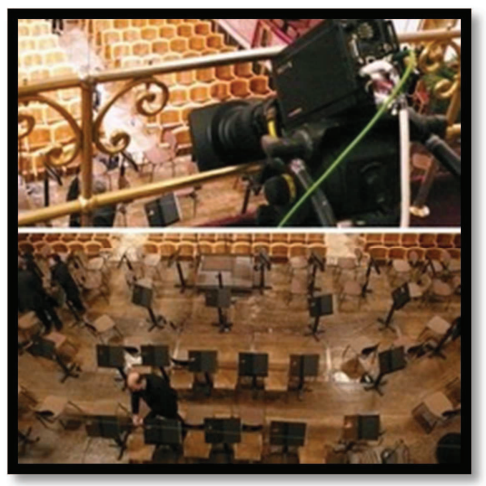

Figura 60 Cámara 14 (Contraplano general desde el primer piso). R. Penzel.

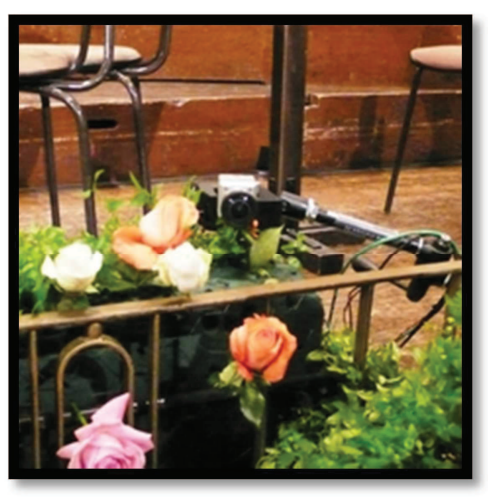

Figura 61 Cámara 14 (a) (al lado del director). R. Penzel.

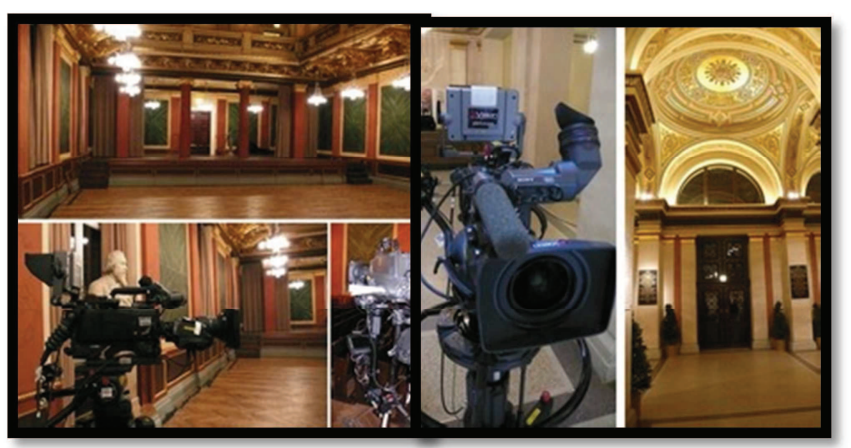

Figura 62 Cámaras 15, 16 y 17 (En el hall, para la realización del Ballet). R. Penzel. 
Las cámaras 4 y 10 cubren un lateral izquierdo y un gran plano general.

En conclusión, nueve cámaras están montadas en el escenario, tres cámaras a mitad de sala y tres cámaras, al final de sala; aparte, están las tres cámaras fuera de sala para el ballet. En cuanto a los puntos de vista, seis cámaras están situadas a izquierda de escenario y cinco cámaras, en la zona derecha. De esta manera, se consiguen, también gracias a las ópticas de cada cámara, diversos puntos de vista de cada zona de instrumentos. Una cámara está situada en contraplano desde el escenario; este plano es muy efectista ya que, aunque la orquesta está de espaldas a la cámara, el director musical y el público, están de cara al espectador que, en ese momento ve la retransmisión. El punto de vista es lo que pueden ver los músicos; perceptivamente para los espectadores que están en casa, es una manera de acercarse a la orquesta y "tocar" el concierto.

También, el hecho de poner una cámara dentro del escenario (plano de violoncelos), acerca la música al espectador desde puntos de vista inusuales.

Es labor del realizador buscar aquellos puntos de vista que pueden enriquecer y dinamizar una retransmisión sin repetir continuamente aquellos puntos de vista esenciales cuando se trata de una retransmisión con un número inferior de cámaras.

\section{b.3) Estrategia: Secuenciación analítica}

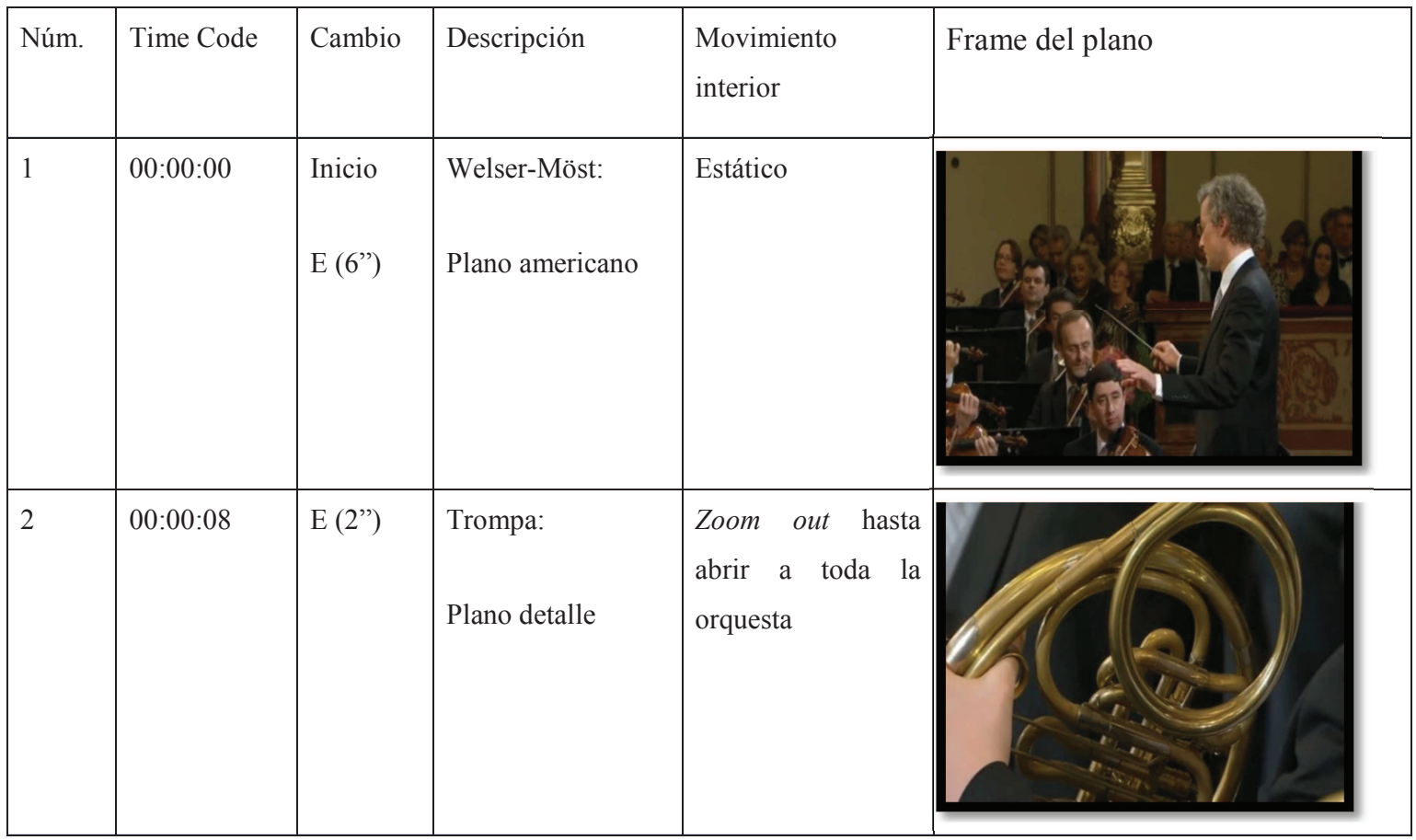




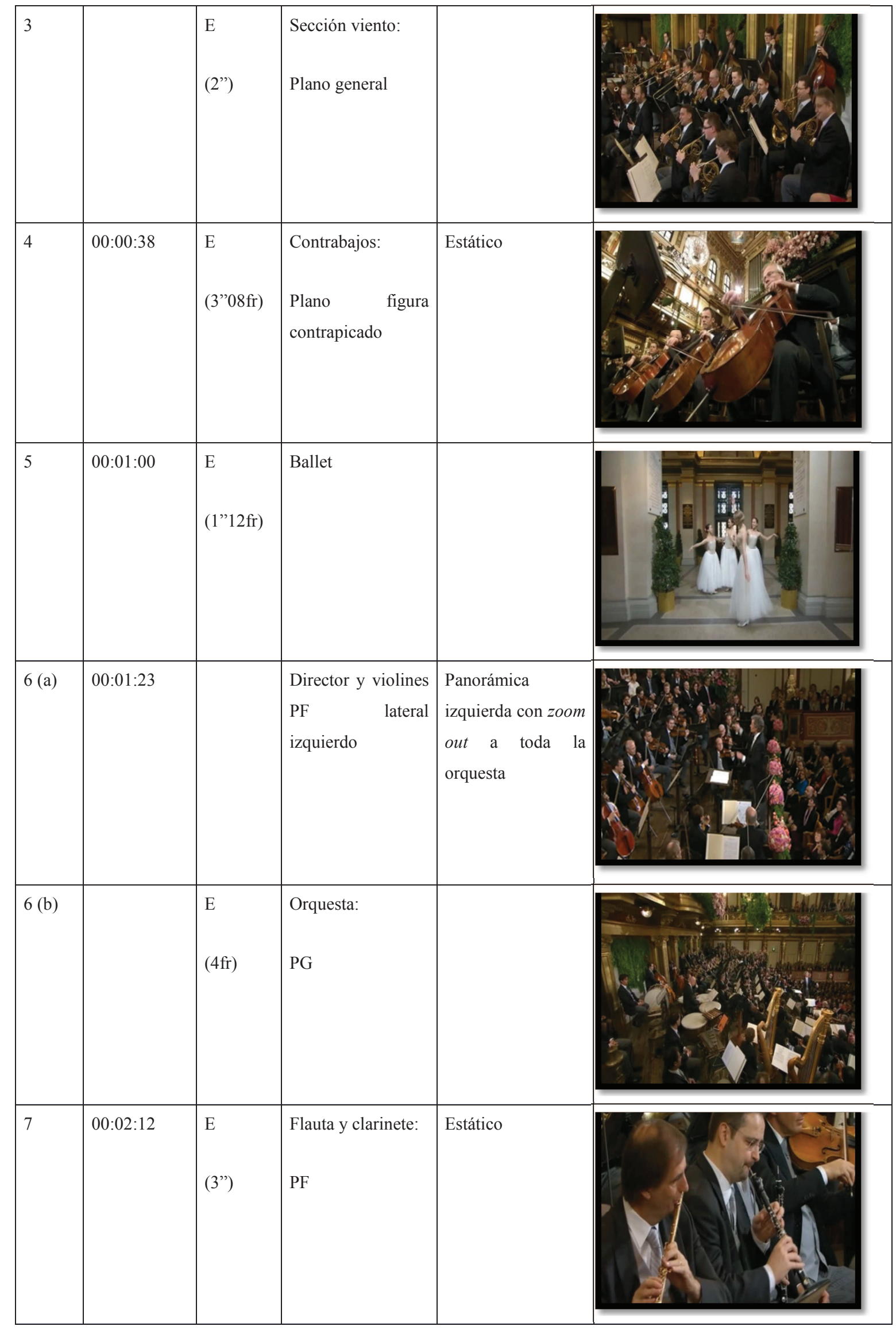


De la partitura a la pantalla: plano y contraplano de una misma realidad - 197

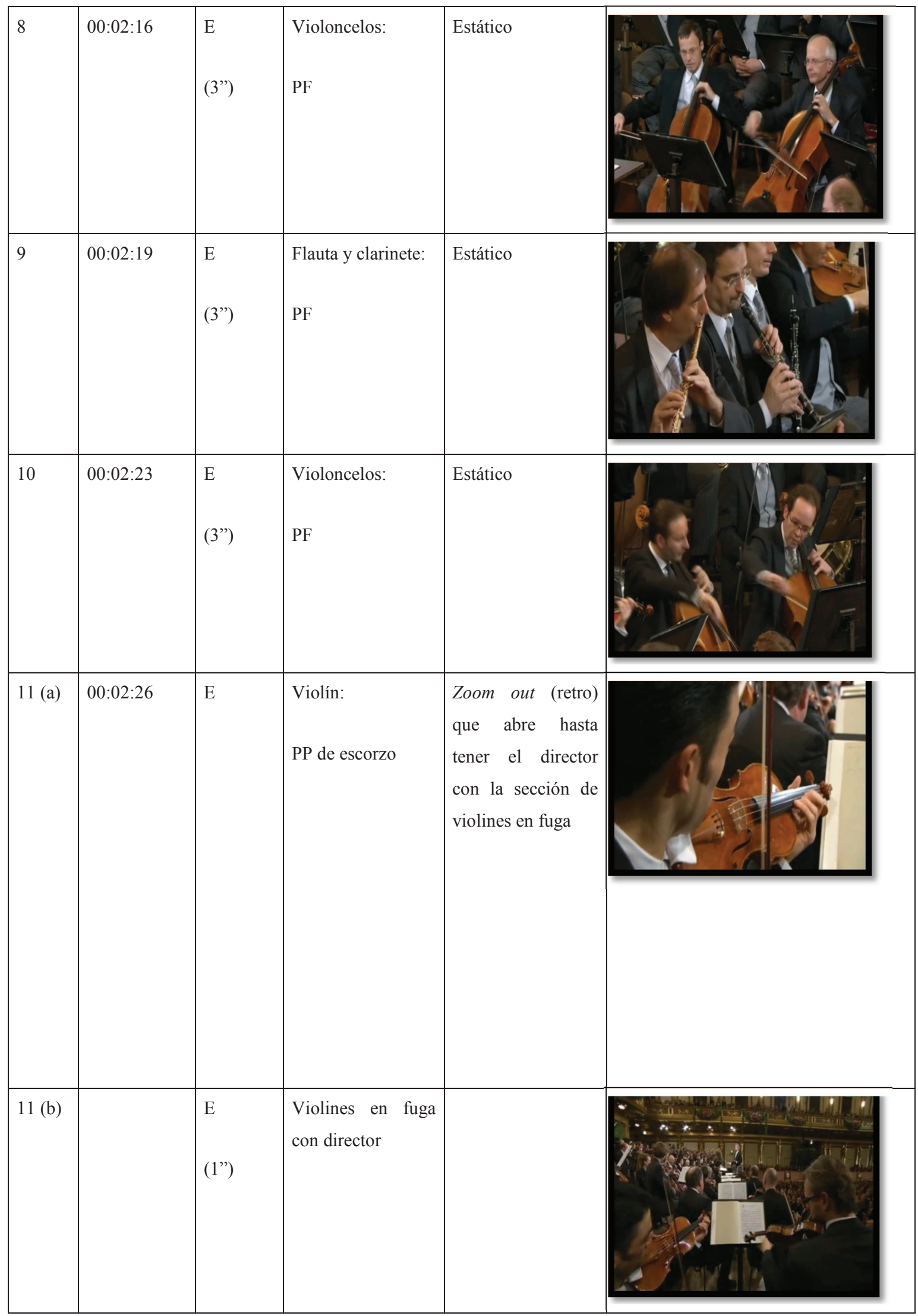


De la partitura a la pantalla: plano y contraplano de una misma realidad - 198

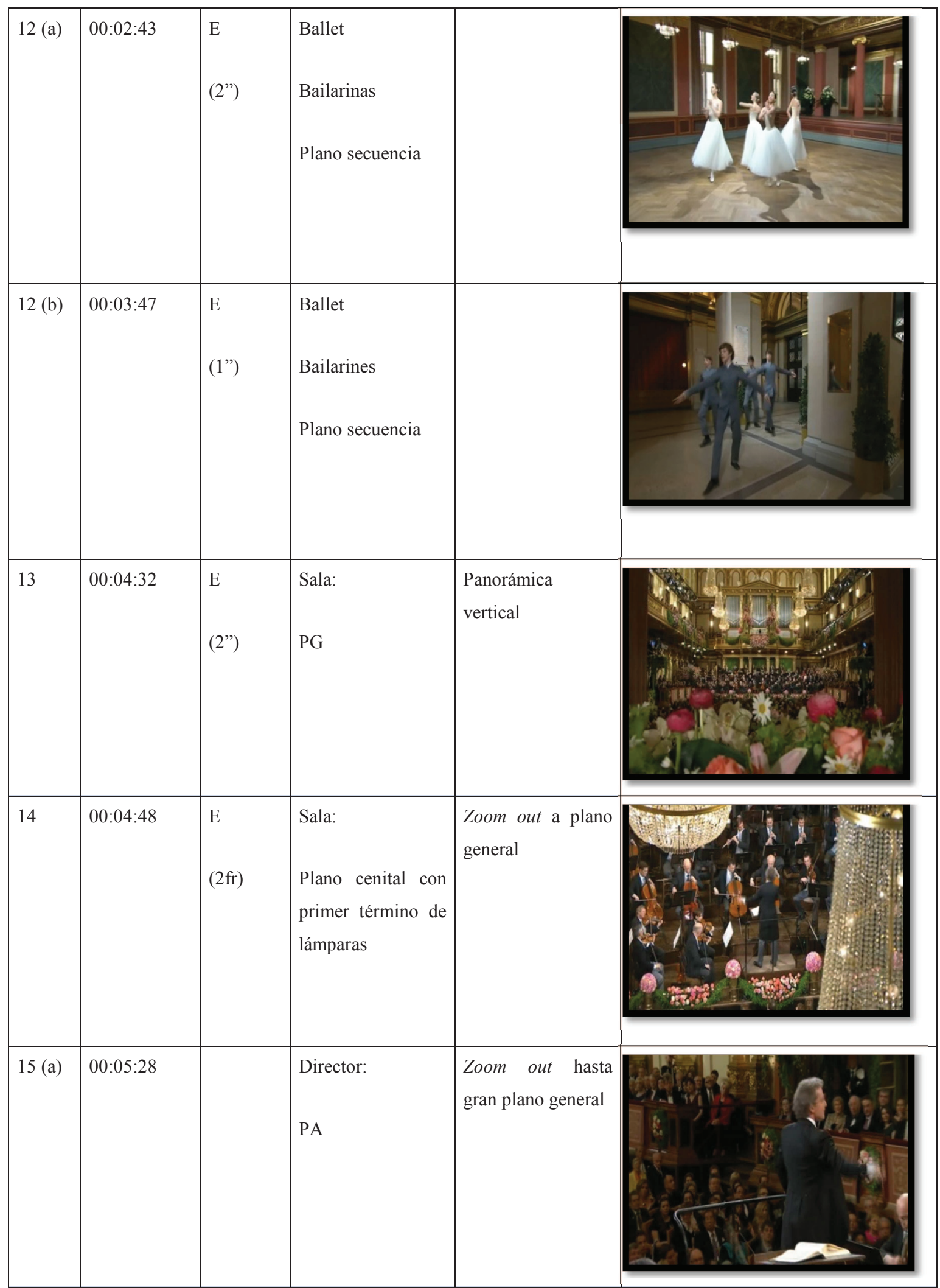


De la partitura a la pantalla: plano y contraplano de una misma realidad - 199

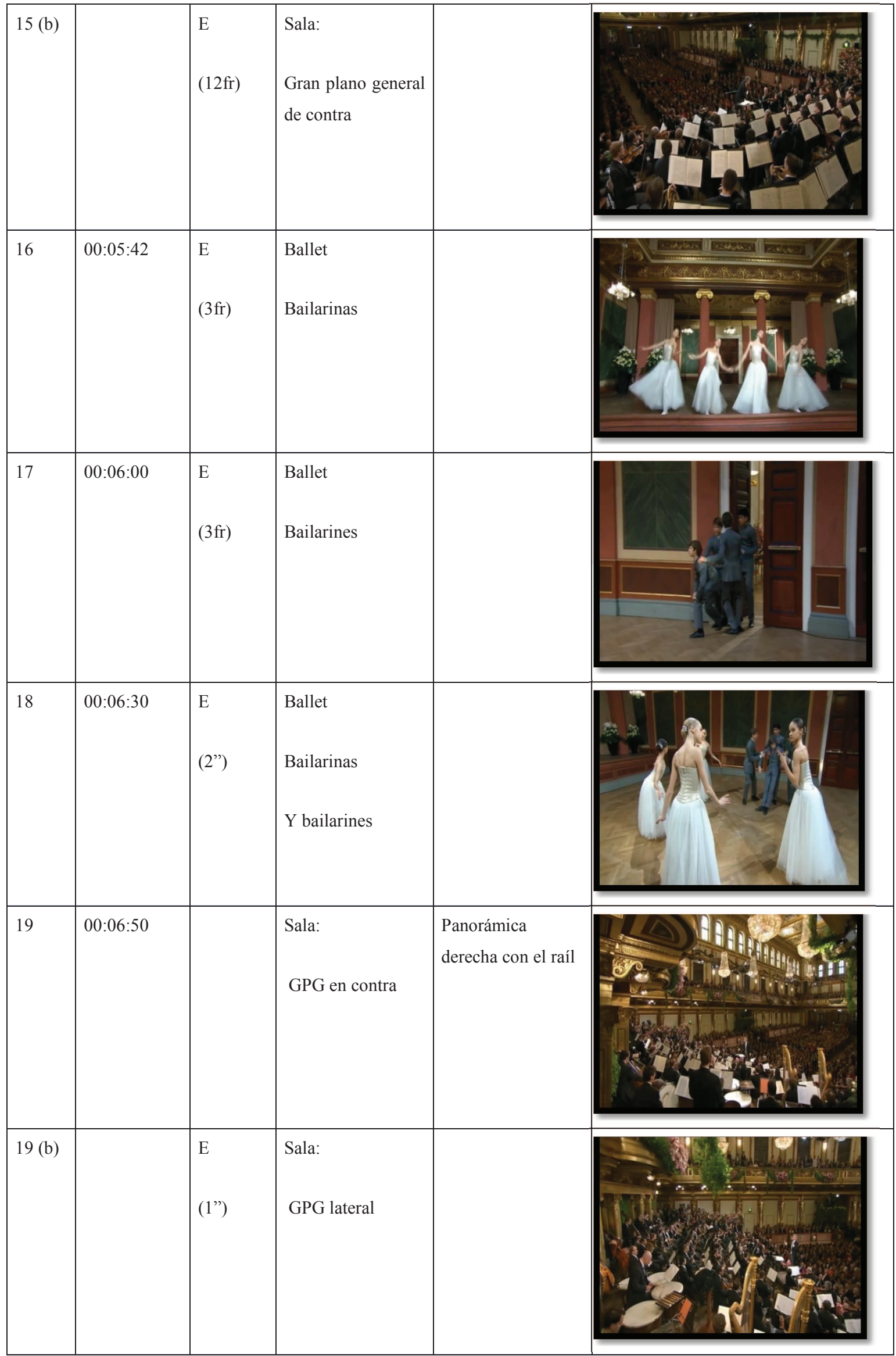




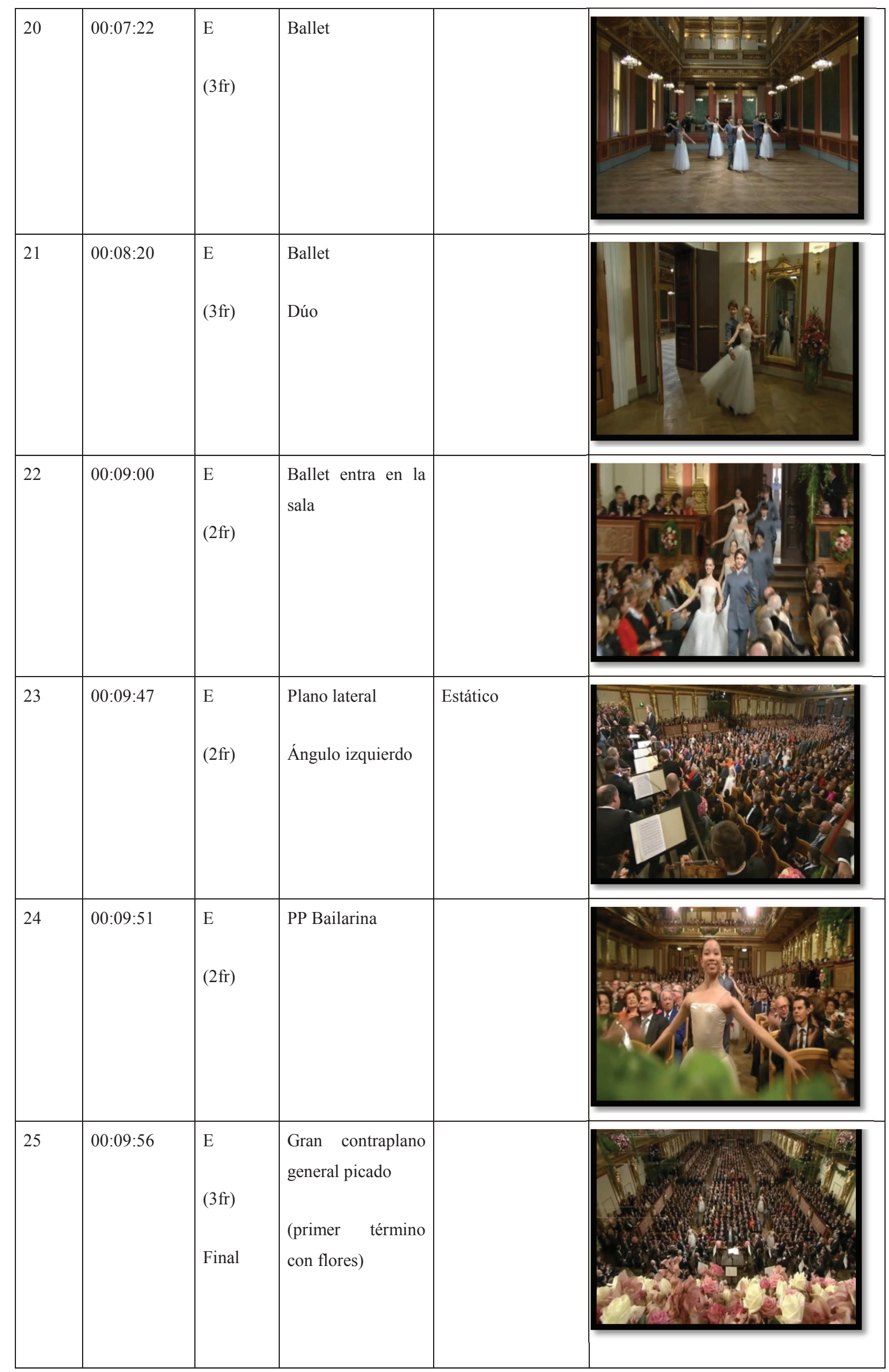




\section{b.4) Comentarios sobre la realización}

En la realización de Brian Large podemos constatar, no sólo una riqueza de planos distintos, sino uno ángulos nuevos en comparación con la realización de Humpfrey Burton de 1987. Empieza con un plano del director, respeta el silencio del inicio y la entrada que da el director a los músicos. A continuación, arranca un plano detalle de la trompa hasta llegar a un plano general de la sección de viento, meticulosamente planificado: podemos ver cómo a medida que la cámara va abriendo el plano, van entrando el resto de instrumentos de viento. En este momento podemos recordar el concepto de cinematografía del cual nos habla José Nieto. Y es que, a medida que va creciendo la densidad de la orquesta, el plano va creciendo en espectacularidad. Seguidamente, nos sorprende con un plano contrapicado de los contrabajos, los cuales están dispuestos perfectamente y podemos apreciar el plano figura de cada uno de ellos. Este inicio es totalmente un lenguaje audiovisual con una lectio score bien trabajada y desmenuzada. Nada ocurre por casualidad.

En el siguiente plano, salimos de la sala y empieza lo que va a ser un ballet muy distinto del que se realizó en el 1987. Después detallaré los elementos de esta coreografía con una narrativa explícita.

Si seguimos con la orquesta, después de veintitrés segundos de ballet y una vez en la sala de conciertos, empieza con un plano del director más el conjunto de violines y, a través de una panorámica lateral izquierda, nos enseña toda la orquesta; volvemos a apreciar la densidad de un crescendo orquestal con un plano general de orquesta que va creciendo. A partir de aquí, se suceden planos de varios instrumentos con la correspondiente preguntarespuesta: flautas, violoncelos y violines.

Después de una salida de sala para continuar con la narración del ballet, volvemos a ella con dos planos generales que empiezan con un mismo concepto: arrancan desde un primer término para ir abriéndose a un plano general; el primero, empieza con un plano de floreselemento ya típico en los conciertos de Año Nuevo; el segundo, con un primer término de las lámparas. Pero, está todo tan meticulosamente ensayado y planificado que, en cuanto llega el forte en el ataque de compás, vemos el gesto del director a través de un plano americano del mismo (plano 15). 
A partir de este momento, se convierten en protagonistas los bailarines con la historia narrativa que interpretan. En la sala se suceden planos generales y, a partir del momento en que entran a escena los bailarines, ya no vemos más la orquesta ni el director.

De esta manera, la realización pasa de tener momentos de riesgo bien planificados a una realización muy pautada sobre los pasos de los bailarines. Al principio, en el hall de entrada, los bailarines han sido presentados a través de planos secuencia que los iban acompañando, poco a poco, la realización implicaba alguna cámara más; hasta que al llegar a la sala, evidentemente, la acción se ha seguido con las cámaras que hasta el momento habían mostrado la orquesta.

Contrasta este baile con el del año 1987. A pesar de llevar veinticuatro años, en esta edición aparece con todos los elementos tópicos: tutú blanco, puntas y pasos de ballet clásico. La historia no es más que una historia común: chico conoce chica, se avergüenza, pero al final, acaban juntos. En fin, un tópico narrativo, llevado a la pantalla de manera magistral por Brian Large.

\section{b.5) Elementos finales}

A continuación expongo un resumen de los elementos de esta realización:

- Riqueza de planos: distintos instrumentos

- $\quad$ Riqueza de valor de planos: planos cortos, planos medios, plano americano del director, planos generales y grandes planos generales.

- Riqueza de ángulos: planos picados, cenitales y contrapicados; así como planos secuencia en el ballet.

- Composiciones fotográficas con elementos decorativos en primer término: lámparas o centros florales (planos 13 y 14; así como el gran plano general picado, con un gran centro de flores en primera línea)

- Perfección en el cambio de planos.

- $\quad$ Seguimiento de la densidad orquestal: cada plano justificaba el momento musical orquestal

- $\quad$ Ritmo pausado, pero sin cesar el movimiento. 
- Los planos cortos de instrumentos no tienen movimiento; no ocurre así en el caso de planos más abiertos o generales, durante los cuales se dan panorámicas o movimientos zoom.

- Los cambios de plano se caracterizan por largos encadenados (de hasta seis segundos en el primer cambio de plano) entre los planos de instrumentos musicales. Sin embargo, en la realización del ballet, los encadenados son mucho más cortos (entre dos y tres frames)

En resumen, Brian Large ofrece una realización cinematográfica de la parte orquestal; pero, no hay duda que los planos más abiertos de director musical con orquesta y el ballet ocupan más de la mitad de la duración del vals. Así, sólo emplea un minuto siete segundos de planos detalle de músicos e instrumentos frente a los casi tres minutos de director más orquesta en plano general y los cinco minutos aproximados de ballet, convierten la realización del vals del Danubio Azul en una realización fundamentada en el ballet. Aún así, la calidad de la realización instrumental es evidente que refleja lo que la partitura aporta.

Se trata de una realización dinámica: poca dedicación a planos de orquesta, pero con una gran variedad de planos y movimiento continuo.

c) Vals Danubio Azul, Concierto Año Nuevo, 2013

\section{Director musical:}

Franz Welser Möst

\section{Director audiovisual:}

Karina Fibich

\section{Ejemplo 12:}

https://www.youtube.com/watch?v=lSm730vHSGM\&feature=youtu.be

(Subido a Youtube por M. Millà)

Karina Fibich fue la realizadora del concierto por segunda vez consecutiva, aunque había ya trabajado como ayudante de Brian Large durante varios años. En el año 2008 ya había sido la realizadora de la señal personalizada para la ORF, mientras Brian Large asumía la dirección de la señal internacional. Así que se mostraba como profesional del medio 
audiovisual y gran conocedora del planteamiento por lo que respecta a la realización de un evento-concierto de tal calibre como es el concierto de Año Nuevo.

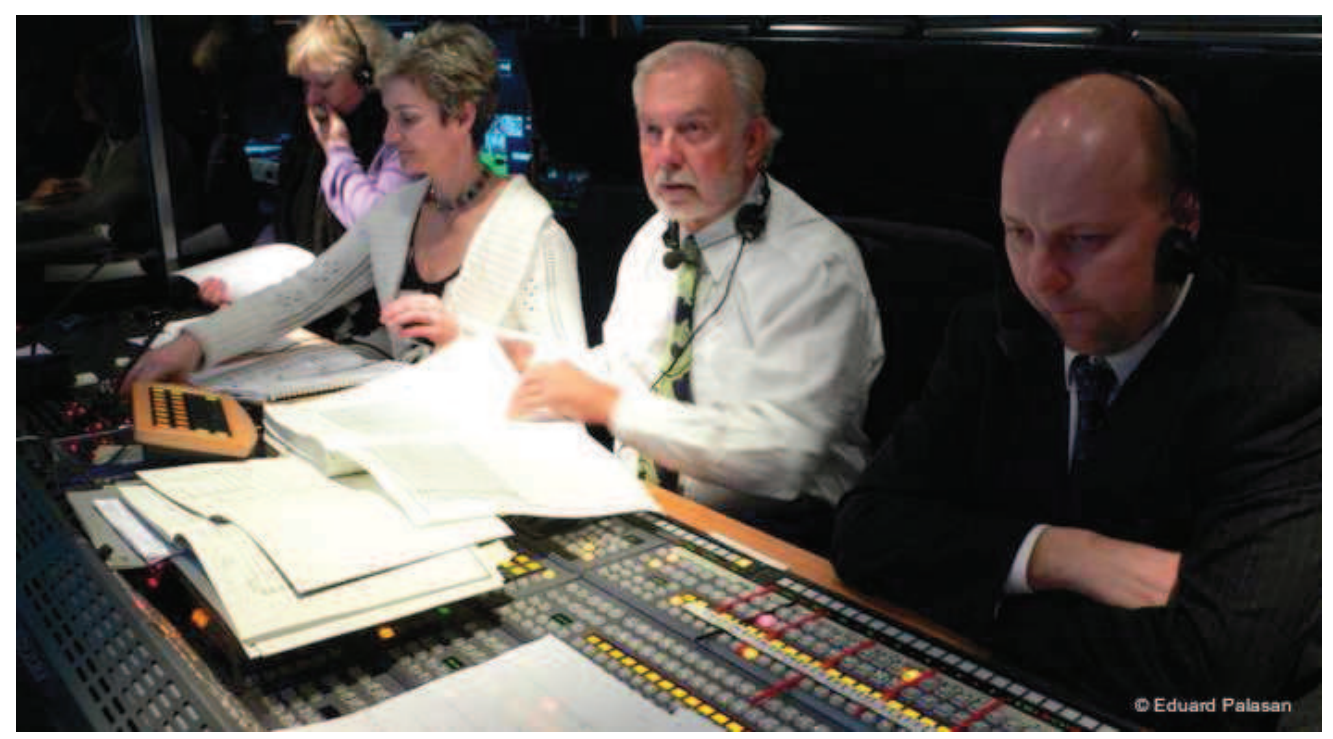

Figura 63 Karina Fibich y Brian Large en el control de realización de la Unidad móvil. E. Palasan.

\section{c.1) Táctica}

Para plasmar en las pantallas la partitura y todo lo que rodea a dicho evento musical retransmitido desde Viena, Karina Fibich dispuso quince cámaras en el interior de la sala y, otras tres, fuera de la sala. Una de estas tres cámaras muestra los momentos del director antes de salir a escena y, otras dos, situadas fuera del edificio, muestran un plano general del edificio y un plano de la entrada al edificio.

Una de las novedades de este año es, precisamente, el plano que el público de la sala no puede ver: el director musical en plano secuencia entrando en la sala y dirigiéndose hacia su sitio. Aporta siempre emoción ver al director musical en sus momentos previos y, poderlo ver, es una "curiosidad" más añadida a la realización.

Por lo que respecta al vals del Danubio Azul, ese año se optó por unas imágenes fotográficas invernales que acompañaban la música fuera de la sala. Eran imágenes, lógicamente, grabadas. Parece que podrían darse problemas de sincronización entre el vídeo y la vuelta a la sala. Para salvar este posible problema en cuanto a la realización, podemos ver cómo Karina Fibich optó por pasar de las imágenes del vídeo a la sala a 
través de imágenes de elementos arquitectónicos o de la decoración floral. De esta manera, podía continuar con la orquesta sin problemas de sincronía. Por ejemplo:

1. Del plano 4 al plano 5 (elemento de decoración floral)

2. Del plano 18 al plano 19 (plano detalle de la lámpara colgante)

3. Del plano 45 al 46 (plano detalle de decoración floral en una de las cariátides)

La disposición de las cámaras sería la siguiente:

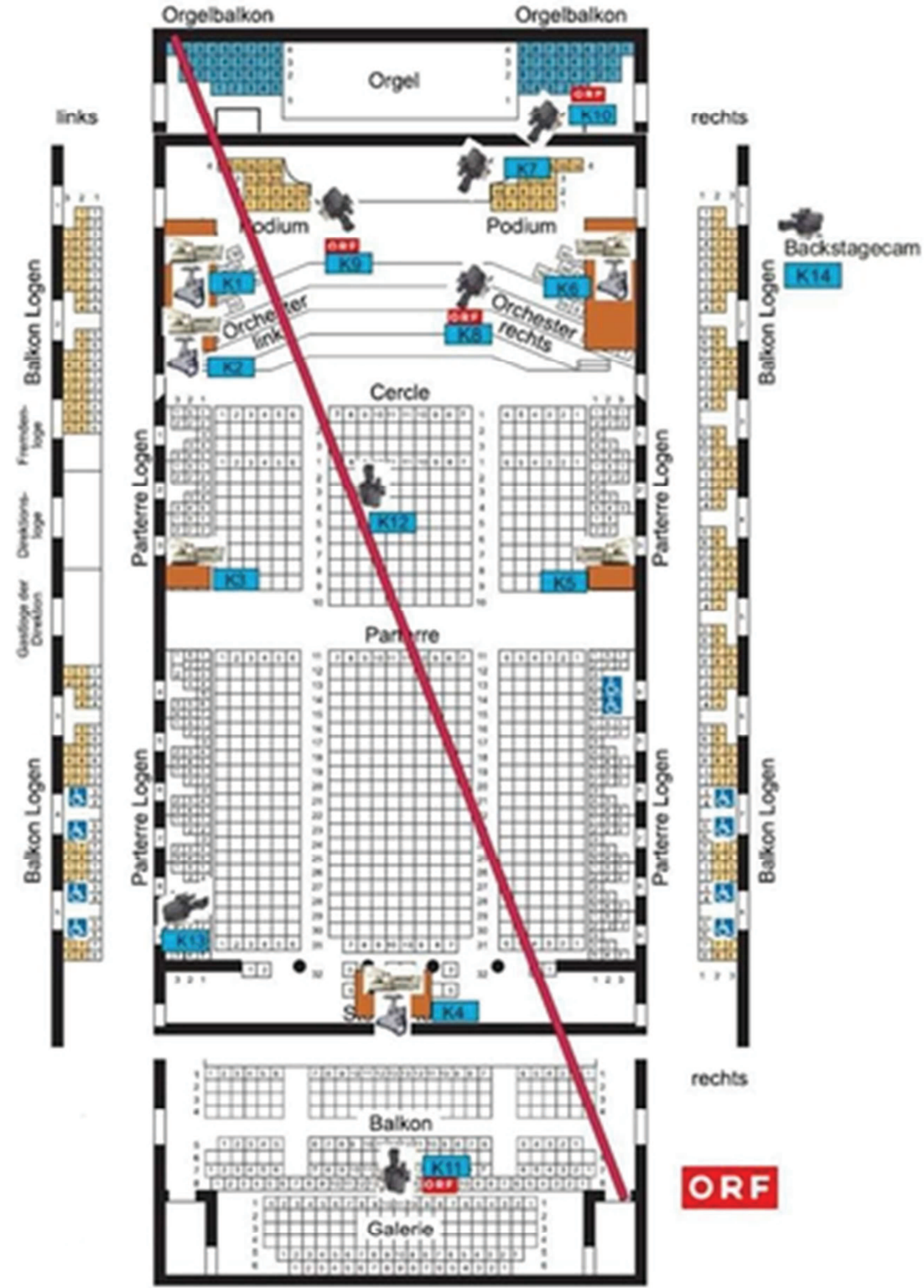

Figura 64 Plano de cámaras para la realización del concierto de Año Nuevo de enero de 2013. 
A continuación, el emplazamiento de las cámaras en la sala Musikverein.
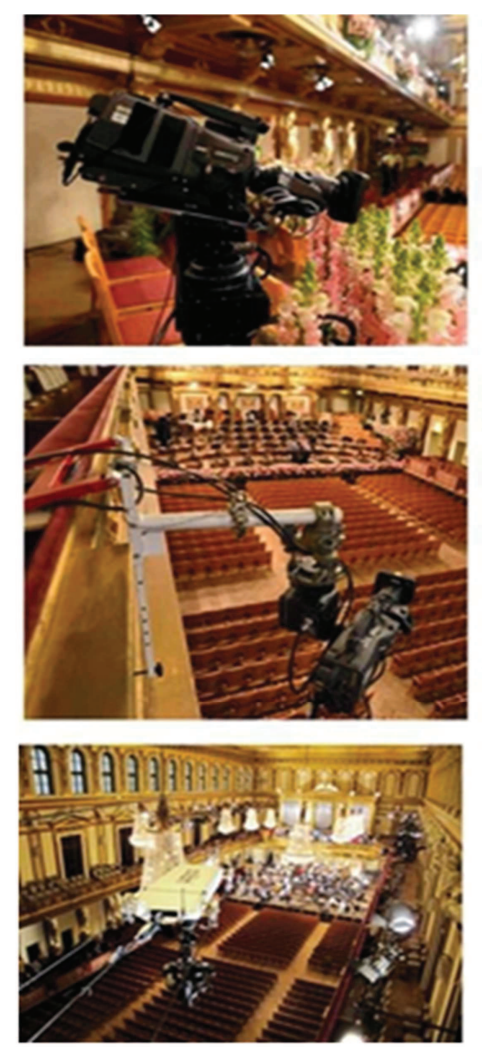

Figura 65 Cámaras 7, 13 y visión de la cámara con raíl desde el piso superior.

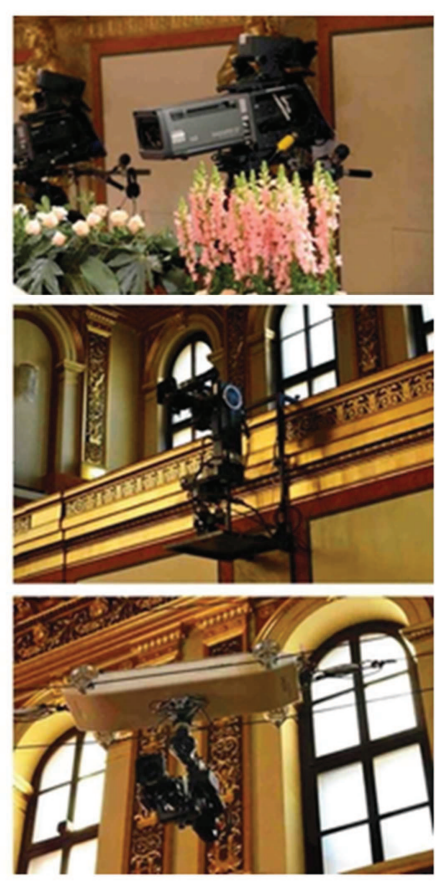

Figura 66 Cámaras 5, 6 y visión de la cámara con raíl contrapicada. 
En estas imágenes, podemos ver el montaje de los raíles donde va la cámara con la que Karina Fibich nos proporciona las imágenes cenitales durante el concierto. Esta tecnología nos acerca a puntos de vista que ni tan solo los asistentes a la sala pueden tener. También podemos ver cómo a través de los centros florales se esconden los anclajes que sustentan las cámaras y las cámaras mismas.

c.2) Estrategia: Secuenciación analítica

\begin{tabular}{|c|c|c|c|c|c|}
\hline Núm. & Time Code & $\mathrm{C} / \mathrm{E}$ & Descripción & $\begin{array}{c}\text { Movimiento } \\
\text { interior }\end{array}$ & Frame del plano \\
\hline 1 (a) & 00:00:00 & & $\begin{array}{l}\text { Plano medio del } \\
\text { director saliendo a } \\
\text { escena: Plano } \\
\text { secuencia }\end{array}$ & $\begin{array}{l}\text { Seguimiento del } \\
\text { director }\end{array}$ & \\
\hline $1(\mathrm{~b})$ & & $\mathrm{C}$ & $\begin{array}{l}\text { Plano Figura del } \\
\text { director entrando en } \\
\text { la sala }\end{array}$ & $\begin{array}{l}\text { Seguimiento del } \\
\text { director }\end{array}$ & \\
\hline 2 & 00:00:10 & & $\begin{array}{l}\text { Llegada del director } \\
\text { al atril }\end{array}$ & $\begin{array}{l}\text { Seguimiento del } \\
\text { director }\end{array}$ & \\
\hline 3 & 00:01:04 & E (2”) & $\begin{array}{l}\text { PF Director marca } \\
\text { inicio }\end{array}$ & & \\
\hline
\end{tabular}




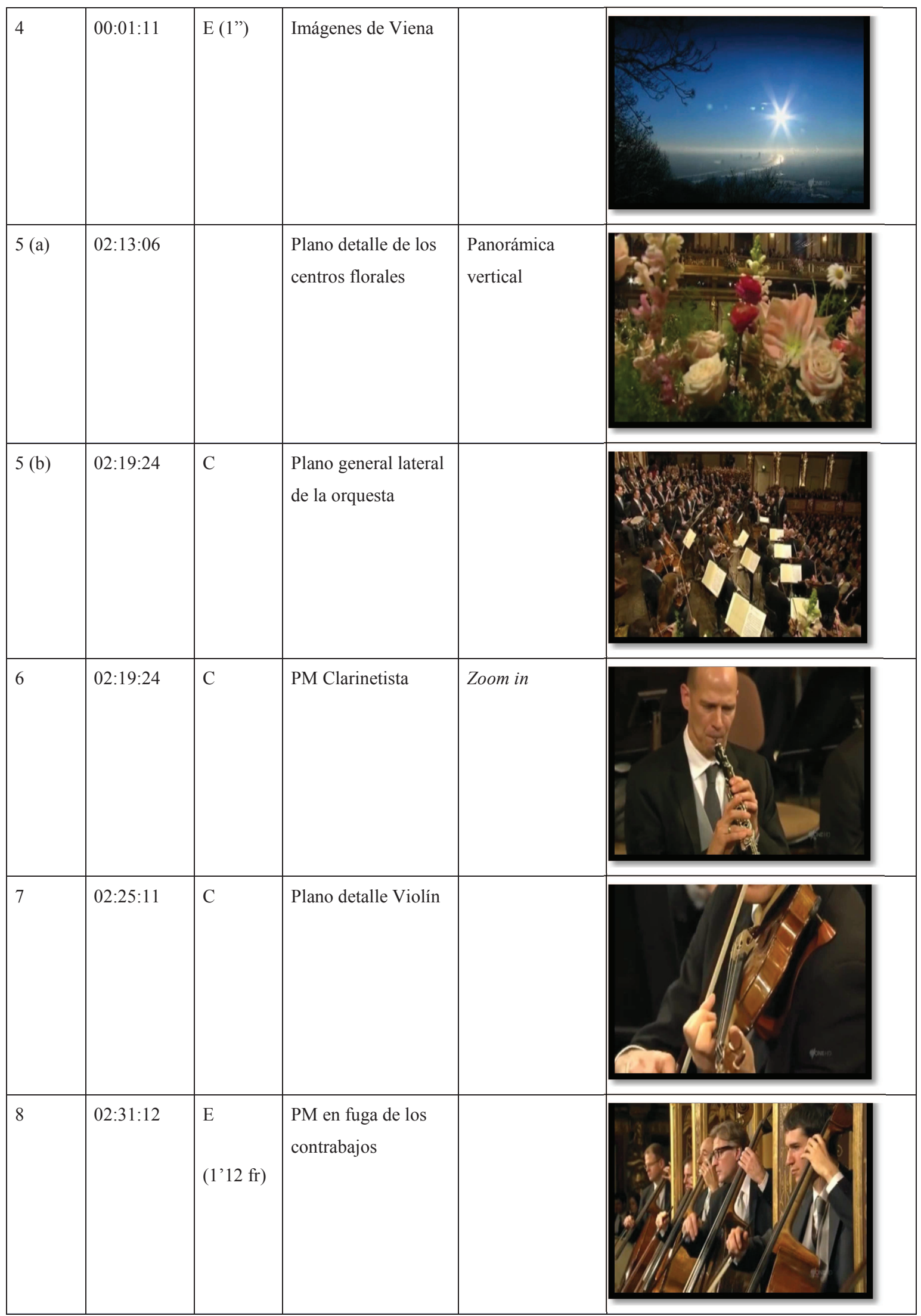


De la partitura a la pantalla: plano y contraplano de una misma realidad - 209

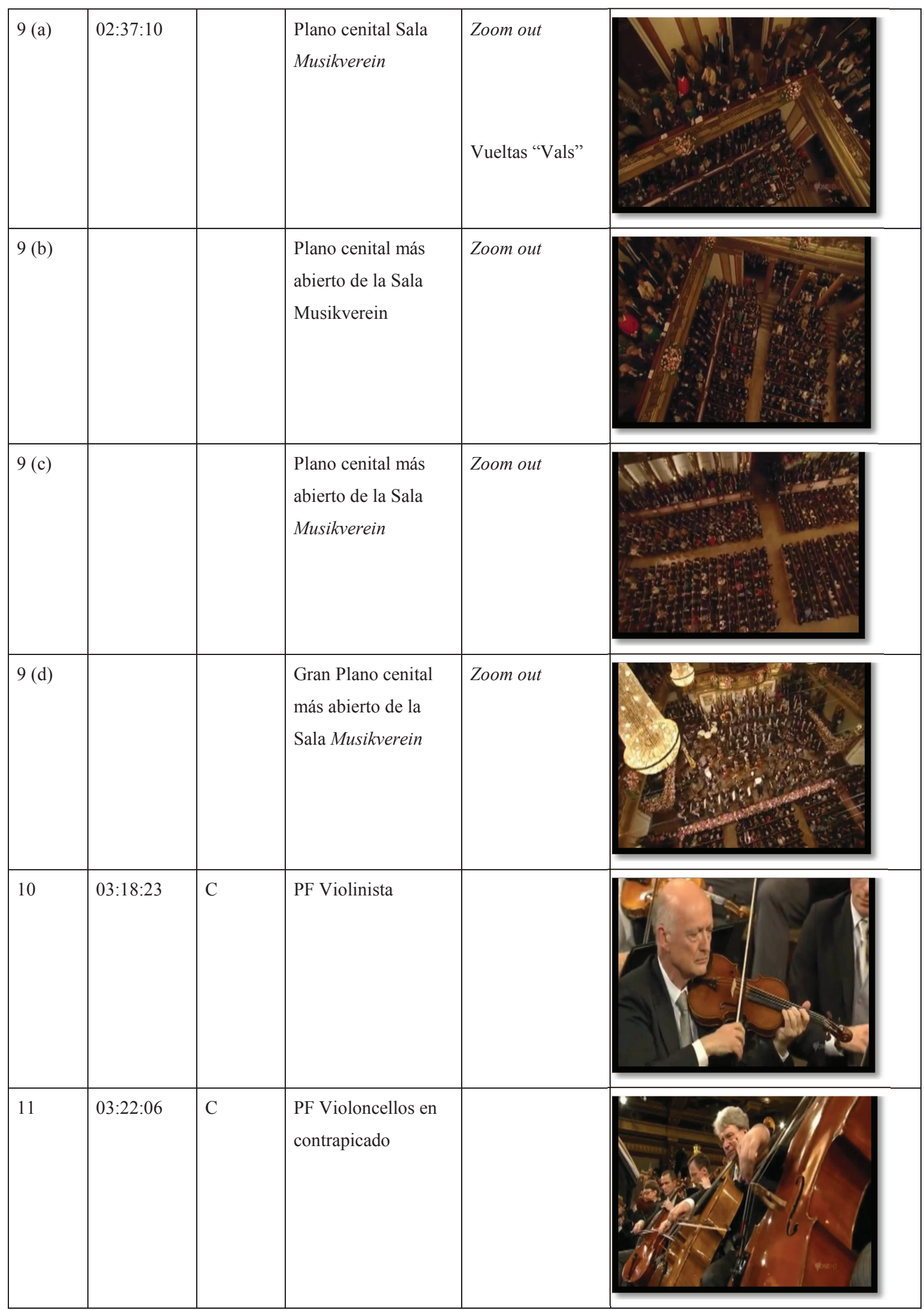




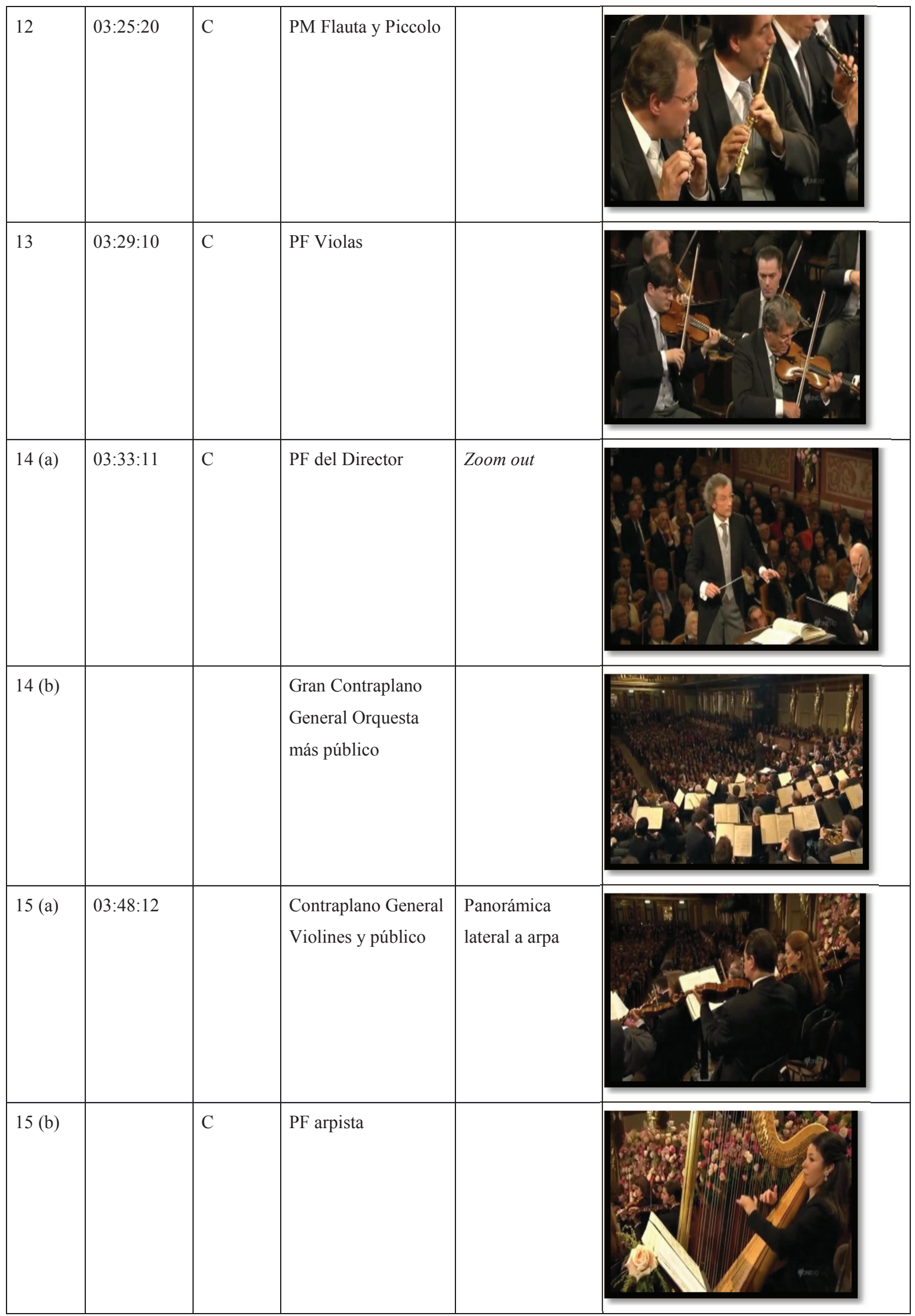




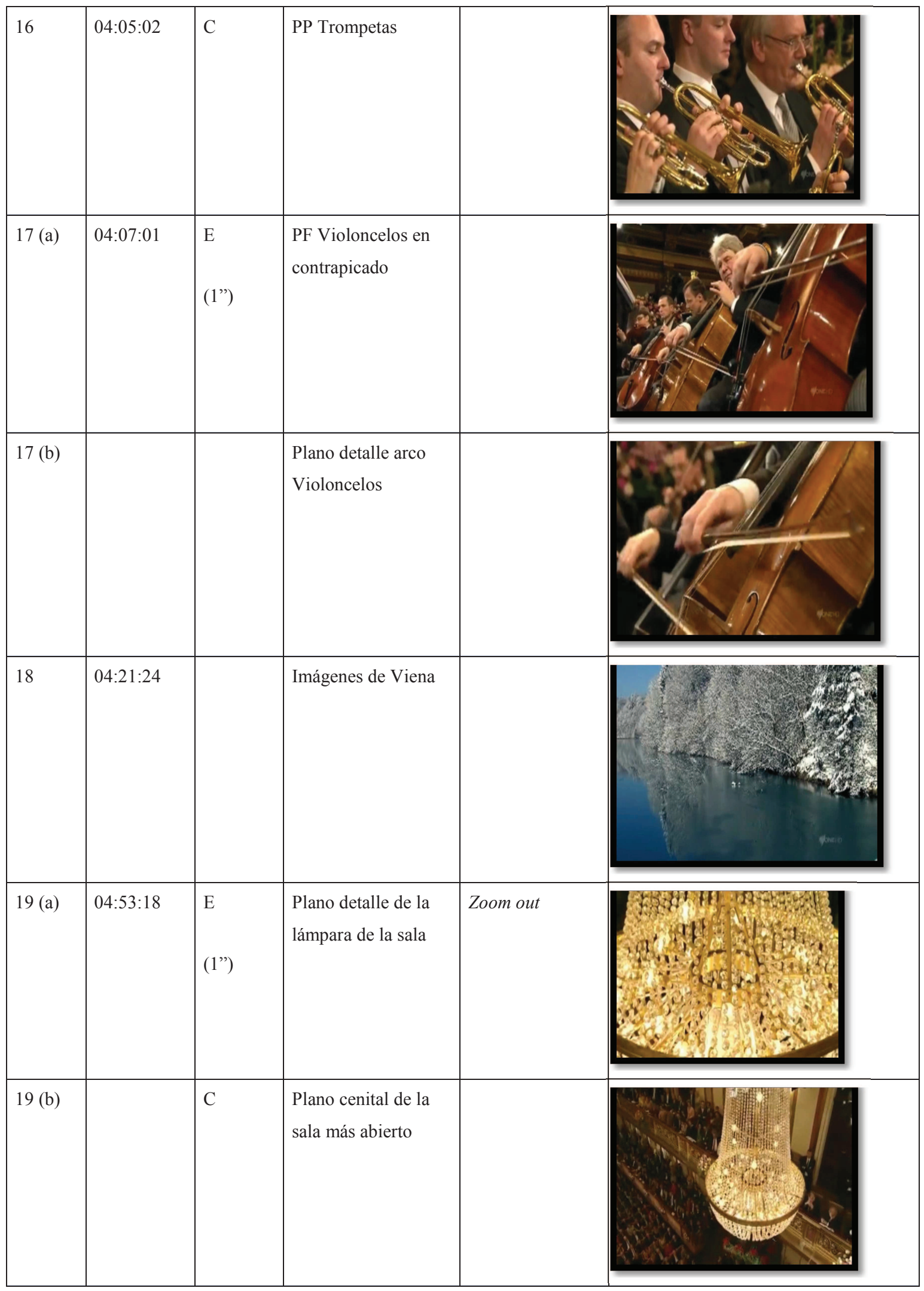




\begin{tabular}{|c|c|c|c|c|c|}
\hline 20 & 05:08:05 & C & $\begin{array}{l}\text { PF lateral en fuga de } \\
\text { la sección de } \\
\text { vientos: trombones } \\
\text { más trompetas }\end{array}$ & & \}$_{11}$ \\
\hline 21 (a) & 05:11:22 & & PF Violinista & Zoom out & sc \\
\hline 21 (b) & & $\begin{array}{l}\mathrm{E} \\
(2 ")\end{array}$ & $\begin{array}{l}\text { PG Orquesta } \\
\text { Frontal lateral }\end{array}$ & & 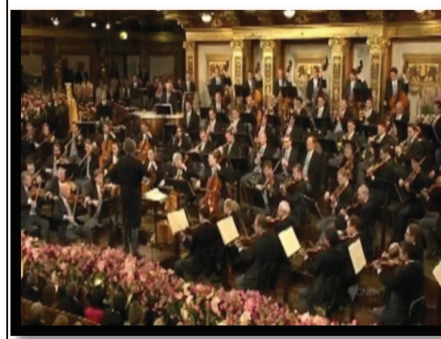 \\
\hline 22 (a) & 05:35:12 & $\begin{array}{l}\mathrm{E} \\
(2 ")\end{array}$ & $\begin{array}{l}\text { Plano detalle de los } \\
\text { centros florales }\end{array}$ & Zoom Out & 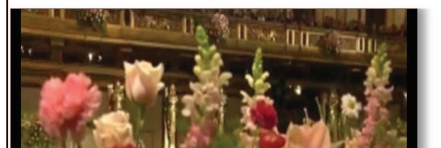 \\
\hline 22 (b) & & & $\begin{array}{l}\text { PG } \\
\text { Lateral de Cuerda y } \\
\text { director }\end{array}$ & & $=1$ \\
\hline $22(\mathrm{c})$ & & & PA director & & \\
\hline
\end{tabular}


De la partitura a la pantalla: plano y contraplano de una misma realidad - 213

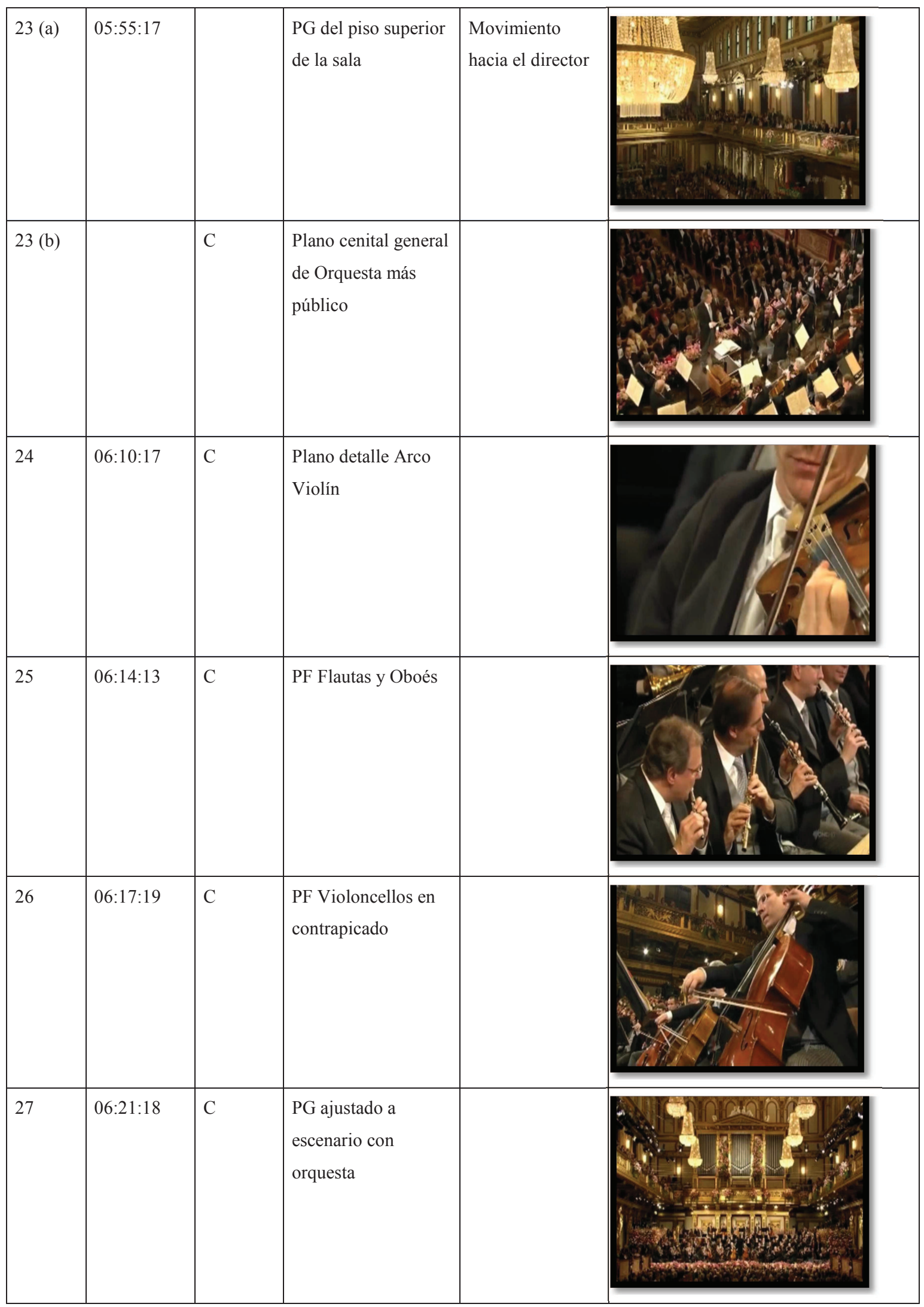




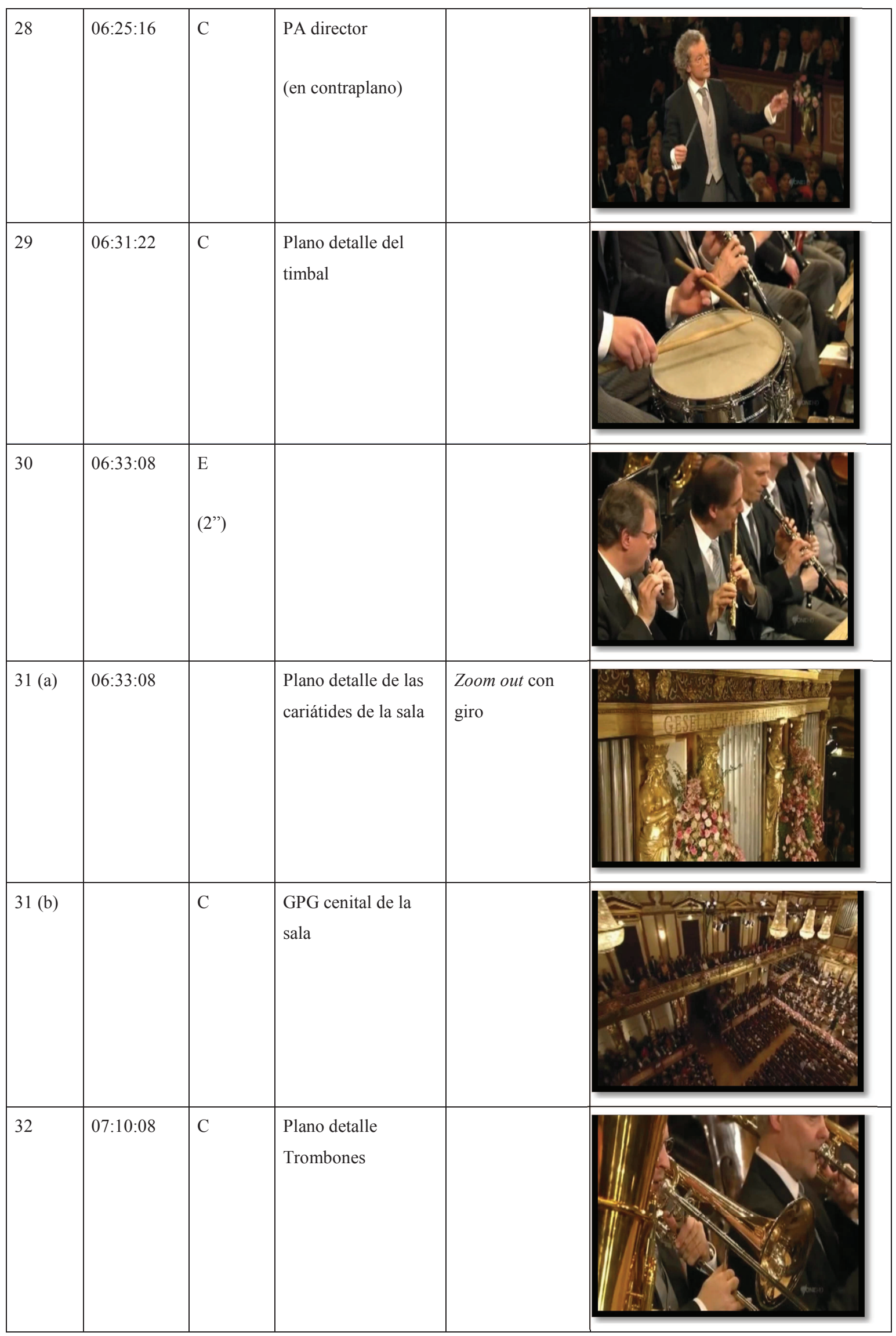


De la partitura a la pantalla: plano y contraplano de una misma realidad - 215

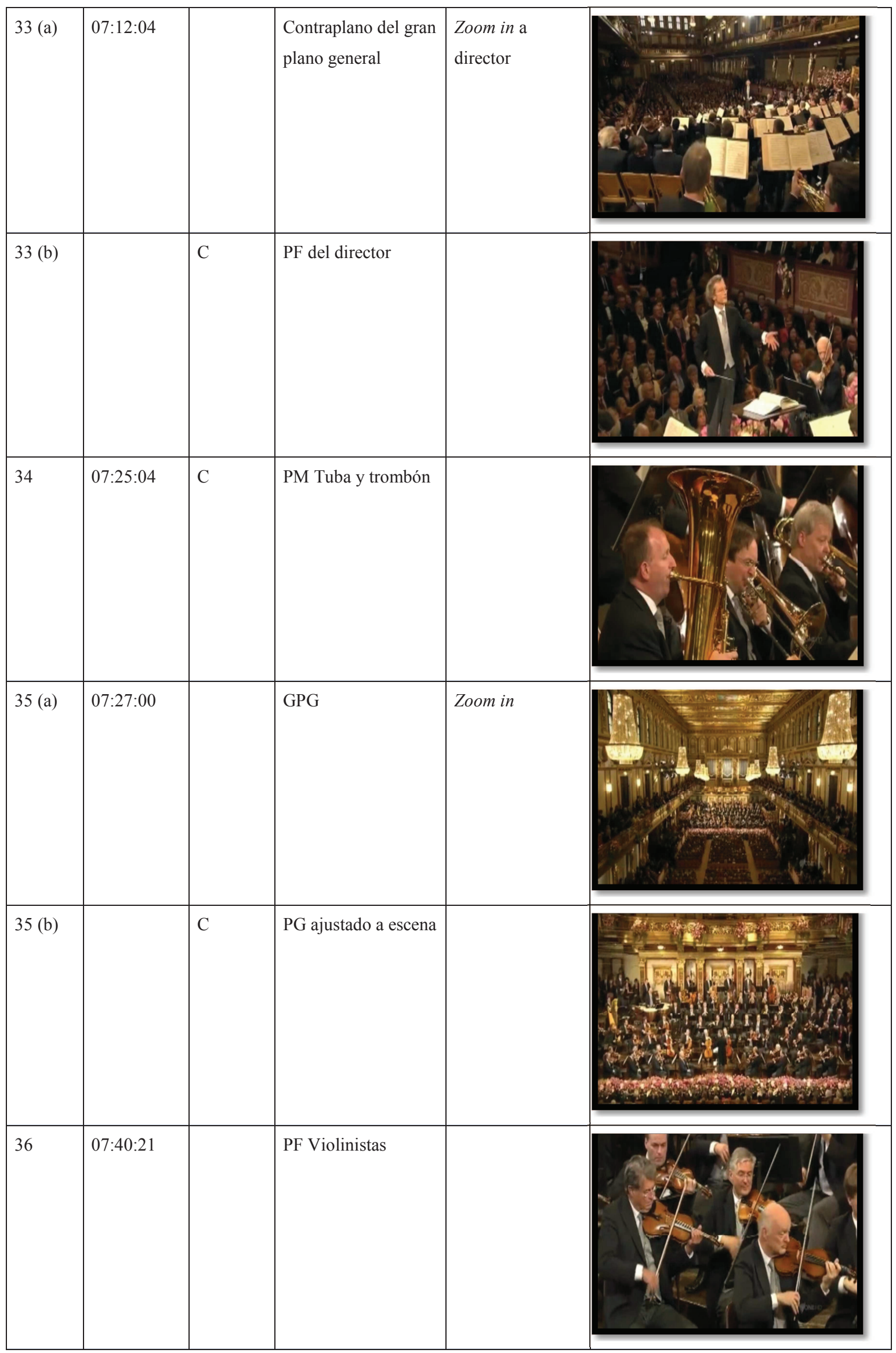


De la partitura a la pantalla: plano y contraplano de una misma realidad - 216

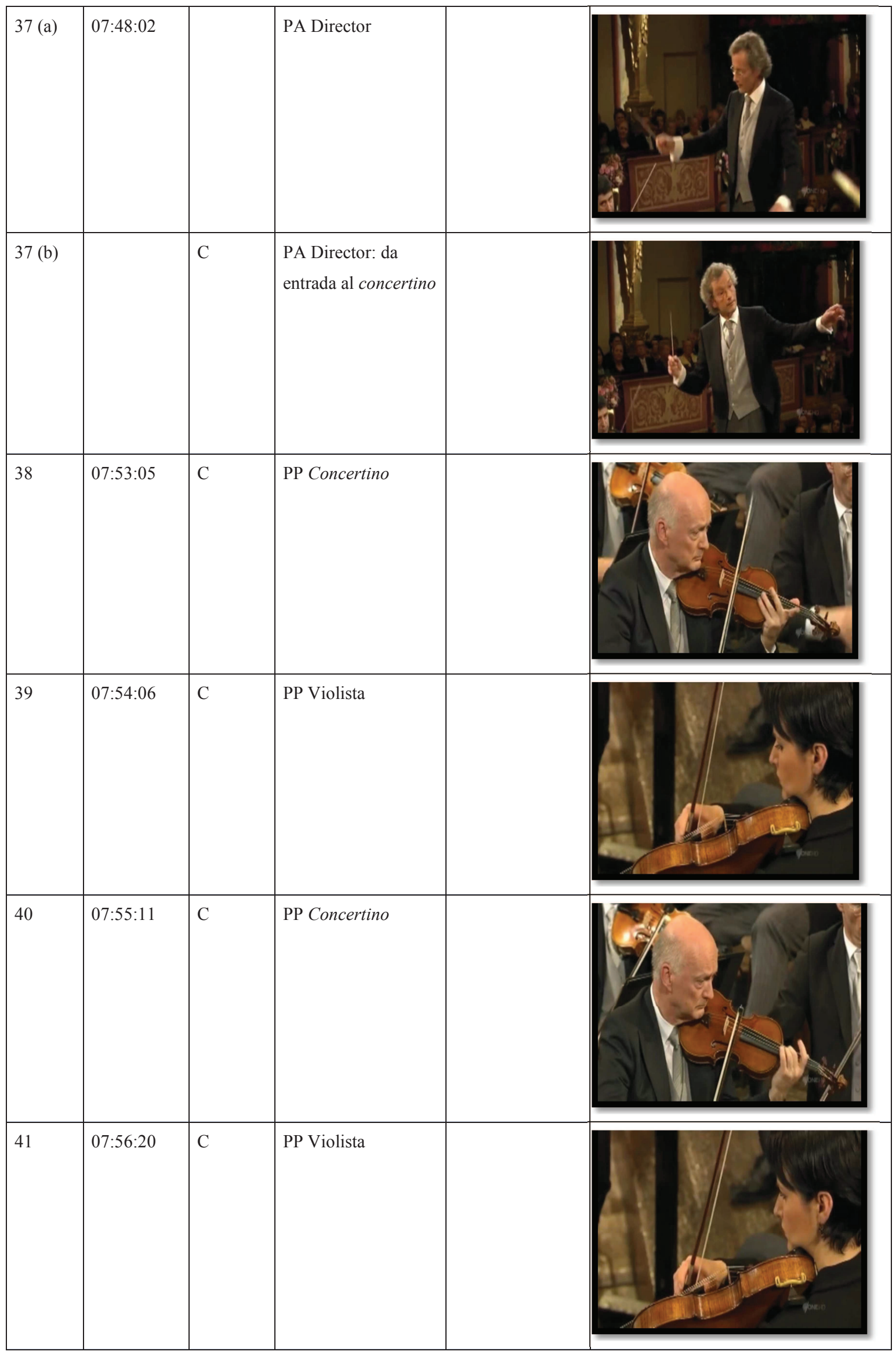




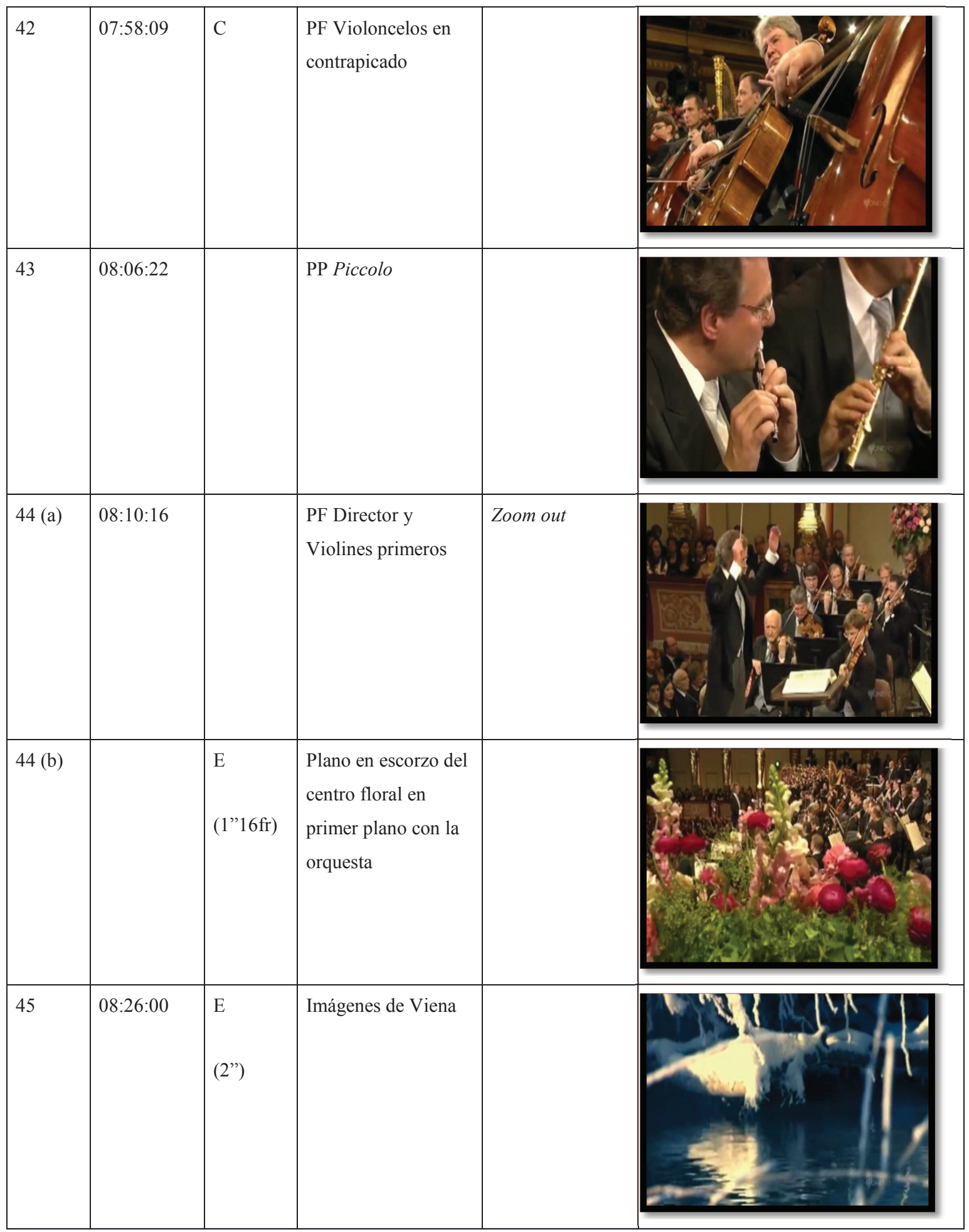


De la partitura a la pantalla: plano y contraplano de una misma realidad - 218

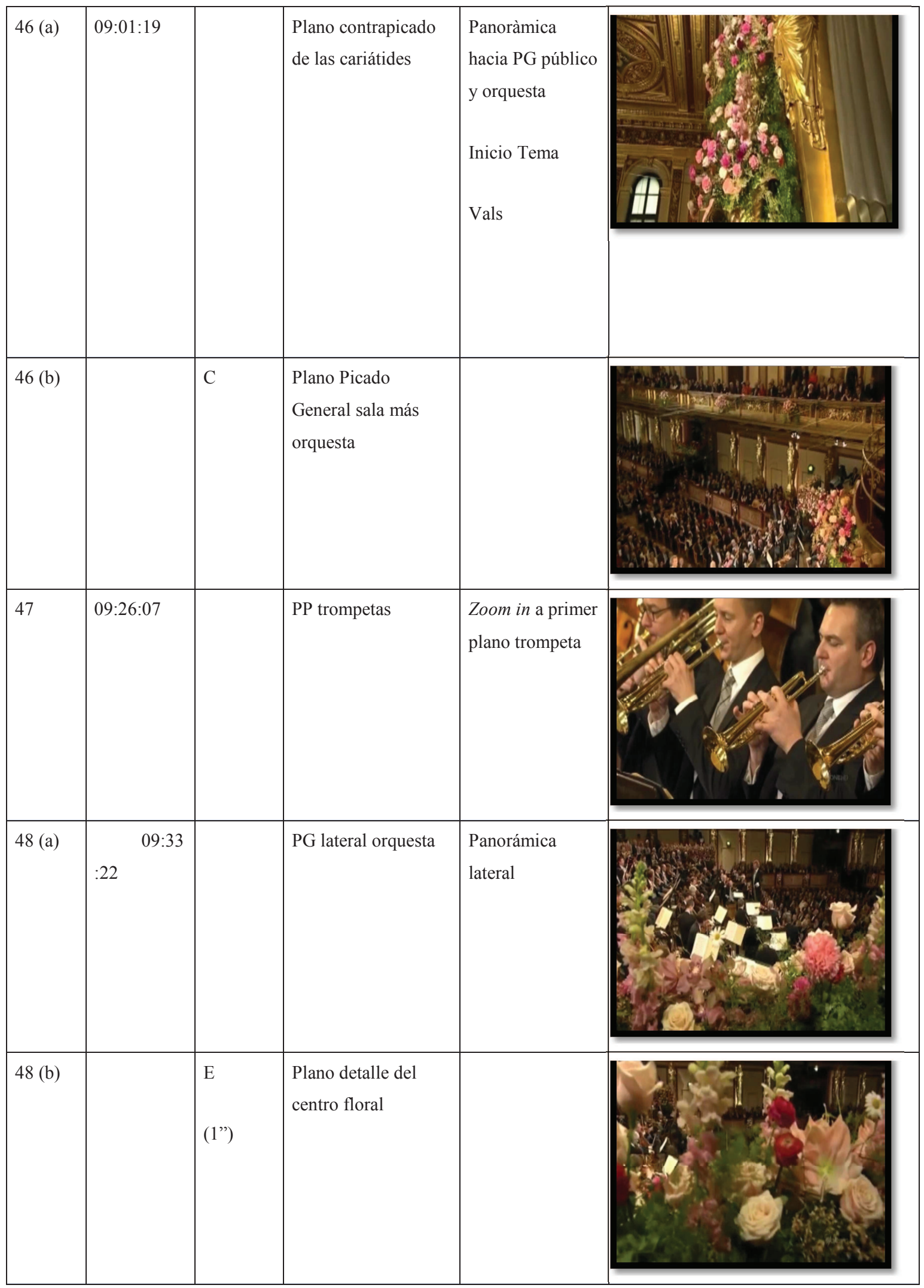


De la partitura a la pantalla: plano y contraplano de una misma realidad - 219

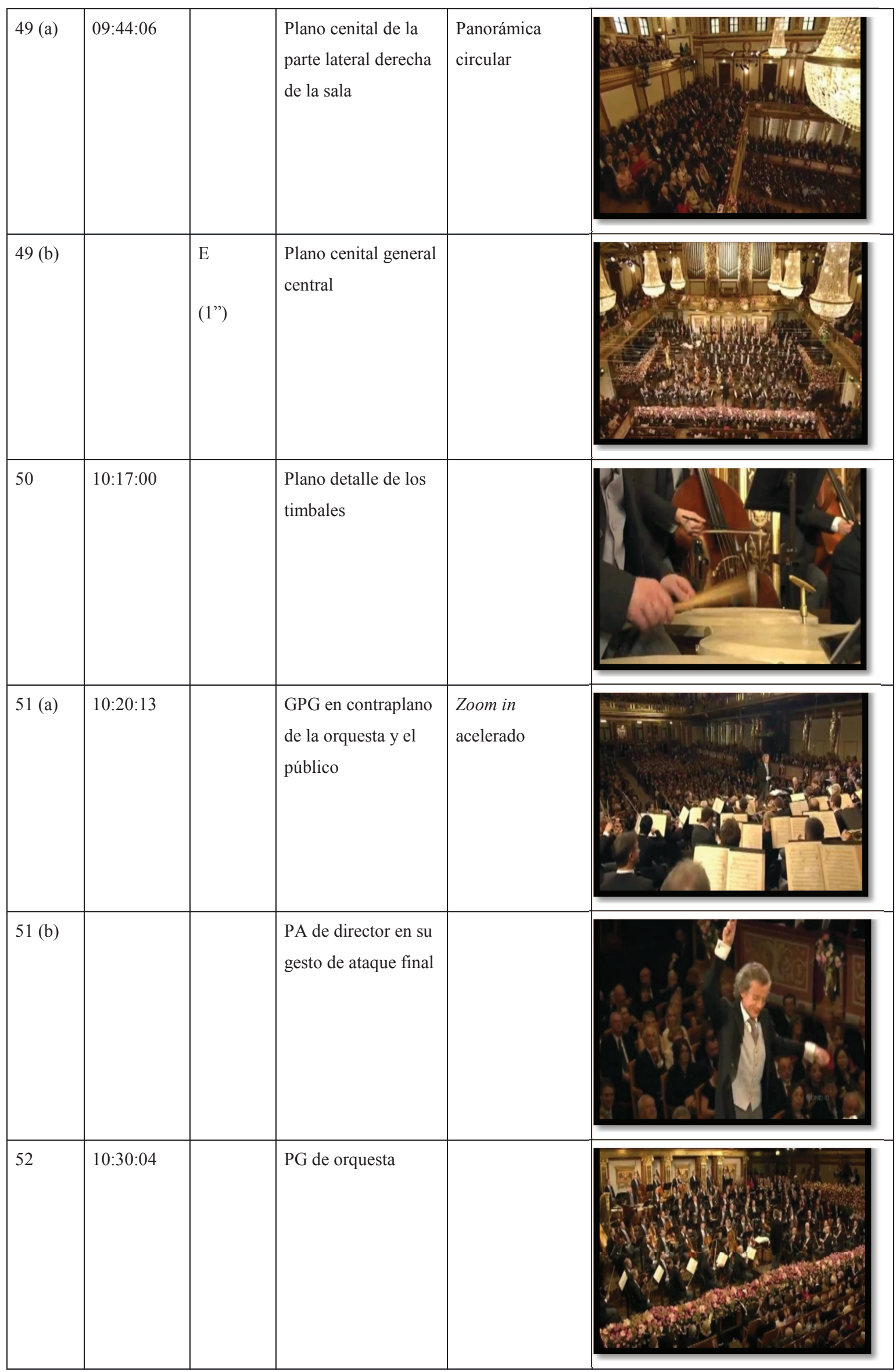


c.3) Comentarios sobre la realización

Aquí nos encontramos con un inicio muy distinto al de las otras dos retransmisiones escogidas. Para empezar, el plano secuencia novedoso, ya comentado anteriormente, del director musical entrando en la sala desde el backstage. A continuación el plano de espera y entrada de la orquesta del mismo director $y$, sin pasar por ningún instrumento musical, ya empiezan las imágenes pregrabadas. A pesar de entrar tan pronto, no serán imágenes que sobrepasen los minutos de la orquesta en imagen. Al contrario, un minuto después regresamos a la orquesta a través de una panorámica vertical que parte de un plano detalle de flores hasta llegar al plano lateral de la orquesta. A partir de aquí, varios planos encadenados por corte y sin movimiento (clarinete, violín y contrabajos) llevarán al espectador a uno de los momentos especialmente pensados para ilustrar la partitura en la pantalla. Con el inicio del tema del vals, empieza un movimiento circular de la skycam, la cámara colgada del techo y que recorre la sala de punta a punta diagonalmente. Es importante remarcar este movimiento porque, como todos sabemos, el baile del vals supone, precisamente, dar vueltas en movimiento de rotación sobre uno mismo y de traslación en el espacio. Así, Karina Fibich traslada dicho movimiento a la pantalla. Vimos semejante "vals de las esferas" en la película dirigida por Stanley Kubrick 45 años antes: 001, Odisea en el espacio.

Hasta las nuevas "imágenes-postal", la realizadora pasa por diversos planos de instrumentos. Después de dichas imágenes, vuelve a la sala con un plano detalle de la lámpara. Dichos encuadres recuerdan la manera de realizar y mostrar la sala de su maestro Brian Large. Se trata de encuadres con un gran primer plano - arquitectónico o floral- que va descubriendo la sala o la orquesta.

Podría afirmar que la realización de Karina Fibich sigue un patrón en cuanto a la sintáctica de la realización:

1. Imágenes de postal con las que se regresa a la sala a través de planos detalle, este recurso funciona como elemento estético a la vez que técnico ya que evita cualquier problema de sincronización "imagen-partitura"

2. Planos estáticos de instrumentos musicales

3. Encadenados a planos de la sala para potenciar todos sus elementos decorativos y arquitectónicos 
Las idas y venidas de estos planos vendrán marcados por lo que la música va "describiendo".

Por lo que respecta al director, el tamaño del plano siempre es americano y el punto de vista, invariablemente, desde derecha o izquierda de escenario. Si la entrada del director la vemos desde el punto de vista de los violines primeros, el acorde final lo vemos interpretado desde el lado opuesto.

c.4) Elementos finales

A priori, quiero subrayar el gran número de planos de orquesta, hecho evidente si tenemos en cuenta que en esta realización las salidas de escena sólo llenan dos minutos diez segundos del total de la interpretación del Danubio Azul.

Las principales características de esta realización son:

1. Gran cantidad de primeros planos de instrumentos. Todos, o casi todos, aparecen en primer término: clarinete, violín, piccolo, flauta, trompeta, violoncelo, trombón, tuba, caja viola y timbales.

2. Pocos planos de conjunto de instrumentos, aunque sí hay un elevado número de vistas picadas de la sala desde la cámara colgada (skycam)

3. Pocos puntos de vista distintos. Con esto me refiero a que el plano de los violoncelos siempre es el plano contrapicado desde la derecha de escena ${ }^{60}$; o bien, el plano de las flautas o conjunto de madera, siempre aparece también desde el mismo punto de vista, izquierda de escenario.

4. Continuo movimiento, sin prisas, mediante zoom in o zoom out y panorámicas verticales u horizontales. Sólo permanecen estáticos los planos de instrumentos.

5. Edición por corte entre planos de instrumentos y edición por encadenado entre planos que dan paso a las imágenes externas de vídeo o a detalles de la sala.

6. Planos en fuga o composiciones con puntos de vista extremos: cenitales o contrapicados

${ }^{60}$ Excepto en el último plano en el que aparecen desde el punto de vista opuesto. 
Finalmente, quiero añadir que, en este caso, la realización ha tenido que tener en cuenta más planos de instrumentos debido a los escasos dos minutos de imágenes externas. Esto lleva a tener en consideración que el número de planos de orquesta sea el doble aproximadamente: 27 y 25 en las anteriores realizaciones y 51 en la realización de Karina Fibich.

Como evaluación genérica, y por lo que puede apreciarse, estamos ante una realización con decisiones tomadas que aportan seguridad en el momento del directo: pocos cambios de ángulo, casi inexistente movimiento interior de plano y encadenados a planos "subjetivos" de decoración o elementos arquitectónicos al volver a la sala de conciertos.

\section{d) Vals Danubio Azul, Concierto Año Nuevo, 2016}

\section{Director musical:}

Mariss Jansons

\section{Director audiovisual:}

Michael Beyer

Ejemplo 13: https://www.youtube.com/watch?v=S fk5aoEfl4

(Subido a Youtube por "Egon Hilgers")

Michael Beyer es considerado por el crítico Borja Terán un realizador "preciso y analítico" $"$. Lo que significa esta definición lo podemos evaluar después del análisis de su realización del Danubio Azul.

En primer lugar, ¿quién es Michael Beyer? Y, es que hay que reconocerlo, Brian Large se convirtió en el realizador archiconocido de este evento musical; después vino su ayudante Karina Fibich...pero, ahora, es Michael Beyer quien nos traslada con su mirada a uno de los conciertos emblemáticos que podemos ver a través de la pantalla.

\footnotetext{
${ }^{61}$ Consultado desde http://blogs.lainformacion.com/telediaria/2016/01/01/concierto-de-ano-nuevo-cuatrovalores-televisivos-para-su-exito/
} 
Michael Beyer, de origen alemán, estudió piano y teatro musical. Sus estudios le llevaron como asistente del director de la ópera de Hamburgo; pero, también, profesionalmente fue asistente de Brian Large. Establecido como profesional autónomo ha llevado a cabo numerosas grabaciones de conciertos y óperas. Así pues, una importante trayectoria académica y profesional en el ámbito musical para poder llegar a la realización del concierto con el que cualquier profesional del medio sueña: el Concierto de Año Nuevo. Durante los años 2010, 2012 y 2013 realizó las secuencias de ballet. Posteriormente, fue el responsable de la realización del concierto en su globalidad durante los años 2014, 2015, 2016 y 2017.

Hoy en día, podemos afirmar que este concierto tiene dos directores principales, dos actantes del concierto: el director musical y el director de realización. Los dos deben tener una buena comunicación y coordinación entre ellos ya que el concierto se ha convertido ya en una "historia audiovisual" con ballet, "músicos-actores" que intervienen en las bromas, público que participa gestualmente, entre otras anécdotas. Así pues, quiero destacar en esta realización $\mathrm{y}$, tal como he remarcado cuando hablaba de las convenciones sociales en el punto dedicado al concierto dirigido por Herbert Von Karajan y realizado por Humpfrey Burton, que ya en este momento el realizador sabe perfectamente que tiene que dedicar su realización a la broma inicial: antes de empezar la interpretación del Danubio Azul, el director hace sonar la trompa solista y hace parar en ese momento la orquesta para recibir los aplausos de la gente y desear el feliz año a los asistentes y a todos los espectadores que ven la retransmisión. El realizador ordena un primer plano del director en ese momento, en espera de la expresión para mostrar que es la broma anual. Sin embargo, en el momento de iniciar, ya en serio, la interpretación, el realizador omite el plano inicial del director musical Maris Jansons para empezar con un gran plano general y seguir con el plano corto del violón en tremolo. Evidentemente, a partir de estos minutos iniciales, ya podemos considerar una estrategia planificada por parte del realizador.

\section{d.1) Táctica}

Michael Beyer empleó quince cámaras, ocho de las cuales fueron operadas con control remoto. Uno de los retos era poder hacer invisible la tecnología a los ojos del espectador y, eso, fue conseguido. Es muy difícil esconder cualquier elemento tecnológico -desde las cámaras al cableado-, sin embargo, Beyer logró que fuera así. 
También, tuvo una valoración positiva trabajar en una unidad móvil con una capacidad tecnológica de muy alto nivel.

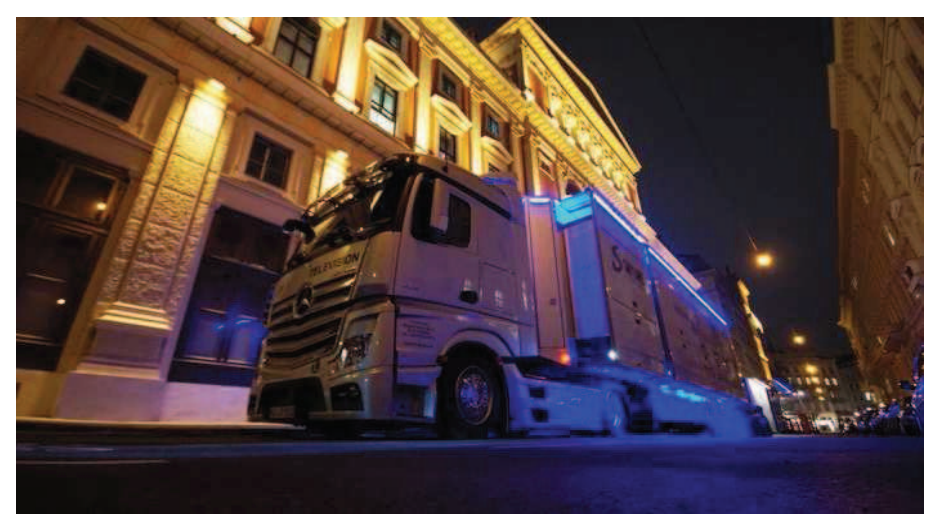

Figura 67 Unidad móvil- TV Skyline Ü8- para el concierto de Año Nuevo de Enero 2016.

Es muy importante tener dispuestas las cámaras bien en la regie para que, con una ojeada, se pueda ver toda la planificación de las cámaras con sus planos respectivos. Y, es que es muy distinto, realizar en directo que en diferido. La planificación, la comunicación y la coordinación en una retransmisión no se pueden dejar a una improvisación que, en mi experiencia, puede dar más de un disgusto en el momento del directo. Con las siguientes palabras del realizador del Digital Konzert Hall, Robert Gummlich, queda expresada la importancia que tiene una buena disposición de cámaras en el control de realización:

He did not always use the best pictures but often only the ones from the middle (K5 / 6). I know the problem: You might loose the cameras, that are not directly in front of you, out of the focus when you are improvising. And I think especially the choir looked better from the sides in profiles (Robert Gummlich, director, Digital Konzert Hall $)^{62}$.

Robert Gummlich, en su evaluación sobre la realización, constata dos problemas:

$\checkmark$ La improvisación al realizar, sin una planificación de cada uno de los planos.

$\checkmark$ Mirar sólo el centro del panel donde están los monitores con cada uno de los planos de las cámaras.

${ }^{62}$ Gummlich, R. (comunicación personal, 1 julio 2013) 
La consecuencia de estos dos errores es que la realización no fluye y se pierde la riqueza que pueden dar el resto de los planos dados por los cámaras.

Referente al concierto de Año Nuevo, para estar preparados para el día del concierto, todo el equipo técnico y artístico realizaron cinco ensayos con la orquesta entre los días 27 y 29. El día 30 ensayaron con la orquesta ya vestida como el día del concierto y con público. El día 31 por la mañana efectuaron una grabación del concierto y el día 1, ya llegó la retransmisión en directo. Es decir, antes de llegar a las televisiones -o pantallas- de todo el mundo, ya se habían realizado siete ensayos con cámara. Sólo de esta manera se puede improvisar si aparece cualquier problema durante la retransmisión.

El número de cámaras empleadas son quince. De éstas, tres cámaras están situadas en torres elevadas y otras dos en raíles laterales a derecha e izquierda; uno de ellos con una curvatura de $90^{\circ}$.

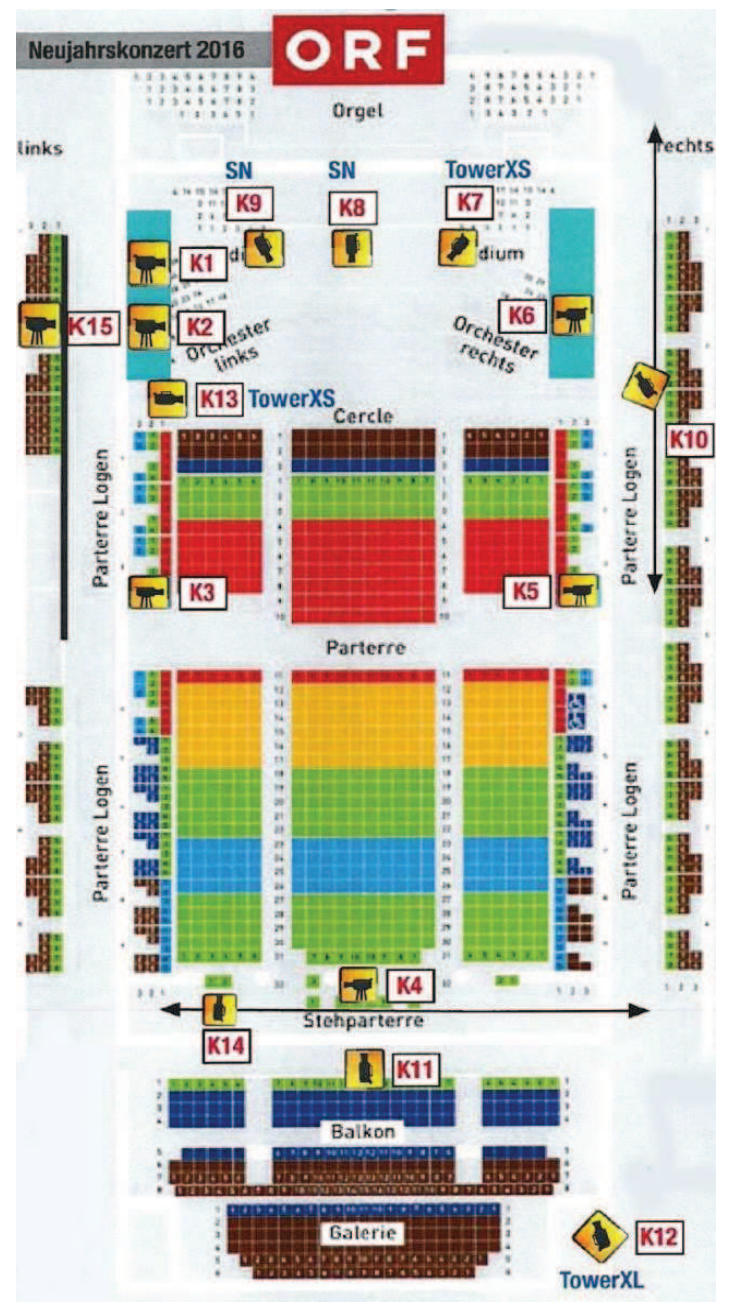

Figura 68 Plano de cámaras para la realización del concierto de Año Nuevo de enero de 2016 
A continuación, muestro las distintas cámaras desde su ubicación:

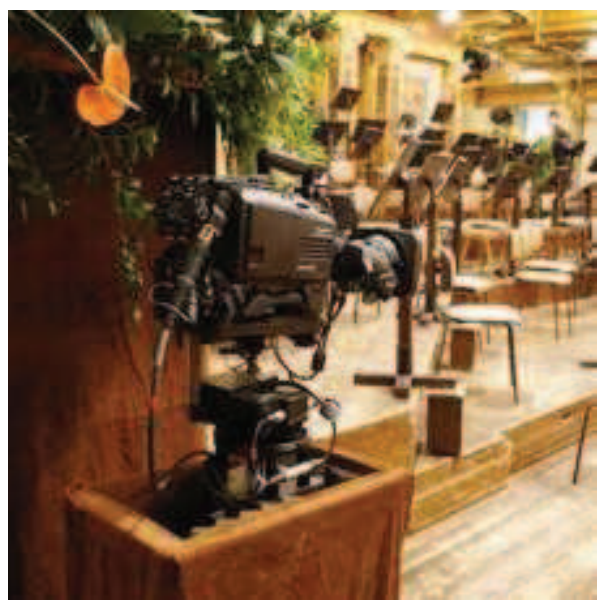

Figura 69 Cámara 2 (lateral izquierdo escenario)

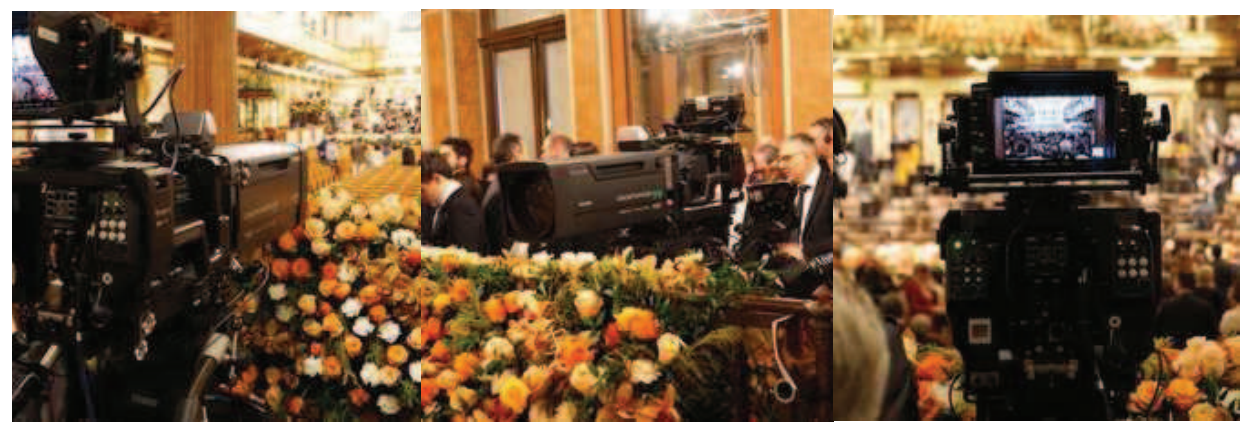

Figura 70 Cámara 4 (frontal escenario-fondo sala)

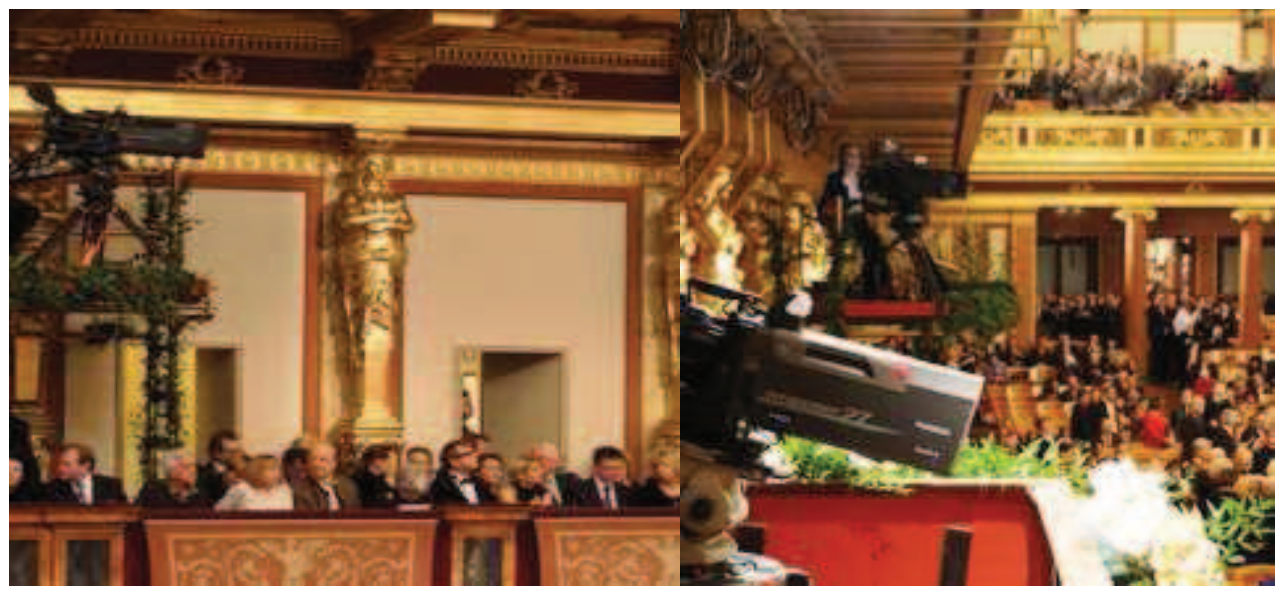

Figura 71 Cámaras 6 y 5 (lateral derecho) 


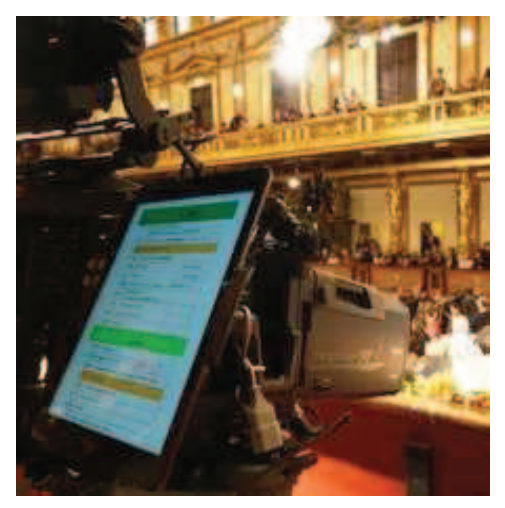

Figura 72 Cámara 6 (indicaciones al cámara en una Tablet, script)

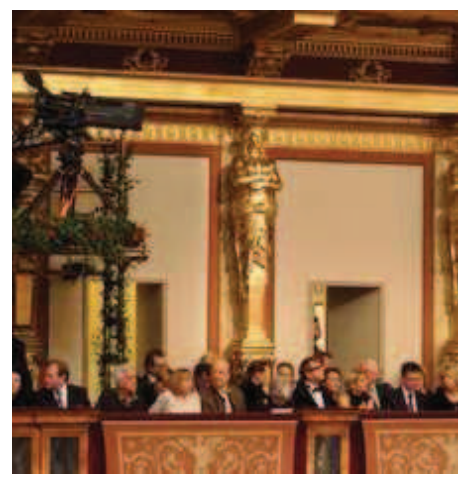

Figura 73 Cámara 5 (lateral derecho)

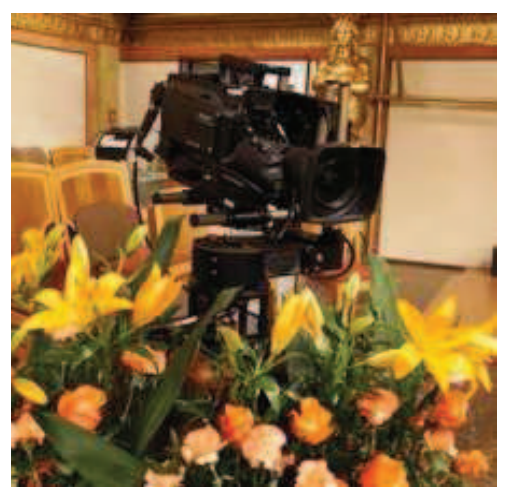

Figura 74 Cámara 7 (lateral izquierda escenario, contraplano)

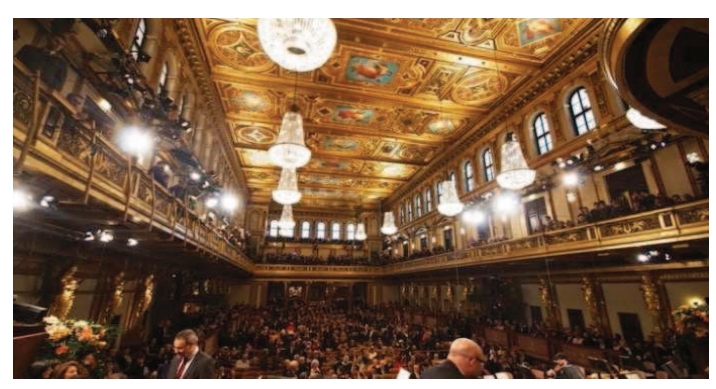

Figura 75. Cámara 7 (lateral izquierda escenario, vista del contraplano) 


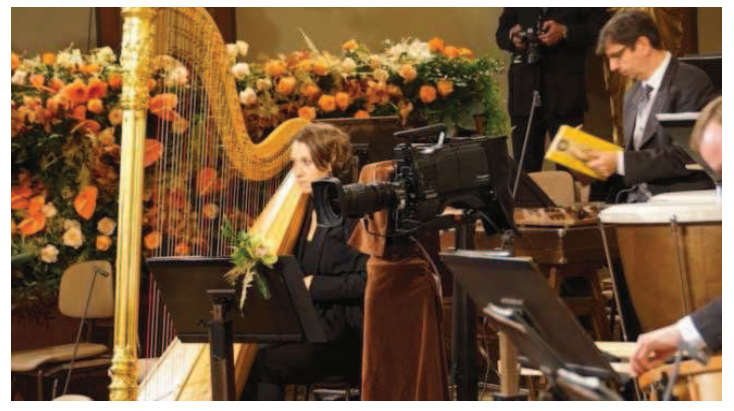

Figura 76 Cámara 8 (centro escenario, contraplano sala y director)

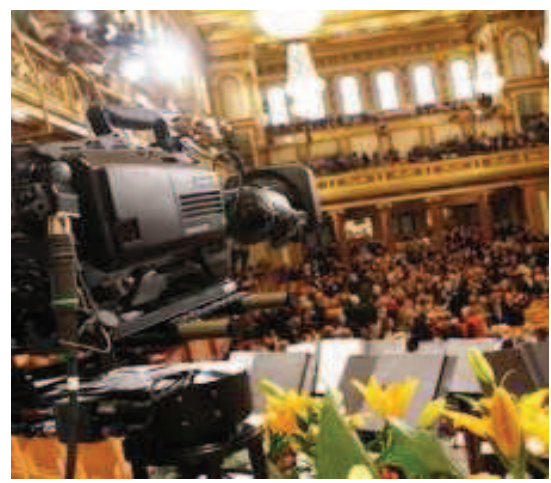

Figura 77 Cámara 9 (lateral derecho escenario, contraplano sala y director)

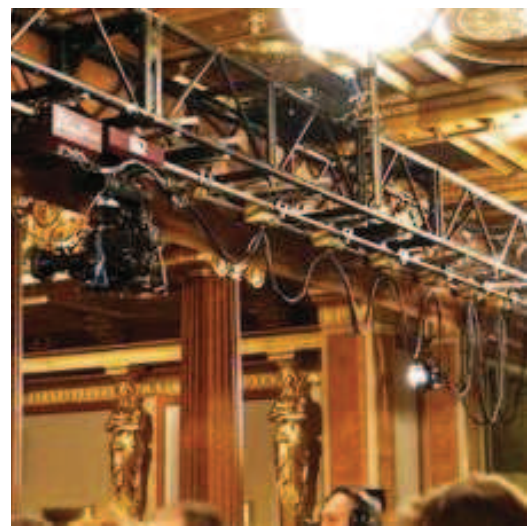

Figura 78 Cámara 14 (plano frontal, con raíl y control remoto)
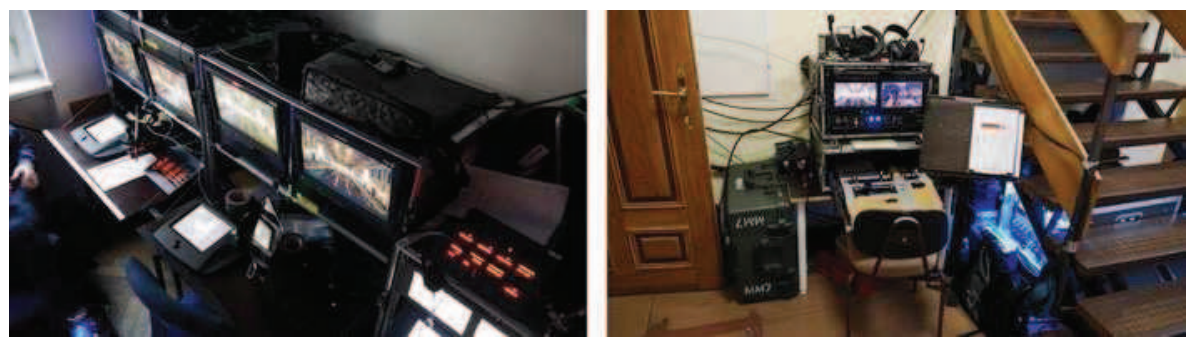

Figura 79 Controles remotos de cámaras fuera de la sala Musikverein. 


\section{d.2) Estrategia: Secuenciación analítica}

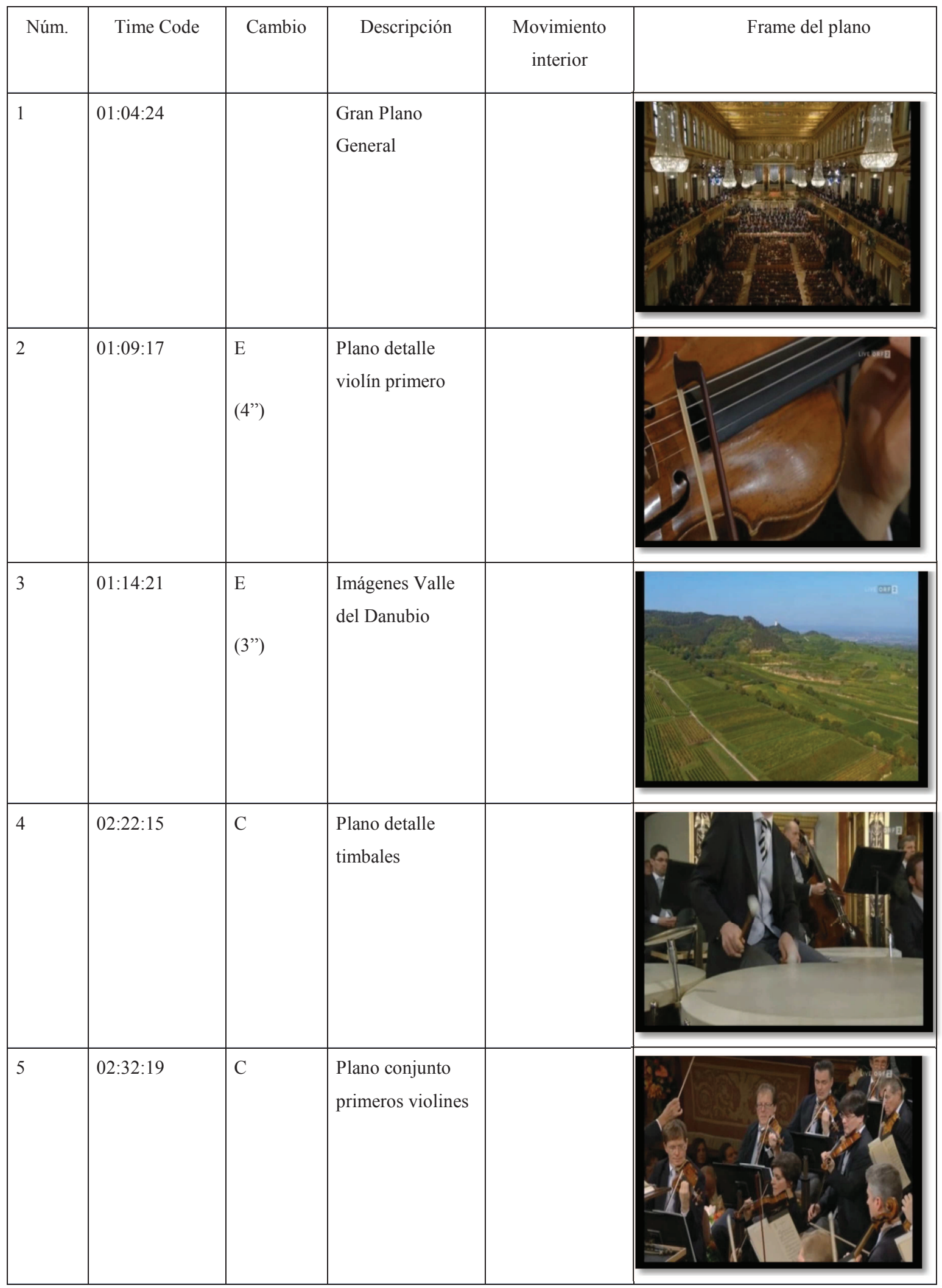




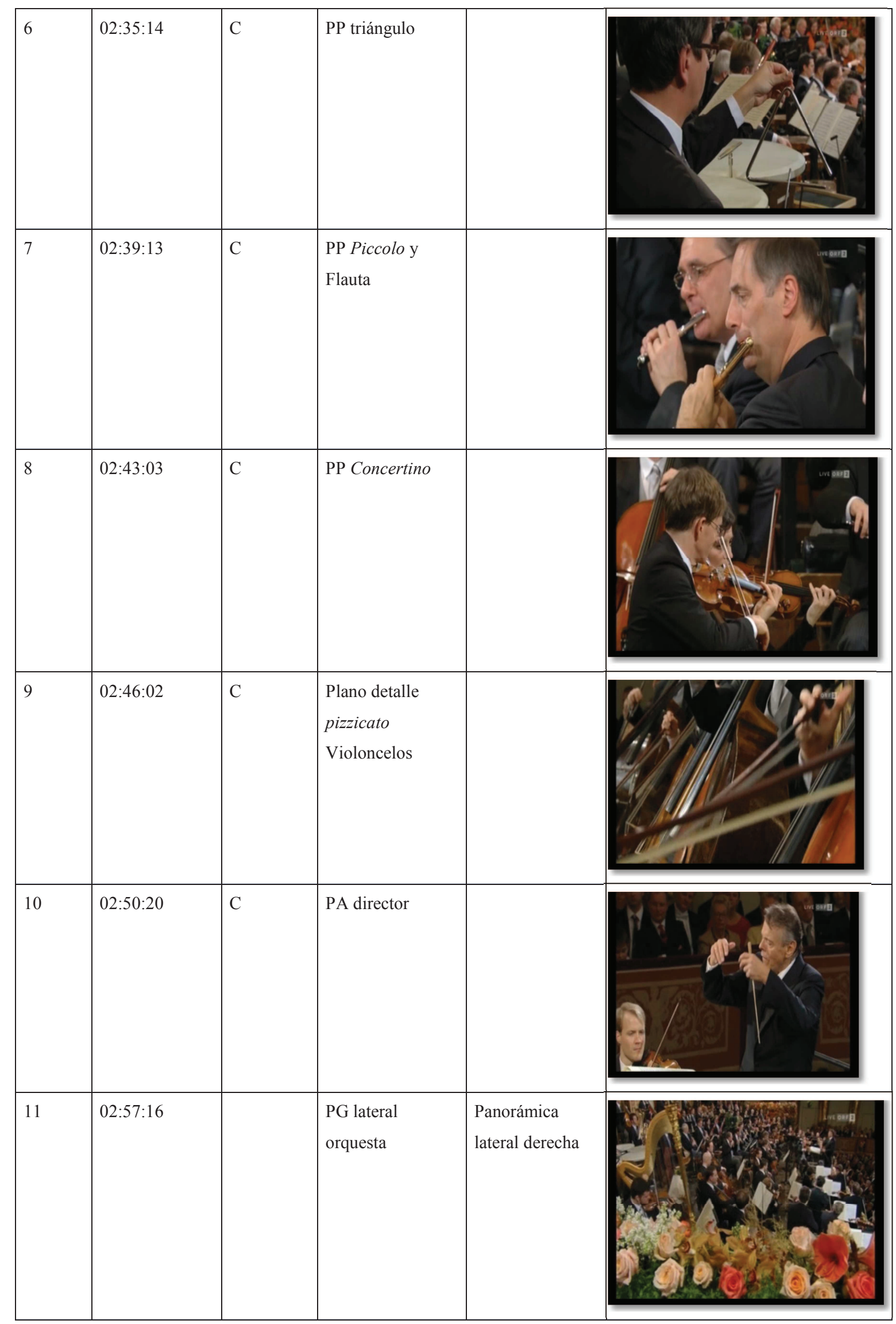


De la partitura a la pantalla: plano y contraplano de una misma realidad - 231

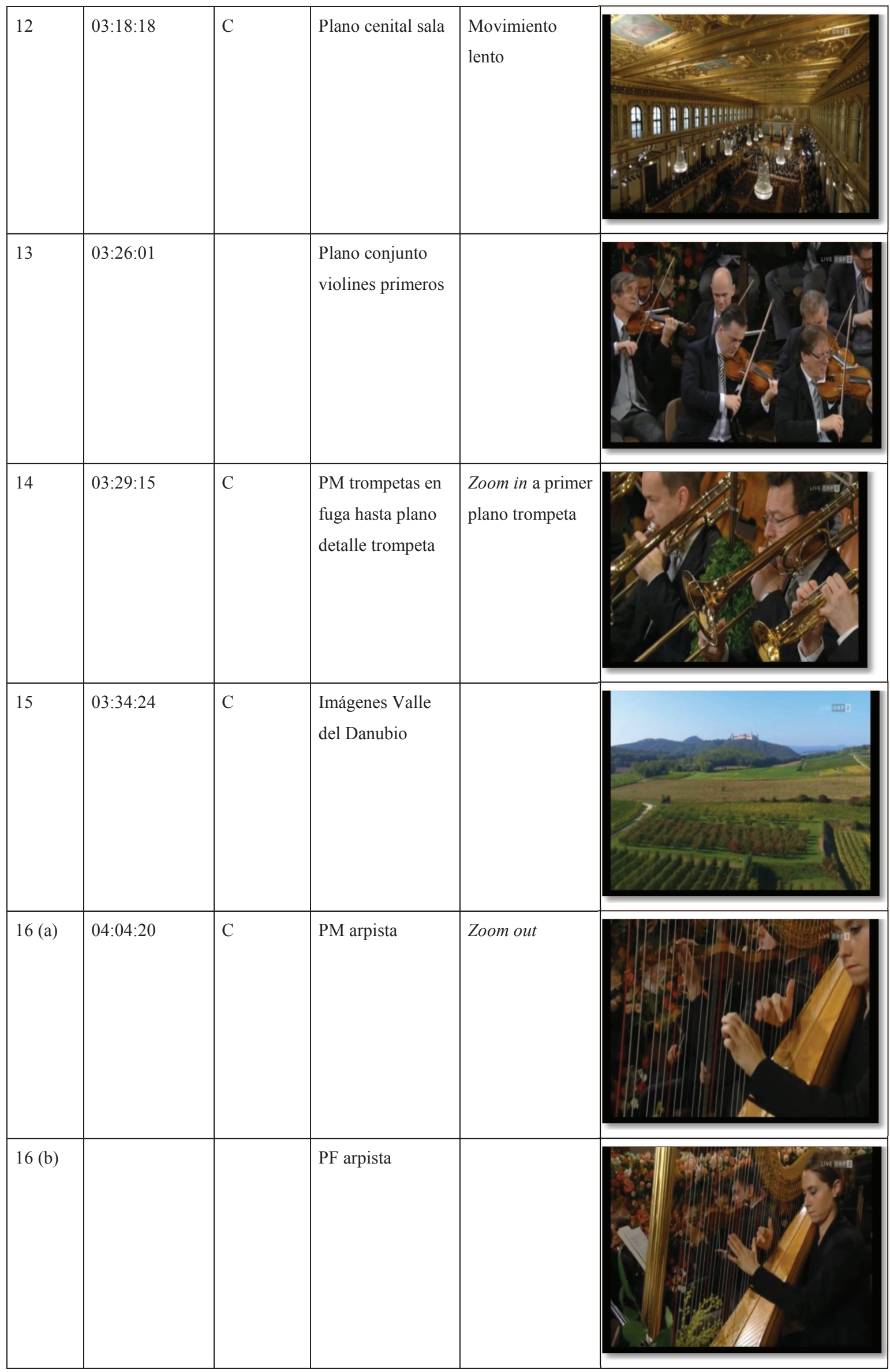




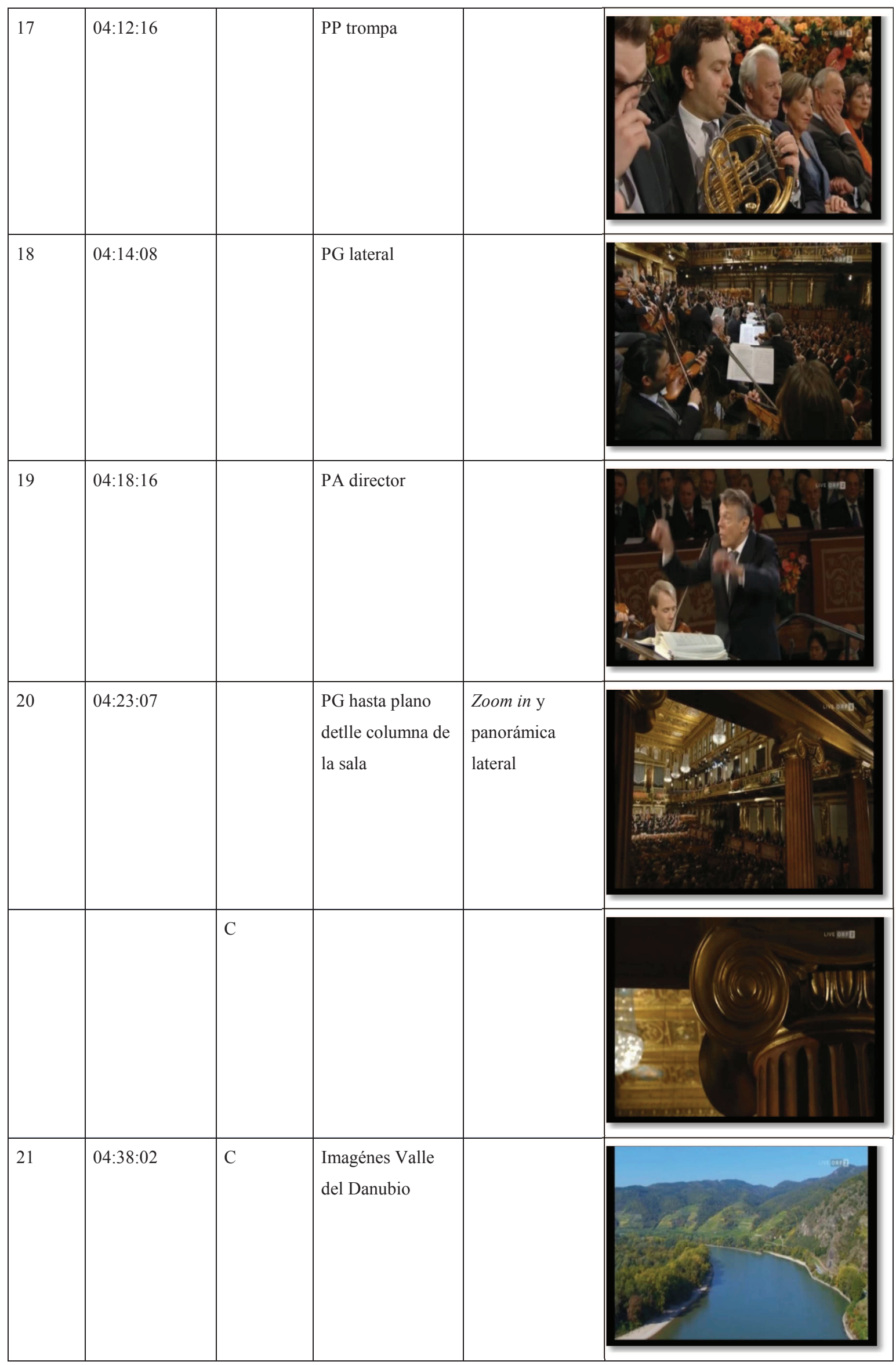


De la partitura a la pantalla: plano y contraplano de una misma realidad - 233

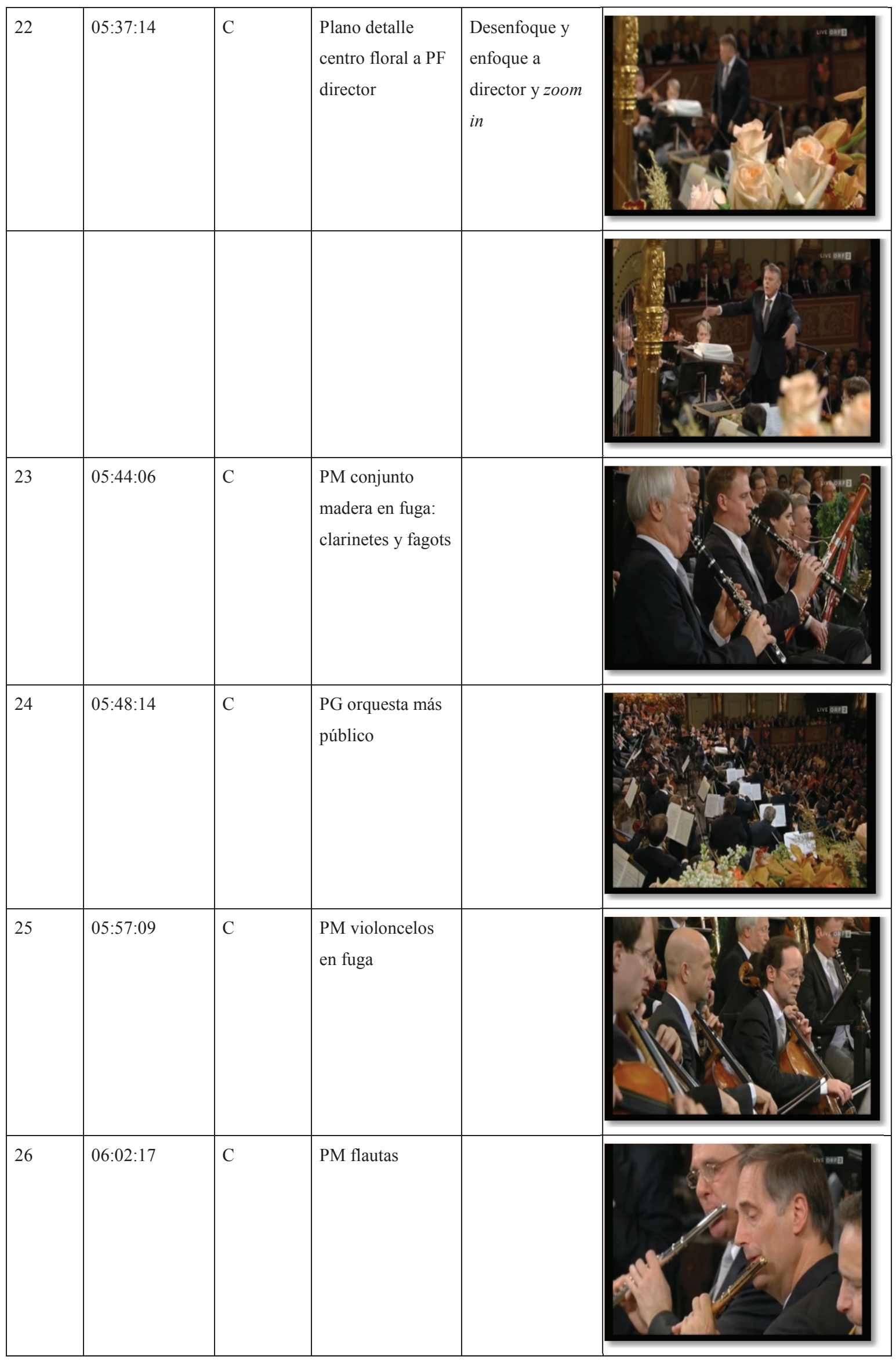




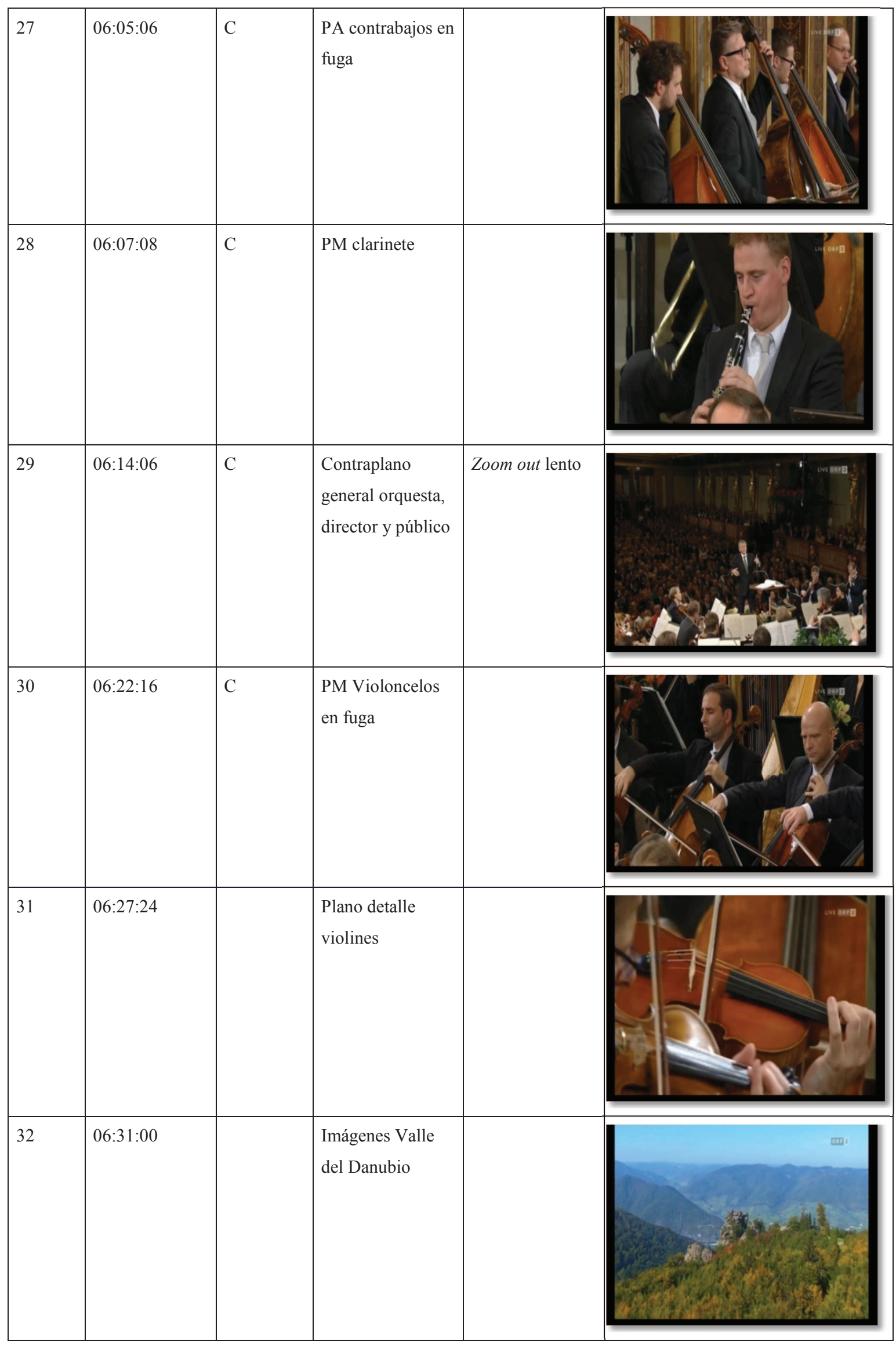


De la partitura a la pantalla: plano y contraplano de una misma realidad - 235

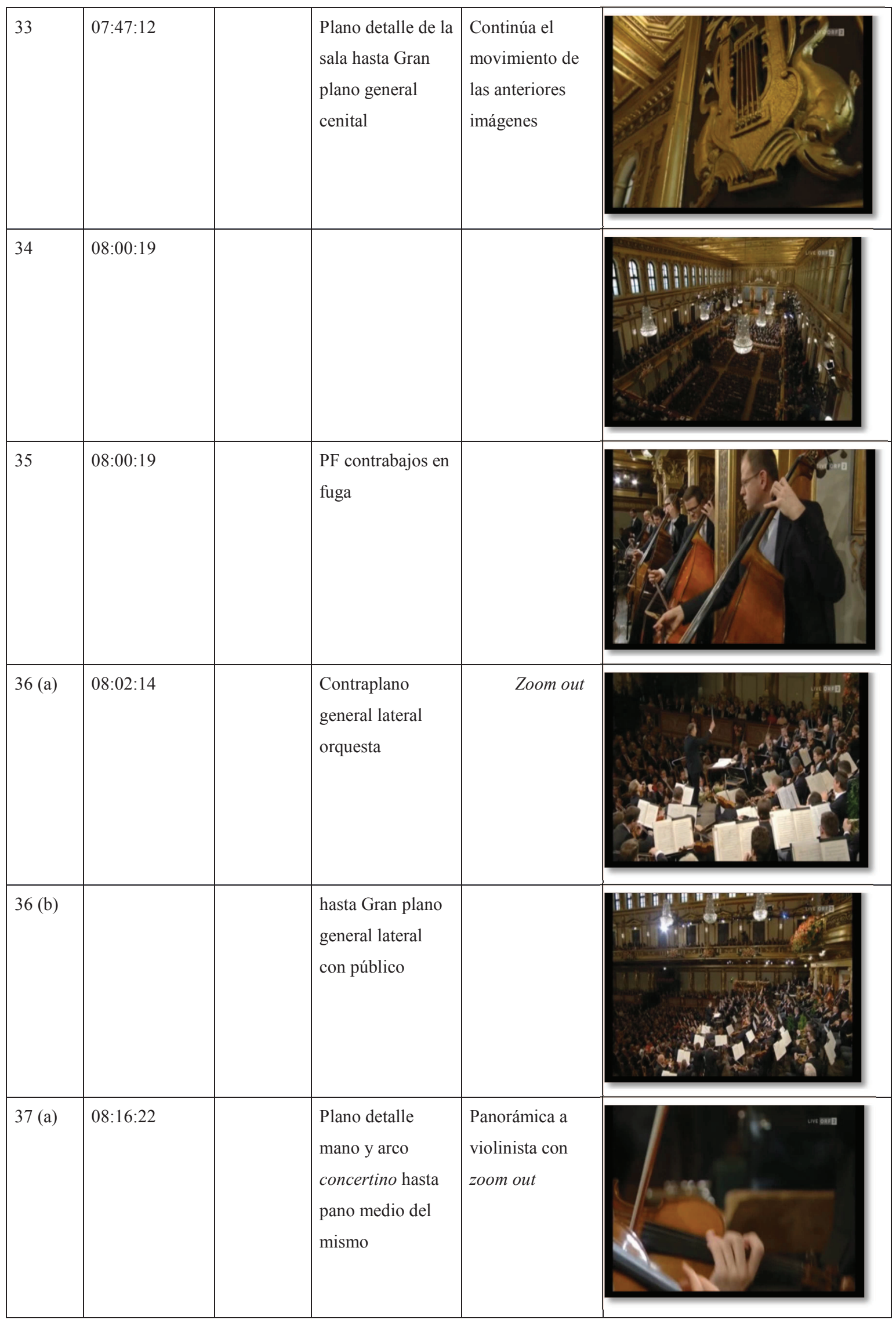




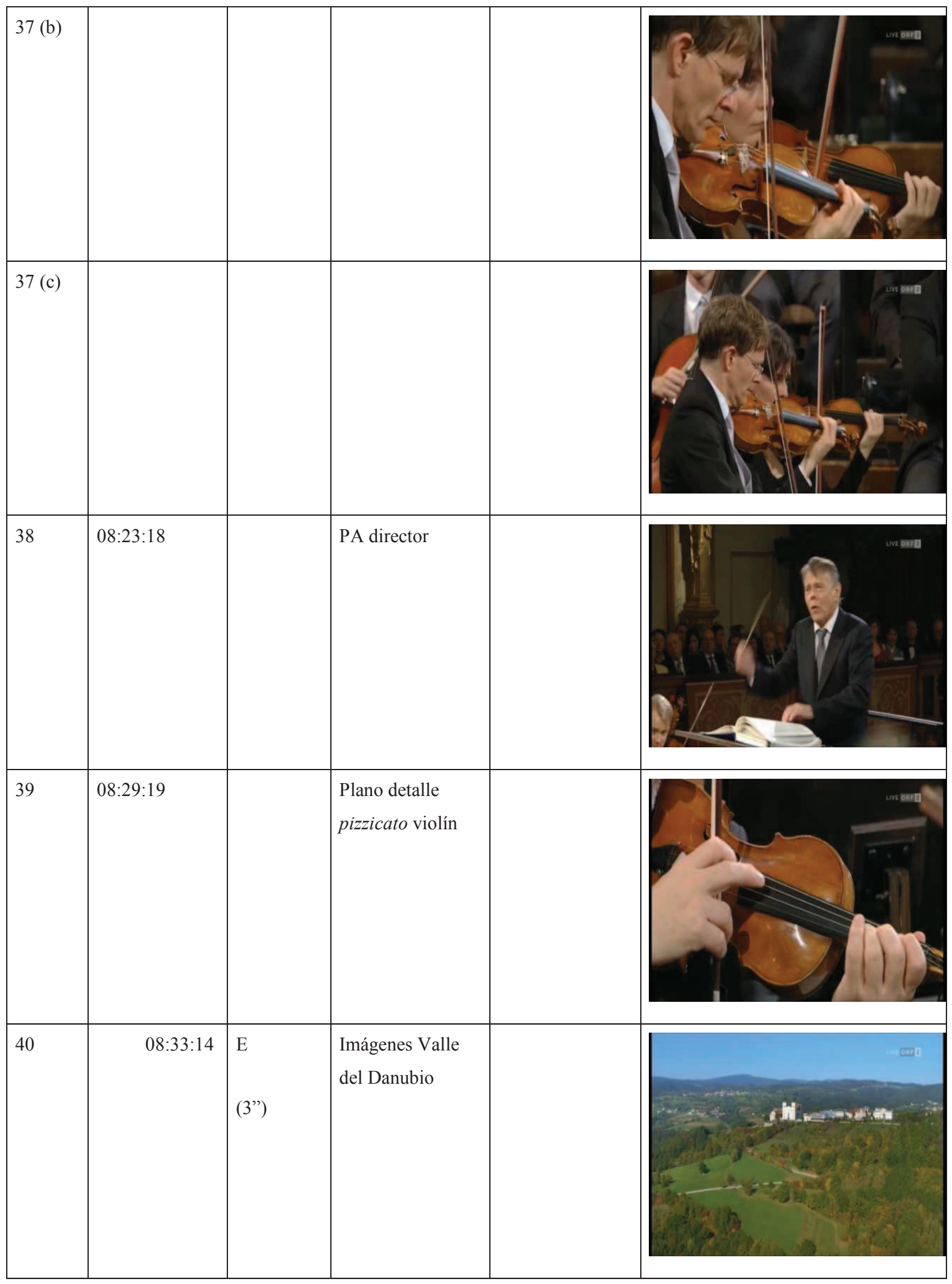


De la partitura a la pantalla: plano y contraplano de una misma realidad - 237

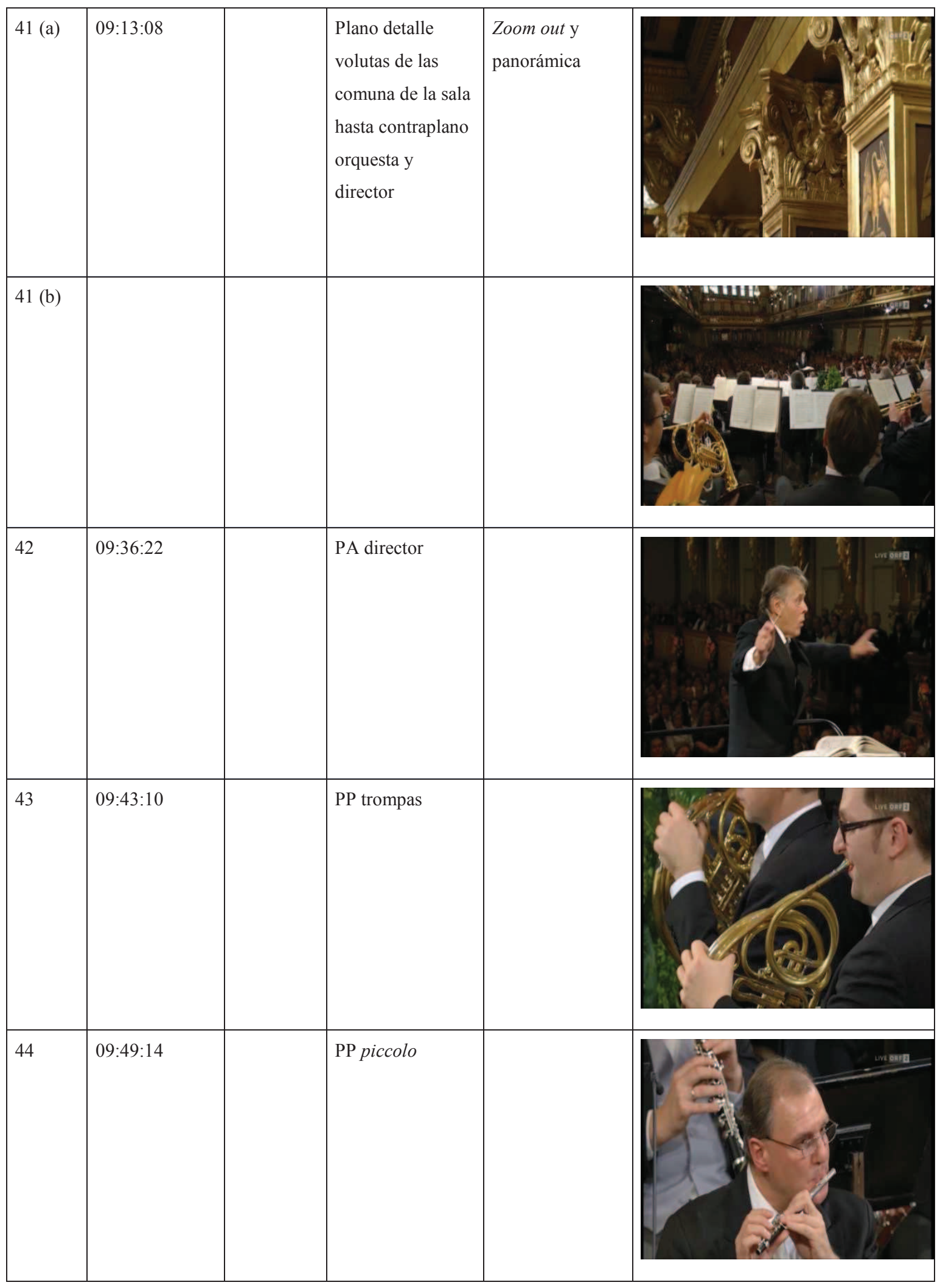




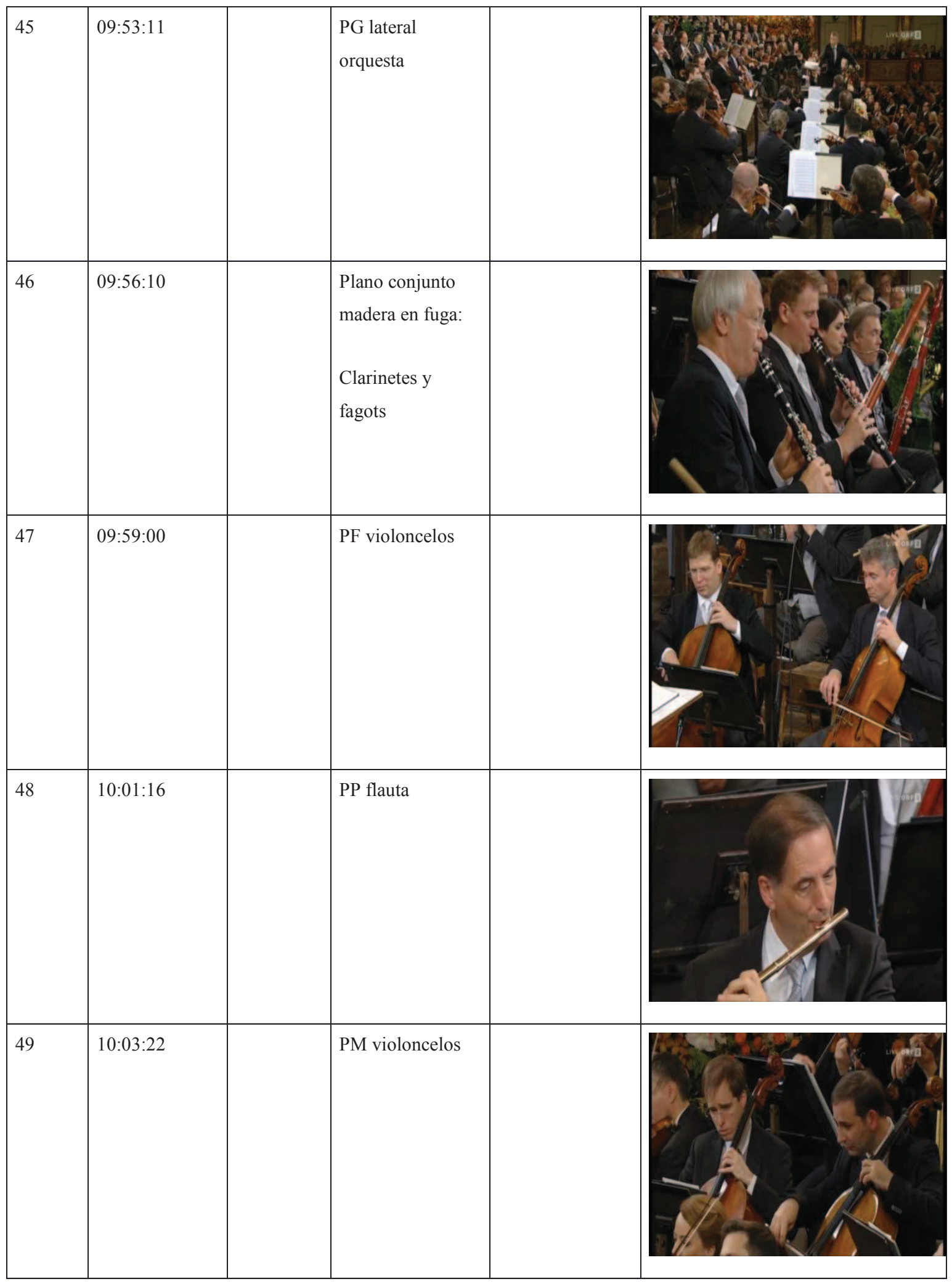




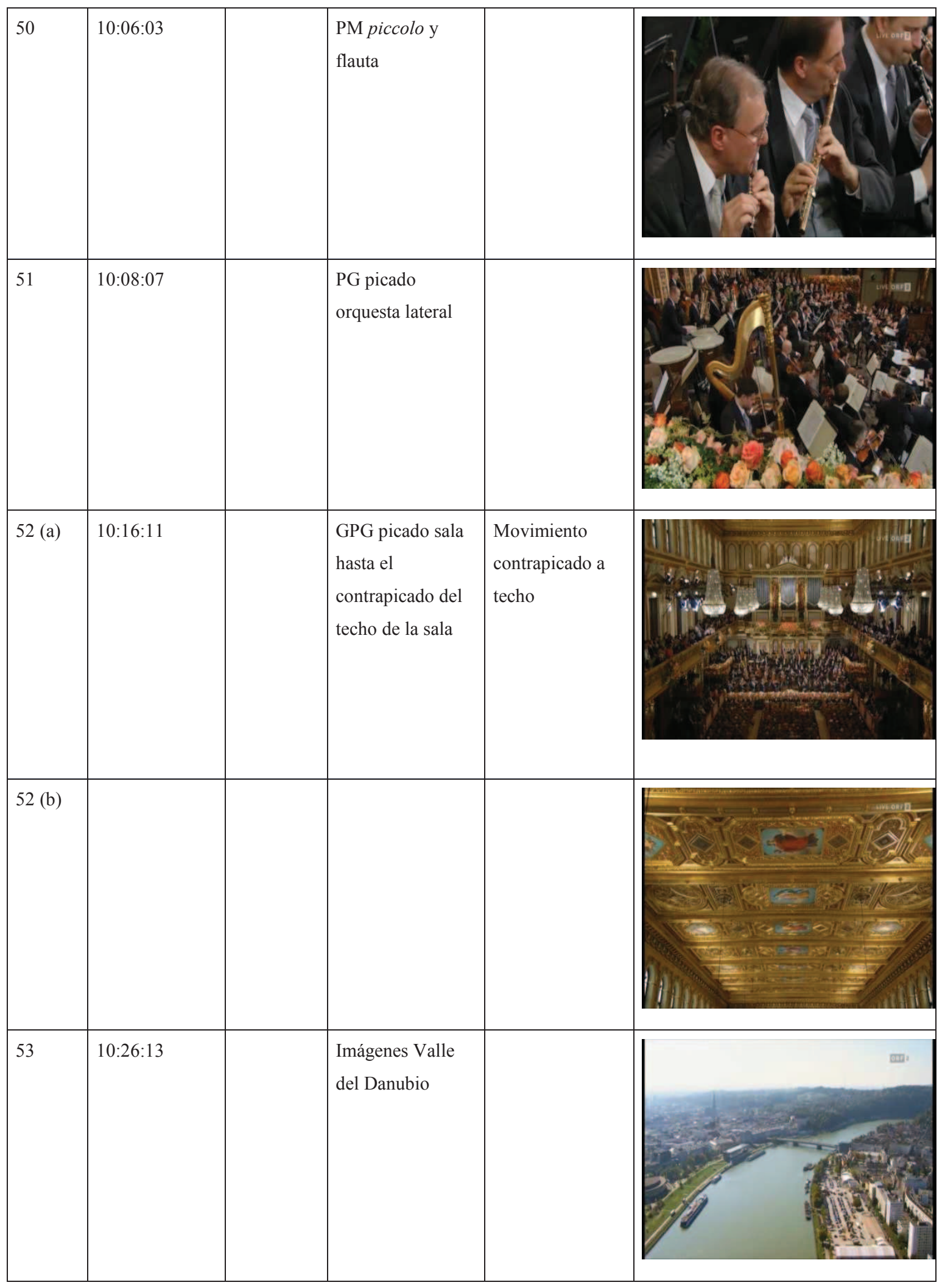


De la partitura a la pantalla: plano y contraplano de una misma realidad- 240

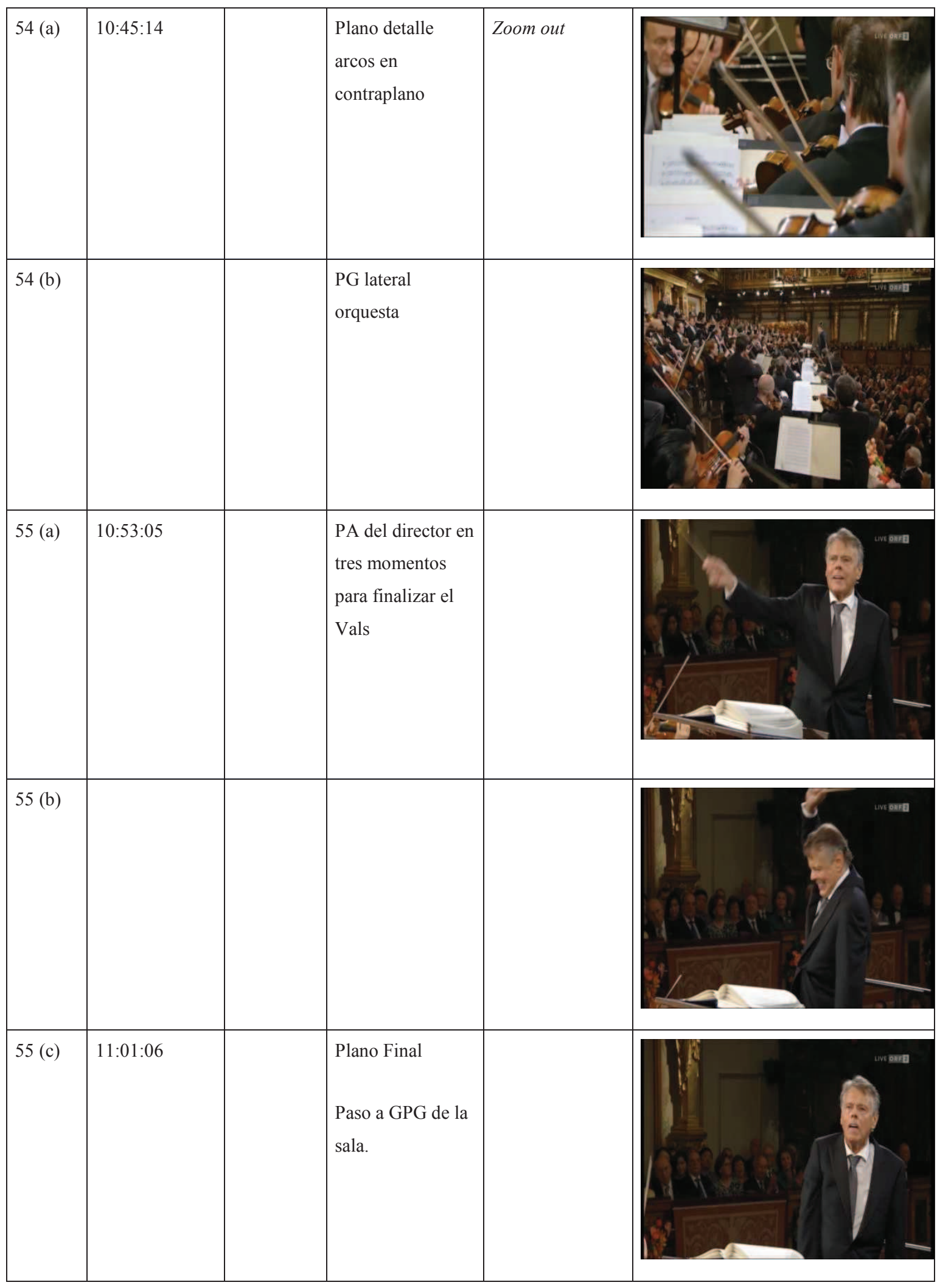


d.3) Comentarios sobre la realización

En primer lugar, quiero destacar, después de analizar las imágenes el equilibrio entre la duración de la realización en el interior de la sala y la realización de las imágenes exteriores. Mitad de la retransmisión se dedica a la orquesta (cinco minutos) y los otros cinco minutos restantes se dedican a la orquesta. Respecto a las imágenes del valle del Danubio, se trata de un trabajo muy bien elaborado, tanto por lo que se refiere a la grabación como lo que se refiere a la postproducción. Un aspecto más a valorar y a tener en cuenta es la medida del tempo, el ritmo que siguen las imágenes aéreas, sin precipitación y mostrando todo el valle del Danubio hasta llegar a la ciudad de Viena en el último tramo musical. Realmente, sólo con este inicial análisis, podemos hablar de un realizador "analítico y preciso". A ello, se le suma que se atreve a volver a la sala desde las imágenes exteriores a planos de orquesta, con lo cual, se supone que lleva una medición y un control del tempo absolutamente controlado.

Como ejemplo, el primer paso de imágenes de vídeo grabado a la sala Musikverein. En este primer paso, entra, de manera perfectamente sincronizada, con el percutir de los timbales a través de uno de los pocos encadenados de los que se servirá para la realización. Este paso representa un estudio minucioso de la partitura que no dejará ya hasta el final. Así mismo, representa un gran control en todos los aspectos: comunicativo, preparativo, técnico y artístico.

Antes de dar paso a la orquesta en sala, el giro de las imágenes aéreas del valle del Danubio parece anunciar el título: Tempo di valse. Lo que Karina Fibich realiza sobre la música en el plano giratorio de la skycam, Michael Beyer nos lo anticipa. A partir de aquí, las imágenes de orquesta están asombrosamente planificadas según la partitura y entran en plano meticulosamente en su momento. La primera secuencia seguida de planos estáticos de orquesta: timbales, violines, triángulo, contrabajos y director, con entre dos y cuatro minutos de duración de planos, no puede realizarse sin su planificación y sus ensayos previos. En el momento siguiente, empieza una lenta panorámica lateral de la orquesta con giro incluido. Ahora sí, música e imagen parecen andar de la mano ya totalmente.

Beyer no ha planificado muchos planos en movimiento, únicamente hace uso de alguna panorámica y algún zoom. Así que es de destacar la gran planificación de planos 
instrumentales estáticos. Y, esto, precisamente es lo que da dinamismo a la pieza realizada. Otro elemento importante y es imprescindible destacar, es la puntuación que va siguiendo. Sólo existen dos encadenados para pasar a imágenes del valle del Danubio. El resto de la edición es toda por corte. También este dato aporta dinamismo a la realización y la "acelera" más que la "ralentiza". Parece que Michael Beyer tiene clara confianza en su directo.

d.4) Elementos finales y estudio comparativo

Ya he nombrado algunas de las características de esta realización. Propondré alguna más en este apartado:

- Gran variedad de tamaño de planos: planos detalle, primeros planos, planos de conjunto, planos por secciones (madera, cuerda), planos figura, planos generales y grandes planos generales.

- Planos con punto de vista más natural y no tan extremos: los violoncelos, por ejemplo, están a la altura de nuestros ojos. No se dan contrapicados extremos. Aunque sí aparecen vuelos cenitales.

- Planos de instrumentos en fuga, muy valorados estéticamente: planos de contrabajo, violines con los arcos, sección de madera, violines con director, entre otros.

- Mismos instrumentos desde distintos ángulos de vista: flautas, trompas, violoncelos. Estos distintos ángulos de vista enriquecen la realización.

- $\quad$ Edición por corte casi en su totalidad.

- Poco movimiento de los planos, casi siempre son estáticos. Solo 11 planos, de los 50 realizan algún tipo de movimiento. Michael Beyer se queda con el movimiento gestual de los músicos.

- Uso puntual del transfoco: cambio de foco desde el centro de flores al director

- $\quad$ El tempo está llevado de manera magistral.

- $\quad$ El plano del director es estático, pero como respira durante tiempo, muestra perfectamente la rica y comunicativa gestualidad de Maris Jansons. Un claro ejemplo es el final de la obra. Sólo muestra el director y no pasa al gran plano general hasta el silencio orquestal y los aplausos. Respecto a este final, quiero resaltar el contraste con el final de Herbert Von Karajan quien, veinte minutos antes del final ya deja la orquesta que acabe sola, sin su dirección. 
Michael Beyer creo que realmente es un realizador analítico. Esta realización cuidada y sobria, con pocos elementos que desarrollen una estética demasiado romántica, constituye una diferente concepción de la realización.

En la sigiuiente tabla, presento una comparación de los cuatro tipos de realización ante una obra que se repite año tras año. En ella quedan analizados los distintos elementos que he ido comentando a lo largo del presente capítulo.

Tabla 2. Tabla comparativa de los aspectos de realización en cuatro versiones del Danubio Azul.

\begin{tabular}{|c|c|c|c|c|}
\hline $\begin{array}{l}\text { DANUBIO AZUL } \\
\text { Johann Strauss }\end{array}$ & $\begin{array}{c}\text { Herbert von } \\
\text { Karajan (1987) } \\
\text { Humprey Burton }\end{array}$ & $\begin{array}{c}\text { Franz Welser- } \\
\text { Möst (2011) } \\
\text { Brian Large }\end{array}$ & $\begin{array}{l}\text { Franz Welser- } \\
\text { Möst (2013) } \\
\text { Karina Fibich }\end{array}$ & $\begin{array}{c}\text { Maris Jansons (2016) } \\
\text { Michael Beyer }\end{array}$ \\
\hline Duración & $10 ' 30 "$ & 10 ' & $10 ' 30 "$ & 11 ' \\
\hline Imágenes extra & Ballet & Ballet (en directo) & $\begin{array}{c}\text { Postales de } \\
\text { invierno }\end{array}$ & Valle del Danubio \\
\hline $\begin{array}{l}\text { Número de } \\
\text { cámaras }\end{array}$ & $8(?)$ & \begin{tabular}{|c}
14 en la sala \\
3 en el hall-ballet
\end{tabular} & $\begin{array}{l}15 \text { en la sala } \\
1 \text { en el bakstage } \\
2 \text { en el exterior }\end{array}$ & 15 en la sala \\
\hline Planos Inicio & $\begin{array}{l}\text { - Largo plano } \\
\text { director (30”)/ } \\
\text { - Plano detalle } \\
\text { trompa }\end{array}$ & $\begin{array}{l}\text {-PA Director (8”) } \\
\text {-Zoom out: Plano } \\
\text { Detalle Trompa a } \\
\text { GPG Orquesta }\end{array}$ & \begin{tabular}{|l}
-PA Director \\
-Imágenes \\
pregrabadas
\end{tabular} & $\begin{array}{l}\text {-GPG } \\
\text {-Plano detalle violín } \\
\text {-Imágenes } \\
\text { pregrabadas }\end{array}$ \\
\hline Planos Final & $\begin{array}{l}\text {-Ballet } \\
\text {-F/Orquesta }\end{array}$ & $\begin{array}{l}\text {-PF Bailarina } \\
\text {-PG Orquesta }\end{array}$ & $\begin{array}{l}\text {-PG: zoom in a } \\
\text { director } \\
\text {-PG Orquesta }\end{array}$ & -Director \\
\hline
\end{tabular}


De la partitura a la pantalla: plano y contraplano de una misma realidad - 244

\begin{tabular}{|c|c|c|c|c|}
\hline Valor planos & $\begin{array}{l}\text { Gran variedad: } \\
\text { Planos detalle } \\
\text { Primeros plano } \\
\text { Planos de } \\
\text { conjunto } \\
\text { Planos generales }\end{array}$ & $\begin{array}{l}\text { Gran variedad: } \\
\text { Planos detalle } \\
\text { Primeros plano } \\
\text { Planos de } \\
\text { conjunto } \\
\text { Planos generales }\end{array}$ & $\begin{array}{l}\text { Más variedad de } \\
\text { instrumentos: } \\
\text { Planos detalle } \\
\text { Primeros plano } \\
\text { Planos de } \\
\text { conjunto } \\
\text { Planos generales }\end{array}$ & $\begin{array}{l}\text { Primeros planos de } \\
\text { instrumentos: } \\
\text { aparecen el arpa, el } \\
\text { triángulo y las } \\
\text { trompetas }\end{array}$ \\
\hline Angulación & $\begin{array}{l}\text { Punto de vista a la } \\
\text { altura de los ojos. }\end{array}$ & $\begin{array}{l}\text { Gran uso de } \\
\text { contrapicados y } \\
\text { cenitales }\end{array}$ & $\begin{array}{l}\text { Contrapicados y } \\
\text { cenitales en } \\
\text { extremo }\end{array}$ & $\begin{array}{l}\text { Punto de vista a la } \\
\text { altura de los ojos. Sólo } \\
\text { algún cenital. }\end{array}$ \\
\hline $\begin{array}{l}\text { Movimiento } \\
\text { interior del } \\
\text { plano }\end{array}$ & $\begin{array}{l}\text { Continuo } \\
\text { movimiento }\end{array}$ & $\begin{array}{l}\text { Continuo } \\
\text { movimiento } \\
\text { Planos cortos } \\
\text { estáticos }\end{array}$ & $\begin{array}{l}\text { Continuo } \\
\text { movimiento } \\
\text { Planos cortos } \\
\text { estáticos }\end{array}$ & $\begin{array}{l}\text { Predominan los planos } \\
\text { estáticos. }\end{array}$ \\
\hline Editaje & $\begin{array}{l}\text { Largos } \\
\text { encadenados y } \\
\text { desenfocados }\end{array}$ & Encadenados & $\begin{array}{l}\text { Combinación de } \\
\text { encadenados y } \\
\text { corte }\end{array}$ & $\begin{array}{l}\text { Todo por corte (sólo } \\
\text { dos encadenados) }\end{array}$ \\
\hline Ritmo & Muy pausado & Pausado & Pausado & $\begin{array}{l}\text { Pausado con algún } \\
\text { momento de ritmo ágil } \\
\text { entre instrumentos }\end{array}$ \\
\hline
\end{tabular}

Nota. Tabla comparativa de los aspectos de realización en cuatro versiones del Danubio Azul, de M. Millà, 2017.

\section{5- Coda}

Con unos medios técnicos muy avanzados, puedo afirmar que las cuestiones técnicas conducen a cuestiones metodológicas y, en el caso del concierto de Año Nuevo, está claro que estas cuestiones metodológicas han evolucionado junto con las técnicas gracias a realizadores del nivel de los cuatro directores presentados en esta investigación, 
puesto que se pueden tener todos los medios y avances técnicos al alcance pero no emplearlos en metodología. Cuando en este estudio hablo del ámbito metodológico no me refiero al positivismo, al interpretativismo o a otras muy diversas teorías; sino que me refiero al ámbito de la escritura con la luz, de la escritura con el color, de la escritura con el ritmo, el tempo y a tantas escrituras que hacen que la partitura llegue a la pantalla y la percepción del espectador se convierta en una experiencia estética y viva. Se trata de una visión holística de todo el proceso creativo que parte de la escritura musical.

$\mathrm{Y}$ es esta percepción del receptor la que da la medida para valorar y ponderar cualquier elemento audiovisual y evaluar con criterios de calidad toda construcción visual de aquello que permanece latente en la partitura.

Si se lleva la metodología al extremo a partir de la tecnología, nos encontramos con casos quizás exagerados de realización audiovisual-musical como el de los conciertos dirigidos por André Rieu. Este director y, también, violinista ha querido popularizar la música clásica y, de hecho, es capaz de llenar grandes estadios. André Rieu toca con un violín fabricado por el mismo Stradivarius en el año 1667. Neerlandés de nacimiento, creó la Orquesta Johann Strauss, a la cual pertenecen actualmente unos 150 músicos. ¿Cuál ha sido su revolución metodológica? Pues incluir elementos dentro de sus conciertos que rompen cualquier esquema que un espectador tenga de la música clásica:

\section{Ejemplo 14: $\underline{\text { https: } / / \text { www.youtube.com/watch?v }=I D a J 7 r F g 66 A^{63}}$}

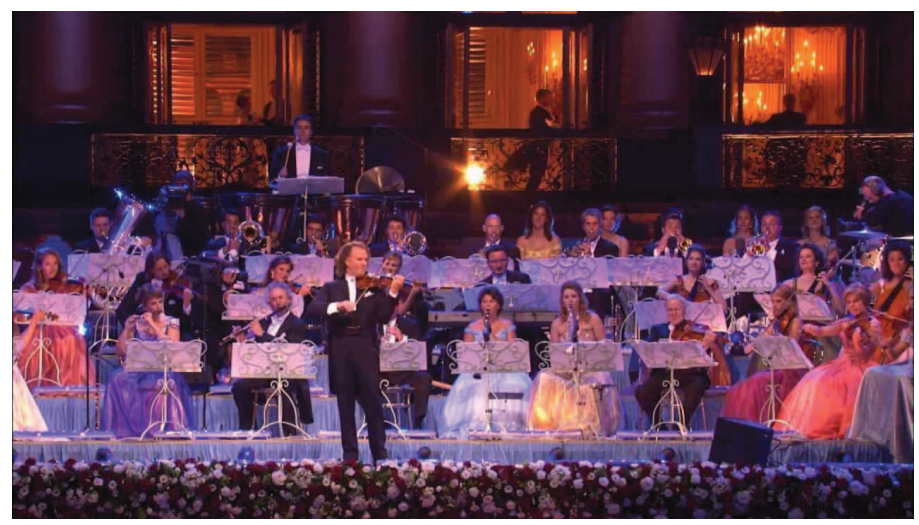

Figura 80 Fotograma extraído del DVD André Rieu At Schönbrunn, Vienna.

${ }^{63}$ Clip del DVD "André Rieu At Schönbrunn, Vienna" 
- Ha sido capaz de construir un decorado, copia idéntica, que reproduce el castillo de Schonbrun y llevarlo en sus giras.

- $\quad$ Él mismo toca su violín mientras dirige la orquesta y está permanentemente en comunicación con su público. La polivalencia del director musical durante la ejecución hasta convertirse en showman o elemento dinamizador del concierto

- Vestuario de época para los músicos

- Pantallas situadas a ambos lados del escenario en las que se ve la mayor parte del tiempo a André Rieu en primer plano dirigiendo

- Bailarines de la Austrian Elmayer Dancing School situados dentro del palacio

- Logra la integración entre el concierto y el público ya que éste baila el vals unido a los bailarines profesionales

En el enlace anterior podemos ver todos estos elementos que convierten los conciertos de André Rieu en conciertos populares, muy lejos de la elegancia y el elitismo al que parece entregarse el Concierto de Año Nuevo. En él, el público permanece sentado $\mathrm{y}$, aunque también se da interacción entre dicho público, la orquesta y el director, se aprecia un tipo de "popularidad" muy distinta. Sería realmente extraño ver André Rieu como director musical del Concierto de Año Nuevo y, está claro, que su público no aceptaría ver a los músicos “disfrazados” en escena. Aunque no podemos dejar de lado la teatralización a la que se ha llegado en la retransmisión del concierto que conlleva una "extranarrativa audiovisual" que emociona cada año a millones de espectadores. Este año nos hemos quedado sin el conocido José Luis Pérez de Arteaga, quizás más conocido por su voz en las retransmisiones anuales del concierto de Año Nuevo que por su calidad como musicólogo. Y, precisamente, su voz grave y su narración llena de curiosidades, datos y efemérides donaban a la retransmisión del concierto aquel punto de "teatralización y emotividad" que imprimía su sello personal inconfundible.

Existe la posibilidad de pensar que el trabajo del director artístico depende del director musical escogido cada año. Yo prefiero afirmar que dicha dependencia no existe, sin embargo sí existe la adaptación a un concierto que ya es una marca en sí misma y que conlleva ciertos rasgos connotativos que no hay que dejar de lado. El equilibrio entre esta realización connotativa y su mensaje musical denotativo que surge de cada frase de la partitura es lo que hace que no sucumba en el hecho social 
extremadamente popular al que, Rieu, por ejemplo ha convertido cada uno de sus conciertos.

Robert Gummlich, realizador del Digital Concert Hall, empresa audiovisual dedicada a la retransmisión o filmación de los conciertos en la Philharmonie Berlin, resume bien su trabajo como "narrador" ante una filmación o retransmisión:

There is a general thought: For me it is absolutely Director's work to choose the instruments, the angles and the shots. It is most important not only to have the right instrument. I also try to think if the music calls for a detail / close-up of an instrument or wide shots, pans or even a crane-movement. I try to hear this in the music when I do the preparations. And if you improvise you can not think about these categories anyway but you have to take what you can get because you do not have the time to concentrate on the music and change camerapictures. So for me as a director I think I loose a great part of my creative tools if I only improvise.

And this is the last thought: Preparations. You told me that you never use scripts in any productions situation. The result is that all of you together have to give the camera crew a lot of information in the right moment. And because in every mobile all over the world there are communication problems and the music is sometimes very loud and sometimes three persons talk at the same time, this creates a situation where misunderstandings and faults a to be expected. So I would think of doing a little paperwork (perhaps not a whole plan, but a small list for every cameraperson for every piece so she / he can concentrate on the tasks and prepare) ${ }^{64}$.

Es decir, en primer lugar,

- $\quad$ es el director-realizador quien decide qué instrumentos, los ángulos desde donde se realiza el plano y qué tipo de plano.

- No sólo se trata de "fotografiar" el instrumento correcto, sino de pensar qué es lo que la música requiere. Es el "sentido cinematográfico" del cual habla José Nieto: plano detalle, plano con movimiento en zoom in, plano general, panorámicas o movimiento de grua.

- "Escuchar" estos elementos en la música durante la preparación.

${ }^{64}$ Gummlich, R. (comunicación personal, 1 julio 2013). Ver Apéndice II - Entrevistas 
- No se trata de improvisar a cada momento porque uno no puede concentrarse en lo que la música requiere y preparar el plano al mismo tiempo.

- $\quad$ Si se deja todo a la improvisación, se pierde gran parte de la creatividad

- Preparación de scripts (lista de planos) para los cámaras para evitar dar excesivas órdenes desde la unidad móvil, evitar tener problemas de comunicación con los cámaras, evitar ambientes de nervios y de varias personas dando órdenes, o contraórdenes, al mismo tiempo.

Antes de pasar al capítulo dedicado al estudio empírico, quiero considerar un resumen de lo que Xavier Garasa, realizador entrevistado para este trabajo de investigación, me ha aportado como elementos clave desde la táctica y la estrategia a partir de lo que yo llamo, lectio score:

- Cada producción es distinta y, por tanto, antes de hacer una táctica o una estrategia hay que documentarse. Esto es aplicable a cualquier producción.

- Pensar que cada producción o evento tiene una disposición diferente.

- Para documentarse y para retratar bien un concierto o para grabar bien un concierto hay que ver:

a. qué elementos tiene la producción que se va a filmar que la hace diferente a los demás (partido de fútbol, concierto...) .

b. qué lectura quiero hacer yo de esta producción.

c. qué táctica voy a hacer yo luego para explicar esta producción.

d. con la táctica que yo haga, que se entienda de la manera que yo quería que se representase.

e. si tienes los conocimientos suficientes, mirar las partituras, los instrumentos o el rider que hay.

f. pensar detenidamente, en función de los medios que tienes, qué cámaras o cómo las vas a utilizar.

g. pensar qué sitios vas a priorizar en el escenario.

- $\quad$ El realizador puede alterar el ritmo audiovisual.

- $\quad$ Es mucho más interesante que cada plano tenga movimiento interno.

- Dar los contrapuntos en todo.

- Adaptación de la realización al lenguaje audiovisual que quieras dar. 
- La renuncia a algún plano concreto no es, a veces nada preparado, sino porque otra cámara te está mirando y piensas en ese momento que te va a funcionar mejor.

- Son fundamentales la experiencia y la intuición que te aporta dicha experiencia

- Para la imagen, cuantas más cámaras y puntos de vista, mejor. Para el sonido, mejor un buen micrófono y bien situado que muchos y mal situados.

- No hay nada indispensable, todo es necesario.

- En cada momento se puede dar algo clave, pero...no hay nada que sea clave absolutamente.

Me quedo con dos observaciones que entroncan con lo visto hasta aquí: documentarse y prepararse cada producción por lo que de distinto y único pueda ofrecer y, la importante observación que es la cámara la que te está mirando. Y es que no podemos olvidar que el ojo de la cámara es el ojo del espectador y, ahí, está el secreto de una buena comunicación. Es por ello que he querido dedicar el último capítulo a un estudio empírico a partir de muy distintas miradas. 
De la partitura a la pantalla: plano y contraplano de una misma realidad-250 
PARTE III: ESTUDIO EMPÍRICO: MÚSICA Y AUDIOVISUAL 
De la partitura a la pantalla: plano y contraplano de una misma realidad- 252 
Capítulo 4: Percepción del plano y contraplano a través de fragmentos de conciertos filmados 
De la partitura a la pantalla: plano y contraplano de una misma realidad - 254 


\section{1- Enfoque, objetivos y diseño metodológico}

Cualquier investigación se enfrenta a realidades complejas y no estáticas. En el tema de mi investigación, me enfrento a una realidad cuya complejidad y evolución van a velocidades vertiginosas y conducen a un análisis desde diferentes perspectivas a tener en cuenta. Se trata de una investigación dentro de un campo cuyas manifestaciones artísticas no sólo tienen su origen en áreas disciplinarias tradicionales dedicadas a la percepción o a la historia del arte, sino que se trata de un análisis dentro de los nuevos estilos visuales, como son el cine, la televisión o el videoarte. Estamos ante estilos nacidos y desarrollados durante el siglo XX que, actualmente, progresan exponencialmente en su evolución tecnológica, en el desarrollo de su lenguaje narrativo y en el auge de diferentes géneros adaptados a lo que los signos de los tiempos actuales nos conducen diariamente. Es por ello que he querido indagar e invertir tiempo en cómo los espectadores reciben actualmente uno de los géneros audiovisuales que les permiten acercarse a la música clásica: la filmación y la traducción de la partitura a la pantalla, sea a través de conciertos en directo o de filmaciones en diferido, con el uso de medios tecnológicos cada vez más avanzados que permiten una estética visual imposible de percibir desde la localidad de una sala de conciertos.

El objetivo principal de la investigación artística que propongo no queda encerrado en el conocimiento que las obras generan en cada una de las personas que han colaborado en este estudio, sino que queda abierto a cada una de sus reflexiones críticas, muchas e interesantes. Creo, sinceramente, que dichas reflexiones han superado las expectativas en cuanto a la evaluación de los procesos creativos y las prácticas audiovisuales llevadas a cabo ${ }^{65}$.

Tal y como apunta Rubén López-Cano en su manual sobre Investigación artística en música (p. 43-44), se dan dos tipos de investigación: la documental y la cuantitativa. Este capítulo es fruto de un estudio analítico a través de métodos, como veremos, no sólo cuantitativos. Otro de mis objetivos era investigar qué distancia existe entre lo que un artista audiovisual quiere transmitir y lo que recibe, finalmente, el espectador; es por ello que quise abordar la percepción que los espectadores tenían -se tratara de personas con conocimientos musicales o profanos en la materia- de los conciertos de música a través de las pantallas. De hecho, gracias a los cuestionarios enviados, obtuve valoraciones y reacciones que han ayudado de modo transparente a encontrar respuestas a mis objetivos.

\footnotetext{
${ }^{65}$ El cuestionario junto con todas las respuestas se puede consultar en el Apéndice III.
} 
Como tercer objetivo a partir de este método empírico, planteo lo que sería "un objetivo fuera de los objetivos"; se trata de generar, en las personas que han recibido este cuestionario, nuevos planteamientos y retos respecto a este mundo auditivo-musical; nuevos apuntes hacia una manera de entender la música desde el planteamiento del realizador. De hecho, cada partitura llevada a la pantalla es un producto socio-cultural creado, no sólo desde unas convenciones artísticas dentro del mundo audiovisual -ya presentadas en el primer capítulo y analizadas en los dos siguientes- sino, desde múltiples lenguajes creativos quizás no interpretados por la gran mayoría de las personas debido a que su sentido y significado proviene de fuentes alejadas de la tradición disciplinaria audiovisual. El conocimiento para llegar a su comprensión o percepción proviene de cuatro fuentes: trasfondo sociocultural del espectador, trasfondo sociocultural del realizador, usos artísticos para el desarrollo de cada estética visual y usos tecnológicos. La combinación de las cuatro fuentes da como resultado mensajes interpretativos afines a cada persona.

Así, esta cualidad interpretativa personal e intransferible la he recogido a través de un diseño metodológico que parte de lo que, comúnmente, llamamos encuesta pero que quise convertir en múltiples pequeñas entrevistas para ver cómo cada pieza muestra, interpreta o comunica mensajes singulares en cada persona. Ahí está la dificultad del paso de la partitura a la pantalla por parte del realizador, que dos lenguajes universales como son la música y la narrativa audiovisual se interrelacionen, a través de una táctica y una estrategia, para llevar un mensaje particular y único. Este mensaje será didáctico, evocativo, emocional...según la combinación de dichos factores que subyacen durante el proceso creativo e interpretativo.

Así, he preferido partir, no sólo de métodos cuantitativos que me permitan cuantificar de alguna manera los resultados obtenidos; sino, también de métodos cualitativos que me permitan una mayor comprensión de cada significado a partir de la experiencia y de la historia personal de cada uno, sabiendo que entro también, y como no podía ser de otra manera, en un mundo subjetivo ya que cada persona interpreta cada plano o secuencia desde sus conocimientos o experiencias.

Mi diseño metodológico parte, en primer lugar, de dos cuestionarios personales o encuestas que integran lo que sería el método cuantitativo de mi investigación:

- Un primer cuestionario personal cuyo contenido incluye el sexo, la edad, los estudios civiles, la profesión y los estudios musicales, en caso de tenerlos. 
- Un segundo cuestionario personal que incluye preguntas referentes a los hábitos o costumbres en cuanto a la asistencia a conciertos y la visión o no de los mismos a través de pantallas: internet, televisión, blue-ray o DVD y cine.

Los cuestionarios que siguen a continuación se enmarcan dentro de lo que sería la metodología cualitativa. Se trata de cuatro cuestionarios dedicados a cada uno de los ejemplos escogidos. Si en las dos anteriores encuestas las preguntas eran cerradas, en este cuestionario decidí que las preguntas fueran abiertas. No quería inducir las respuestas y llevar las personas al terreno que, de algún modo, manipulara los posibles resultados. El hecho de convertir estas encuestas en pequeñas entrevistas ha supuesto un enriquecimiento en mi investigación y le ha dado un gran valor perceptivo. Digo esto porque creo que es importante afirmar que la riqueza de estas entrevistas a través de una encuesta, con preguntas abiertas, al final, han supuesto una riqueza mucho mayor en cuanto a la calidad de la comprensión audiovisual que si hubiese dado más importancia a preguntas cerradas y quizás, inducidas, aunque fuera mayor su número.

Como último cuestionario, dedico tres preguntas a lo que correspondería una encuesta evaluativa con una última pregunta abierta a posibles cuestiones o constataciones por parte de los entrevistados.

Soy consciente de la heterogeneidad de las personas a quienes he realizado los cuestionarios. Se trata de encuestas en diferido, de manera que cada persona la ha podido realizar cuándo ha podido. Es por ello que, de las ciento cincuenta personas a quien me he dirigido, he recibido cien respuestas. El feedback recibido y las impresiones de algunas de ellas han sido muy positivas ya que soy consciente que se trata de una encuesta, quizás, fuera de lo común. Avisaba de ello en el mensaje enviado, así que tanto las personas que han contestado como sus respuestas son de un gran valor significativo $\mathrm{y}$, ahí, puede realizarse ya una primera lectura. Esta primera lectura parte del hecho de que, a pesar de tratarse de un lanzamiento de cuestionarios o encuestas a partir de una plataforma digital, motivo por el cual a muchas personas no conocía, sí puedo decir que soy consciente e identifico qué colectivos han recibido mi cuestionario. Es por ello que quiero advertir de antemano que han contestado muy pocas personas menores de veinte años, así como de veintiuno a treinta cinco años; sin embargo, las personas situadas en la franja comprendida entre los treinta y seis y los cincuenta y cinco años es de la que más respuestas he recibido. Puedo arriesgarme y 
deducir las causas de las pocas respuestas recibidas por parte de los más jóvenes: por un lado, los menores de veiente años, por la falta de conocimientos o lectura audiovisual; la siguiente franja, a pesar de tratarse de personas ya inculturadas audiovisualmente, por su falta de tiempo, y quizá de compromiso con este tema tan específico de investigación.

Antes de pasar a los resultados, quiero constatar que la elección de las personas ha sido totalmente aleatoria. He querido que el abanico de edades, condición social, sexo, estudios y profesión fuera amplio para que saliera un estudio lo más abierto posible y que me sirviera como modelo para llegar a un sector amplio de la población. Es por este motivo, que no he querido encuestar, mayoritariamente, a profesionales de los medios de comunicación ${ }^{66} \mathrm{o}$ músicos que no sean docentes que me pudieran conducir hacia resultados tan profesionalizados que no me ayudaran en el análisis de la percepción "audiovisual-musical".

Otro punto importante es que los vídeos que iban adjuntados a la encuesta los tuve que recortar en cuanto a su duración debido a las pruebas que hice previamente con algunas personas. Ellas fueron quienes me recomendaron mandar piezas breves para que no se les hiciera tan denso y largo el procedimiento. Creo que fue una decisión acertada puesto que, seguramente, el número de respuestas hubiera sido menor.

También es interesante destacar la confusión que existe en cuanto a la terminología "música clásica". Ciertas personas han confundido entre lo que es estrictamente "música clásica", entendido como concierto, única y exclusivamente, con orquesta y lo que es una ópera o, incluso, un ballet, como El Lago de los cisnes. Aún así, dicha confusión, no ha impedido recoger respuestas muy interesantes y válidas como recogida de datos a tener en cuenta. Pero, quiero constatar la falta de formación-o información- en este aspecto. Es por ello que, referente a mi investigación, quiero dejar claro el objeto y las características de los distintos discursos narrativos dentro de los distintos formatos musicales, tal como explico en el primer capítulo. De esta manera, convierto en centro de investigación el concierto de música clásica.

En los siguientes apartados, analizo los resultados obtenidos no solamente de manera lineal sino con un análisis cruzado a partir de las características personales y sociales de cada una de las personas que han respondido. Así, he podido analizar:

\footnotetext{
${ }^{66}$ A este sector profesional le dedico una investigación más a fondo a través de entrevistas, así como a músicos o compositores.
} 
- Cómo interpretan el efecto audiovisual del desenfocado desde las diferentes edades o profesión/estudios

- Lectura del plano general

- Coherencia entre imágenes y música de los cuatro vídeos según la formación profesional o el hábito de consumo musical a través de pantallas

- Coherencia entre imágenes y música de los cuatro vídeos según la edad

- Poca participación en las respuestas según el desconocimiento o conocimiento de la obra

- Relación entre innovación y metodologías “caducas” o convencionales

A modo conclusivo, quiero dejar constancia que mi objetivo metodológico no es un estudio estadístico sino un conjunto significativo de entrevistas/encuestas realizadas a más de cien personas para obtener unas conclusiones más amplias y no inducidas a partir de estudios audiovisuales disciplinares.

Antes de pasar al estudio y/o análisis de los resultados obtenidos, también quiero realizar un breve análisis músico-histórico de cada uno de los ejemplos.

Las cuatro obras escogidas para la encuesta son:

$\square \quad$ Adagio para cuerdas, de Samuel Barber (1938)- Dirigida por Pablo González y filmada en “L’Auditori” de Barcelona. Director de la realización: Medici.

Ejemplo 15: https://youtu.be/DKsY-0NS8Ew

$\square \quad$ El vuelo del moscardón de Rimsky-Korsakov (1899-1900)- Dirigida por Xavier Puig y filmada en “L'Auditori” de Barcelona, 2014. Director de la realización: Xavier Garasa.

Ejemplo 16: https://youtu.be/WTHT8aR1MKI

$\square \quad$ Bagatela de Ligeti, Allegro con spirito- (1953)- Interpretada por el "Wind Quinte Carl Nielsen" y filmada en la Mogens Dahl Koncertsal (Sala de conciertos de música clásica) de Copenhaque, Dinamarca, (2014). Director de la realización: Carion.

Ejemplo 17: https://youtu.be/2aSqc0CSZFA 
$\square \quad$ Vals El Danubio azul, op. 314, de Johann Strauss (1866)- Dirigido por Franz Welser Möst y retransmitida en directo el 1 de enero de 2011 por la ORF.

Ejemplo 18: https://youtu.be/e6UndYrcDAk

Como primer dato a tener en cuenta, estas obras alcanzan un siglo entre las cuatro. No fueron escogidas específicamente por su momento histórico, sino por sus formas compositivas tan alejadas entre sí y por ser filmadas a partir de procesos muy distintos.

En primer lugar, la gran diferencia entre ellas está entre la realización de El Danubio Azul y la de las tres restantes. La primera, música retransmitida en directo para todo el mundo, es ampliamente conocida y, podríamos afirmar, mundialmente famosa gracias a la retransmisión de la cadena televisiva austríaca ORF.

Como he demostrado en los dos anteriores capítulos, existe una gran diferencia entre un planteamiento de una obra musical en directo, con la responsabilidad de ser vista y oída por un elevado número de telespectadores de todo el mundo, y un planteamiento de una filmación apoyada por una postproducción antes de ser emitida por una cadena televisiva o elaborada para dar lugar a un DVD/Blue-Ray.

Otra diferencia entre el conocido Vals de Johann Strauss y las tres obras restantes es la duplicidad de espacios y la inclusión de una segunda arte escénica: el ballet.

Entre las tres restantes filmaciones, también existen diferencias y por ello han sido objeto de mi elección:

- El espacio- Una sala de conciertos específica para música clásica y de dimensiones reducidas, una sala de conciertos con público y una sala de conciertos vacía.

- El tempo musical.

- La formación musical: quinteto de viento, orquesta de cuerda y orquesta completa.

- Concepto audiovisual muy distinto: "videoclip"67 o filmación clásica de un concierto.

- Música prejuzgada como muy conocida y popular frente a música de un compositor menos conocido como Ligeti y con un lenguaje innovador.

\footnotetext{
${ }^{67}$ Pongo entrecomillado el concepto de videoclip puesto que recibe un tratamiento de videoclip sin serlo ni ofrecer todas las características de esta forma audiovisual.
} 
Todos estos componentes, sumados, hicieron que fueran mi definitiva elección para elaborar la encuesta. A continuación, presento una breve propuesta de análisis musical para cada una de ellas y, de esta manera, ver qué distintos lenguajes musicales pueden ser llevados a la pantalla, a un lenguaje universal como ya lo es el "lenguaje audiovisual".

\section{Adagio para cuerdas, de Samuel Barber (1938) ${ }^{68}$}

Samuel Barber, compositor americano, compuso el Cuarteto para cuerdas n.1, op. 11 en 1936. El día que terminó su segundo movimiento, el movimiento lento, supo que sería una obra memorable. Y, así fue. El encargado de dirigirla dos años después como una obra independiente, Adagio for strings, fue Arturo Toscanini. A partir de entonces, esta obra se ha convertido en un hit que aparece en varias películas y, sobretodo, se convirtió en la música escogida para la conmemoración en el World Trade Center del atentado del 11 de septiembre del 2001 de las Torres Gemelas de New York.

No voy a realizar un análisis de todo el Cuarteto de cuerdas del compositor, pero sí quiero avanzar que el segundo movimiento está creado a partir de unos elementos formales que pertenecen a polifonías renacentistas y está fundamentado en terceras armónicas mayores y menores. Los movimientos primero y tercero presentan armonías más avanzadas, con atisbos de atonalidad.

Nos encontramos con un segundo movimiento en Si bemol menor que viene de un Si Mayor y se dirige, nuevamente, en el tercer movimiento a esta misma tonalidad. El análisis formal que se encuentra en el primer capítulo de esta investigación nos explica toda la trayectoria melódica: qué instrumentos siguen dicha melodía y qué pasa cuando se alcanza el clímax (compases 50-52) interpretado por el concertino.

Toda la obra supone un ascenso hacia este clímax. Una vez alcanzado este momento, desciende nuevamente hasta el acorde final en Fa Mayor, acorde dominante.

\footnotetext{
${ }^{68}$ Para un análisis formal del Adagio, véase el capítulo 1
} 
Mathew BaileyShea, en su artículo Agency and the Adagio: Mmetic Engagement in Barber's Op.11 Quartet, nos advierte, después de un análisis exhaustivo y excelente de esta obra musical, cómo el segundo movimiento, el Adagio, está creado a partir de formas renacentistas y de una fuga polifónica. Pero, lo importante de esta obra musical, no son los tópicos que la envuelven desde su creación y por los cuales es escogida para acompañar imágenes, sino su narración musical. Y es esta narratividad musical la que hay que poder trasladar a la pantalla.

The Adagio exhibits many topics and tropes that create a mournful atmosphere - the slow moving strings, the ubiquitous sighing motives, and the Renaissance "sacred" polyphony, to name a few-but melodic agency and musical narrative are especially important. The piece hinges, in many ways, on our sense of a persona struggling upward against tremendous resistance. What I hope to have shown with this essay is that the musical embodiment in such passages actually resonates throughout the quartet, coalescing into a larger story. And although the gestures that I focus so much attention on are fairly simple, rooted in straight-forward attempts at leading-tone resolution, they have considerable ramifications (p.36).

Pero, lo significativo de esta obra musical, no son los tópicos que la envuelven desde su creación y por los cuales es escogida para acompañar imágenes, sino su narración musical. Y es esta narratividad musical la que hay que poder trasladar a la pantalla.

\section{El vuelo del moscardón, de Rimsky-Korsakov- (1899-1900)}

De nuevo, nos encontramos con una obra que resulta ser un extracto de otra obra. $E l$ vuelo del moscardón es un interludio que está integrado en la ópera rusa de RimskyKorsakov: El cuento del zar Saltan. El momento en el que se interpreta esta composición está entre el final del tercer acto y el principio del cuarto. Un cisne convierte en moscardón el príncipe Gvidón Saltánovich para que pueda encontrar a su padre, el zar. 
Esta obra cogió entidad propia quizás debido al virtuosismo que se supone debe tener el intérprete ya que su ejecución es muy rápida y cuenta con un gran número de notas encadenadas. Se trata de semicorcheas cromáticas con un tempo frenético. Dicha célula rítmica y melódica va pasando de unos instrumentos a otros de la orquesta y puede visualizarse cómo el vuelo del moscardón va pasando de unos a otros instrumentos: concertino, flauta y clarinete apoyados por los pizzicati de otros instrumentos de la orquesta como son los contrabajos y violas.

\section{Bagatela de Ligeti, Allegro con spirito (1953)}

He escogido Ligeti para mi estudio empírico por tratarse de un compositor cuyo lenguaje es un referente del siglo XX. Con una personalidad propia, Ligeti se presenta como un compositor que quiere alejarse de las formas caducas, como el sistema temperado, y crear nuevos lenguajes desde la búsqueda de nuevos métodos y procedimientos. Sin embargo, no rehúye el estudio del pasado musical para la composición de sus obras. Así pues, nos encontramos con un compositor que busca lo auténtico de manera transversal y con múltiples intereses, pero, siempre, con la mirada puesta hacia lo nuevo, hacia un futuro cuya creación musical deja atrás lenguajes caducos.

La obra que he escogido, esto es, la primera Bagatela encuentra su origen en la Musica Ricercata del mismo compositor (1951-53), en concreto, en el Ricercare número tres. Como vemos, son obras contemporáneas en la vida del autor.

Una de las características de dicha Bagatela es la jocosidad. Se presenta como una forma popular y simple con acentos irregulares. En ella se puede vislumbrar cierta influencia de Béla Bartók ya que el uso del acorde Do, Re sostenido, Mi y Sol es una armonía usada por dicho compositor húngaro. Por otro lado, el contrapunto tiene una presencia notable y lleva a poder describir esta pieza como una obra cuyo diálogo entre instrumentos es claramente visible. En el quinteto que interpreta esta primera Bagatela, podemos apreciar cómo el diálogo se convierte en un elemento "teatral" imprescindible para la filmación. 


\section{Vals Danubio Azul, de Johann Strauss}

Esta obra resultó ser un encargo del compositor y director austríaco Johann Franz von Herbeck a Johann Strauss para la sociedad coral Wiener Männergesangverein. La letra padeció sus confrontaciones entre su creador y los cantantes debido a la situación política. Sin embargo, a pesar de sus vicisitudes, el Vals llegó a estrenarse el trece de febrero de 1867. También la música obtuvo sus críticas, incluso por parte de miembros de la misma familia Strauss. Se interpretó, posteriormente en la Exposición Universal de París bajo la batuta de su compositor, Johann Strauss, donde fue aclamado y, posteriormente, en el Covent Garden de Londres. En nuestros días, es indudable su fama, principalmente, por ser uno de los bises más esperados en el concierto de Año Nuevo.

Formalmente, se trata de un ritmo ternario con un ligero acento en el primer tiempo ${ }^{69}$. las notas agudas interpretan la melodía a través de dinámicas que van desde el pianísimo (el inicio de la trompa, por ejemplo) hasta el forte de toda la orquesta. Las notas más graves mantienen el ritmo durante el Vals. Su estructura simple y su ritmo la convierten en una pieza bailable, es por ello que, en muchos conciertos de Año Nuevo, aparecen bailarines para interpretarla.

Stanley Kubrik usó esta composición en su película 2001, Odisea en el espacio. La sinergia entre esta obra y el "baile de las esferas" es uno de los usos musicales más comentados y analizados dentro de la disciplina audiovisual.

\section{2- Resultados obtenidos: Cuestionarios personales}

Envié la encuesta a través de plataforma digital entre el primer y el segundo año de mi investigación (julio 2016-agosto 2017); el hecho de recibir respuestas simultáneamente a mi investigación me ha ayudado a dar importancia a diferentes tipos inesperados de respuestas. Quiero avanzar una indicación importante respecto a la redacción de las respuestas. Todas las

\footnotetext{
${ }^{69}$ Algunos compositores prefieren especificar que se trata de compases binarios con subdivisión ternaria.
} 
cantidades proporcionadas por los resultados de cada uno de los cuestionarios las presento con números arábigos para su mayor agilidad de lectura y comprensión.

a) Cuestionario personal 1

Se trata de ciento cincuenta personas (75 mujeres y 75 hombres) de distinta edad, condición social, estudios y profesión. De las ciento cincuenta encuestas enviadas, fueron respondidas cien; es por eso que, finalmente, no hay paridad en cuanto al sexo.

\section{1) Sexo y Edad}

Específicamente, las respuestas fueron 64 mujeres y 36 hombres. Es decir, que más de la mitad de las personas que contestaron, fueron mujeres (64\%).
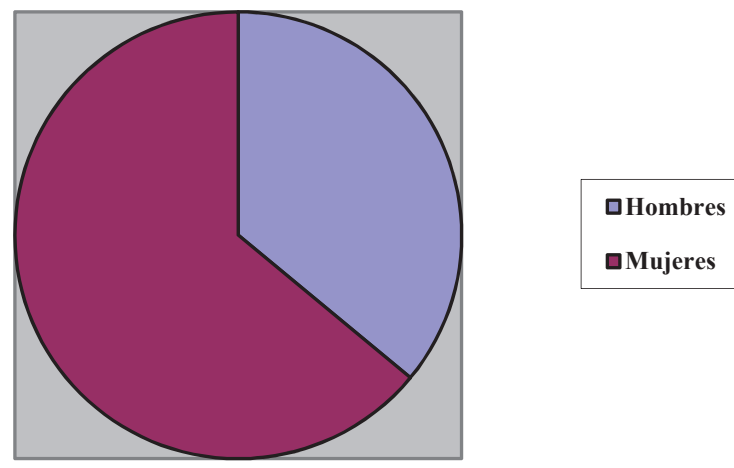

Figura 81 Sexo de las personas que respondieron la encuesta, M. Millà.

Respecto a las edades, de las 64 mujeres, respondieron 4 de menos de 20 años; 12 , con edades comprendidas entre 21 y 35 años; 36, entre 36 y 55 y 12 mujeres de más de 56 años. 


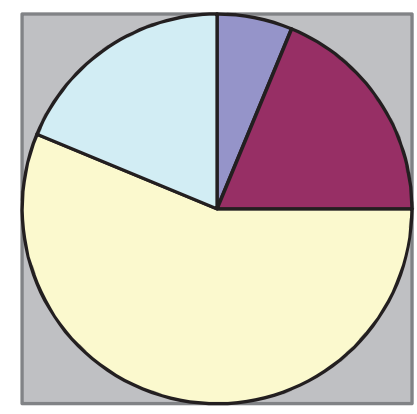

口Menos de 20 años

ロ21-35 años

口36-55 años

口Más de 56 años

Figura 82 Edad de las mujeres que respondieron la encuesta, M. Millà.

En cuanto a los hombres, de los 36 que respondieron, 2 tenían menos de 20 años; 4, entre 21 y 35; 22, entre 36 y 55 y, finalmente, 8 de más de 56 años.

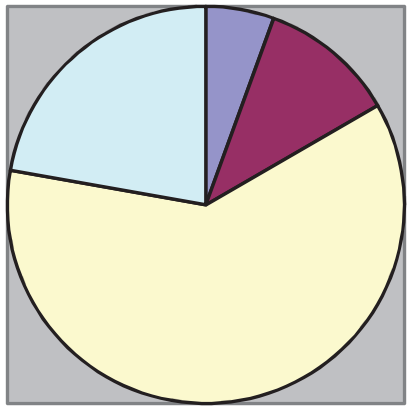

$\square$ Menos de 20 años

口21-35 años

口36-55 años

口Más de 56 años

Figura 83. Edad de los hombres que respondieron la encuesta, M. Millà.

2) Estudios y profesión

Detallo a continuación qué estudios poseen las personas encuestadas:

- Doctorado- 6

- Universitarios- 76

- Formación profesional- 8

- $\quad$ Bachillerato- 7

- EGB- 1 
- Educación Secundaria- $2^{70}$

En cuanto a las profesiones, debido a que son diversas, enumero la lista con el número de personas al lado:

- Docencia- 26 personas

- Administrativo/a- 11

- Publicidad/Márketing/Comunicación- 4

- Funcionarios- 3

- Psicólogo/a - Psicopedagogo/a- 3

- Enfermero/a- 3

- Contable- 4

- Bibliotecario/a- 1

- Periodista- 1

- Camarero/a- 1

- Investigador/a- 2

- Informático/a- 1

- Vigilante de seguridad- 1

- Realizador/a de televisión- 1

- Musicólogo/a- 1

- Médico- 5

- Empresario/a- 2

- Dependiente/a- 1

- Músico-Compositor/a- 1

- Jurista- 1

- Gerencia- 1

- Ingeniero/a- 1

- Ilustración/Diseño- 2

- Abogado/a- 1

- Politólogo/a- 1

- Farmacéutico/a- 1

- Químico/a- 2

\footnotetext{
${ }^{70}$ Cabe destacar que las dos estudiantes de secundaria aún están en realizando los estudios que les corresponden por edad. Sin embargo, Las personas que cuentan con el título de EGB y Bachillerato, están ya dentro del mundo laboral.
} 
- Técnico/a- 1

- Estudiante- 8

- Jubilado/a- 8

- Paro- 1

3) Estudios de Música

Han realizado estudios musicales 37 personas, así que 63 no tienen ningún tipo de estudio musical.
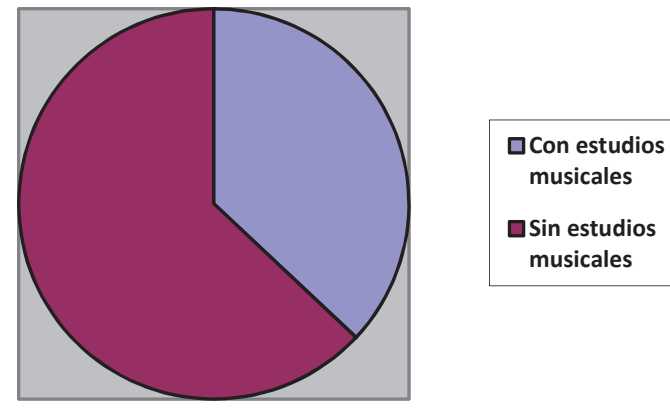

Figura 84 Personas encuestadas con estudios musicales, M. Millà.

De las 37 personas que han realizado estudios de música, 30 tienen estudios superiores, quedan sólo 7 personas con estudios no universitarios.

Referente al sexo, 24 mujeres tienen estudios de música; frente a 13 hombres.

Concerniente a qué tipo de estudios musicales, 5 personas tienen título Superior; 9 personas tienen título Profesional y 10 personas tienen título Elemental.

Las 13 personas restantes dicen tener estudios musicales básicos o de iniciación en Escuelas de Música o Conservatorios en edad escolar, sin poseer ningún título. 

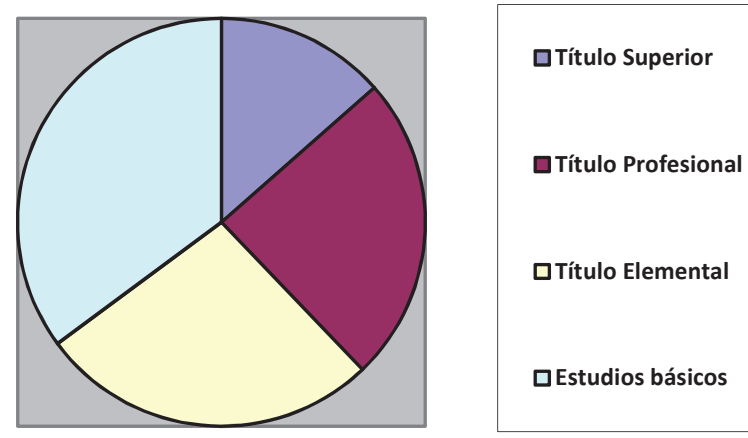

Figura 85 Nivel académico de estudios musicales, M. Millà.

\section{Comentario:}

Como primera observación, quiero destacar la mayor respuesta recibida por parte de mujeres, puesto que había mandado la encuesta a hombres y mujeres por igual. También el grupo de edad es importante, algunas personas mayores de 56 años, no entendieron muy bien qué les pedía con la encuesta y, por ello, no la acabaron y, consecuentemente, no la mandaron; sin embargo, las personas que tienen entre 36 y 55 años, no sólo han manifestado a través de las respuestas su interés, sino que han llegado a ponerse en contacto para manifestar su agradecimiento por acercarles a este mundo.

El hecho de ser personas ya formadas dentro de un mundo audiovisual, es lo que ha ayudado a que la comprensión de lo que se les pedía en la encuesta fuera mayor. Lo mismo ocurre con las personas entre 21 y 35 años. Sin embargo, la respuesta ha sido minoritaria.

Quiero resaltar en este primer cuestionario personal el hecho de que un $81 \%$ de las personas que tienen estudios musicales durante su infancia o juventud, poseen estudios civiles superiores.

Dado que me han respondido más mujeres que hombres, no es significativo que el número de mujeres que han estudiado música sea mayor. 
b) Cuestionario personal 2

El segundo cuestionario personal lo he dedicado a la parcela personal dedicada a la asistencia o no a conciertos, así como el tiempo dedicado a la divulgación de obras fílmicas a través de distintos formatos tecnológicos, tales como Internet, DVD-Blue-Ray, Internet, cine o televisión.

\section{1) Asistencia a conciertos}

79 personas sí asisten a salas de conciertos para ver y escuchar música en directo (sea clásica o no). Por lo que respecta a sus estudios, de las 21 personas que no asisten a conciertos en directo, 15 tienen licenciatura universitaria, 4 tienen estudios de FP, 2 tienen bachillerato y uno es diplomado universitario. Proporcionalmente, con estos datos, vemos que no es indicativo el tener o no estudios universitarios, sino, al contrario, el abanico de público es abierto y plural.

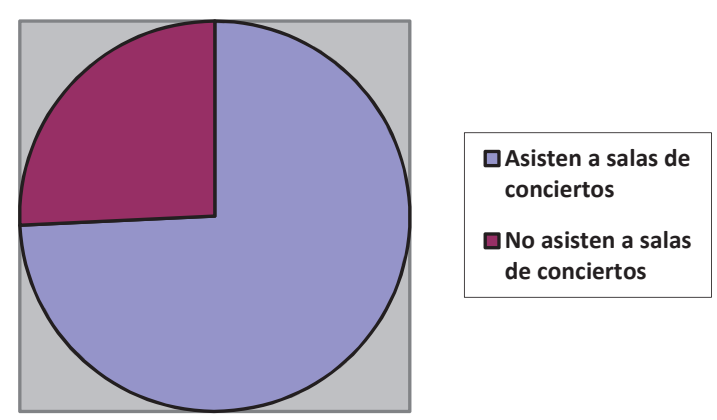

Figura 86 Asistencia a salas de conciertos, M. Millà.

Respecto a la frecuencia en cuanto a dicha asistencia, llama la atención que, únicamente, 4 personas van una vez a la semana y pertenecen a mundos muy distintos (camarera, un docente y dos jubilados). La mayoría, concretamente, 44 personas, van menos de 3 o 4 veces al año y 16 personas dicen ir 1 vez al mes. El resto, concretamente 15 , van entre 3 y 4 veces al año. 

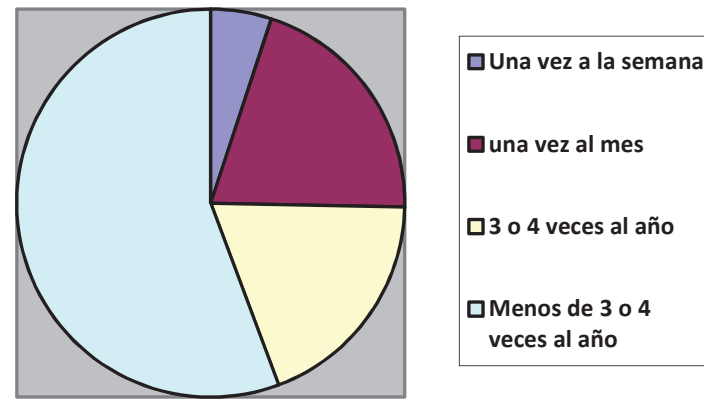

Figura 87 Frecuencia de asistencia a los conciertos, M. Millà.

2) ¿Qué obra de música clásica despierta en ti un interés especial? ¿Por qué motivo?

Transcribo la pregunta al completo porque resulta interesante ver cada una de las respuestas. La segunda cuestión la dejo para después:

- $\quad$ No responden- 8

- Muchas obras- 7

- Ninguna obra- 4

- No tiene conocimientos de música clásica- 1 persona

- Beethoven $^{71}-14$

- Ópera y $\operatorname{arias}^{72}-13$

- Johann Sebastian Bach $^{73}-10$

- Vivaldi (Las estaciones) $)^{74}-9$

- Carmina Burana de Carl Off- 2

- Año Nuevo (Valses de Johann Strauss)- 6

- Tchaikovsky $^{75}-6$

- Rachmaninov- 2

- Ravel- Bolero-

- Concierto de Aranjuez- 3

\footnotetext{
${ }^{71}$ Principalmente, las sinfonías (9a Sinfonía, especialmente), Concierto del Emperador y Cuartetos 117 y 131.

${ }^{72}$ Vemos aquí la confusión de términos. La pregunta iba dirigida a qué obra de música clásica como obra orquestal y no como obra operística. Puccini es el compositor más nombrado.

${ }_{74}^{73}$ Cantatas, Conciertos de Brandenburgo y Pasión según San Mateo

${ }^{74}$ Destacar por parte de una persona sin formación musical que indica: La primavera de Mozart. Pero lo entiendo como error y la incluyo en Vivaldi.

${ }^{75}$ Incluye los ballets El lago de los cisnes y Cascanueces
} 
- Dvorak - Sinfonía del Nuevo Mundo-

- Chopin- 2

- Stravinsky- La consagración de la primavera- 2

- Mahler- 2

- Ludovico Einaudi

- $\quad$ Mozart- 4

- $\quad$ Brahms- 3

- Pachelbel- Canon- 3

- Albinoni- Adagio en sol menor-

- Haëndel- El Mesías

- Elgar- Variaciones Enigma

- Cant dels ocells- anónima

- Música compuesta por mujeres

- Barroco-

- Hasta el siglo XIX

- Obras relacionadas con la guitarra

- Conciertos para violoncelo

- Las obras más populares de la música clásica

Es significativo que el tramo temporal de obras musicales, en su gran mayoría, no pasa del siglo XIX ni es anterior al 1600.

Después de la enumeración de las obras de música clásica consideradas de interés especial para cada uno de los encuestados, paso a comentar la cuestión más importante a tener en cuenta en esta misma pregunta: ¿cuál es el motivo por el cual una obra recibe más acogida en una persona?

Empezamos a entrar ya en la cuestión de la percepción. Desde un primer nivel de comentario y sin profundizar en lo que el resto de la investigación nos puede aportar, aquí tenemos las razones principales: 
- "despierta emociones y amplía horizontes"

- "por su belleza, su capacidad evocativa, emocional"

- "por ser una exaltación de la vida"

- "Me pone la piel de gallina"

- "Me gusta"

- "Me conmueve"

- "por su intensidad"

- "Son preciosas, distintas, profundas, con mucha sensibilidad"

- "Porque tuve la oportunidad de interpretarla con el coro donde cantaba y me transporta a ese momento"

- "Porque son obras que conozco muy bien y me apasionan"

- "Recuerdos personales"

- "es muy emotiva y pasional"

- "motivo relajación"

- "porque me encanta las melodías que compone"

- "Me emocionan"

- "me hace sentir especial"

- “Tiene fuerza, es emotiva, desarrolla la imaginación”

- "Es poderosa y apasionada"

- "Es una obra muy "plástica", sugiere muchas imágenes"

- "Me gusta su sonido musical"

- "sugiere el misterio humano"

- "consigue iluminar mi día"

- "combina belleza, espiritualidad y religiosidad"

- "es sentimental"

A partir de aquí, estas otras razones que se apoyan en criterios muy distintos de los anteriores:

- “Toda aquella relacionada con la guitarra, motivo evidente, ¿no?”,76

- "porque es una música con muchos cambios de intensidad"

- "Es muy amplia, muy creativa, de mucha calidad y poco conocida"

\footnotetext{
${ }^{76}$ La persona encuestada toca la guitarra; su motivo no es tanto de percepción, sino que se acerca más a la razón: aquello que uno conoce.
} 
- "Por el libretto y la calidad musical"

- "totalmente innovadora, incluso fuera de contexto"

- "Por su contenido"

- "Su riqueza, el virtuosismo del piano y la compenetración con la orquesta"

- "me parece una música sublime"

- "por la sonoridad original y única"

- "por la excelencia de sus obras"

- "porque la encuentro brillante y es un canto a la libertad y a la amistad"

- "me encanta la variedad y la riqueza sonora de esta obra"

- "melodía fúnebre y ritmo trepidante"

En el primer bloque, podemos apreciar que todas las razones parten de una emoción, de un recuerdo, aquello que un día se percibió de manera especial. Sin embargo, el segundo bloque atañe más al conocimiento, a aquello que puede ser más objetivo: la calidad, la excelencia, la variedad, los cambios de intensidad, lo que "es" o se dice que es ("un canto a la libertad").

\section{3) Música y Medios}

En este tercer apartado, he querido investigar sobre qué medios utiliza la gente para ver conciertos que no sea la asistencia a conciertos en vivo: televisión, Internet, DVDBlue-Ray o salas de cine $^{77}$.

El análisis de esta pregunta da como resultado que 35 personas no miran nunca conciertos a través de pantallas. De entre estas personas, sólo hay 7 que ni miran conciertos a través de estos medios, ni asisten en directo. Pero, sí existe una tercera parte -30 personas- que, a pesar de no verlos a través de pantallas, va a verlos en directo.

14 personas no asisten a las salas de conciertos, pero sí los miran a través de pantallas.

El resto de personas, que son la mayoría (65 personas), combinan la asistencia a salas de concierto con los medios audiovisuales.

\footnotetext{
${ }^{77}$ Unificaré estos medios a través de la palabra "pantallas".
} 

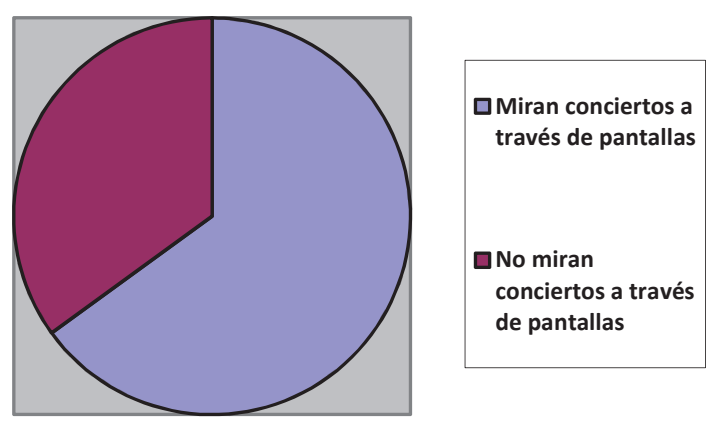

Figura 88 Hábito de consumo audiovisual de conciertos, M. Millà.
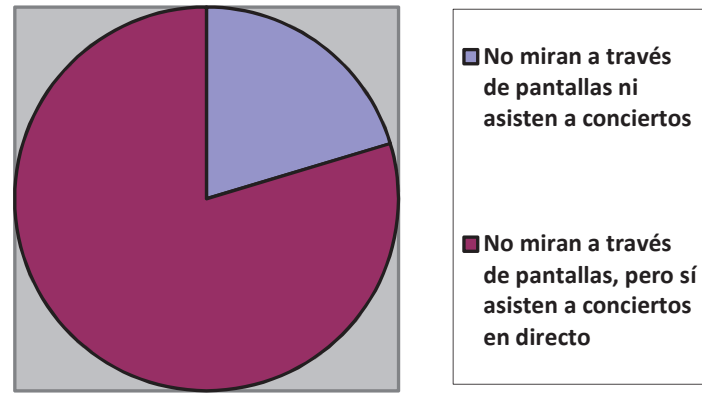

Figura 89. Porcentaje de personas que no consumen audiovisualmente y asisten o no a conciertos en directo, M. Millà.

A modo conclusivo:

- Es minoritario el público que mira conciertos a través de pantallas.

- Mayoritariamente, las personas encuestadas combinan la asistencia en directo con el visionado de medios audiovisuales.

- La mayoría de personas que no van a conciertos en directo -y tampoco miran conciertos a través del mundo audiovisual- se sitúan entre los 36 y los 55 años. Son personas que se supone que están en su plenitud dentro del mundo laboral y con plena dedicación familiar. Sólo 4 pasan los 56 años y una tiene menos de 20 . 
Respecto a los medios usados por los espectadores, los resultados son:

- Televisión- 42 (21 de los cuales usan también otros medios audiovisuales).

- Internet - 30 (13 personas usan exclusivamente Internet, el resto lo combinan con otros medios)

- Blue-Ray-DVD- 10 (sólo 2 usan exclusivamente este medio)

- $\quad$ Salas de cine- 3

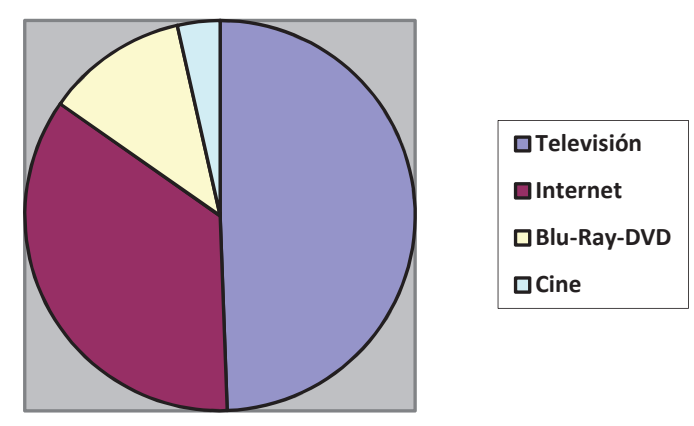

Figura 90 Porcentaje de medios audiovisuales empleados para ver conciertos, M. Millà.

Concerniente a los que sí miran a través de pantallas y cuál es la obra que más recuerdan, cabe destacar que, en este caso, el círculo de obras se cierra y la mayoría (25 personas) indican que su filmación preferida es el Concierto de Año Nuevo desde Viena. El resto son las siguientes piezas orquestales:

- Concierto para piano de un intérprete chino ${ }^{78}$

- Conciertos de Brandenburgo para guitarra

- Programa "Oh, Happy Day"79

- Sherezade, Philharmonica de Stuttgart

- OBC desde la playa (retransmisión)

- Festival de música de Alemania (J. S. Bach)

- Festival de jazz (Donosti)

- Wolfmother

\footnotetext{
${ }^{78}$ No nombra el compositor y me atrevo a afirmar que el pianista chino no es otro que Lang Lang, pero, repito, es suposición de la investigadora debido a la mediatización de dicho pianista.

${ }^{79}$ Se trata de un programa de conjuntos corales de una televisión autonómica (TVC).
} 
- Concierto n.3 de Prokofiev (Marta Argerich con la London Symphonie, dirigidos por Claudio Abbado)

- Concierto de Sant Esteve (Palau de la Música Catalana)

- Conciertos en directo desde el Royal Albert Hall de Londres

- Concierto en Ramallah (Barenboim), forma parte de un reportaje.

- $9 a$ Sinfonía de Beethoven

- Otelo

- Aida

- La Flauta Mágica- 2

- Il Trovatore

- La Bohème

- El lago de los cisnes- 2

- Cascanueces

- Freddy Mercury con Montserrat Caballé

- End of the beginning- Black Sabbath

4.3- Resultados obtenidos: cuestionarios sobre los ejemplos de realización audiovisual-musical.

En todos estos cuestionarios, las preguntas son las mismas. Parten del desconocimiento o no de la pieza musical como pregunta principal a tener en cuenta y siguen con preguntas acerca del tratamiento audiovisual.

\footnotetext{
a) Adagio para cuerdas, Samuel Barber - https://youtu.be/DKsY-0NS8Ew

1- ¿Conoces a su autor y la obra?

- No conoce autor ni obra- 42

- Conoce autor y obra- 15

- Conoce obra, pero autor no- 37

- Conoce autor, pero obra no- 4

- 2 personas no contestan- un jubilado y un menor de 20 años que estudia Bachillerato.
} 

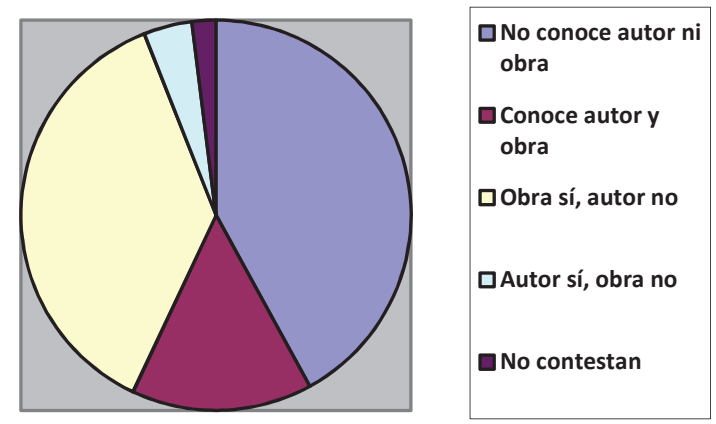

Figura 91 Conocimiento de autor y obra (Adagio, Samuel Barber), M. Millà.

Comentario:

Como primera observación, quiero destacar que estamos ante una obra muy conocida por la mitad de los encuestados y, sin embargo, de dicha mitad, solamente 15 personas conocen el compositor. Se trata de una obra usada no solo en películas sino también en eventos públicos de importancia internacional; es, quizás, debido a este motivo que se ha convertido en una obra popular.

Las características de las 15 personas que conocen obra y autor son: estudios superiores, la gran mayoría pertenece a la franja de edad entre los 36 y los 55 años y sólo 3 personas no poseen estudios musicales. Quiero remarcar que únicamente 12 personas de las 37 que dicen conocer la obra pero no su autor tienen estudios musicales (sean superiores, medios o elementales).
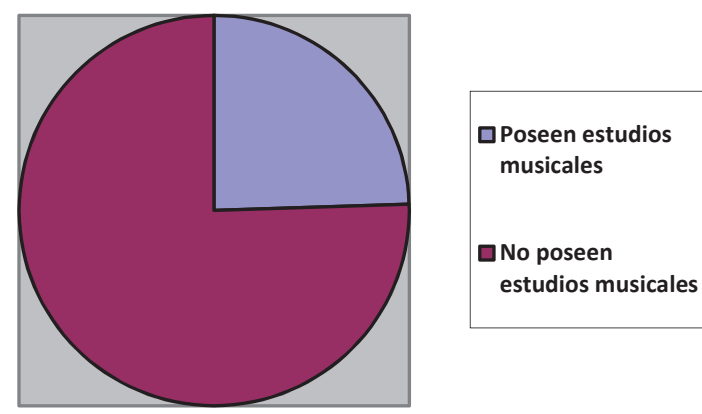

Figura 92 Porcentaje de personas que conocen la obra y poseen estudios musicales, M. Millà. 
Añadir, también, que las personas que pertenecen a este grupo "conozco obra, pero no autor" tienen diferente nivel de estudios; no todos tienen estudios superiores. Así pues, deduzco que esta obra es ampliamente conocida, seguramente, por su uso social.

\section{2- En una primera impresión, ¿te ha llamado la atención algún momento en concreto? ¿Cuál?}

Los elementos que más han llamado la atención han sido:

a) la transición de la primera parte a la segunda de la composición. Queda formulado de distintas maneras ya que algunas lo expresan como un momento de transición; sin embargo, otras personas, lo expresan como:

- "el paso a la segunda parte"

- "cambio de tempo"

- "el momento en que paran todos los instrumentos de sonar a la vez"

- "el silencio largo"

- "cuando parece que la obra haya terminado"

b) Los desenfoques y encadenados. Expresados de distinta manera, pero indican el momento de transición entre planos que no se realiza por corte.

c) La musicalidad del conjunto de cuerdas y el clímax. La mayoría lo expresa a través del crescendo musical.

d) El director. Aparece en muchos planos y, sobretodo, concuerdan en el plano de las manos. Alguna persona hace hincapié en que este director toca sin batuta.

e) Primeros planos: constatan una gran presencia de primeros planos y, alguna persona, opina que son excesivos.

f) En cuanto a la coherencia entre la música y la filmación, sólo opinan dos personas explícitamente. Mientras una ve como resultado positivo dicha coherencia; otra persona, juzga como asincrónica dicha relación. Cabe decir, que la segunda persona es músico y 
compositor y la primera no; con este dato, simplemente constatar los conocimientos de la partitura de uno y otro.

Comentario:

Sólo quiero hacer evidente que, respecto a la pregunta, que era abierta en cuanto a posibles respuestas, bastantes personas han analizado los tipos de planos: demasiados planos cortos o de detalle y poco uso del plano de situación, plano general de la orquesta. La mayoría se han referido a la musicalidad transmitida y a la forma en que se han realizado los cambios de plano: desenfoques, valorándolo, como veremos, unos, positivamente $\mathrm{y}$, otros, negativamente.

\section{3- ¿Qué valoras como positivo en la filmación de la obra?}

- El trabajo en equipo: director-orquesta/ Comunicación entre director y músico

- Comunicación del sentimiento del director

- Interpretación a través de la gestualidad del músico

- Transmite la sensibilidad de la obra

- El sonido

- Primeros planos de arcos y cuerdas. Los primeros planos generan emotividad y comunican intimidad y fuerza

- Desenfoques

- Primeros planos y planos detalle manos del director

- Planos de grupo de músicos, no sólo del director

- Plano contrapicado del cello

- Detalles de los intérpretes

- Primeros planos de arcos y cuerdas

- Se enseña lo que suena

- Filmación desde diferentes ángulos (puntos de vista)

- Se ven muy bien los violoncelos

- Combinación entre planos generales y primeros planos

- No hay cambios bruscos entre planos. La cámara acompaña los movimientos y el ritmo de la música. Se sigue la cadencia y el tempo musical. 
- Es una apuesta diferente a la que estamos acostumbrados: "Esperas ver la melodía reflejada en los diferentes instrumentos por los que pasa y no es as'́”. El realizador parece resaltar las melodías secundarias (cellos y violas)

- La cámara acompaña los movimientos y el ritmo de la música. Se sigue la cadencia musical.

- Se enseñan entradas especiales de instrumentos

- Cambios de planos para constatar la comunicación entre director y músicos

- Iluminación y sonido correctos

Comentario:

En esta pregunta, cabe resaltar que 30 personas han valorado como positivo el hecho de que en la realización abunden los planos cortos y de detalle de instrumentos. Entramos ya en lo que a lenguaje audiovisual se refiere puesto que, incluso, algunos de ellos han llegado a sacar la conclusión del porqué estos planos: para generar emotividad en el espectador, así como intimidad y fuerza.

Otro importante elemento valorado por varios de los encuestados y que, no puede quedar como anécdota es la combinación de planos, la sintaxis de la imagen: pasar de planos generales a planos cortos a través de desenfocados. Es importante resaltar el cambio del plano del director al de la orquesta para llegar a percibir la conexión entre ellos y valorar este trabajo en equipo.

Y, para terminar, una importante observación por parte de algunas personas: la valoración positiva del movimiento de la cámara que acompaña el ritmo de la música, la cadencia. Así pues, entre todas las respuestas, hallamos un evidente análisis audiovisual: tipos de plano (gramática del plano), relación entre ellos (sintaxis audiovisual) y movimiento o ritmo que sigue la cámara (narración audiovisual).

\section{4- ¿Qué valoras como negativo en la filmación de la obra?}

- No valoran nada como negativo quince de las personas encuestadas.

- No transmite emoción 
- No se ve un plano general de la orquesta

- Aparece demasiado el director

- No se ve la ejecución de los dedos

- Planos "borrosos" tipo de recurso técnico.

- Es una opinión muy generalizada que no hay ningún plano general o de conjunto; sin embargo, hay demasiados planos del director y planos demasiados cerrados.

- En general, "realización cerrada y falta de aire".

Comentario:

Coincidencia mayoritaria en la observación de falta de planos más abiertos y de conjunto (muy elocuente la descripción de "realización cerrada") así como la visión de los desenfocados como error.

\section{5- ¿Ves coherencia entre lo que expresa la música y la realización visual? ¿Por qué?}

- Sí- 69 personas

- No- 10

- En ciertos momentos, sí- 2

- No sabe- 3

- No contesta- 16

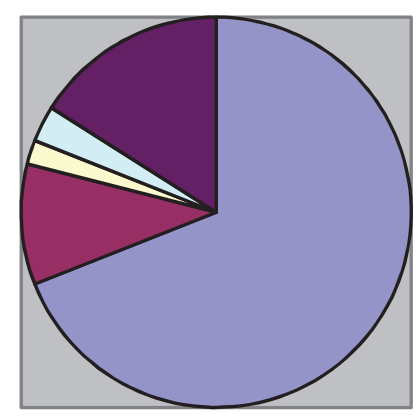

口Sí

$\square$ No

DEn ciertos

momentos

口No sabe

Q No contesta

Figura 93 Percepción de coherencia entre música e imagen (Adagio, Samuel Barber ) M. Millà.

\footnotetext{
80 Se sobreentiende que los encuestados que definen un plano como "borroso", se refieren a los planos desenfocados o encadenados.
} 
- Los estudios y oficios de los que no ven coherencia en esta obra son:

- Universitarios/Docente- 4

- Grado Superior de Música/ Docente

- Psicología/ Gestión de escuela de música

- Estudios Superiores/ Jubilada

- Doctorado/Investigación científica

- Grado Superior de Música/Musicóloga

- Estudios universitarios/Clínica

Respecto a los que no han contestado, el perfil es el siguiente:

- Bachillerato/Jubilada

- Magisterio/Docente

- Universitario/Jubilado

- Ingeniero/Docente- 2

- Formación Profesional/Administrativo- 2

- Formación Profesional/Dependienta

- Medicina/Médico

- Superiores/ Administrativo- 2

- Derecho/ Abogado

- Universitarios/Docente

- Formación Profesional / Técnico de calidad

- Estudiantes- 2

Una amplia mayoría de personas afirman una coherencia entre música e imagen. La mayoría lo justifican por el ritmo y la cadencia musical acompañada por el ritmo lento del movimiento de las cámaras. Sin embargo, algunas opinan junto a esto, falta de riesgo y creatividad ya que el resultado es muy plano y monótono. Por lo que respecta a los que no ven coherencia, existen diversos motivos: uno define la obra como muy lírica y lenta, por ello, no le ve coherencia. Otro afirma: "es una obra que vive del todo, de la harmonía y de la cohesión, y no de pequeños planos" y, similar a dicha razón, otras dos personas afirman que la música es superior a la realización. 
Observaciones a partir del Adagio de Samuel Barber:

- A partir del ejemplo del Adagio de Samuel Barber, en el que se constata un gran uso de imágenes desenfocadas con un objetivo específico por parte del realizador, quiero constatar que muy pocas personas valoran positivamente los desenfoques o las transiciones largas entre plano y plano. Se trata de personas que no pertenecen a un colectivo homogéneo en cuanto a edad o profesión. Sin embargo, un gran número de encuestados cuestionan dicha opción estética y la interpretan como un error técnico o una opción que no les ayuda en la narración musical. Entre ellos, predominan las personas dedicadas a la docencia. Cabría suponer que los docentes tienen una lectura audiovisual más avanzada ya que acostumbran a hacer uso de estos medios para con sus alumnos; sin embargo, son muchos los que han interpretado este efecto como error de realización. También, un grupo de encuestados, aún estudiantes, valoran negativamente el desenfoque de las imágenes; $\mathrm{y}$, sin embargo, dicho colectivo se autodenomina como "nativo digital”. Quizás, esta falta de interpretación por lo que respecta a un recurso digital, es debido a que les faltan conocimientos para analizar dichos efectos desde la narrativa audiovisual que acompaña la música. También ocurre con alguna persona de más de 56 años; en este caso, es debido, no tanto a la lectura interpretativa sino a la menor formación en audiovisuales.

- La mayoría de profesionales dentro del ámbito musical o, incluso, personas de otra profesión pero con estudios musicales avanzados, no valoran los primeros planos o planos detalle tan cerrados porque no pueden ver bien la ejecución o interpretación de los músicos. Así lo explica alguno de los encuestados y, así lo expresa José Nieto, compositor, de manera contundente en la entrevista que incluyo en esta investigación. No se trata tanto de que un realizador luzca su genialidad, sino de mostrar aquello que está en la partitura.

- Como complemento a la anterior observación, quiero remarcar cómo muchos músicos, intérpretes o compositores, encuentran a faltar el plano general de la orquesta, el plano de situación.

- En definitiva, sorprende que una intención estética a partir del análisis de la partitura sea vista como error por la gran mayoría de las personas. Es decir, los encadenados largos entre imágenes han sido una opción por parte del realizador a partir del clímax de la obra, puesto que, en la primera parte, los cambios entre planos son por corte. Y, aún sorprende más 
que, a pesar de esta valoración negativa, muchas personas han evaluado positivamente la coherencia entre música e imagen a nivel global.

- b) Vuelo del moscardón, Rimsky-Korsakov - https://youtu.be/WTHT8aR1MKI

\section{1- ¿Conoces a su autor y la obra?}

- No conoce autor ni obra- 17

- Conoce autor y obra- 60

- Conoce obra, pero autor no- 19

- Conoce autor, pero obra no- 2

- No contestan dos personas- un estudiante de Bachillerato y una abogada entre 21 y 35 años.
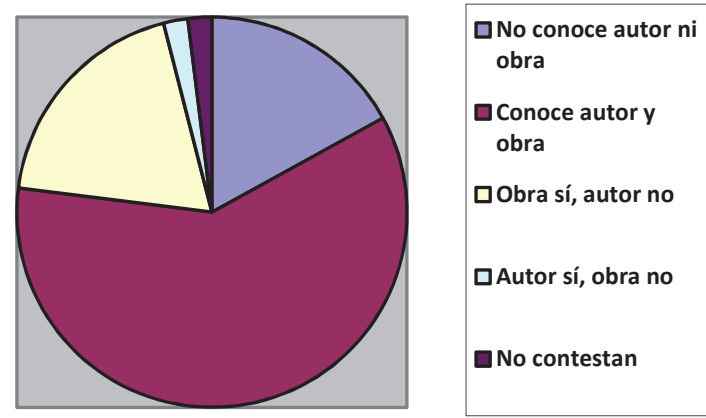

Figura 94 Conocimiento de autor y obra (Vuelo del moscardón, Rimsky-Korsakov),M. Millà.

\section{Comentario:}

A pesar que de las 79 personas que conocen esta obra, 19 no conocen a quién pertenece, estamos, evidentemente, ante una obra popular. Llama la atención que 17 personas no conozcan ni obra ni autor. Entre estas personas la mitad poseen estudios superiores y, la otra mitad, estudios de FP, Bachillerato o EGB. Sólo 2 personas tienen estudios musicales, aunque de nivel básico. 
2- En una primera impresión, ¿te ha llamado la atención algún momento en concreto? ¿Cuál?

A 29 personas no les ha llamado la atención nada en especial.

Entre las personas que han respondido afirmativamente, los elementos que más han llamado la atención han sido:

- El inicio de la realización

- El ritmo rápido de la música

- El ritmo rápido de los cambios de plano: en concreto, una persona ya lo ha definido como "videoclip"

- Como constatación negativa, alguna imagen desenfocada y planos demasiado cortos y de espaldas

- Plano del director cuando da el inicio con la batuta. ${ }^{81}$

Comentario:

Esta pieza musical es la que menos comentarios ha recibido en esta misma pregunta; sin embargo, todos ellos lo hacen sobre la realización o filmación.

\section{3- ¿Qué valoras como positivo en la filmación de la obra?}

- La cámara seguía el movimiento del moscardón

- Alternancia planos generales y cortos

- Cambios de plano rápidos ${ }^{82}$

- Plano corto del violinista con la partitura de fondo

- Plano del instrumento que toca en cada momento

- Primeros planos de los músicos

${ }^{81}$ Comentario que el compositor José Nieto realiza en la entrevista como observación a tener en cuenta (Apéndice II).

$82 \mathrm{O}$, lo que es lo mismo, poca duración de los planos. 
- Muestra todos los músicos y las diferentes técnicas de instrumentación

- Coherencia entre la música y el plano del instrumento que toca

- Parece dar más importancia a la realización visual que a la pieza o su ejecución, no se enseña casi el músico ${ }^{83}$

- Se sigue el tema principal y los pizzicati

- Intención de sincronía entre la música y la realización

- Expresividad de los músicos

- Buena interpretación y trabajo entre director y músicos

Comentario:

Como resumen de lo valorado positivamente podríamos destacar tres ámbitos de la realización:

1- Se enseña el instrumento solista o que tiene importancia en ese momento. Se añade un matiz en esta observación que va más allá del mero plano del instrumentista: se enseña la ejecución y/o la técnica de la ejecución instrumental. ${ }^{84}$

2- Alternancia de planos cortos con planos generales: sintaxis de la imagen, del discurso.

3- Seguimiento del ritmo musical del vuelo del moscardón a través de la cámara

Es importante resaltar la opinión de una persona que lo ve como un producto que da más importancia a lo visual que a la ejecución misma.

Es la visión de una profesional del mundo de la realización y, es importante añadir que, el resto de encuestados ajenos a esta profesión opinan que les ha gustado, precisamente, poder ver la ejecución profesional de los músicos. Este sería un valor a añadir en esta pieza fílmica: la "didacticidad" de una filmación para llegar a los espectadores.

${ }^{83}$ En este caso, dicha observación la constata una realizadora de televisión.

${ }^{84}$ Véase la entrevista al compositor José Nieto, en el Apéndice II - Entrevistas 


\section{4- ¿Qué valoras como negativo en la filmación de la obra?}

31 personas no valoran nada como negativo; sin embargo, el resto, coinciden en valorar negativamente el ritmo vertiginoso de las imágenes que se traduce en expresiones como:

- cambios bruscos y excesivos

- realización caótica

- repetición constante del mismo recurso

- ritmo de "Videoclip" 85

- Pocos planos generales

\section{Comentario:}

En realidad, esta obra es valorada a partir del ritmo de la realización. Valoración positiva o negativa, depende del punto de vista perceptivo del encuestado.

\section{5- ¿Ves coherencia entre lo que expresa la música y la realización visual? ¿Por qué?}

- Sí- 79 personas

- No- 7

- En ciertos momentos, sí- 3

- No sabe- 1

- No contesta- 10
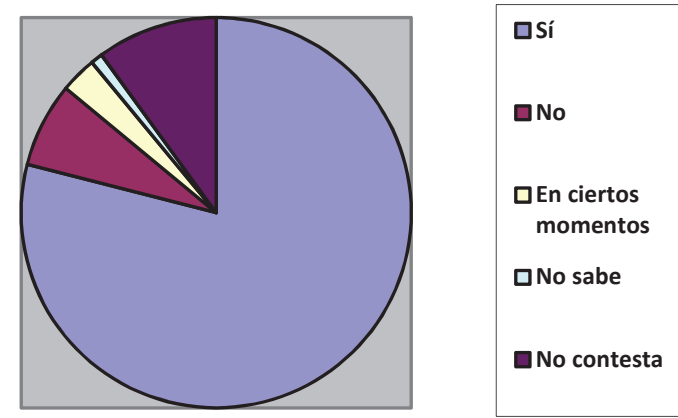

Figura 95 Percepción de coherencia entre música e imagen (Vuelo del moscardón, RimskyKorsakov), M. Millà.

\footnotetext{
${ }^{85}$ Es curiosa esta observación. Existen videoclips de ritmo rápido y de ritmo lento y, sin embargo, para esta persona encuestada, "ritmo videoclip"= Ritmo vertiginoso e "histérico".
} 
Los estudios y oficios de los que no ven coherencia en esta obra son:

- Superiores/Jubilado

- Ingeniero/ Docente

- Superiores/ Docente- 2

- EGB/Vigilante de seguridad

- Sociólogo/Análisis Político

- Graduado medio/Técnico

Los estudios y oficios de los que no contestan en esta obra son:

- Formación Profesional/ Dependienta

- Universitario/Jubilado

- Bachillerato/Jubilado

- Medicina/Médico

- Derecho/Abogado

- Bachillerato- Estudiante

- Grado Medio/Jubilado

- Universitario/Administrativo

- Bachillerato- Estudiante

- Formación Profesional/ Funcionario

Solamente 4 personas con estudios superiores no contestan. Respecto a los encuestados que responden afirmativamente a la cuestión de la coherencia, principalmente es por dos motivos:

a) el ritmo de la música es acompañado por el ritmo del movimiento de las cámaras y por el editaje o montaje de planos.

b) se enseñan los instrumentos que tocan en cada momento la melodía.

Sólo añadir que tres personas hubiesen querido un ritmo de montaje y de movimiento de cámara más acelerado. Una de las personas constata que el realizador conoce la obra en la 
manera de transmitirla. ${ }^{86}$ No en vano, la persona que realiza dicha observación posee estudios musicales y puede apreciar el trabajo que ha habido previo a la filmación.

Únicamente tres personas con estudios musicales no ven coherencia entre la música y la imagen en esta obra.

Observaciones a partir del Vuelo del moscardón de Rimsky-Korsakov:

Quiero destacar la unanimidad casi total en las respuestas referentes a la realización de esta obra. Es importante destacar cómo personas de distinta profesión y edad, con estudios musicales o no, han valorado la "transparencia" entre la partitura y la "puesta en pantalla". No sólo docentes, sino personas de ámbitos profesionales tan distintos que van desde las humanidades a lo técnico, pasando por el ámbito de la salud, realizan comentarios desde una visión narratológica de la música con una profundidad de conocimiento que llama la atención. Podemos afirmar que el trabajo anterior a la filmación ha tenido sus efectos en los receptores y ha logrado comunicar aquello que quería el realizador. Como dice una persona, profesional de la musicología, la pedagogía seguida en la realización para ir ilustrando los distintos grupos instrumentales y la coherencia entre ritmo e imagen convierten esta filmación en una pieza desde la que podemos afirmar que los espectadores quedan atrapados por un valor significativamente músico-visual. No se han detenido, mayoritariamente, en el valor de los planos visuales o su ritmo, si embargo, su valoración global destaca cómo las “cámaras" siguen el ritmo visual.

c) Seis Bagatelas, Giorg Ligeti - https://youtu.be/2aSqc0CSZFA

\section{1- ¿Conoces a su autor y la obra?}

- No conoce autor ni obra- 80

- Conoce autor y obra- 8

\footnotetext{
${ }^{86}$ En las entrevistas realizadas a profesionales, es un dato importante el hecho de saber música para interpretar la partitura.
} 
- Conoce obra, pero autor no- 4

- Conoce autor, pero obra no- 7

- 1 persona no contesta: menor de 20 años y estudiante de bachillerato
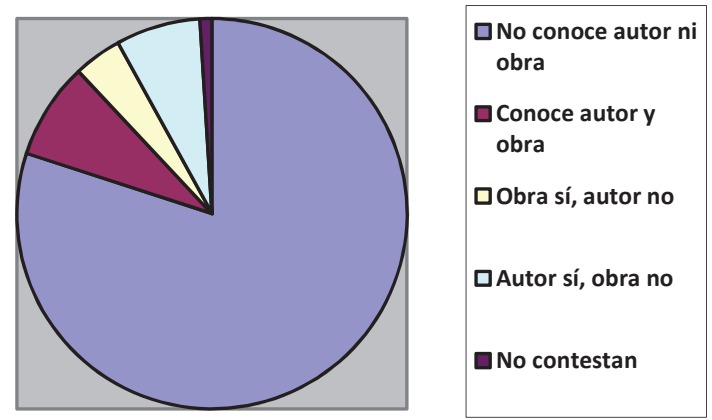

Figura 96 Conocimiento de autor y obra (Bagatela, Georg Ligeti), M. Millà.

\section{Comentario:}

En principio, escogí esta obra porque pensé que no sería muy conocida entre los encuestados, pero con una realización ágil y fuera de lo "preestablecido", podría obtener respuestas interesantes. Efectivamente, únicamente 8 personas conocen Ligeti y sus Seis bagatelas. De estas 8 personas, seis poseen estudios de música de nivel medio o superior. Afirmar, también, que de las restantes 11 personas que conocen o autor u obra, 9 tienen estudios musicales. Como conclusión, Ligeti no podemos definirlo como compositor popular dentro de la sociedad

\section{2- En una primera impresión, ¿te ha llamado la atención algún momento en} concreto? ¿Cuál?

- No destacan nada, explícitamente o sin responder, 23 personas

- Toda, en general, 5 personas.

- El inicio- 5 personas

- El final- 7 personas- Sólo una de ellas resalta el final del fagot.

- El espacio en el que se realiza el concierto o "la falta de escenario"- 17 personas.

- Interacción y complicidad entre los músicos. Es importante destacar la observación de dos personas respecto al diálogo, no sólo entre los músicos, sino con la cámara. Incluso, uno 
de los encuestados plantea la coreografía como eje principal para que se pueda llevar a cabo una buena realización. A 22 personas les ha llamado la atención esta comunicación.

- La interpretación de la flautista.

- Virtuosismo e informalidad. Uno de los encuestados expresa esta visión como "los músicos a su rollo" y, otro, como que "parece un diálogo de teatro"

- Por último, sólo 4 personas han destacado tipos de plano:

- Primer plano general

- Planos detalle cuando la cámara se acerca mucho a los músicos

- Salida de plano de la flautista (cambio del piccolo por la flauta)

- Combinación entre planos cortos y plano general

Comentario:

Vemos cómo, en esta obra desconocida por la mayoría de los encuestados -sólo 12 personas conocen la obra, de las cuales, ocho conocen además su autor-, la visión global y no los planos en concreto llaman la atención.

En el Adagio de Samuel Barber, no se enseñaba el espacio y, sin embargo, en esta obra se ha dado importancia al espacio escénico, simple, pero que potencia la interpretación de los músicos que integran el quinteto. De hecho, 22 de los encuestados han dado importancia al lenguaje expresivo entre los músicos y han subrayado su gestualidad.

\section{3- ¿Qué valoras como positivo en la filmación de la obra?}

- Nada- 14. Todas ellas son personas que no contestan. Así pues, que diga explícitamente que no, no hay nadie.

- Creatividad y originalidad-

- Cambios de posición en los músicos, se rompe la rigidez, frescura y modernidad, informal y desenfadado, interacción de los músicos con la cámara, "es música viva"-

- Variación entre planos cortos y planos generales- 
- Al ser un conjunto instrumental más pequeño, es más fácil poder transmitir la música al espectador

- Diálogo entre músico e instrumentos, diálogo entre parejas de instrumentistas.

- La actitud de los músicos, la ejecución, expresividad y movimiento de los músicos.

- Se enseña a los solistas, uno toma consciencia de la importancia de cada músico.

- Humor

- La claridad del fondo, el espacio, la luz

- Prioriza el discurso musical y cuenta la narración de la musica

- Agilidad y realización activa, dinamismo, teatralización

\section{Comentario:}

Aparecen nuevas observaciones después de ver esta realización:

- Creatividad.

- Interacción, ejecución y expresividad de los músicos.

- Llama la atención el espacio

y la ya analizada observación en las otras obras: planos de los solistas.

Como conclusión, es importante resaltar la priorización del discurso musical. Diría que la realización está latente y es implícita. La explicitación es tan novedosa que nadie se detiene en analizar el cómo, sino qué le ha llegado. ${ }^{87}$

En general, no se ha percibido nada como negativo. Se valora más el conjunto en general como algo muy positivo que lo poco que puede haber de lectura negativa, como la salida de la flautista de plano. ${ }^{88}$

No cabe duda que, después de analizar las respuestas, en esta filmación aparecen elementos de análisis nuevos dignos de mención ya que son compartidos por un número significativo de personas encuestadas.

87 José Nieto, compositor alude a esta experiencia. Cuando le atrae una filmación, no se entretiene en el análisis de lo que va viendo.

${ }^{88}$ Jusificado por el cambio de instrumento: deja la flauta y entra, nuevamente, en plano con el flautín. 


\section{4- ¿Qué valoras como negativo en la filmación de la obra?}

- Nada- 65 personas

- Pocos planos cortos de los músicos

- La imagen de los músicos queda "partida", planos poco cuidados

- El plano general está tomado desde muy lejos, así como algún plano detalle

- En la presentación, se ve gente deambulando y, durante el concierto, no se ve el público

- Músicos demasiado pendientes de la cámara

- Seguir a los músicos en planos cortos hace perder la visión de conjunto

- La flautista entra y sale de escena

- El seguimiento de los músicos

- Pérdida de atención o de importancia de la pieza musical

- Durante la realización, no ver a los cuatro músicos ${ }^{89}$

\section{5- ¿Ves coherencia entre lo que expresa la música y la realización visual? ¿Por qué?}

- Sí- 75 personas

- No- 10 personas

- En ciertos momentos, sí- 0

- No sabe- 2

- No contesta- 13
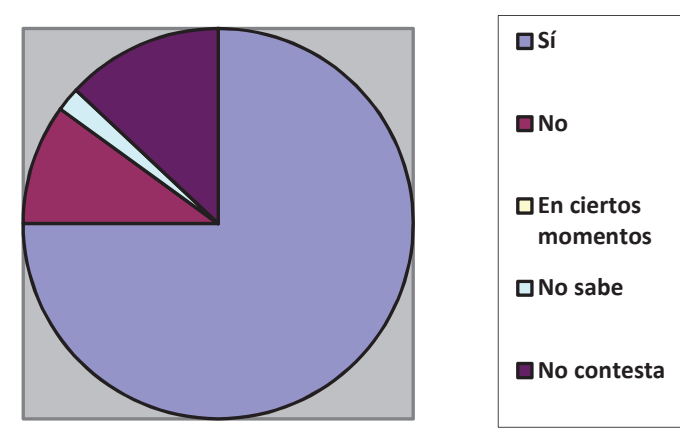

Figura 97 Percepción de coherencia entre música e imagen (Bagatela, Georg Ligeti), M. Millà.

${ }^{89}$ Observación errónea: son cinco músicos y sí existen planos generales de ellos durante la realización. 
Los estudios y oficios de los que no ven coherencia en esta obra son:

- Administrativo/Contable

- Universitarios/contable

- Universitarios/ Docente- 2

- Medicina/Médico

- Derecho/Abogado

- Universitarios/Clínica

- Universitarios/Jubilado

- Técnicos/Técnico

- Universitarios/Estudiante

Los estudios y oficios de los que no contestan en esta obra son:

- Formación Profesional/ Administrativo

- Bachillerato/Funcionario

- Universitarios/Salud

- Formación Profesional/ Dependienta

- Universitarios Jubilado- 2

- Medicina/ Médico- 3

- Estudios Superiores/ Administrativo

- Grado Medio/ Jubilado

- Bachillerato/Estudiante- 2

Comentario:

La contundente respuesta positiva demuestra que hay un trabajo de análisis de la obra musical para poder llegar a esta simbiosis "filmación-música".

Expongo a continuación el porqué sí ven que hay coherencia:

- Instrumentos protagonistas en primer plano

- Vitalidad, dinamismo y movimiento

- Diálogo 
- Cambios de plano que siguen la música; podríamos llamar puntuación audiovisual que sigue las pausas de la música.

- $\quad$ El plano visual transmite la emoción y la música

- La actitud informal de los músicos es coherente con la realización a través de planos inestables.

- Implicación de los músicos en su “teatralización”, gestualidad y expresividad.

- $\quad$ Plano a la misma altura que los músicos

Las personas que no perciben dicha coherencia lo atribuyen a que el espacio comunica serenidad y la música no. También observan que los cambios de plano son poco rápidos respecto al ritmo de la música. De las 10 personas que no ven dicha coherencia, 3 sólo responden con una negación, sin razonar la respuesta.

Llama la atención que la Bagatela de Ligeti, a pesar de ser una obra desconocida para la gran mayoría de los encuestados, ha llegado muy positivamente a todos ellos. A través de sus comentarios, vemos que la dificultad que, en un principio, podría "bloquear" el acercamiento a la obra, no se produce gracias al planteamiento fílmico.

Es importante hacer notar, sin embargo, la siguiente observación por parte de dos personas: el hecho de tratarse de un tipo de realización distinta, original y, podríamos llamar, "teatralizada", puede hacernos perder lo que es la música en sí.

De hecho, nadie ha comentado nada de la música, como en las otras obras. Sin embargo, ha valorado muy positivamente el trabajo de los músicos junto con la realización. Sólo dos personas de las que dicen no encontrar coherencia, tienen estudios musicales. Así que, por parte del realizador, resulta muy positivo que, entre los que valoran la coherencia exista un público mixto entre estudiantes o profesionales de la música y los que no poseen dichos estudios. Incluso, la persona que se muestra radicalmente ajena a la música clásica aprecia esta realización y se atreve a expresar su opinión: "bonito lugar para tocar...el tono de la luz y el plano de la cámara de frente a la misma altura de los músicos". Creo que, sólo por la descripción de esta persona es imprescindible poder trabajar cada realización desde un concepto audiovisual distinto y que parta de un buen estudio de la partitura. Dicha persona, totalmente ajena a este mundo, ha detallado tres aspectos fundamentales: 
- $\quad$ El espacio

- $\quad$ El aspecto artístico- tono de luz

- $\quad$ Perspectiva o punto de vista de la cámara: a la altura de los ojos.

A veces, incurrir en el riesgo, provoca que los espectadores se acerquen a un mundo audiovisual que no tiene por qué ser elitista.

Respecto a una percepción más generalizada de los encuestados, quiero destacar el diálogo entre los músicos y su implicación en cuanto a la expresividad. Así, y para cerrar el apartado dedicado a Ligeti, tres elementos de análisis, a mi modo de parecer muy relevantes:

- $\quad$ el movimiento y expresividad de los músicos

- $\quad$ la frescura y la modernidad de la realización en su conjunto

- $\quad$ el diálogo de los músicos con la cámara; me gustaría añadir, más que con la cámara, con el espectador. No olvidemos que el ojo de la cámara es el del espectador que está al otro lado de la pantalla..$^{90}$

Observaciones a partir de la Bagatela de Ligeti:

Al igual que en la obra anterior, las observaciones de la gran mayoría de las personas, independientemente de su formación, profesión o edad, parten de la importancia del espacio en el que se ha realizado la filmación (por lo que de diferente hay respecto a las filmaciones a las que estamos acostumbrados) y del diálogo entre los músicos. Para ello, es importante resaltar la entrevista realizada para mi investigación a Albert Nieto como intérprete que ha acertado a resaltar la gestualidad y la comunicación entre músicos dentro del mundo audiovisual.

Sorprende la generalidad en no destacar nada negativo en esta filmación, sobretodo, teniendo en cuenta que es la obra menos conocida por los encuestados y que podría haberse tratado de una obra musical con una dificultad añadida a la hora de ser escuchada por los espectadores. Únicamente una persona dedicada al mundo audiovisual critica los encuadres, por otra parte valorados por el resto de los encuestados al ver como

\footnotetext{
${ }^{90}$ Alusión al libro En el momento del parpadeo de Walter Murch (Editorial Ocho y medio, Madrid, 2003). También, el realizador Xavier Garasa, menciona el hecho de la cámara como "espectador" (Apéndice IIEntrevistas)
} 
positiva su genialidad y creatividad. Puedo afirmar que estamos ante una filmación cuya previa elaboración ha contribuido a que, pese a tratarse de música conocida minoritariamente, haya llegado de manera positiva al receptor. Se trata pues de una filmación muy bien valorada por parte de un gran público heterogéneo que ha sabido realzar la puesta en escena y el escenario escogido para esta ocasión.

Gracias a este estudio, podemos concluir que una de las maneras de acercar el público joven a la música clásica puede ser el ofrecer realizaciones audiovisuales totalmente evolucionadas a través de metodologías originales que aproximen los músicos a los espectadores. Ligeti y su bagatela es un buen ejemplo de realización que acerca el público joven, no sólo a la música clásica sino a la música clásica contemporánea, de difícil escucha y atención por parte de los espectadores.

\section{d) Danubio Azul, Johann Strauss - https://youtu.be/e6UndYrcDAk}

\section{1- ¿Conoces a su autor y la obra?}

- No conoce autor ni obra- 3

- Conoce autor y obra- 85

- Conoce obra, pero autor no- 4

- Conoce autor, pero obra no- 6

- No contesta- 2: estudiante de bachillerato, menor de 20 años y Mujer entre 36 y 55 años, con estudiós de FP y de profesión, dependienta.
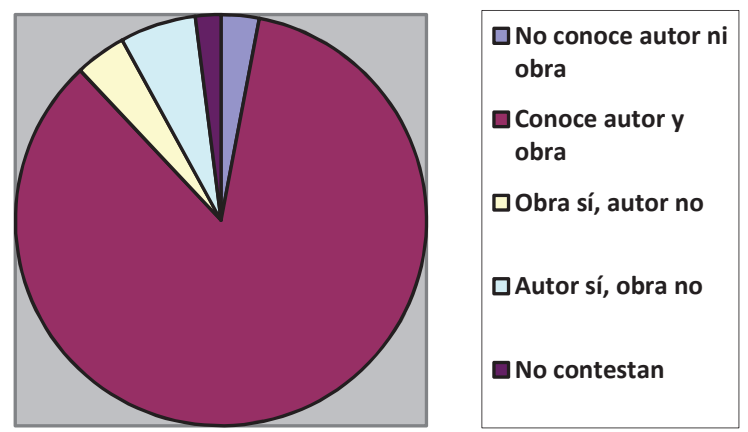
Comentario:

Ante estos resultados, quiero destacar que, aunque se podía presuponer que todas las personas sin excepción conocerían la obra y el autor, sorprendentemente, hay 3 personas que desconocen estos datos; 4 conocen obra, pero no el autor; 6 , sí conocen autor, pero desconocen obra y las dos restantes no contestan. Si bien, una de las personas con formación a nivel de EGB, sin estudios musicales y que confiesa sinceramente no gustarle la música clásica, es pronosticable que no conozca el Danubio Azul; no puedo dejar de destacar que las otras dos personas, con estudios universitarios, desconozcan ambos: autor y obra.

Así mismo, también quiero evidenciar aquellas personas que conocen el autor y la obra, no; en concreto, de las 6 personas que afirman esto, 3 poseen estudios musicales.

\section{2- En una primera impresión, ¿te ha llamado la atención algún momento en} concreto? ¿Cuál?

- Nada, por ser tan conocida- 17

- Virtuosismo

- Plano contrapicado de los violoncelos

- Combinación de concierto y ballet clásico

- Ritmo lento

- El in crescendo

- El cambio de tempo

- Imagen de los músicos a través de las trompas

- Sección larga de la orquesta, después de los bailarines

- Cambios de planos de instrumentos

- Crescendo de la orquesta con zoom de la imagen, al inicio. Retroceso de la cámara desde el primer trompa. Cómo se suman los instrumentos al plano

- Planos detalle de los instrumentos

- El ángulo de vista

- Plano general demasiado largo

- Gran plano general

- Entorno majestuoso 
- Sensibilidad del Plano general largo (1'25')

- Cambios de plano suaves (encadenados) o siguiendo el ritmo

- Contextualización, se ensña la sala

- Alternancia entre instrumentos de cuerda y de viento

- No ver todo el teatro ni todos los músicos

- La imagen

Comentario:

Sorprende la cantidad de observaciones dedicadas, en un primer momento, a la filmación. Dichas observaciones se detienen en distintas capas o secciones de la realización:

a) Tipos de plano:

- Plano contrapicado de los violoncelos.

- Plano de los músicos a través de las trompas

- Gran plano general

b) Movimiento interno del plano:

- Zoom out o retroceso de la cámara desde las trompas hasta el plano general

- Plano General valorado positiva y negativamente: plano demasiado largo y "sensibilidad" del plano.

c) Angulación del plano:

- $\quad$ Apreciación y valoración positiva de los distintos ángulos de vista.

- Cambios de plano

- $\quad$ Ritmo lento

- Cambios de plano de los instrumentos

- Cambios de plano suaves (encadenados) o siguiendo el ritmo

- Alternancia entre instrumentos de cuerda y de viento

Musicalmente, son pocos los comentarios: 
Virtuosismo, cambio de tempo e importancia del in crescendo.

Quiero destacar la referencia explícita al entorno y la importancia a la contextualización, así como a la duplicación de espacios: ballet exterior y sala de conciertos.

\section{3- ¿Qué valoras como positivo en la filmación de la obra?}

- No contesta- 12

- Nada- 6

- Todo- 8

- Combinar orquesta y danza- 10

- Zoom out para abrir el campo de visión- 8

- Seguimiento de los instrumentos que tocan en cada momento

- La música se oía muy bien-

- Planos desde diferentes perspectivas o ángulos

- Entorno-

- Formalidad y elegancia

- Tempo coherente entre filmación y música

- Planos largos, continuos y muy cuidados

- Seguimiento con la cámara

- Movimiento interno de la cámara, se ajusta a la música

- Se ven todos los instrumentos

- Clasicismo en la alternancia de planos de instrumentos, director y planos generales ${ }^{91}$ o realización sobria

- Agilidad

- Es el concierto de Año Nuevo

- Plano contrapicado de los violoncelos

- Plano detalle de algún instrumento

- Cambios tranquilos y no repentinos que dan solemnidad

- Enseñar cada instrumento cuando empieza a sonar

\footnotetext{
91 Se entiende que el encuestado, con la palabra "clasicismo", quiere hacer referencia a un tipo de realización o filmación clásica, sin planos extremos o fuera de lo preestablecido y percibido como común.
} 
- Pieza muy conocida, pero que siempre sorprende

- Plano de conjunto

Comentario:

En referencia a lo que han valorado como positivo, al igual que en el punto anterior, han destacado elementos artísticos o estéticos de la realización. Además de los ya citados en el punto anterior, es importante destacar:

- Valoración del sonido: es el primer momento en que alguien destaca un aspecto técnico.

- Seguimiento de los instrumentos que tocan en cada momento: supuesto conocimiento musical del director o realizador o, simplemente, asesoramiento por parte de un músico de lo que "explica" esta obra musical.

- Coherencia entre filmación y música: tempo coherente.

- Se muestran los instrumentos en el momento del inicio de su respectiva frase musical.

- Sobriedad, elegancia y formalidad frente al hecho de sorprender a pesar de ser vista y oída año tras año.

\section{4- ¿Qué valoras como negativo en la filmación de la obra?}

- Nada- 22 personas

- No contestan- 20

- Las bailarinas han desaparecido y despista un poco-

- No son necesarias las bailarinas-

- Algunos planos demasiado largos y rígido-

- Poco innovador, no se sale del guión, realización formal, convencional-

- No se ve bien el ballet

- No está la obra entera ${ }^{92}$

\footnotetext{
92 Como ya he anunciado al principio del capítulo, 1 hecho de no mostrar las piezas enteras ha supuesto una toma de decisión difícil. También he dejado de mostrar las cinco Bagatelas que faltan de Ligeti y que configuran una obra de conjunto; pero, en una prueba inicial que realicé con cinco personas, vi que poner las obras enteras comportaría el abandono de la realización de la encuesta.
} 
- Pocos primeros planos de instrumentos

- Demasiados planos generales

- Abuso del zoom

- Pieza demasiado oída

- Lejanía, falta de calidez

- Planos de la sala incoherentes

- Aparece poco el director

- No ver la orquesta entera al inicio del concierto

\section{Comentario:}

Es una filmación valorada como positiva por la amplia mayoría de las personas encuestadas. Sorprende que las anteriores razones por las cuales las observaciones son positivas, sirvan para que otros realicen una valoración negativa:

- No es necesario el ballet.

- Pocos primeros planos de instrumentos.

- Abuso del zoom

- Poco innovador.

Sin embargo, stá ampliamente demostrado que la percepción es de coherencia total entre música y filmación.

\section{5- ¿Ves coherencia entre lo que expresa la música y la realización visual? ¿Por qué?}

- Sí- 73 personas

- No- 13 personas

- En ciertos momentos, sí- 2

- No sabe- 1

- No contesta- 11 

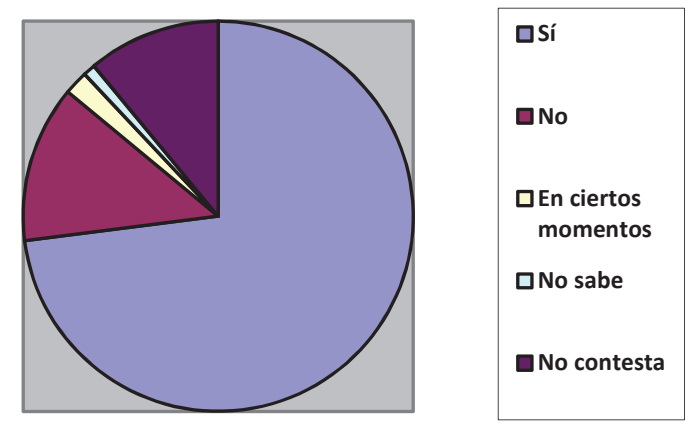

Figura 99 Percepción de coherencia entre música e imagen (Vals Danubio Azul, Johann Strauss), M. Millà.

Los estudios y oficios de los que no ven coherencia en esta obra son:

- Universitarios/Psicólogo

- Universitarios/Jubilado

- Superiores/Musicóloga

- Universitarios/Docente- 3

- Administración/Contable

- Universitarios/Gestor

- Ingeniería/Empresario

- Medicina/Médico

- Superiores/Administrativo

- Universitarios/Auxiliar Administrativo

- Universitarios/Estudiante

Los estudios y oficios de los que no contestan en esta obra son:

- Universitarios/Enfermera

- Formación Profesional/Dependienta

- Bachillerato/Auxiliar dministrativo

- Universitarios/Jubilado

- Universitarios/Psicopedagogo

- Bachillerato/Jubilado 
- Derecho/Abogado

- Grado Medio/ Funcionario

- Universitarios/Farmacia

- Bachillerato/Estudiante-2

En un principio y tal como opina alguna persona, parece más coherente porque es un concierto más conocido y estamos acostumbrados; sin embargo, también existen respuestas que no ven esta coherencia entre música e imagen. Y, entre estas, quiero destacar que hay más personas que, sabiendo música, no ven esta coherencia respecto a las tres obras anteriores. Con este vals, las opiniones son mucho más críticas, precisamente, por tratarse de una obra mucho más popular que las anteriores.

A pesar de ser mayoritariamente críticos con esta obra y verla con ojos "populares" y definirla como una realización de corte clásico, ha sido valorada muy positivamente por personas de distintas edades, estudios y profesiones quizás debido a lo nostálgico que resulta este concierto para cada una de ellas.

Observaciones a partir del vals del Danubio Azul de Johann Strauss:

No existe correlación entre las personas que ven conciertos a través de pantallas cine, televisión, DVD-Blue Ray o Internet- y la lectura audiovisual que la gran mayoría de las personas encuestadas hacen de esta conocida obra clásica en esta filmación. Sin embargo, al analizar las respuestas, puedo afirmar que es la obra musical que ha recibido más comentarios analíticos respecto a los planos o secuencias que el realizador ha propuesto para esta obra conocida por el casi 100\% de los encuestados. En las respuestas, aparece un claro elogio al plano contrapicado de los contrabajos, así como a la secuencia inicial del vals: inicio desde el plano detalle de la trompa y zoom out hasta llegar al plano general de la orquesta. Dicha observación, desde una lectura absolutamente audiovisual de los planos, es llevada a cabo por parte de personas provenientes de distintos ámbitos y, muchas, sin estudios musicales, por lo que de conocido resulta este concierto de Año Nuevo. Así, a pesar de no tratarse de personas que tengan como hábito ver conciertos a través de pantallas, sí tienen muy asimilado, casi de forma natural, este concierto en su formato audiovisual gracias a su retransmisión anual desde Viena. Deduzco de la observación anterior que, implícitamente, ver conciertos a través de pantallas sí educa la visión que de ellos tienen los espectadores y 
los convierte en analistas expertos en audiovisuales. Sorprende que, musicalmente, no se comente casi nada y predominen los comentarios sobre planos y ritmo visual.

Las personas a quienes no ha gustado la filmación son docentes, excepto la persona que ha manifestado que no le gusta la música clásica y que ejerce de vigilante de seguridad. Todas ellas están en la franja de edad comprendida entre los 36 y 55 años. Entre los que no contestan se incluyen estudiantes menores de 20 años y personas que no tienen estudios superiores, en su mayoría. Sólo tres personas con estudios superiores no contestan.

Otro dato a tener en cuenta es que, de las 22 personas que no han valorado nada como negativo en esta filmación, 17 no tienen estudios musicales. Se puede afirmar, pues, que la mayoría de las personas que, en esta pregunta, se han mostrado más críticas, sí poseen estudios musicales. Sin embargo, la valoración general de la filmación es positiva ya que lo fundamentan en un trabajo muy bien hecho en cuanto a planos de instrumentos y ritmo.

Creo que se puede realizar una afirmación general: cuanto más conoce una obra el espectador, más crítico es con la coherencia entre música e imagen.

\section{4- Cuestionario comparativo de las cuatro filmaciones}

\section{1- ¿Qué filmación te ha resultado más atrayente?}

- Adagio, Samuel Barber- 19

- Vuelo del moscardón, Rimsky Korsakov- 17

- Bagatelas, Ligeti- 45

- Vals Danubio Azul, Johann Strauss- 29

Quiero especificar que algunas personas no han respondido y otras han dado dos obras como más atrayentes. 

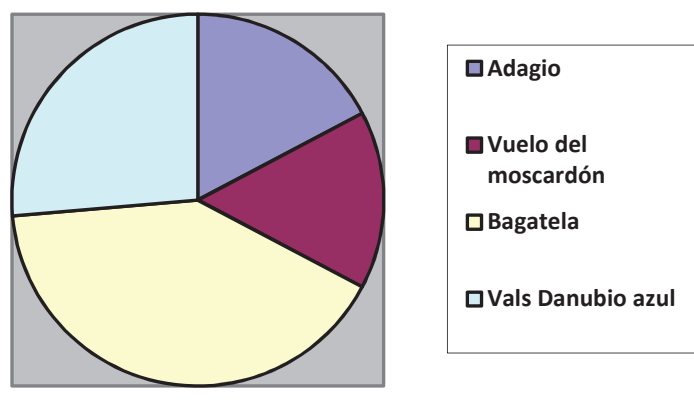

Figura 100 Obra más atrayente en su formato audiovisual, M. Millà.

\section{2- ¿Qué motivos te han llevado a valorar positivamente tu elección?}

- Movimiento de cámara que se ajusta al sonido, ritmo visual, coherencia

- Originalidad en la filmación y en la puesta en escena, innovador

- Muy elaborado, realización bien hecha

- ágil, dinámica

- Más actual

- planos de instrumentos adecuados al momento

- Puesta en escena adecuada

- Música conocida y bien filmada

- Música muy bella

- Cambios de intensidad

- Emotividad de los músicos y diálogo

- Interacción de los músicos con la cámara

- Frescura

- Las manos del director

- Diferentes ángulos y planos

- Sensibilidad

- Desenfoques

- Transmite alegría

- Dirección orquestal de Barber

- Clasicismo, elegancia

- Recuerdo del primer día del año 
- Espacio

- Acústica

- La música transmite

- Sentimiento de tristeza

- Calidad

- Predilección por los adagios

- La música en sí

3- Al contrario, ¿qué filmación te ha resultado menos atrayente?

- Adagio, Samuel Barber- 32

- Vuelo del moscardón, Rimsky Korsakov- 18

- Bagatelas, Ligeti- 16

- Vals Danubio Azul, Johann Strauss- 30

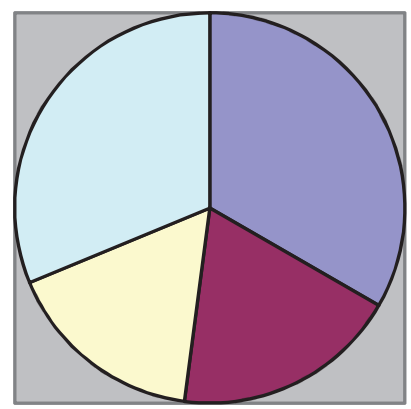

口Adagio

avuelo del moscardón

口Bagatela

$\square$ Vals Danubio azul

Figura 101 Obra menos más atrayente en su formato audiovisual, M. Millà.

4- Qué motivos te han llevado a valorar como menos atrayente tu elección en la pregunta tres.

- Las bailarinas desaparecen

- Poca originalidad, falta de innovación, monotonía, neutra

- Abuso del barrido

- Menos elaborado

- Demasiado focalizado en los primeros planos 
- Valora más las grabaciones con más músicos ${ }^{93}$

- Demasiado caos

- Porque no gusta

- Prefiere primeros planos

- No ha enganchado

- Demasiado teatralizado

- Realización hiperactiva, despista y desorienta

- Siempre se espera algo más en una filmación

- Los "zoom"

- Mala interpretación

- La música no atrae

- No provoca sentimientos

- Al ser una obra filmada cada año, no es fácil su realización

- No le gusta que se vea tanto el director

- Falta oxígeno

- Es la más vista

- No gusta por desconocida

- No se ve la orquesta al completo

- No le gusta cómo dirige el director

- El resultado final son unas imágenes para la música y no una música con imágenes (Vuelo del moscardón)

\section{Comentario:}

En el cuestionario comparativo, la filmación más atrayente resulta ser la obra menos conocida musicalmente: la Bagatela de Ligeti.

Como obra menos atrayente, sorprende que sea, precisamente, una de las obras más conocidas musicalmente, Adagio, casi en igual lugar que el popular Danubio Azul. Como conclusión: no es importante partir de lo conocido para apreciar el trabajo hecho "audiovisualmente".

93 Encuestado que, en la respuesta anterior, había contestado las Bagatelas de Ligeti. 
Es interesante el hecho de haber valorado una filmación por lo que la música transmite: alegría, tristeza, recuerdos, emotividad. No sólo se habla de la realización y sus elementos, sino de la percepción del espectador; aquello que llega a cada uno.

Cuando hablamos de coherencia es curioso resaltar que nadie o casi nadie habla de tipos de plano sino de la sintaxis musical y del ritmo. Y, ciertamente, no puede existir un aspecto sin el otro. Sin una buena gramática, no existe una buena sintaxis y, sin ellas...no es posible un buen discurso narrativo, en este caso, audiovisual. Creo que es positivo por parte de las personas encuestadas que hagan una valoración global de la obra para referirse a su coherencia y no que se detengan en el valor de los planos o los detalles. Esto significa que el concepto de flow prevalece y es uno de los valores a tener en cuenta por parte del realizador.

La Bagatela de Ligeti es la obra musical realizada mayor valorada y más atrayente por personas que están entre los 21 y 35 años (56\%); la siguiente franja de edad, con un $46 \%$, es la de 36 a 55 años de edad. Solamente uno de los menores de 20 años se ha sentido atraído por esta obra. Es importante destacar que de los mayores de 56 años, sólo un $40 \%$ ha encontrado esta pieza como la más interesante o atrayente.

Puedo deducir que, precisamente, Ligeti, compositor contemporáneo, con una música cuyos oídos deben estar educados en una escucha más abierta a nuevas formas musicales, es precisamente la pieza que menos ha atraído a los más jóvenes y a los más mayores.

Por otro lado, un elevado porcentaje de personas jóvenes, concretamente un $66 \%$ de menos de 20 años y un 50\% de personas de edades comprendidas entre 21 y 35 años, considera menos atrayente la pieza de Samuel Barber, el Adagio. En el lado opuesto y con porcentajes claramente inferiores, podemos encontrar las personas de más edad, esto es, a partir de los 36 años en adelante: 22\% de 36 a 55 años y 30\% más de 56 años.

La posible causa de este significativo resultado es, tal como expresan en su explicación posterior, el ritmo lento, la poca originalidad y el hecho de valorarla como una realización plana y aburrida.

Es decir, quiero destacar principalmente dos observaciones: 
- Los menores de 20 años no valoran la obra de Ligeti y el 66\% consideran menos atrayente la obra de Barber. Sí valoran El vuelo del moscardón, por su ritmo rápido, y el vals, por ser una obra conocida.

- $\quad$ Proporcionalmente, la personas comprendidas entre los 21 y 35 años valoran más la originalidad y la creatividad dados los resultados superiores en la obra de Ligeti.

A continuación, presento un análisis por edades de las personas que sí han constatado coherencia.

- $\quad$ Adagio de Samuel Barber (Total- 69 personas)

- Menos de 20 años- 4 (66\% respecto los de su edad)

- De 21 a 35 años- 9 (56\% respecto los de su edad)

- $\quad$ De 36 a 55 años- 44 (75\% respecto los de su edad)

- Más de 56- 11 (55\% respecto los de su edad)

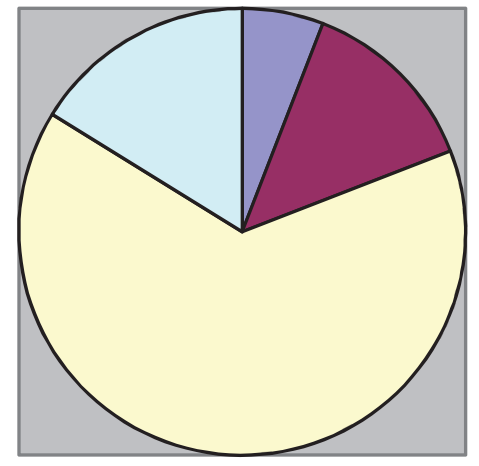

口Menos de 20 años

口De 21 a 35 años

口De 36 a 55 años

口Mas de 56 años

Figura 102 Interpretación de coherencia según edad. Adagio de Samuel Barber, M. Millà.

- Vuelo del moscardón de Rimsky-Korsakov (Total- 79 personas)

- $\quad$ Menos de 20 años- 4 (66\% respecto los de su edad)

- De 21 a 35 años- 12 (75\% respecto los de su edad)

- De 36 a 55 años- 48 (82\% respecto los de su edad)

- Más de 56- 13 (65\% respecto los de su edad) 


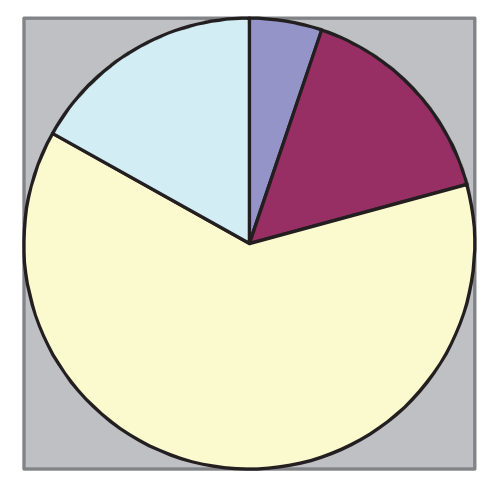

$\square$ Menos de 20 años

口De 21 a 35 años

口De 36 a 55 años

$\square$ Mas de 56 años

Figura 103 Interpretación de coherencia según edad. Vuelo del moscardón de RimskyKorsakov, M. Millà.

- Bagatela de Georg Ligeti (Total- 75 personas)

- Menos de 20 años- 4 (66\% respecto los de su edad)

- De 21 a 35 años- 13 (81\% respecto los de su edad)

- De 36 a 55 años- 41 (70\% respecto los de su edad)

- Más de 56- 14 (70\% respecto los de su edad)

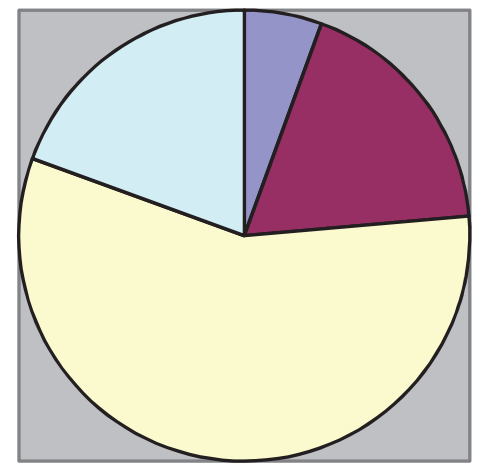

口Mas de 56 años

Figura 104 Interpretación de coherencia según edad. Bagatela de Georg Ligeti, M. Millà.

- Vals Danubio Azul de Johann Strauss (Total- 73 personas)

- Menos de 20 años- 4 (66\% respecto los de su edad)

- De 21 a 35 años- 10 (62,5\% respecto los de su edad) 
- $\quad$ De 36 a 55 años- 43 (74\% respecto los de su edad)

- Más de 56- 14 (70\% respecto los de su edad)
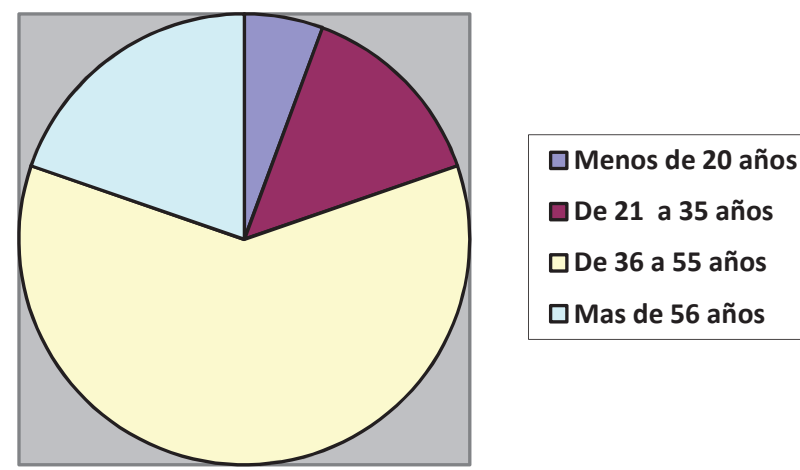

Figura 105 Interpretación de coherencia según edad. Vals Danubio Azul de Johann Strauss, M. Millà.

La pieza musical en la que leen más coherencia la mayoría de los encuestados es el Vuelo del moscardón y, a continuación, la Bagatela de Ligeti. Curiosamente se trata de las dos obras cuya realización pasó por una postproducción. Resulta coherente dicha visión puesto que, al poder editar planos en una sala de postproducción, el realizador puede elaborar el flow y trabajar más minuciosamente el plano adecuado en cada momento según la lectura previa de la partitura.

Partiendo del hecho de que las personas menores de 20 años se muestran menos críticas y cada uno de los vídeos lo evalúa como coherente entre imagen y música; el resto de las personas presentan diferencias. Proporcionalmente, las personas encuestadas de edades comprendidas entre 21 y 35 años ven como realización más coherente la Bagatela de Ligeti; quizás debido a ser personas que han crecido junto con el mundo audiovisual y tienen la lectura de "videoclip" más interiorizada. Quiero recordar que, en el capítulo uno, precisamente, destaco algunas de las características principales que diferencian este estilo músico-audiovisual de lo que es una retransmisión o grabación de un concierto. Entre ellas, la "actuación" de los intérpretes. Es por ello que me atrevo a sacar como conclusión que el hecho de la sincronía diálogo-respuesta de los instrumentos y la proximidad de los músicos a través del acting interpretativo, son dos factores que influyen en la visión y análisis de las personas de esta franja de edad. 
El Adagio de Barber y el Vuelo del moscardón de Rimsky-Korsakov son leídos como más coherentes por personas entre 36 y 55 años; la lectura es más interpretativa y puede ser fruto de un mayor conocimiento cultural y capacidad de análisis.

Por otro lado, cabe destacar la involuntaria pedagogía del concierto de Año Nuevo que, año tras año, "educa", en cierta manera, a los espectadores que siguen el concierto a través de cualquier pantalla. Se refleja en la proporciones equitativas y resultados homogéneos entre las distintas franjas de edades.

\section{5- Cuestionario sobre el didacticismo de las filmaciones}

Se trata de un cuestionario realizado con una voluntad puramente evaluativa, a través del cual he podido constatar la voluntad participativa y el agradecimiento por acercarse a un mundo "desconocido" por la mayoría: la suma entre las dos disciplinas, música y audiovisual.

1- A través de la "visión musical", ¿has descubierto o aprendido algunos elementos que no hubieras apreciado en caso de haber asistido en directo a la sala de conciertos?

- $\quad$-Sí- 72

- No- 23

- No contesta- 5

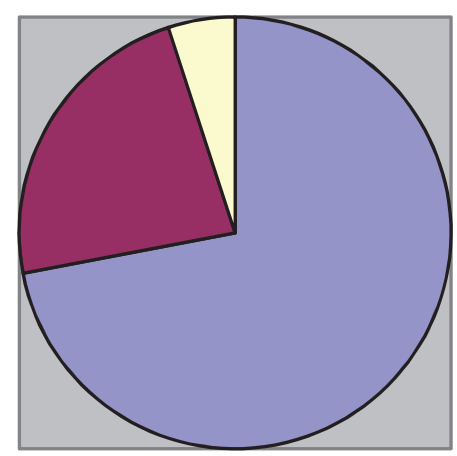

口Sí

$\square$ No

$\square$ No contesta

Figura 106 Valoración del didacticismo del formato audiovisual a través de los cuatro anteriores ejemplos, M. Millà. 


\section{2- En caso afirmativo, ¿qué has descubierto o aprendido?}

- Se aprecian más los instrumentos y la ejecución de la obra con la realización y se ven desde diferentes puntos de vista, diferentes perspectivas, primeros planos, detalles, la gestualidad de los músicos

- Se puede asociar la música con elementos externos: danza o museo

- Estás atento al momento de entrada de los instrumentos

- La intervención de los "solos"

- Cantidad de músicos e instrumentos

- Expresión del director (facial y gestual) y de los músicos (pasión), Inmersión en la orquesta

- La movilidad de las cámaras permiten "pasear” entre los músicos.

- La realización puede dar una visión sorprendente de una obra ya conocida

- La sincronización de los músicos

- Relacionar sonidos con instrumentos

- No me gusta escuchar y ver musica con un filtro y la interpretación de un realizador

- Detalles de interpretación

- Es bonito seguir los temas y contratemas, pero no necesario. A no ser que quieras usarlo como material pedagógico

- La luz y la acústica son muy importantes

- Sientes más la música

- Se oye mejor- en directo, escuchas al vecino

- La realizacion audiovisual de un concierto en vivo puede llegar a condicionar nuestra atención, impresión, interés y hasta opinión sobre las obras. Según nos planteemos una obra musical, cambia nuestra percepción. La realización te ayuda a seguir y a sentir la música (en la sala de conciertos, no tienes esta ayuda)

- Se pierde el efecto mágico del sonido en directo

- Un intérprete puede tocar la música dejándola sentir; o bien, forzar más dicha comunicación teatralizando su interpretación 


\section{3- Me gustaría que acabaras este cuestionario con cualquier aportación que no} hayas podido expresar en ninguna de las preguntas anteriores.

- Me ha gustado la experiencia y agradecimiento

- Sugiero que no se hubiera predispuesto a las respuestas

- Demasiado formalismo, en general, en las realizaciones. Esto disuade a los profanos en la materia

- Sería interesante estudiar la realización con interpretaciones vocales

- Acompañar con otras imágenes: naturaleza.

- Deberían emitirse conciertos en mejores horarios

- A través de la realización, la música clásica se puede hacer más atractiva. Importancia de la filmación para disfrutar la música y para enriquecerla-5

- No me gusta que pase por el filtro del realizador

- Puedes percibir más aspectos visuales

- No me gusta la música clásica y no la entiendo

- Combinación didáctica y de poder ver aquello que no se ve en directo

- Que la filmación dé su "versión”

- Debido a la falta de educación musical en este país, es necesaria una filmación más didáctica

- Sin embargo, los músicos agradecemos estilos de filmación más arriesgados, novedosos y menos didácticos

- Valoro la intención de buscar nuevos formatos

- Están bien las iniciativas para ver música de manera más económica

- Las salas cerradas agobian

- Estaría bien una mezcla de cada una de las distintas filmaciones

- Emoción en una de las filmaciones

- "Si pudiéramos dibujar la música, ¿qué imagen o imágenes deberíamos tener en la mente en el momento de plantear una realización determinada? ¿Sabemos algo sobre el compositor y/o el momento en que creó la obra? En caso afirmativo ¿ayudaría ello a que la realización fuese diferente, mejor, peor...? ¿Comprendemos o entendemos el sinfín de detalles sobre la forma y lenguaje que está escrita la obra? ¿Lo plasmamos en la imagen? ¿Es interesante hacerlo? ¿Ayudará a la comprensión o confundirá? Delante de tantas cuestiones 
que se nos pueden plantear, sólo tenemos una solución: el estudio y, sobretodo, la escucha interior de lo que queremos representar. El resto, técnica." 94

- Se tiene que ver el público o para quién tocan

- No sé valorar la parte técnica de la filmación, pero sí la parte "artística"

- No tengo conocimientos musicales

- He echado de menos el nombre del director y la orquesta

- Me gusta más escuchar un concierto en directo

\section{6- Comentarios sobre preguntas no respondidas}

Para terminar, una consideración para las personas que no han contestado ninguna pregunta en alguno de los cuestionarios o sólo han dado alguna respuesta.

Esta constatación la he relacionado con el hecho de conocer la obra o no.

- Adagio de Samuel Barber (6 no contestan nada)

- Desconoce autor y obra- 13

- Conoce autor y obra- 0

- Obra sí/Autor no- 5

- Autor sí/Obra no- 2
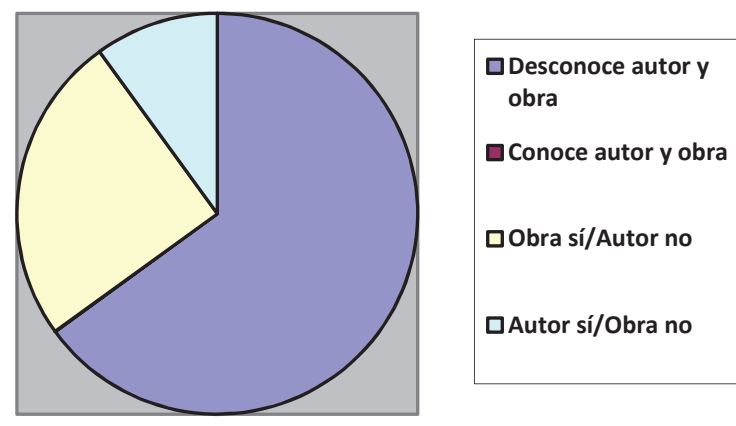

Figura 107 Relación entre el conocimiento de la obra y las preguntas no respondidas (Adagio, Samuel Barber), M. Millà.

${ }^{94}$ Incluyo toda la respuesta de la persona encuestada ya que son reflexiones difíciles de resumir o parafrasear. 
- Vuelo del moscardón de Rimsky-Korsakov (10 no contestan nada)

- Desconoce autor y obra- 6

- Conoce autor y obra- 5

- Obra sí/Autor no- 6

- Autor sí/Obra no- 0
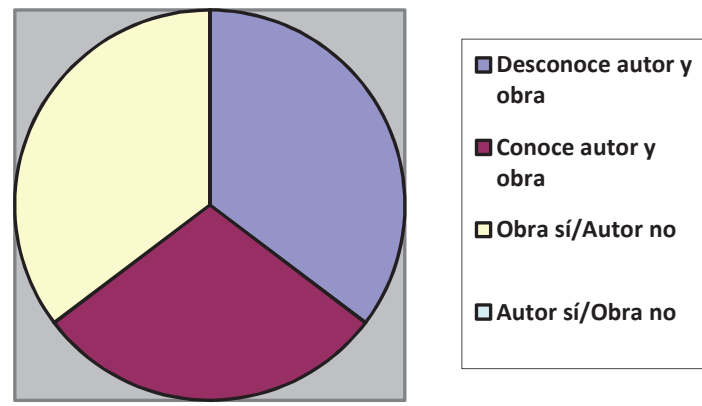

Figura 108 Relación entre el conocimiento de la obra y las preguntas no respondidas (Vuelo del moscardón, Rimsky-Korsakov), M. Millà.

- Bagatela de Georg Ligeti (11 no contestan nada)

- Desconoce autor y obra- 15

- Conoce autor y obra- 1

- Obra sí/Autor no- 2

- Autor sí/Obra no- 1
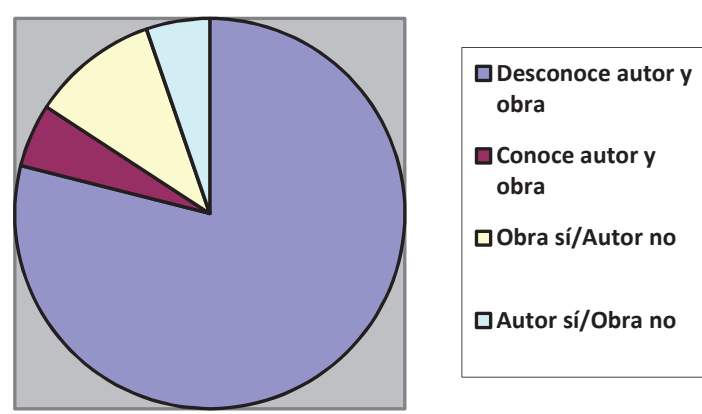

Figura 109 Relación entre el conocimiento de la obra y las preguntas no respondidas (Bagatela, Georg Ligeti), M. Millà. 
- Vals Danubio Azul de Johann Strauss (4 no contestan nada)

- Desconoce autor y obra- 2

- Conoce autor y obra- 4

- Obra sí/Autor no- 0

- Autor sí/Obra no- 0
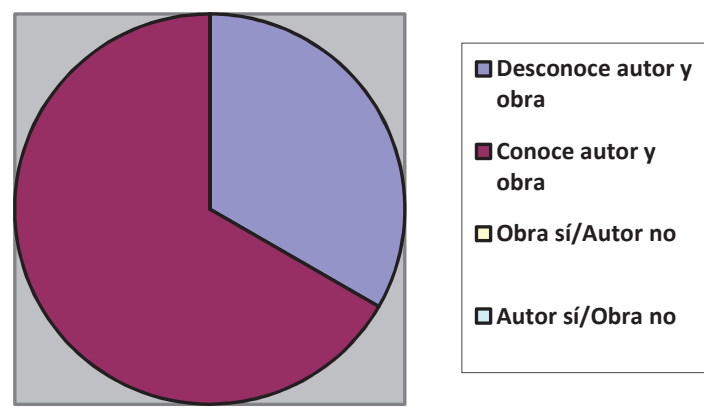

Figura 110. Relación entre el conocimiento de la obra y las preguntas no respondidas (Vals Danubio Azul, Johann Strauss), M. Millà.

Según los resultados anteriores, dos de las obras no obtienen respuestas por su desconocimiento: Bagatela y Adagio. Pocas personas que dicen conocer dichas obras no responden a las cuestiones planteadas. Sin embargo, el Danubio Azul y el Vuelo del moscardón no obtienen respuestas a pesar de ser conocidas. Llama la atención que, en el caso del Vuelo del moscardón, 11 personas que conocen la obra no respondan el cuestionario. Puede ser por varios motivos, incluso porque se trata de un cuestionario al que se debe dedicar un tiempo mayor del que quizás uno espera y no contesta, precisamente, por esta falta de tiempo. También puede ser porque es, precisamente una obra cuya realización implica respuestas más elaboradas por su formato de "videoclip", a pesar de no ser el trato que el realizador quiere darle. Así que, cualquier deducción al respecto es temeraria de ser errónea y no tiene explicación. Lo que realmente resulta una respuesta objetiva es que son fruto del desconocimiento de la obra las pocas respuestas o ninguna respuesta por parte de algunos. Sin embargo, esto no implica que personas que la desconocen se atrevan a contestar, incluso con vocabulario de conocimiento audiovisual.

Así mismo y para terminar esta observación, sólo tres personas no contestaron ninguna pregunta de los cuatro ejemplos; no puedo extraer ninguna conclusión puesto que son personas sin ningún tipo de relación profesional, de edad ni de oficio. Incluso una de las 
personas no responde sobre la obra más conocida, el Danubio Azul y sí se atreve a contestar en las otras tres obras.

\section{7- Epílogo}

Creo que queda diáfanamente expresado que la interrelación, implícita, entre realizador y espectador es lo que, finalmente, hace que el significado, sea accesible. Todas aquellas técnicas audiovisuales o tecnológicas pueden ayudar a la transmisión de una obra musical y es su uso, dentro y fuera de las convenciones preestablecidas como modelo tradicional lo que conducirá a los espectadores a considerar una obra musical como una "obra de arte" que se acerca a todos los públicos.

También quiero acercarme aquí a lo que Philipp Tagg indica a través de su teoría. Quiero recordar que Tagg parte de la teorización de la música aplicada a la imagen y, en el caso de mi investigación, se trata de la imagen aplicada a la música; es por ello que una de sus conclusiones principales, en este caso, queda alejada de los resultados que he obtenido en este trabajo empírico. Según Tagg, todas las asociaciones, a partir de la música en cuanto a su género, estilo, compositor u otros componentes descriptivos, las conecta y referencia con recuerdos y experiencias según el imaginario afectivo de cada persona. Es cierto que ha habido muchas expresiones de personas que, en cuanto se les ha preguntado por la música de cada uno de los vídeos, han manifestado, sobretodo, experiencias emocionales, recuerdos vividos o historias personales y resulta muy clara esta codificación cuando se refieren al Danubio Azul; oír este vals es llevar al espectador a los recuerdos del primer día del Año Nuevo. Sin embargo, he constatado que, si en el campo de la ambientación musical es posible cierta codificación con mensajes emocionales altamente dirigidos, en el campo de la realización audiovisual romper con esta codificación es lo que convierte la audiovisualización musical, no sólo en disciplina artística interesante, sino que la deriva hacia una evolución, progreso y transformación con unas expectativas que pueden llevar el imaginario del espectador, no hacia el pasado sino hacia un futuro que pueda llegar a cambiar los usos y costumbres musicales y artísticos de la sociedad en general.

Xuan Bello (2017) lo expresa de manera poética: "valorar la armonía del tópico y los destellos de la originalidad" (p.102). Pues bien, en este estudio empírico, hemos podido 
comprobar muchos de estos destellos que, sin romper con la armonía, caminan hacia un futuro prometedor en el entramado músico-visual. 
De la partitura a la pantalla: plano y contraplano de una misma realidad - 322 


\section{CONCLUSIONES}

Durante el transcurso de esta tesis doctoral me he sentido como persona nómada de la cultura visual a través de diferentes disciplinas académicas en las que me he basado para esta investigación: música, lingüística, semiótica, estética e historia del arte; así como a través de mis diferentes experiencias profesionales en los mass media.

- Opinión generalizada que deduzco de las encuestas es que la cultura visual, no viene dada sólo por naturaleza sino que se trata de una herencia cultural que, además se construye en el día a día.

- Hay quien ha establecido disonancias entre las artes disciplinares dedicadas a la percepción (estética visual) o historia del arte (estudio histórico) y las nuevas formas visuales de representación: cine, televisión o videoarte entre otras formas. No se está al día entre teoría y consumo.

Según Mitchell (2003), los estudios visuales deberían pertenecer a un campo más extenso de lo que suman la historia del arte y la estética como disciplinas juntas. De esta manera, incorpora, ya en el año 2001, la imagen en medios tecnológicos, la televisión, la semiología, la antropología visual entre otros aspectos visuales. La "ansiedad académica" de la que nos habla él, queda eclipsada y renovada por un concepto académico de mayor amplitud que integra todas las disciplinas que tienen como objeto la imagen.

- A través del estudio del marco analítico de las cuatro versiones del Vals del Danubio Azul he podido profundizar en el papel que juega el discurso musical dentro de la gramática audiovisual.

Es muy importante destacar cómo dicho análisis conduce a una percepción de las diferencias entre dichas versiones y la importancia del trasfondo sociocultural de este concierto de Año Nuevo.

- Dentro del objetivo que he planteado sobre el análisis del discurso musical dentro de la gramática audiovisual, después de las obras objeto de estudio de esta tesis, se confirma que se trata de un todo estructurado, no de elementos sueltos ya que la percepción final audiovisual es la suma de la percepción de cada uno de los componentes. 
- Así mismo, desde el punto de vista del realizador y pensando en el espectador, en lo que él quiere que vea, se deben de proyectar las relaciones que existen entre los instrumentos, los papeles que desempeñan cada uno de ellos o la ubicación en el escenario y no mostrar meramente datos cuantitativos sobre la composición de la orquesta.

- Gracias al visionado de los ejemplos escogidos y al posterior estudio y secuenciación de grabaciones junto con la partitura original, he identificado en una primera fase los elementos característicos del lenguaje audiovisual para potenciar el lenguaje musical existente en la partitura: músicos, movimiento, entorno, sonido, iluminación, vestuario, ubicación de cada instrumento.

- Una vez analizado el trabajo del realizador con la partitura original en las obras escogidas, he podido deducir que existen unas relaciones verticales, "córdicas" o sintagmáticas; es decir, cómo en un momento puntual inciden todos los elementos: qué instrumento o instrumentos, qué tipo de plano, con qué óptica, qué iluminación, qué debe sonar, vestuario (si es el caso), entre otros elementos.

- De la misma manera, la segunda fase de este proceso es comprobar que también existe un análisis paradigmático para las relaciones horizontales; es decir, un análisis lineal donde se ve cómo se relacionan los elementos a través de una secuencia temporal con una "normativa" de cambios de plano (valor de plano y punto de vista) y de tipo de encadenado ( fundido, por corte, encadenado sutil de un frame de segundo).

La relación paradigmática puede realizarse, o no, con subrayados de música e imagen en repeticiones melódicas o de temas; lo que provoca que entre dos momentos, por ejemplo en las formas de canon o fuga, las entradas sucesivas de instrumentos sigan una sintaxis visual.

- Hay un elemento común cinematográfico integrador entre música e imagen en los dos procesos inversos, por una parte, llevar la música a unas imágenes ya editadas, por otra parte y en relación inversa, buscar la realización multicámara para un concierto. Esto lo percibimos tanto en compositores con experiencia de años escribiendo música aplicada o incidental, como en realizadores que, sabiendo música, se guían por la partitura para establecer el juego de planos en una filmación o retransmisión en directo. 
- En la ambientación musical, según Tagg, se dan códigos emocionales que conducen al emisor a través de las imágenes; gracias a la realización musical, se rompe dicha codificación, conduciendo al espectador a nuevas perspectivas. En el primer caso, el agente o actante-observador se siente cómodo dentro de un imaginario afectivo y prefiere "instalarse" ahí; en el segundo caso, queda comprobado que el poder de adecuación y la construcción de nuevos imaginarios se convierte en una exaltación de aquello que ve.

- Hay una relación que se va creando con el paso del tiempo entre determinados elementos y espacios emblemáticos ya que la existencia de un determinado público en determinados espacios lo convierte en un acontecimiento intrínseco provocando que la gente asista por el evento en sí.

- Después de contextualizar fuentes orales y análisis de realizaciones músicocinematográficas, se valora positivamente que el realizador mantenga un equilibrio entre los elementos connotativos- la función social de un concierto- y los elementos denotativos- el mensaje que quiere transmitir el compositor a través de la partitura. Sin embargo, también a veces se puede encontrar un peso excesivo de los elementos connotativos que, siendo muy comerciales, no transmiten el mensaje del compositor en la partitura interpretada, rozando lo ridículo y lo histriónico.

- Depende de la funcionalidad de cada pieza audiovisual-musical, la realización puede ser más literal -caligráfica o didáctica- o más estético-artística. La unión de ambos aspectos, didacticismo y estética, acrecienta y enriquece el nivel cualitativo de las distintas filmaciones.

- También las encuestas señalan la importancia de ver la expresión del director : se trata del contraplano desde el fondo del escenario cuyo plano no puede ver el público; pero, sí puede ser visto por los espectadores. Otro de los aspectos importantes respecto al director es ver sus gestos mientras transcurre la narración musical. Los ataques de un instrumentista, de un violinista, por ejemplo, suelen estar en imagen; pero es muy difícil situar el gesto del director donde tiene que estar. Si el realizador sabe música, esta sincronía del plano del director, es posible.

- La genialidad del realizador se hace más evidente cuando debido a su dominio del lenguaje musical, el paso del contenido a la forma para no caer en el cliché es el paso de lo 
implícito a lo explícito, donde lo implícito sería el contenido y lo explícito, la forma de mostrarlo, a través de un lenguaje innovador, a través de una forma.

- De la misma forma, gracias a las encuestas, hay una valoración positiva de lo que es la realización durante las tres fases de lo que supone un buen trabajo audiovisual: preproducción, producción y postproducción (en casos concretos de filmación en diferido) . Se percibe ese sentido de genialidad al que hemos apuntado, aunque el nombre del realizador quede, entre los encuestados, en anonimato. Este factor sociocultural puede ir cambiándose, como apuntamos al comienzo, debido al interés creciente que están tomando las producciones en la cultura audiovisual actual.

- No se percibe todavía entre los encuestados una valoración generalizada del status que supone firmar como realizador esa filmación o retransmisión. En cambio, el protagonismo del director musical, sobre todo en eventos periódicos y valorados, eclipsa a los intérpretes, incluso al repertorio en sí.

- Después del análisis de todas las fuentes orales estudiadas, se deduce que un buen realizador tiene en cuenta consideraciones técnicas que ayudan a que los intérpretes se expresen gestualmente para conseguir una comunicación plena con el espectador: por una parte, el virtuosismo de las técnicas instrumentales; y por otra, hacer un uso discreto de planos de detalle en que sea vea el músico focalizado en la partitura, el teclado o su instrumento, llegando incluso a ser dirigidas como actores: movimientos entre ellos o miradas. Así se consigue la libertad de exteriorizar las emociones a través de la gestualidad. 


\section{BIBLIOGRAFÍA}

- Arnheim, R. (1986). El pensamiento visual. Barcelona: Paidós Ibérica.

- Austin, J.L. (1962). Cómo hacer cosas con palabras. Barcelona: Paidós.

- Bello, X. (2017). Escrito en el jardín. Zaragoza: Xordica Editorial.

- Bertetti, P. (2015). La historia audiovisual. Las teorías y herramientas semióticas. Barcelona: Editorial UOC.

- Blaxter, L., Hughes, Ch. y Tight, M. (2002). Cómo se hace una investigación. Barcelona: Gedisa.

- Chion, M. (1993). La audiovisión. Introducción a un análisis conjunto de la imagen y el sonido. Barcelona: Paidós.

- Eliot Gardiner, J. (2015). La música en el castillo del cielo. Barcelona: Galaxia Gutenberg.

- Greimas, A. J., y Courtés, J. (1979). Semiótica: diccionario razonado de la teoria del lenguaje. Madrid: Gredos.

- Jauss, H. R. (1986). Experiencia estética y hermenéutica literaria. Ensayos en el campo de la experiencia estética. Madrid: Taurus.

- Nieto, A. (2015). El gesto expresivo del músico o cómo disfrutar de un concierto. Barcelona: Editorial de Música Boileau, S.L.

- Nieto, J. (1996). Música para la imagen: la influencia secreta. Madrid: SGAE

- Polidoro, P. (2016). ¿Qué es la semiótica visual?. Bilbao: Servicio Editorial de la Universidad del País Vasco.

- Rabiger, M. (2001). Dirección de documentales. Madrid: IORTV.

- Ruiz Antón, V. J. (2016), José Nieto. Un encuentro imprescindible. Salamanca: Amarú.

- Soler, Ll. (1998). La realización de documentales y reportajes en televisión. Barcelona: CIMS.

- Tagg, P. (2012). Music's Meanings: A Modern Musicology for Non-musos. USA: Mass Media Music Scholars' Press.

- Trías, E. (2010). La imaginación sonora. Argumentos musicales. Barcelona: Círculo de Lectores. Galaxia Gutenberg.

- Viñuela, E. (2009). El videoclip en España (1980-1995): gesto audiovisual, discurso y mercado. Madrid: Ediciones del ICCMU. 


\section{CONGRESOS}

- MacFarlane, O. (2008). TV master class. En $2 n$ Congrés Internacional de Música a Catalunya: 8, 9 y 10 de mayo de 2008 (pp. 462-464). Libro de actos. Barcelona: Consell Català de la Música.

\section{DOCUMENTOS ELECTRÓNICOS}

- Terán, B. (2016, enero 1). Concierto de Año Nuevo: cuatro valores (televisivos) para su éxito. [Entrada Blog]. Consultado 20 julio 2016 desde:

http://blogs.lainformacion.com/telediaria/2016/01/01/concierto-de-ano-nuevo-cuatrovalores-televisivos-para-su-exito/

- BaileyShea, M. (2012, agosto). Agency and the Adagio: Mimetic Engagement in Barber's Op.11 Quartet. Gamut: Online Journal of the Music Theory Society of the Mid-Atlantic: Vol. 5 : Iss. 1, Article 3. [Entrada Blog]. Consultado 5 agosto 2016 desde:

http://trace.tennessee.edu/gamut/vol5/iss1/3/ 


\section{WEBGRAFÍA}

- Belsasso, L. (1980). In Memoriam Entrevista a Umberto Eco (1980). Instituto Italiano de Cultura, Radio de la Universidad UNAM (Universidad Nacional Autónoma de México). Recuperado de:

https://www.youtube.com/watch?v=iEw7PCIB0r8

- Ejemplo 1: Gamallo, J.D. (2015, noviembre 19). With my hands, de Furious Monkey House [Videoclip]. Recuperado de:

https://www.youtube.com/watch?v=DwFYbsGsZIU

- Ejemplo 2: Janés, T. (2001). La mujer sin sombra, Richard Strauss. Gran Teatre del Liceu, temporada 2000-01. [Videoclip] .https://www.youtube.com/watch?v=zLPRBZ4gPzc

- Ejemplo 3: Youtube Symphony Orchestra (2011, marzo 24). Abdelazer, de Henry Purcell/Guía de orquesta para jóvenes, op. 34, de Benjamin Britten. Dirigida por Michael Tisob Thomas desde Sidney Opera House. Recuperado de: https://www.youtube.com/watch?v=3HhTMJ2bek0

- Ejemplo 4 (primera parte): Medici TV. Adagio para cuerdas, de Samuel Barber, op.11. https://www.youtube.com/edit?o=U\&video_id=mm11Xwo5UEY

- Ejemplo 5 (segunda parte): Medici TV. Adagio para cuerdas, de Samuel Barber, op.11. https://www.youtube.com/watch?v=6o O4mUcFyo

- Ejemplo 6 (tercera parte): Medici TV. Adagio para cuerdas, de Samuel Barber, op.11. https://www.youtube.com/watch?v=hCgXToXi4Ds

- Ejemplo 7: Garasa, X. (2014). El vuelo del moscardón, de Rimsky-Korsakov. [Videoclip]. https://www.youtube.com/watch?v=WTHT8aR1MKI

- Ejemplo 8: Garasa, X. (2014). Mambo (West Side Story), de Leonard Bernstein. [Videoclip]. https://www.youtube.com/watch?v=Zm-ofiUDtRg

- Ejemplo 9: David, R. y Cellan Jones, S. (2003). Eroica [Película]. England: BBC/Opus Arte. https://www.youtube.com/watch?v=UtA7m3viB70

- Ejemplo 10: Burton, H. (1987). Vals Danubio Azul [Videoclip].. Subido a youtube por: Marta Millà (26 de octubre de 2017). https://www.youtube.com/watch?v=tfRT8T7VX2U

- Ejemplo 11: Large, B. (2011). Vals Danubio Azul [Videoclip]. https://www.youtube.com/watch?v=tEDxGTLAUsQ 
- Ejemplo 12: Fibich, K. (2013). Vals Danubio Azul [Videoclip]. Subido a youtube por : Marta Millà (26 de octubre de 2017).

https://www.youtube.com/watch?v=1Sm730vHSGM\&feature=youtu.be

- Ejemplo 13: Beyer, M. (2016). Vals Danubio Azul [Videoclip]. Subido a youtube por : Egon Hilgers (1 de enero de 2016). https://www.youtube.com/watch?v=S fk5aoEfl4

- Ejemplo 14: Clip del DVD "André Rieu At Schönbrunn, Vienna". Subido a Youtube por André Rieu (16 de septiembre de 2011). https://www.youtube.com/watch?v=IDaJ7rFg66A

- Ejemplo 15: Medici TV. (2011). Adagio para cuerdas, de Samuel Barber [Videoclip]. Subido por: Marta Millà (19 de julio de 2016). https://youtu.be/DKsY-0NS8Ew

- Ejemplo 16: Garasa, X. (2014). El vuelo del moscardón de Rimsky-Korsakov [Videoclip]. Subido por: Marta Millà (19 de julio de 2016). https://youtu.be/WTHT8aR1MKI

- Ejemplo 17: Carion. (2014). Bagatela de Ligeti, Allegro con spirito [Videoclip]. Subido por: Marta Millà (18 de julio de 2016). https://youtu.be/2aSqc0CSZFA

- Ejemplo 18: Large, B. (2011). Vals El Danubio azul, op. 314, de Johann Strauss [Videoclip]. Subido por: Marta Millà (18 de julio de 2016).

https://youtu.be/e6UndYrcDAk 


\section{LISTA DE FIGURAS}

- Figura 1. Casas, P. (2017). Tema musical Abdelazer. [Figura].

- Figura 2. Casas, P. (2017). Tema musical de la Fuga. [Figura].

- Figura 3. Millà, M. (2016). Elementos que intervienen en la preproducción de una filmación. [Diagrama].

- Figura 4. Material cedido por Televisió de Catalunya (2016). Posiciones de cámara posibles en el Palau de la Música Catalana, Barcelona. [Plano].

- Figura 5. Material cedido por Televisió de Catalunya (2016). Posiciones de cámara ya seleccionadas en el Palau de la Música Catalana, Barcelona. [Plano].

- Figura 6. Material cedido por Televisió de Catalunya (2016). Posiciones de cámara ya seleccionadas en el Gran Teatre del Liceu de Barcelona. [Plano].

- Figuras 7 y 8. Millà, M. (2012). Soportes y modos de anclaje de las cámaras en la Philharmonie de Berlín. [Fotografías].

- Figura 9. Millà, M. (2017). Gran plano general de situación exterior "OBC a la platja". [Fotograma].

- Figura 10. Millà, M. (2012). Gran plano general Philharmonie, Berlín. [Fotografía].

- Figura 11. Millà, M. (2014). Plano General de Escena, Palau de la Música Catalana, Barcelona. Budapest Festival Orchestra. Director, Iván Fischer. Quatre últimes cançons de Richard Strauss (1864-1949). Cançons d'un company errant de Gustav Mahler (1860-1911). [Fotograma].

- Figura 12. Millà, M. (2014). Contraplano General de Escena, Palau de la Música Catalana, Barcelona. Budapest Festival Orchestra. Director, Iván Fischer. Quatre últimes cançons de Richard Strauss (1864-1949). "Cançons d'un company errant" de Gustav Mahler (1860-1911). [Fotograma].

- Figura 13. MNAC/Cercle del Liceu/ Judit Fernández/ MMBCN (2016). El Liceu,Ramon Casas [Fotografía].

- Figura 14. Wikimedia Commons L'Orchestre de l'Opéra, Edgar Degas [Fotografía].

- Figura 15. Millà, M. (2012). Plano conjunto de violas. L'Auditori, Barcelona. Adagio de Samuel Barber (OBC). [Fotograma].

- Figura 16. Millà, M. (2012). Plano de Conjunto Viento madera y metal, L'Auditori,Barcelona. Sinfonía n.6 La Patética de Tchaikovsky (OBC). [Fotograma]. 
- Figura 17. Millà, M. (2014). Plano Figura de Natalia Gutman (violoncelo). [Fotograma].

- Figura 18. Millà, M. (2012). Plano Americano de Pablo Pérez, director de orquesta (violoncelo). [Fotograma].

- Figura 19. Millà, M. (2012). Plano medio de violinista, L’Auditori, Barcelona. Sinfonía n.6 La Patética de Tchaikovsky (OBC) [Fotograma].

- Figura 20. Millà, M. (2012). Primer plano de clarinetista, L'Auditori, Barcelona. Sinfonía n.6 La Patética de Tchaikovsky (OBC) [Fotograma].

- Figura 21. Millà, M. (2012). Primer plano de timbales, L’Auditori, Barcelona. Sinfonía n.6 La Patética de Tchaikovsky (OBC) [Fotograma].

- Figura 22. Millà, M. (2012). Primer plano de Violista, L’Auditori, Barcelona. Sinfonía n.6 La Patética de Tchaikovsky (OBC) [Fotograma].

- Figura 23. Millà, M. (2012). Plano detalle de contrabajo (arqueo), L'Auditori, Barcelona. Adagio de Samuel Barber (OBC). [Fotograma].

- Figura 24. Millà, M. (2012). Plano detalle de violín (pizzicato), L’Auditori, Barcelona. Sinfonía n.6 La Patética de Tchaikovsky (OBC) [Fotograma].

- Figura 25. Millà, M. (2012). Plano detalle de timbales, L'Auditori, Barcelona. Sinfonía n.6 La Patética de Tchaikovsky (OBC) [Fotograma].

- Figura 26. Millà, M. (2012). Plano detalle de violín (digitación), L'Auditori, Barcelona. Sinfonía n.6 La Patética de Tchaikovsky (OBC) [Fotograma].

- Figura 27. Millà, M. (2012). Plano de arco y cuerdas, L'Auditori, Barcelona. Sinfonía n.6 La Patética de Tchaikovsky (OBC) [Fotograma].

- Figura 28. Millà, M. (2012). Plano americano del director a través del violín, L’Auditori, Barcelona. Sinfonía n.6 La Patética de Tchaikovsky (OBC) [Fotograma].

- Figura 29. Millà, M. (2012). Plano en escorzo de violín con partitura desenfocada, L’Auditori, Barcelona. Sinfonía n.6 La Patética de Tchaikovsky (OBC) [Fotograma].

- Figura 30. Millà, M. (2012). Contraplano orquesta frontal, L'Auditori, Barcelona. Adagio de Samuel Barber (OBC) [Fotograma] / Millà, M. (2017) Contraplano orquesta lateral izquierda "OBC a la platja” [Fotograma].

- Figura 31. Millà, M. (2016). Plano de grúa en contraplano, Lang Lang en L 'Auditori, Barcelona [Fotograma].

- Figura 32. Millà, M. (2014). Plano realizado con cámara GoPro. Palau de la Música catalana, Barcelona. Budapest Festival Orchestra. Director, Iván Fischer. Quatre 
últimes cançons de Richard Strauss (1864-1949). Cançons d'un company errant de Gustav Mahler (1860-1911) [Fotograma].

- Figura 33. Millà, M. (2014). Contraplano lateral de escena. Palau de la Música catalana, Barcelona. Budapest Festival Orchestra. Director, Iván Fischer. Quatre últimes cançons de Richard Strauss (1864-1949). Cançons d'un company errant de Gustav Mahler (1860-1911) [Fotograma].

- Figura 34. Millà, M. (2010). Plano lateral de escena, Orfeó Català (Palau de la Música Catalana). [Fotograma].

- Figura 35. Plano lateral de escena, Budapest Festival Orchestra. Royal Concertgebouw Orchestra. Director, Iván Fischer. Sinfonía n.7 de Ludwig Van Beethoven.

- Figura 36. Millà, M. (2016). Plano lateral y plano lateral derecho. Lang Lang en L'Auditori, Barcelona [Fotograma].

- Figura 37. Millà, M. (2016). Plano lateral izquierdo. Lang Lang en L'Auditori, Barcelona [Fotograma].

- Figura 38. Millà, M. (2016). Plano corto teclado. Lang Lang en L'Auditori, Barcelona [Fotograma].

- Figura 39. Millà, M. (2007). Plano frontal. Lang Lang. [Fotograma]. https://www.youtube.com/watch?v=viHg kIWUeI

- Figura 40. Millà, M. (2016). Plano posterior. Lang Lang en L'Auditori, Barcelona [Fotograma].

- Figura 41. Millà, M. (2017). Elementos semióticos en la comunicación audiovisual y musical [Diagrama].

- Figura 42. Subirà, P. (2017). Posiciones de cámara para el concierto "Casa Nostra, Casa Vostra" en el Palau Sant Jordi, Barcelona [Plano].

- Figura 43. Millà, M. (2017). Fotograma de la película Eroica [Fotograma].

- Figura 44. Sánchez, M. (2017). Movimiento circular del plano de la cámara, realizando el seguimiento a Beethoven

- Figura 45. Millà, M. (2017). Composición equilibrada, Eroica [Fotograma].

- Figura 46. Millà, M. (2017). Composición angulada y con desequilibrio, Eroica [Fotograma].

- Figura 47. Exterior de la sala Musikverein, Fuente: colección fotos de archivo Framepool) [Fotografía] 
- Figura 48. Millà, M. (2016). Concierto Año Nuevo 1987. [Fotograma] https://www.youtube.com/watch?v=KT2Yg1JJvWI

- Figura 49. Penzel, R. (2010). Plano de cámaras para la realización del concierto de Año Nuevo de Enero 2011. [Plano] http://www.live-production.tv/news/culturalevents/orf-and-sivision-are-ready-broadcast-new-year $\% \mathrm{E} 2 \% 80 \% 99$ s-concert2011.html

- Figura 50. Penzel, R. (2010). Cámaras 1 y 2 (Escenario lateral izquierda). [Fotografía] http://www.live-production.tv/news/cultural-events/orf-and-sivision-areready-broadcast-new-year $\% \mathrm{E} 2 \% 80 \% 99$ s-concert-2011.html

- Figura 51. Penzel, R. (2010). Cámara 3 (interior escenario). [Fotografía] http://www.live-production.tv/news/cultural-events/orf-and-sivision-are-readybroadcast-new-year $\% \mathrm{E} 2 \% 80 \% 99 \mathrm{~s}-$ concert-2011.html

- Figura 52. Penzel, R. (2010). Cámara 5 (Plano general frontal). [Fotografía] http://www.live-production.tv/news/cultural-events/orf-and-sivision-are-readybroadcast-new-year\%E2\%80\%99s-concert-2011.html

- Figura 53. Penzel, R. (2010). Cámara 6- Lateral derecho, sobre platea. [Fotografía] http://www.live-production.tv/news/cultural-events/orf-and-sivision-are-readybroadcast-new-year $\% \mathrm{E} 2 \% 80 \% 99$ s-concert-2011.html

- Figura 54. Penzel, R. (2010). Cámara 7- Lateral derecho, sobre escenario. [Fotografía] http://www.live-production.tv/news/cultural-events/orf-and-sivision-areready-broadcast-new-year $\% \mathrm{E} 2 \% 80 \% 99$ s-concert-2011.html

- Figura 55. Penzel, R. (2010). Cámara 8- Lateral derecho, dentro escenario/ Contraplano. [Fotografía] http://www.live-production.tv/news/cultural-events/orfand-sivision-are-ready-broadcast-new-year\%E2\%80\%99s-concert-2011.html

- Figura 56. Penzel, R. (2010). Cámara 9 (con control remoto)- Plano cenital con raíl. [Fotografía] http://www.live-production.tv/news/cultural-events/orf-and-sivision-areready-broadcast-new-year $\% \mathrm{E} 2 \% 80 \% 99$ s-concert-2011.html

- Figura 57. Penzel, R. (2010). Cámara 11- Lateral izquierdo en el interior de escenario. [Fotografia] http://www.live-production.tv/news/cultural-events/orf-andsivision-are-ready-broadcast-new-year $\% \mathrm{E} 2 \% 80 \% 99$ s-concert-2011.html

- Figuras 58 (a y b). Penzel, R. (2010). Minicámara en el interior de escenario. [Fotografía] http://www.live-production.tv/news/cultural-events/orf-and-sivision-areready-broadcast-new-year $\% \mathrm{E} 2 \% 80 \% 99$ s-concert-2011.html 
- Figura 59. Penzel, R. (2010). Cámara 13- Lateral izquierdo, plano general.

[Fotografía] http://www.live-production.tv/news/cultural-events/orf-and-sivision-areready-broadcast-new-year $\%$ E2\%80\%99s-concert-2011.html

- Figura 60. Penzel, R. (2010). Cámara 14-Contraplano general desde el primer piso. [Fotografía] http://www.live-production.tv/news/cultural-events/orf-and-sivision-areready-broadcast-new-year $\% \mathrm{E} 2 \% 80 \% 99$ s-concert-2011.html

- Figura 61. Penzel, R. (2010). Cámara 14 (a)- al lado del director. [Fotografía] http://www.live-production.tv/news/cultural-events/orf-and-sivision-are-readybroadcast-new-year $\% \mathrm{E} 2 \% 80 \% 99 \mathrm{~s}-$ concert-2011.html

- Figura 62. Penzel, R. (2010). Cámaras 15, 16 y 17- En el hall, para el Ballet. [Fotografía] http://www.live-production.tv/news/cultural-events/orf-and-sivision-areready-broadcast-new-year $\% \mathrm{E} 2 \% 80 \% 99 \mathrm{~s}-$ concert-2011.html

- Figura 63. Palasan, E, (2008). Karina Fibich y Brian Large en el control de realización de la Unidad móvil. [Fotografía]. http://www.live-production.tv/case$\underline{\text { studies/concerts/cultural-event-audience-more-1-billion.html }}$

- Figura 64. (2013). Plano de cámaras para la realización del concierto de Año Nuevo de Enero de 2013. [Plano]. http://www.live-production.tv/news/cultural-events/newyears-concert-2013.html

- Figura 65. (2013). Cámara 7, cámara 13 y visión de la cámara con raíl desde el piso superior. [Fotografía]. http://www.live-production.tv/news/cultural-events/new-yearsconcert-2013.html

- Figura 66. (2013). Cámaras 5, cámara 6 y visión de la cámara con raíl contrapicada. [Fotografía]. http://www.live-production.tv/news/cultural-events/new-years-concert2013.html

- Figura 67. (2016). Unidad móvil- TV Skyline Ü8- para el concierto de Año Nuevo de Enero de 2016 http://www.live-production.tv/news/cultural-events/2016-newyear $\% \mathrm{E} 2 \% 80 \% 99 \mathrm{~s}-$ concert-vienna.html

- Figura 68. (2016). Plano de cámaras para la realización del concierto de Año Nuevo de Enero 2016. [Plano]. http://www.live-production.tv/news/cultural-events/2016new-year $\% \mathrm{E} 2 \% 80 \% 99$ s-concert-vienna.html

- Figura 69. (2016). Cámara 2- lateral izquierdo escenario. [Fotografía]. http://www.live-production.tv/news/cultural-events/2016-new-year\%E2\%80\%99sconcert-vienna.html 
- Figuras 70. (2016). Cámara 4- frontal escenario-fondo sala. [Fotografía]. http://www.live-production.tv/news/cultural-events/2016-new-year\%E2\%80\%99sconcert-vienna.html

- Figuras 71. (2016). Cámaras 6 y 5- lateral derecho. [Fotografía]. http://www.liveproduction.tv/news/cultural-events/2016-new-year\%E2\%80\%99s-concert-vienna.html

- Figura 72. (2016). Cámara 6- indicaciones al cámara en una Tablet, script. [Fotografía]. http://www.live-production.tv/news/cultural-events/2016-newyear $\%$ E2\% $80 \% 99$ s-concert-vienna.html

- Figura 73. (2016). Cámara 5- lateral derecho. [Fotografía]. http://www.liveproduction.tv/news/cultural-events/2016-new-year\%E2\%80\%99s-concert-vienna.html

- Figura 74. (2016). Cámara 7 (lateral izquierda escenario, contraplano). [Fotografía]. http://www.live-production.tv/news/cultural-events/2016-new-year\%E2\%80\%99sconcert-vienna.html

- Figura 75. (2016). Cámara 7- lateral izquierda escenario, vista del contraplano. [Fotografía]. http://www.live-production.tv/news/cultural-events/2016-newyear $\% \mathrm{E} 2 \% 80 \% 99$ s-concert-vienna.html

- Figura 76. (2016). Cámara 8- centro escenario, contraplano sala y director. [Fotografía]. http://www.live-production.tv/news/cultural-events/2016-newyear $\% \mathrm{E} 2 \% 80 \% 99 \mathrm{~s}-$ concert-vienna.html

- Figura 77. (2016). Cámara 9- lateral derecho escenario. Contraplano sala y director [Fotografía]. http://www.live-production.tv/news/cultural-events/2016-newyear $\% \mathrm{E} 2 \% 80 \% 99 \mathrm{~s}-$ concert-vienna.html

- Figura 78. (2016). Cámara 14- plano frontal, con raíl y control remoto. [Fotografía]. http://www.live-production.tv/news/cultural-events/2016-new-year $\% \mathrm{E} 2 \% 80 \% 99 \mathrm{~s}$ concert-vienna.html

- Figura 79. (2016). Controles remotos de cámaras fuera de la sala Musikverein. [Fotografía]. http://www.live-production.tv/news/cultural-events/2016-newyear $\% \mathrm{E} 2 \% 80 \% 99 \mathrm{~s}-$ concert-vienna.html

- Figura 80. (2011)- Fotograma extraído del DVD "André Rieu At Schönbrunn, Vienna". [Fotografía]. https://www.youtube.com/watch?v=IDaJ7rFg66A

- Figura 81. Millà, M. (2016). Sexo de las personas que respondieron la encuesta. [Diagrama].

- Figura 82. Millà, M. (2016). Edad de las mujeres que respondieron la encuesta. [Diagrama]. 
- Figura 83. Millà, M. (2016). Edad de los hombres que respondieron la encuesta. [Diagrama].

- Figura 84. Millà, M. (2016). Personas encuestadas con estudios musicales. [Diagrama].

- Figura 85. Millà, M. (2016). Nivel académico de estudios musicales. [Diagrama].

- Figura 86. Millà, M. (2016). Asistencia a salas de conciertos [Diagrama].

- Figura 87. Millà, M. (2016). Frecuencia de asistencia a los conciertos [Diagrama].

- Figura 88. Millà, M. (2016). Hábito de consumo audiovisual de conciertos [Diagrama].

- Figura 89. Millà, M. (2016). Porcentaje de personas que no consumen audiovisualmente y asisten o no a conciertos en directo [Diagrama].

- Figura 90. Millà, M. (2016). Porcentaje de medios audiovisuales empleados para ver conciertos [Diagrama].

- Figura 91. Millà, M. (2016). Conocimiento de autor y obra (Adagio, Samuel Barber) [Diagrama].

- Figura 92. Millà, M. (2016). Porcentaje de personas que conocen la obra y poseen estudios musicales [Diagrama].

- Figura 93. Millà, M. (2016). Percepción de coherencia entre música e imagen (Adagio, Samuel Barber) [Diagrama].

- Figura 94. Millà, M. (2016). Conocimiento de autor y obra (Vuelo del moscardón, Rimsky-Korsakov) [Diagrama].

- Figura 95. Millà, M. (2016). Percepción de coherencia entre música e imagen (Vuelo del moscardón, Rimsky-Korsakov) [Diagrama].

- Figura 96. Millà, M. (2016). Conocimiento de autor y obra (Bagatela, Georg Ligeti) [Diagrama].

- Figura 97. Millà, M. (2016). Percepción de coherencia entre música e imagen (Bagatela, Georg Ligeti) [Diagrama].

- Figura 98. Millà, M. (2016). Conocimiento de autor y obra (Vals Danubio Azul, Johann Strauss) [Diagrama].

- Figura 99. Millà, M. (2016). Percepción de coherencia entre música e imagen (Vals Danubio Azul, Johann Strauss) [Diagrama].

- Figura 100. Millà, M. (2016). Obra más atrayente en su formato audiovisual [Diagrama]. 
- Figura 101. Millà, M. (2016). Obra menos atrayente en su formato audiovisual [Diagrama].

- Figura 102. Millà, M. (2016). Interpretación de coherencia según edad. Adagio de Samuel Barber [Diagrama].

- Figura 103. Millà, M. (2016 Interpretación de coherencia según edad. Vuelo del moscardón de Rimsky-Korsakov [Diagrama].

- Figura 104. Millà, M. (2016). Interpretación de coherencia según edad. Bagatela de Georg Ligeti [Diagrama].

- Figura 105. Millà, M. (2016). Interpretación de coherencia según edad. Vals Danubio Azul de Johann Strauss [Diagrama].

- Figura 106. Millà, M. (2016). Valoración del didacticismo del formato audiovisual a través de los cuatro anteriores ejemplos [Diagrama].

- Figura 107. Millà, M. (2016). Relación entre el conocimiento de la obra y las preguntas no respondidas (Adagio, Samuel Barber) [Diagrama].

- Figura 108. Millà, M. (2016). Relación entre el conocimiento de la obra y las preguntas no respondidas (Vuelo del moscardón, Rimsky-Korsakov)) [Diagrama].

- Figura 109. Millà, M. (2016). Relación entre el conocimiento de la obra y las preguntas no respondidas (Bagatela, Georg Ligeti) [Diagrama].

- Figura 110. Millà, M. (2016). Relación entre el conocimiento de la obra y las preguntas no respondidas (Vals Danubio Azul, Johann Strauss) [Diagrama]. 


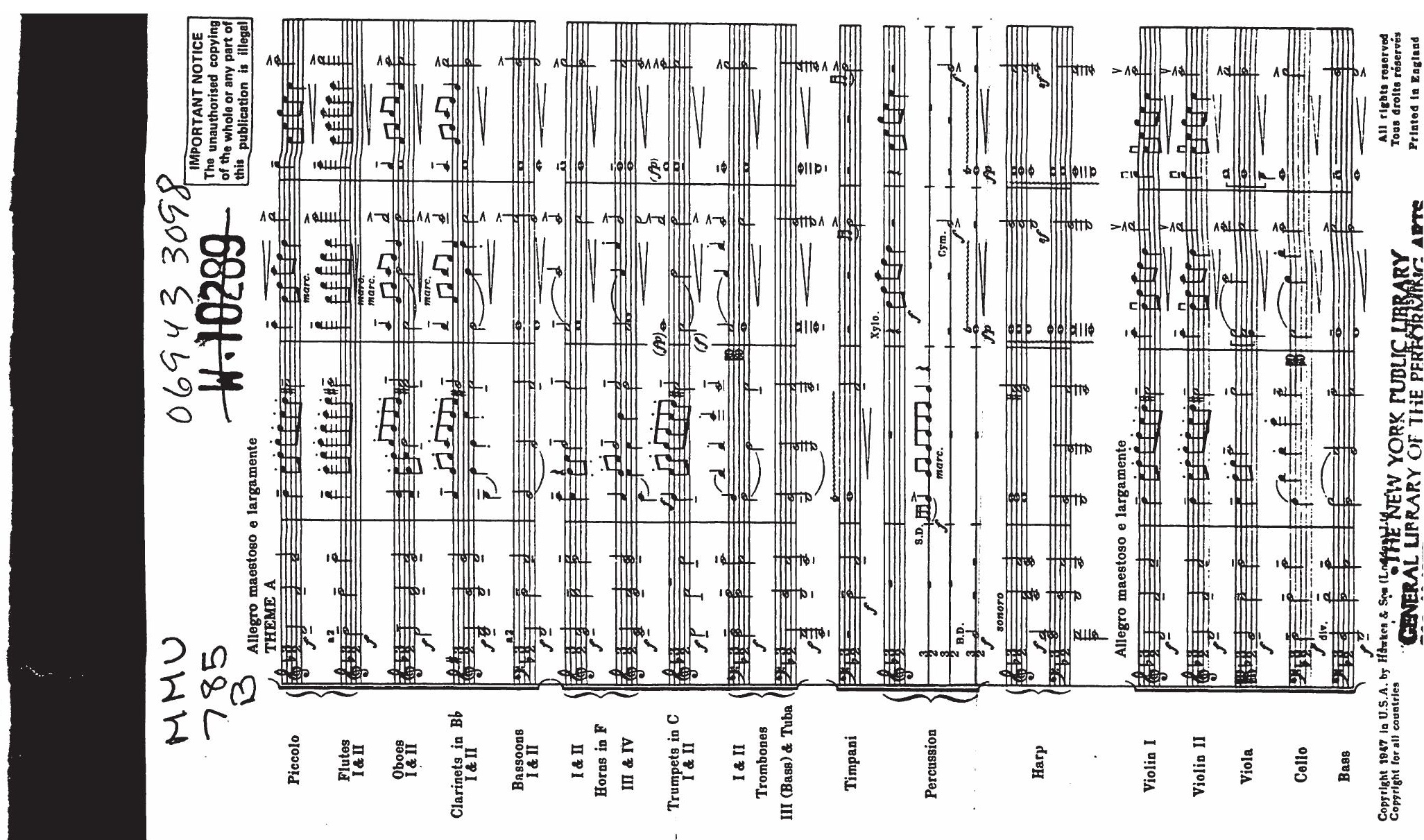




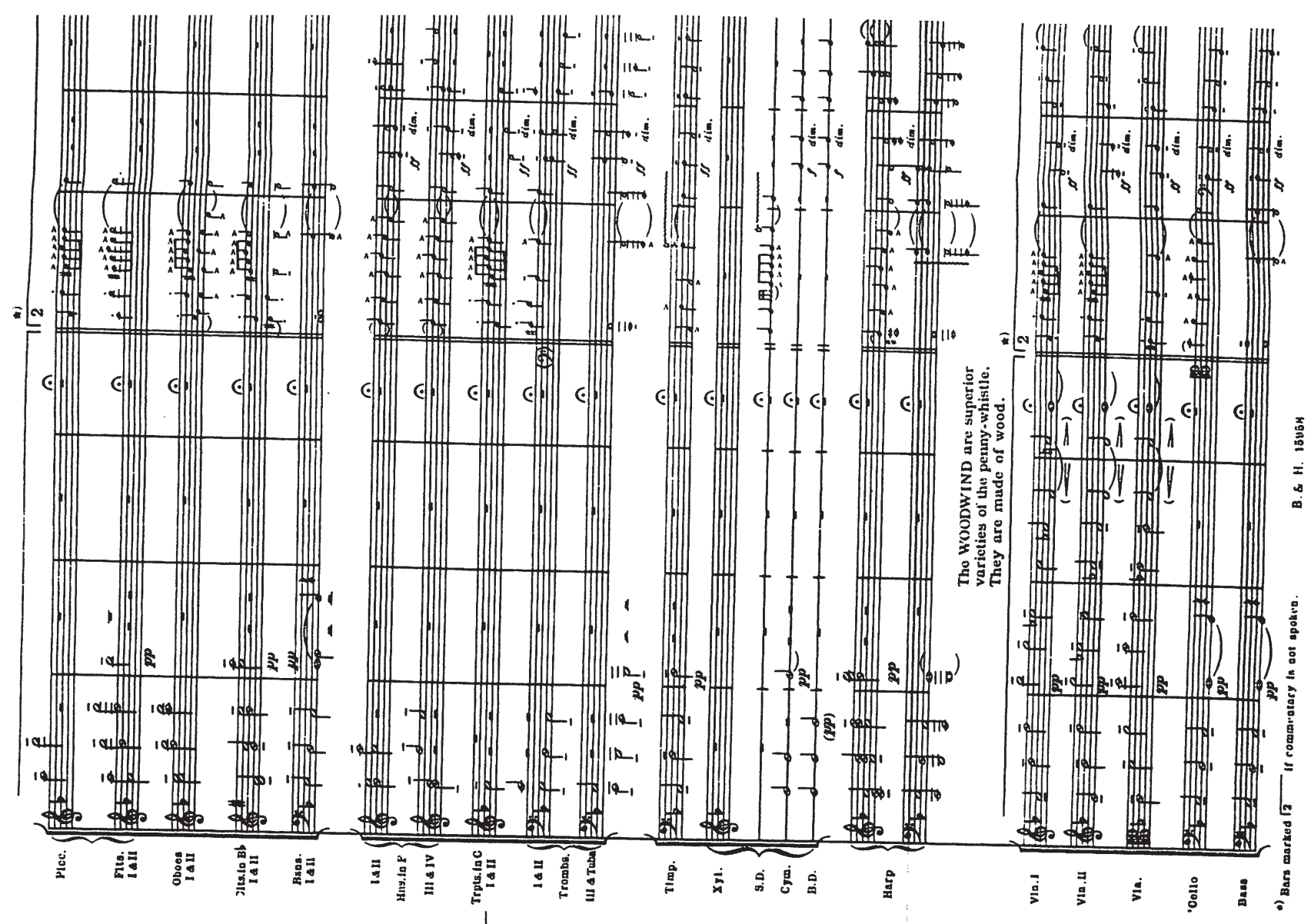

(1) 
ล.

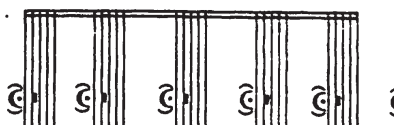

? $\mathrm{s}$ क

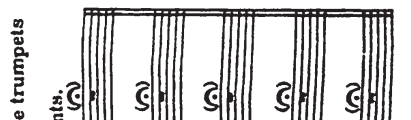

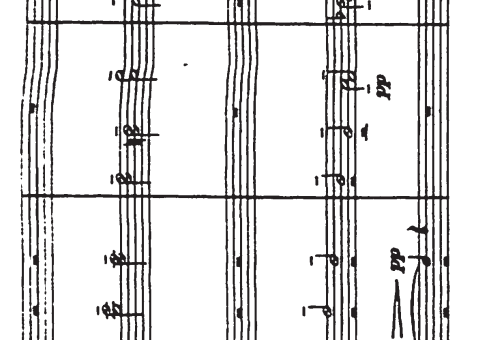

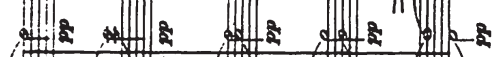
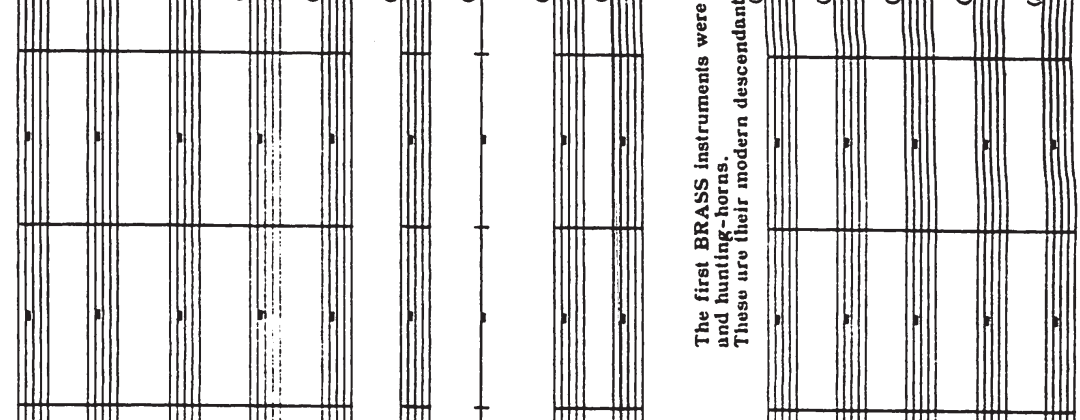

(i. 1 .

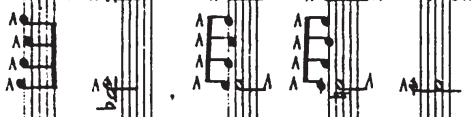

.

:曲

.

霜

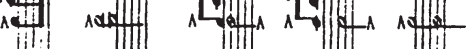

告

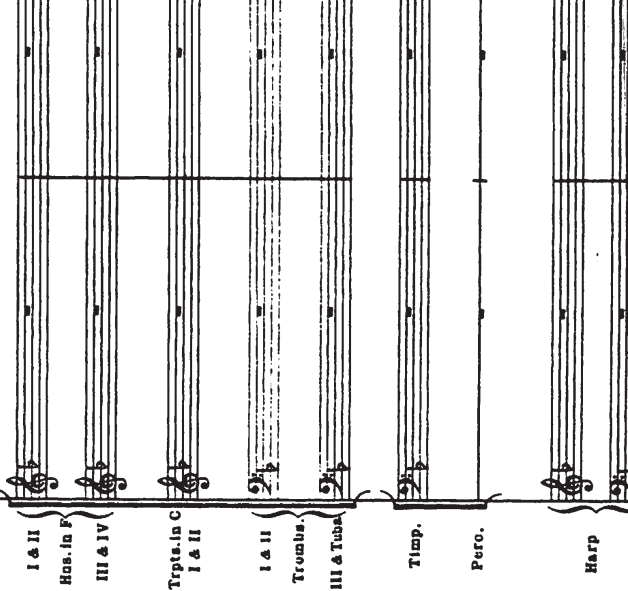

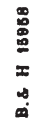

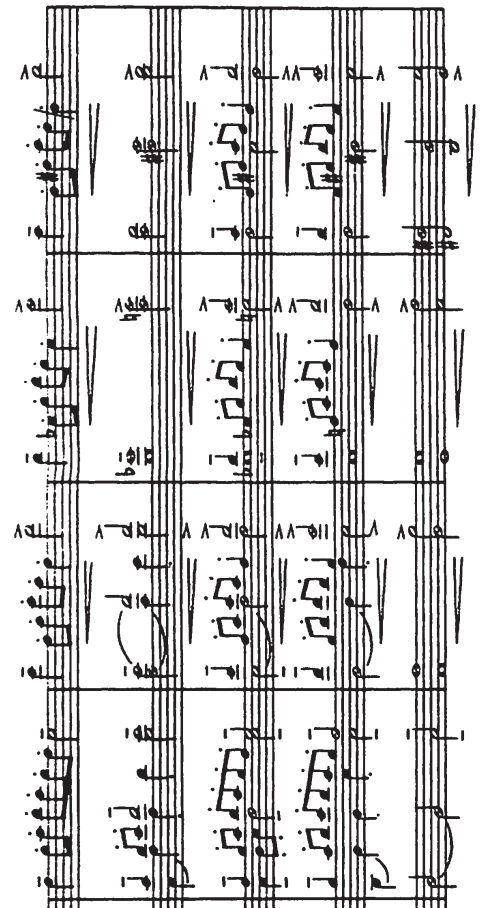

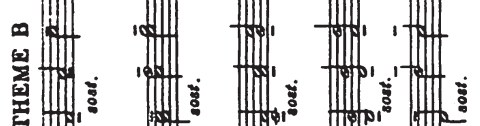

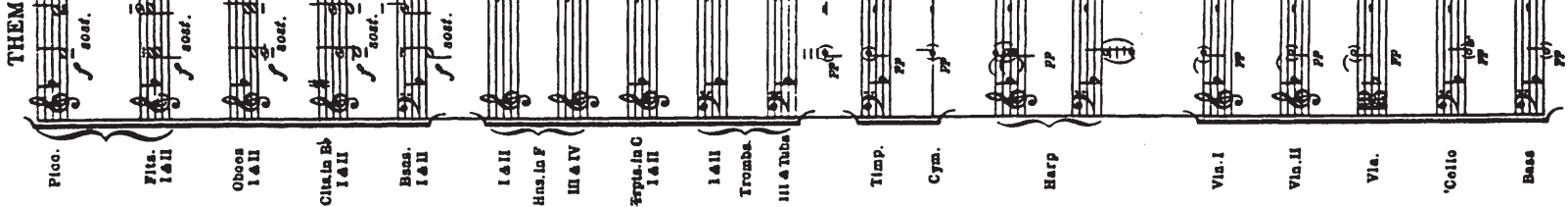

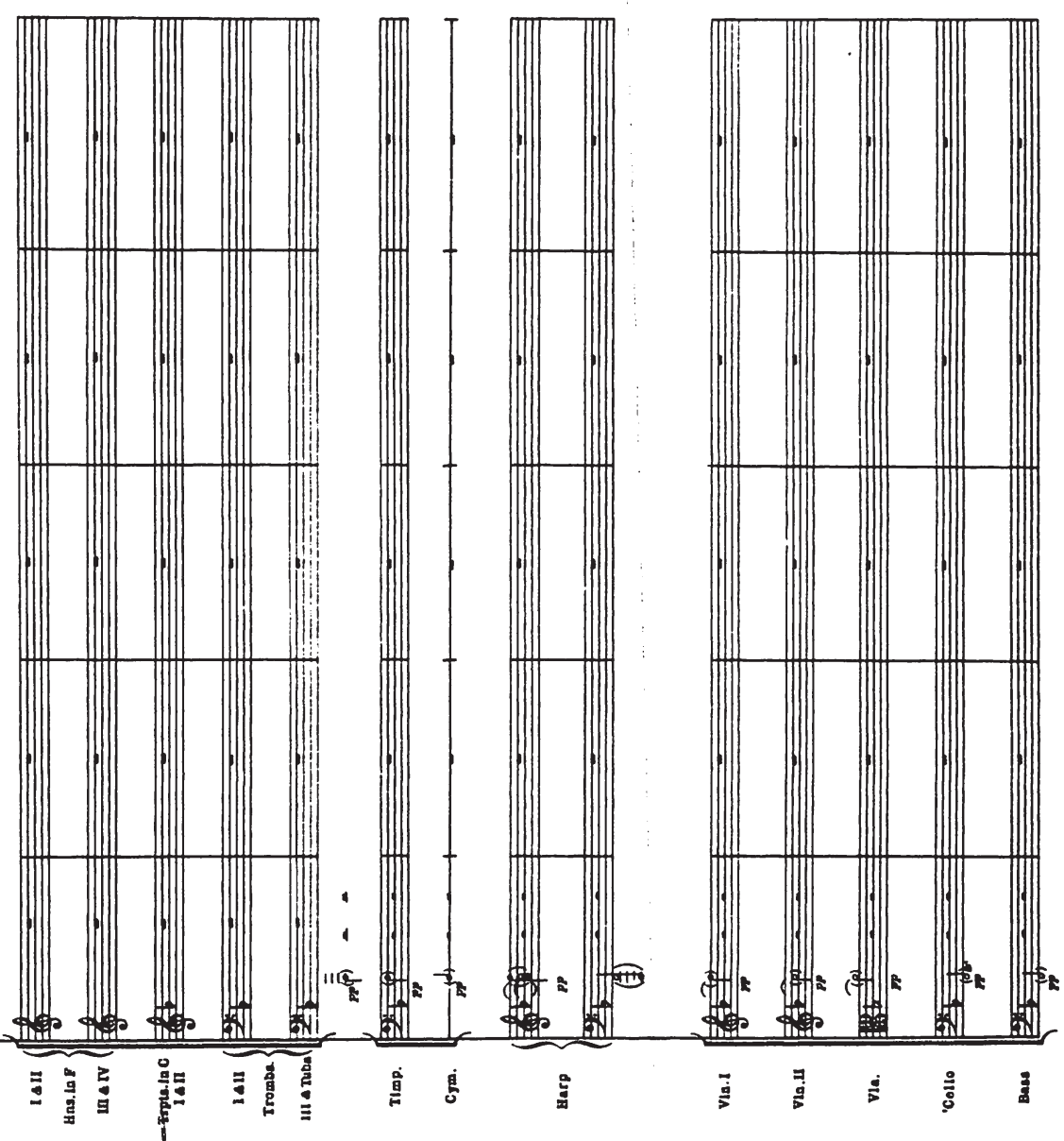



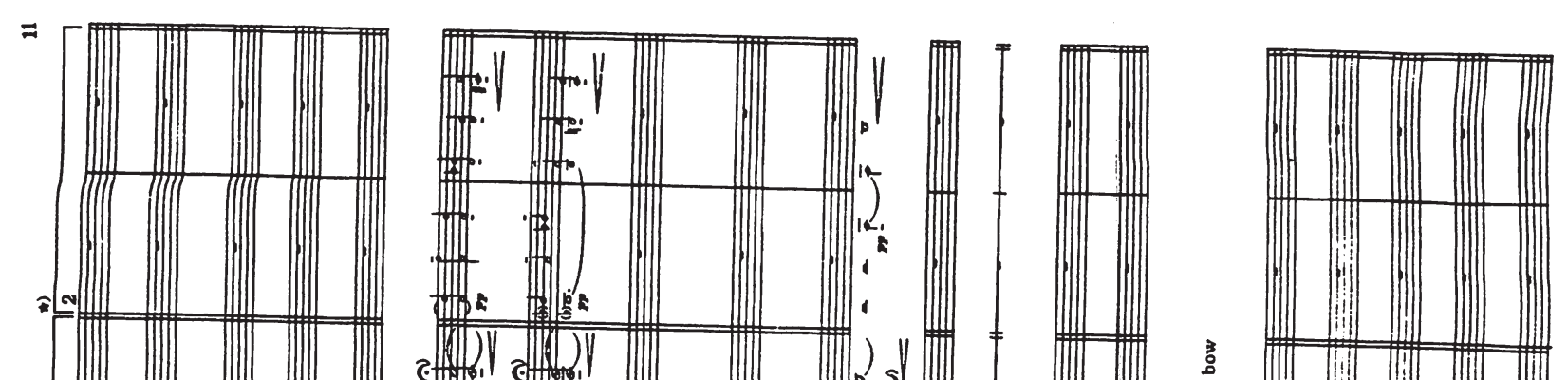

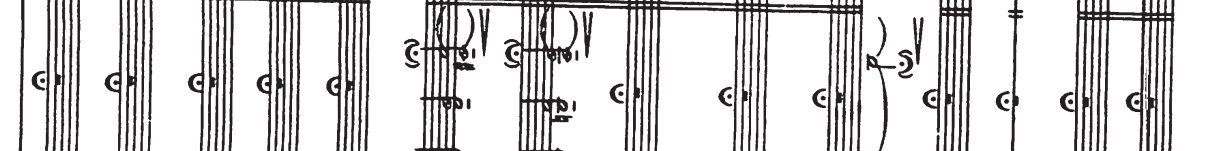
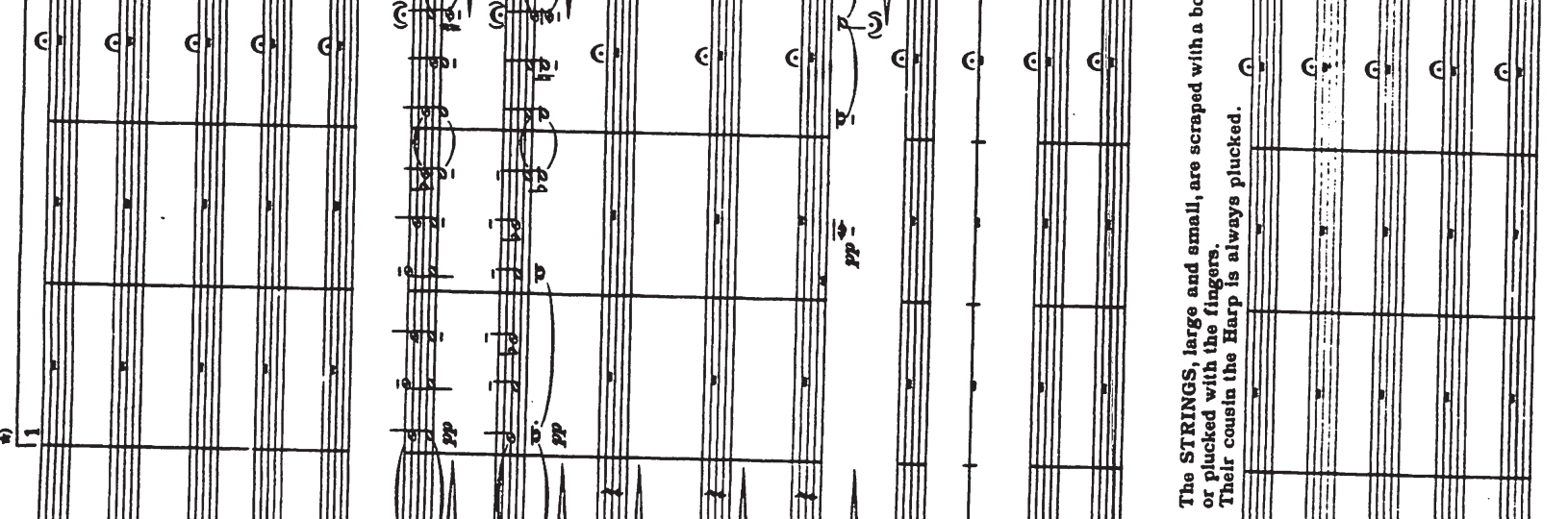

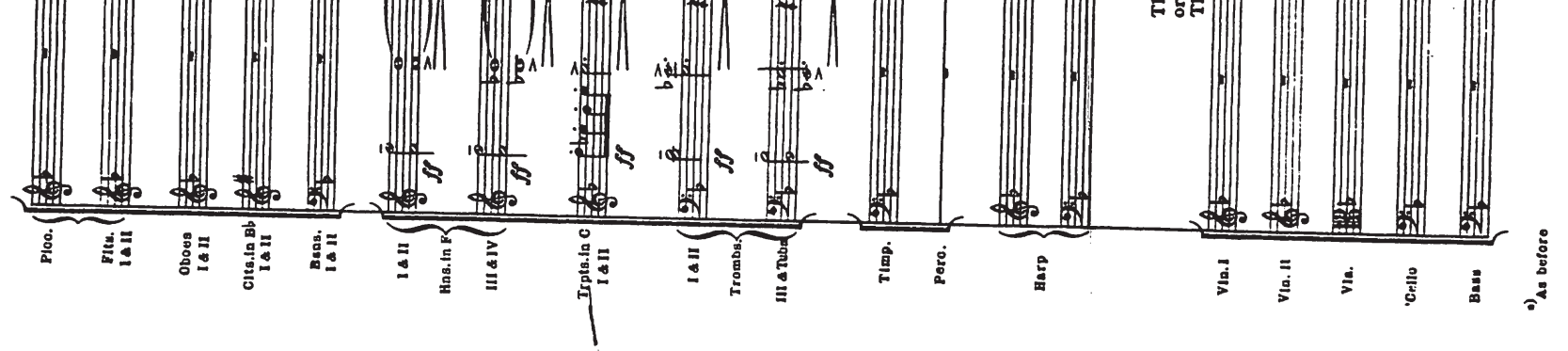
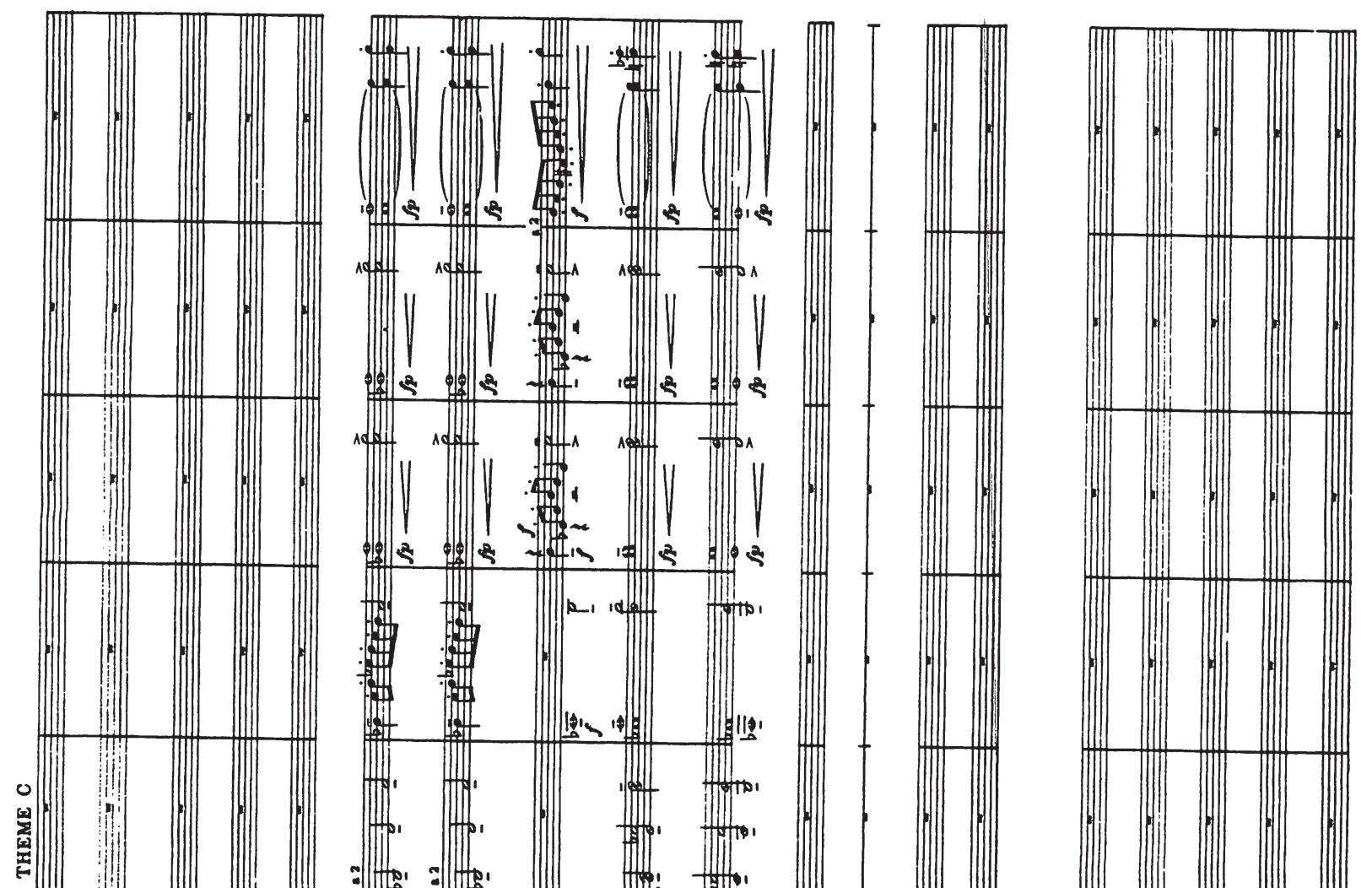

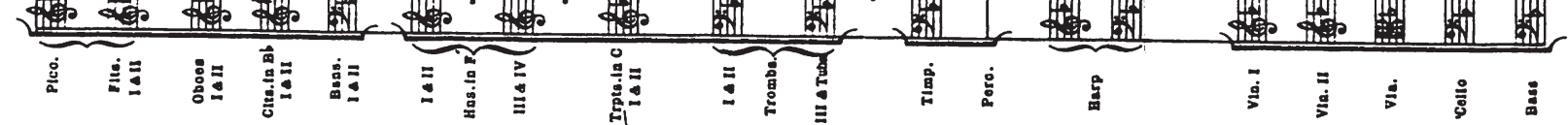



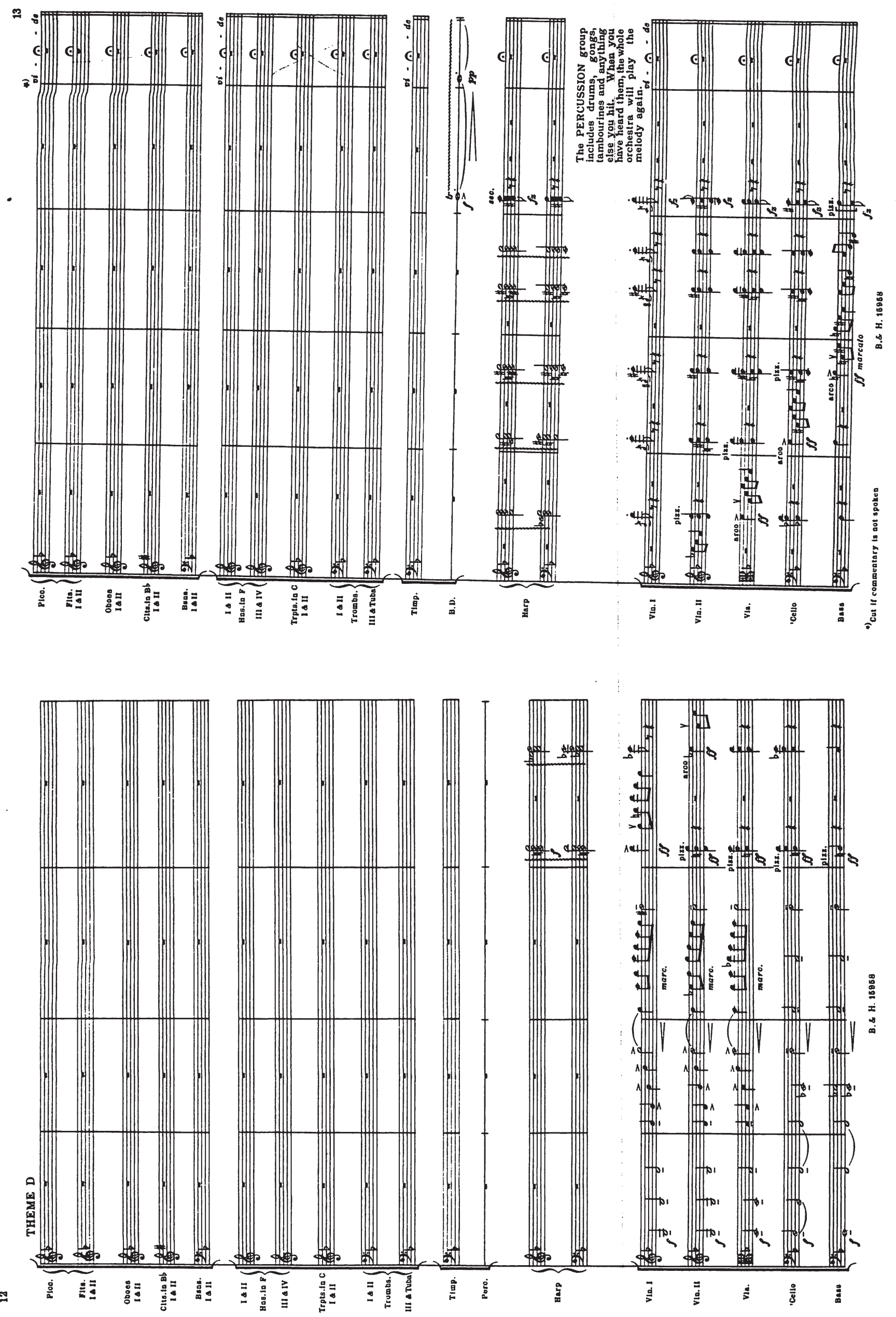
ต

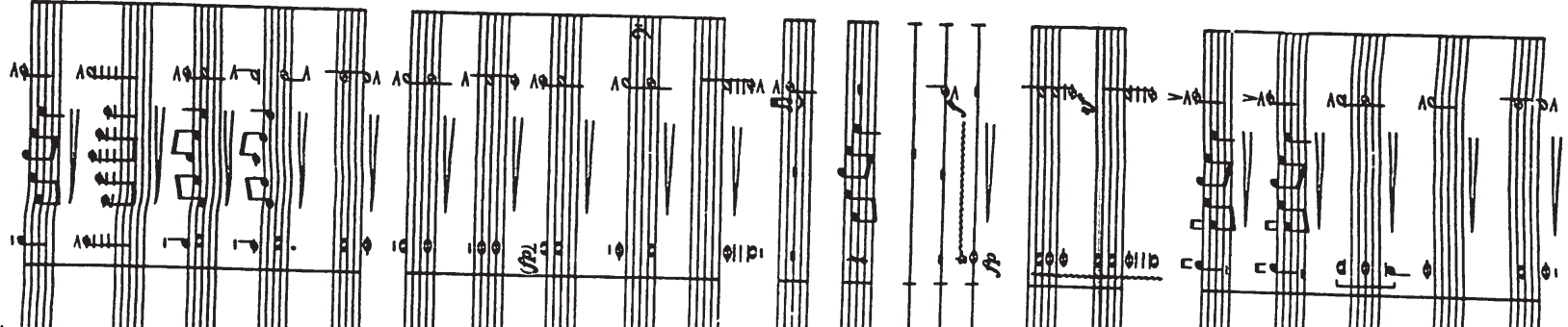

(1)

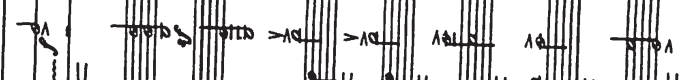

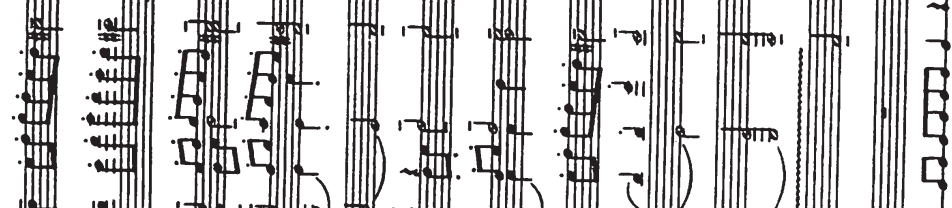

t

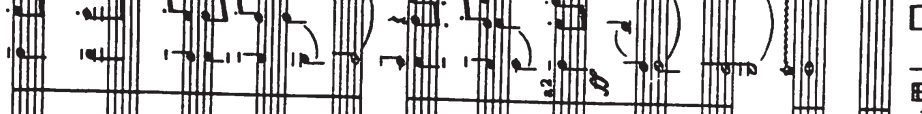

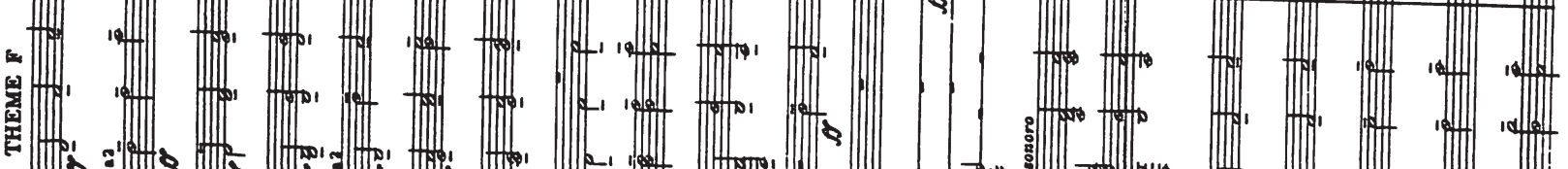

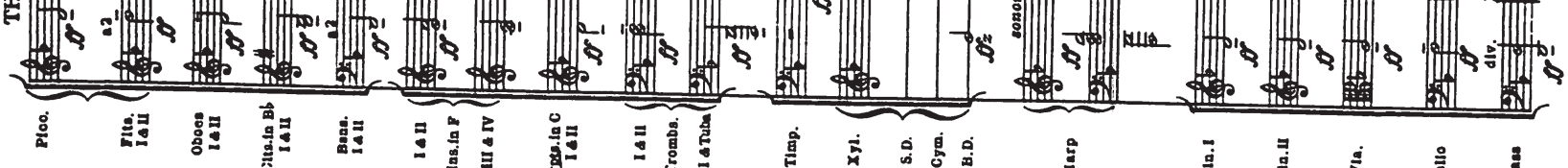

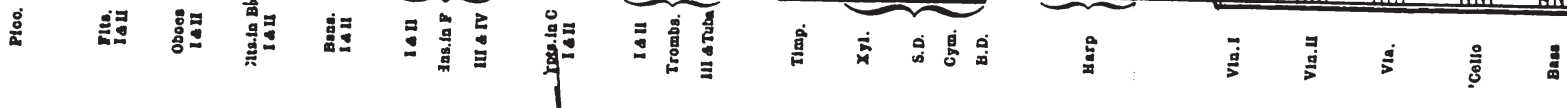
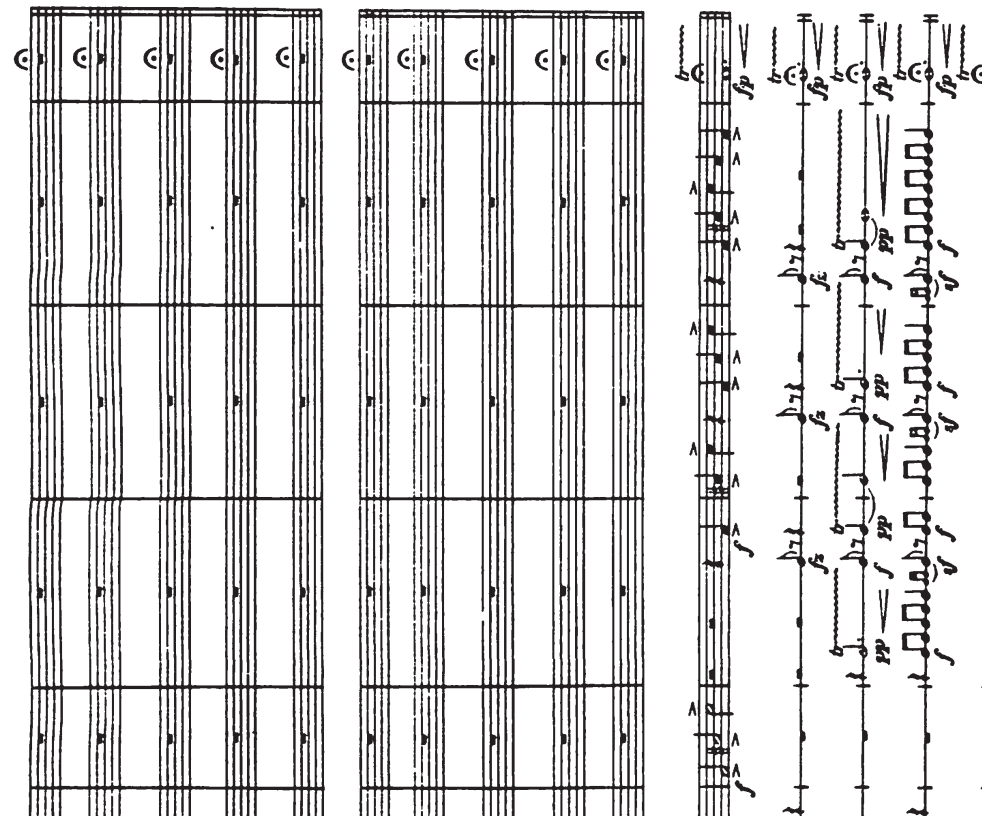

$\rightarrow$ से की

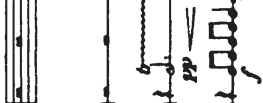

8.

3 . 8)

\section{$\stackrel{\infty}{\circ}$
$\dot{a}$
$\dot{x}$
$\dot{0}$}


$=$

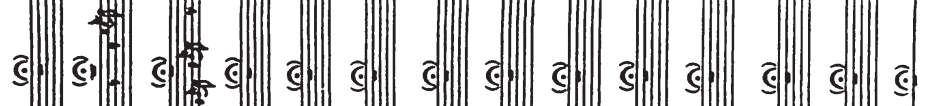

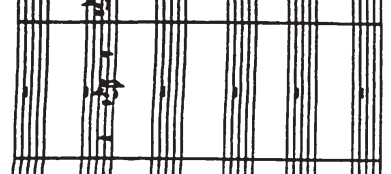

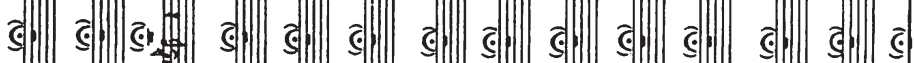

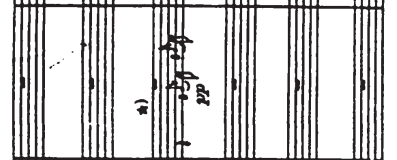

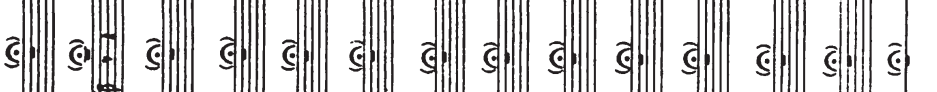

||

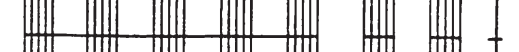

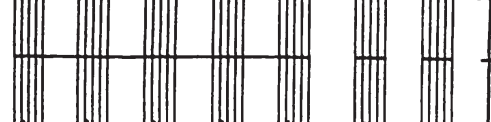

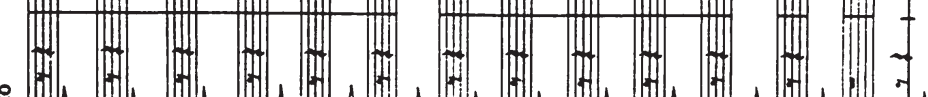

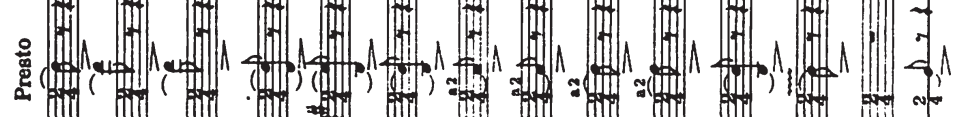

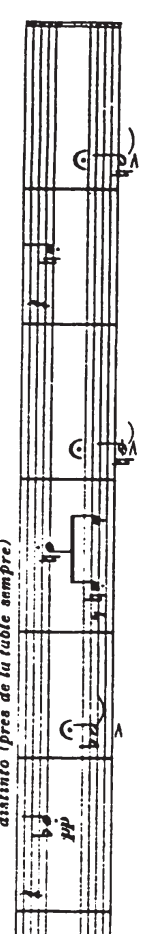

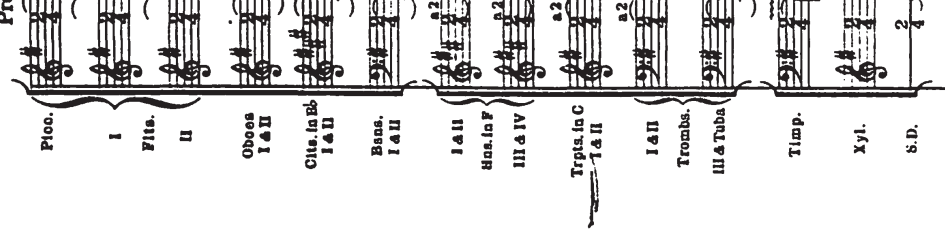

T.

(1)

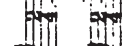

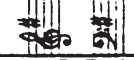

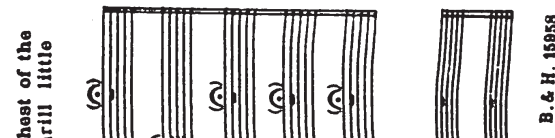

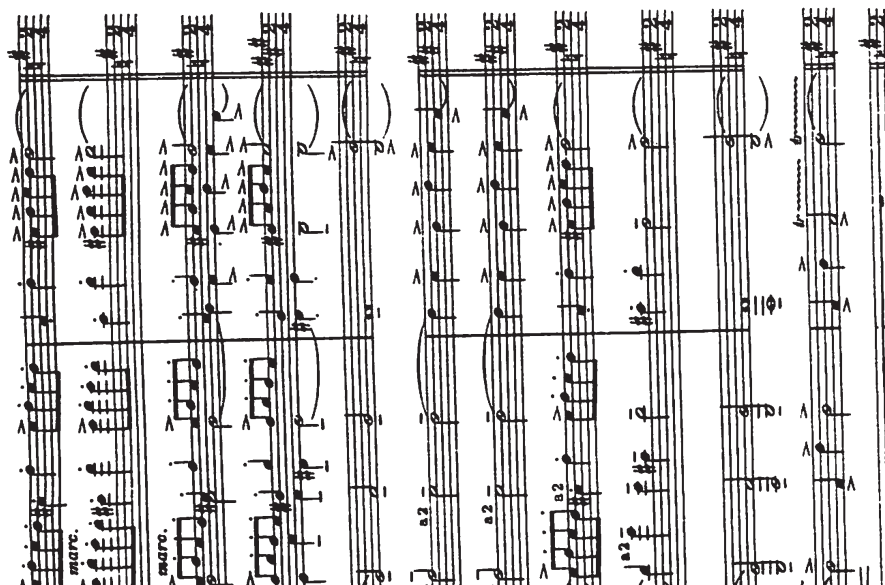

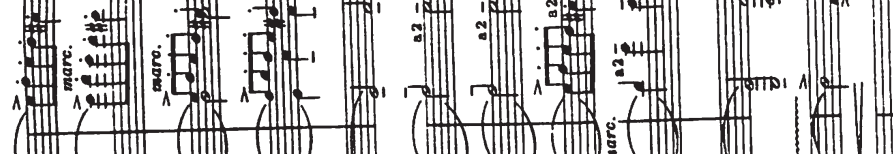

LD $=0$

膟

牒

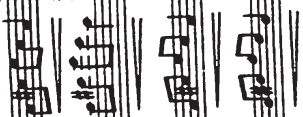

$\rightarrow 1 \quad$ a m

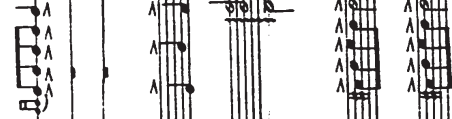

(1)

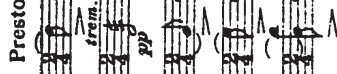

III) niv on a

产

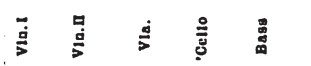

the 

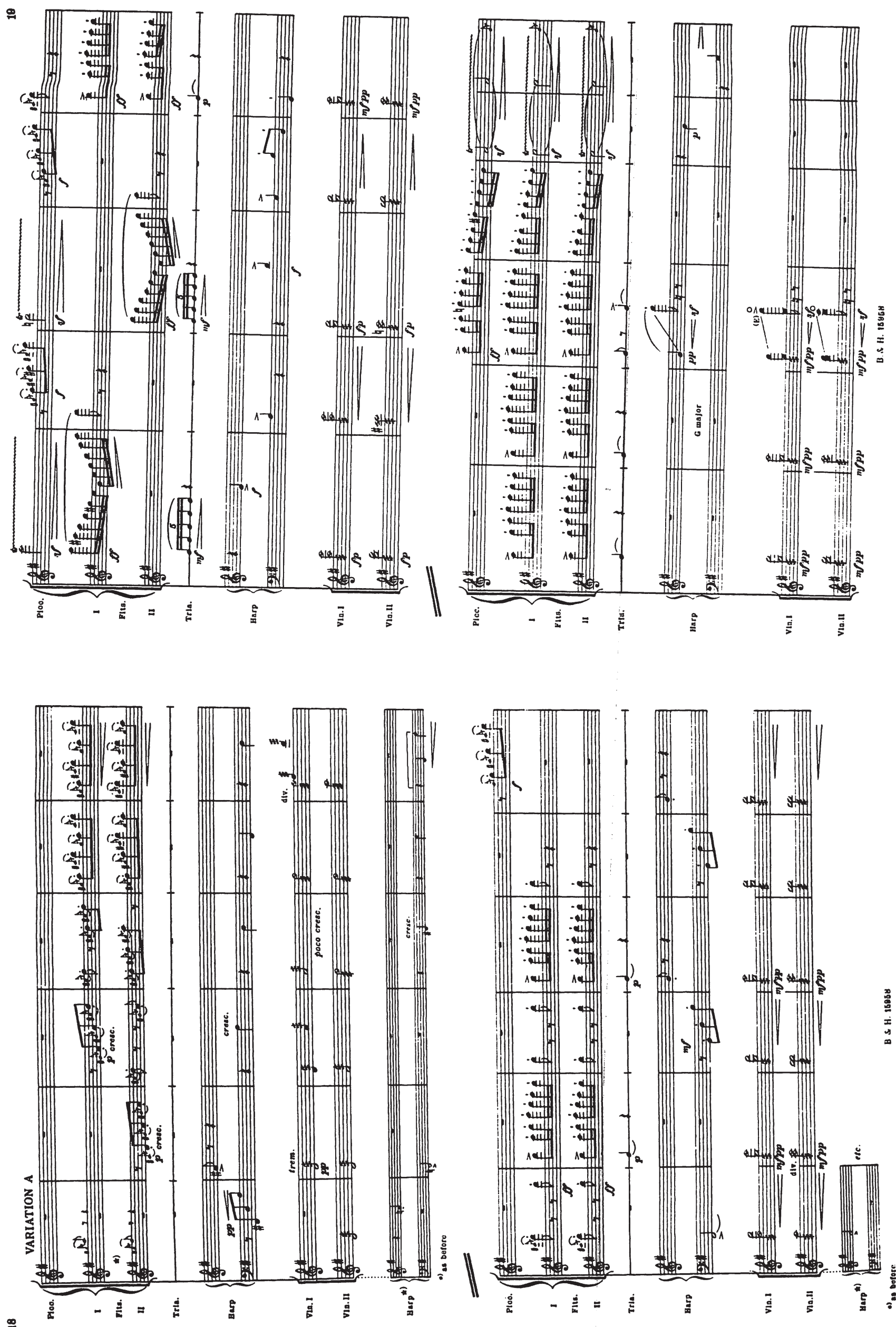

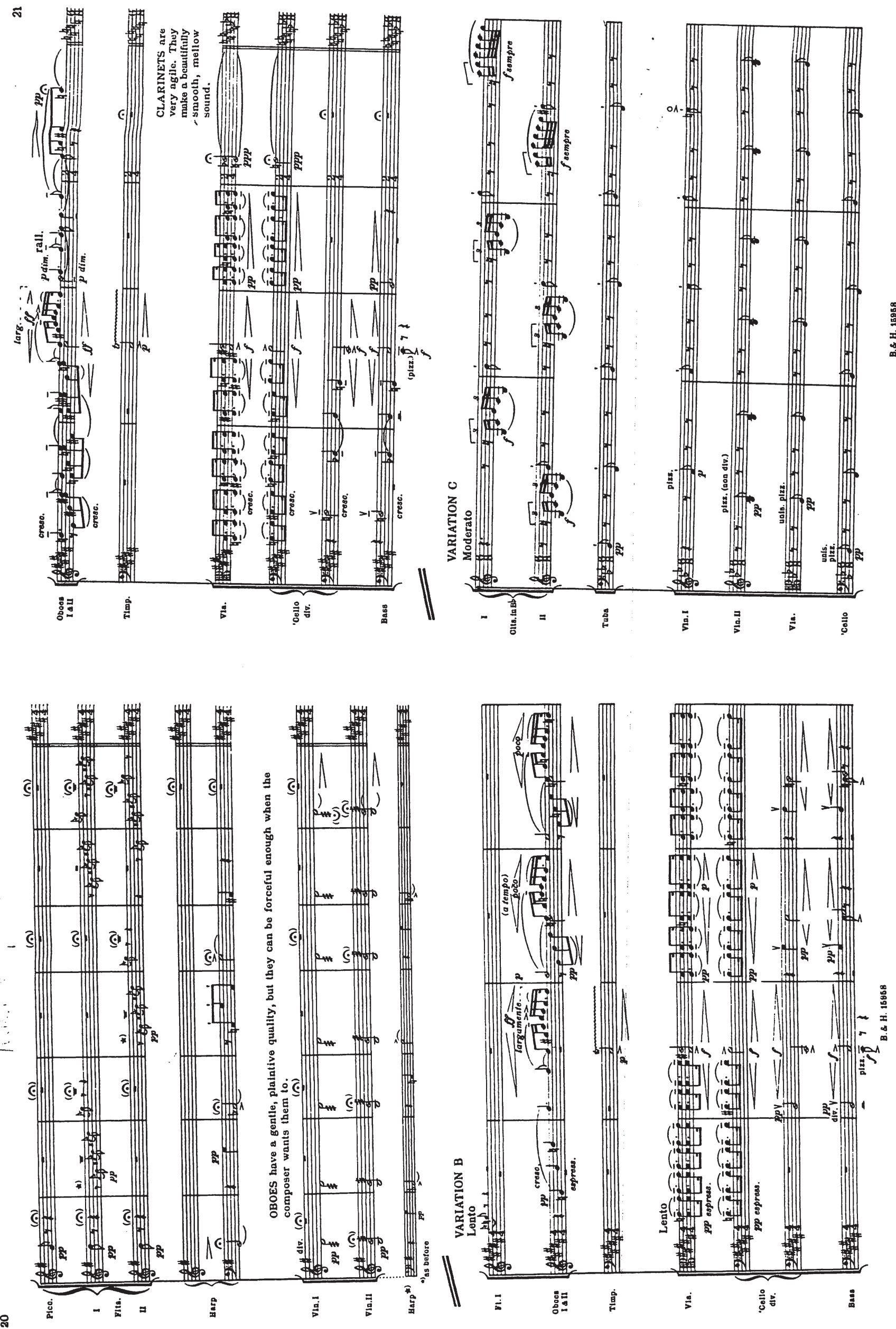
$\infty$

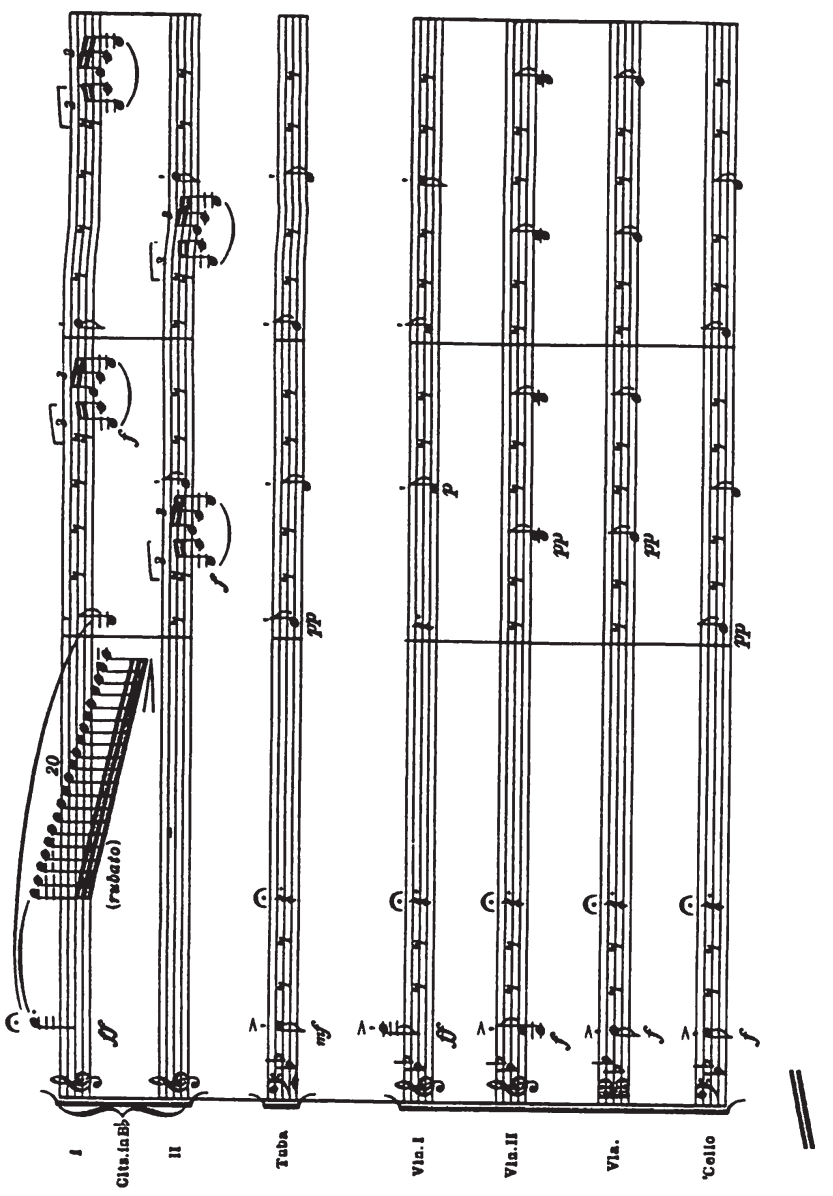

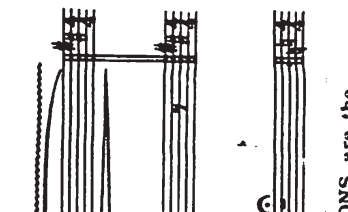
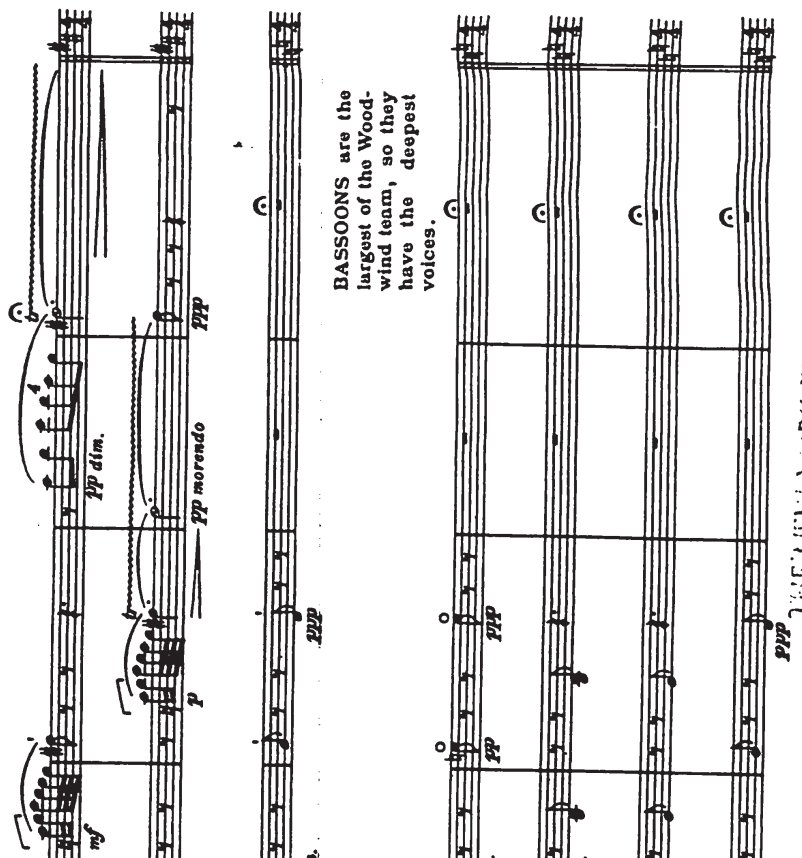

政

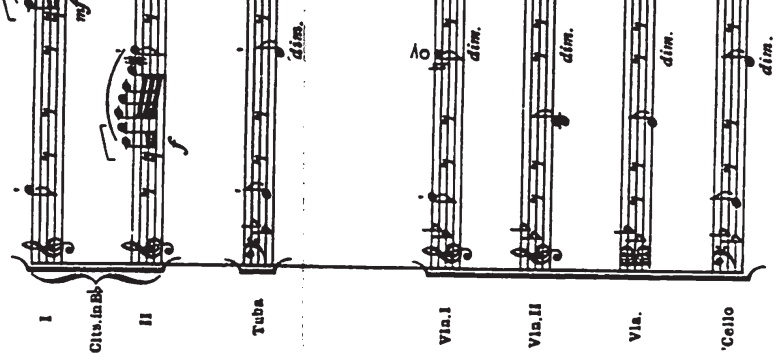

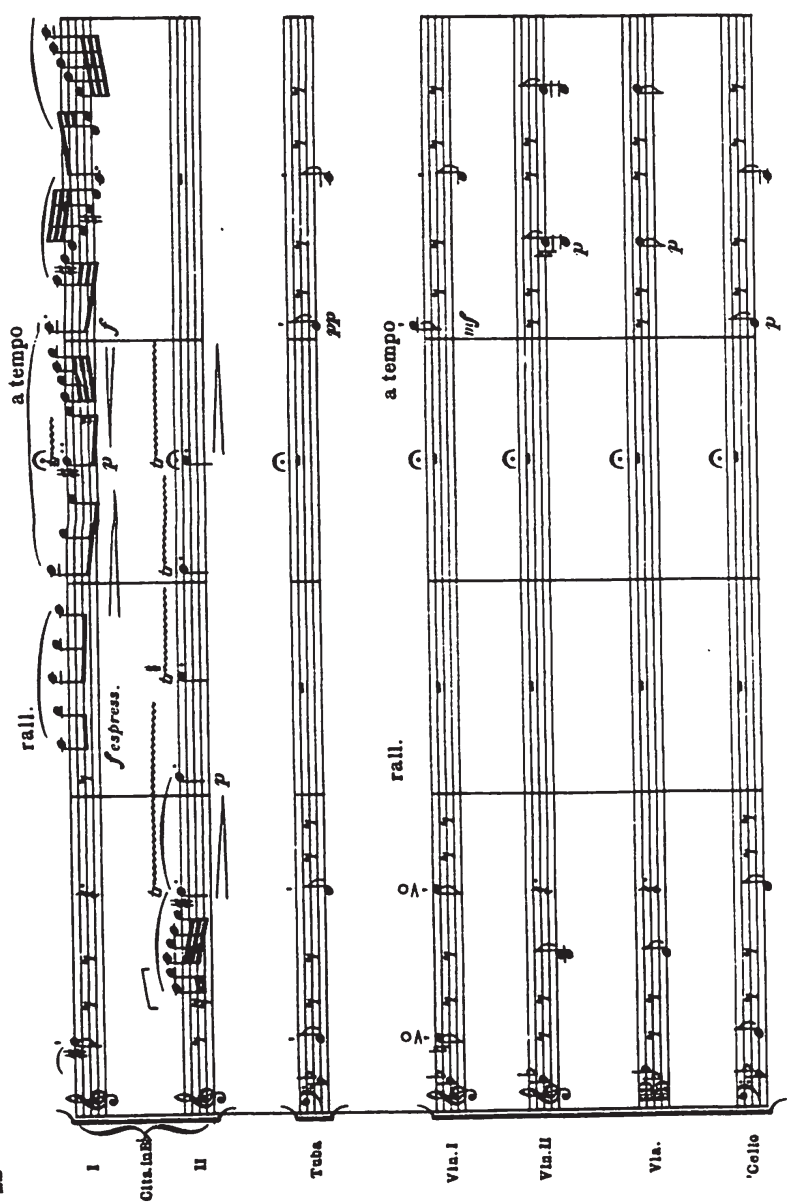

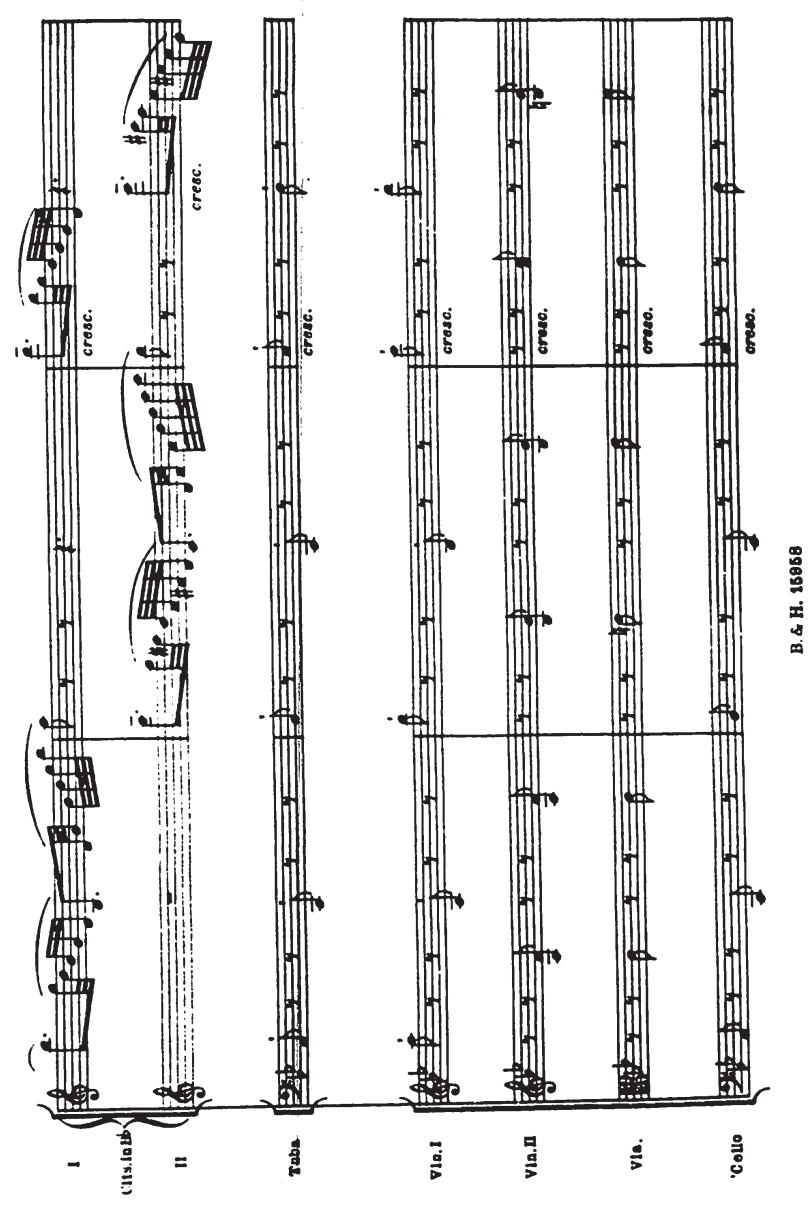


ํำ
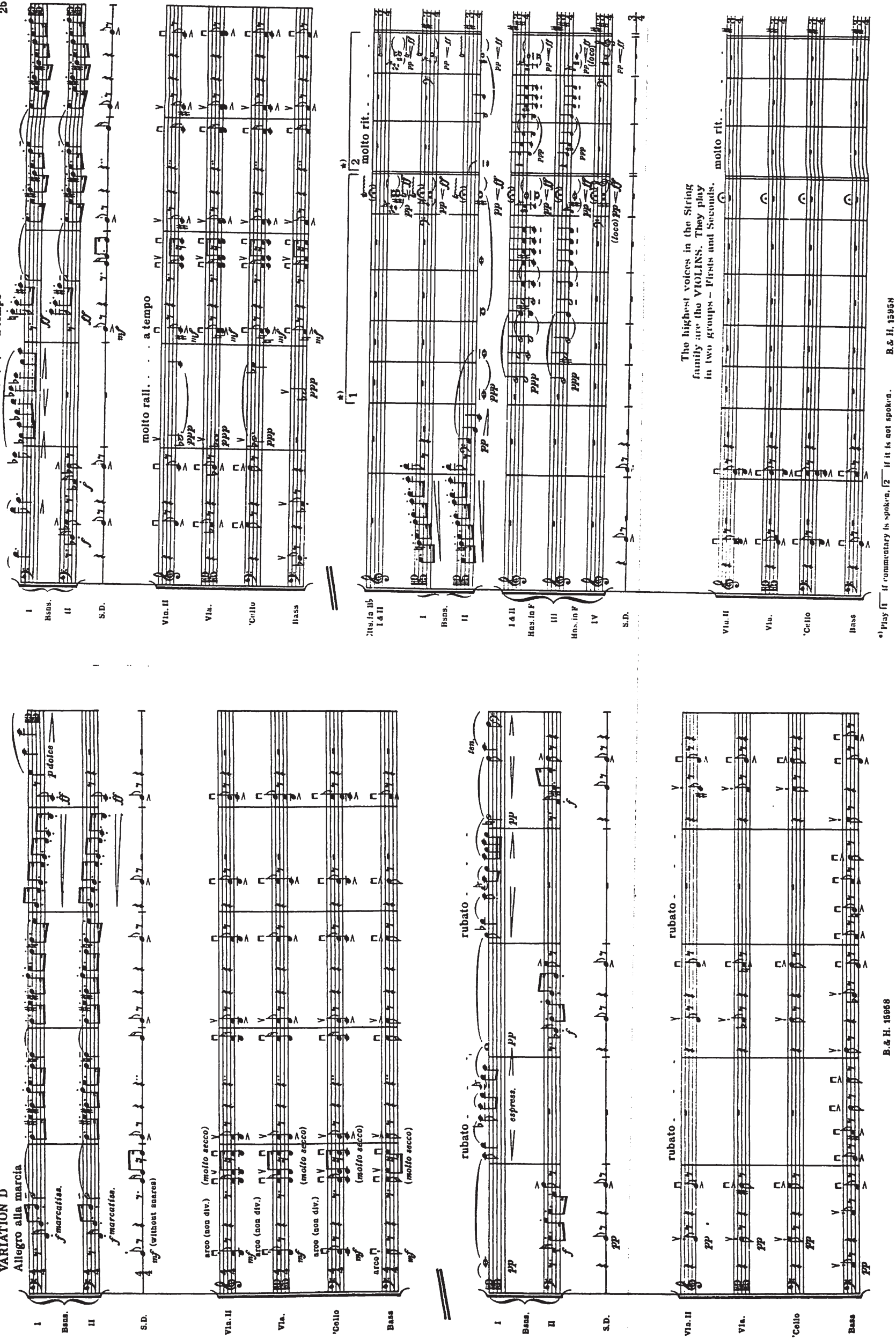
(n)

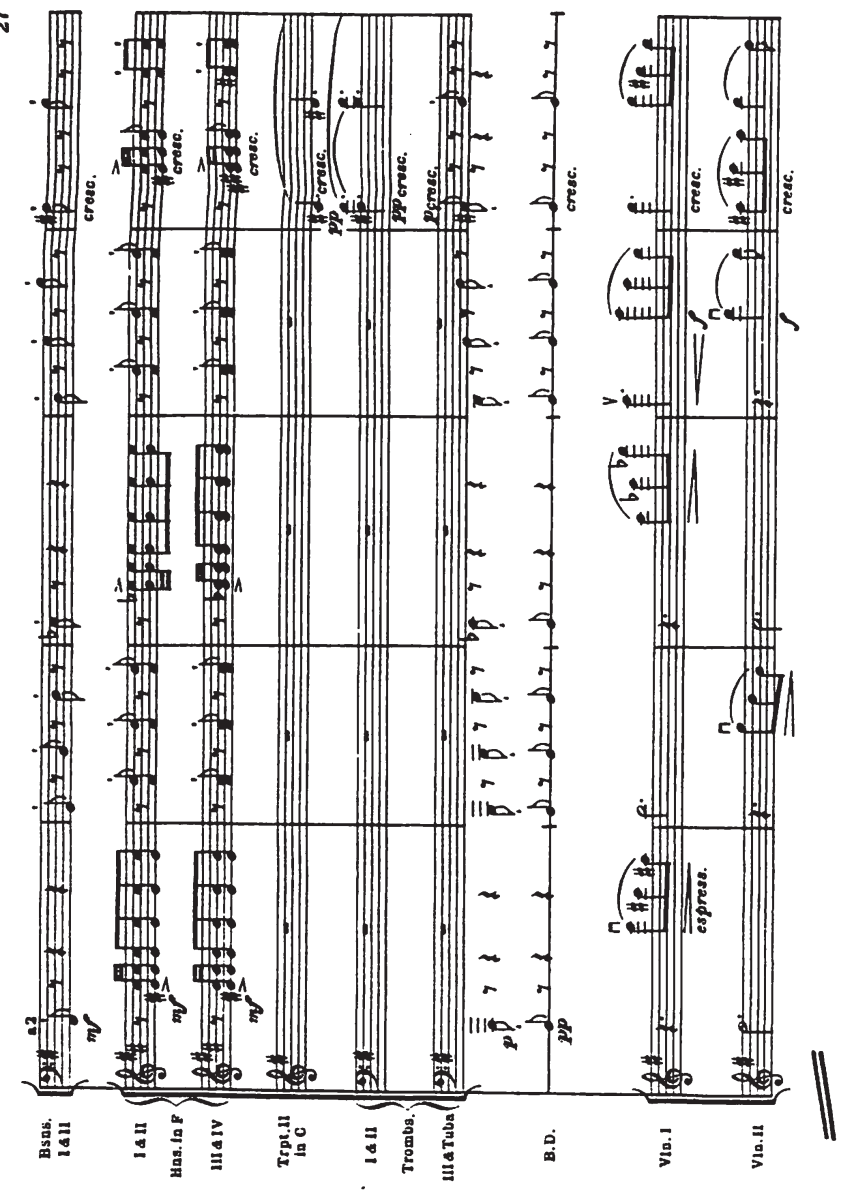

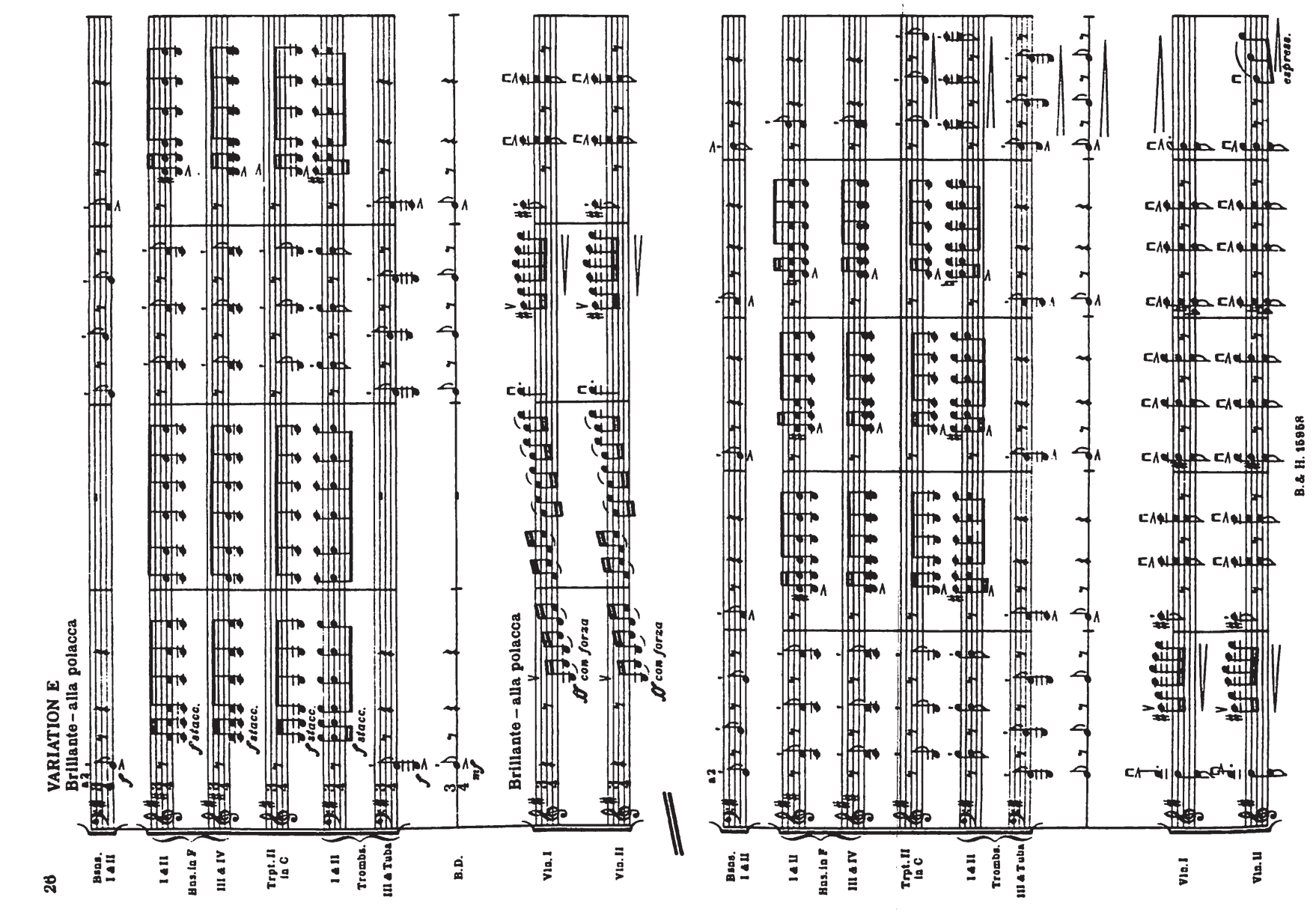


ต

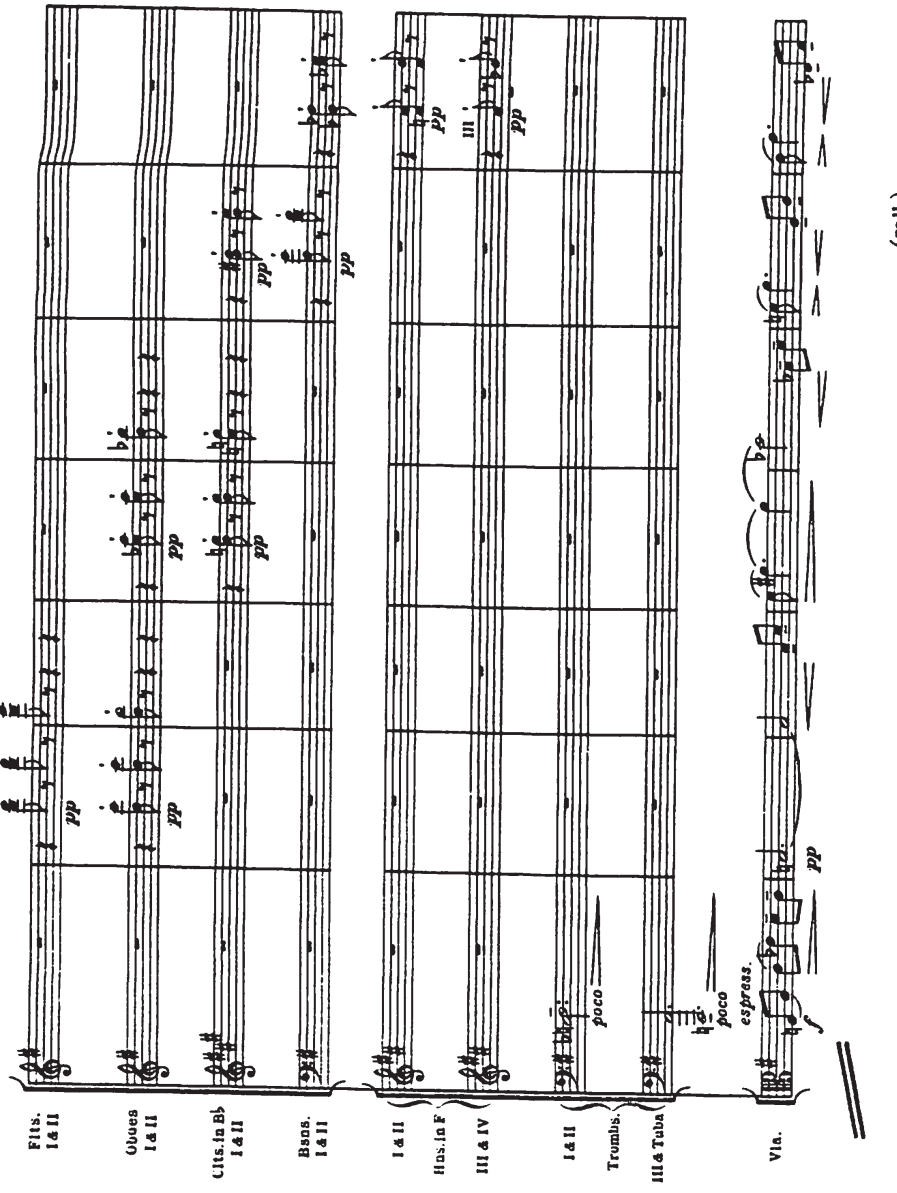

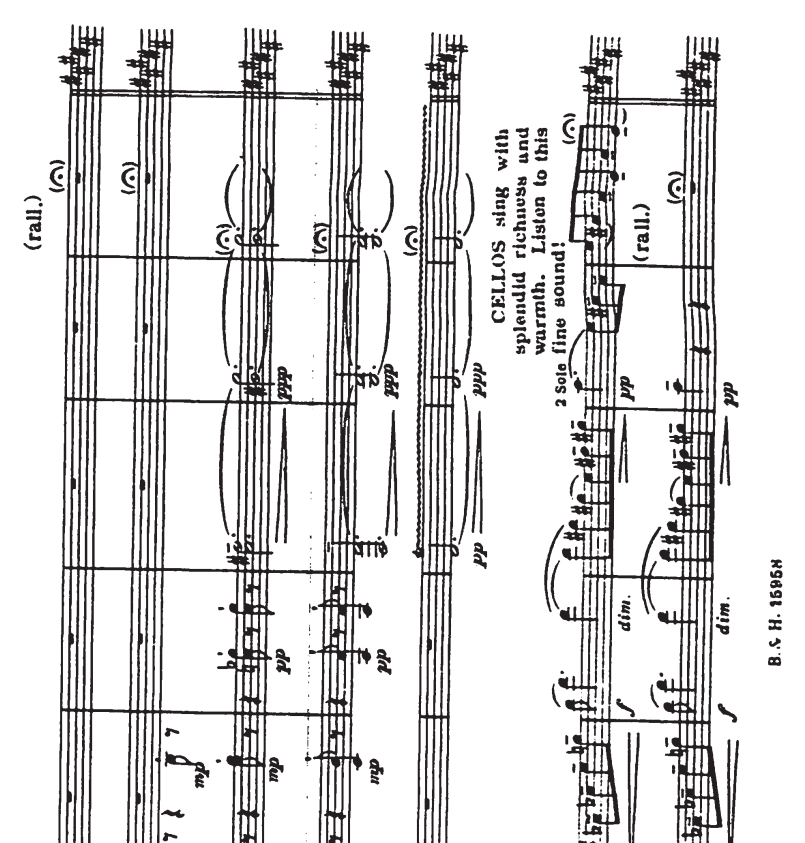

$\left(\ldots-\infty \infty^{2}\right.$

||
制

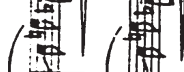

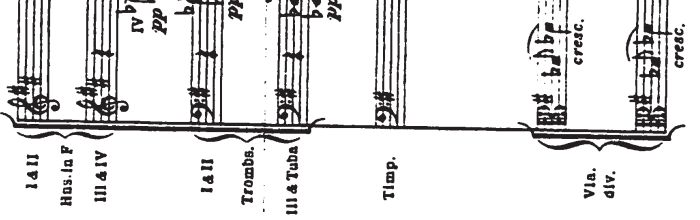
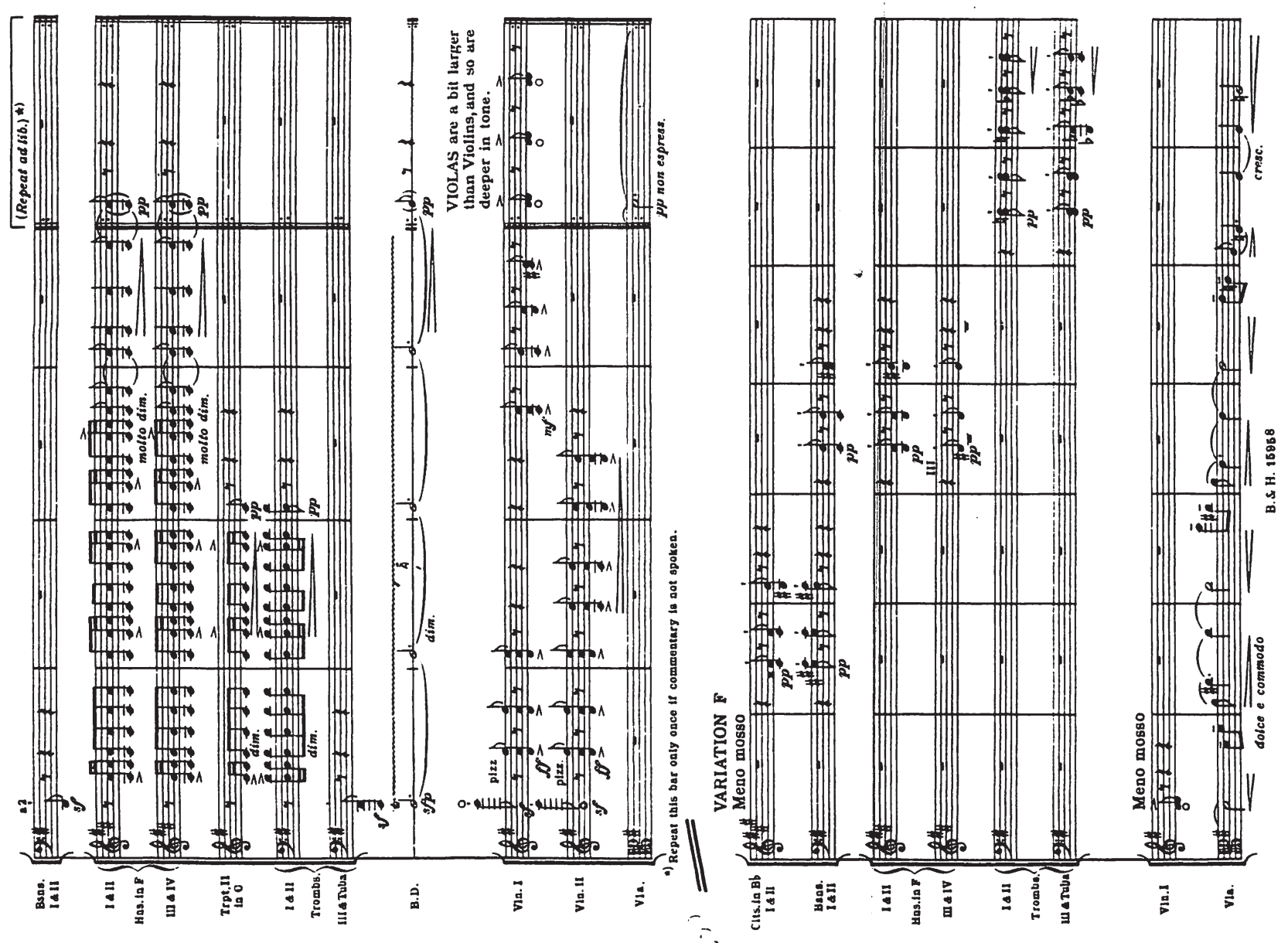

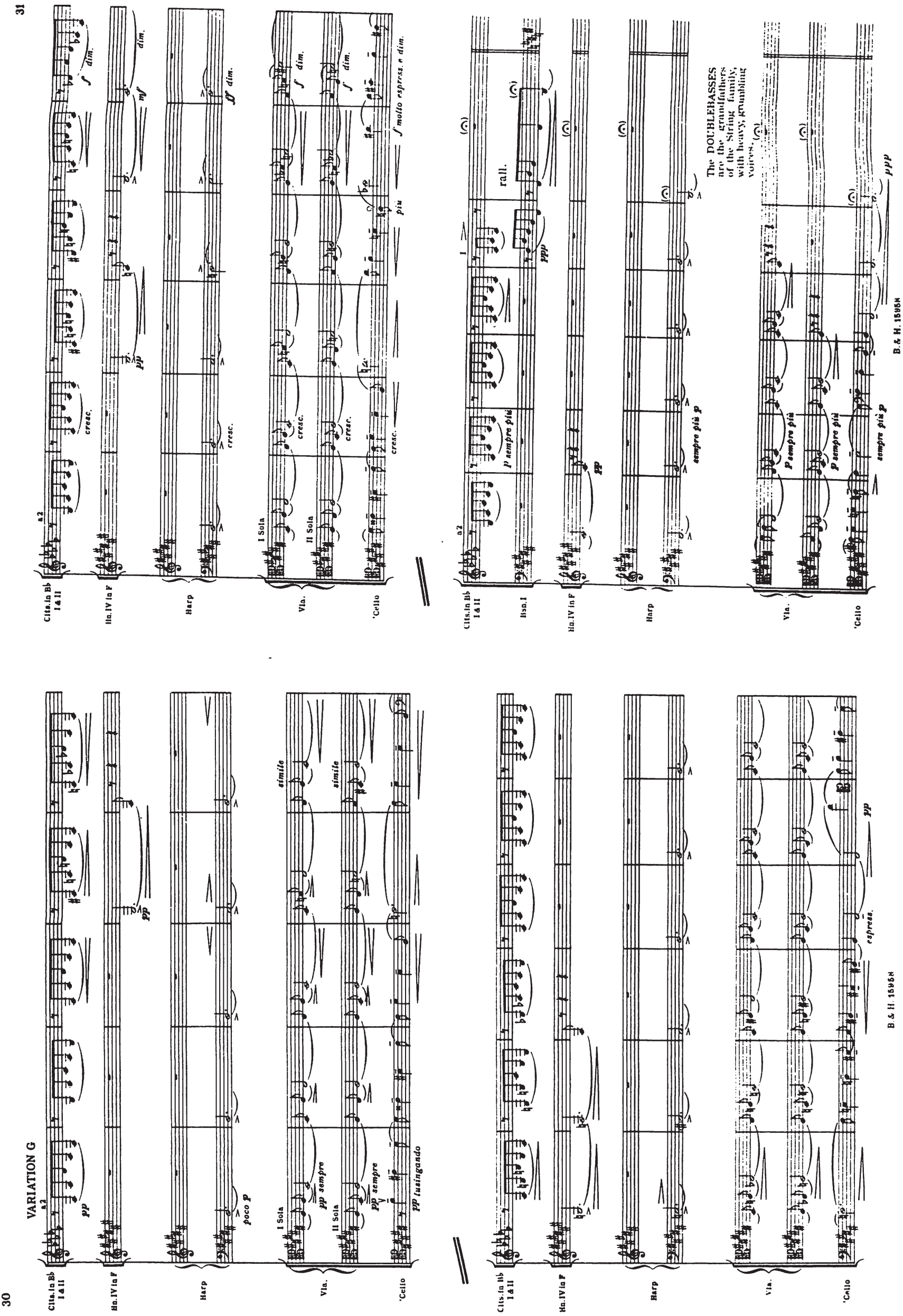

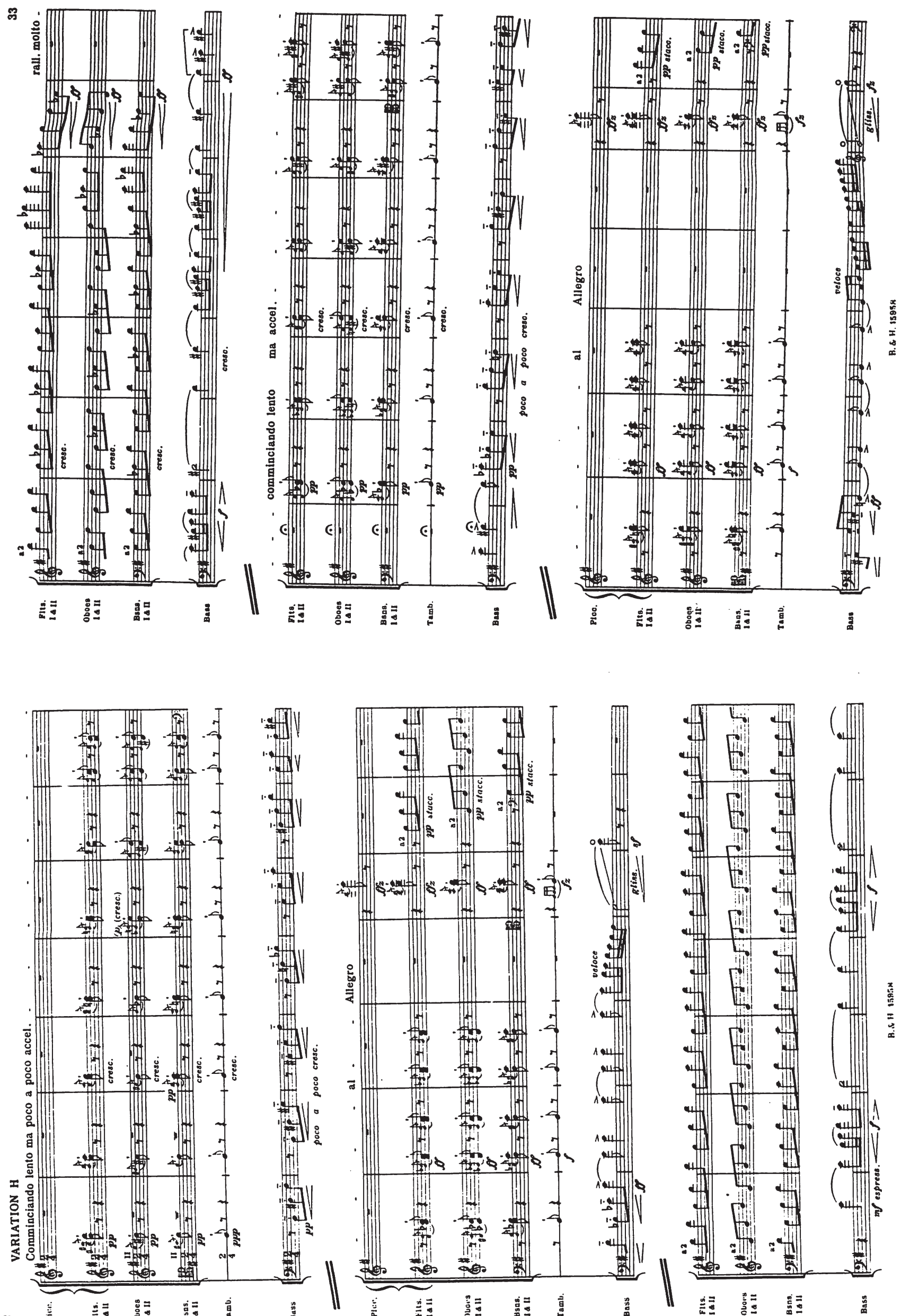
๓̊

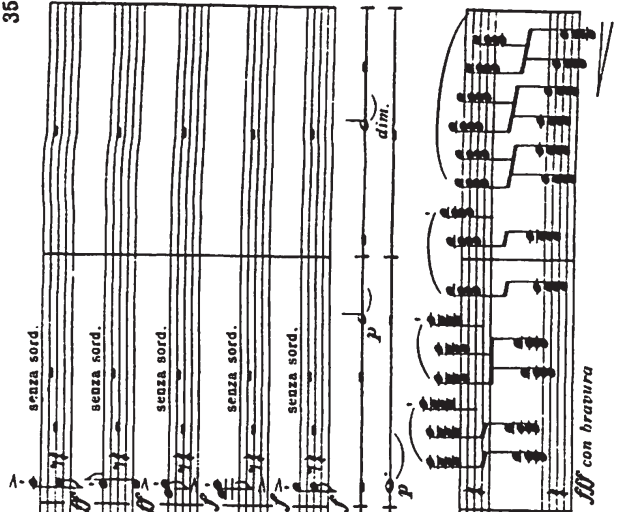

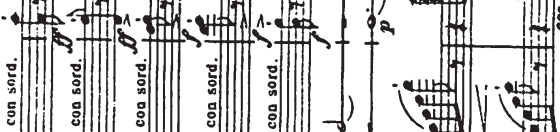

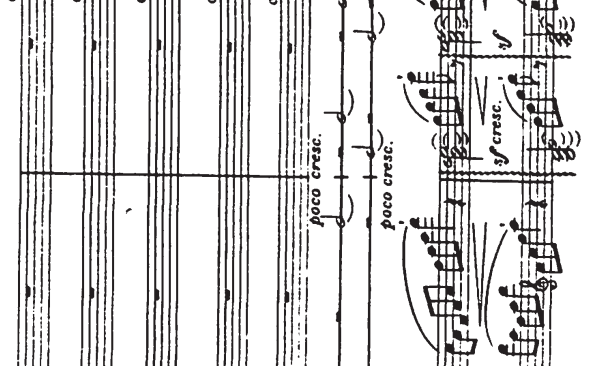

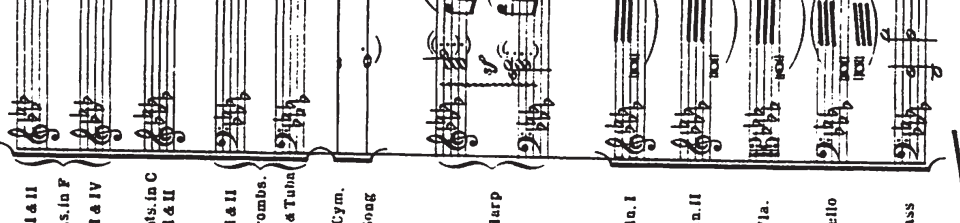

(I.||

Hep (I.)

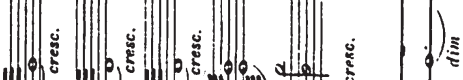

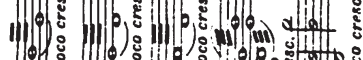

-1 .

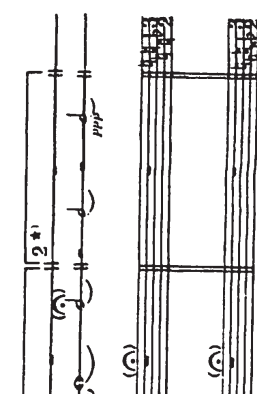

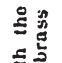
(1)

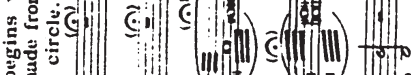

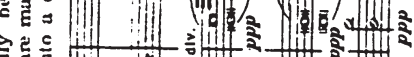
像

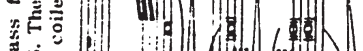

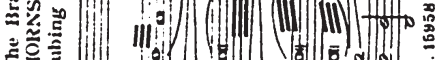

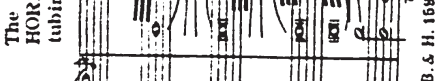
10. 1) (QiiI)

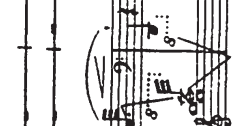

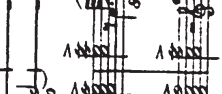
(

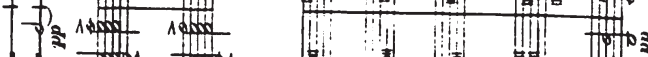
b) $\rightarrow) 15$

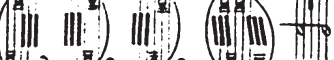

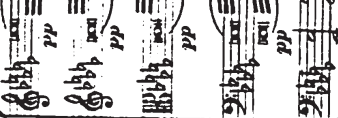

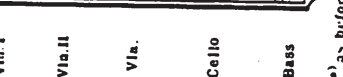

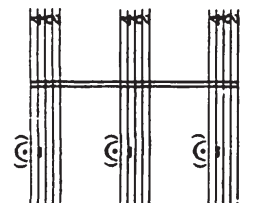

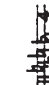

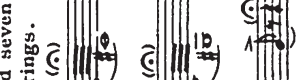
品
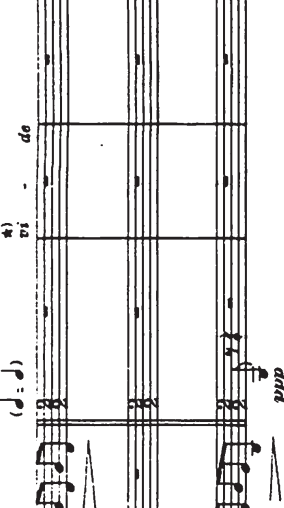

仃 曲 搆 过 1 贯制

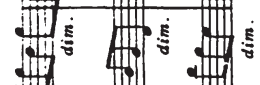

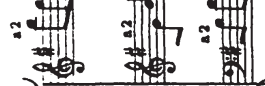

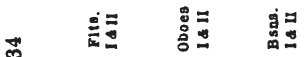
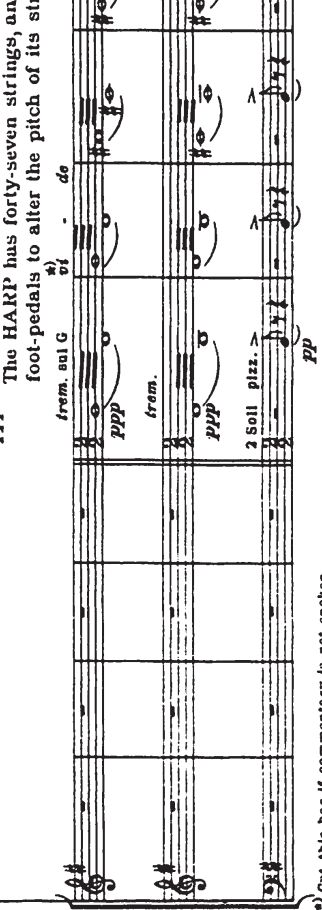

亭离总

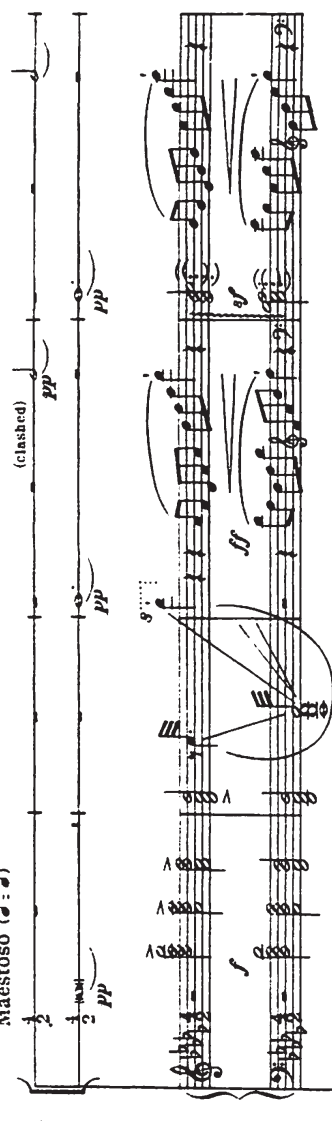

영

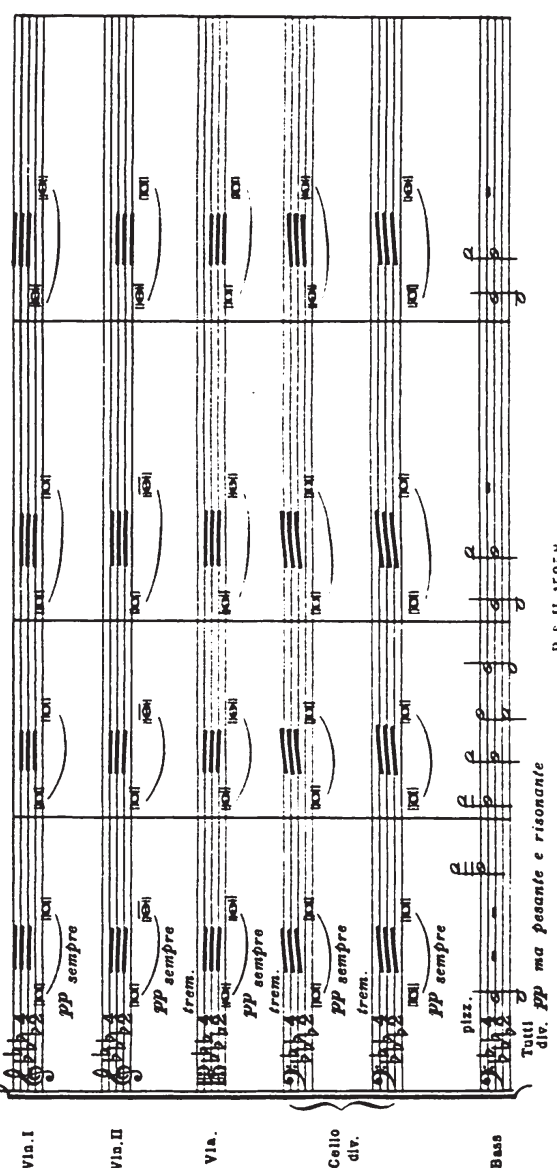



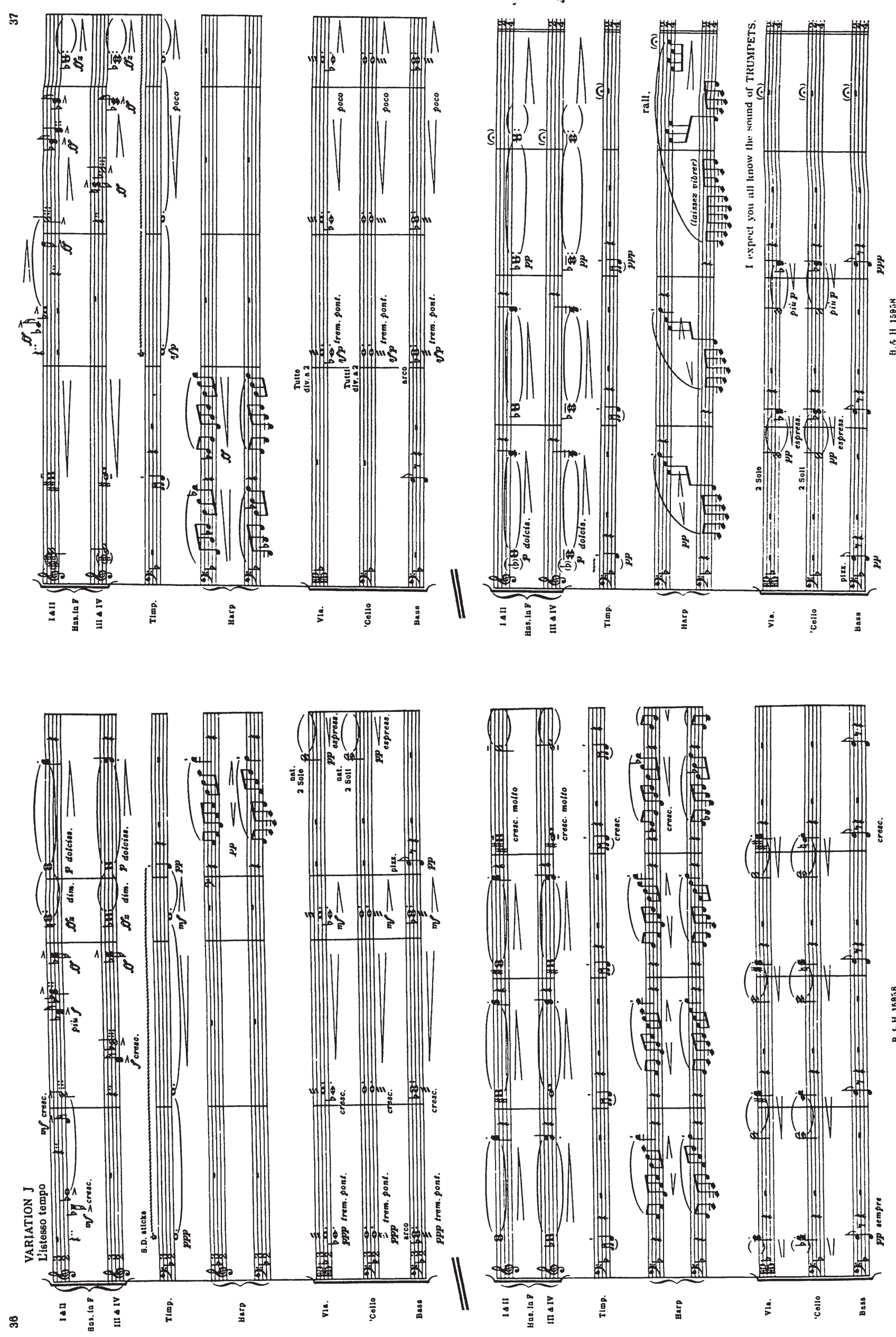

(册、 姗
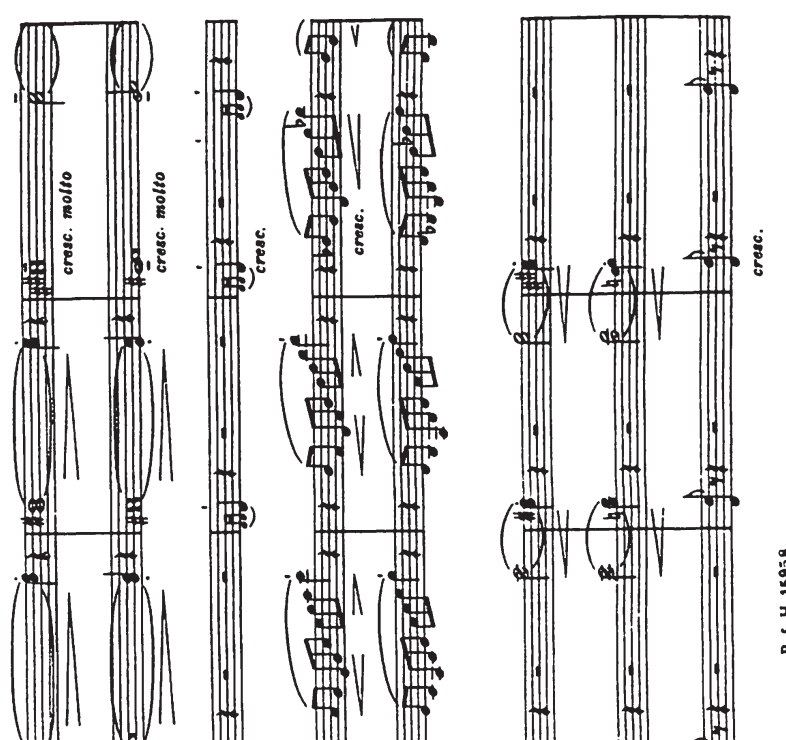

(1)
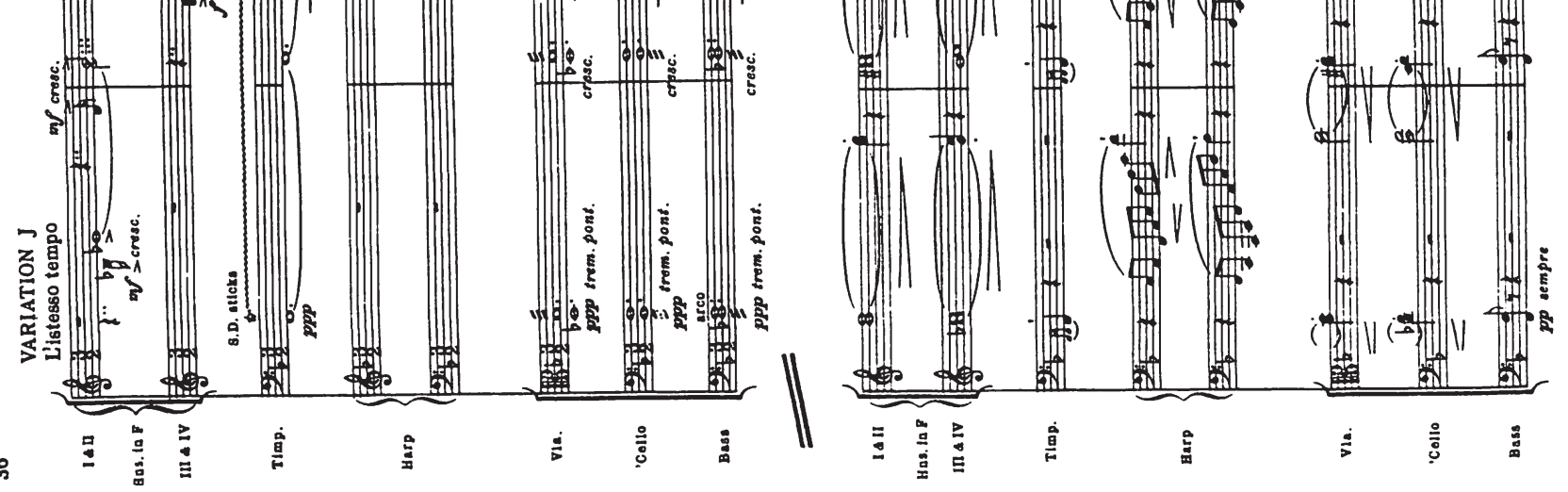
๓

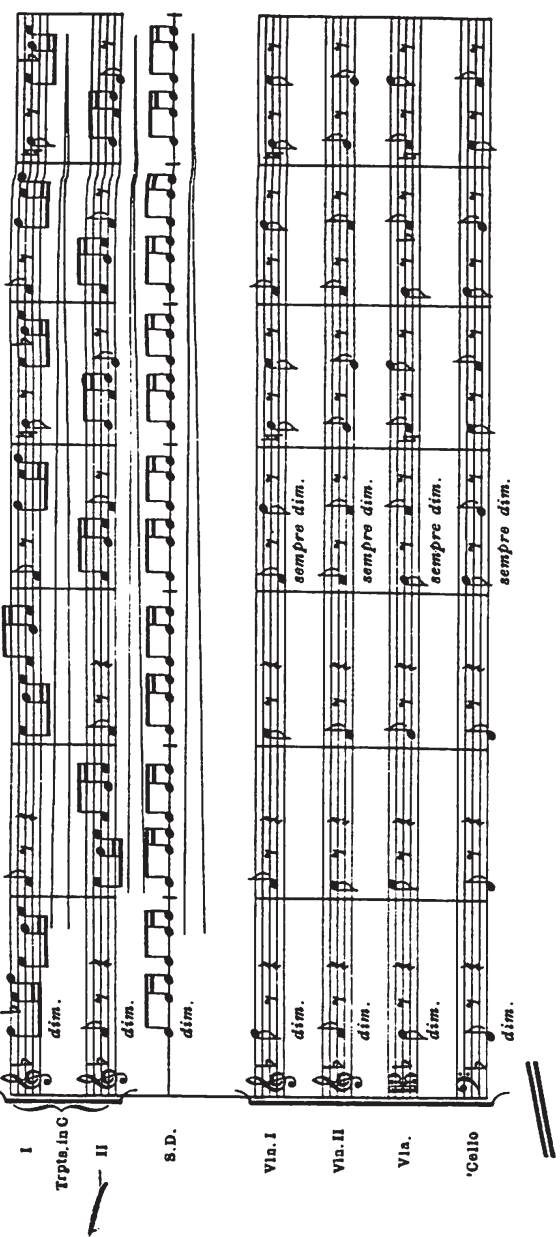

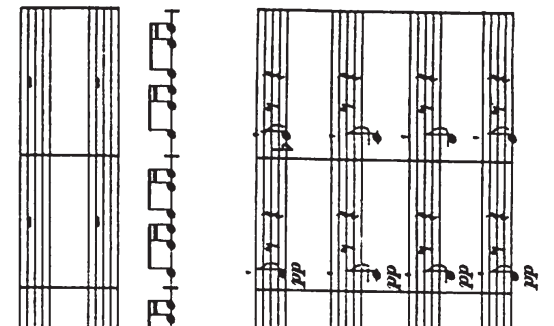

- 4

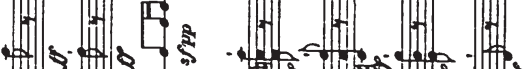
册济 制 \#冊 制 进 删案制?

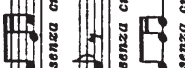
事曲 n 业 曲 官

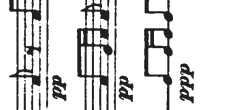
网

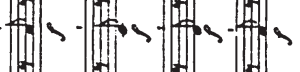

- 2 -

和 我

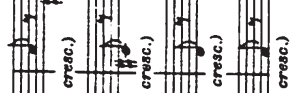

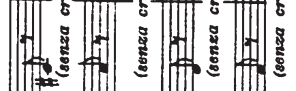

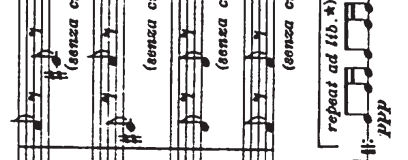

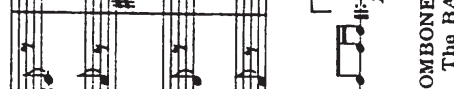

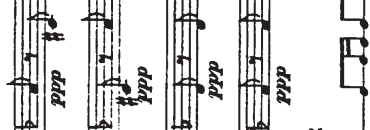
$\frac{50000}{5}$

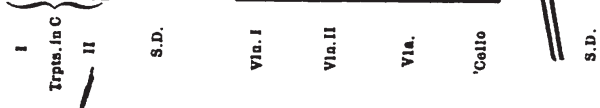

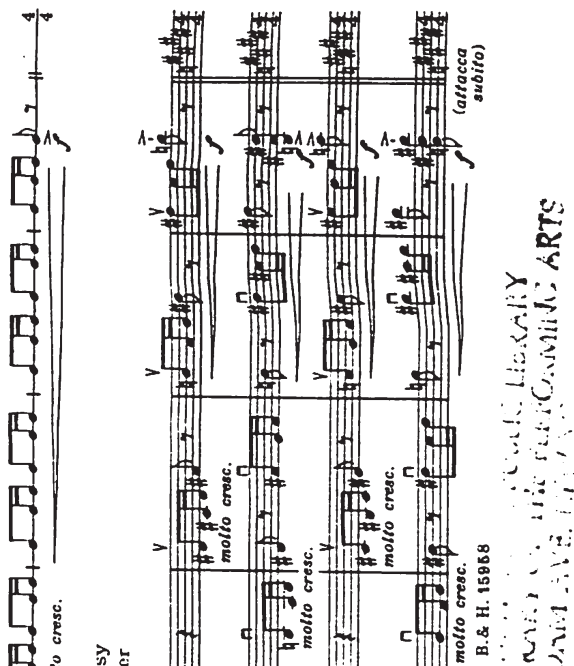

एँ

政

焉

要

IIf

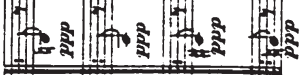
岕实

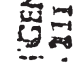

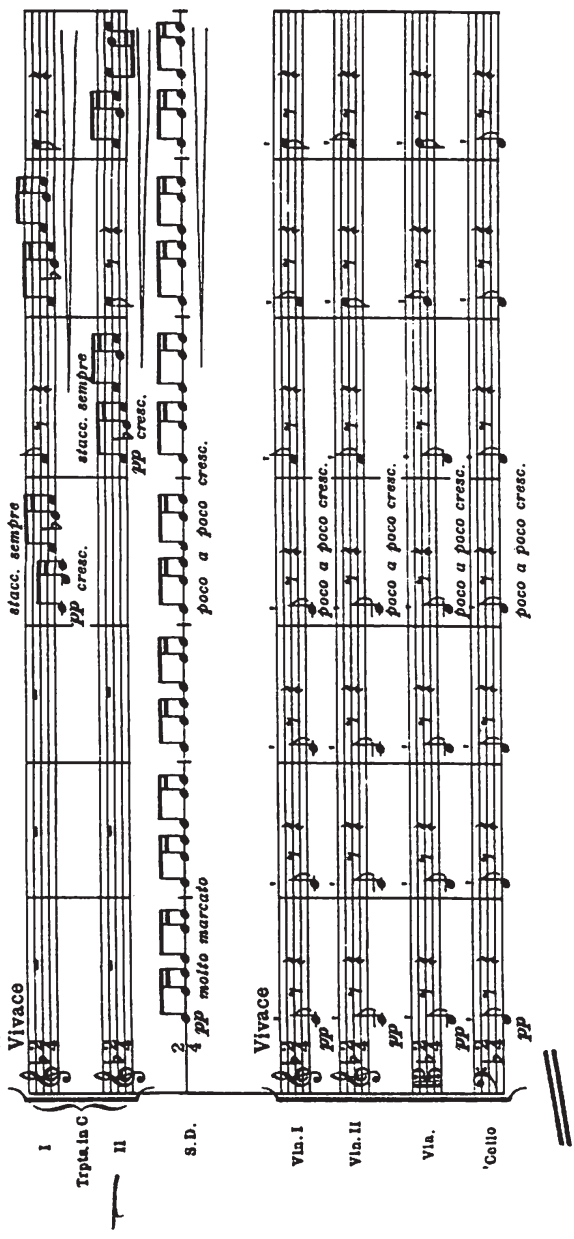

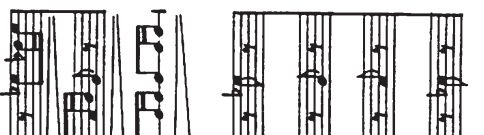
㽖

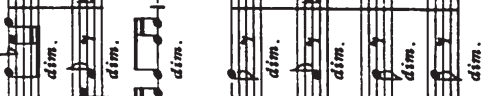

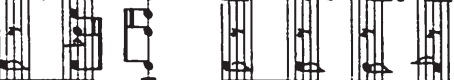

制此制

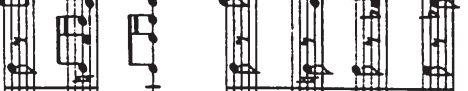

册 制

曲

册

此

册制

制

.

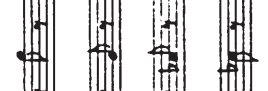

- 5

$-$

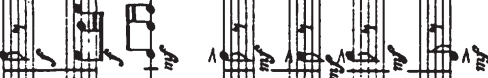

删 (II

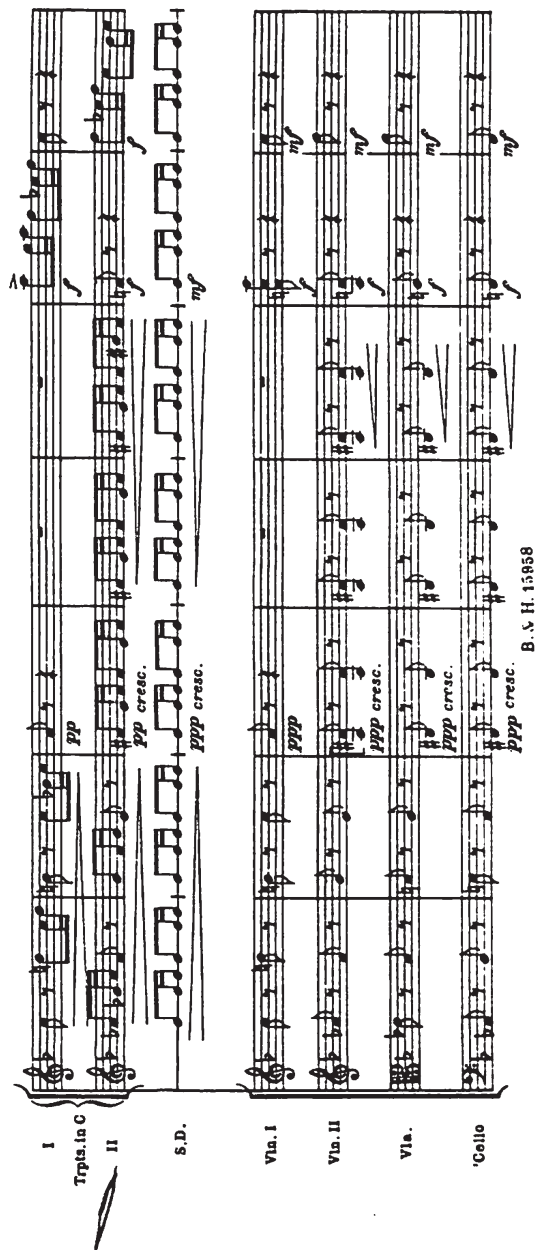


7
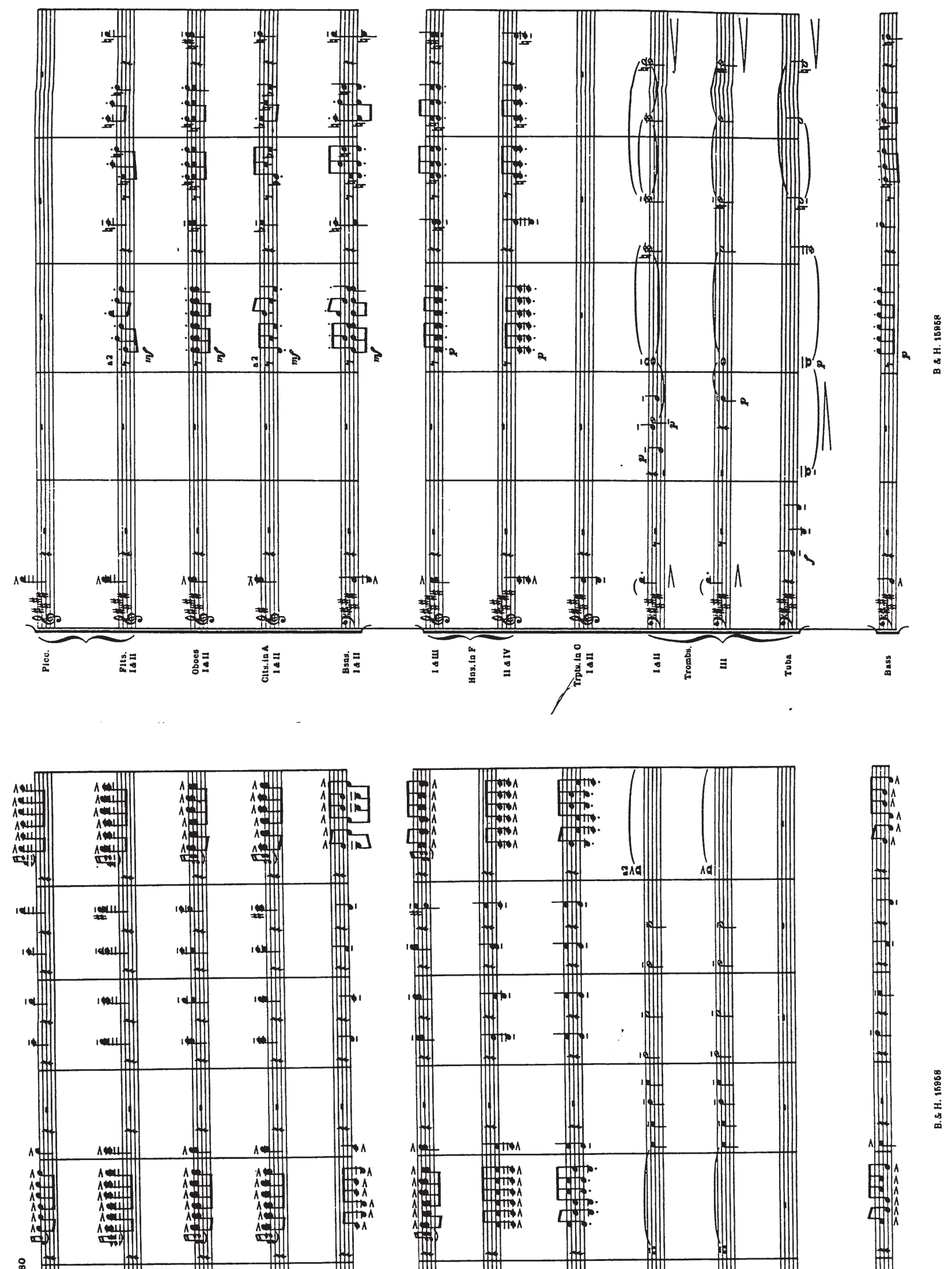

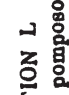

资高

品

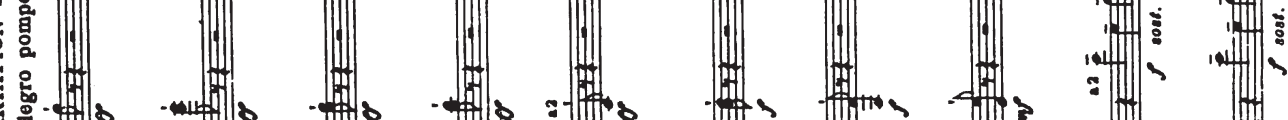

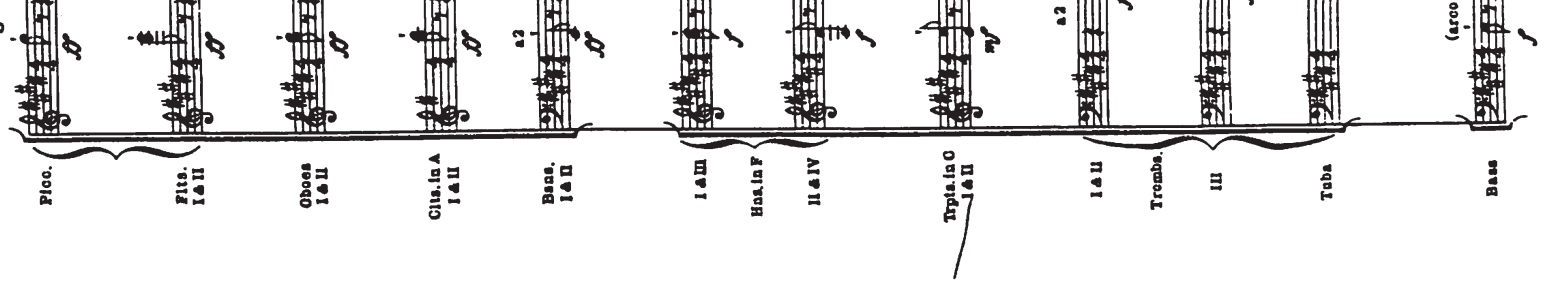


?

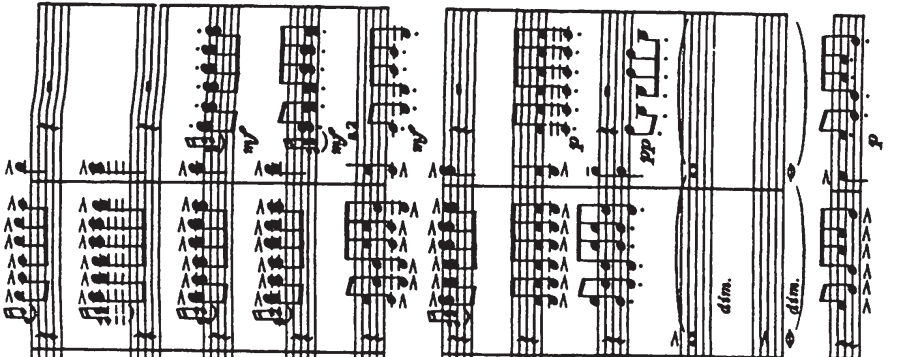

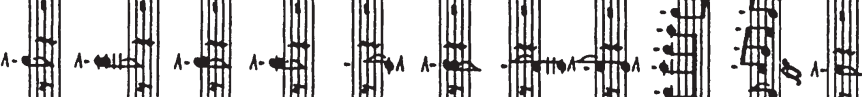
.

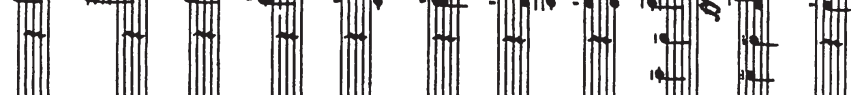
||II) \# \#- W - W

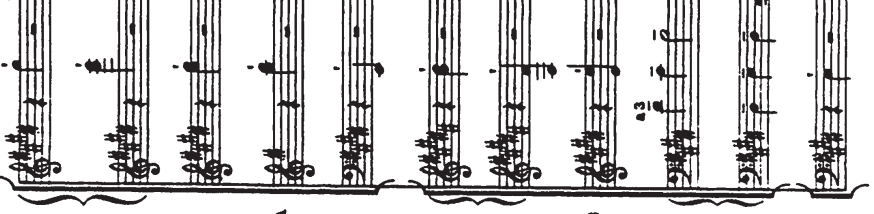

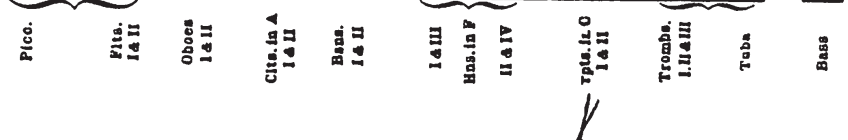

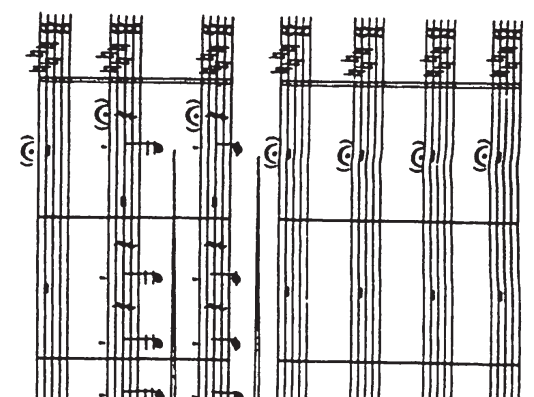

弯竞

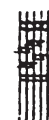

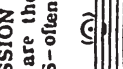

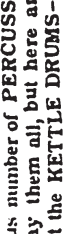
施 政

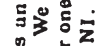

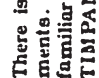

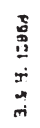

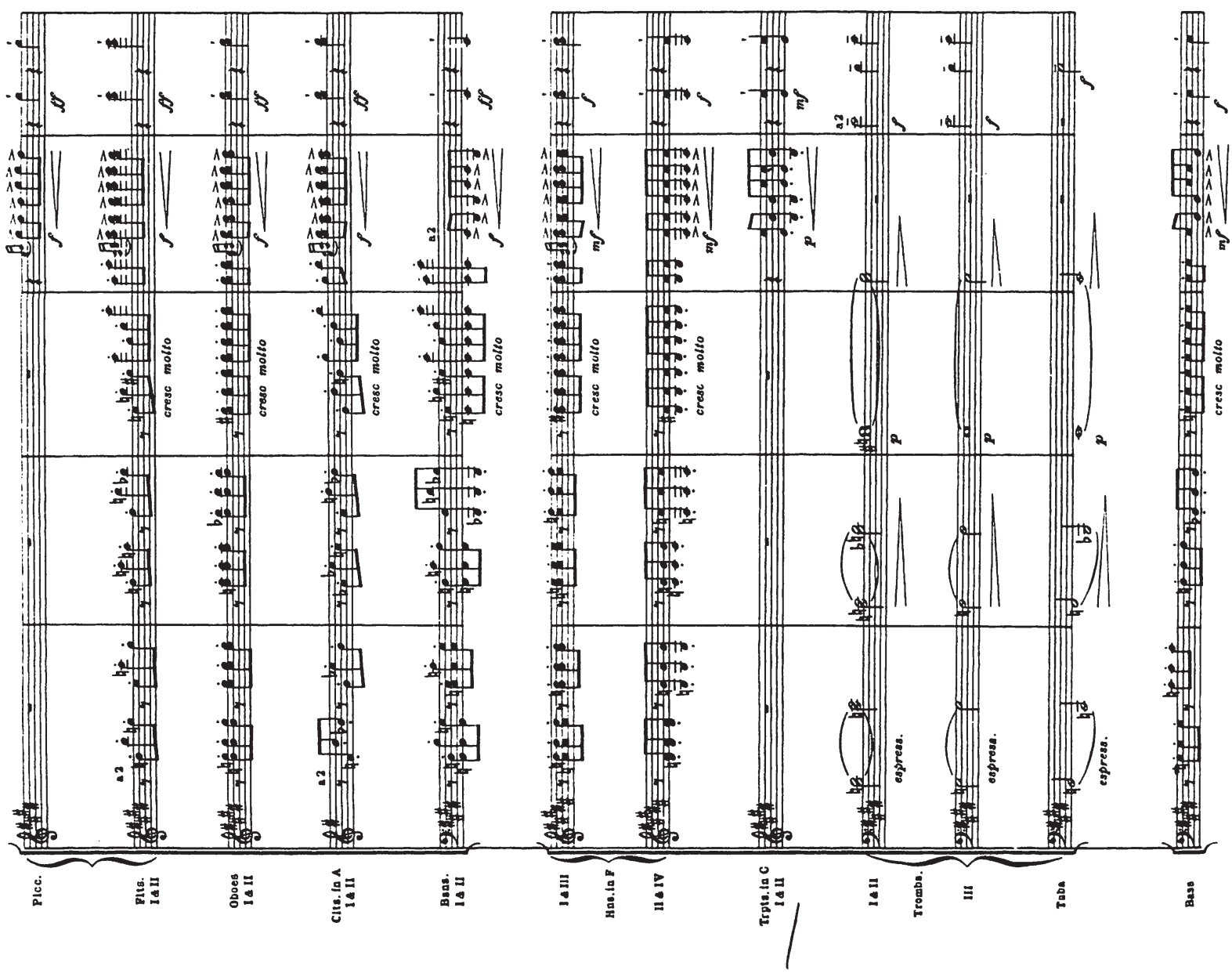


9

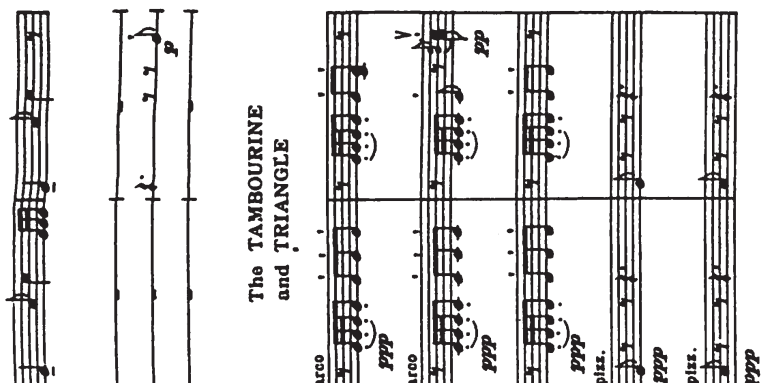

曲与 f -
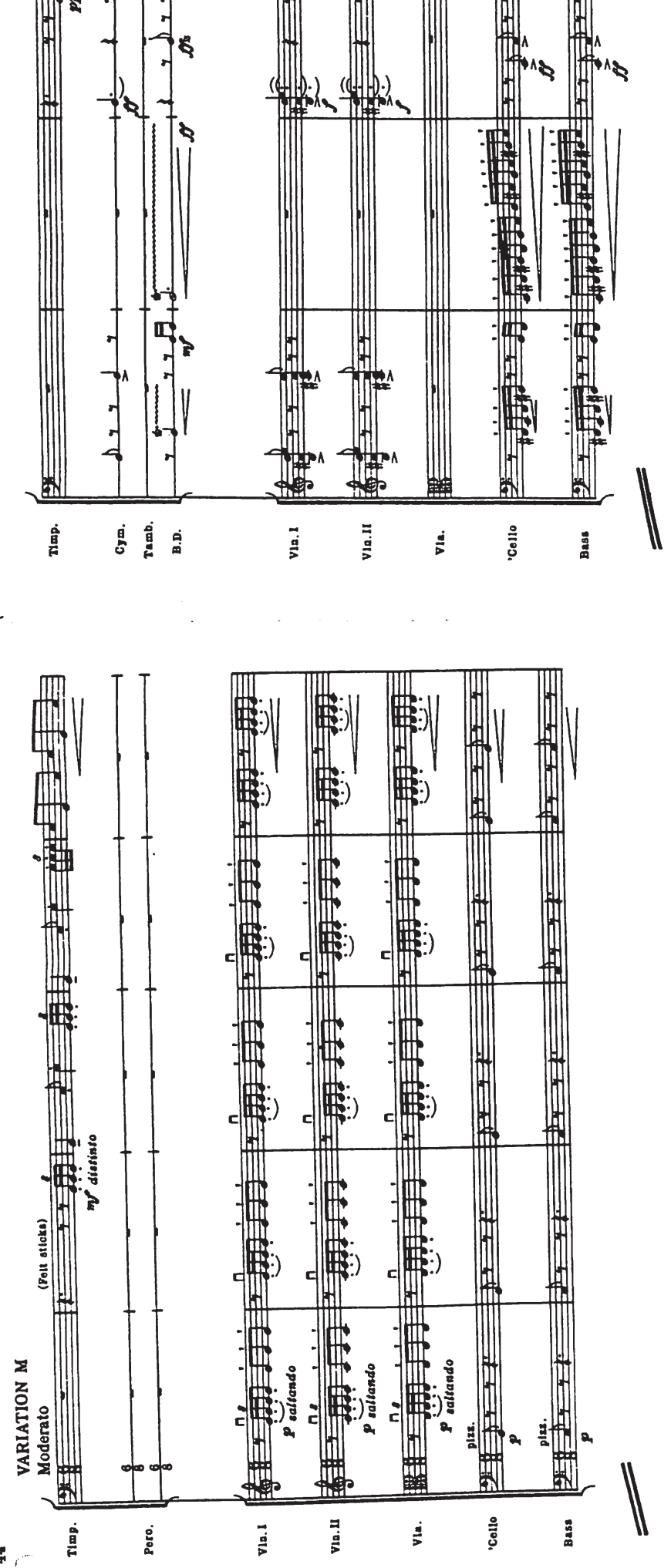
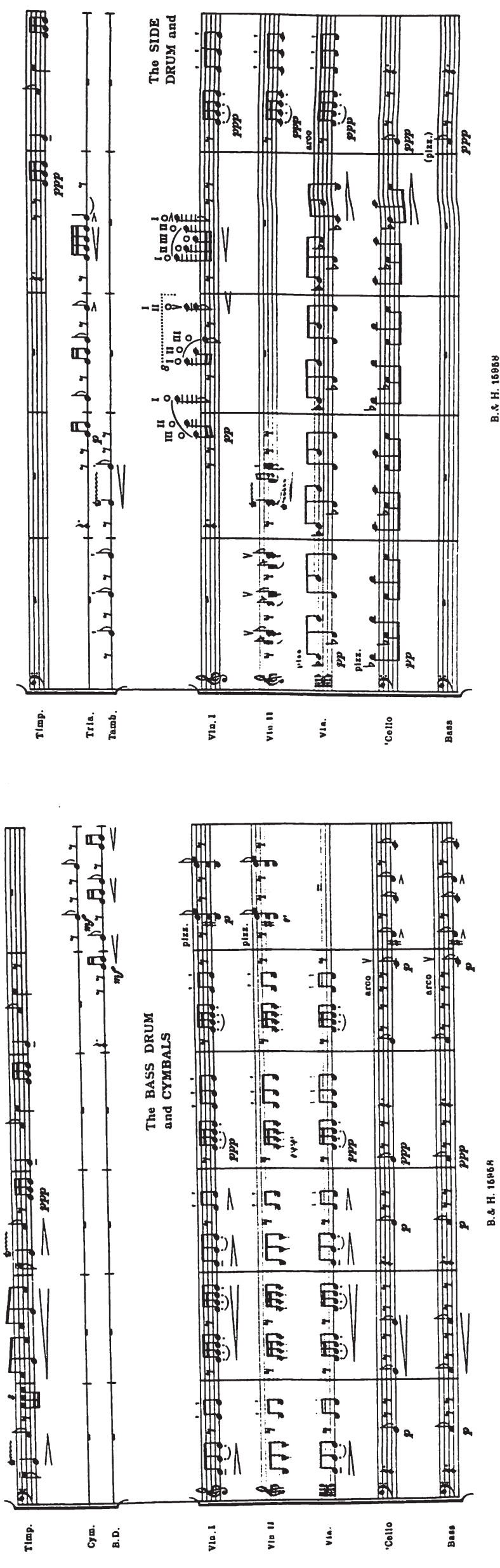
5

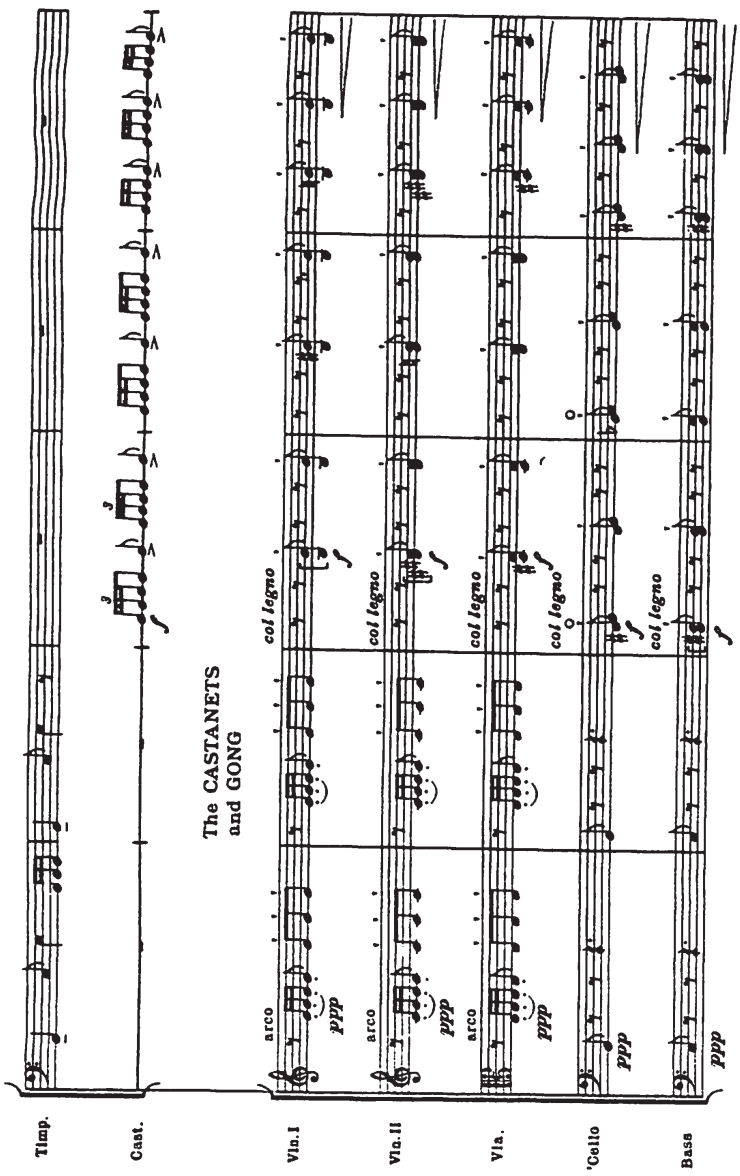

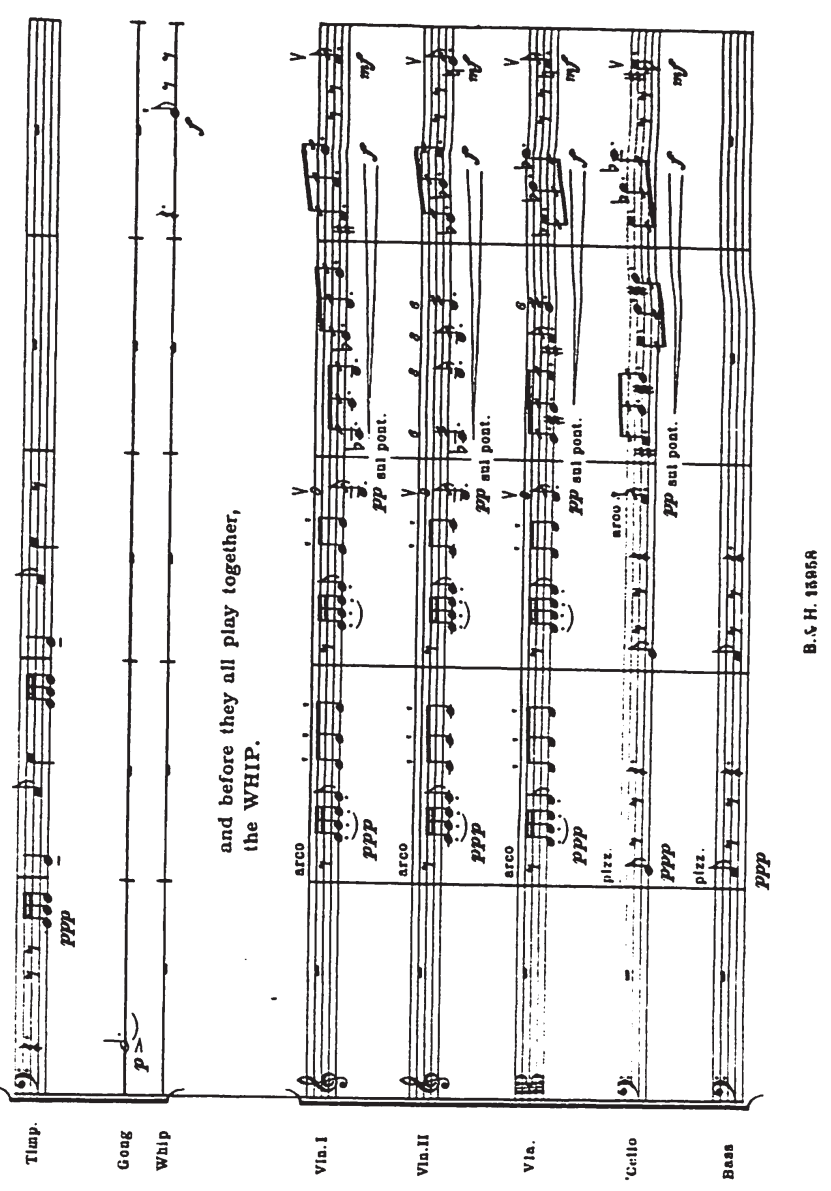
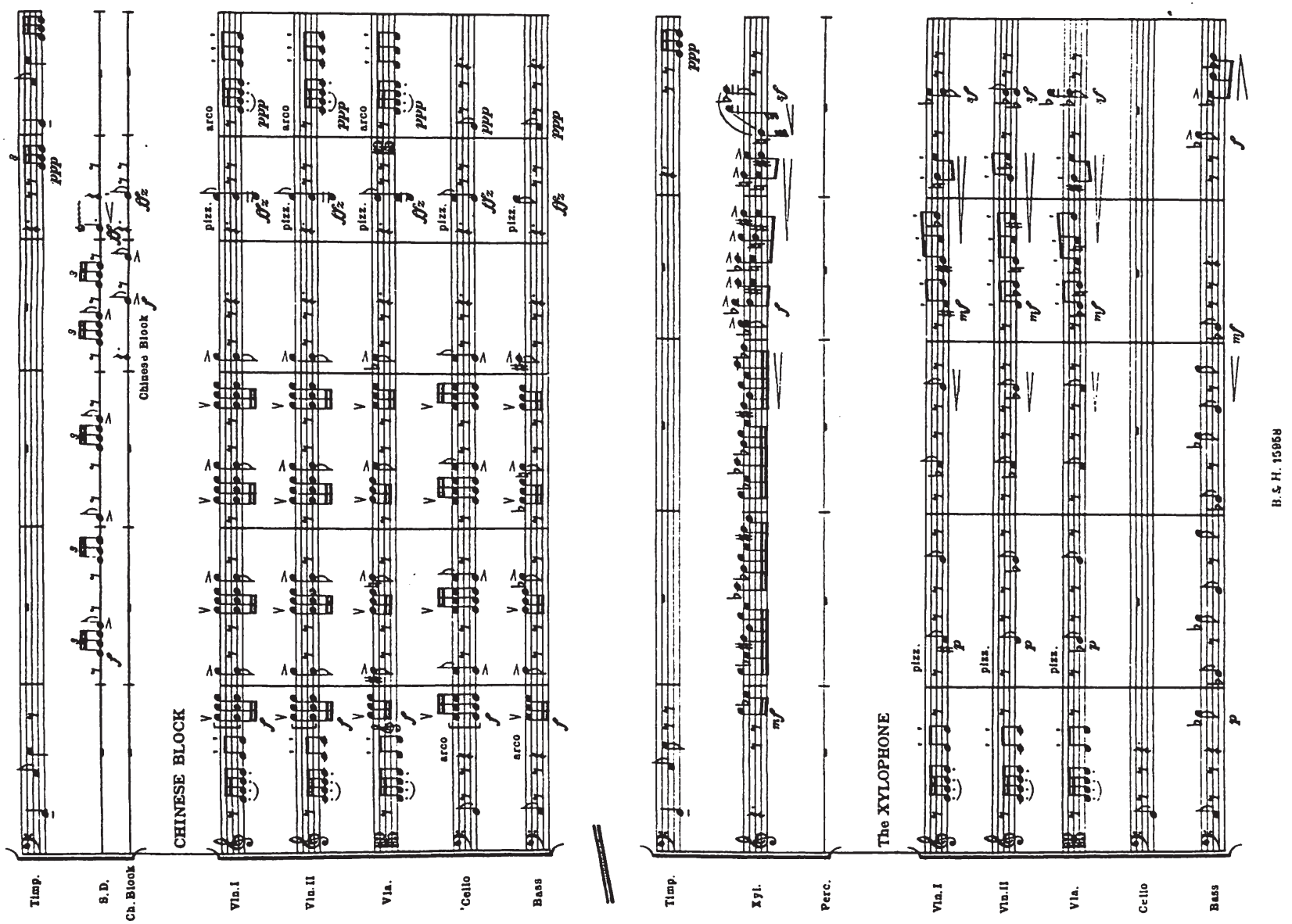

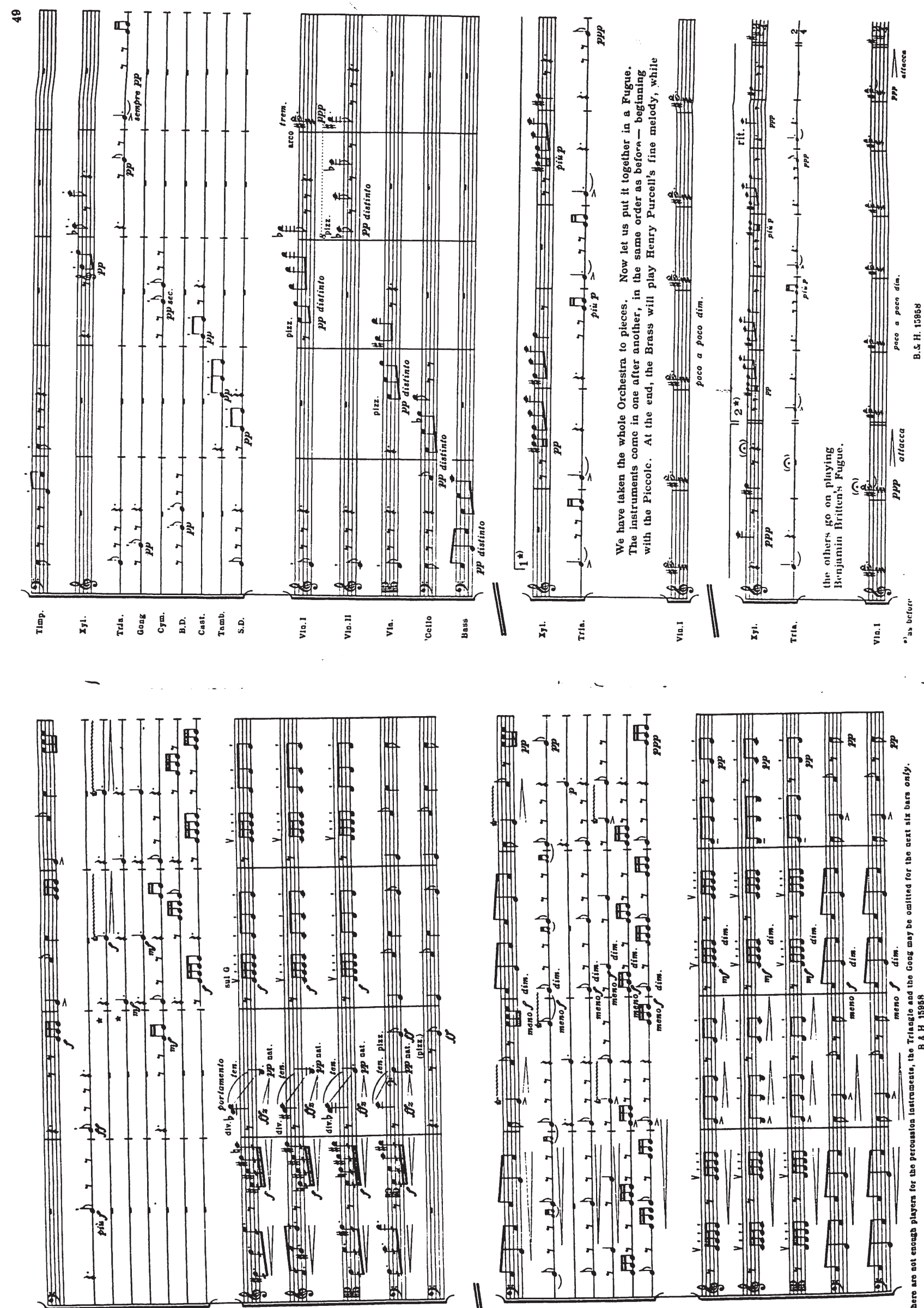

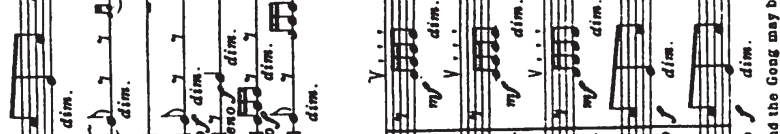

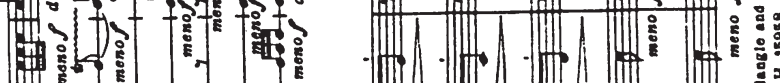
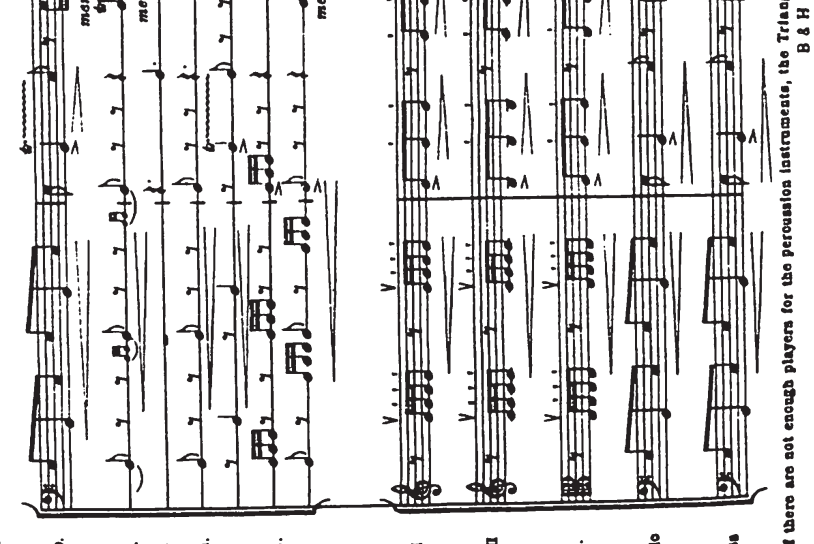

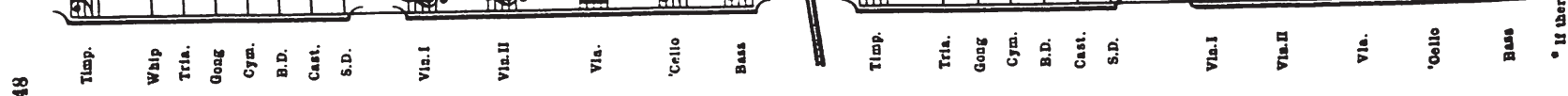


5

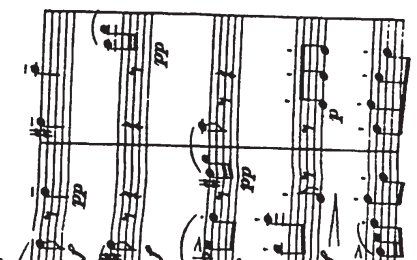

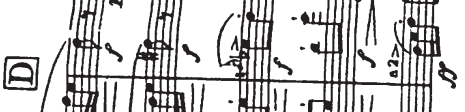
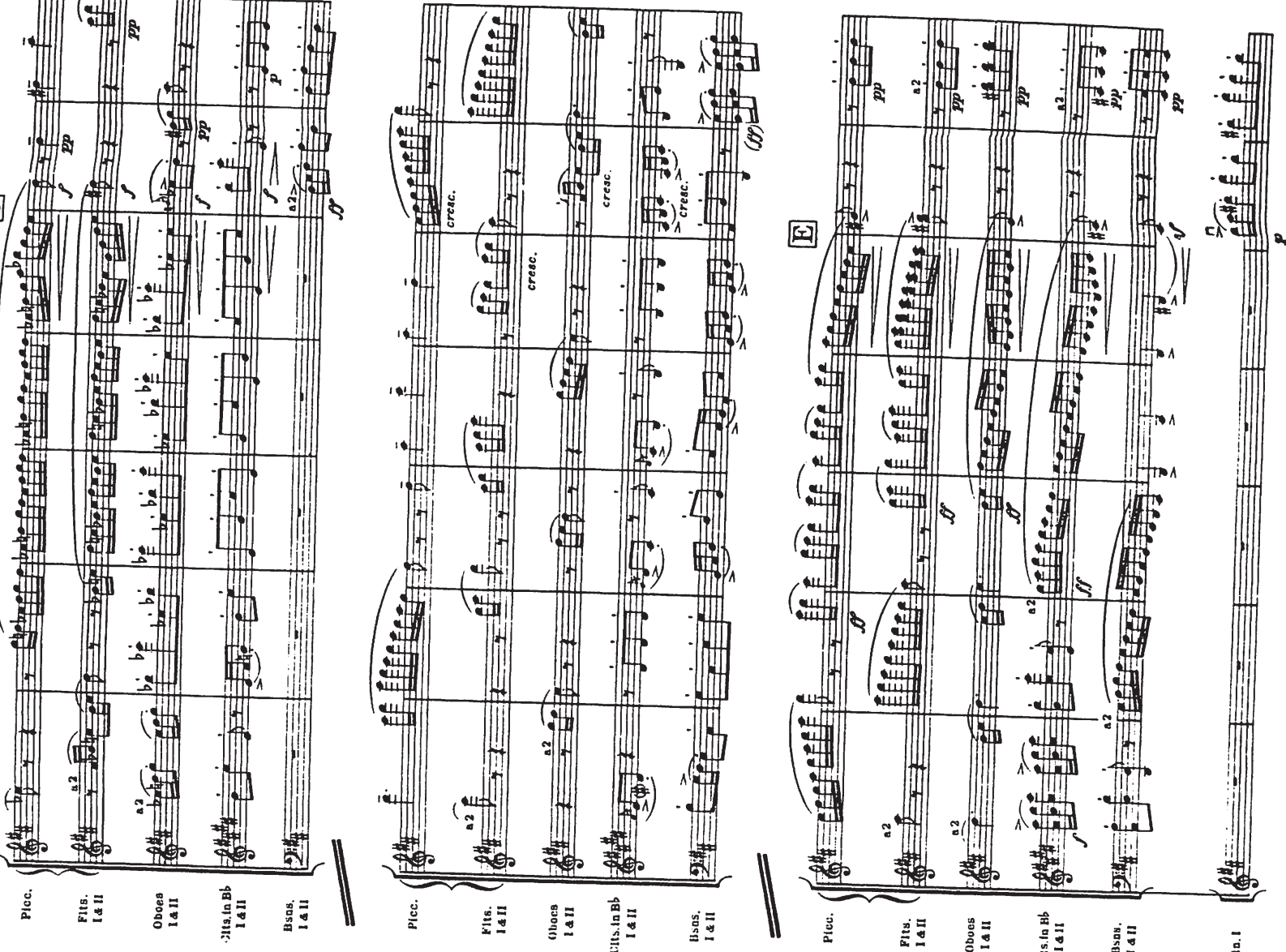

物

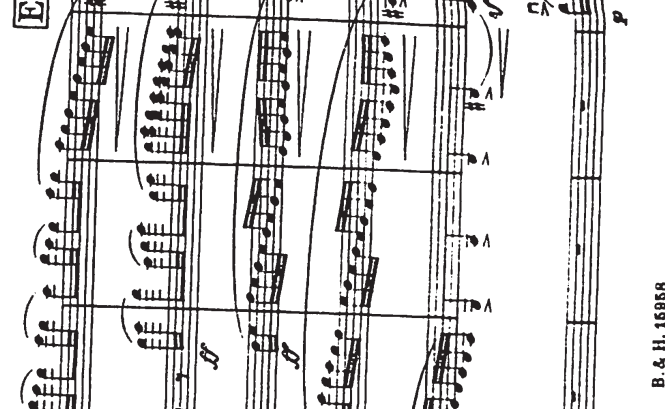

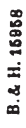

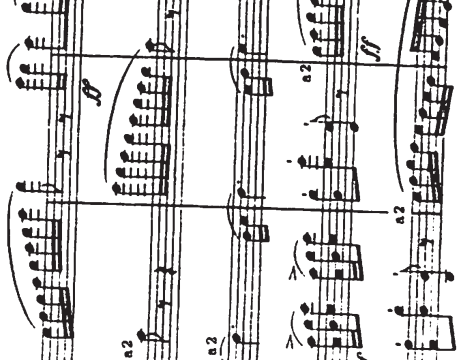

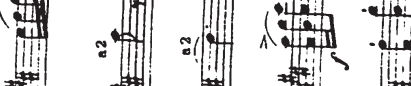

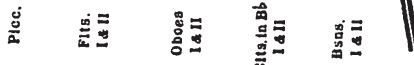

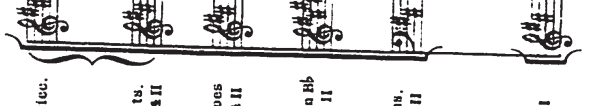

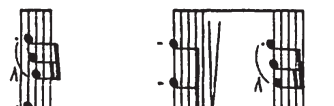

㐩

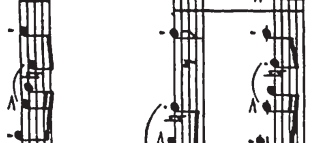

.曲 (n)

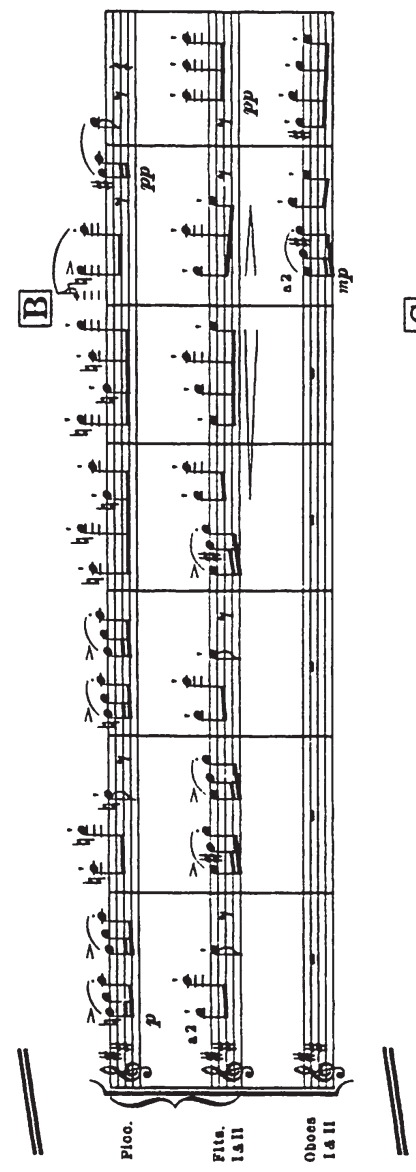

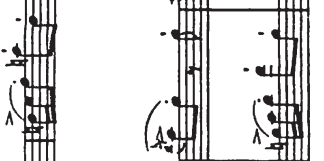

.

牤

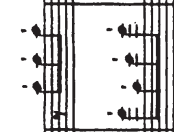

部部

..

?

言. - .

曲 $-1=1$

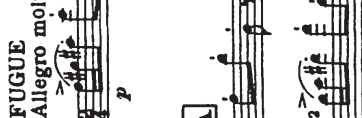

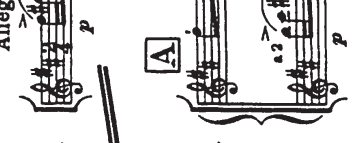

웅
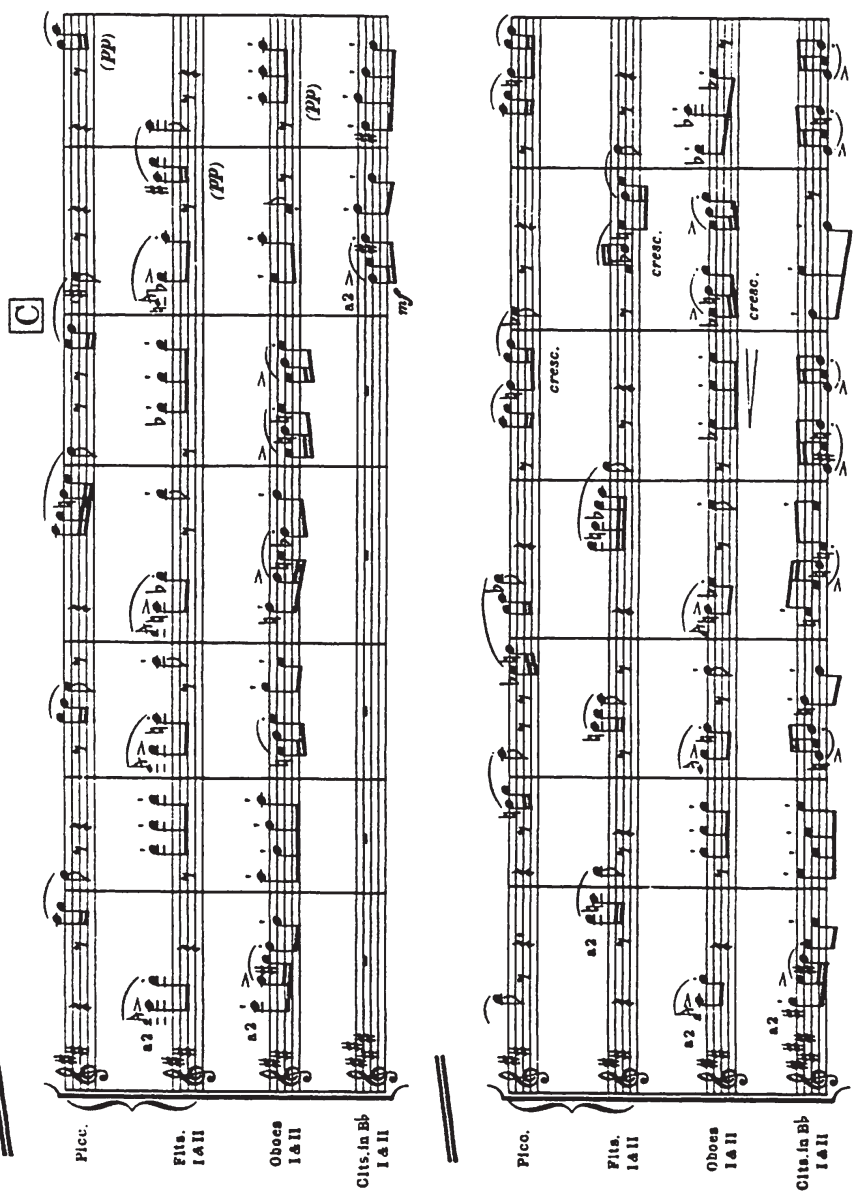
口

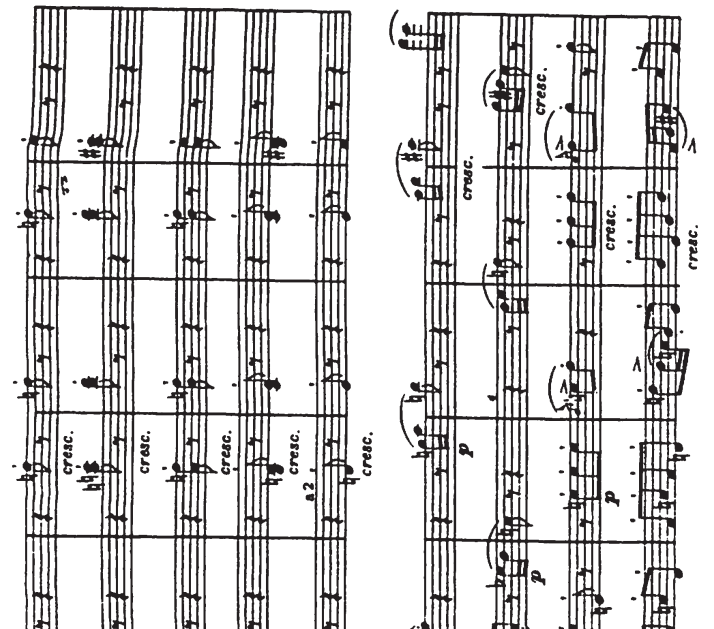

(2)

- $=0+\ldots$

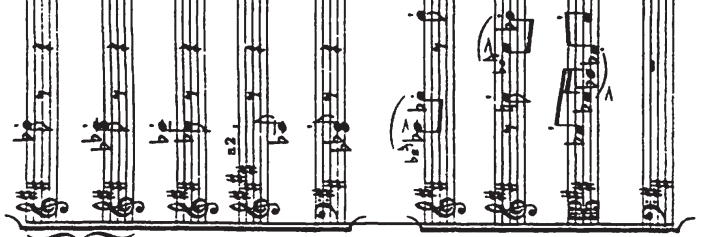

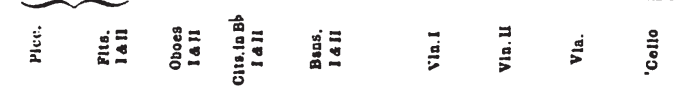

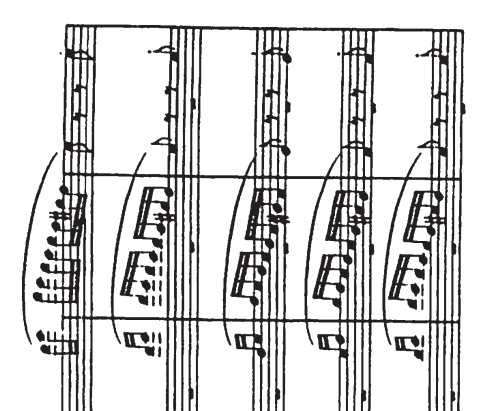

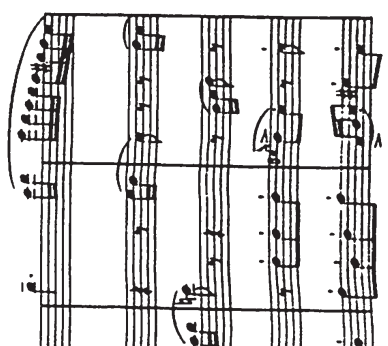

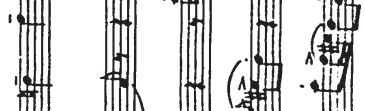

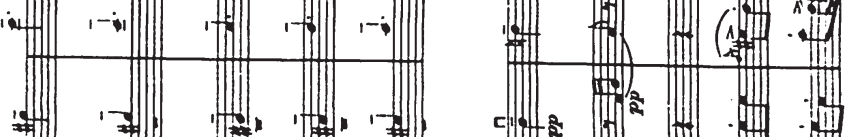

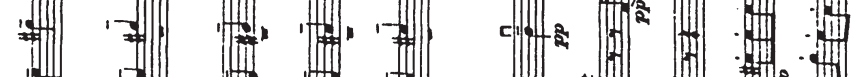

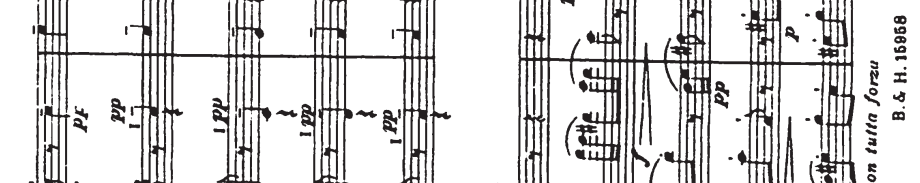

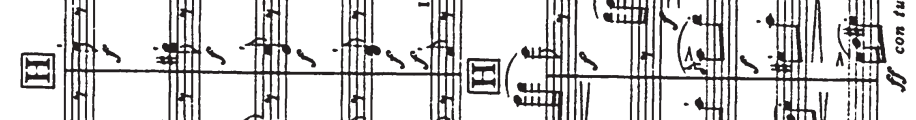

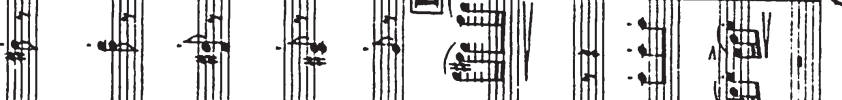

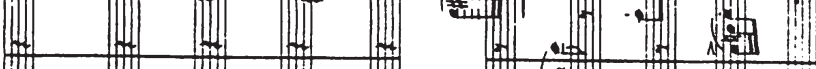

H H H H

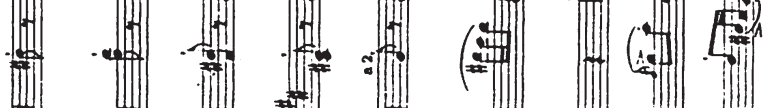

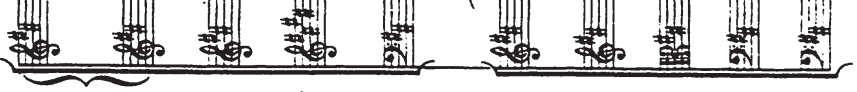

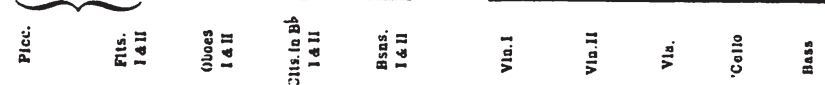

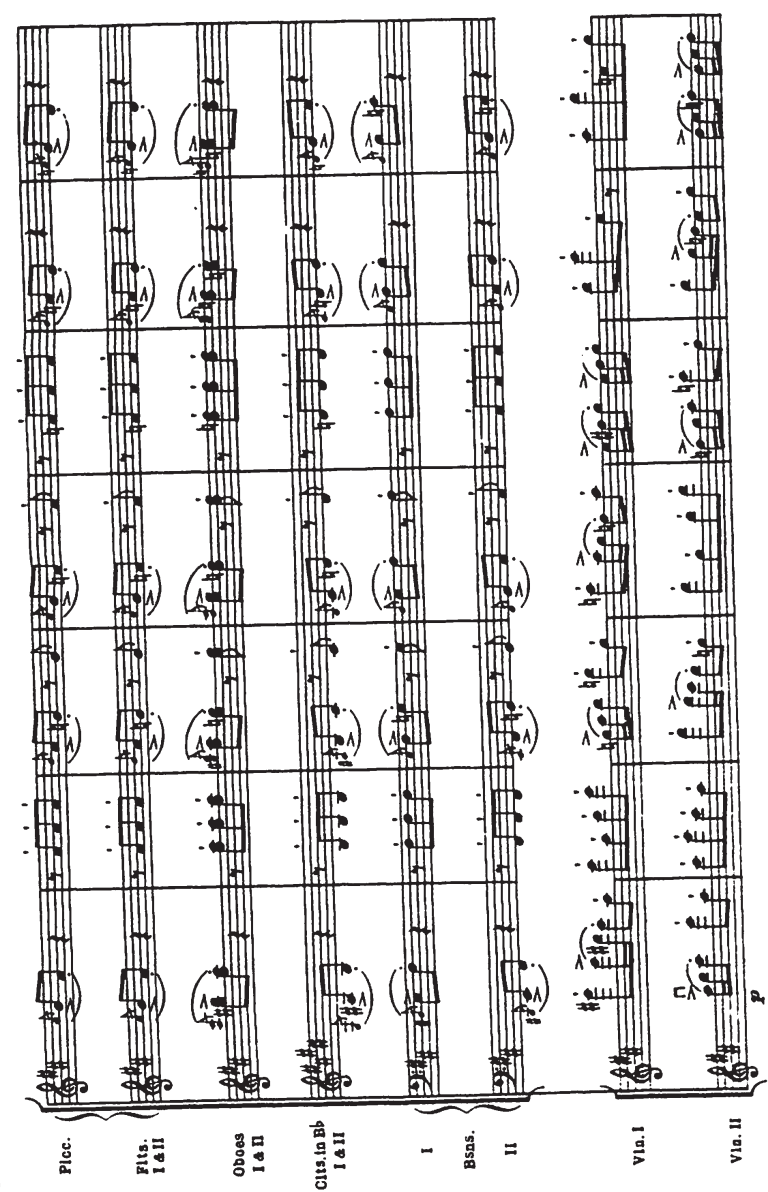

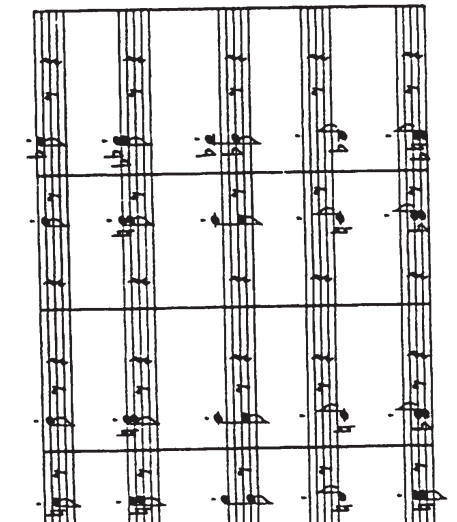

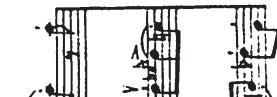

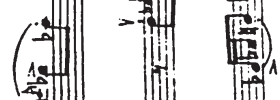

$\therefore$ -

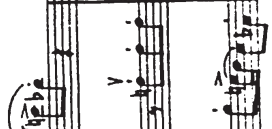

沙

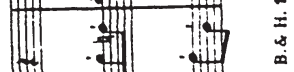

国泪曲次

(哪 . . . .

(.....

(t) (man

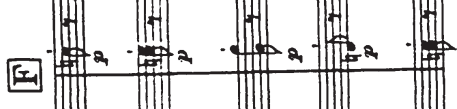

W

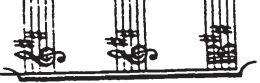

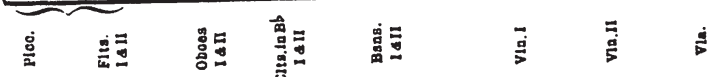



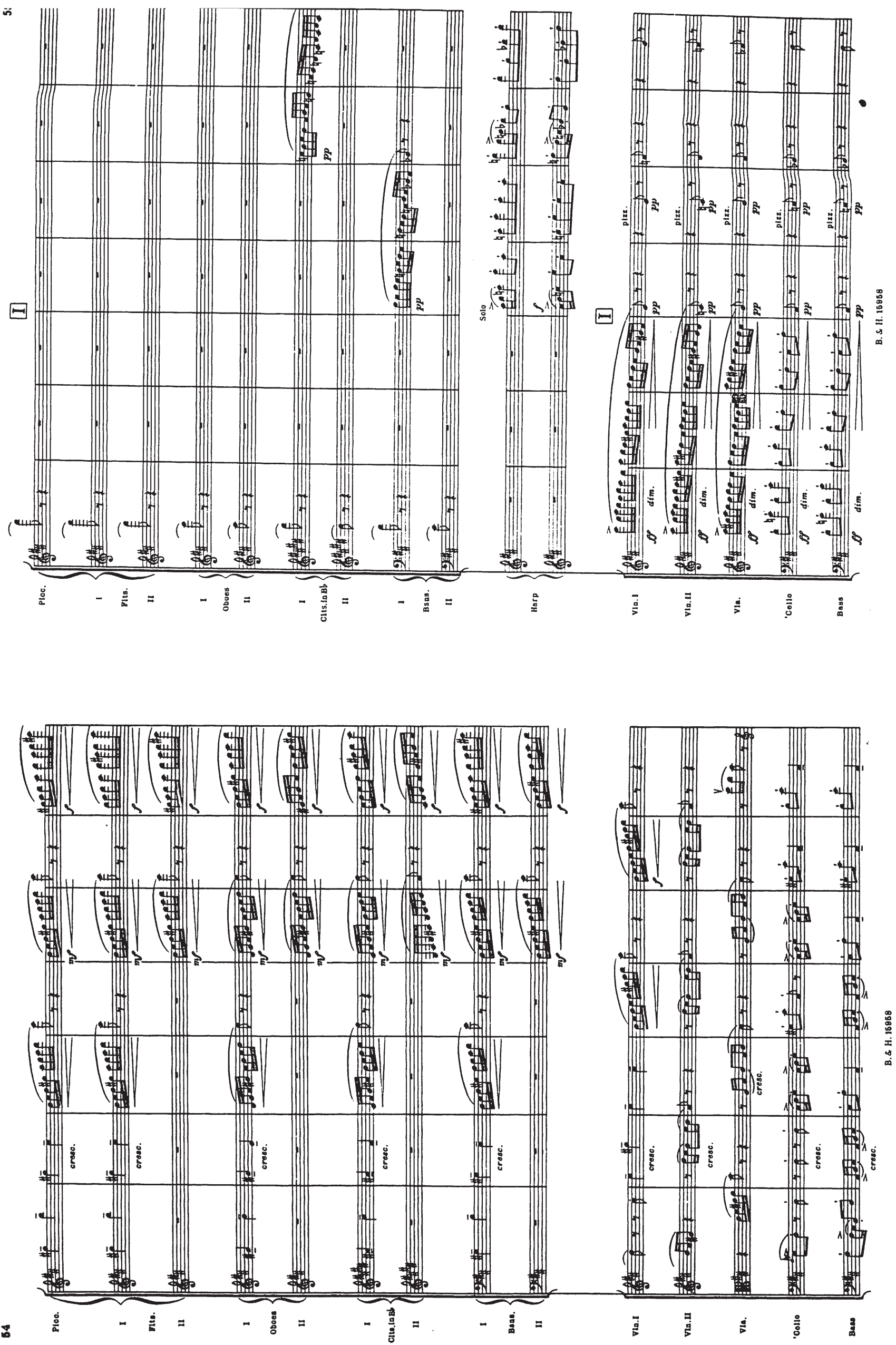
s

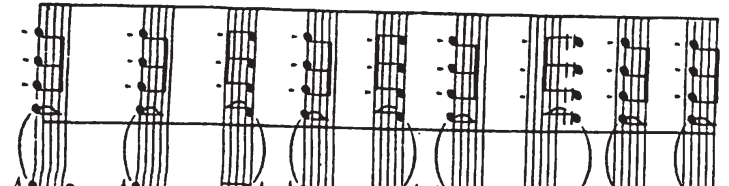
$\square$ -

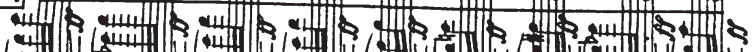
$\therefore$ : $\therefore:$ : 洋

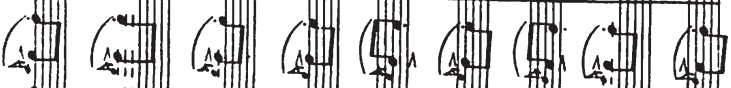

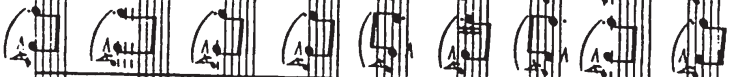

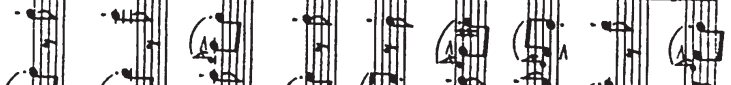

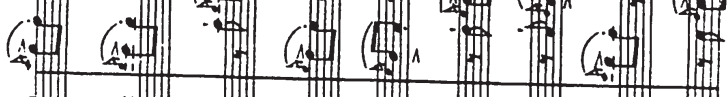

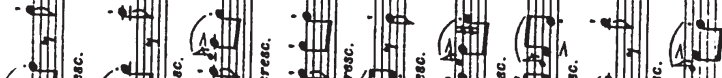

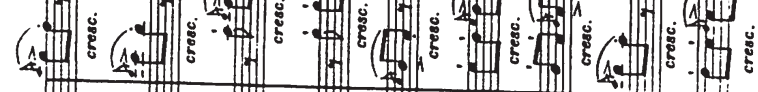
提
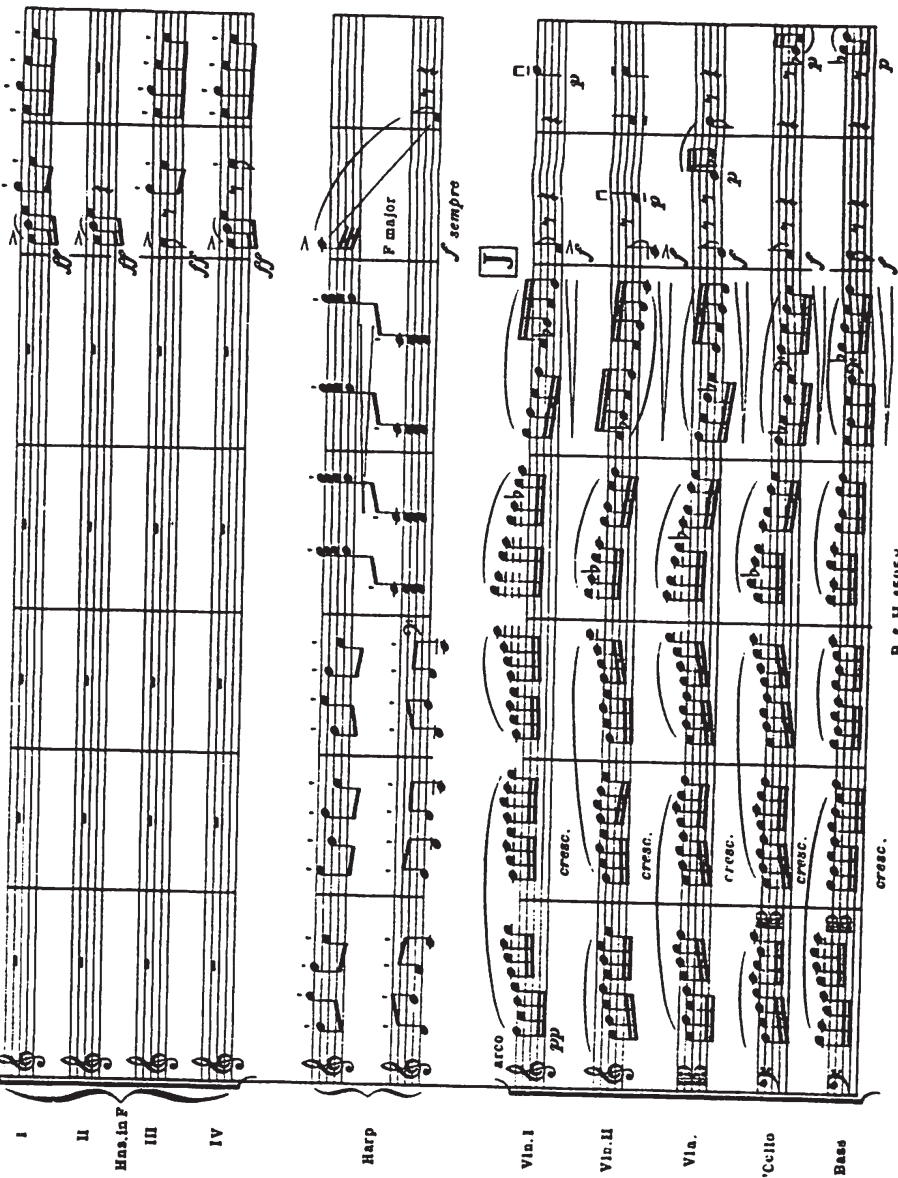

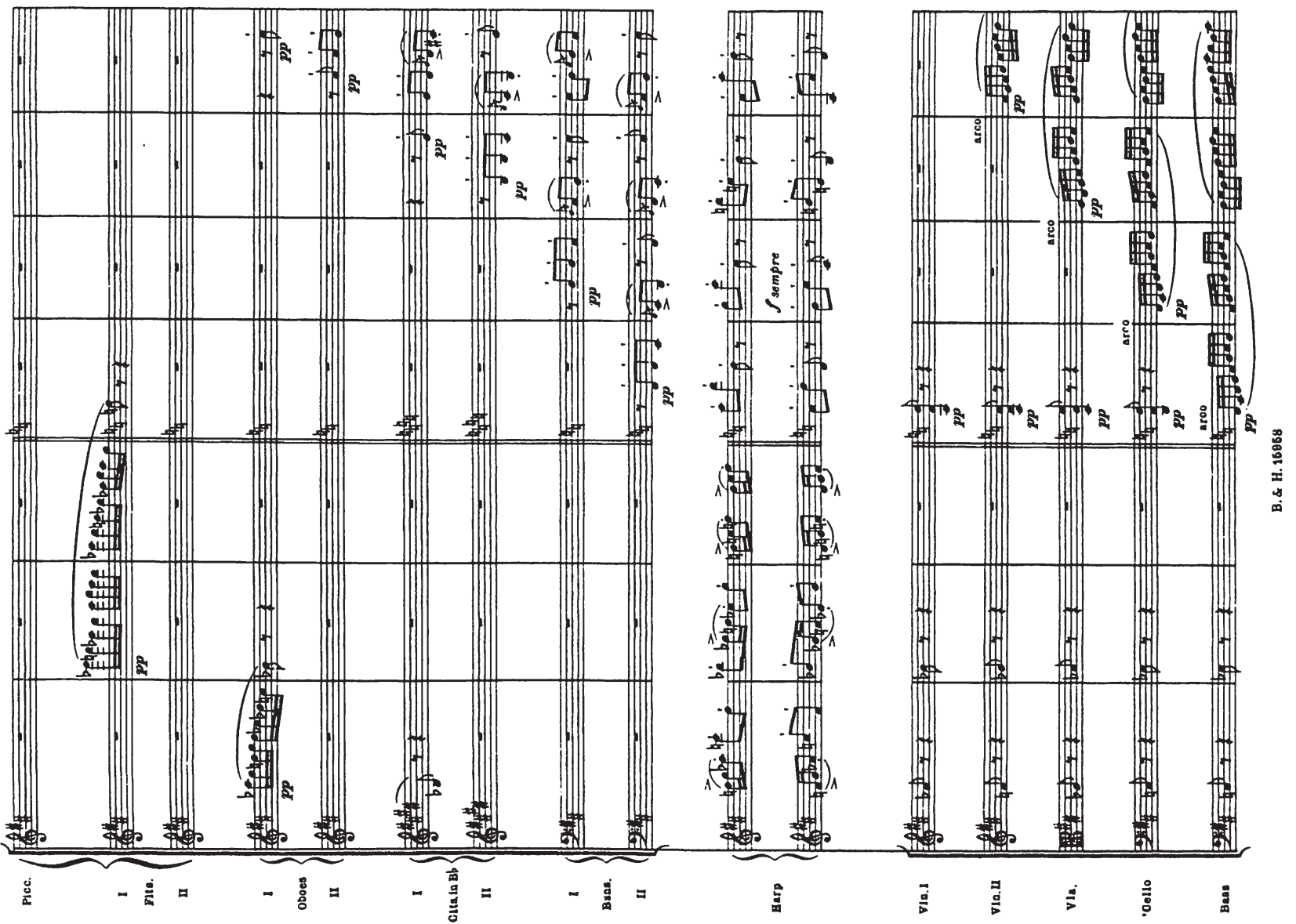


모

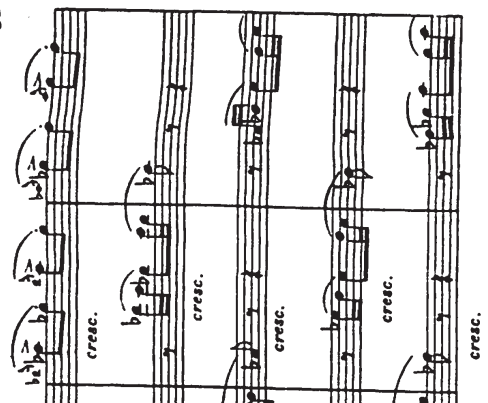

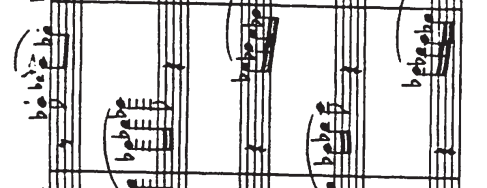

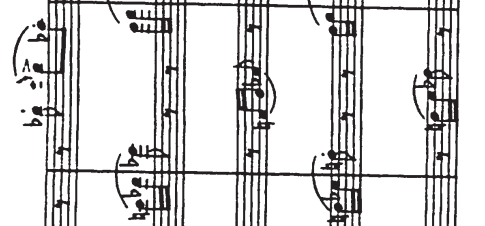

(1)

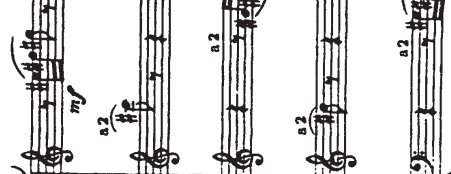

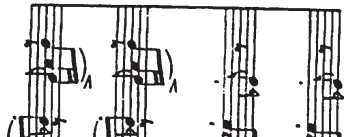

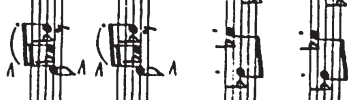

(15)

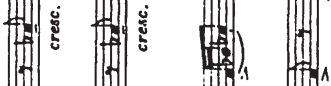

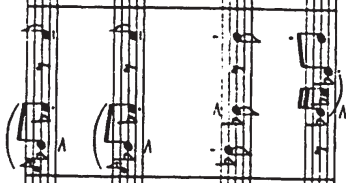

In . In

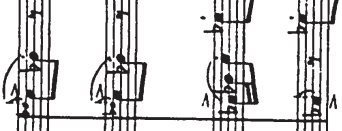

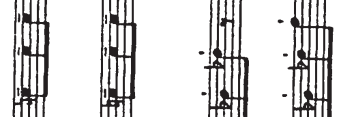

.

sm

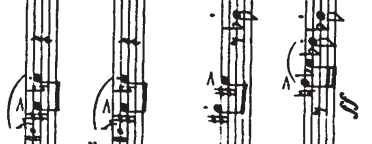

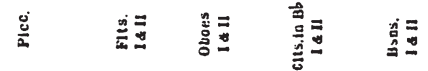

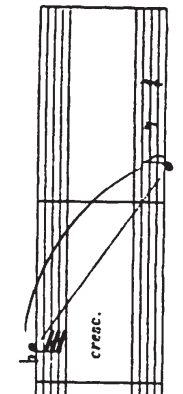

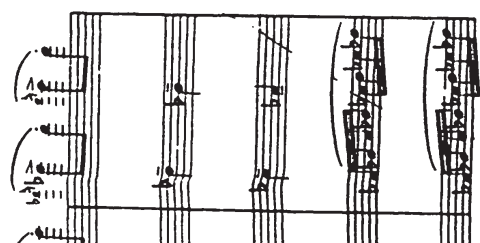

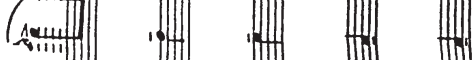

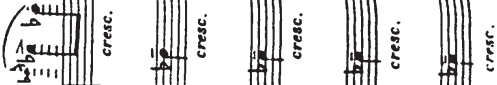

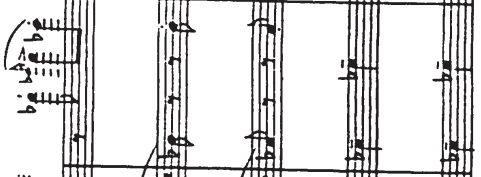

(x) 赫
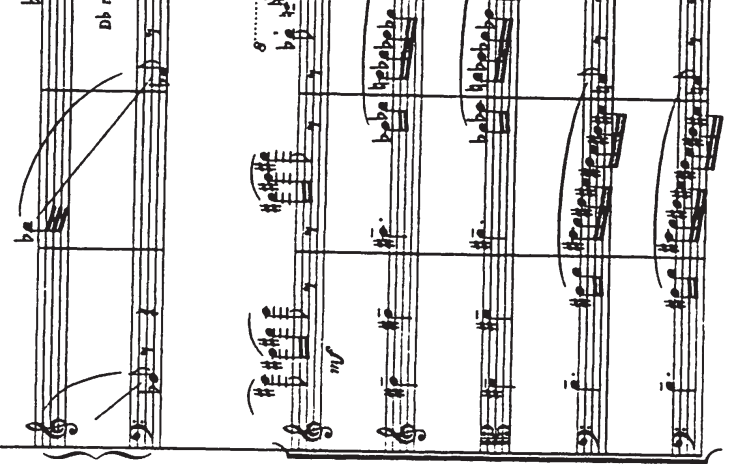

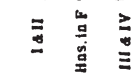

-

$\bar{j}^{1}$

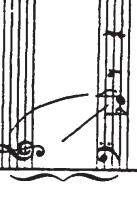

竞

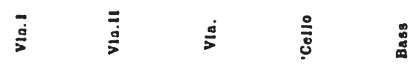

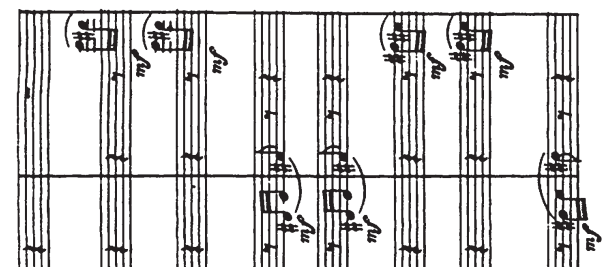

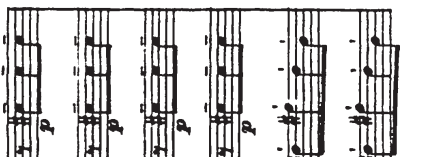
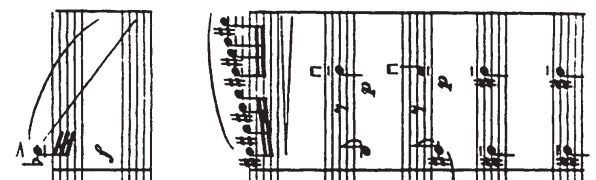

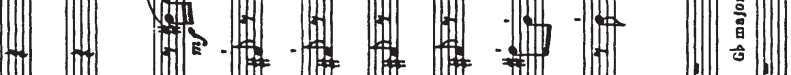

(1) 沙

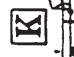

(a)

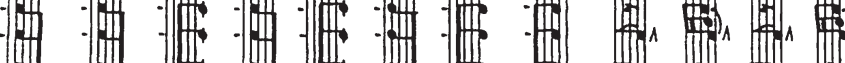

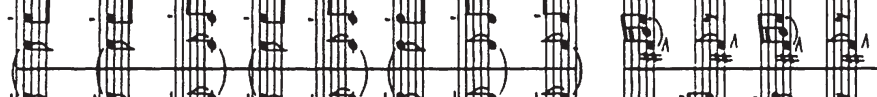

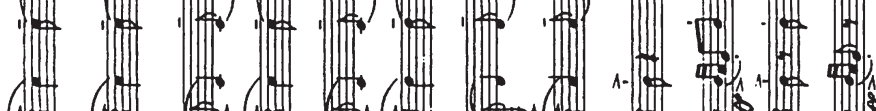

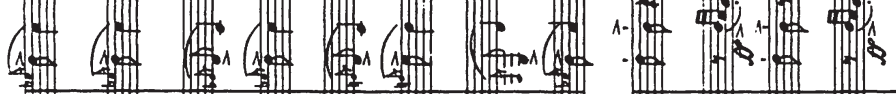

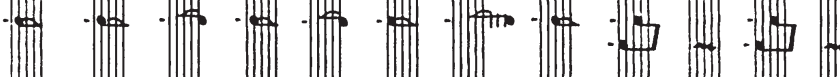

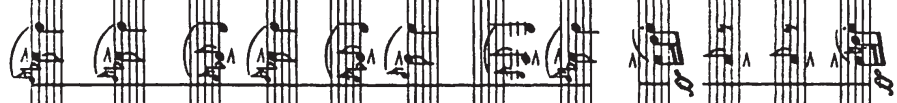

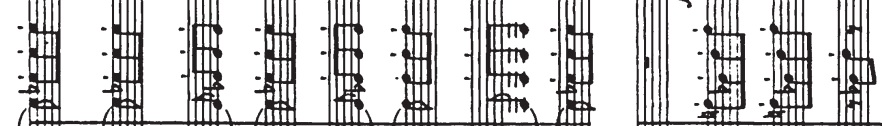

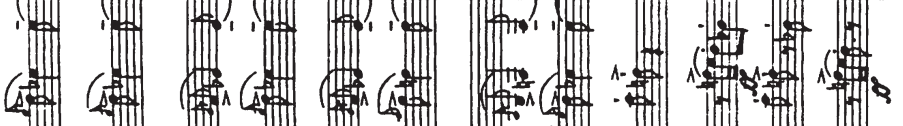

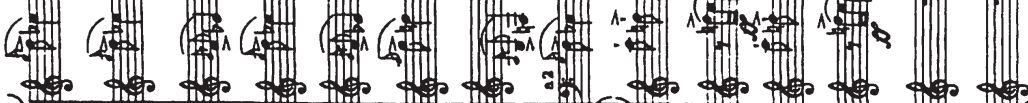

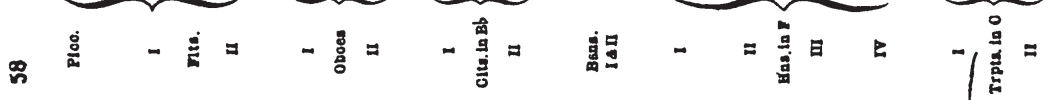
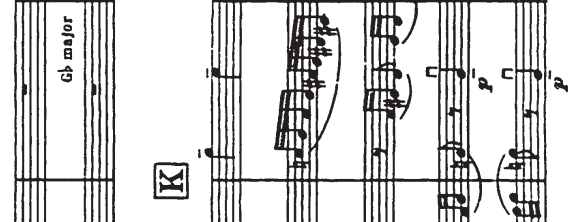

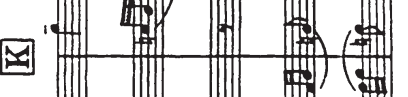
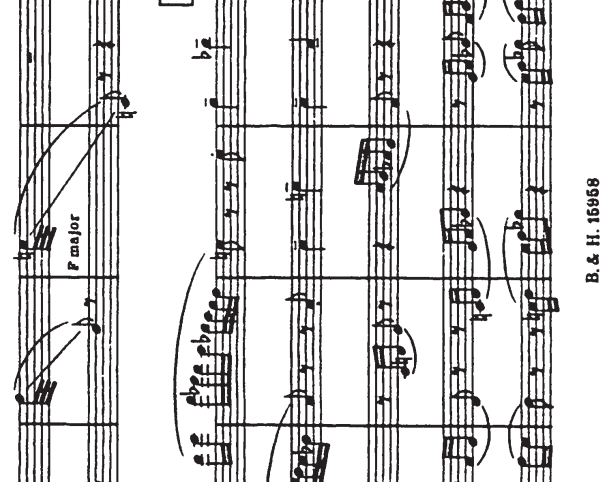

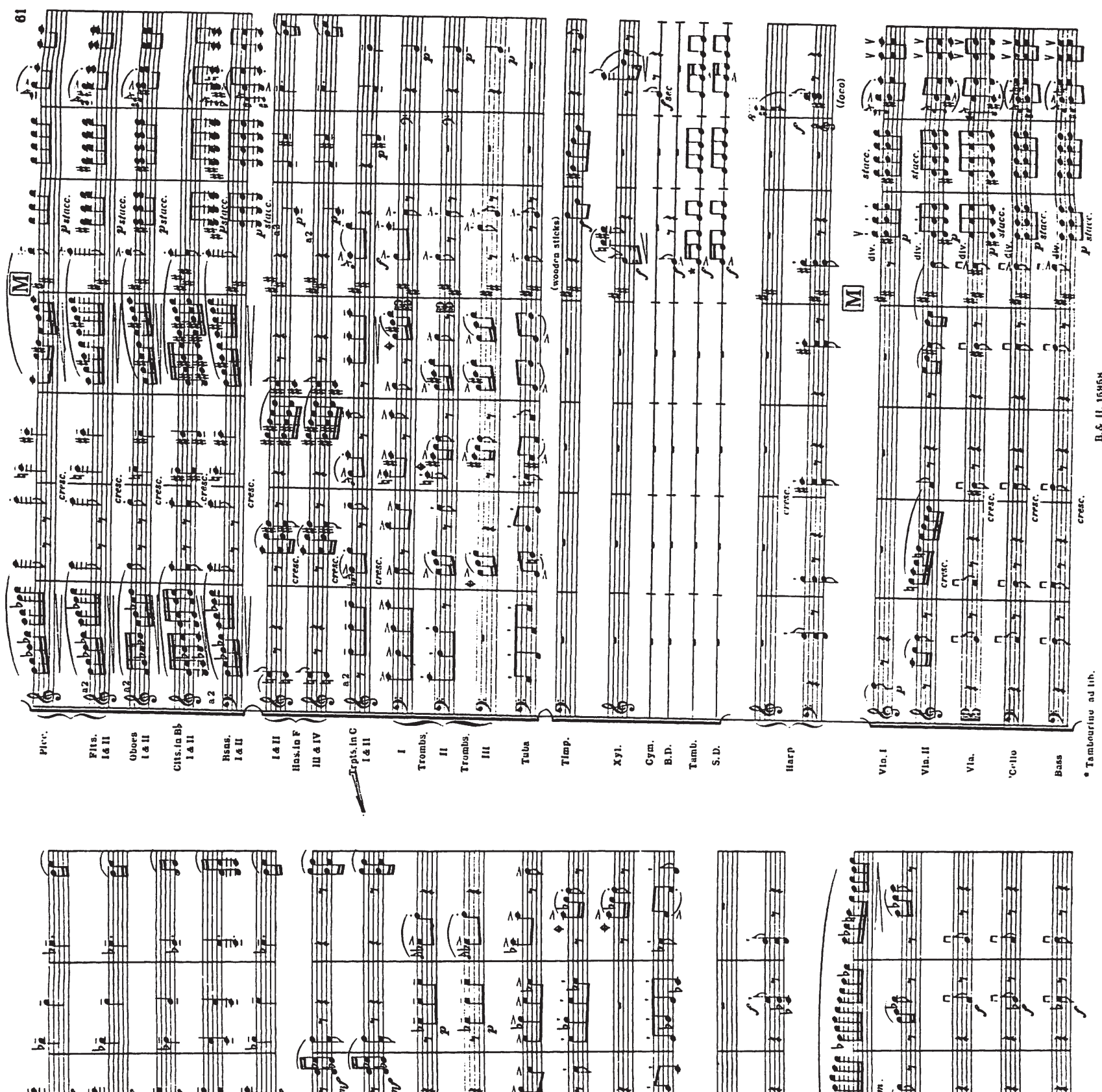

s.m.

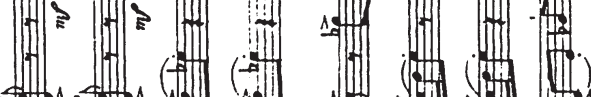

曰

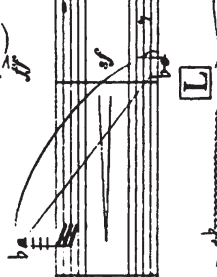

(1)

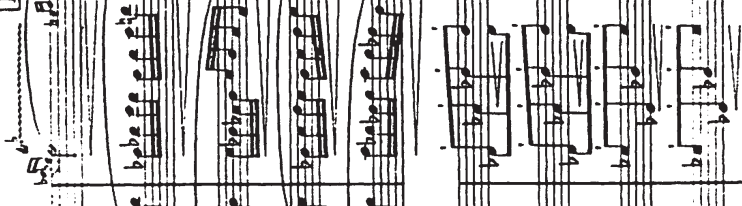

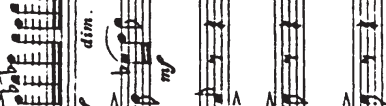

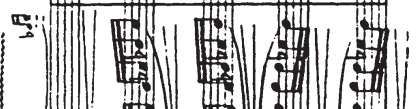

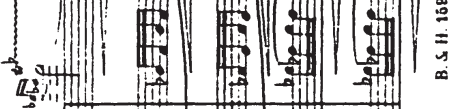

(

遂

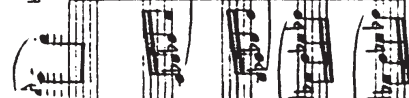

-

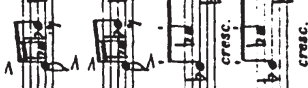

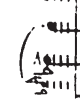

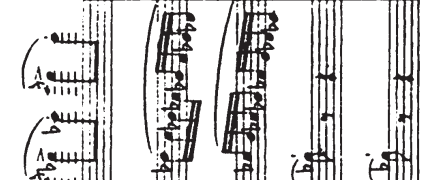

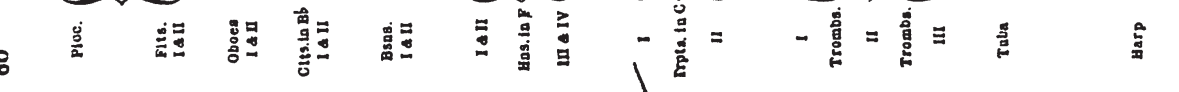

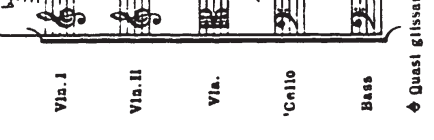




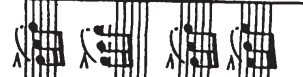

: : : : : : :

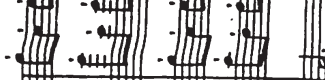

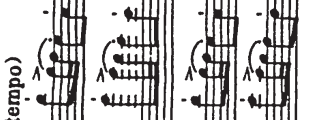

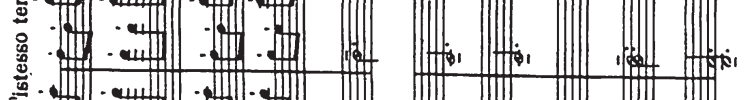

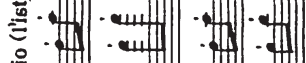

에메

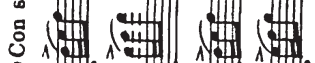

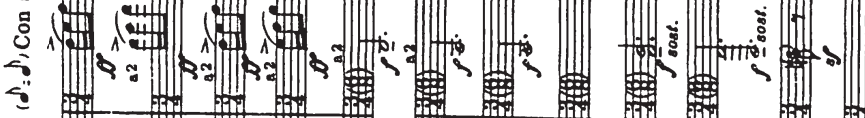

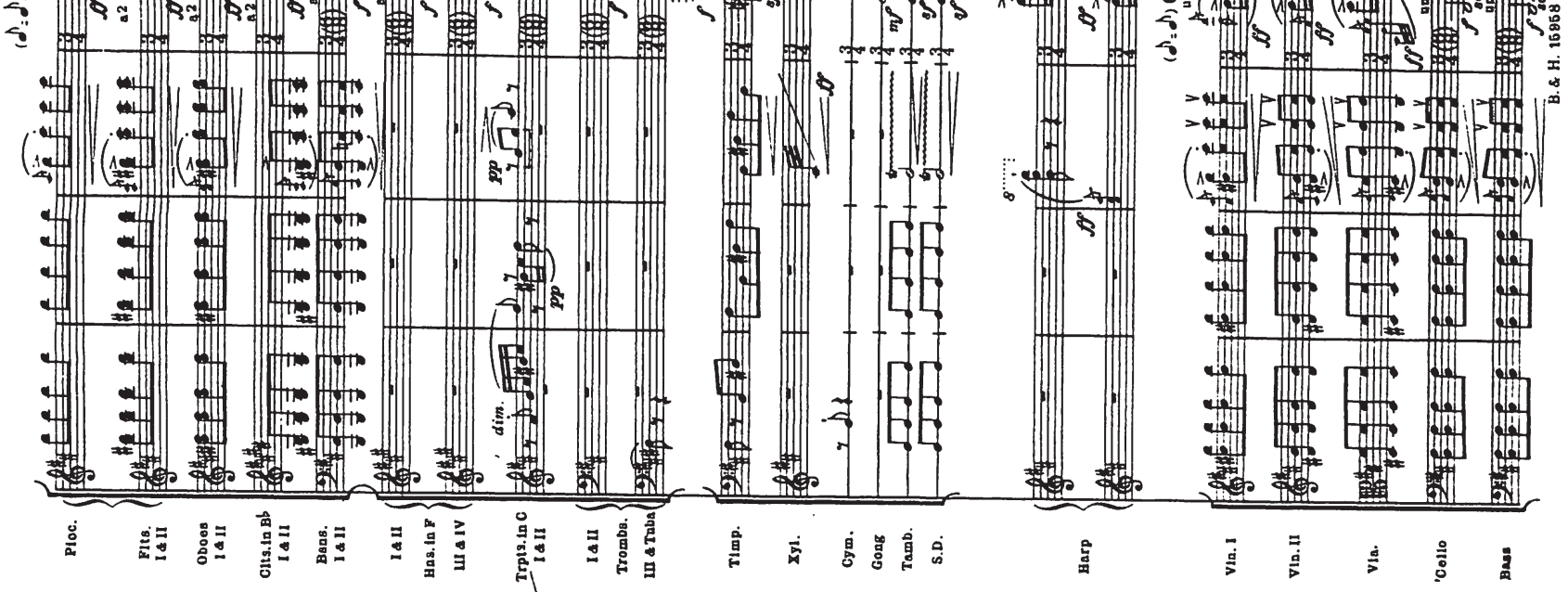

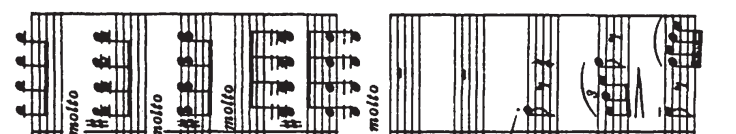

$x^{2}=4$ -

(c) $(5)$

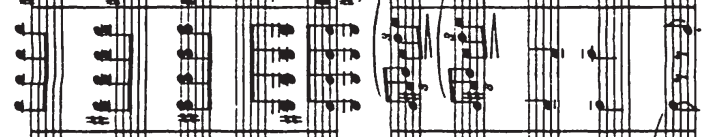

I $\geq \mathbb{L}$.

(4)

-

(i)

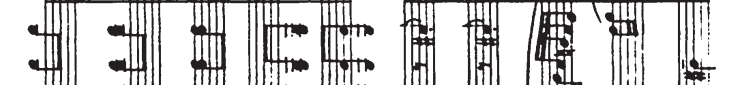

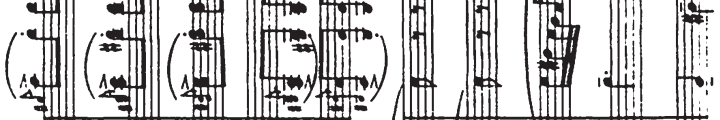

(

(⿻)

果拉

(t)

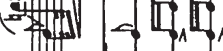

(년

: H

1. D.

- 7 - 79

$3 .-\square[$

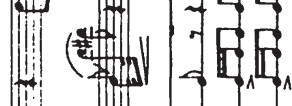

物 渄 咩

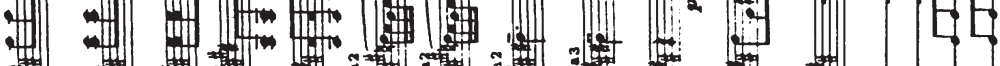

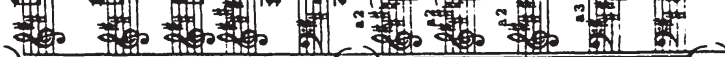

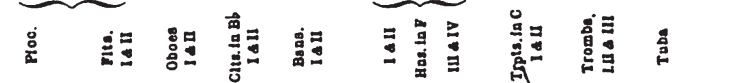

:

ร

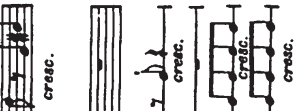

端地

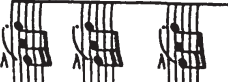

- $\cdot-$

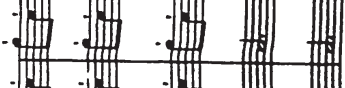

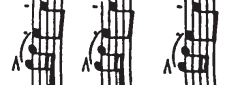

珹

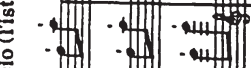

.

(1)
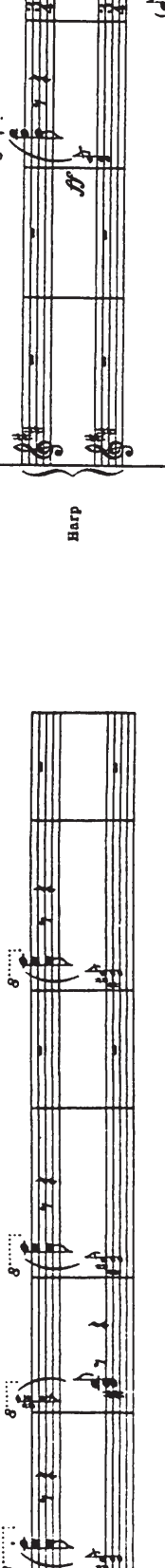

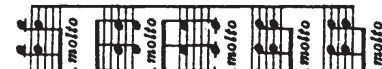

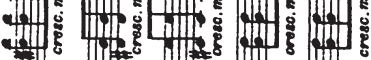

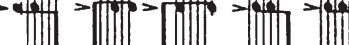

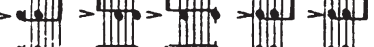

(a)

in D地

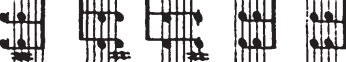

$>>+\infty>\infty=$

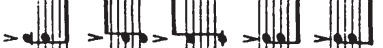

(x)

$>>>\rightarrow>0=0$

(a)

$>\infty+\infty \rightarrow \infty,>0$

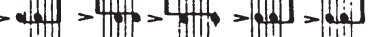

(1)

m

湖

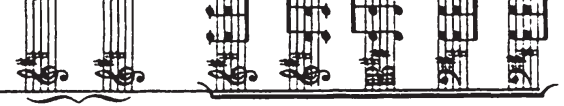

\begin{tabular}{|c|c|}
\hline 9 & $\frac{g}{3}$ \\
\hline
\end{tabular}


8
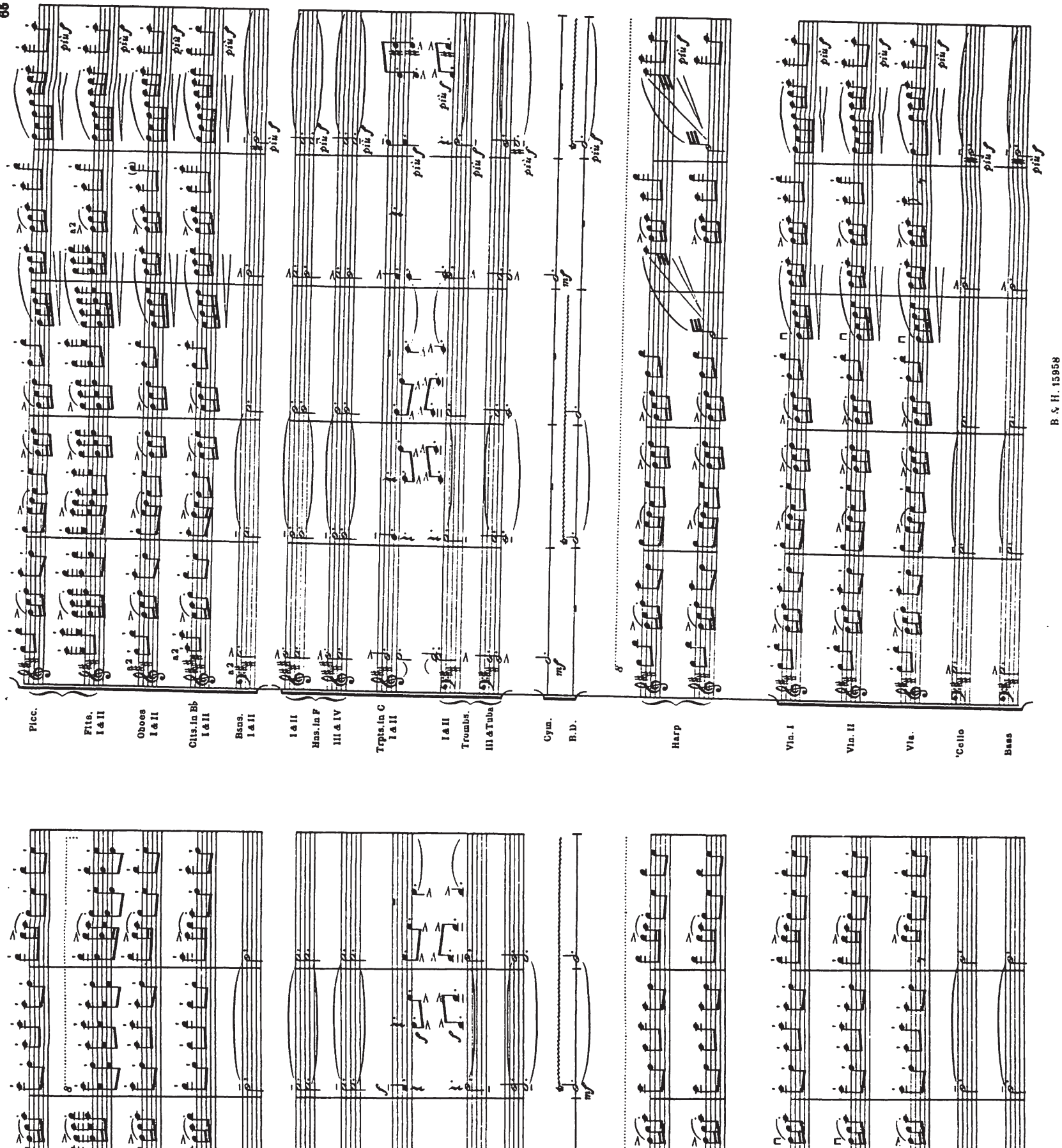

隹

:

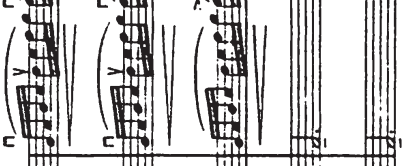

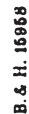

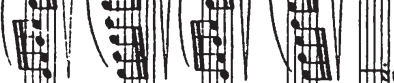

.

畉)

A

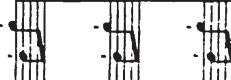

(4.).

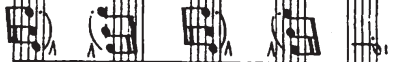

Ning vin

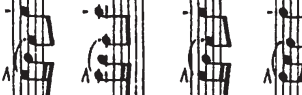

N⿴囗十正

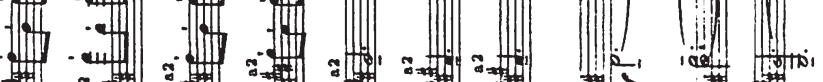

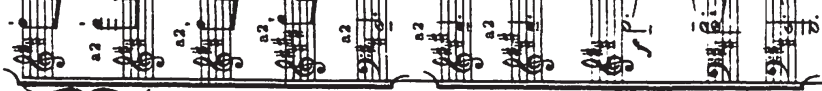

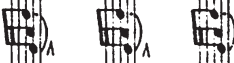

世1 1 1

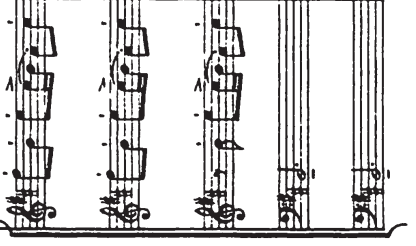

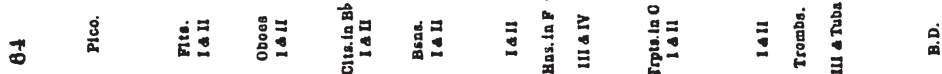

高

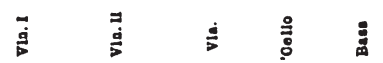


5

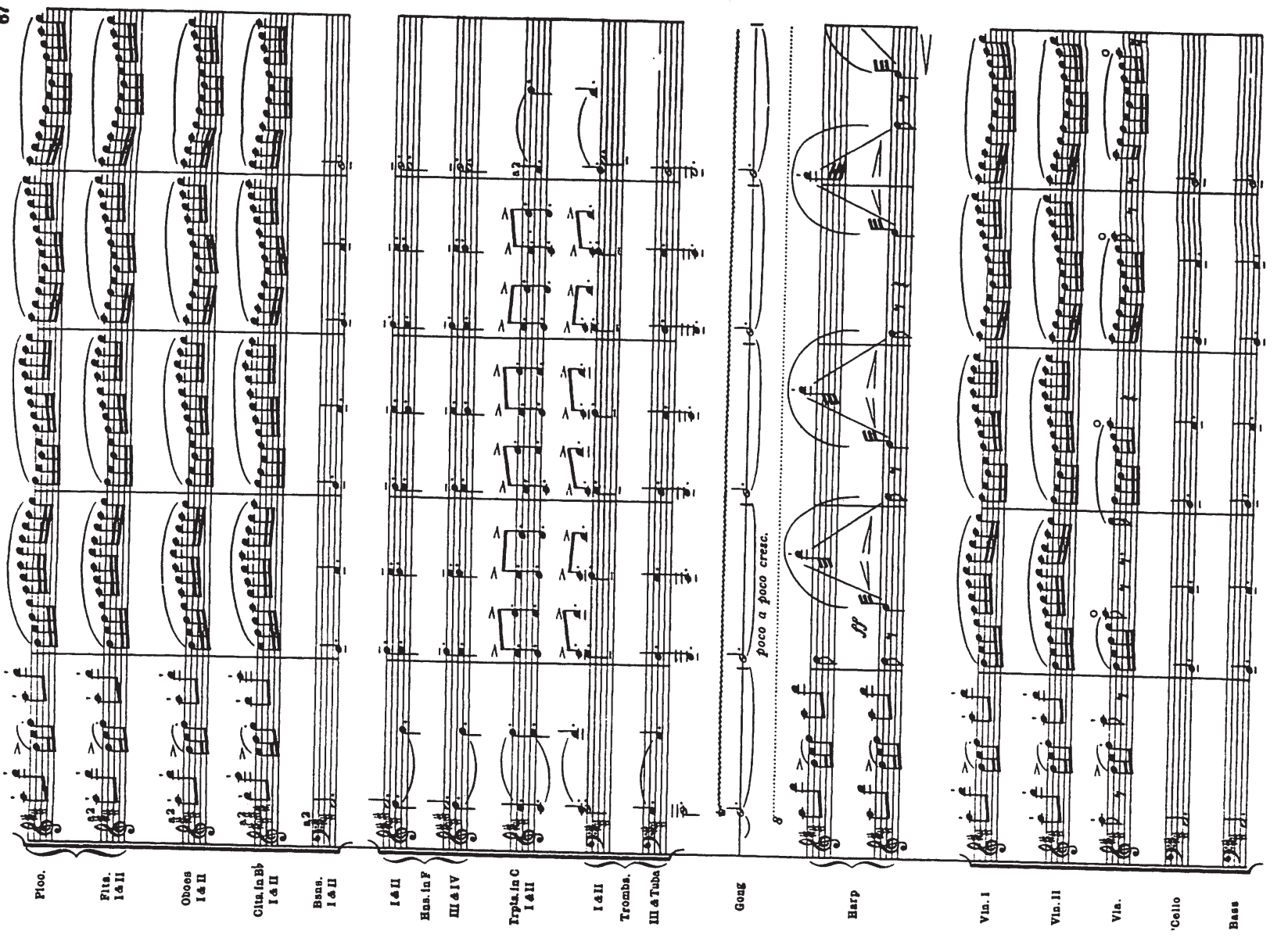

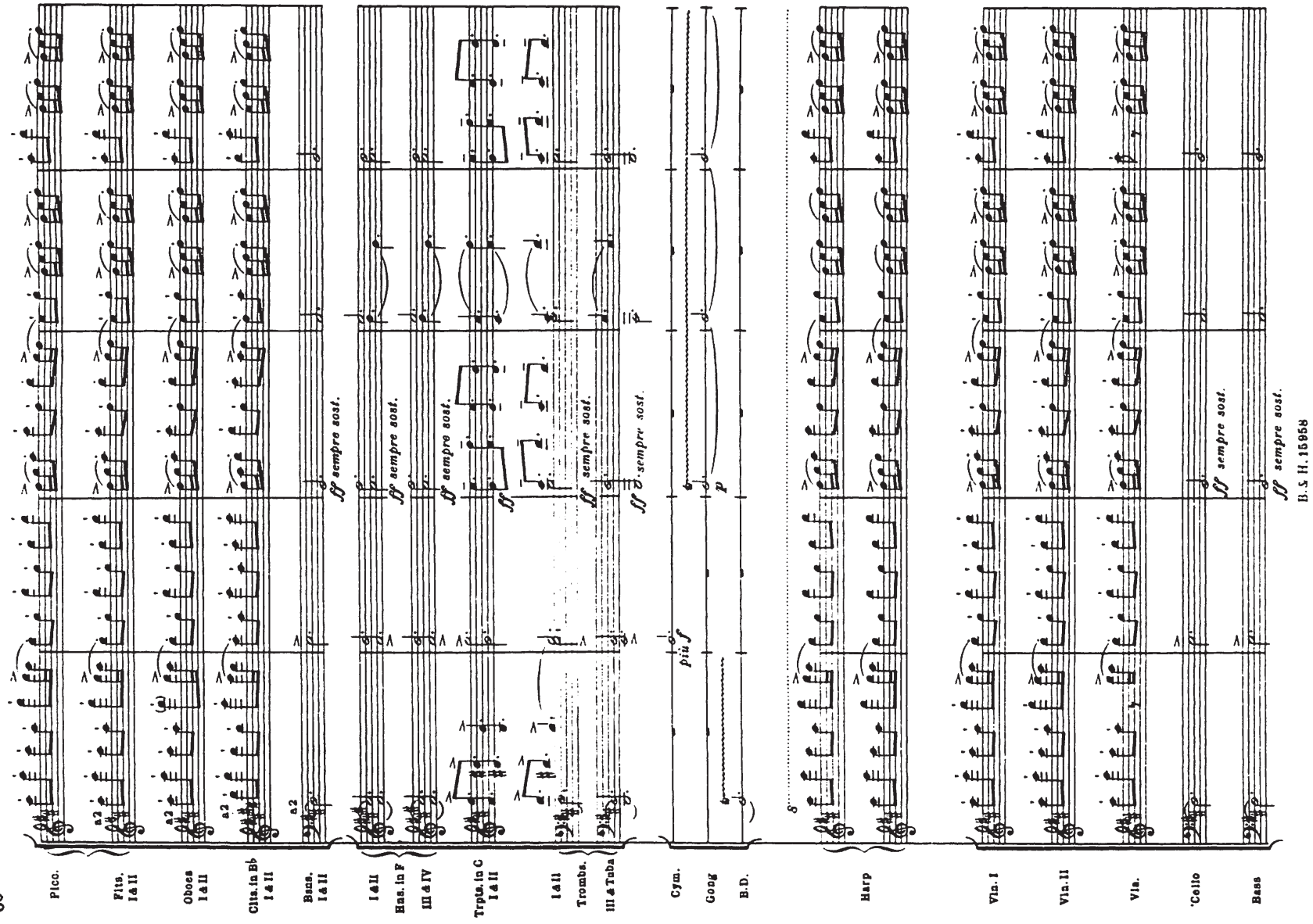




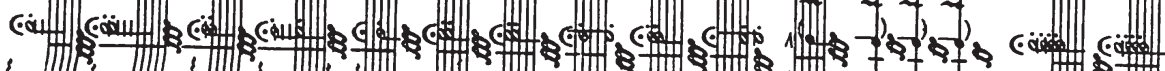

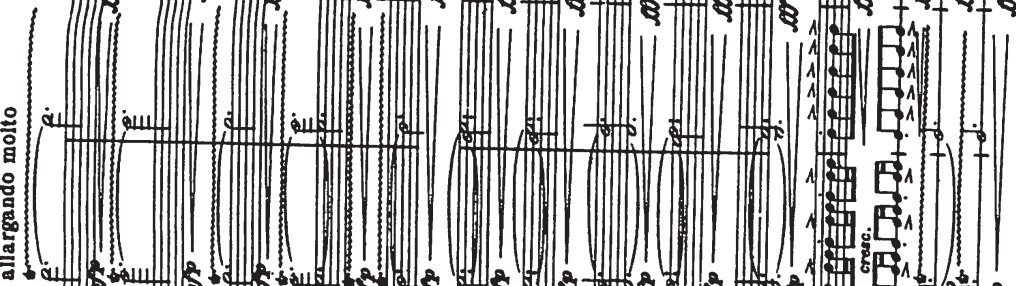

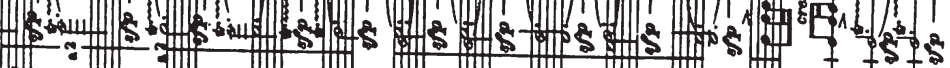

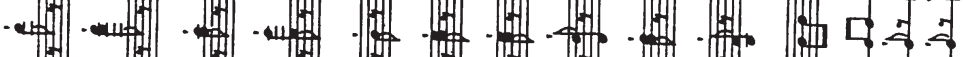

(f.) (c)

- -1 -

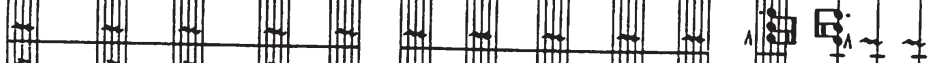

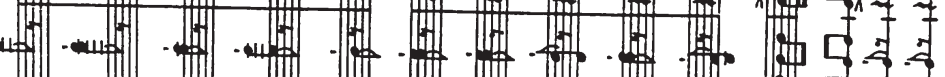

-

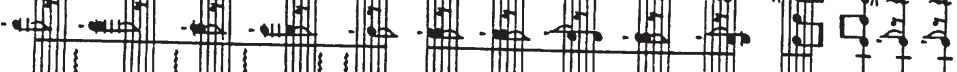

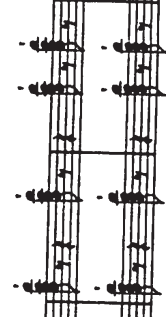
曲要

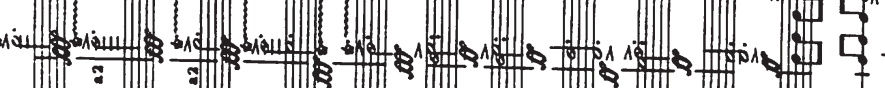

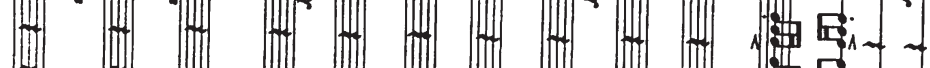

-

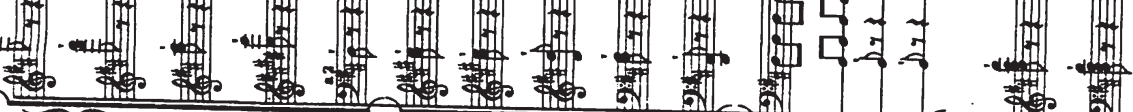

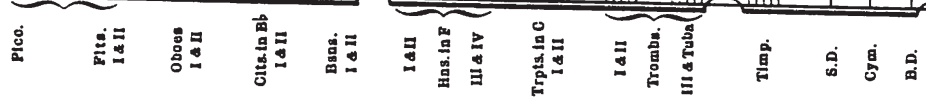
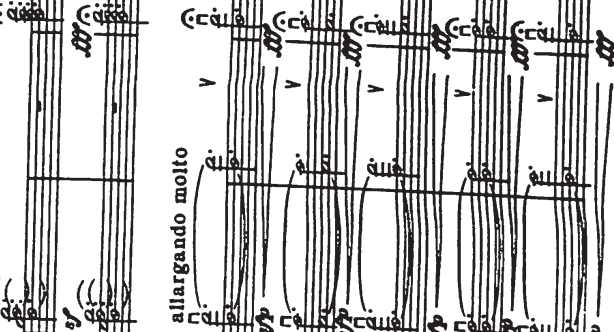

ca.

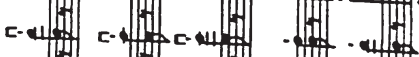

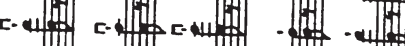

曲 册 册册

1.

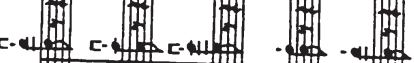

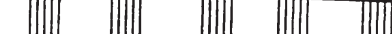

งін)

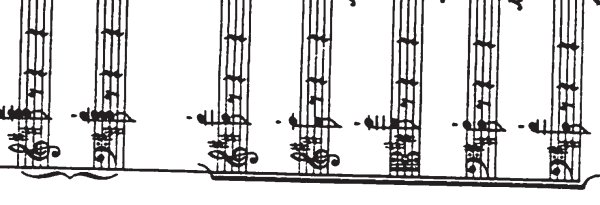

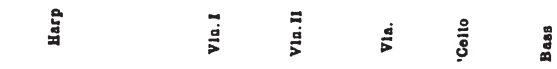

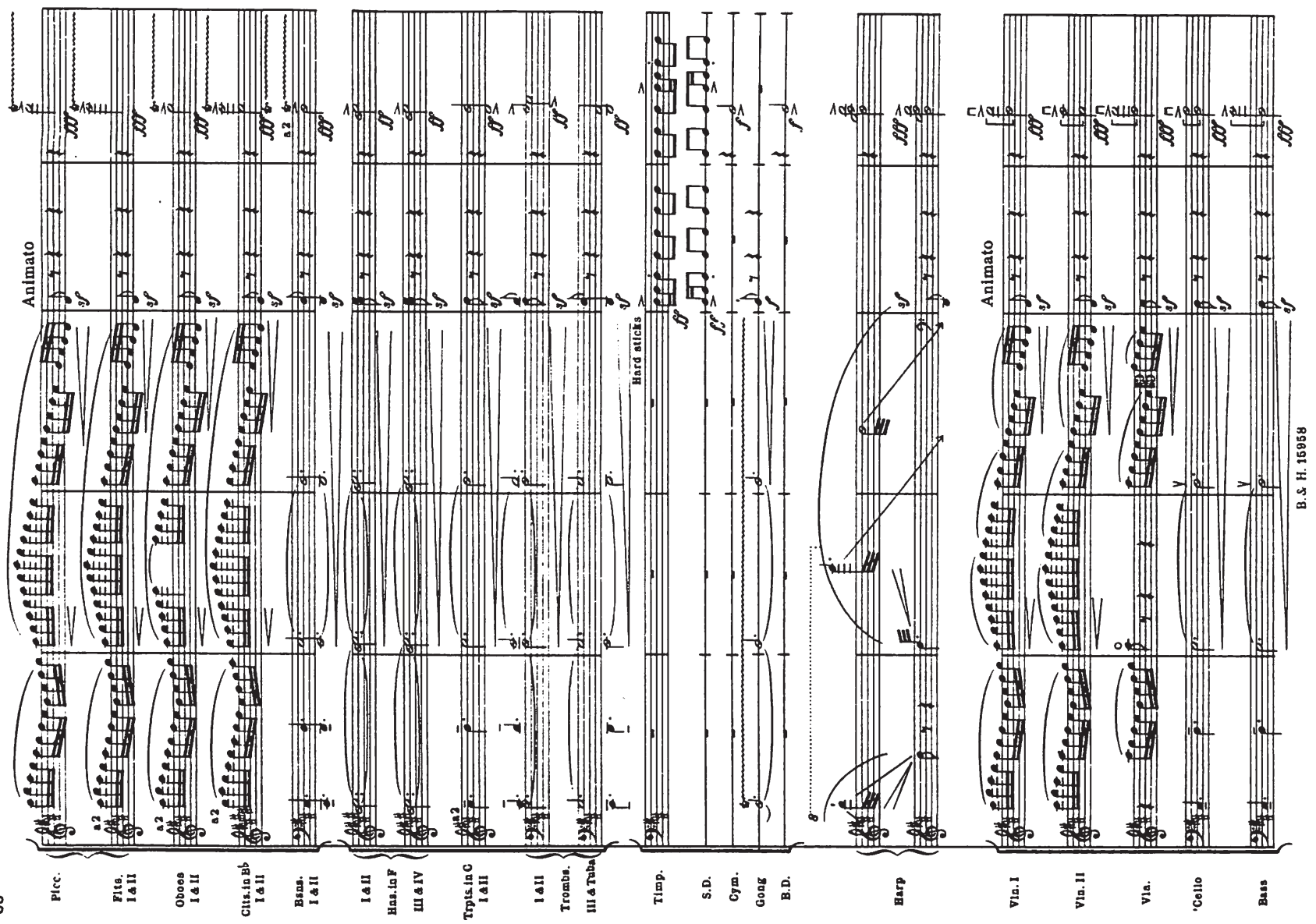


ADAGIO

For

Strings

By

SAMUEL BARBER

ซ

G. SCHIRMER New York/London 
Playing time: $7.8 \mathrm{~min}$.

\section{Adagio for Strings*}

Molto adagio

Samue1 Barber, Op. 11

espr. cantando

Violin I

Violin II

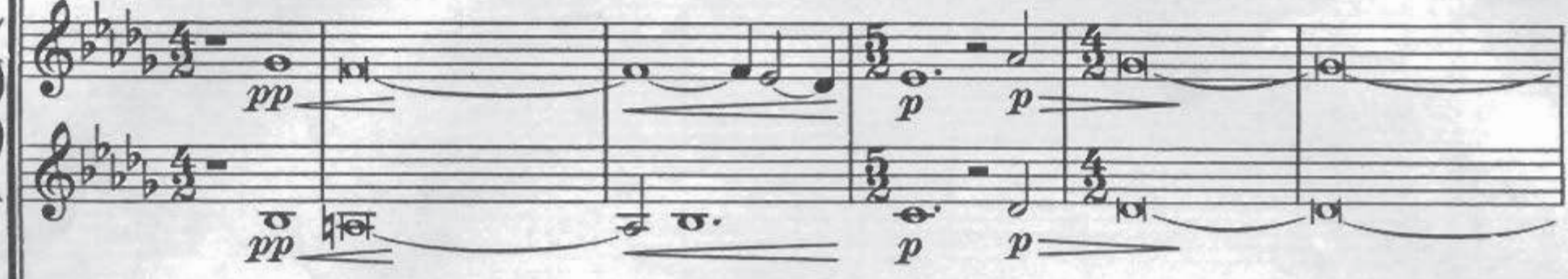

Viola

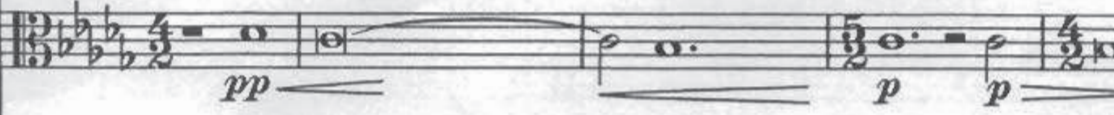

$2+\frac{10}{2}$
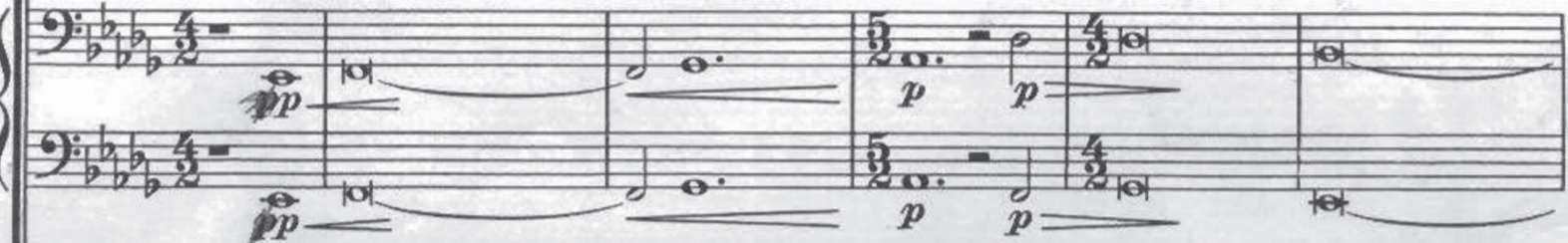

Double-Bass

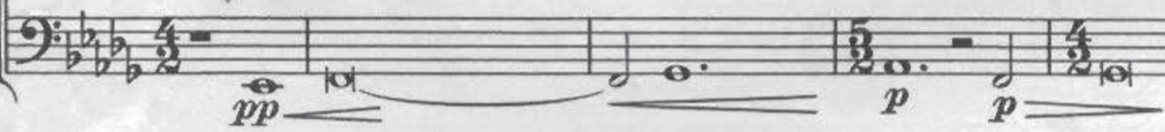

1.

V1n.I

Vin. II

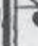

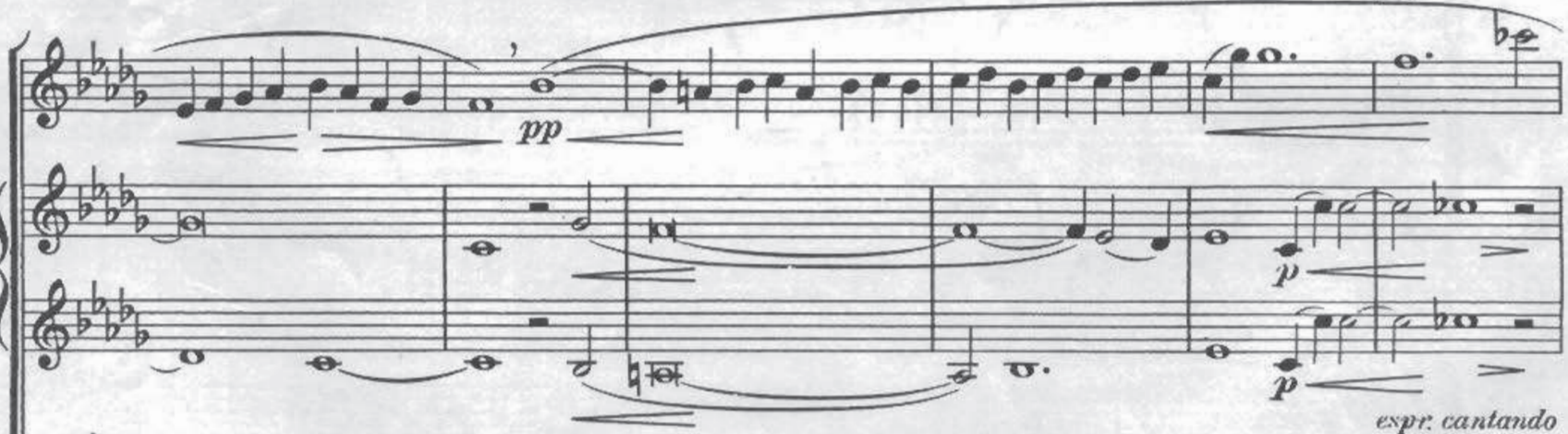

Vla.

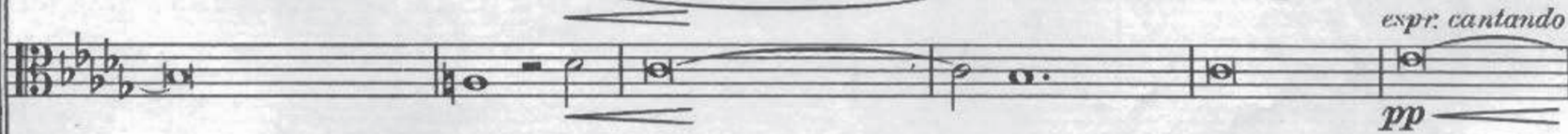

vc. \{

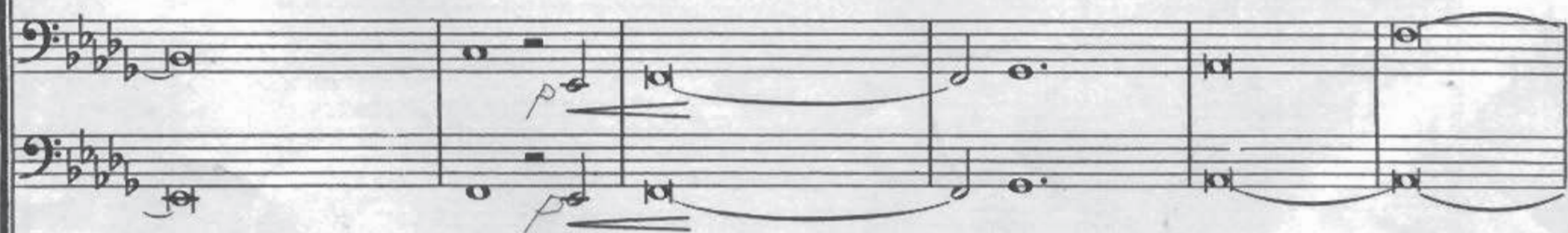

D.-B.
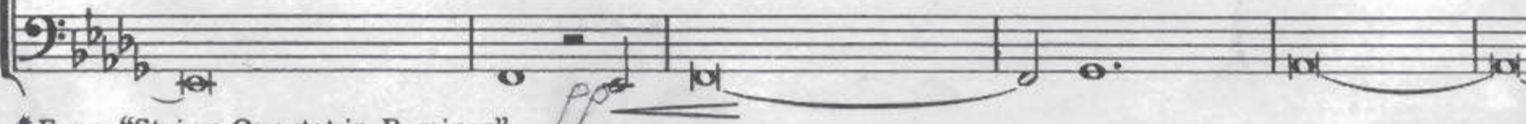

*From "String Quartet in B minor"

Copyright, 1939, by G. Schirmer, Inc. 
4

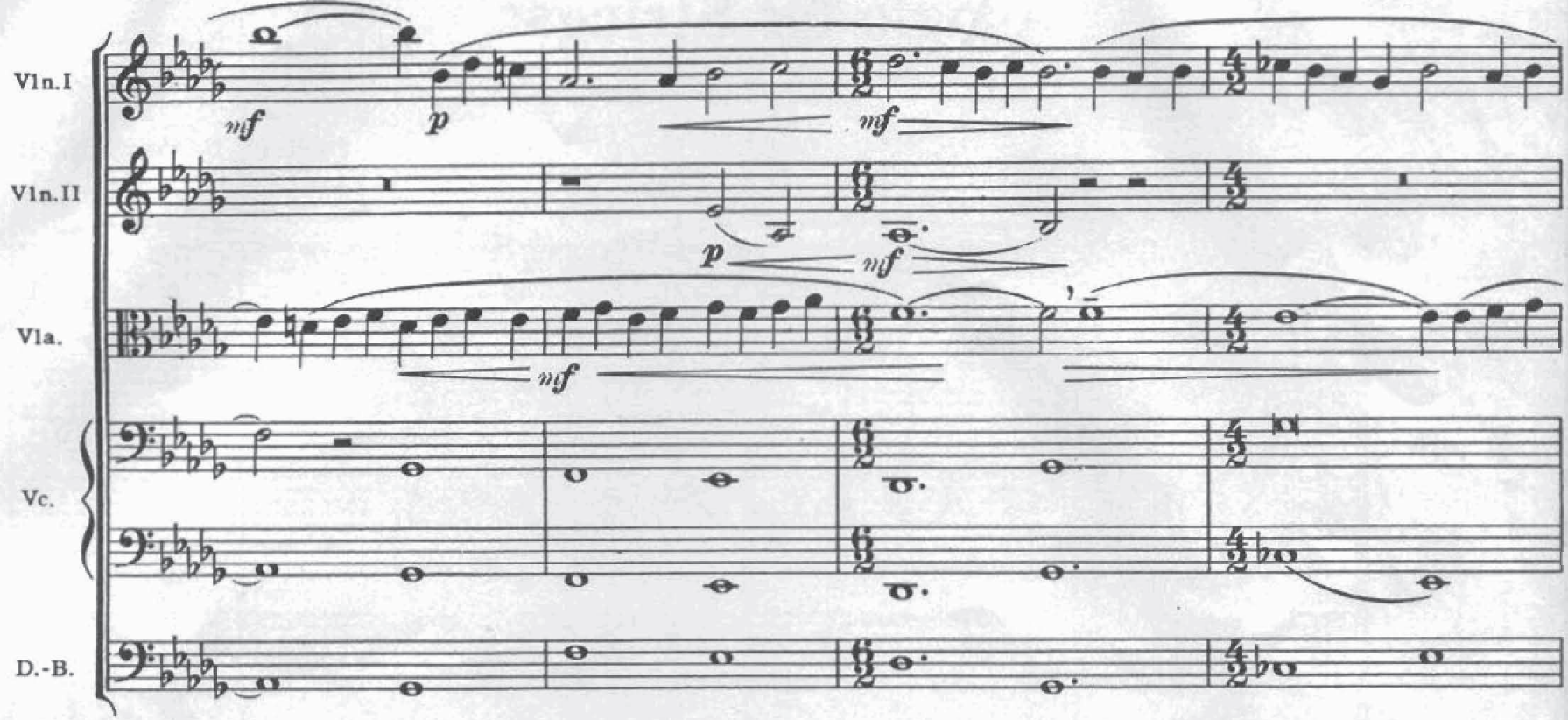

2

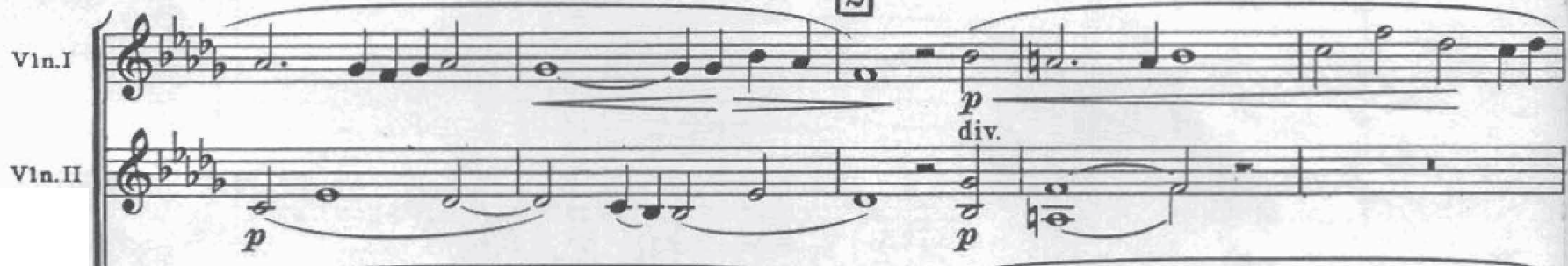

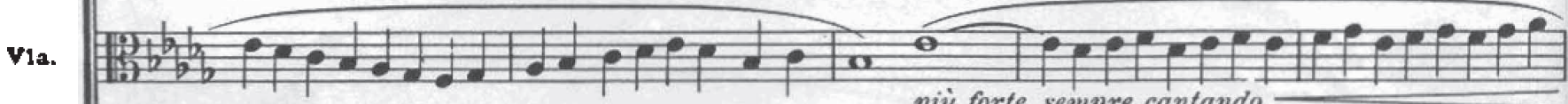

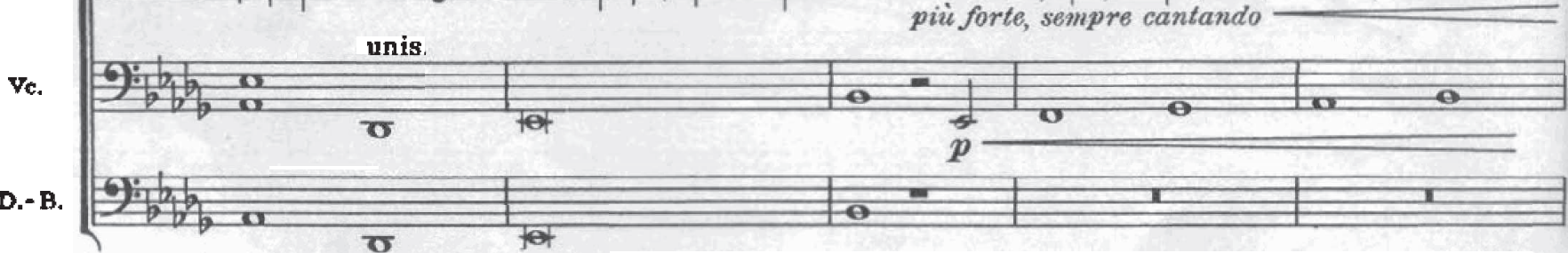

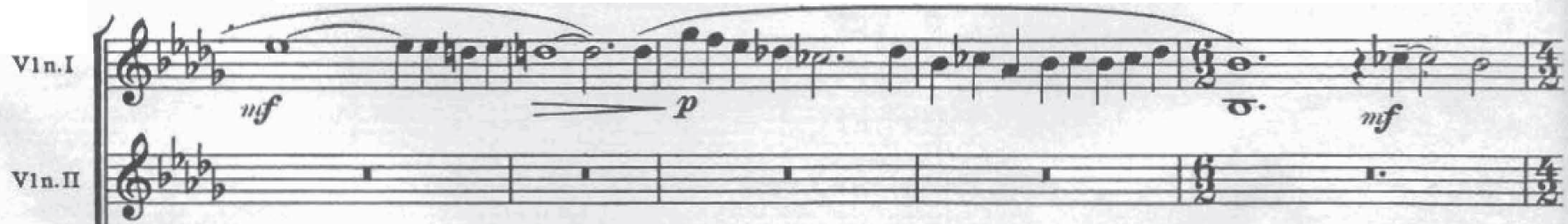

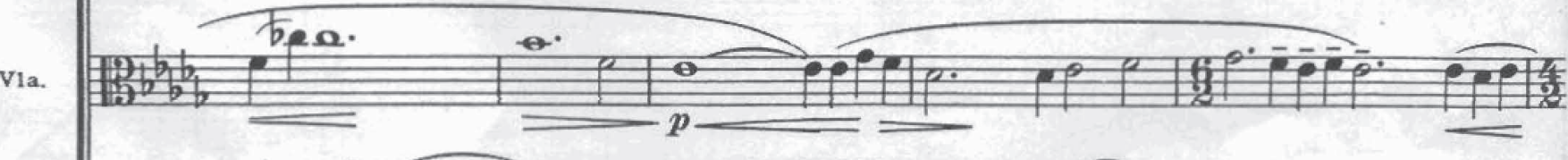

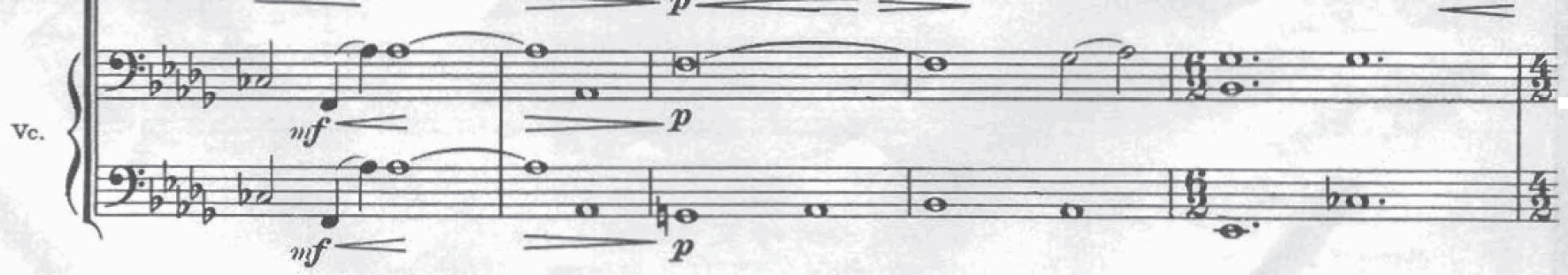


8
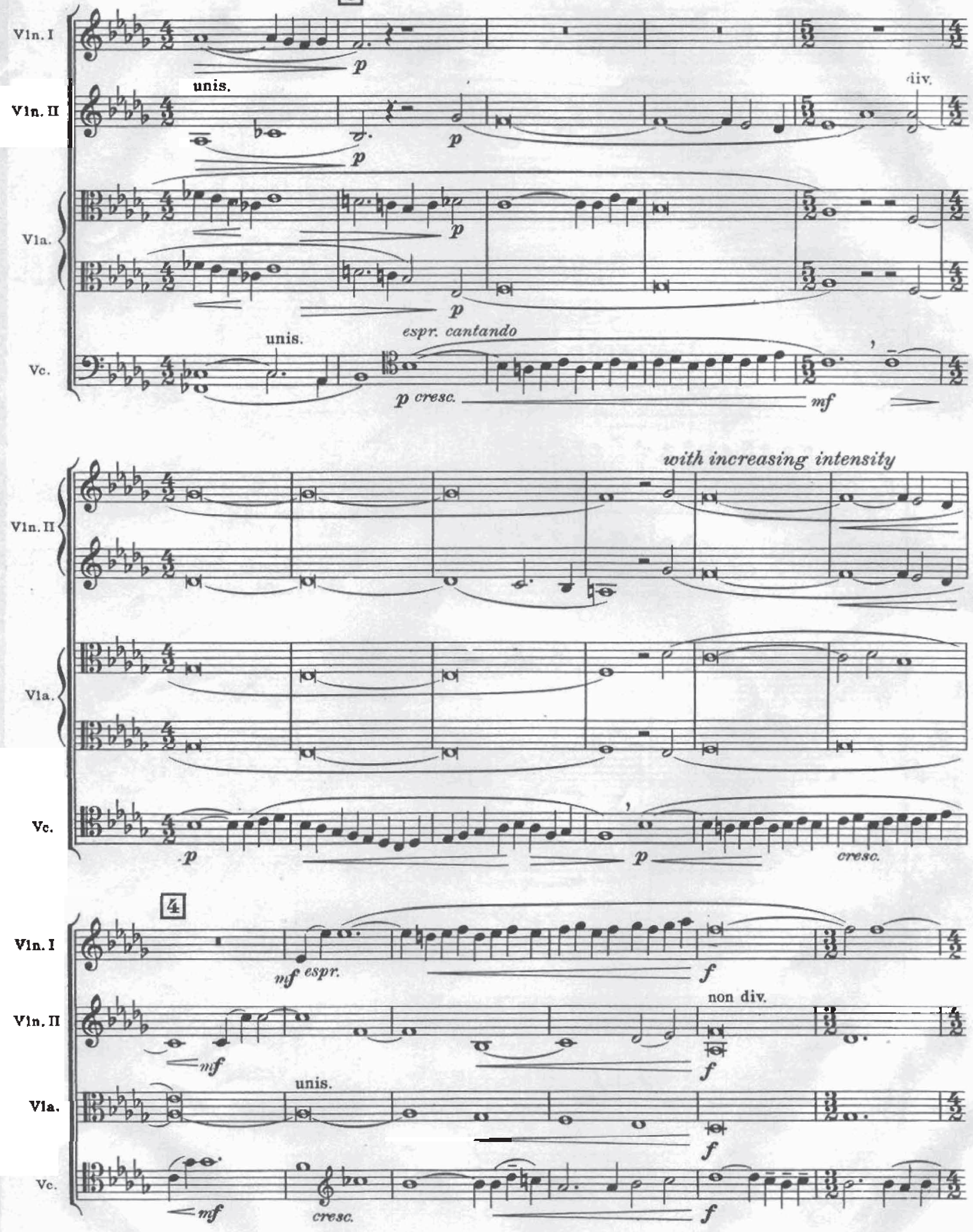
6
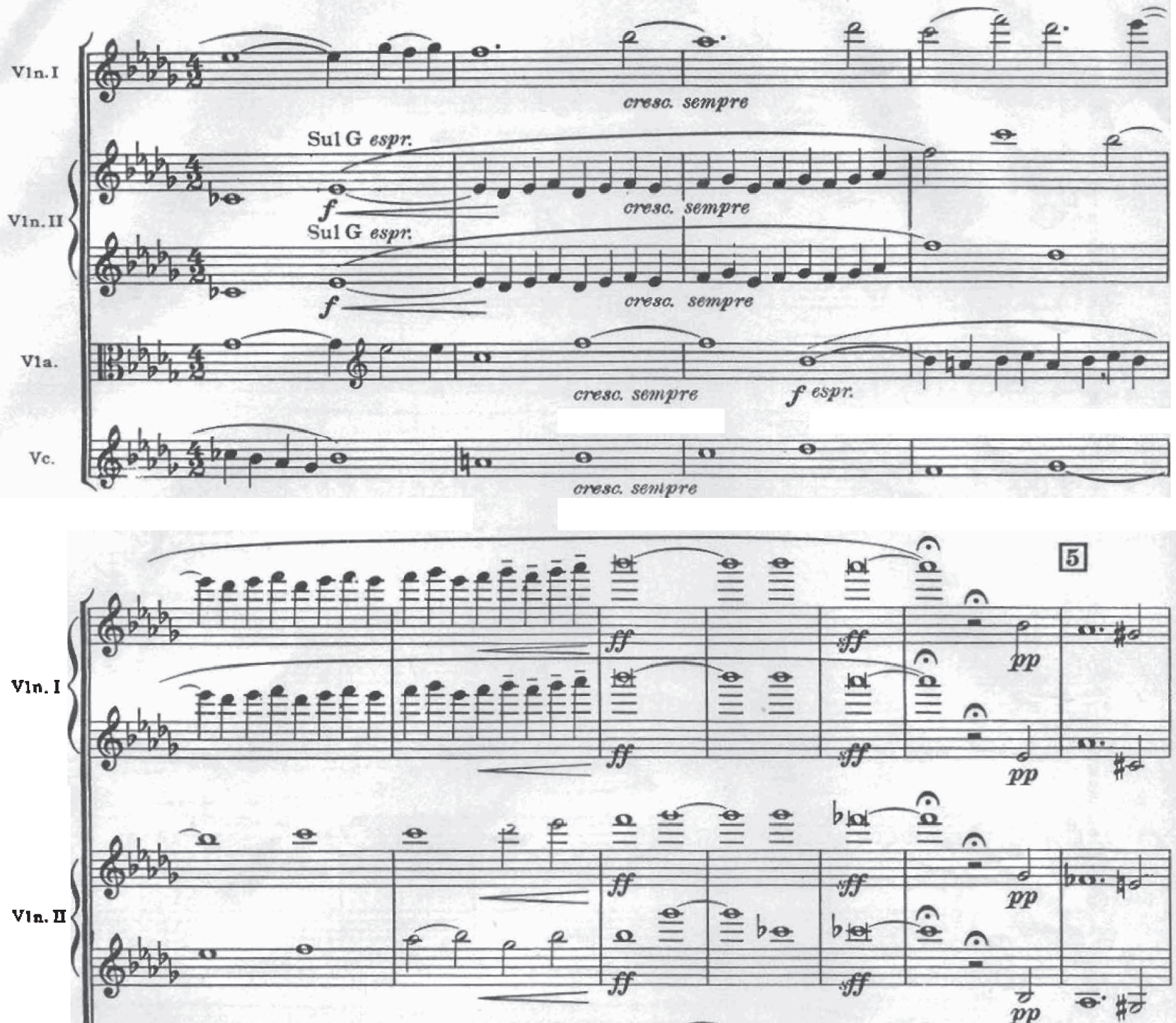

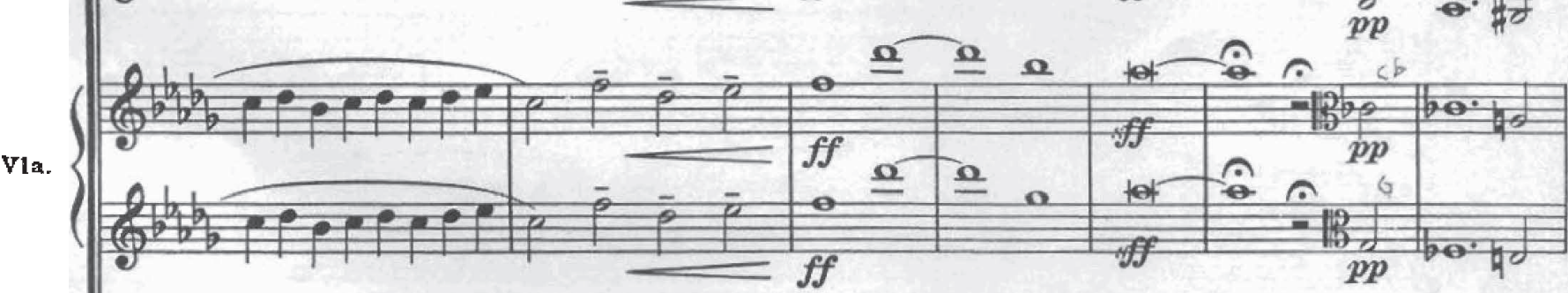
Vin. $\{($ 
Tempo Io (sord. ad lib.)

6

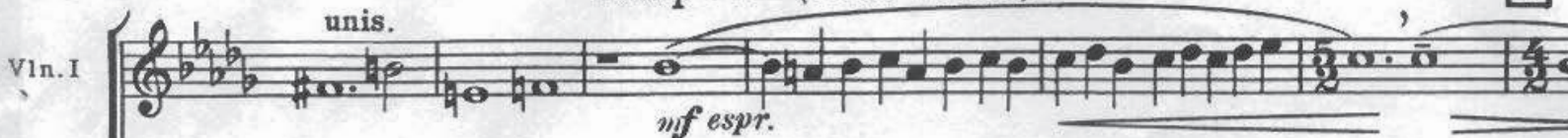

VIn. II

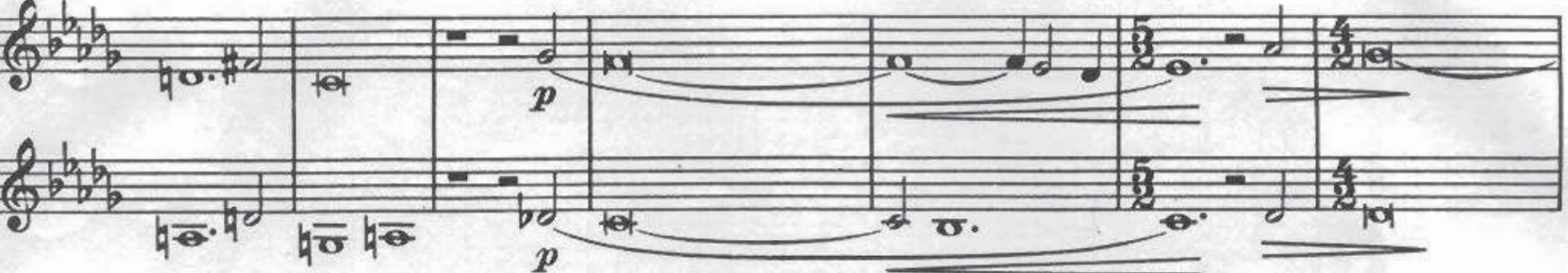

1a.

(av) div.

Vc,

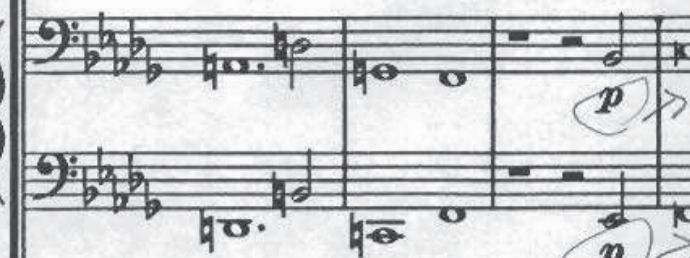

40.

D.-B.

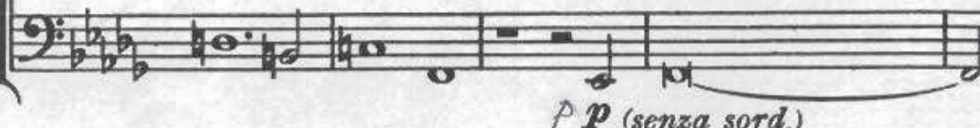

$$
P \boldsymbol{p}_{\text {(senza sord.) }}
$$

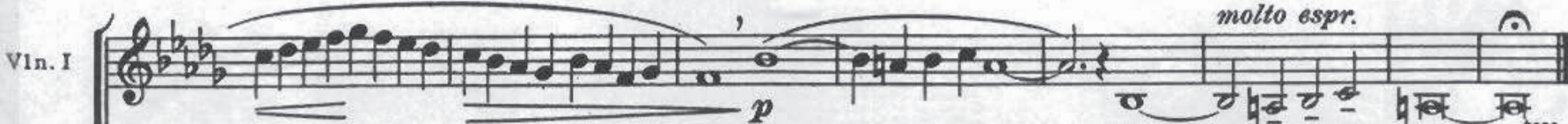
$m f=p p$

Vln. $\mathrm{I}$

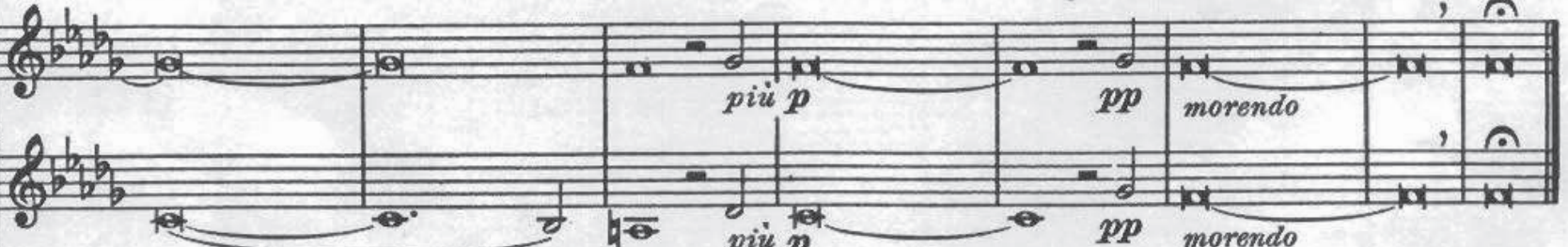

v1a.

角,

D.-B.

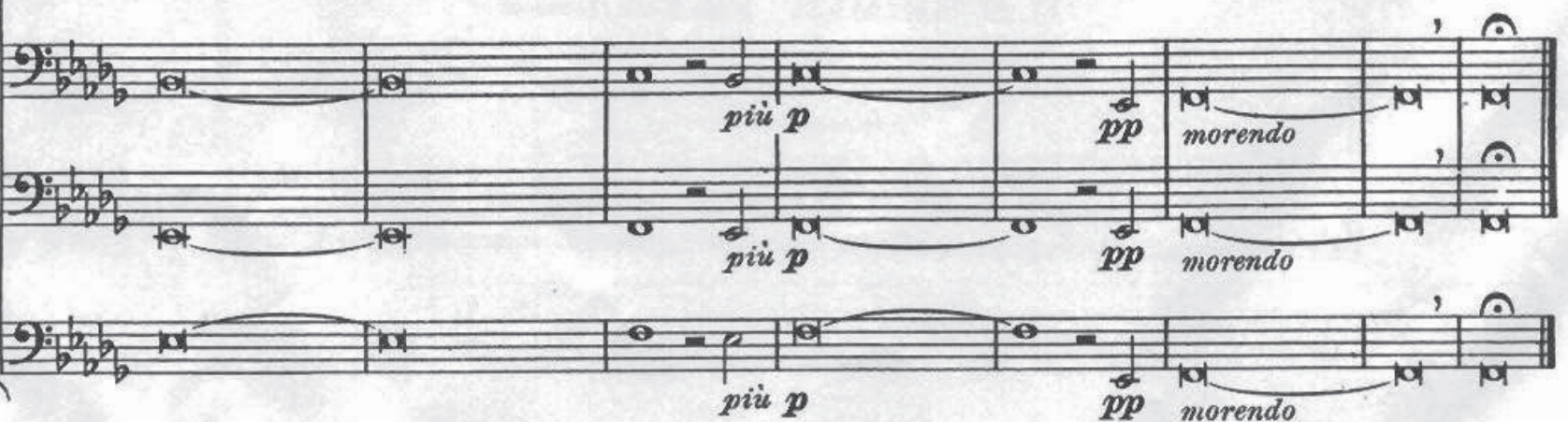




\title{
Symphony No. 3 in E-Flat Major, Op. 55 ("Eroica")
}

\author{
by
}

\section{Ludwig van Beethoven}

\section{Composed in 1803}

CCARH Edition (C) 2008 
Symphony No. 3

P1 I

Flauti 1, 2

Oboi 1, 2

Clarinetti 1, 2

in $B b$

Fagotti 1, 2

Allegro con brio. $(0 .=60)$

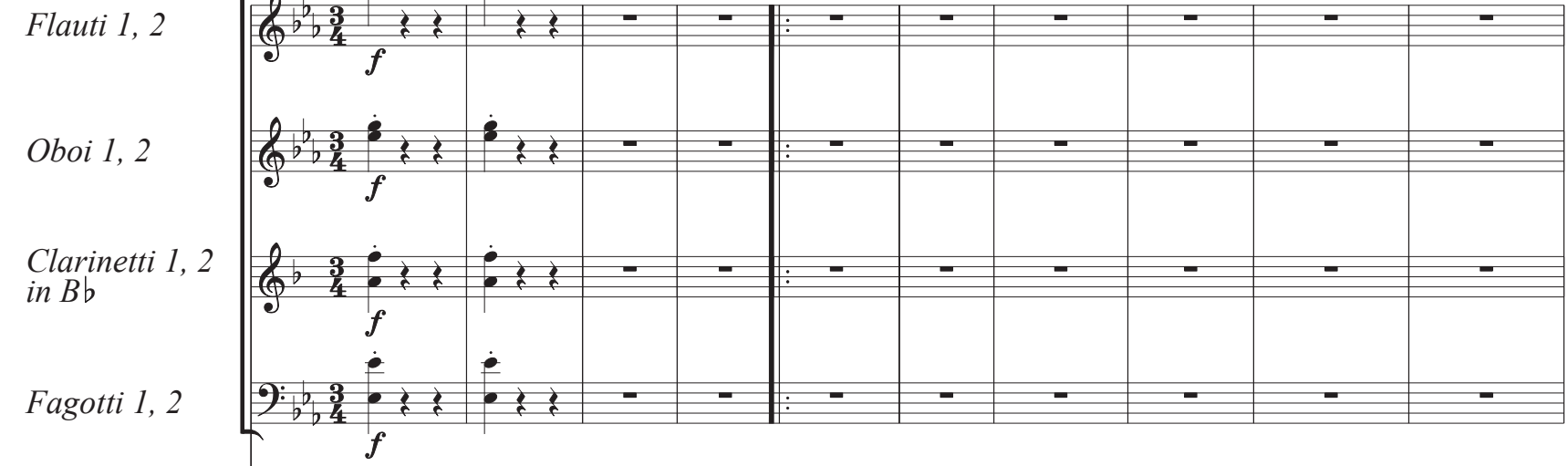

Corni 1, 2

in $E$ b

Corno 3

in $E$ b

Trombe 1, 2

in $E b$

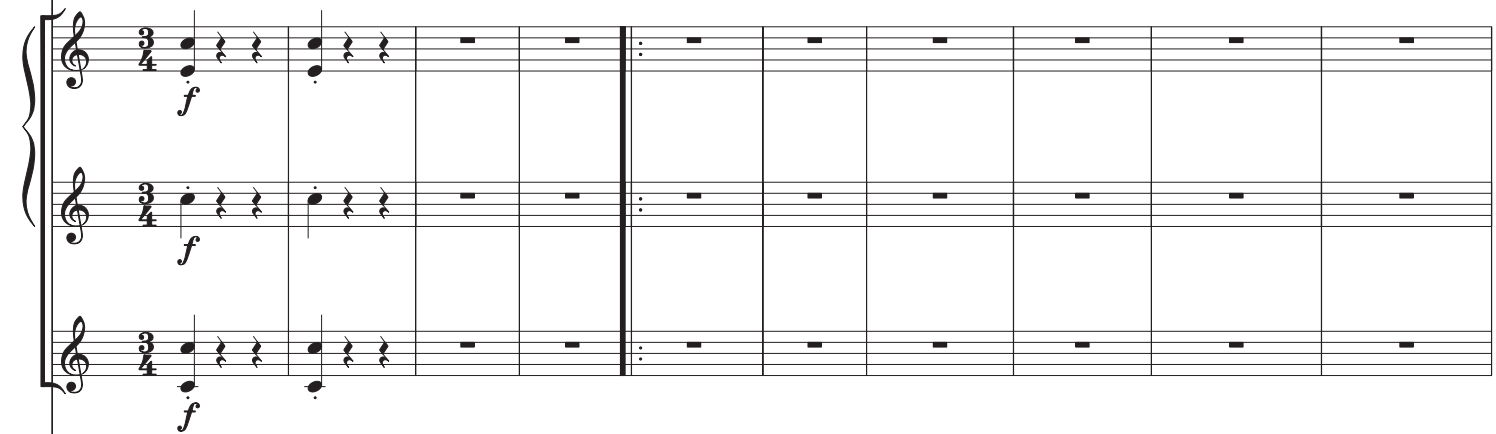

Timpani

in $E b, B b$

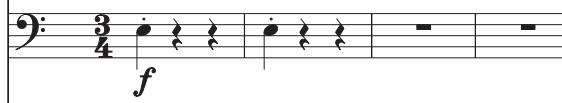

Violino I

Violino II

Viola

Violoncello

Contrabasso

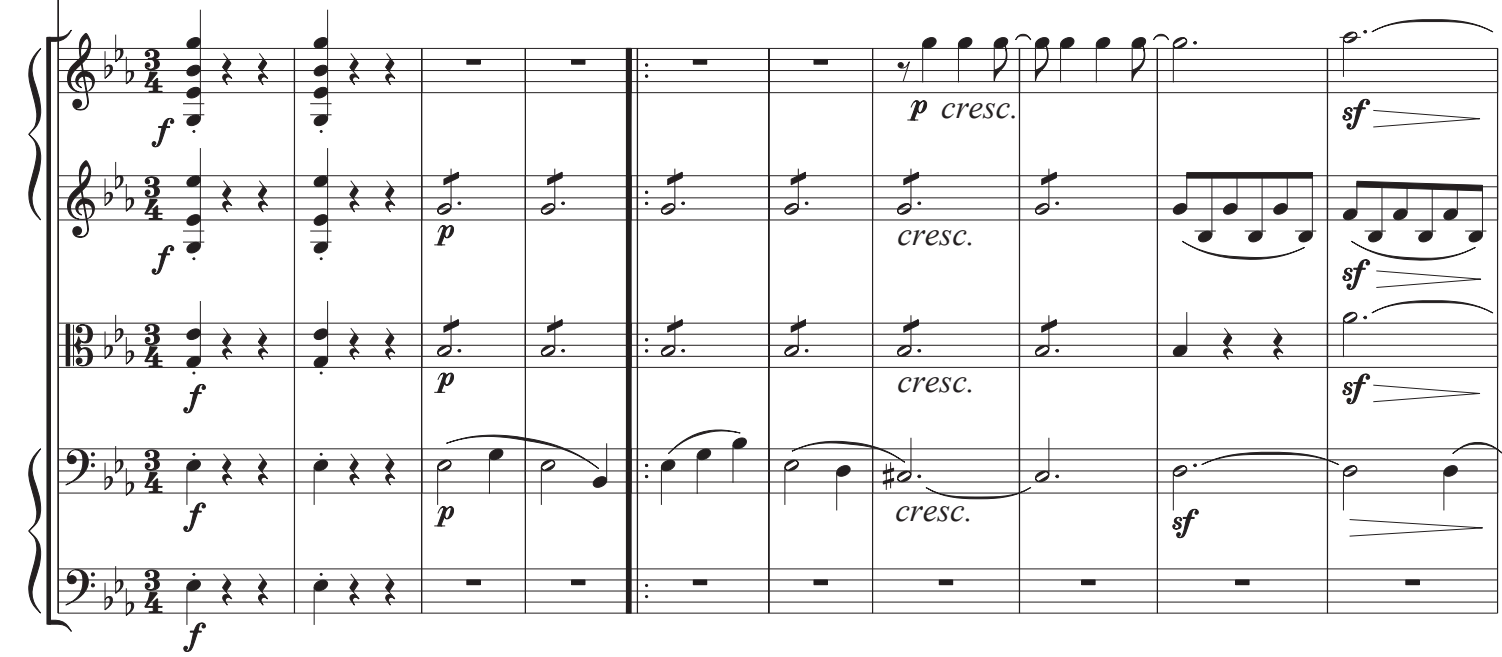




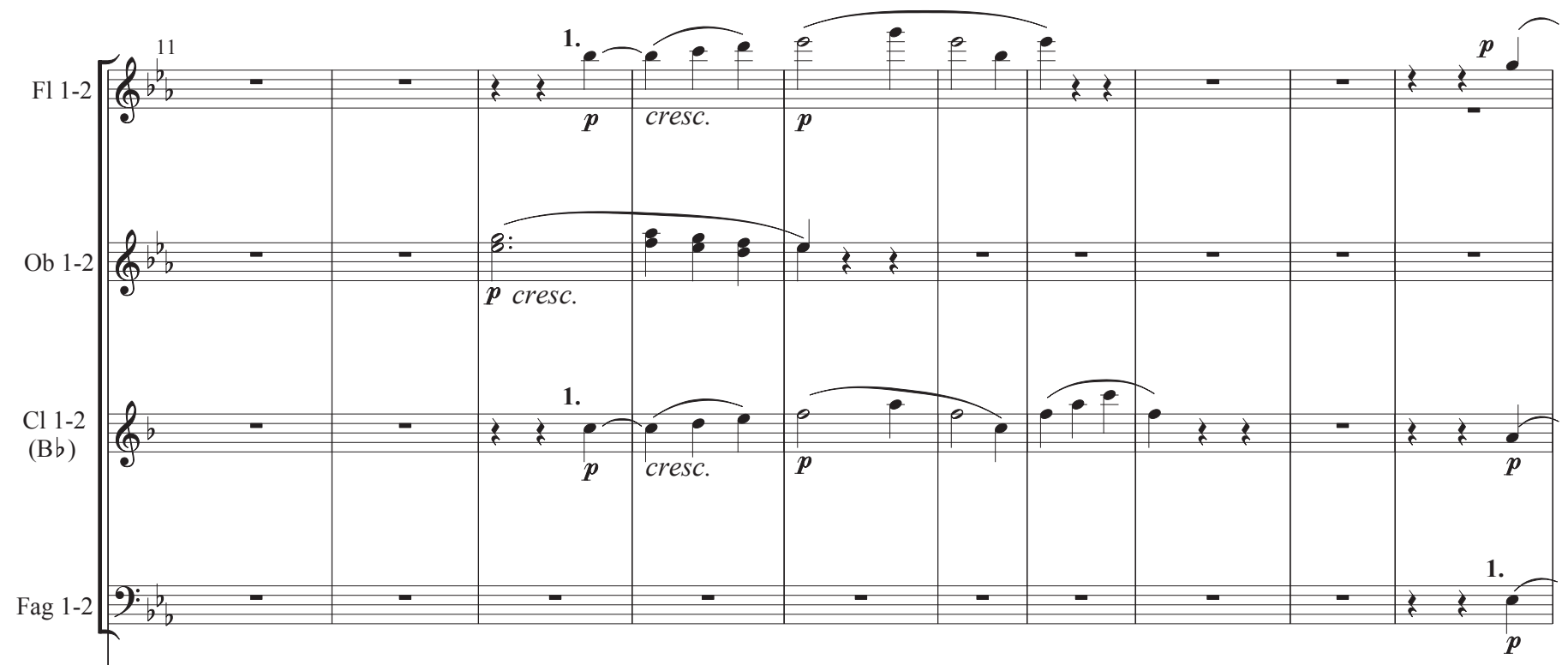

1. 2 .
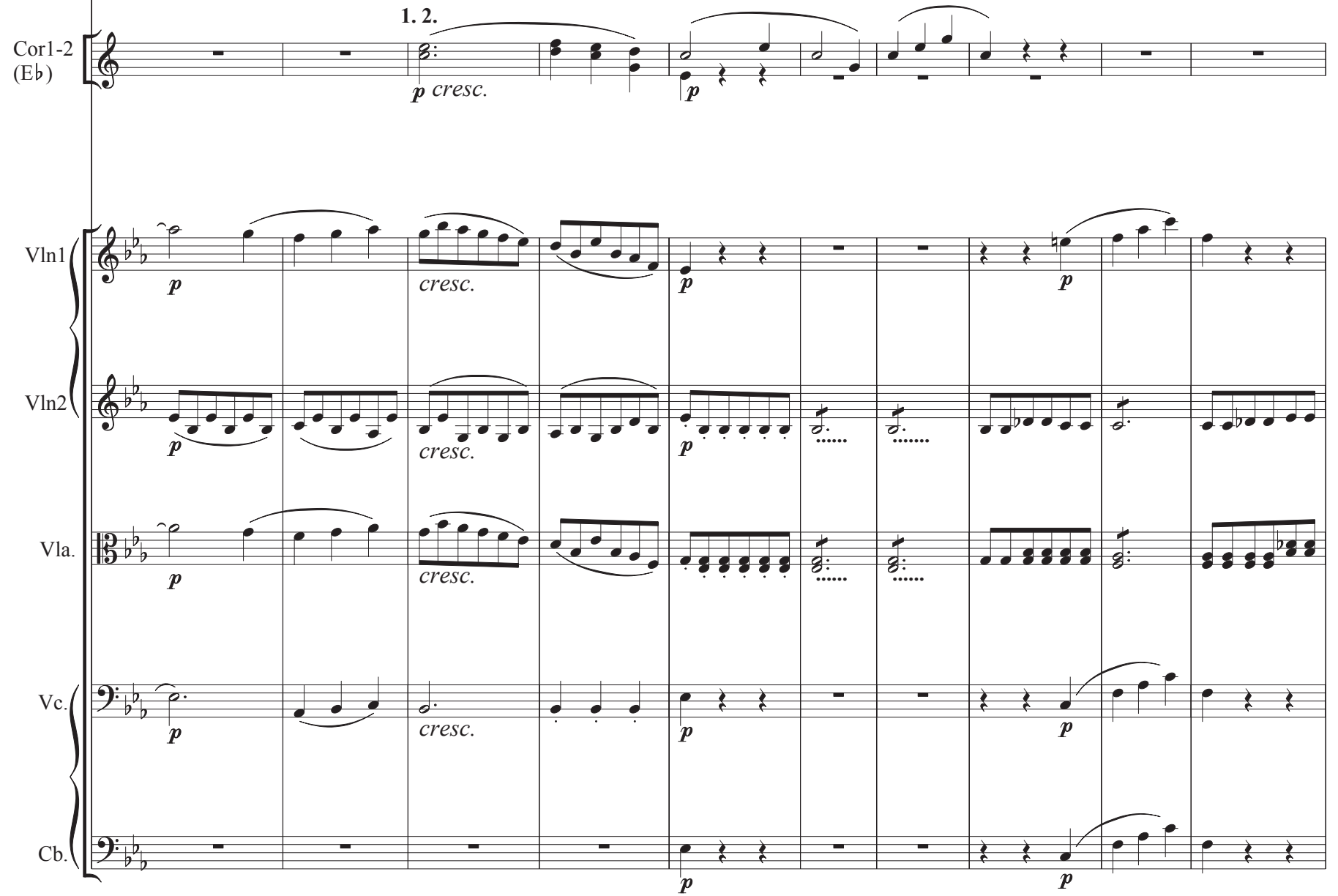

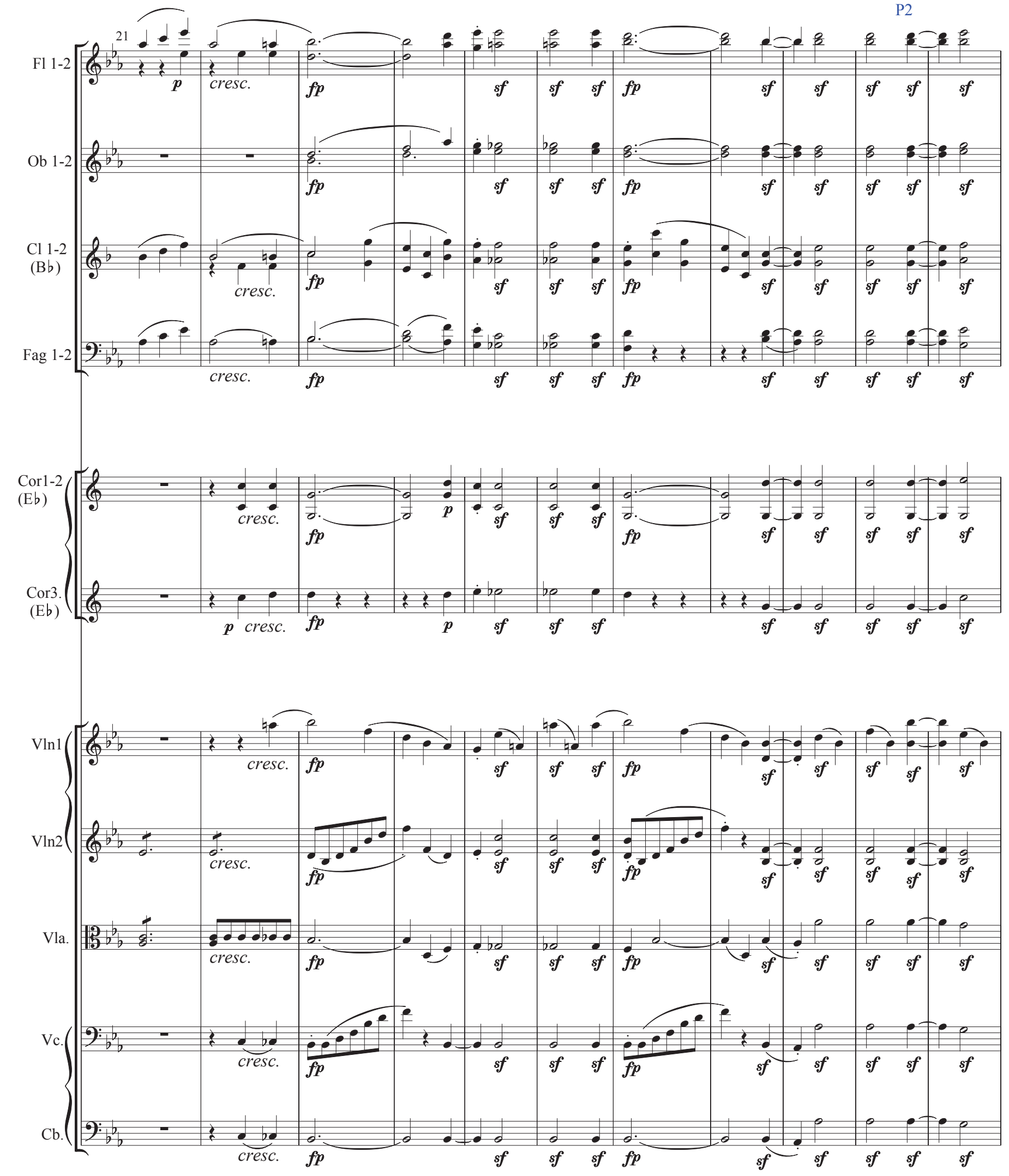

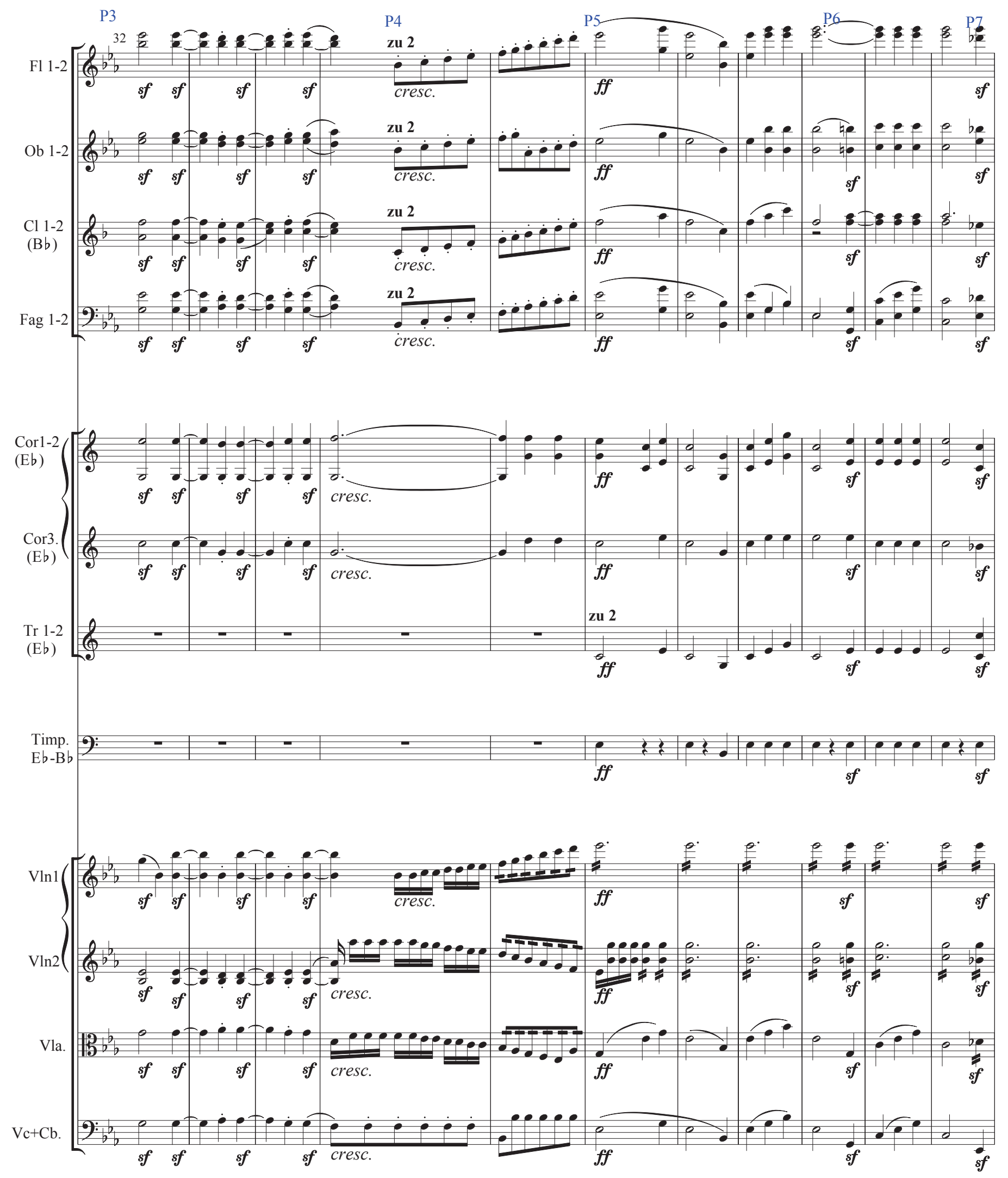


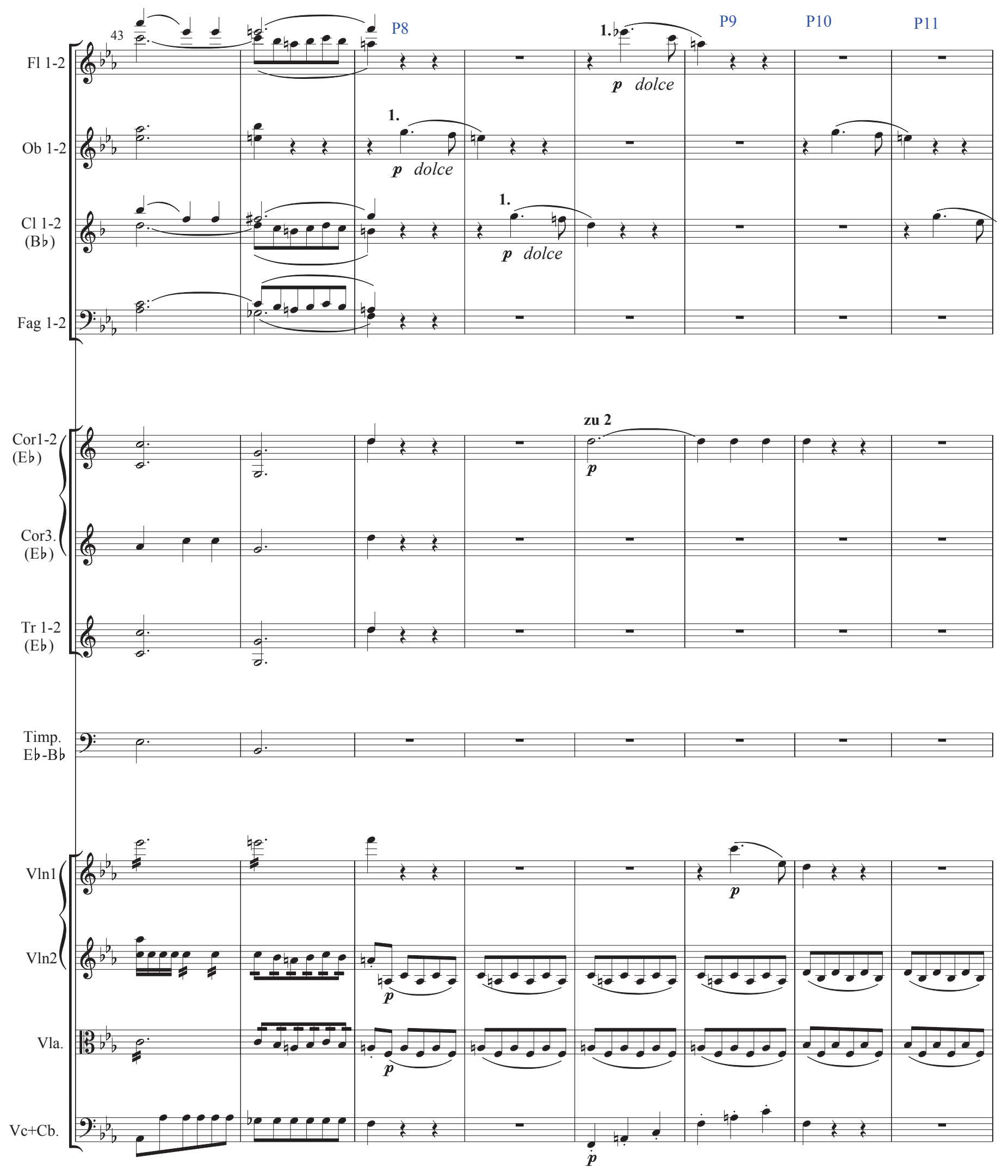



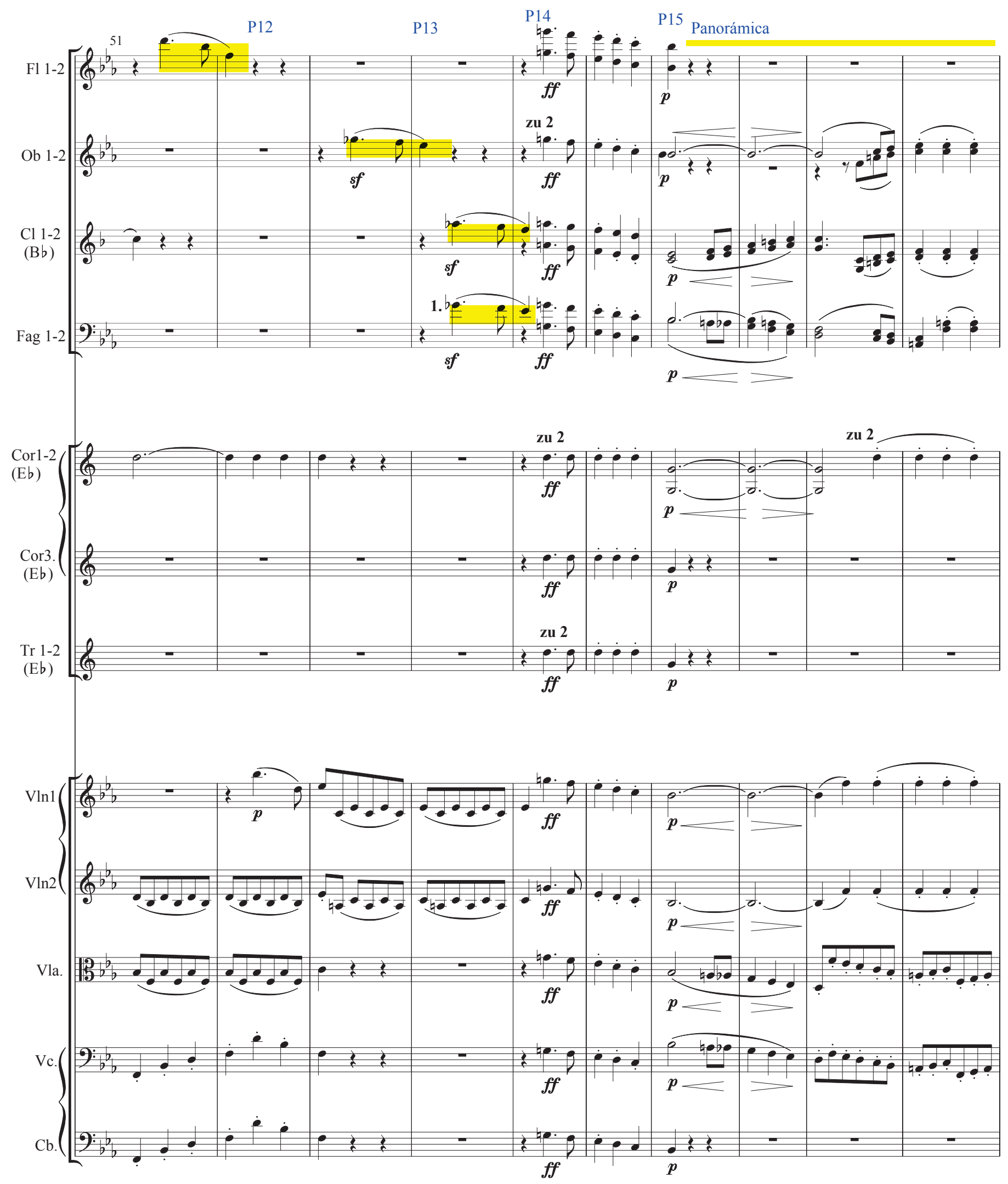


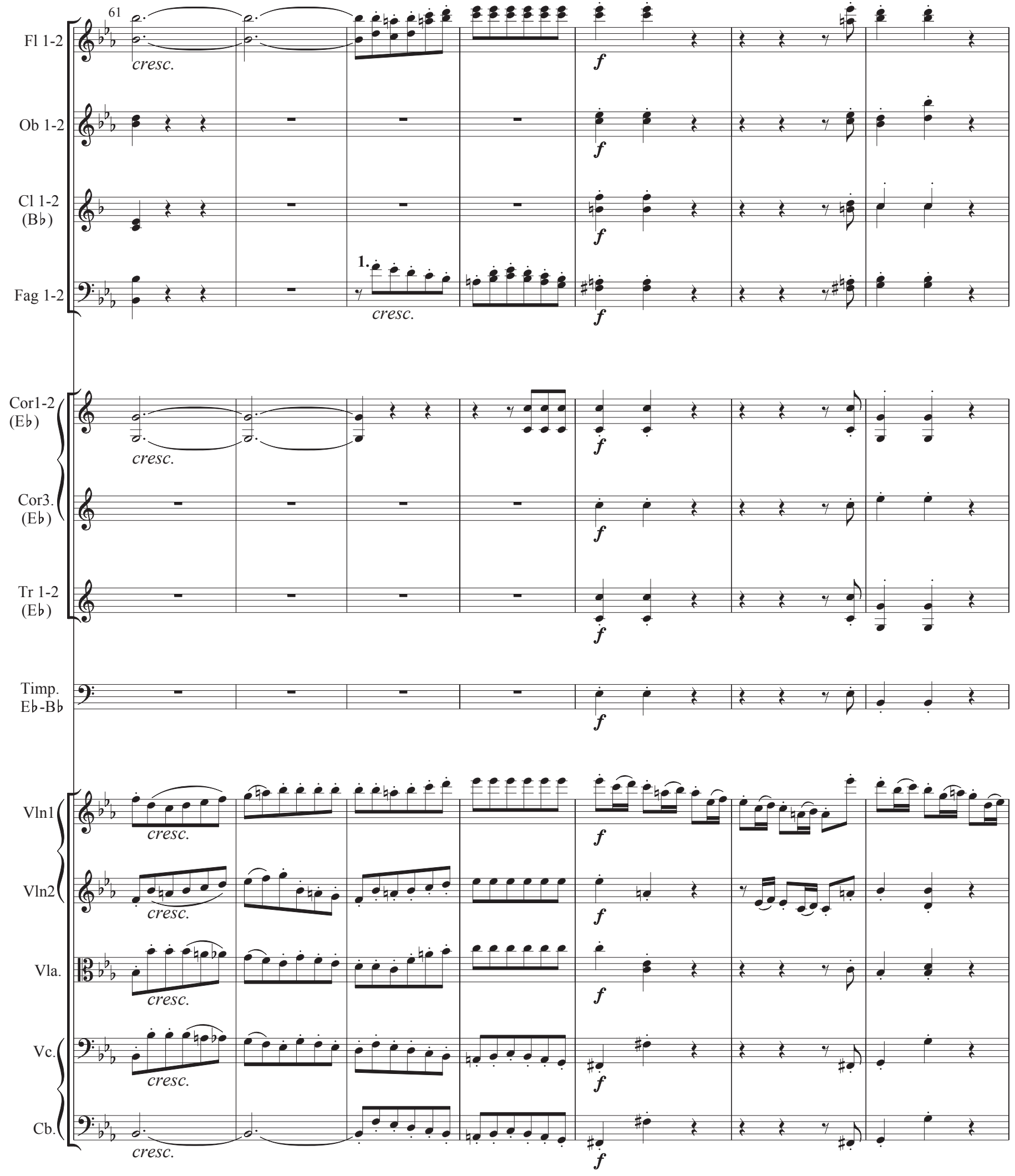


P20 Concertino hasta P 25 Saltos de plano estroboscópicos- Beethoven
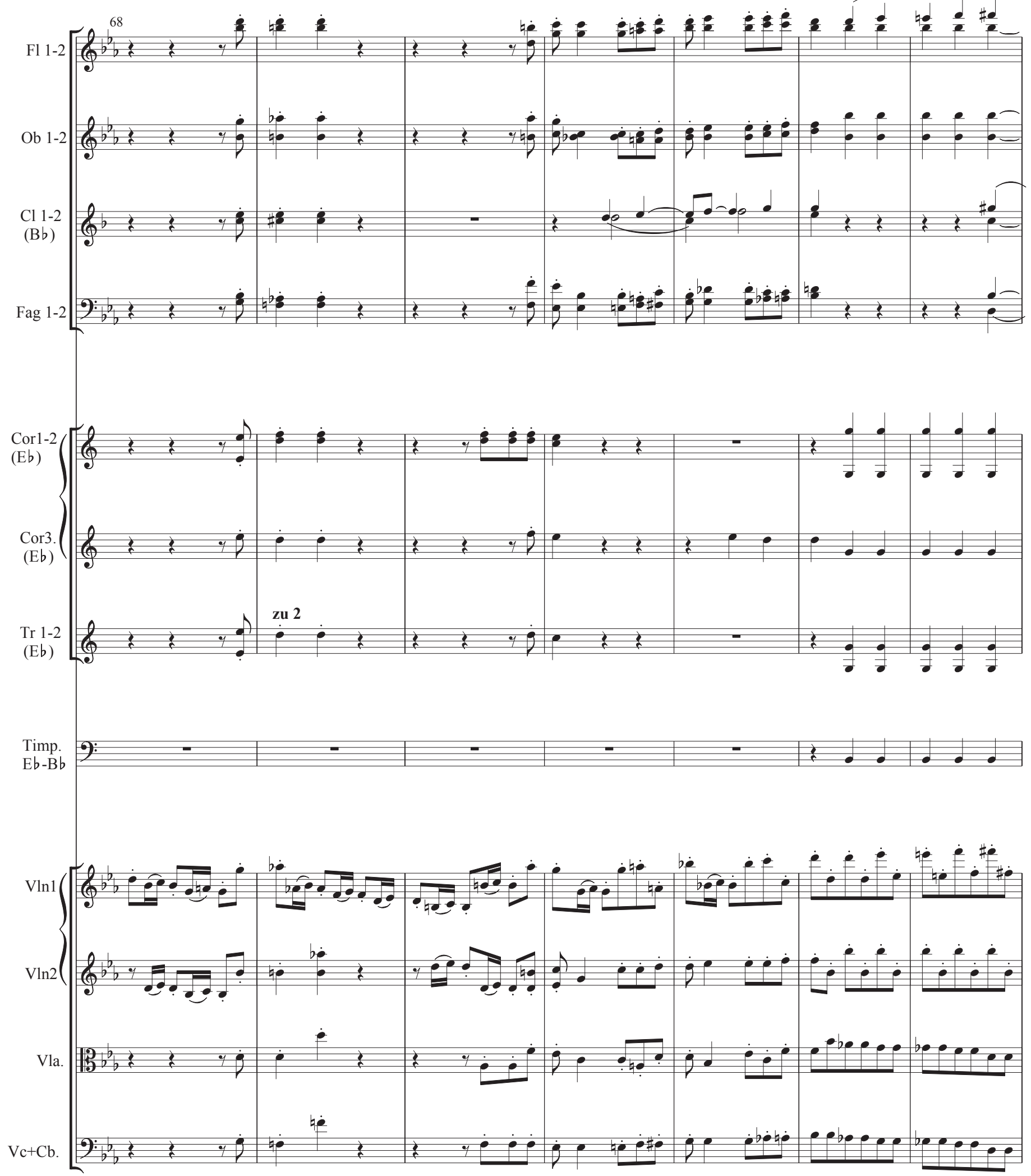

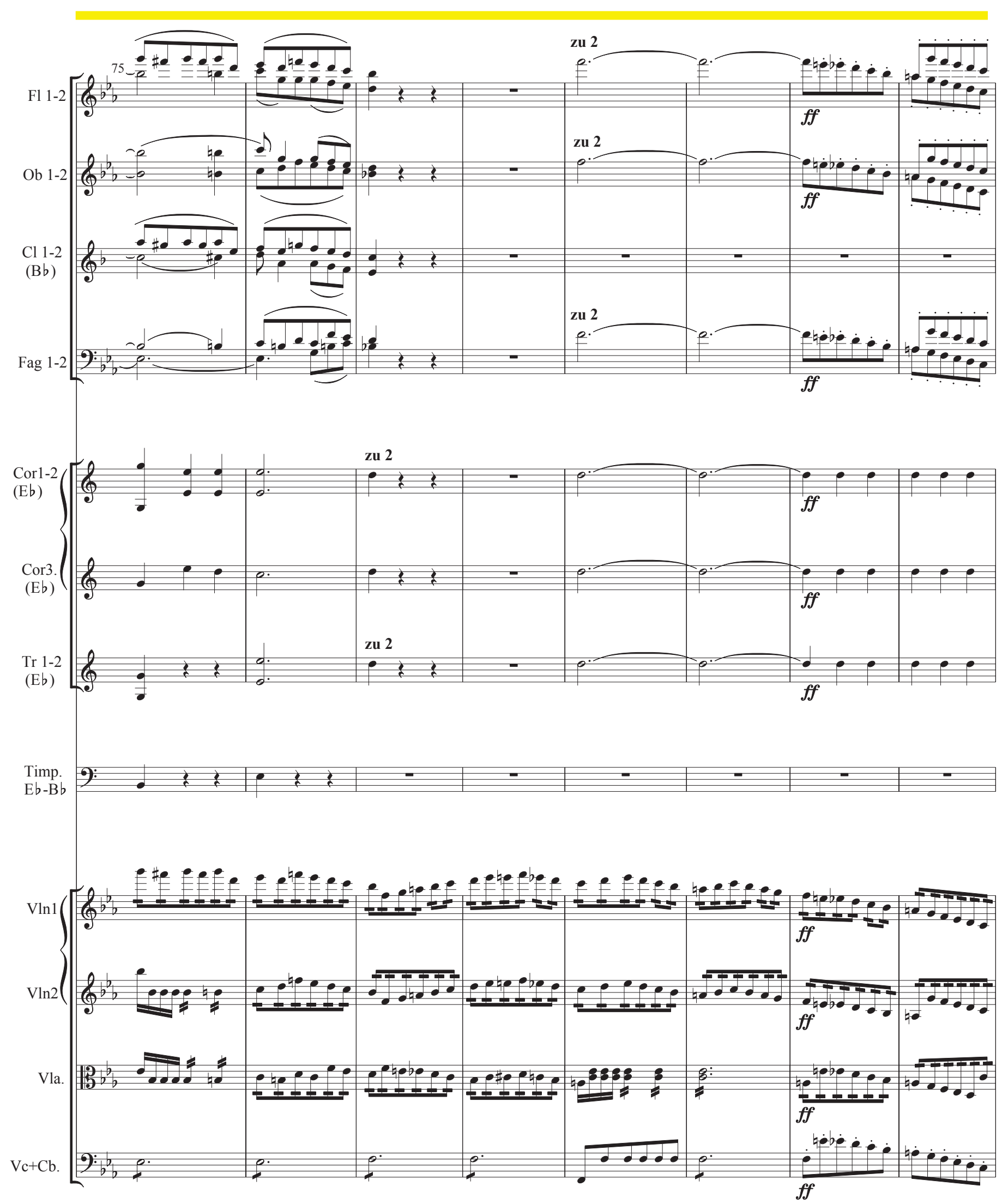

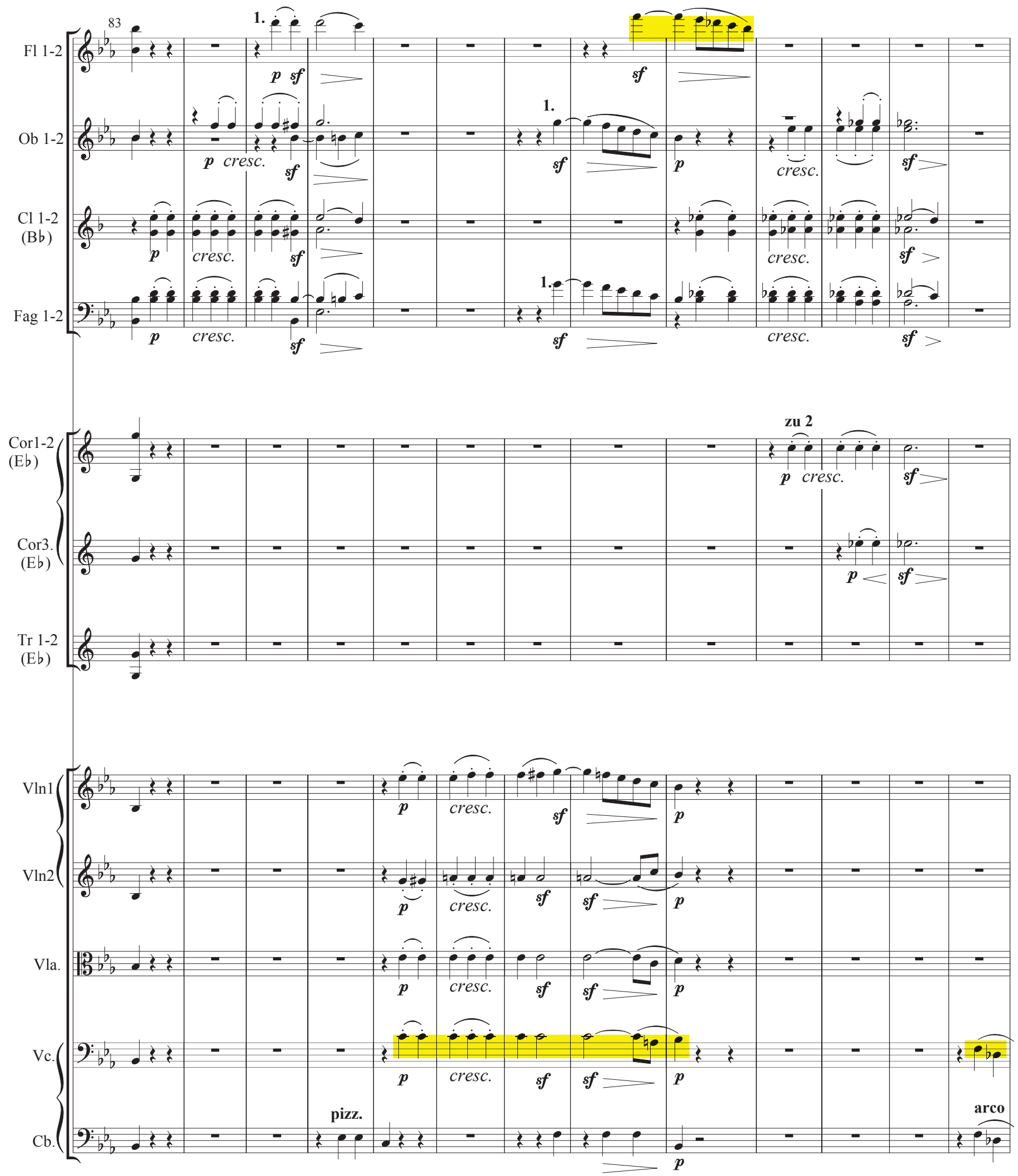
P29

P30 Salida de la escena del ensayo
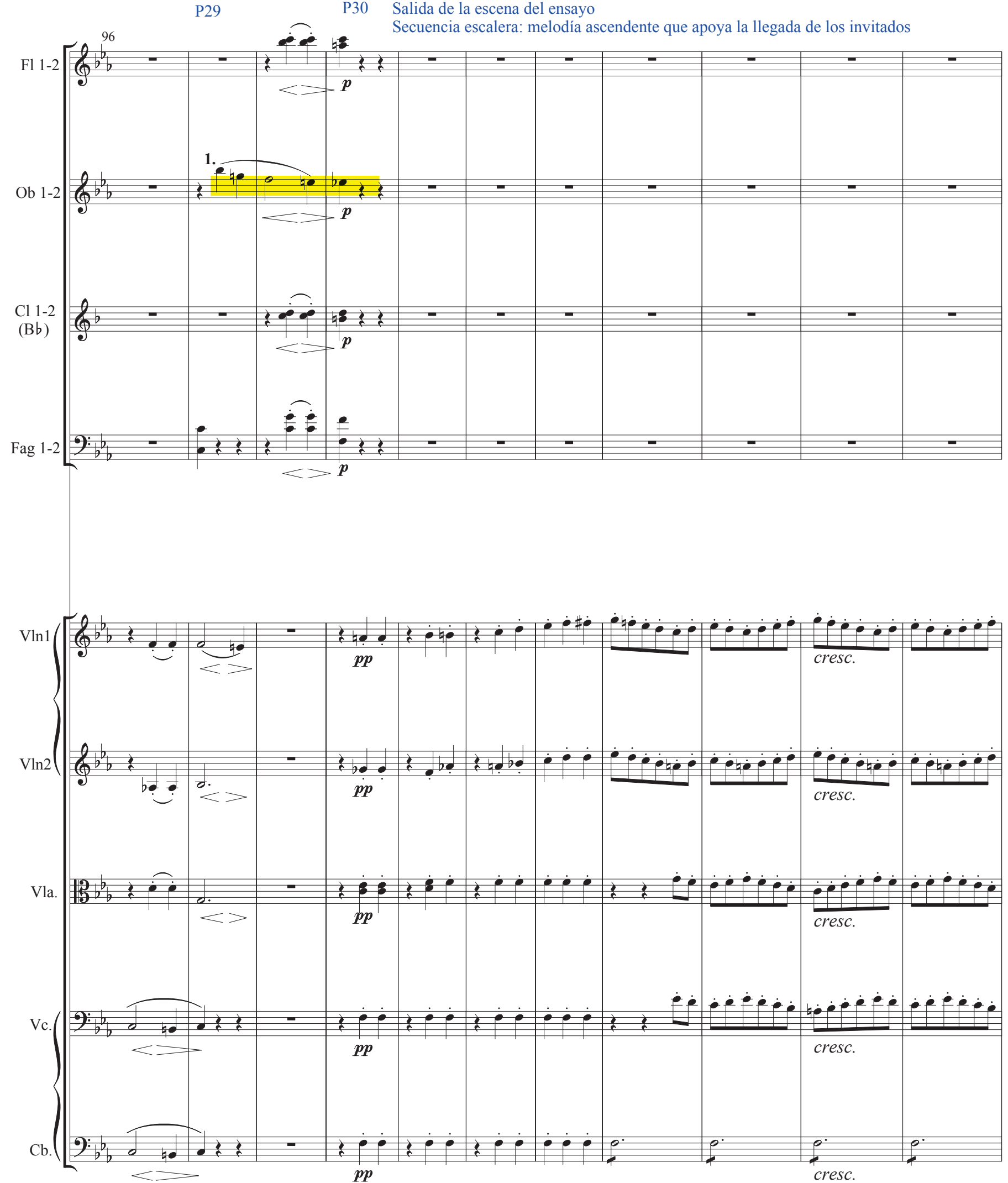
P31

P32 a P45 Planos de orquesta con primeros planos de personajes
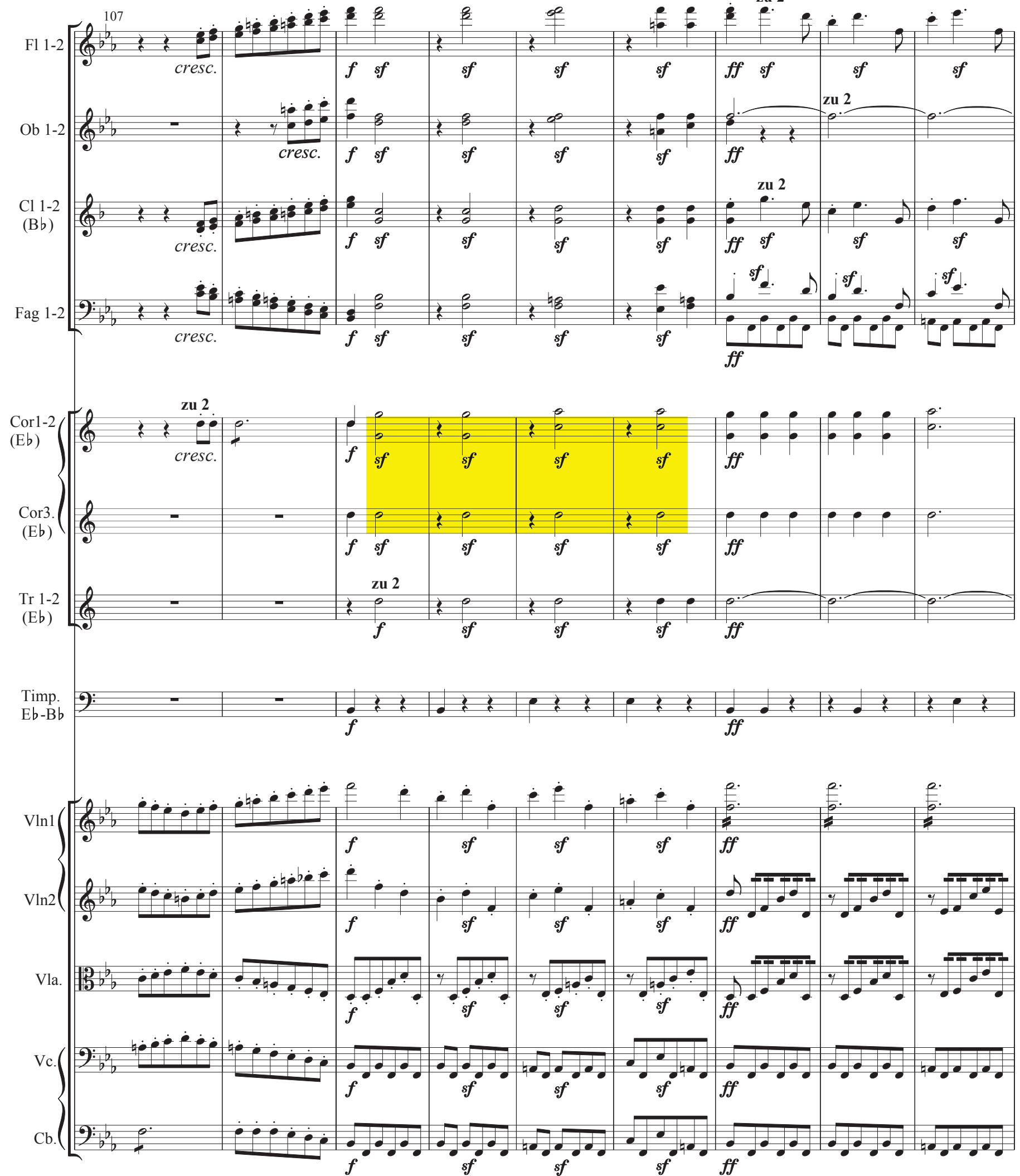

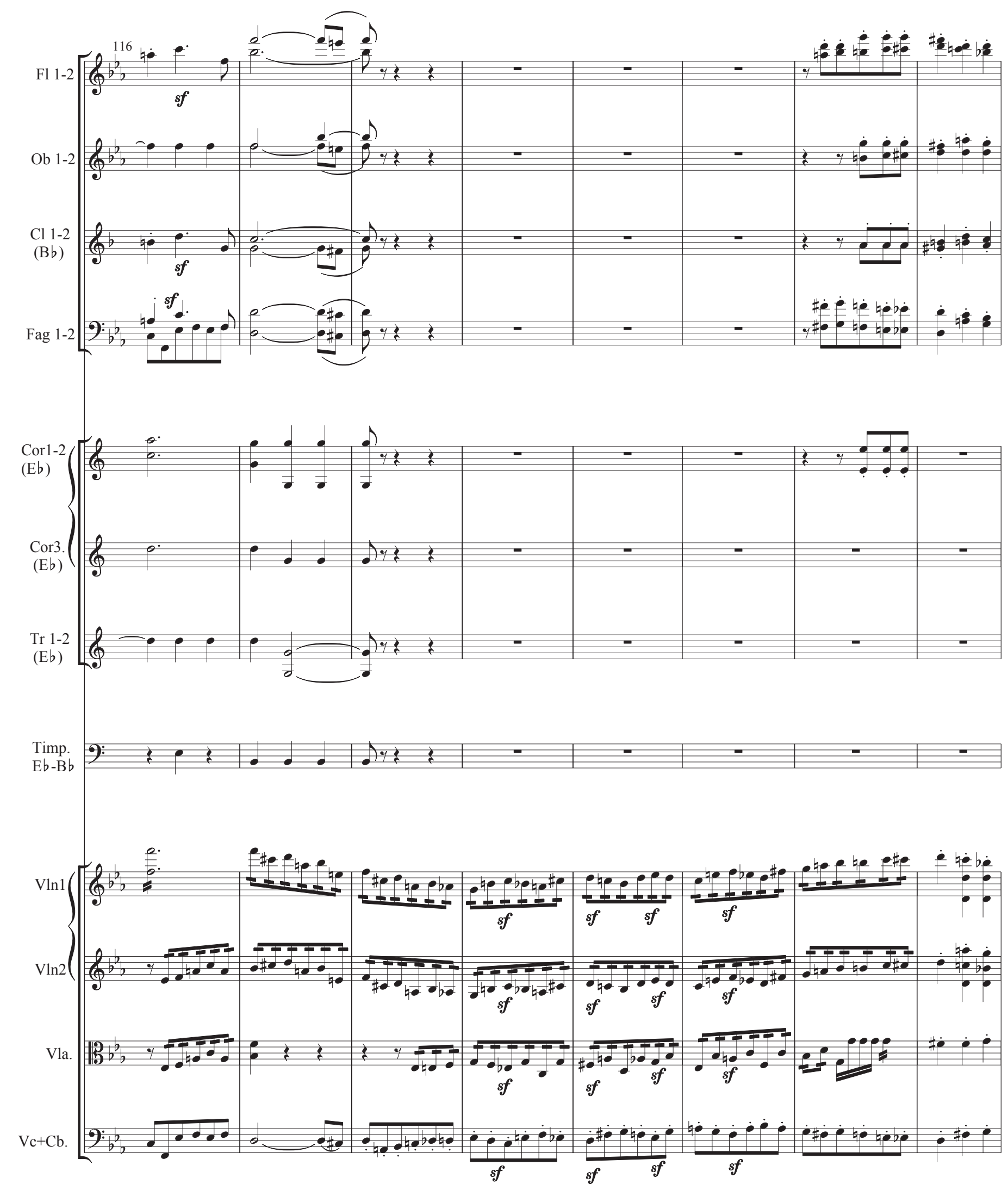
P45 Llegada a la sala

plano de violines de transición
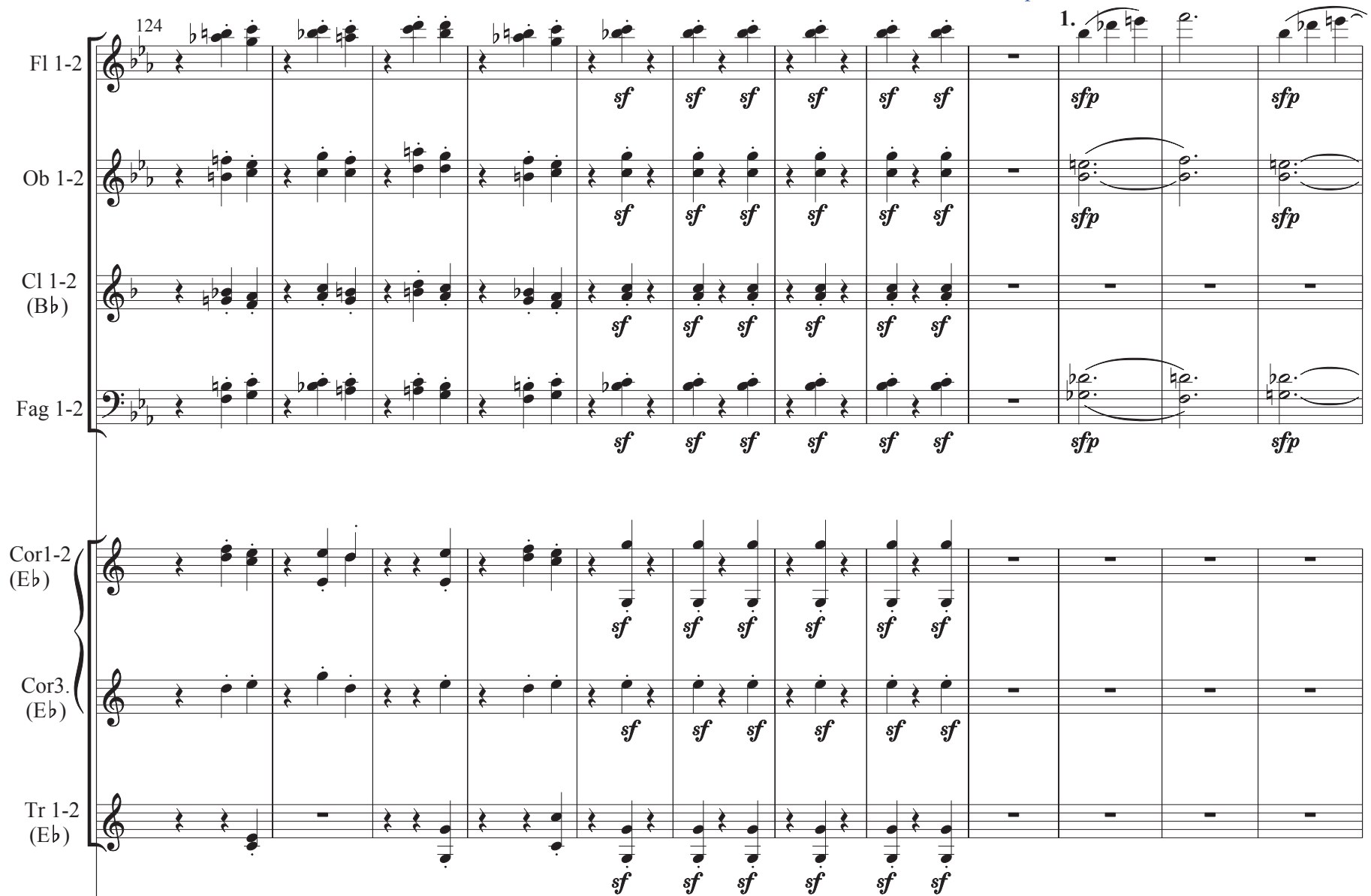

Timp.
$\mathrm{E}-\mathrm{B} b$

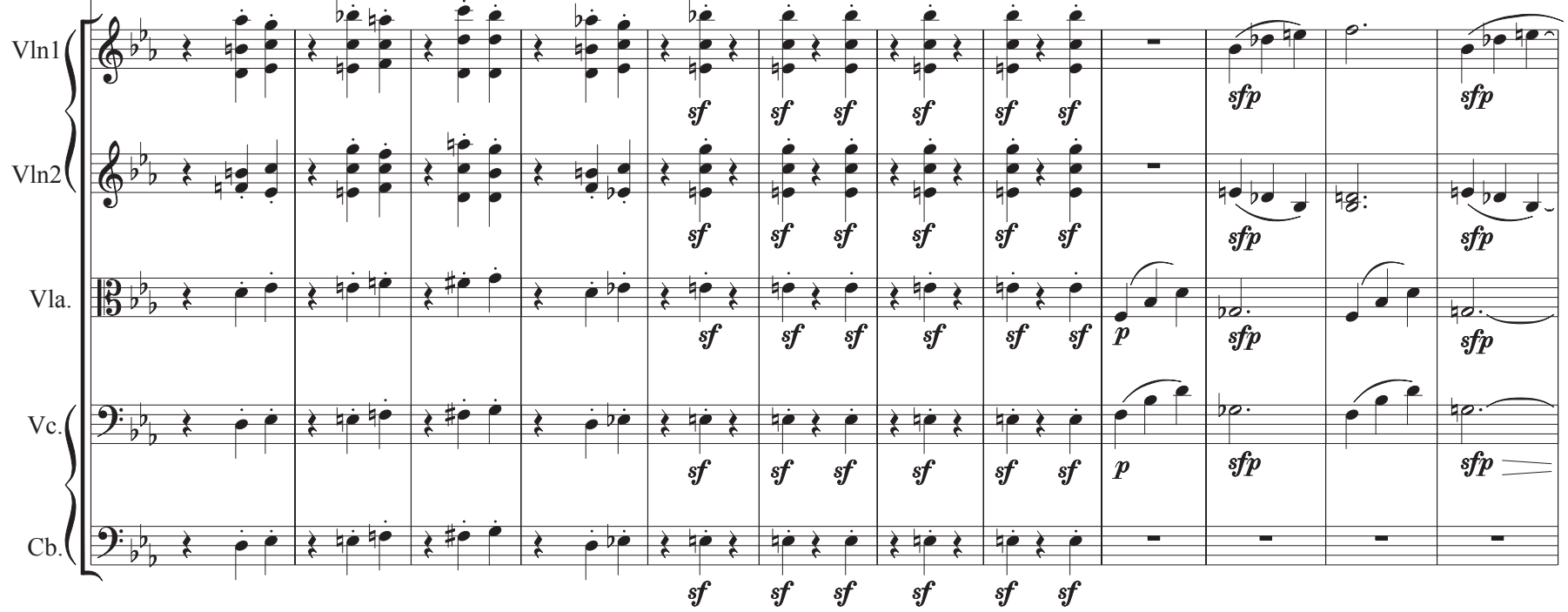



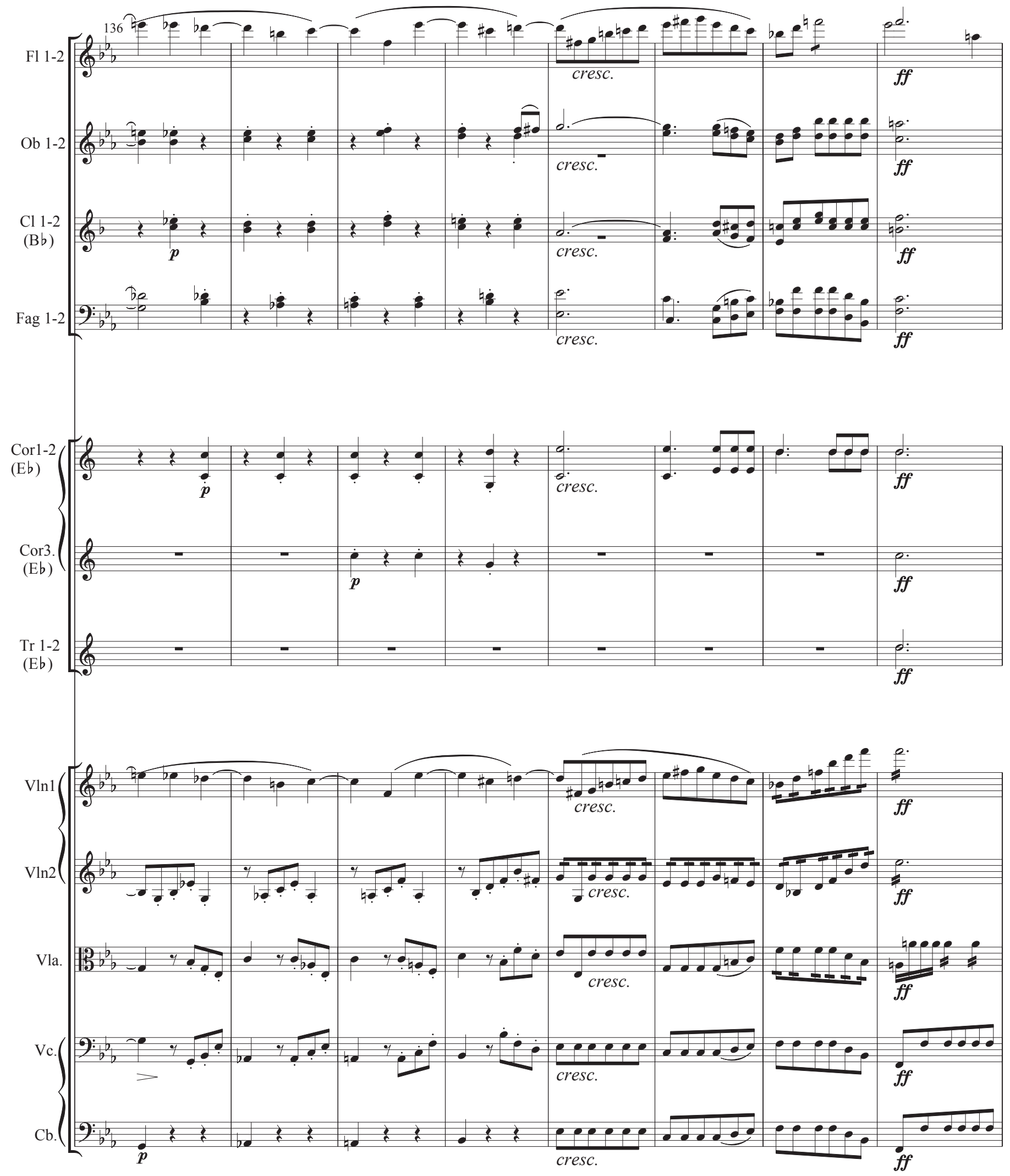
zu 2
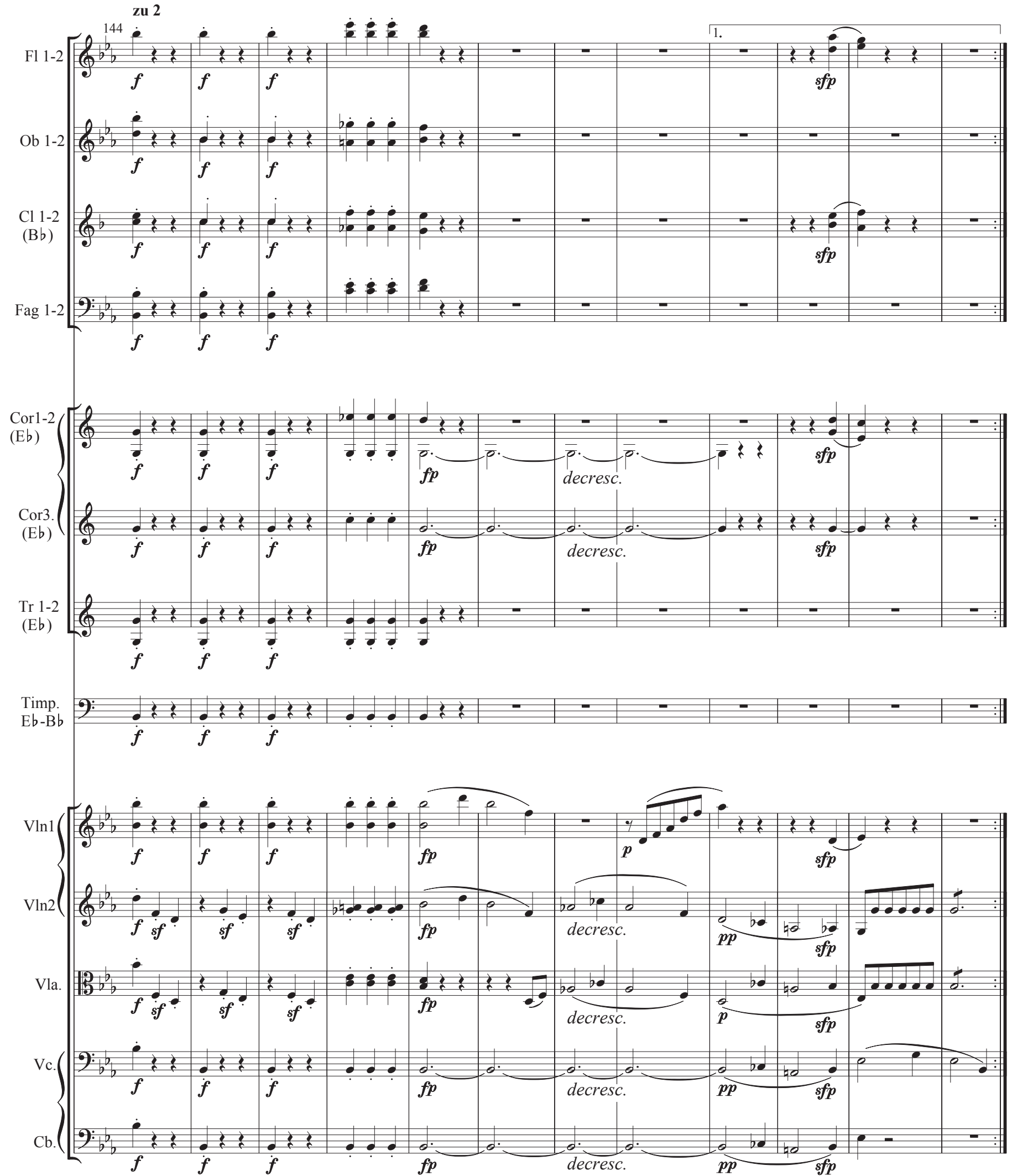

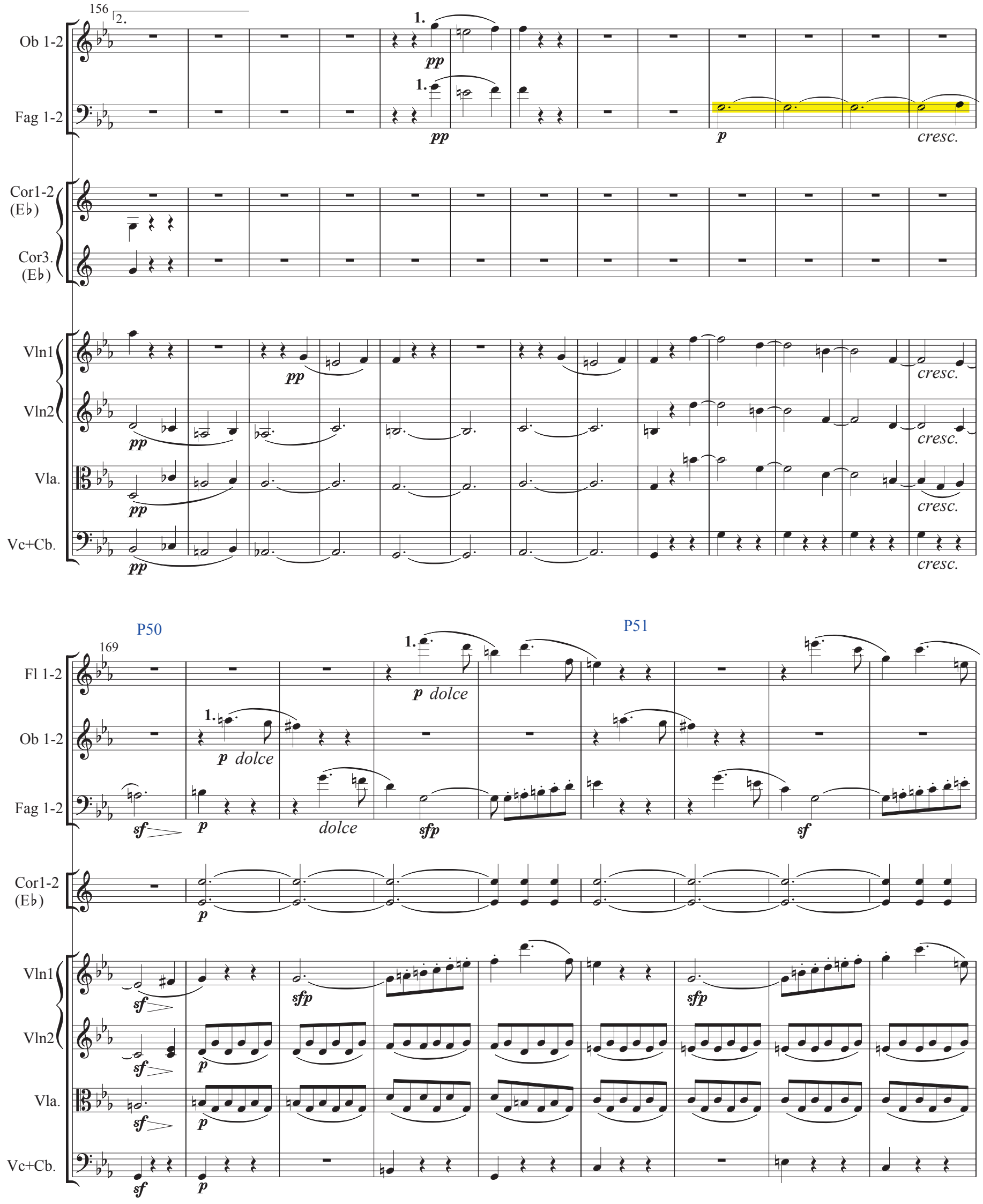


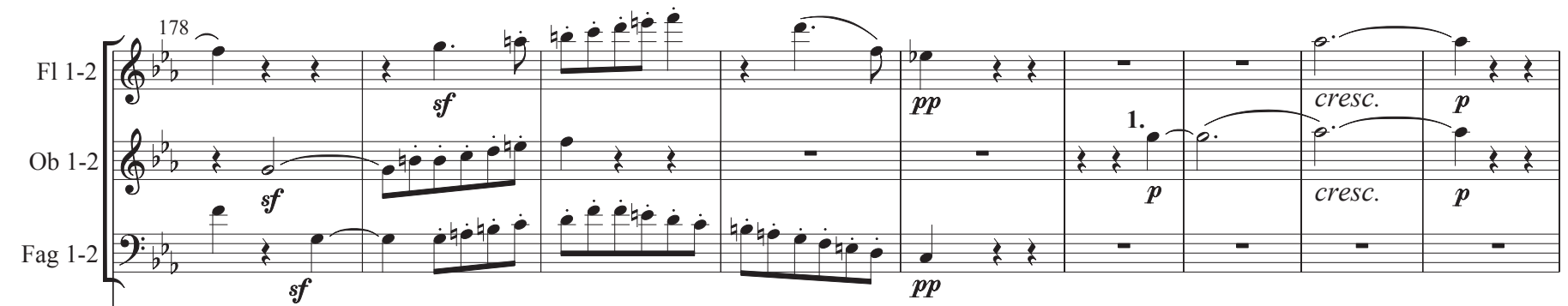

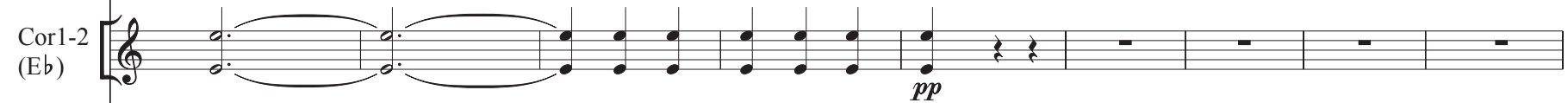
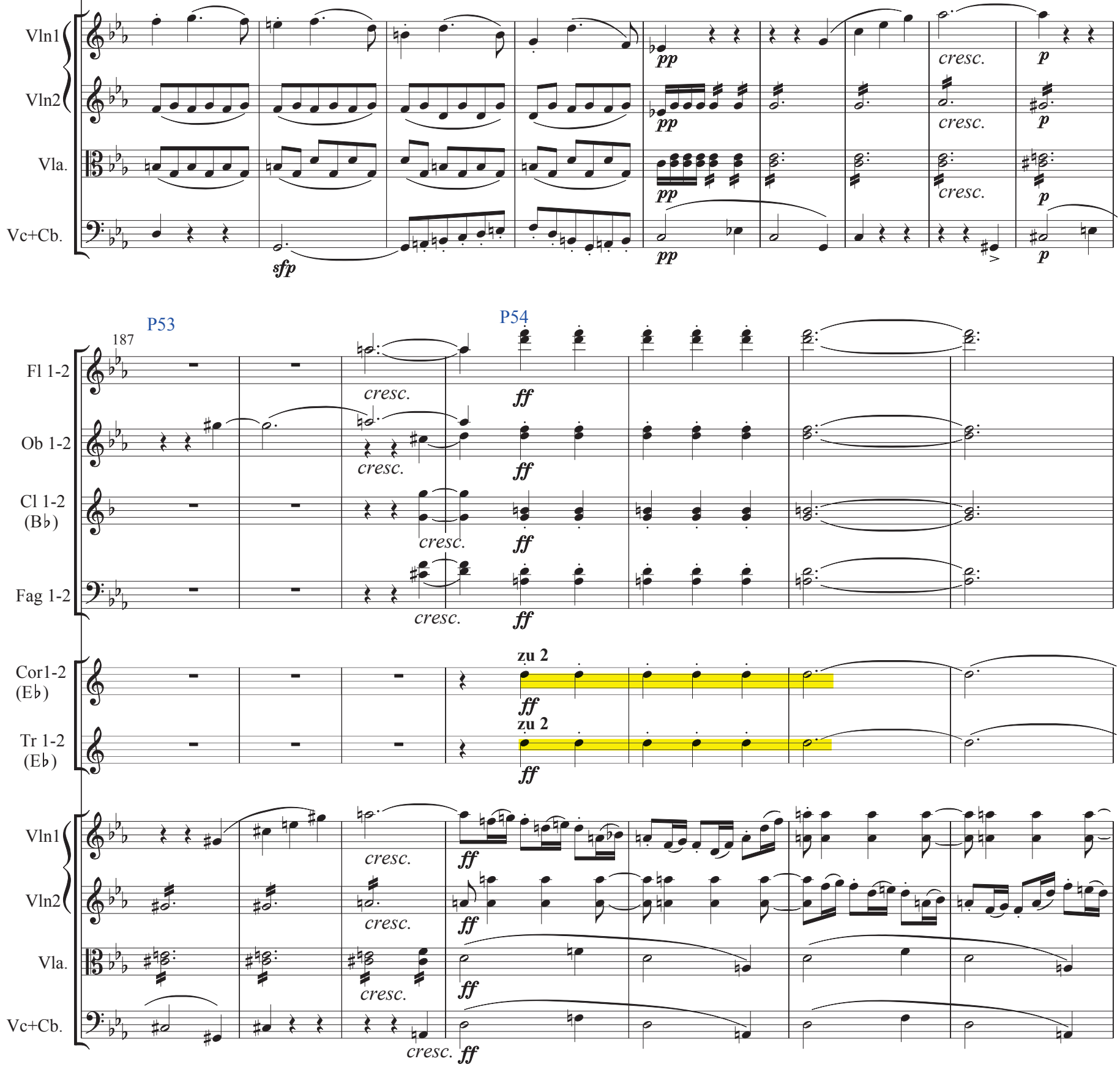

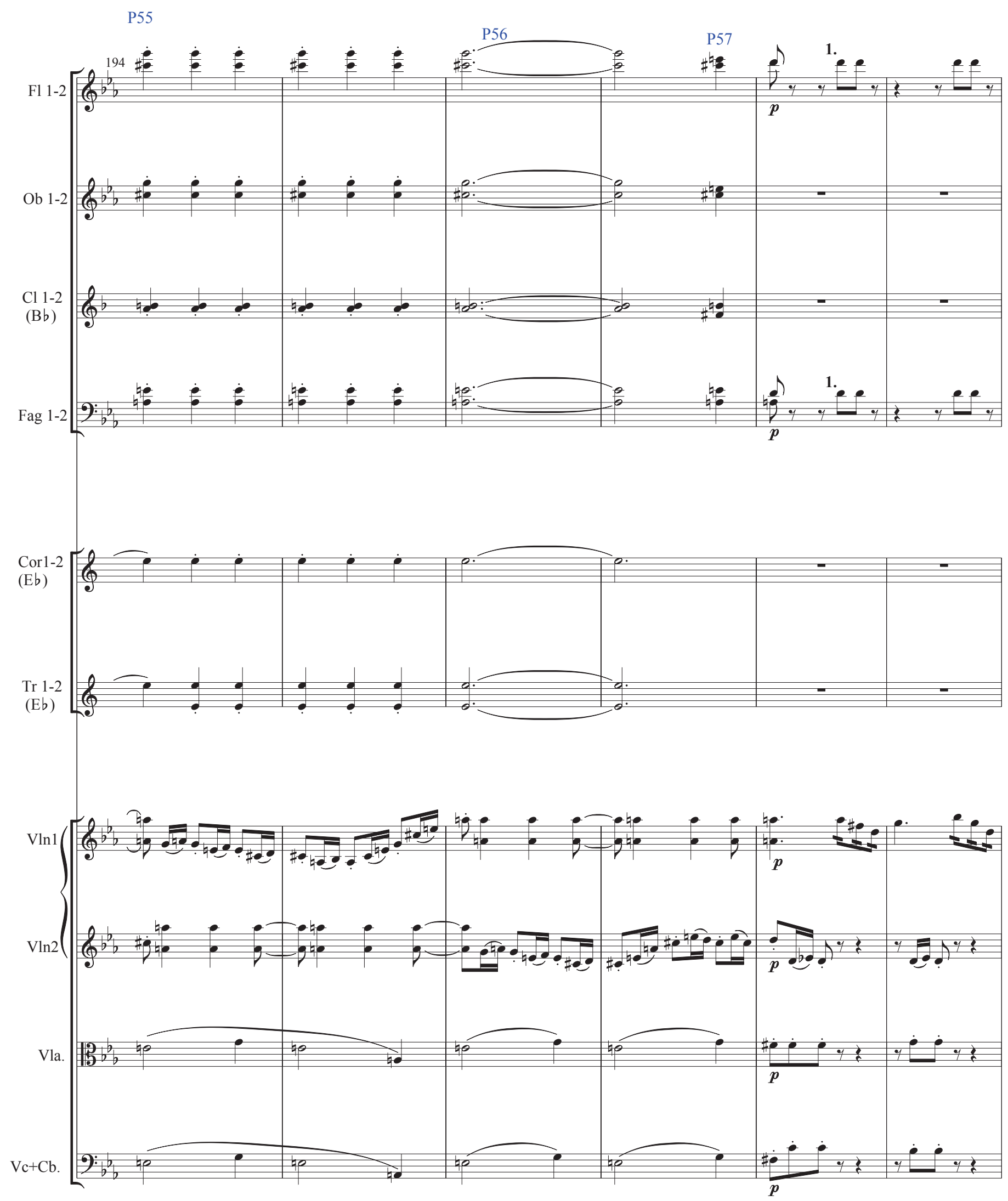


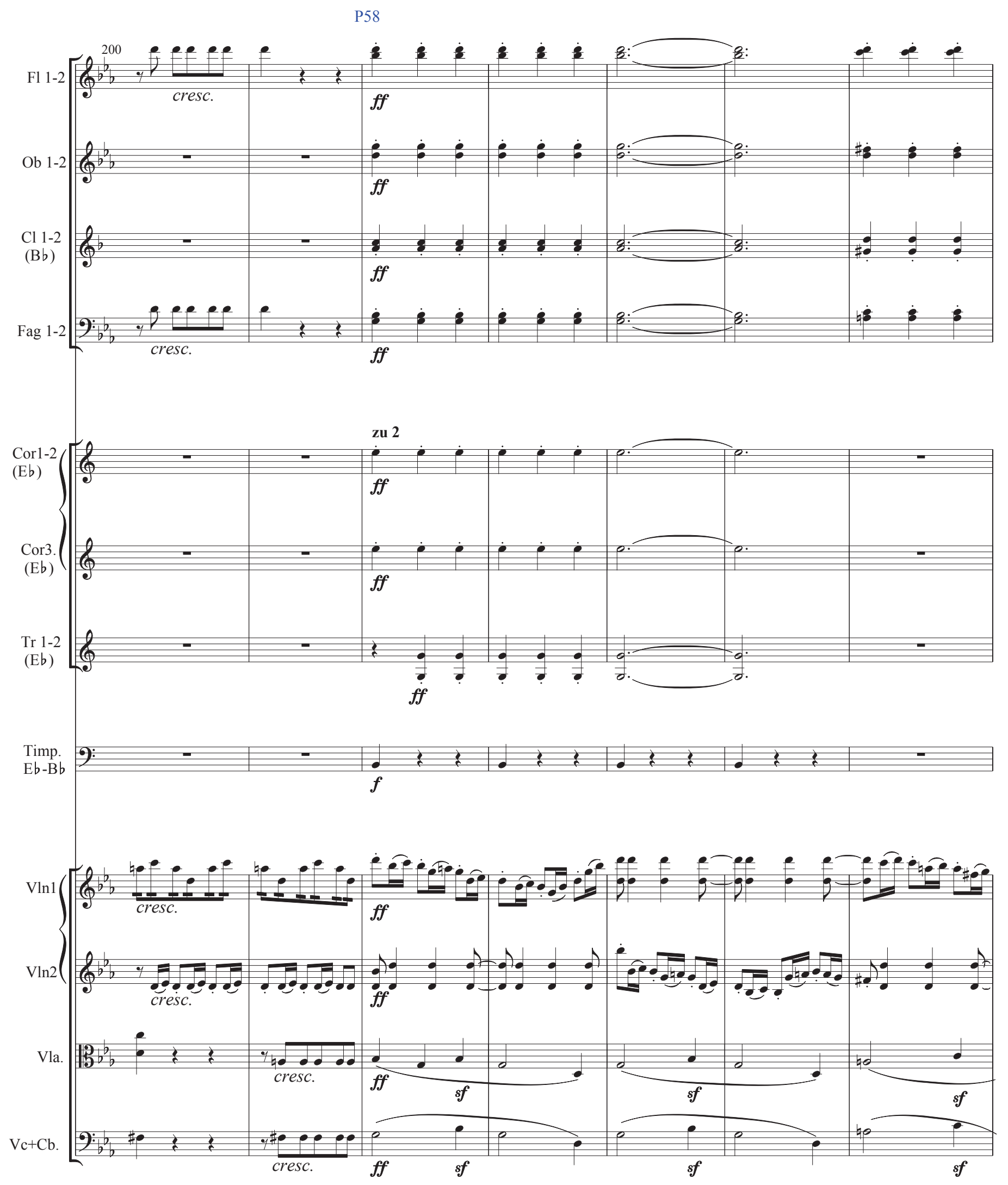



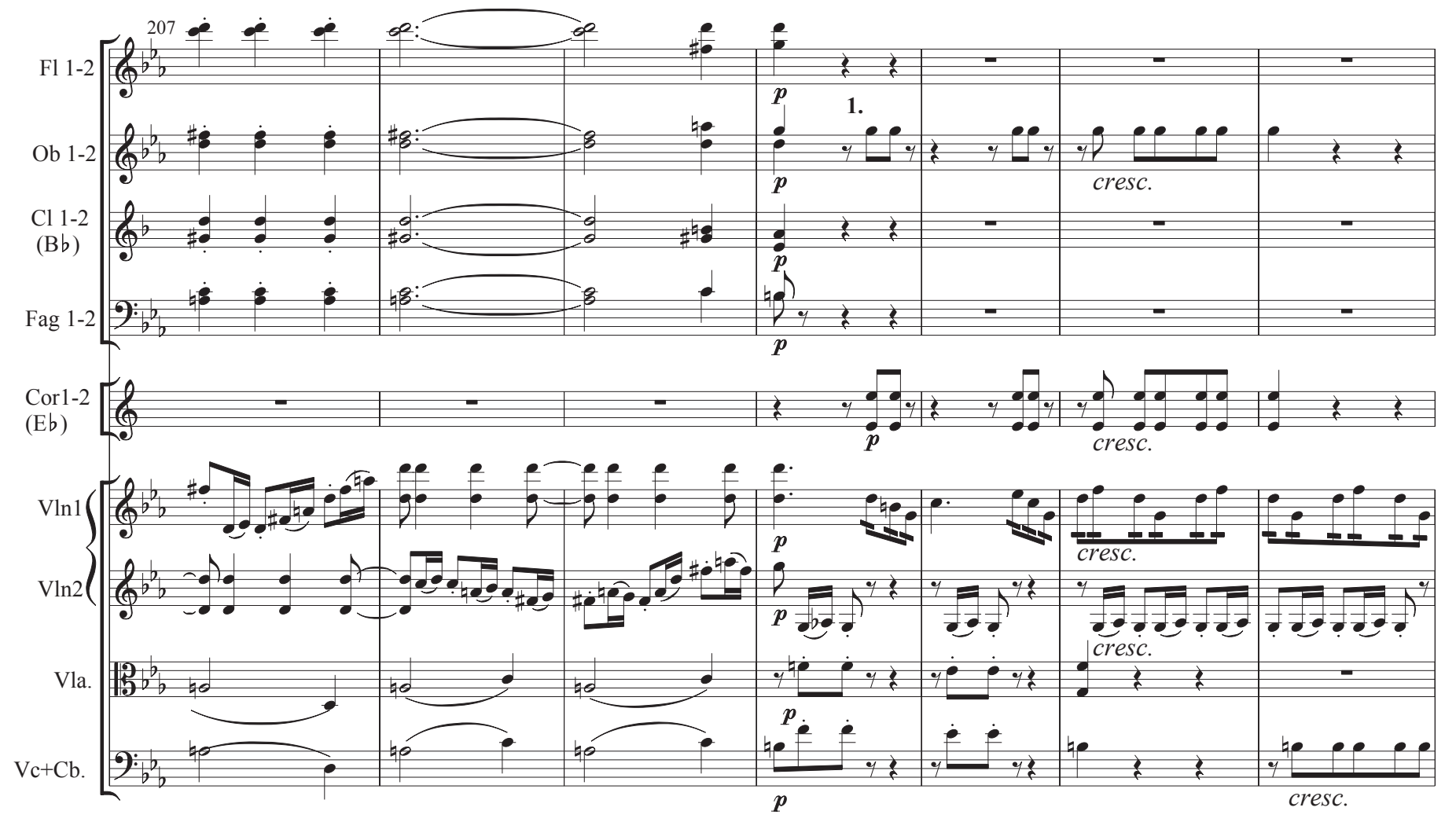

P59 1. P60
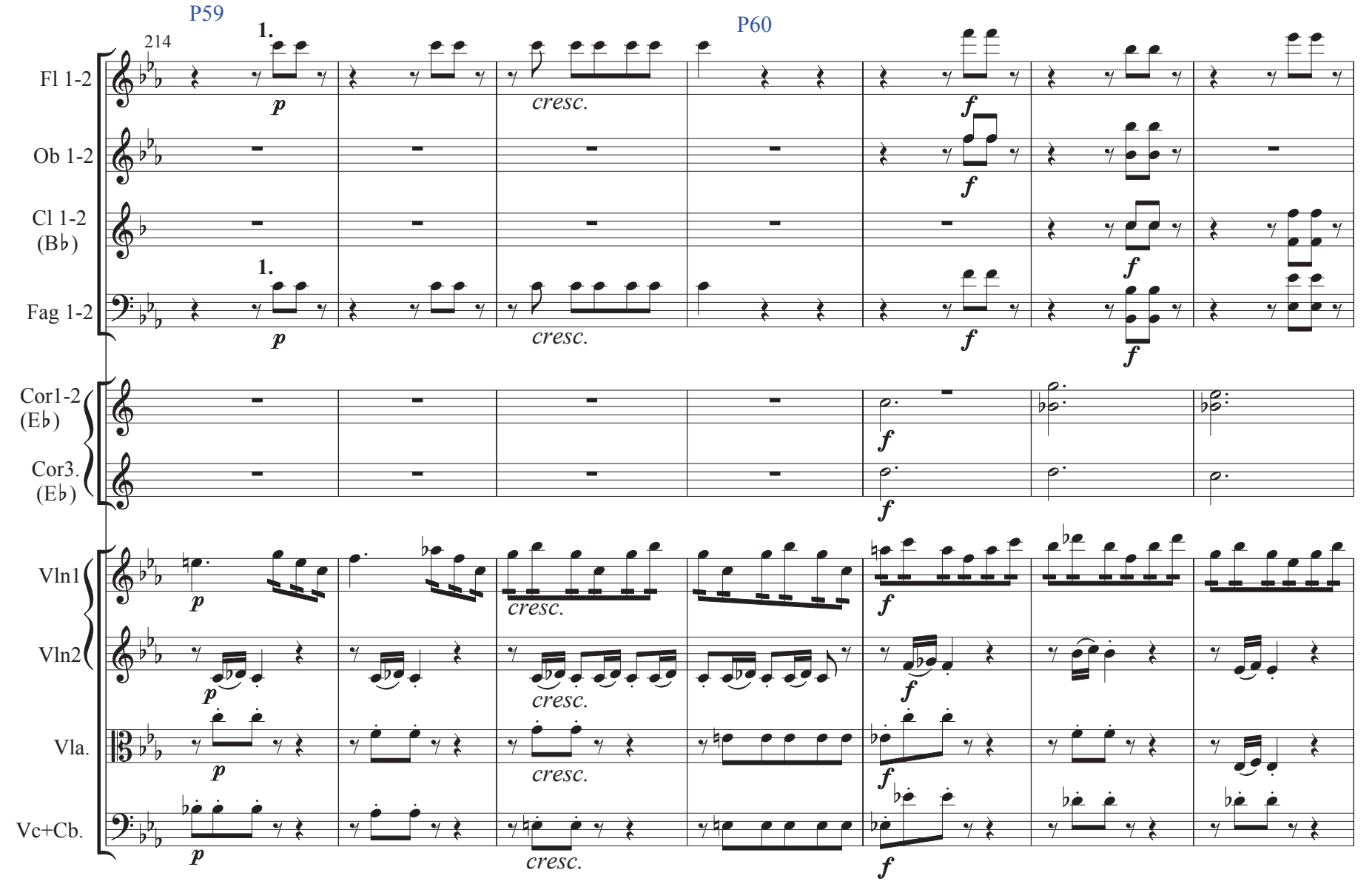

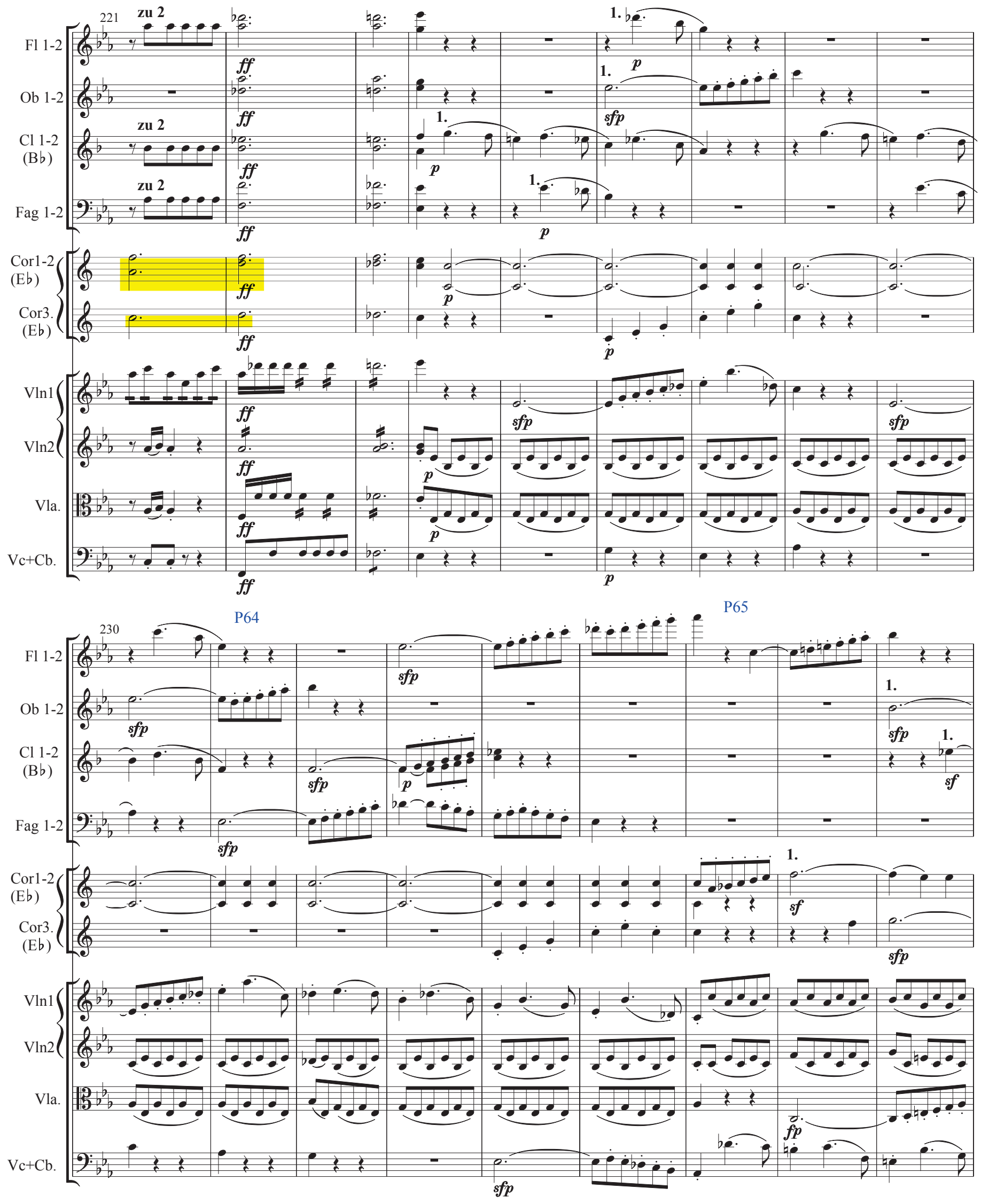

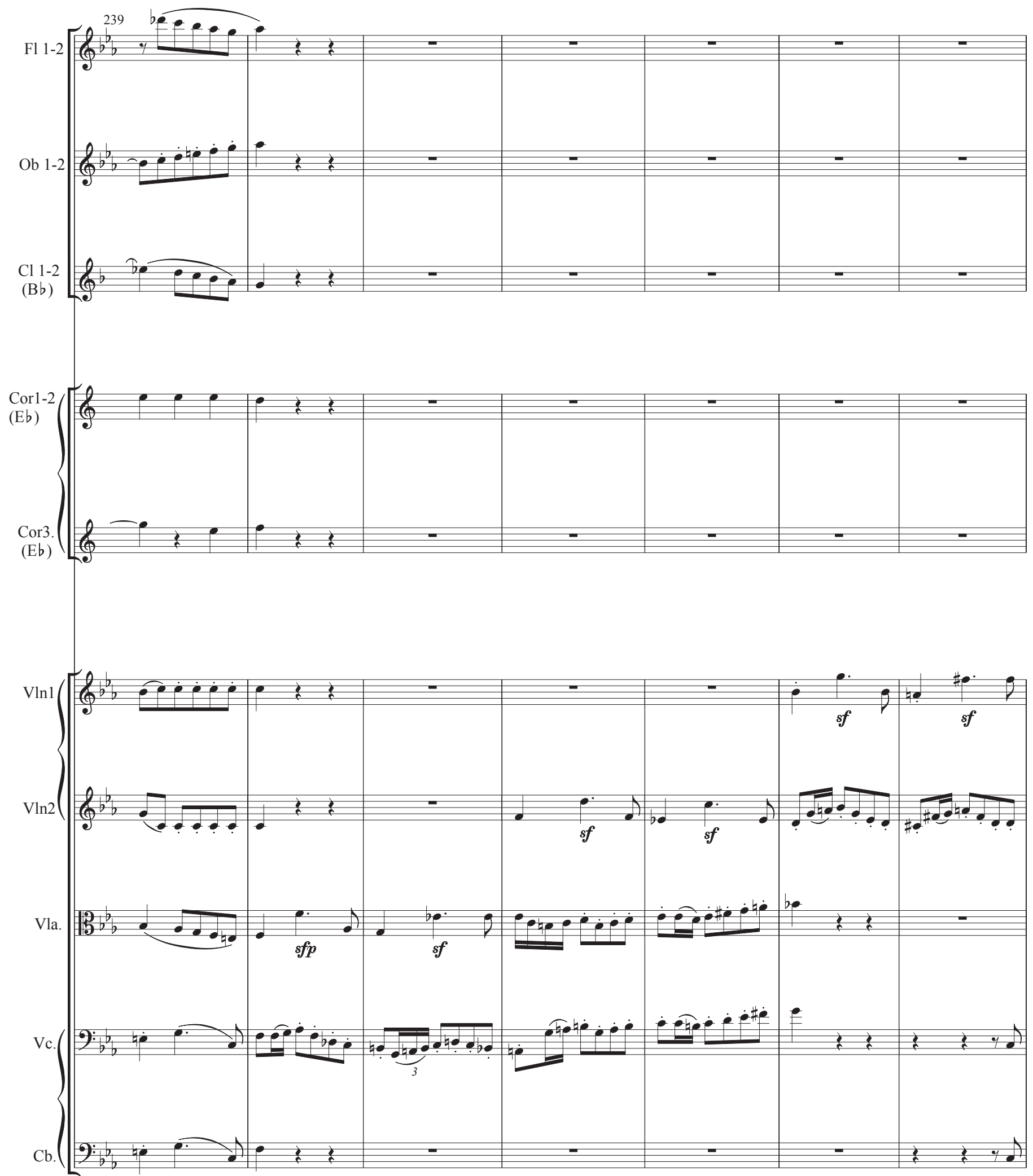

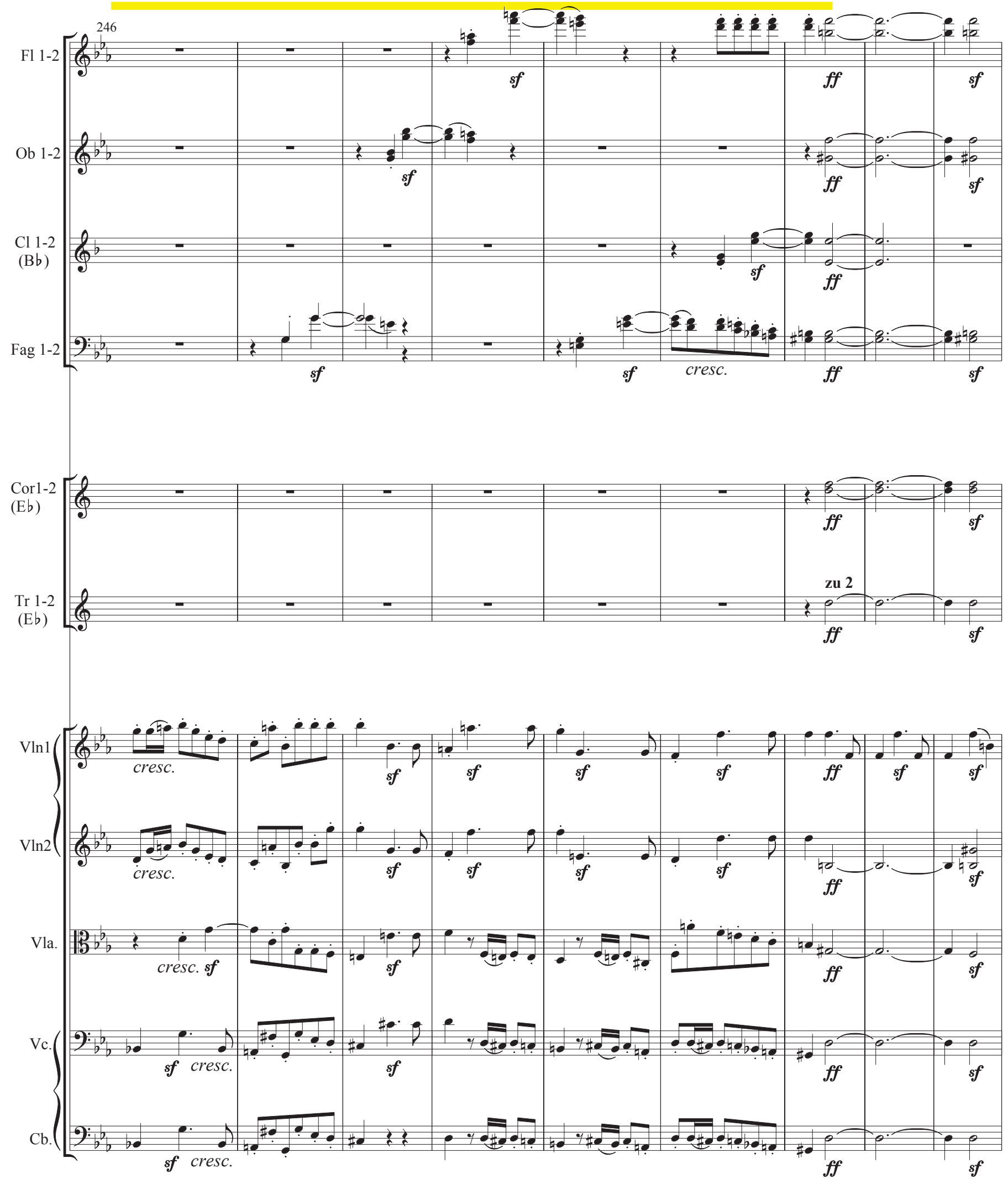
F1 1-
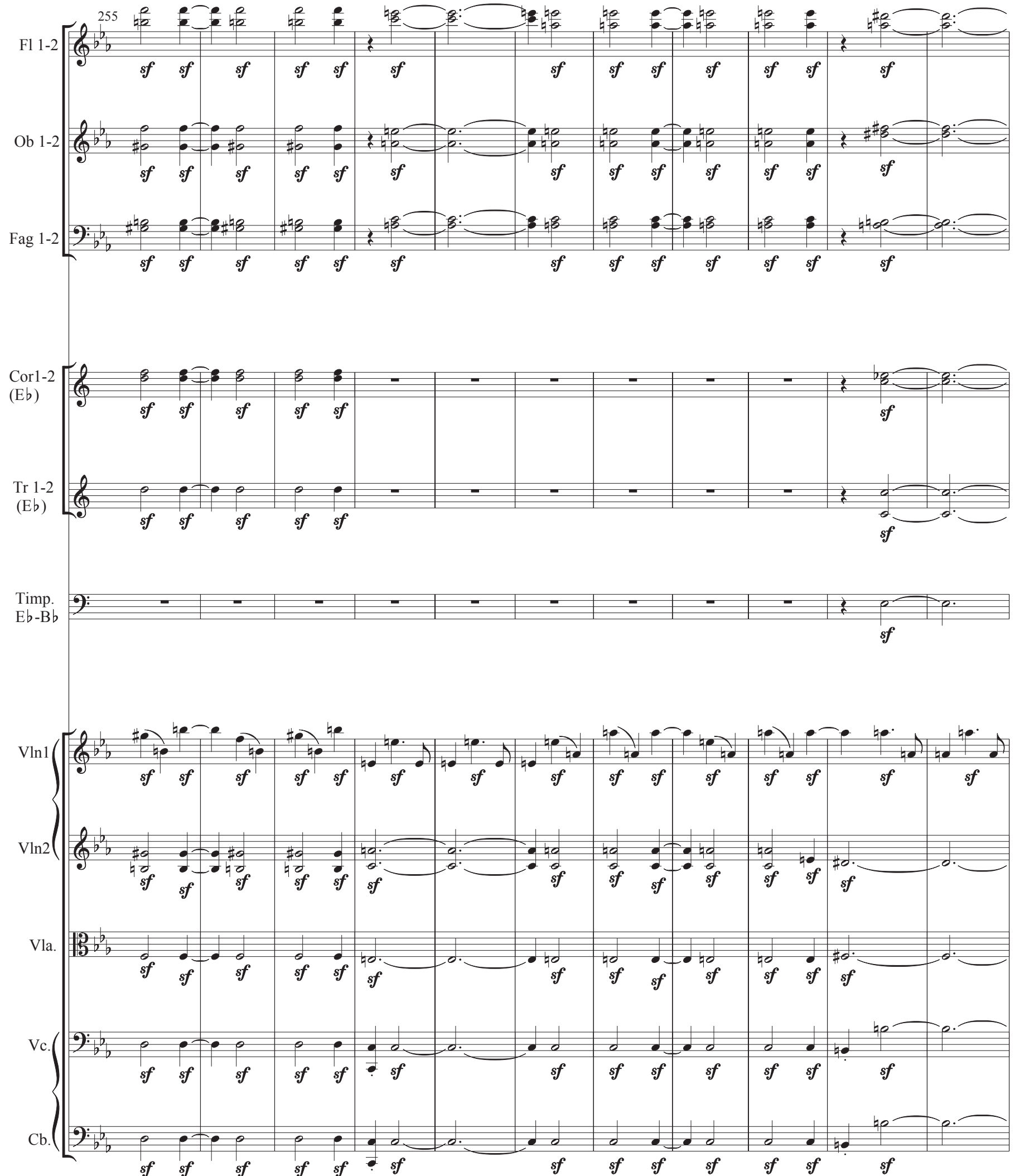
P72

P73

P74 a P81 planos cortos

en cuanto a duración
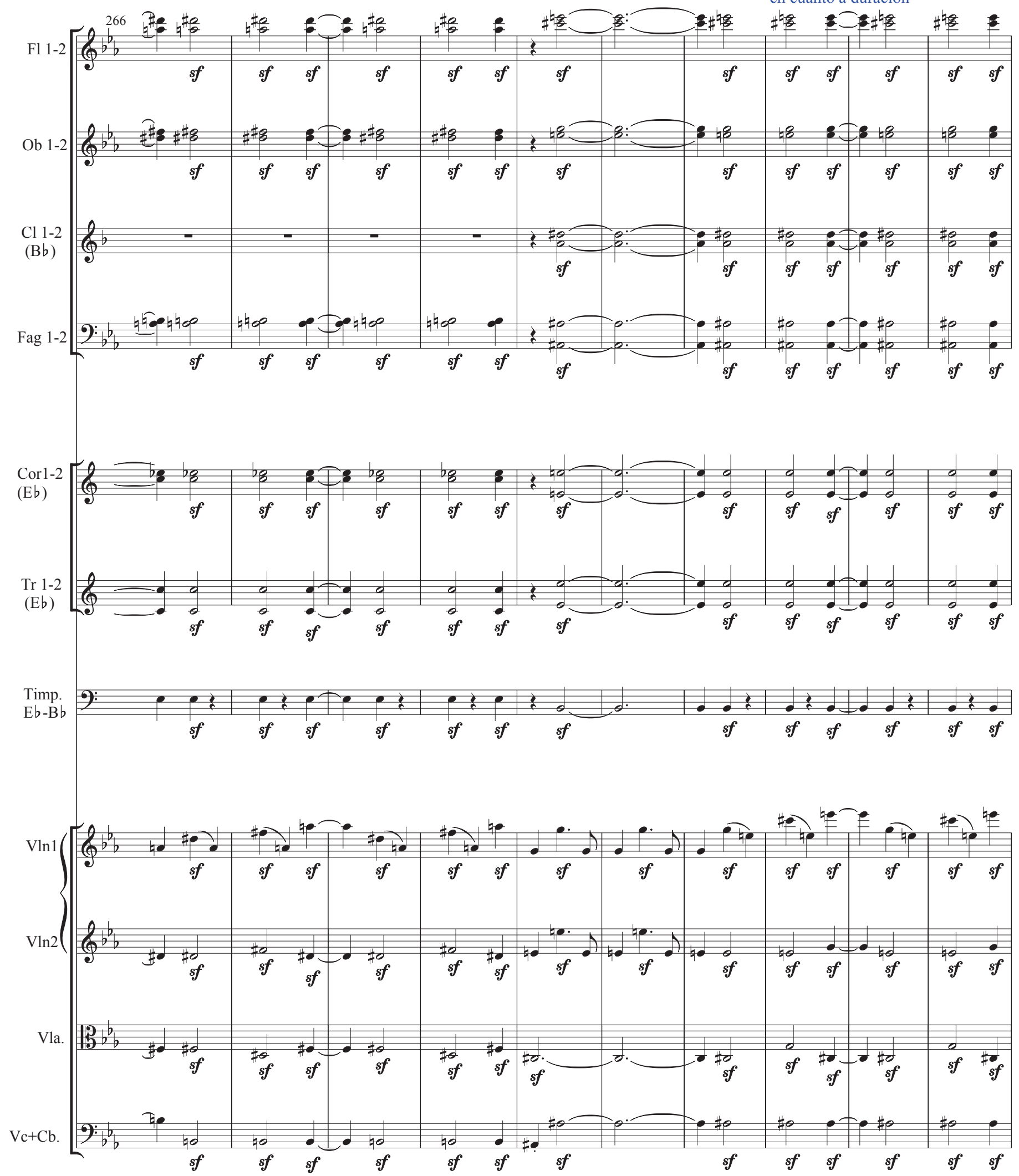


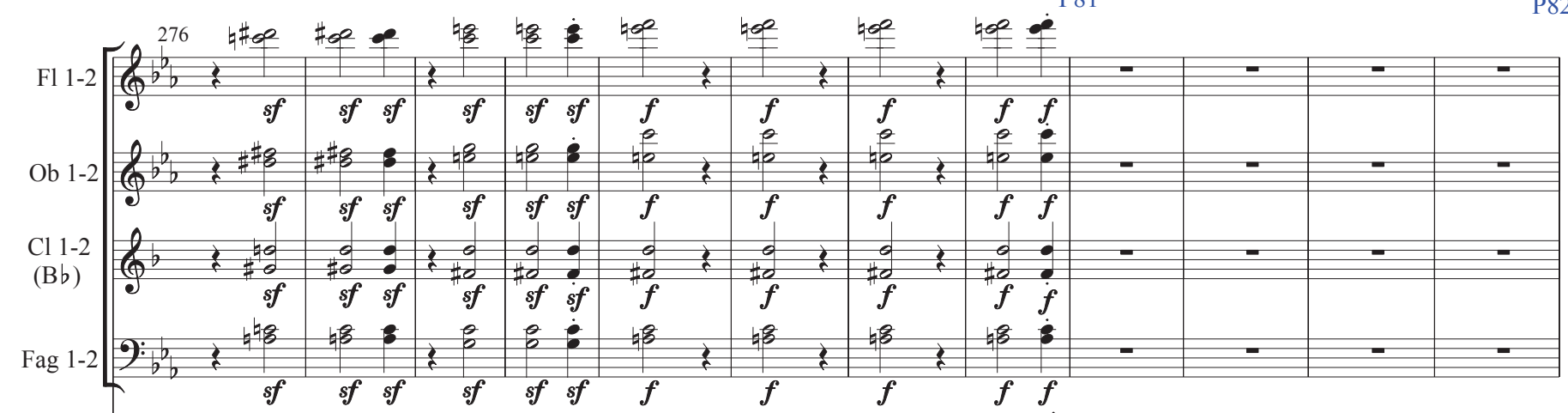

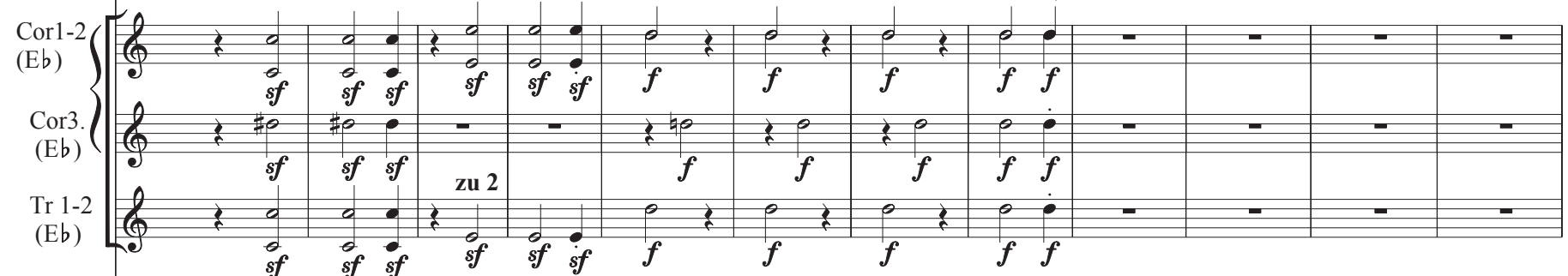
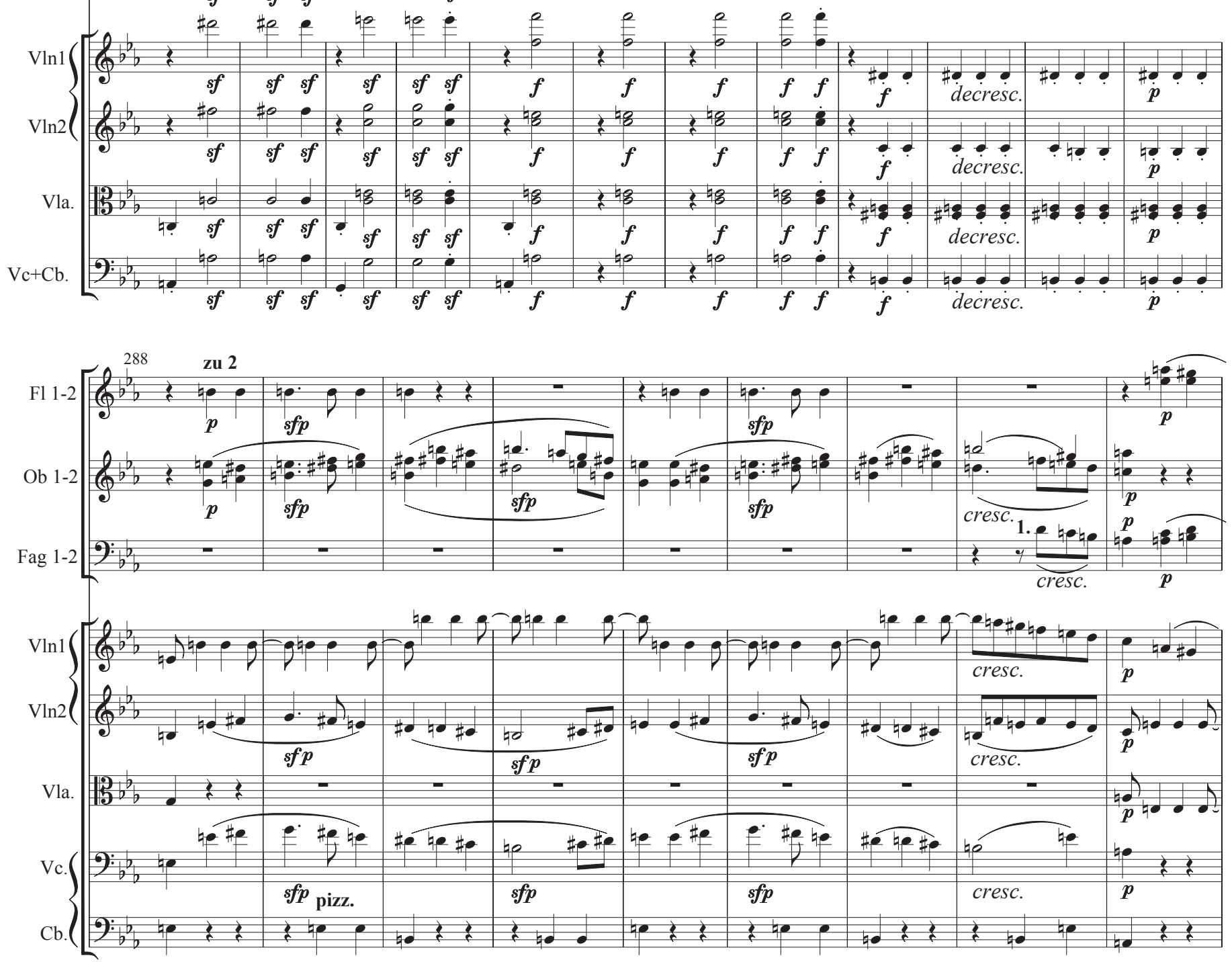
Plano Secuencia circular
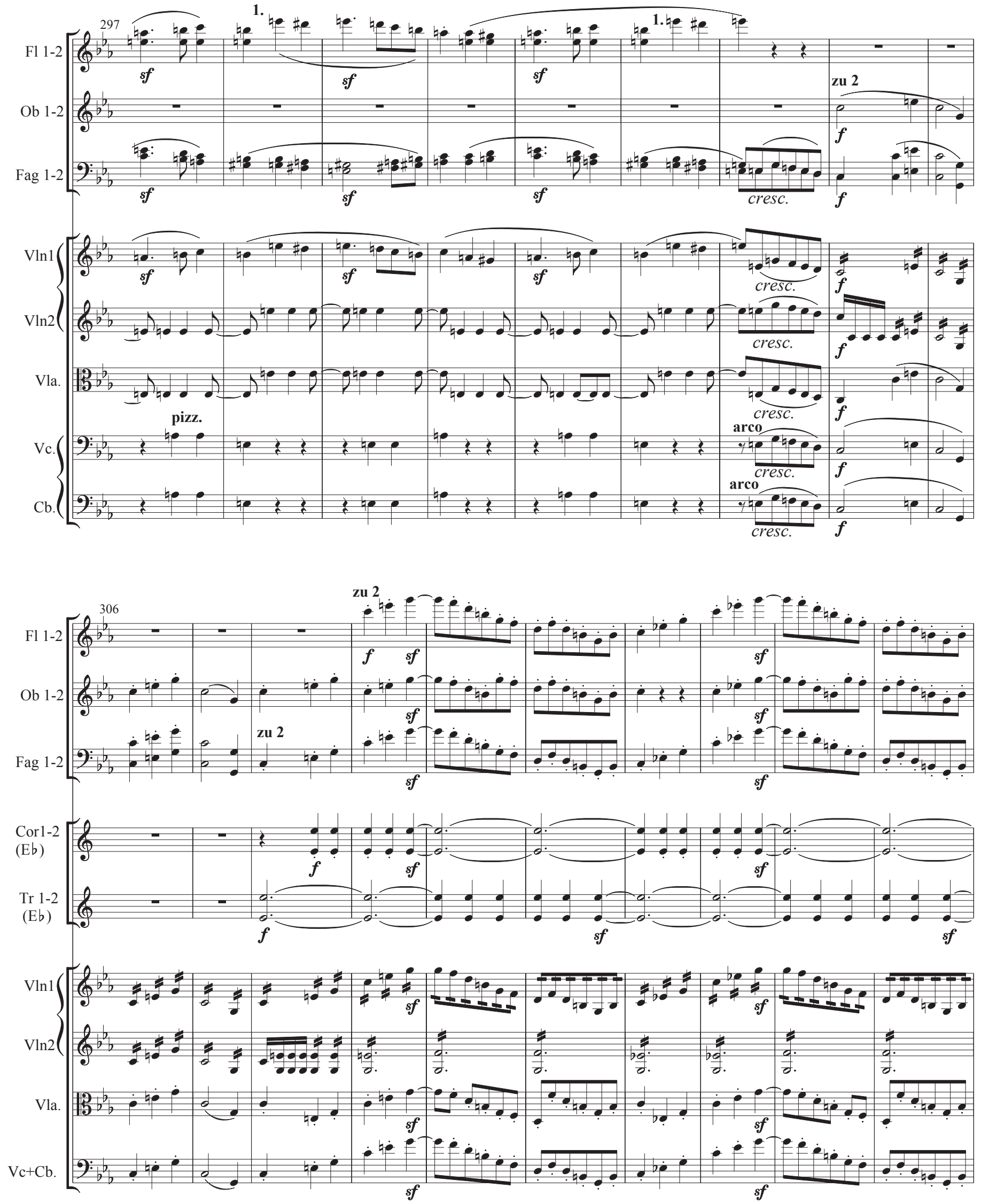

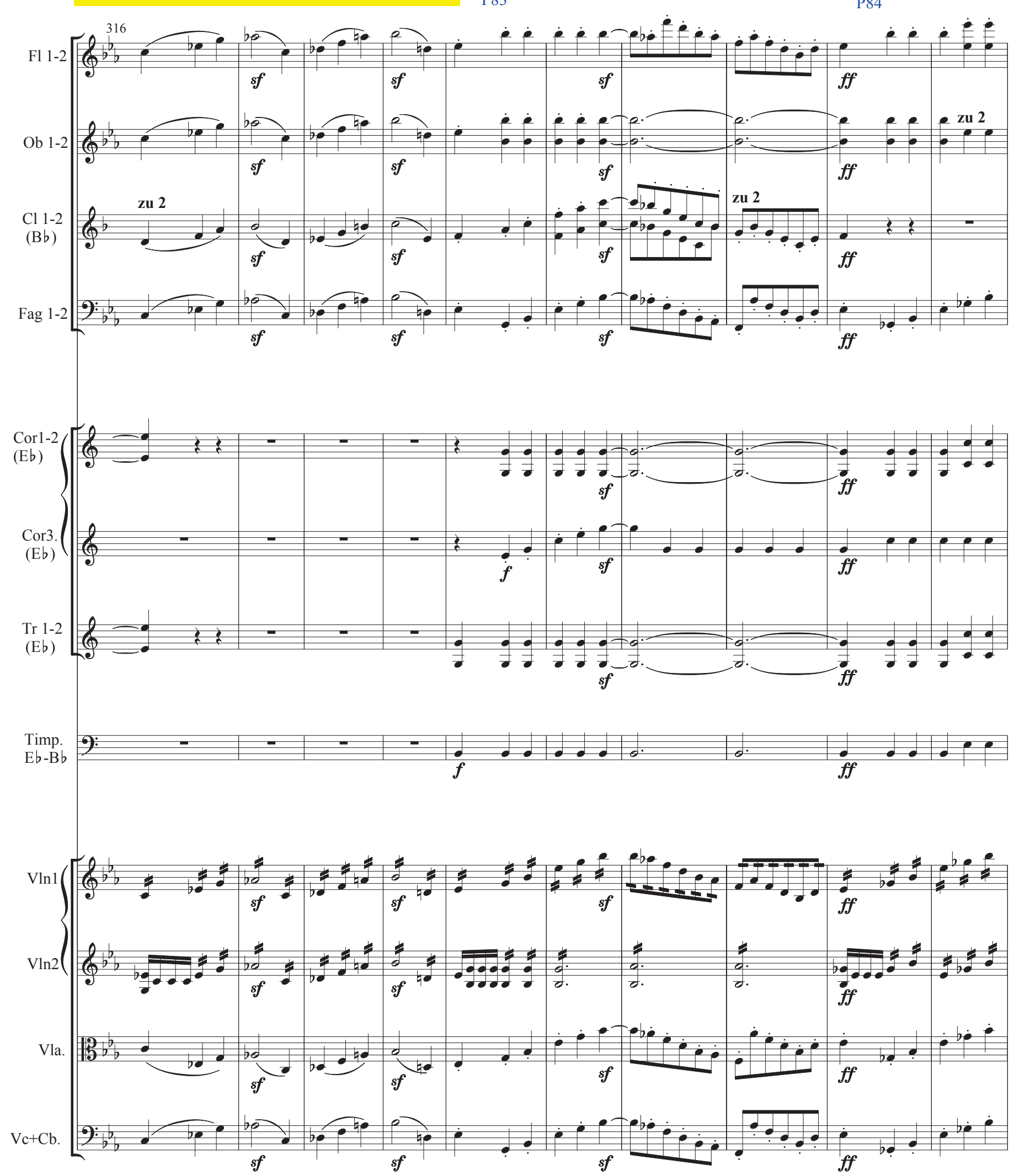

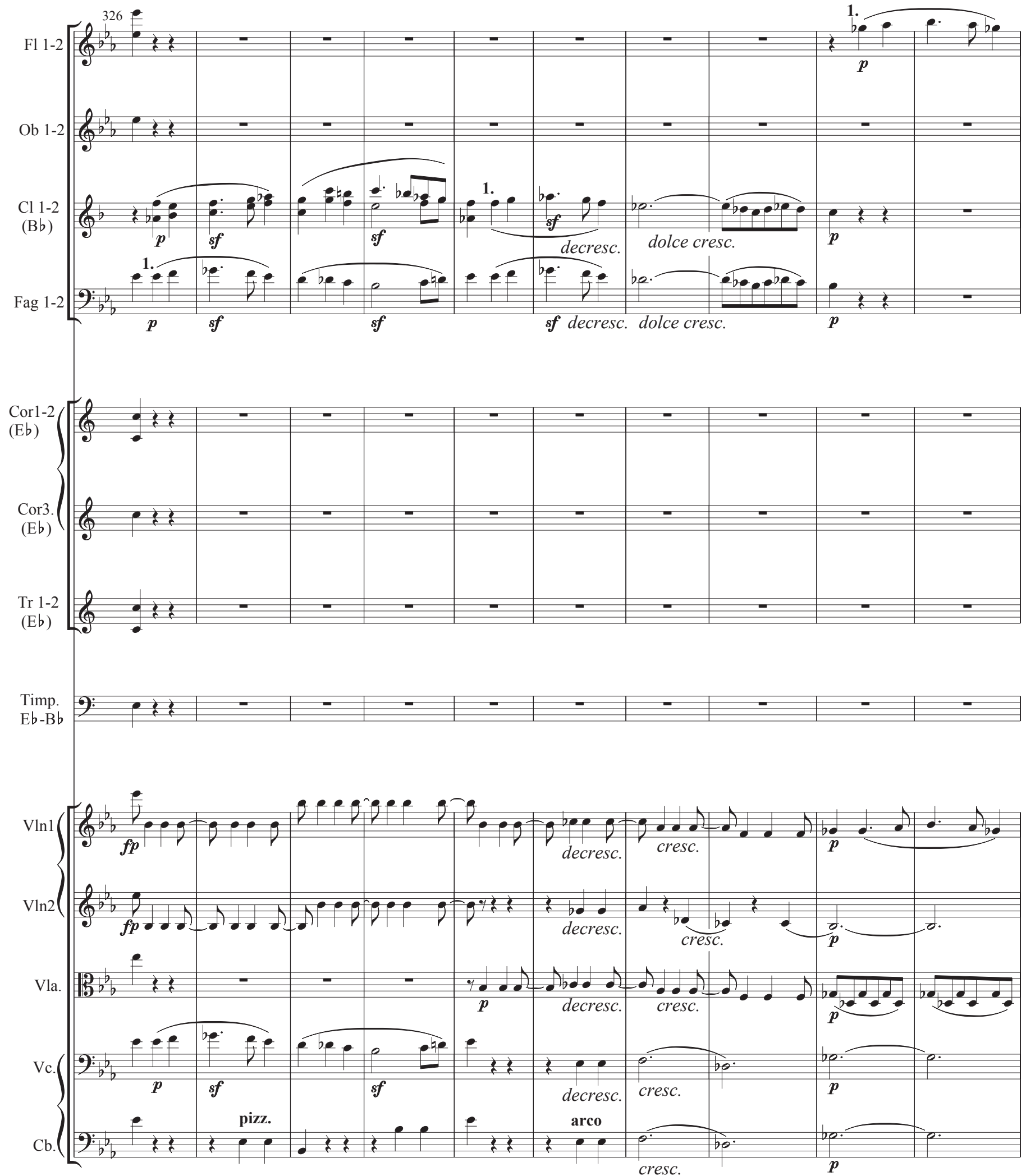


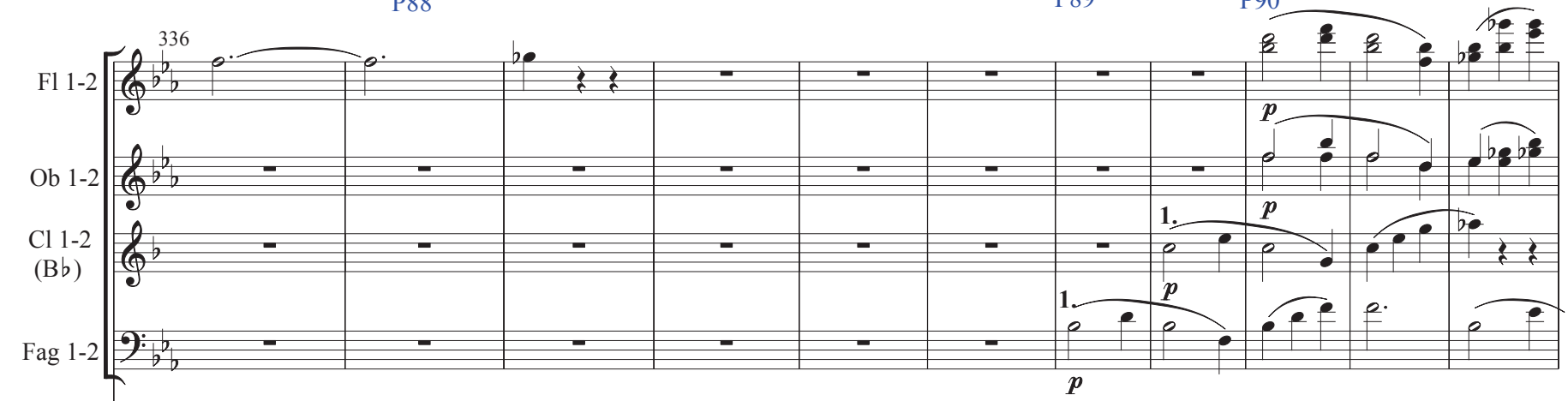

Cor3.

$(6$

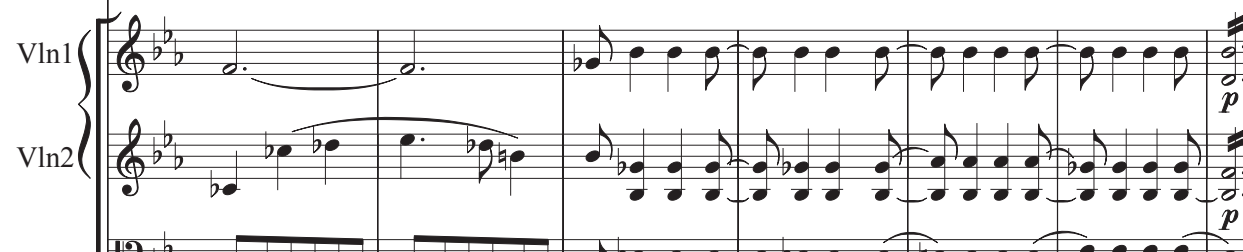

Vla.

$\mathrm{Vc}+\mathrm{Cb}$

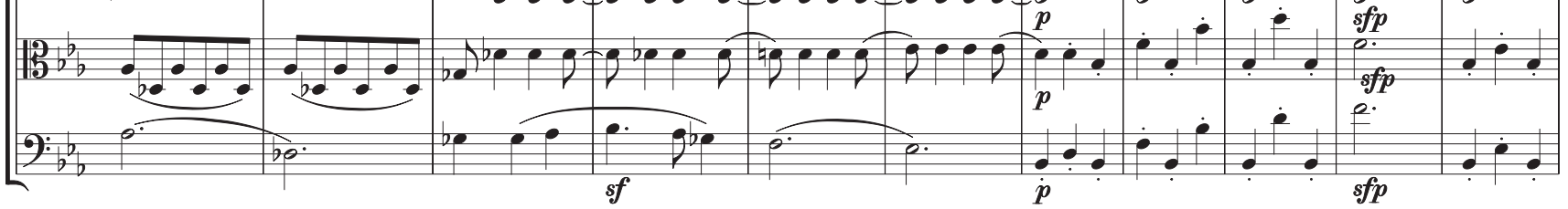

P91
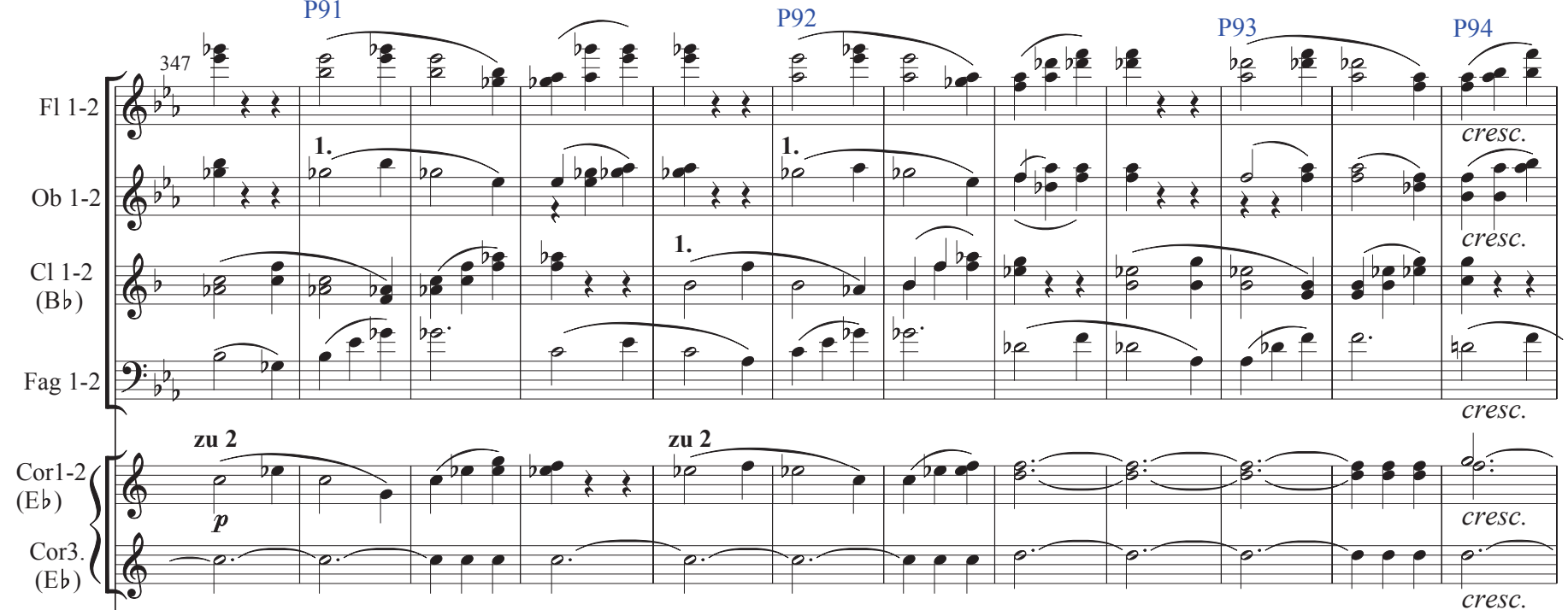

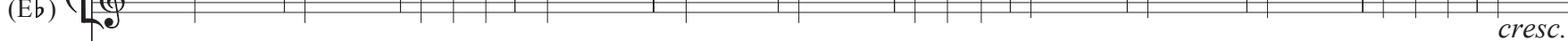

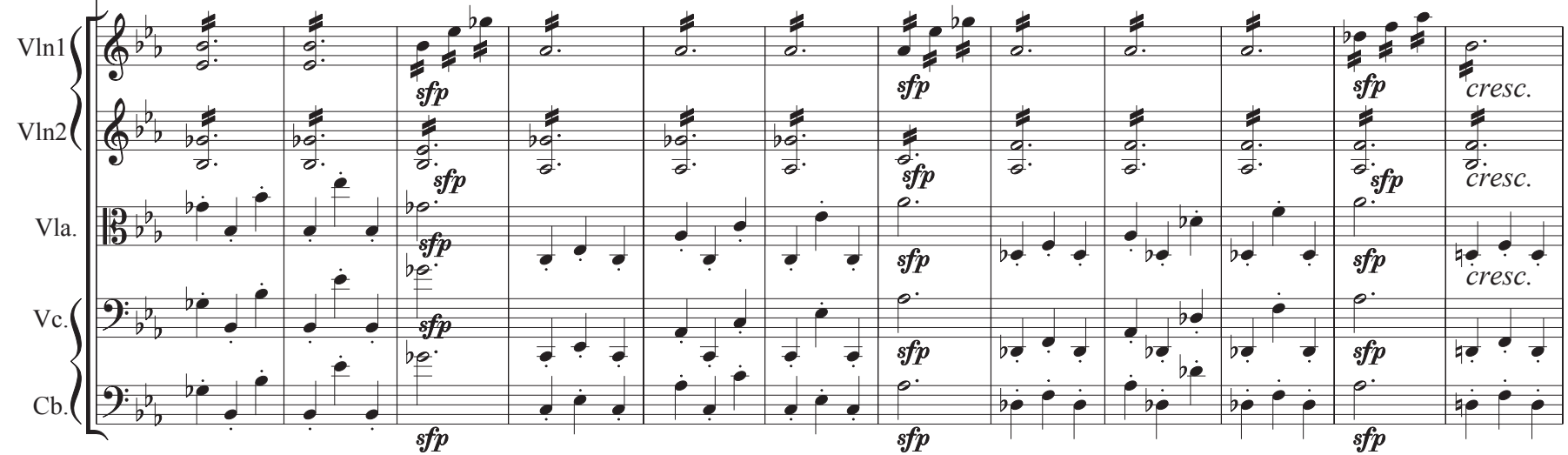



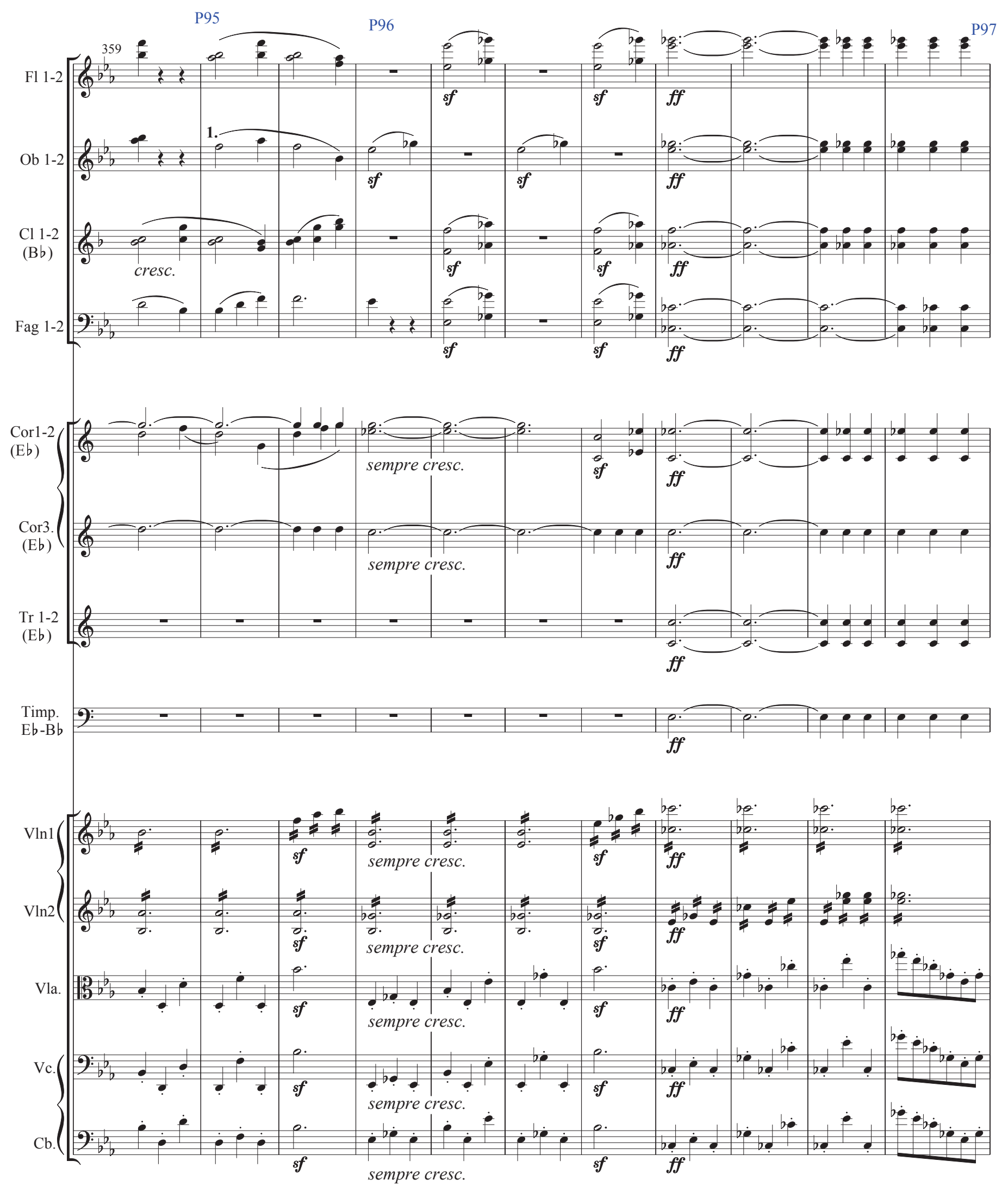


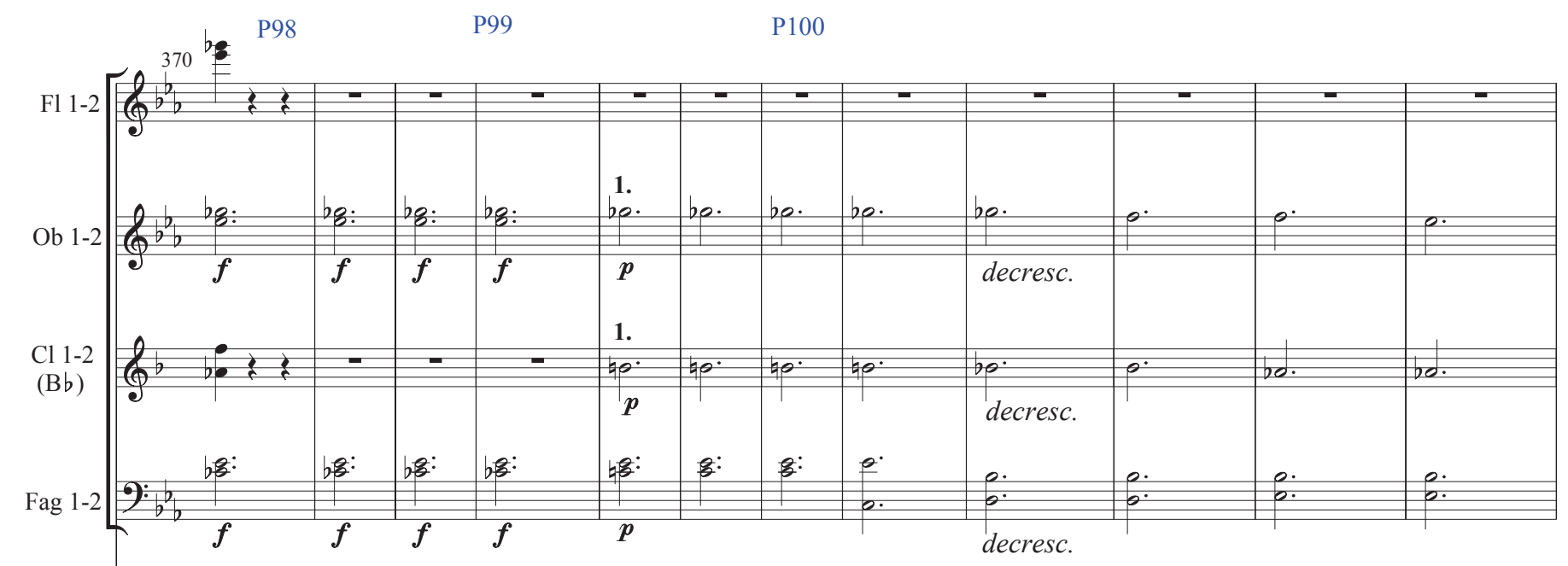

2.
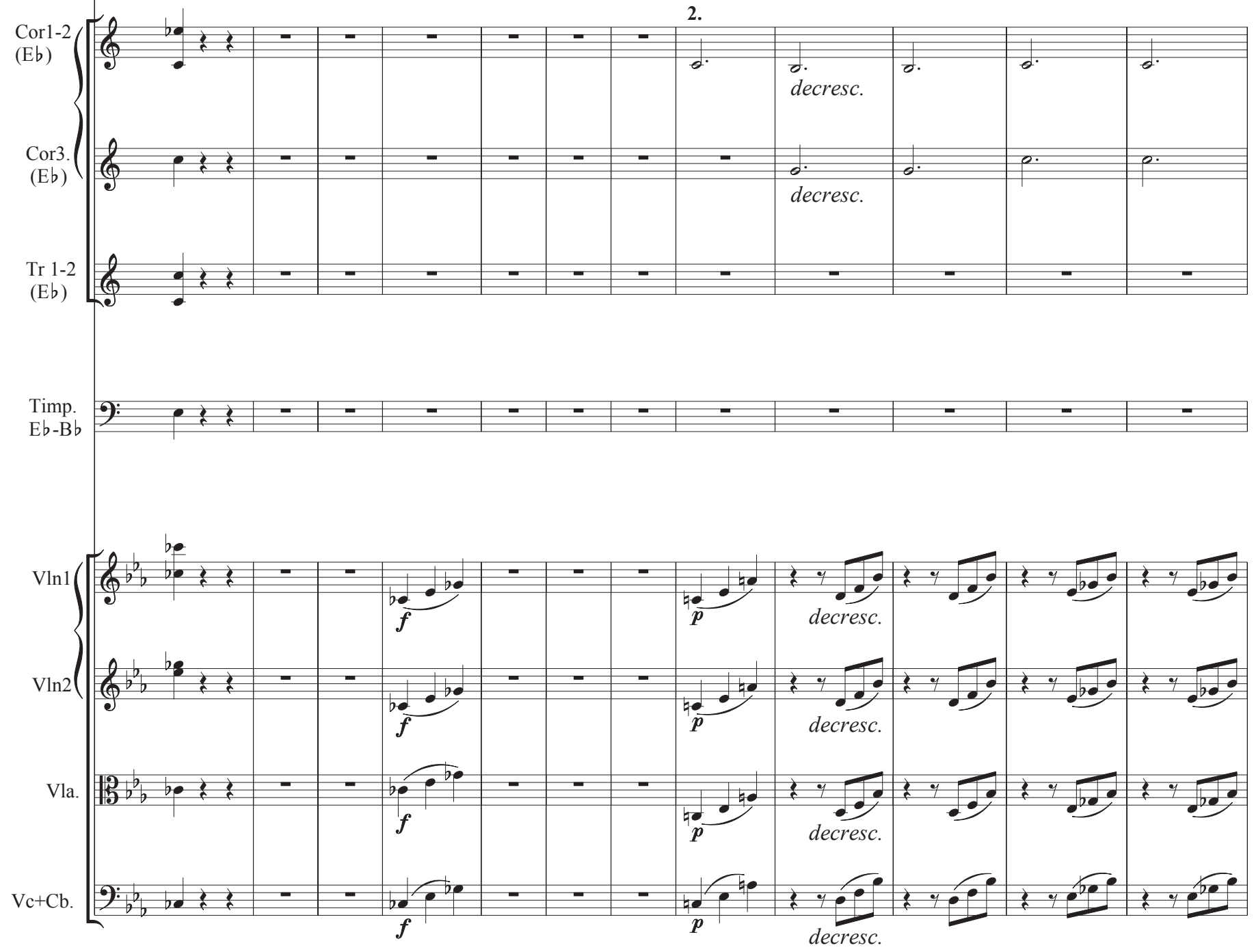

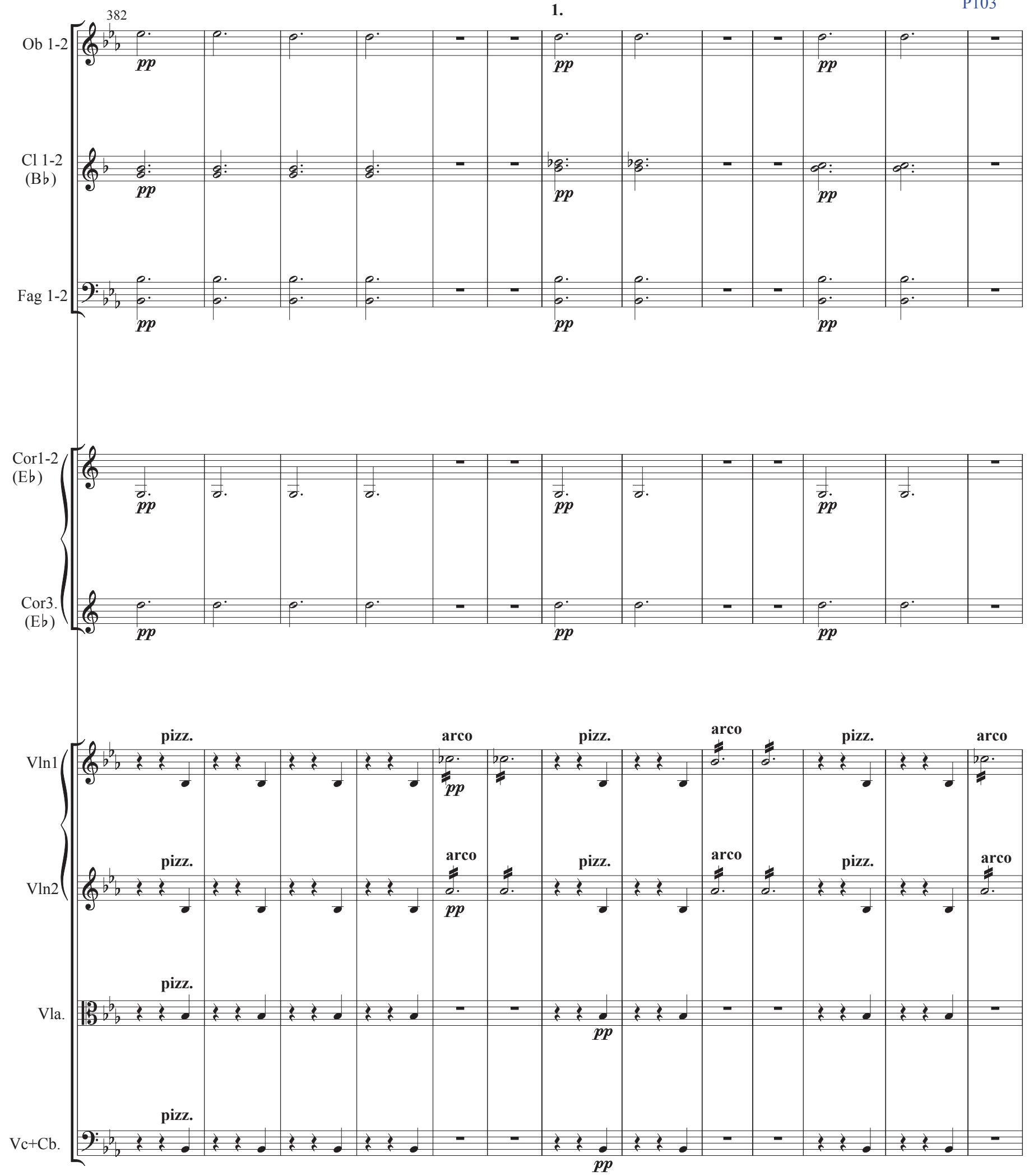
P104 pasa a ser el P112

Interrupción del ensayo

cuando reemprenden el ensayo
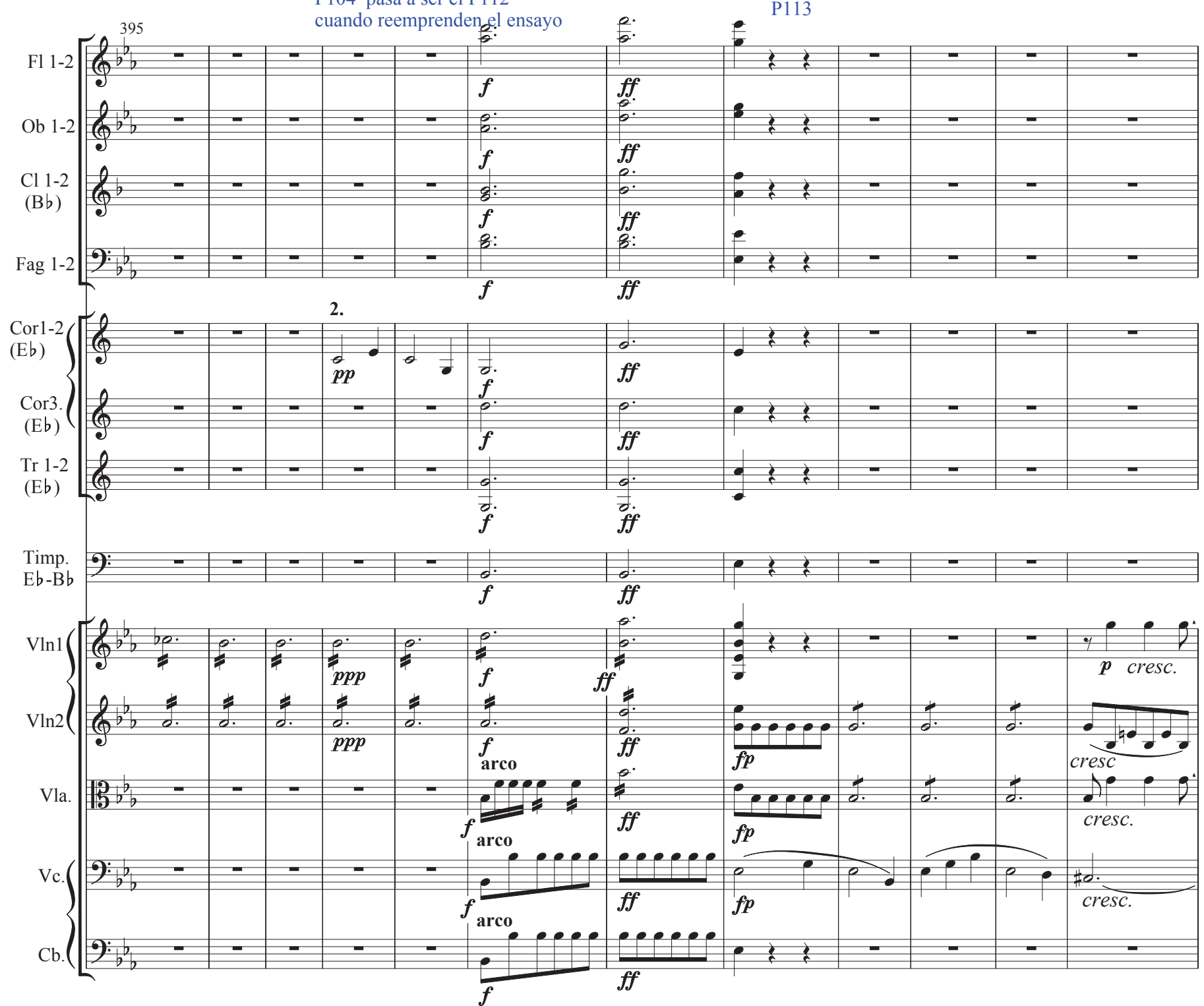

P114

P115

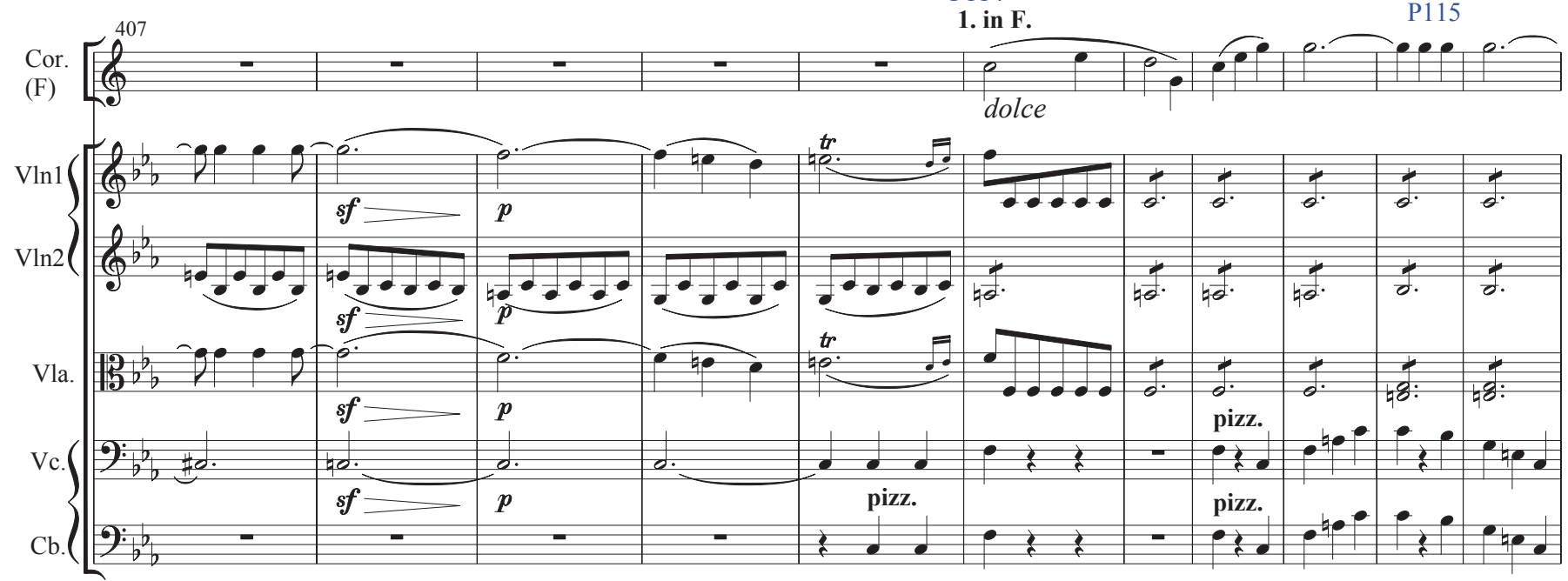


P116

1.

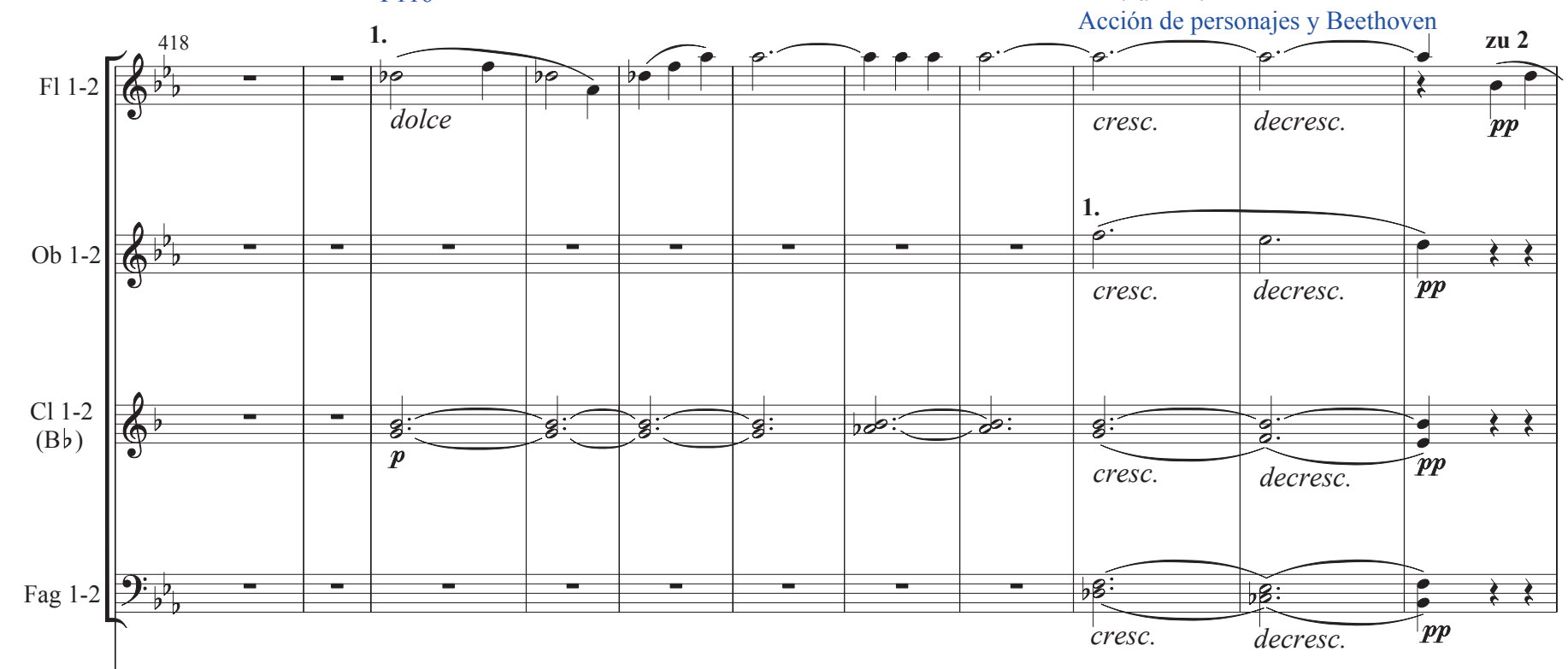

in $\mathbf{E} b$.

2.

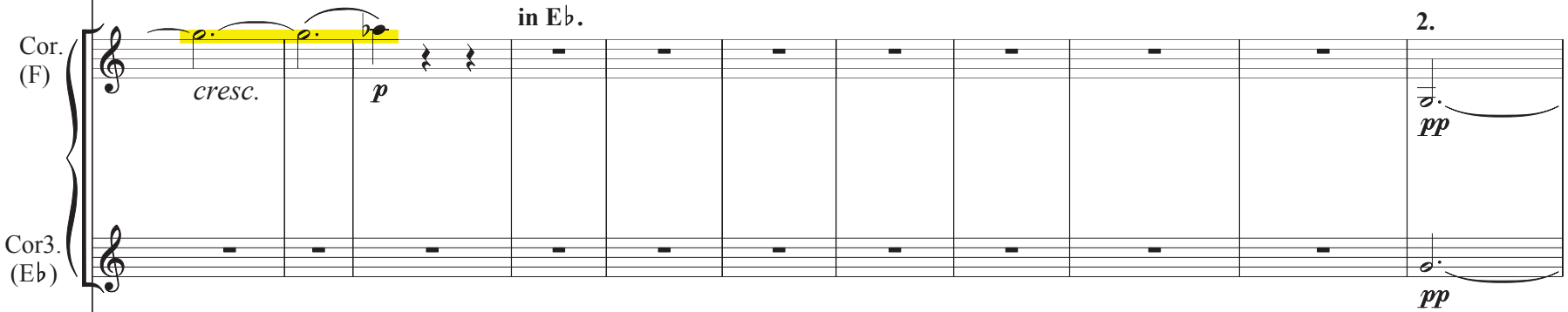

(Eb)

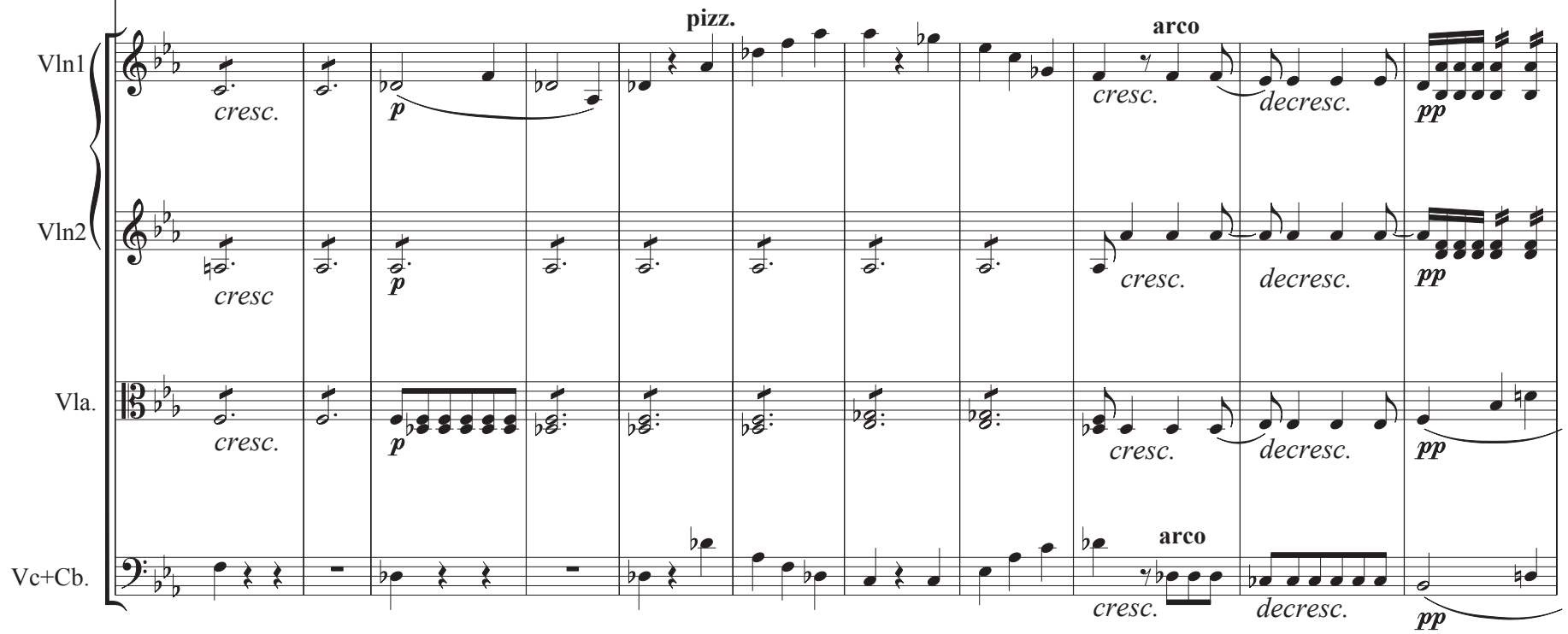




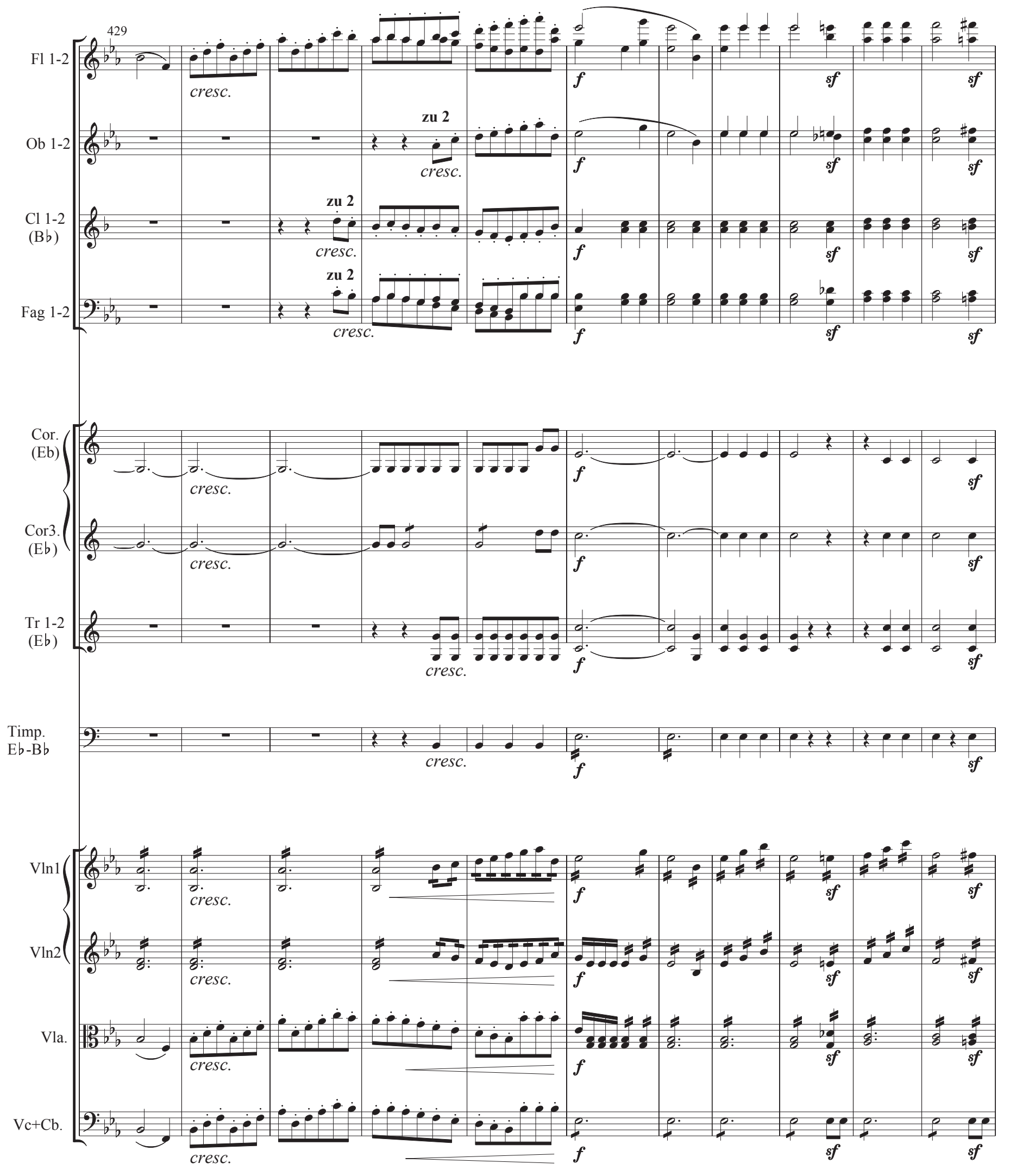

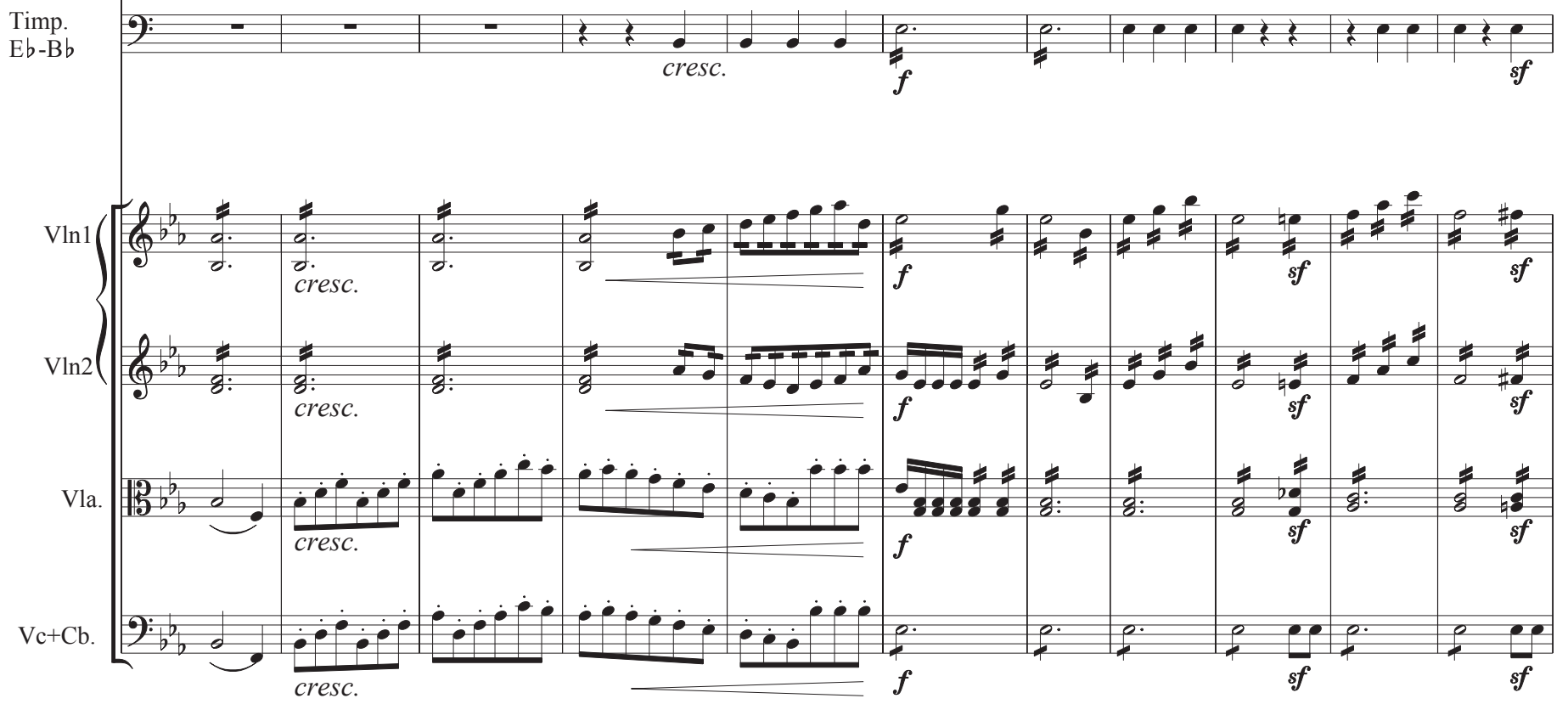



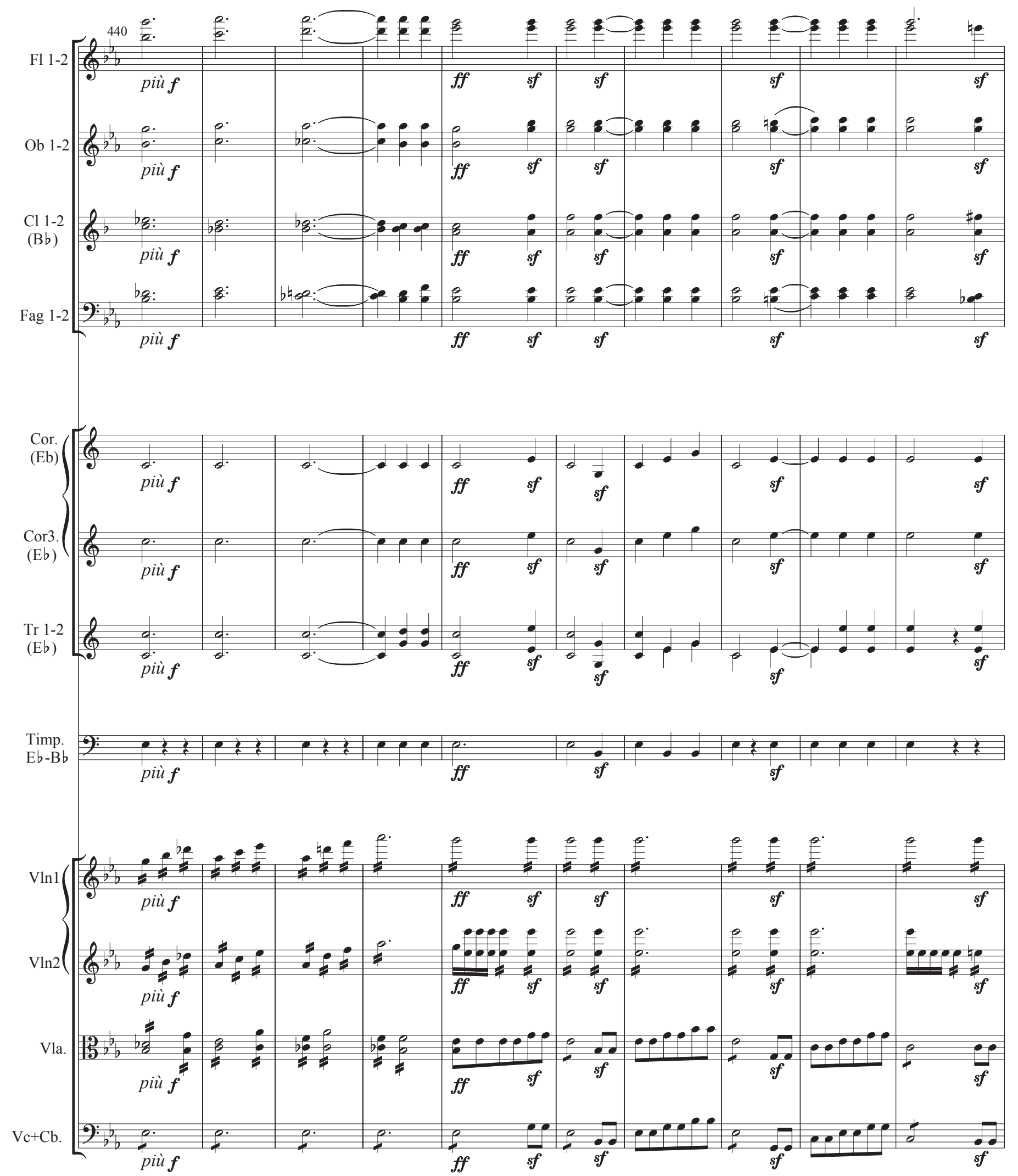
P127
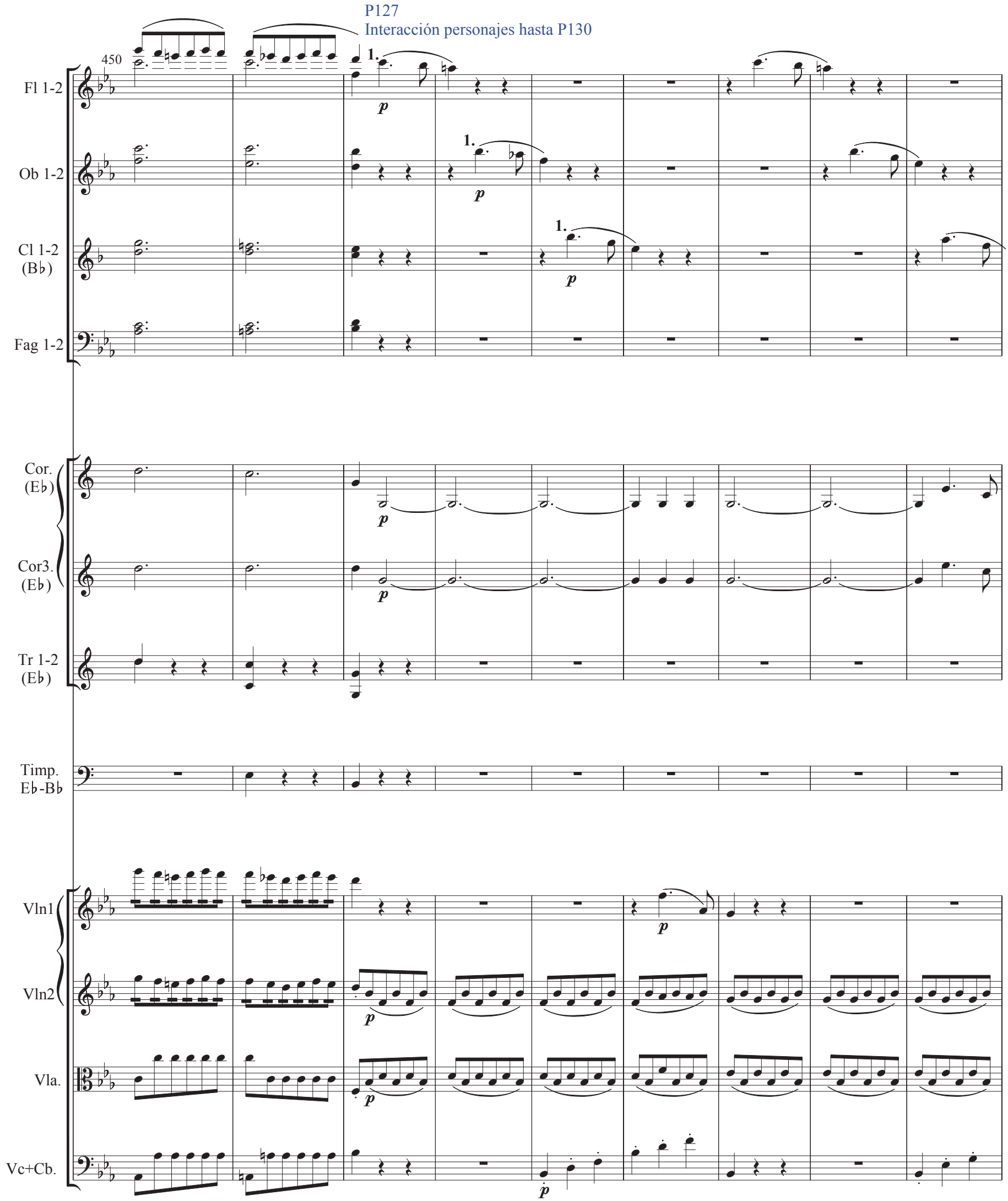


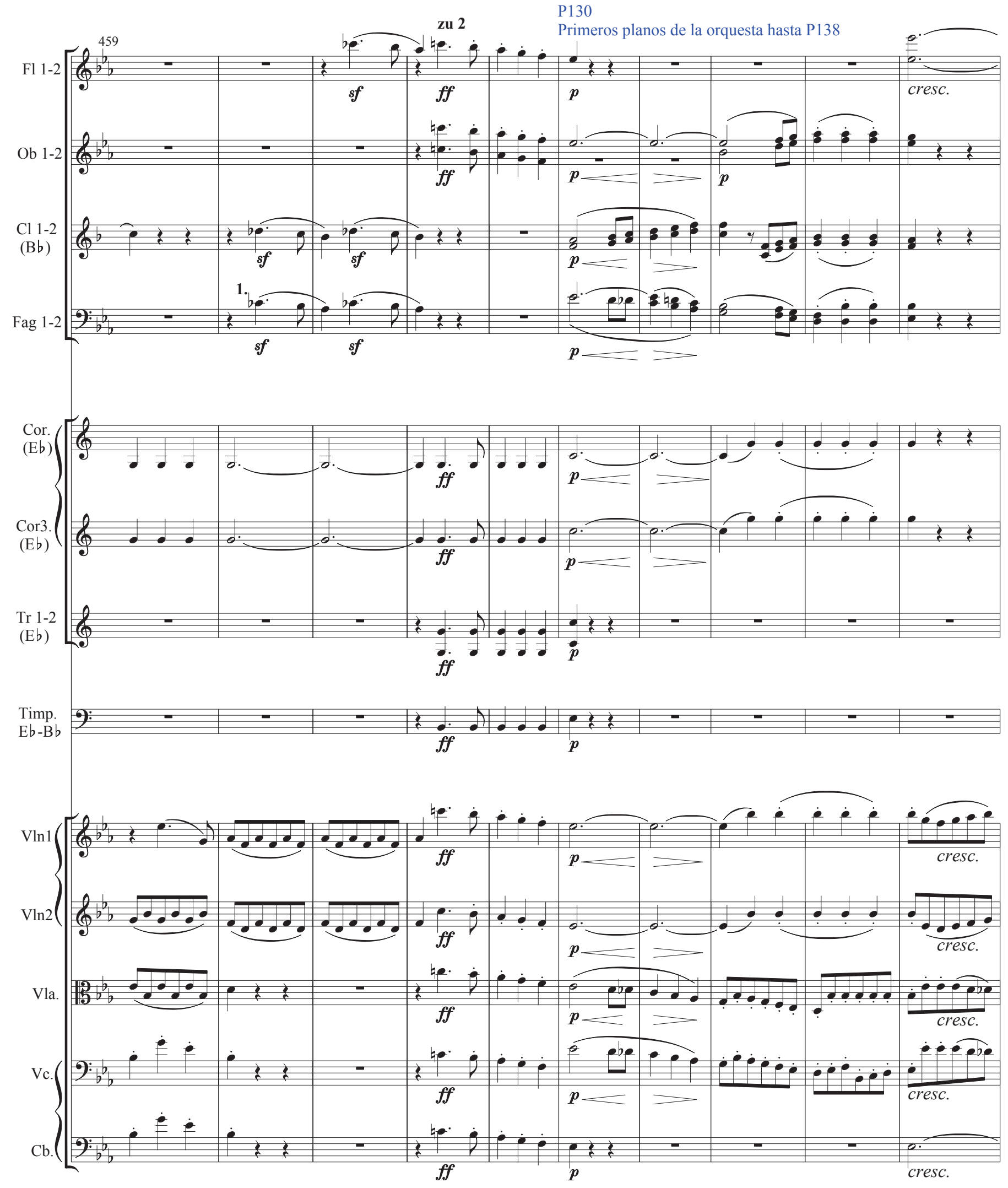



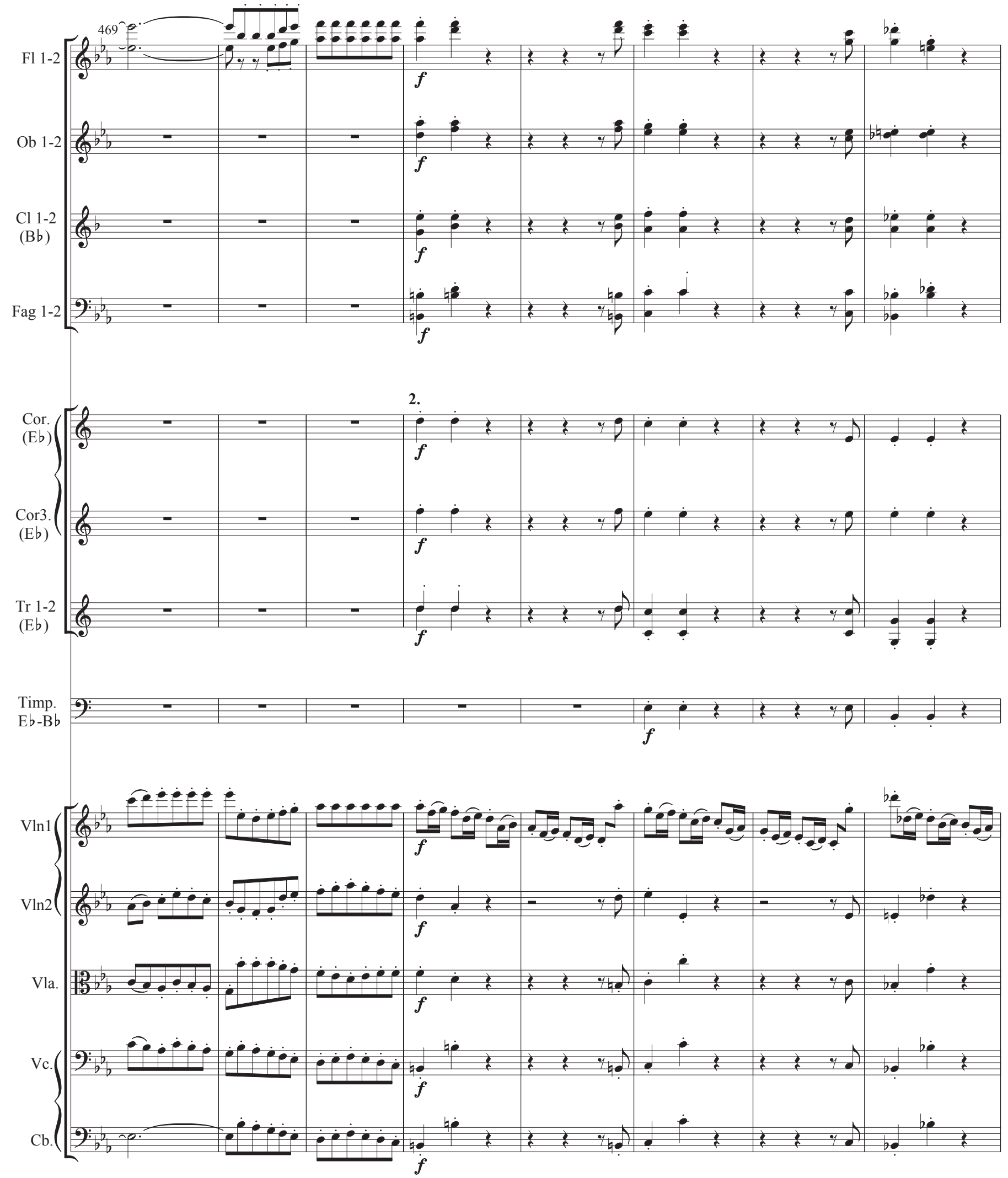


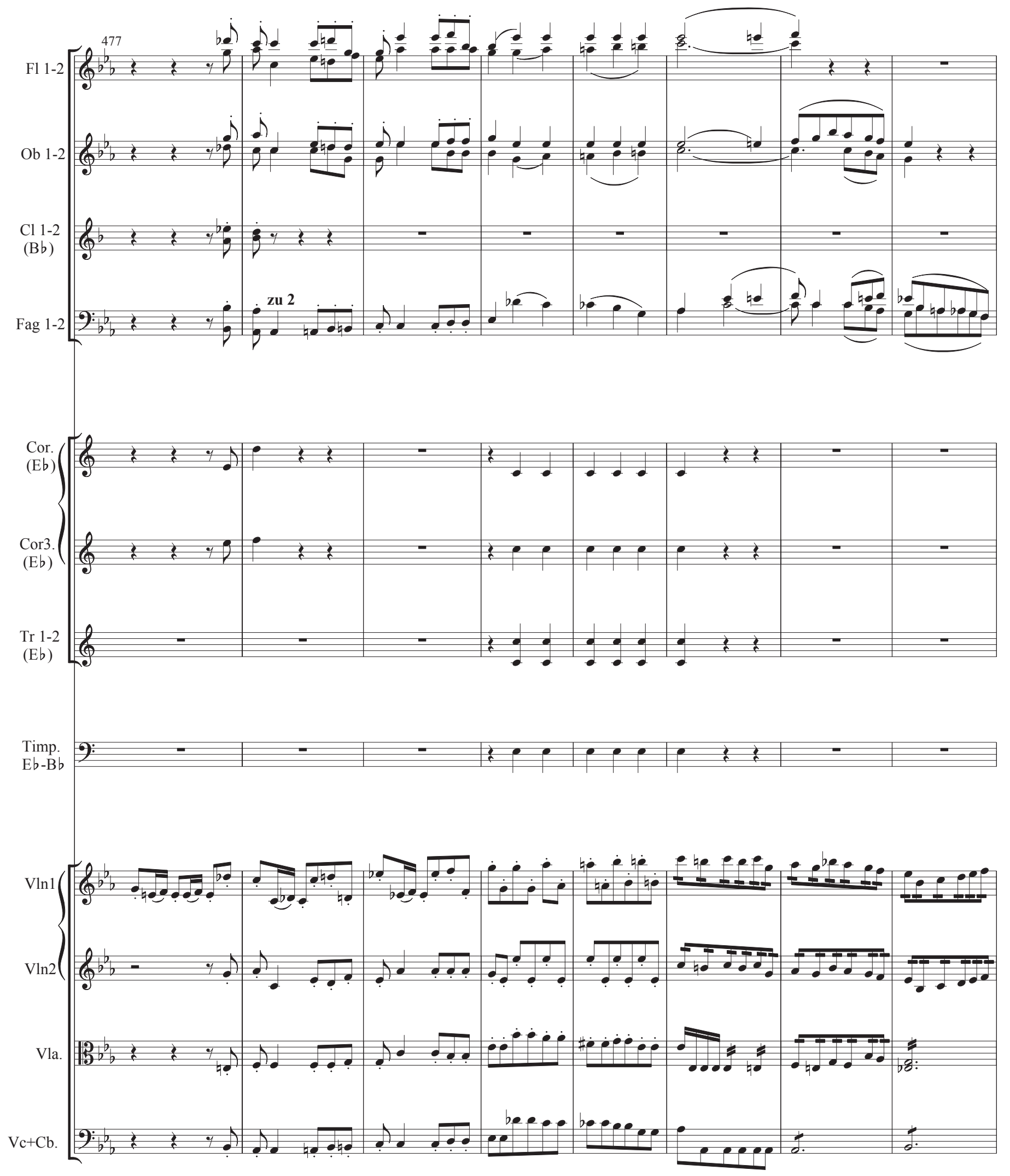



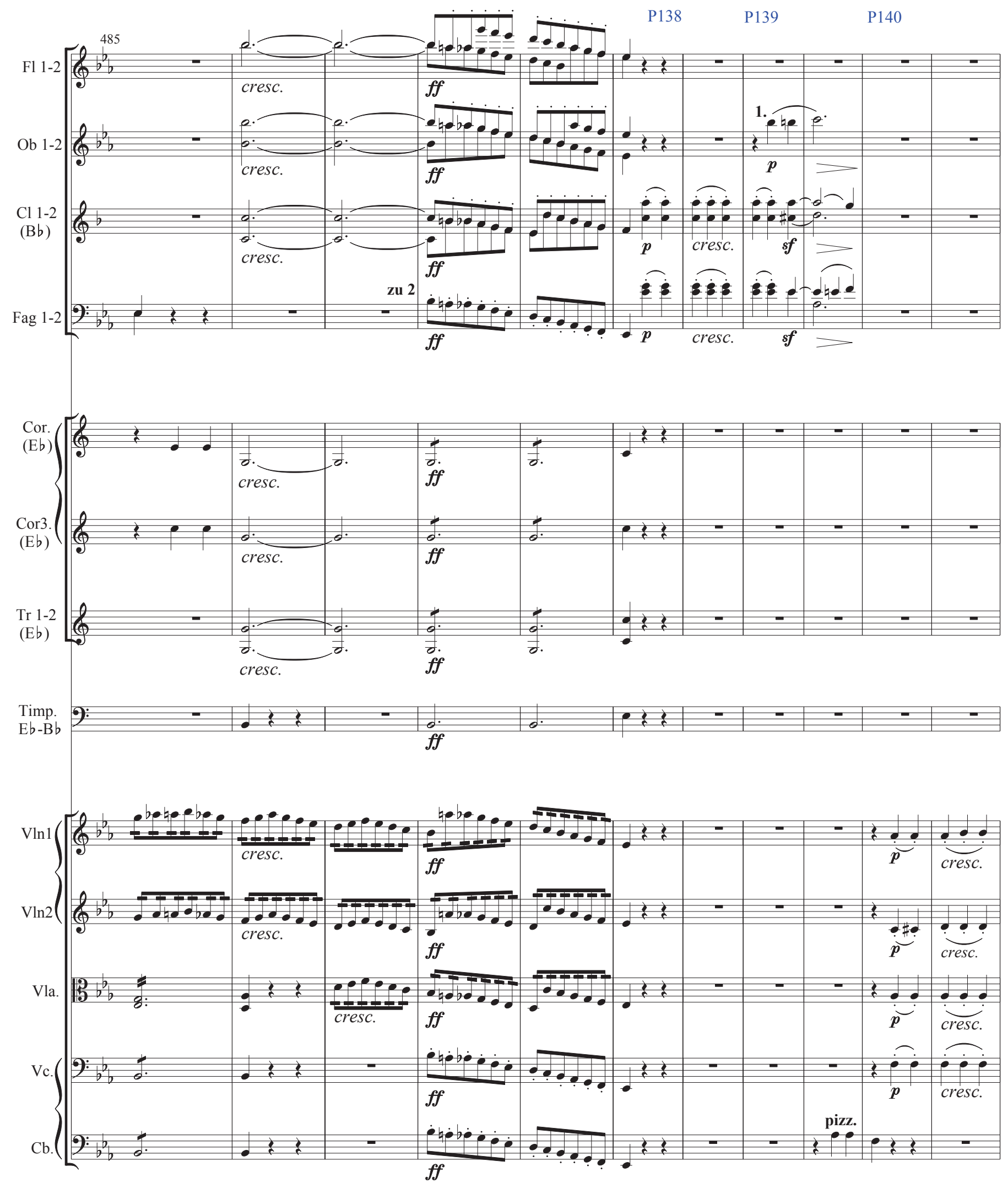


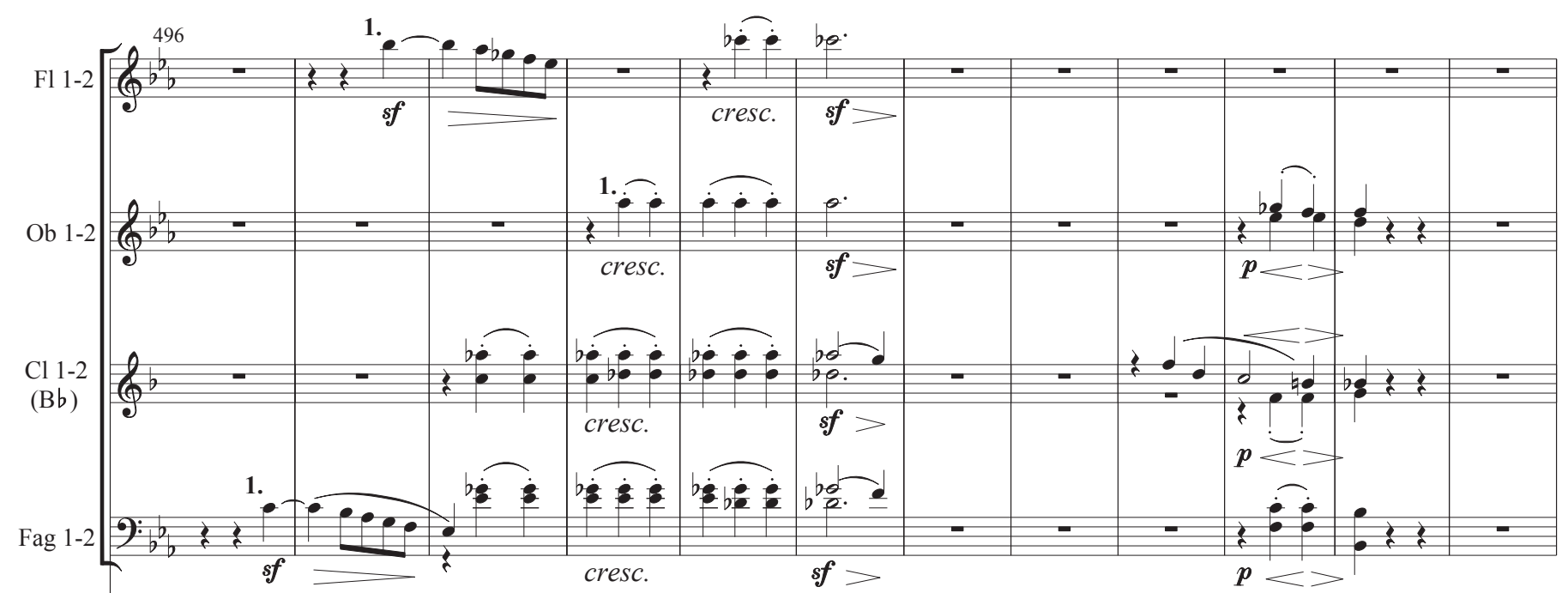

2.
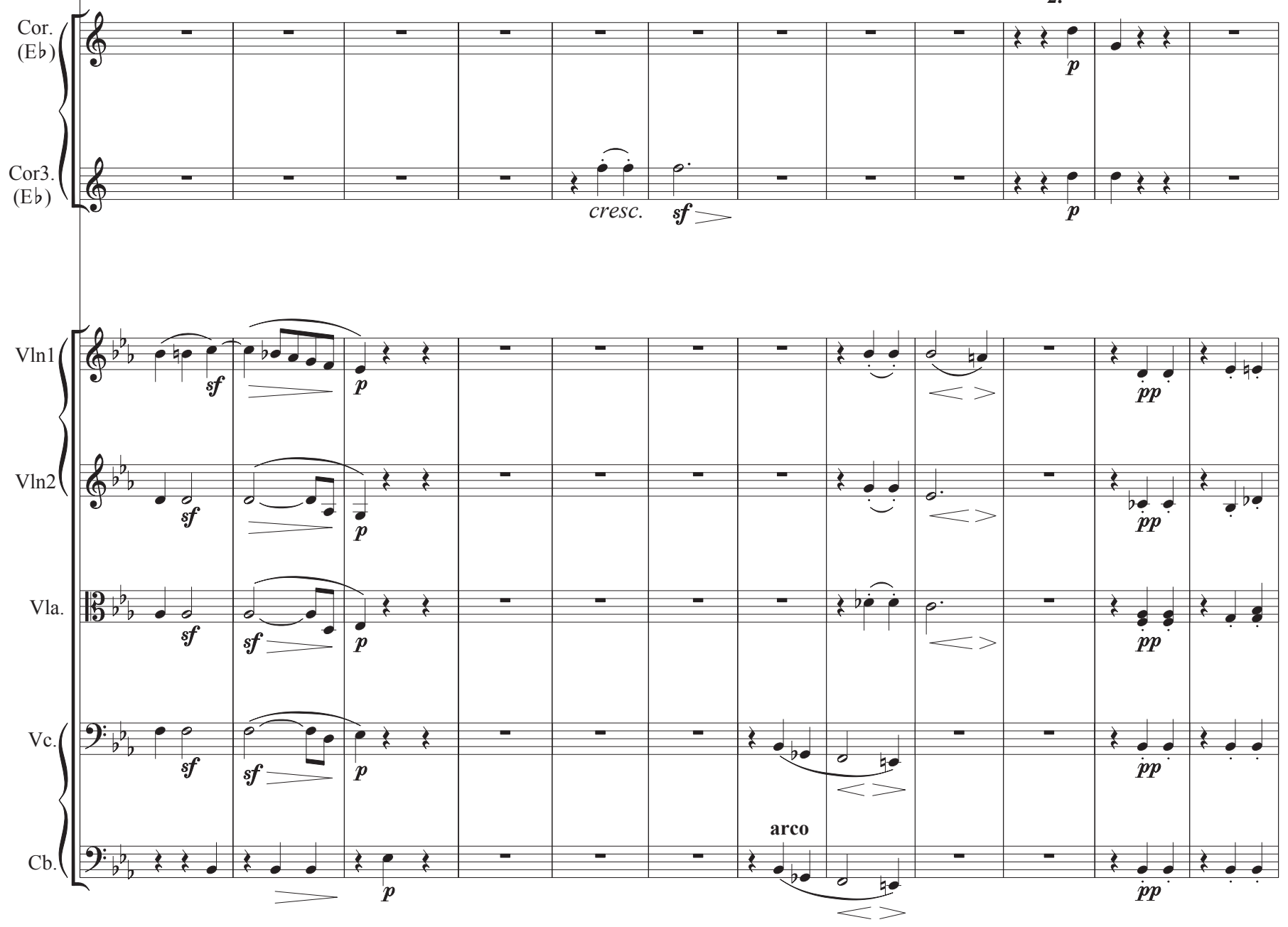
P142 a P158

Beethoven más personajes (ritmo rápido)
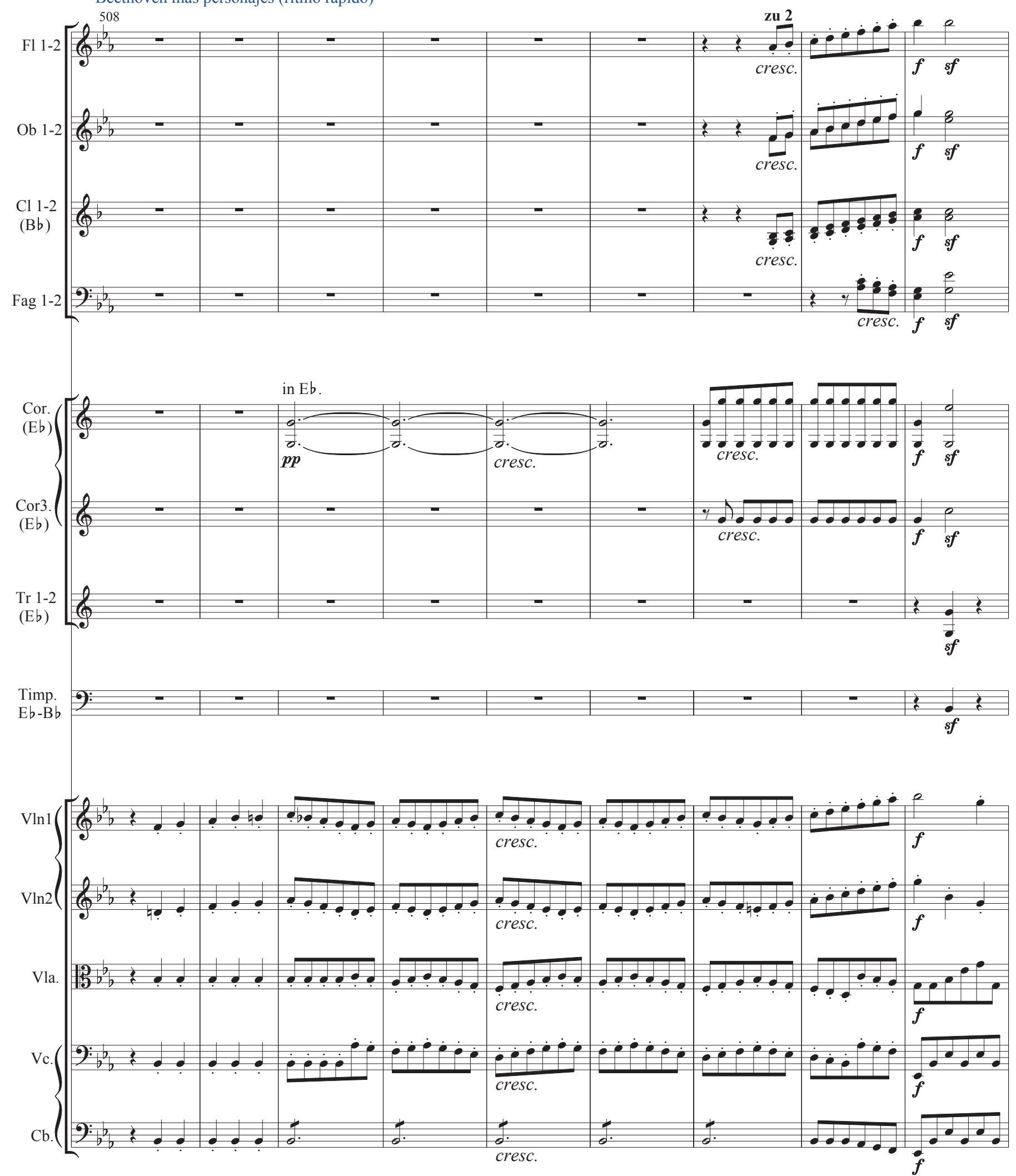

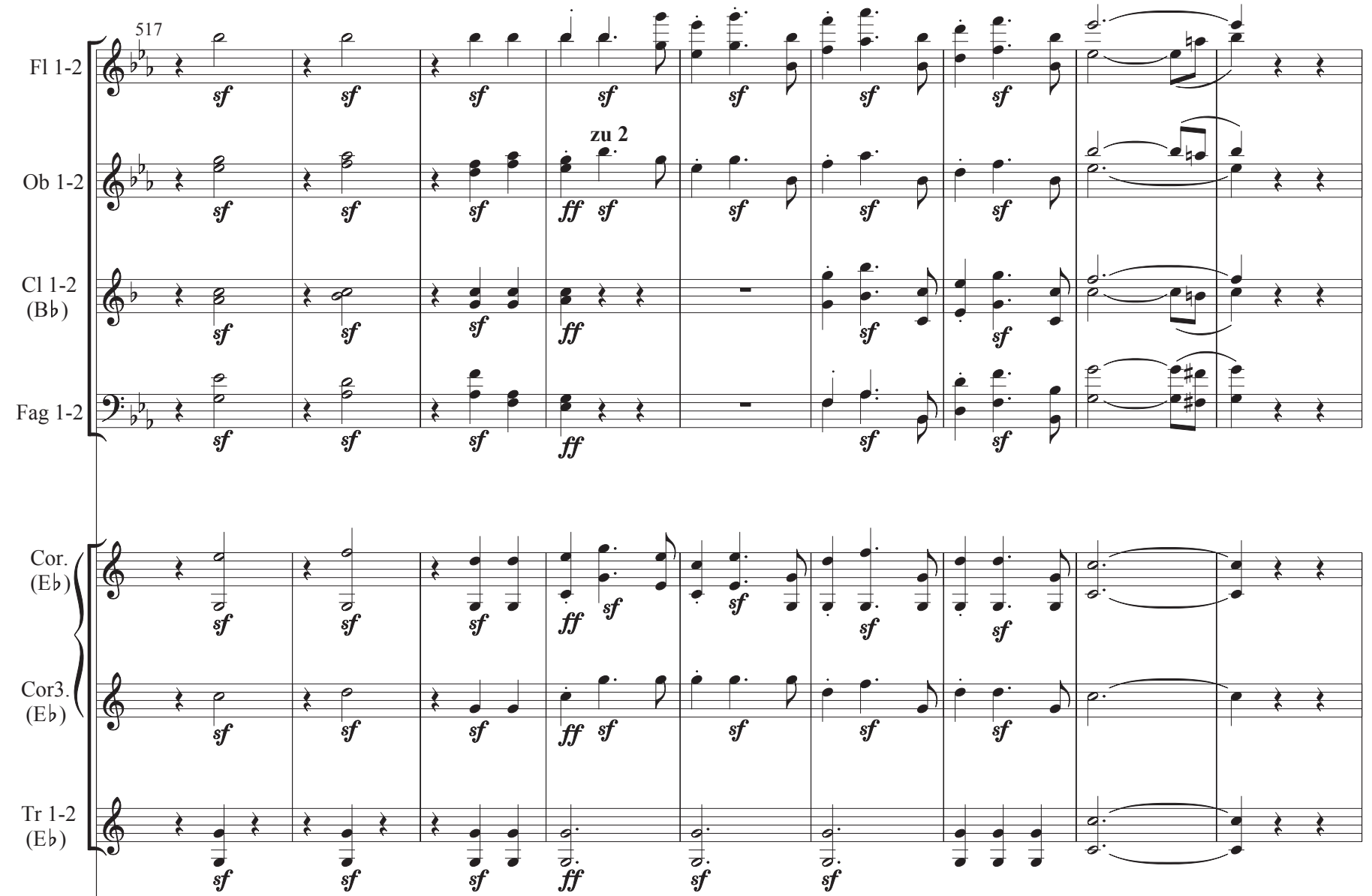

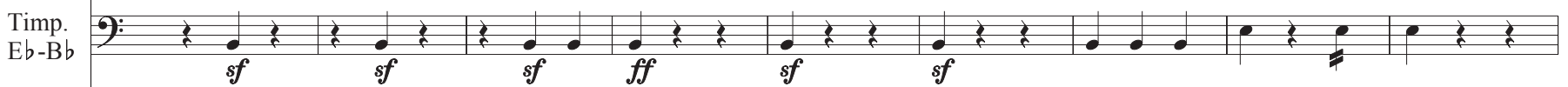

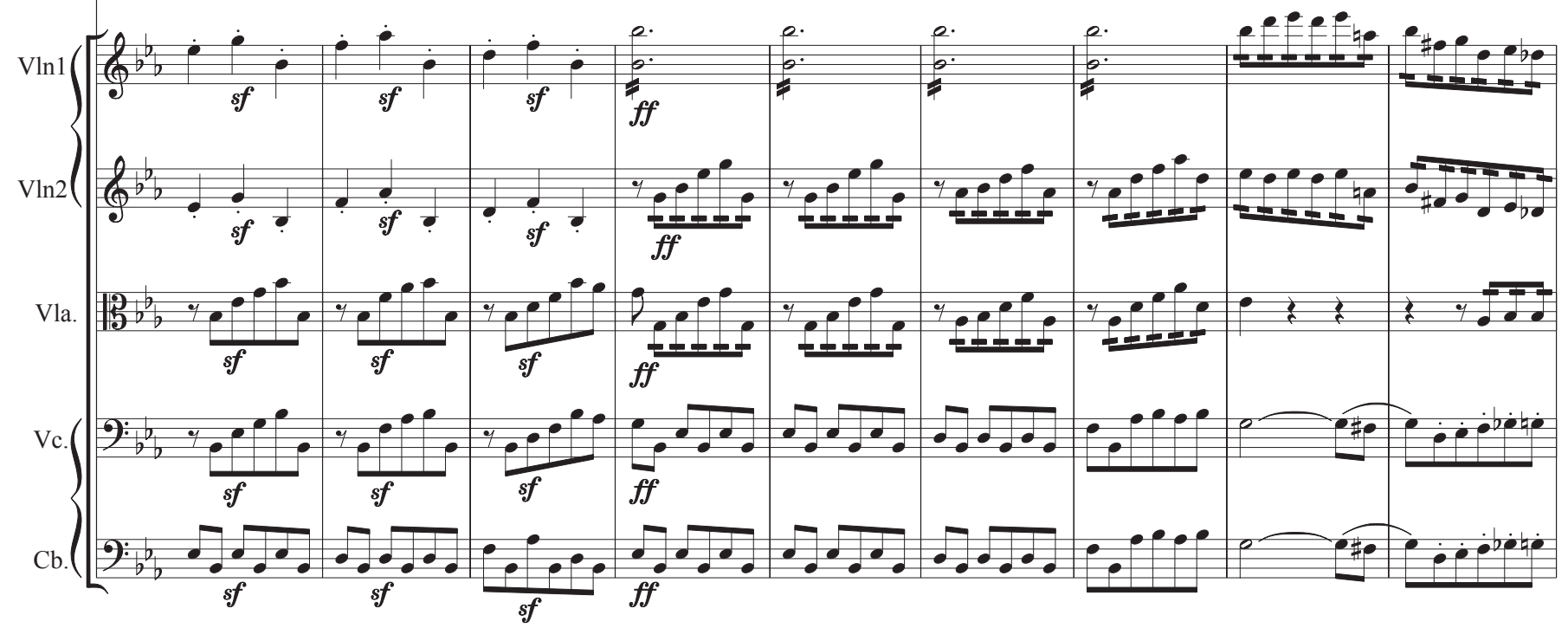



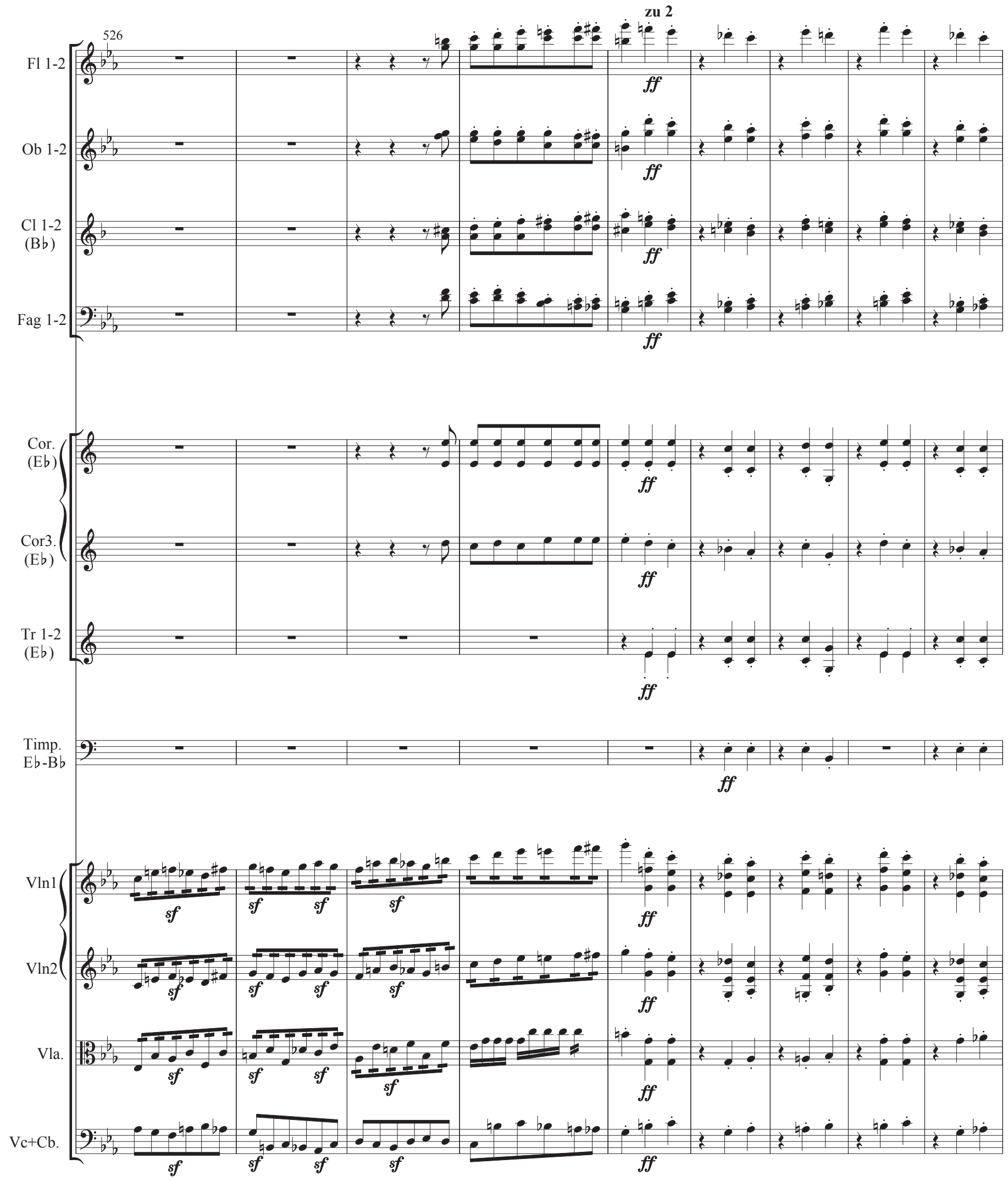

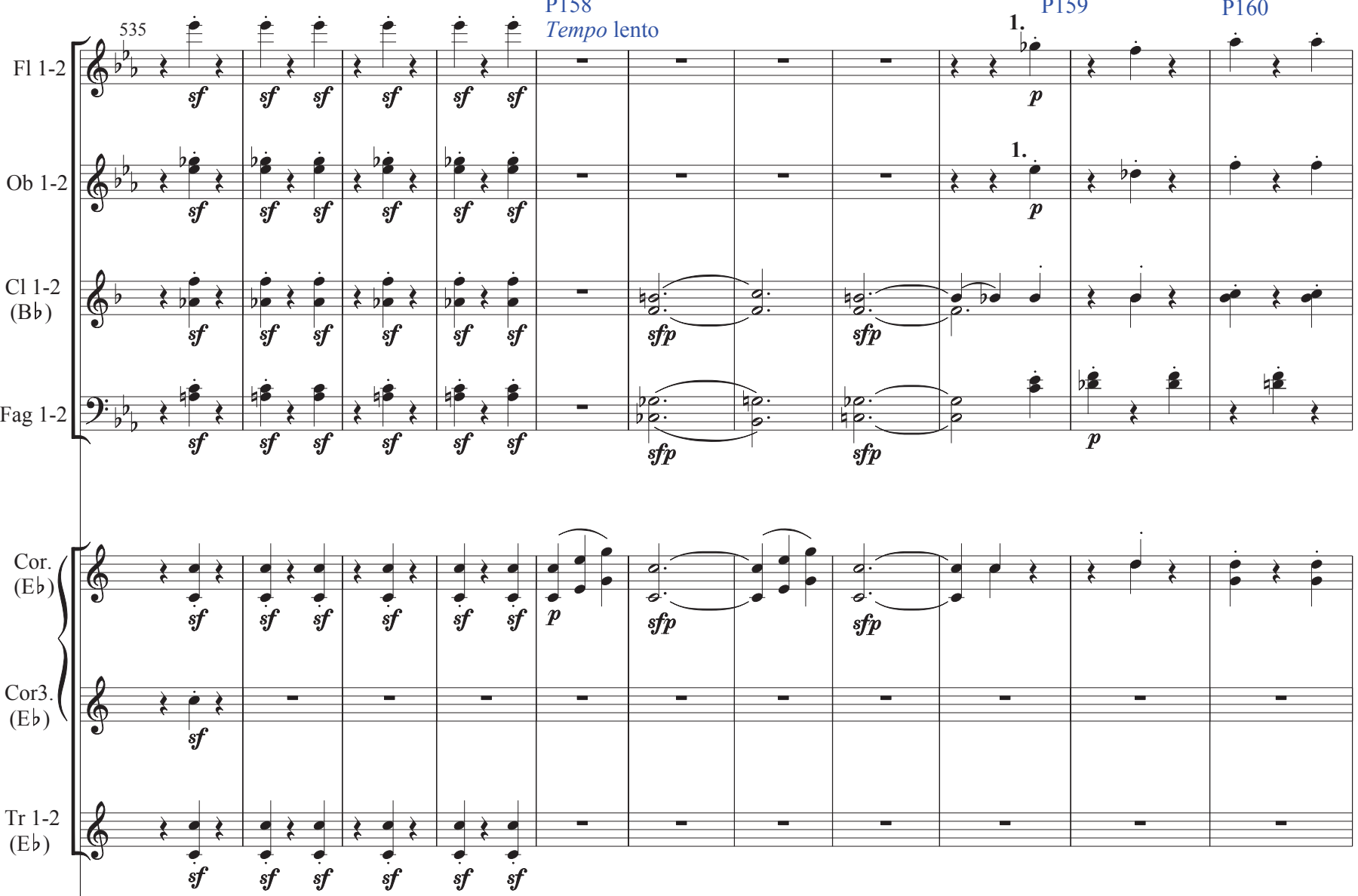

Timp.

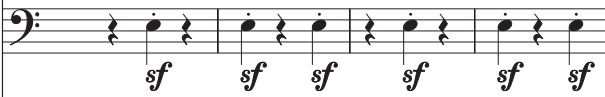

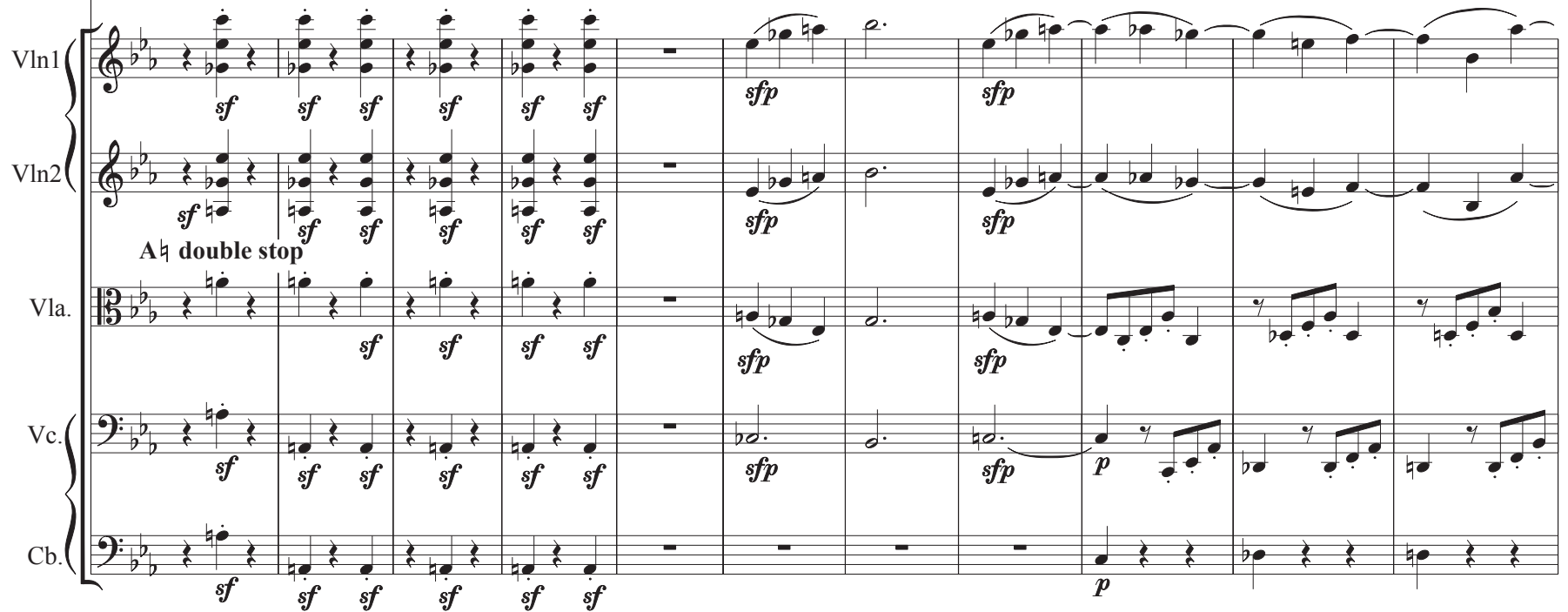



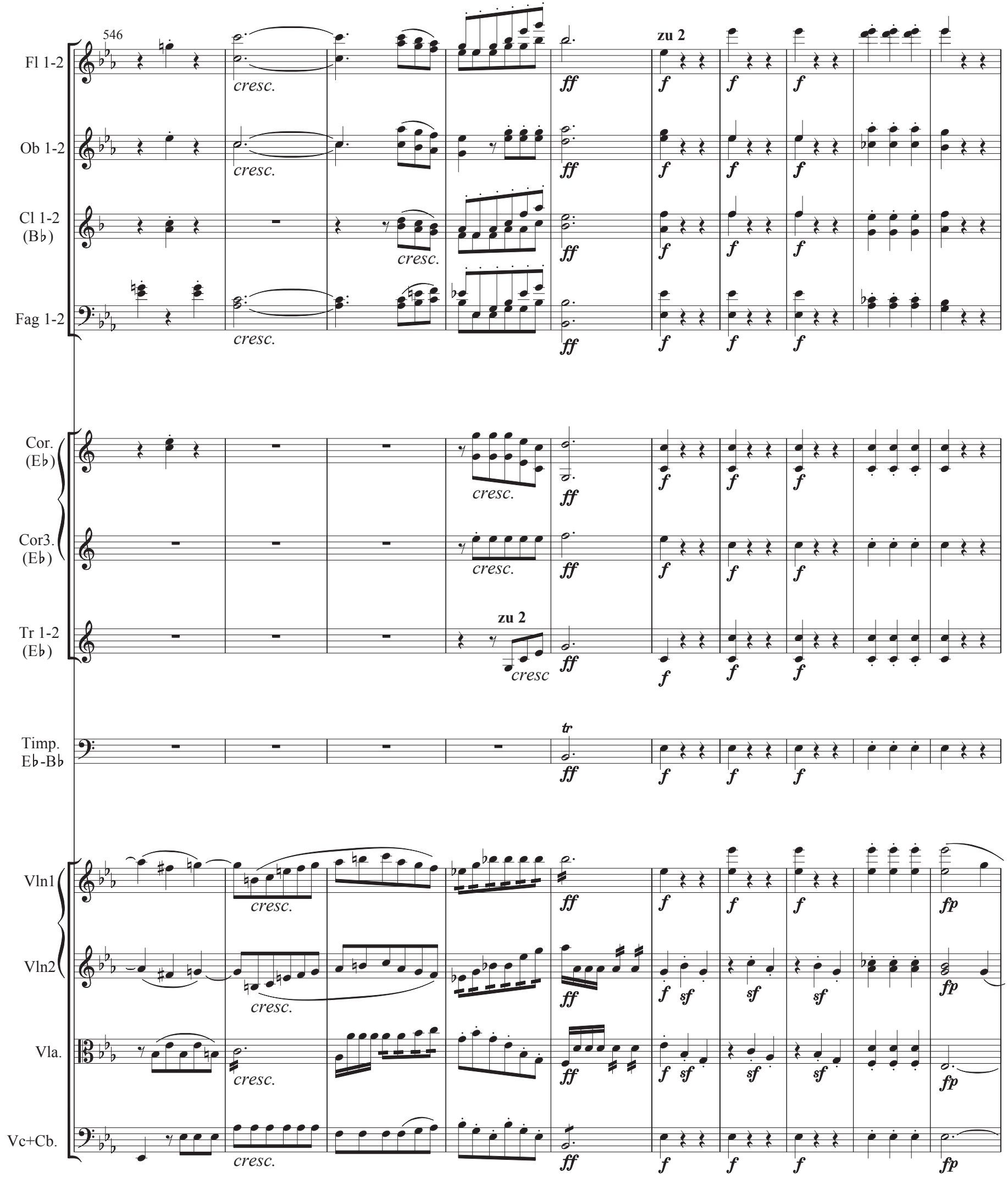

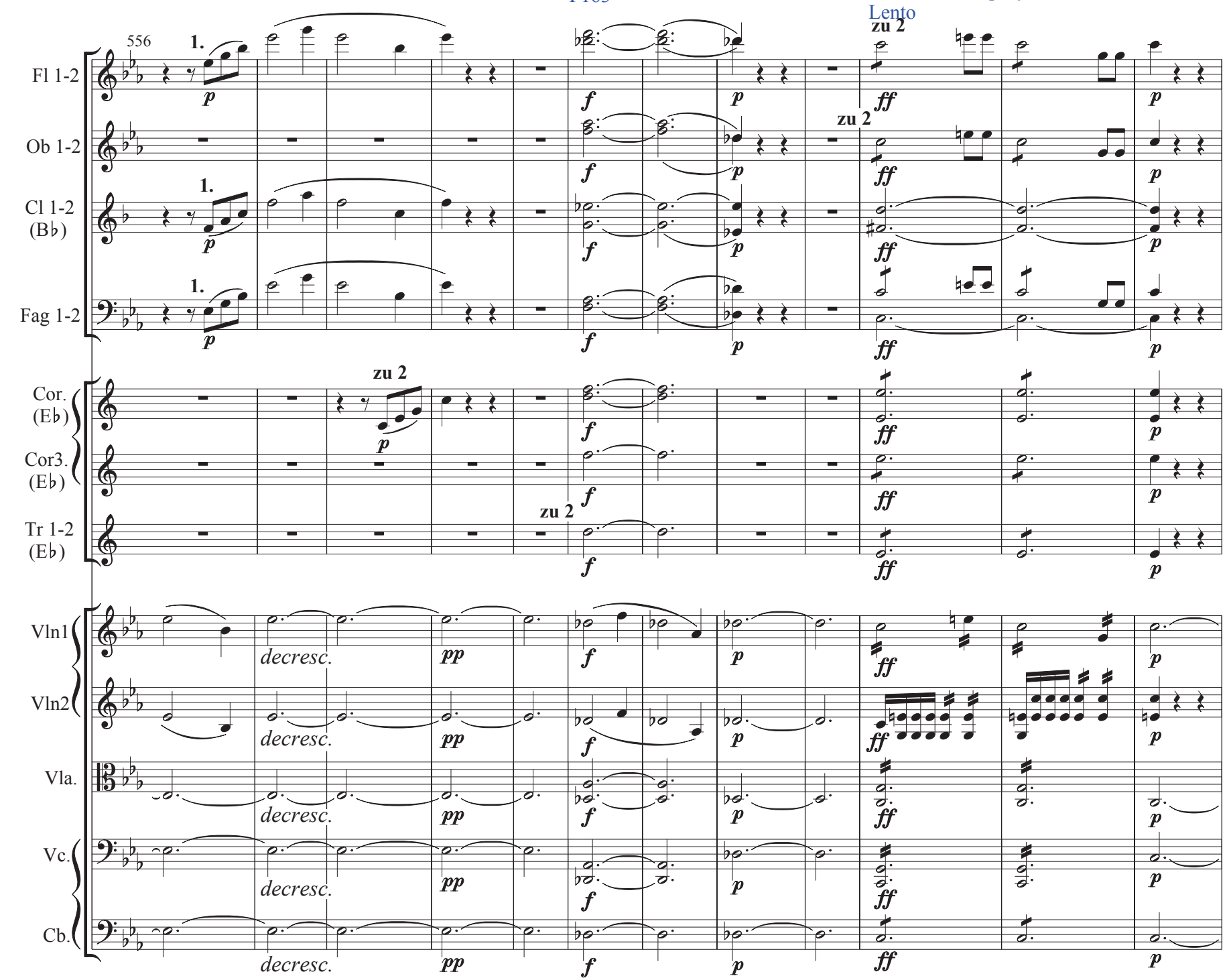

P165
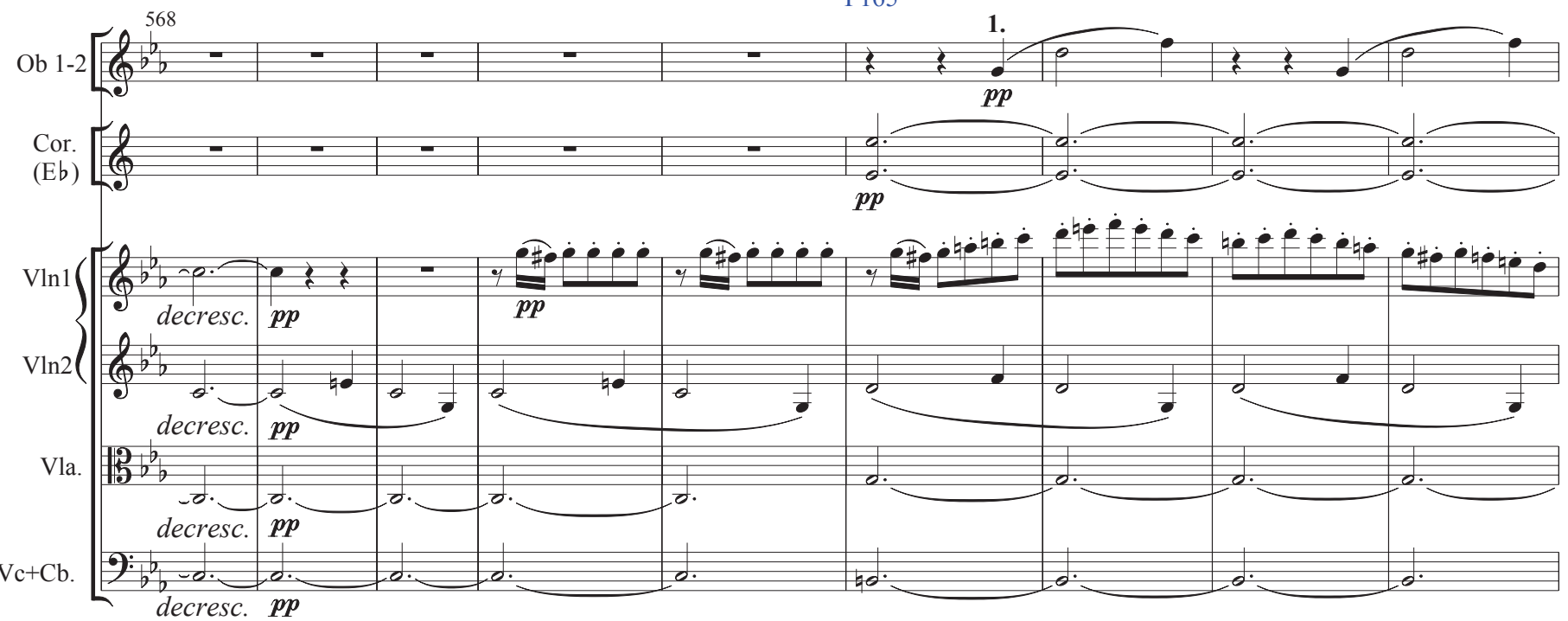

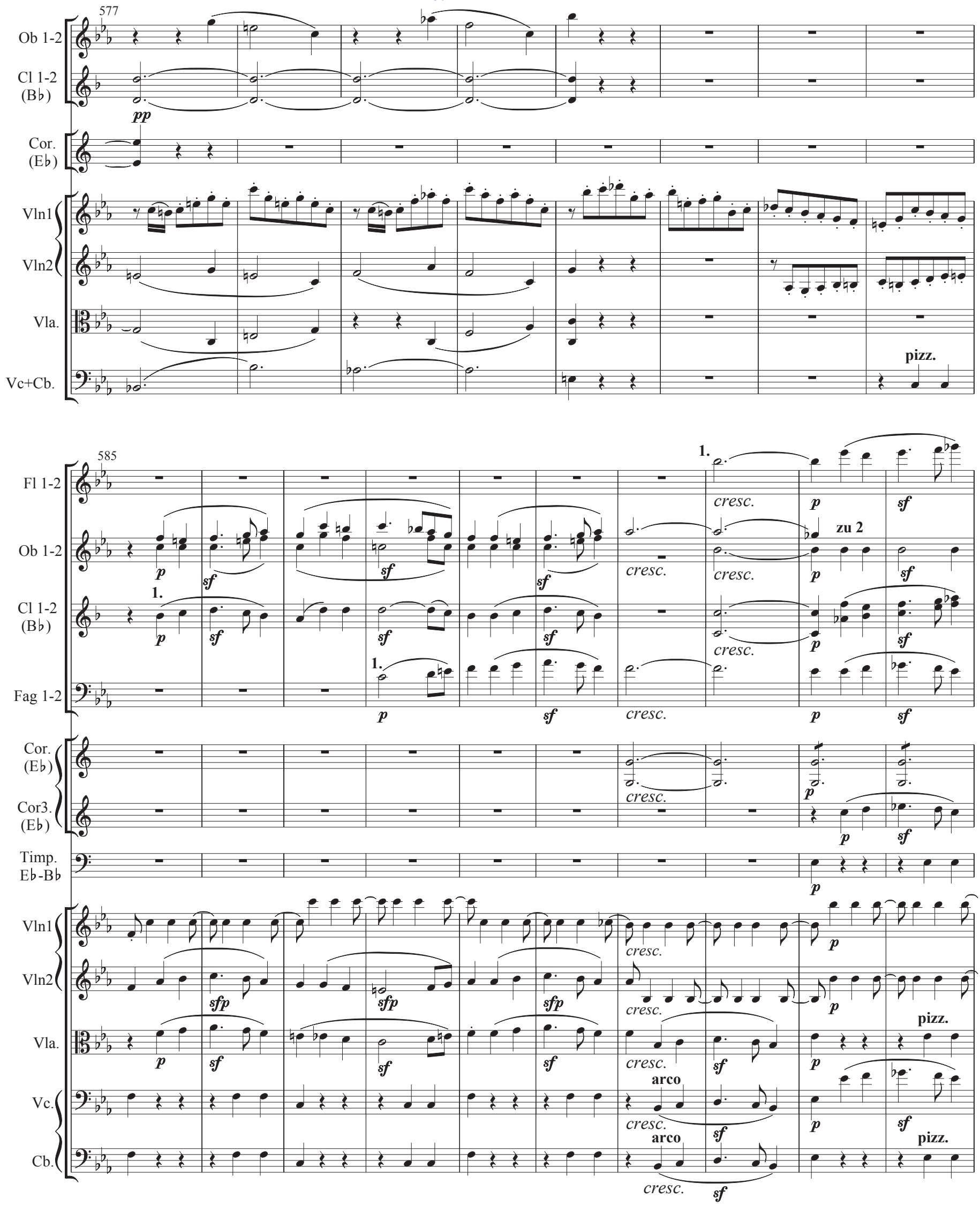

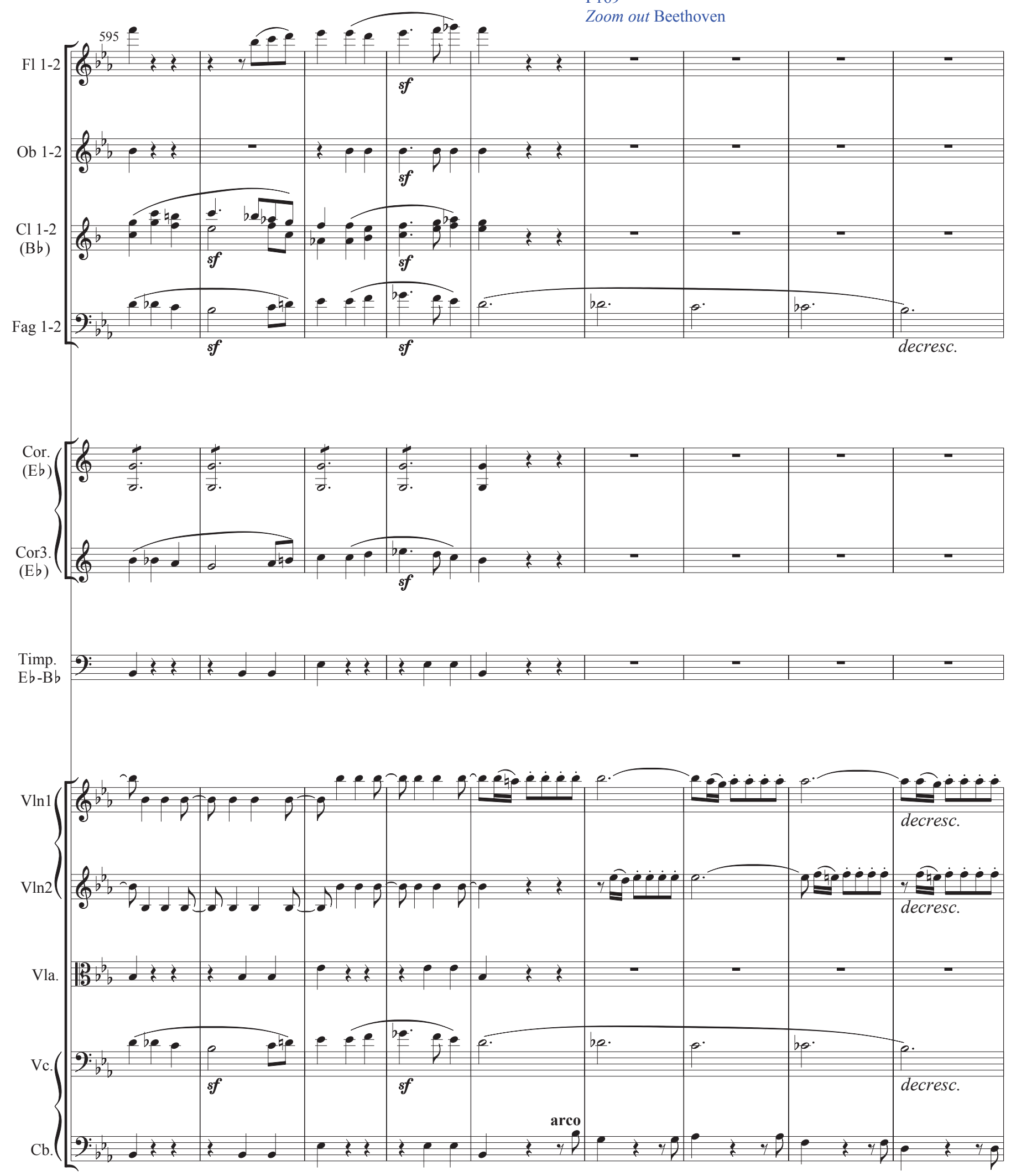
P170
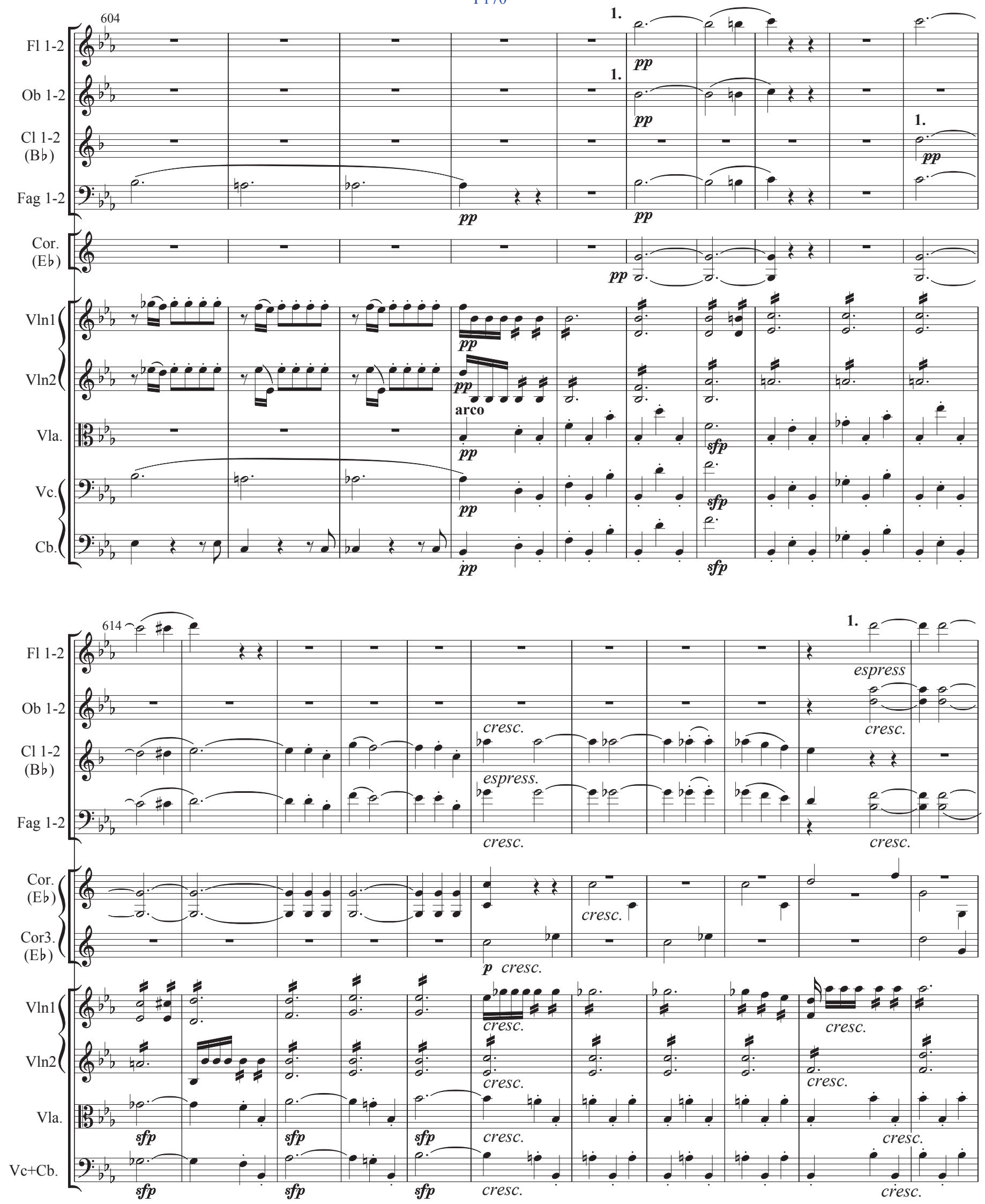

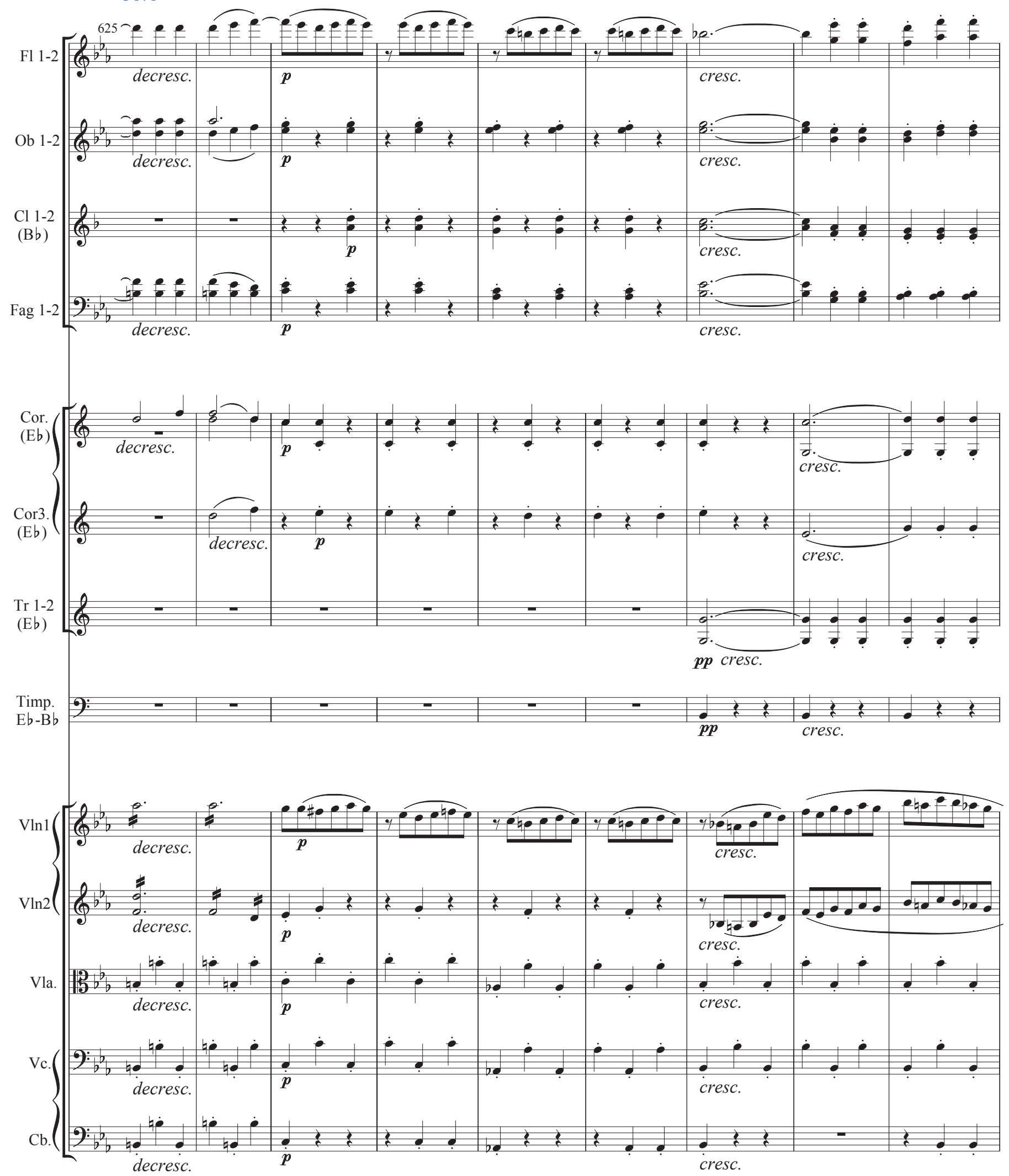

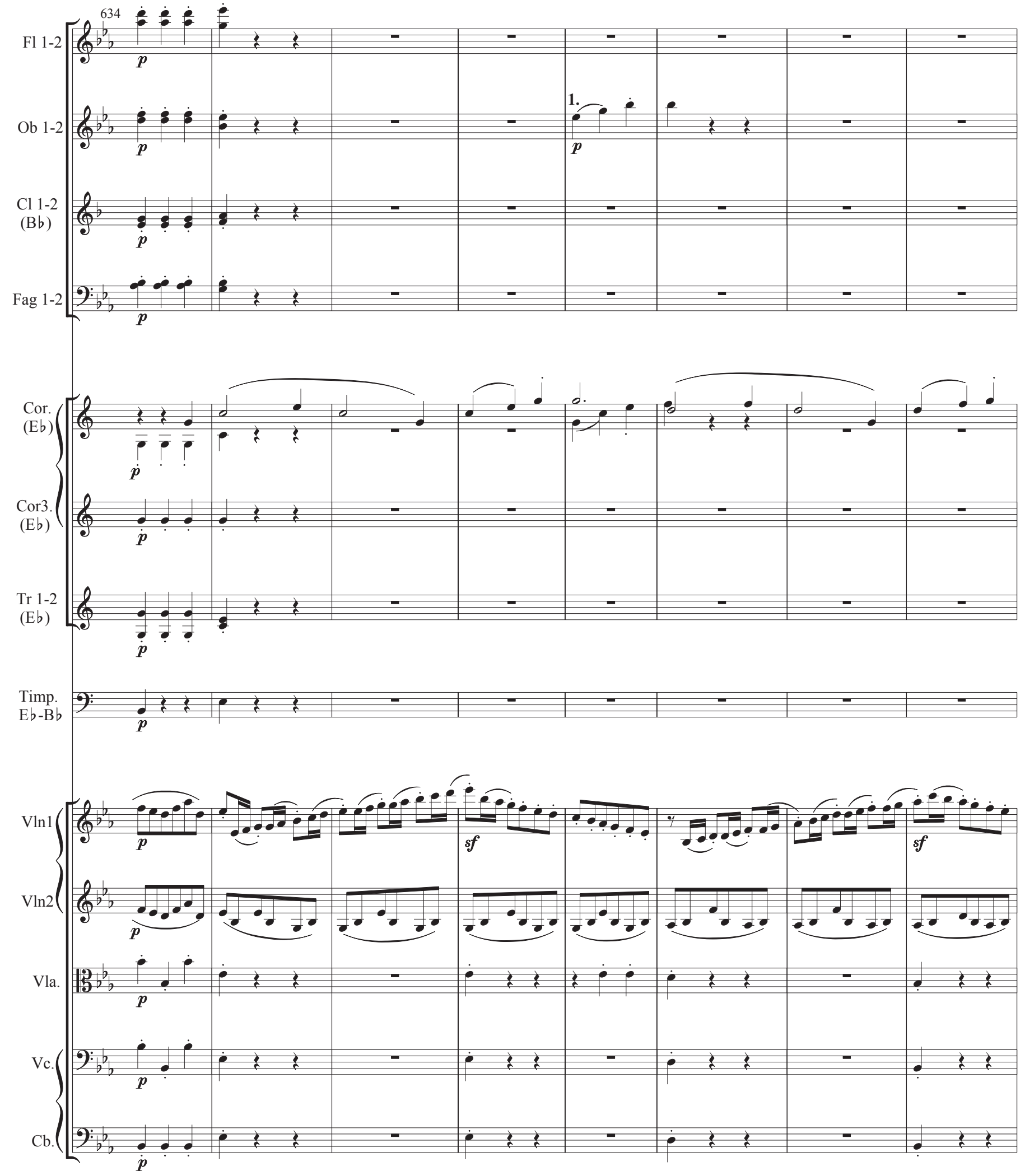
P175

Intérpretes de la orquesta, personajes y Beethoven hasta el final

zu 2
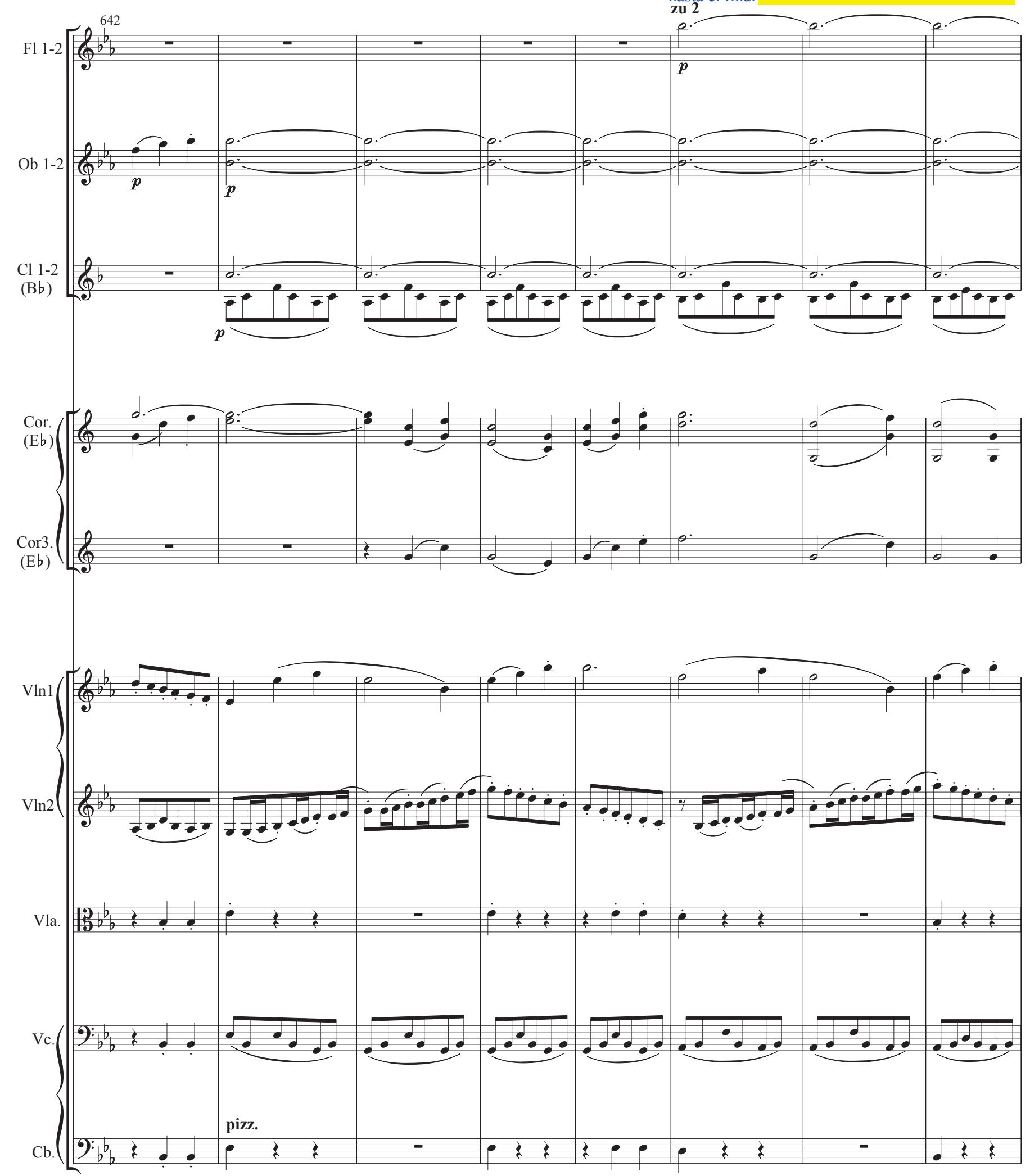

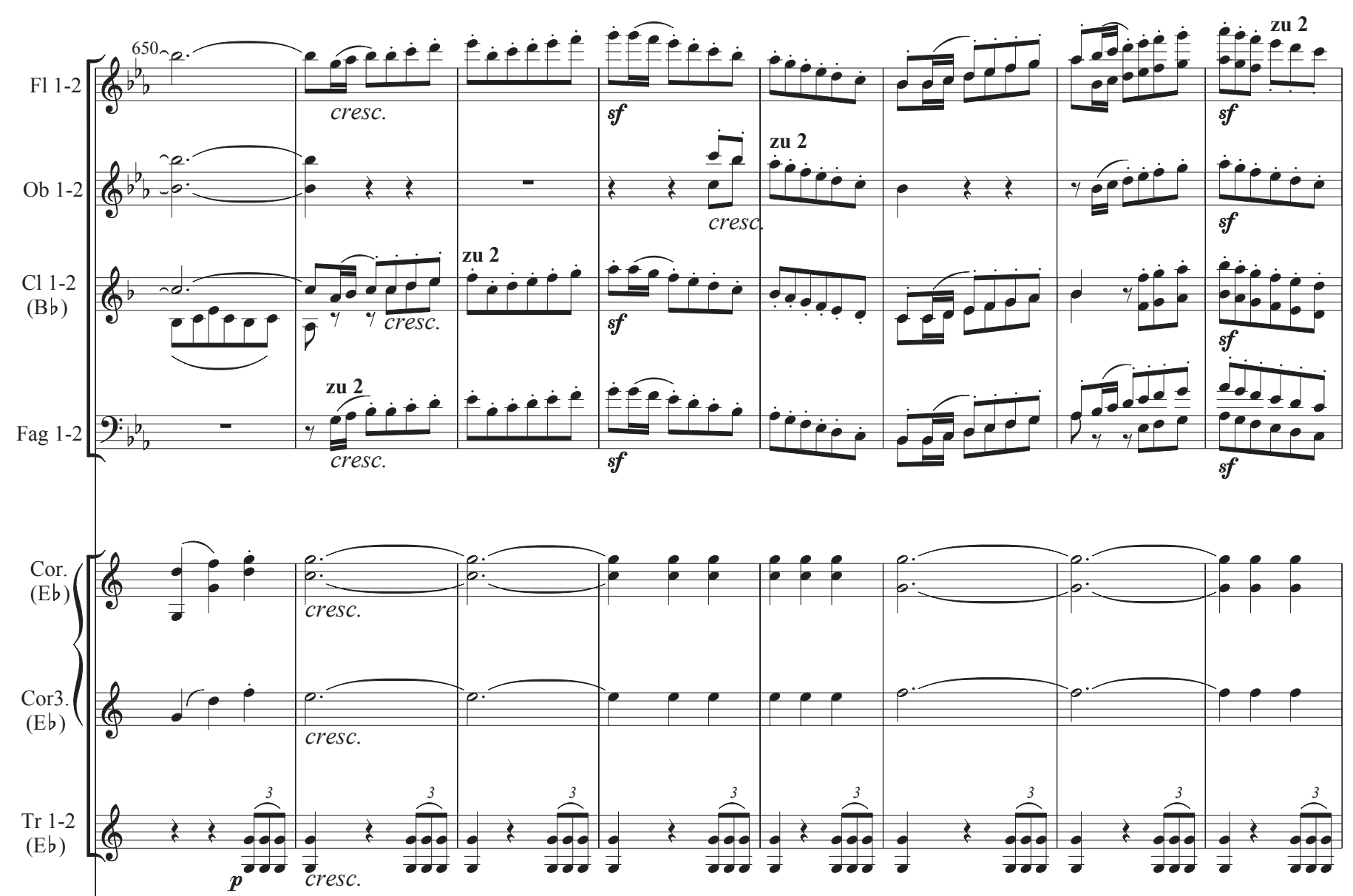

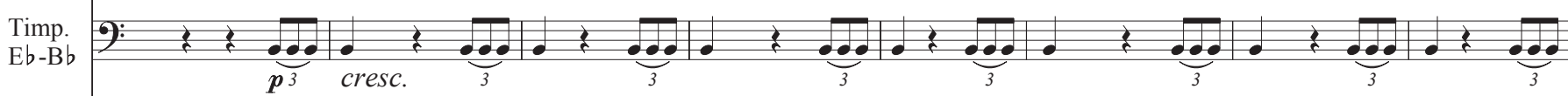

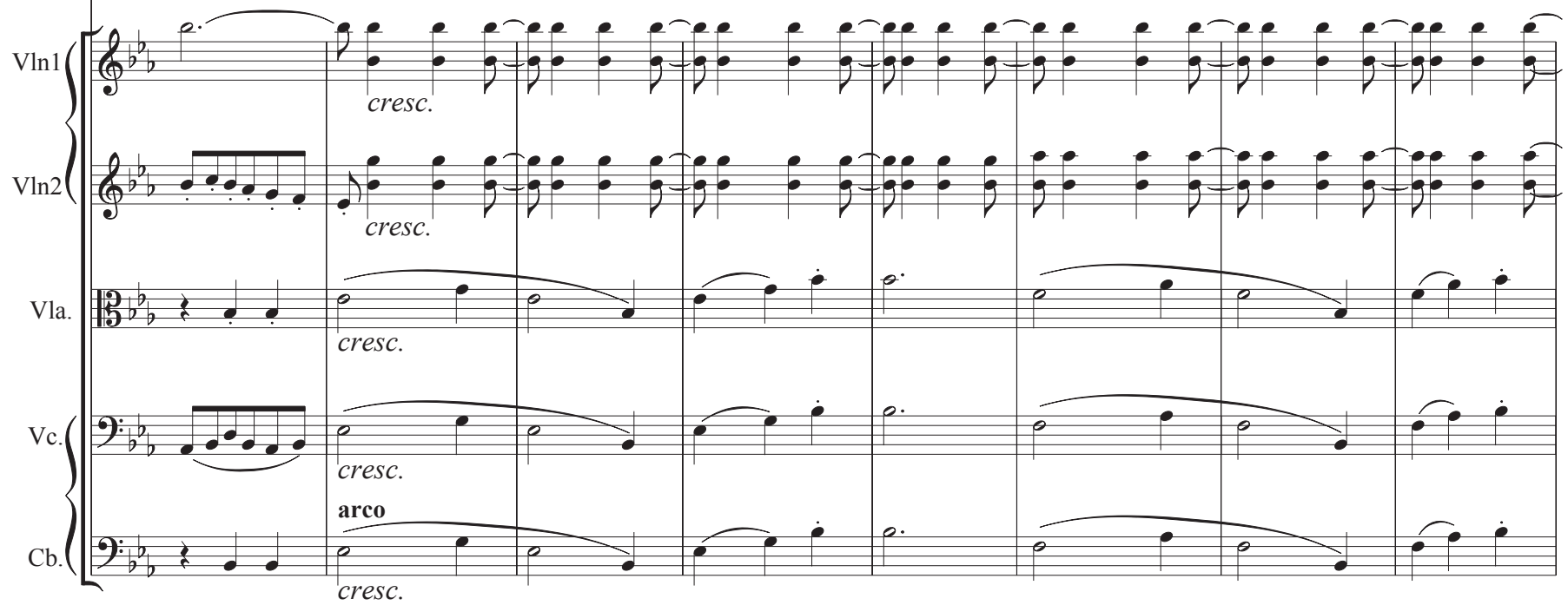



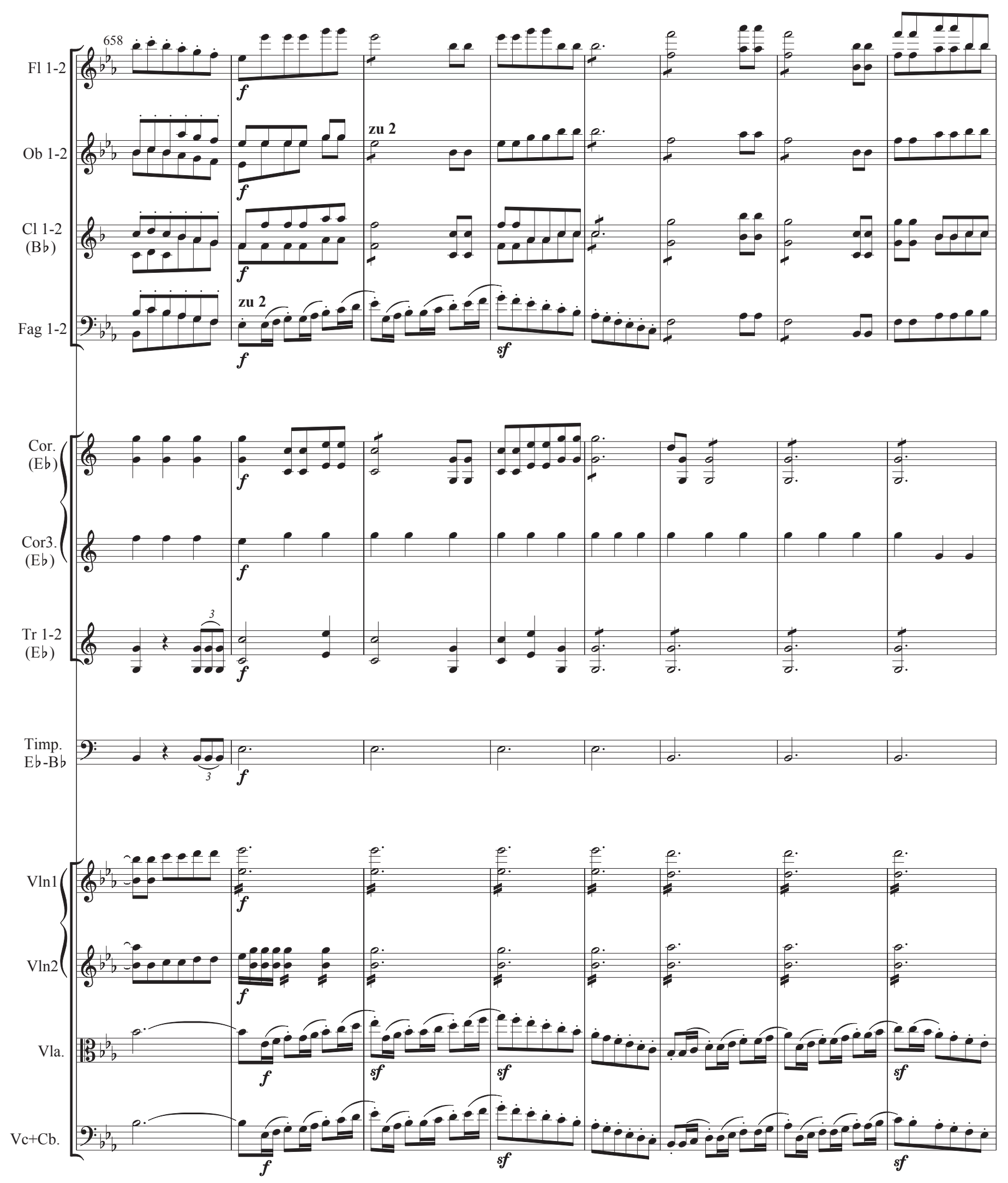

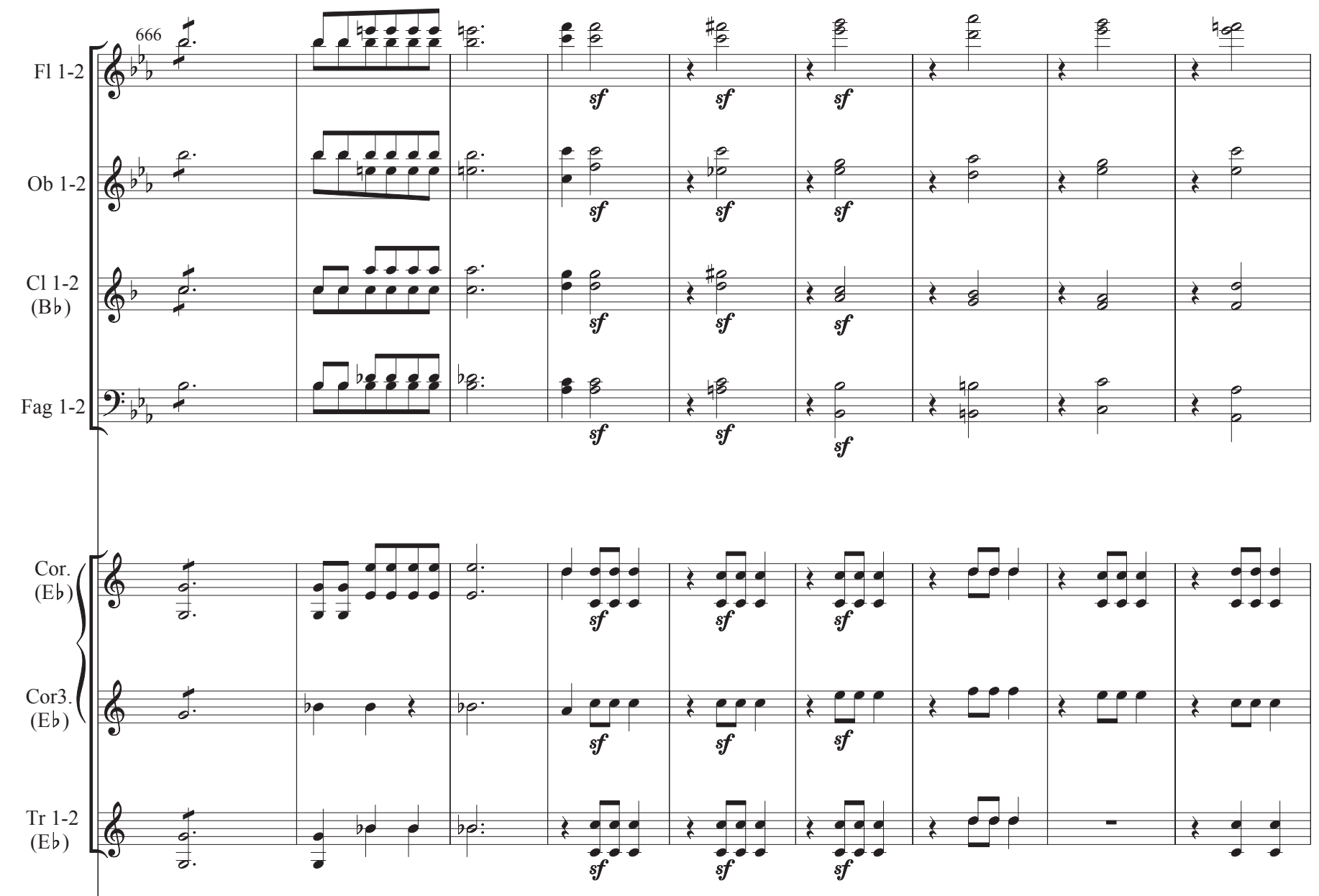

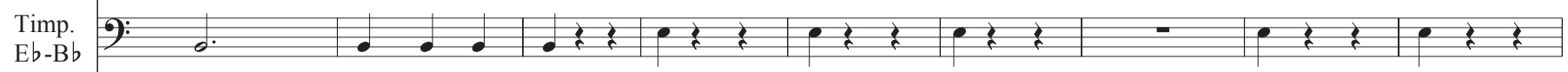

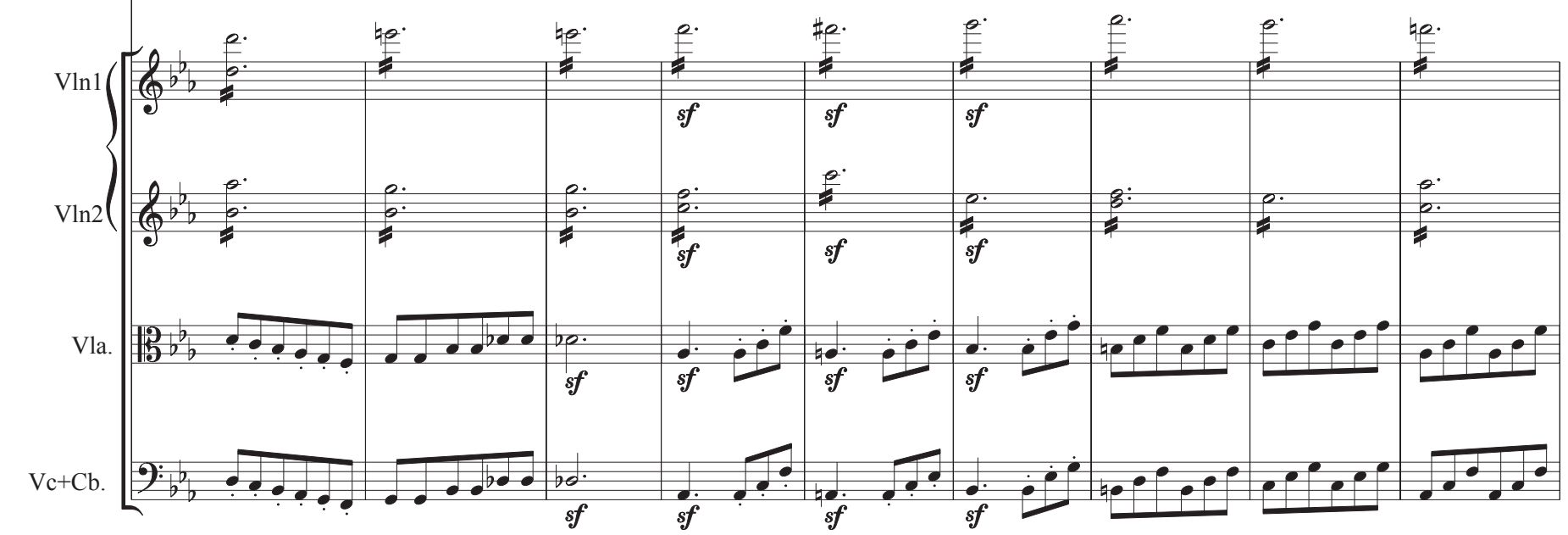



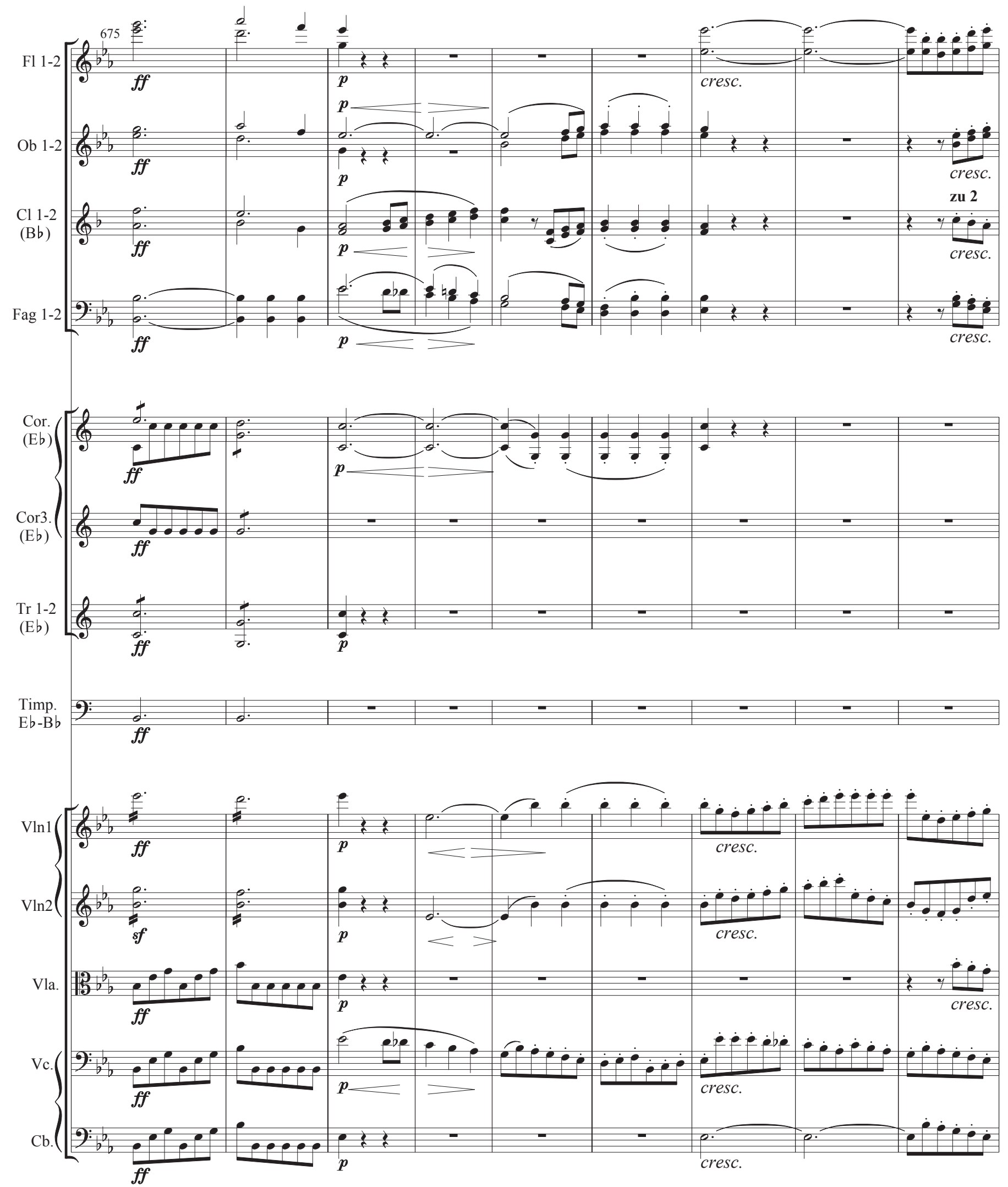

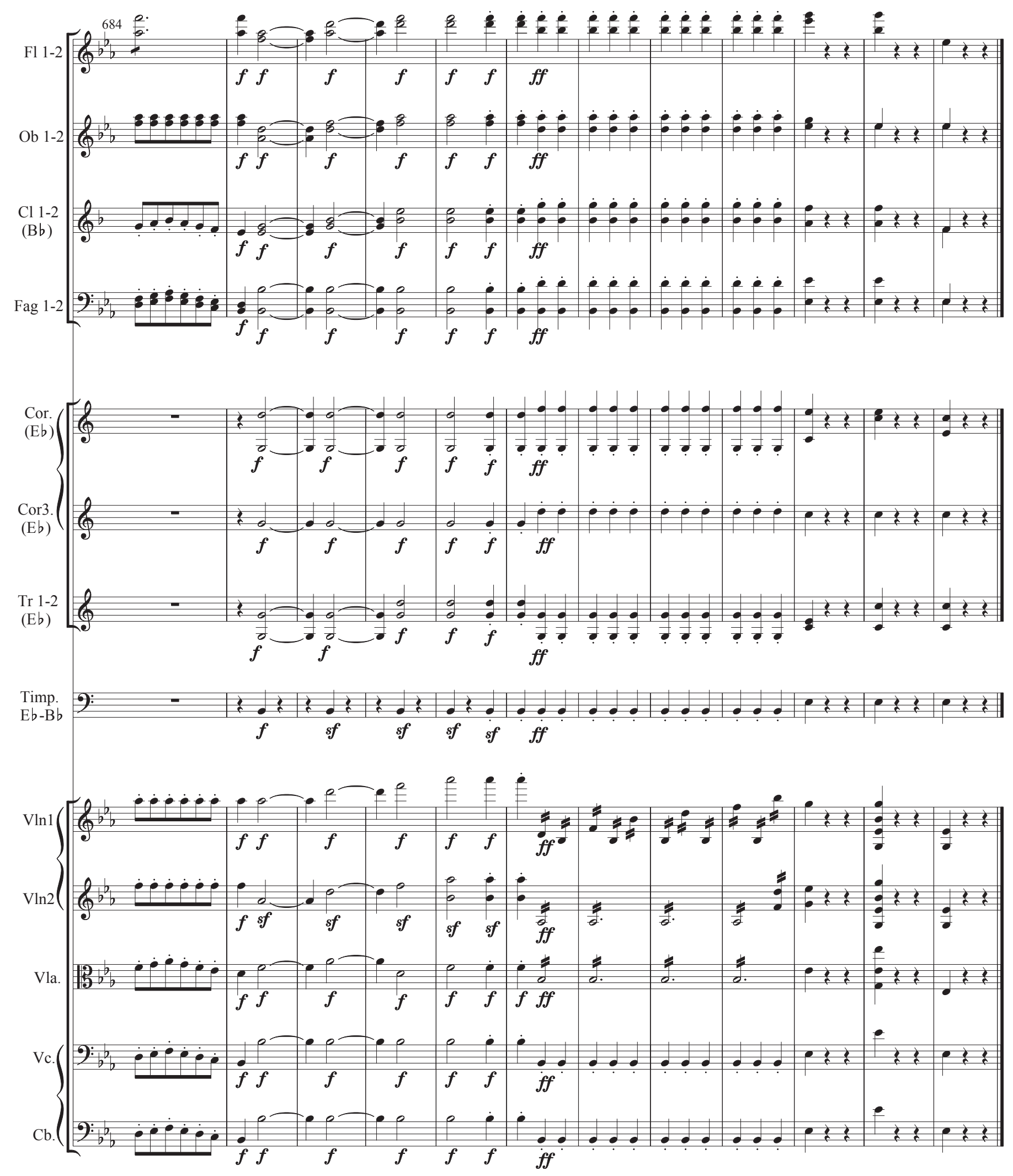
II.

P1 Concertino

$\mathrm{P} 2$

Marcia funebre.

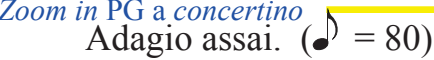

Flauti 1, 2
Oboi 1, 2
$\begin{aligned} & \text { Clarinetti 1, } 2 \\ & \text { in Bb }\end{aligned}$

Fagotti 1, 2

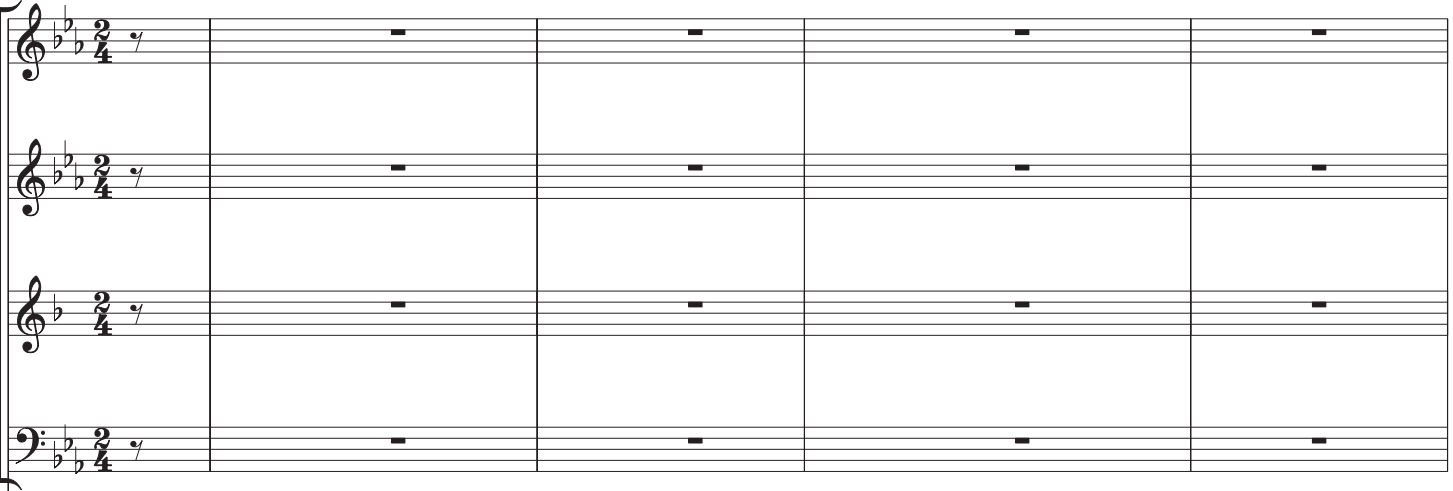

Corni 1, 2 in $C$

Corno 3 in $E$ b

Trombe 1, 2 in $C$

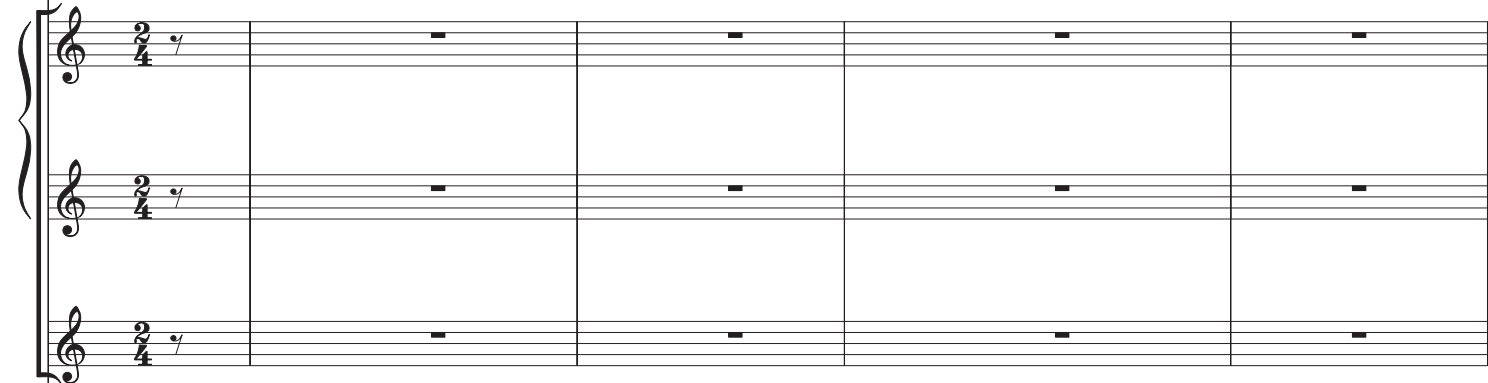

Timpani

in $C, G$

\section{$9 \div \quad 2$}

Violino I

Violino II

Viola

Violoncello

Contrabasso

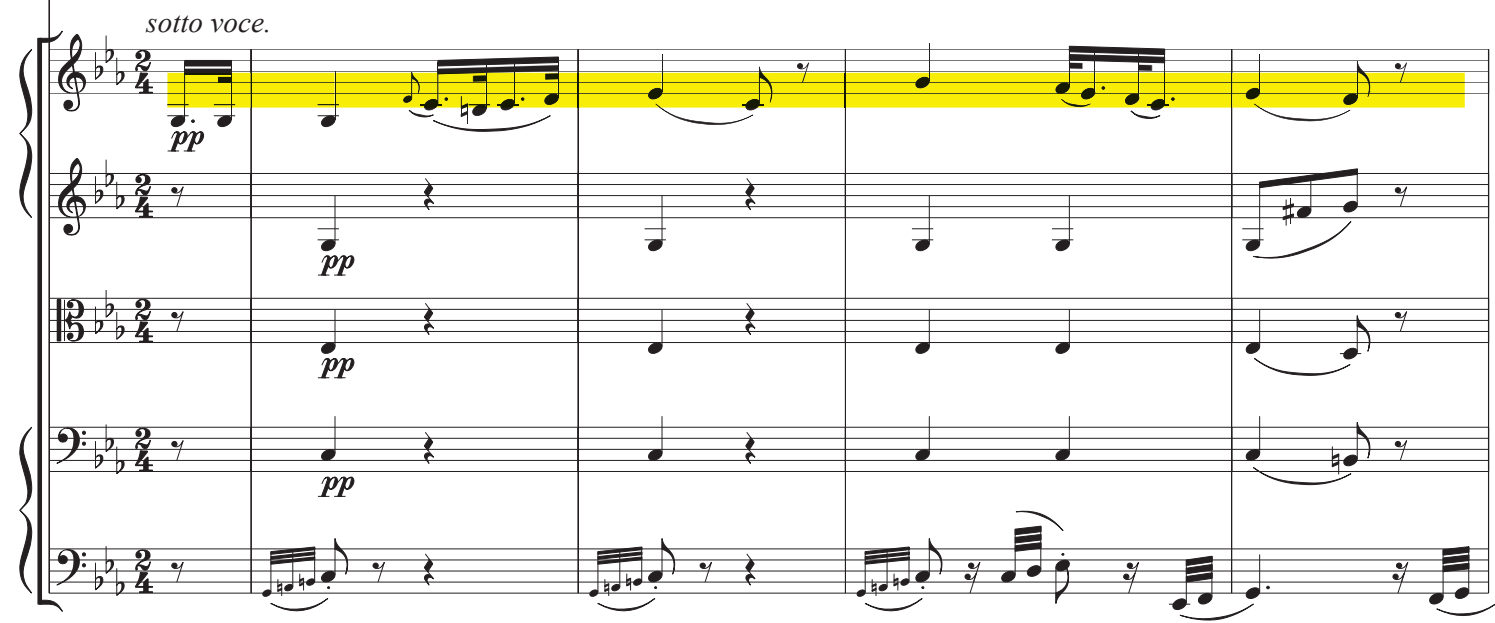




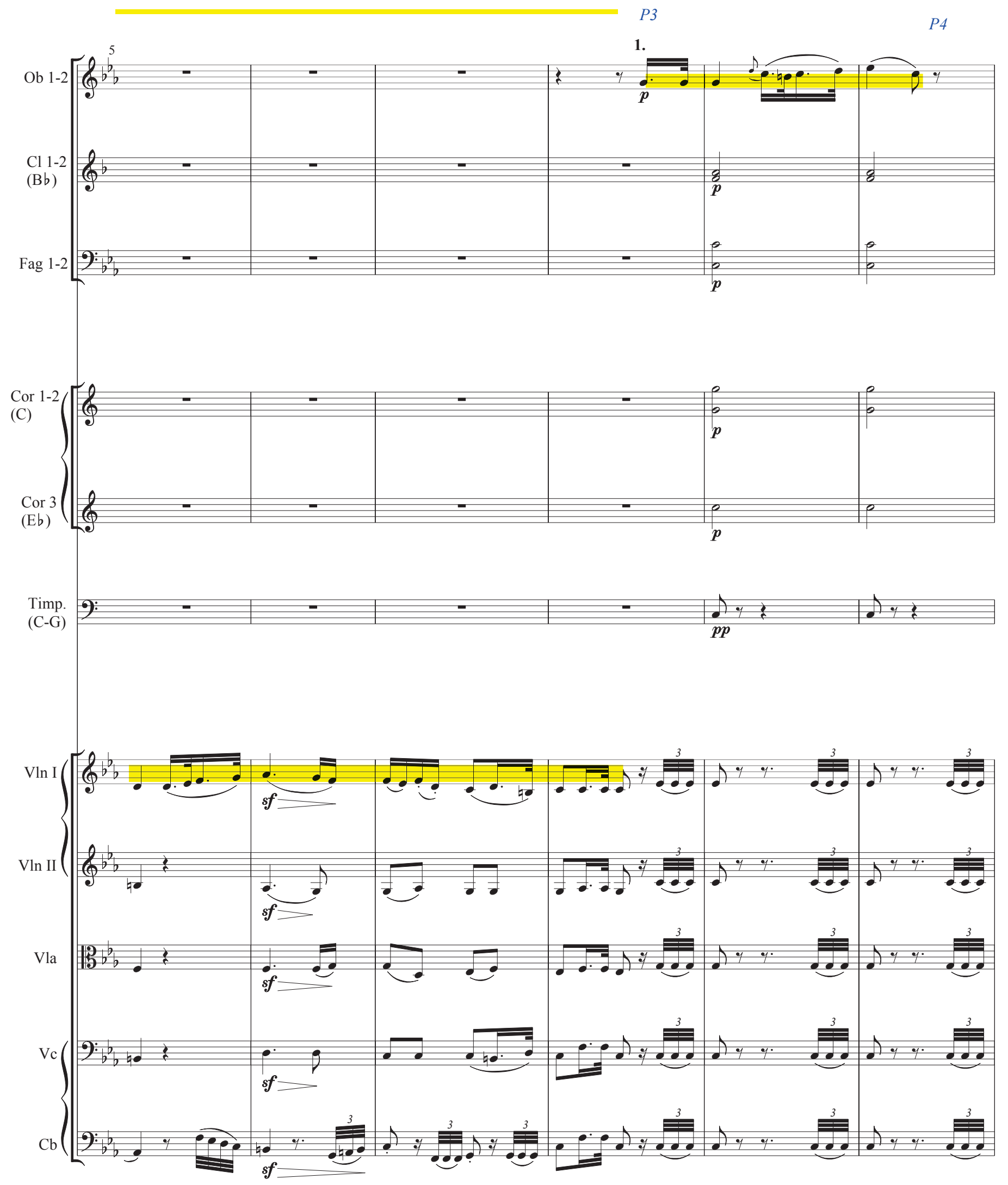



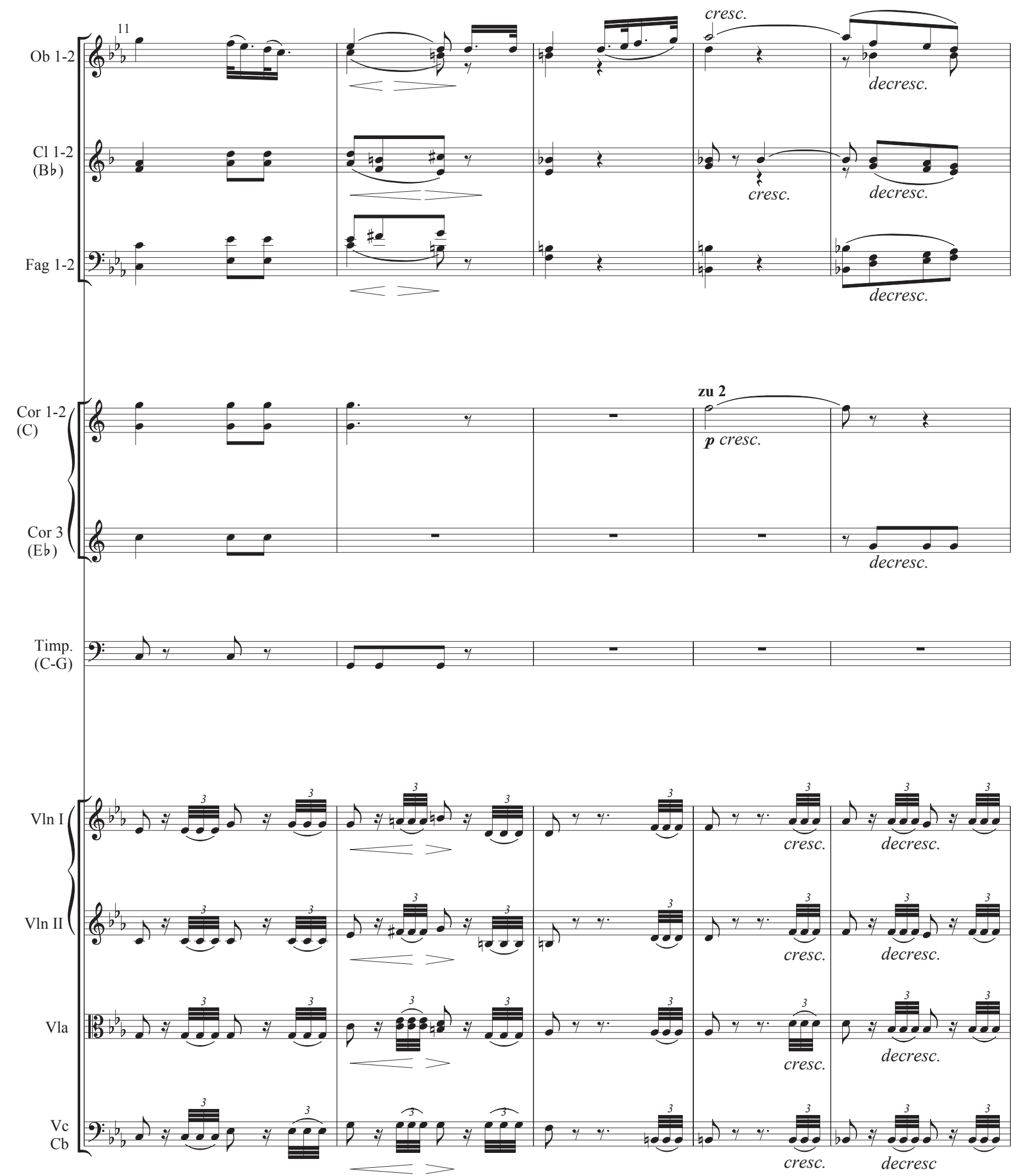


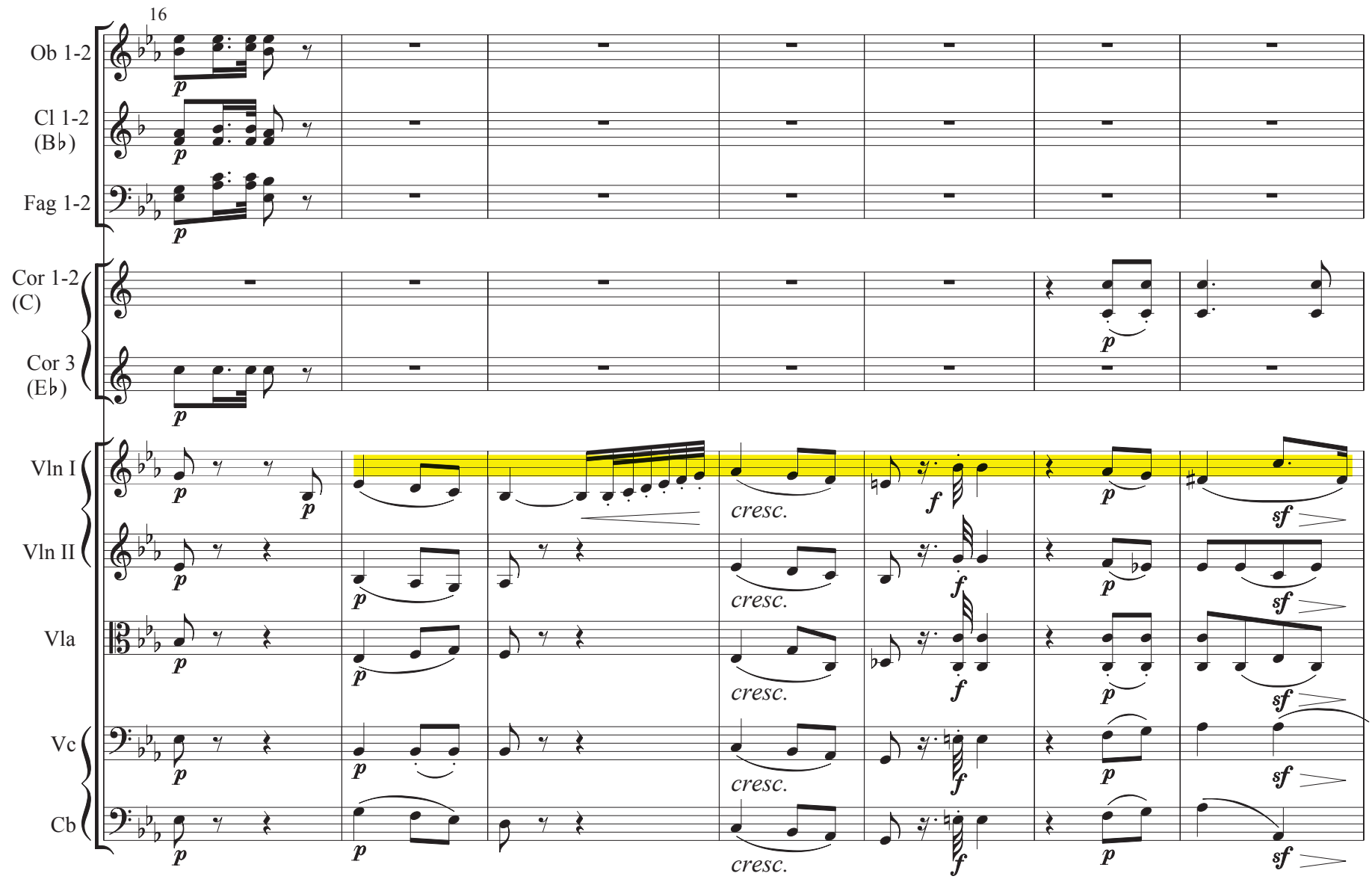

P7

${ }_{23}$ Panorámica

1.

P8 Violoncelos

P9

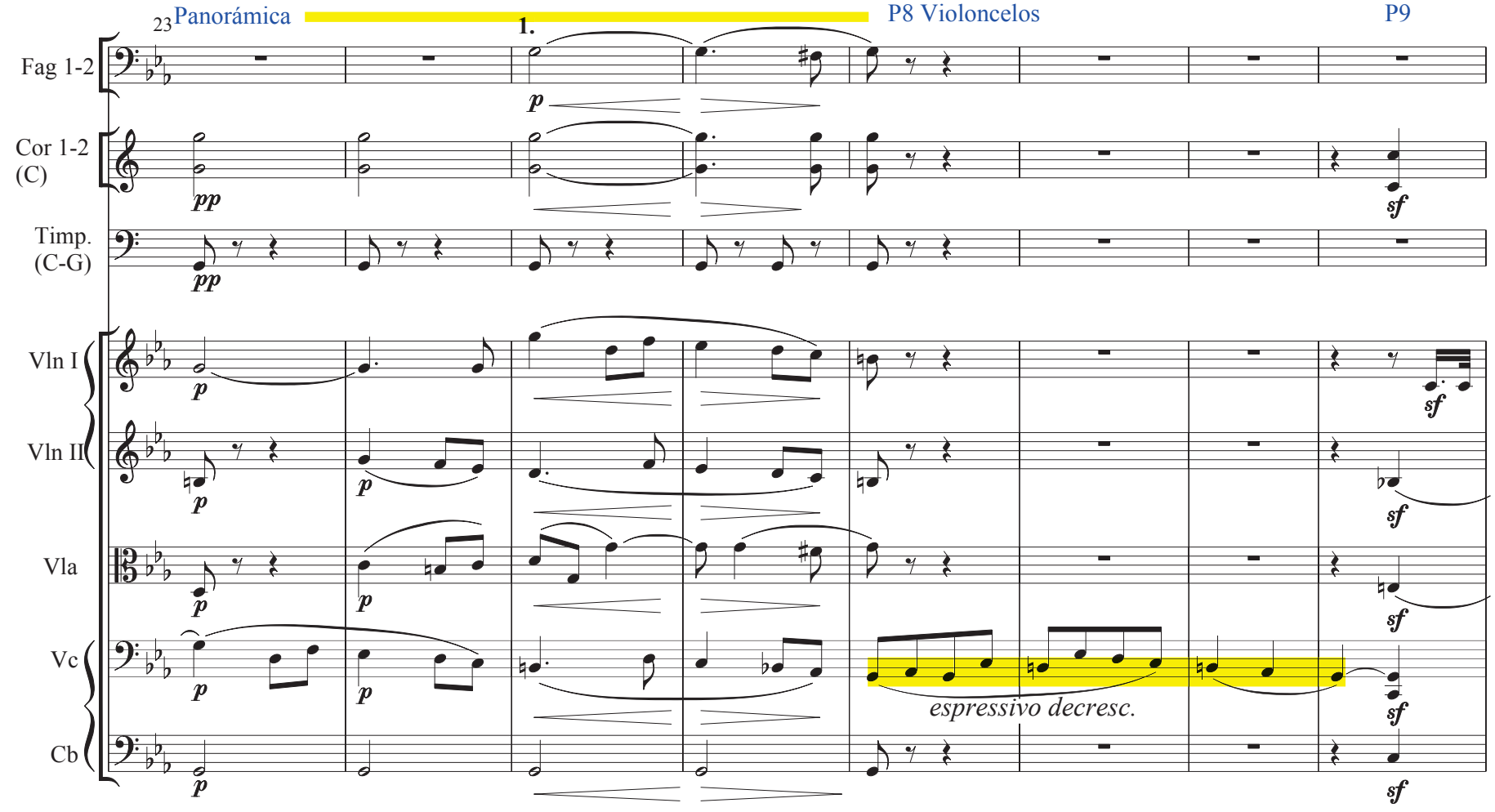



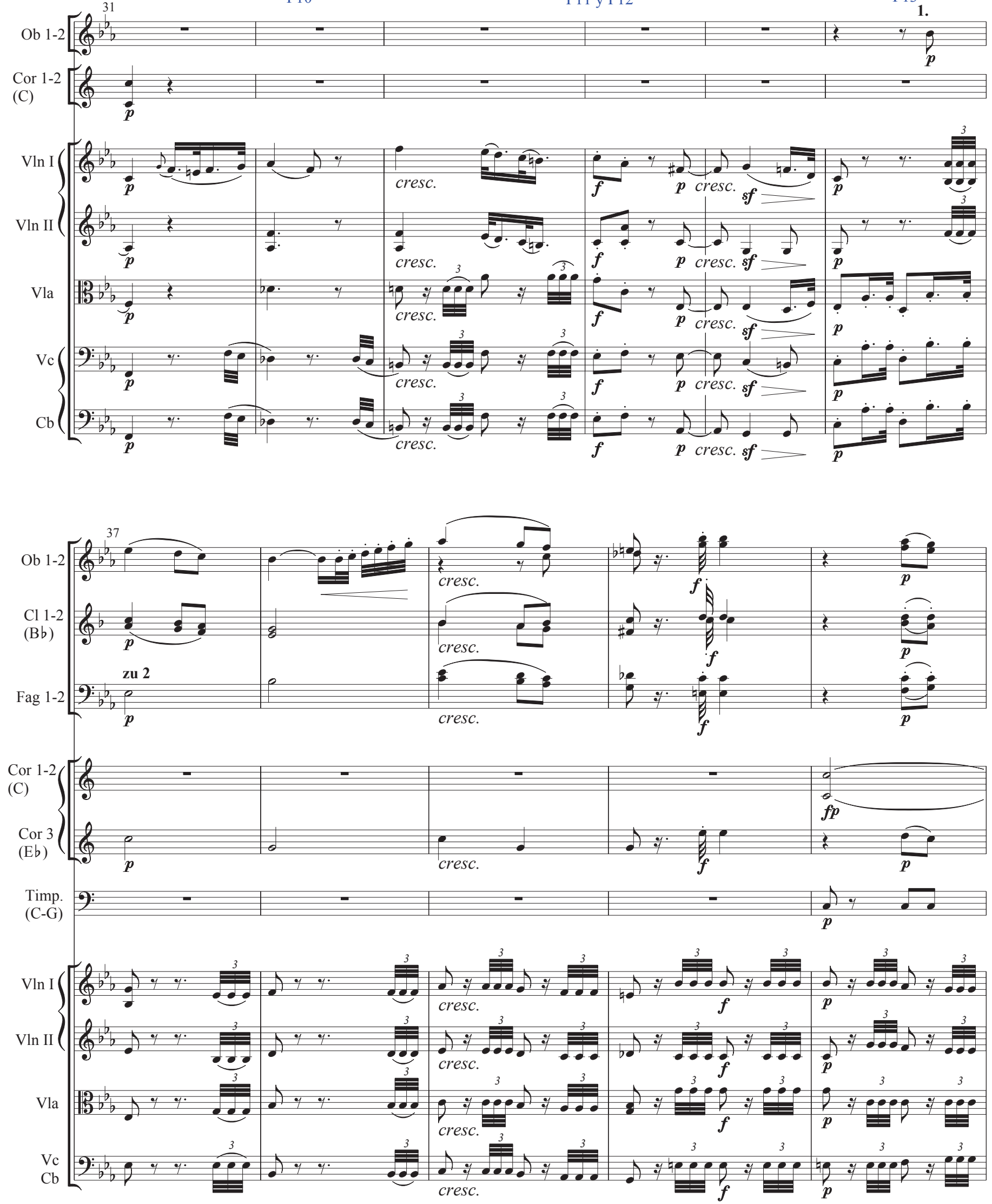


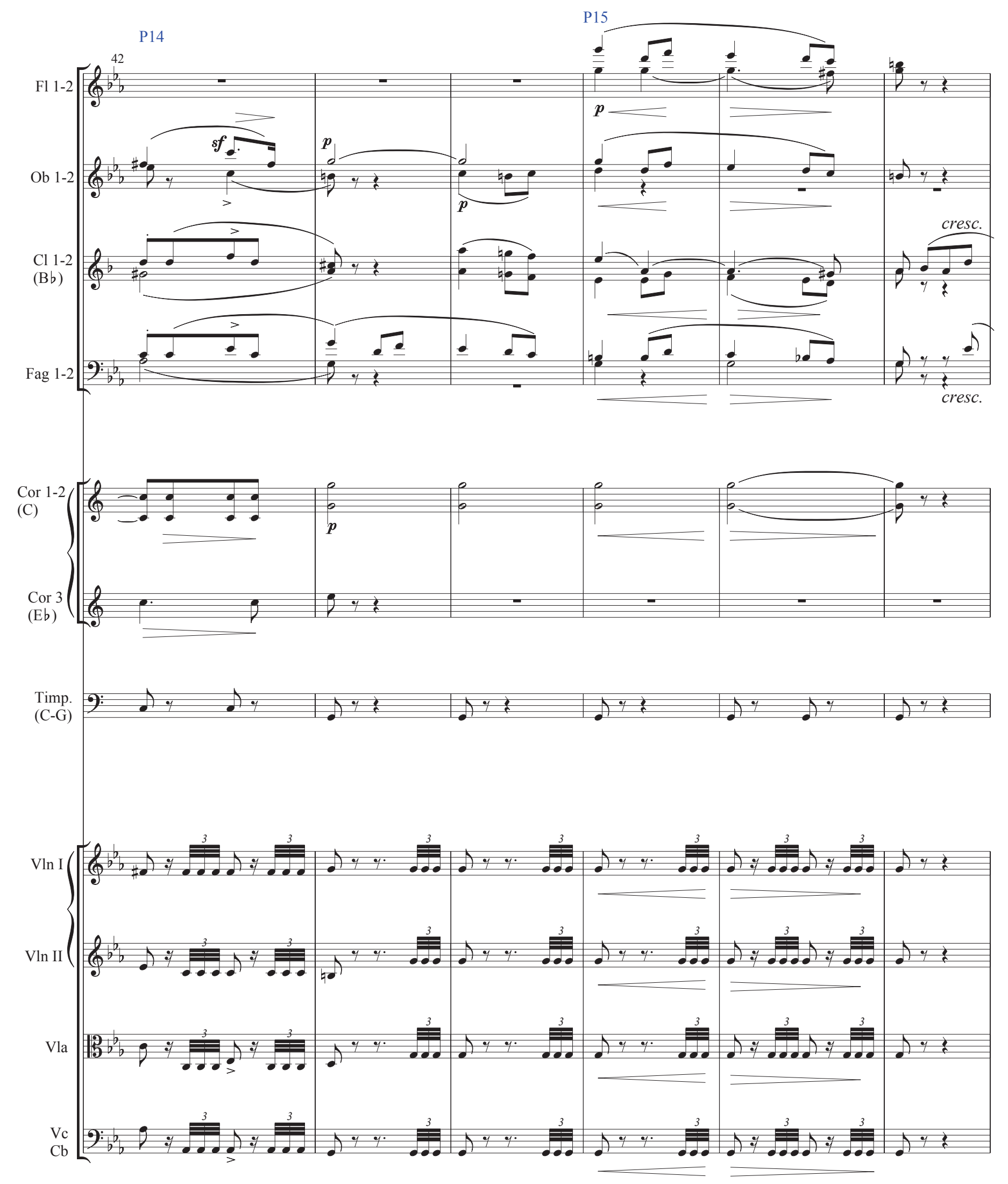



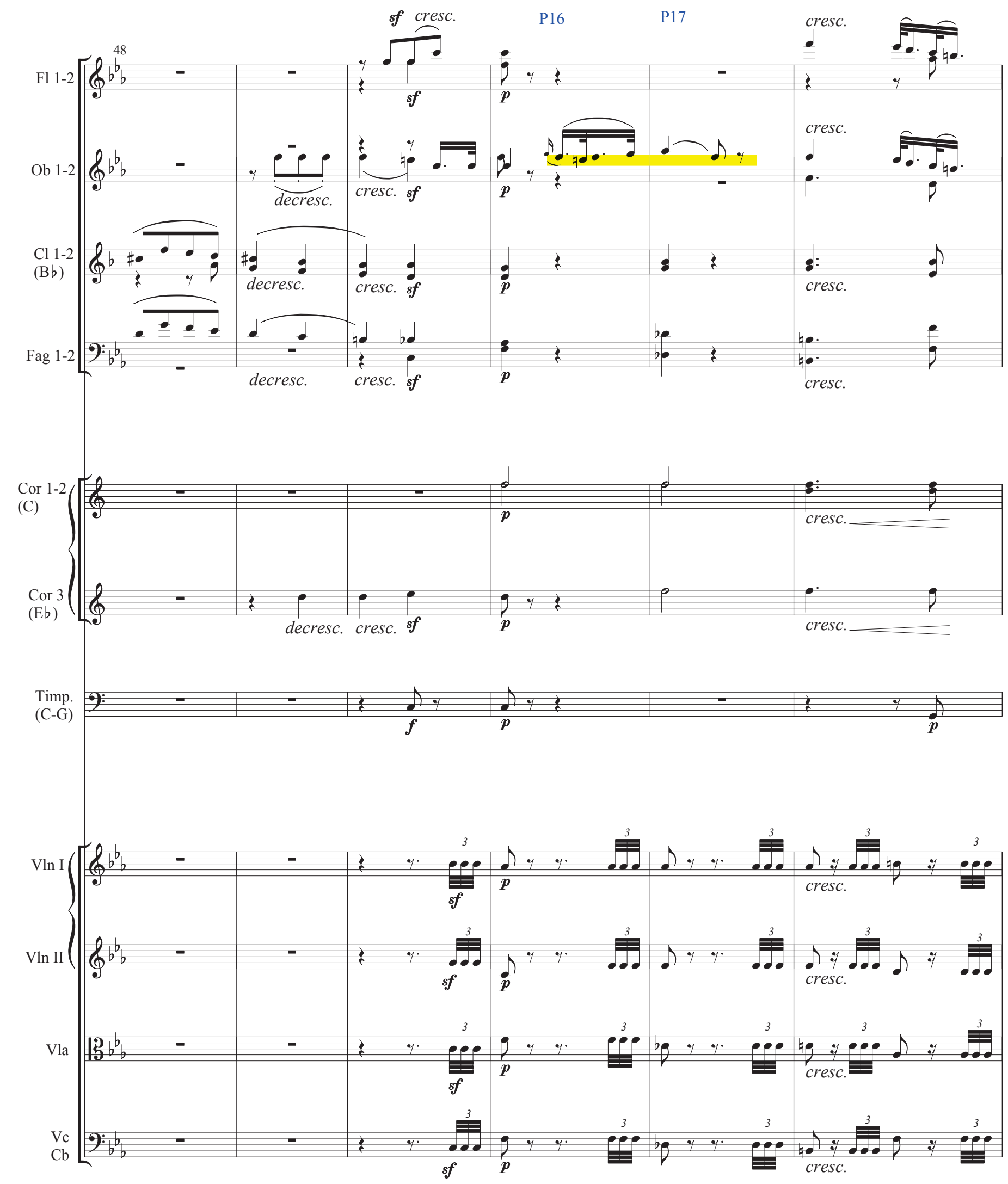


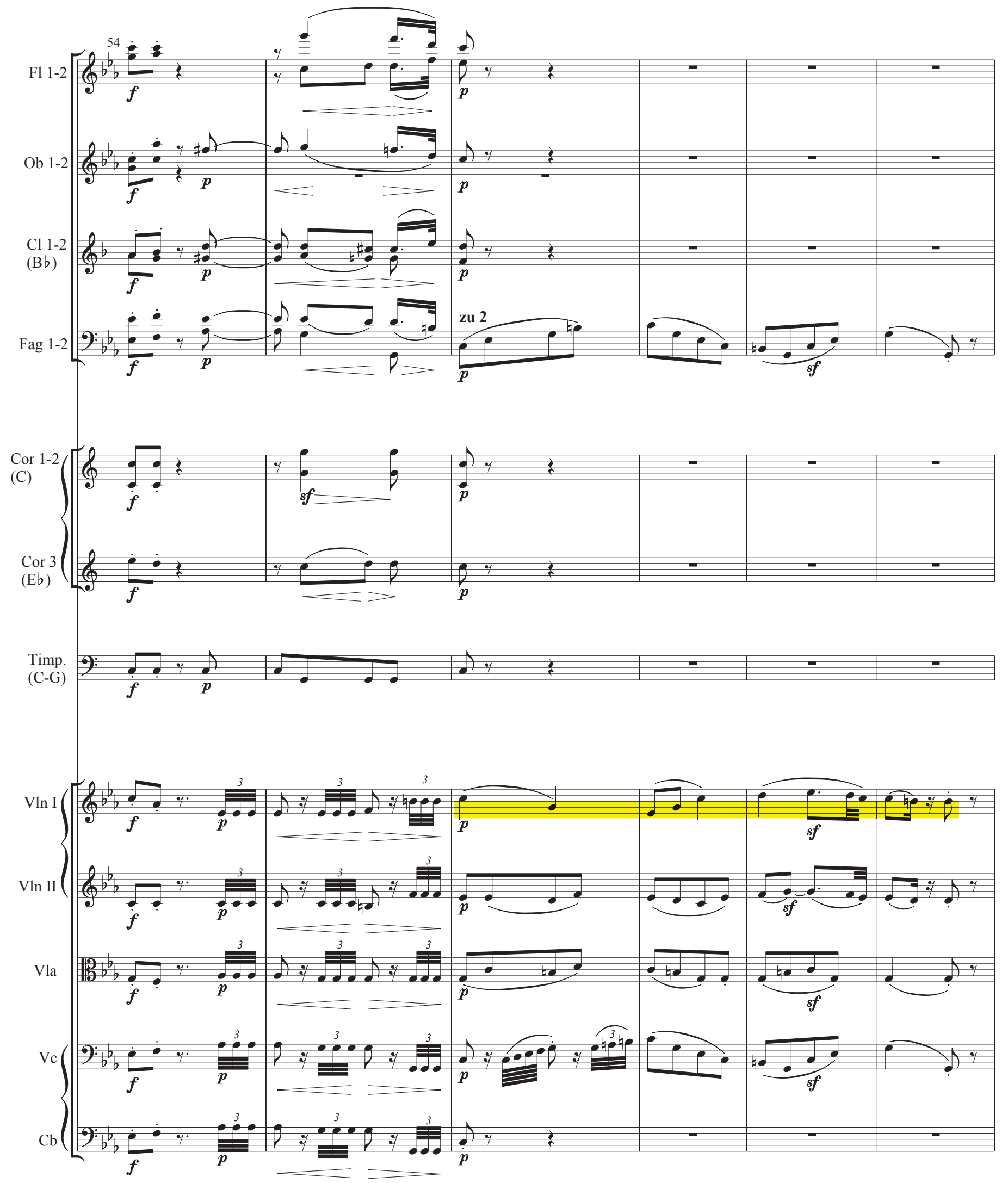




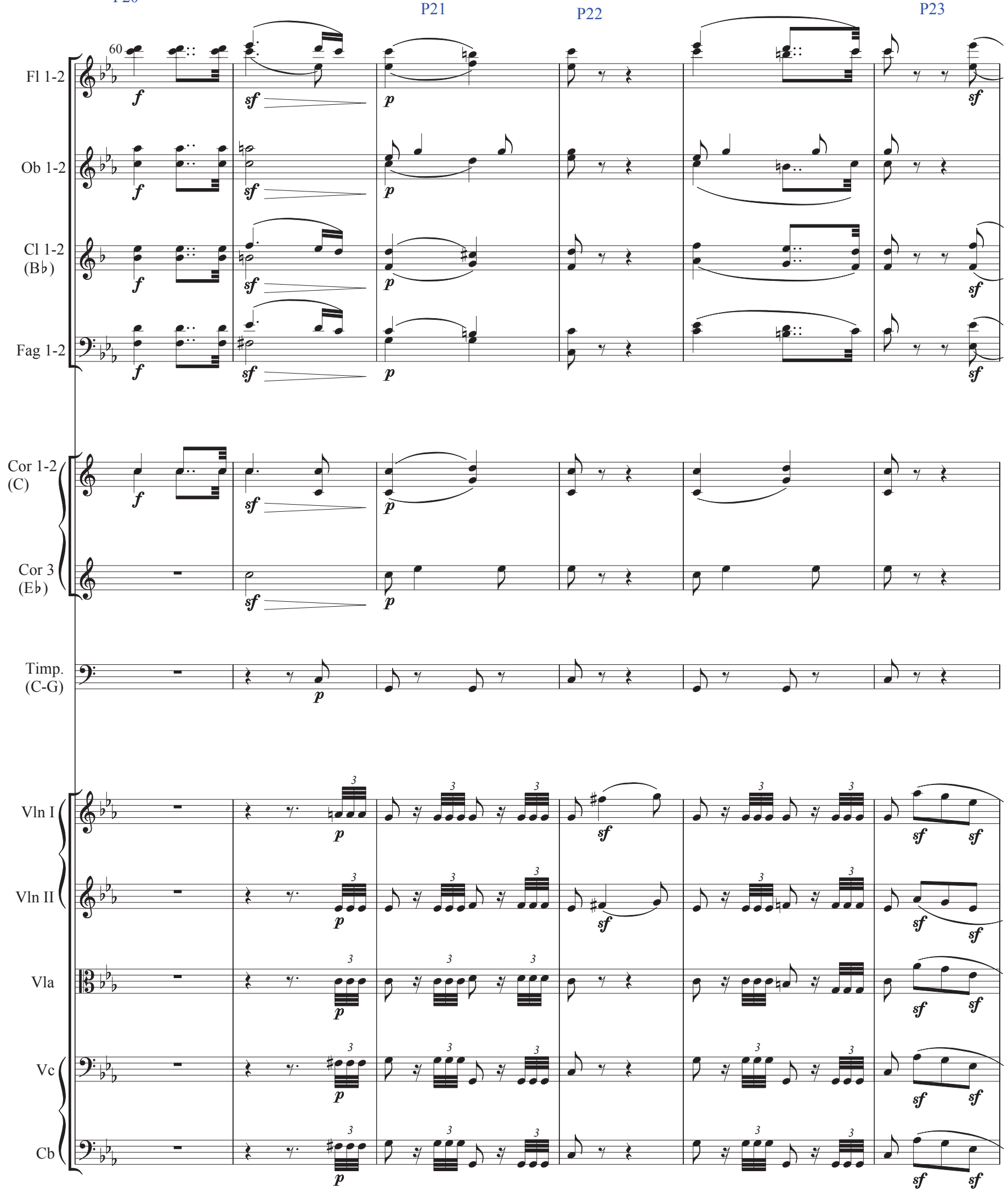




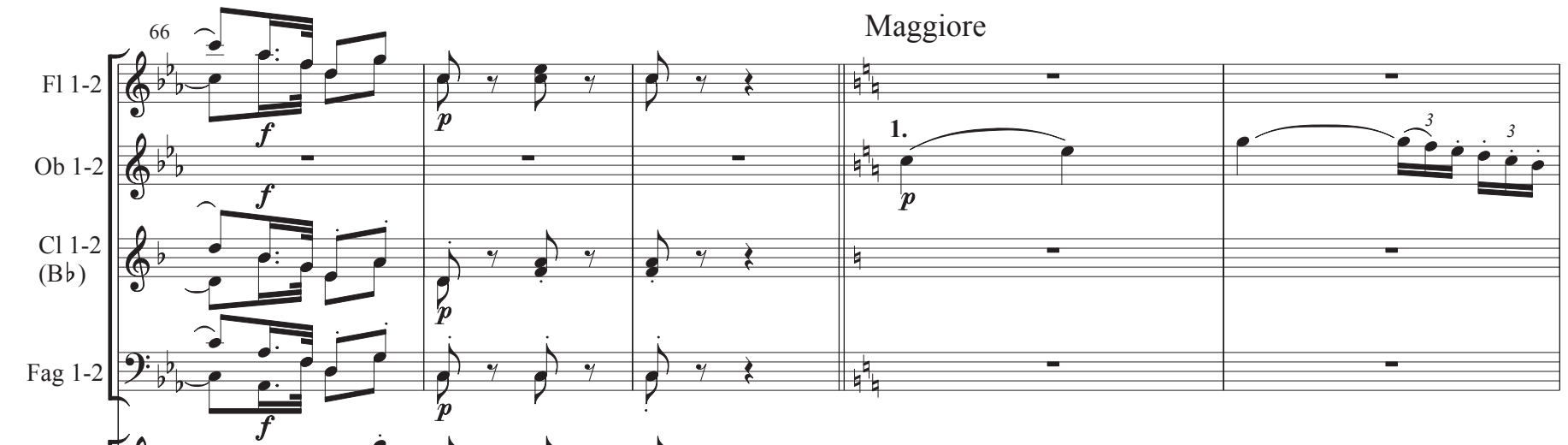

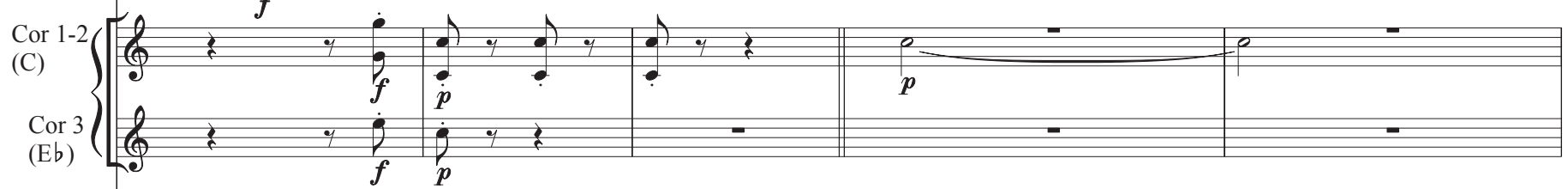

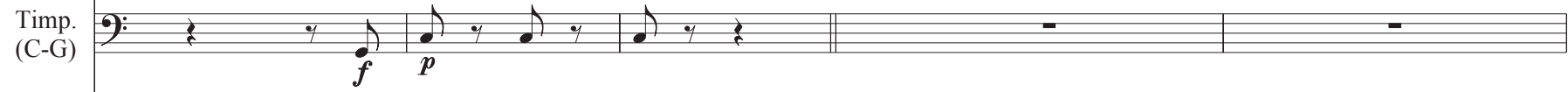

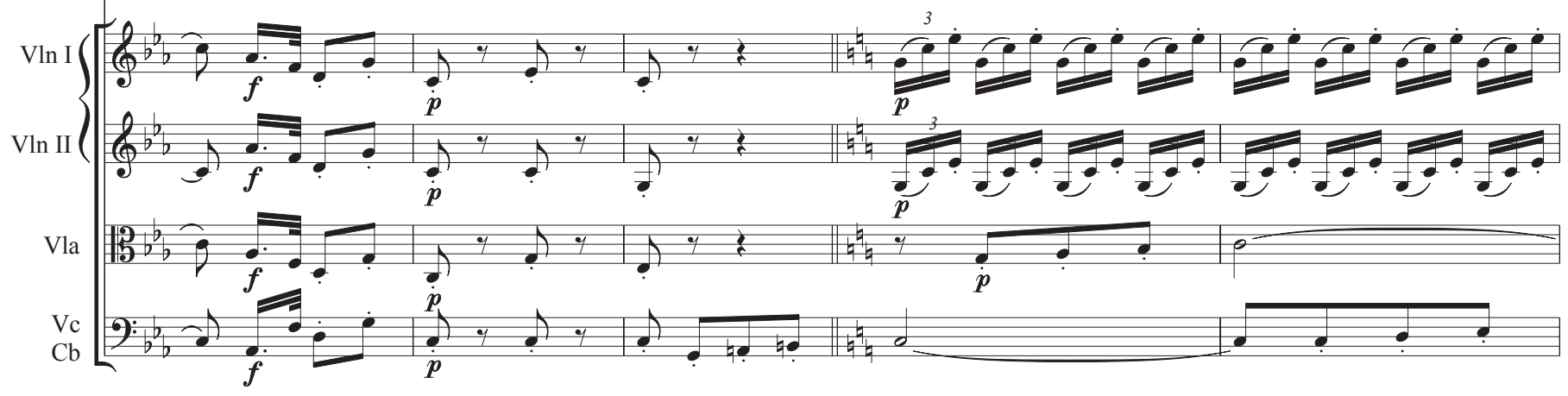

P25
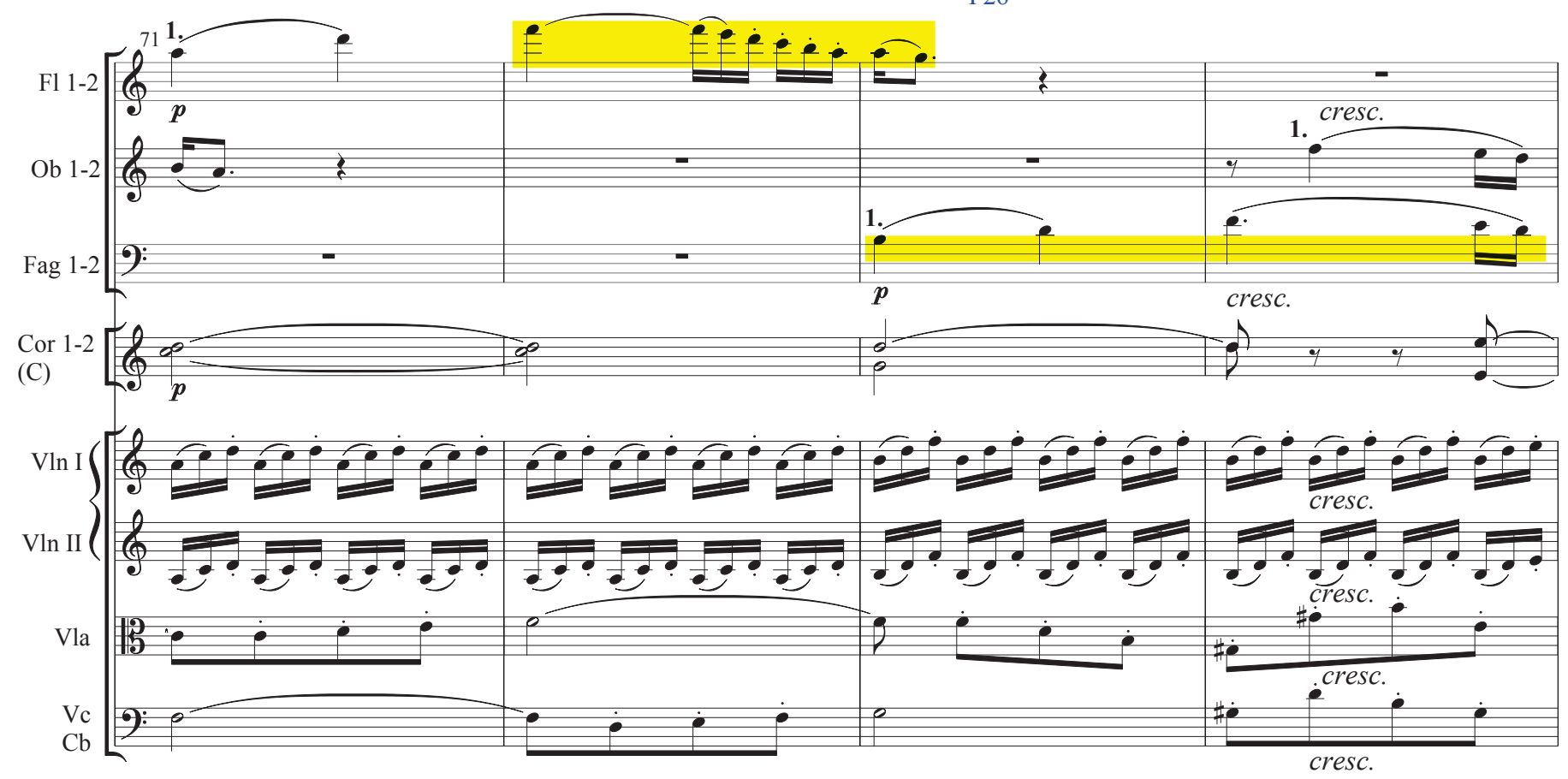


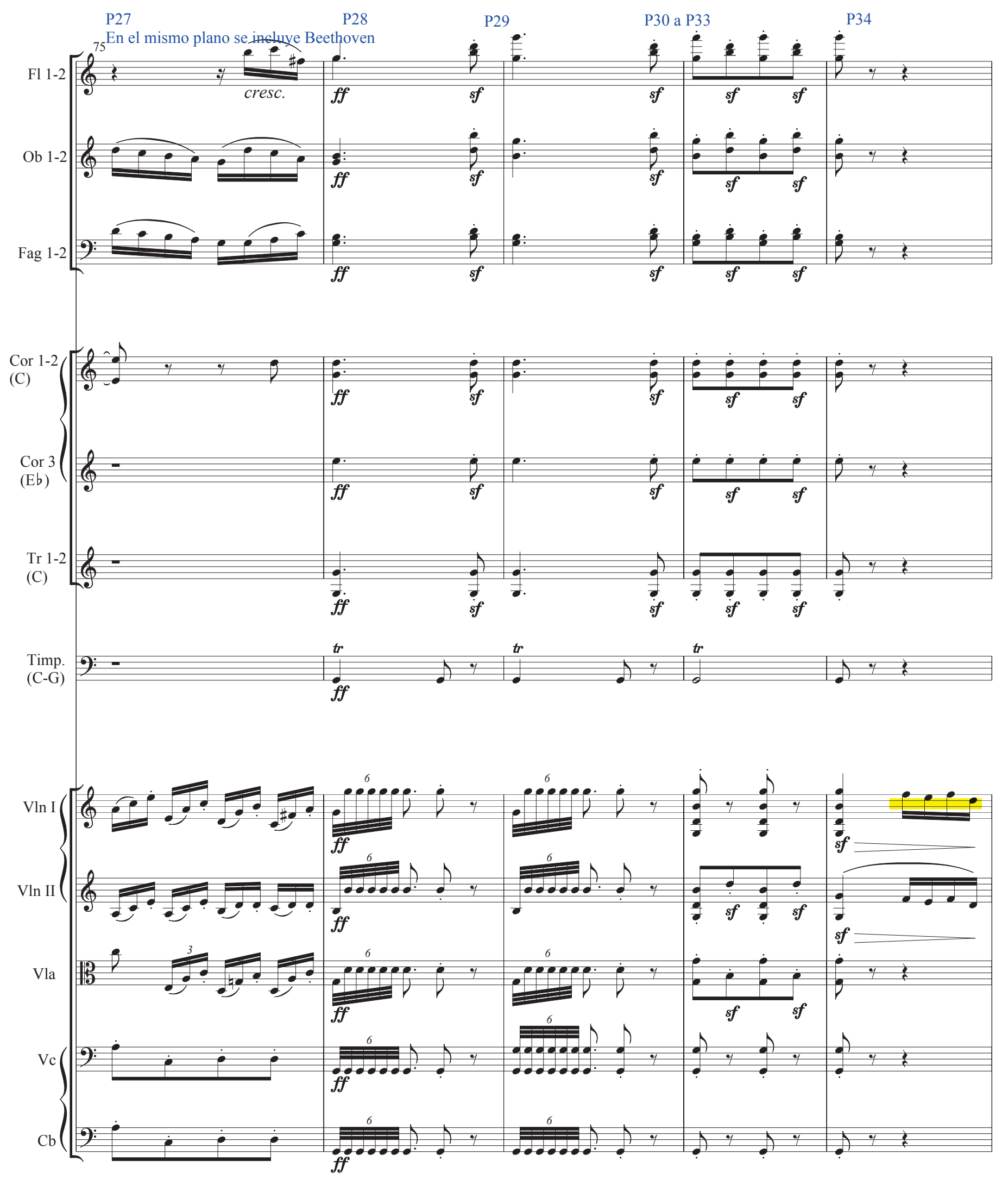



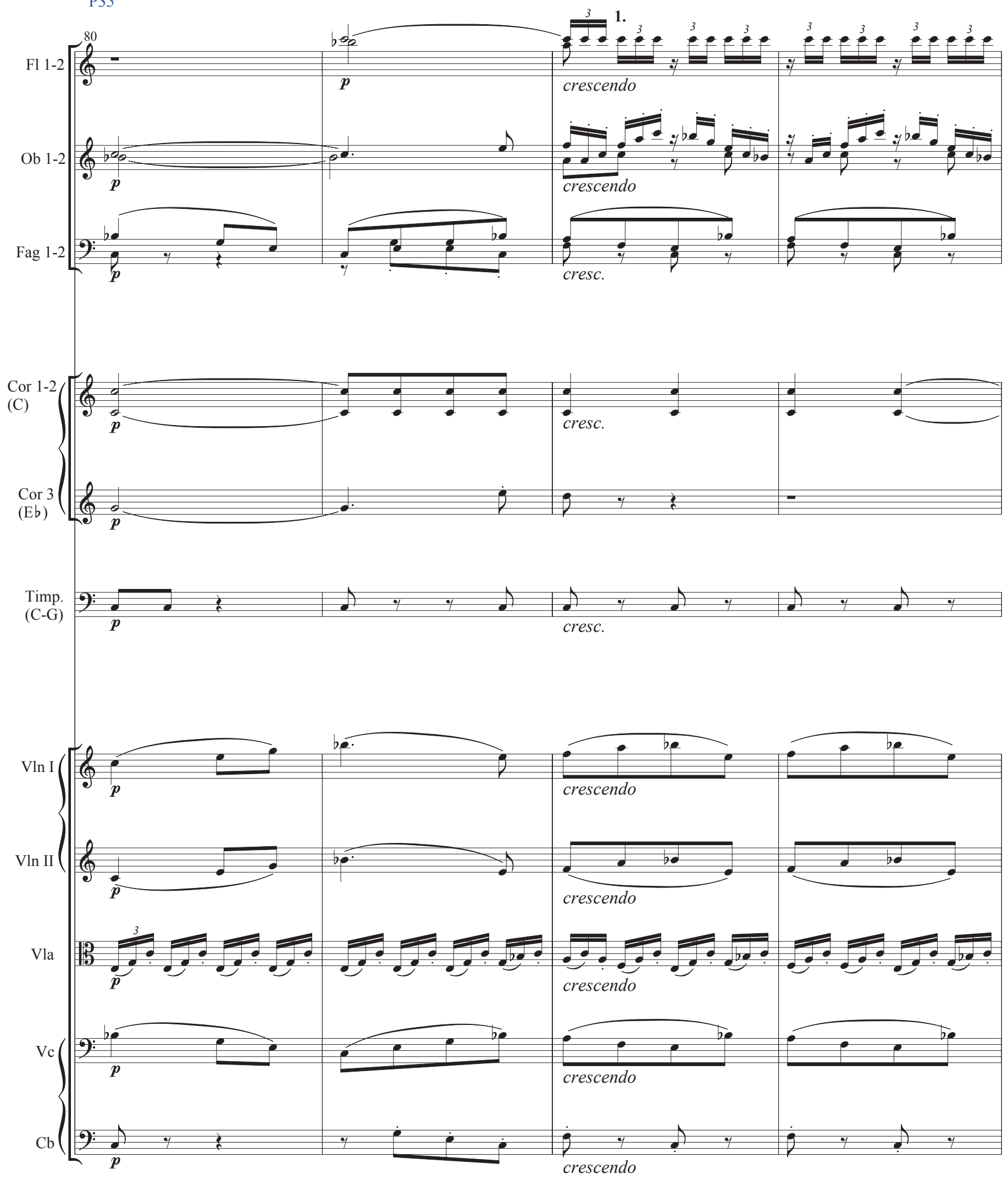

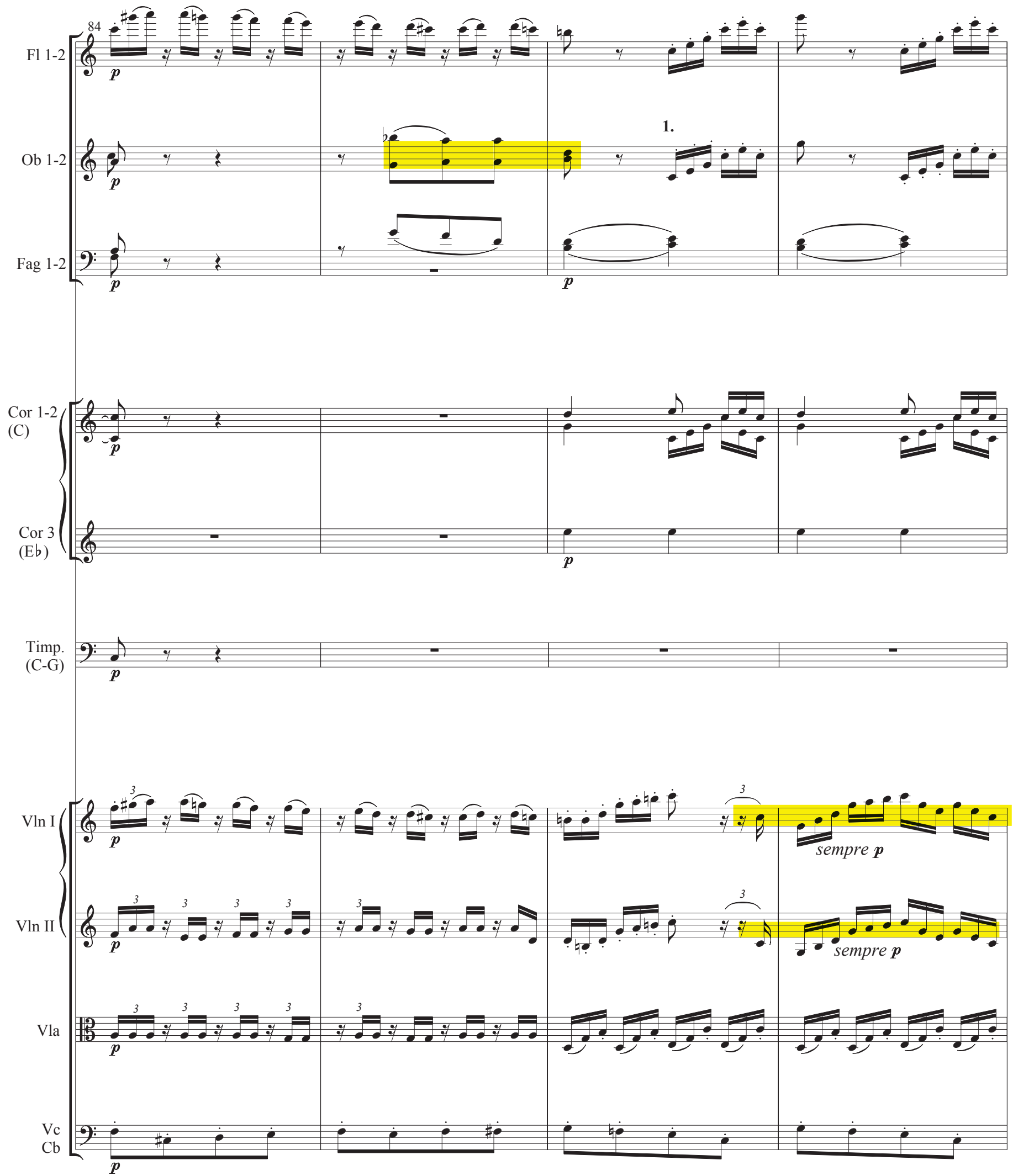

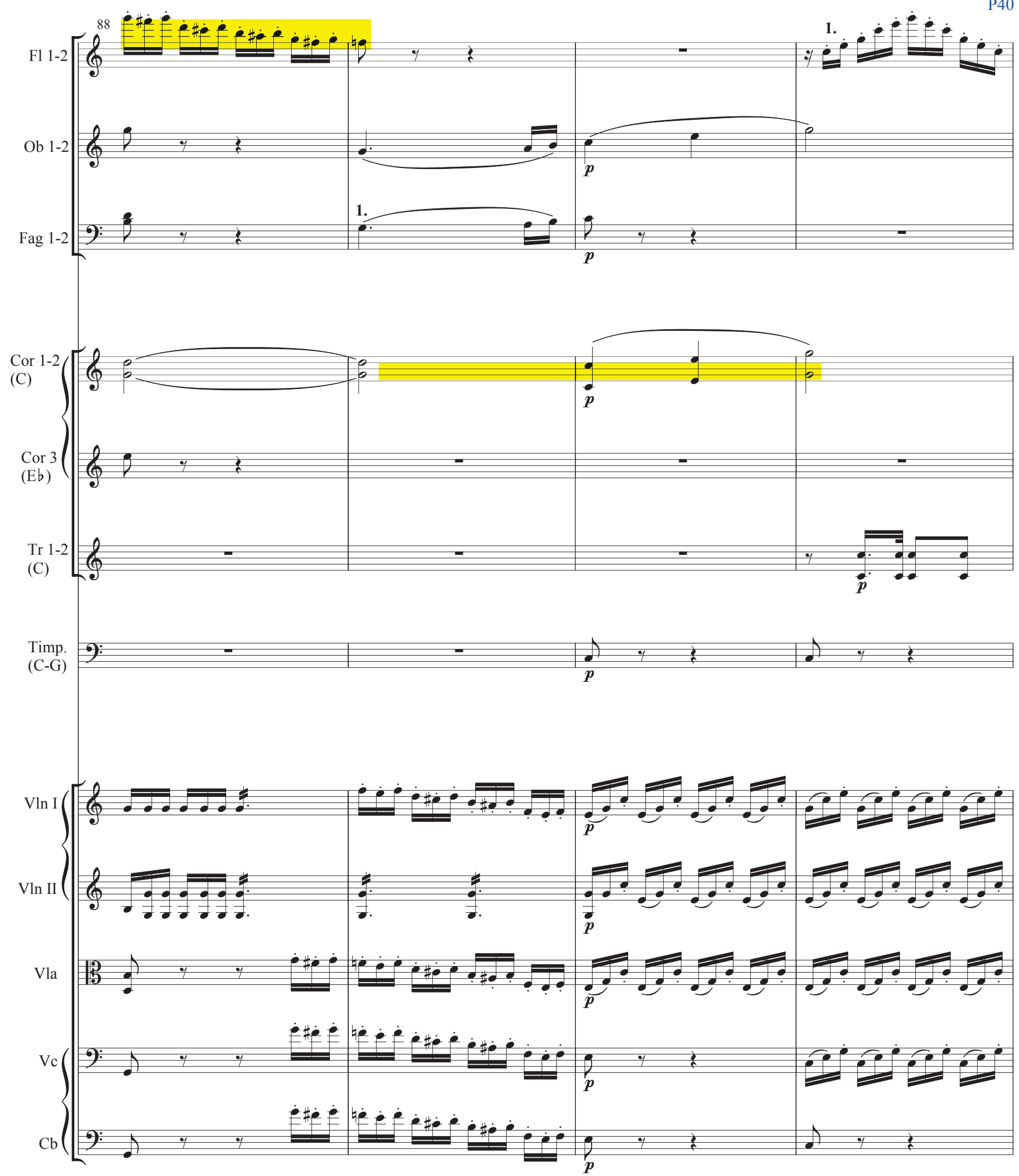

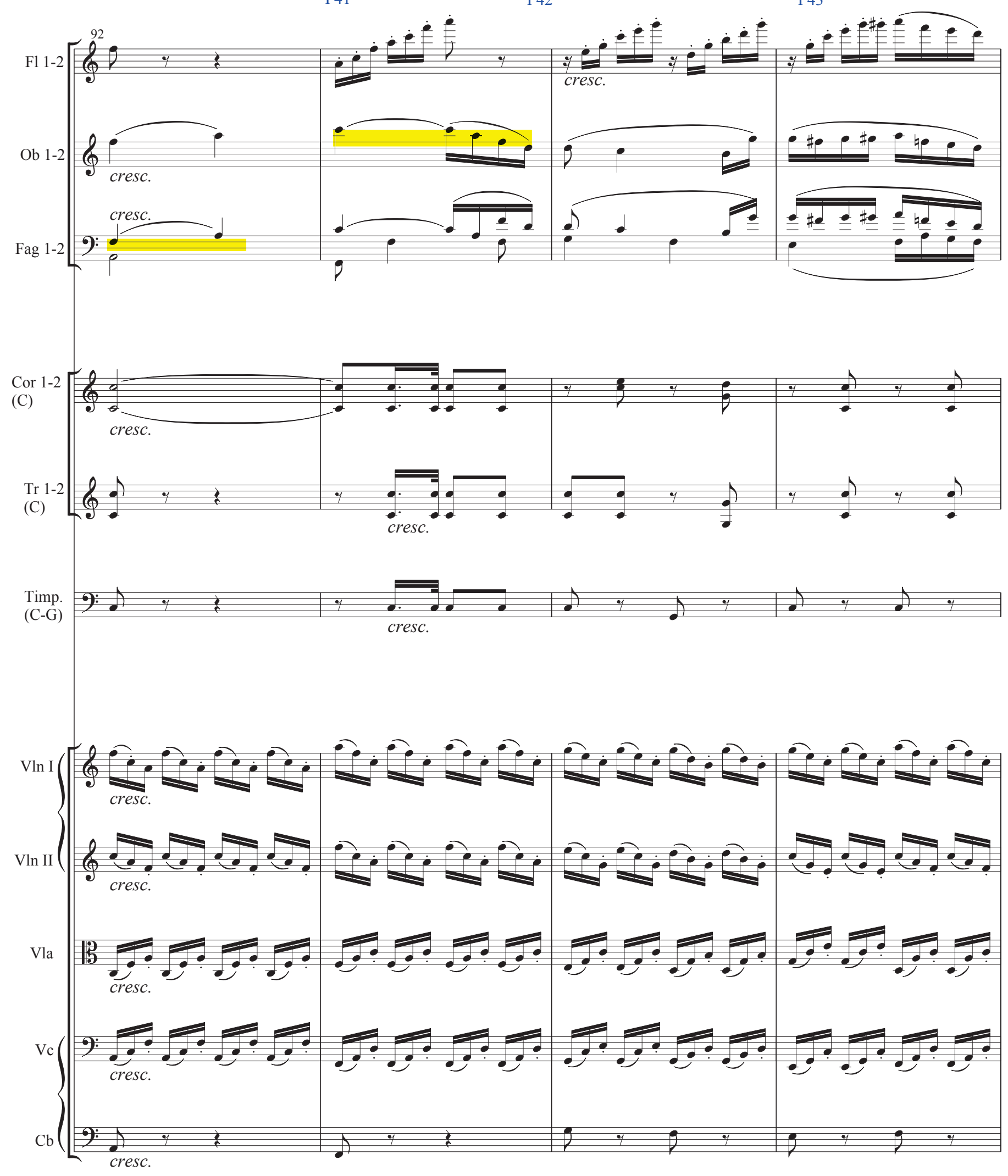


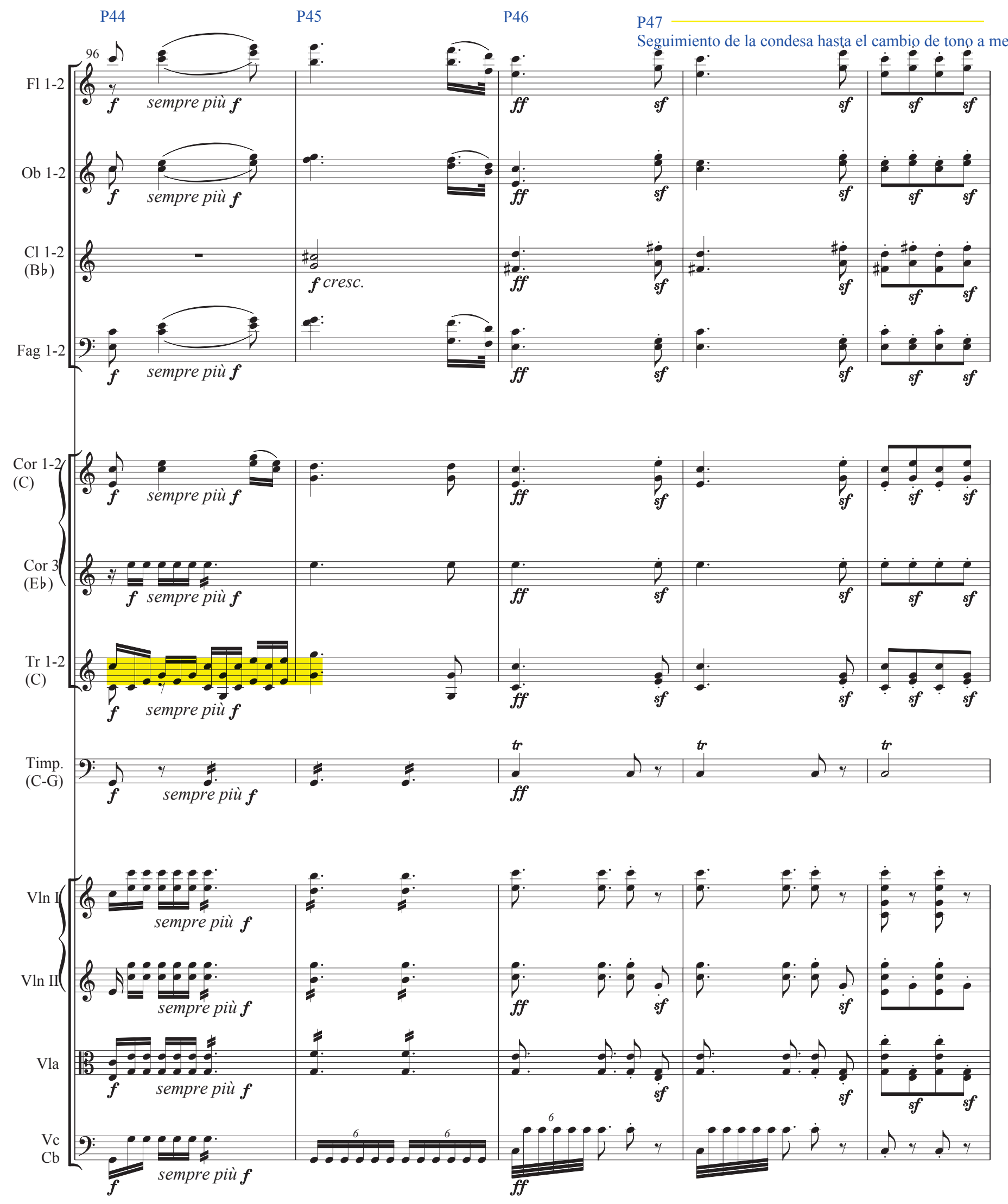



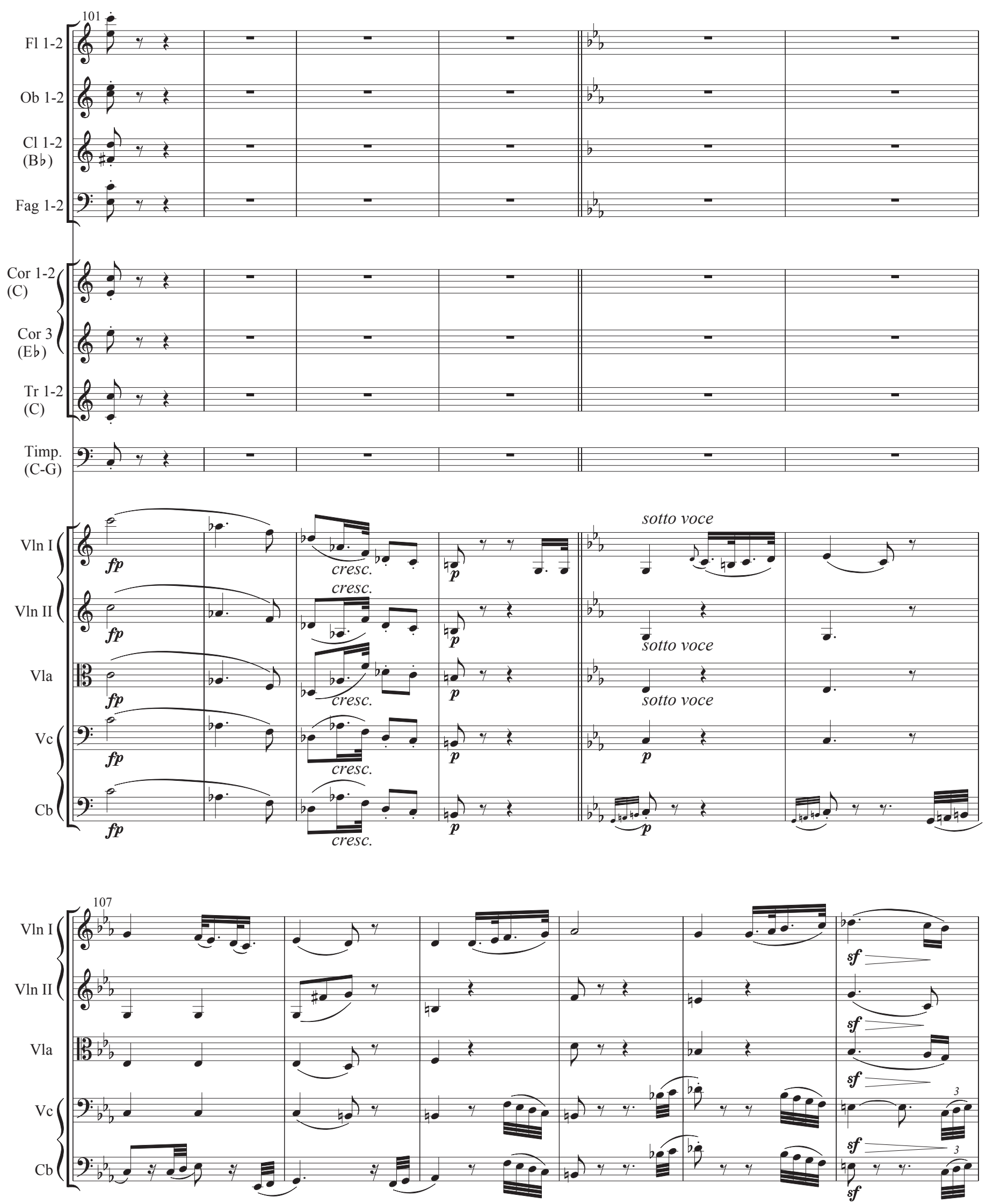

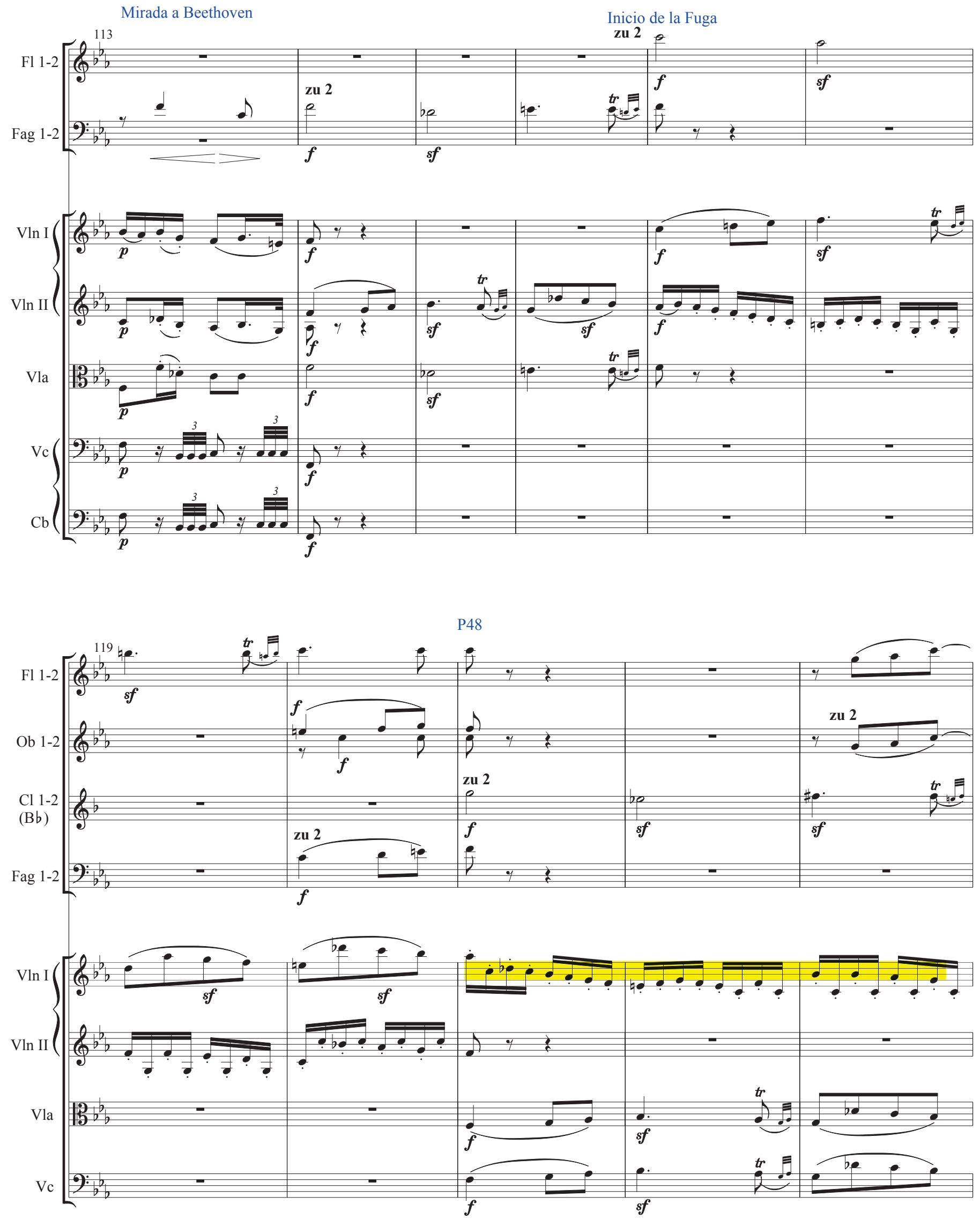


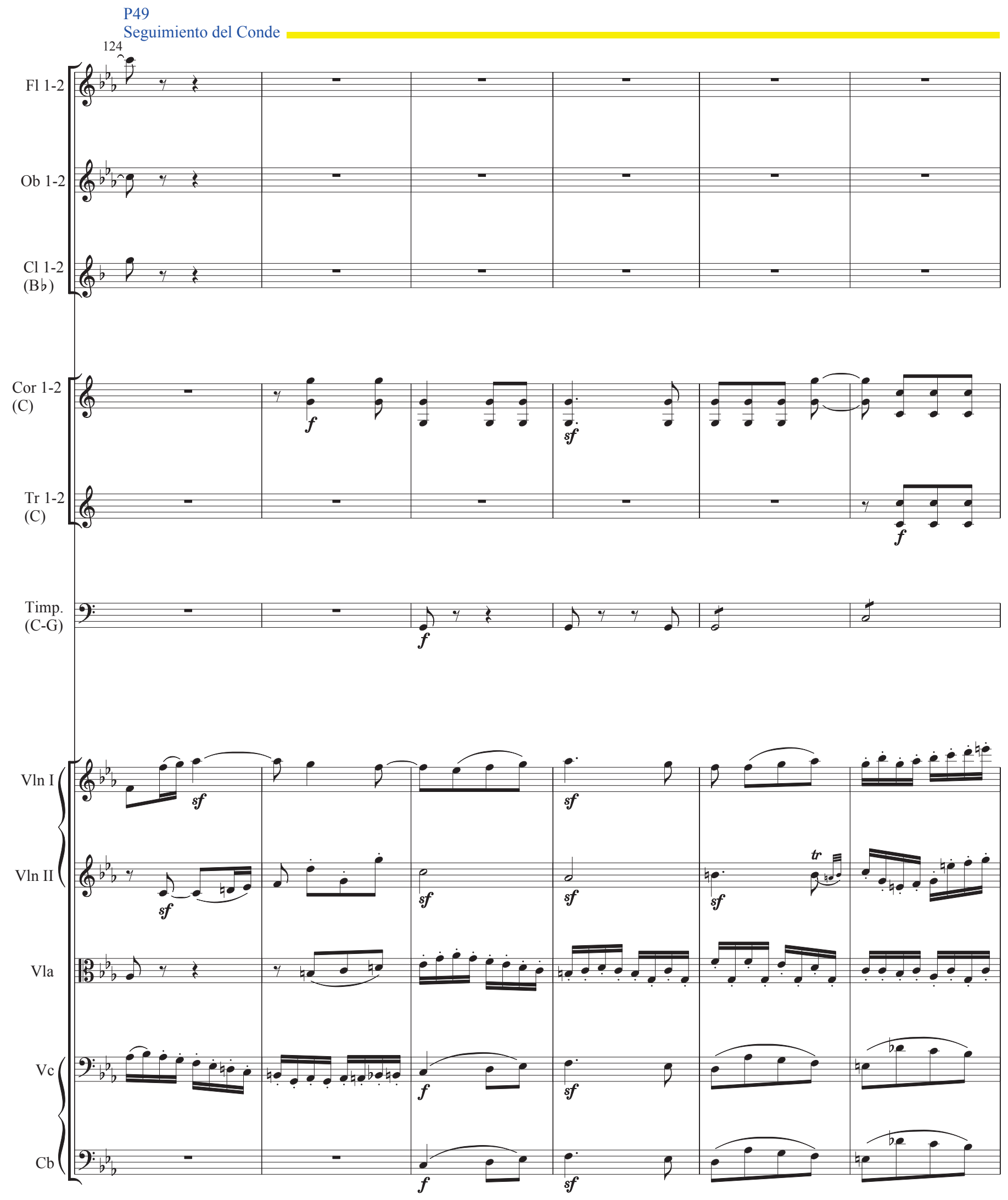




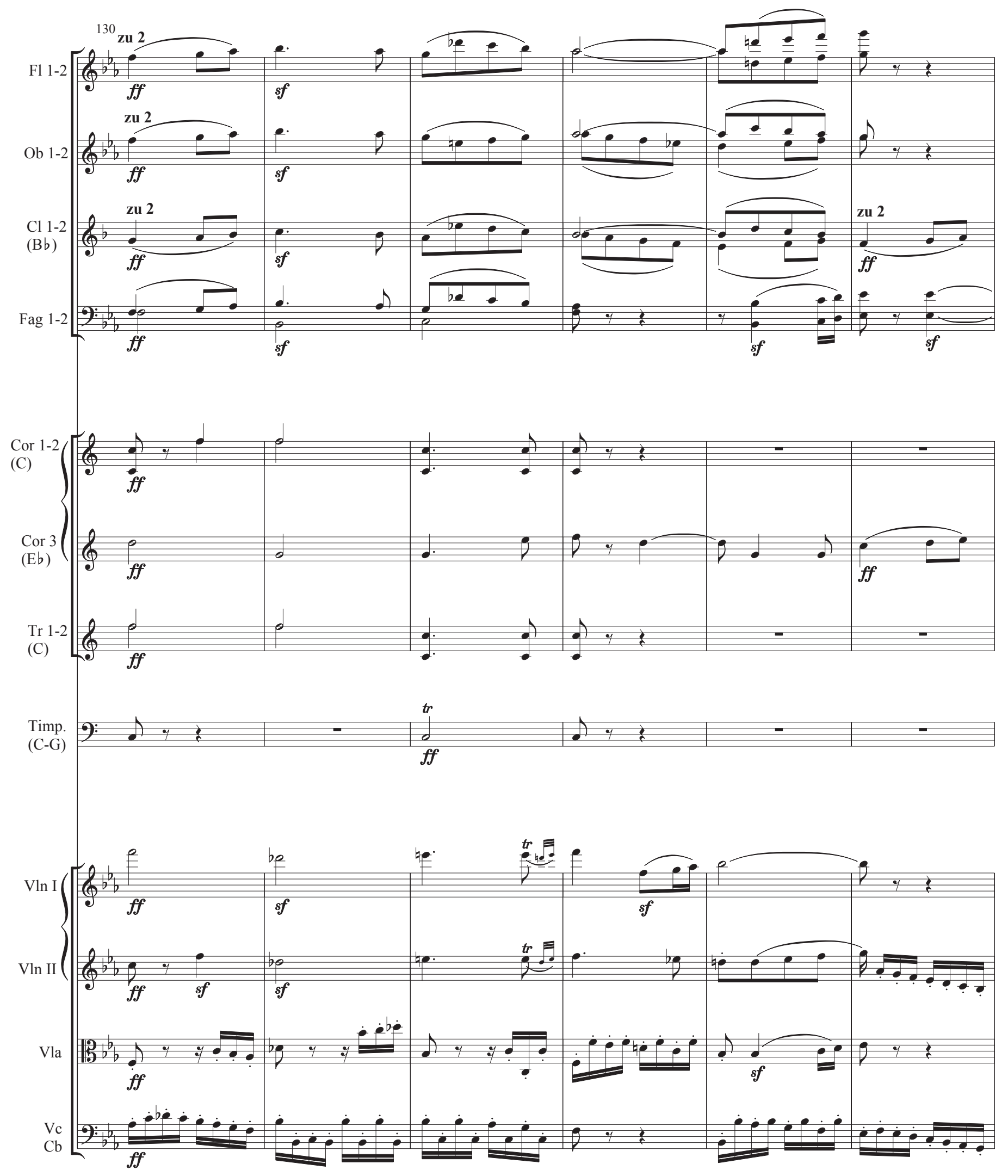


Crece la tensión emocional.

Apoyo musical y de imagen: zoom in
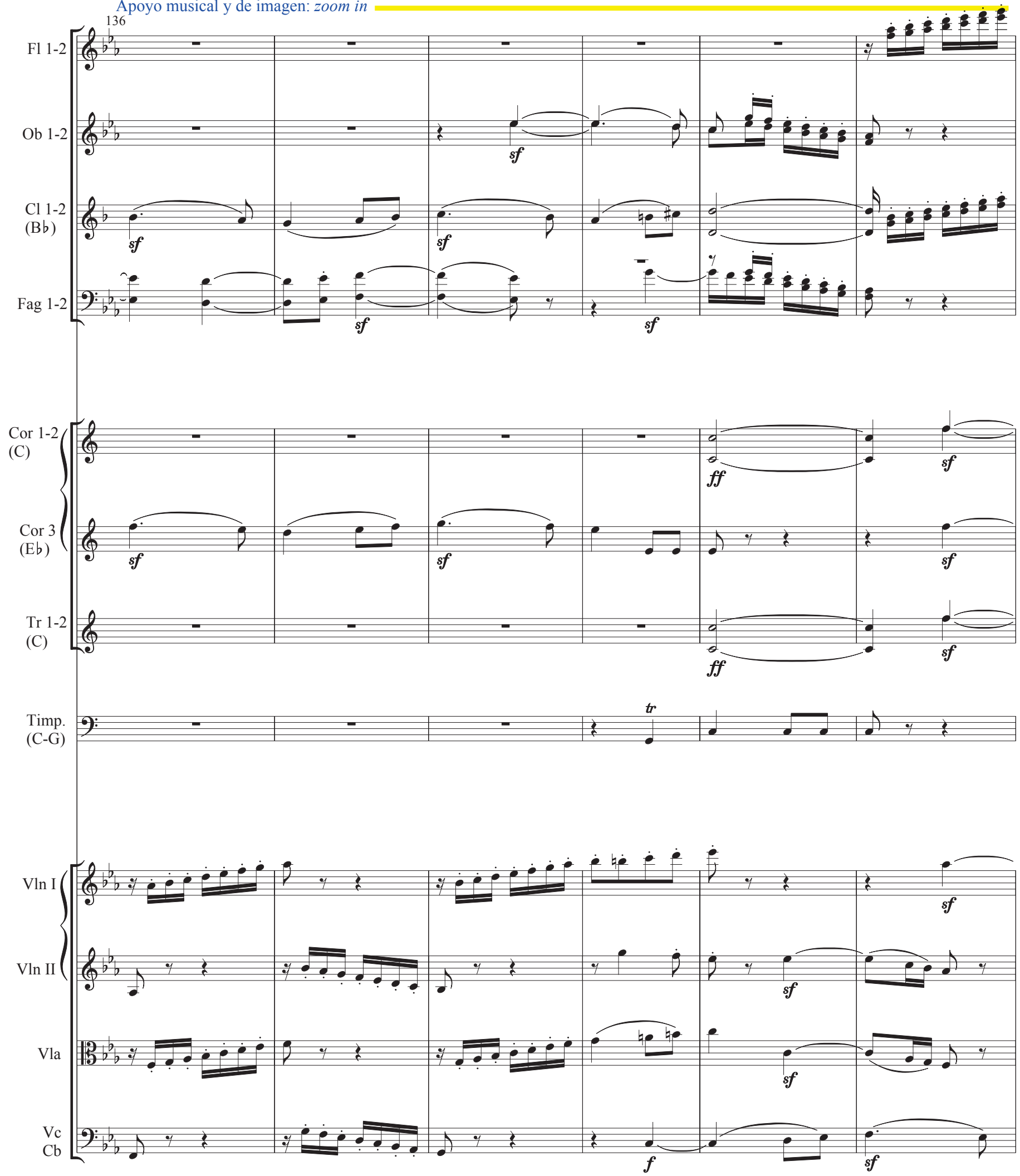


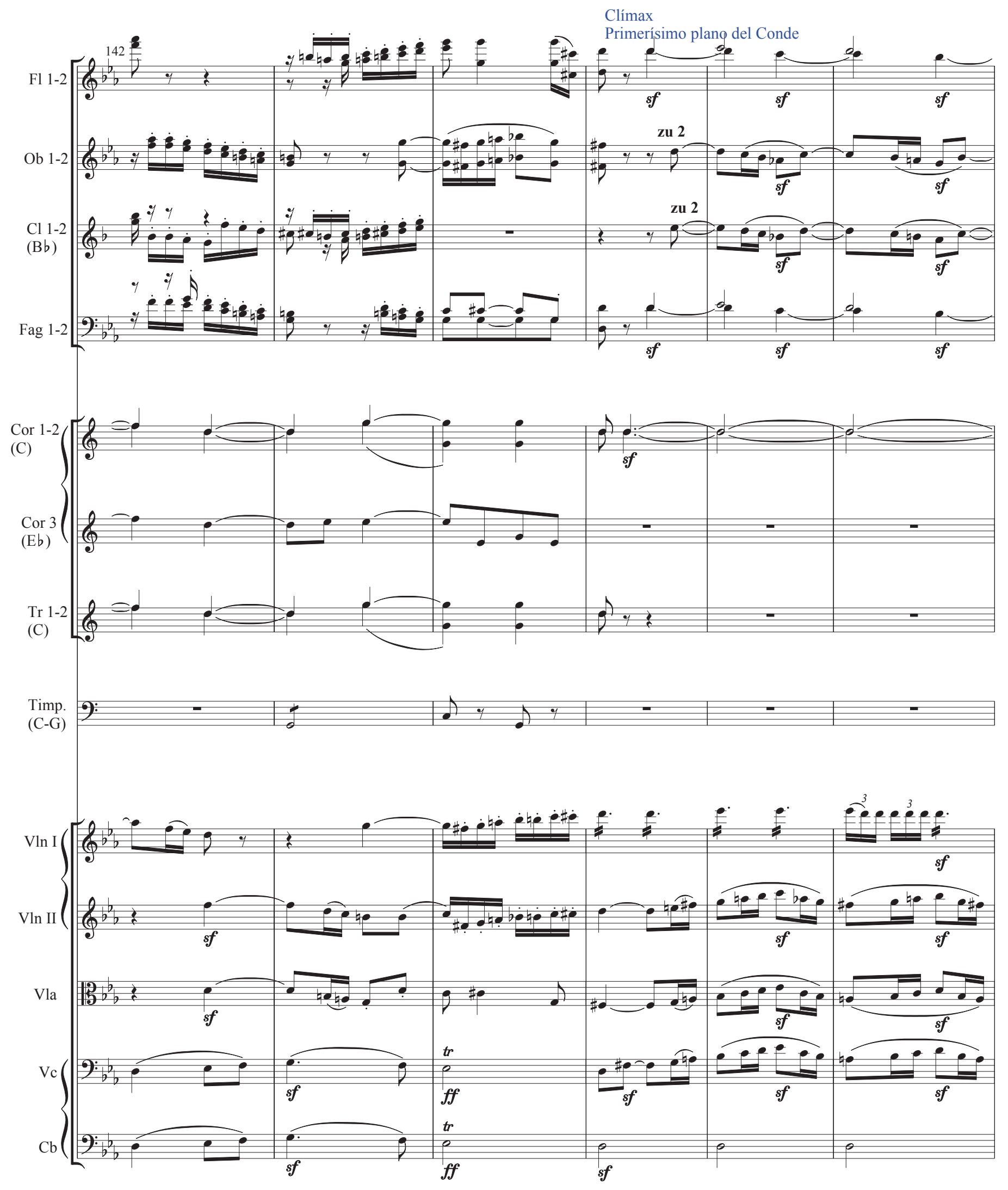



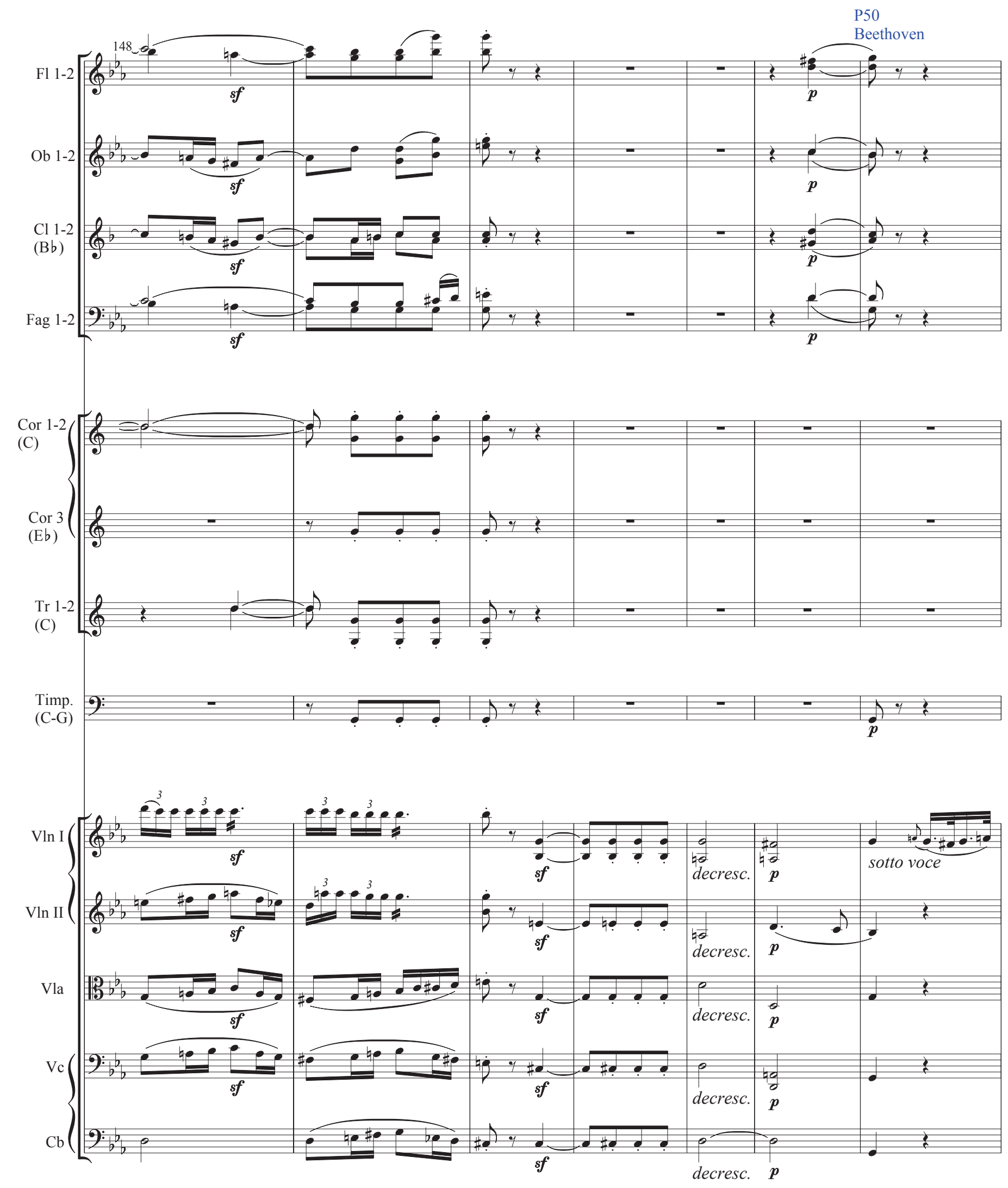

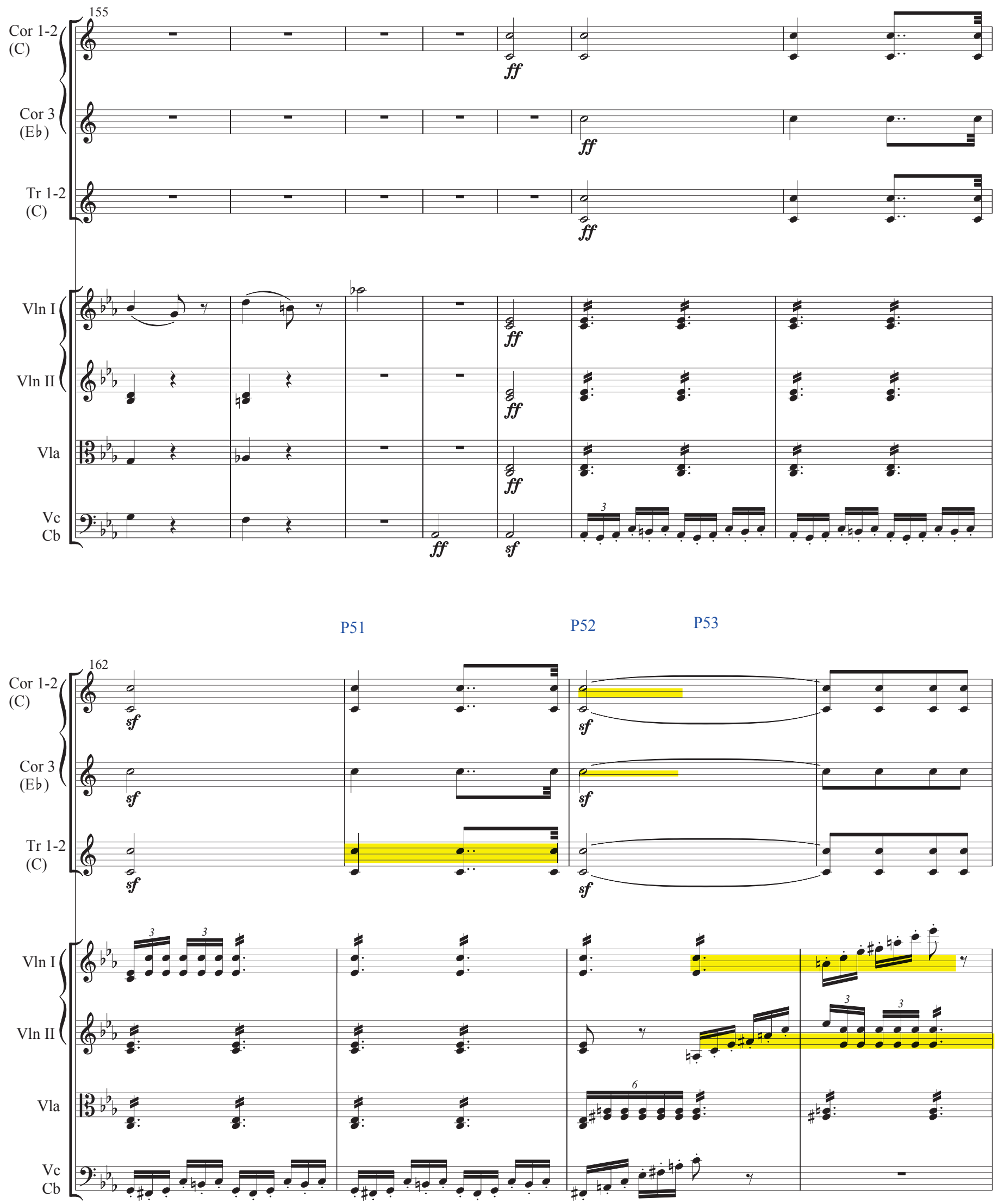


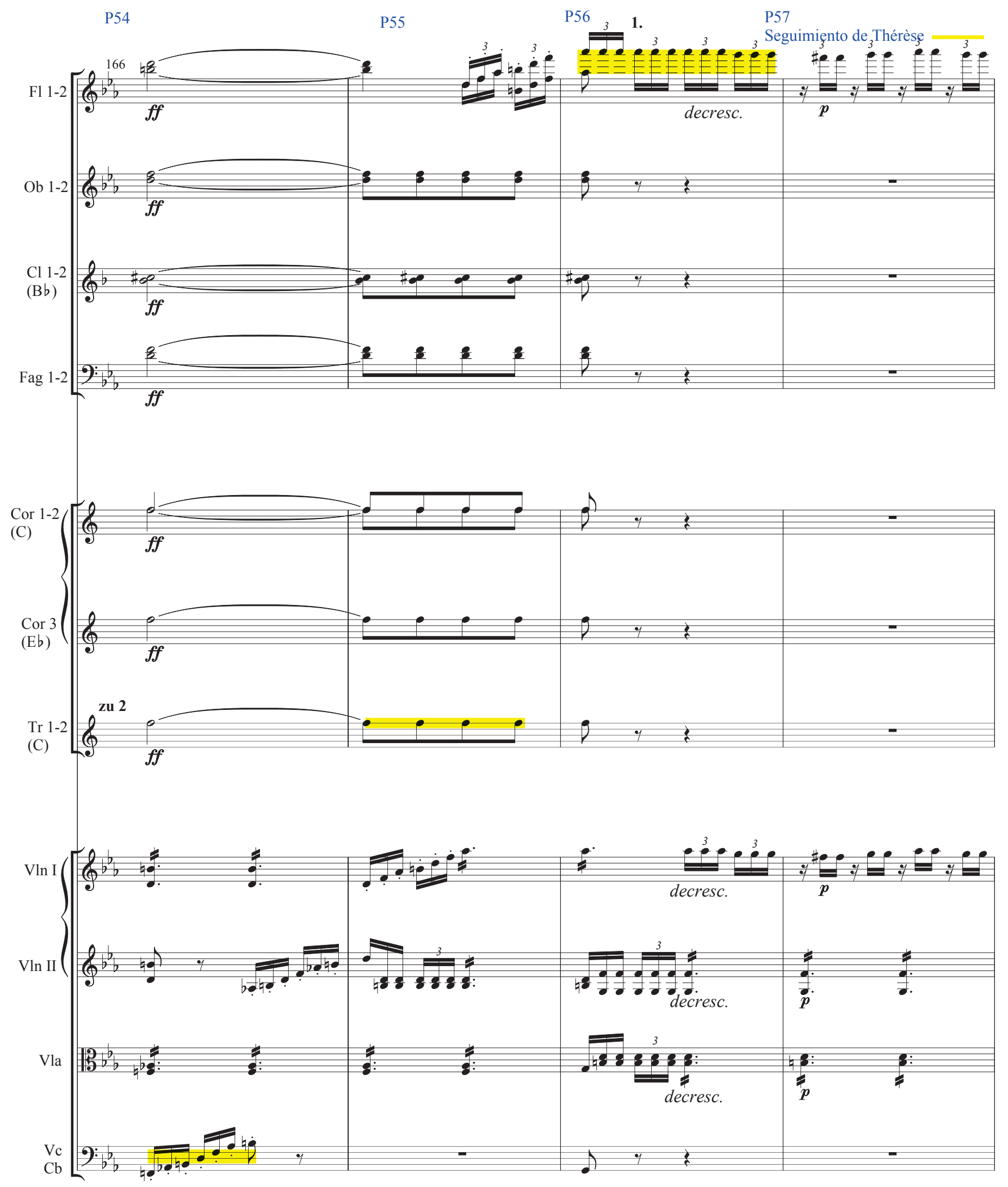



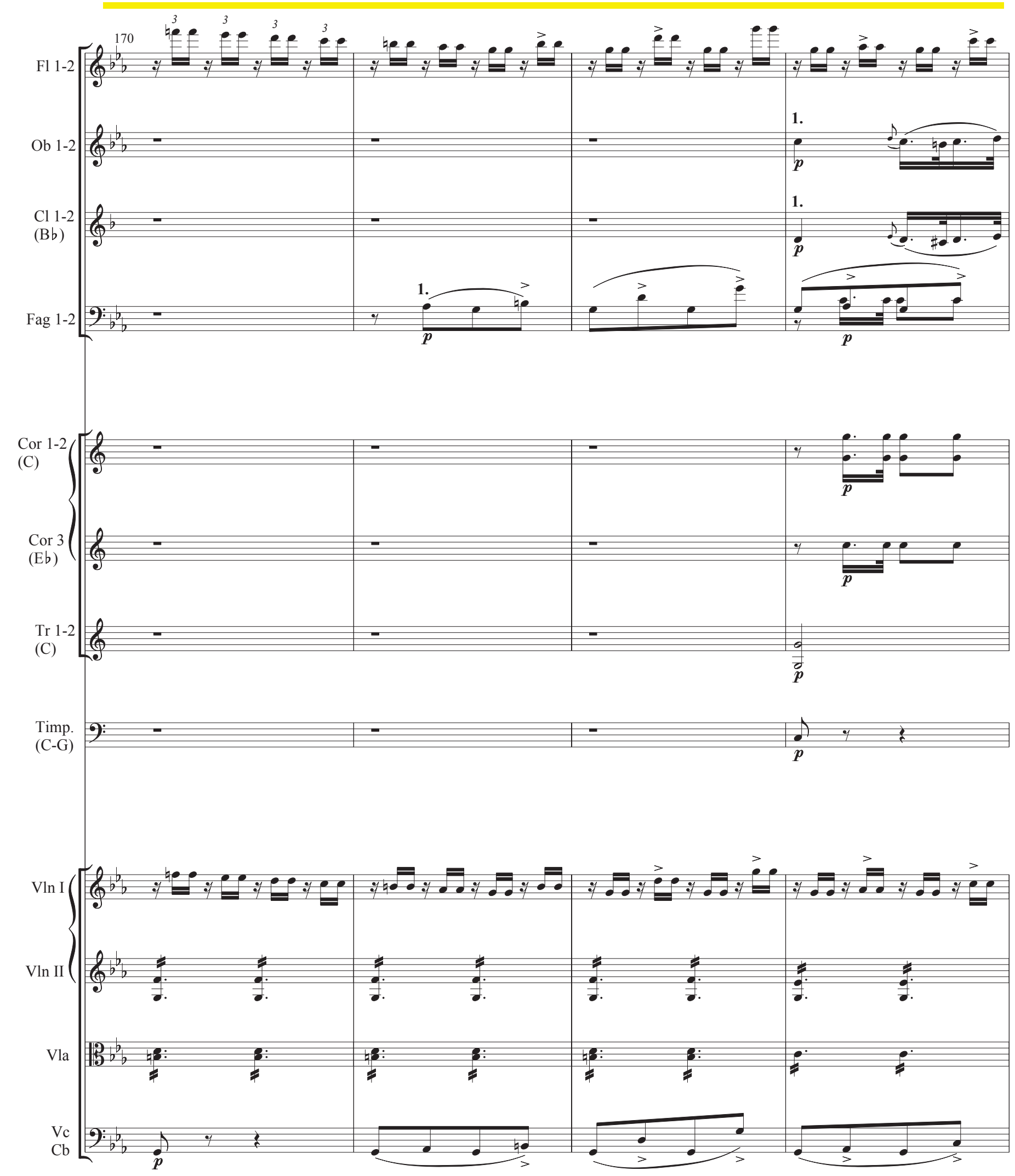

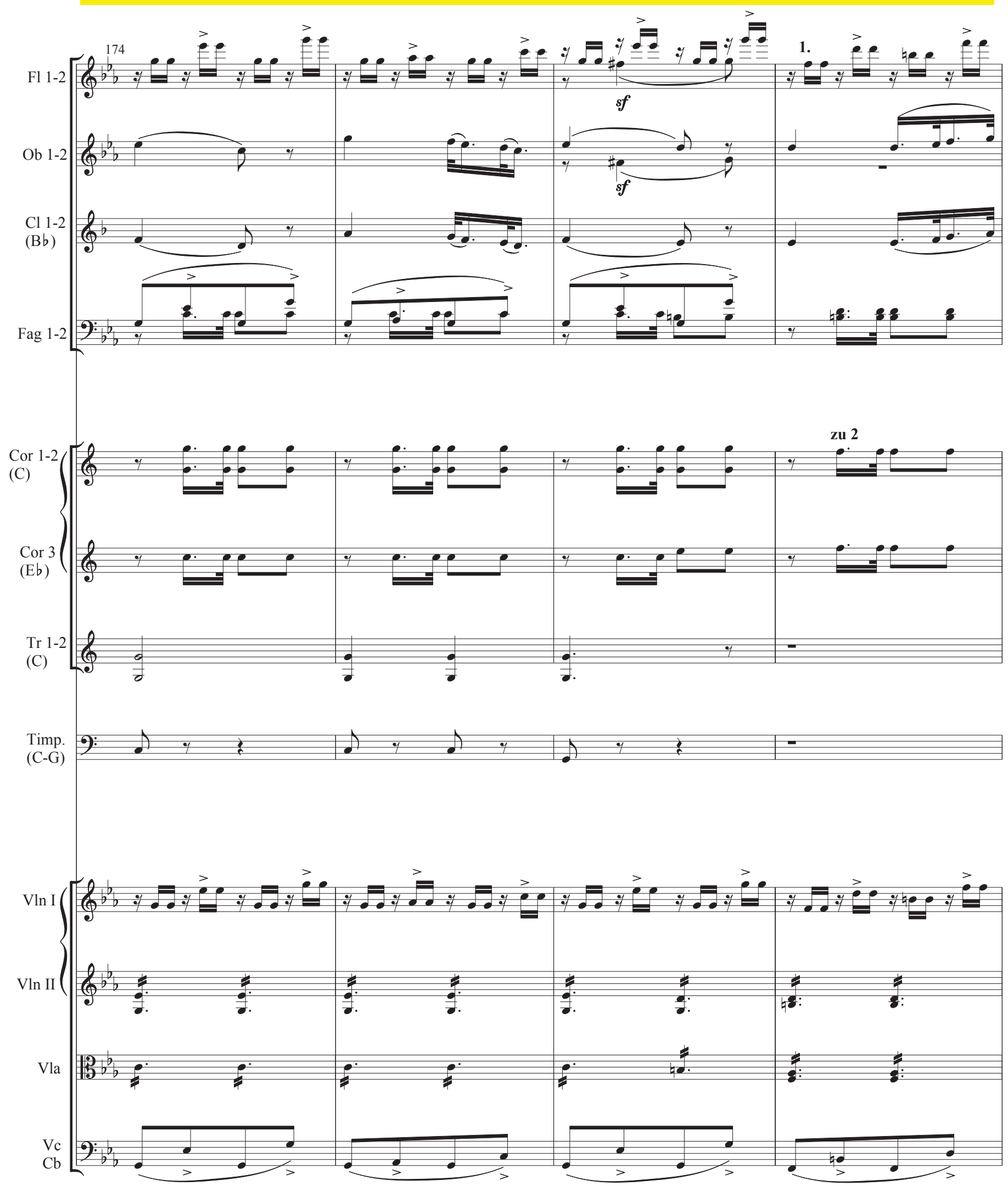


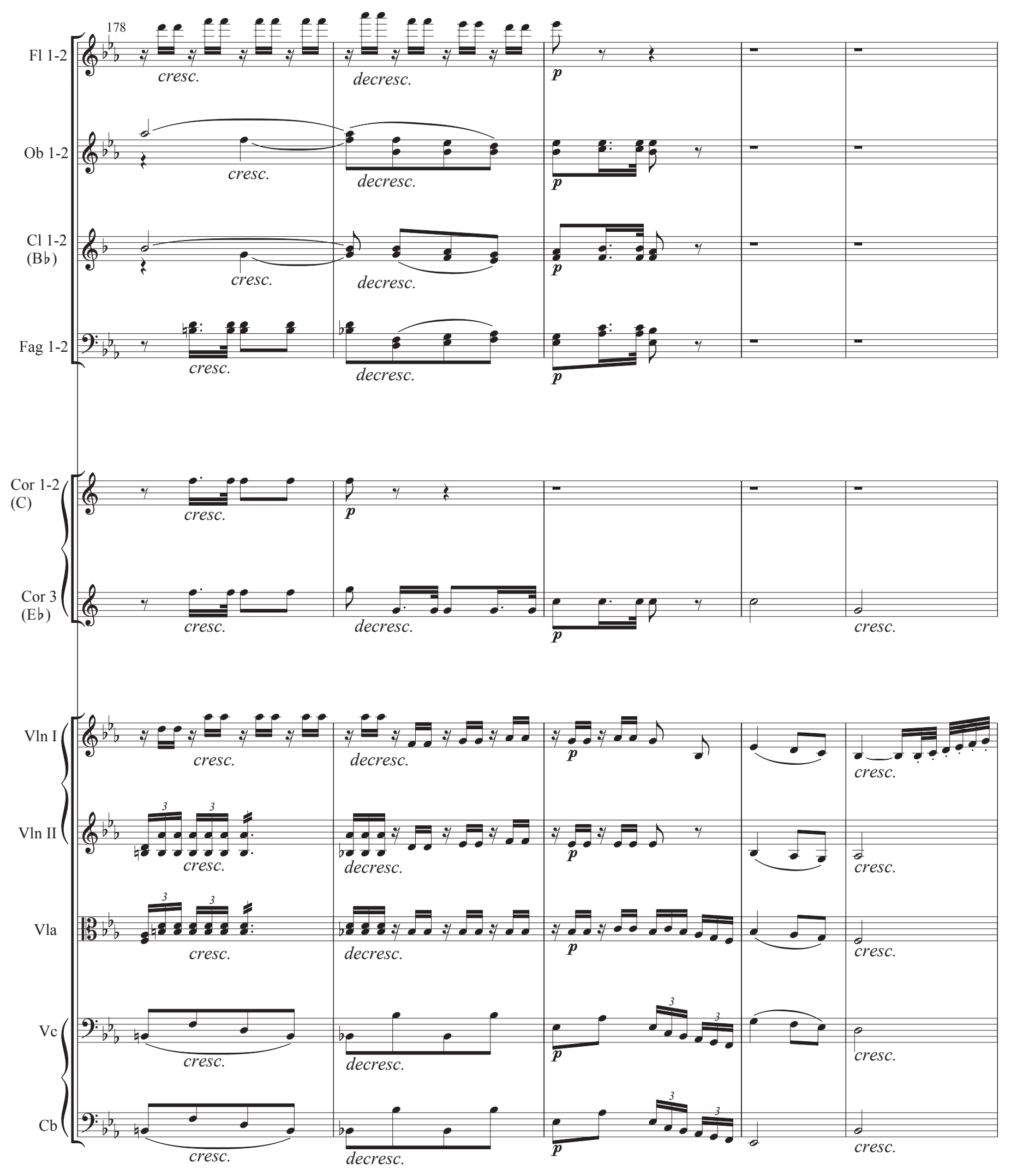




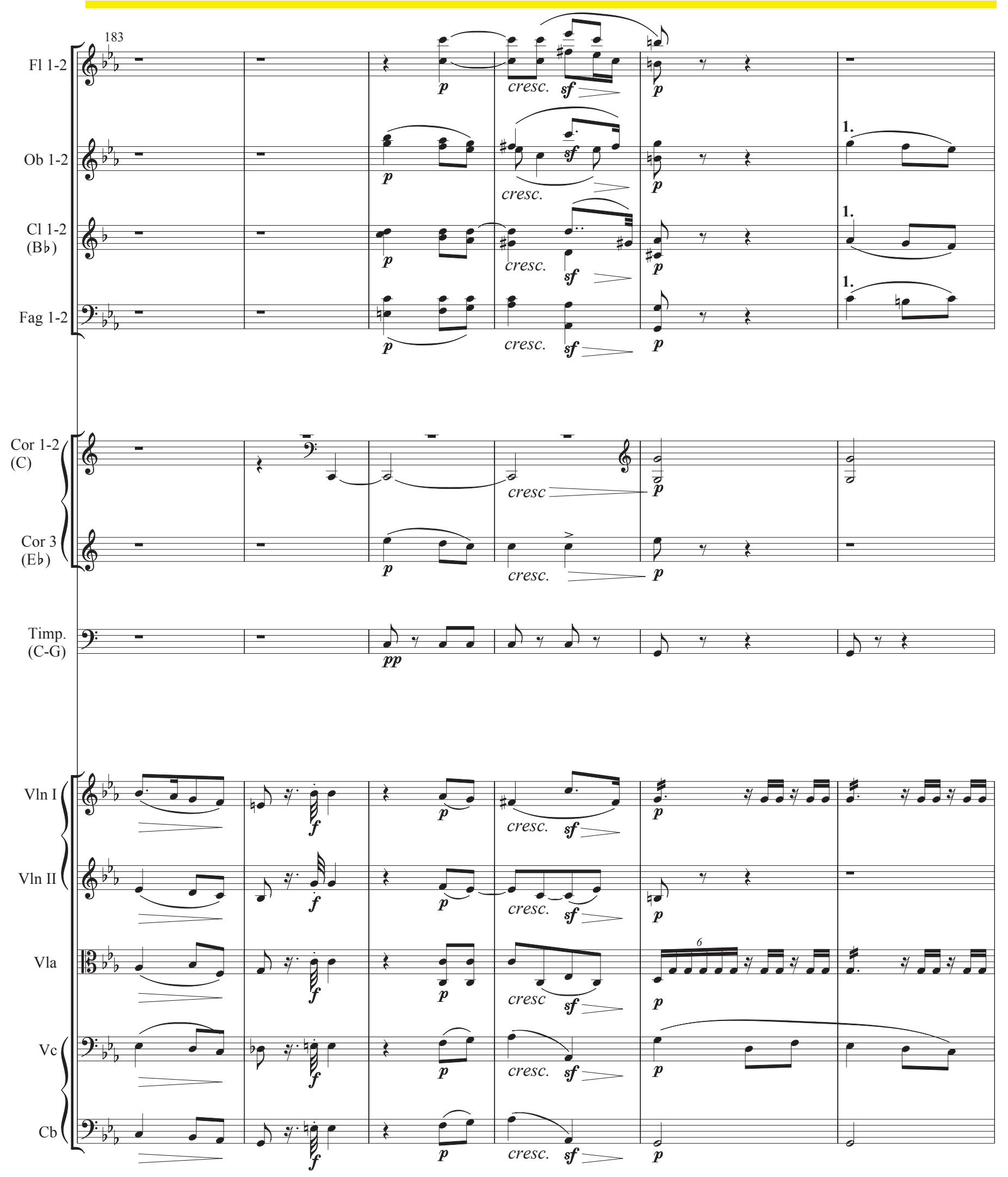




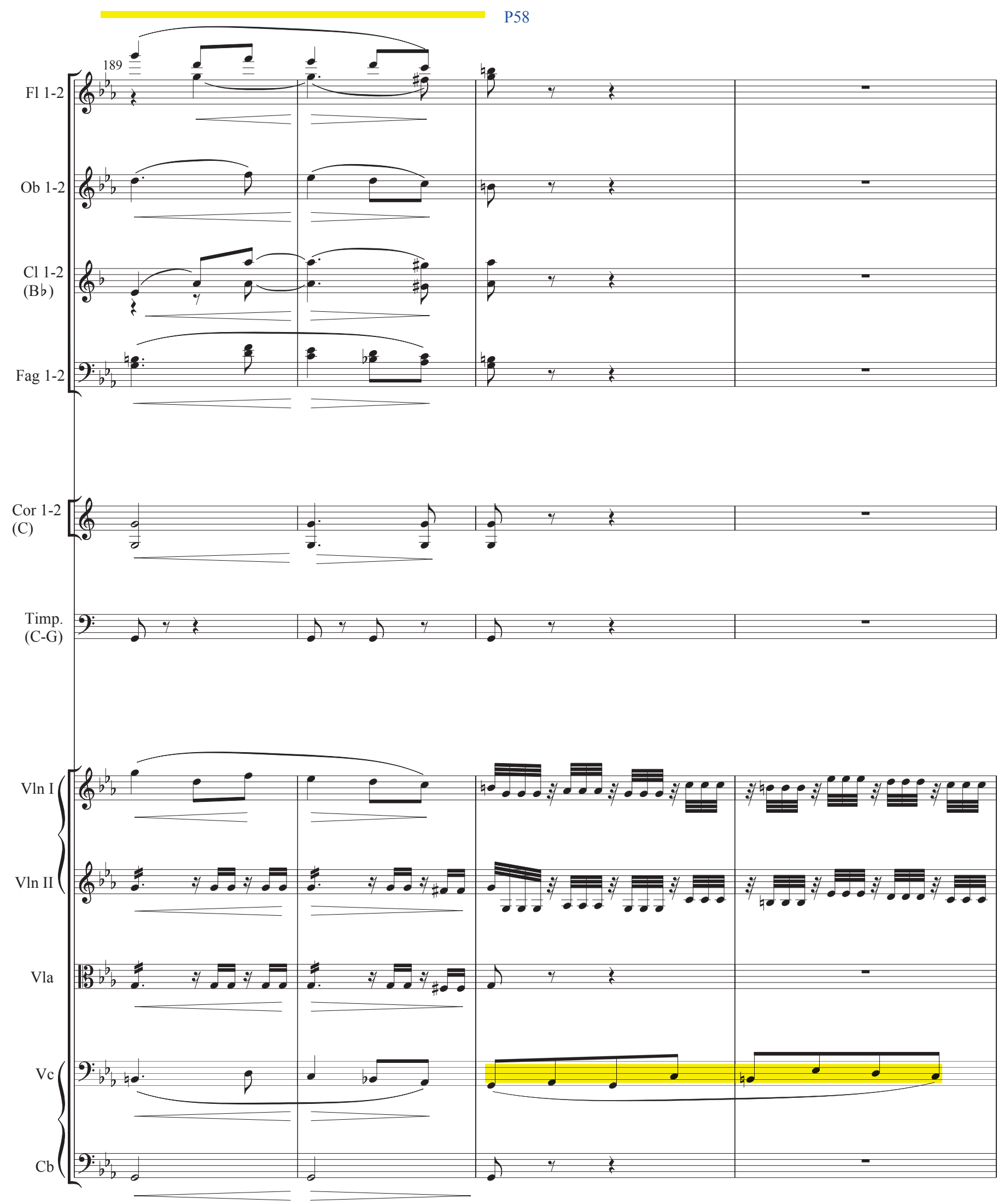




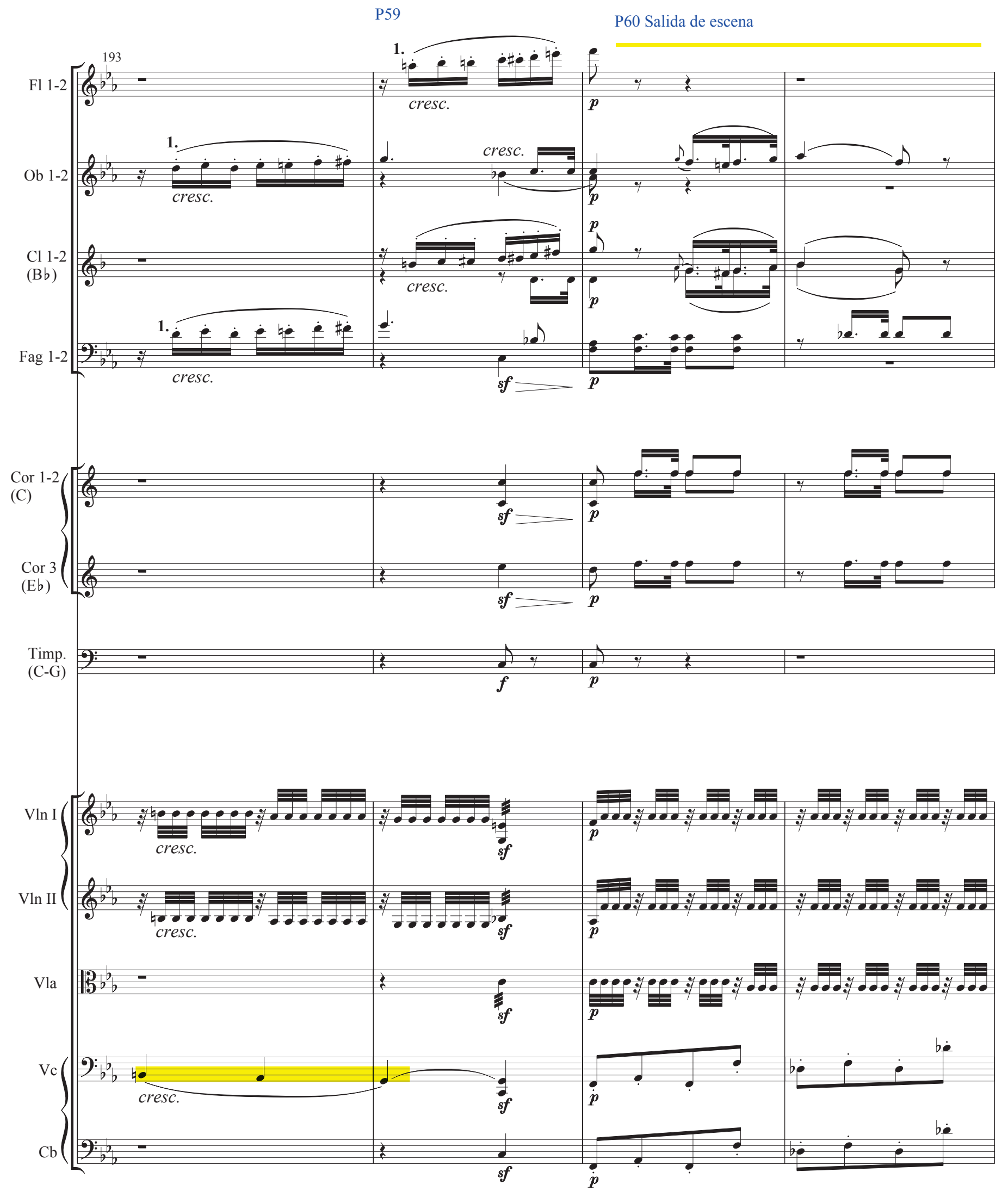




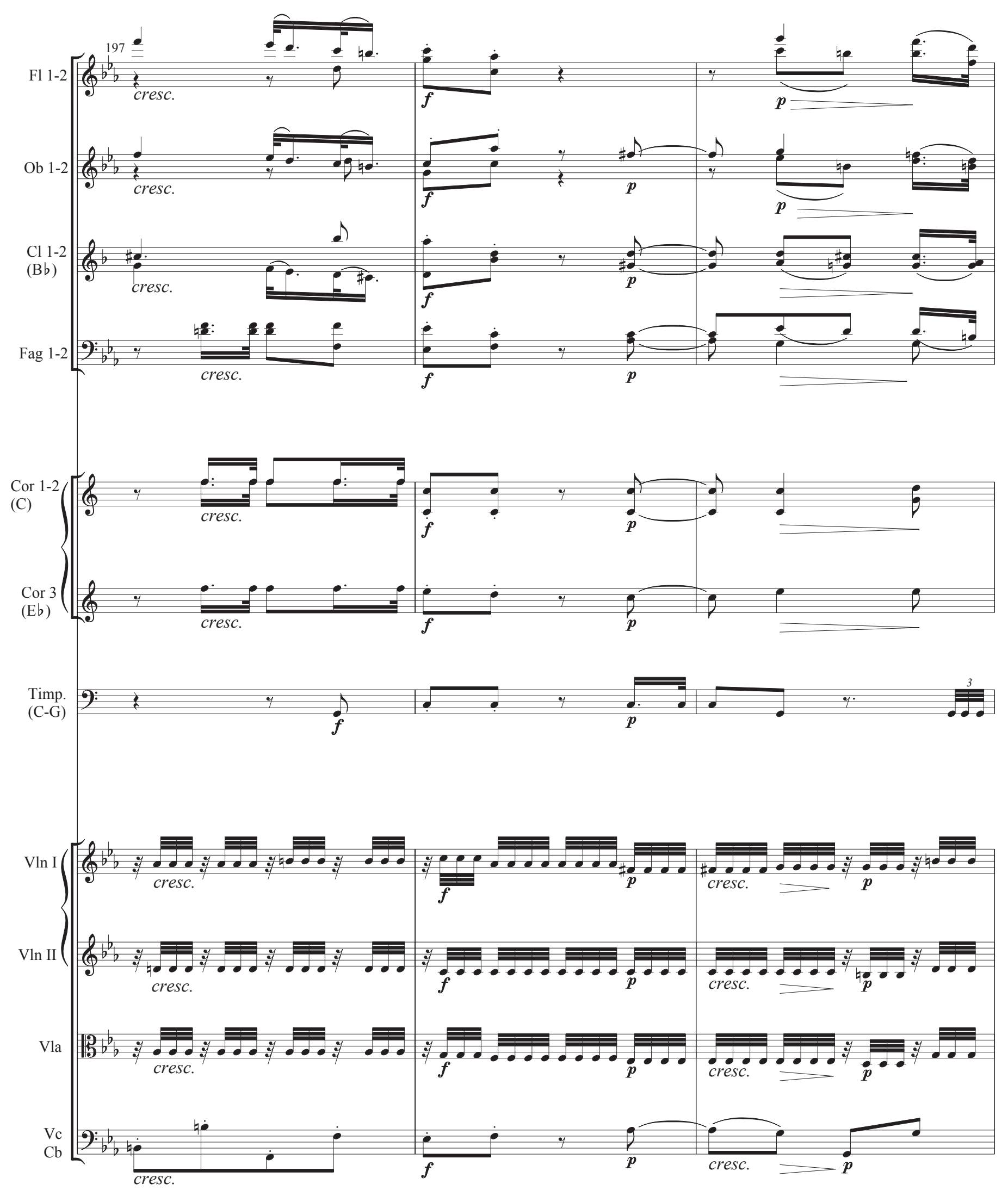



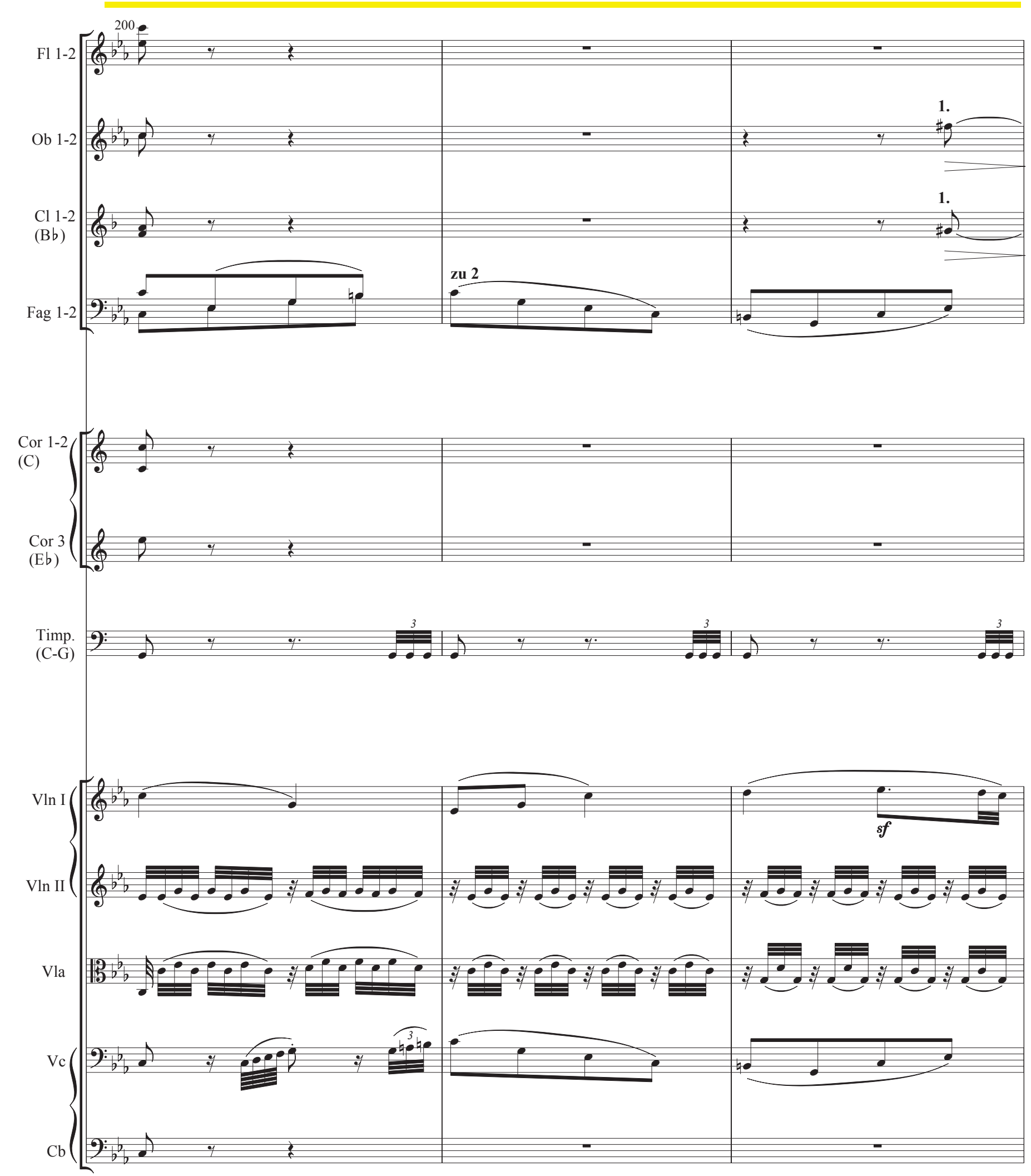
P61 P62

Sentimientos Príncipe

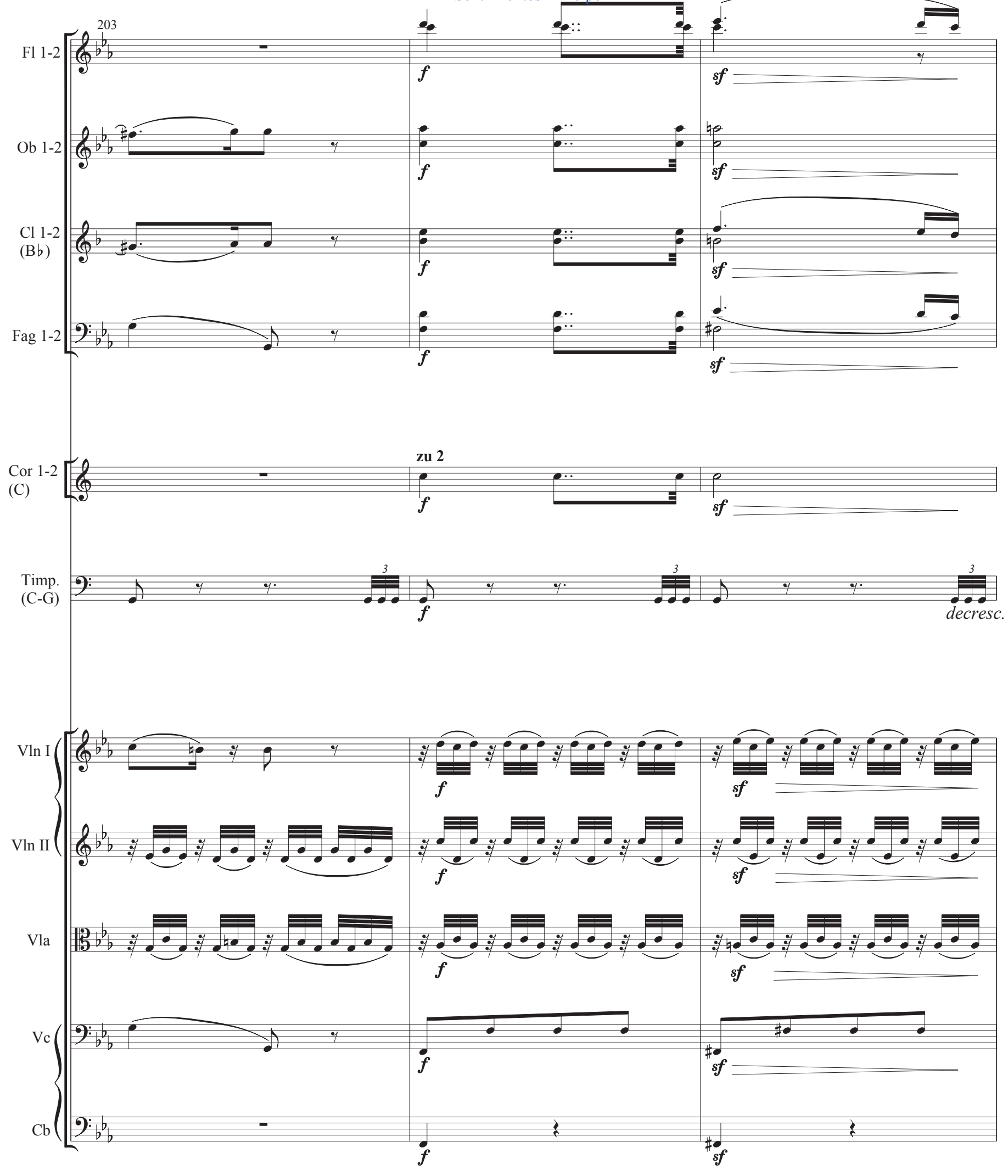



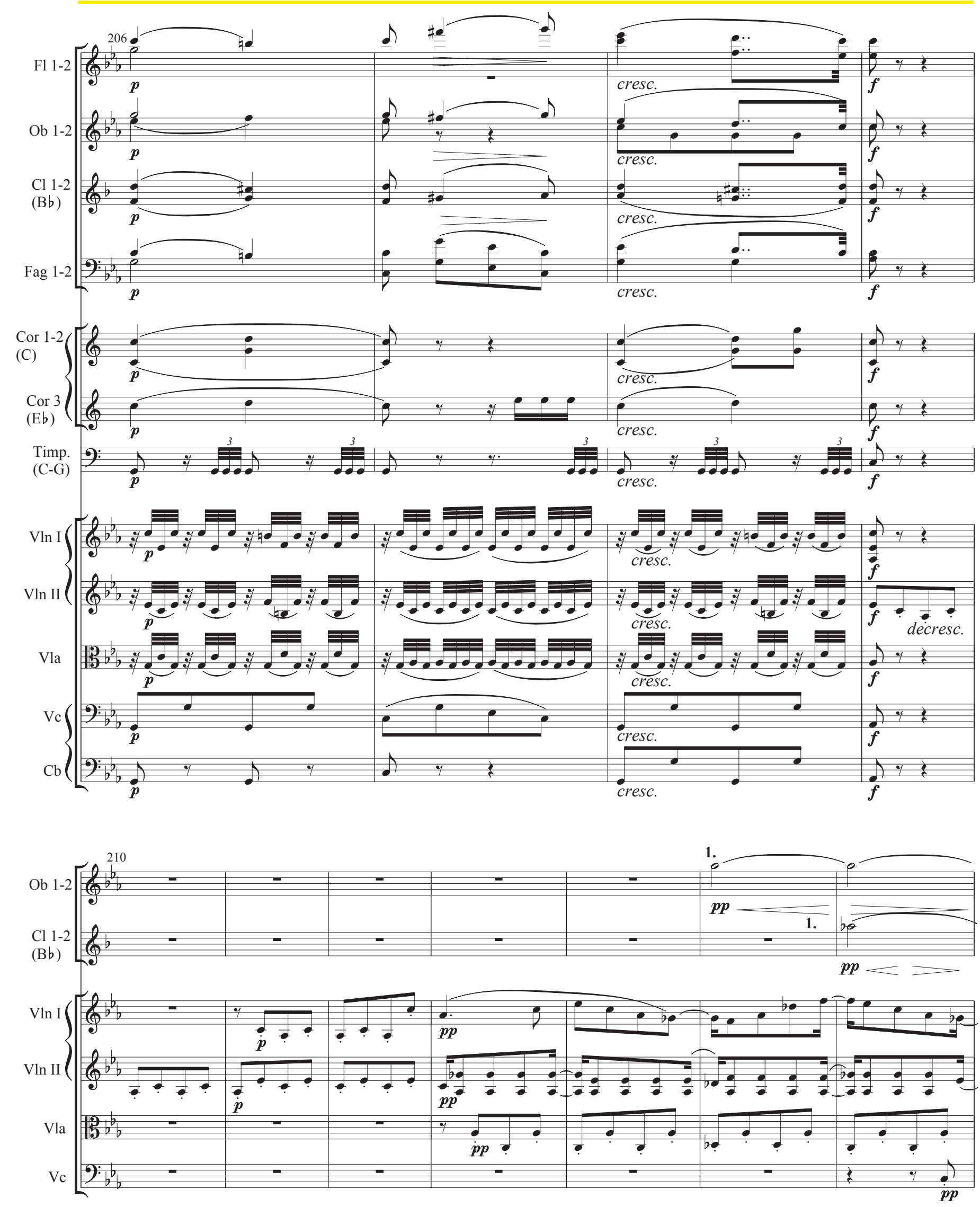

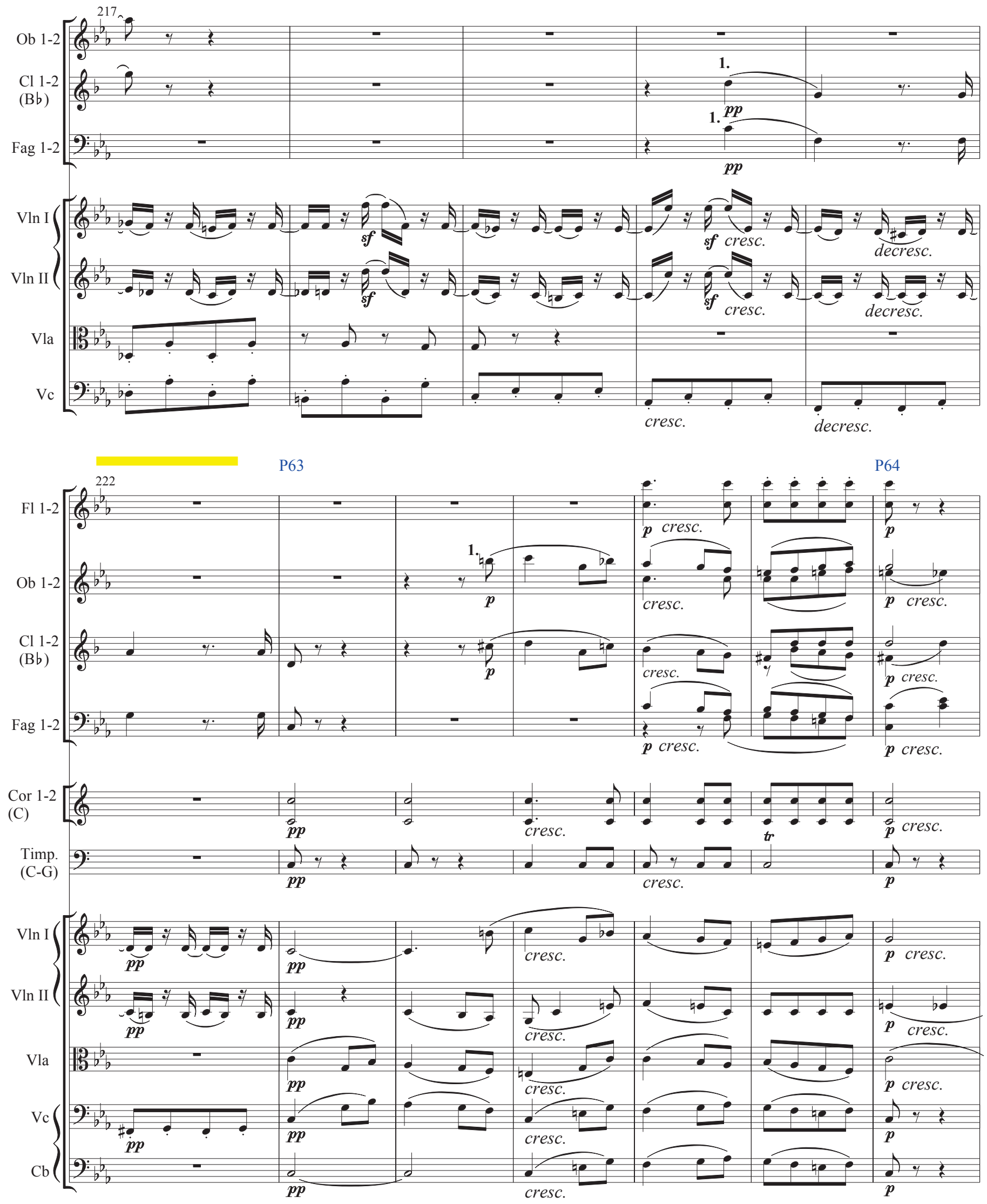


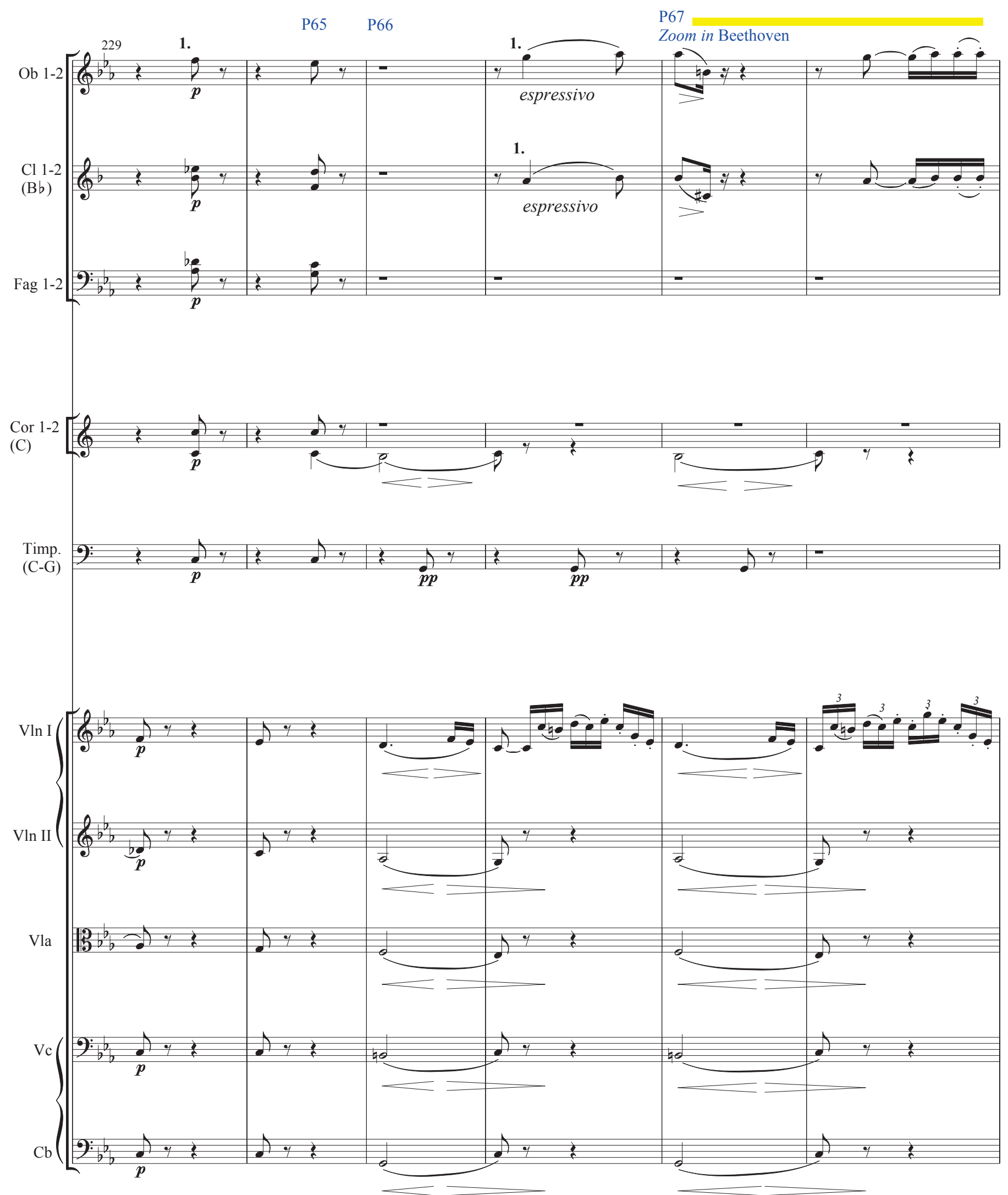




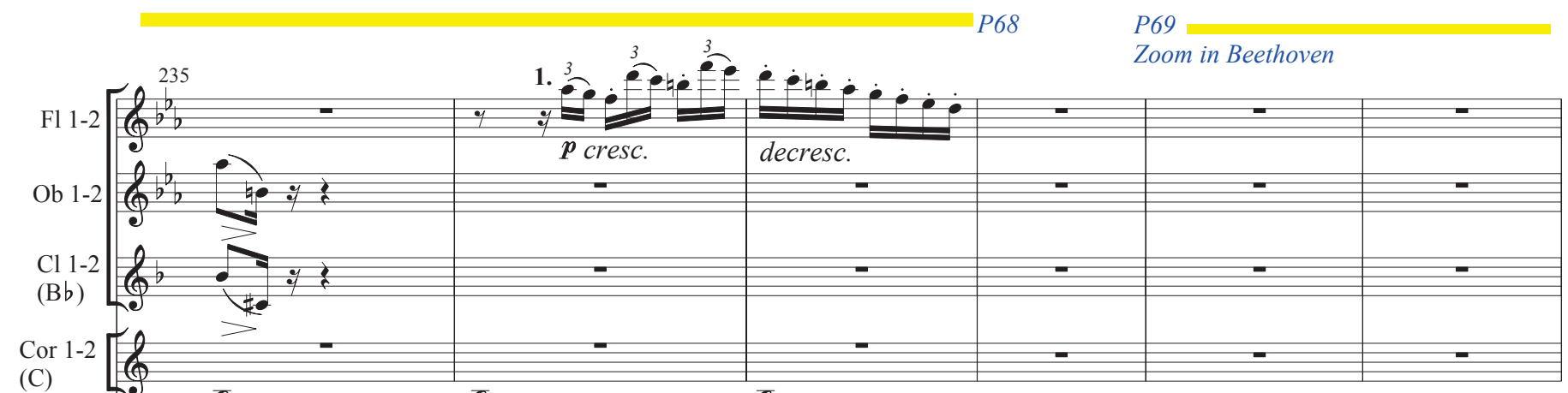

(C)
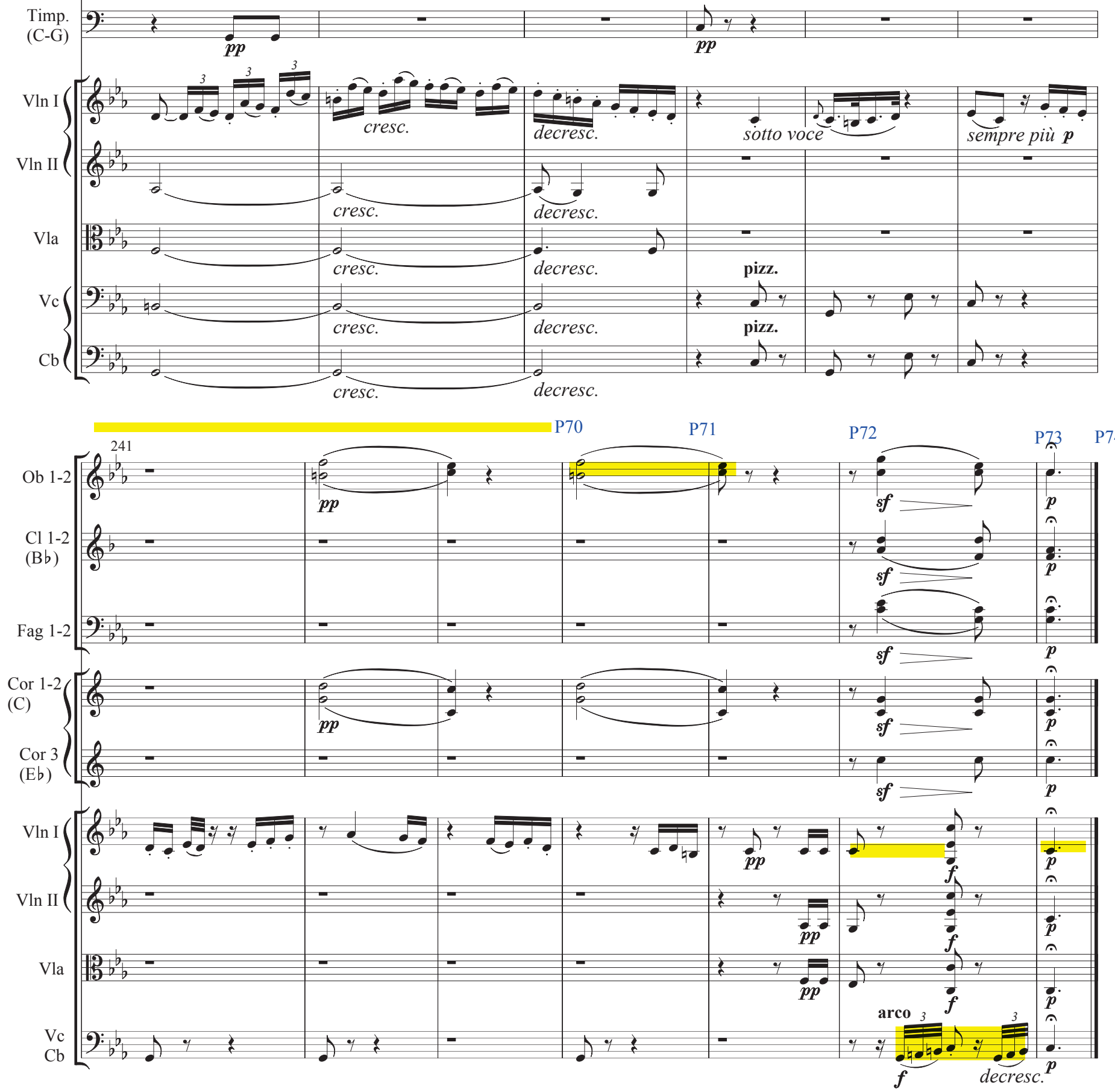
III.

Allegro vivace. $\left({ }^{\circ} .=116\right)$

Flauti 1, 2

Oboi 1, 2

Clarinetti 1, 2 in $B$ b

Fagotti 1, 2

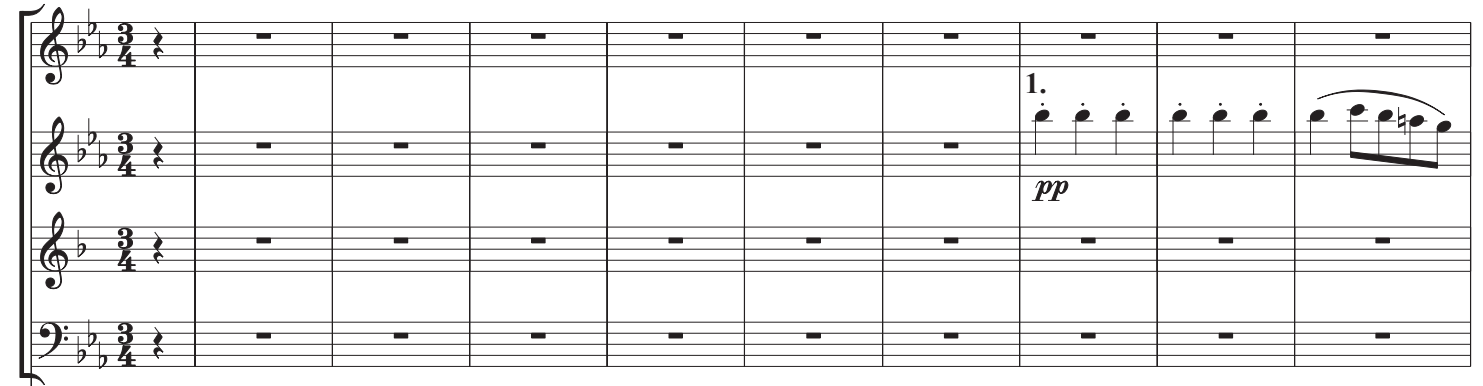

Corni 1, 2

in $E b$

Corno 3

in $E$ b

Trombe 1, 2

in $E b$

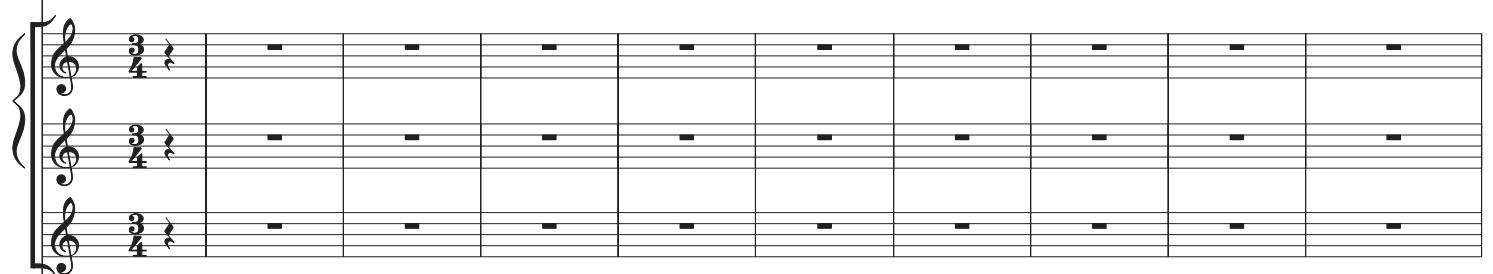

Timpani

in $E b-B b$

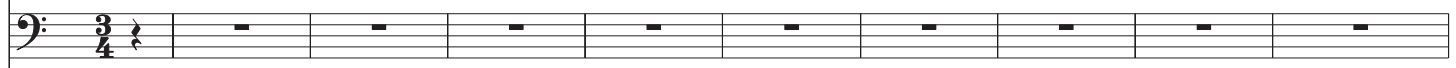

Violino I

Violino II

Viola

Violoncello

Contrabasso
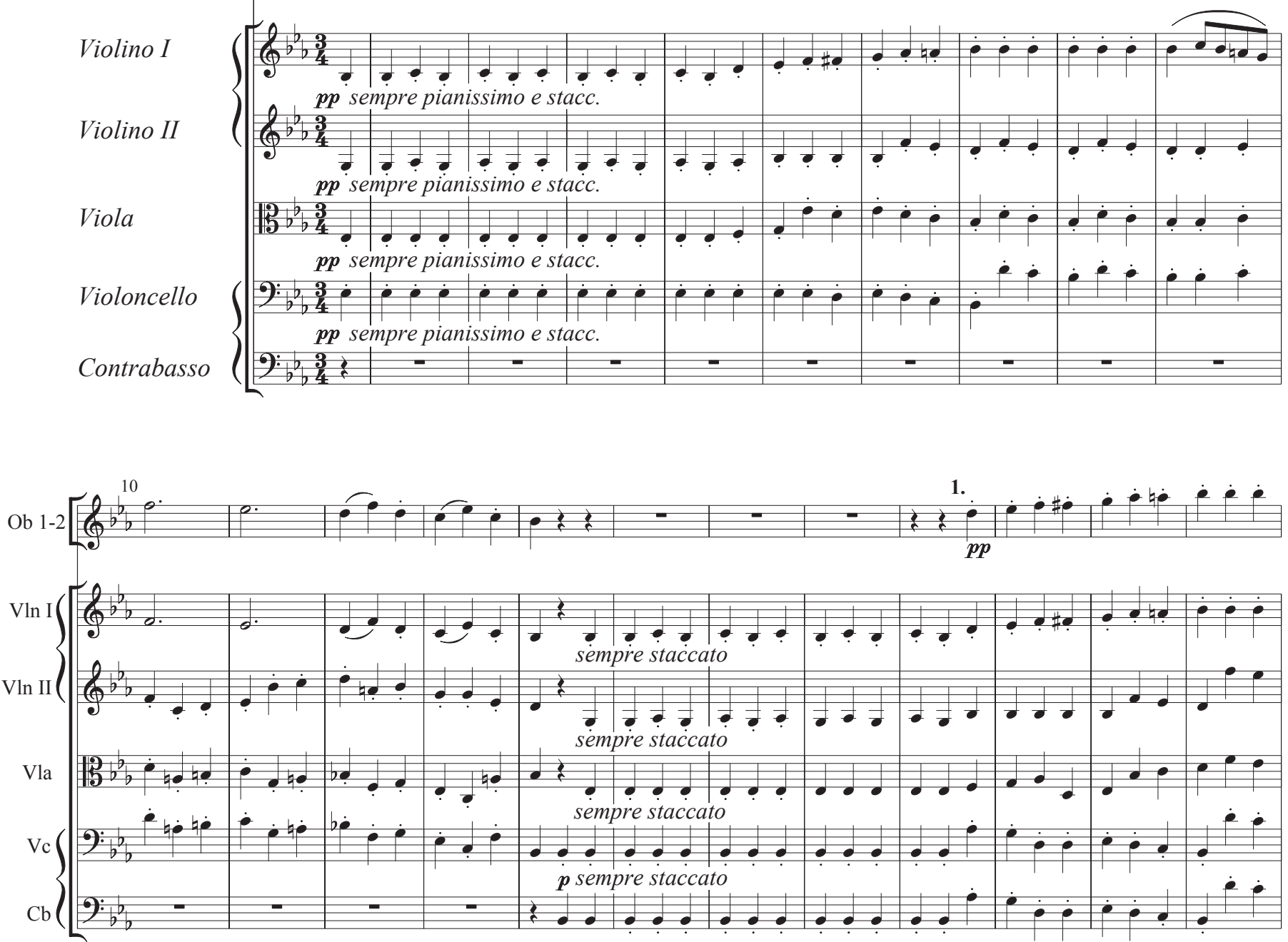

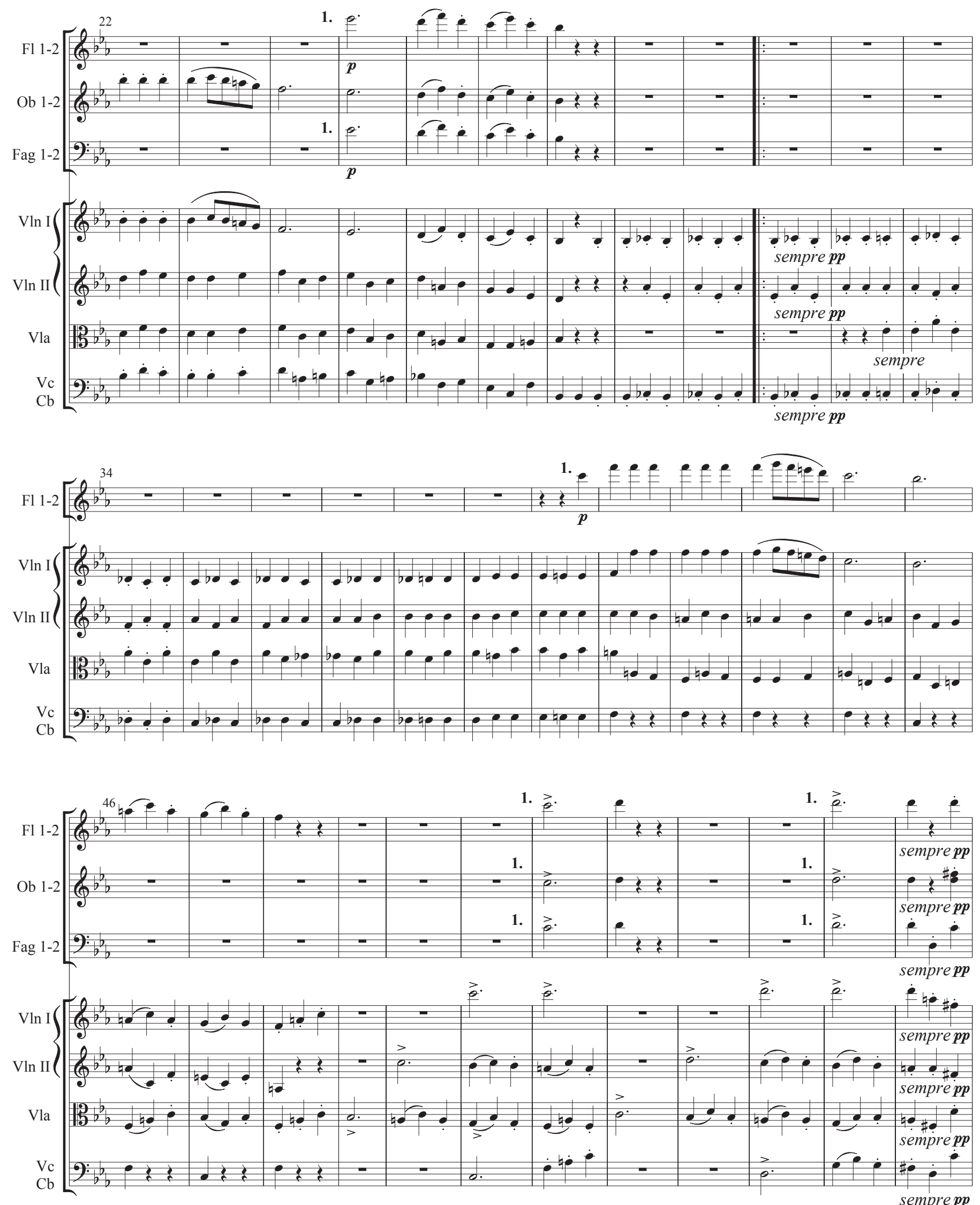

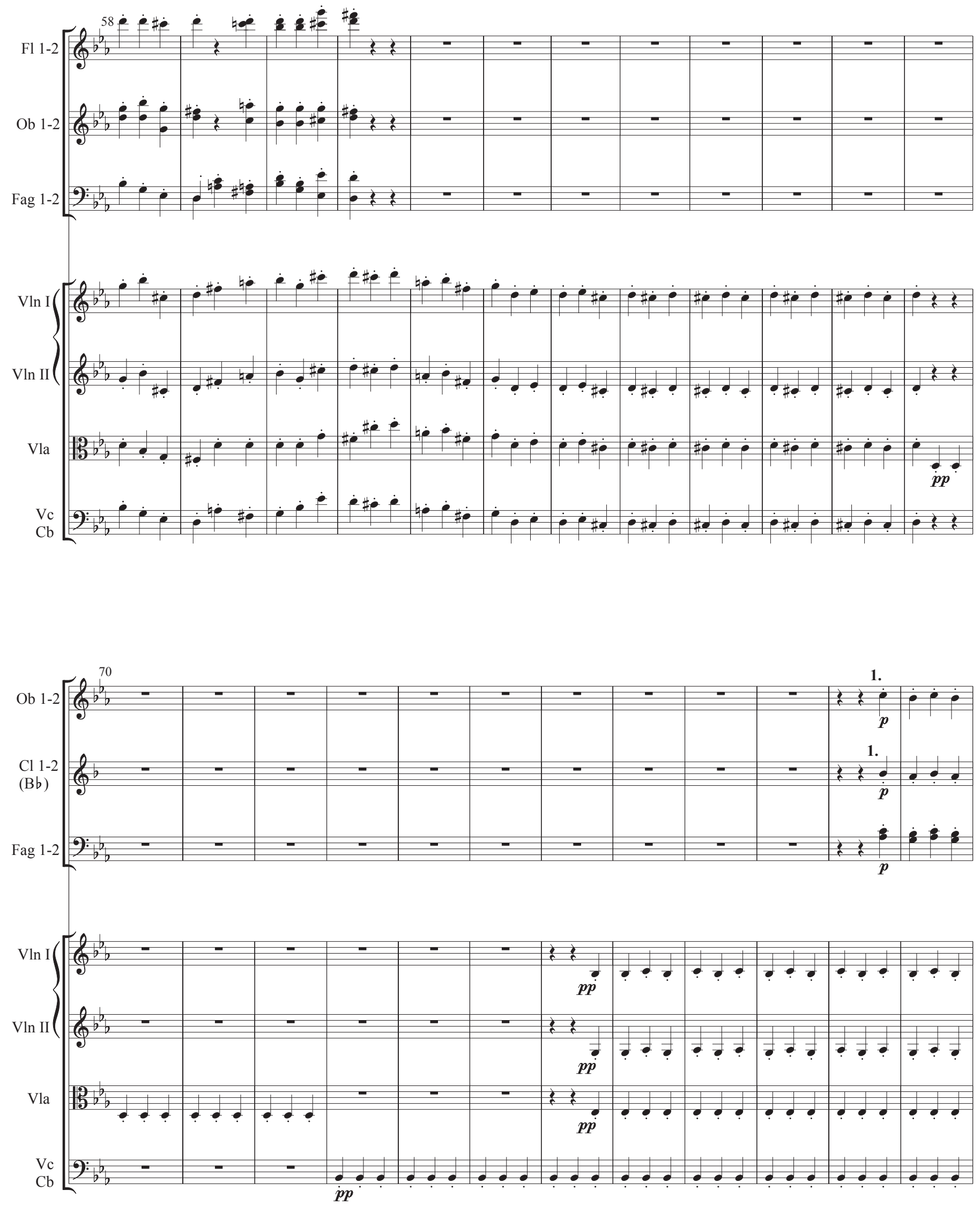

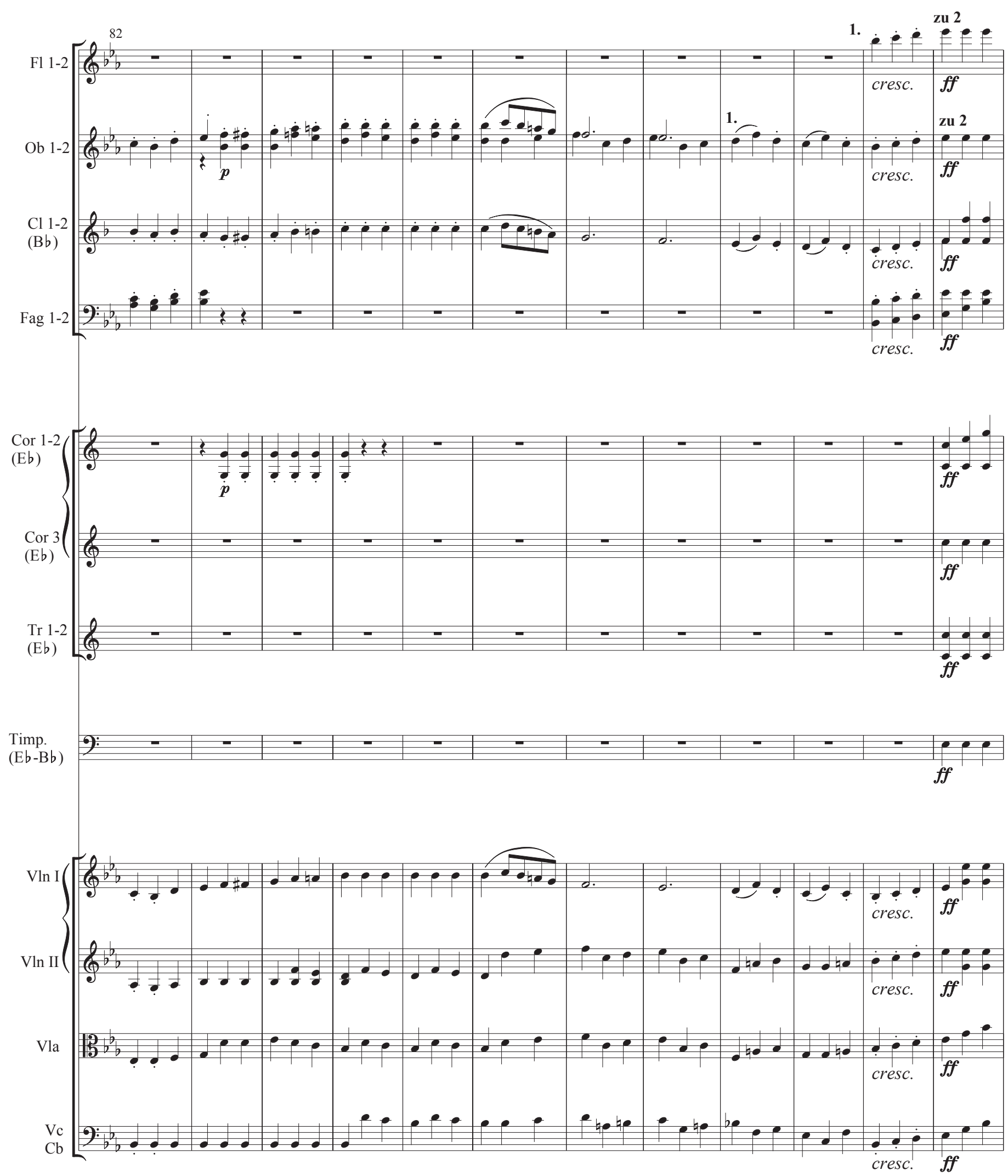

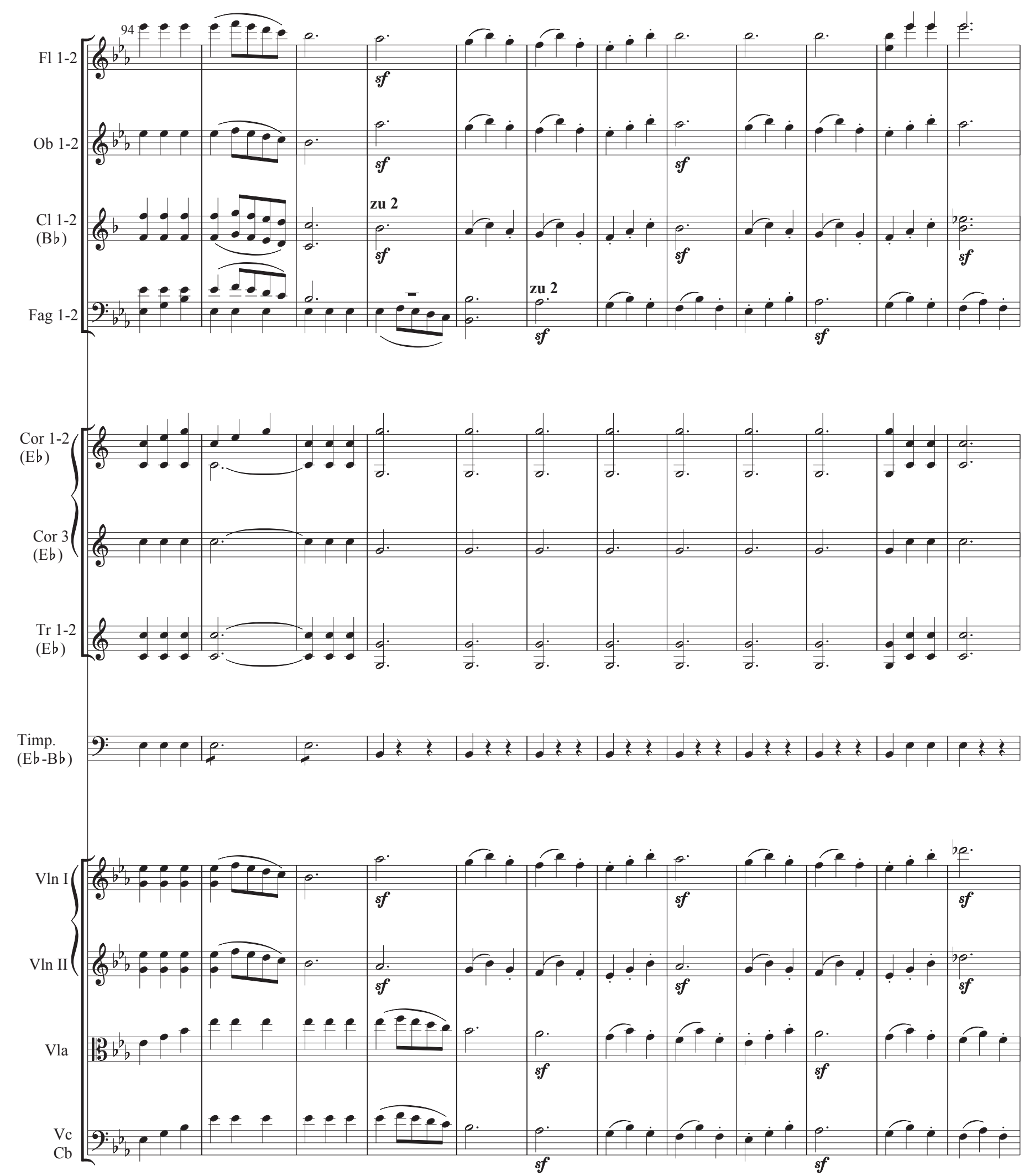

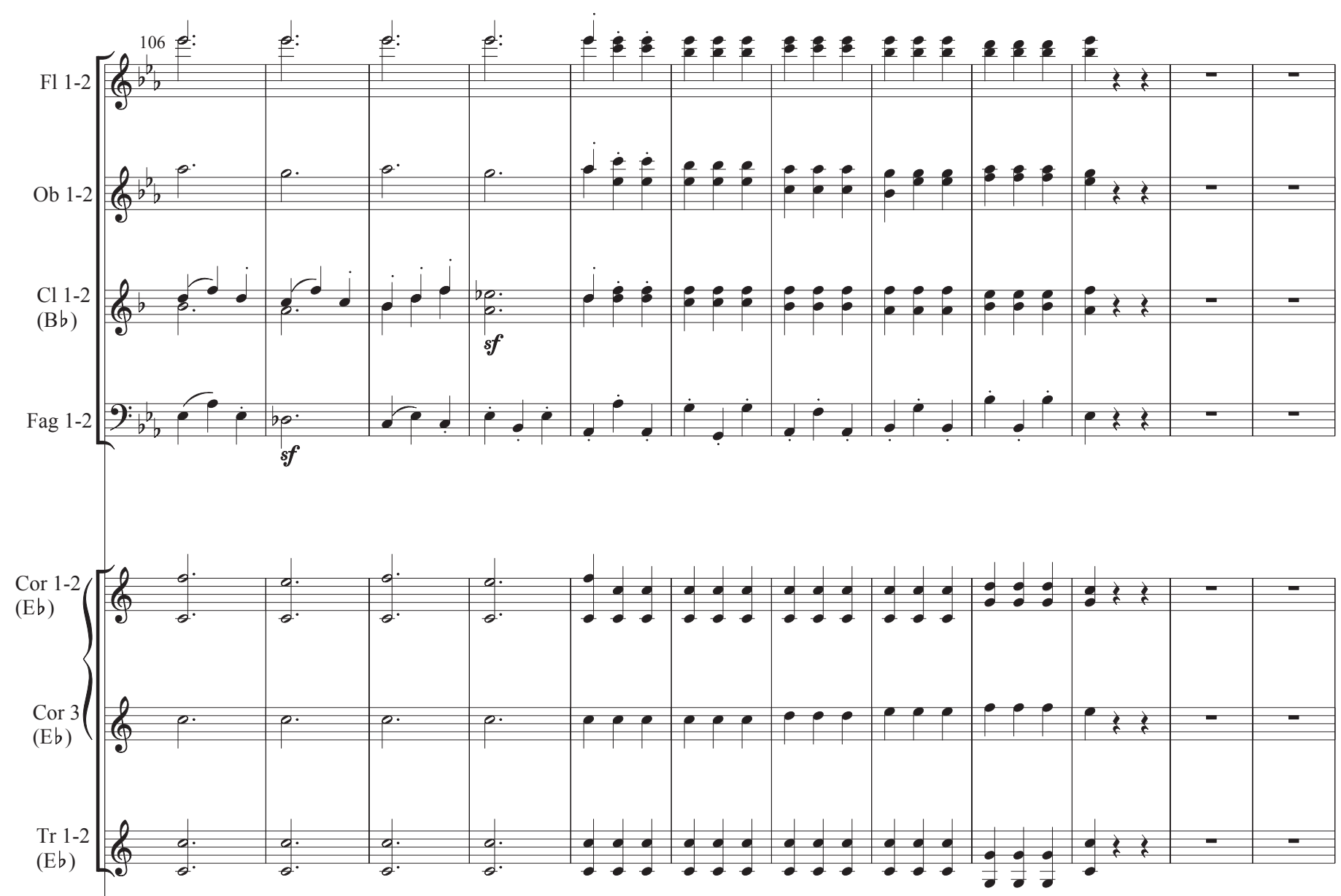

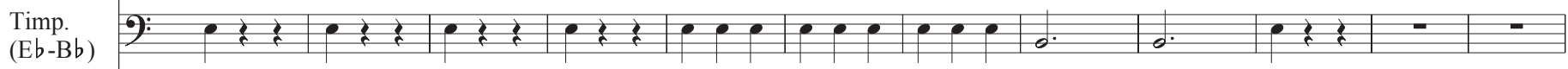

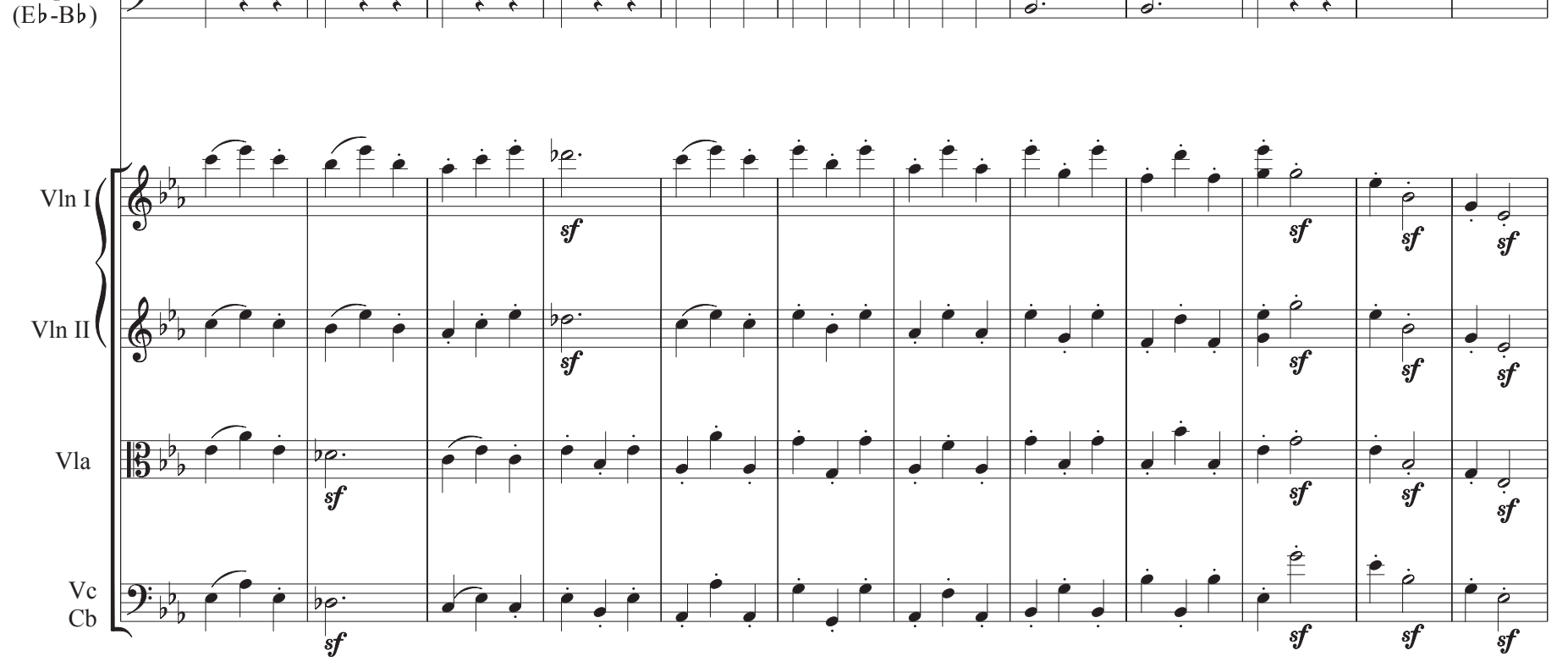



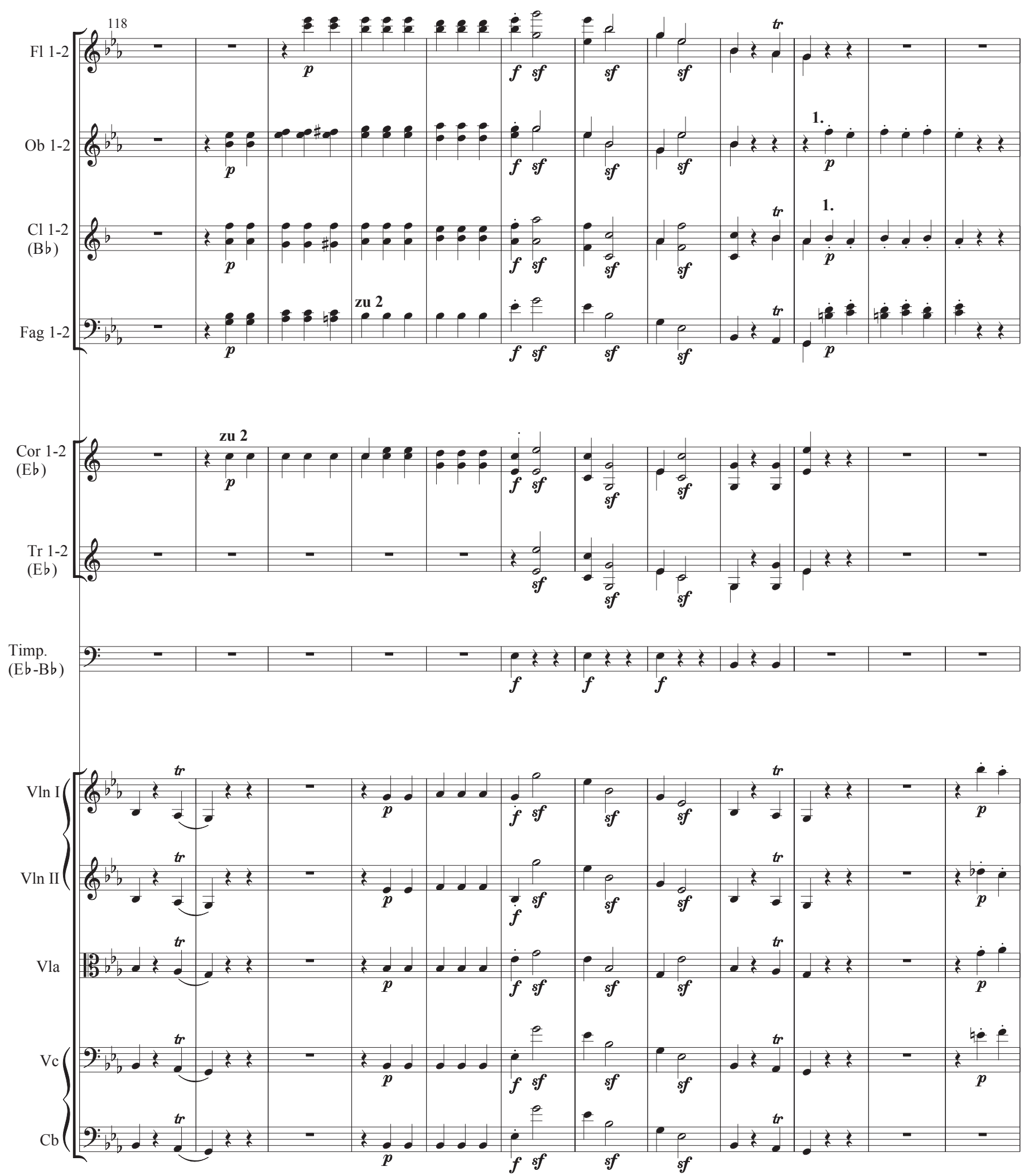

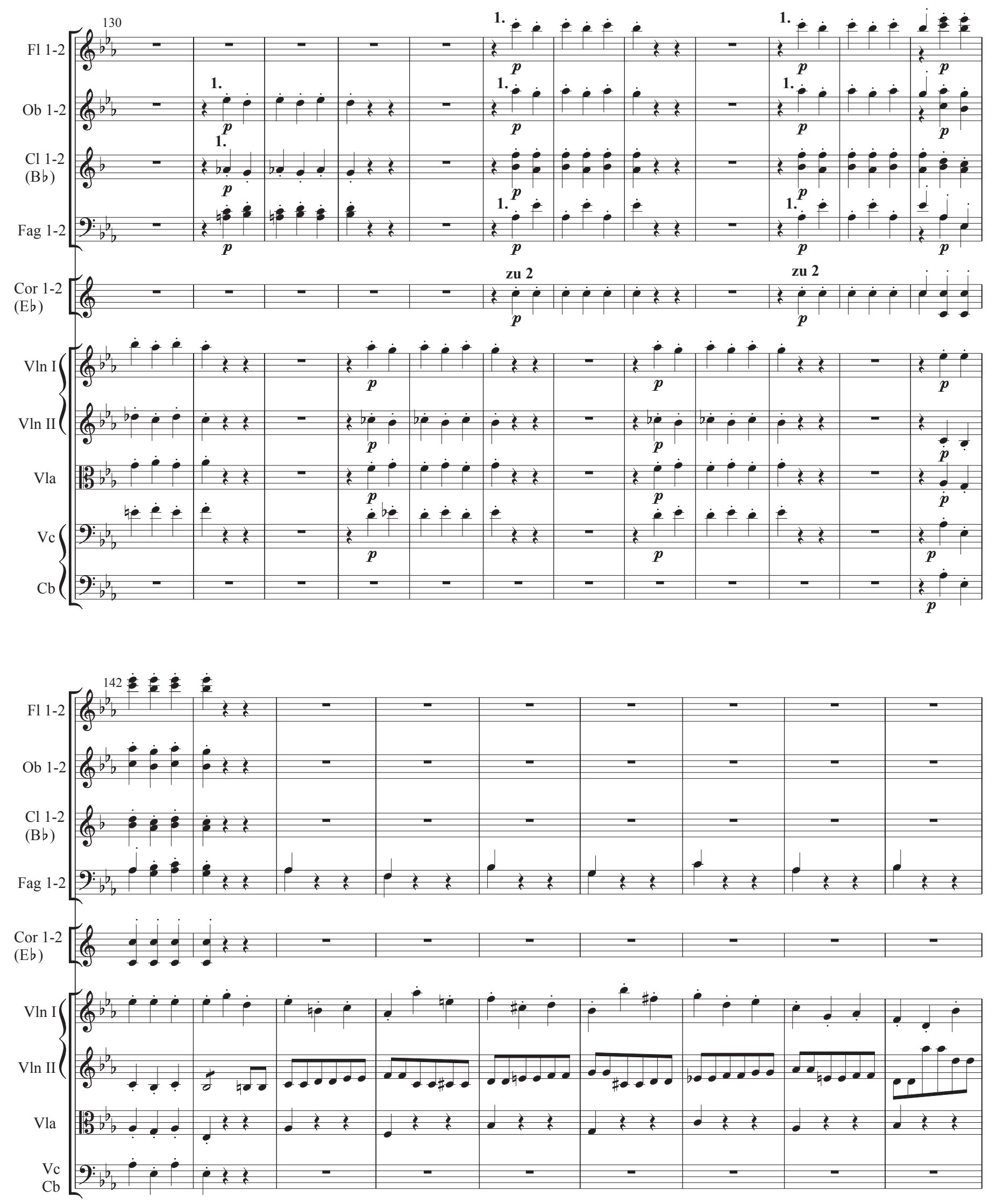

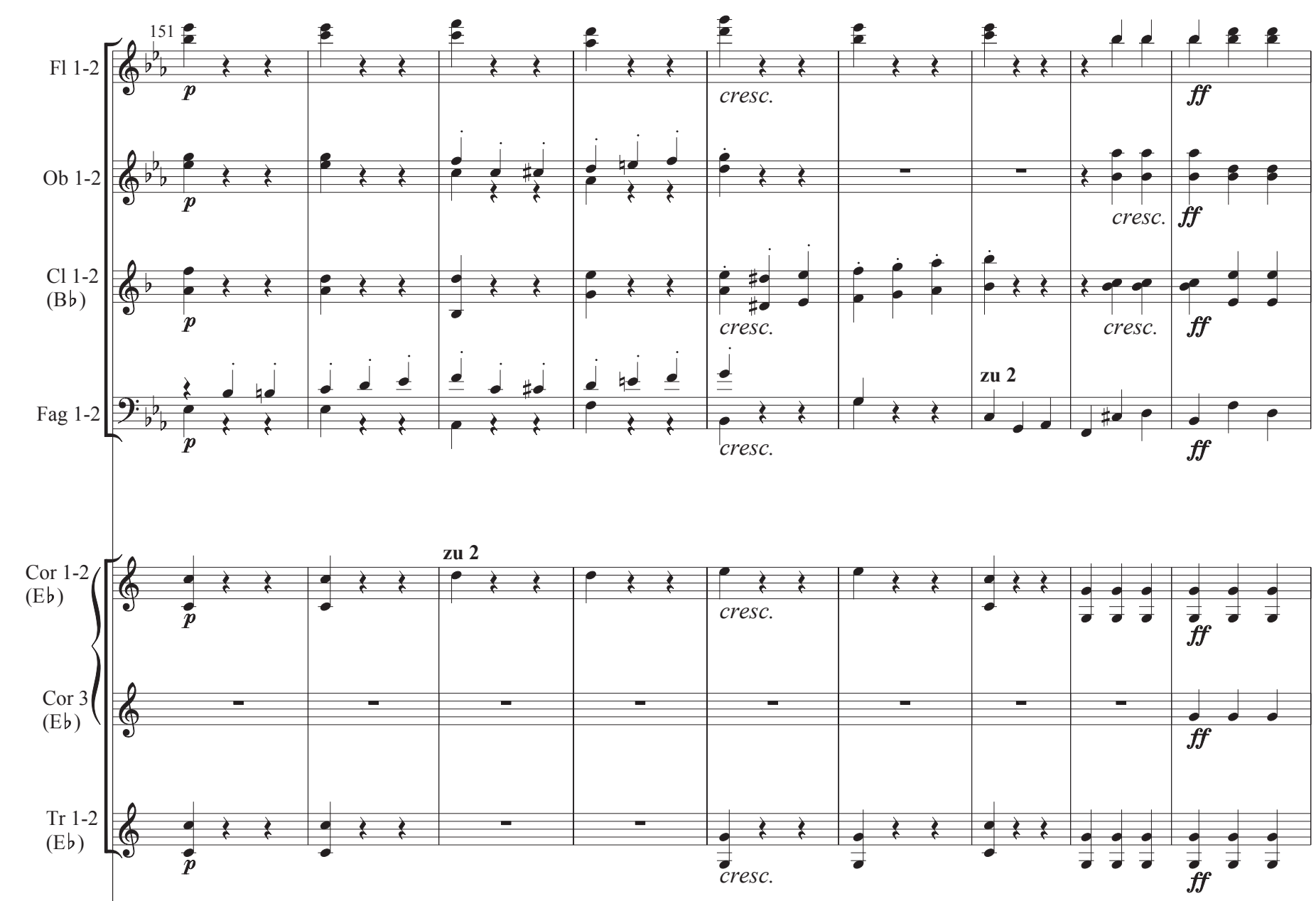

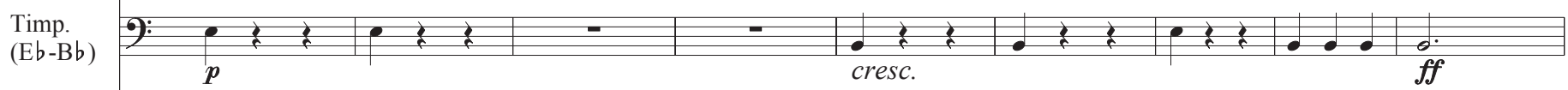

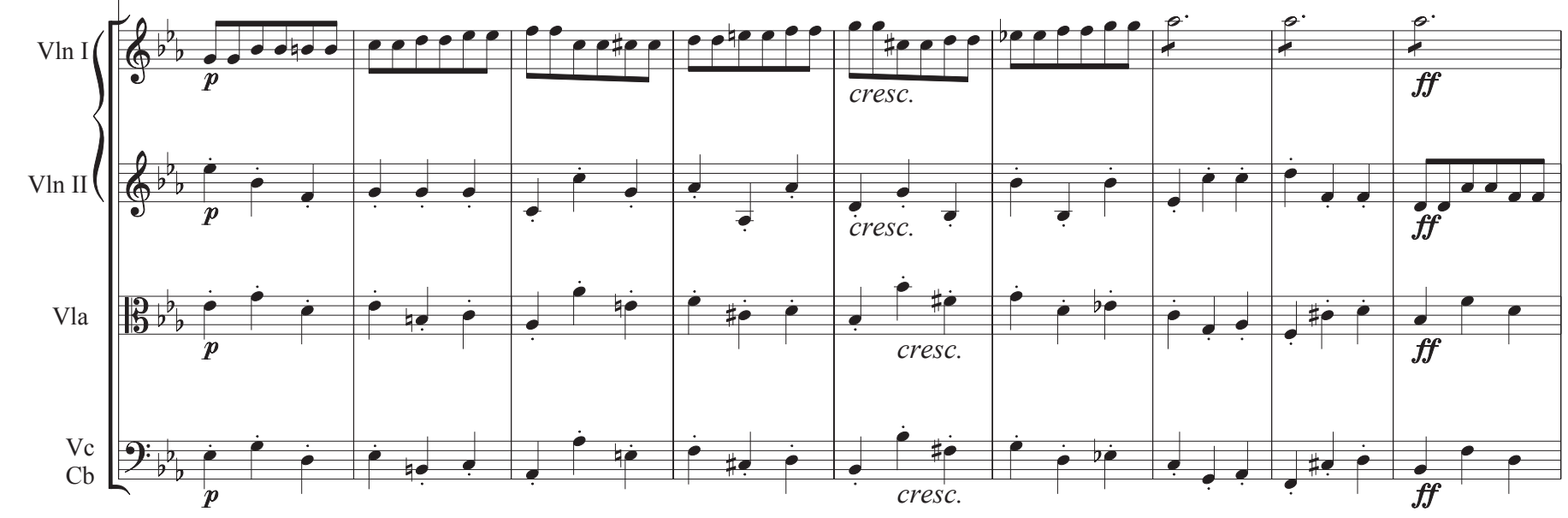



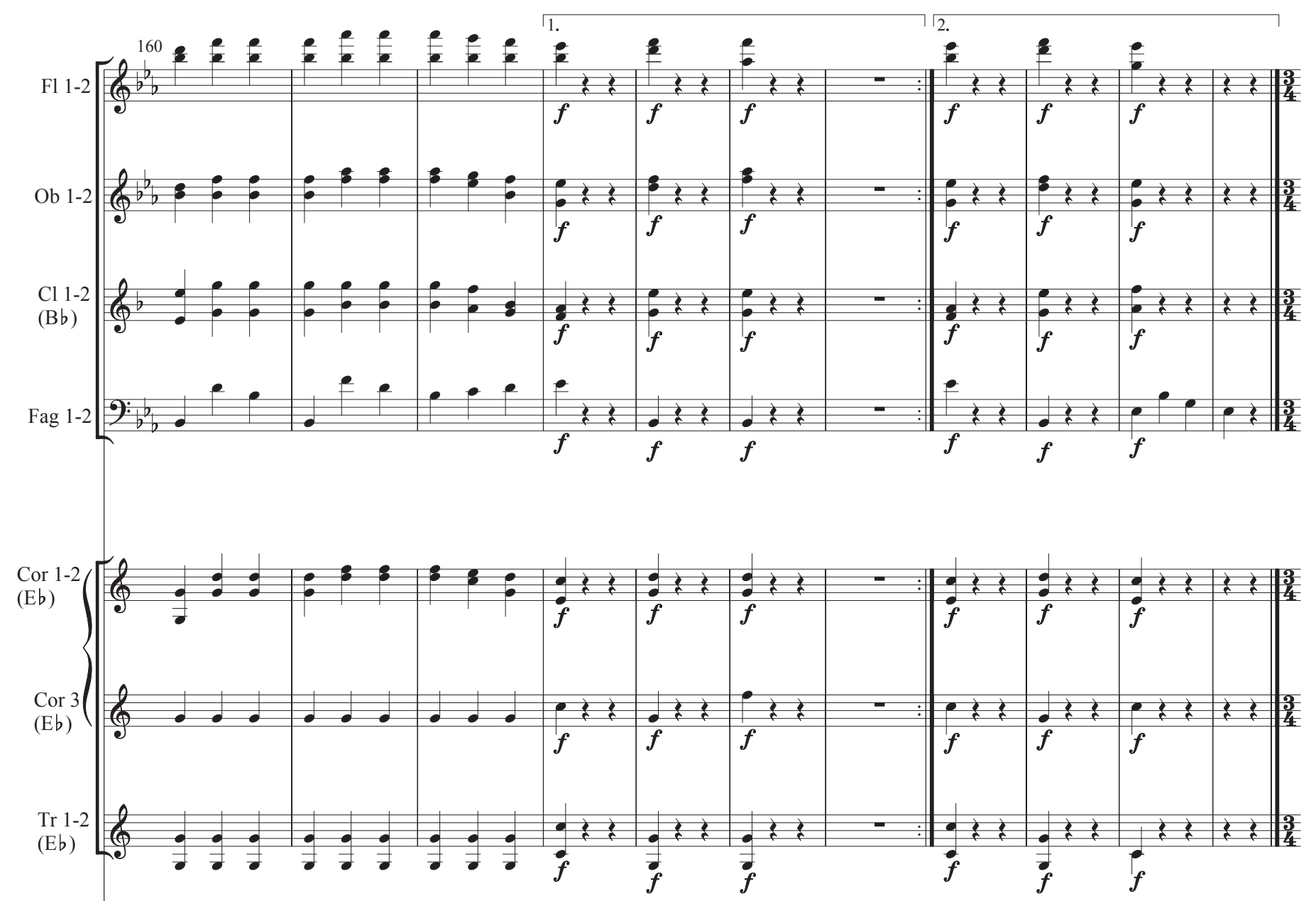

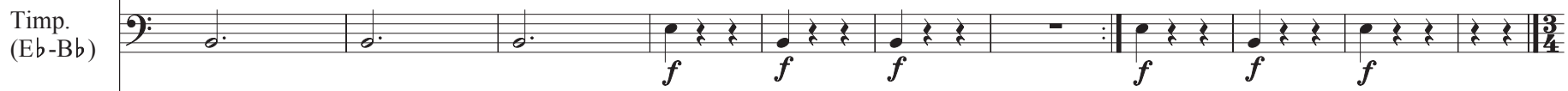

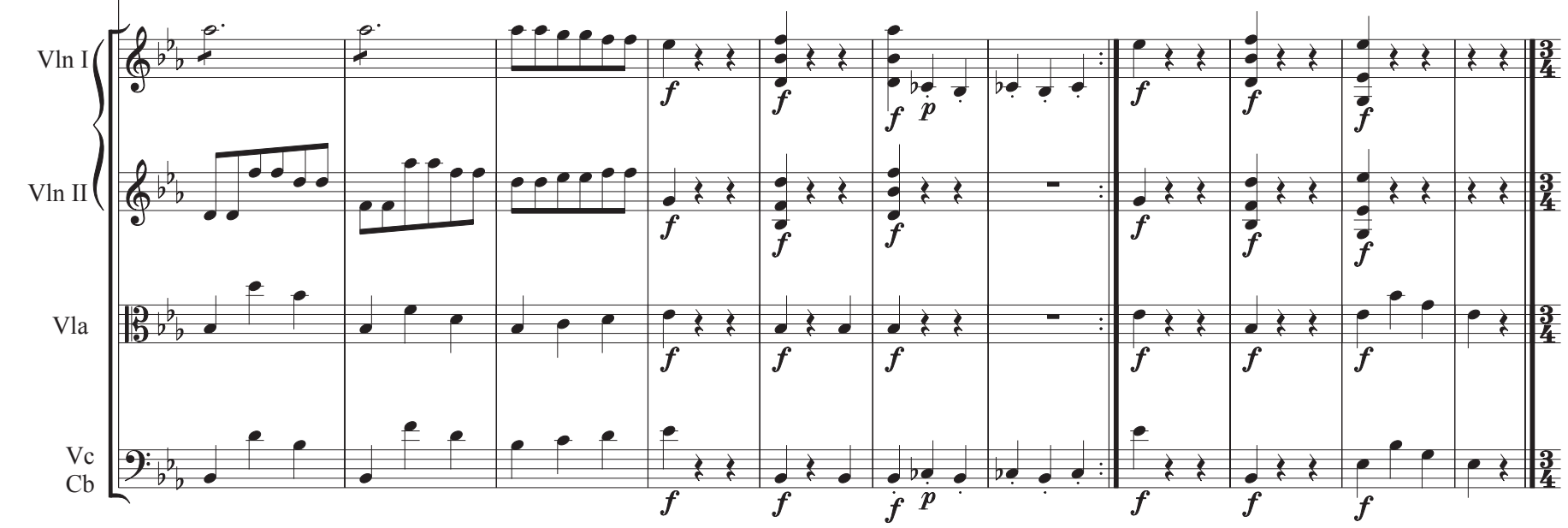


Trio

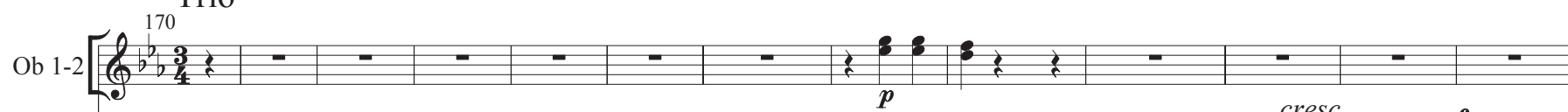

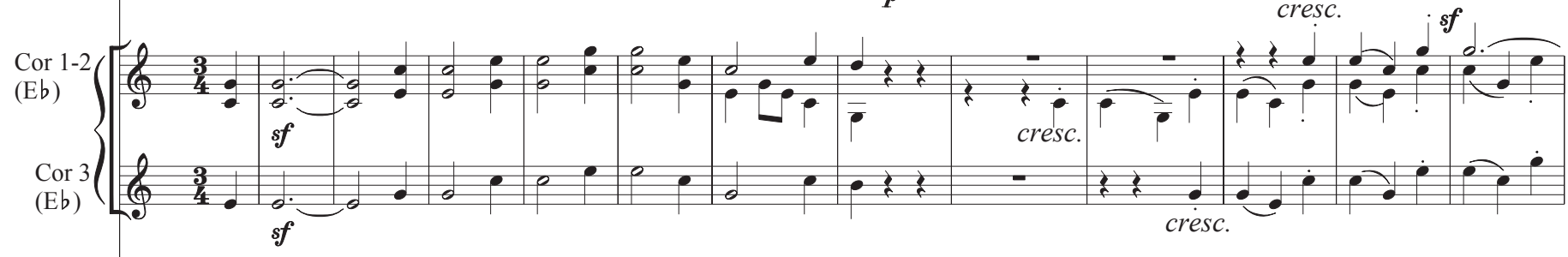

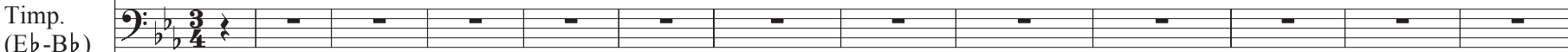
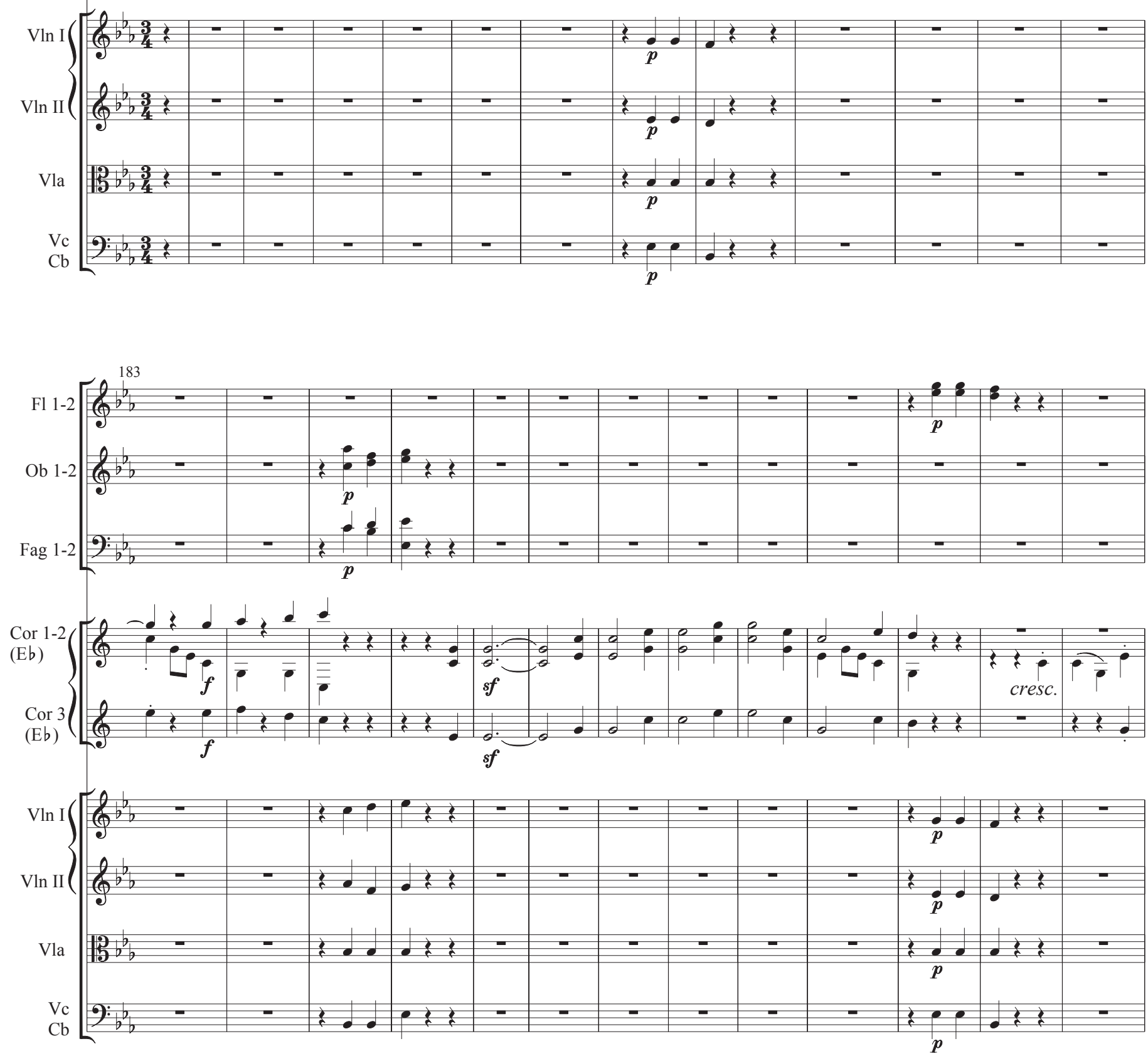

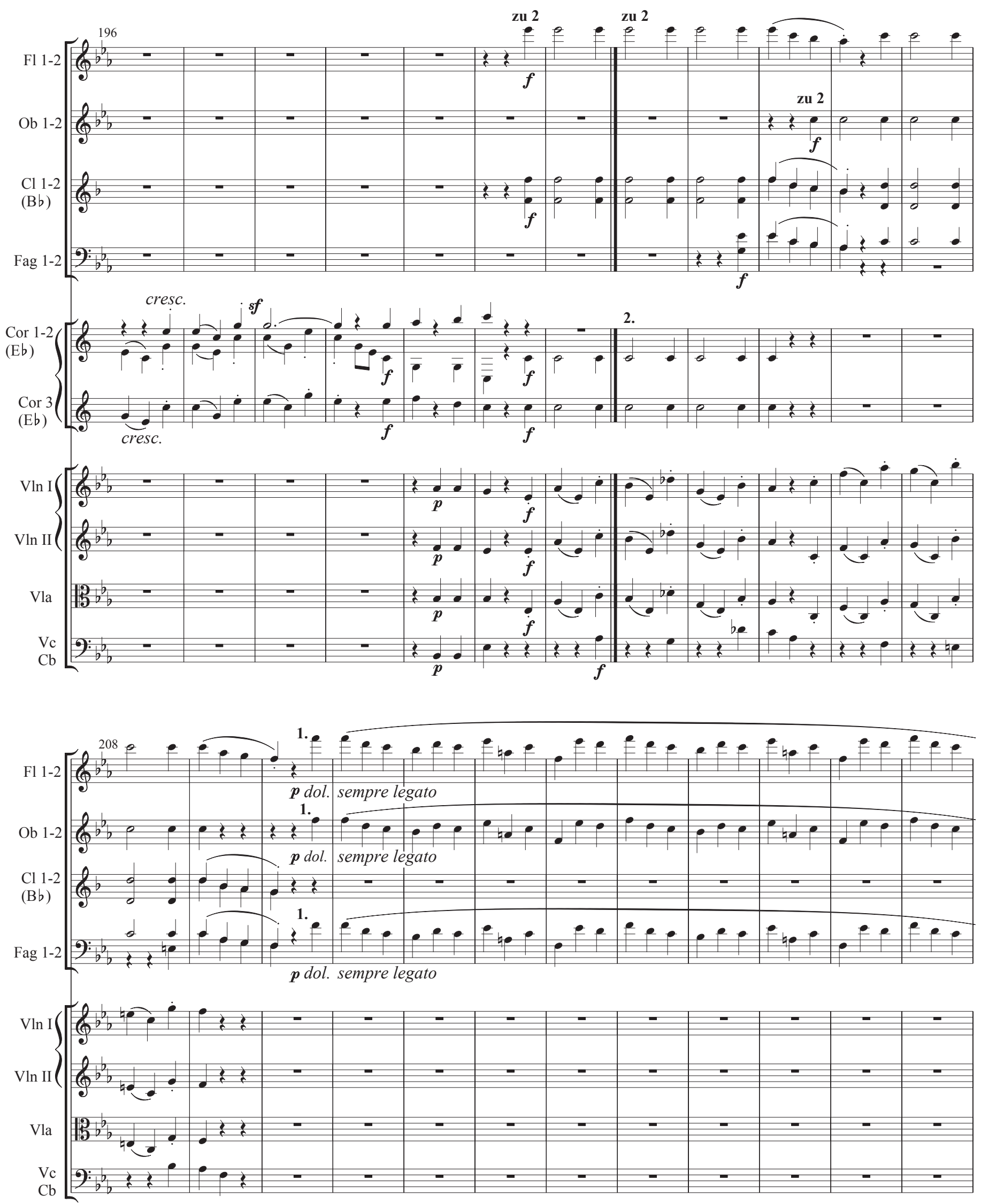

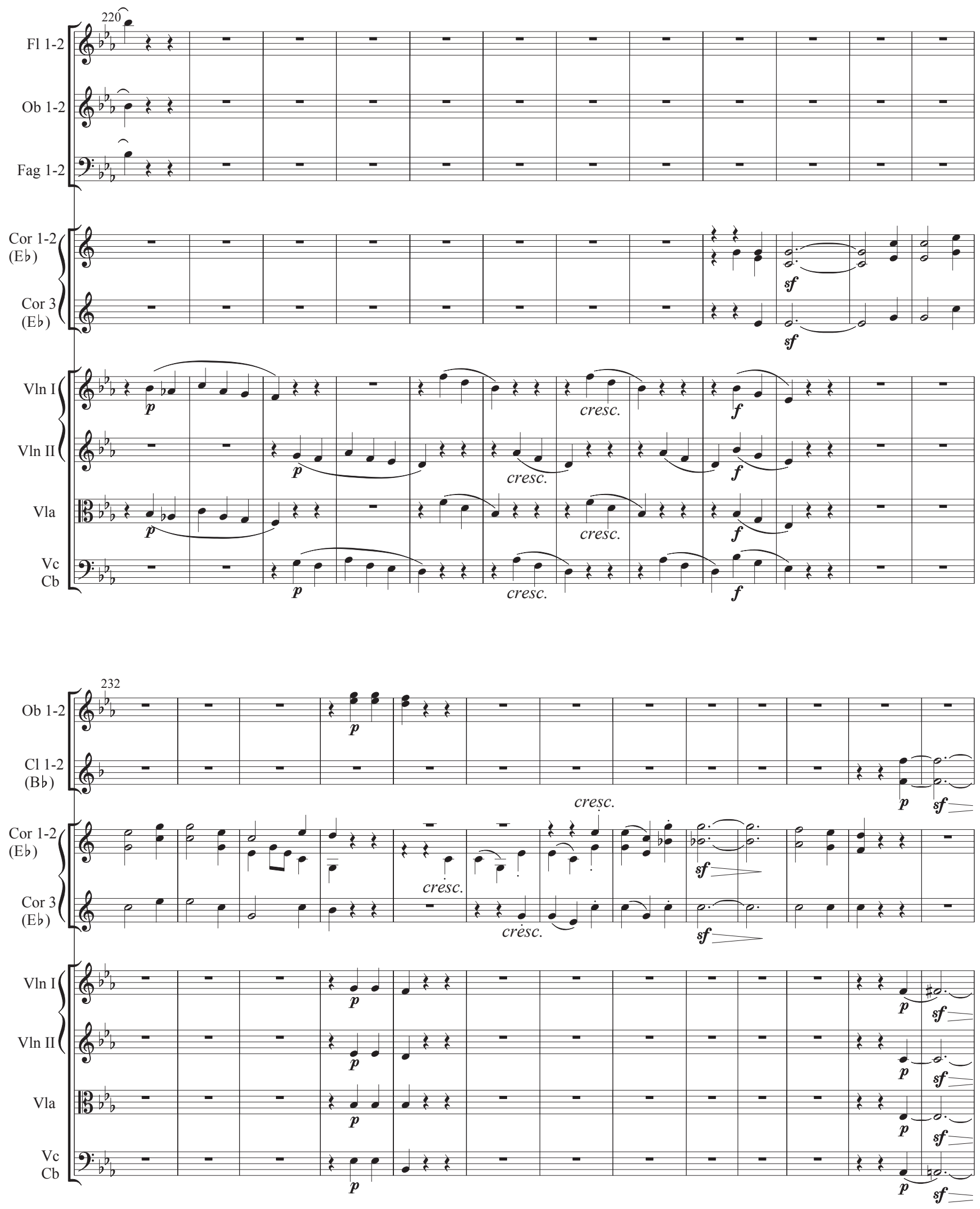


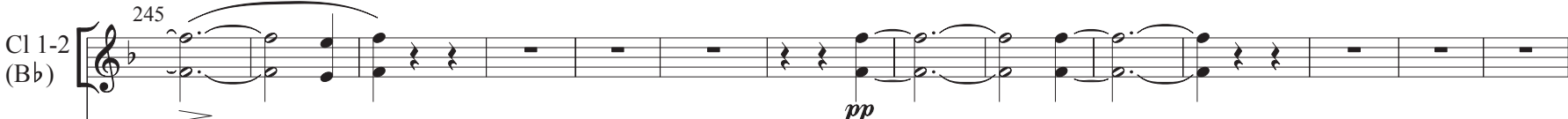
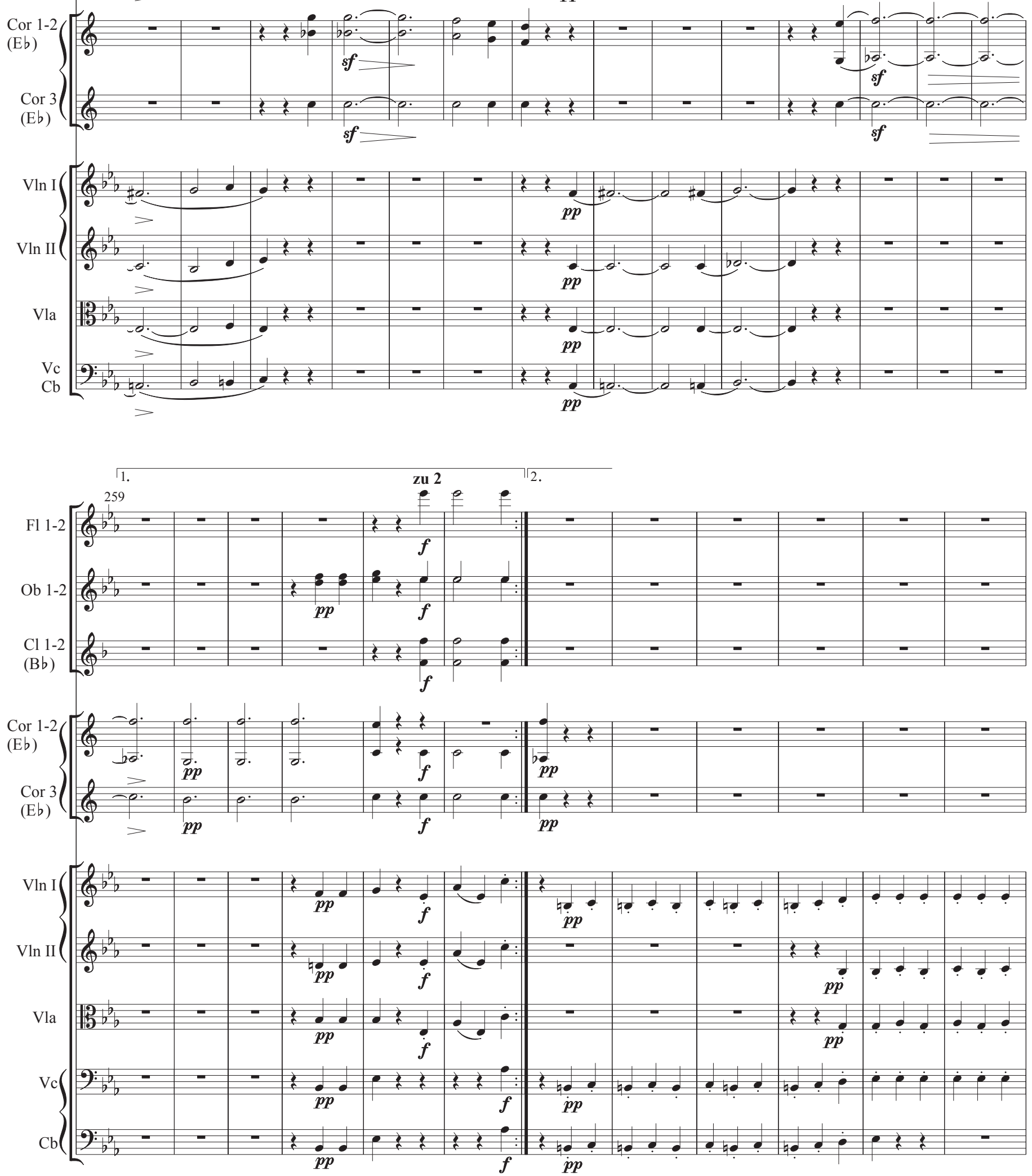
1.
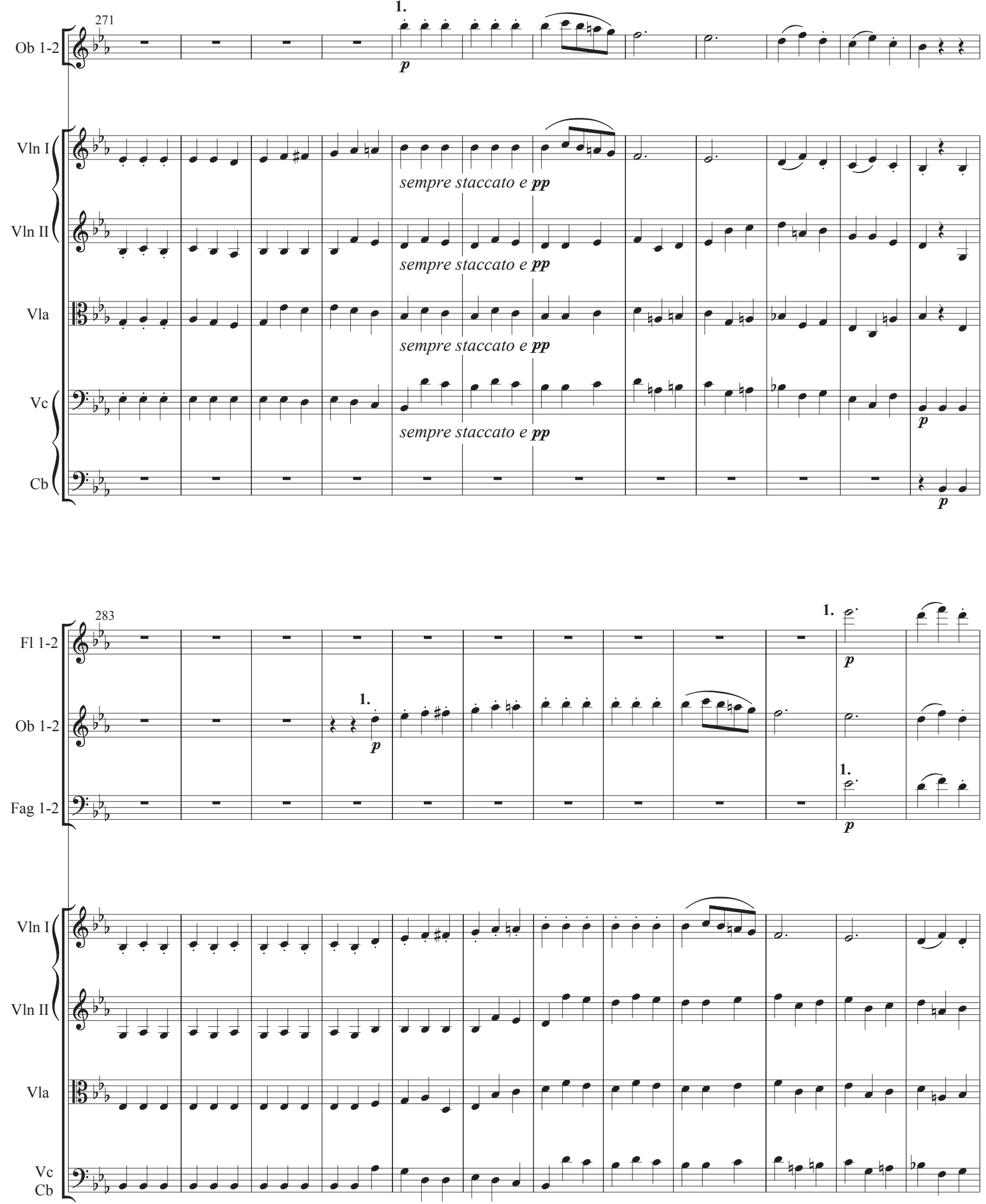

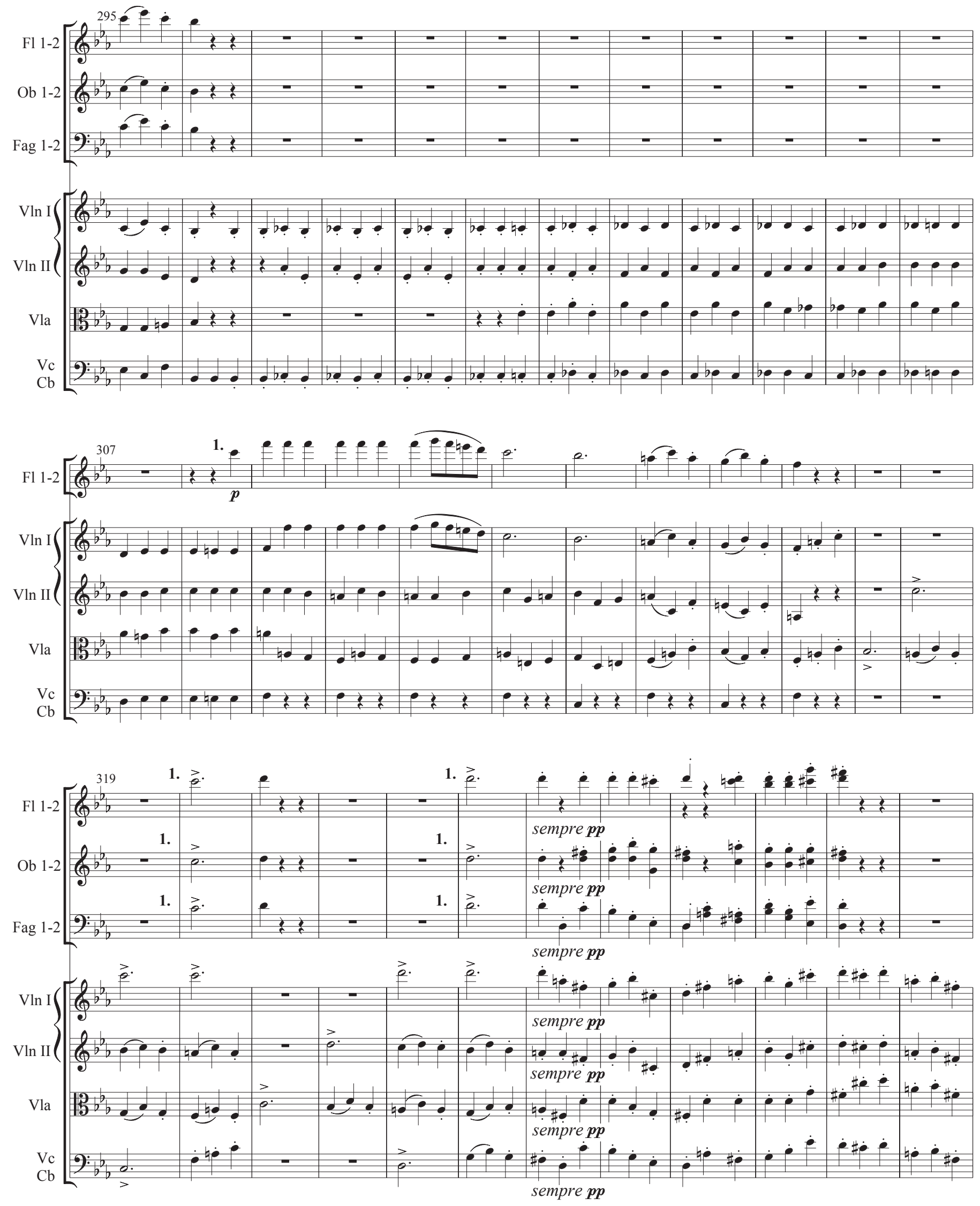

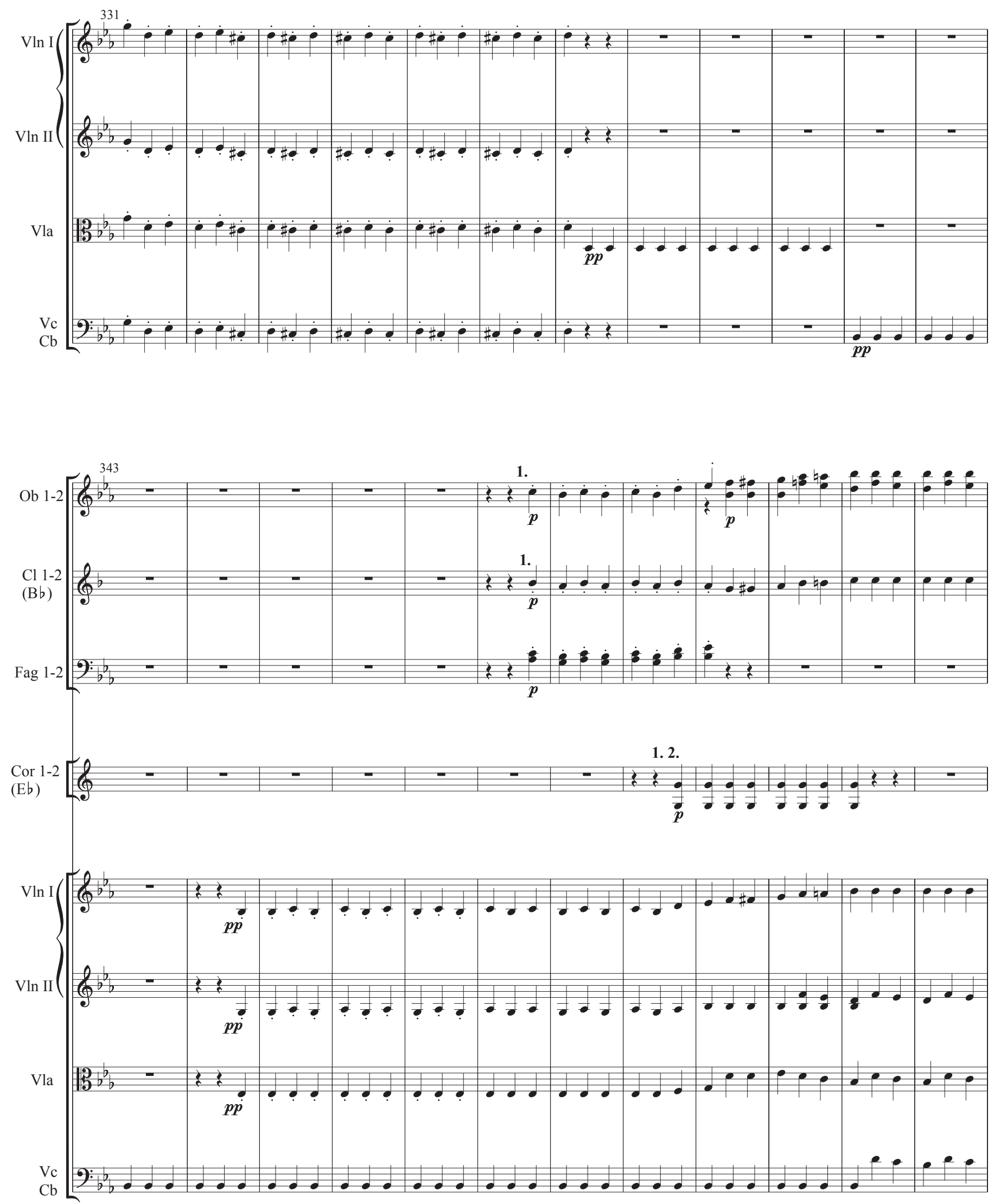

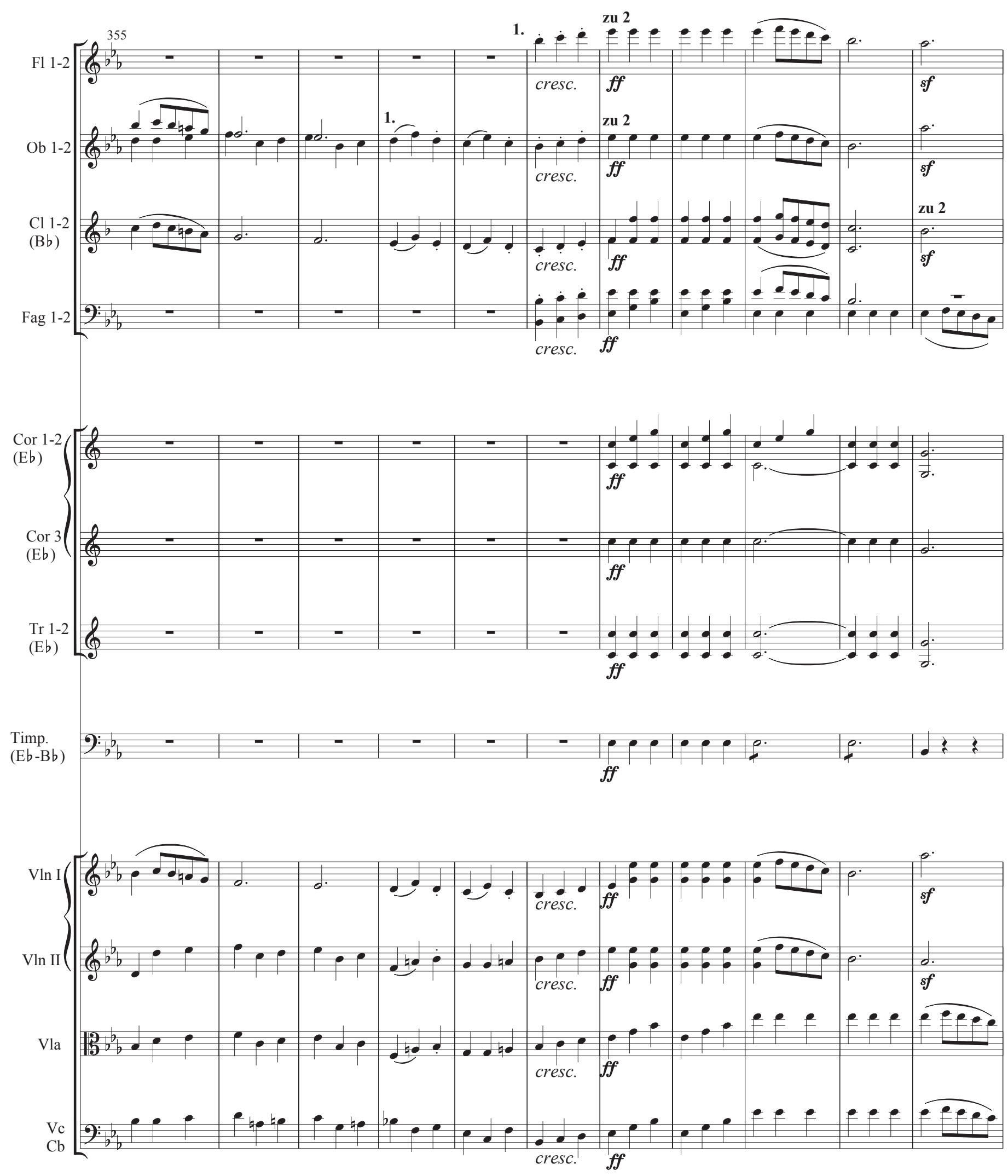

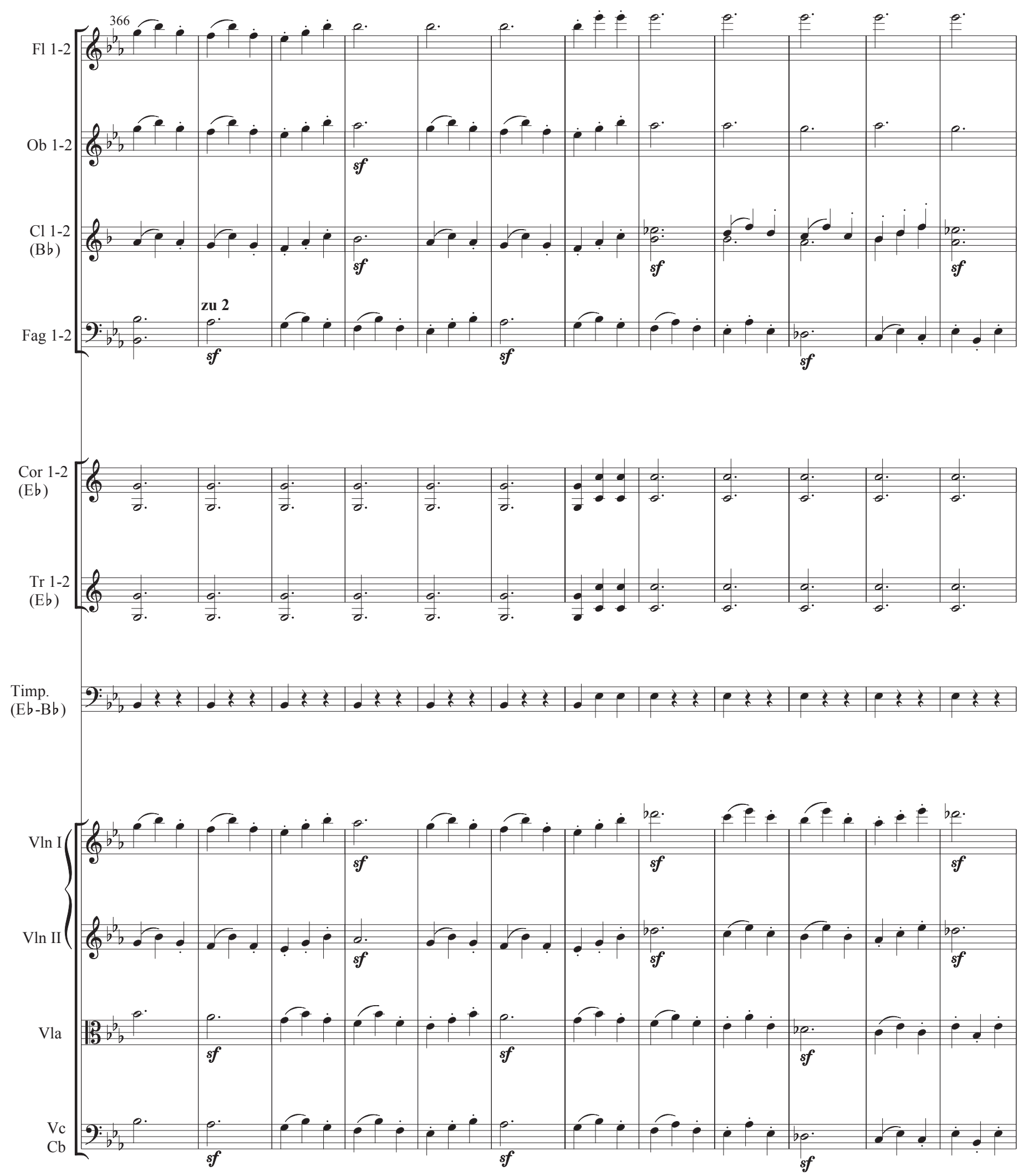

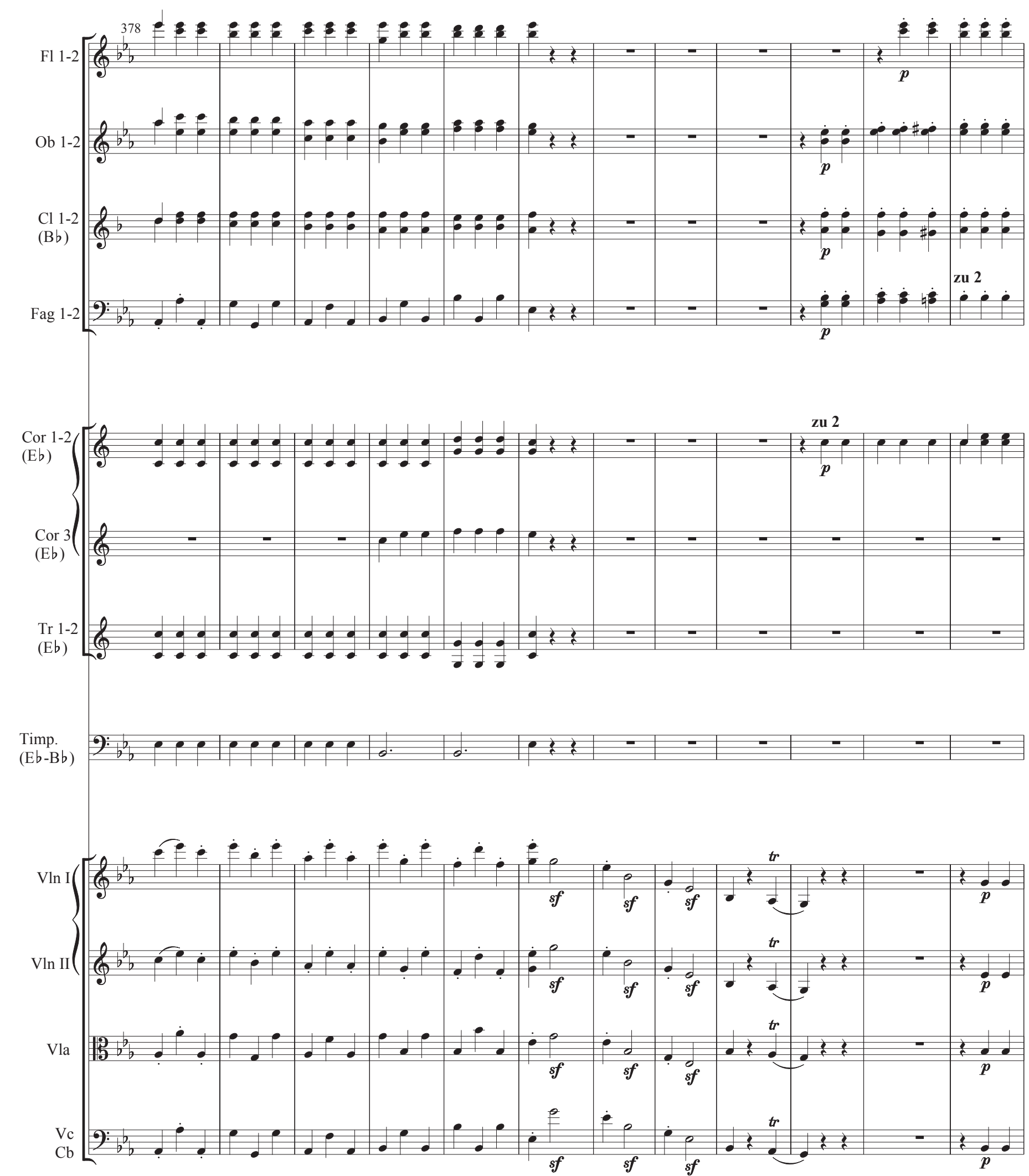
Alla breve.
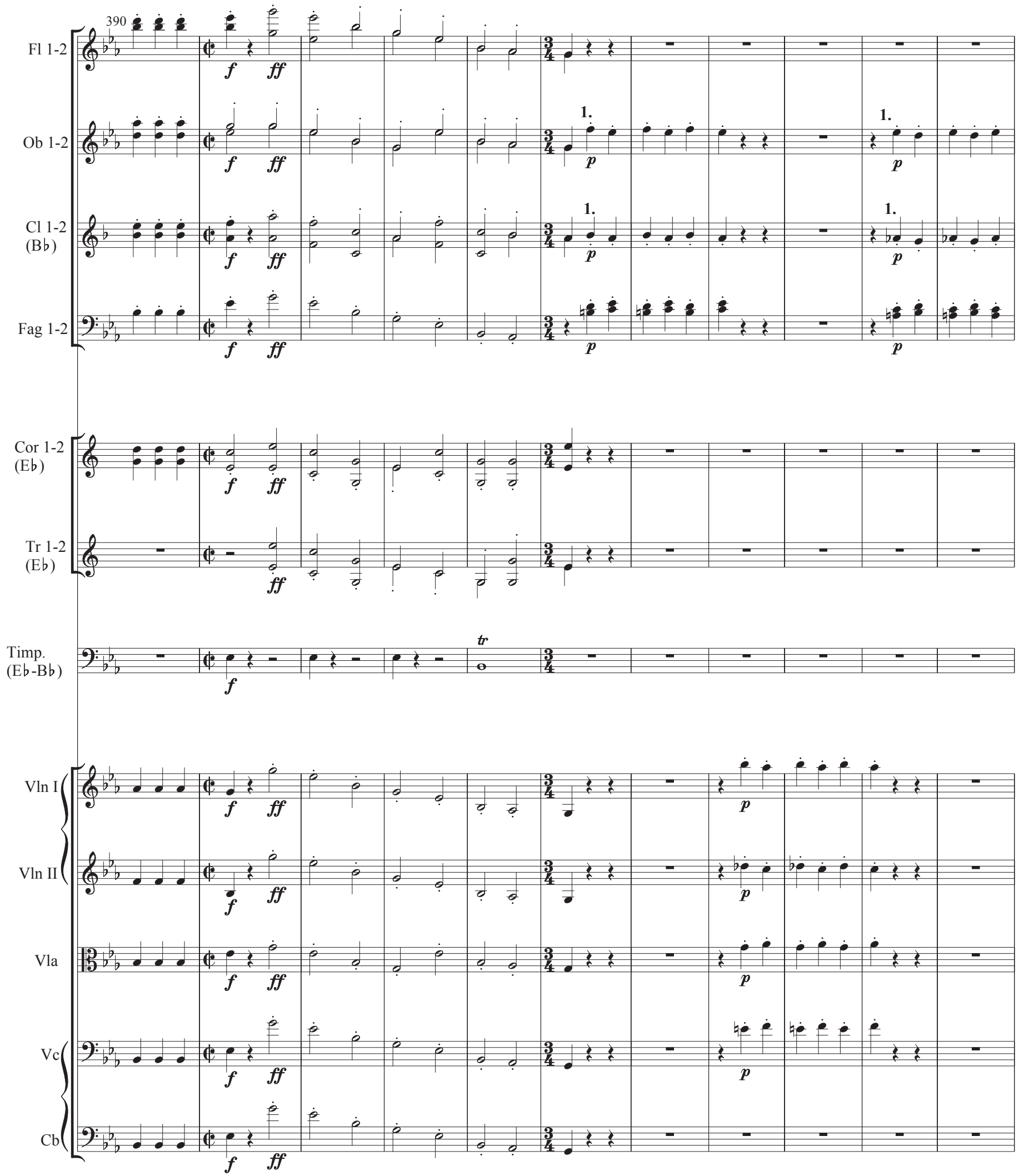


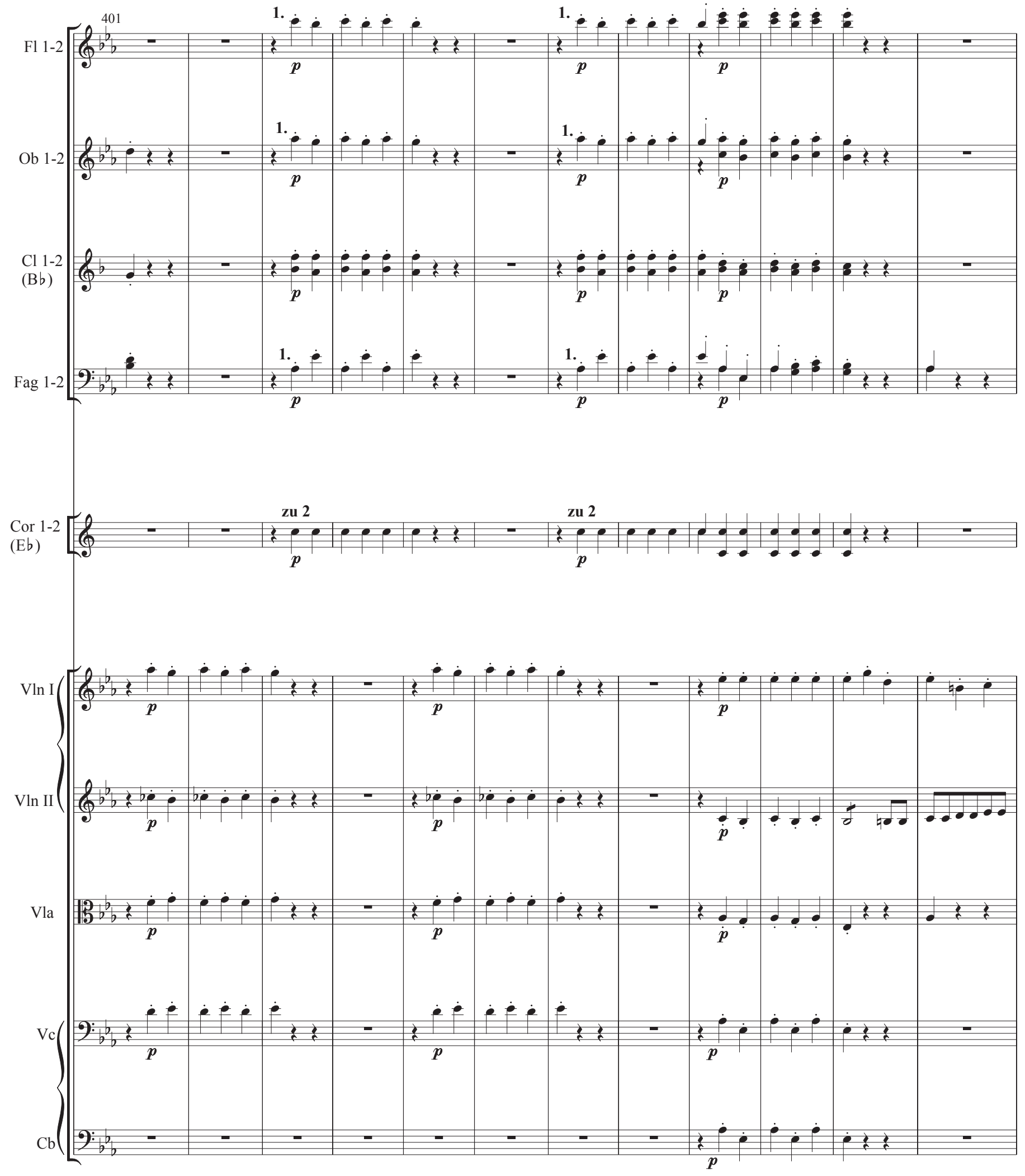



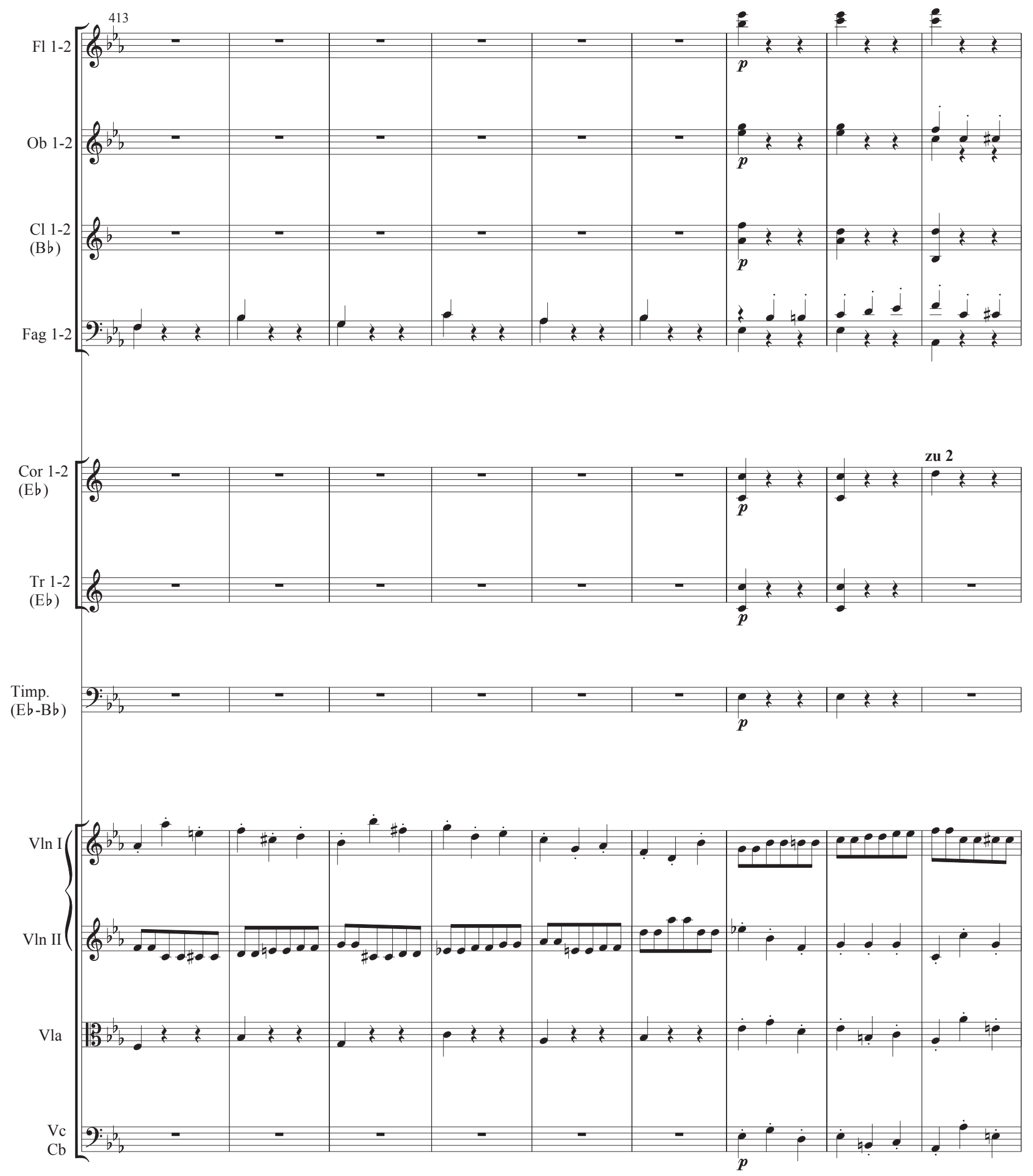

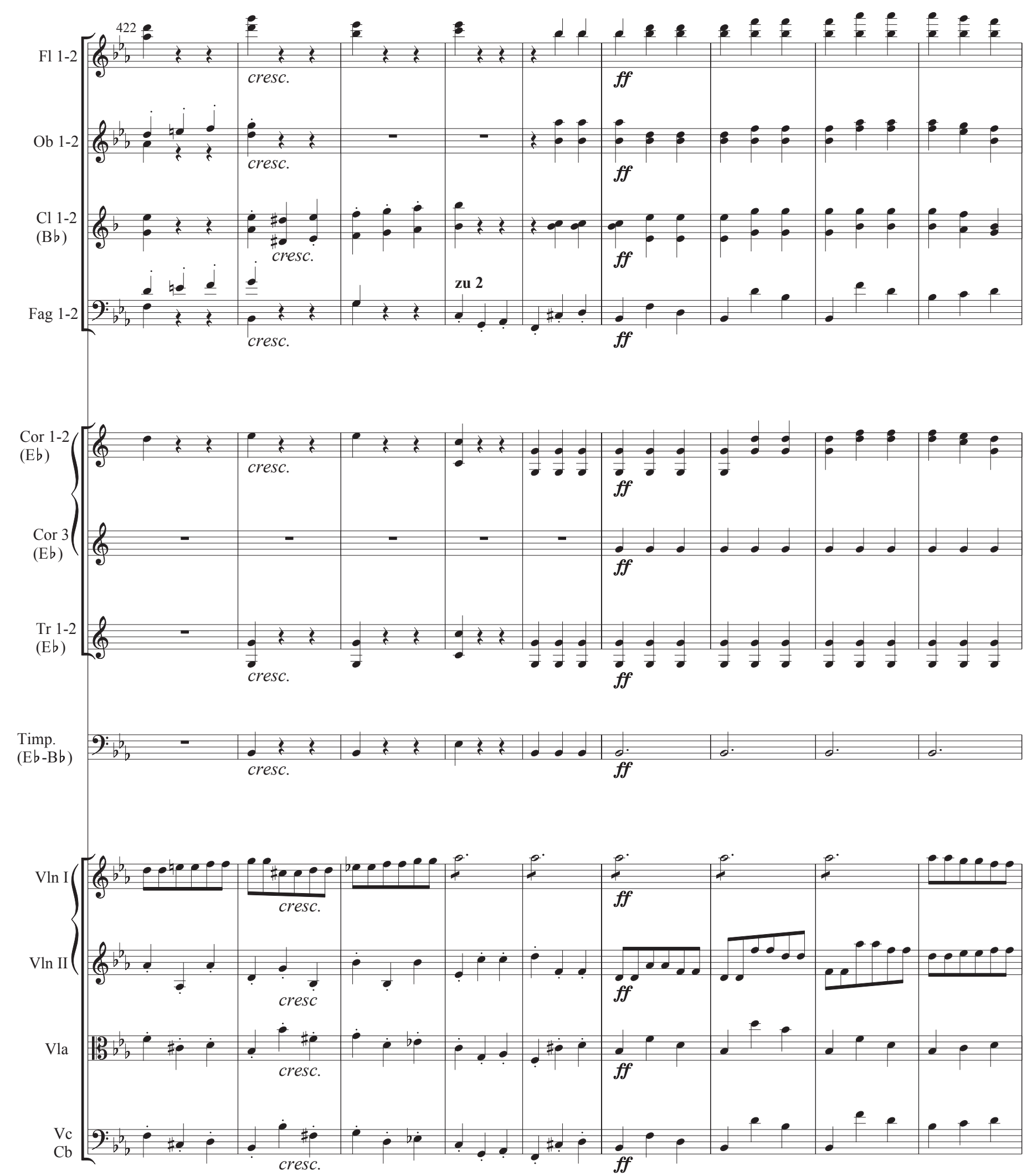

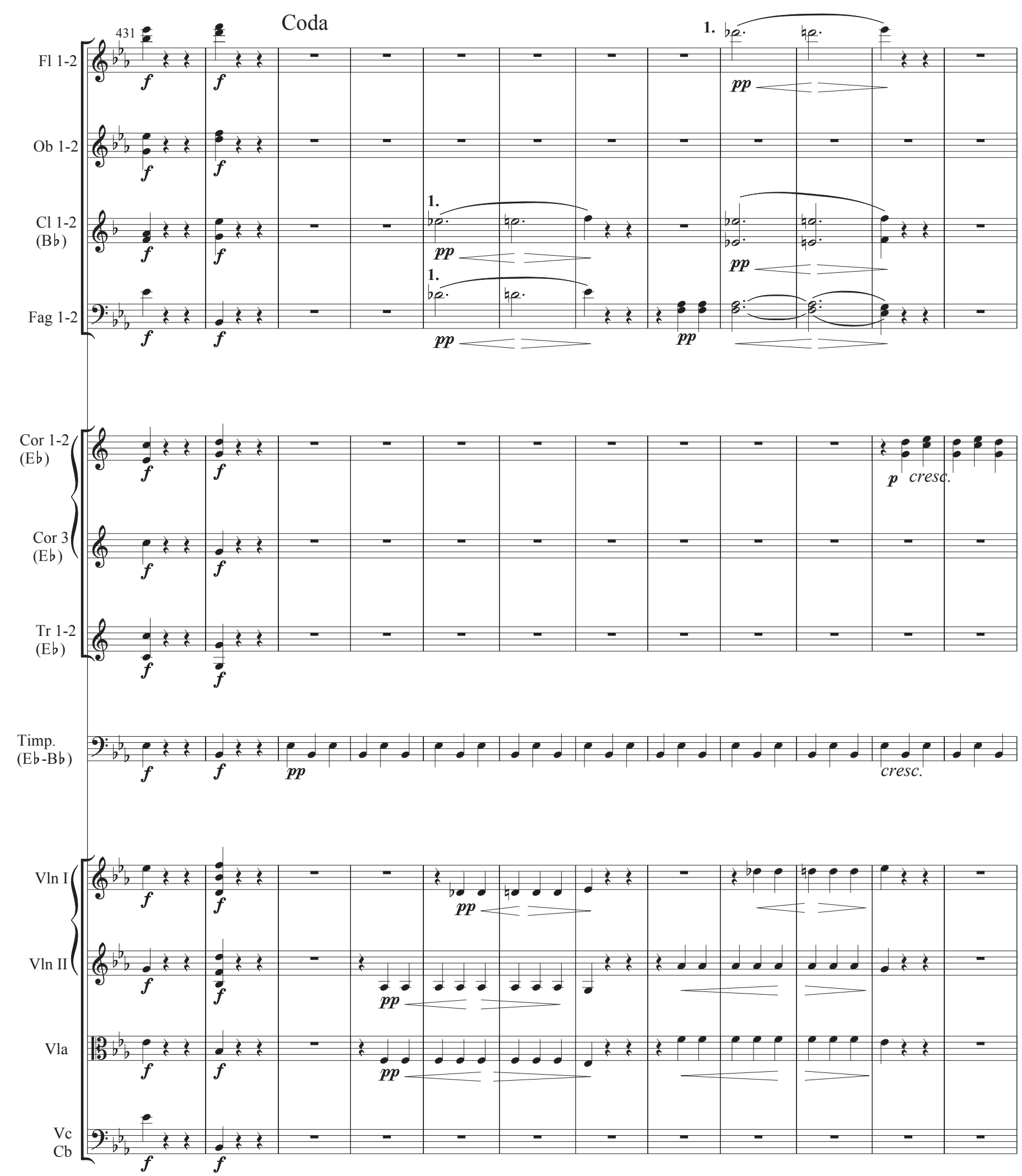

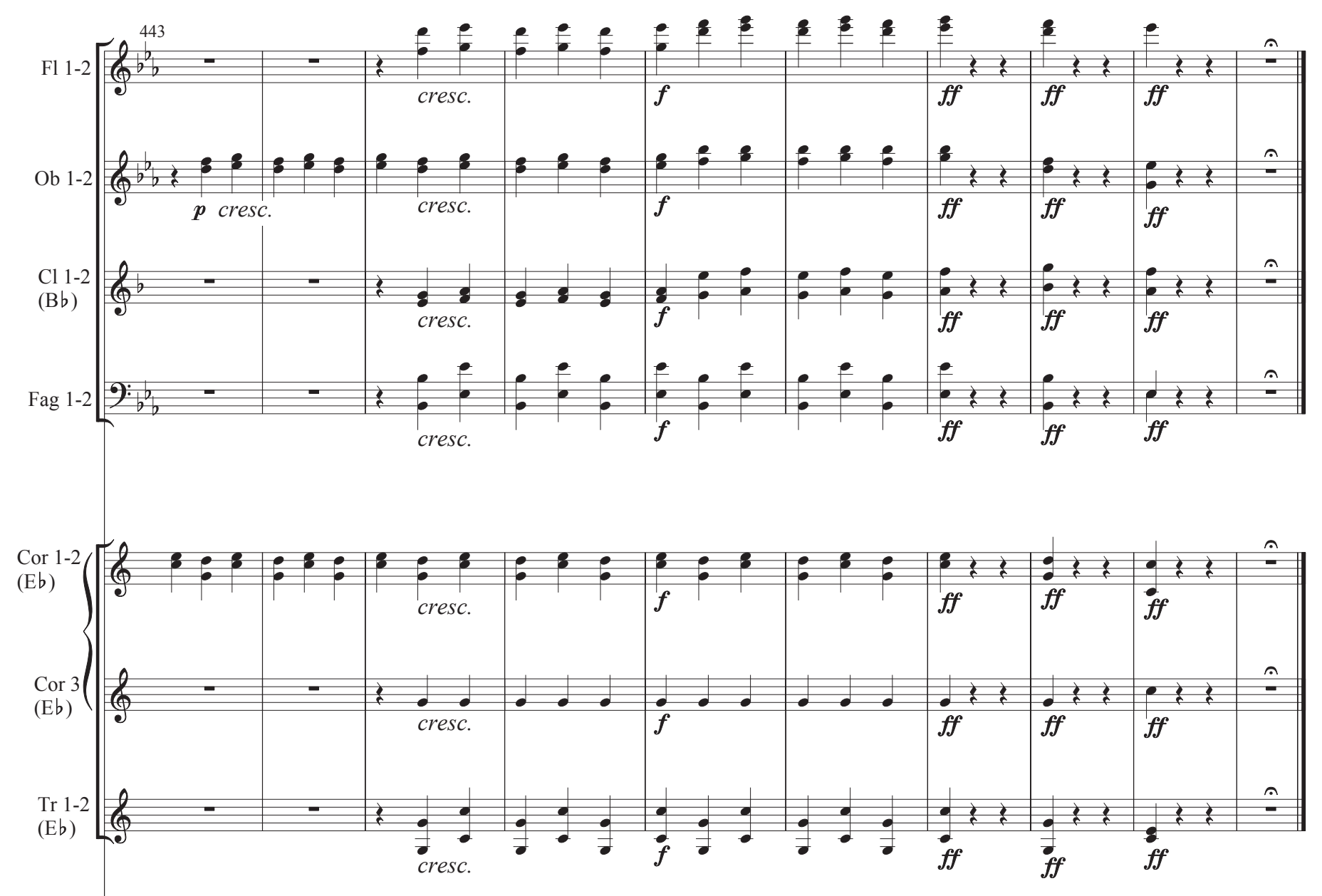

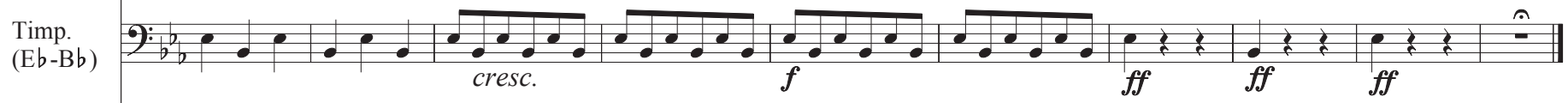

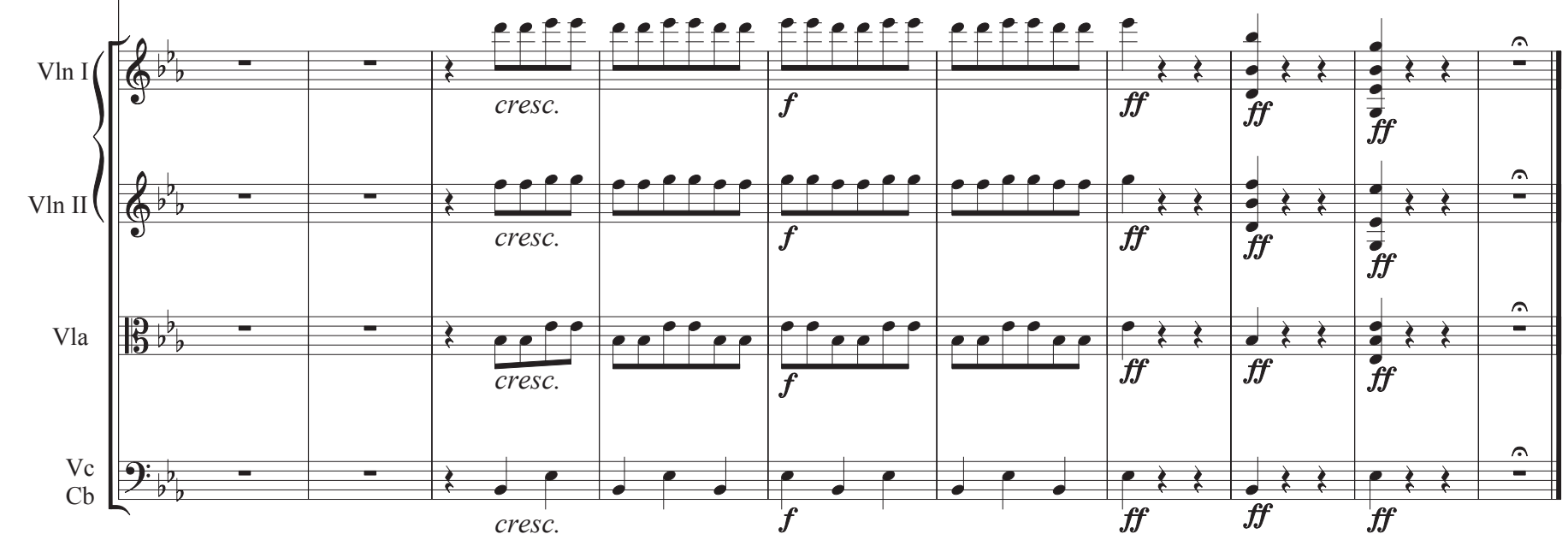


IV.

Allegro molto. $(d=76)$

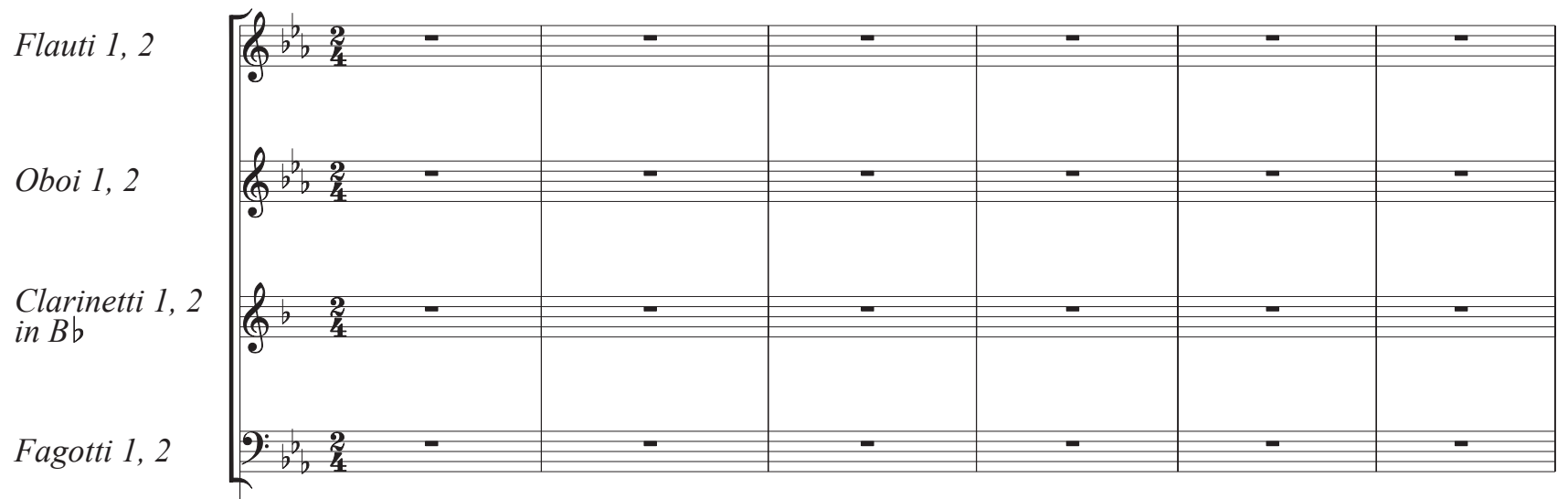

Corni 1, 2

in $E$ b

Corno 3

in $E$ b

Trombe 1, 2 in $E$ b

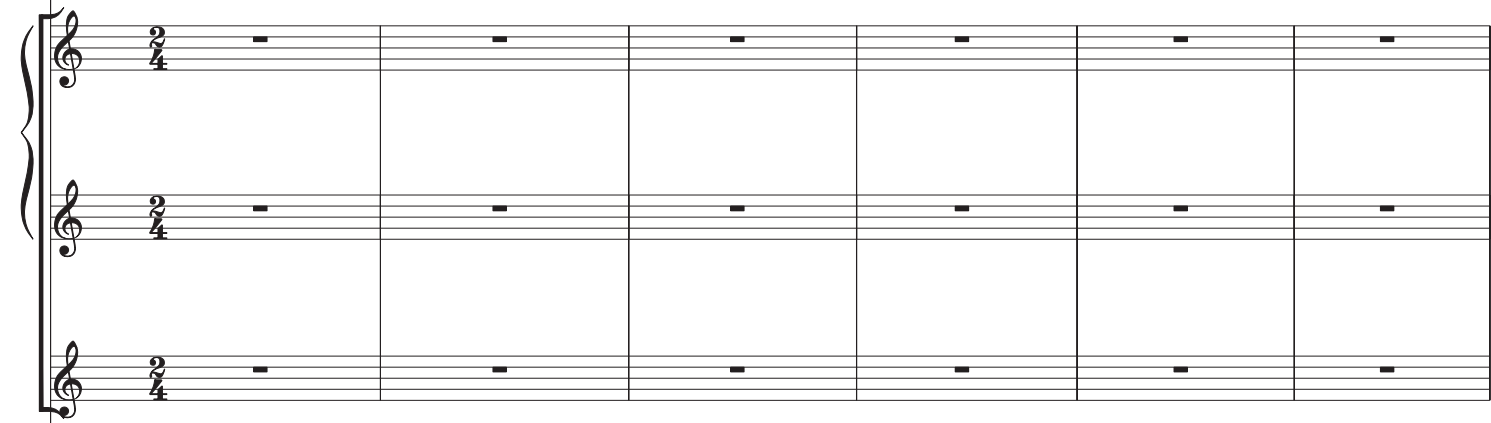

Timpani

in $E b-B b$

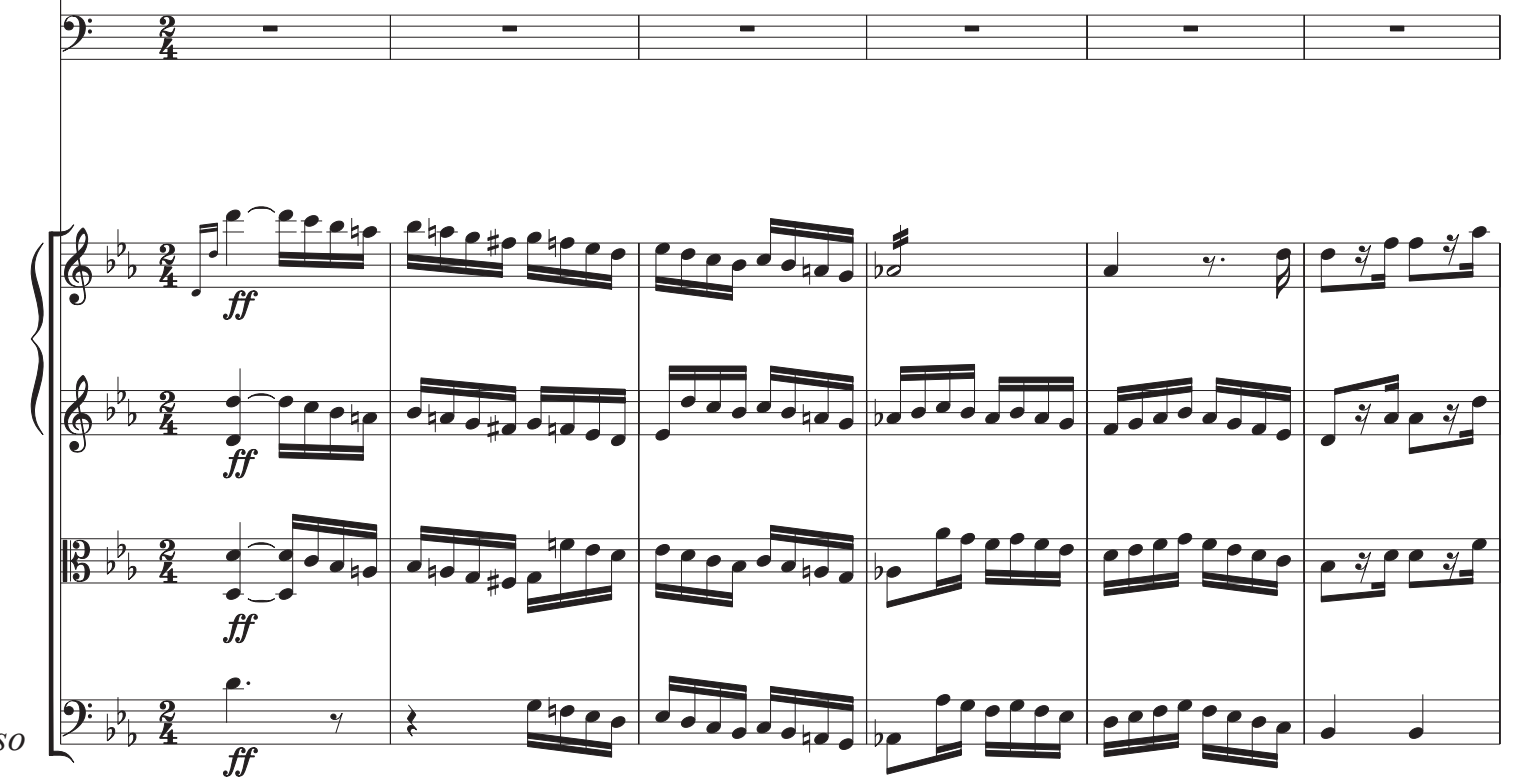

Violino I

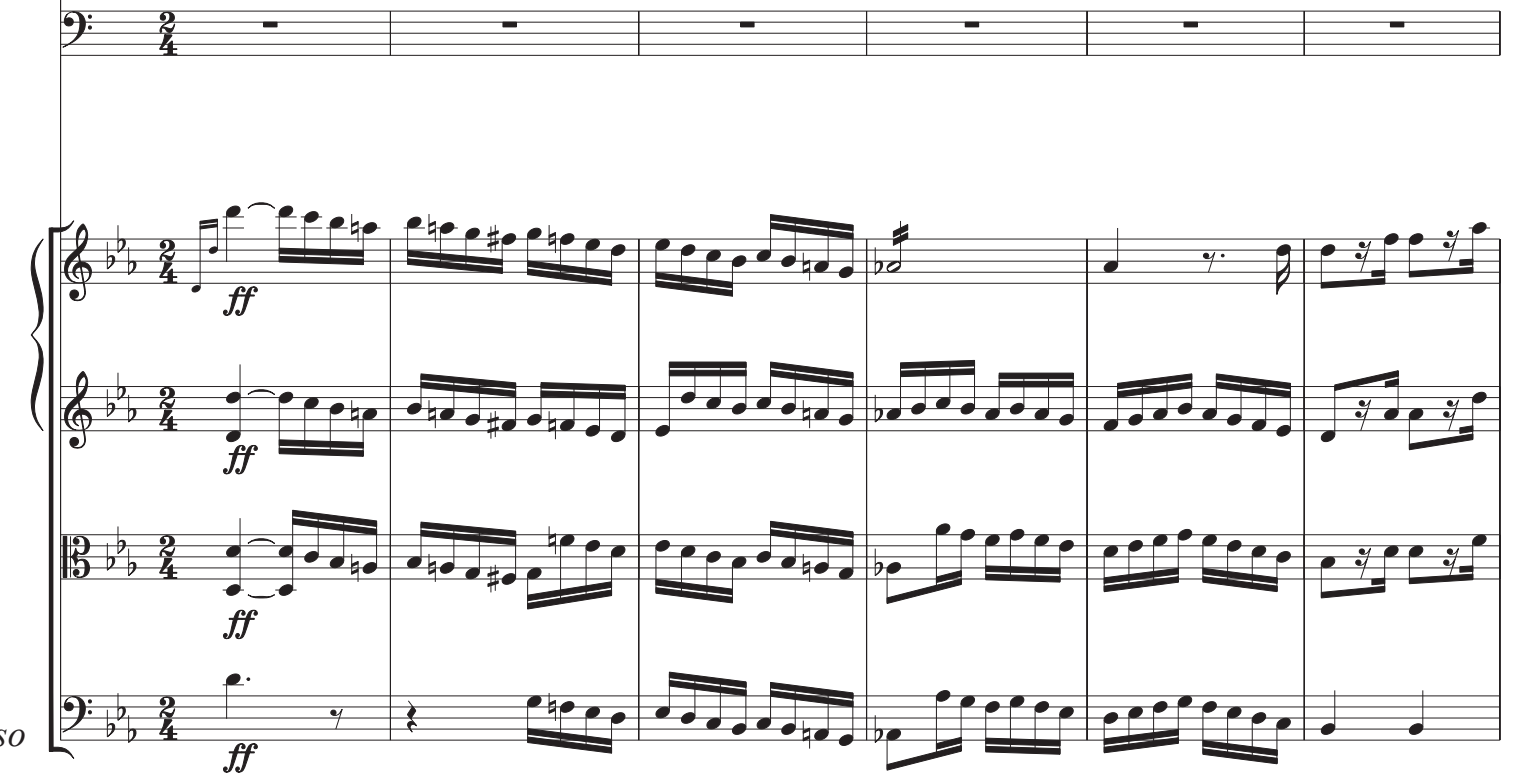

Violoncello

e Contrabasso 

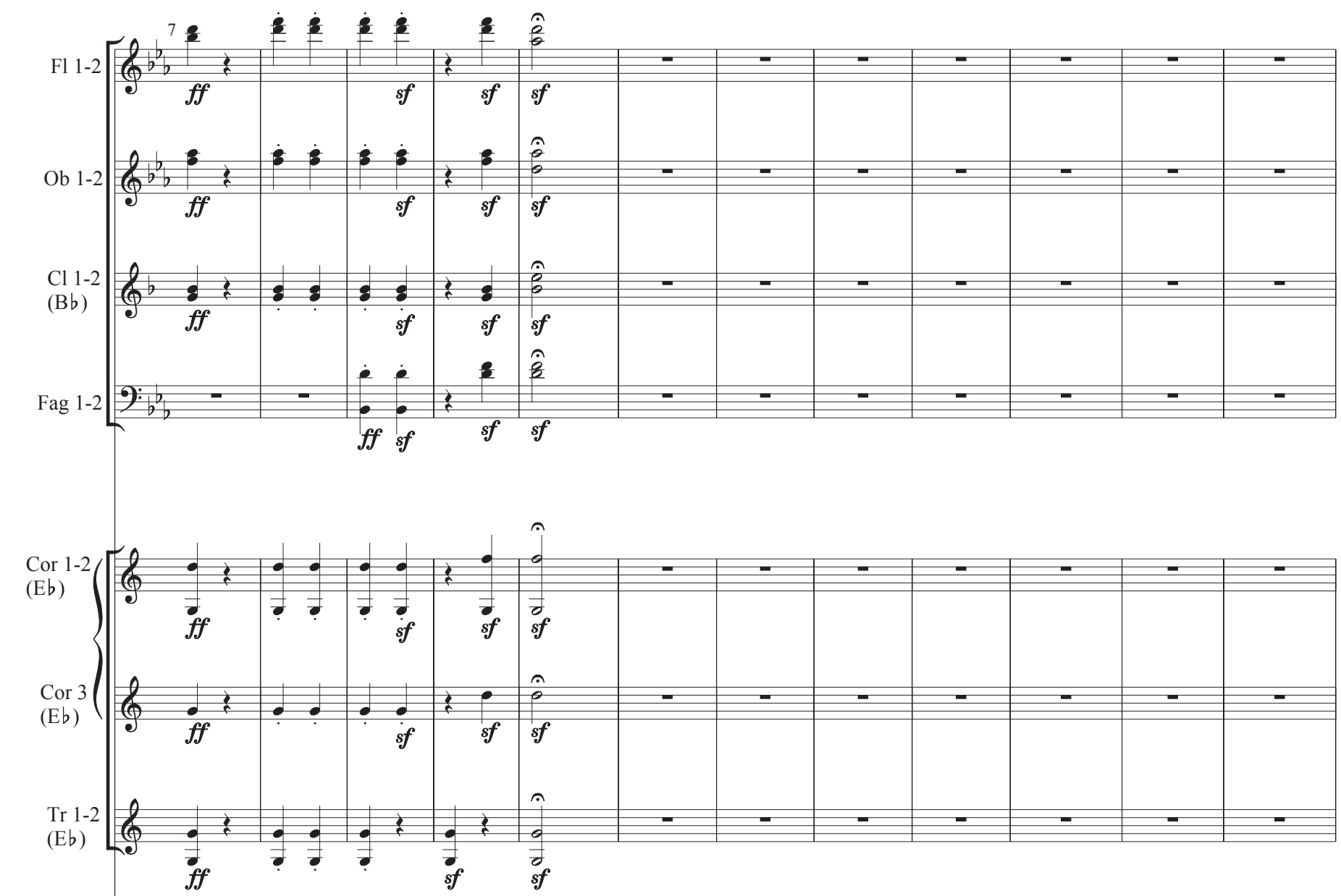

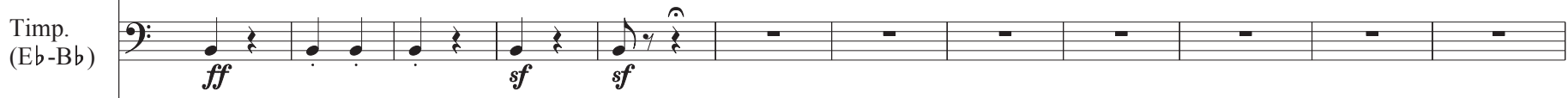

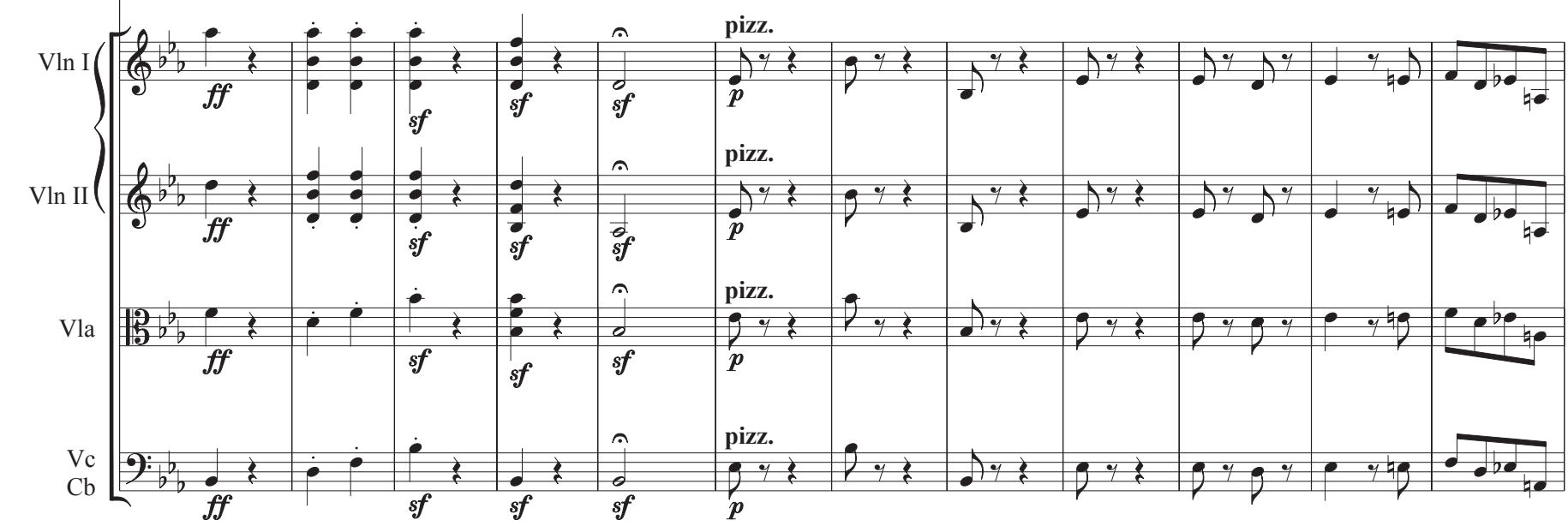




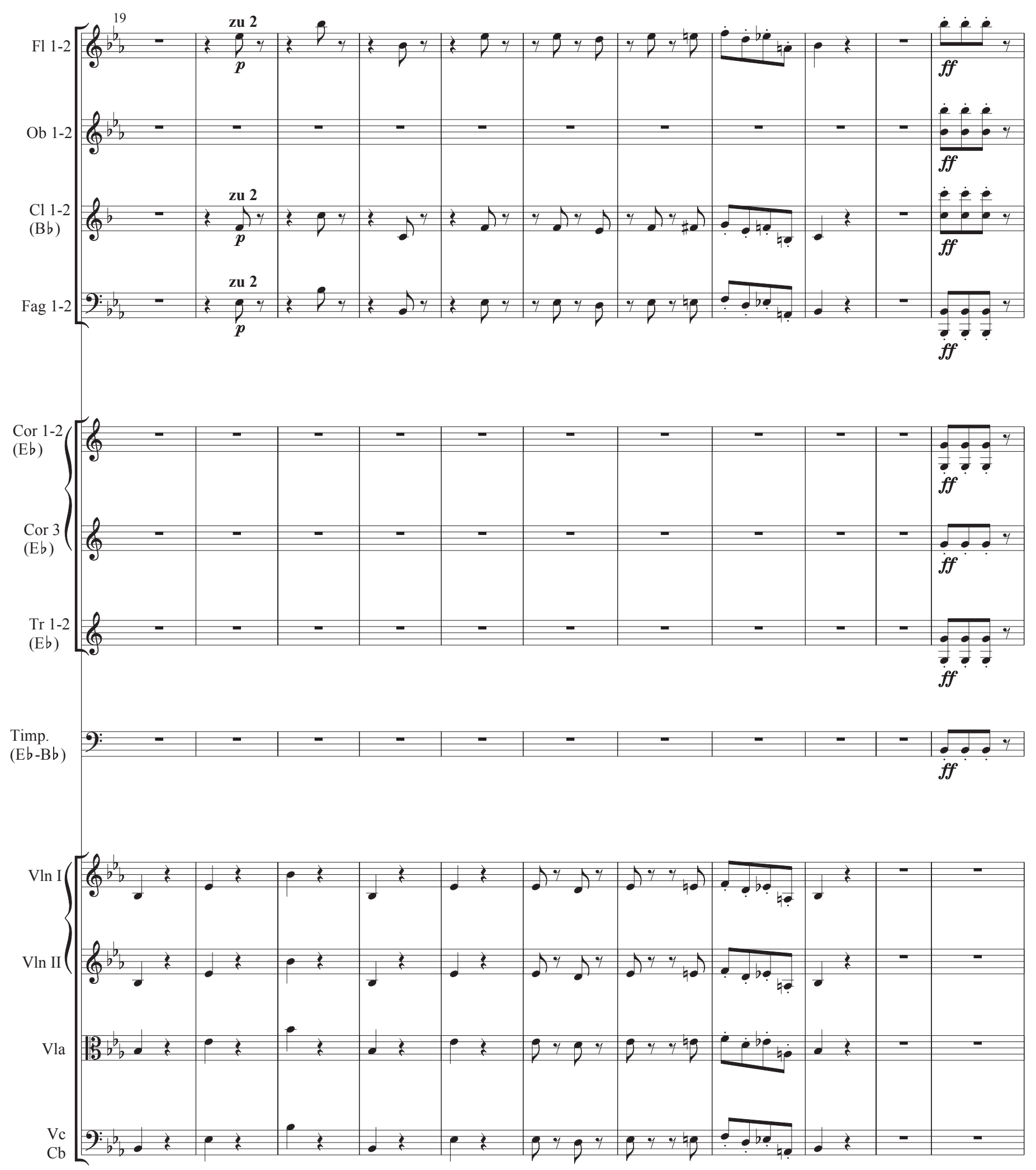



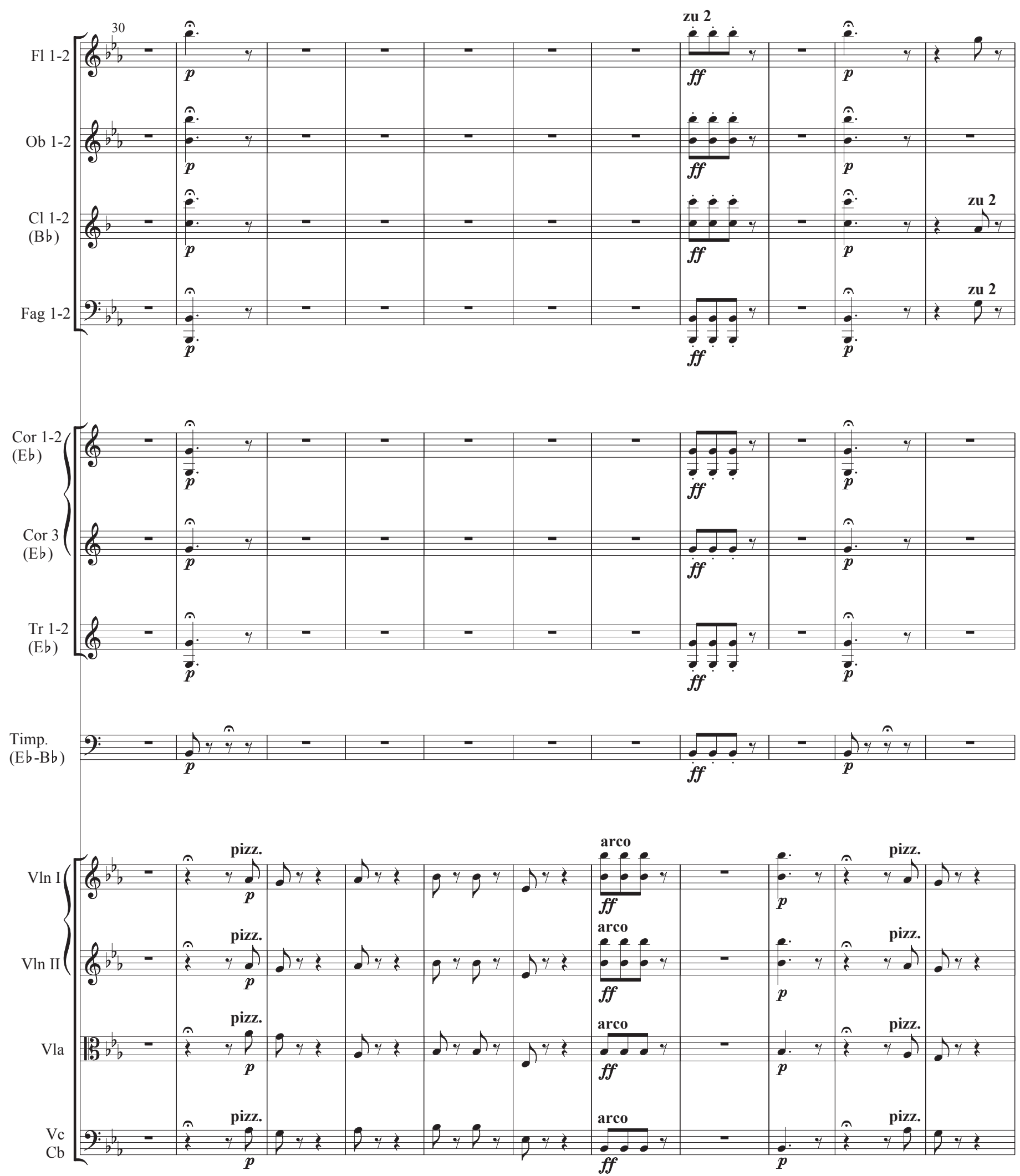

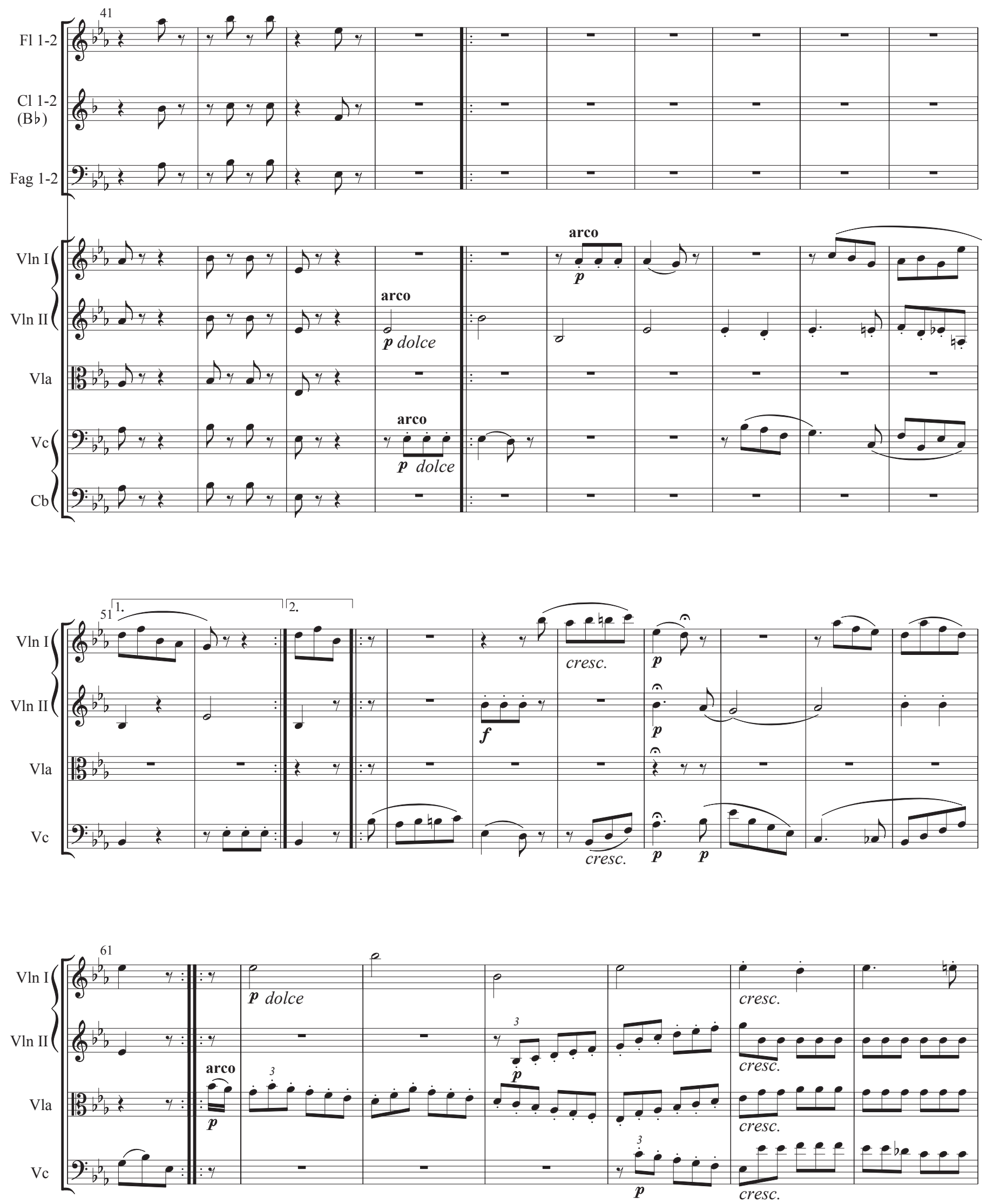

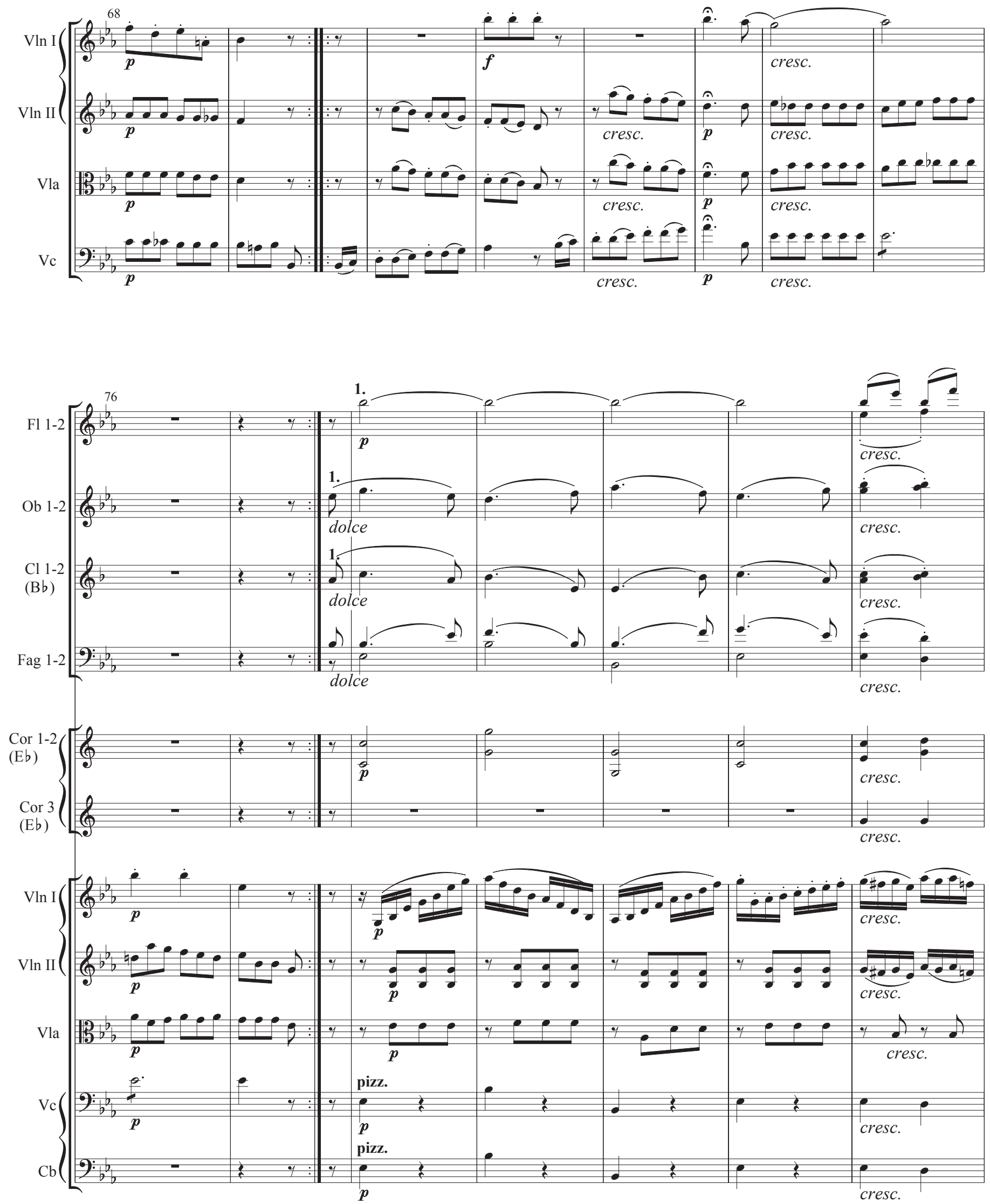


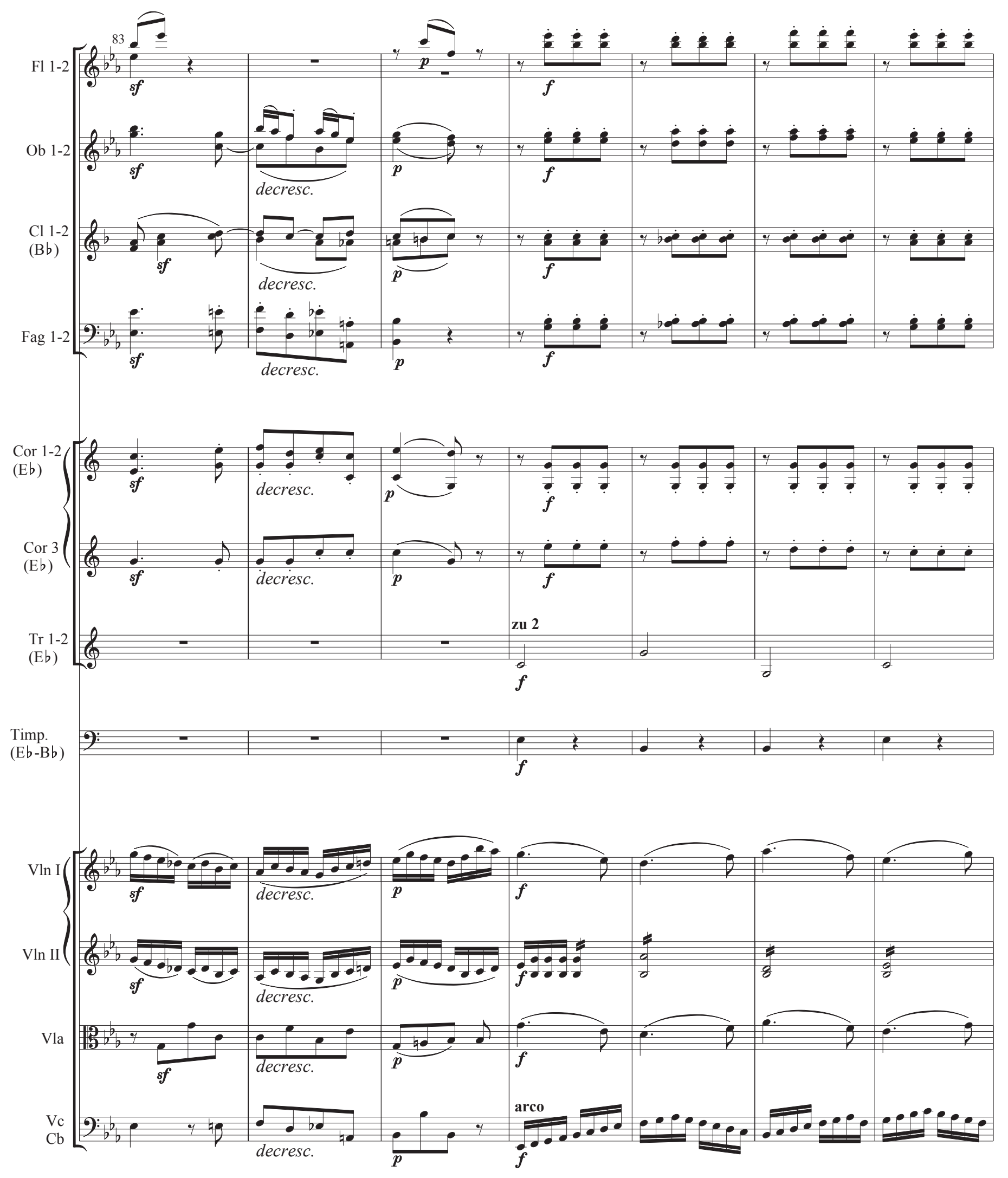




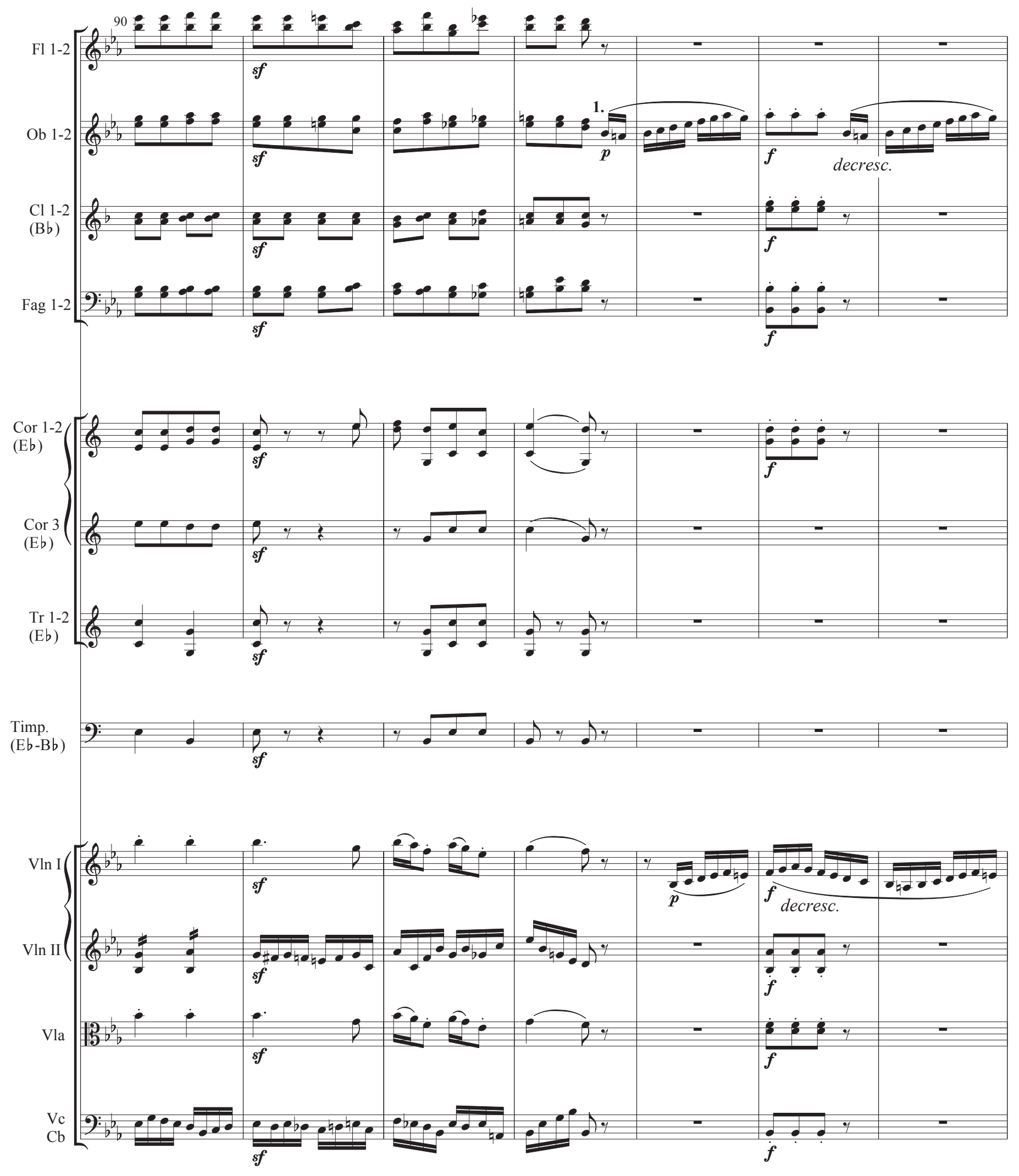



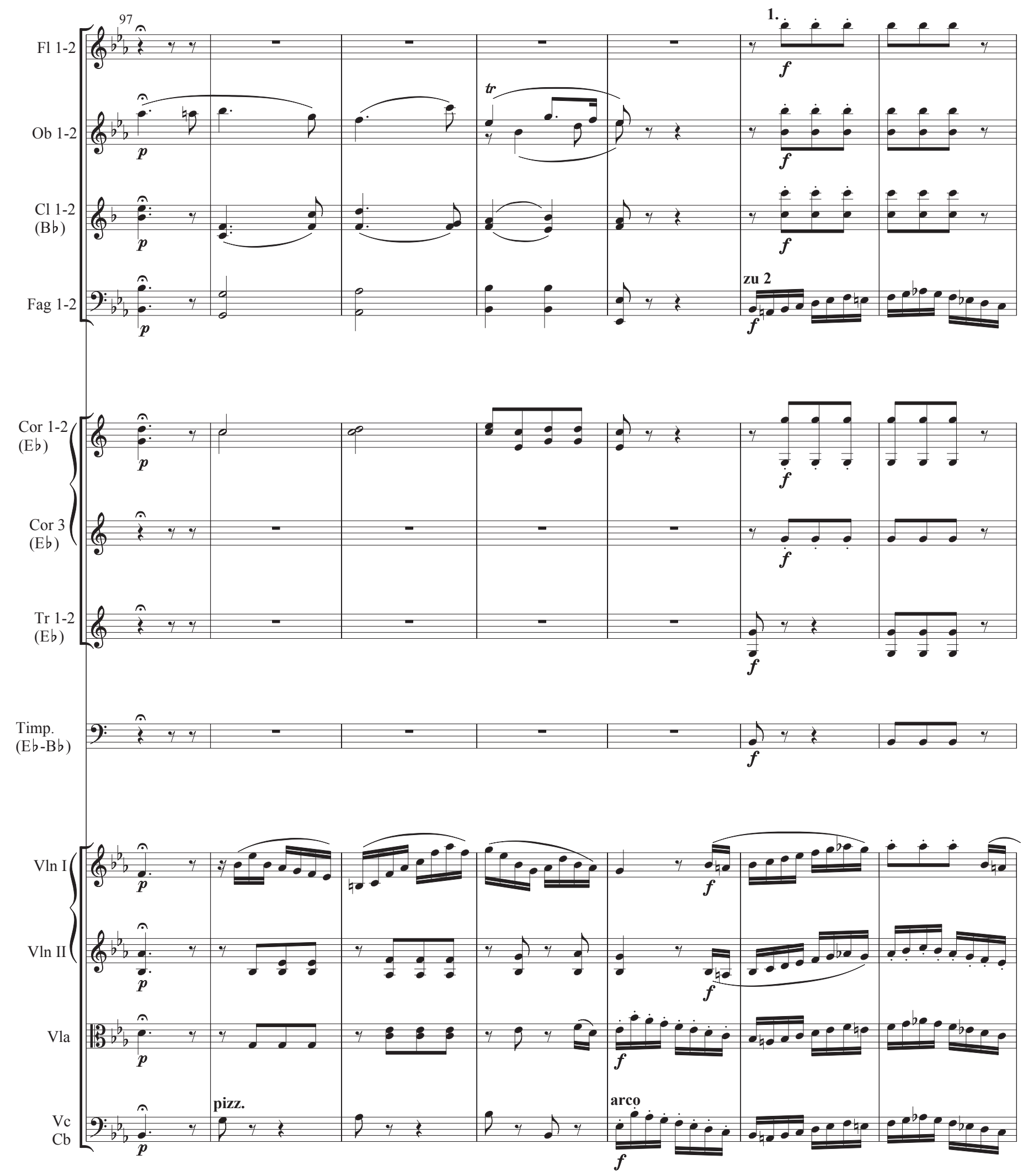

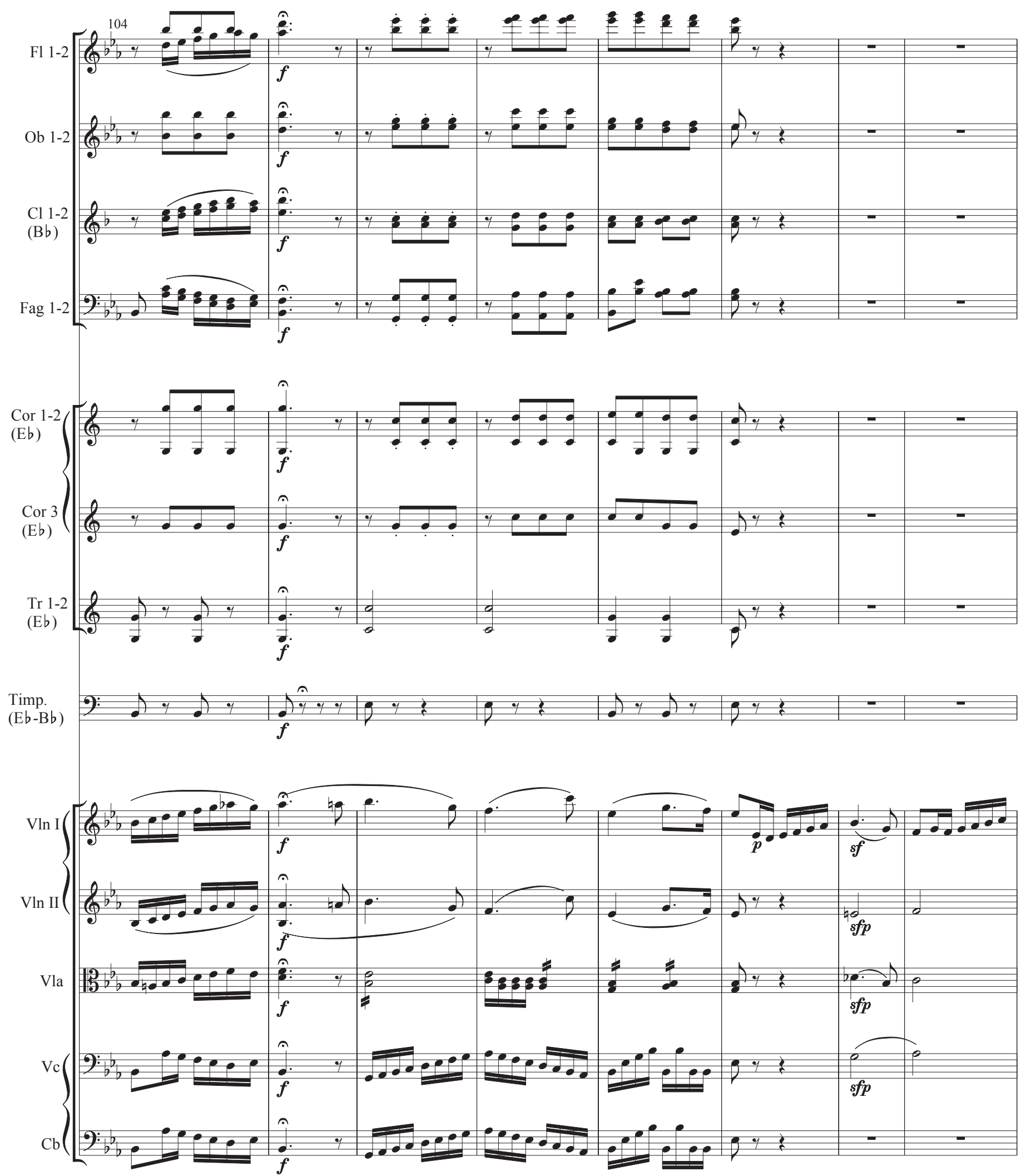

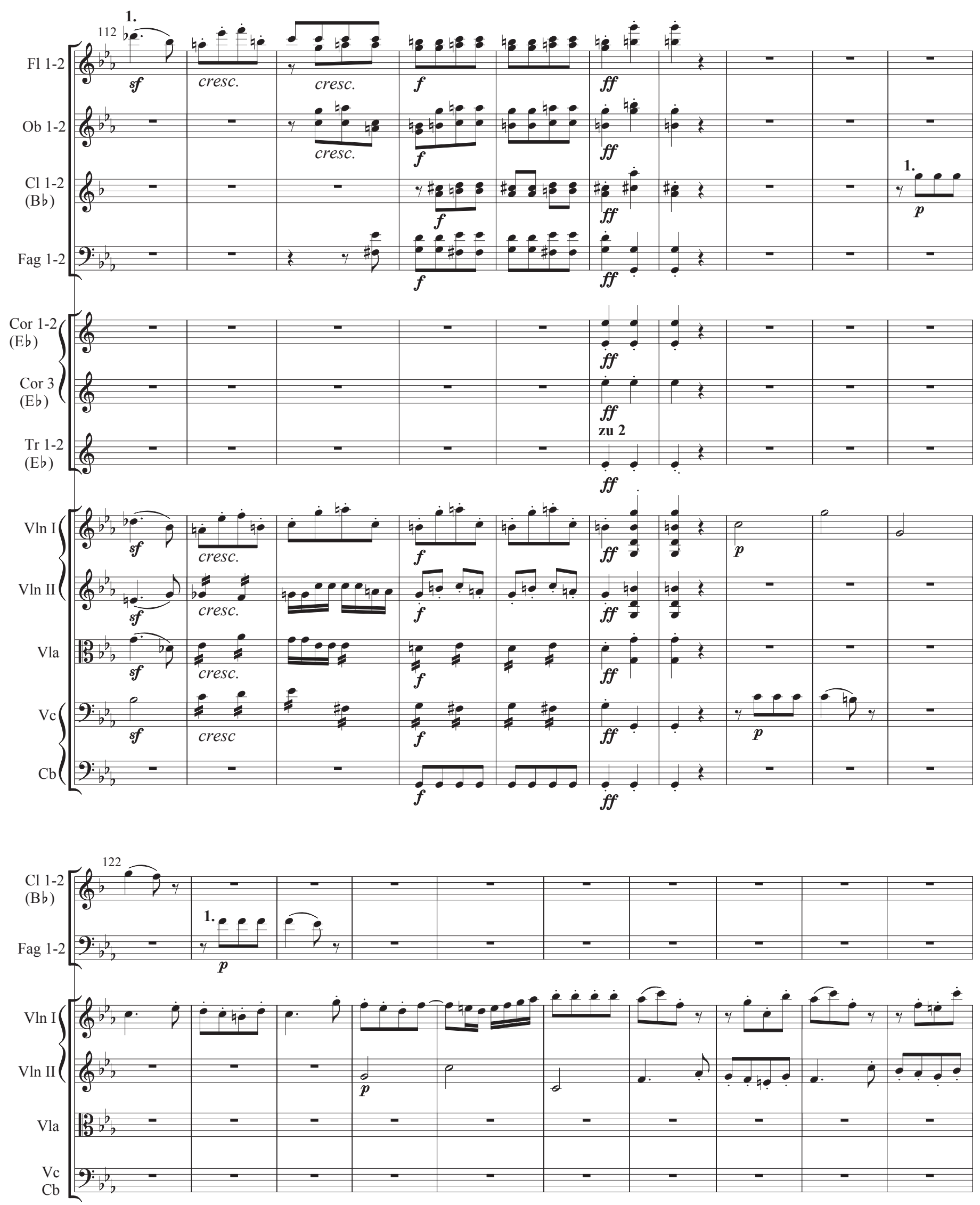

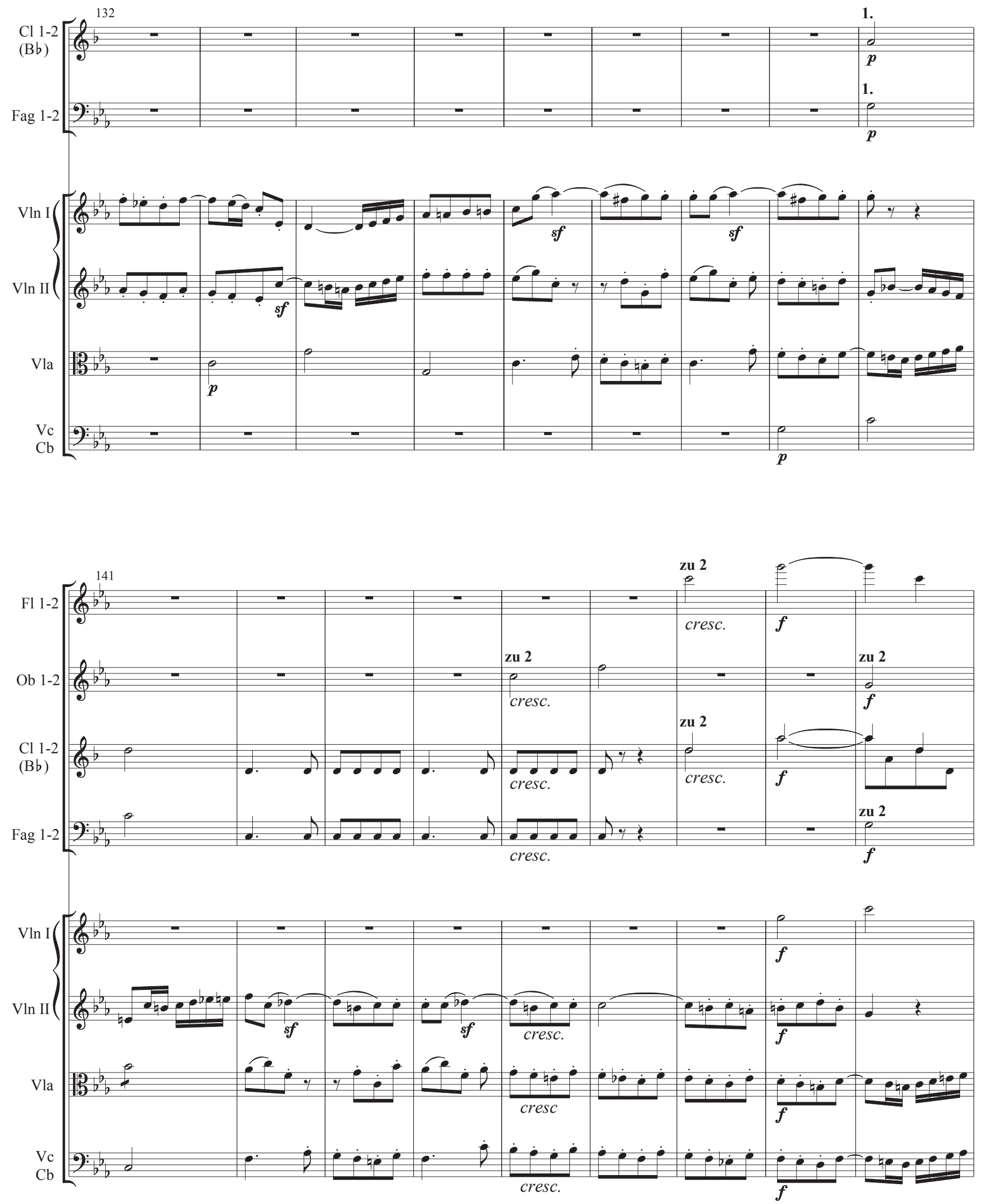


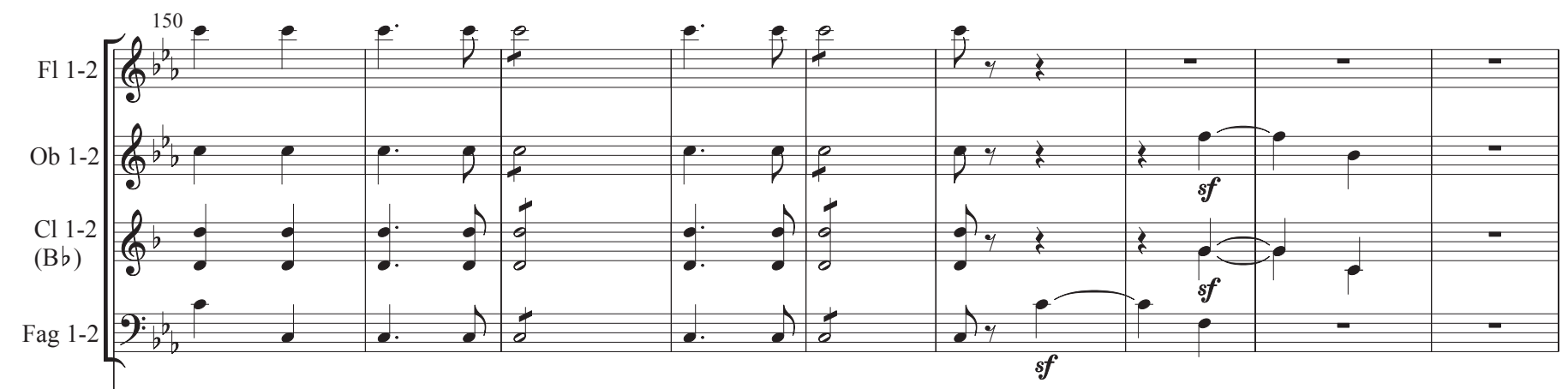

$\begin{array}{llllllllll}\text { Cor } 1-2 & (\mathrm{~Eb})\end{array}$
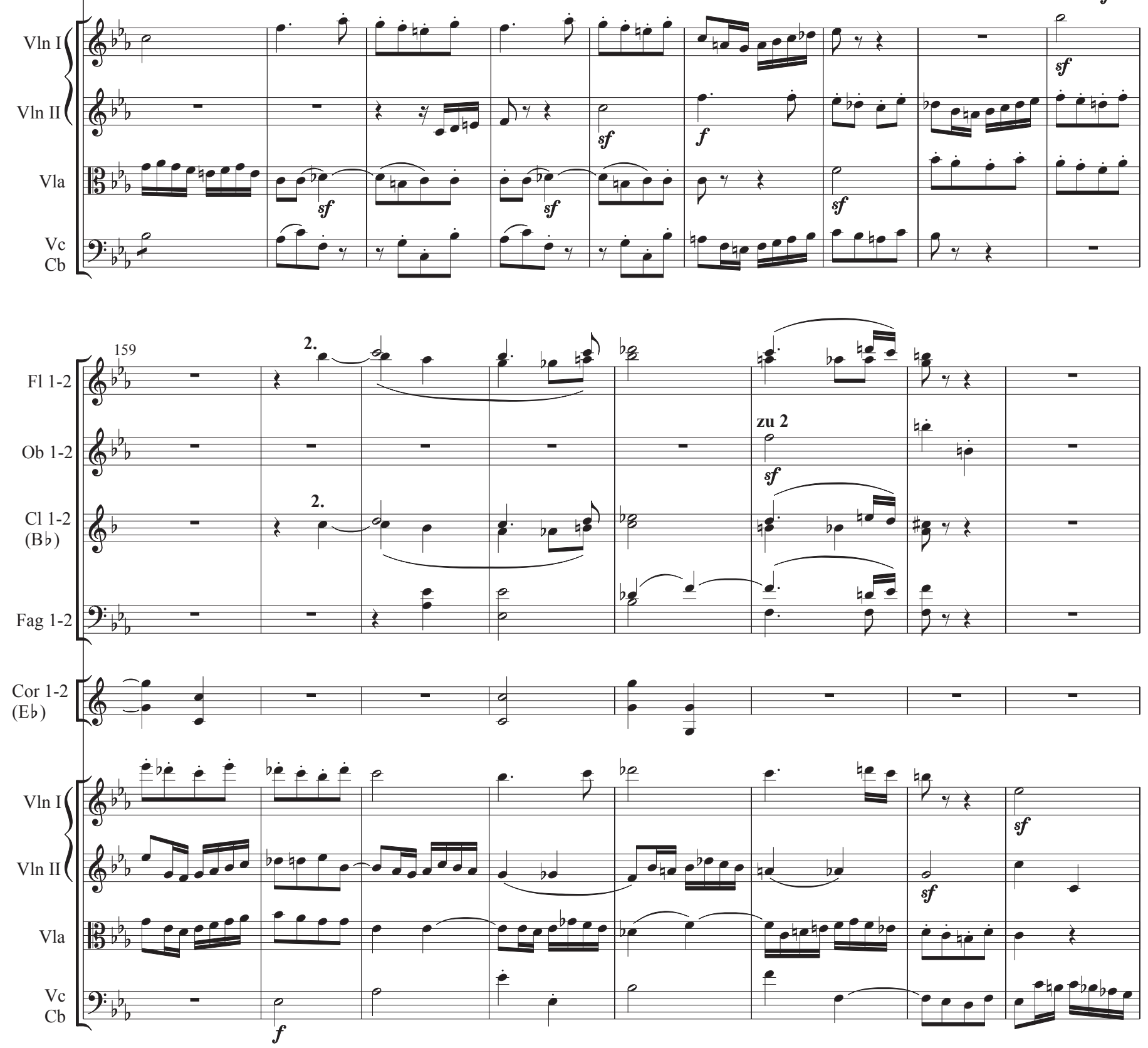

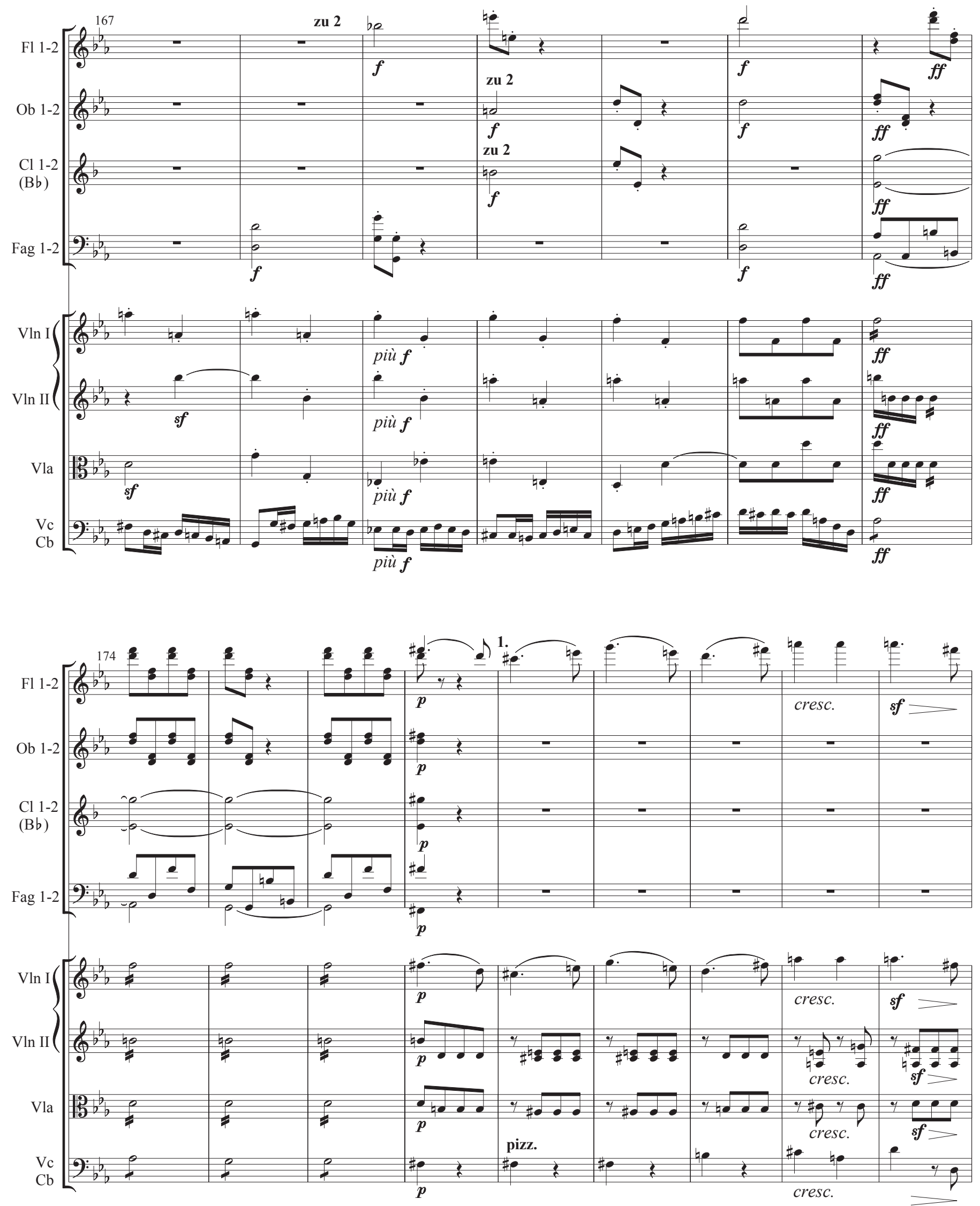

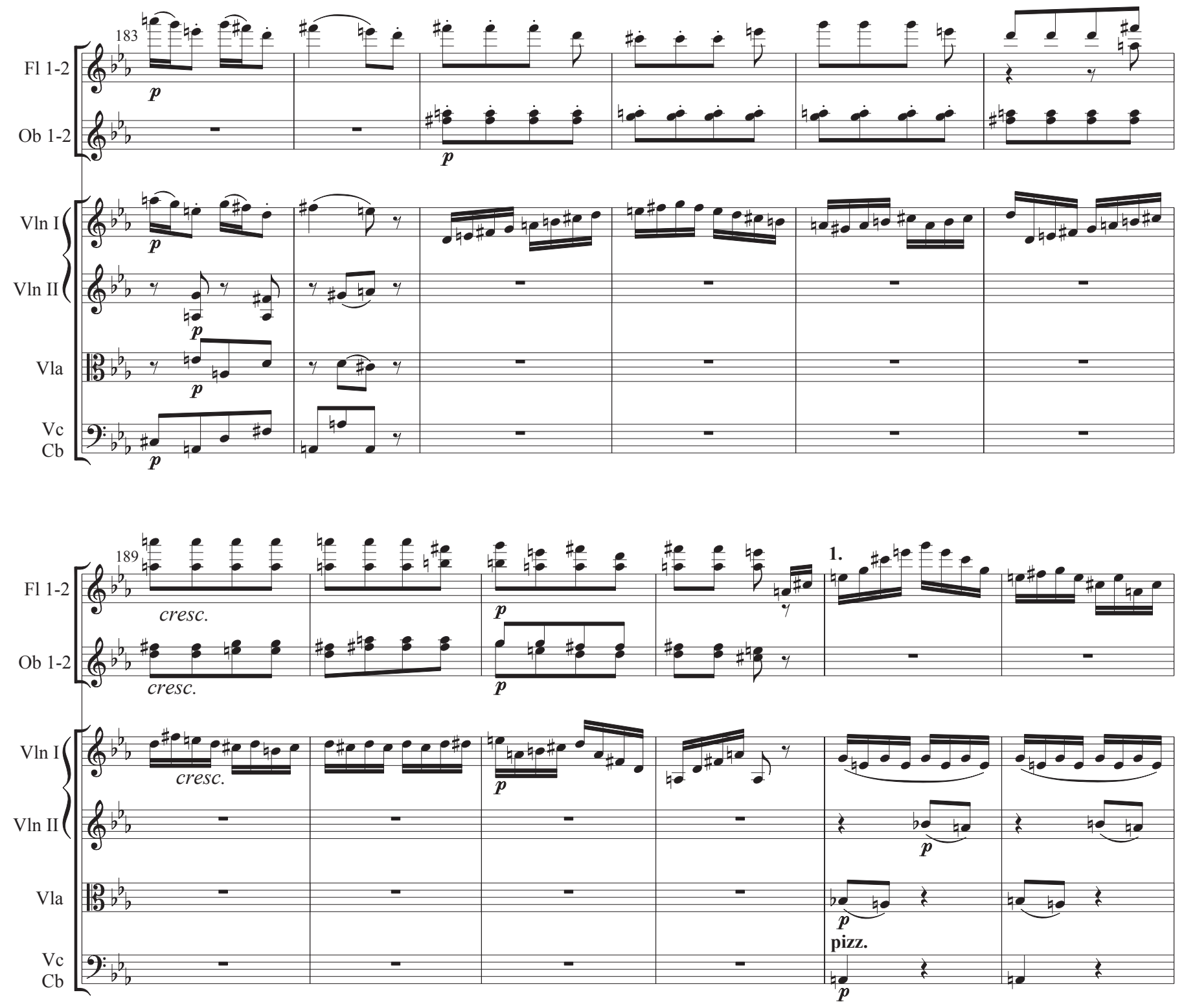

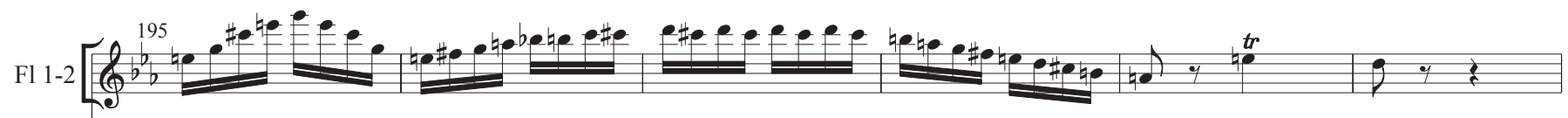

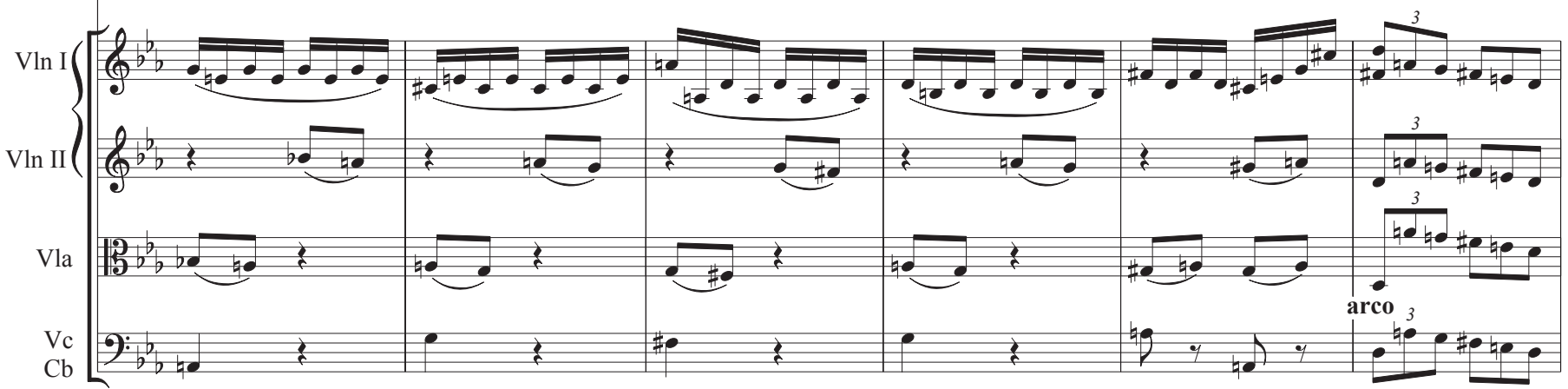



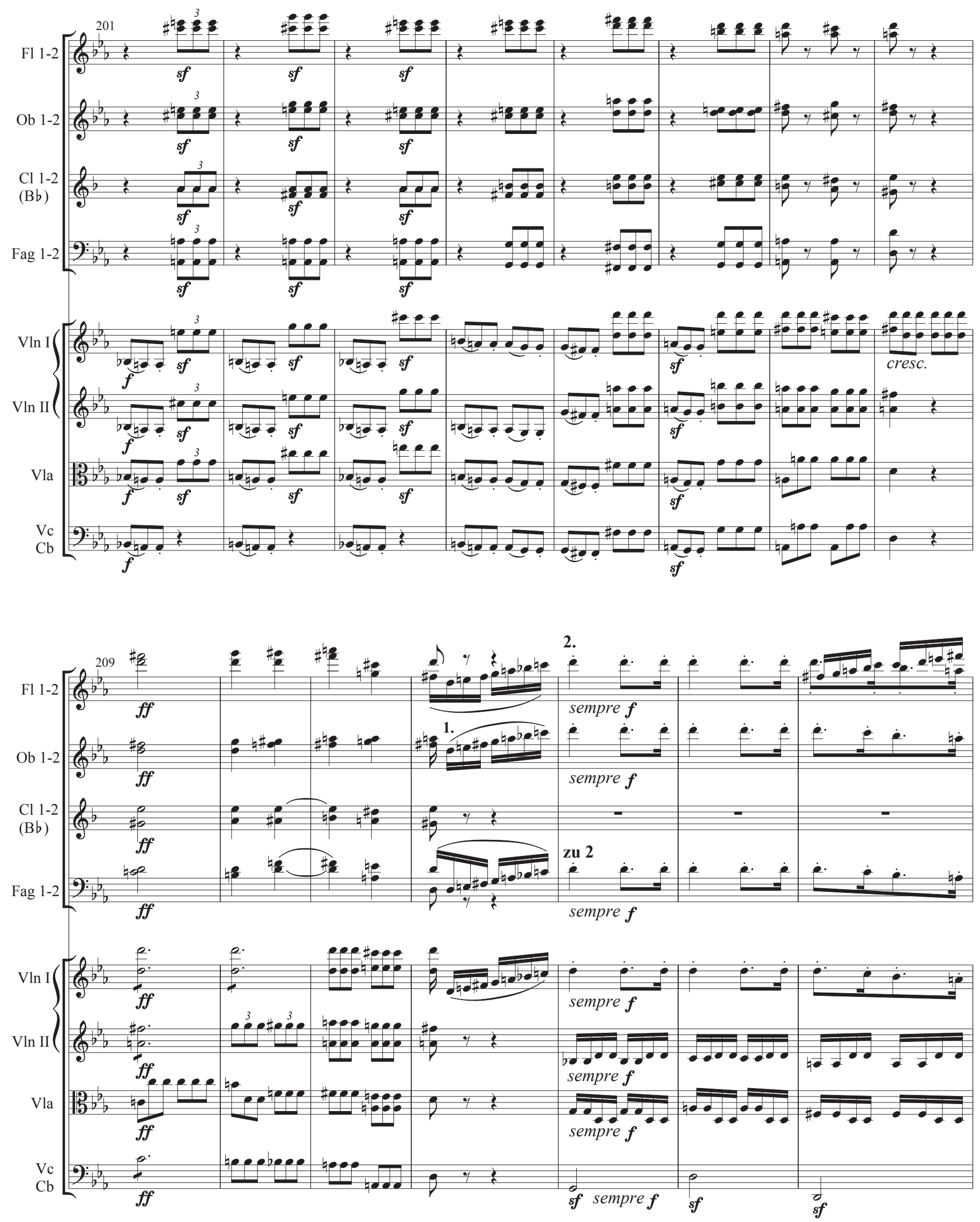

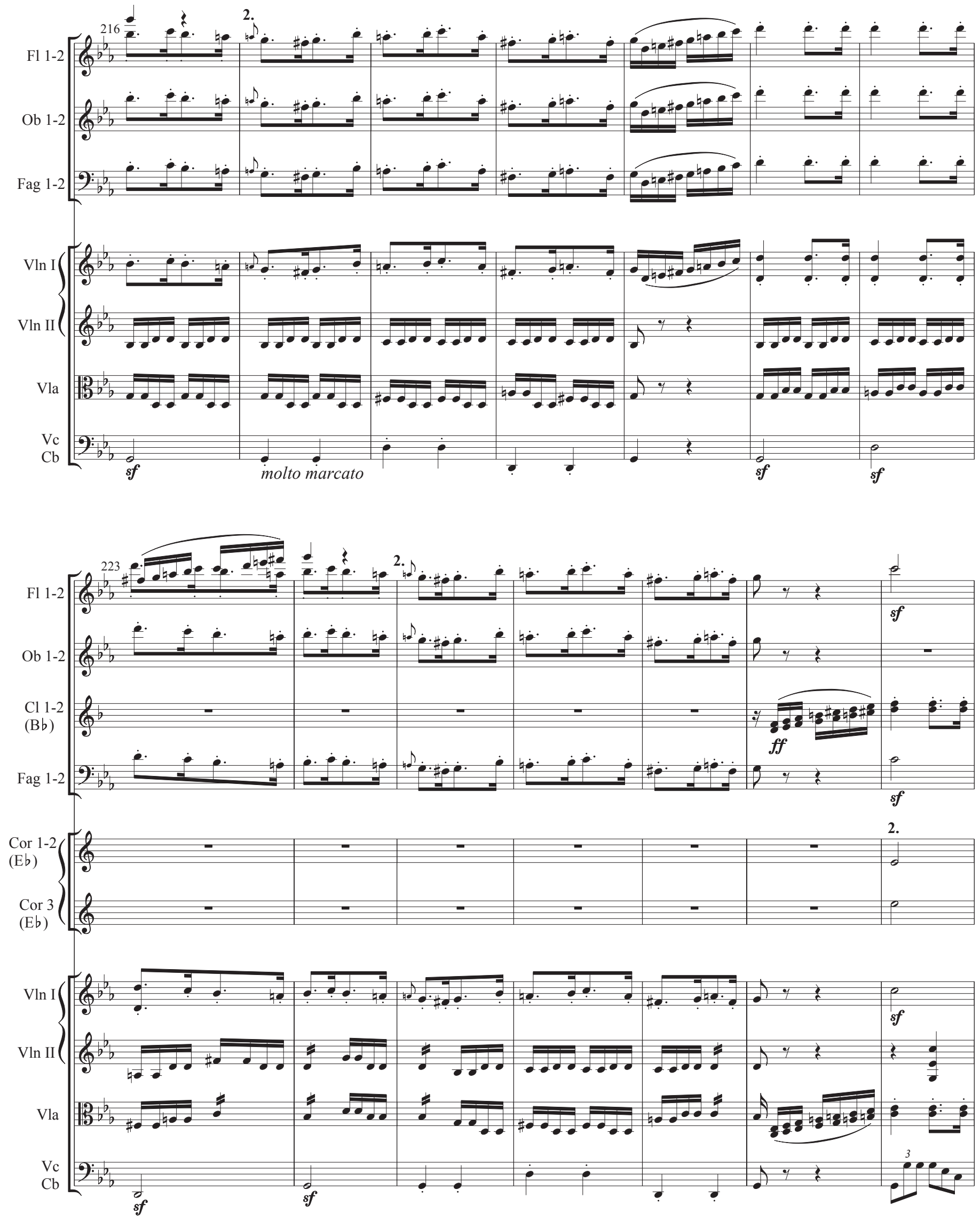

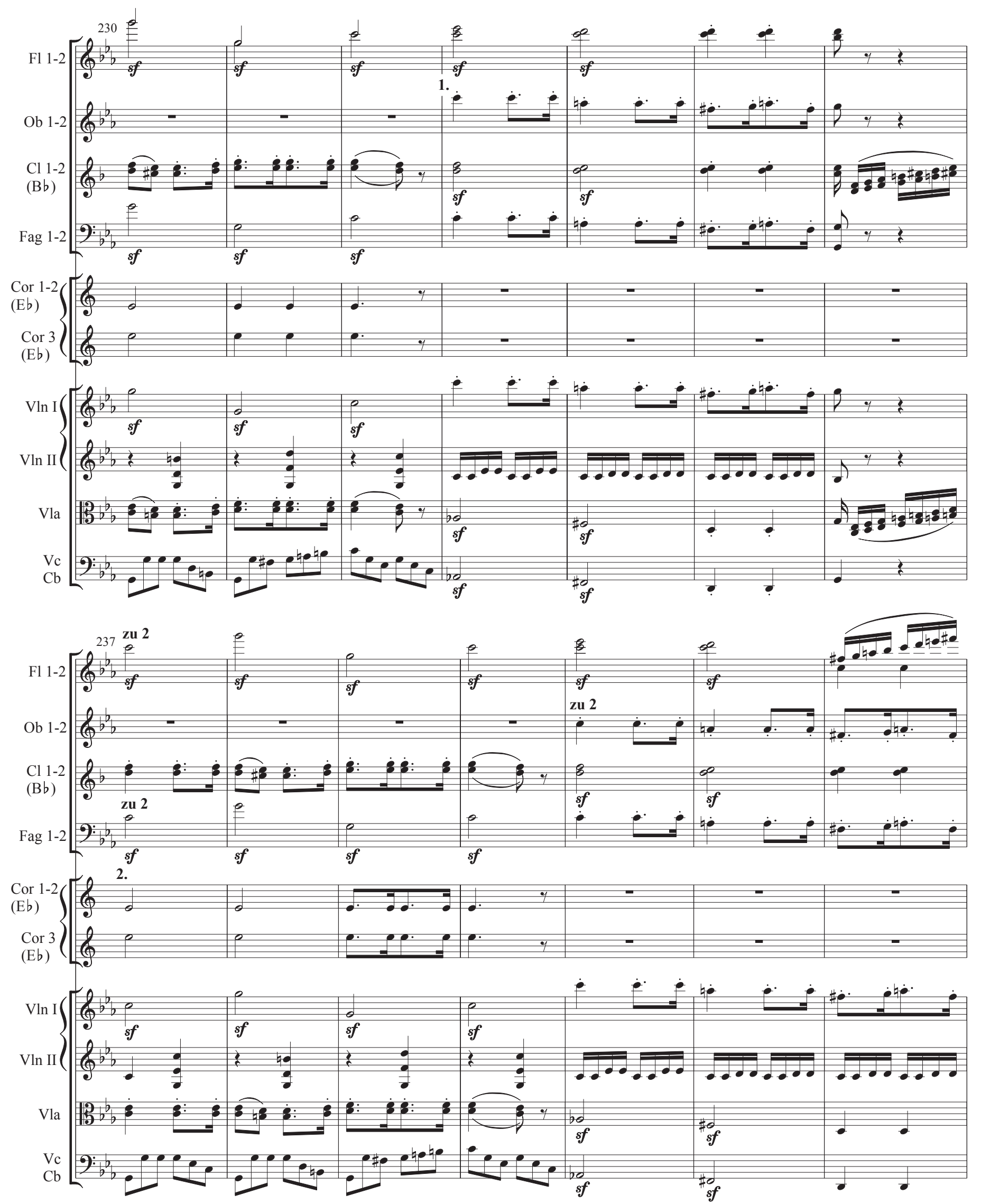

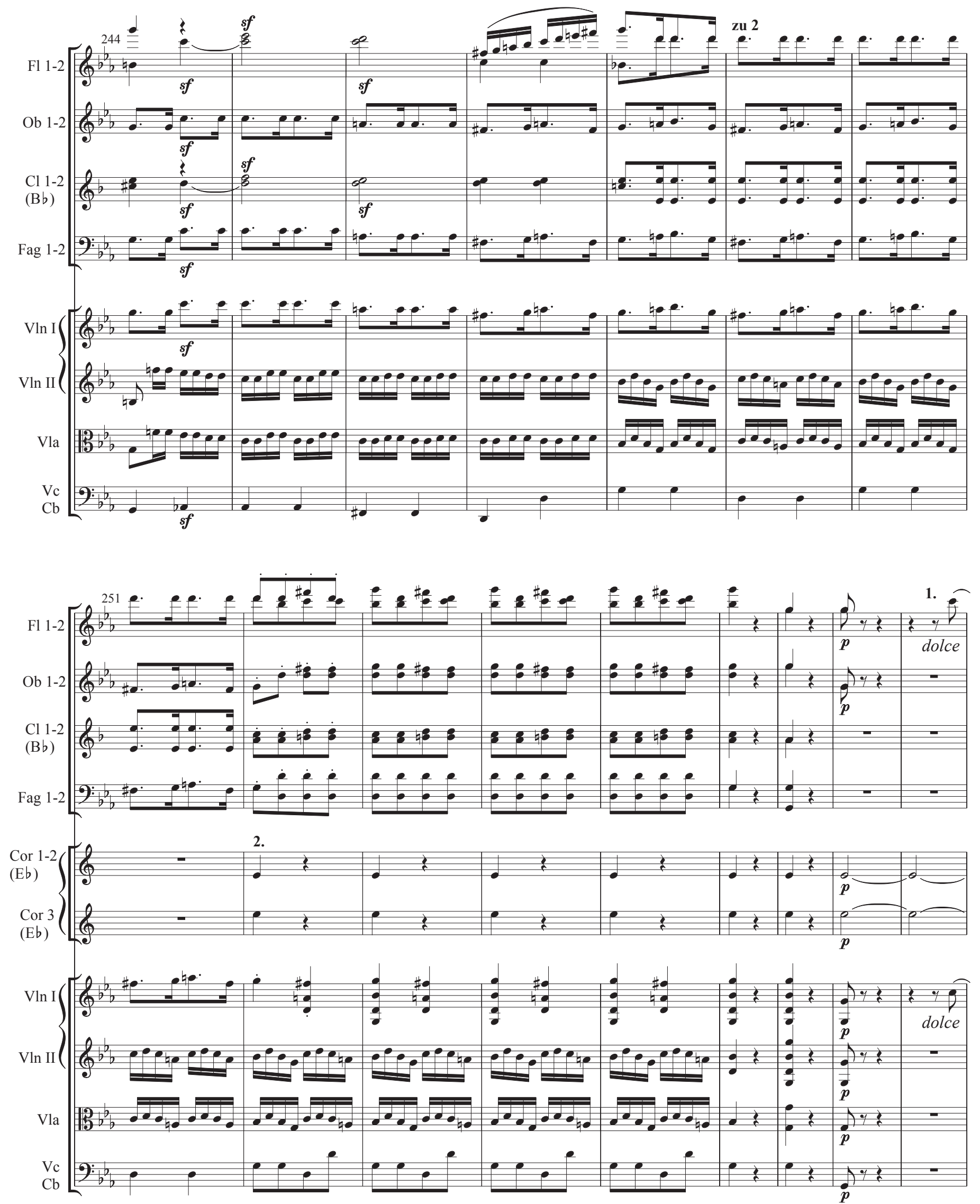

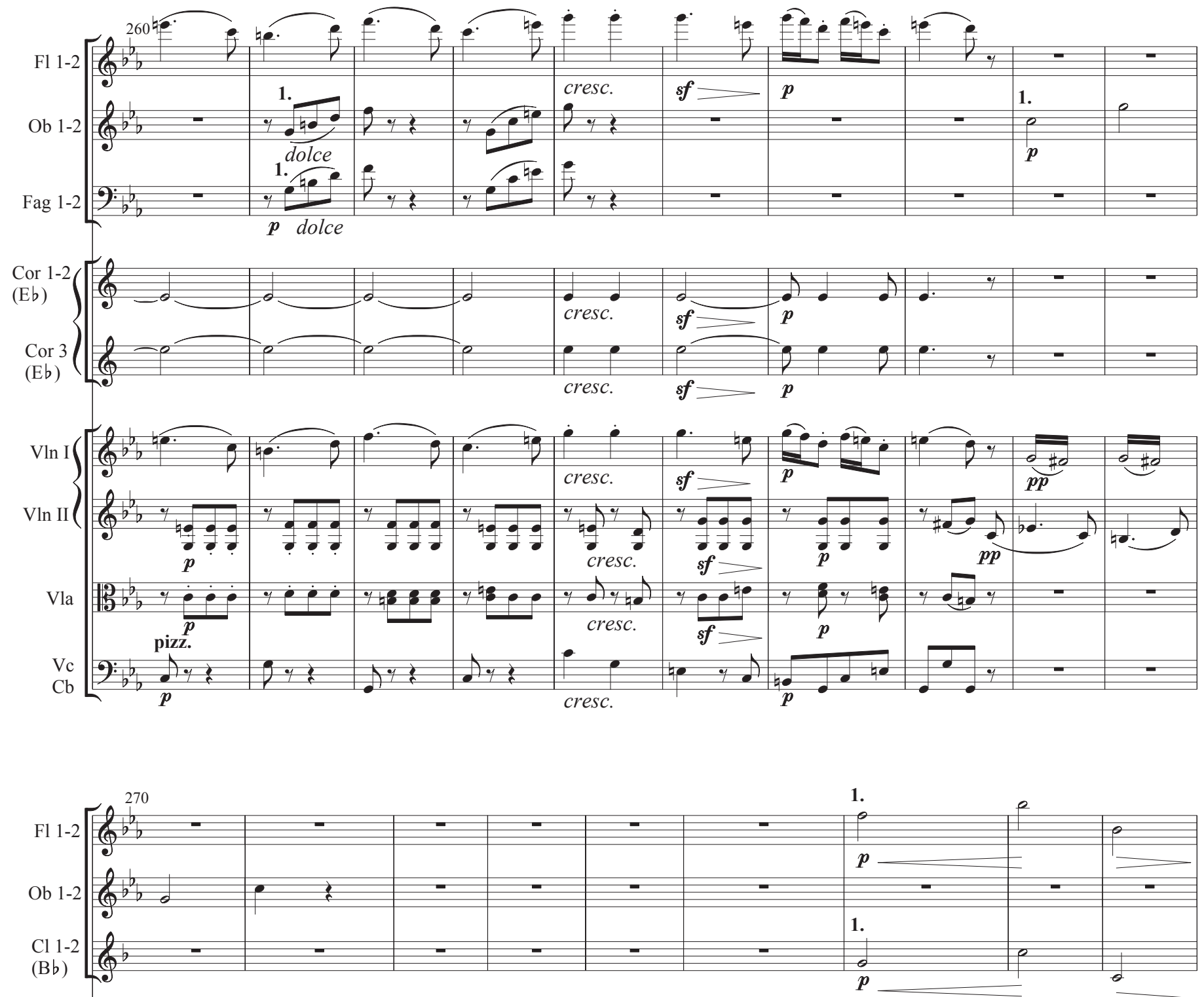

1. in $F$.

2. in $\mathbf{E} b$.
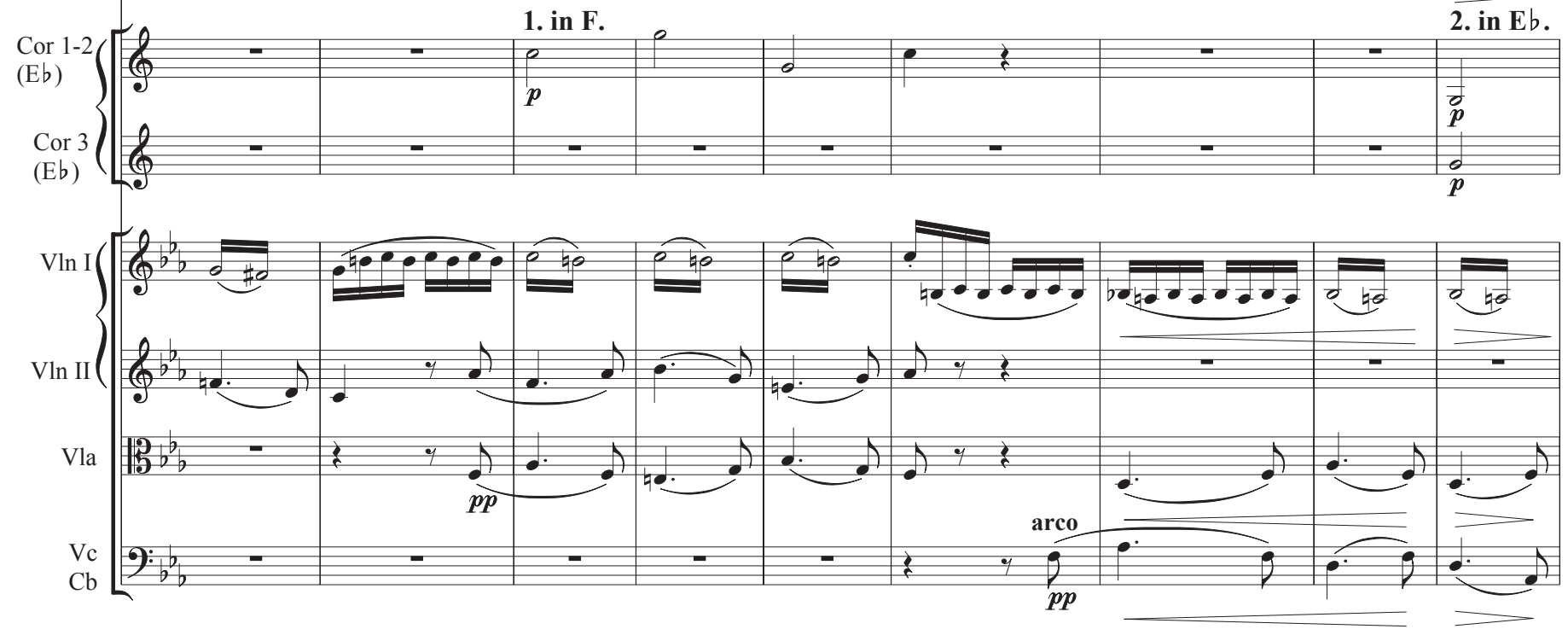

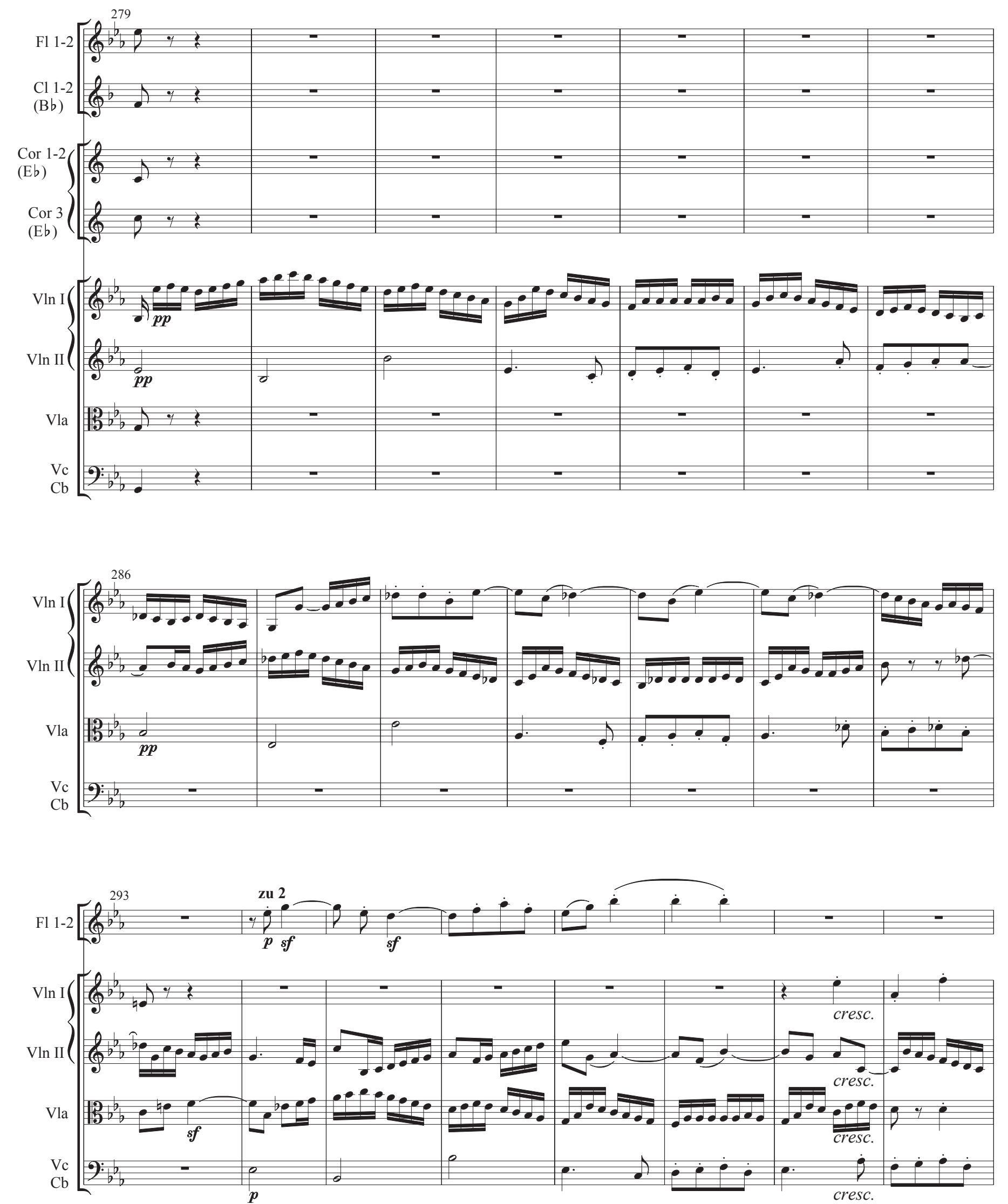

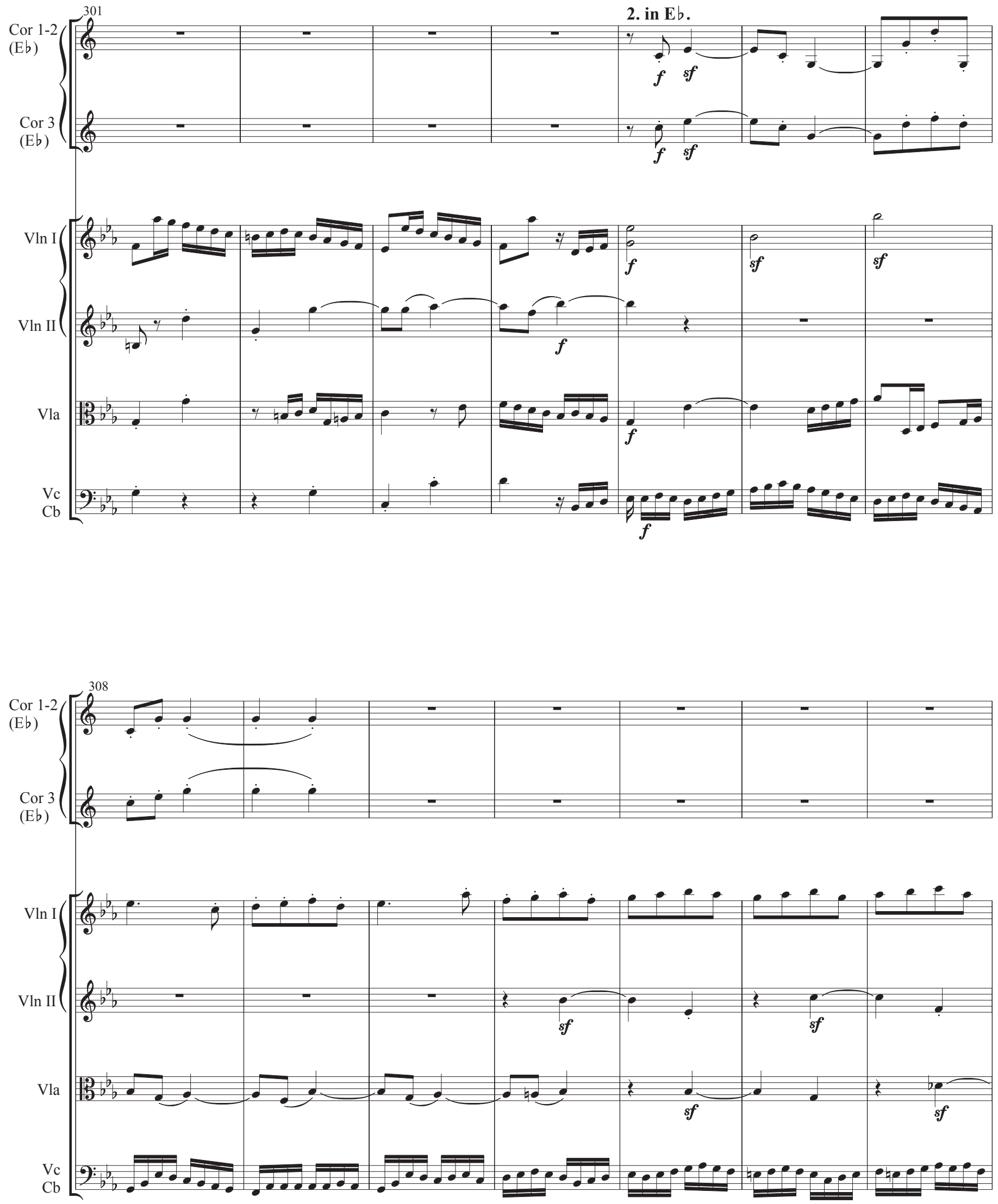


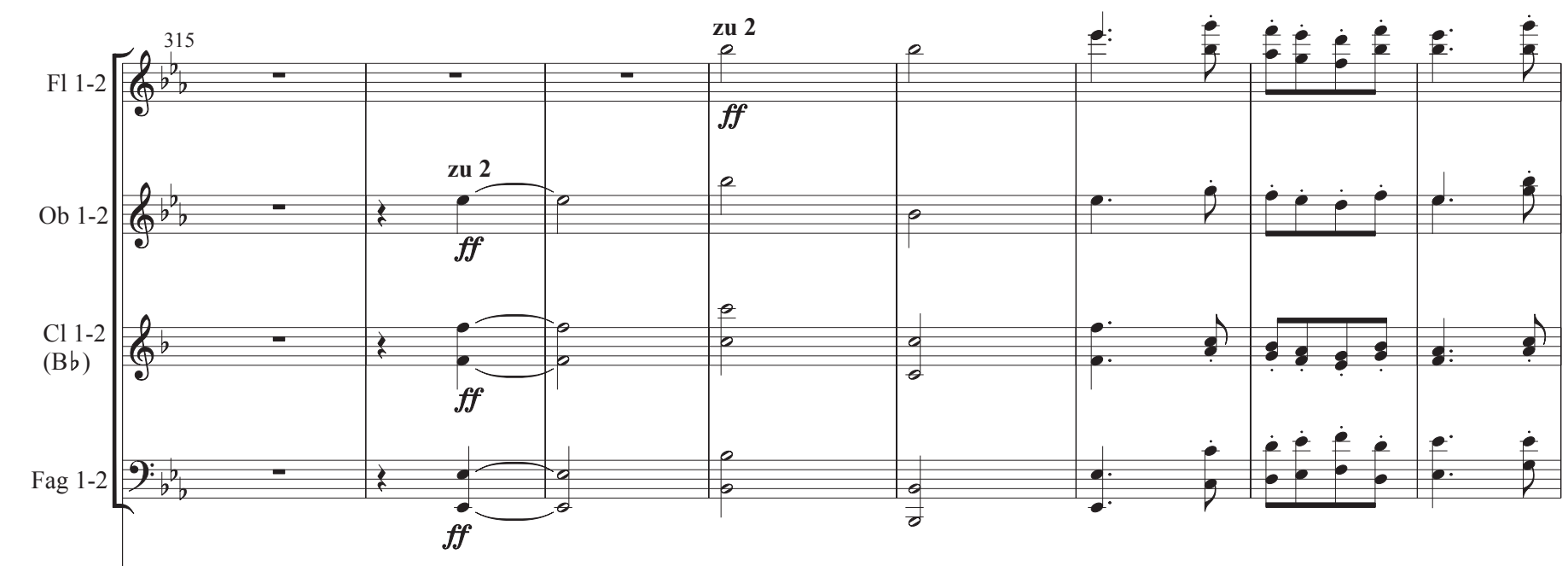

2. in $\mathbf{E} b$.
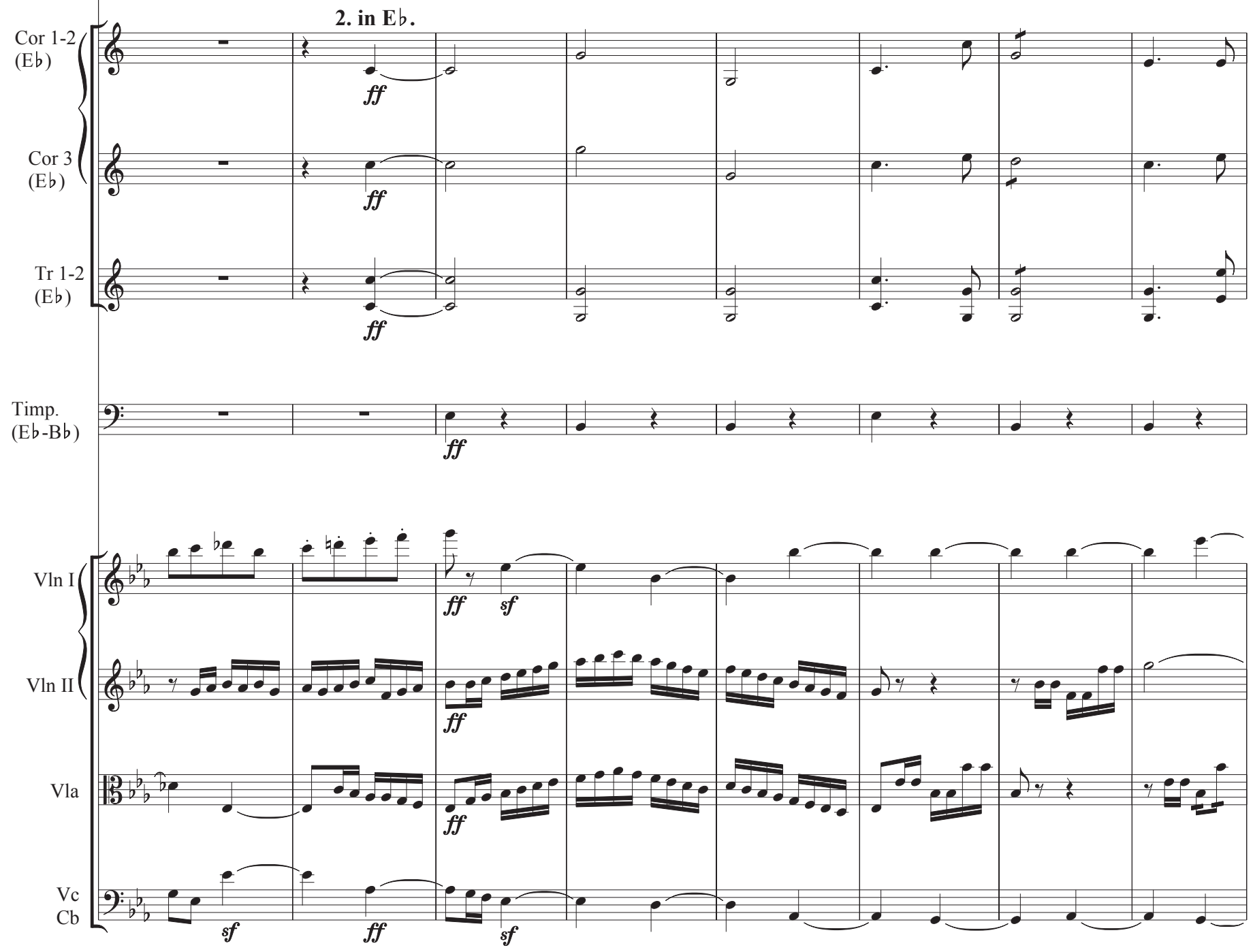

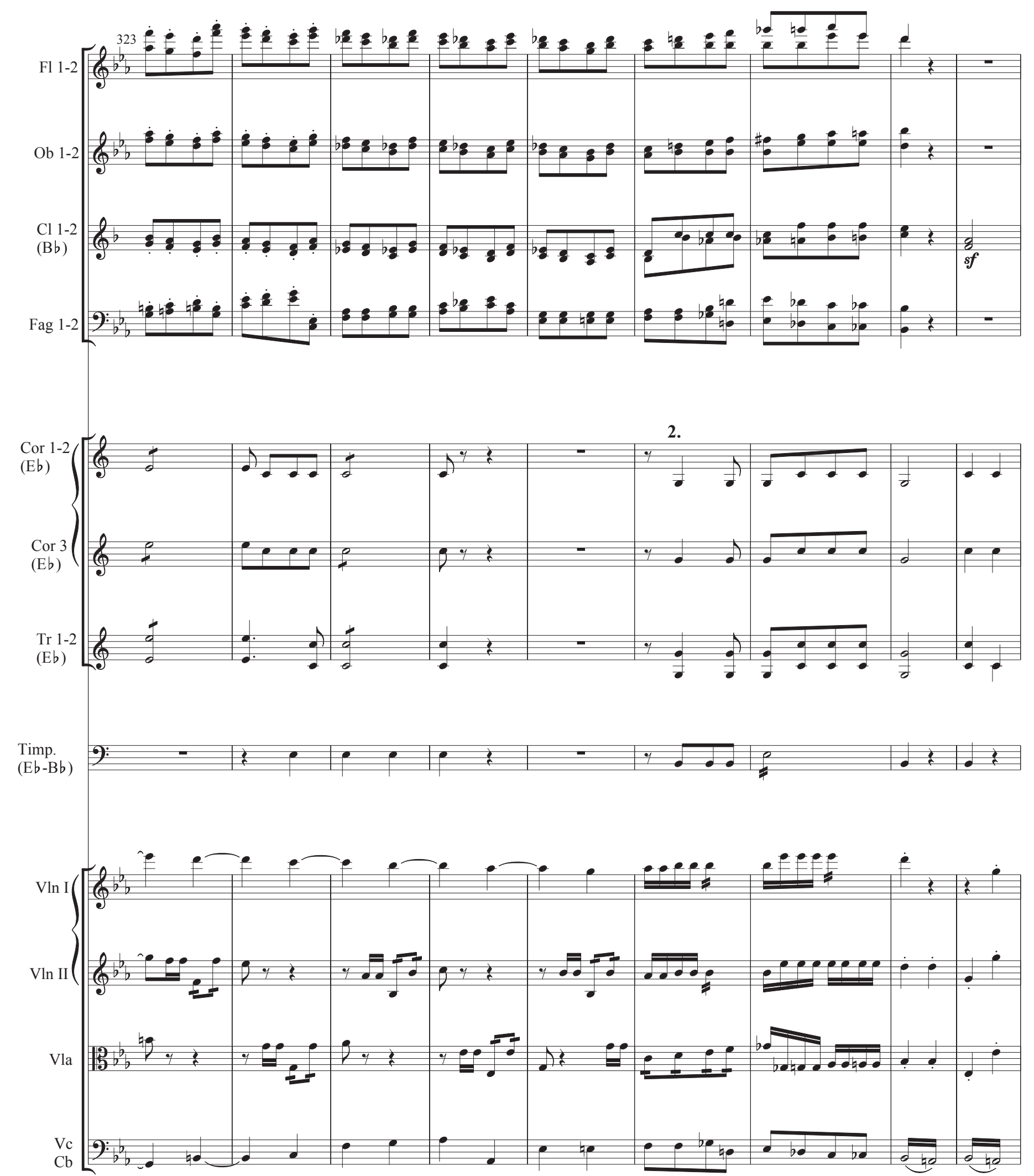

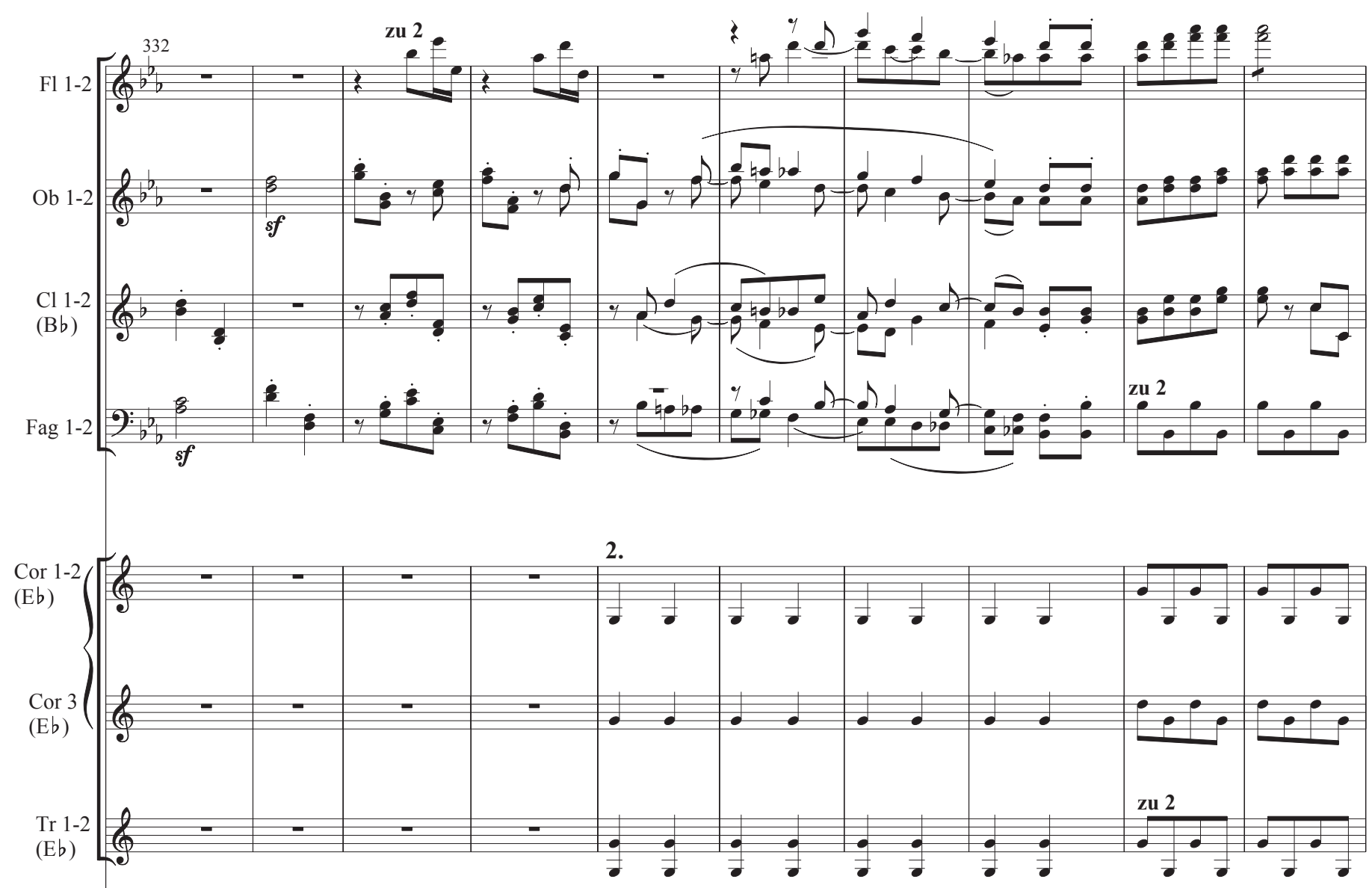

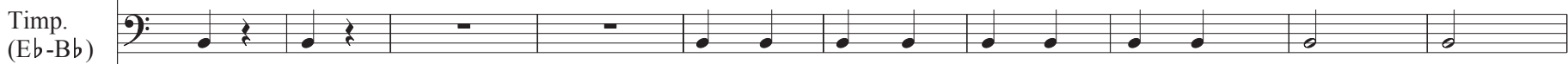

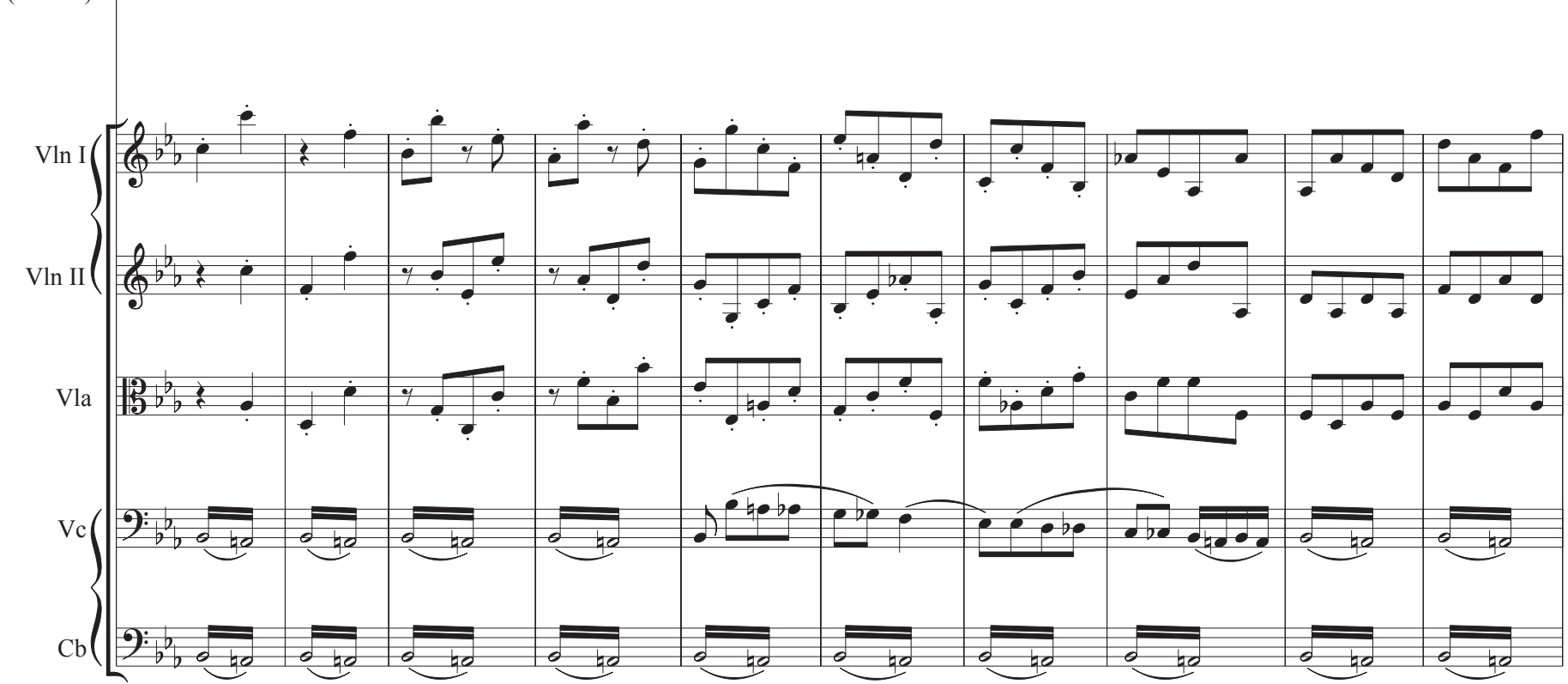




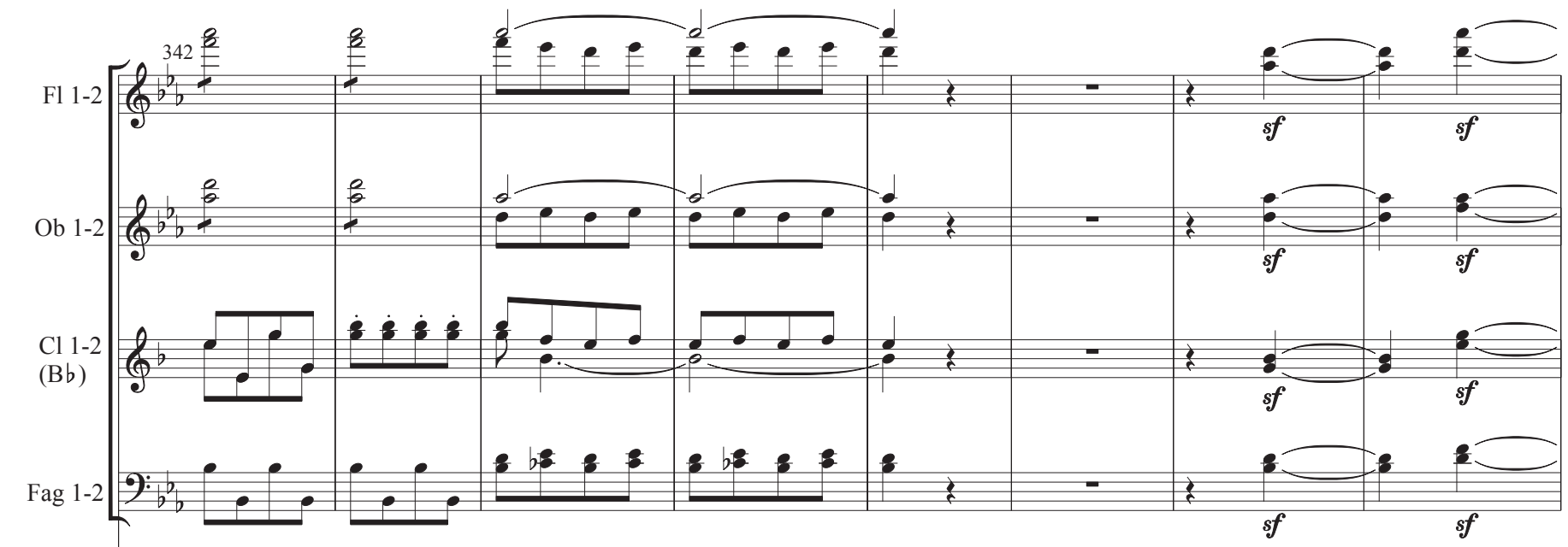

$\mathbf{z u} 2$ in $\mathbf{E} b$.
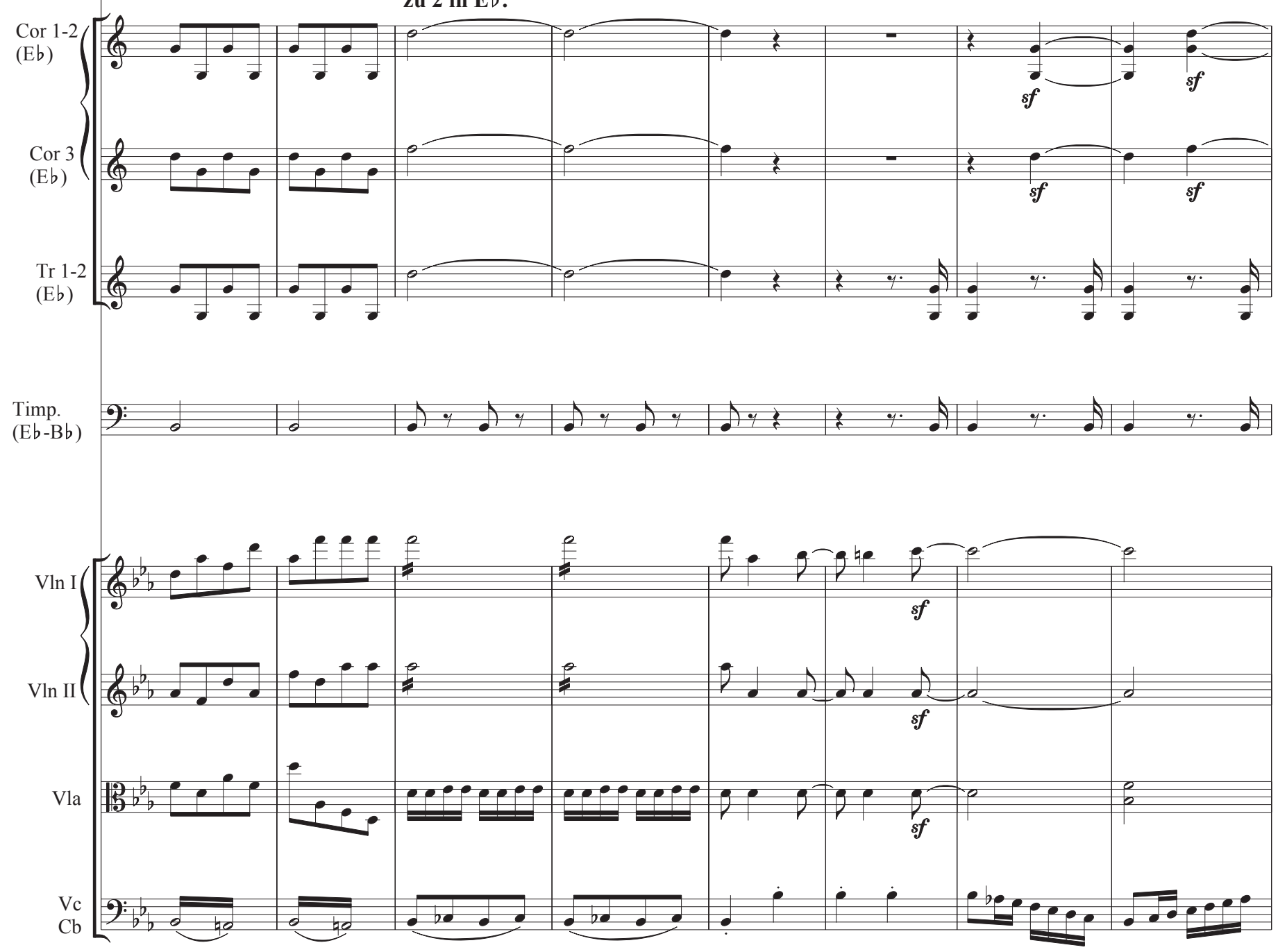
Salida de Escena
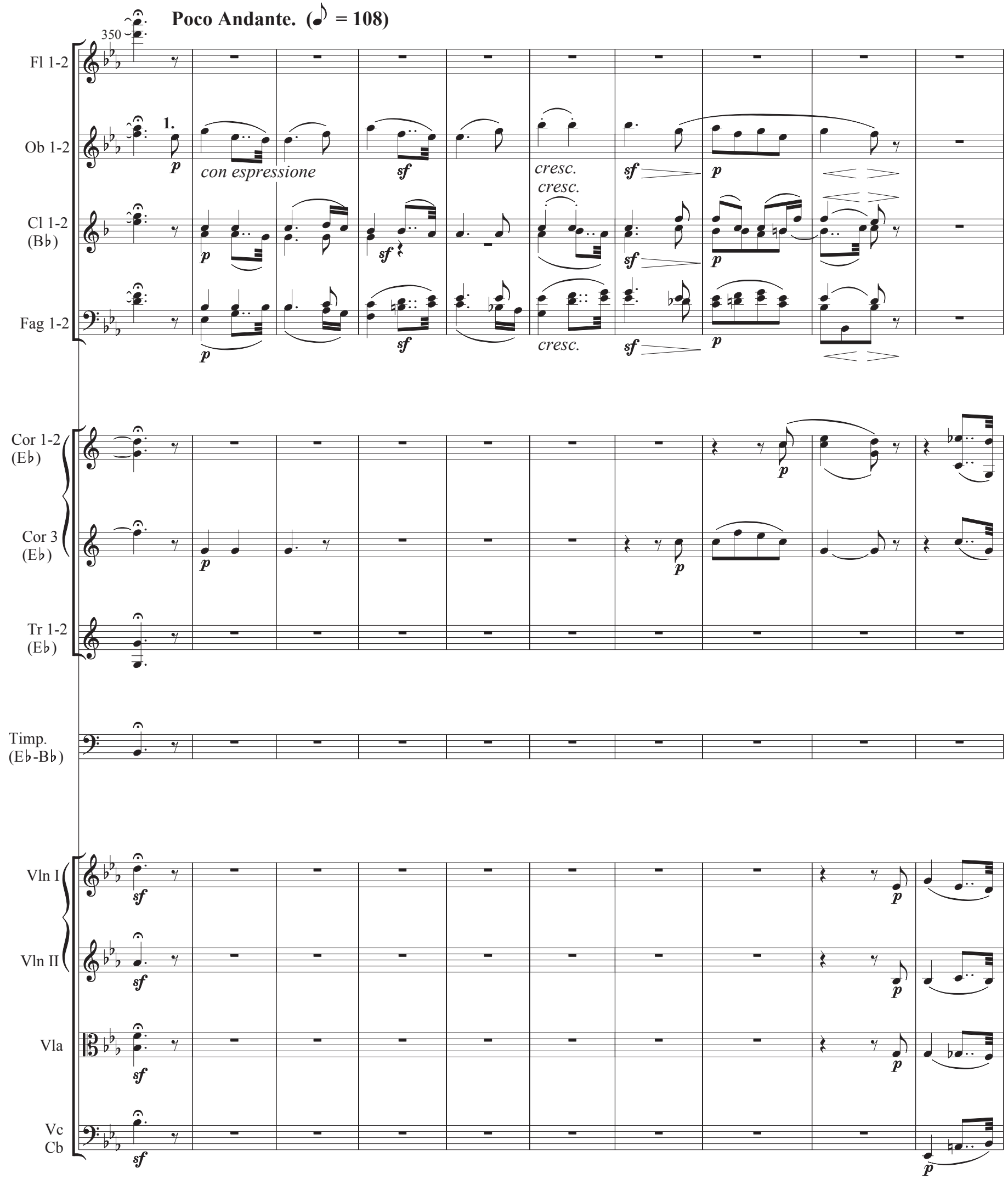

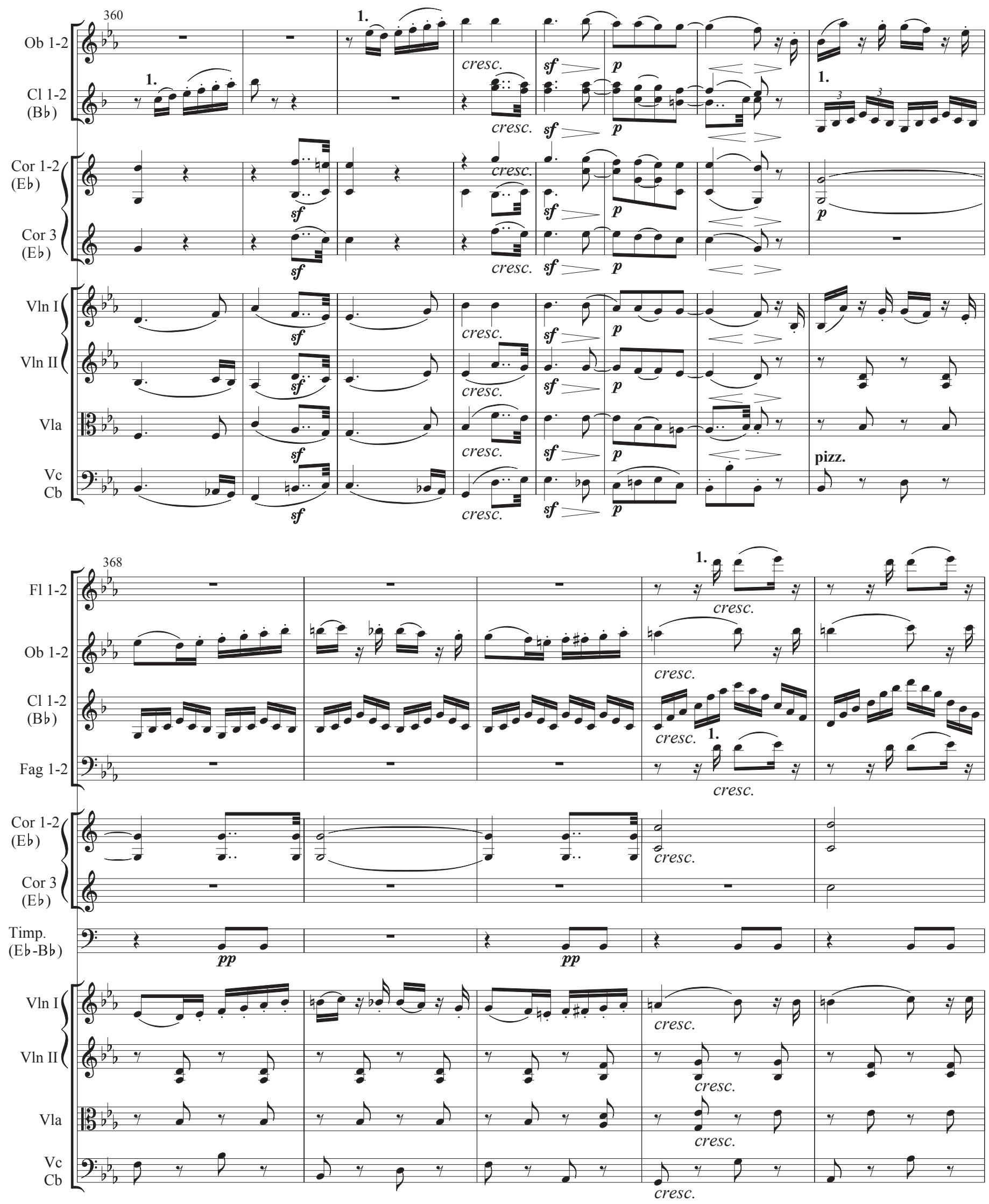


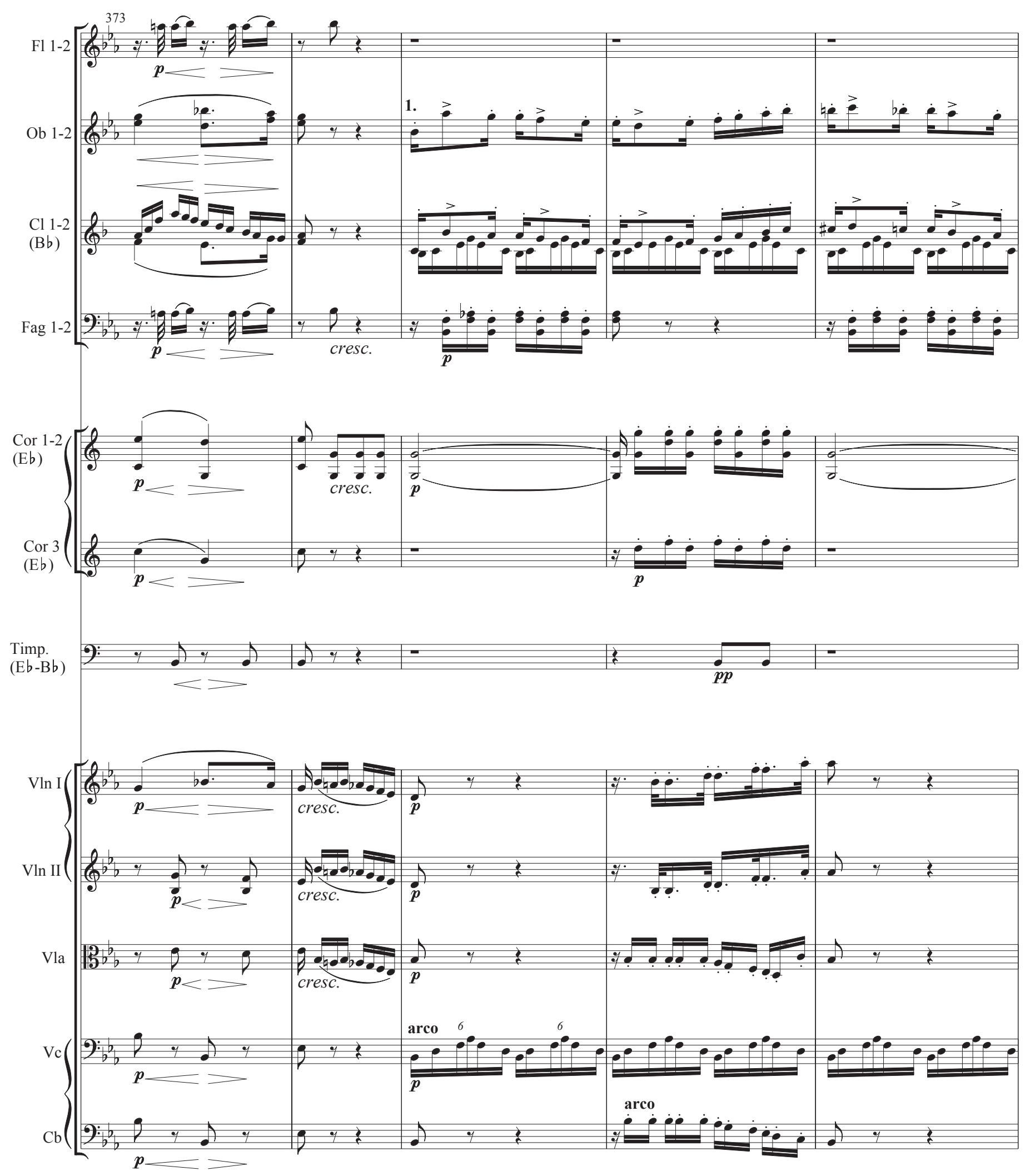




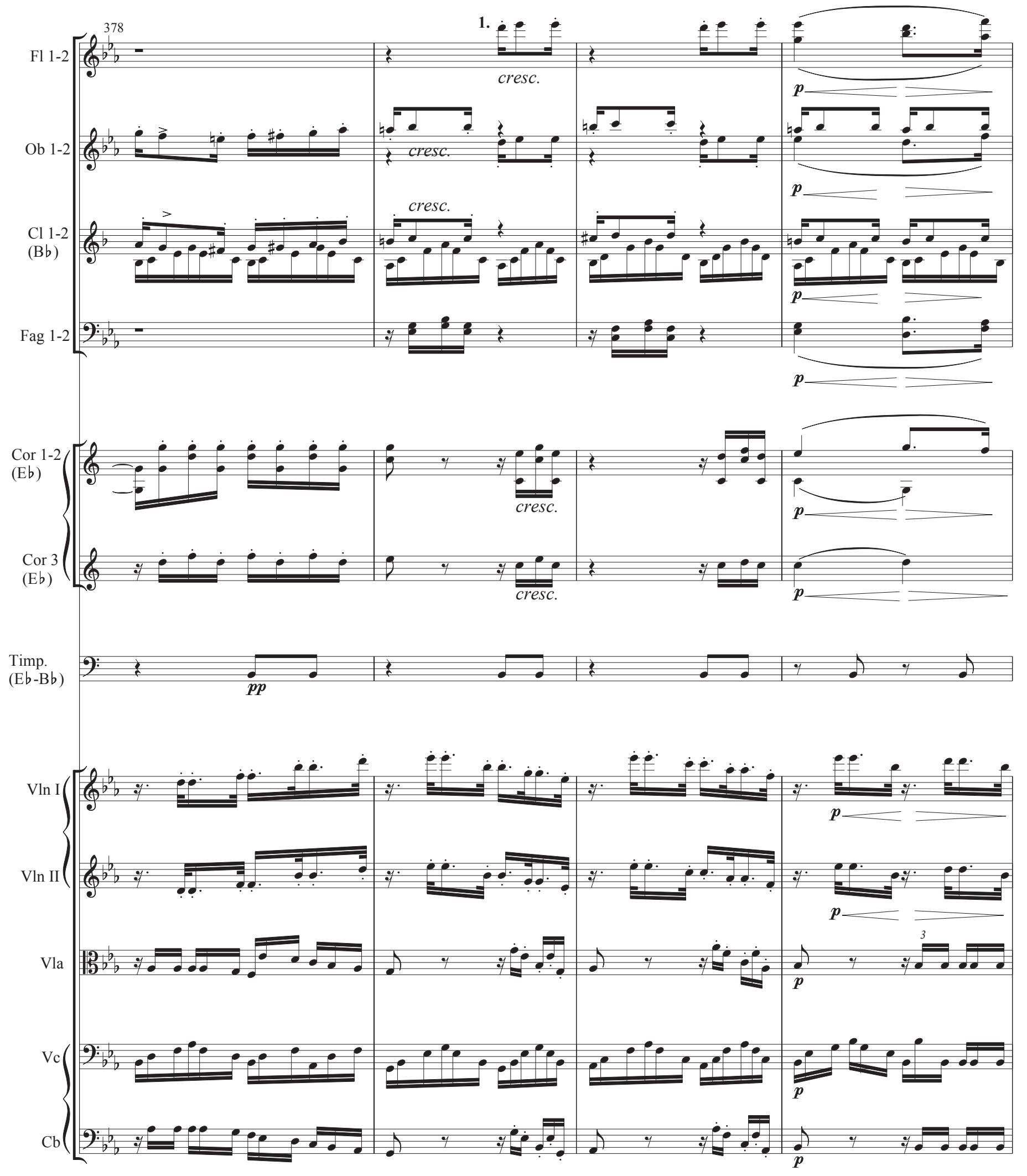


Vuelta a escena
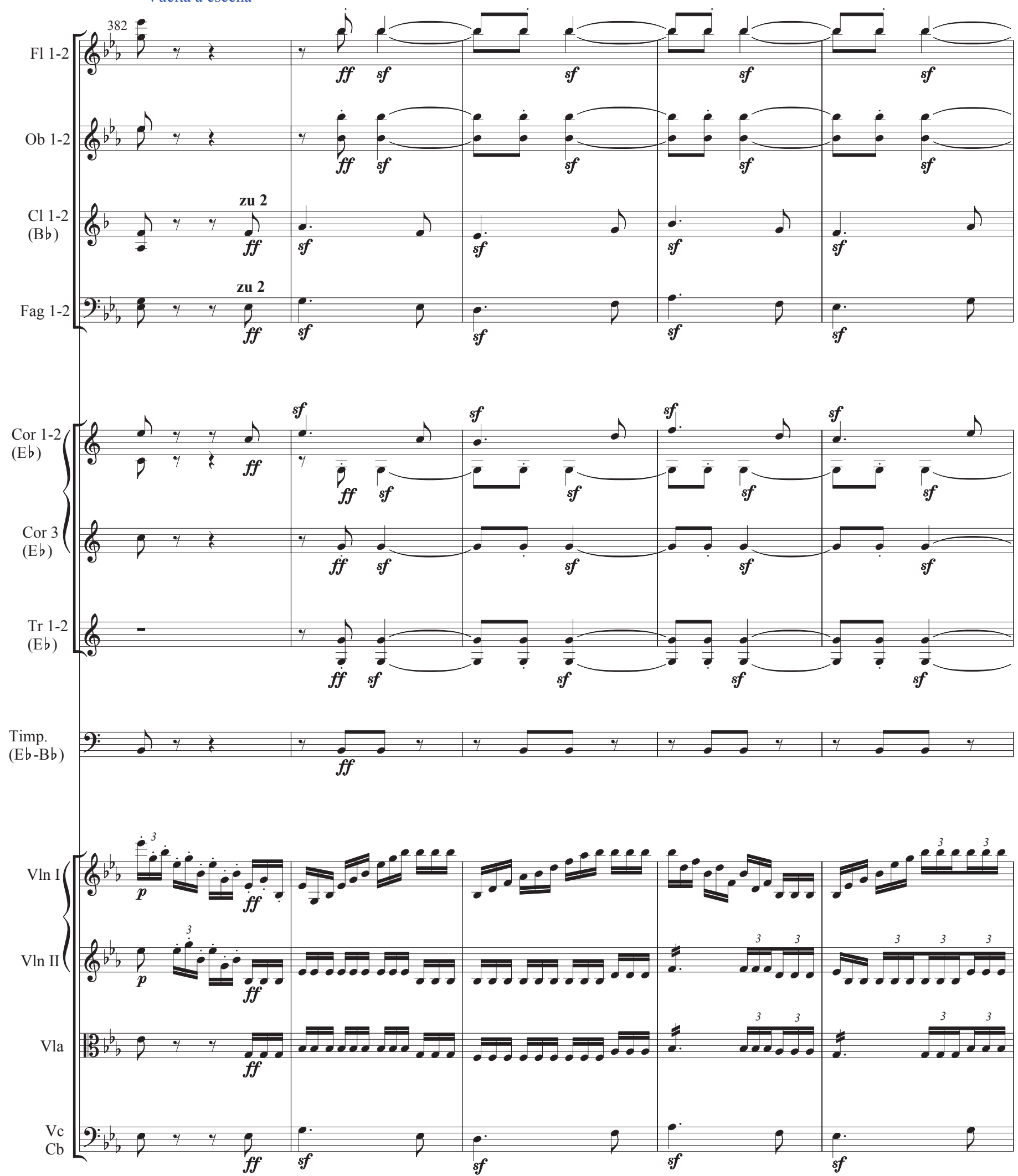
Taberna: Beethoven y discípulo

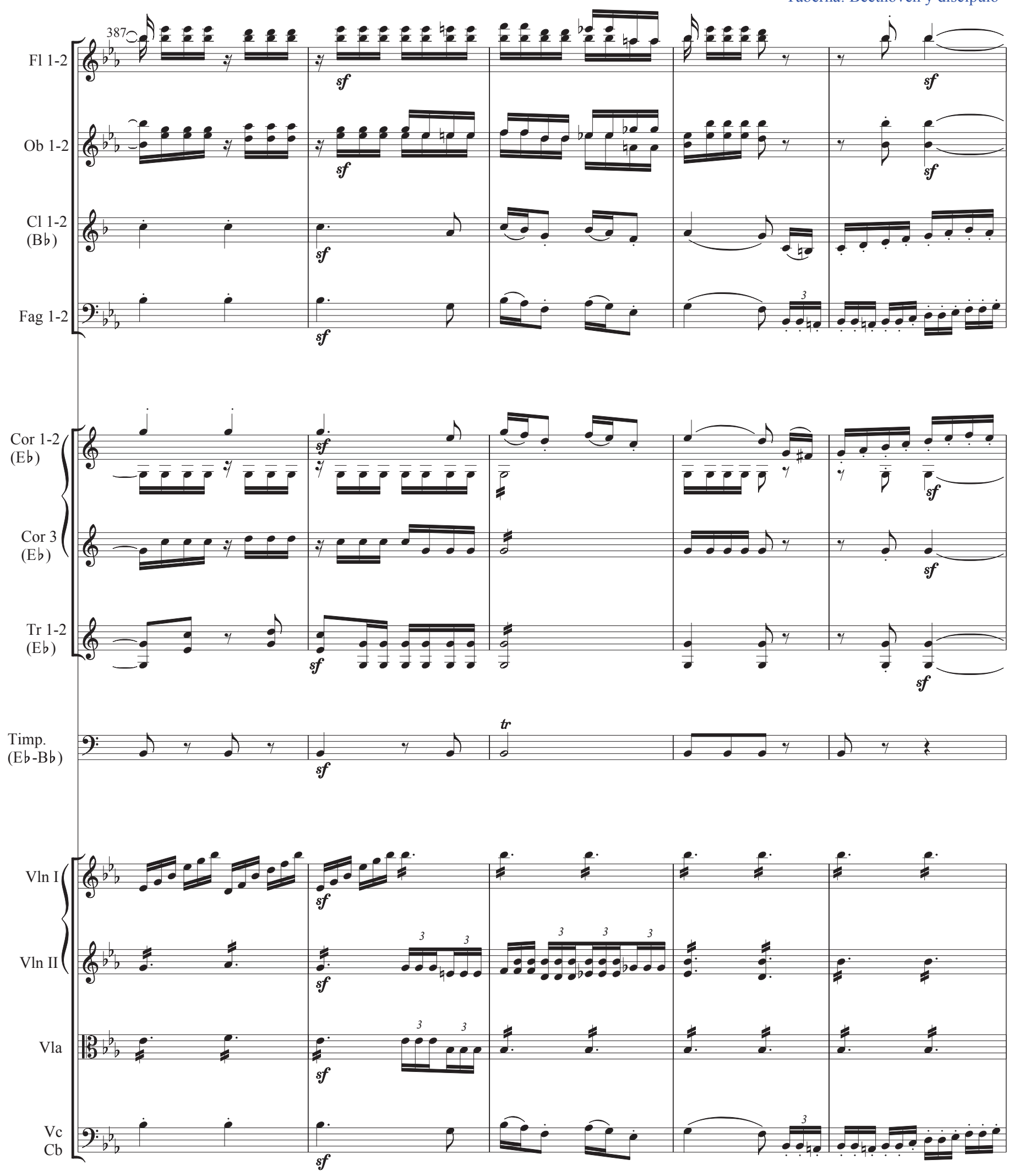



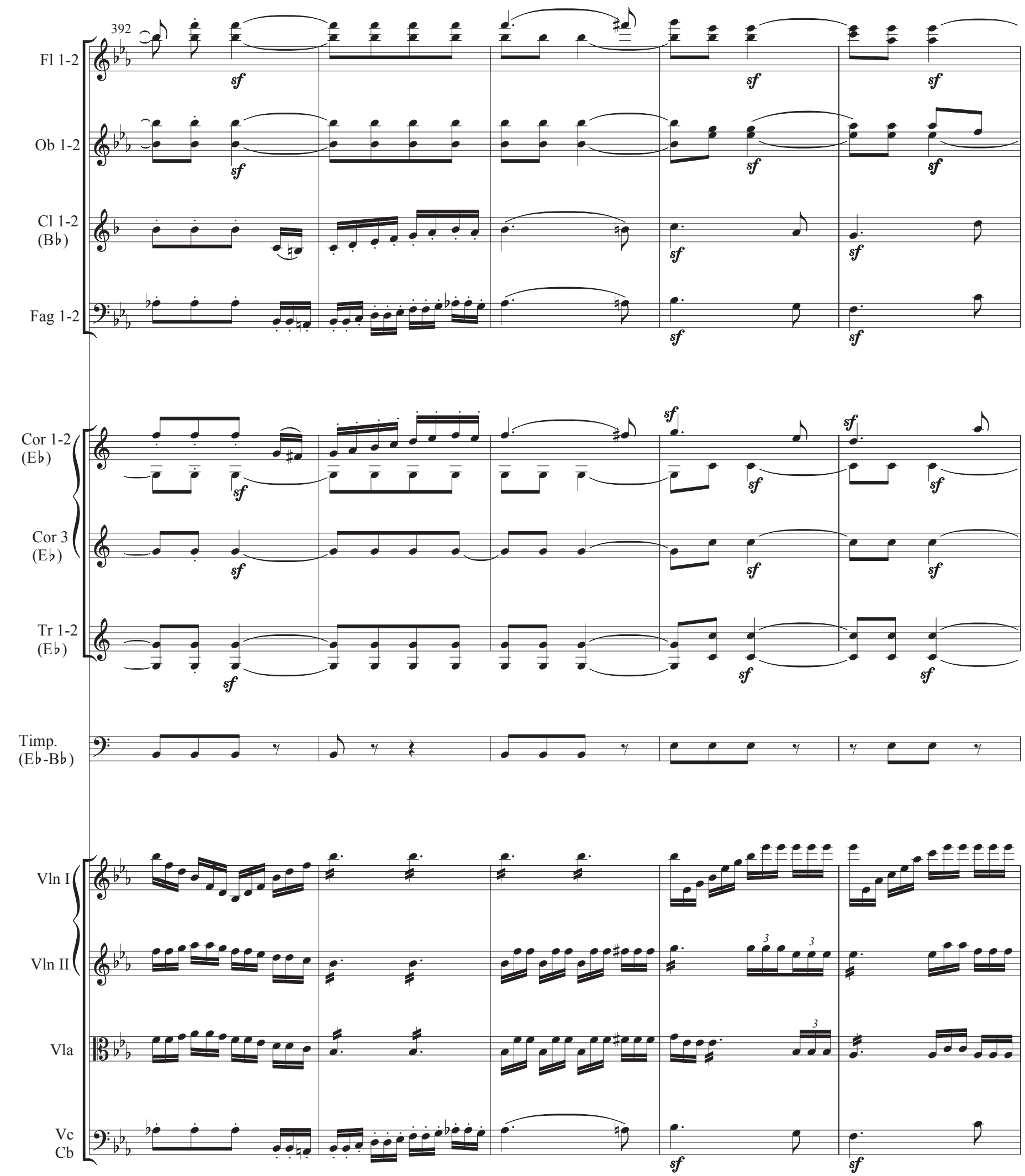

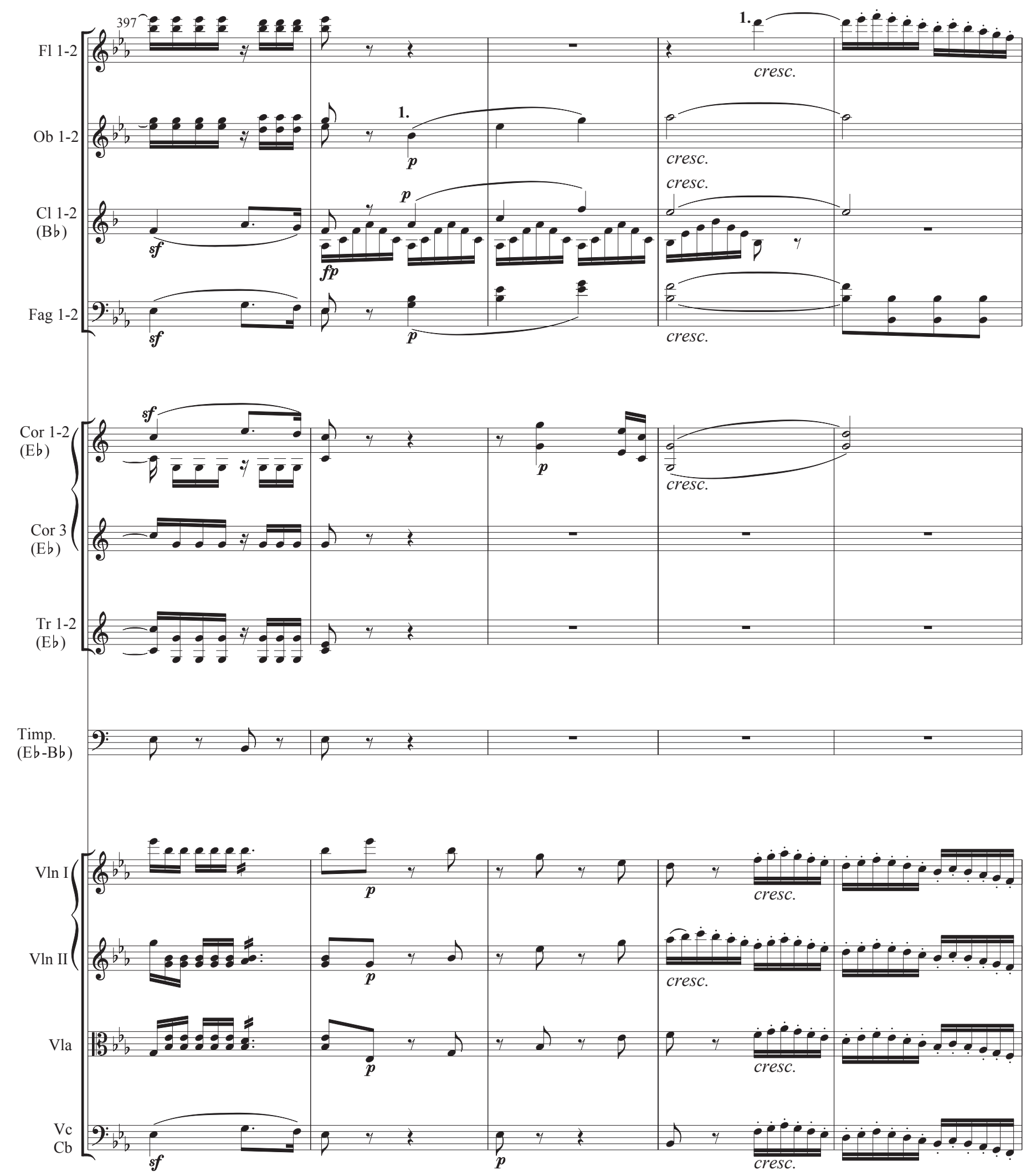


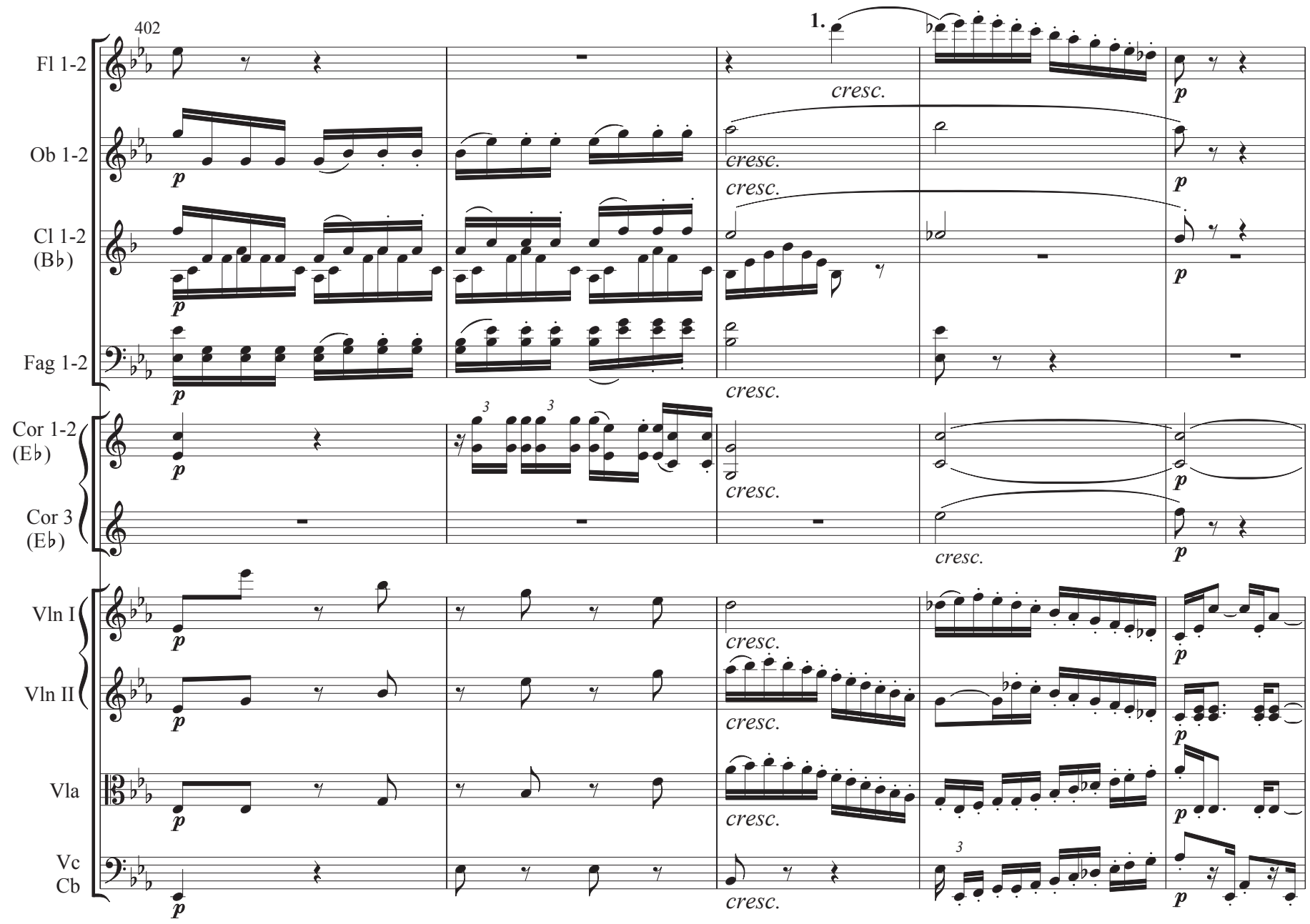

Taberna hasta el Presto final
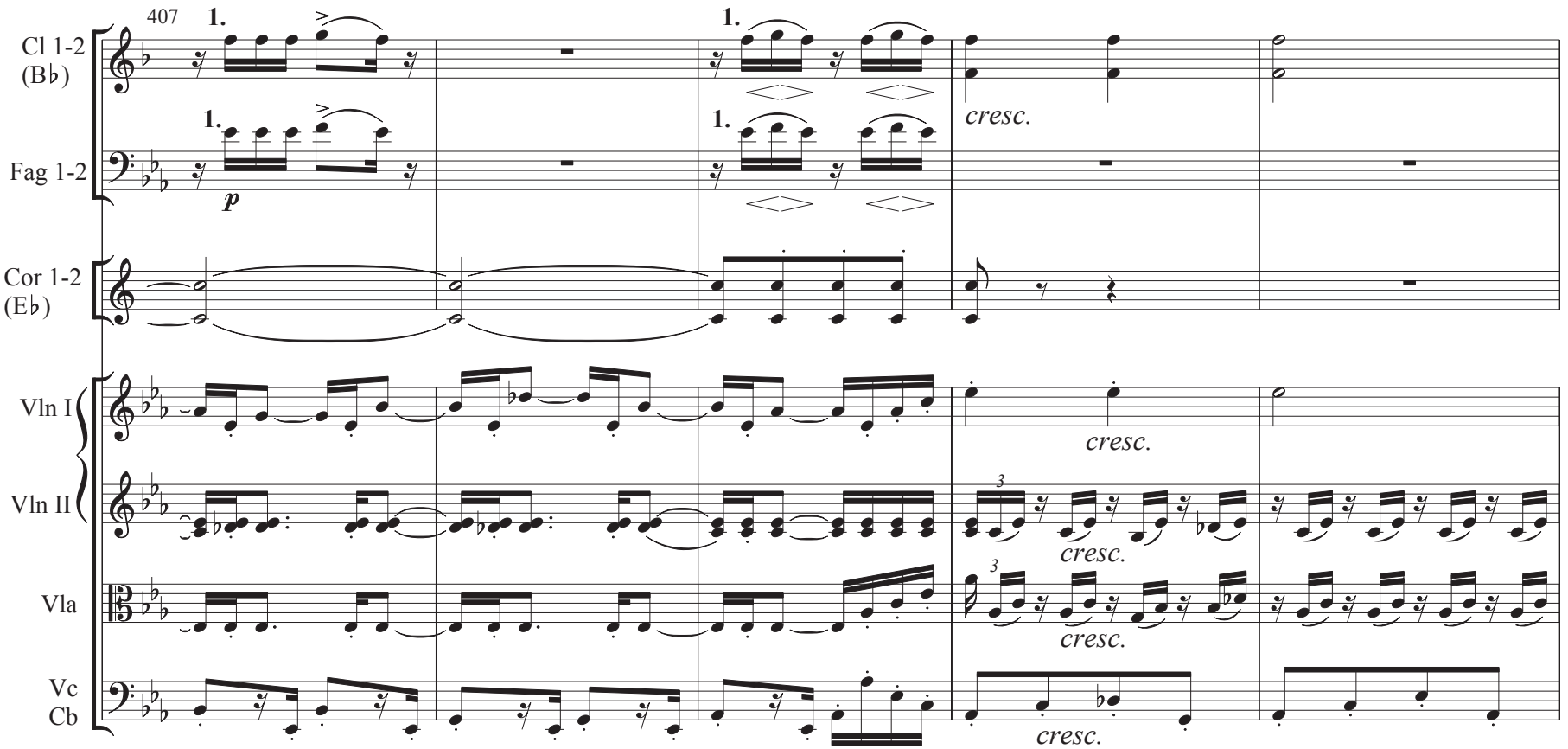

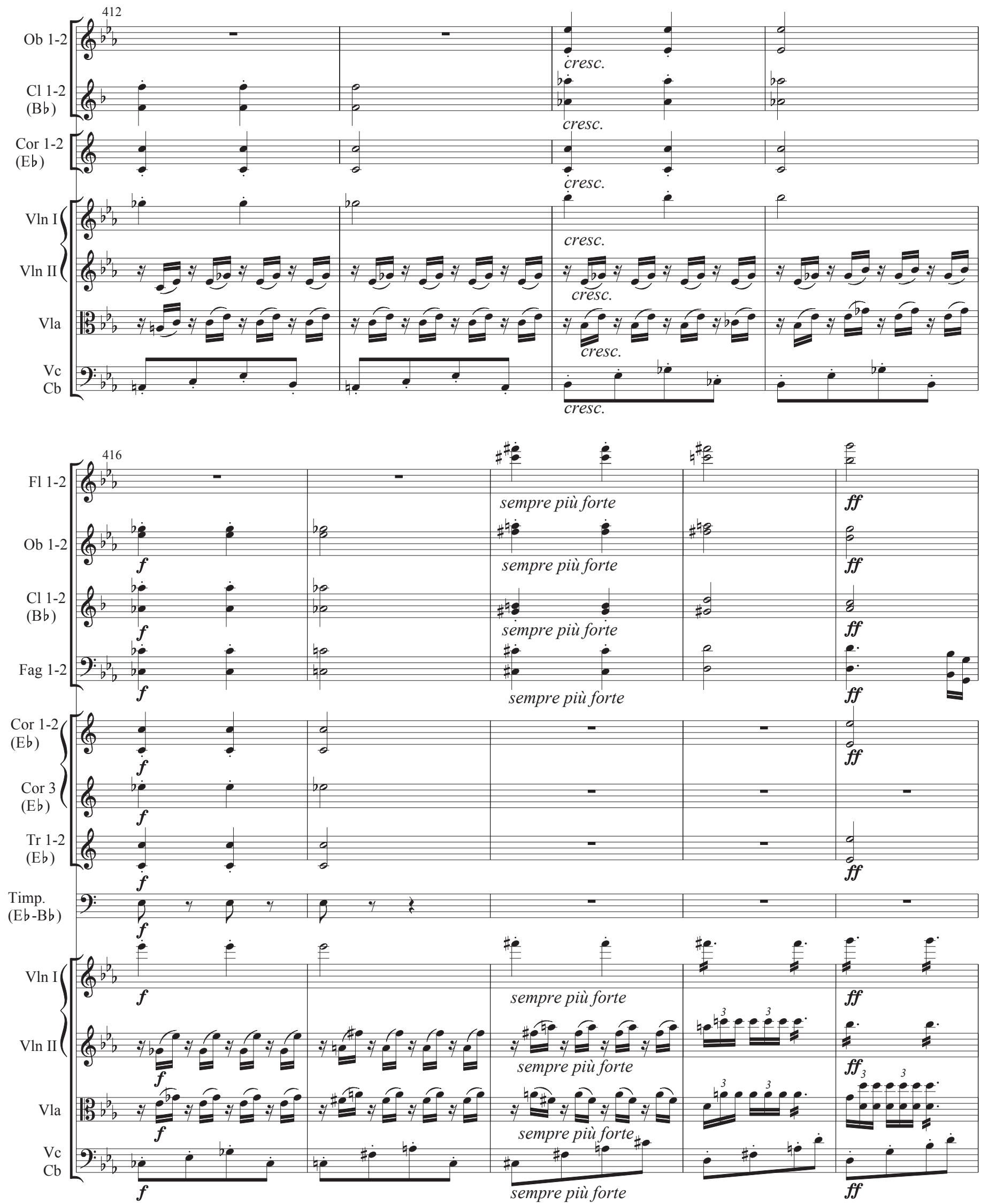

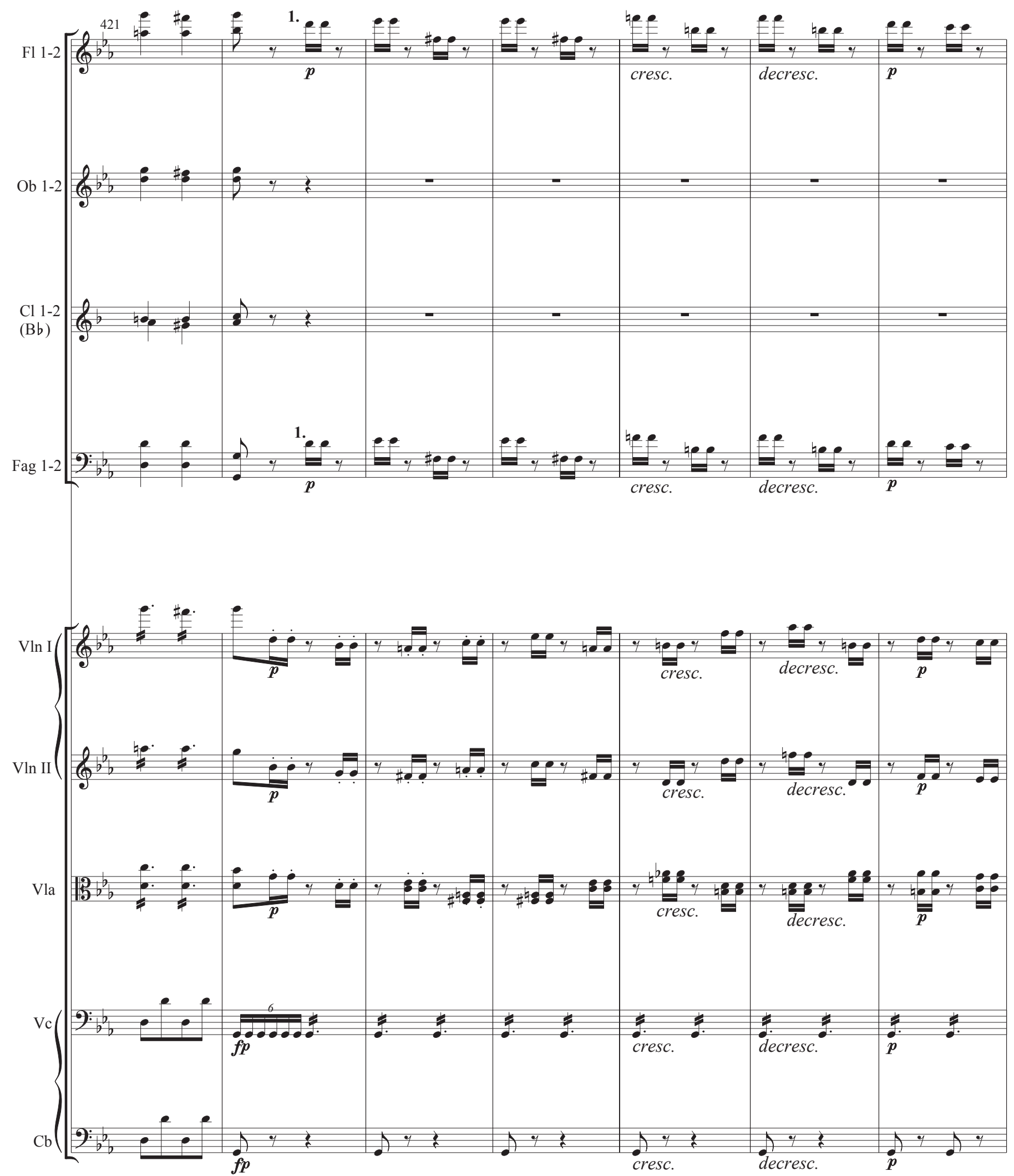
P1 a P76 (45")

Edición con planos muy cortos

Presto. $\left({ }^{\prime}=116\right)$
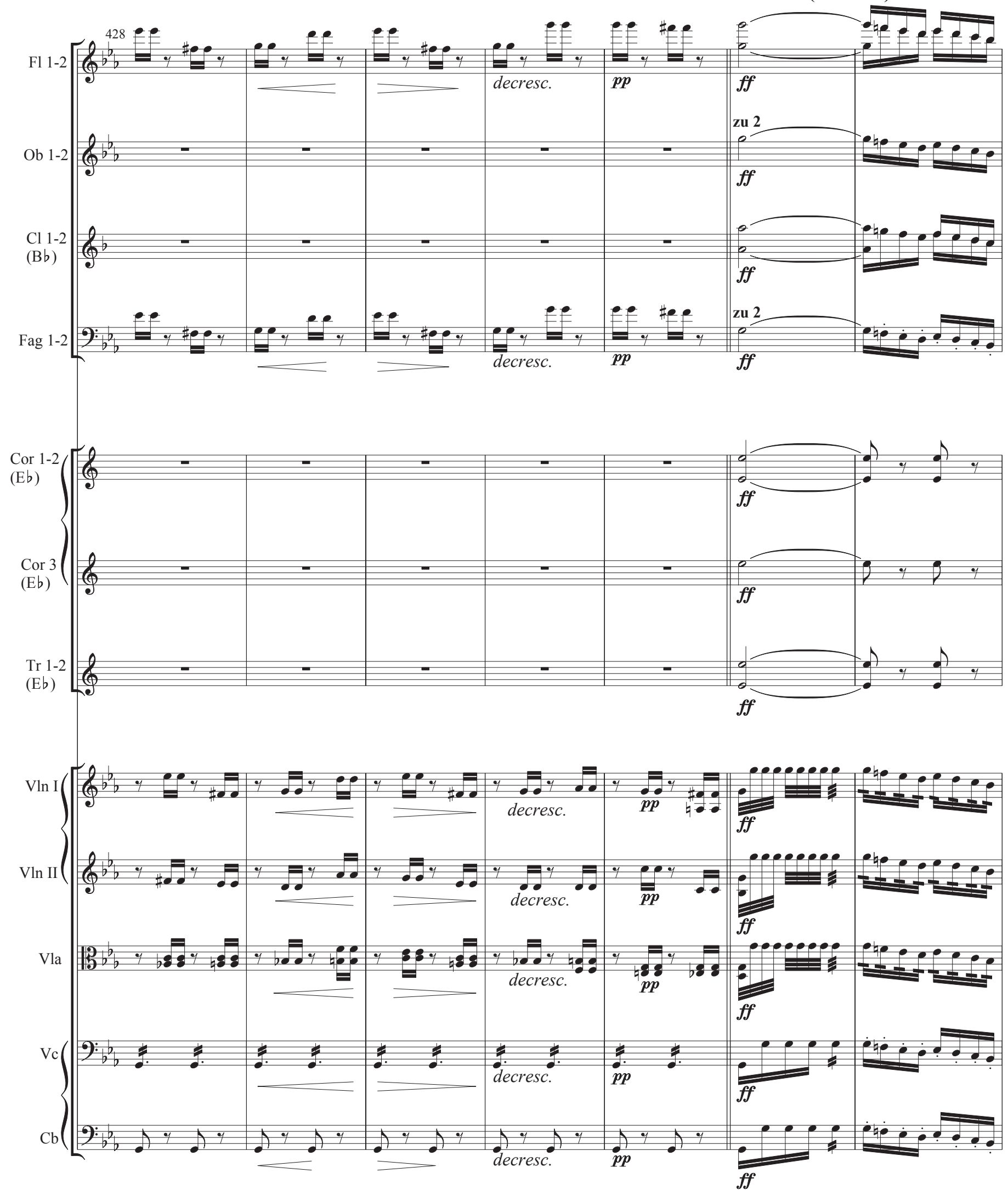

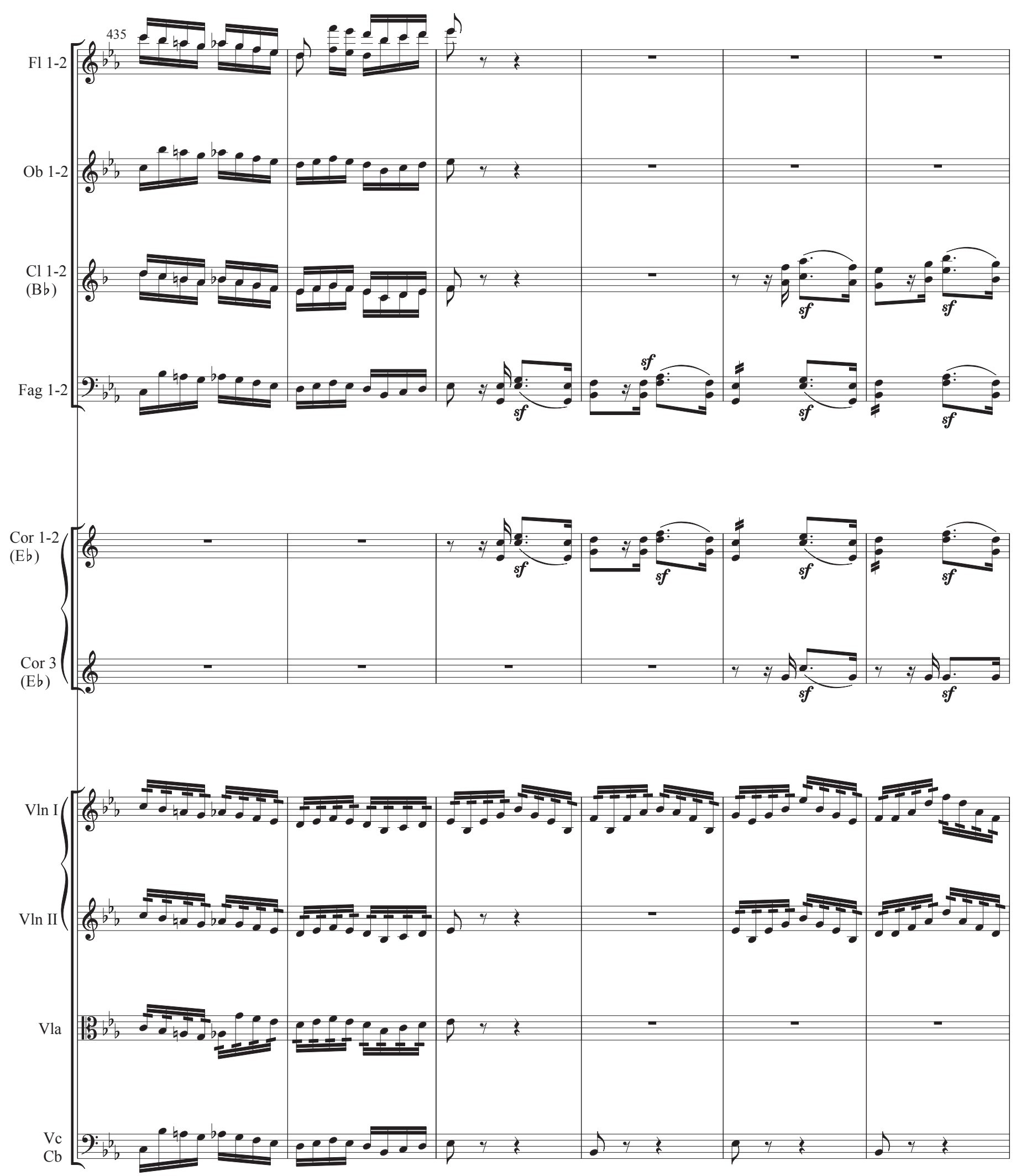


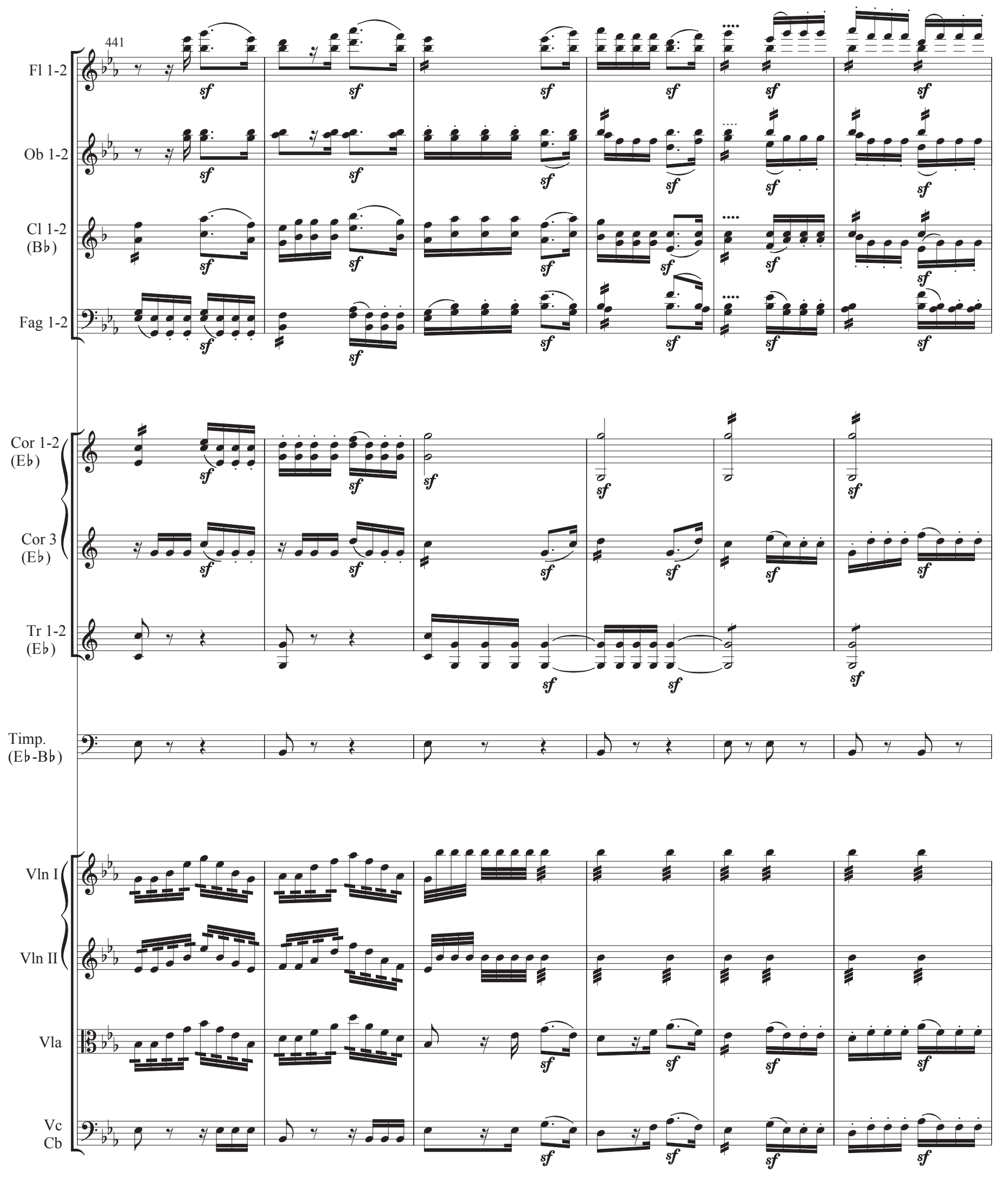




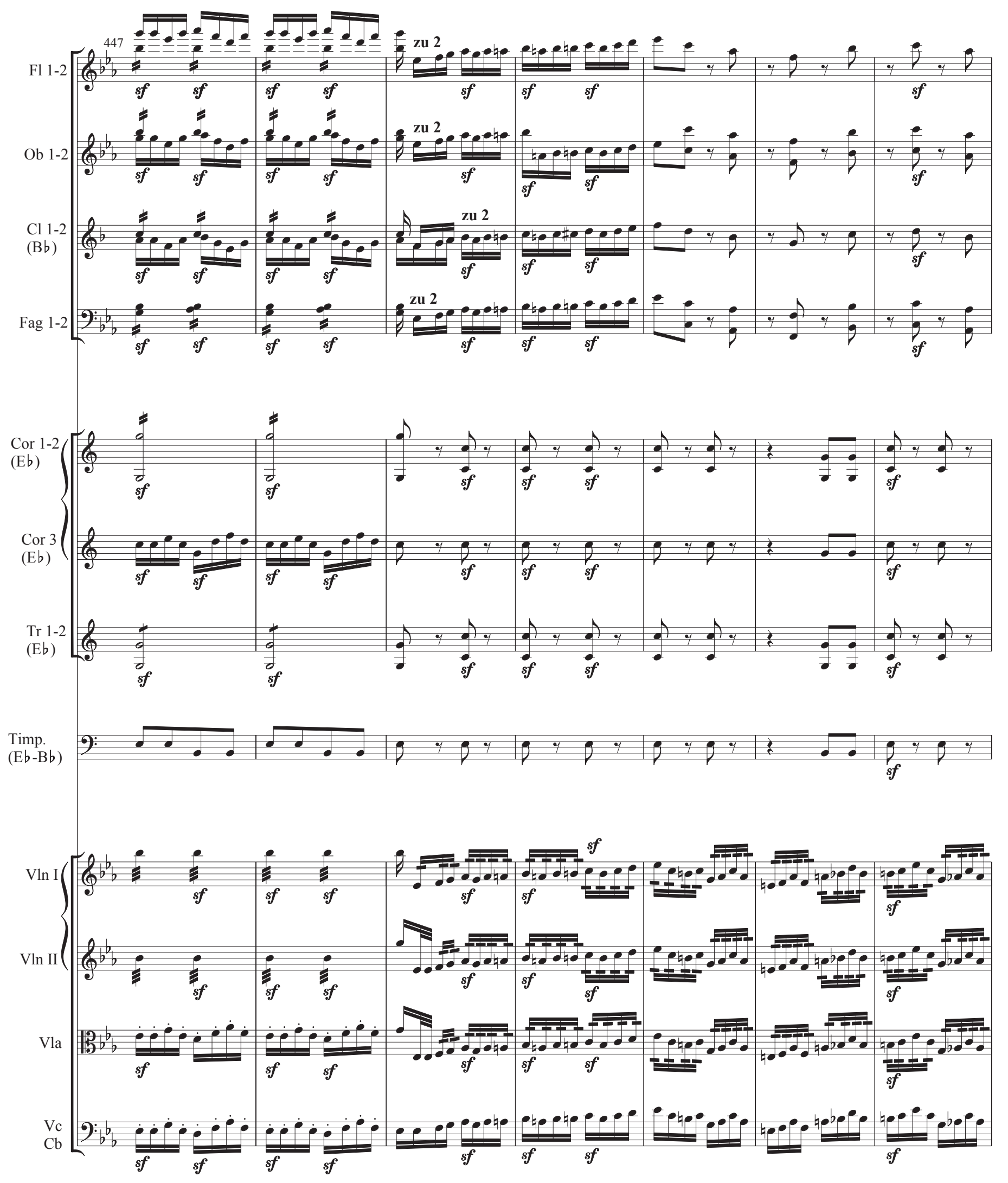




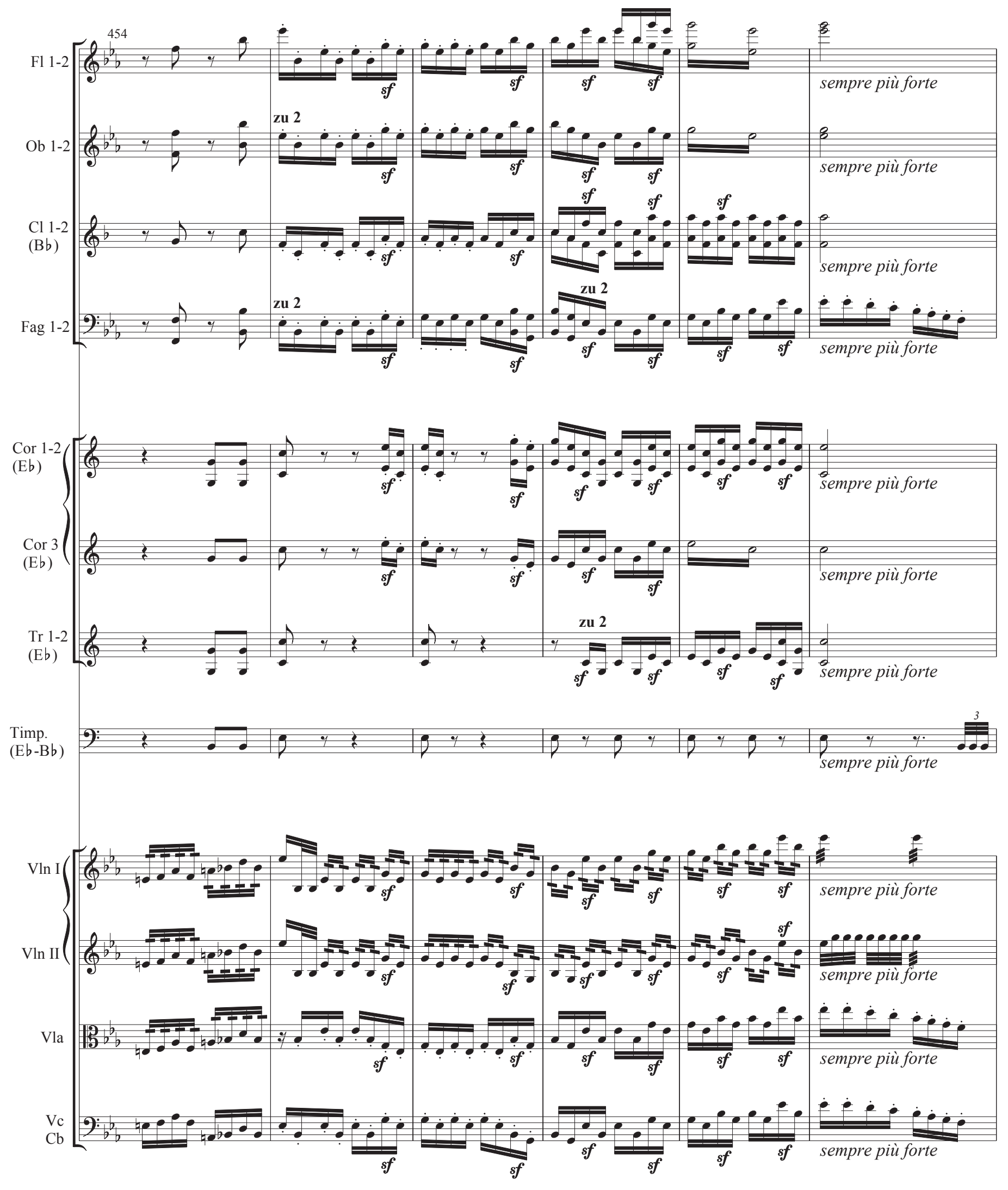



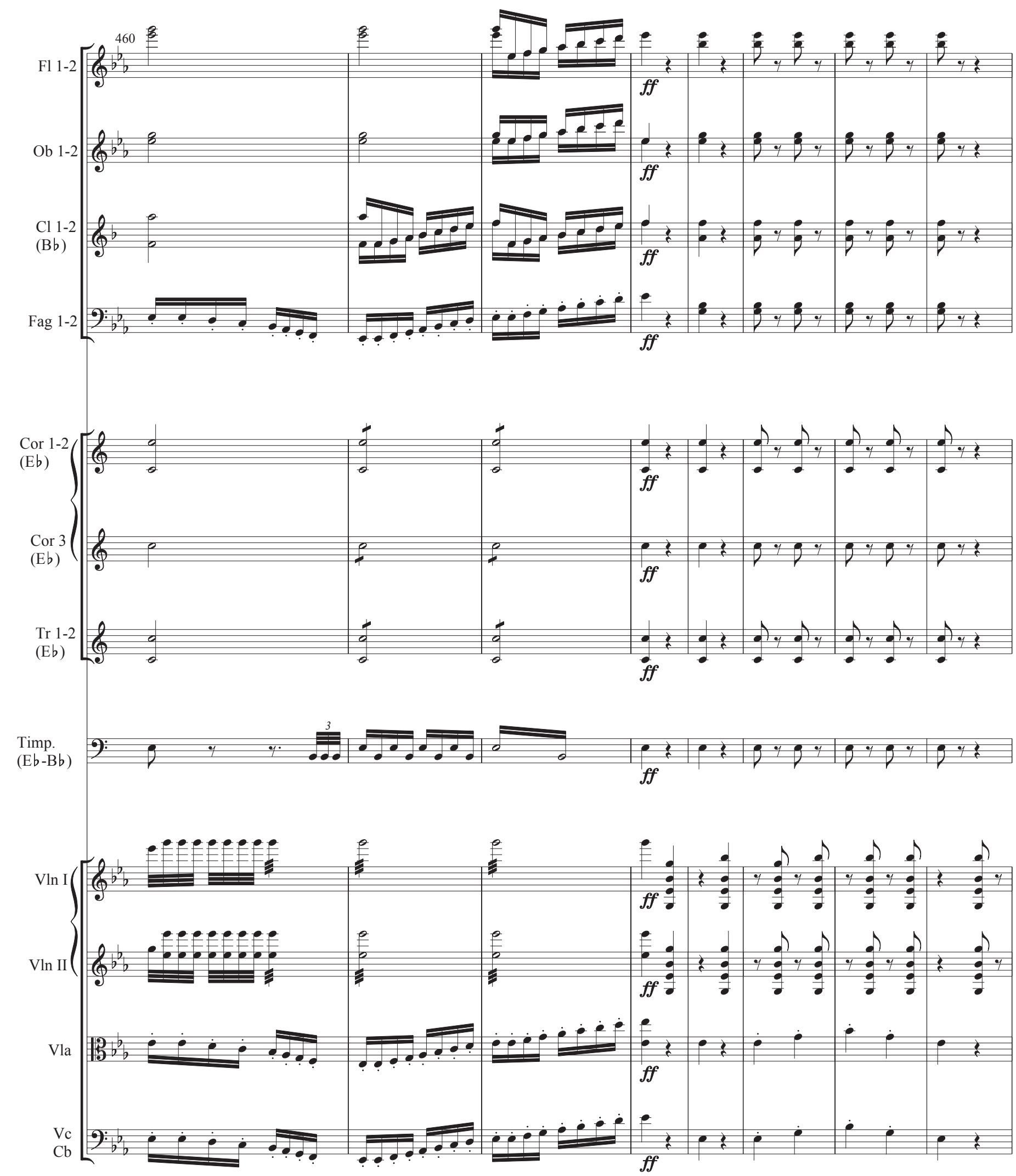

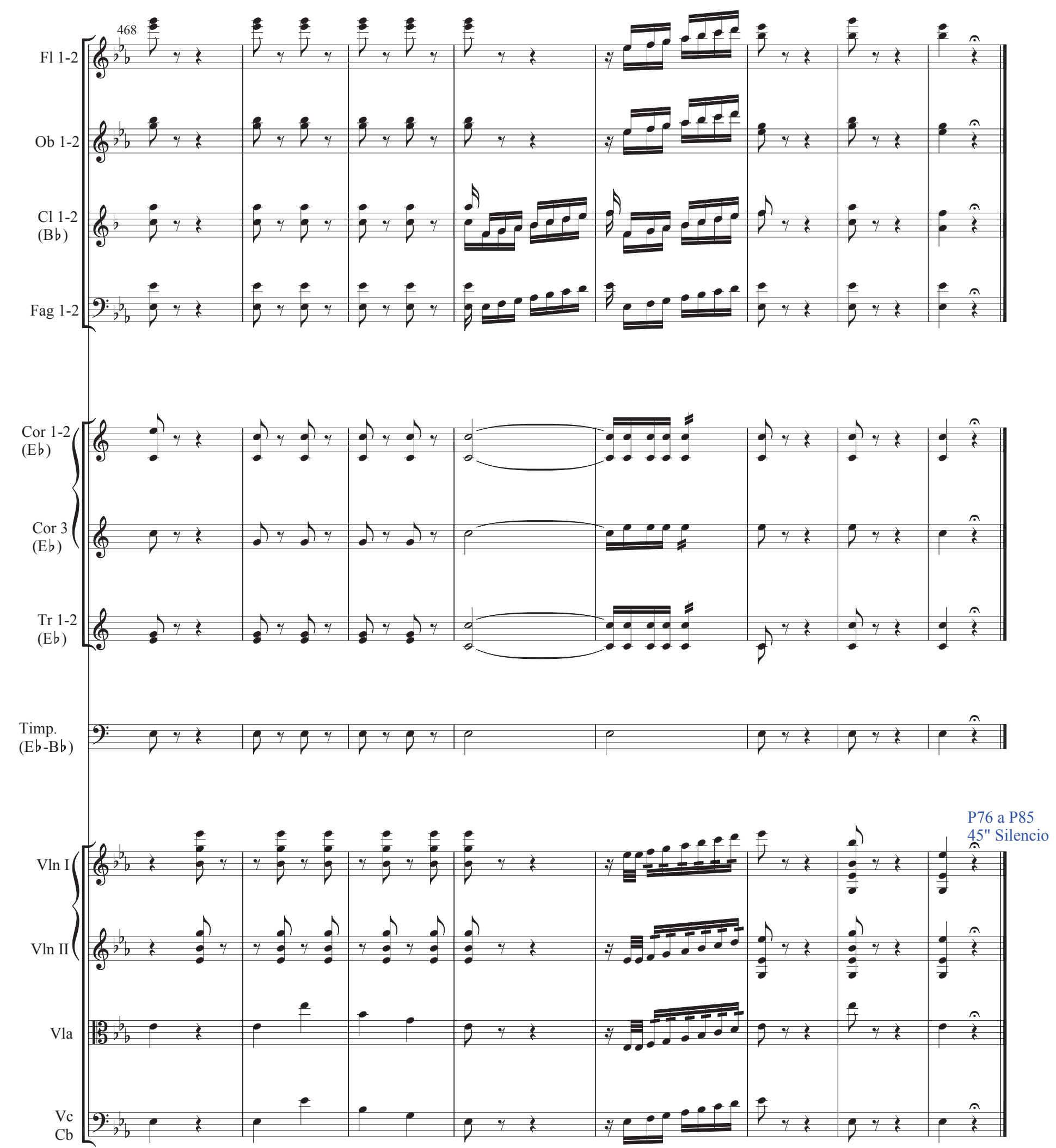
2

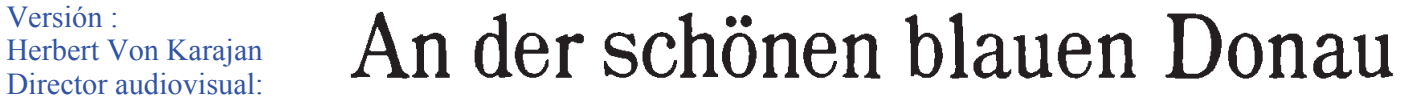

Humprey Burton

P1 y P2

Introduktion

Andantino

\section{Walzer}

Johann Strauß, op. 314

P3

Flöte I

Flöte II

Kleine Flöte

Oboen

Klarinetten in C

II

Fagotte

Hörner in $\mathrm{F}$

I II

Trompeten in $\mathrm{F}$

Baß-Posaune

Tuba

Pauken

Kleine Trommel

Triangel u.

große Trommel

Harfe

II

III IV
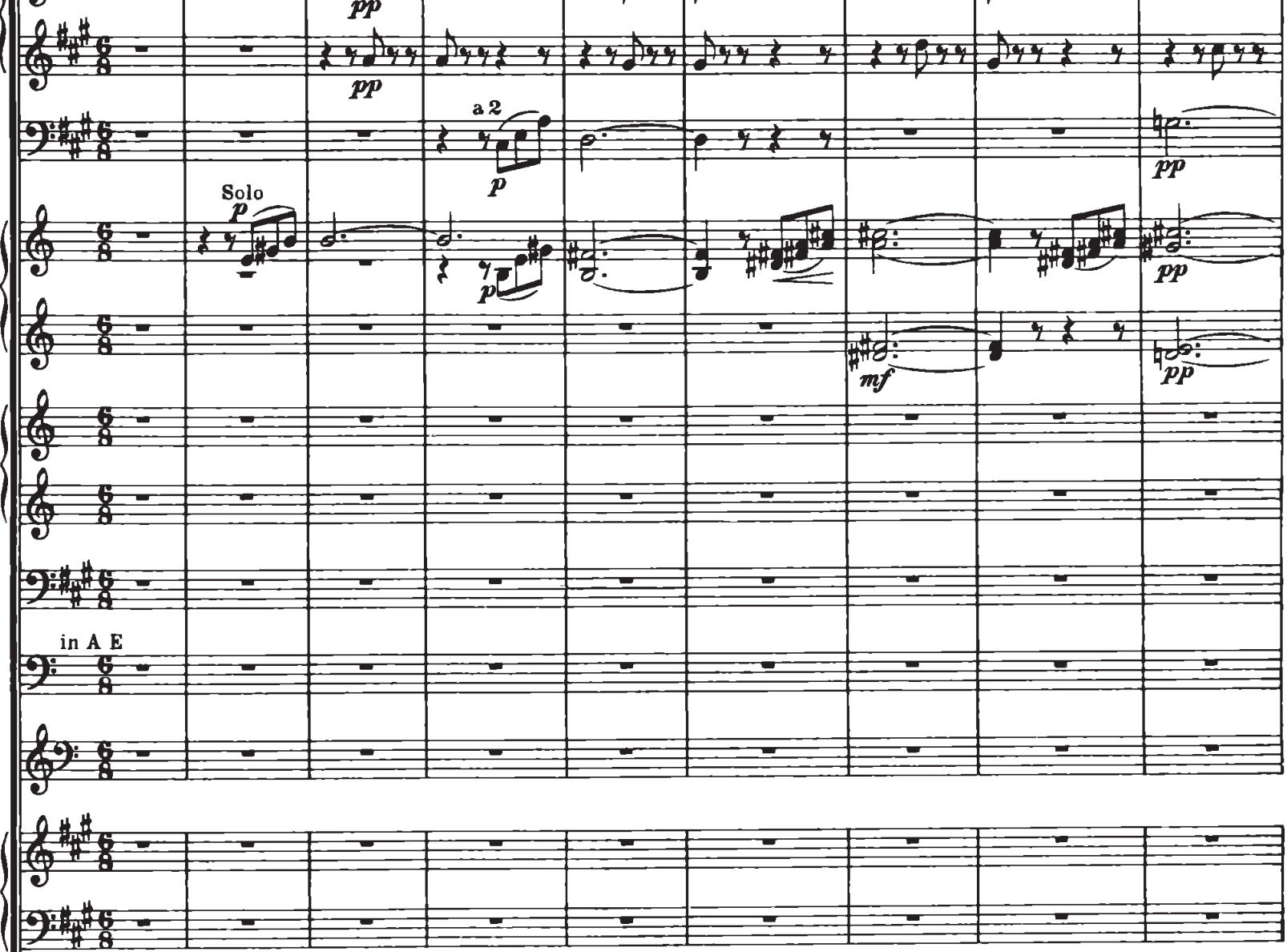

Andantino

Violine I

Violine II

Viola

Violoncello

Kontraba $\beta$
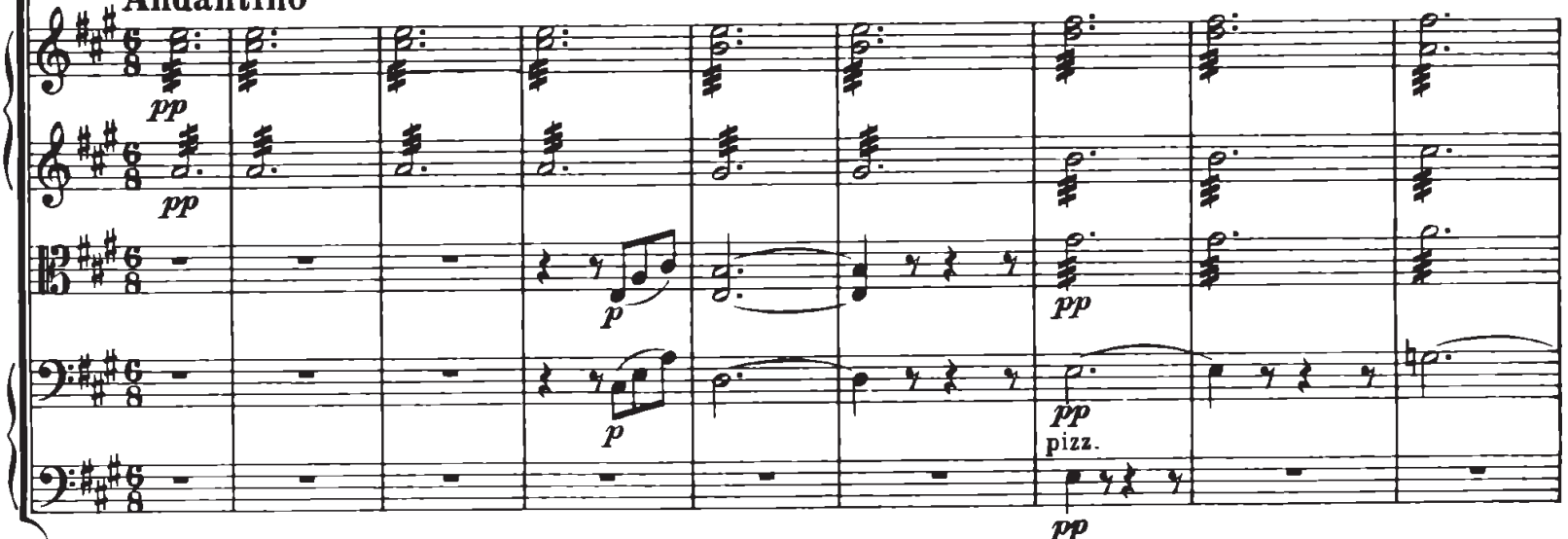


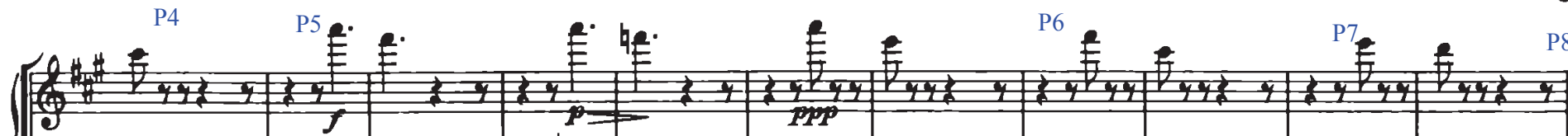

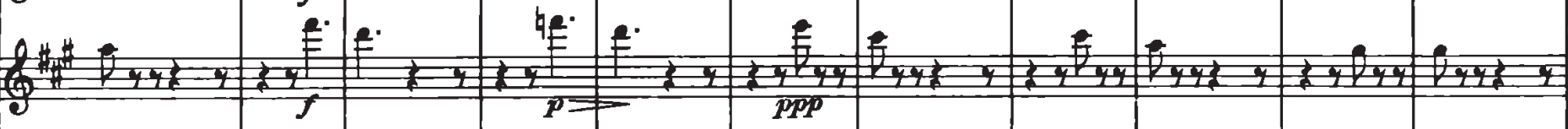
2.

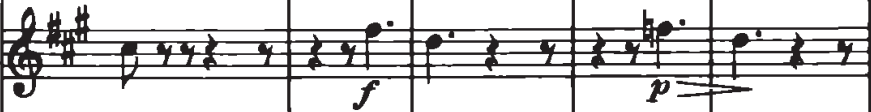

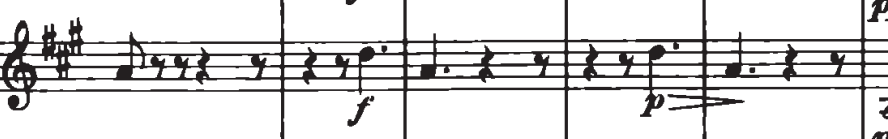

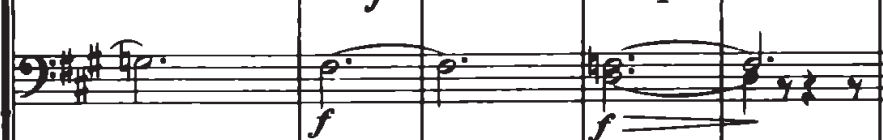
(2)

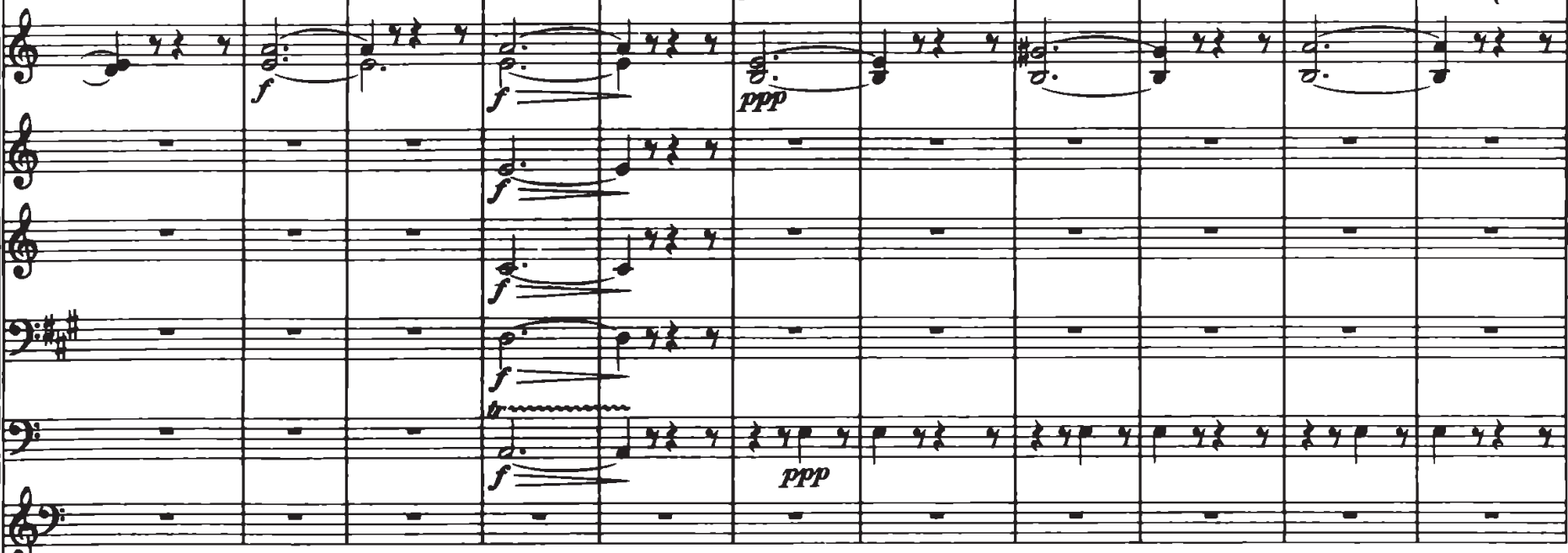

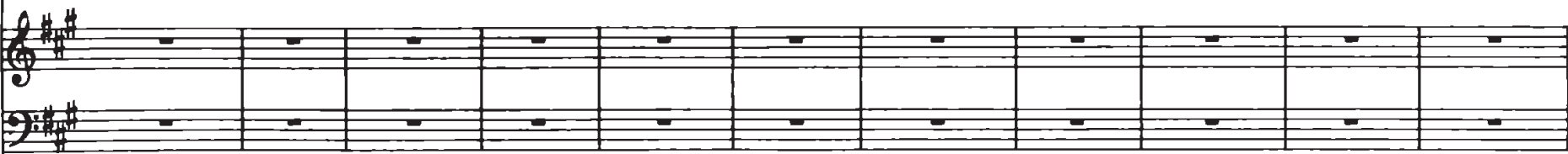

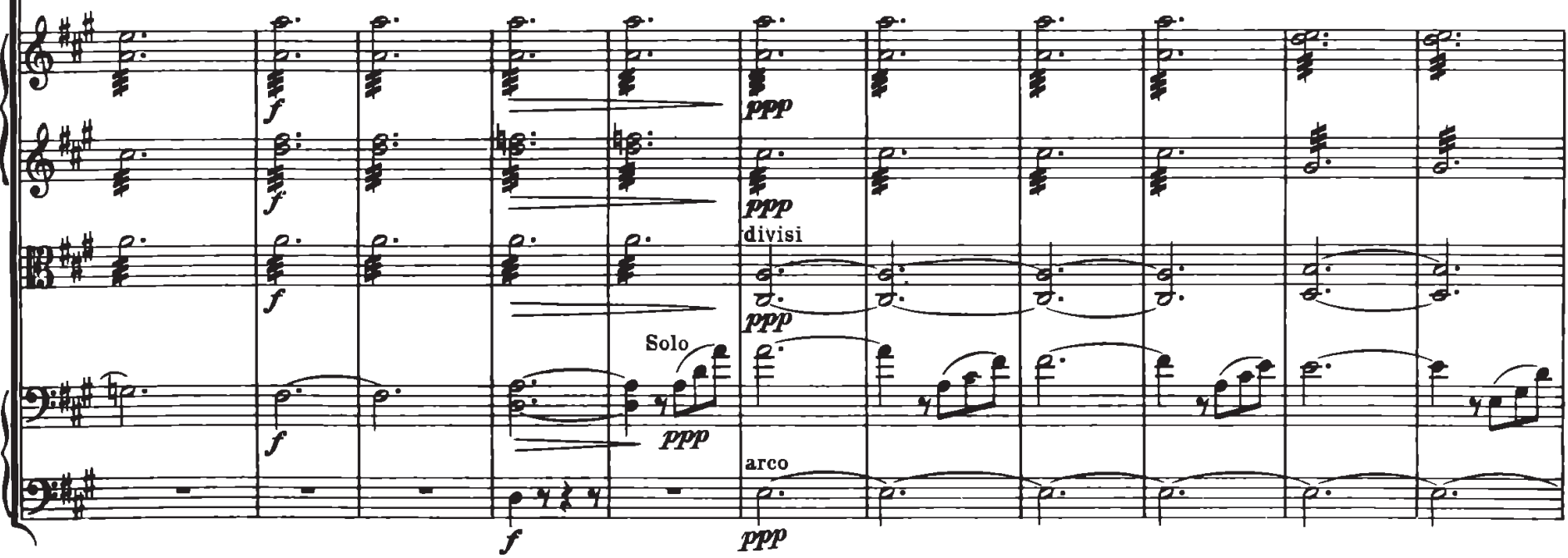



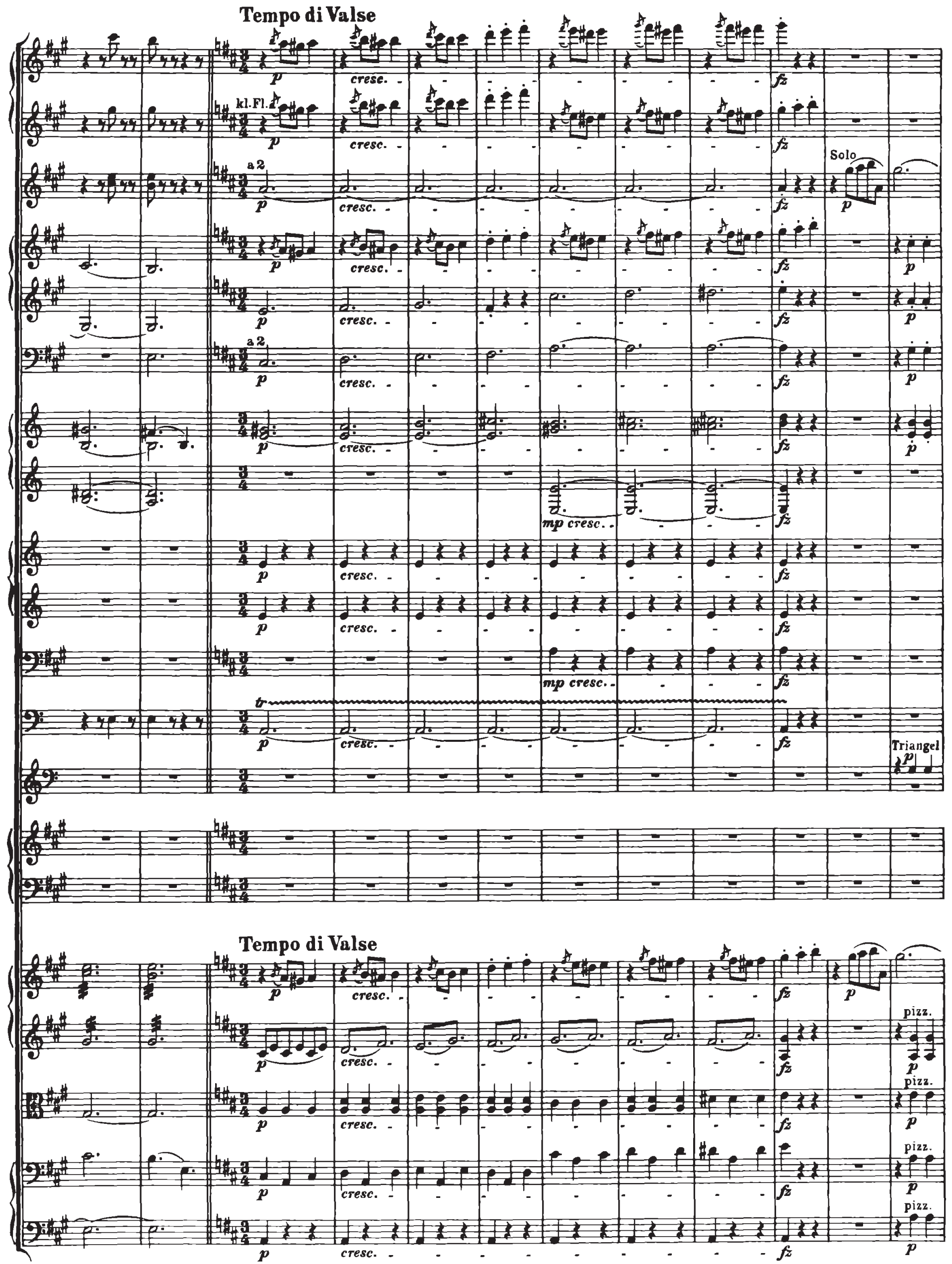


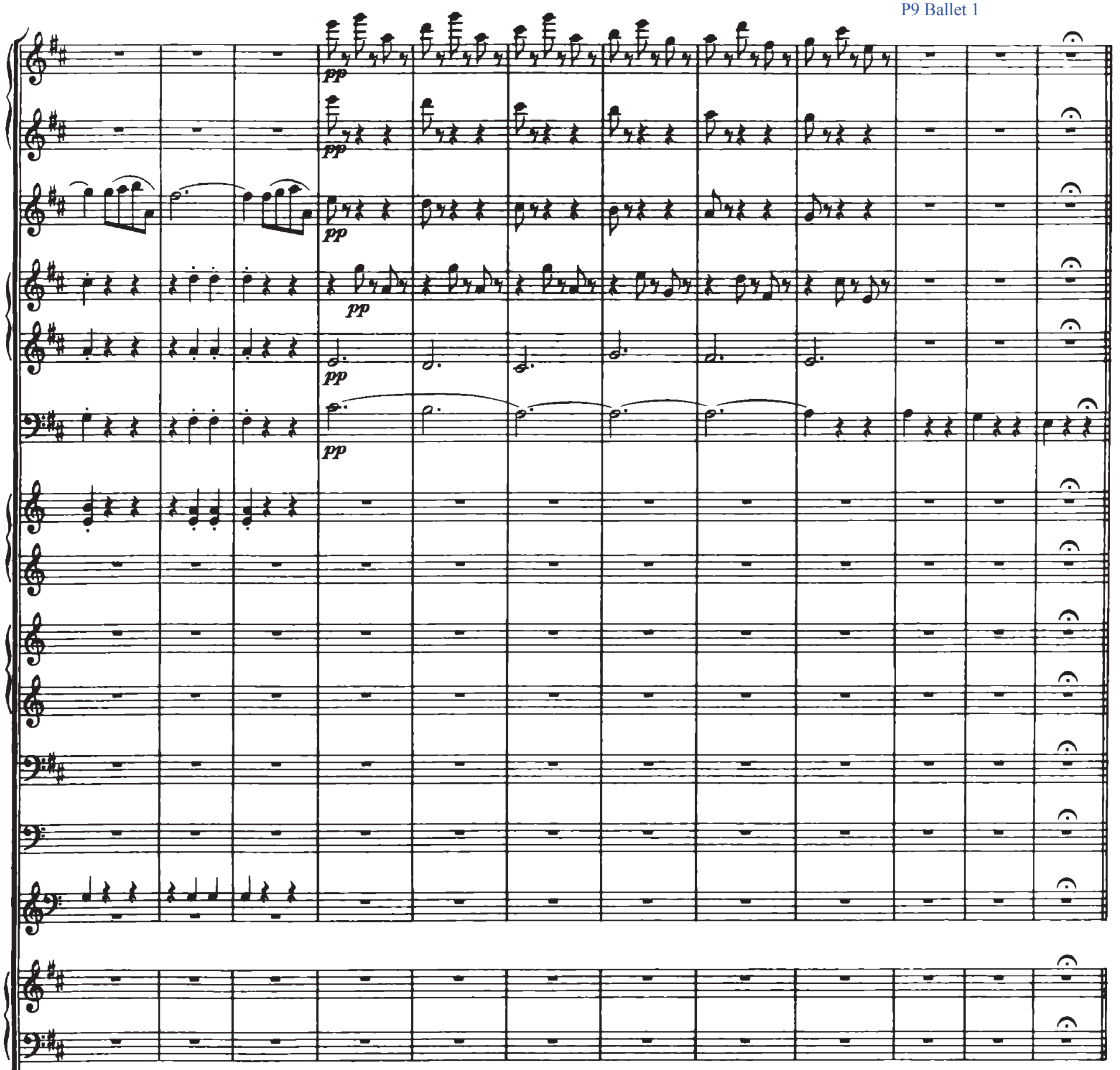

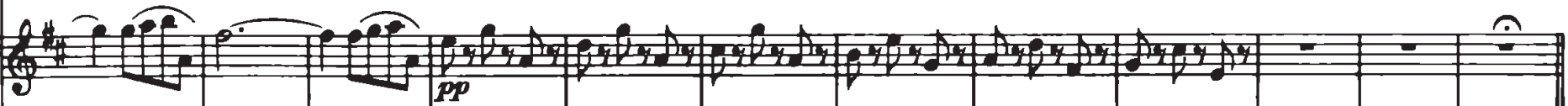

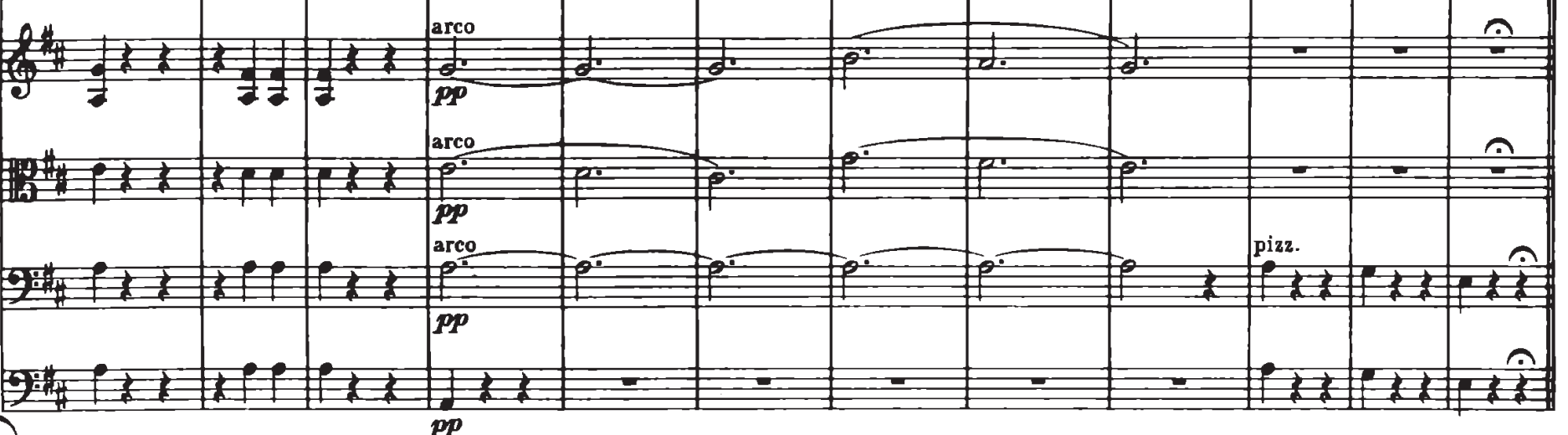


Nr.1 Walzer

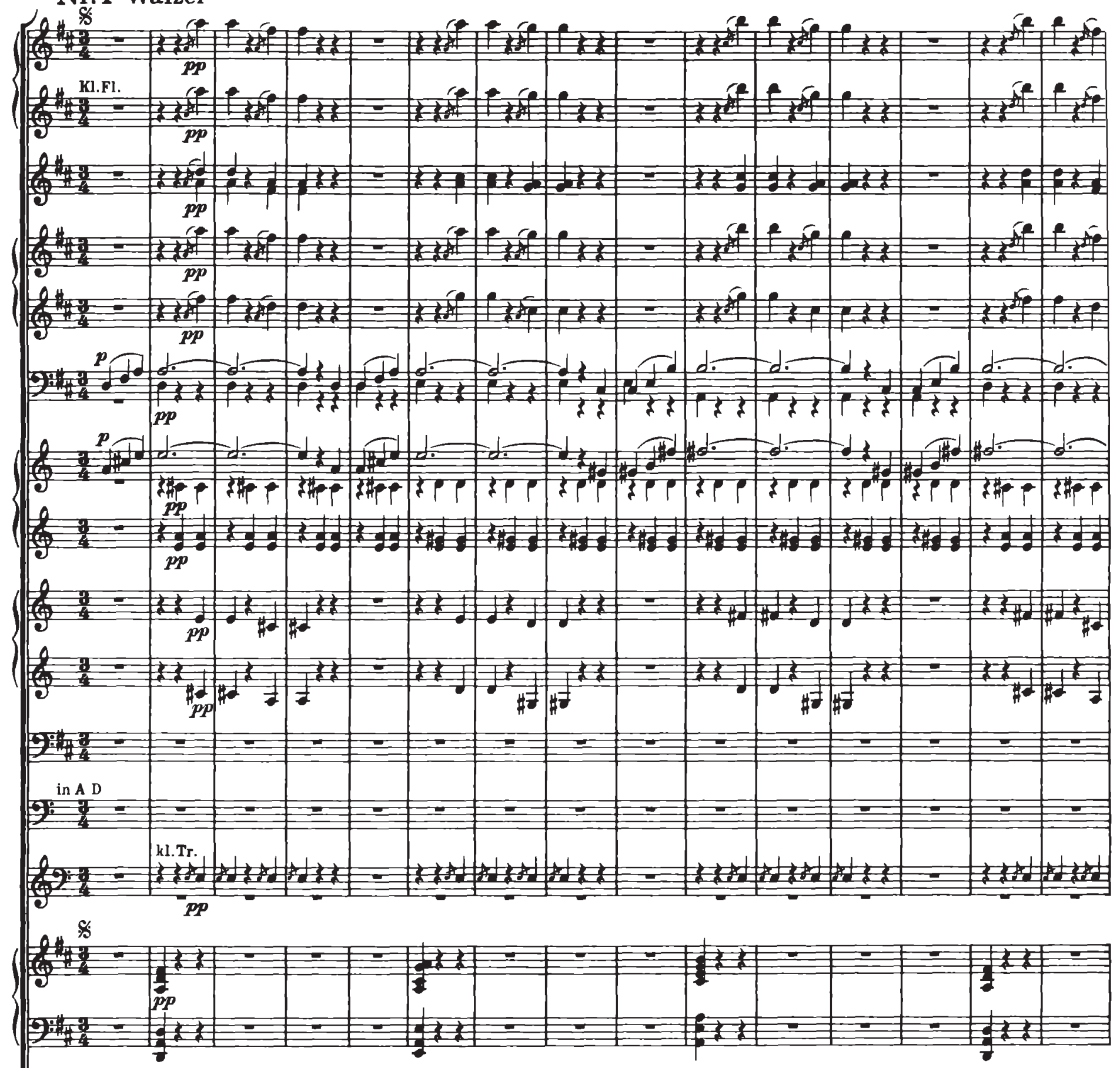

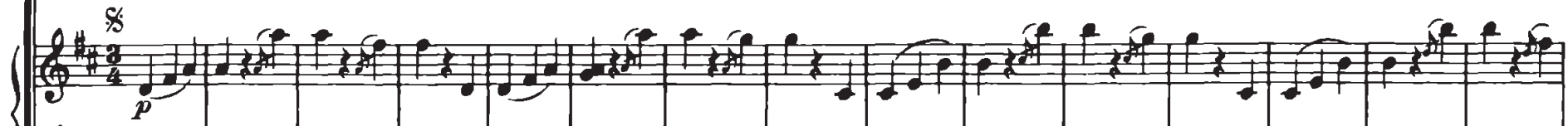

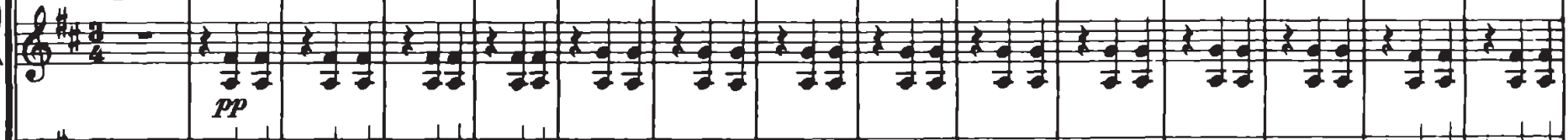

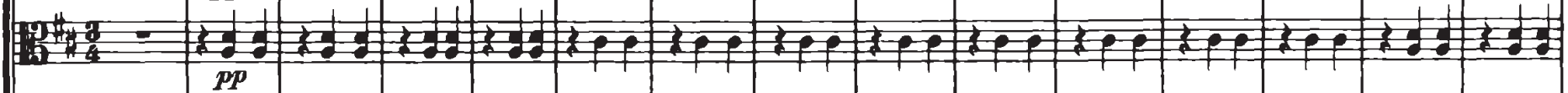

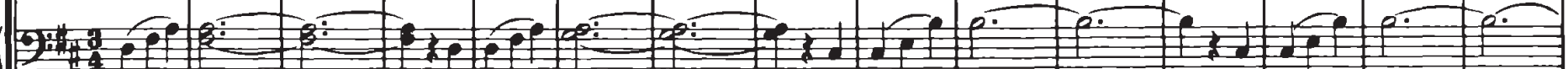

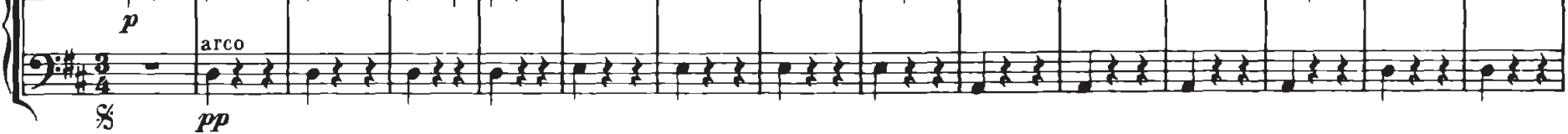




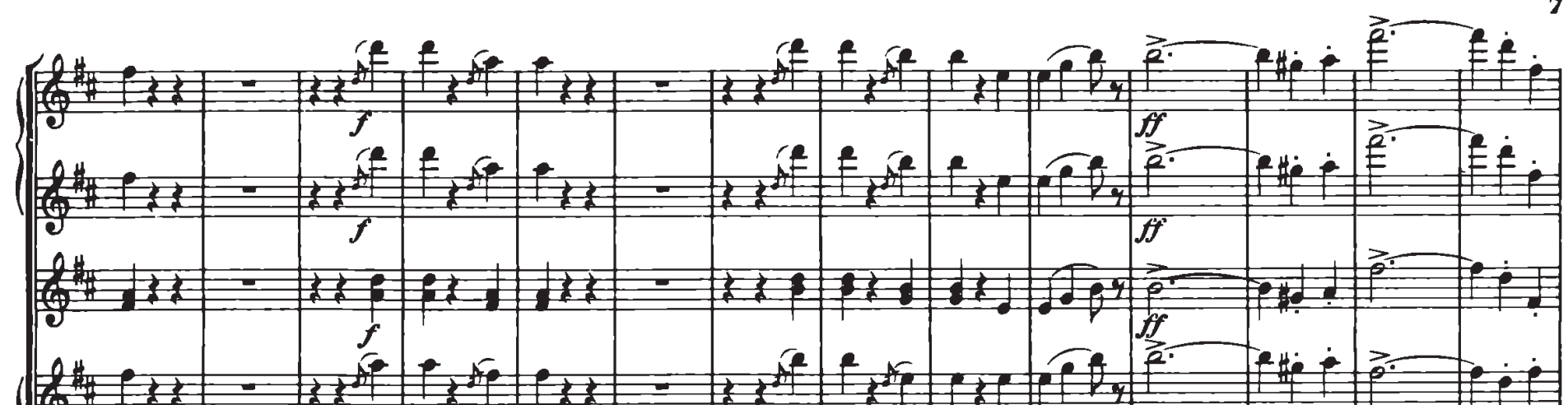
2.

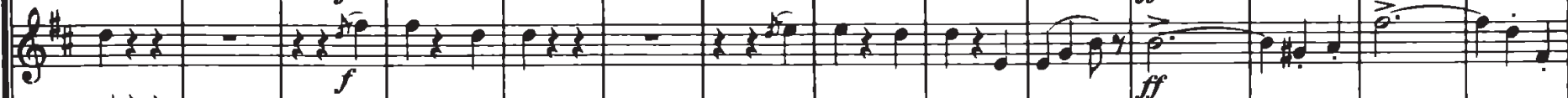

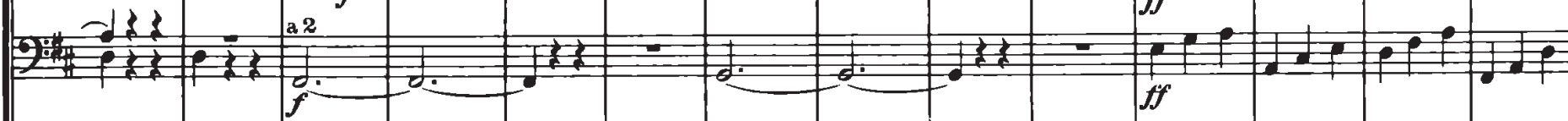

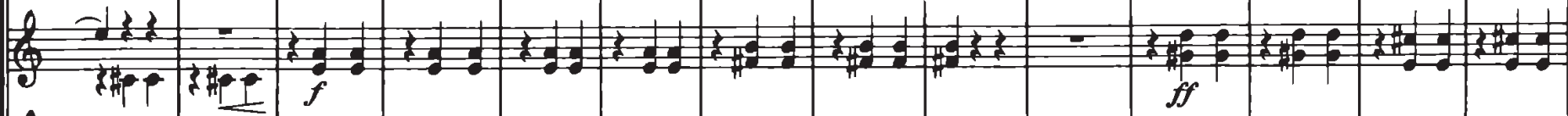

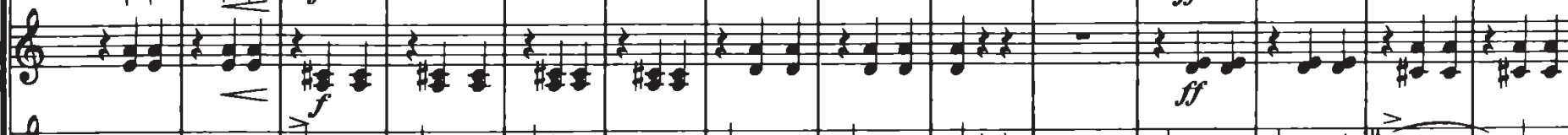
(2) Q

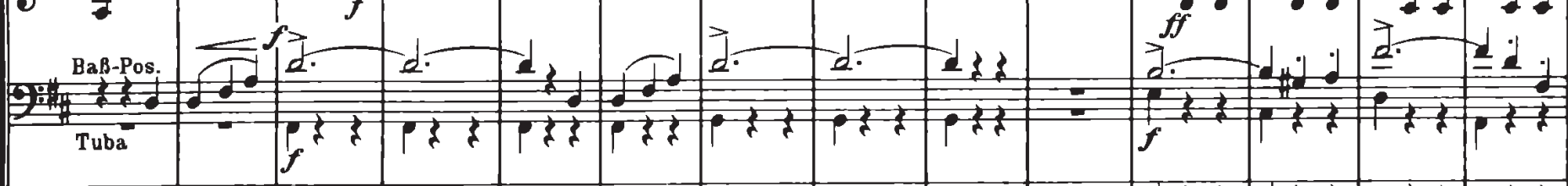

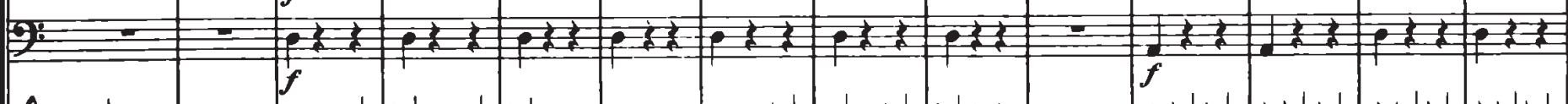

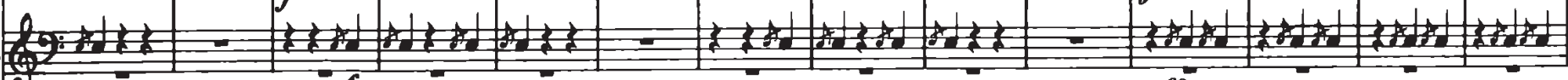

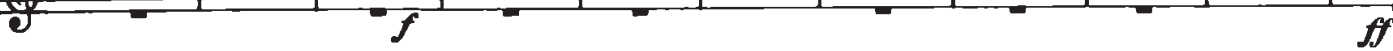

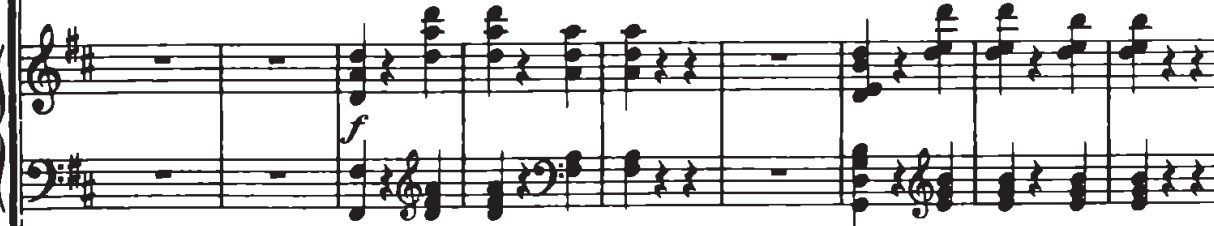

(10 (2)

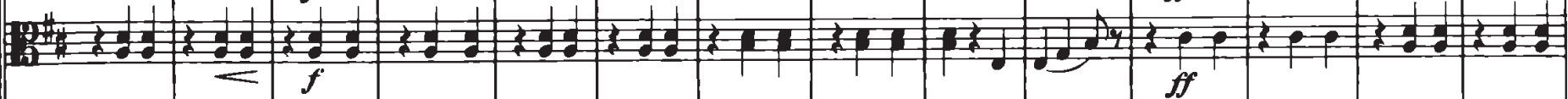

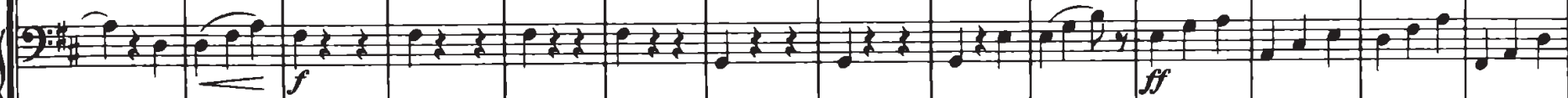

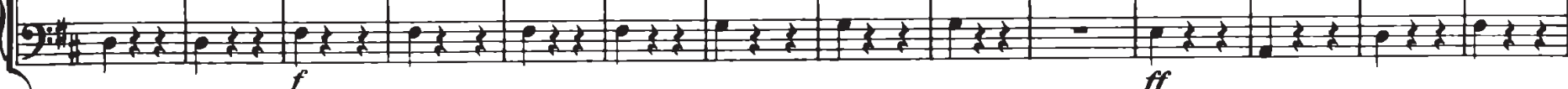




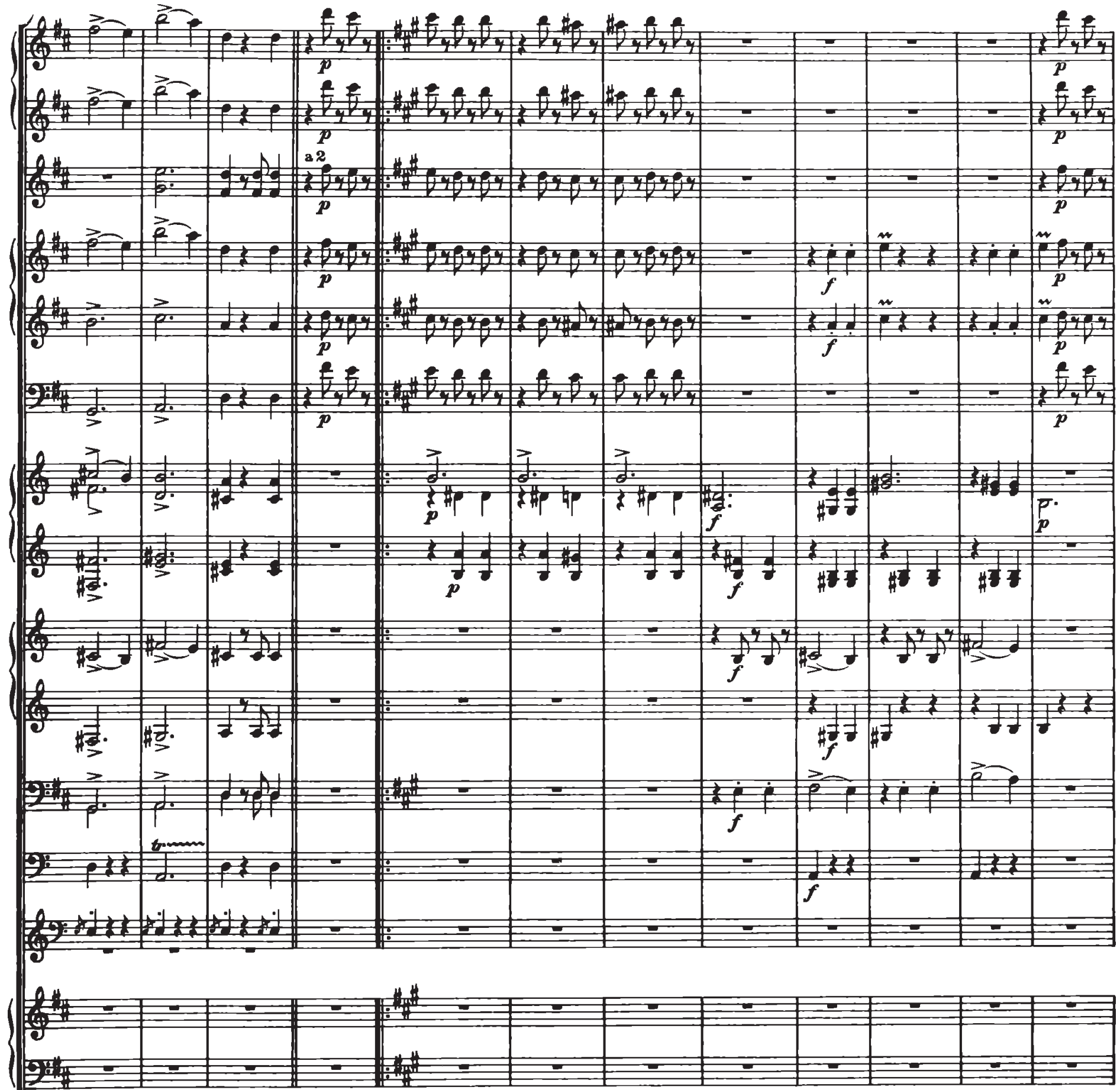

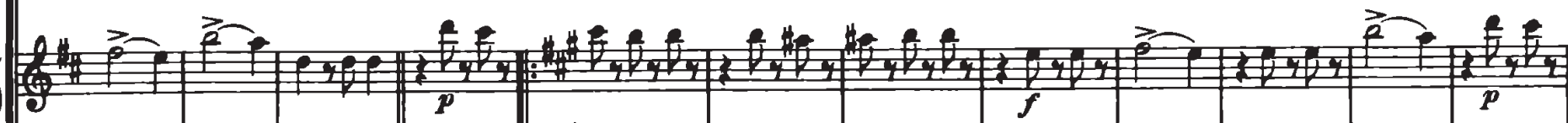

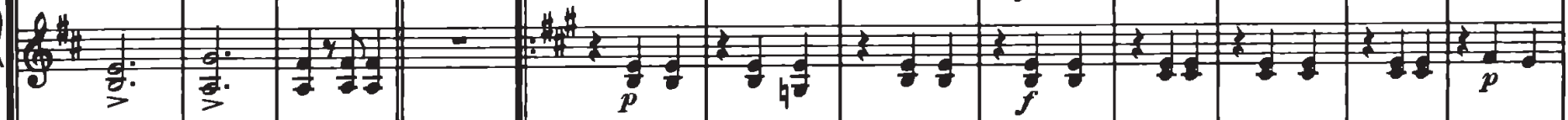

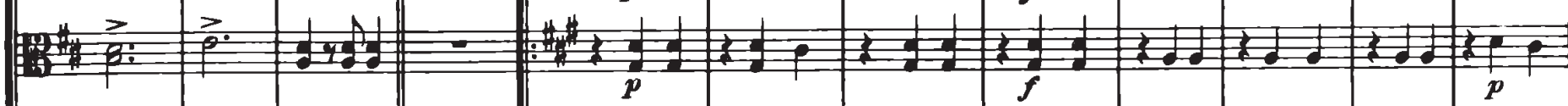

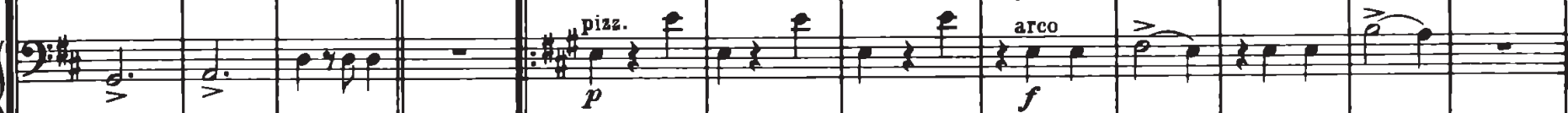
(2) 


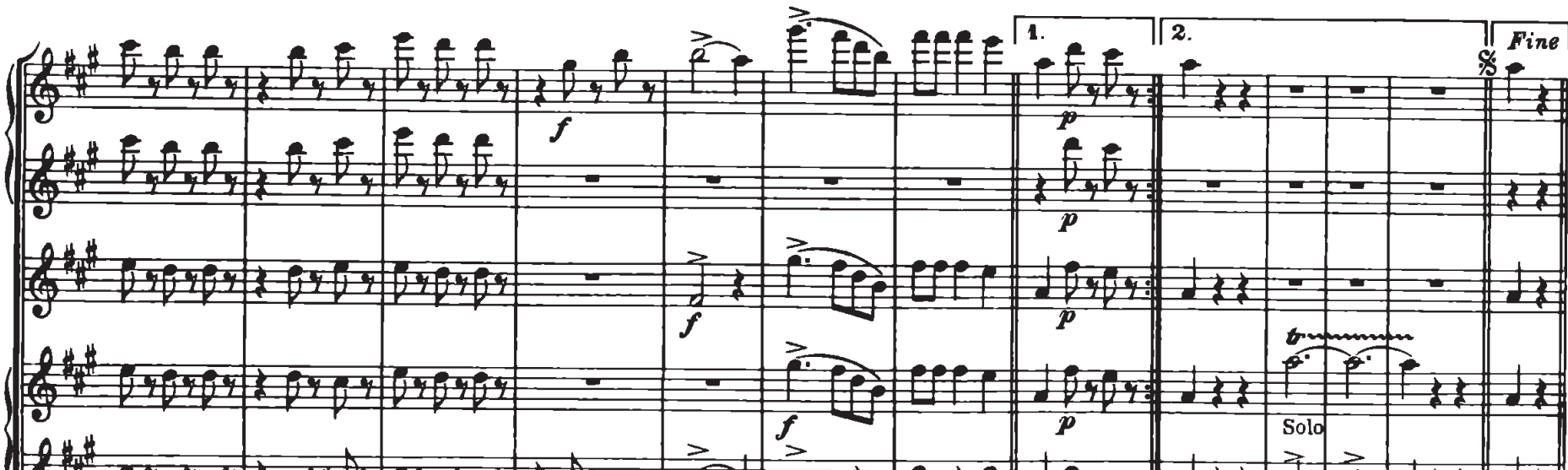

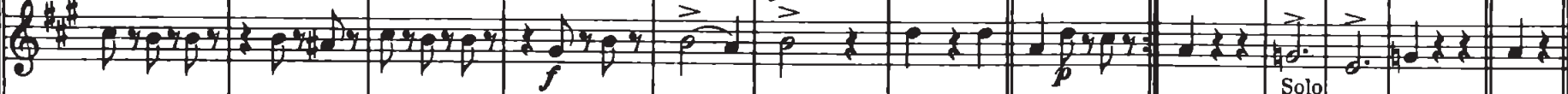

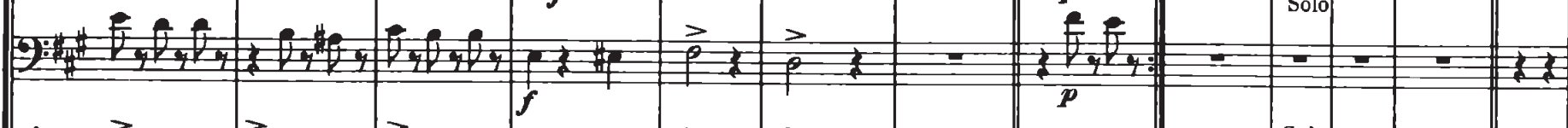

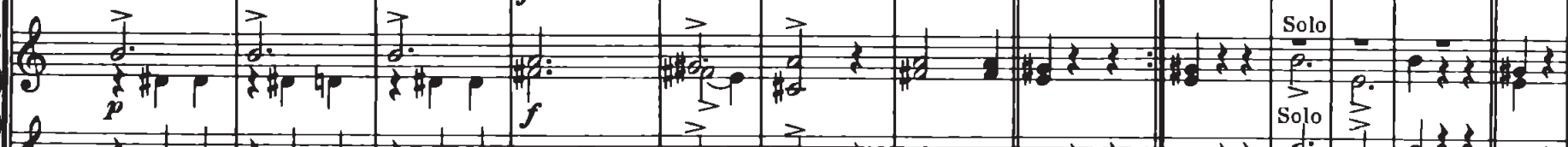

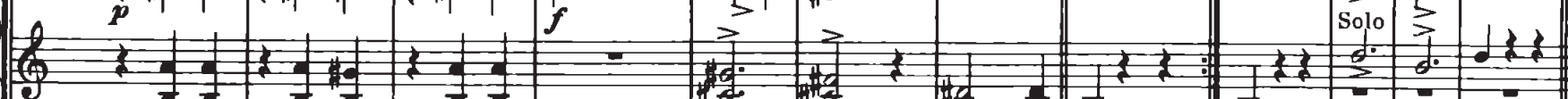

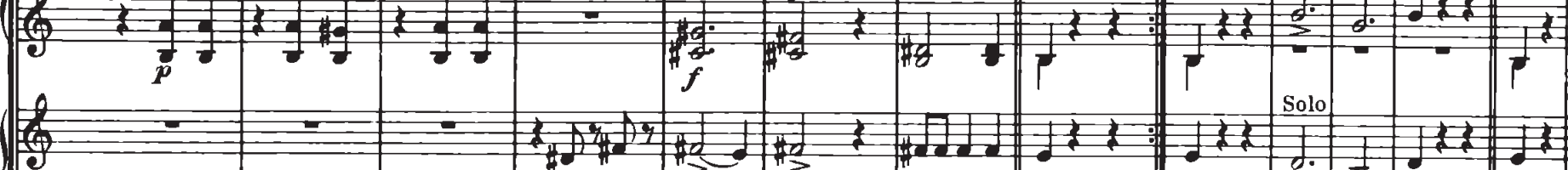
3

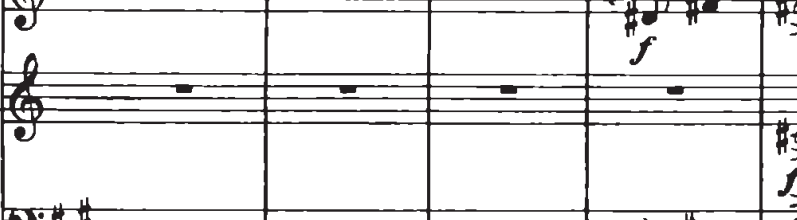

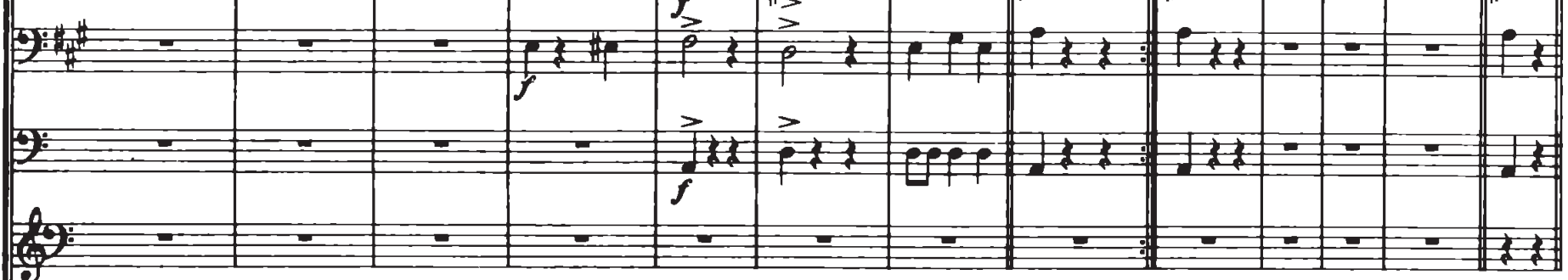

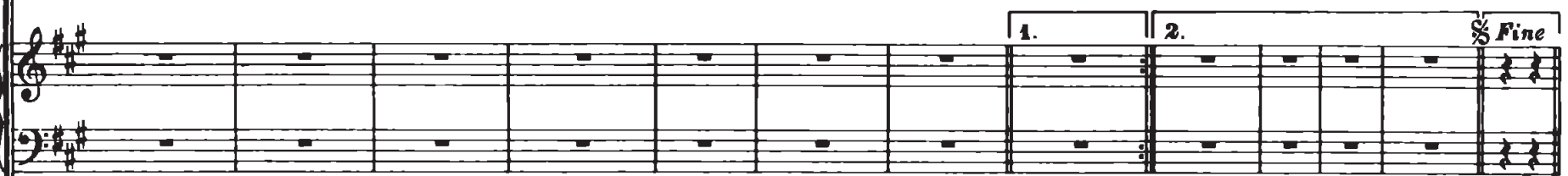

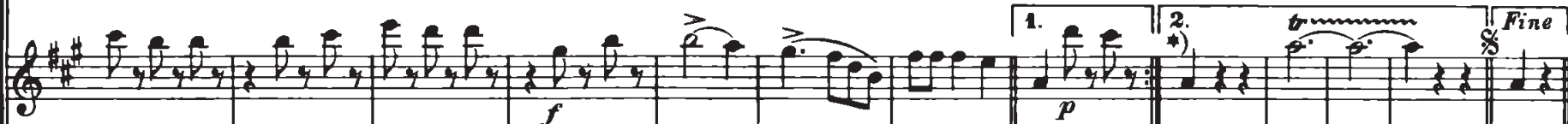

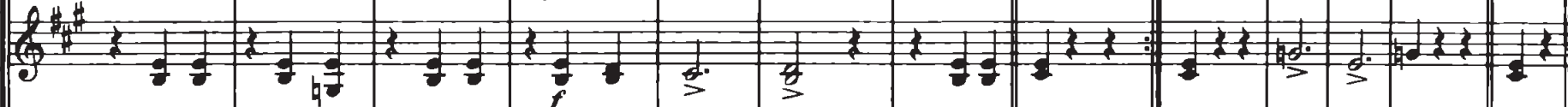

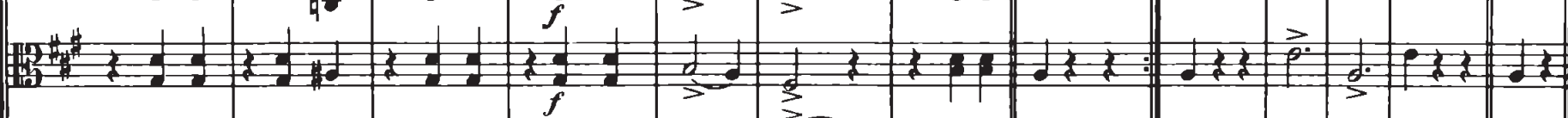

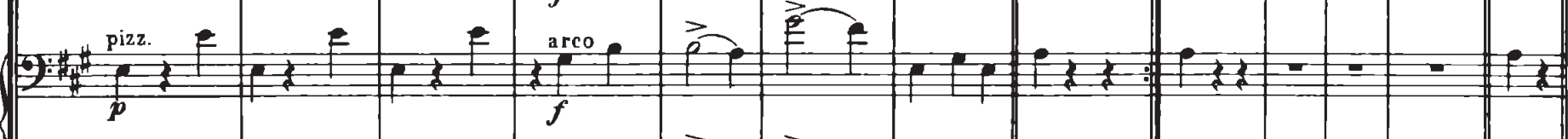

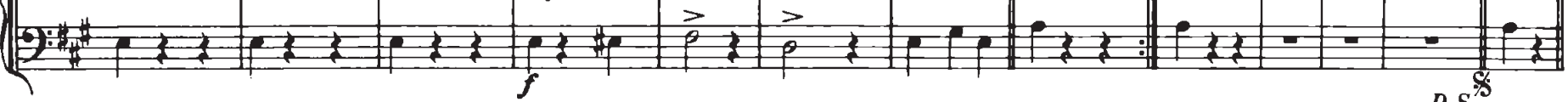
*) Bei Mitwirkung des Chors fallen 2da und Dal Segno weg 
10

Nr. 2

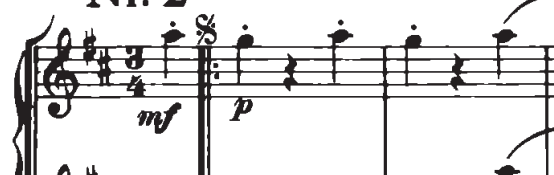

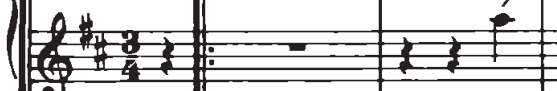

: 12

P10 (en la repetición)

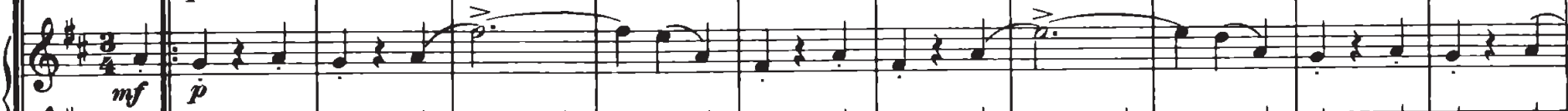

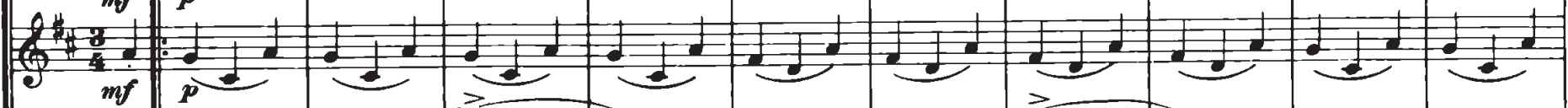
एक:

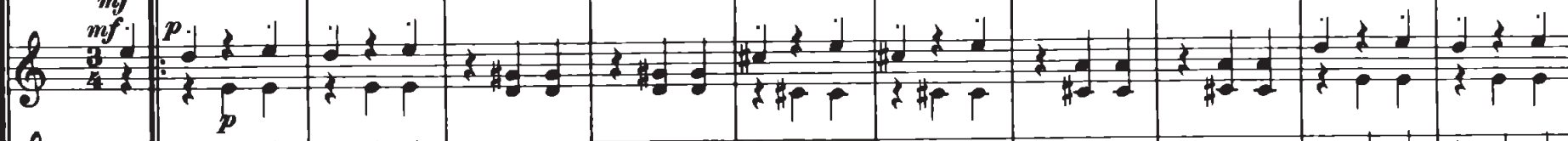
(3) (b) 6 : 2: $284^{3}={ }_{p p}^{\text {solo }}$

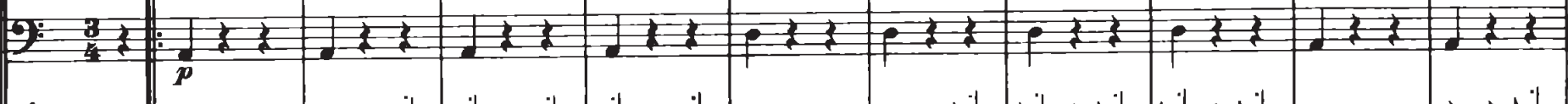
(1)

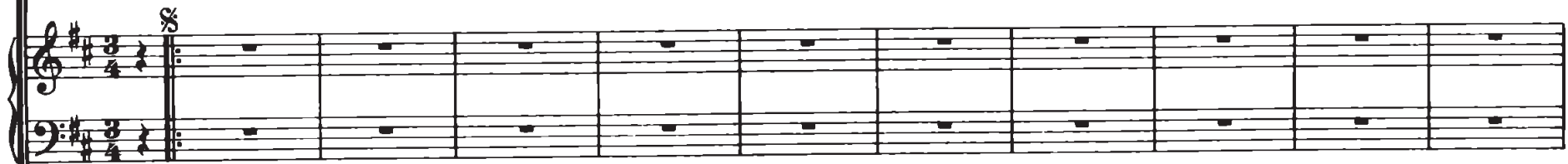
(3) 64

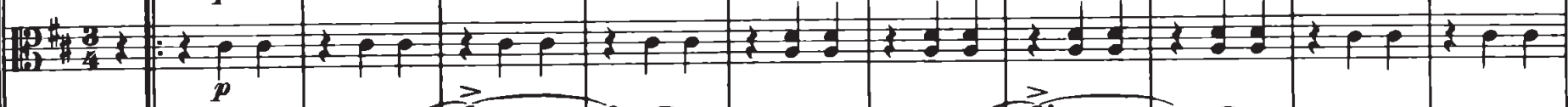

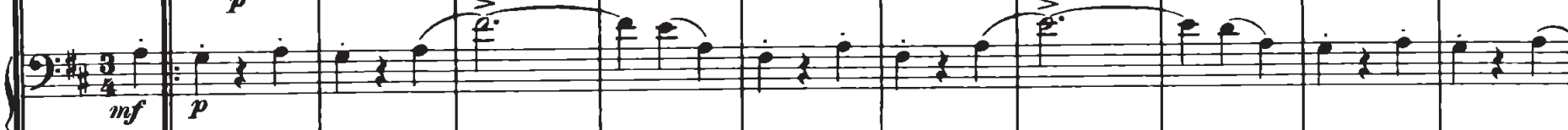
(2) 


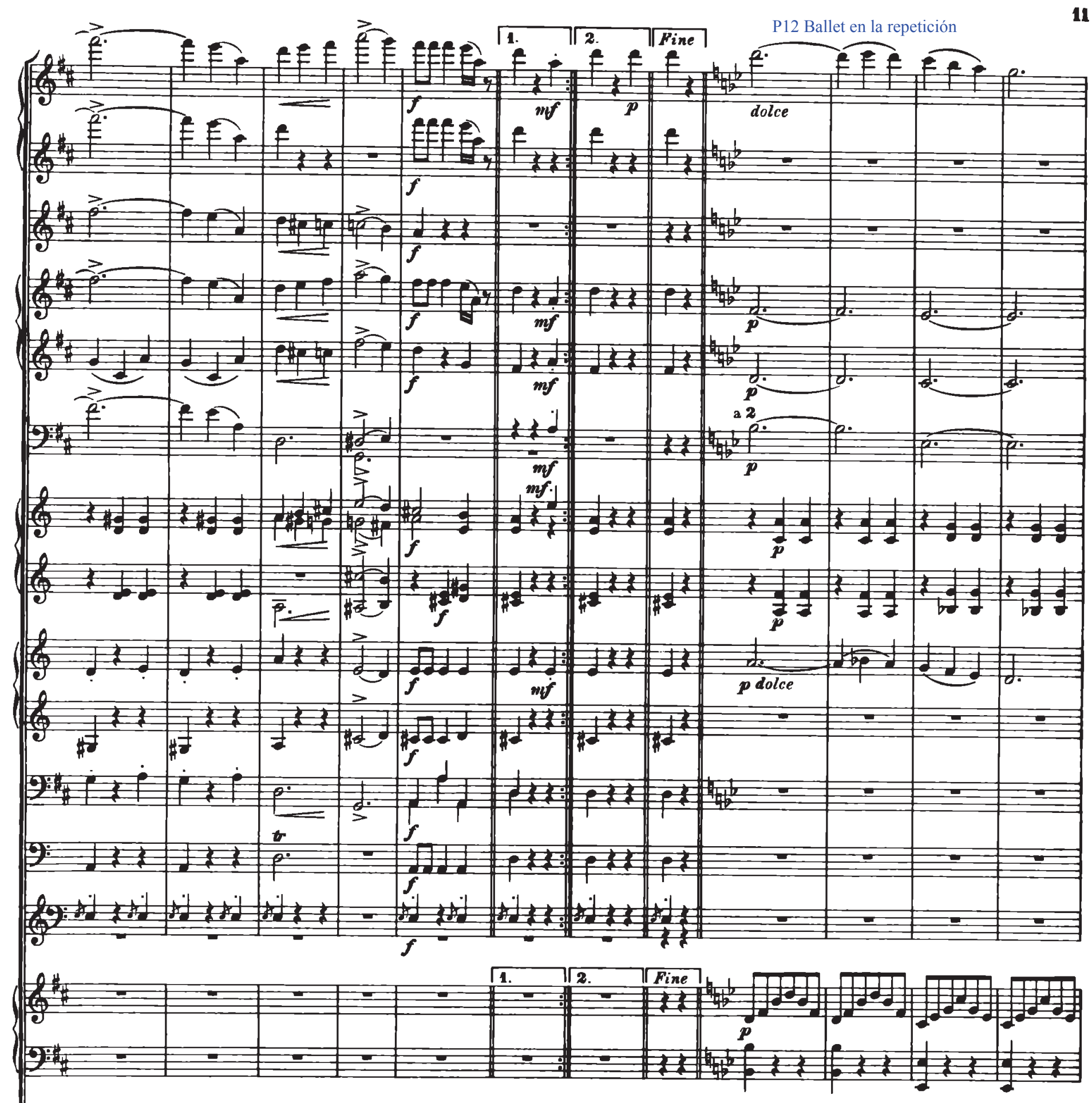

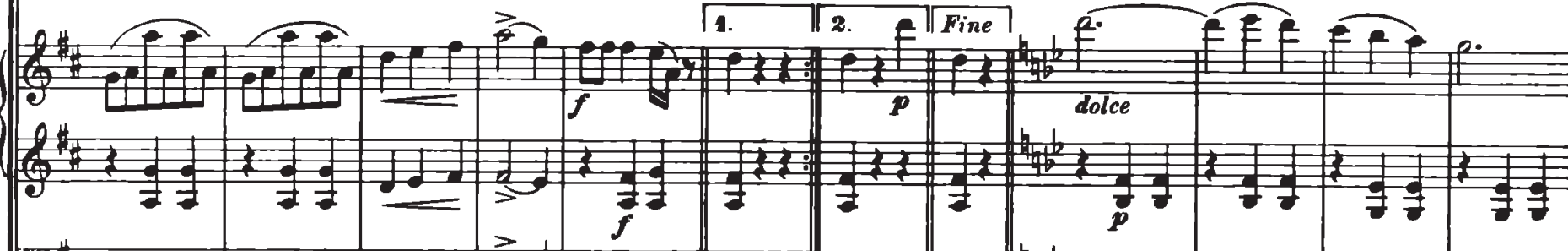

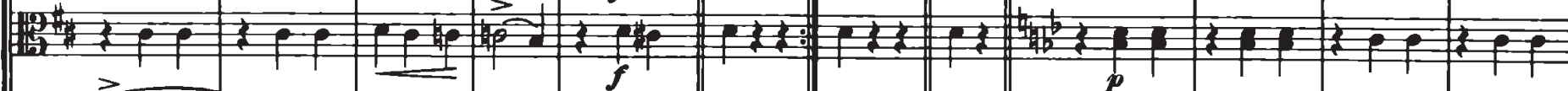

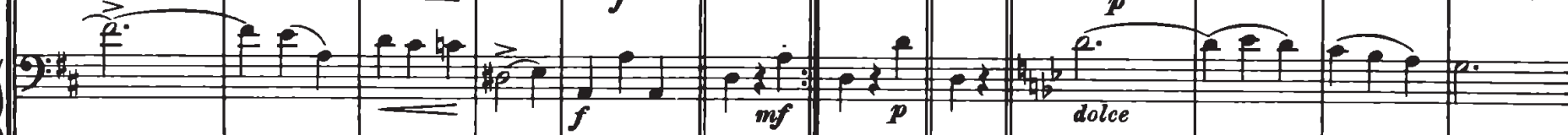

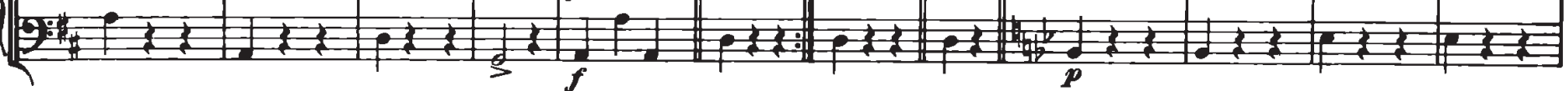




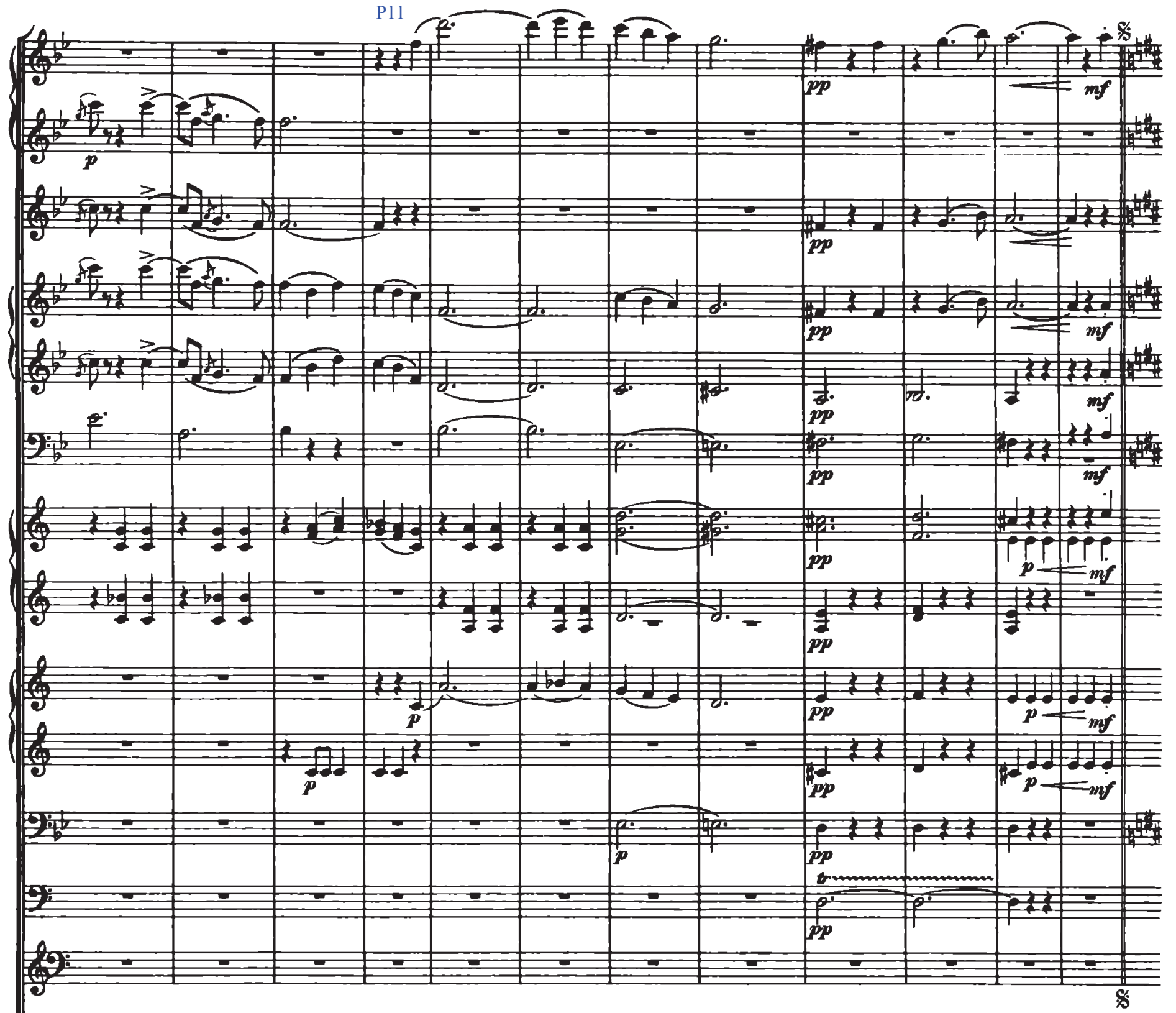

(2)

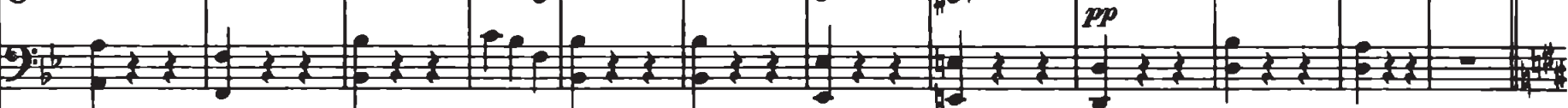

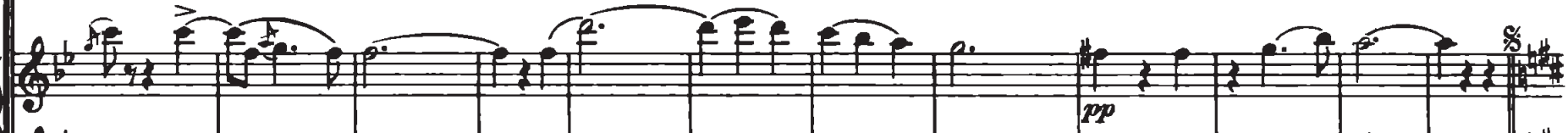

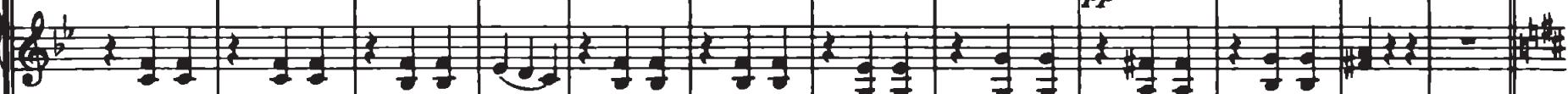

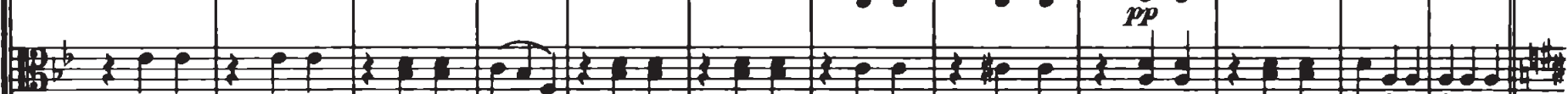

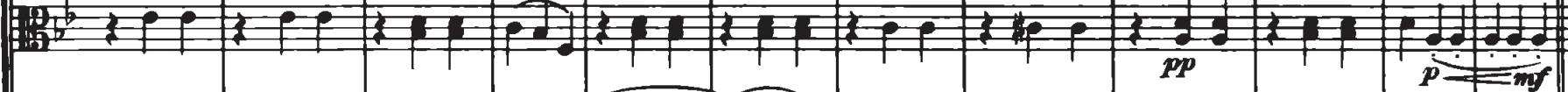

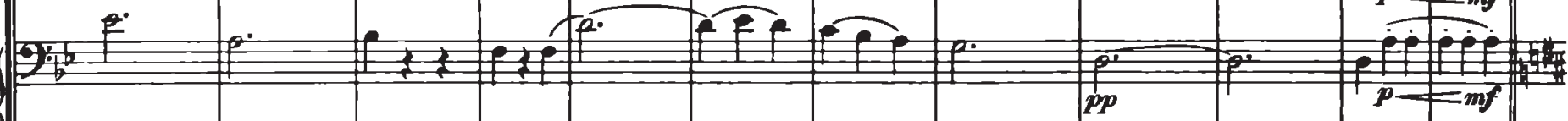

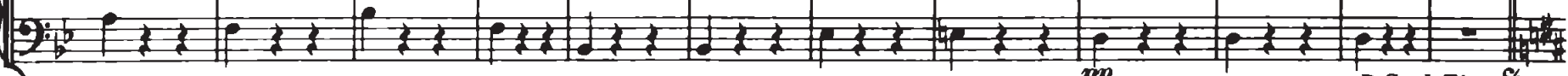
D.S. al Fine $\%$ 


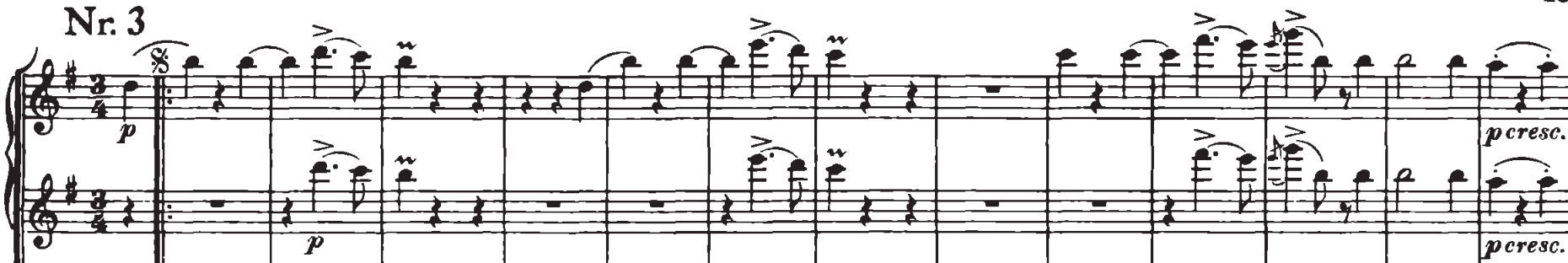

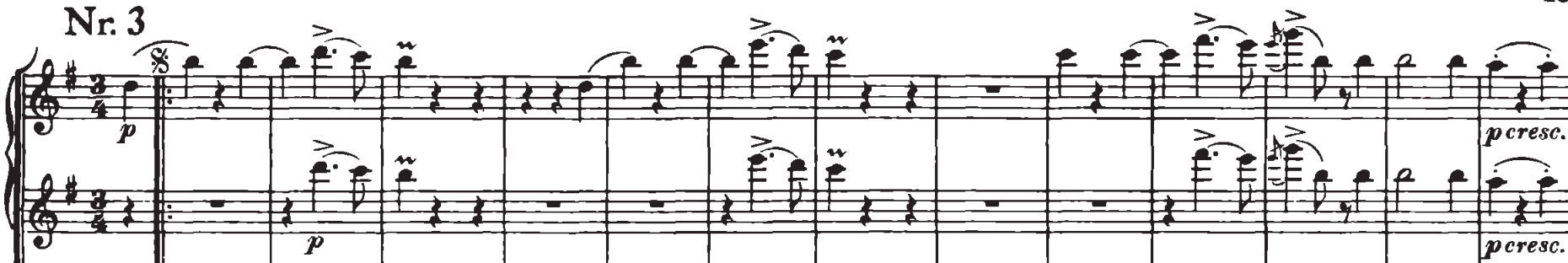

2.

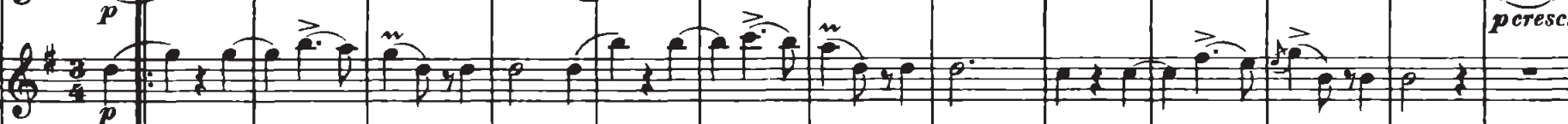

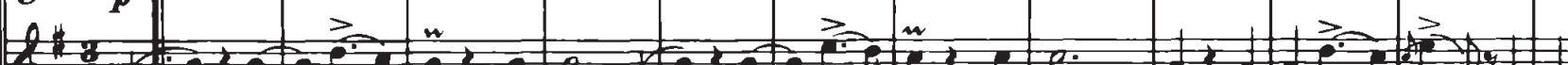
3.

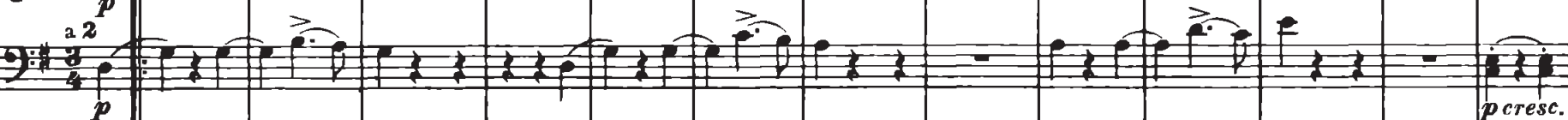
3.

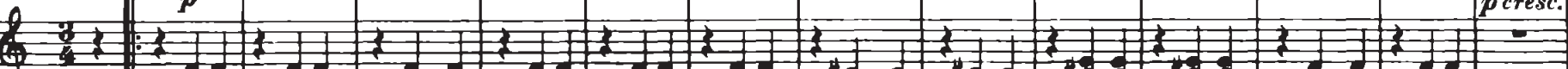
2

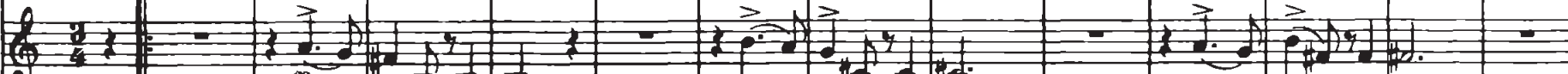

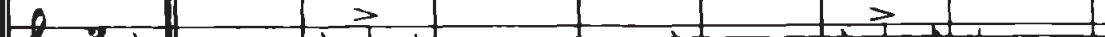

2.

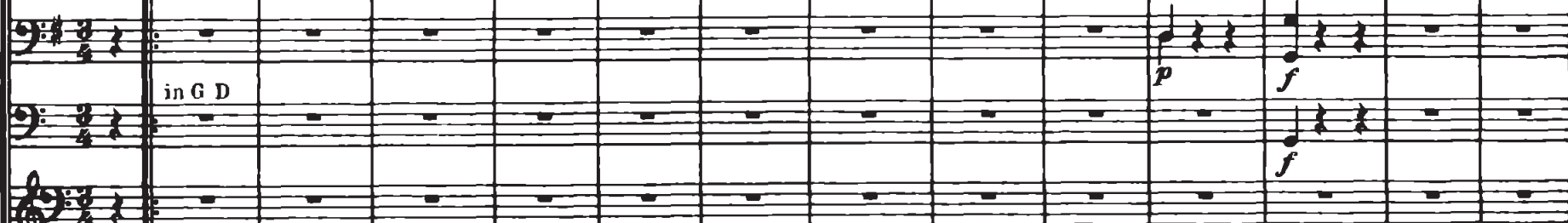
8

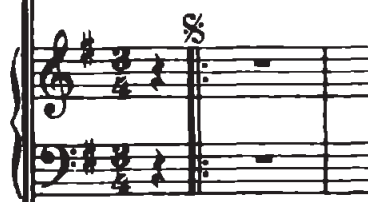

(2)

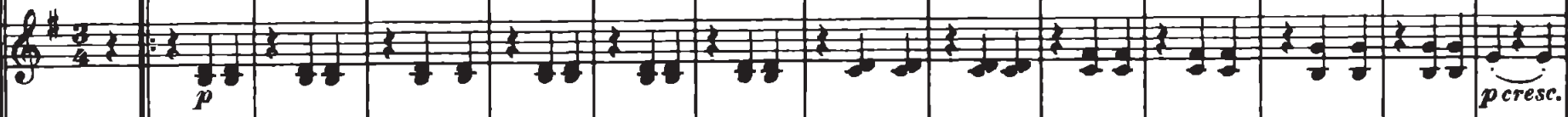

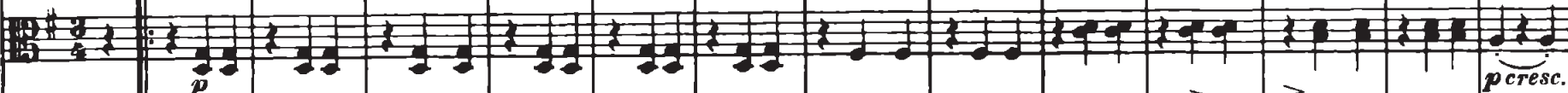
(2)

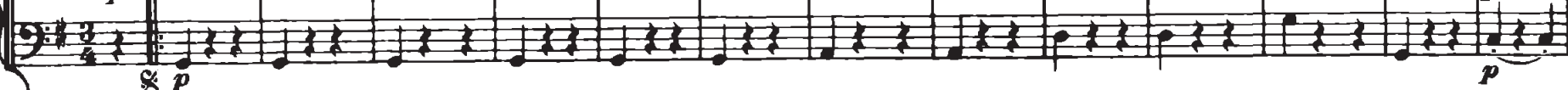


14
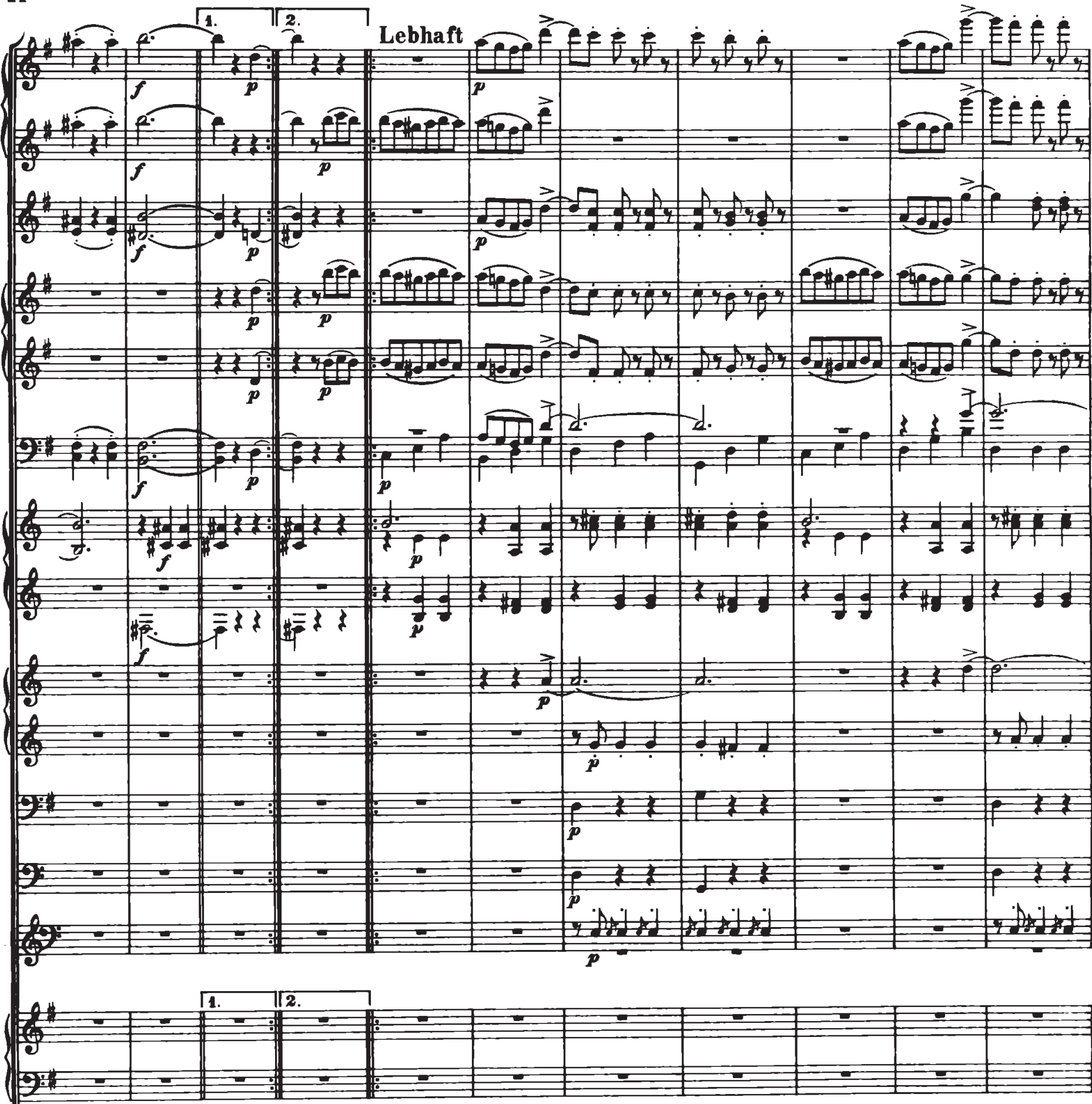

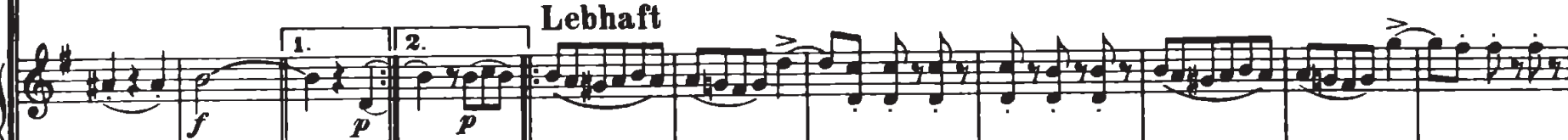

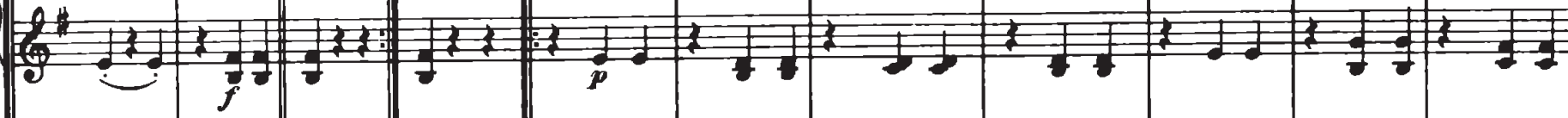

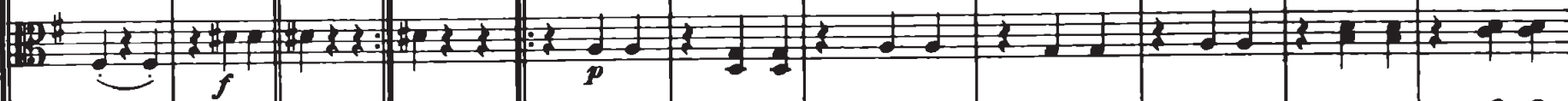

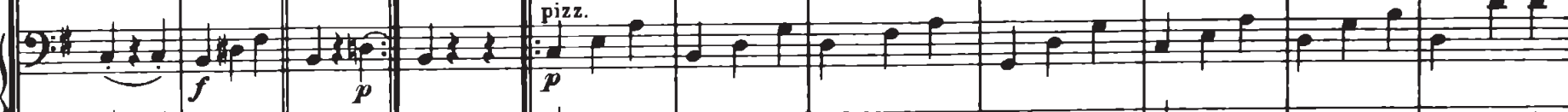

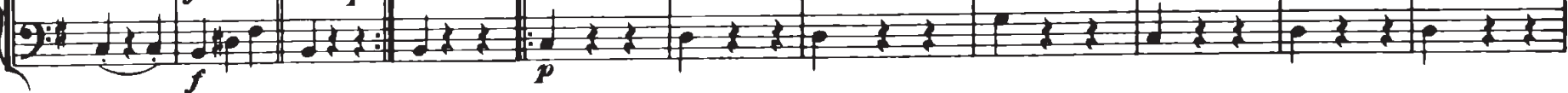


P13 orquesta
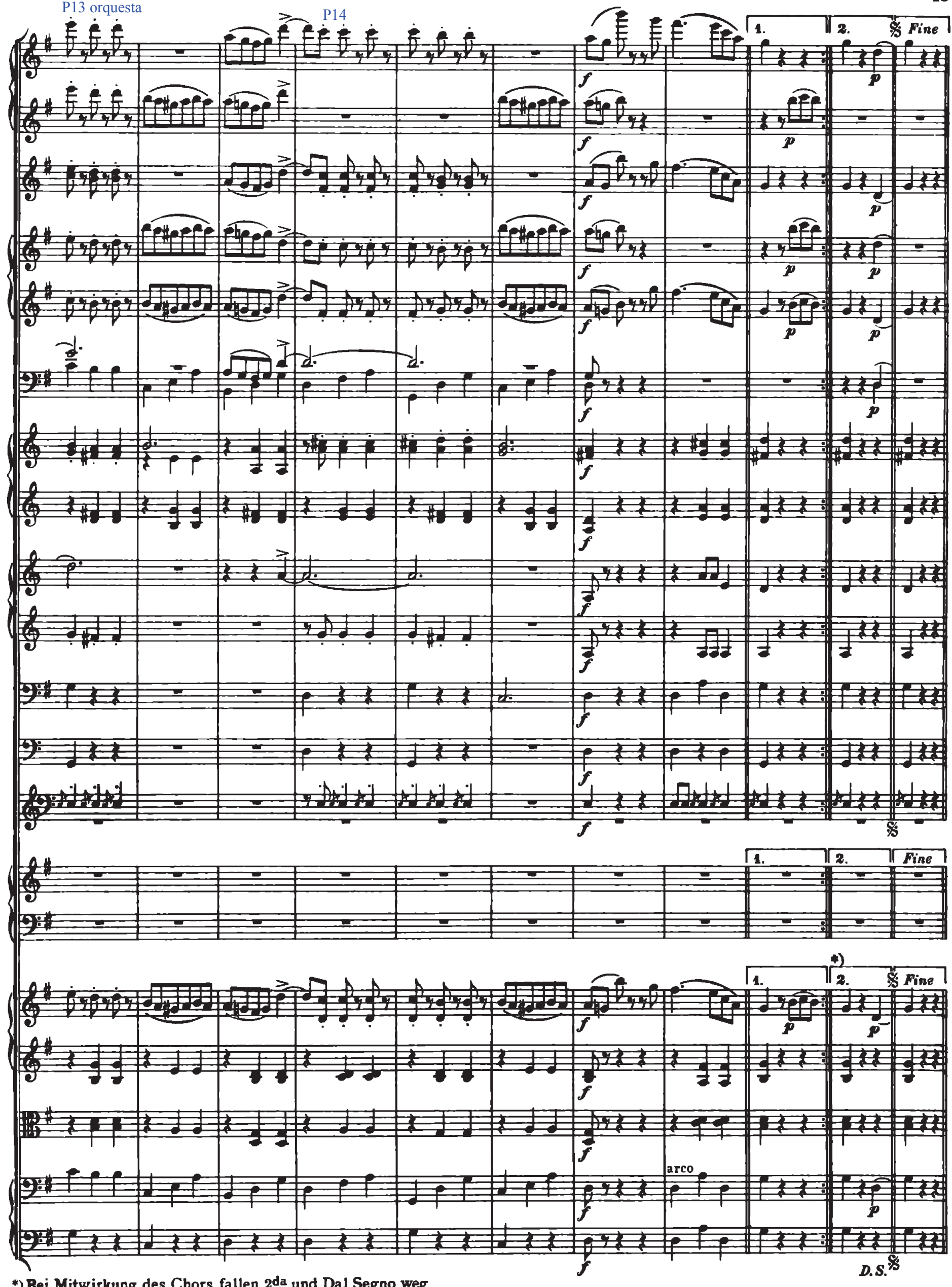

*) Bei Mitwirkung des Chors fallen 2da und Dal Segno weg D.S. \% 
16

Nr. 4

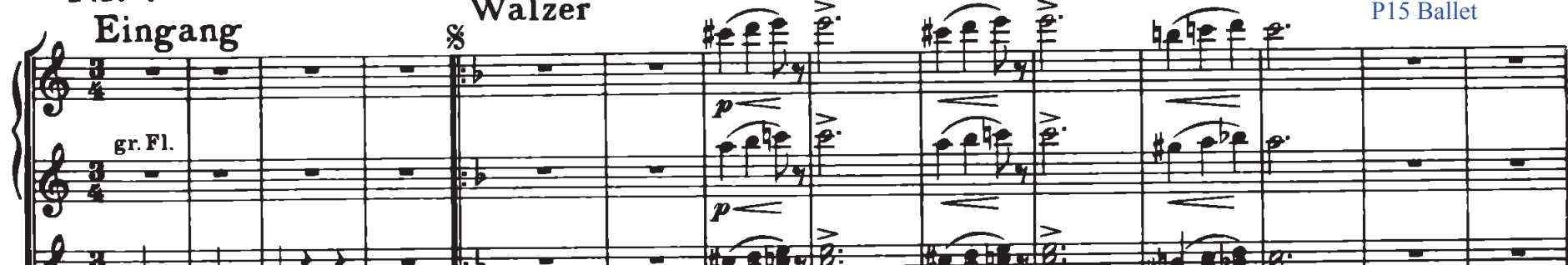

Walzer

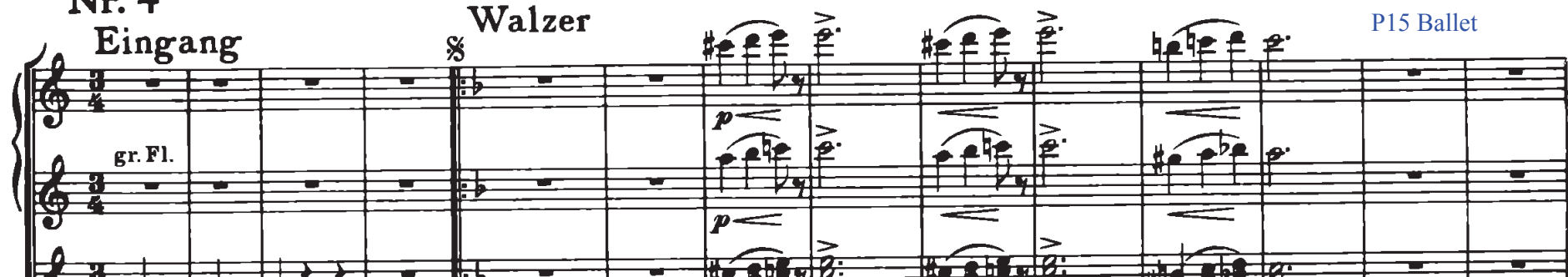

P15 Ballet

$e^{2}+\frac{1}{20}=$

,

\begin{tabular}{|l|l|l|l|l|l|l|l|}
\hline$y$ & & & \\
\hline 2 & & & $p$ \\
\hline
\end{tabular}

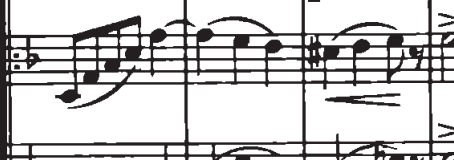

4

1

\begin{tabular}{|l|l|l}
\hline+2 & &
\end{tabular}

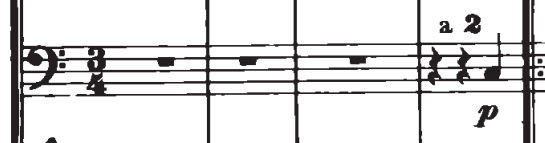

- $\begin{aligned} & 1 \\ & 2\end{aligned}$

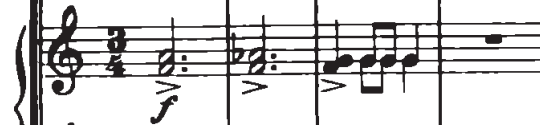

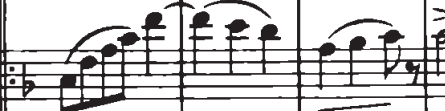

$\overrightarrow{0}$

tef

$0^{8}+2+0=$

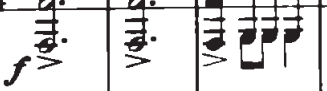

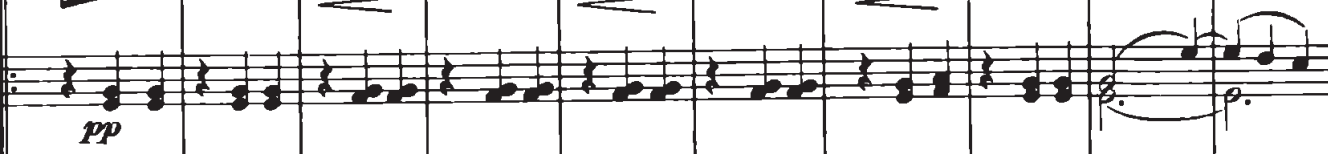

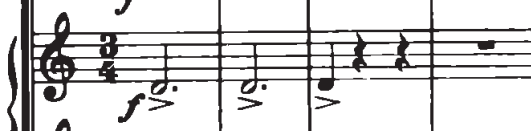

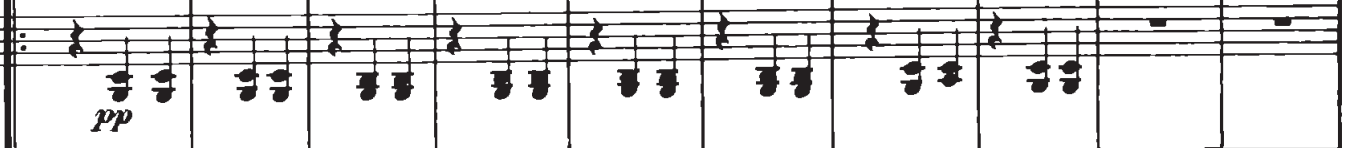

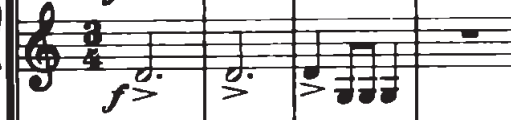

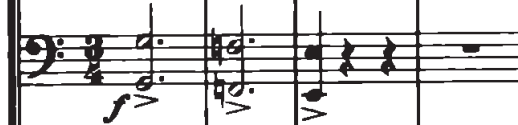

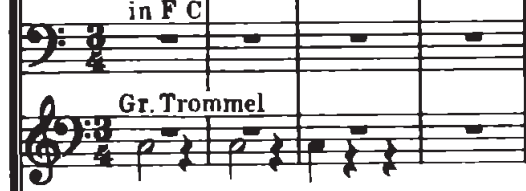

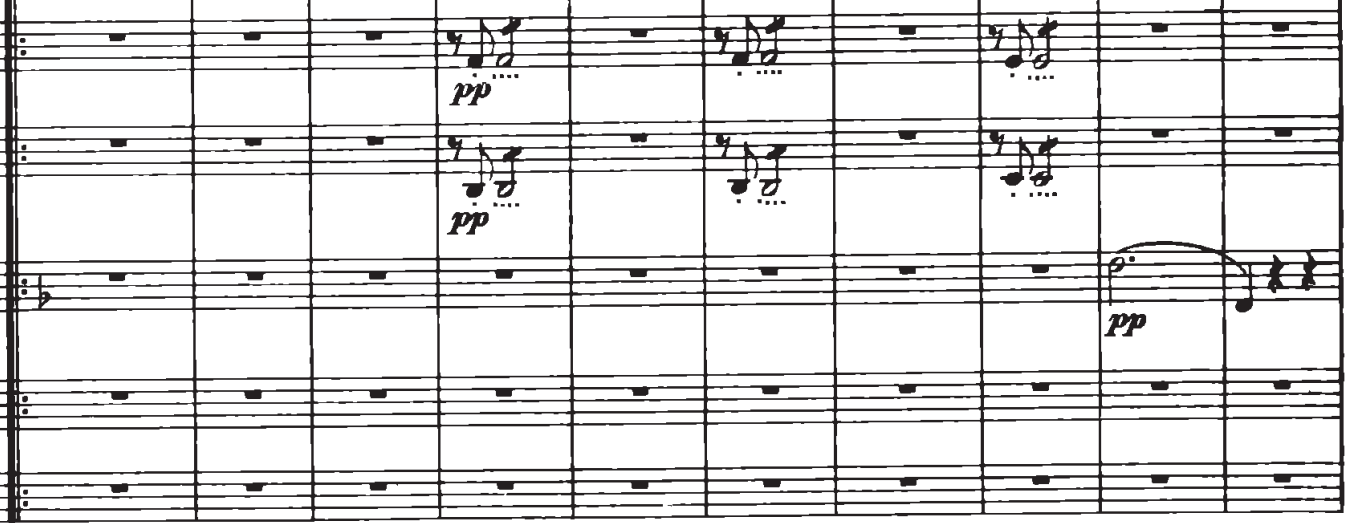

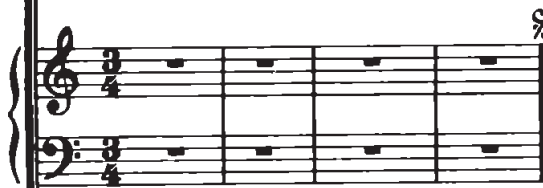

$\%$

$\frac{1}{62}=$

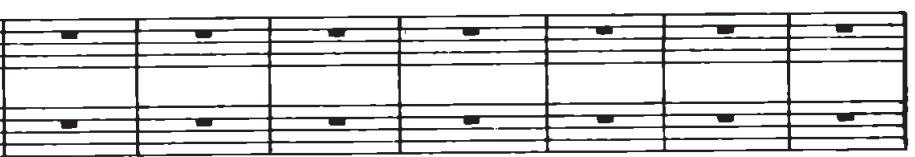

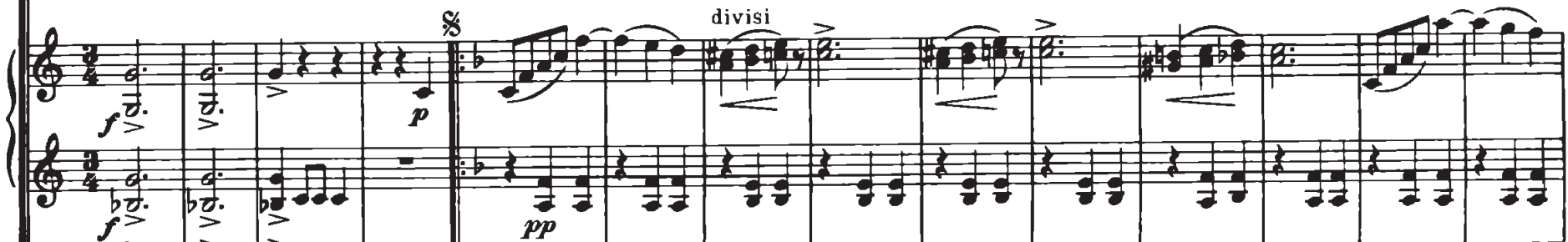

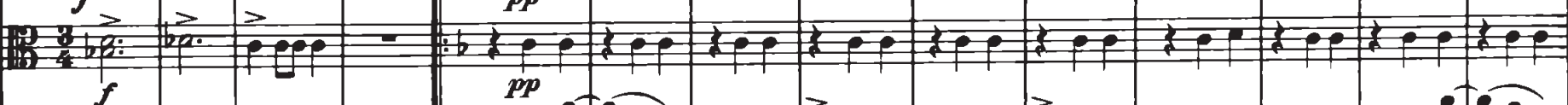

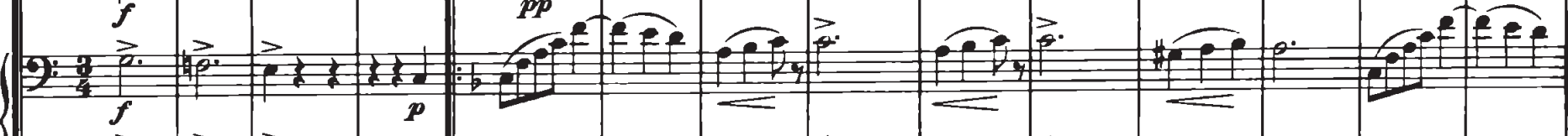

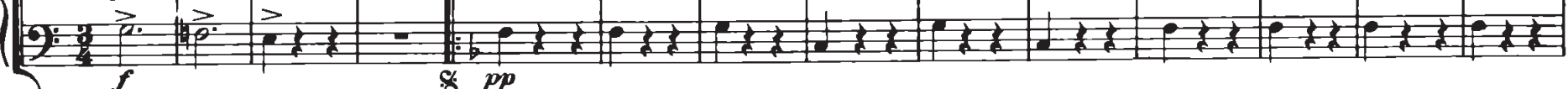



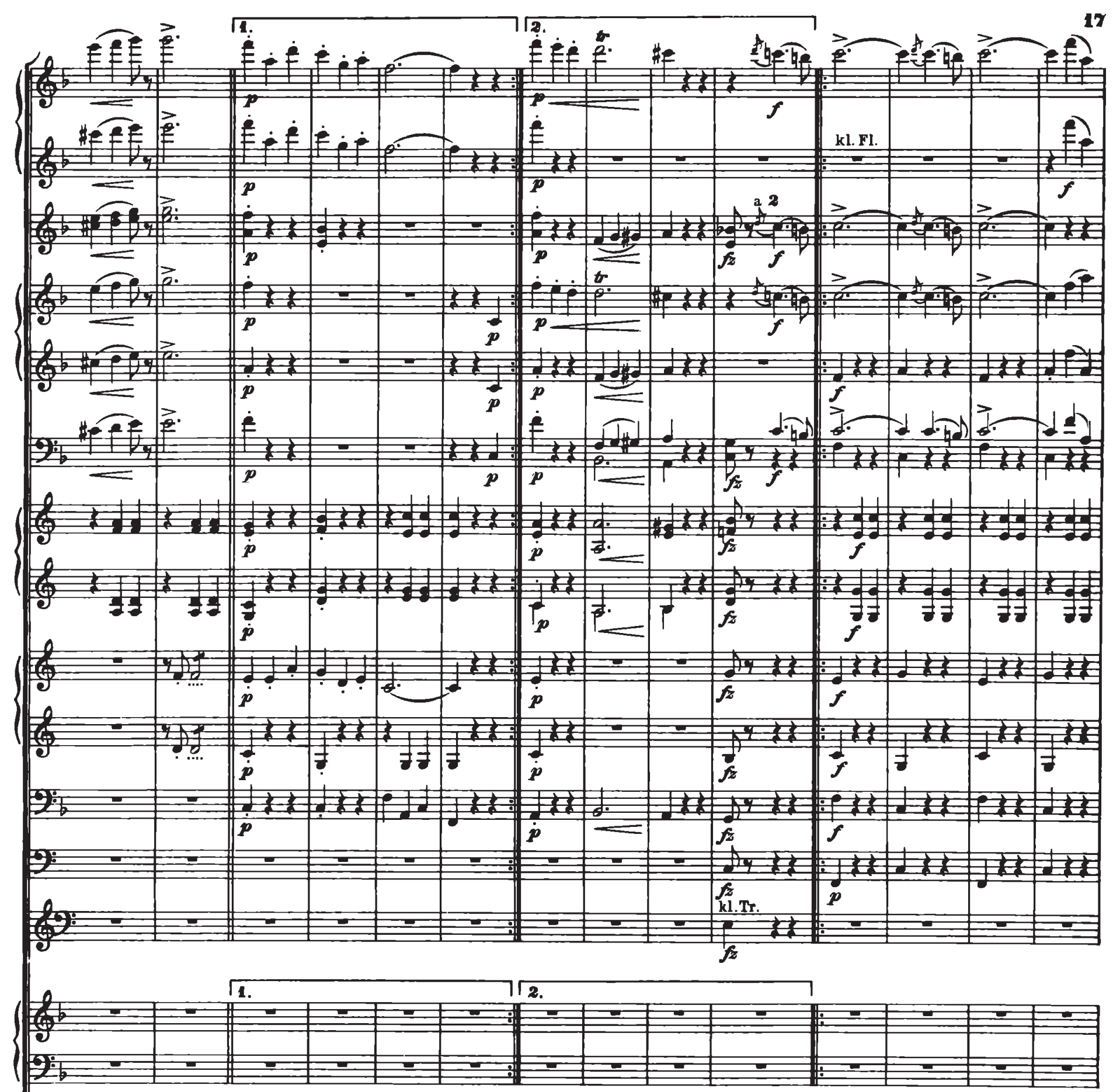

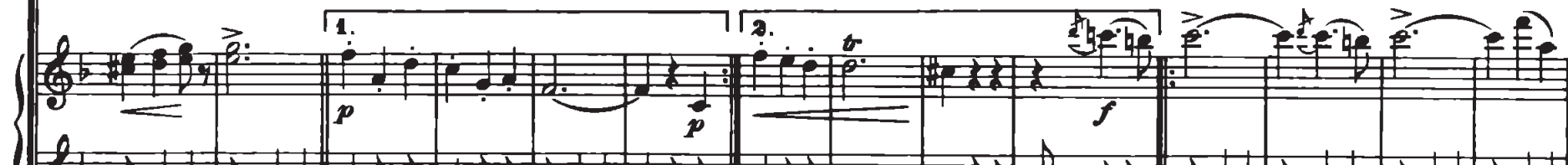

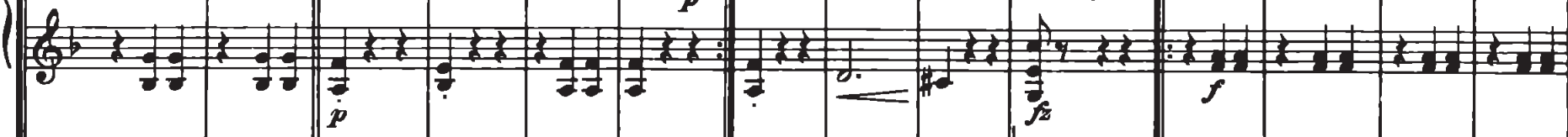

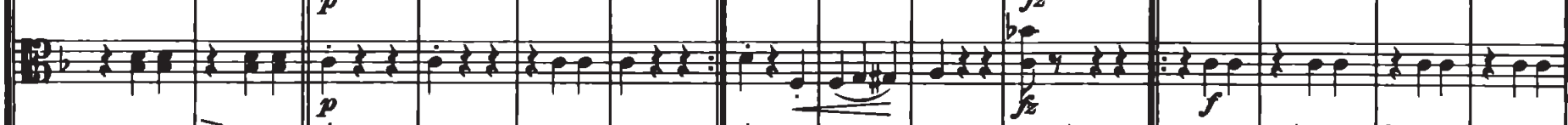

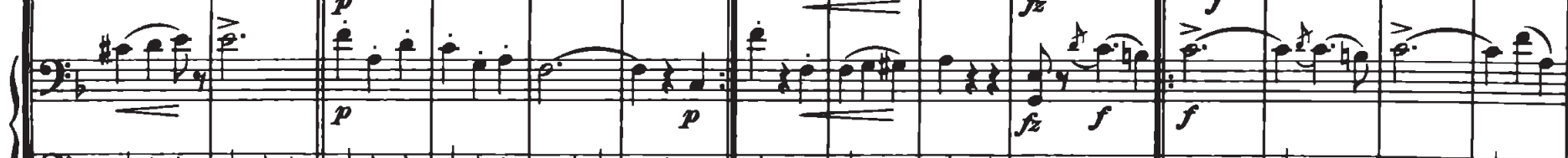

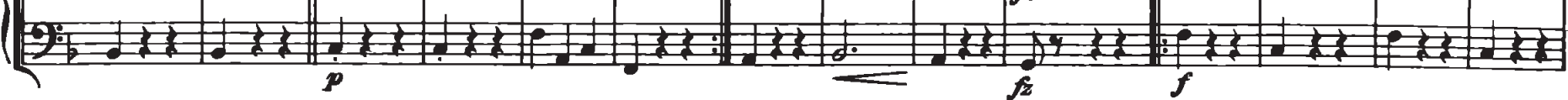


18

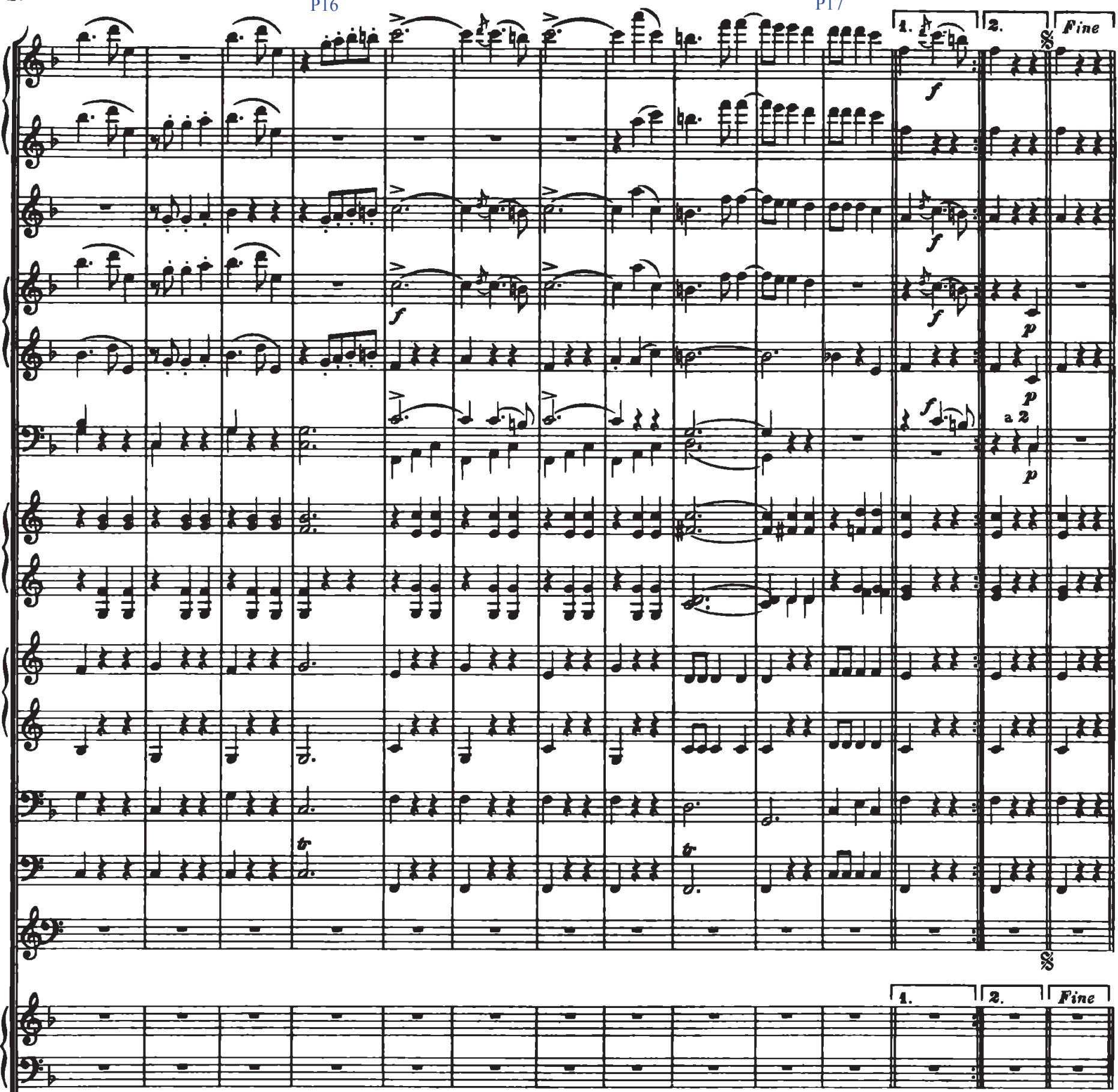

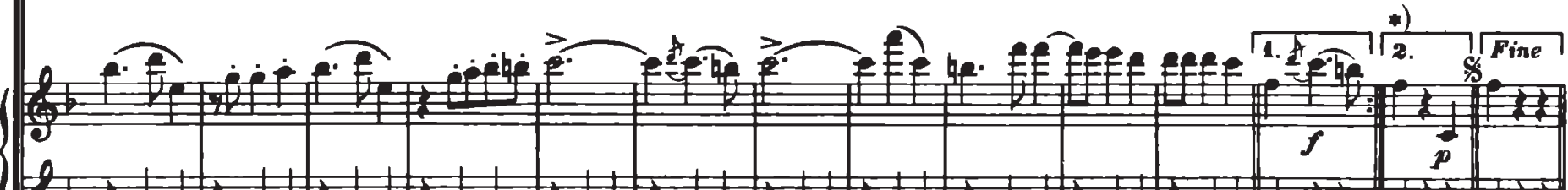

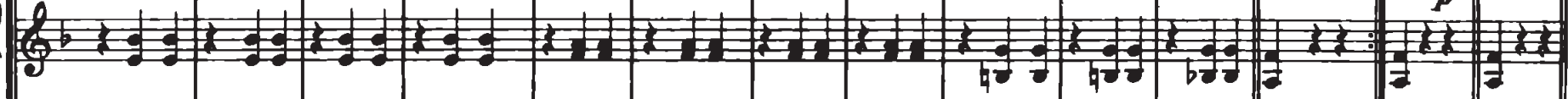

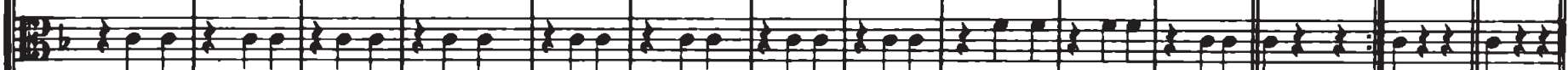

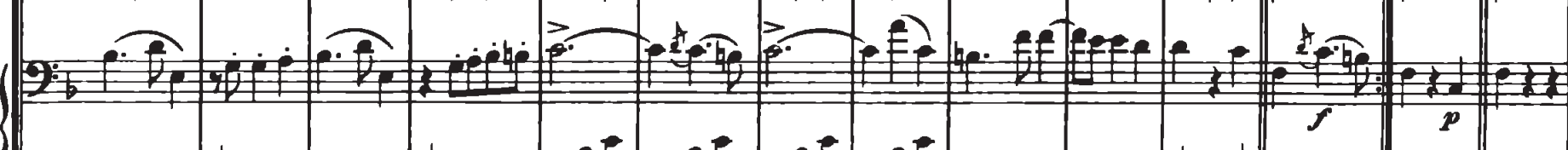

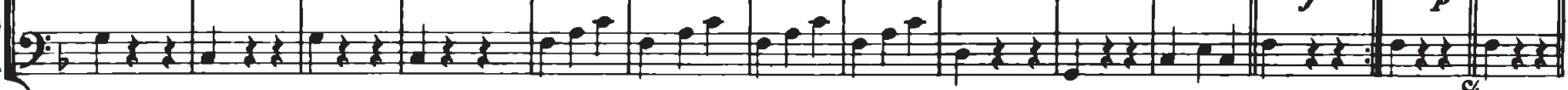

*) Bei Mitwirkung des Chors fallen 2da und Dal Segno weg 
Nr. 5 P18
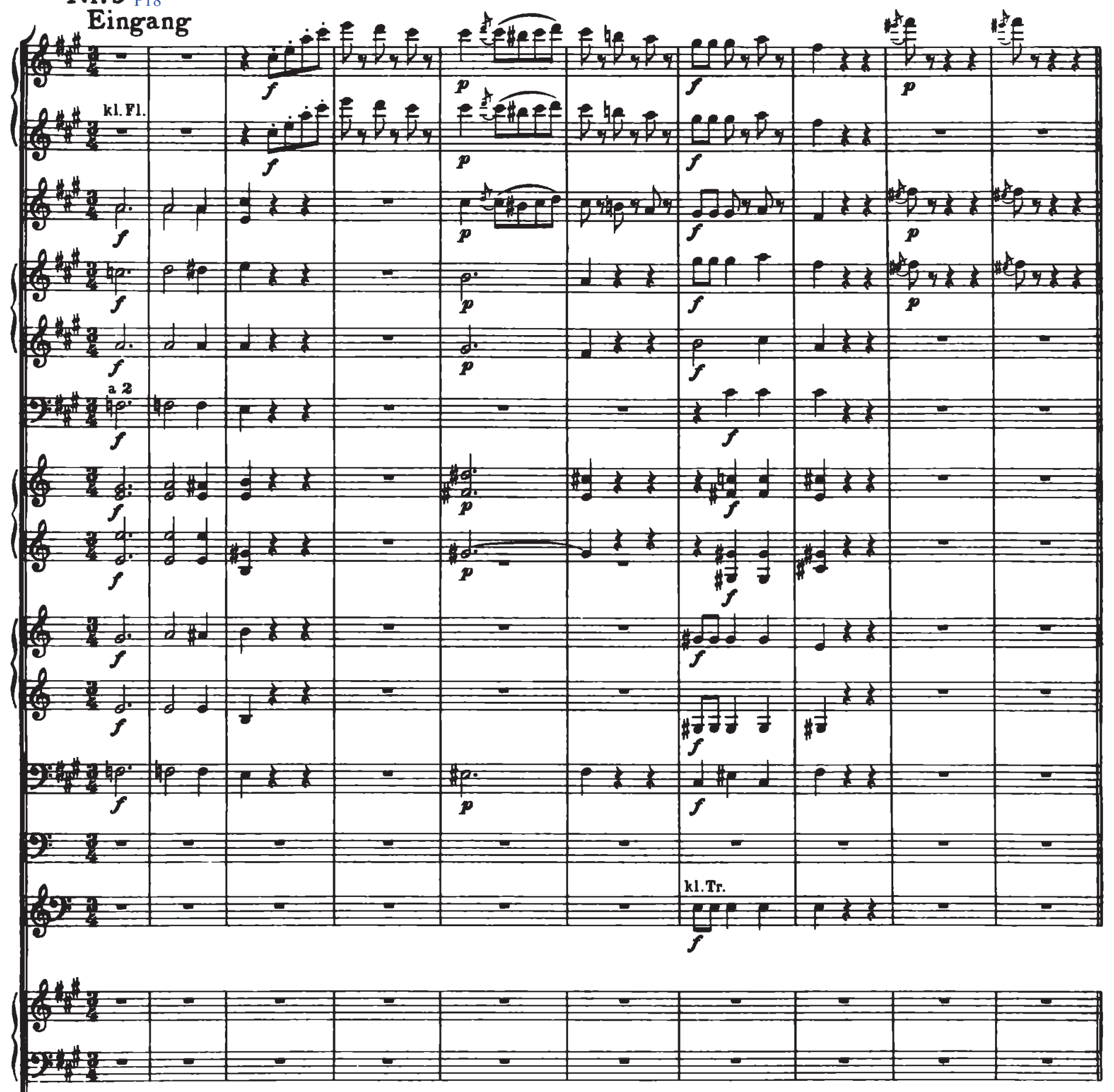

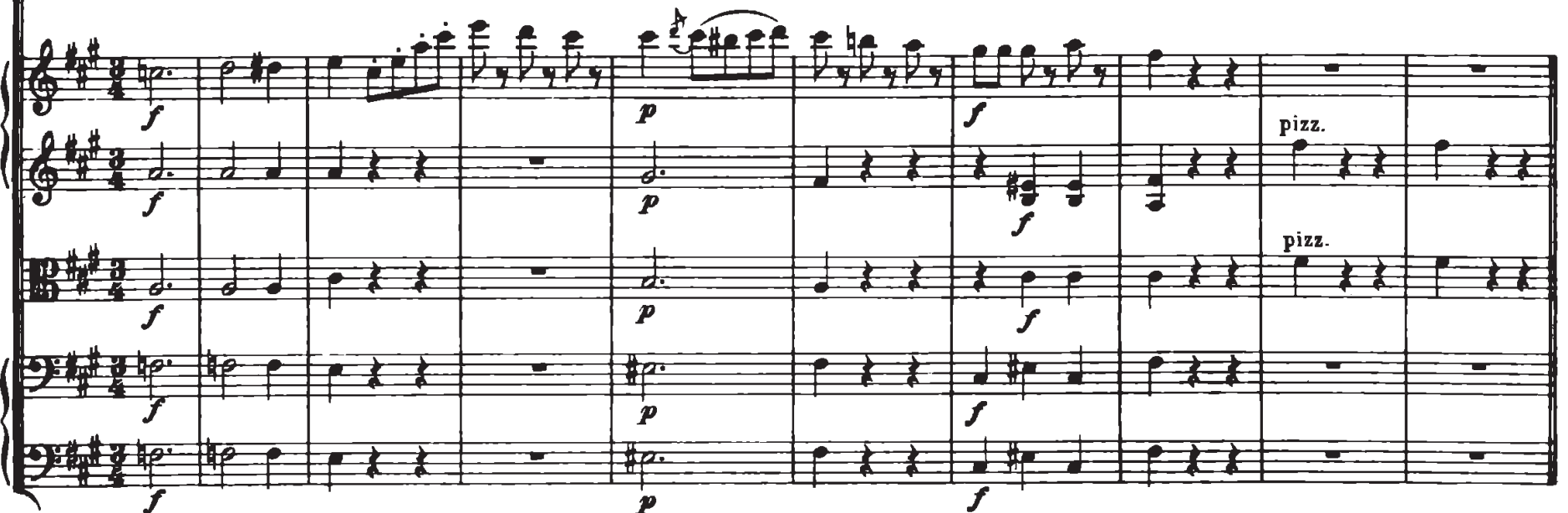


Walzer

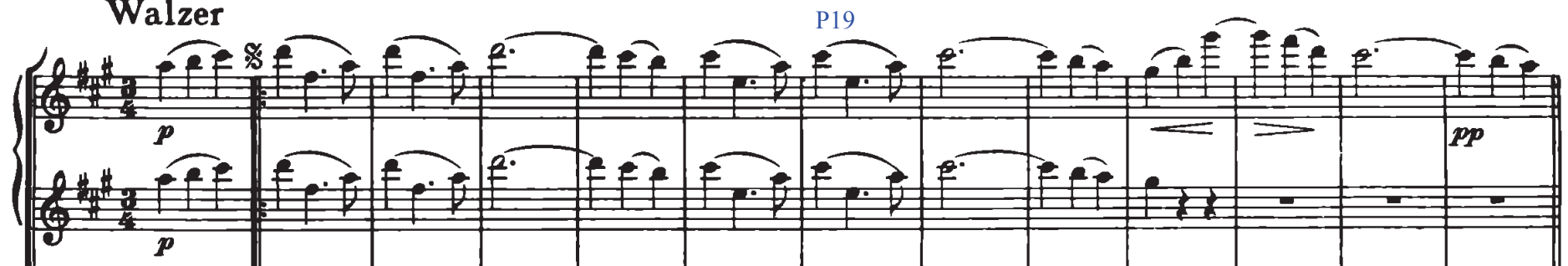

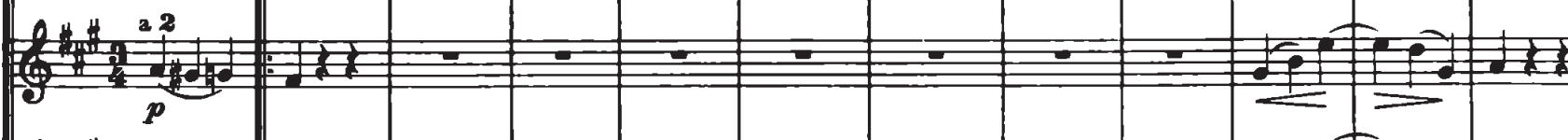

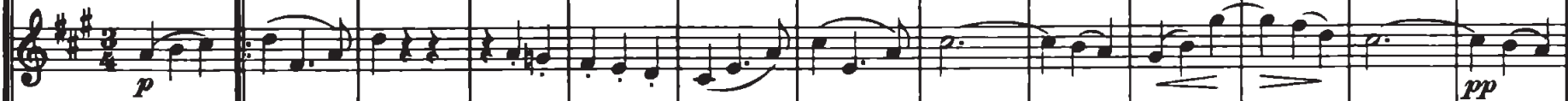
2.

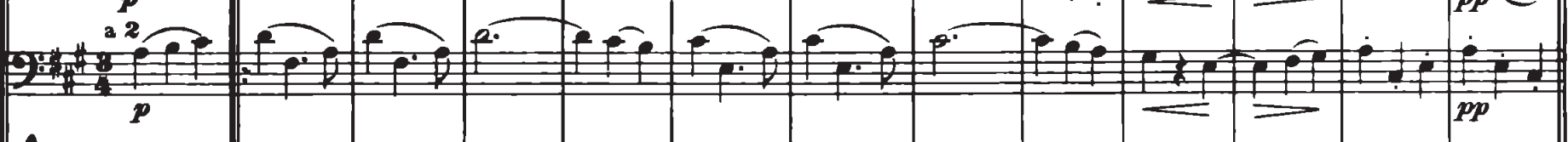

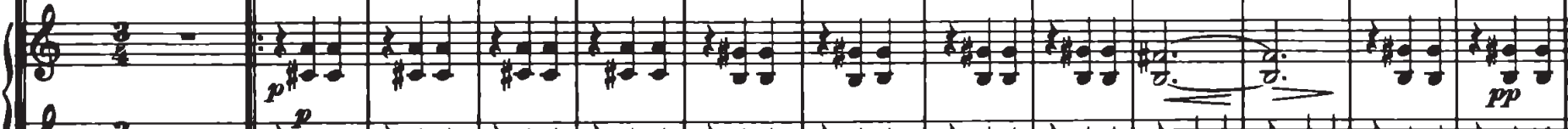
(2010

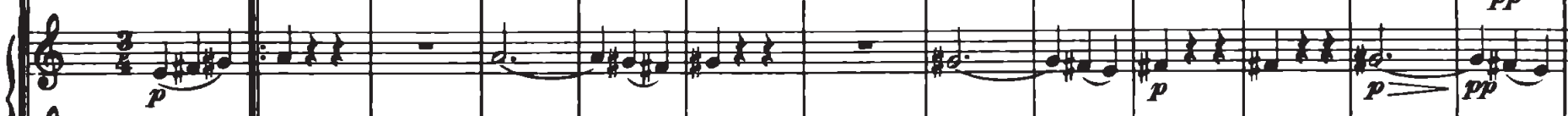

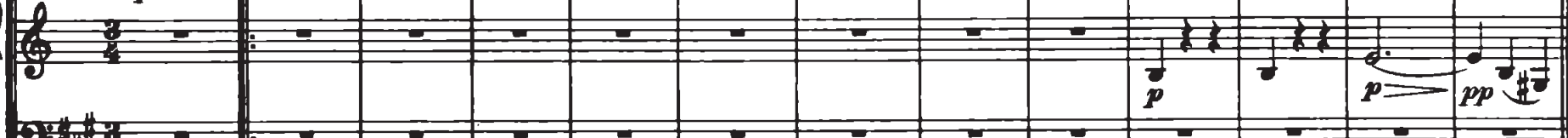

\begin{tabular}{|l|l|l|l|l|l|l|l|l|l|l|l|l|}
\hline & \\
\hline
\end{tabular}

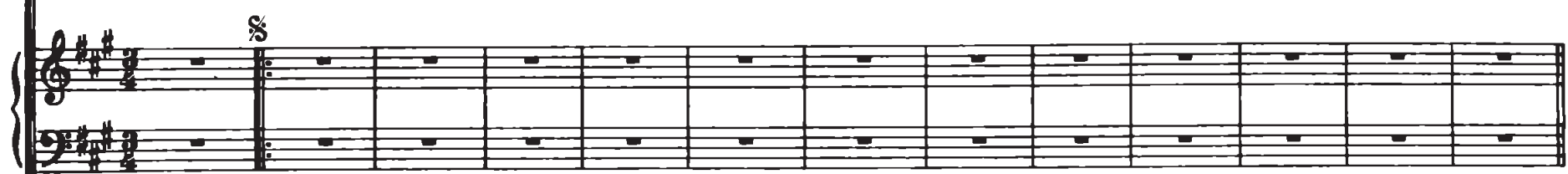

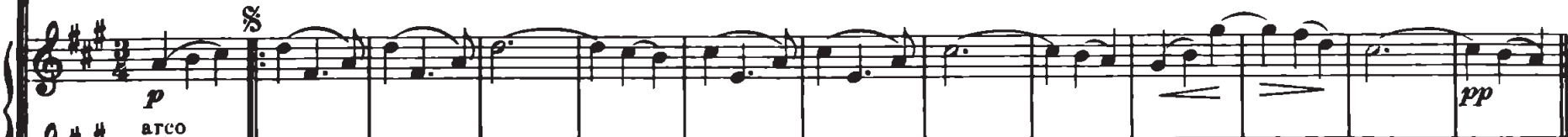

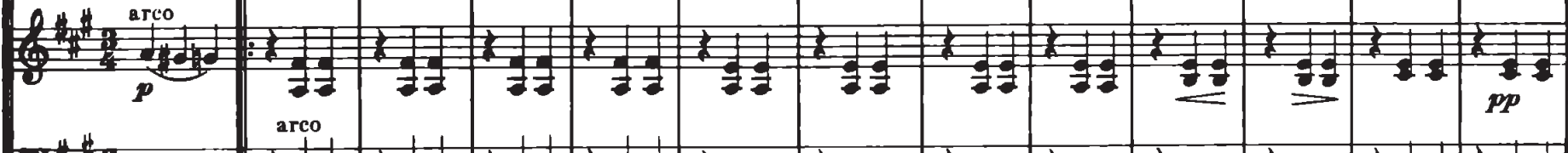
月.

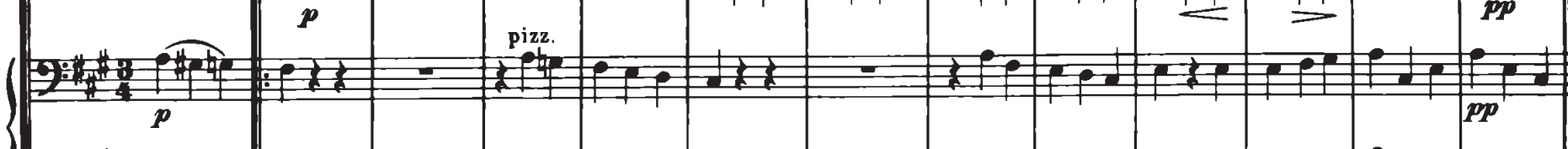

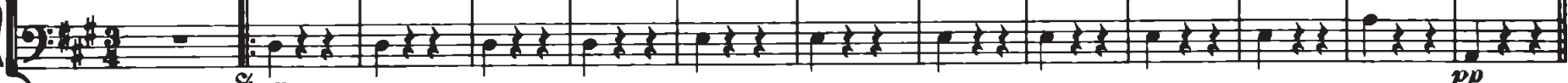
$\$ p$ 
1. शि?

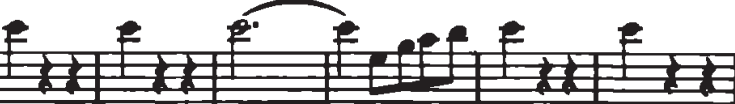

P

$f \longrightarrow$

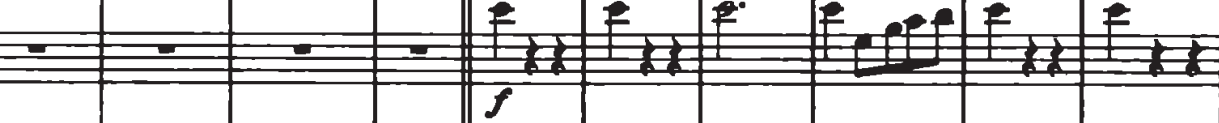

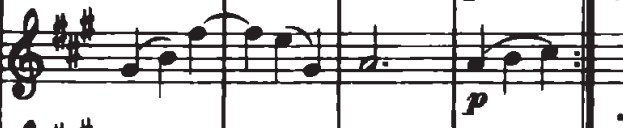

ref

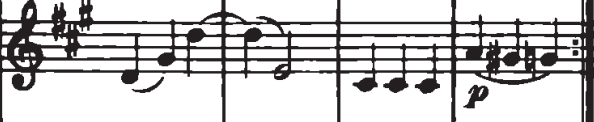

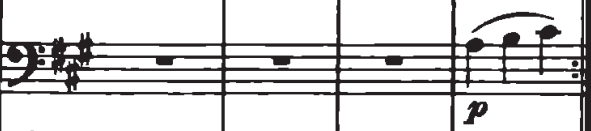

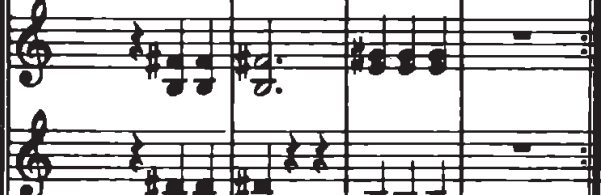

2=-1)

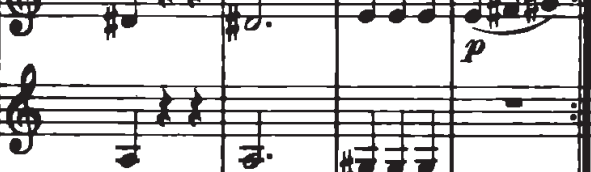

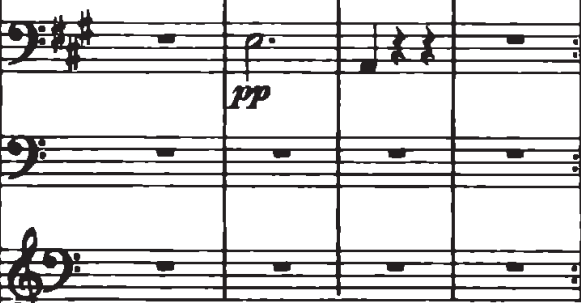

\begin{tabular}{l|l|l}
\hline+2 \\
\hline
\end{tabular}

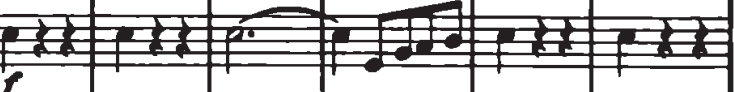

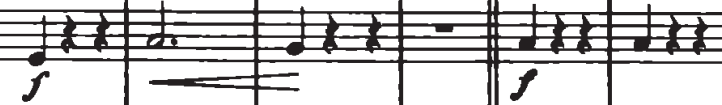

कटत्ट

fef

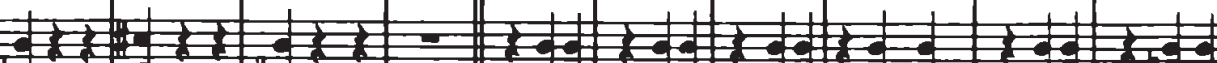

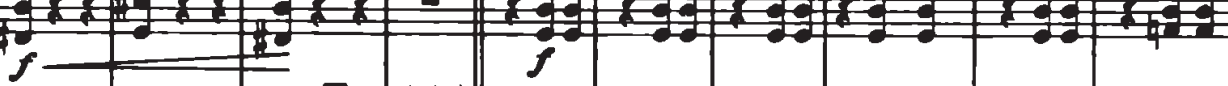

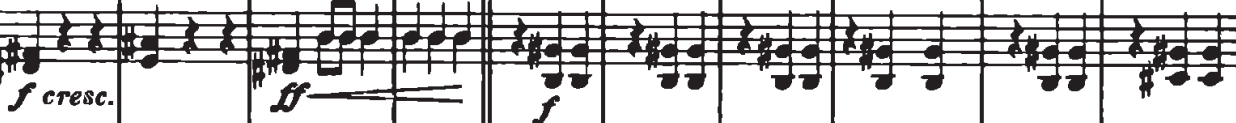
foresc.

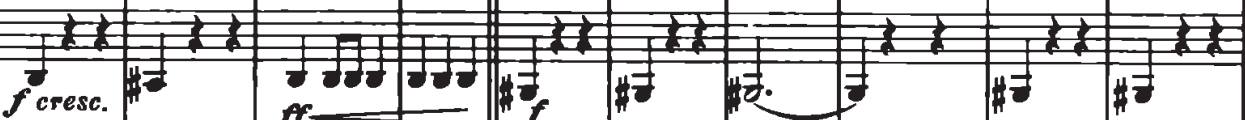

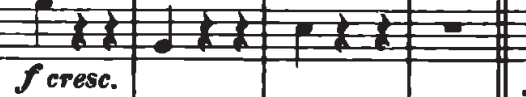
(leo\begin{tabular}{l|l|l} 
f cresc. & & \\
\hline
\end{tabular} $f$

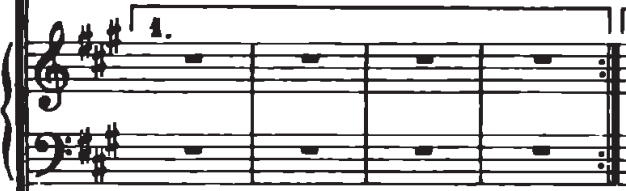

$7 \longdiv { 2 . }$

K1.Trommel Gr.Trommel $f$

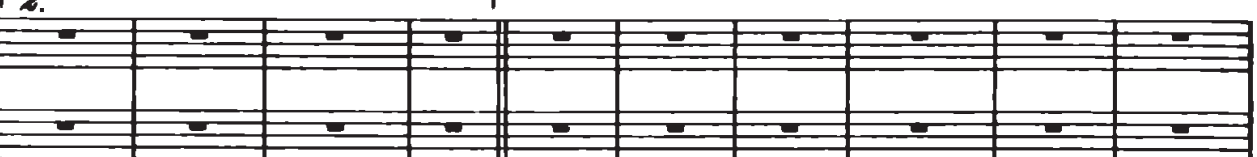

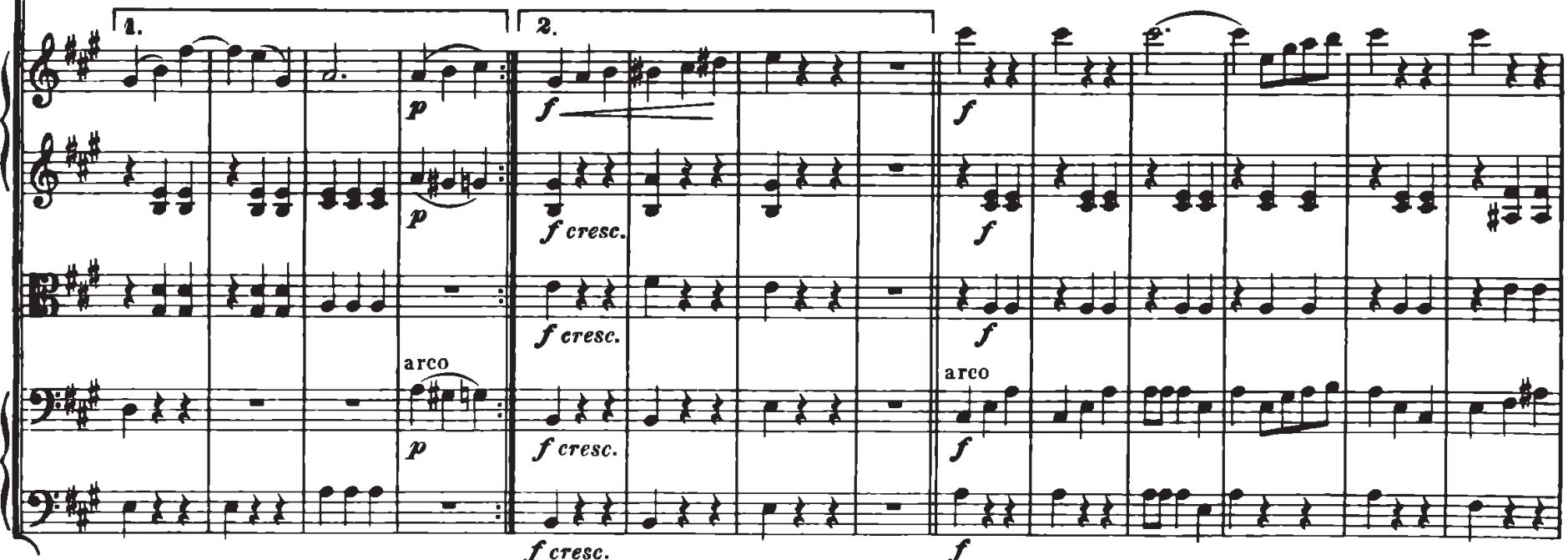


22

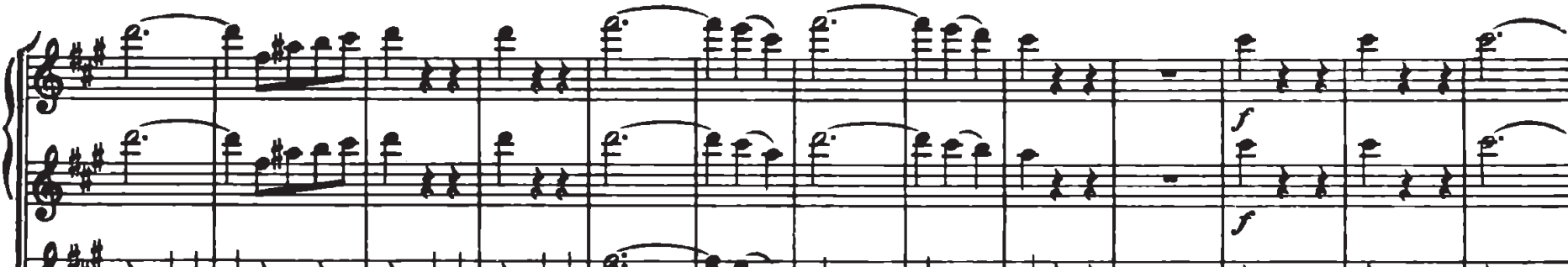

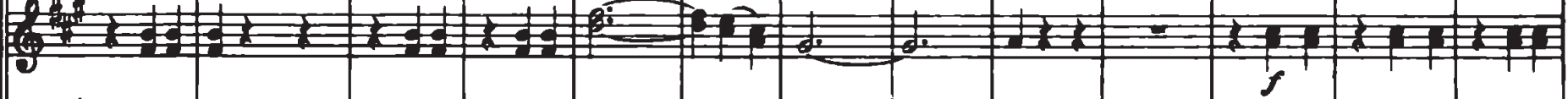

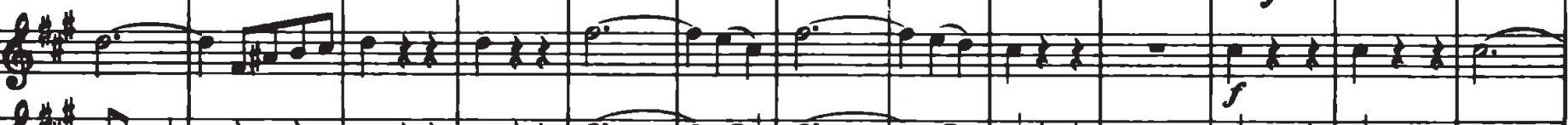

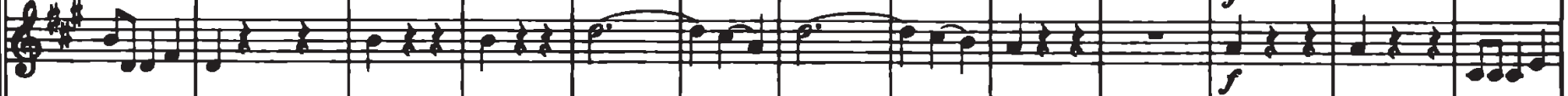

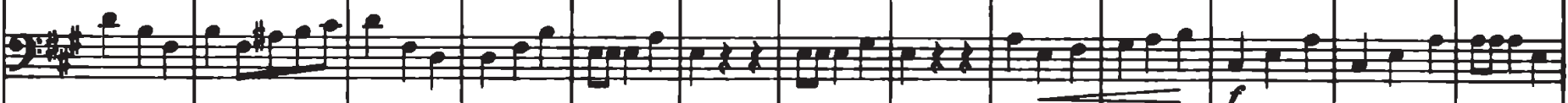

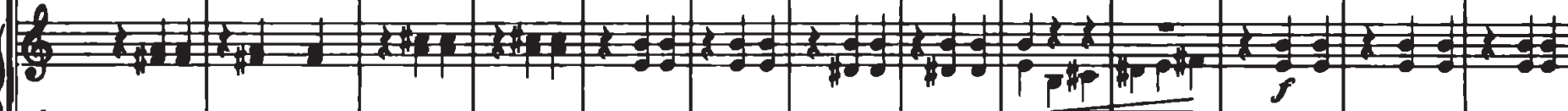

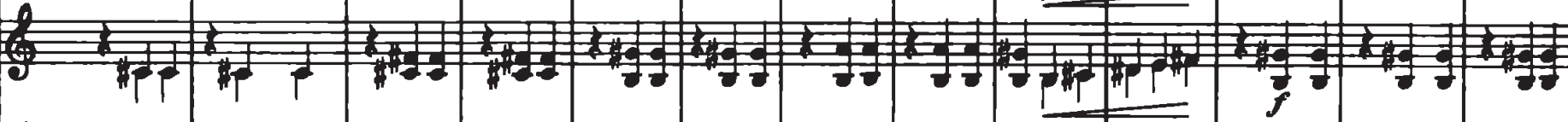

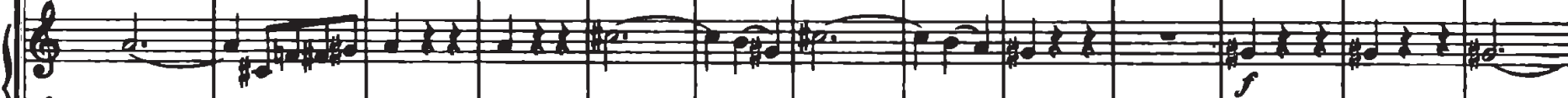
(2)

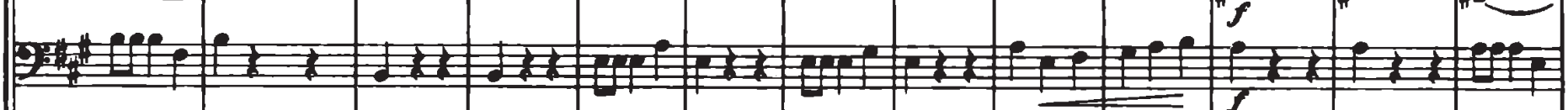

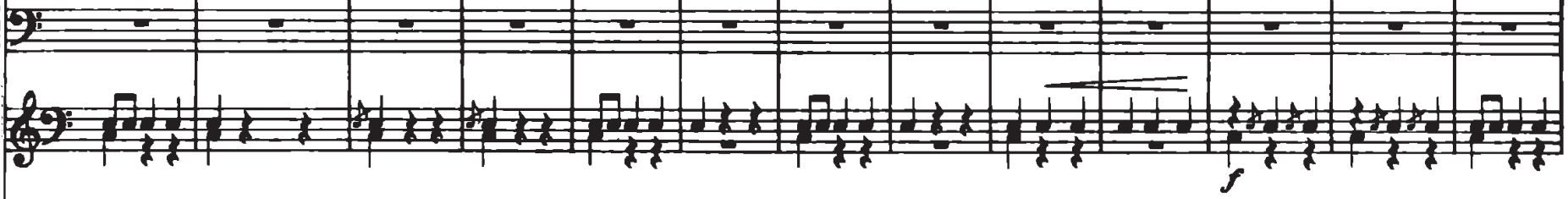

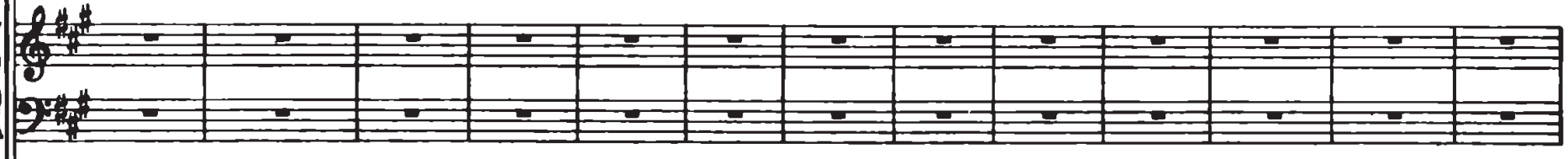

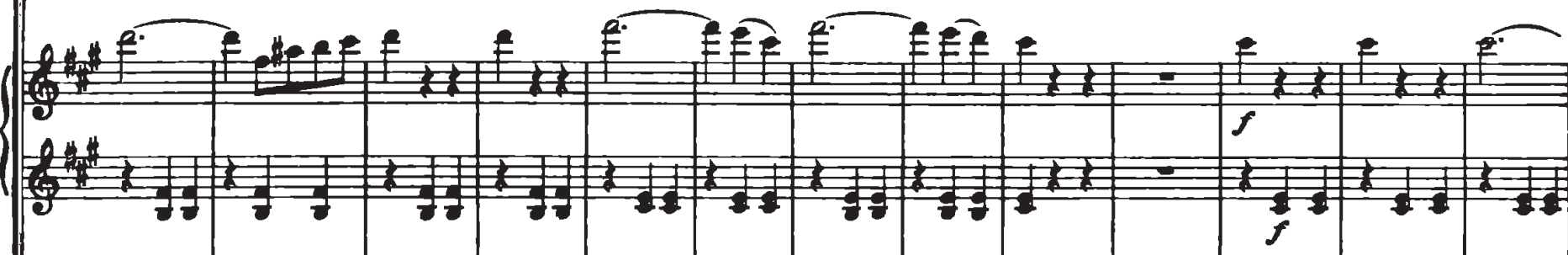
|l

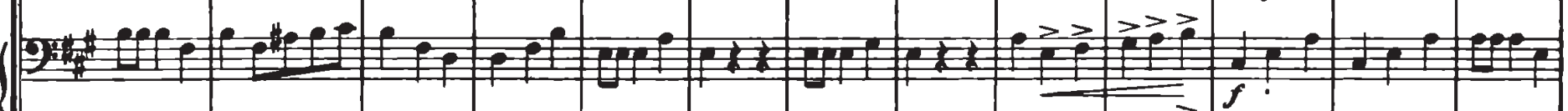

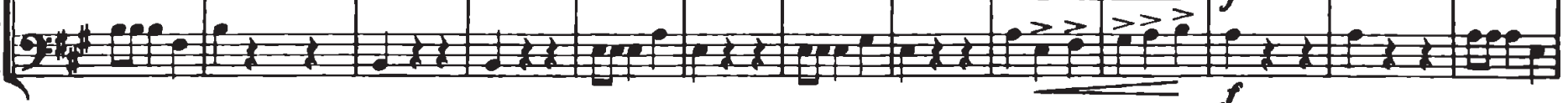



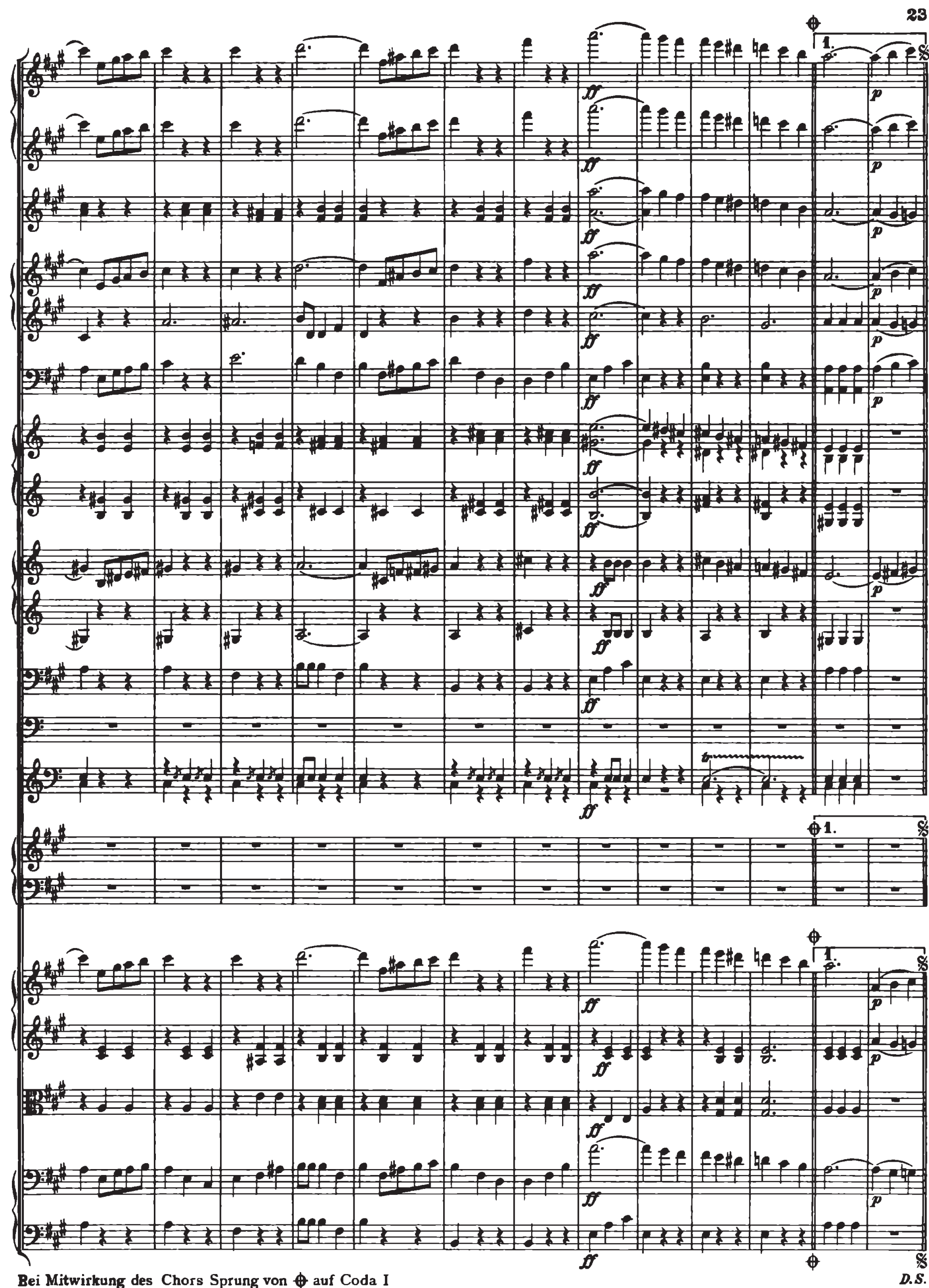
24
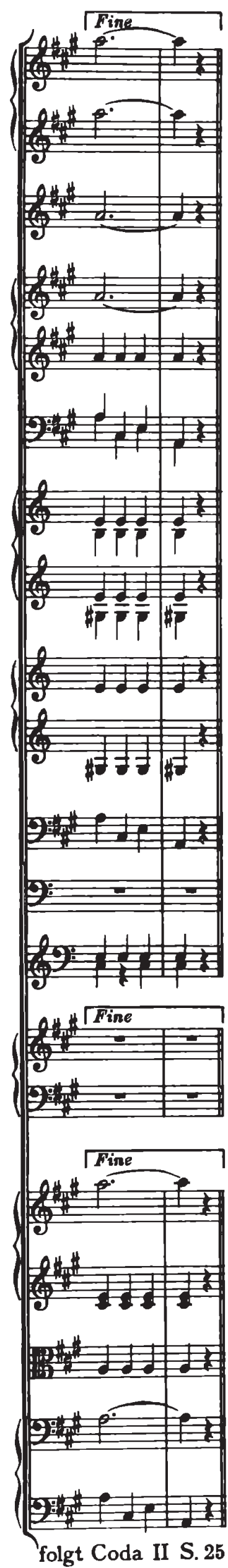

Coda I Nur bei Mitwirkung des Chors

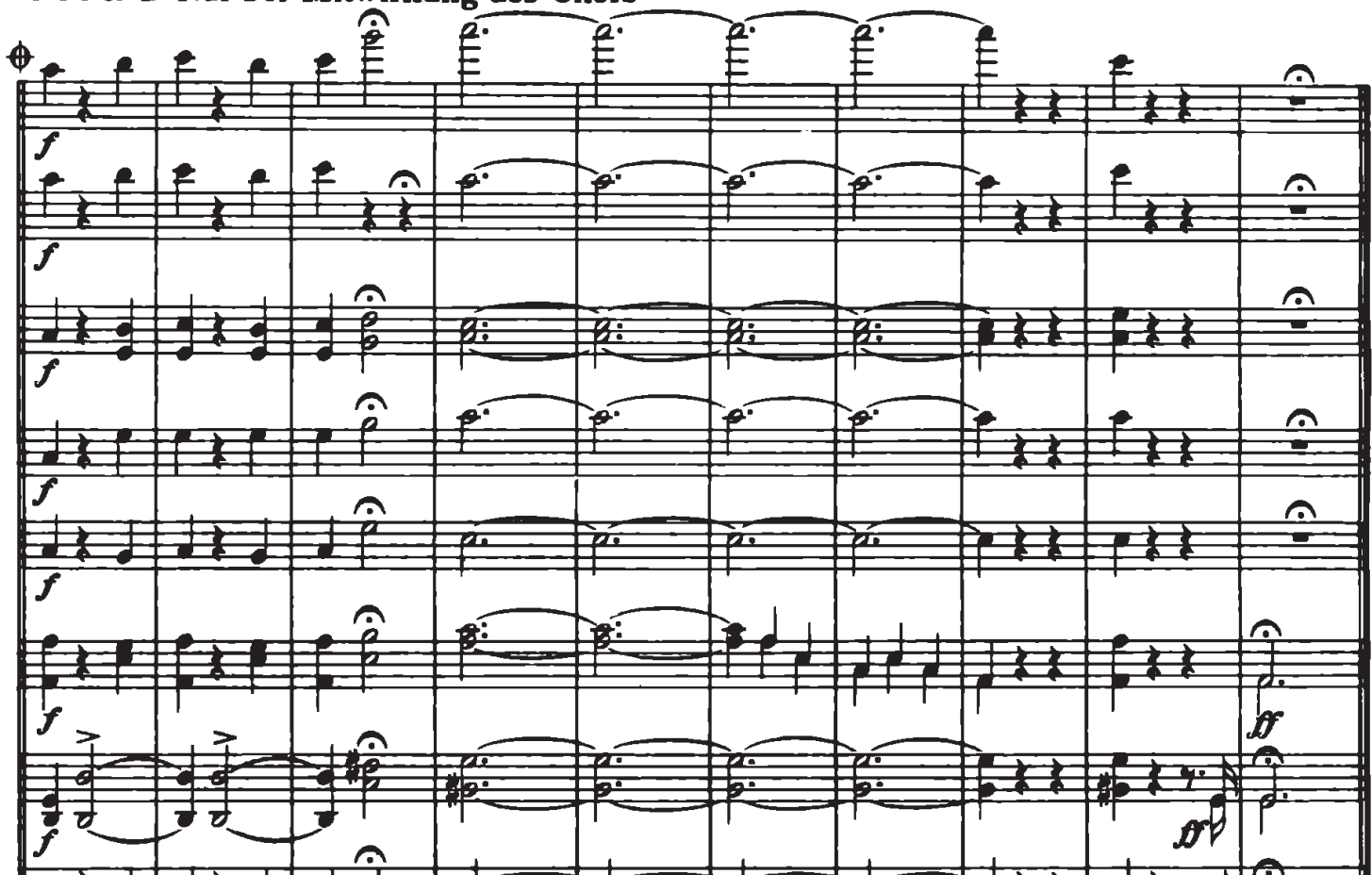

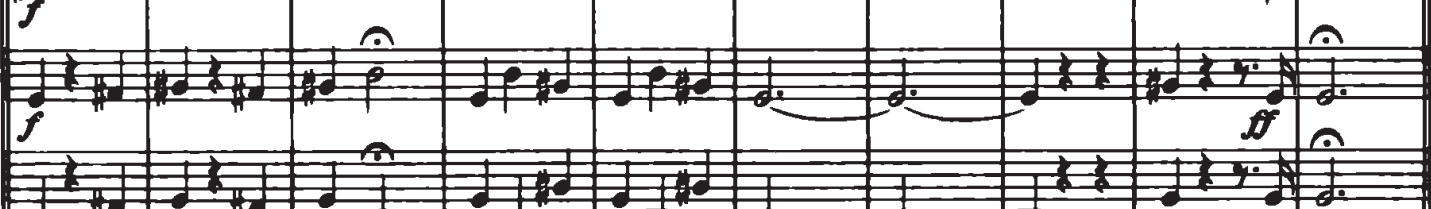

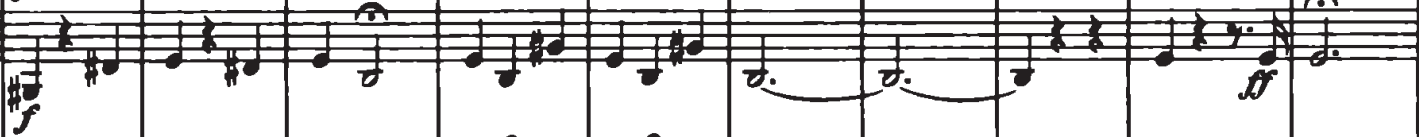

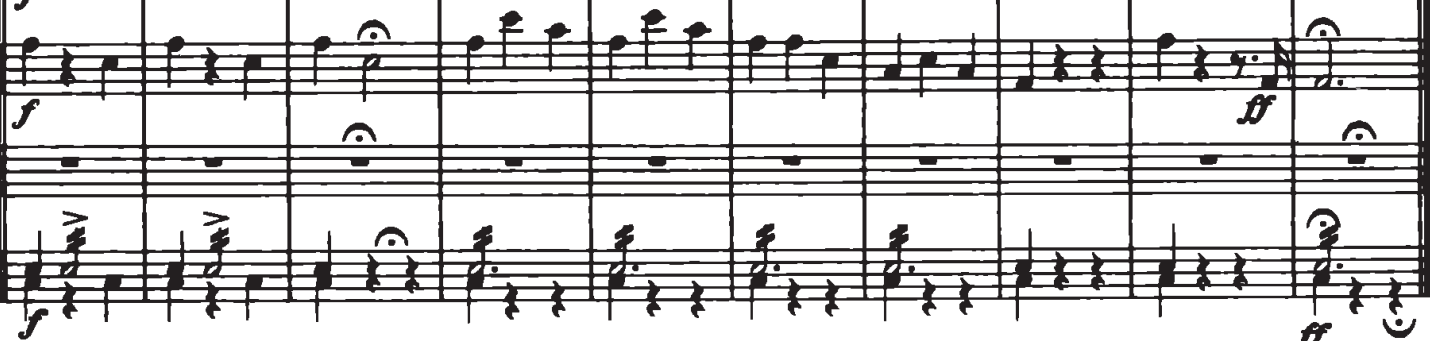

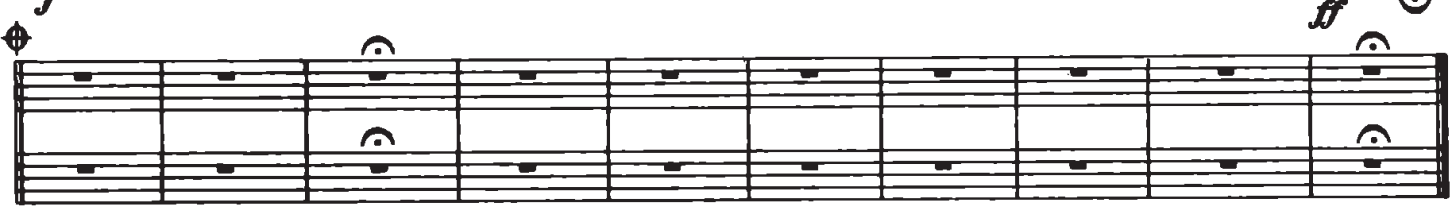

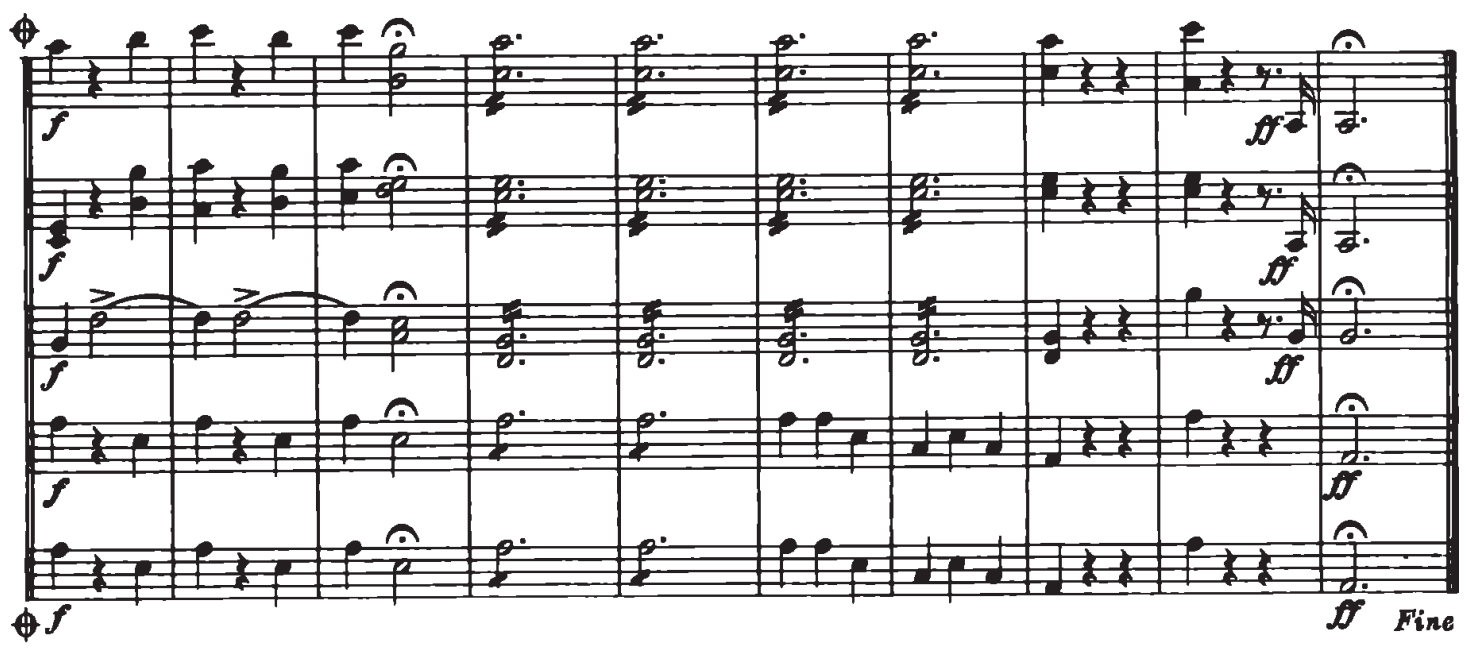


Coda II

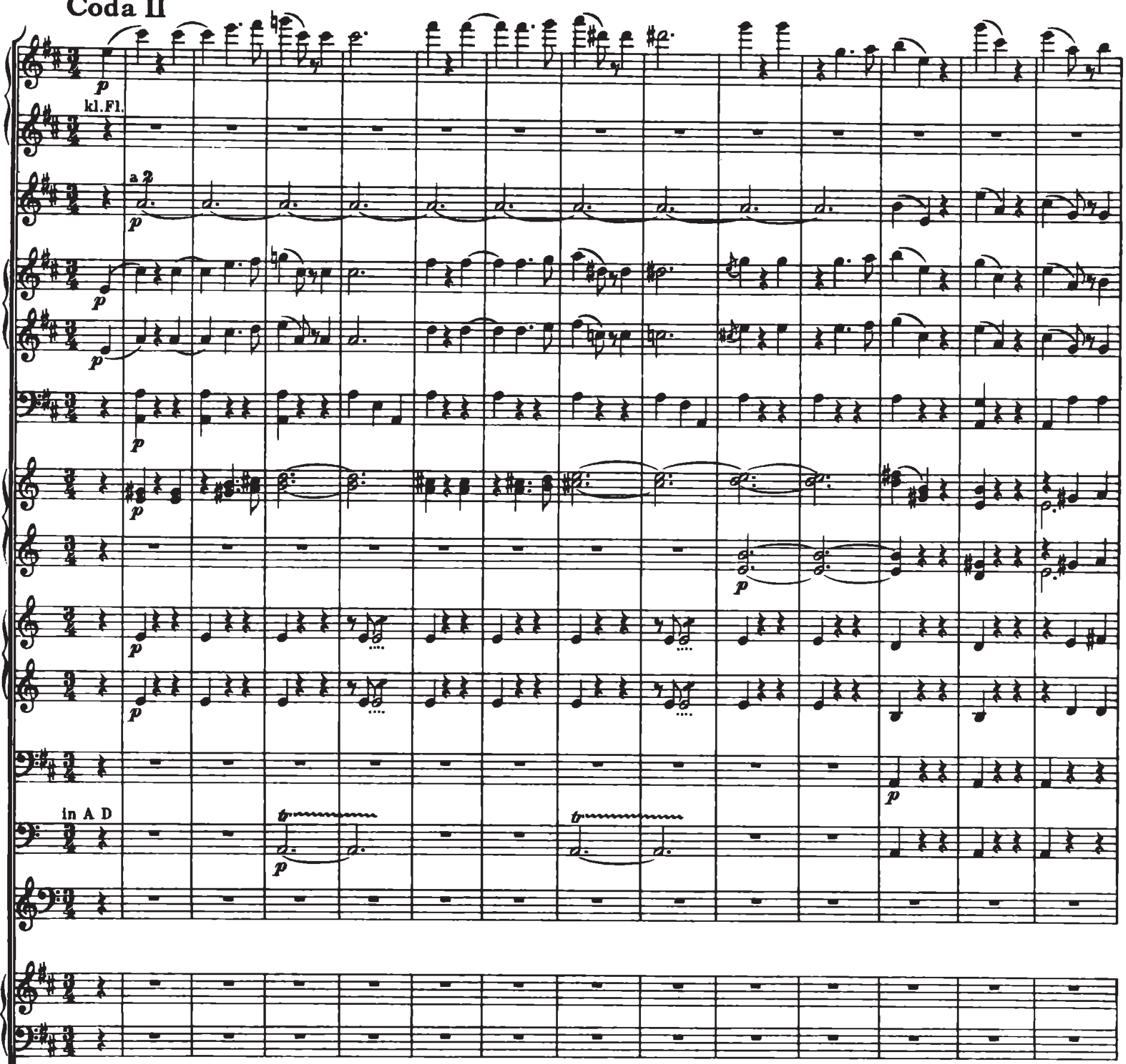

(2)

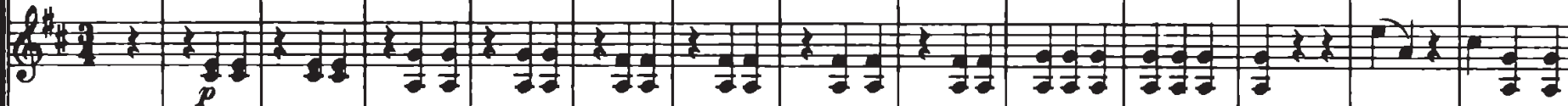

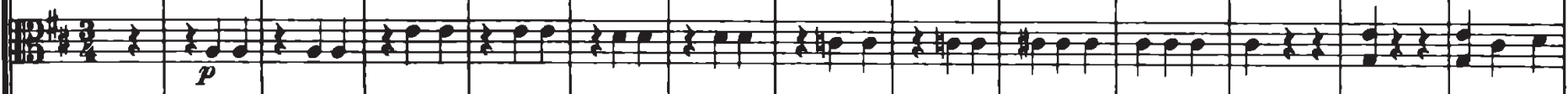

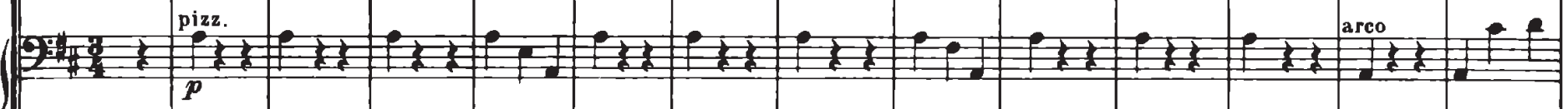

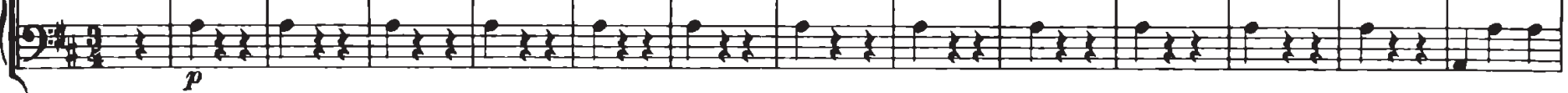




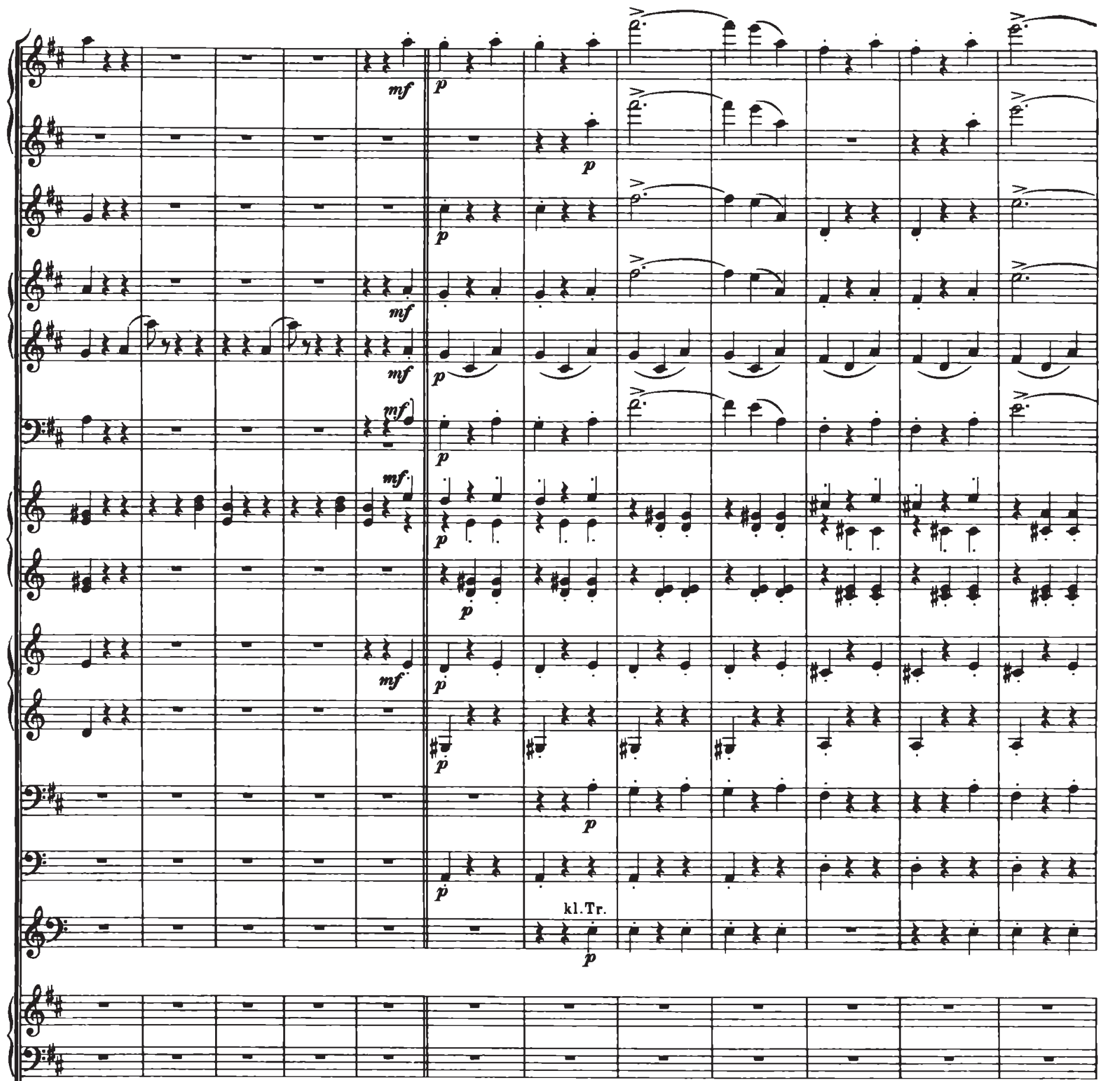

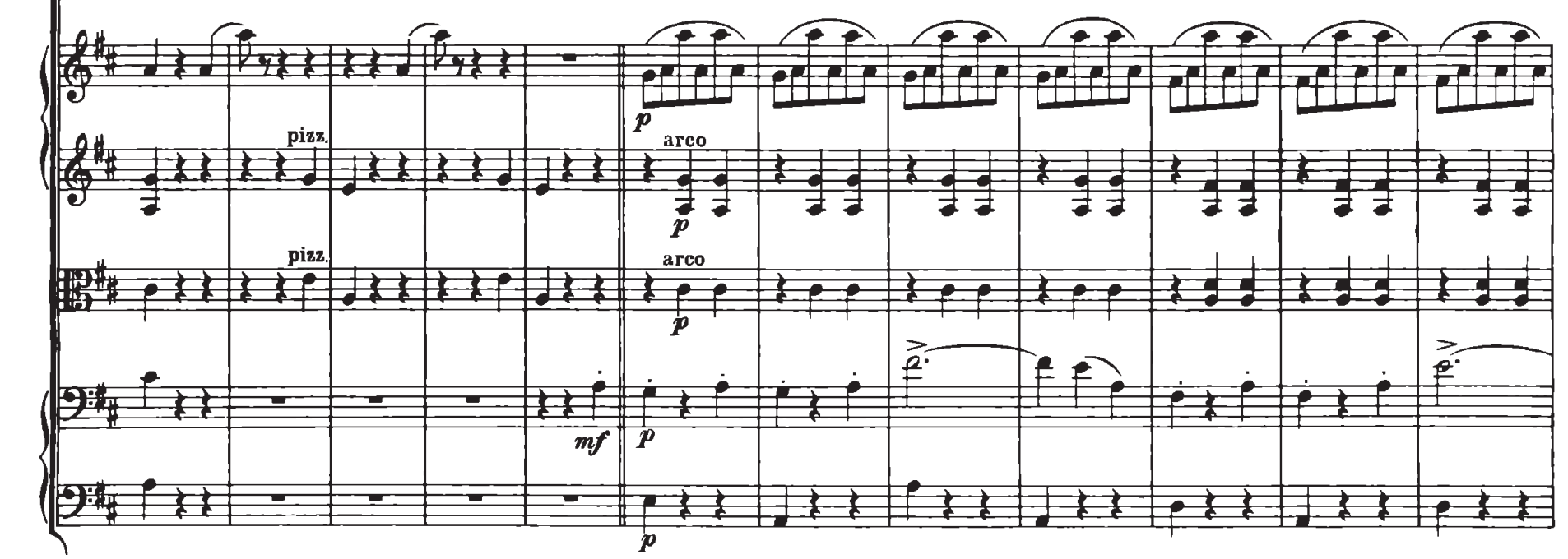

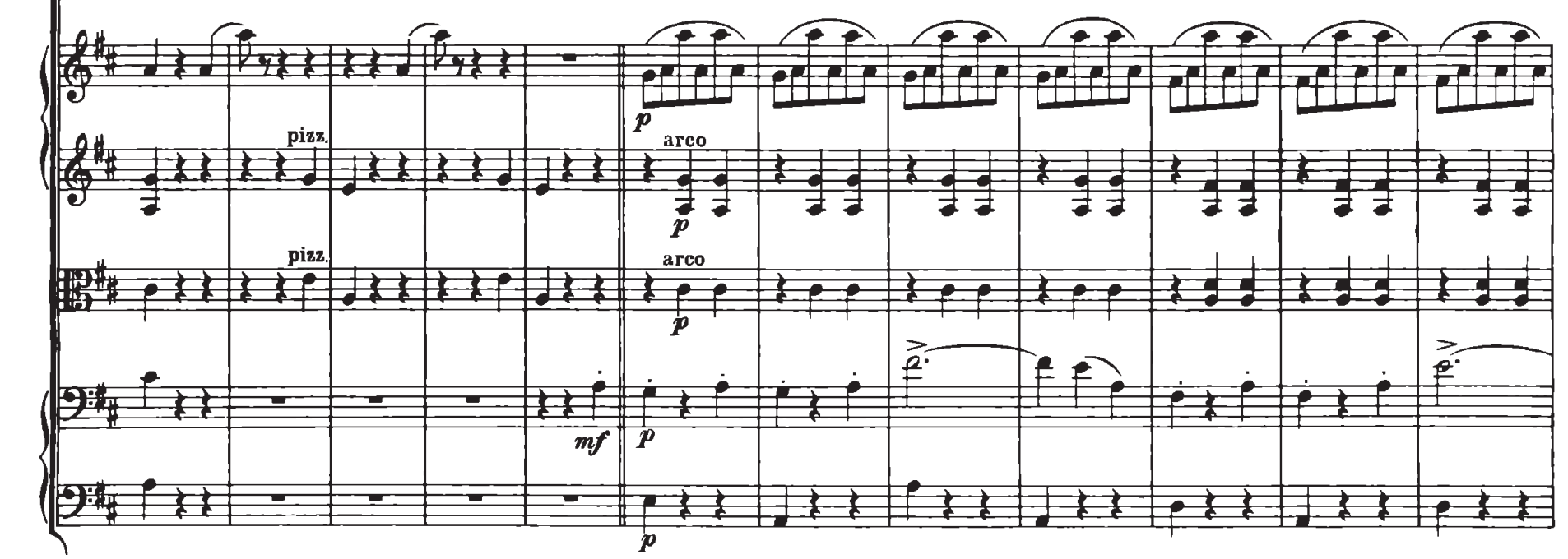

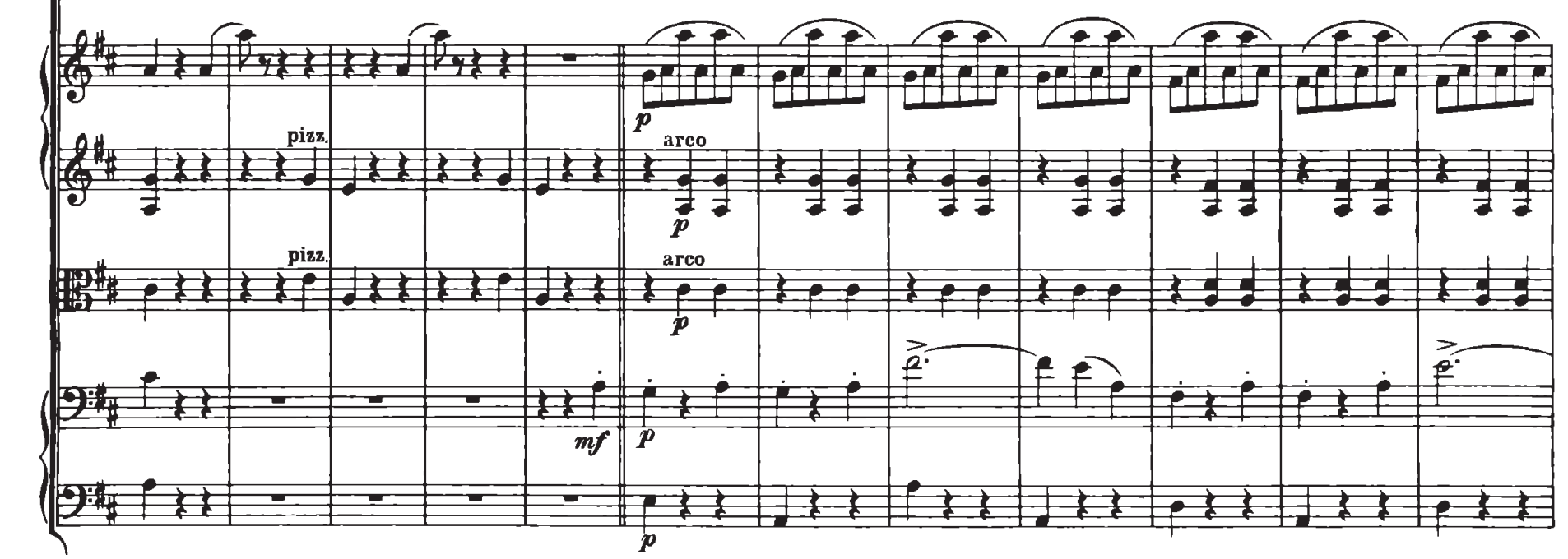

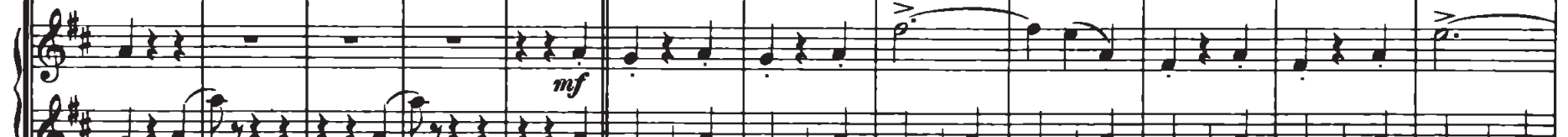

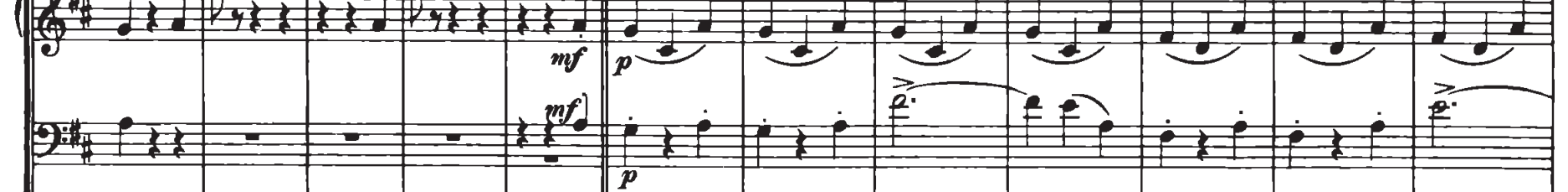

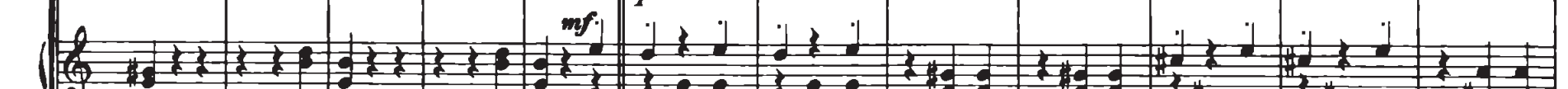

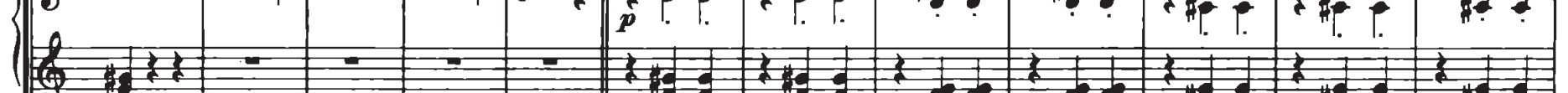

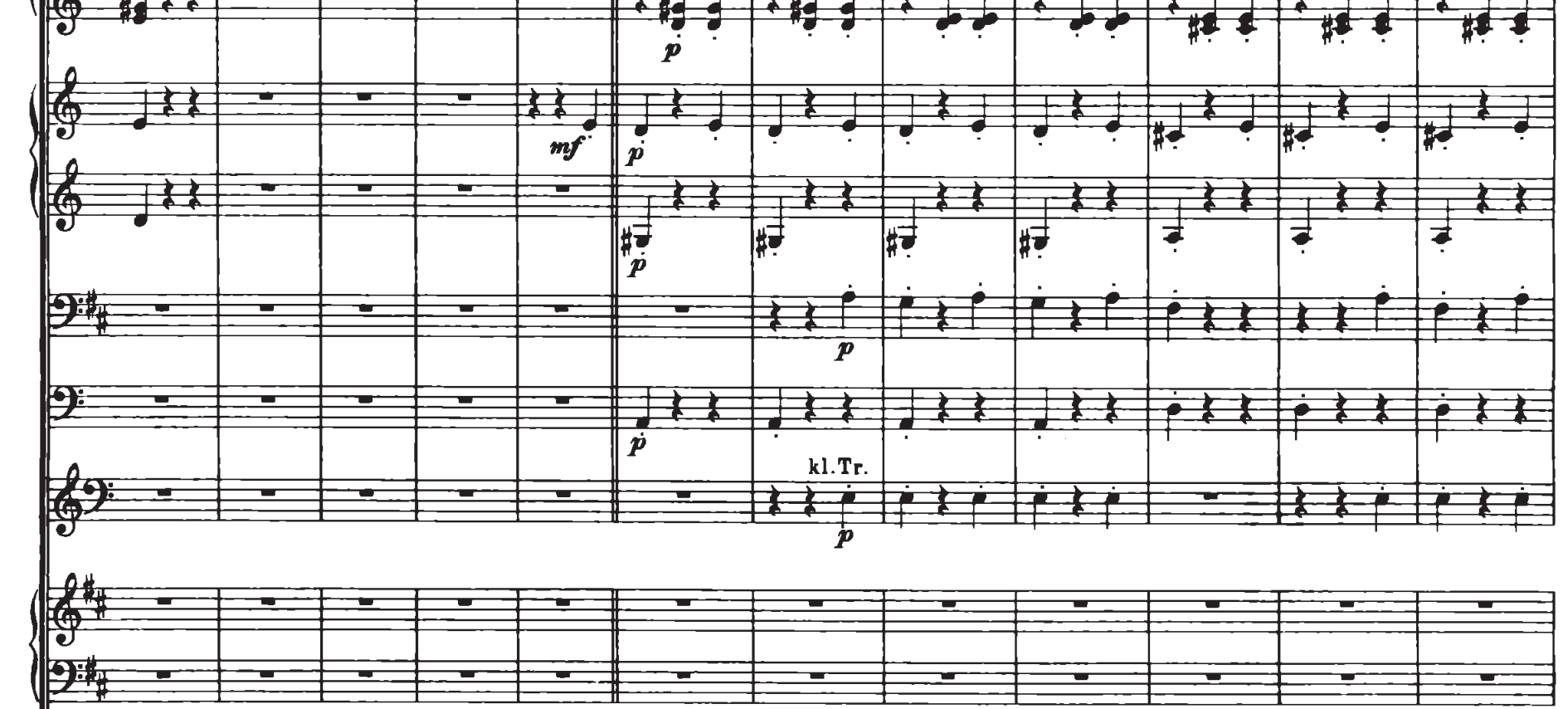


(1)

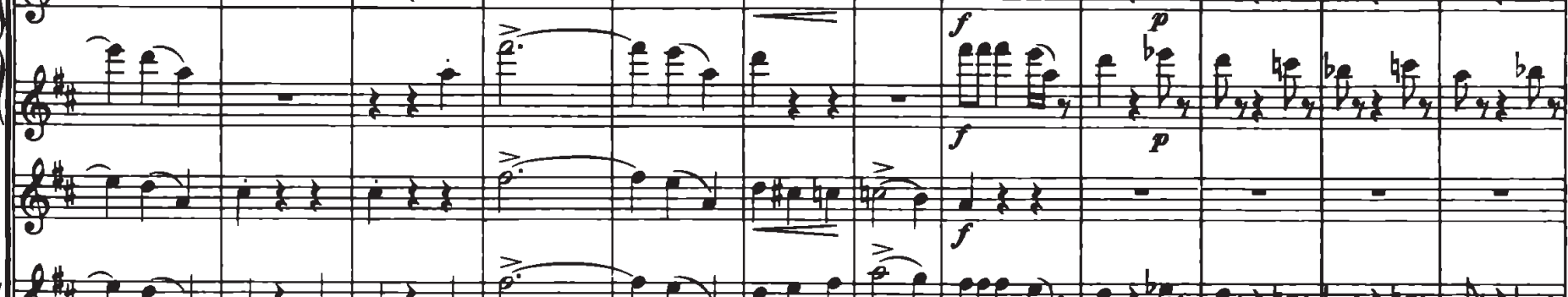
(5)

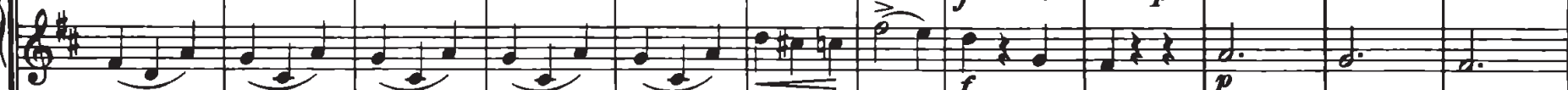

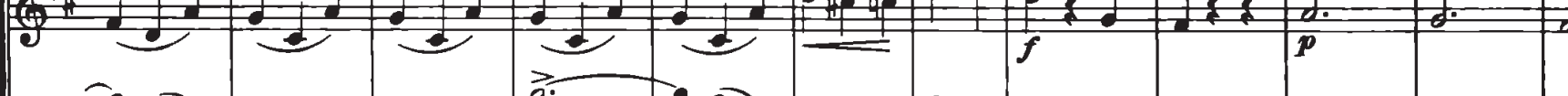
24.

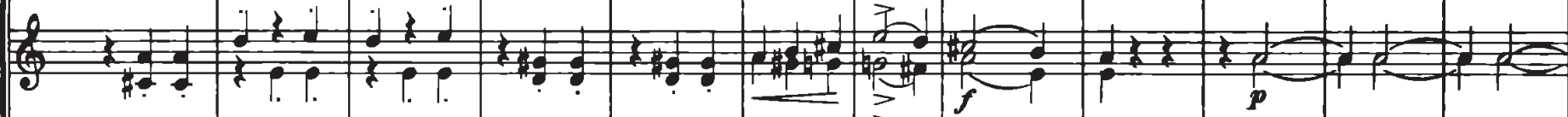
(2)

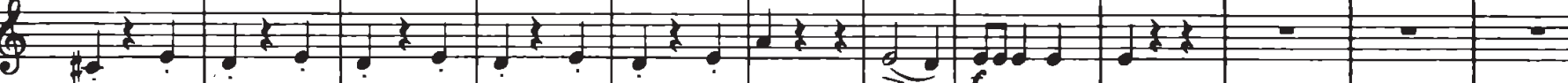
0 (2) द

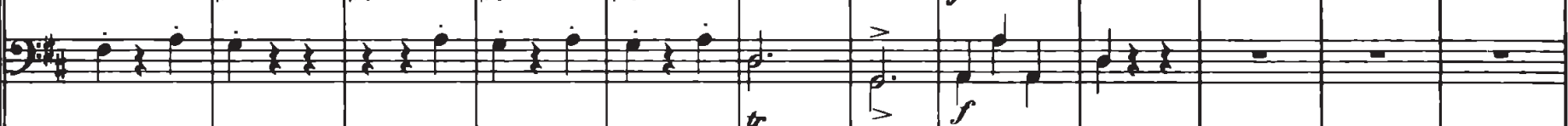

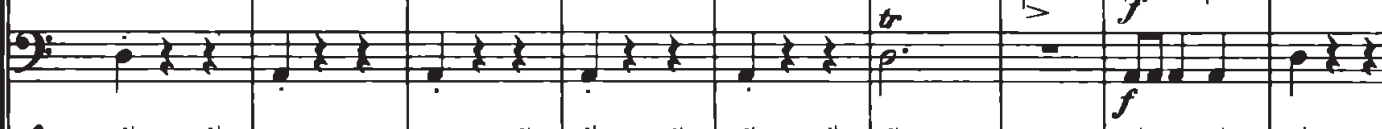

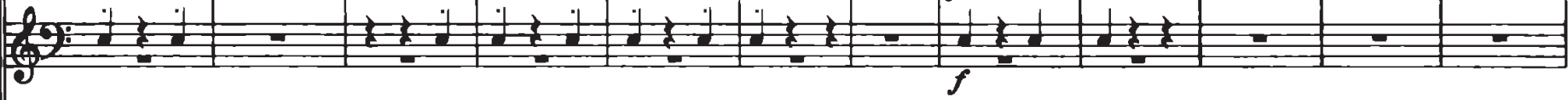

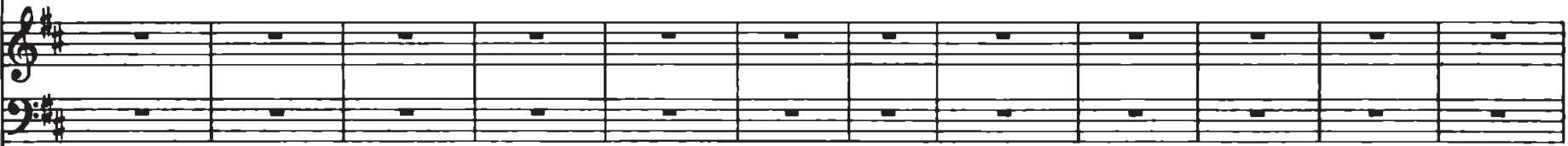

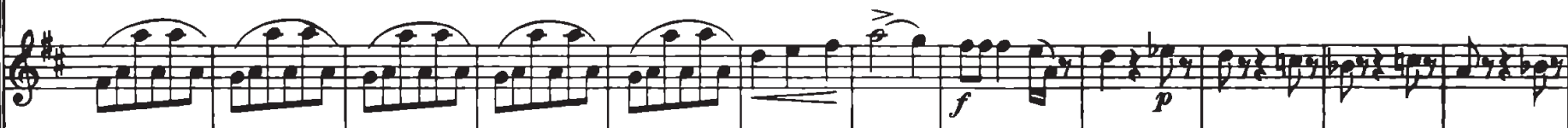

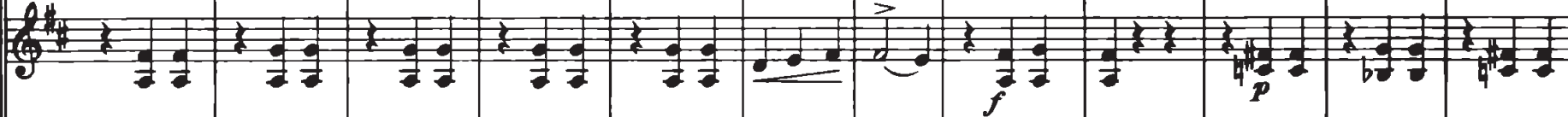
-

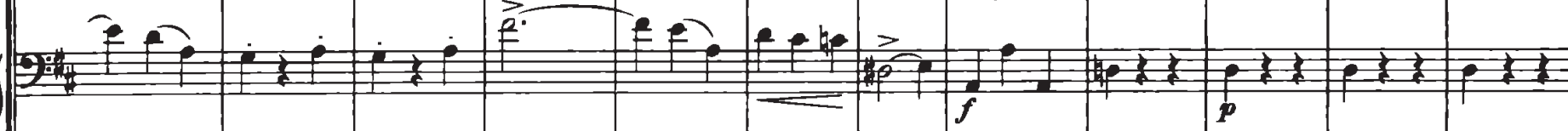

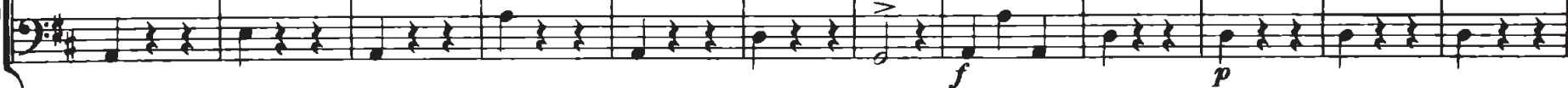




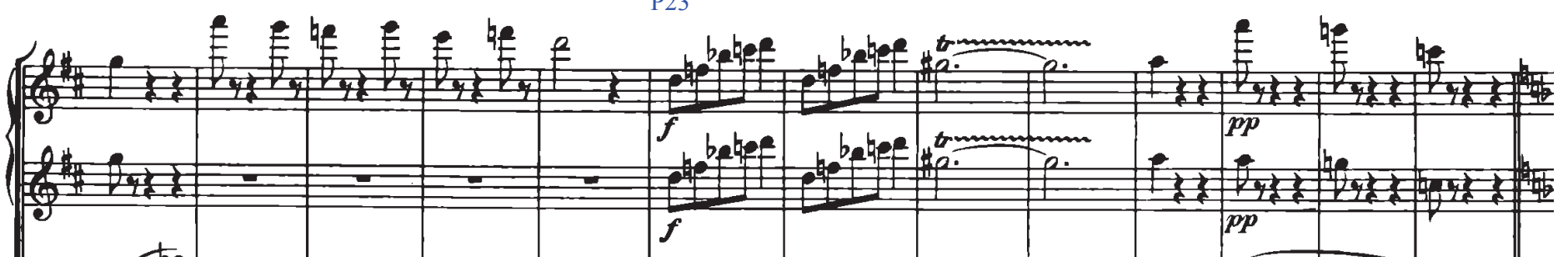
2.

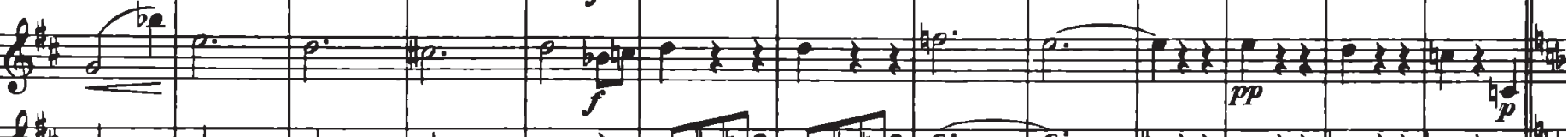

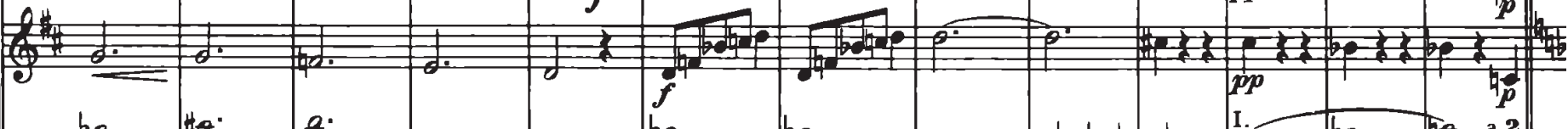
3. be.

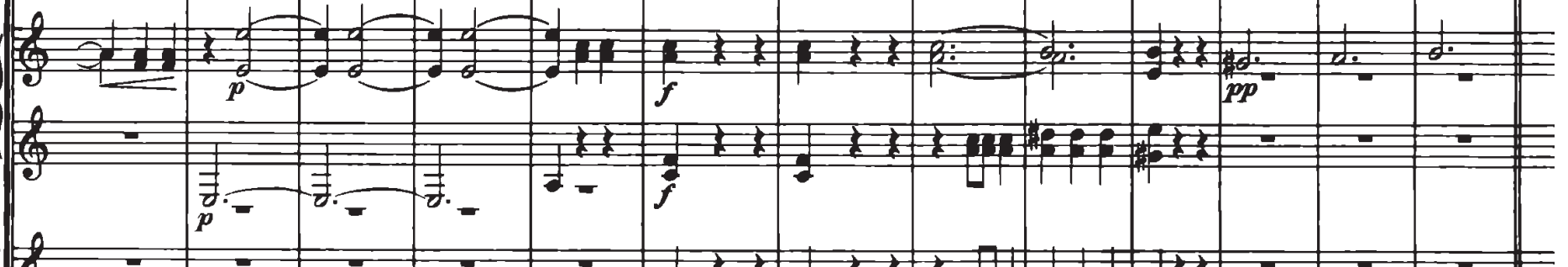

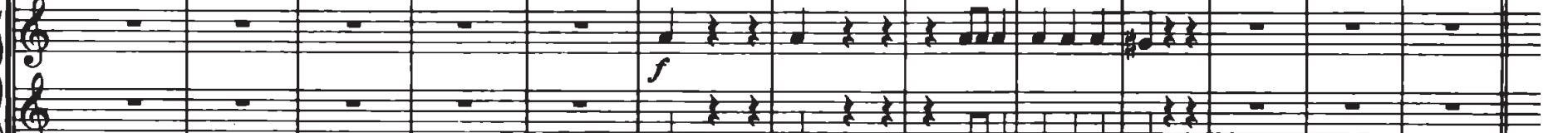

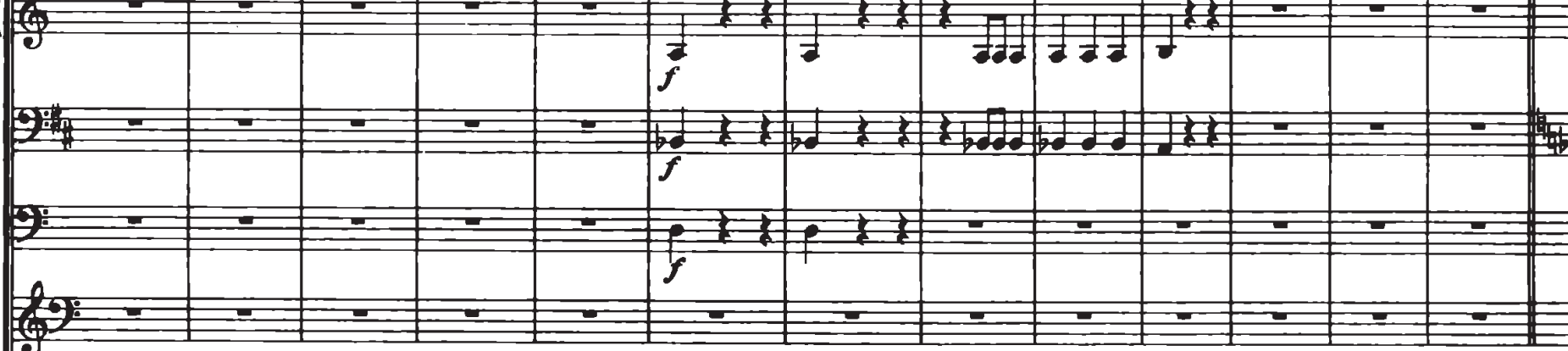

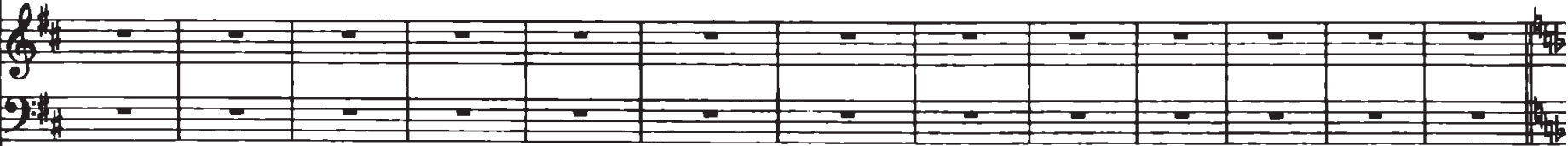

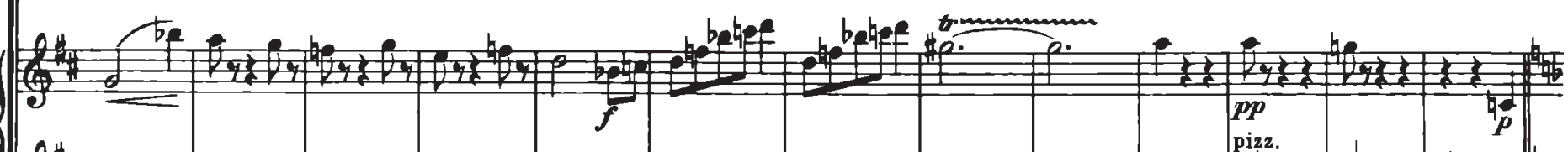

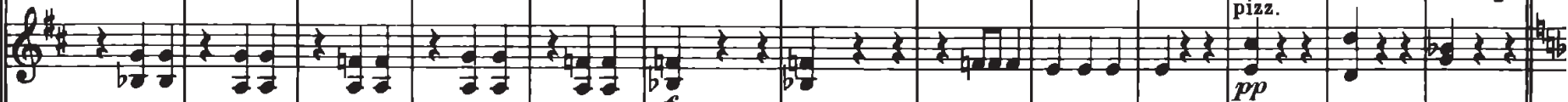
(1)

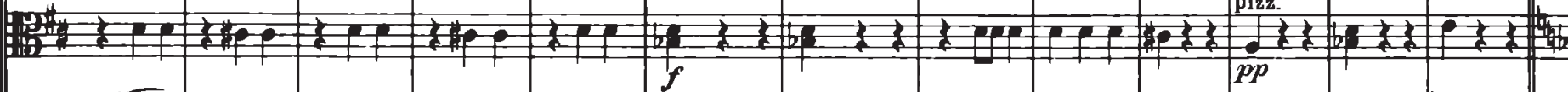

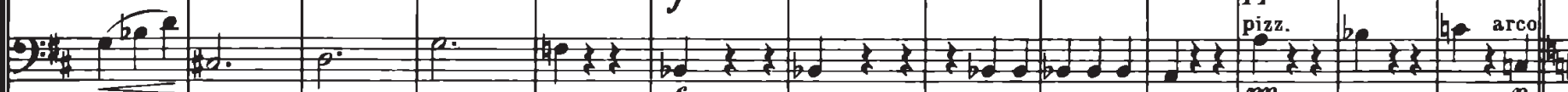

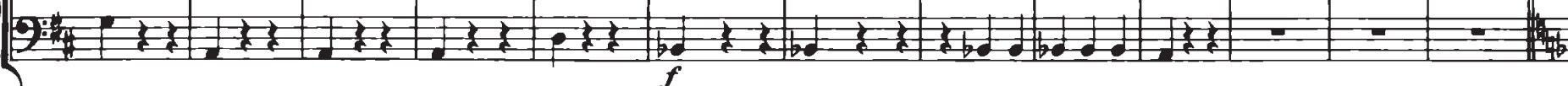




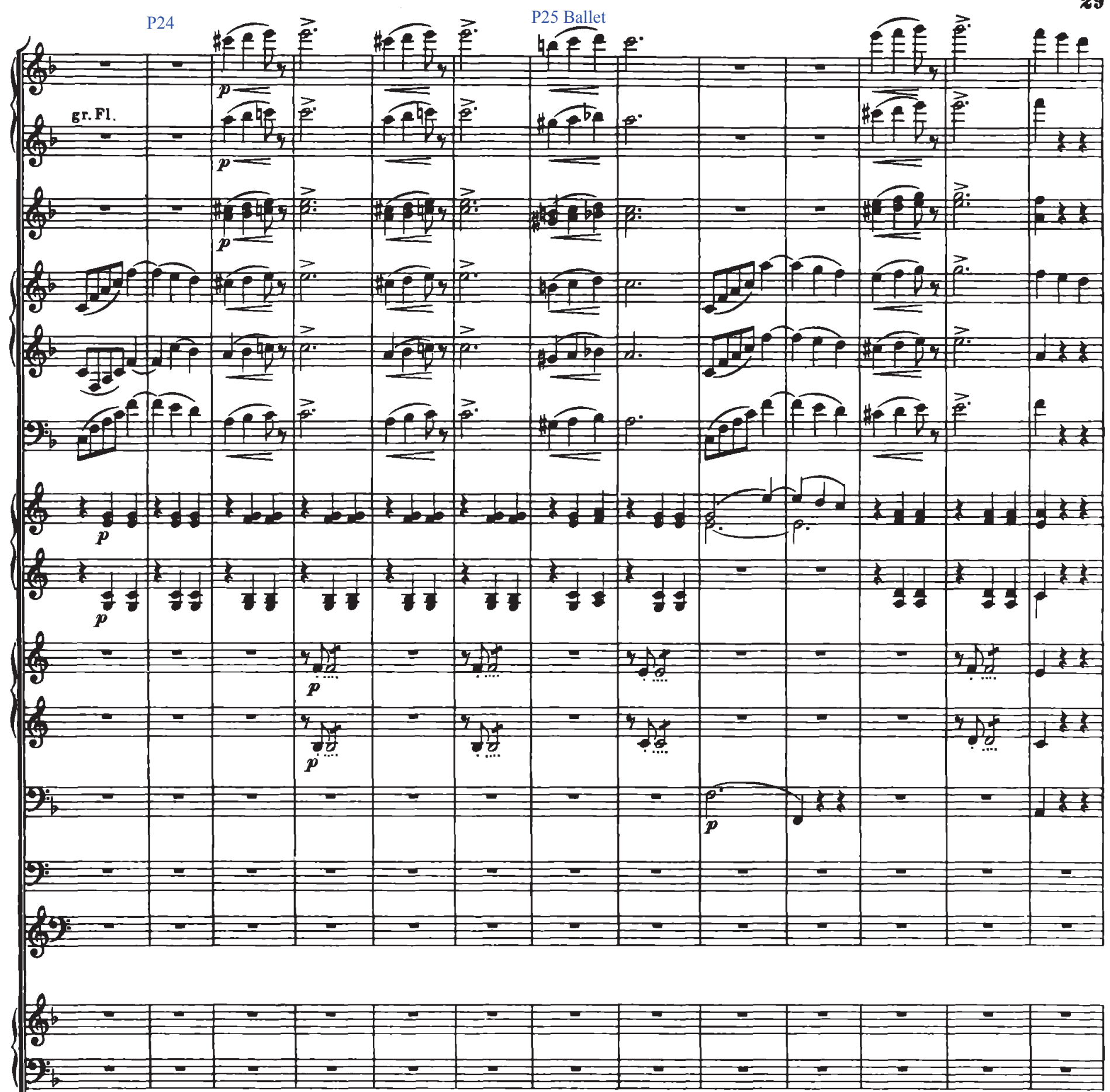

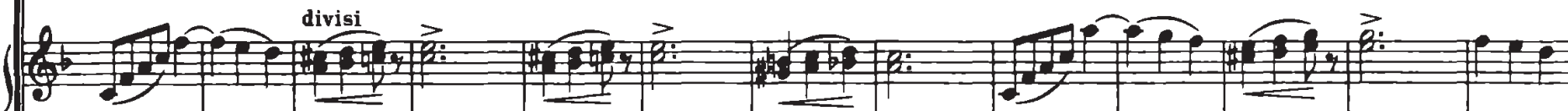

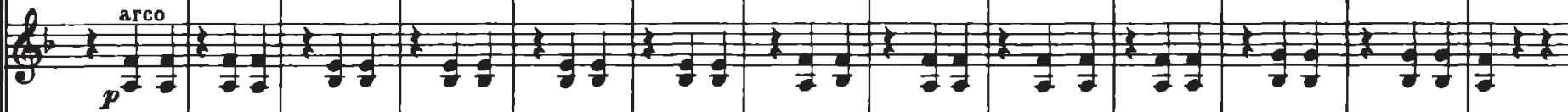

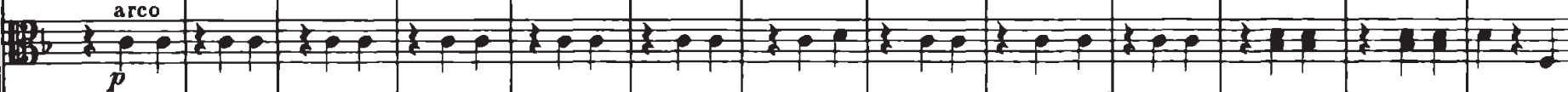

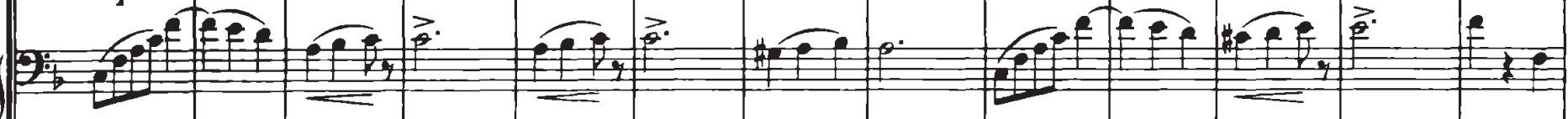

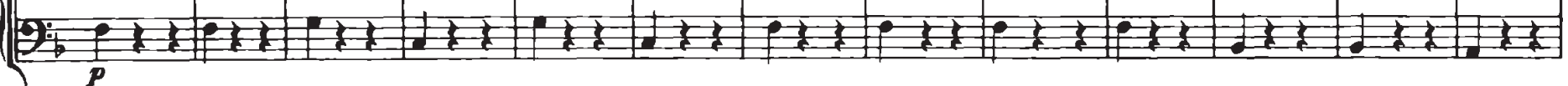



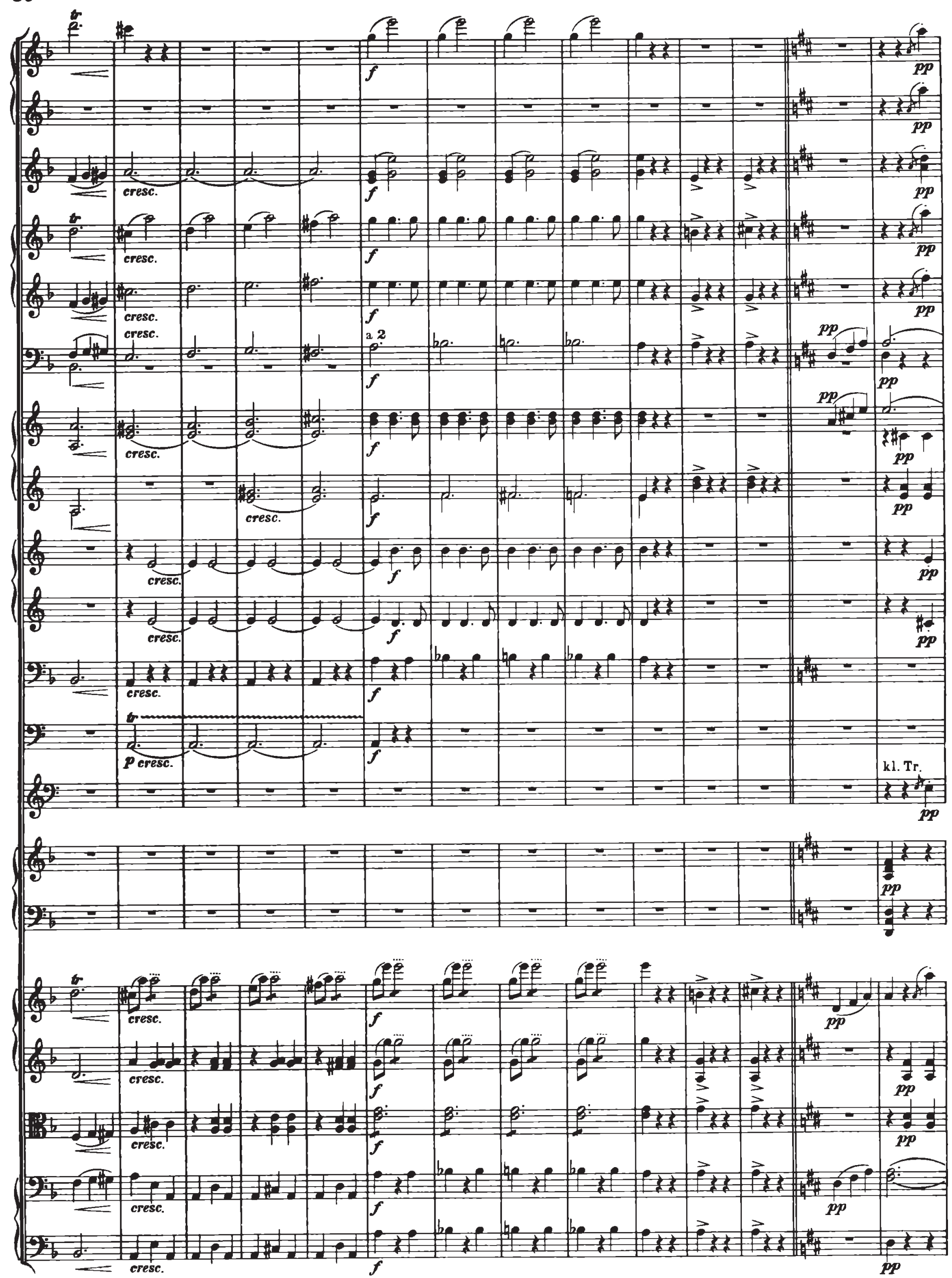


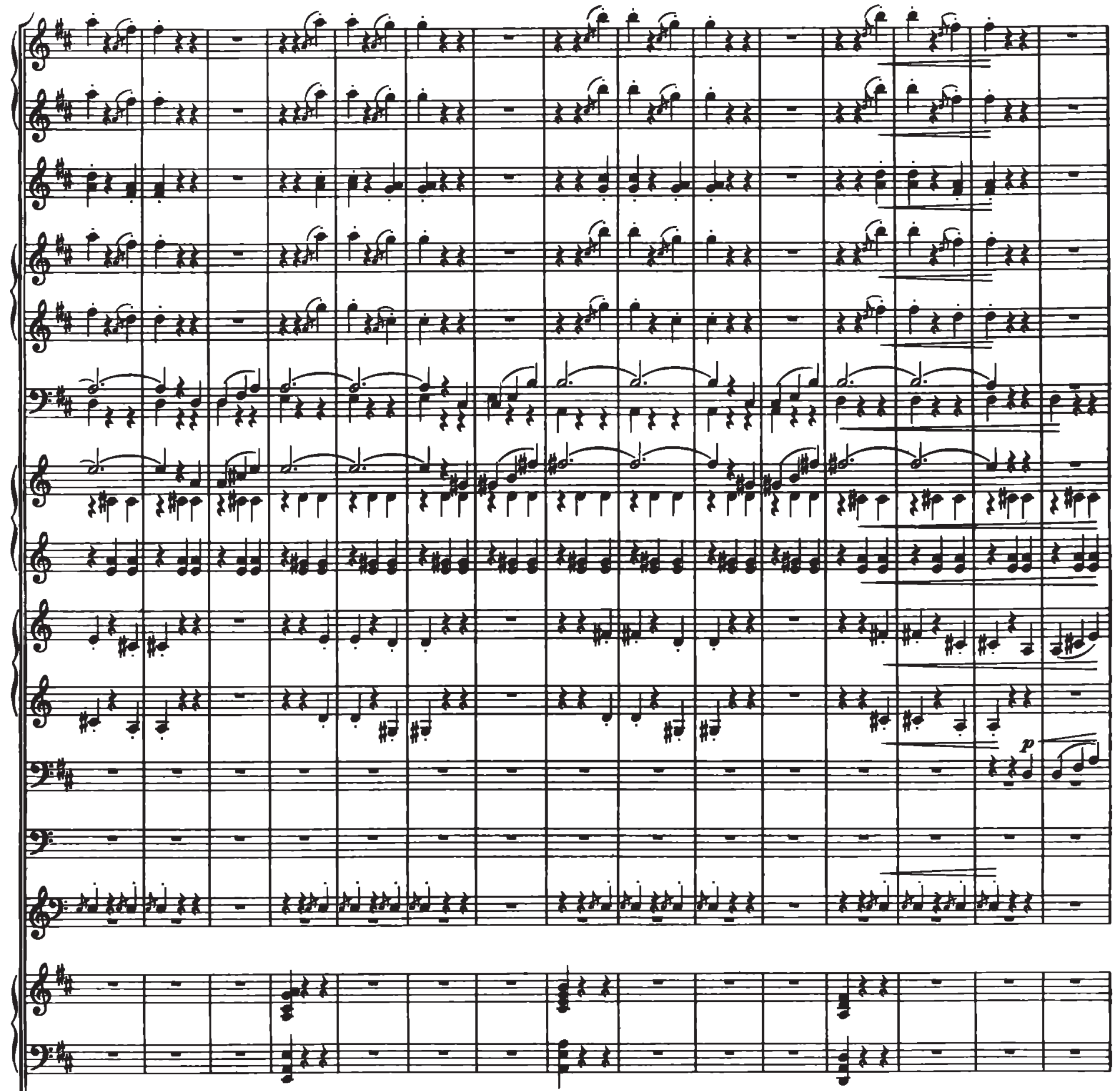

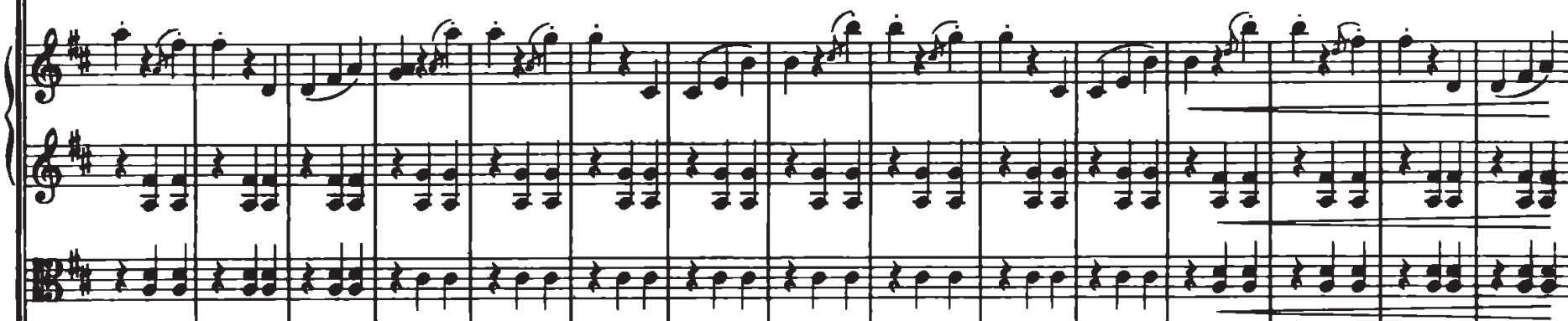
(2) 9 \%

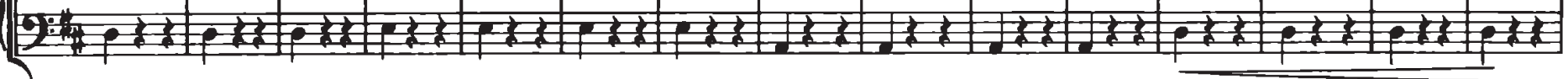




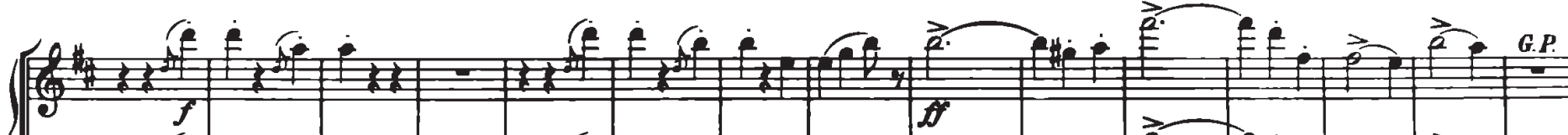

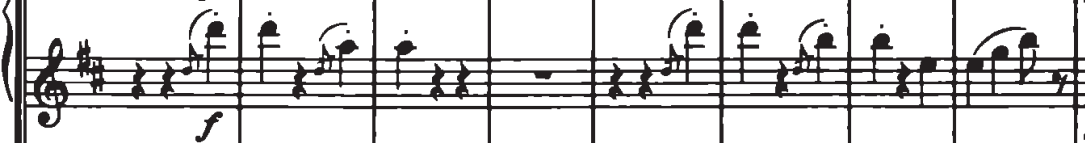

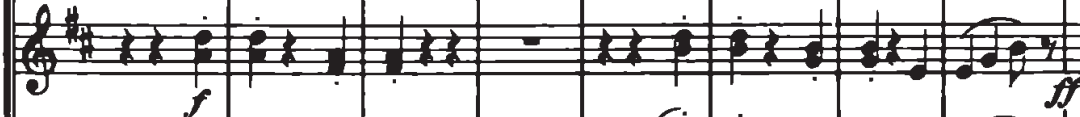

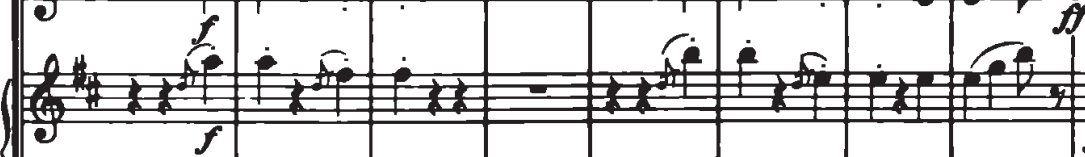
1
1

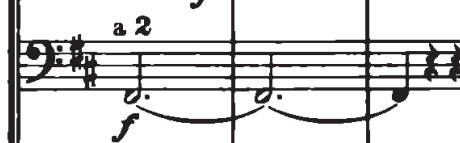

|

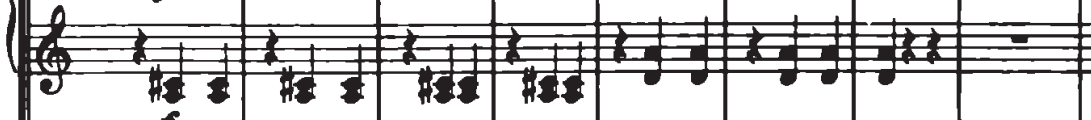
(b)

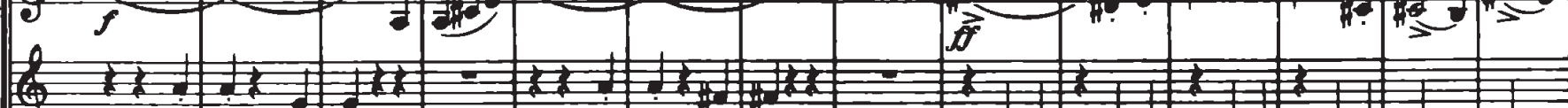
Pos.

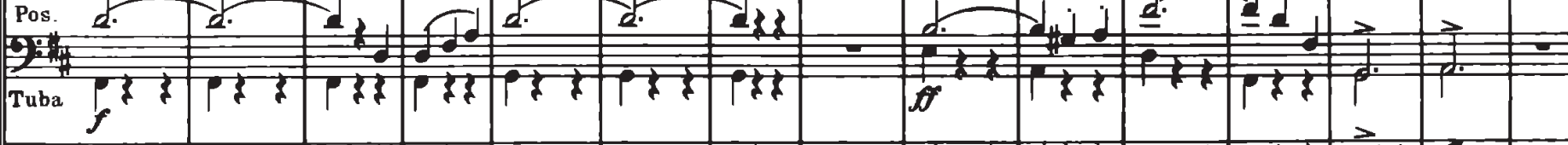

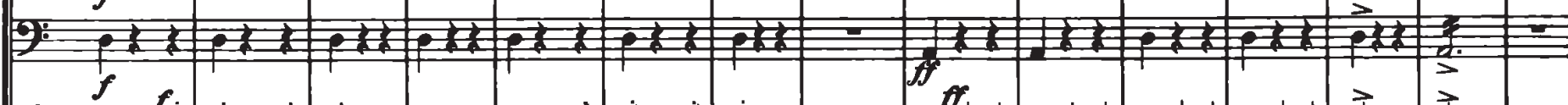

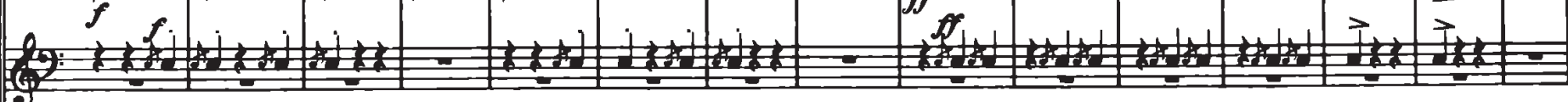

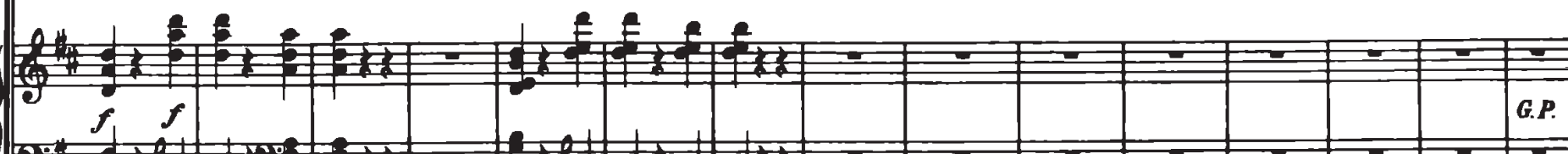
(2)

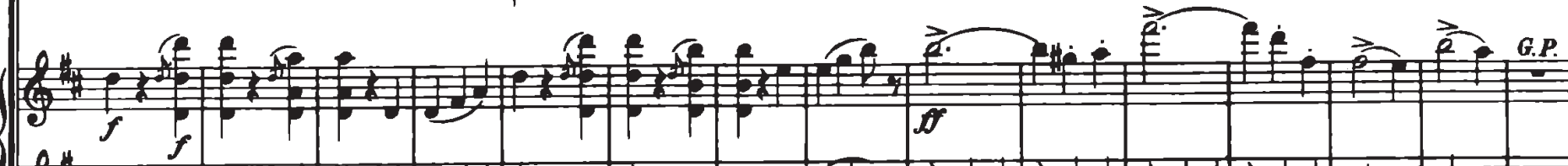

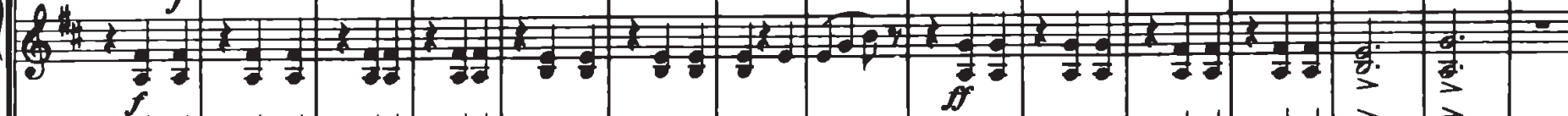

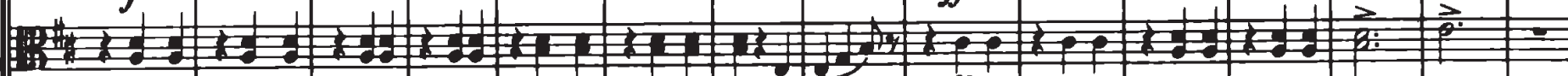

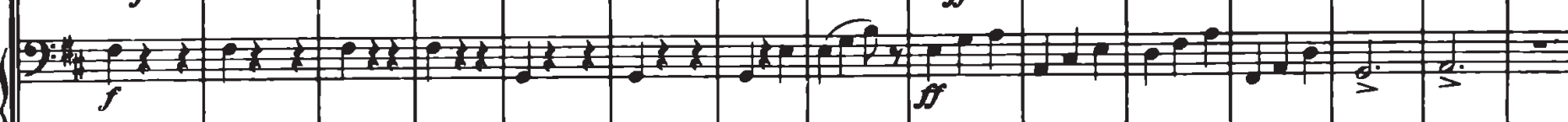

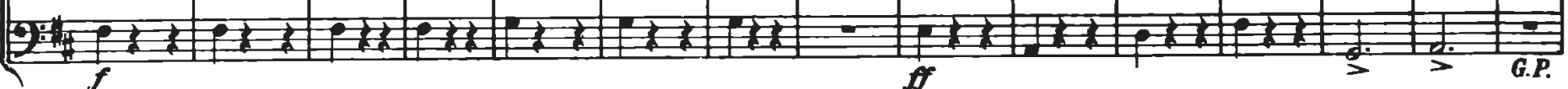



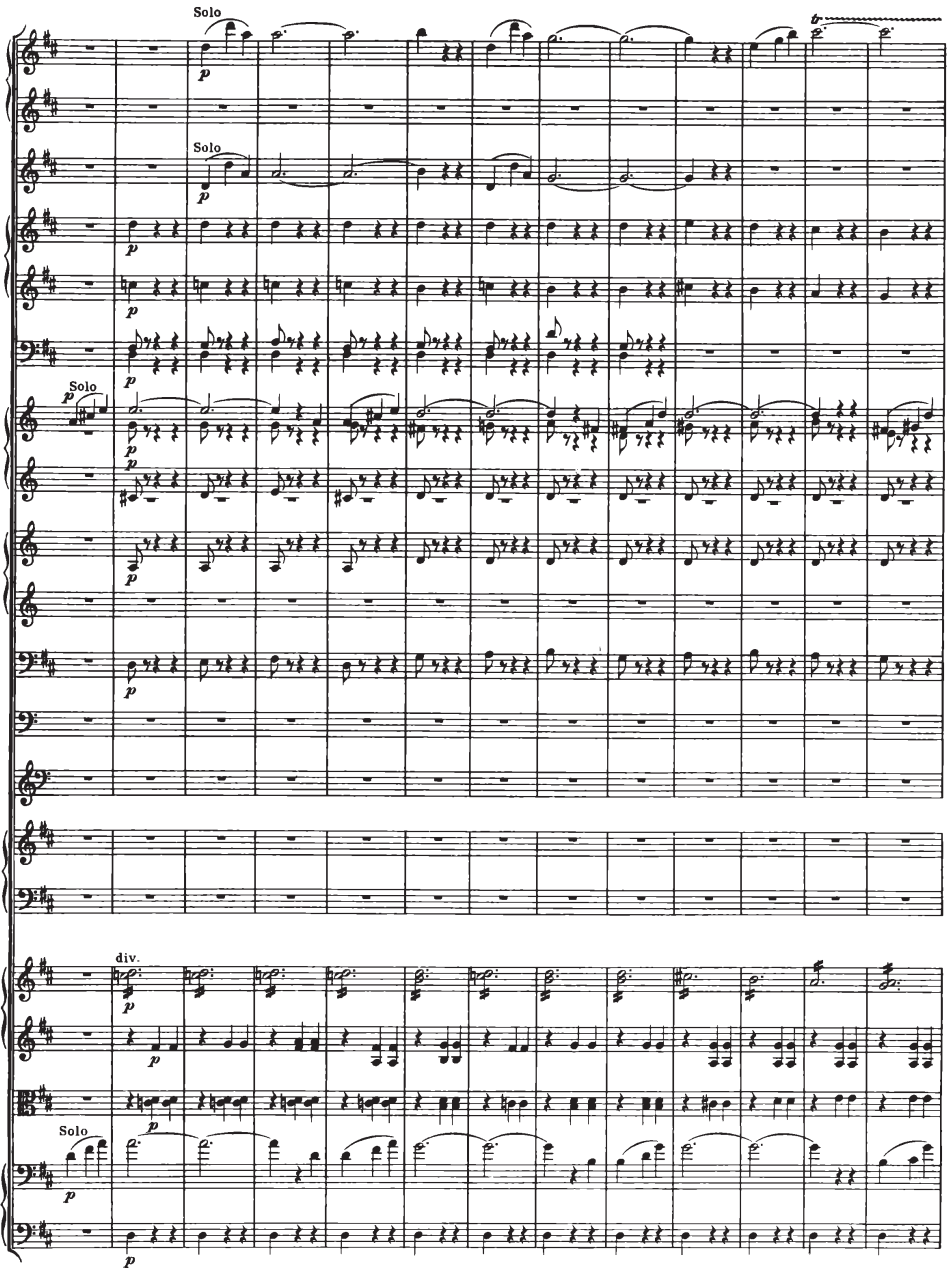

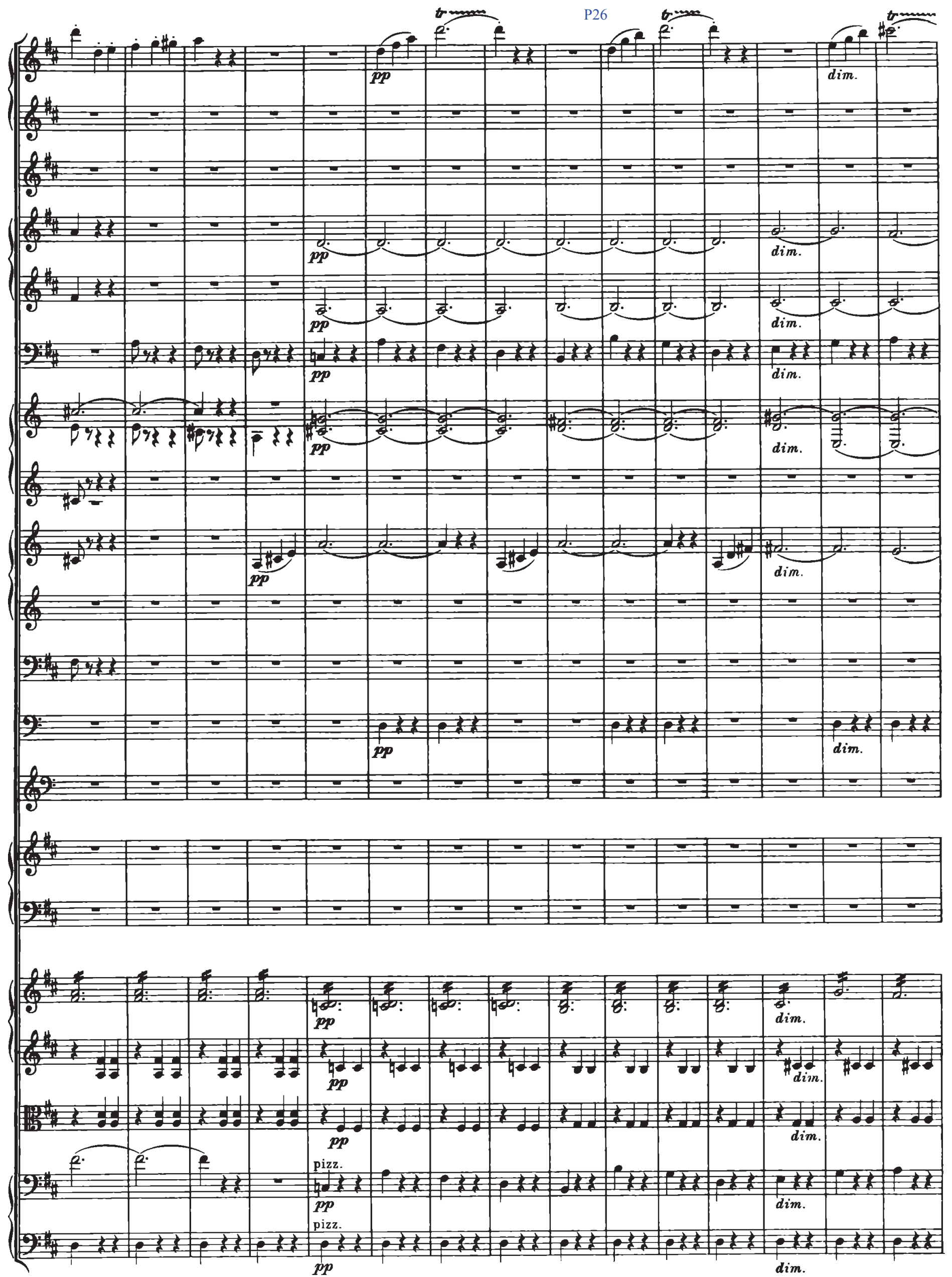


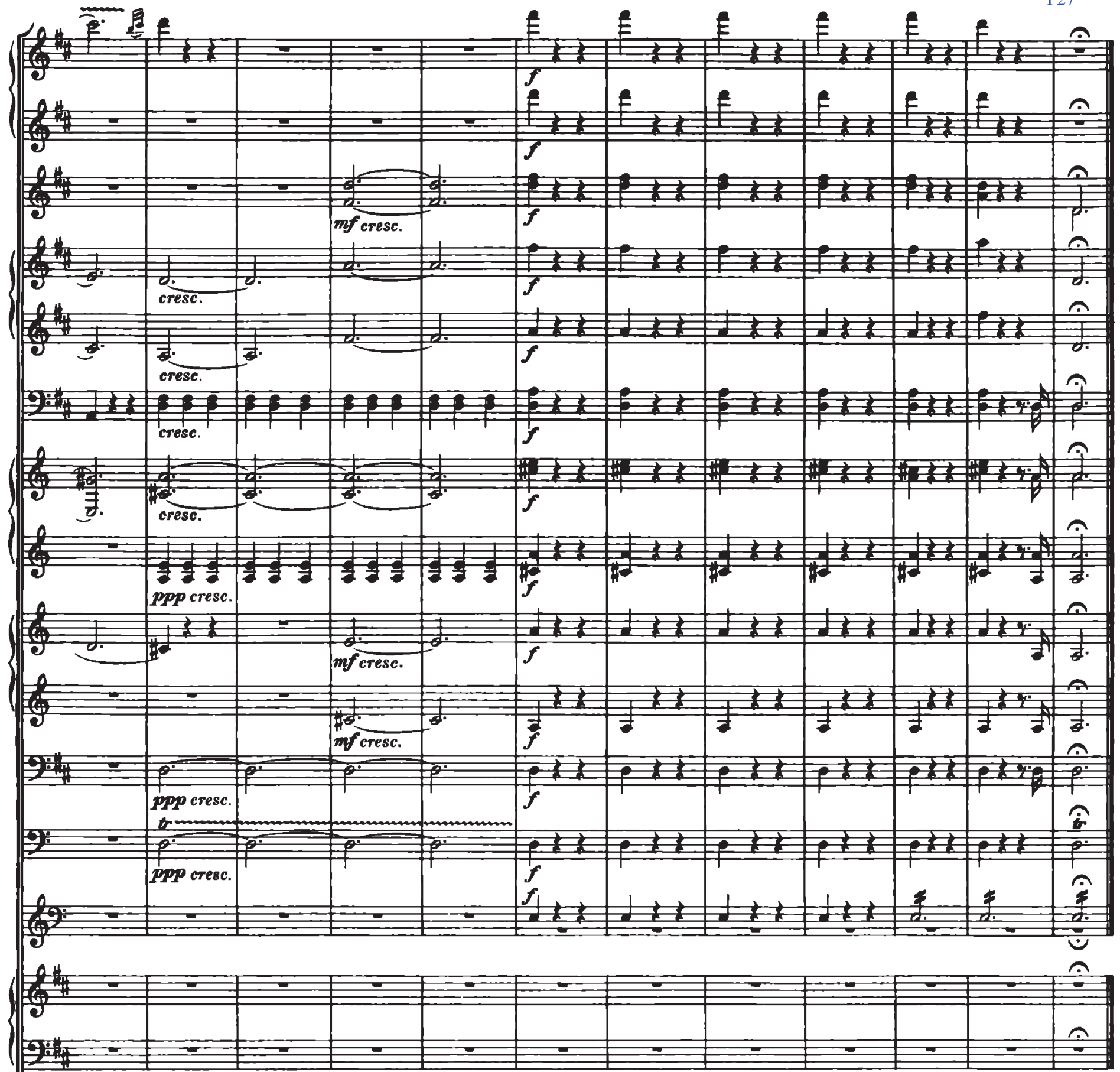

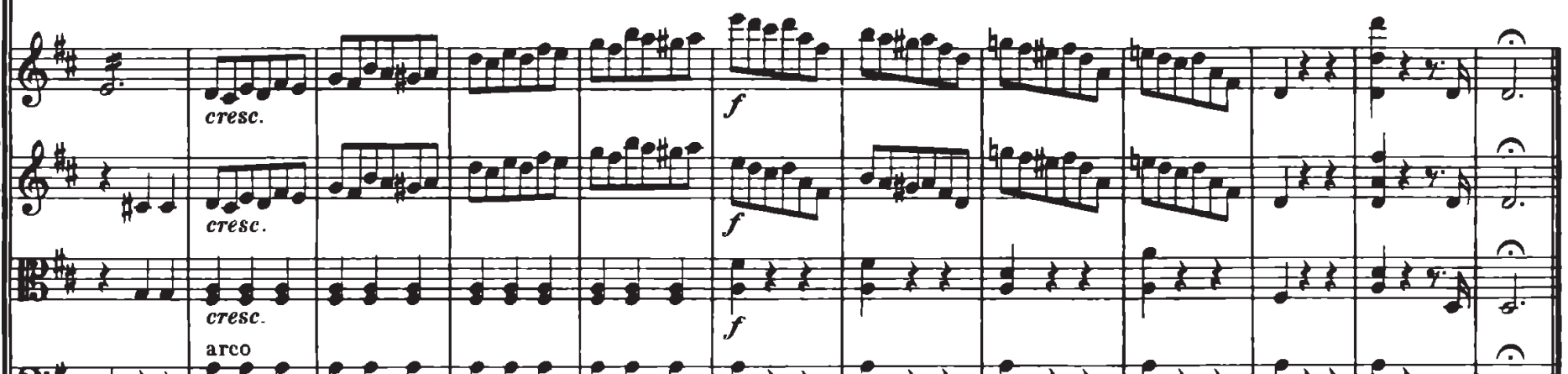

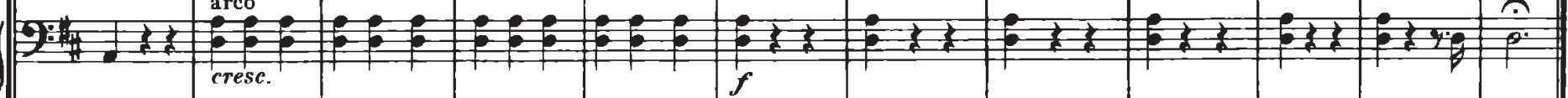

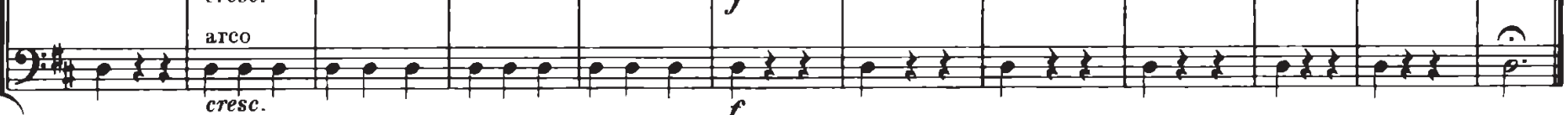


2

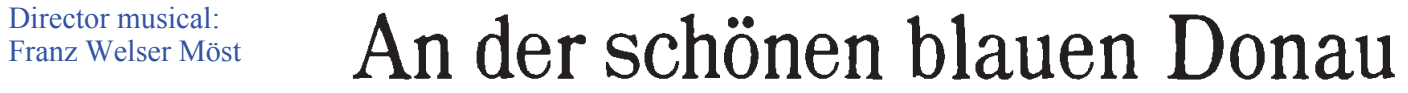

Director audiovisual:

Brian Large

P2 Zoom out Trompa a PG

Walzer

P1 Introduktion

Johann StrauB, op. 314

Andantino

Flöte I

Flöte II

Kleine Flöte

Oboen

Klarinetten in C

II

Fagotte

Hörner in F

I II

Trompeten in $\mathrm{F}$

Baß-Posaune

Tuba

III IV

Pauken

Kleine Trommel

Triangel u.

große Trommel

Harfe

II)
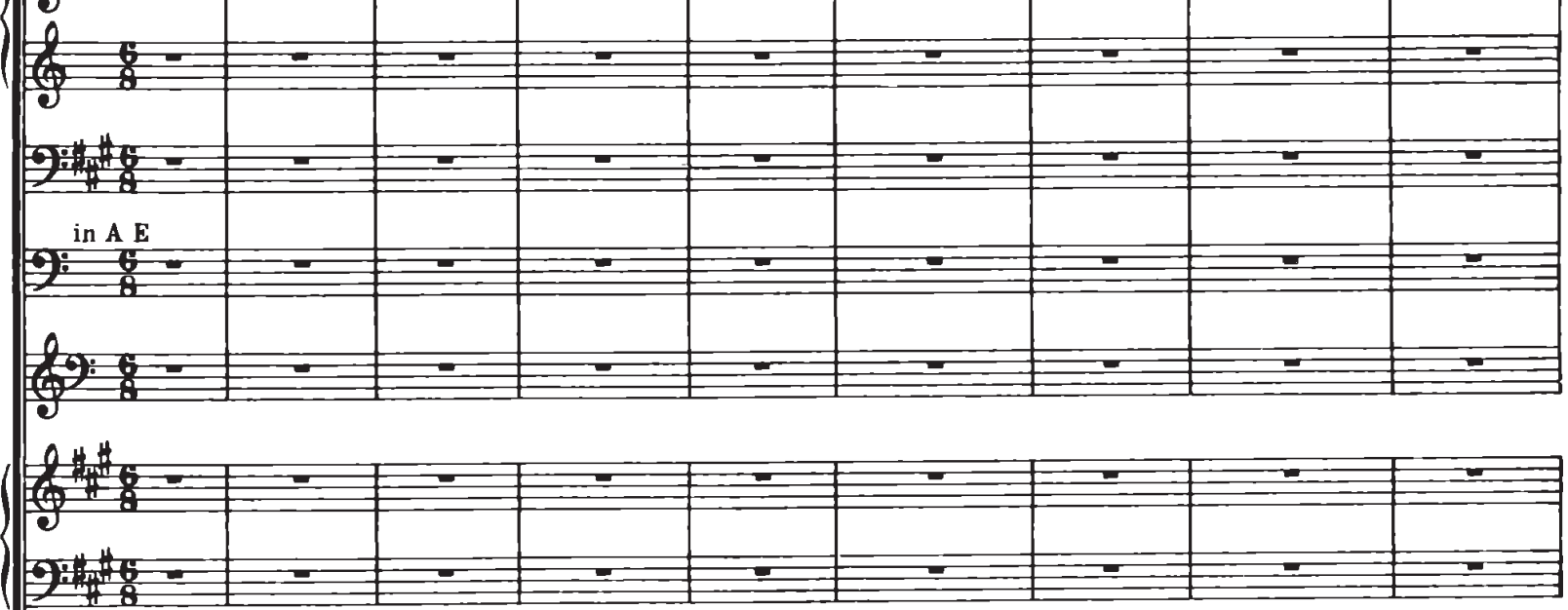

Andantino

Violine I

Violine II

Viola

Violoncello

Kontraba $\beta$
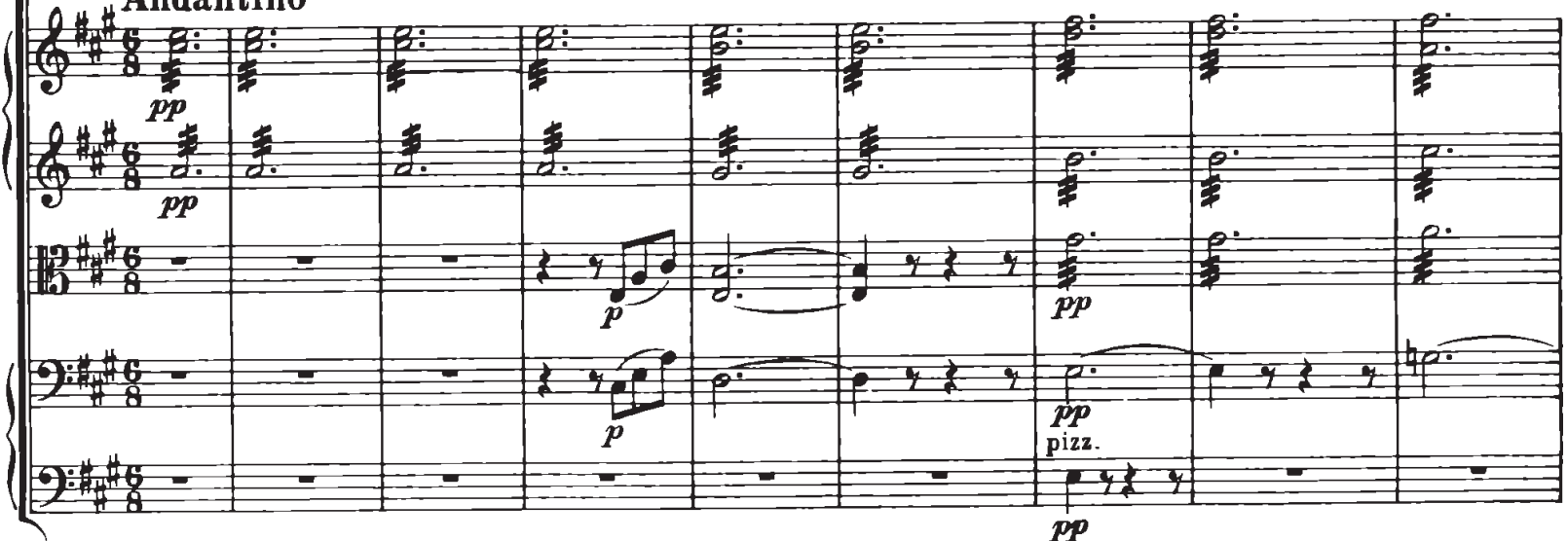
(4) (3) + 201.

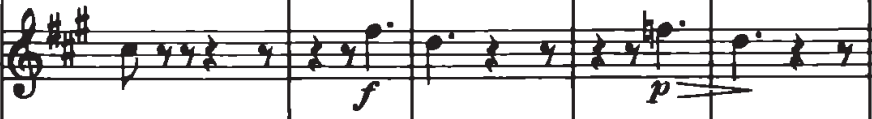

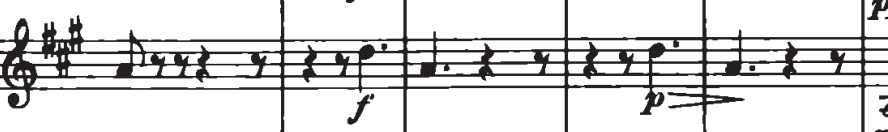

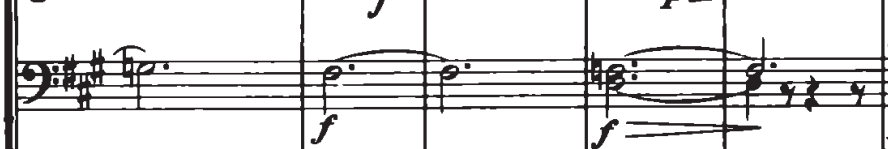
(2)

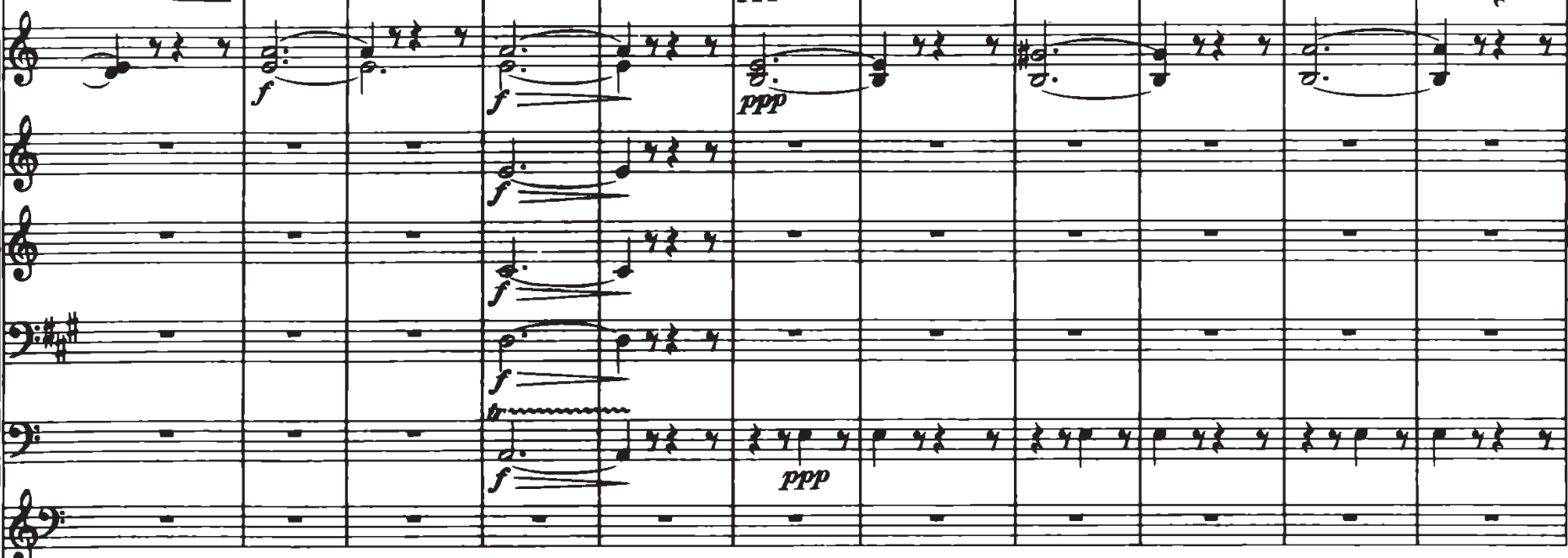
\begin{tabular}{|l|l|l|l|l|l|l|l|l|l|l|}
\hline & 0 \\
\hline
\end{tabular}

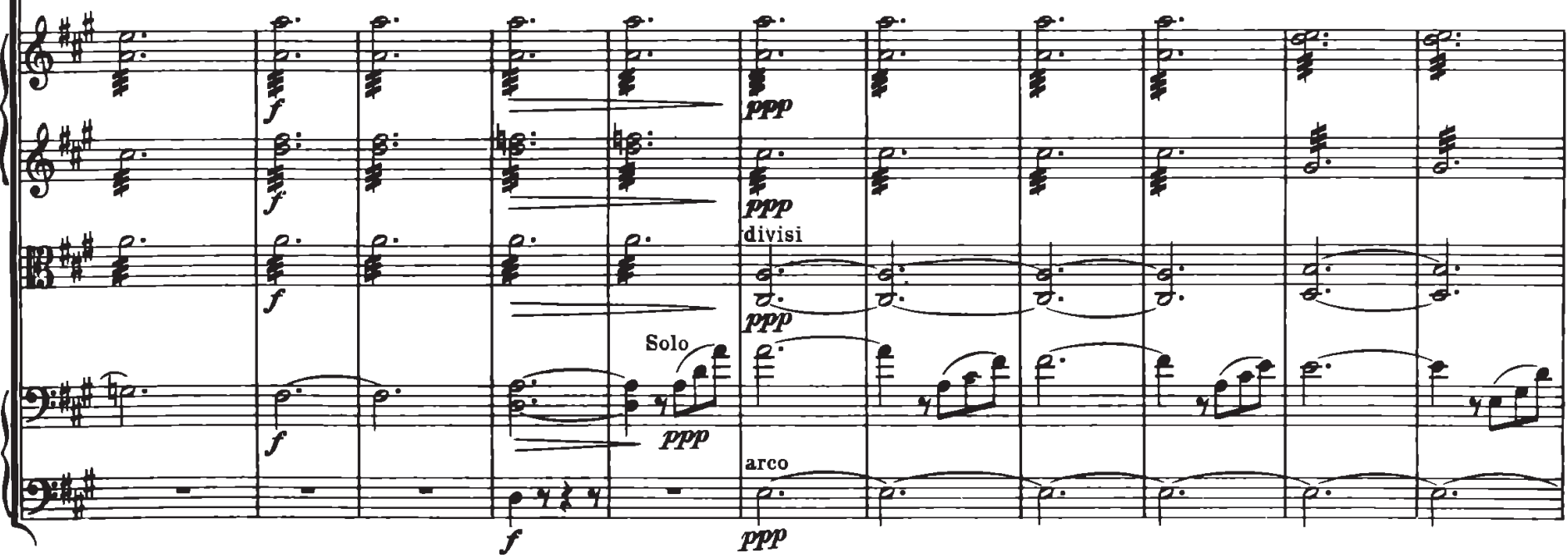



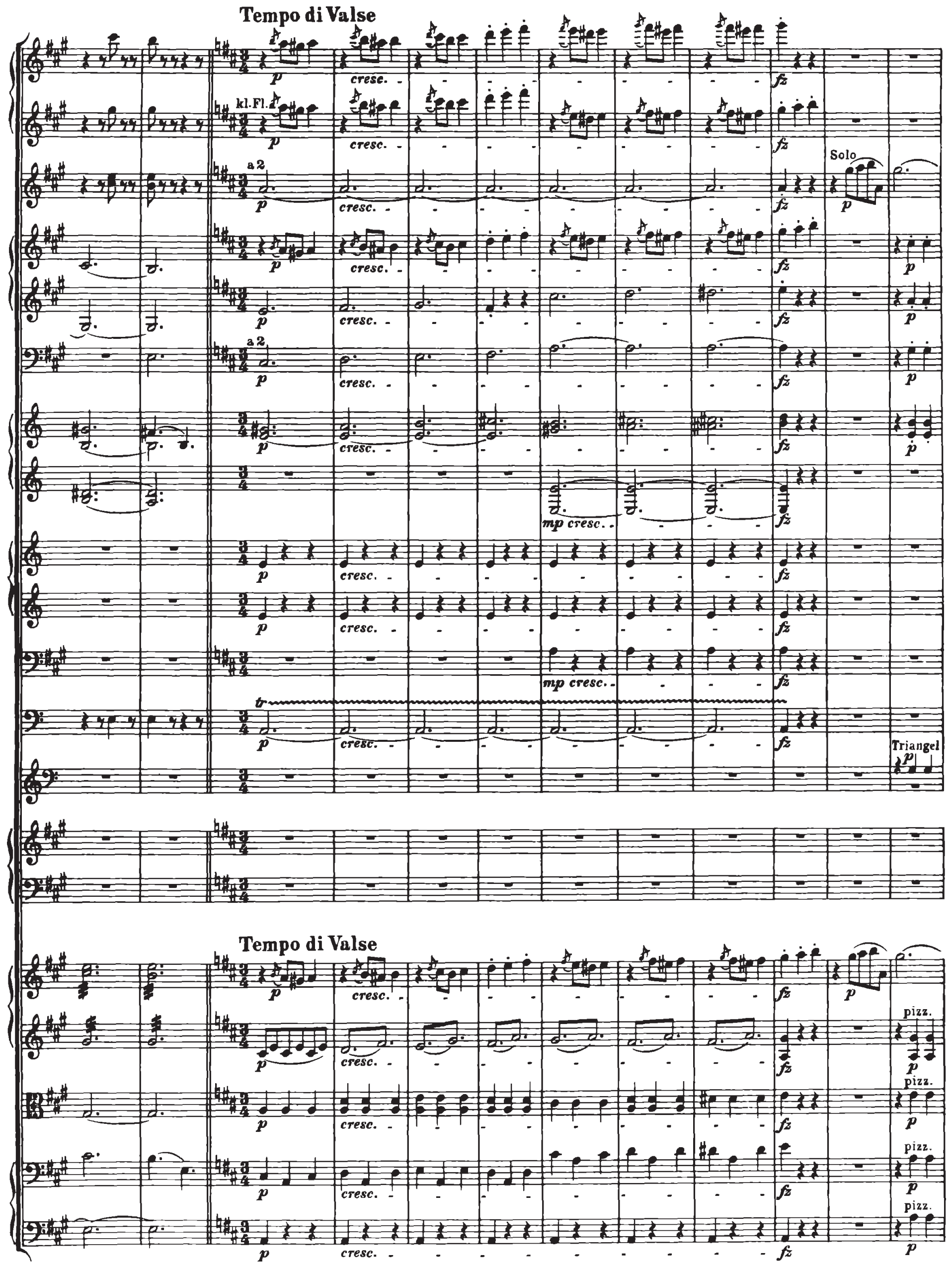


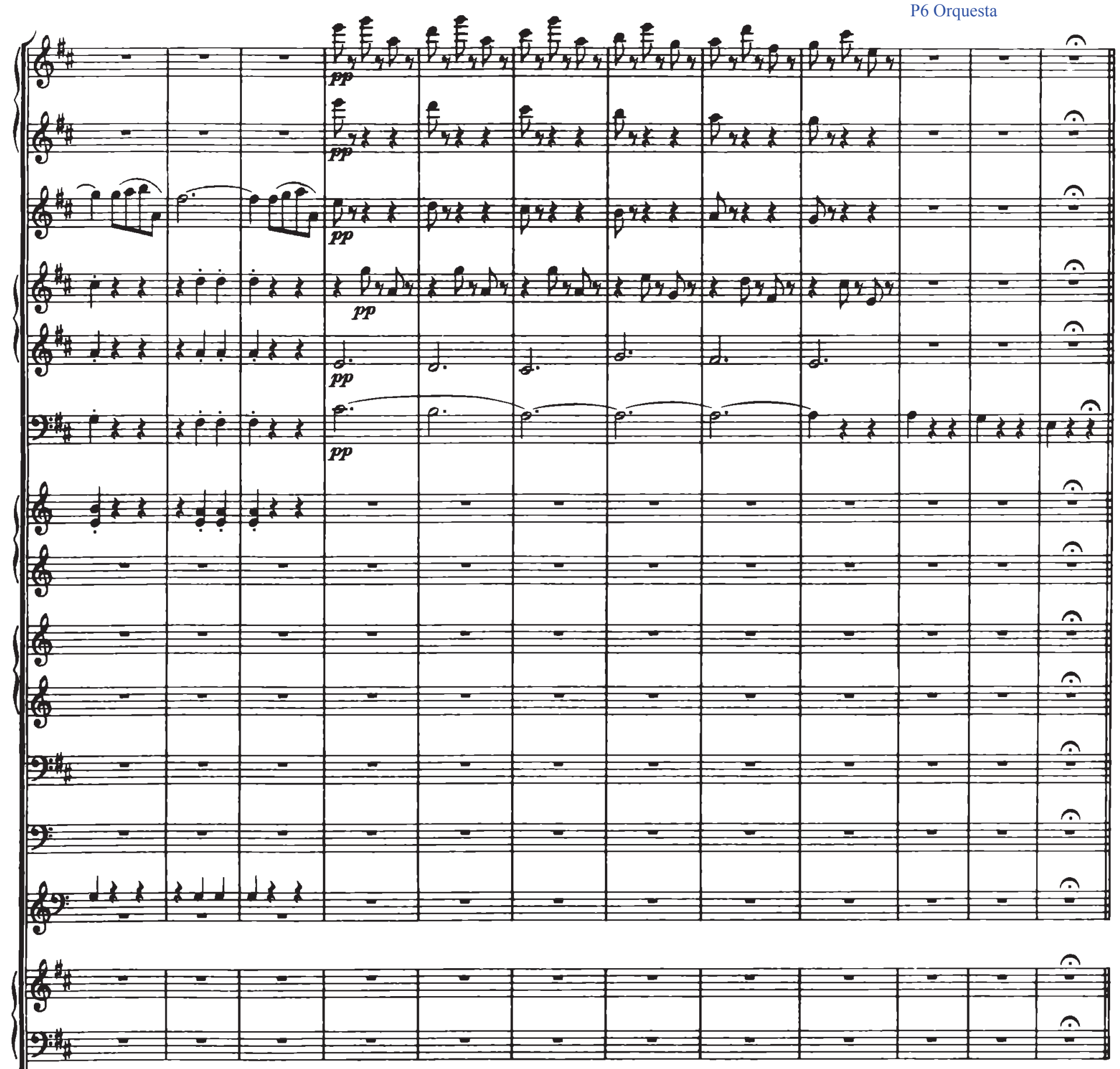

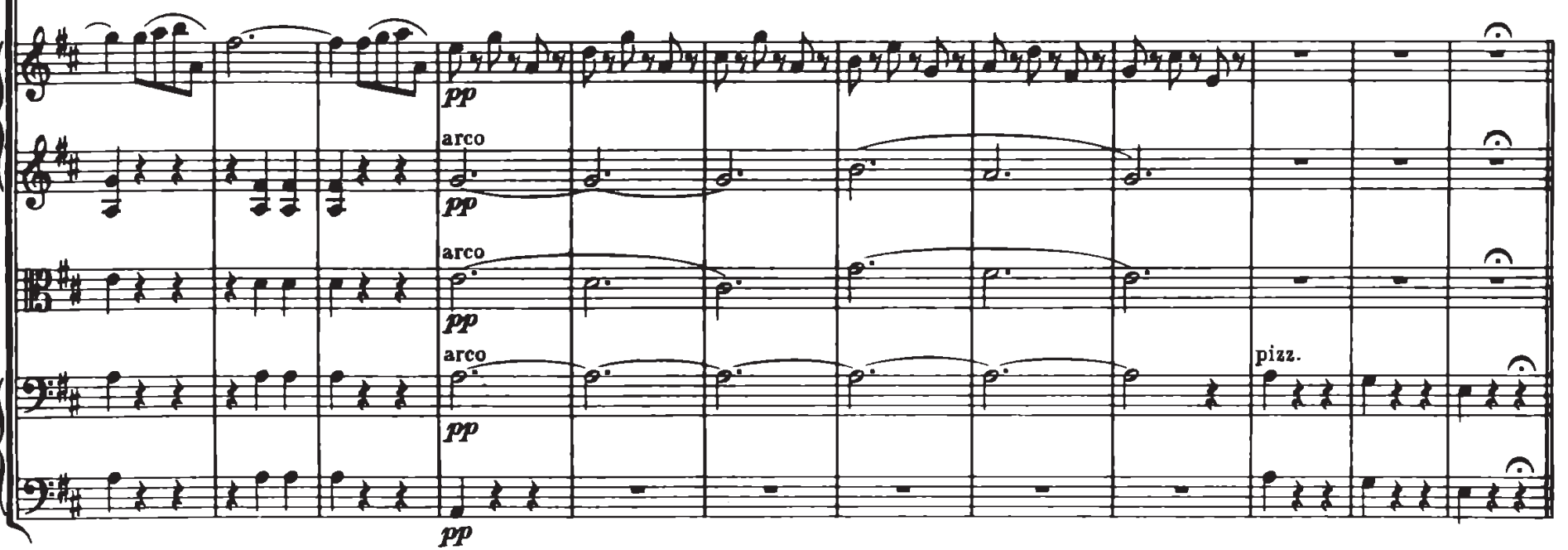


Nr.1 Walzer

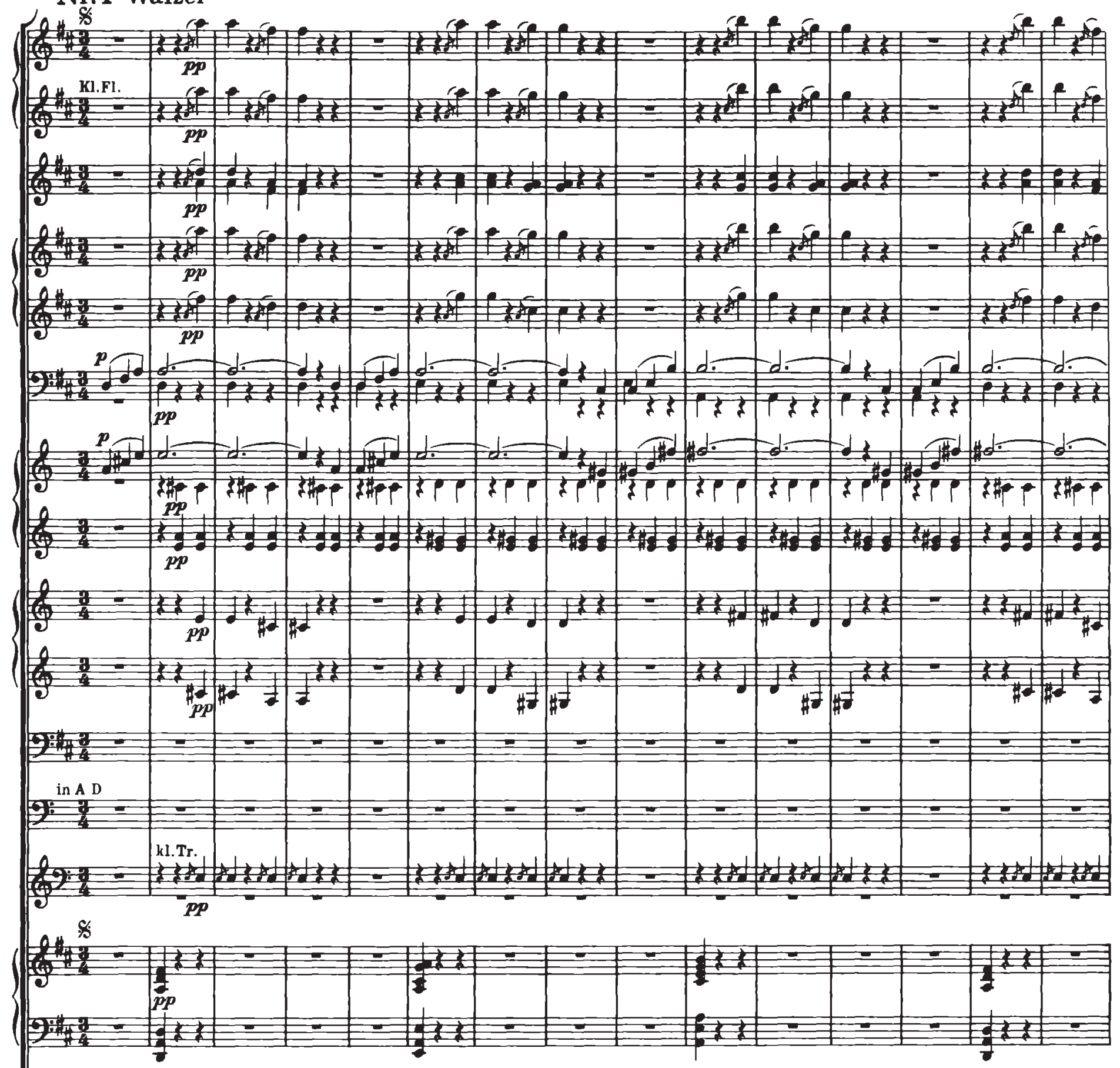

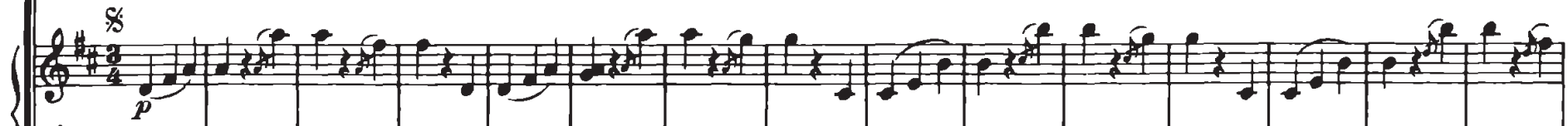

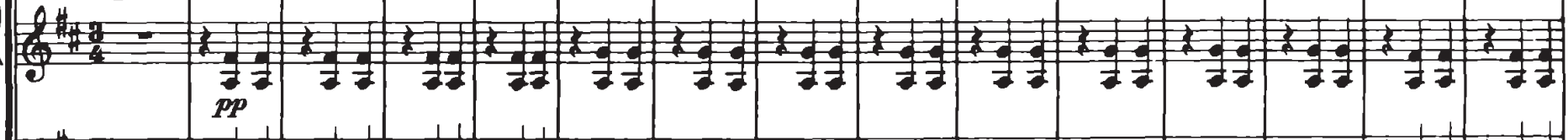

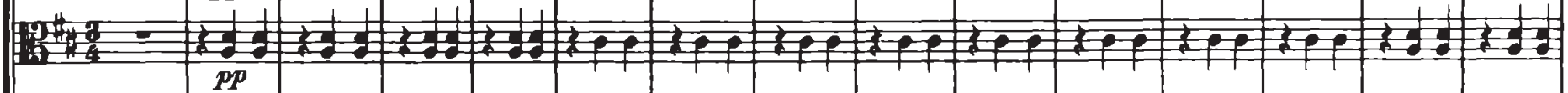

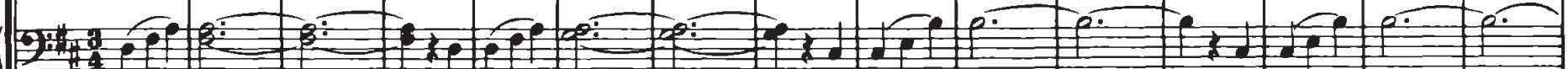

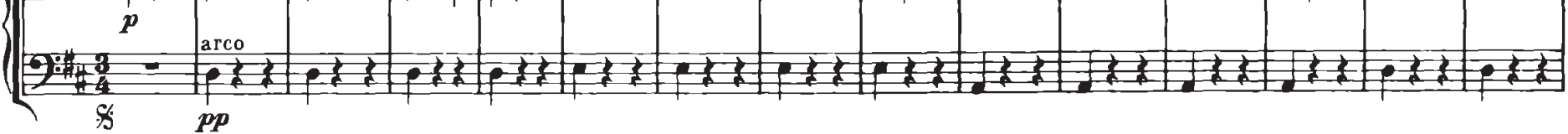




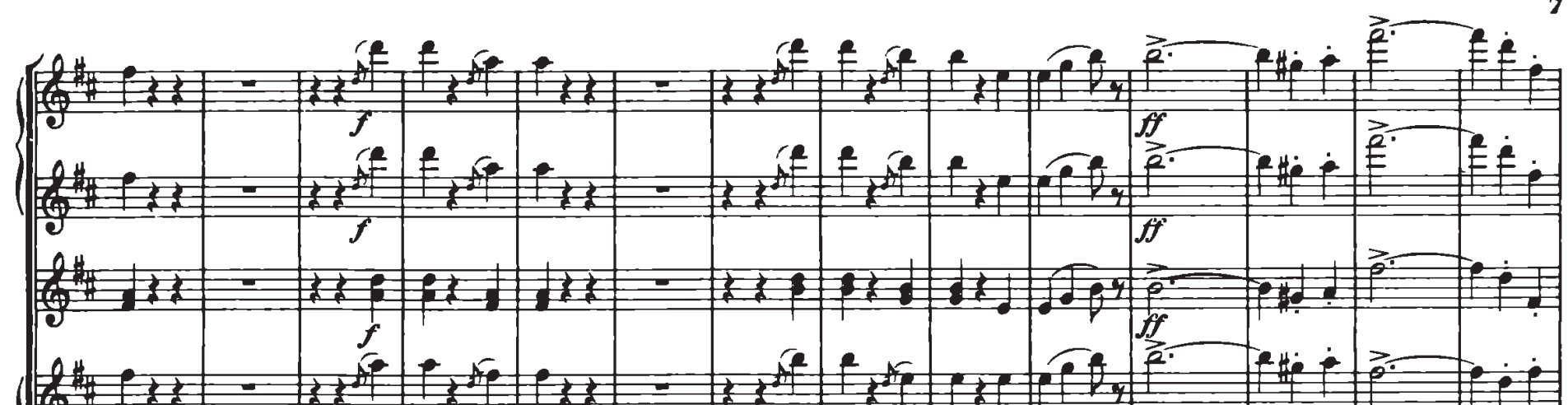
2.

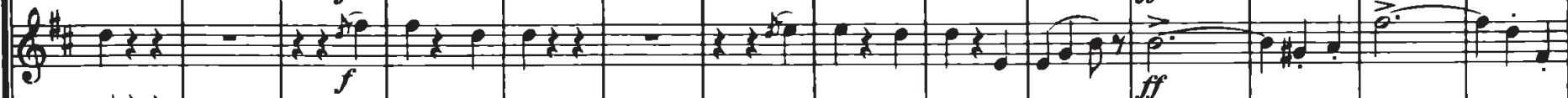

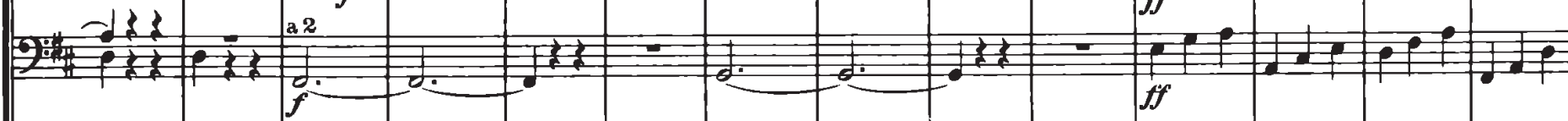

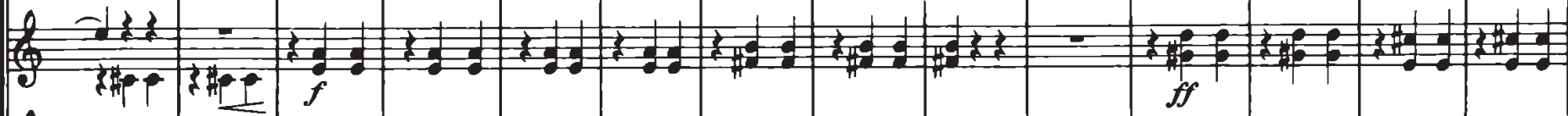

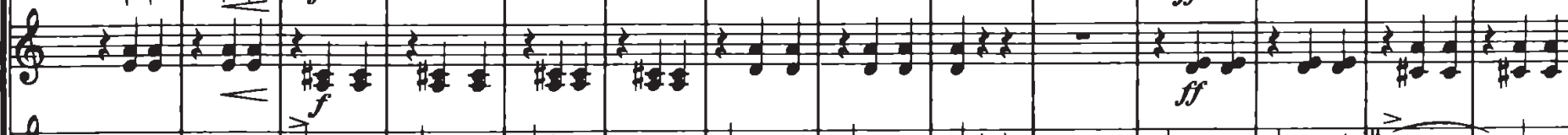
(2) Q

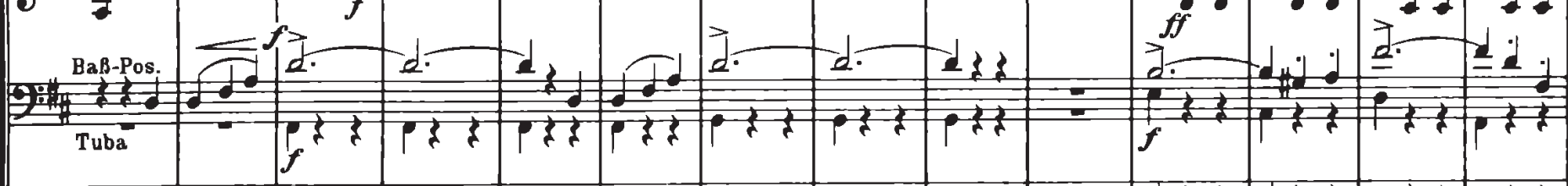

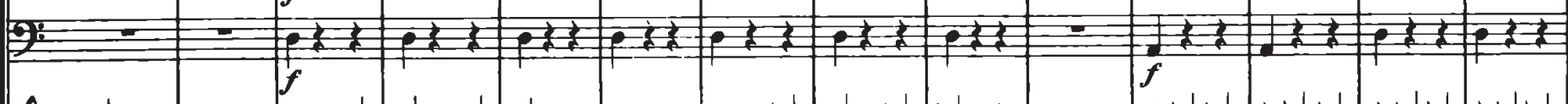

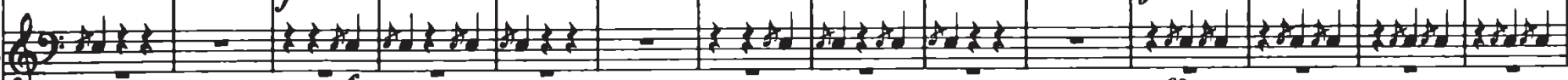

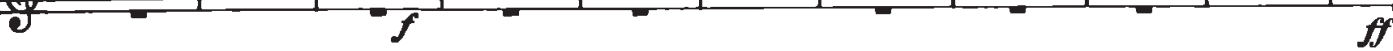

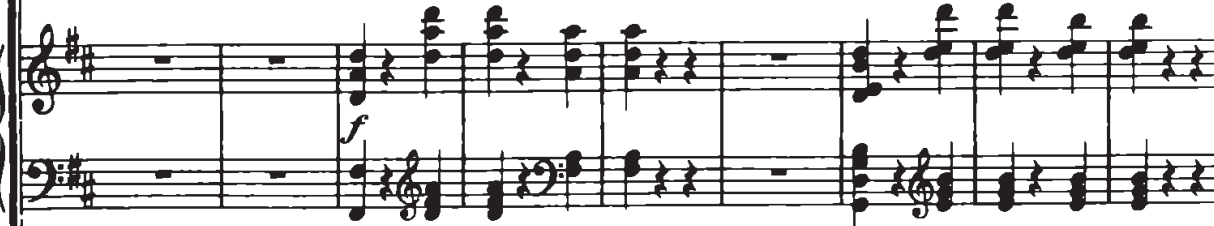

(10 (2)

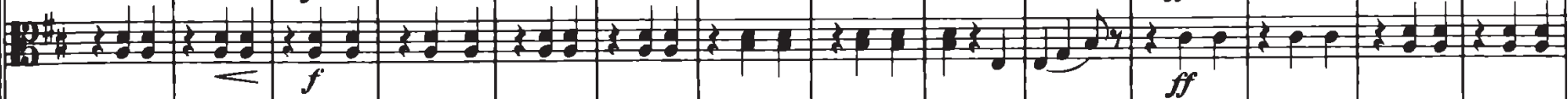

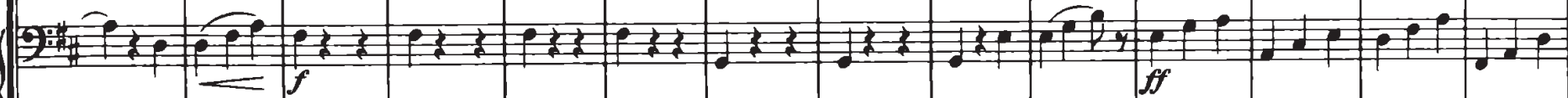

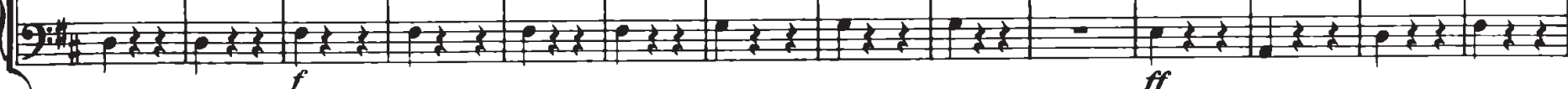



2.1.

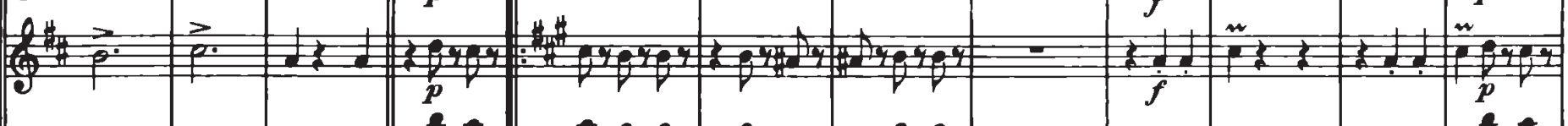

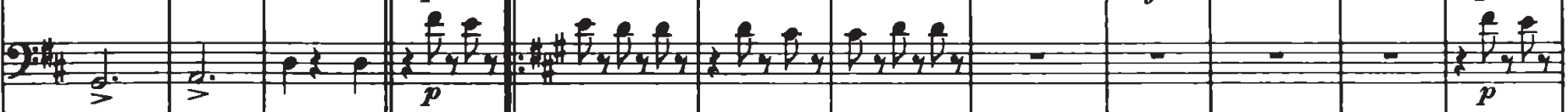

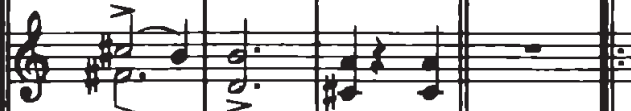

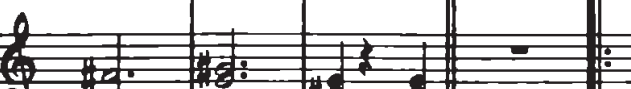
(3)

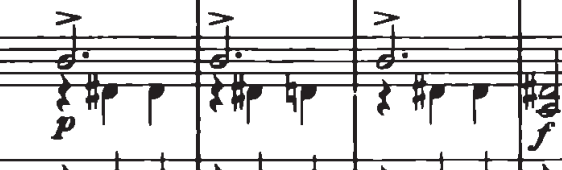
2

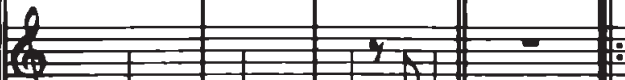

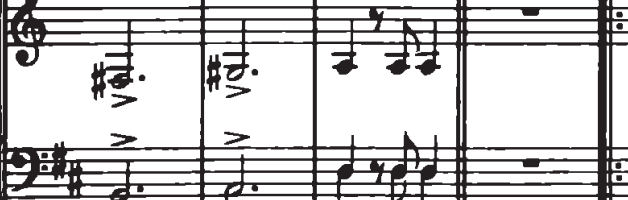

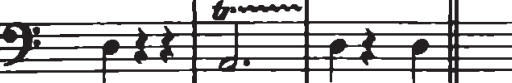

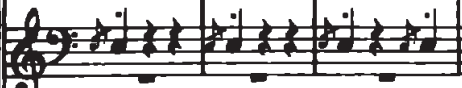

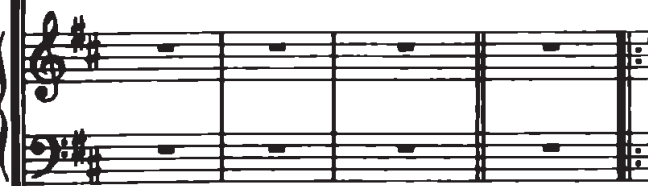

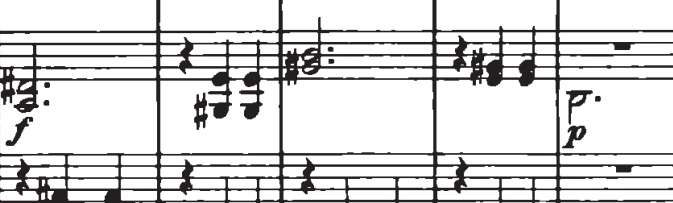

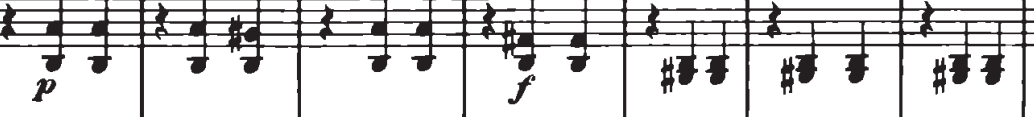

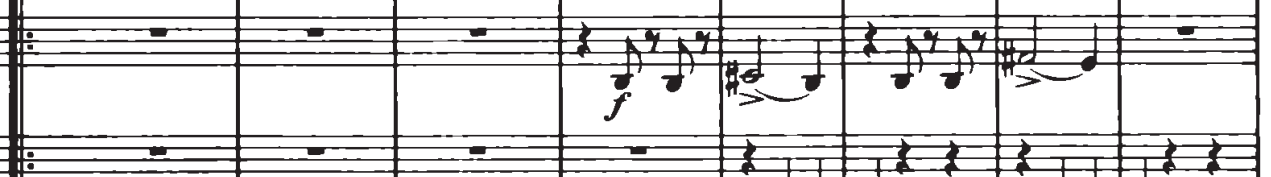

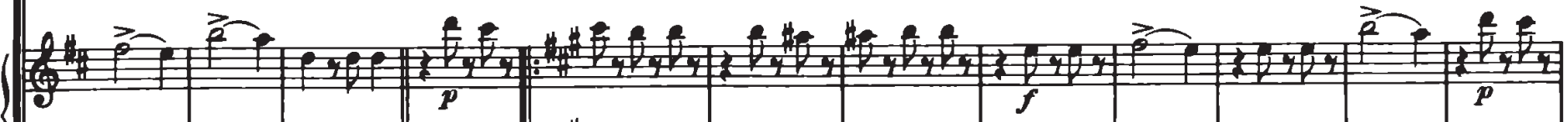

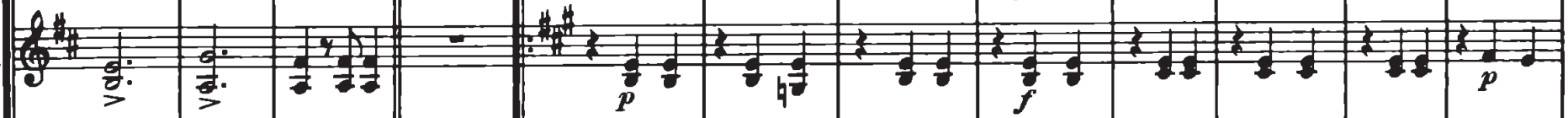

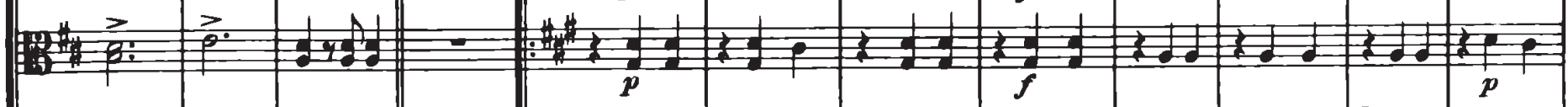

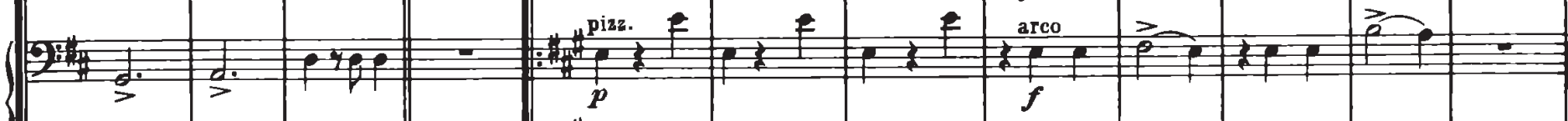
Q20 


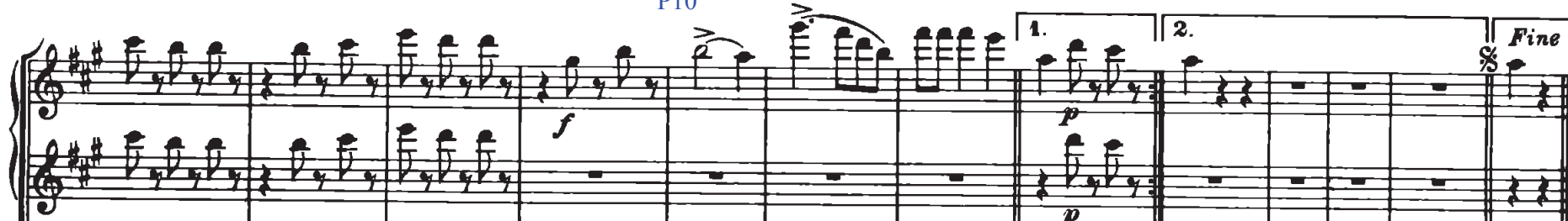

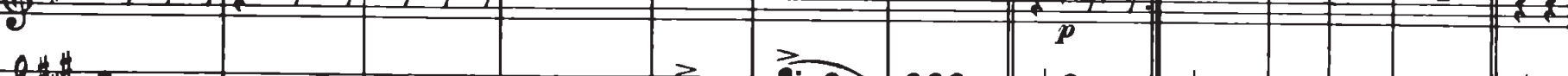

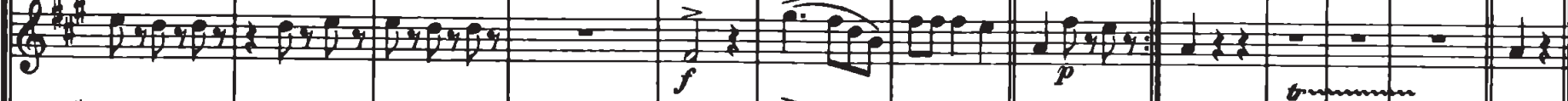

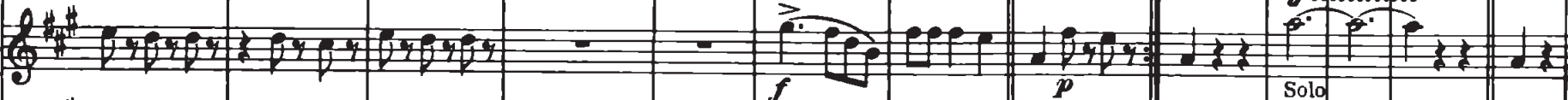
2.

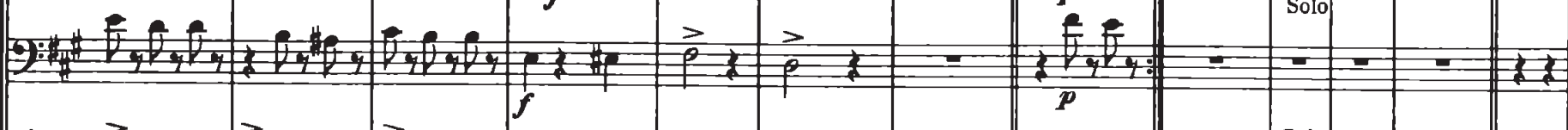

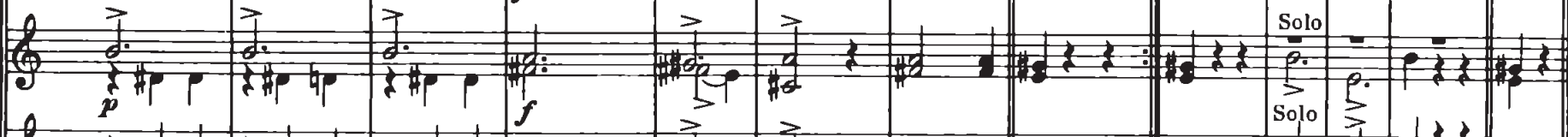

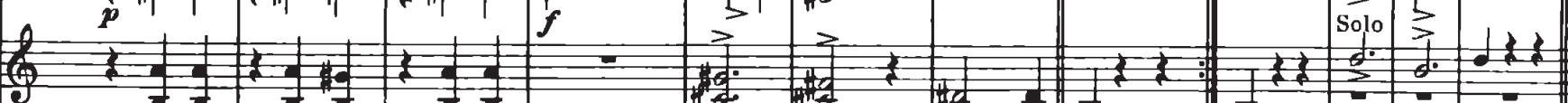

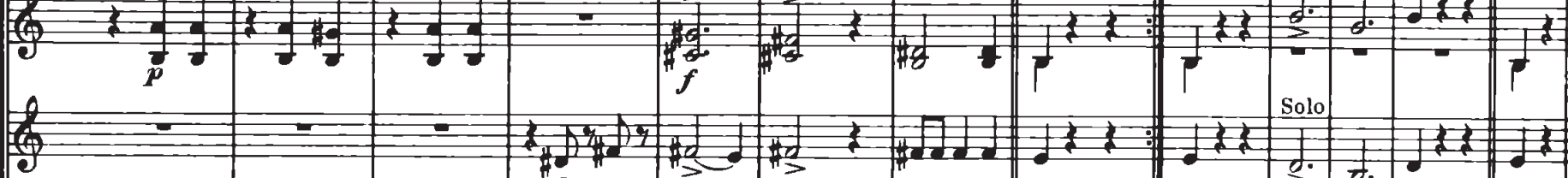
$\left\{\left(-\frac{9}{2}\right.\right.$

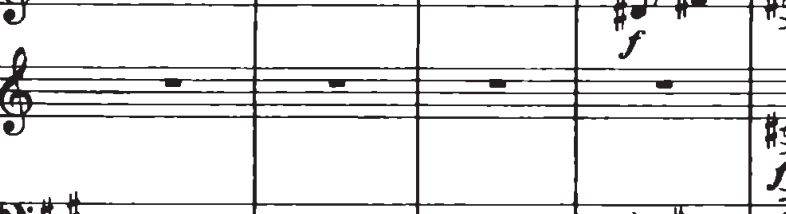

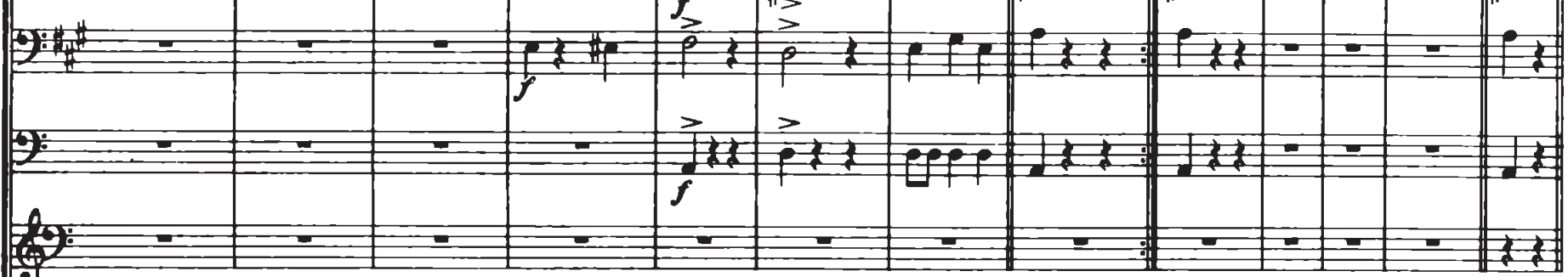

\begin{tabular}{|c|c|c|c|c|c|c|c|c|c|c|c|c|}
\hline & & & & & & & 1. & \multicolumn{4}{|l|}{2.} & \multirow{2}{*}{$\begin{array}{l}\text { Sine } \\
\text { Pat }\end{array}$} \\
\hline$=$ & $=$ & $=$ & $=$ & $=$ & $\bar{E}$ & $E$ & - & $=$ & $=$ & $=$ & $=$ & \\
\hline 9: & $=$ & - & $=$ & $=$ & $=$ & 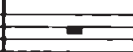 & 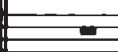 & 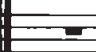 & $=$ & $=$ & E् & 7 \\
\hline
\end{tabular}

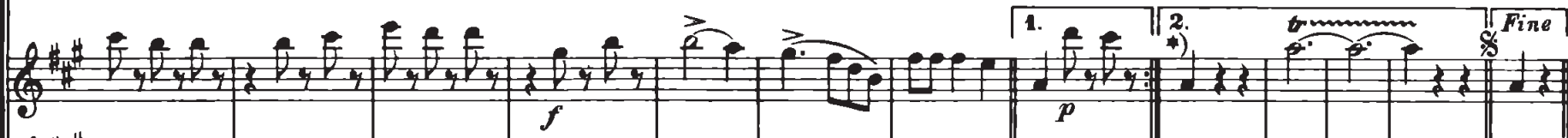

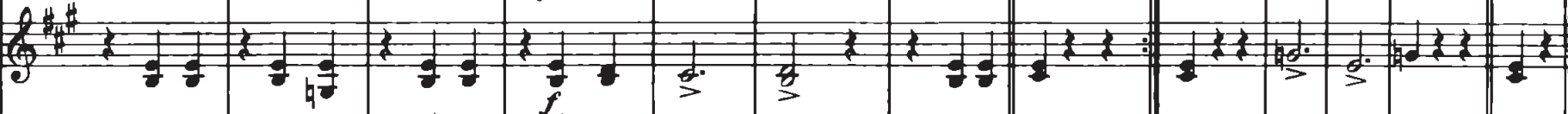

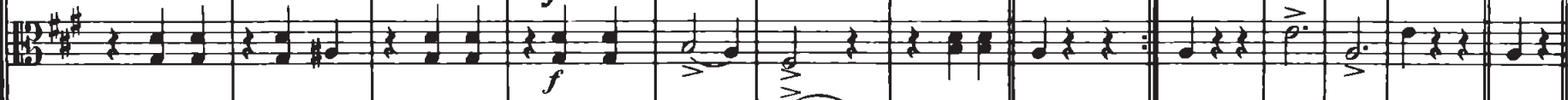

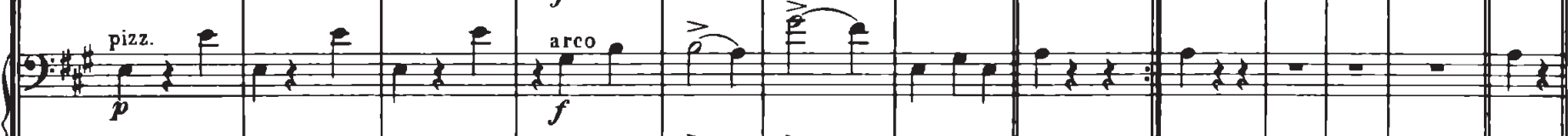

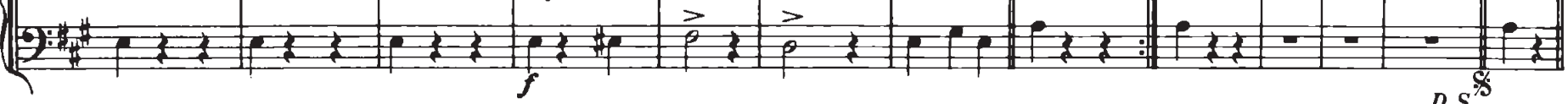
*) Bei Mitwirkung des Chors fallen 2da und Dal Segno weg 
10

P12 Ballet

Nr. 2

$\left(\begin{array}{lll}0 & \$\end{array}\right.$

定.

F+? Q $3=1$

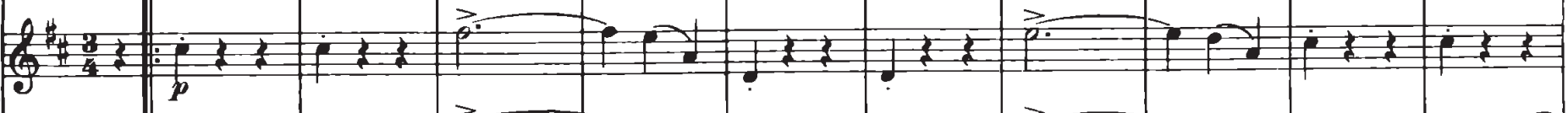

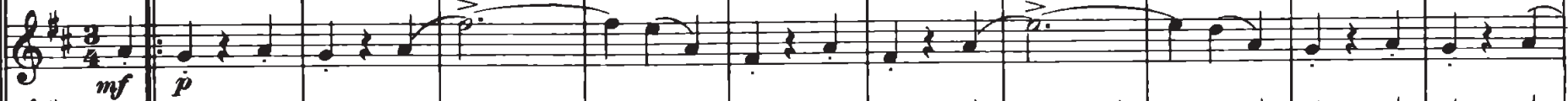

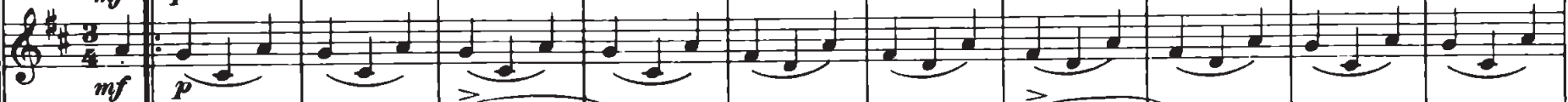
2 If

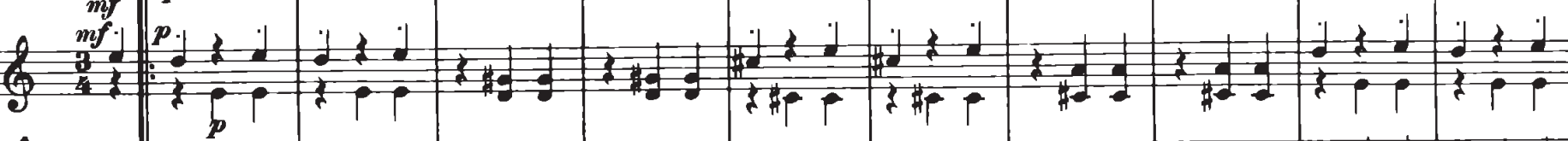

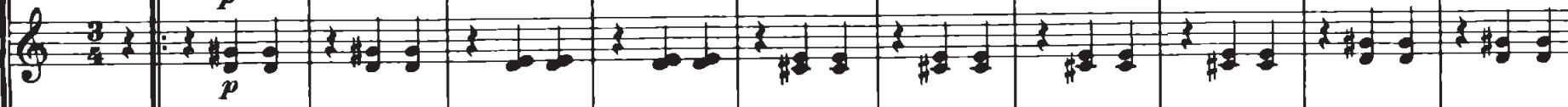
(b

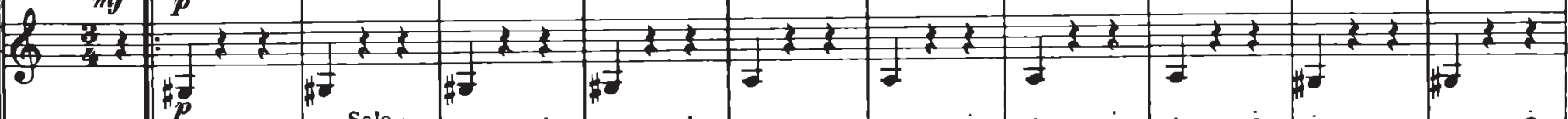

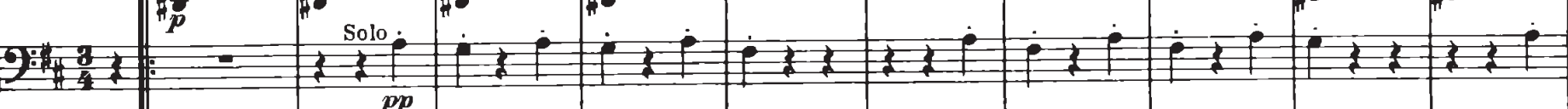
$2 \%$ a 13.1.

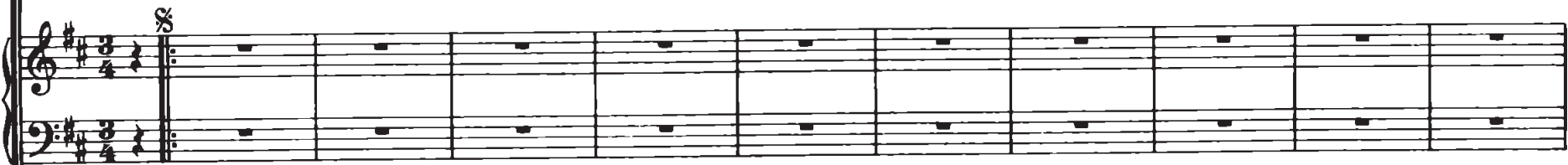
3) 64

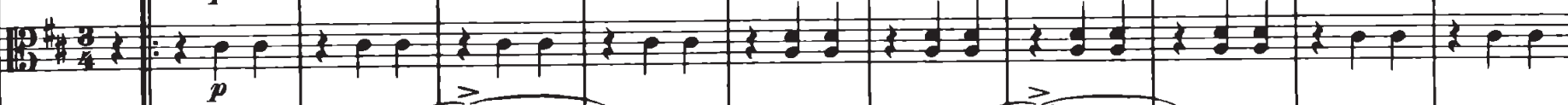

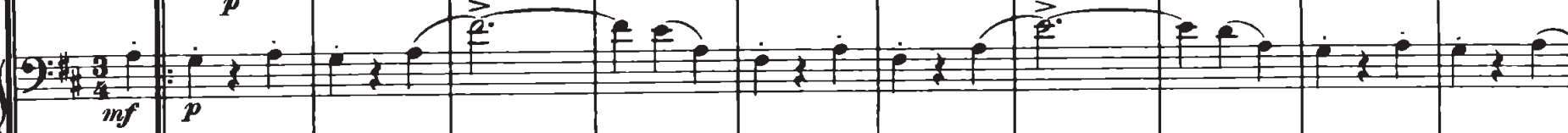
(24: 


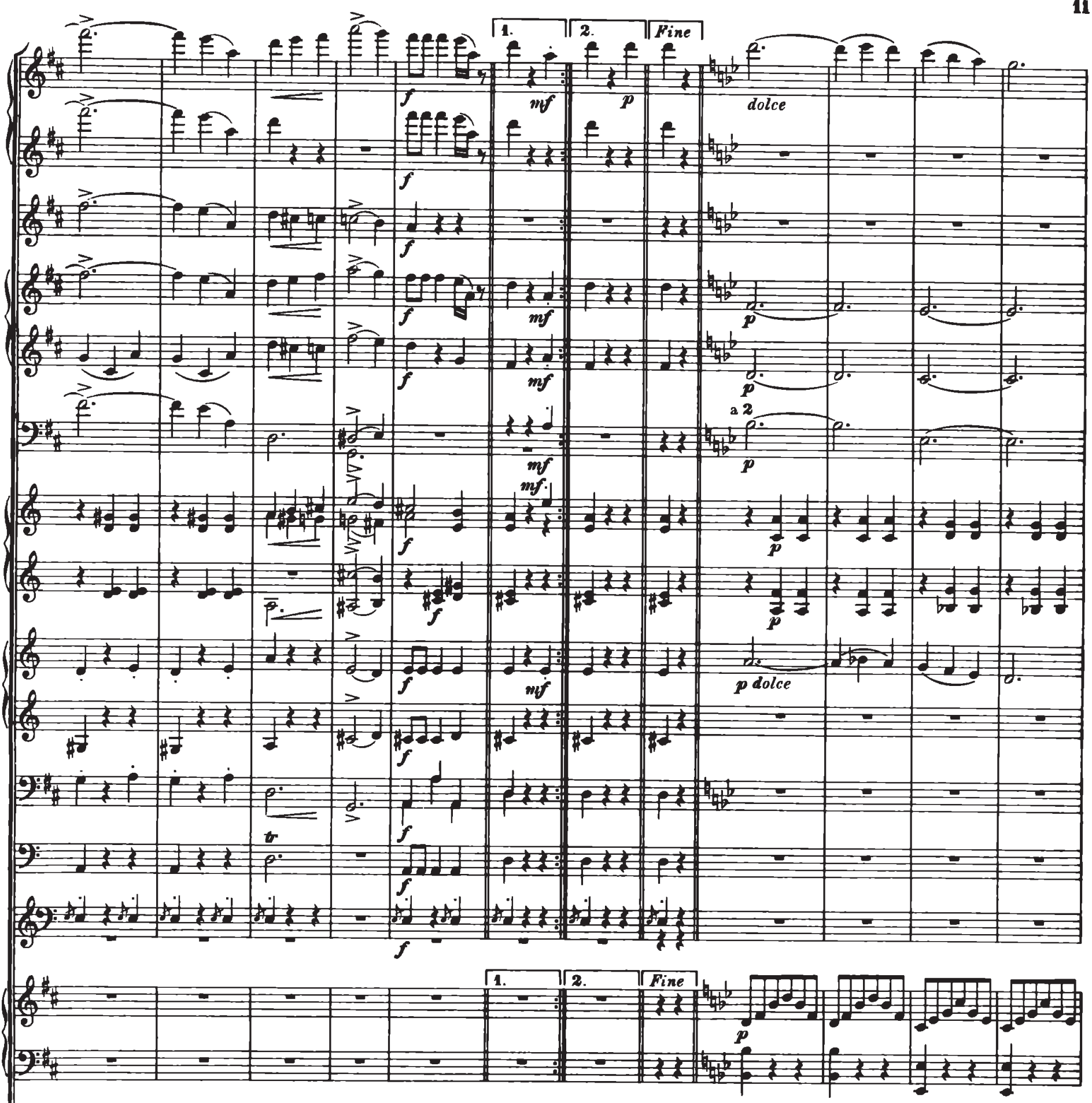

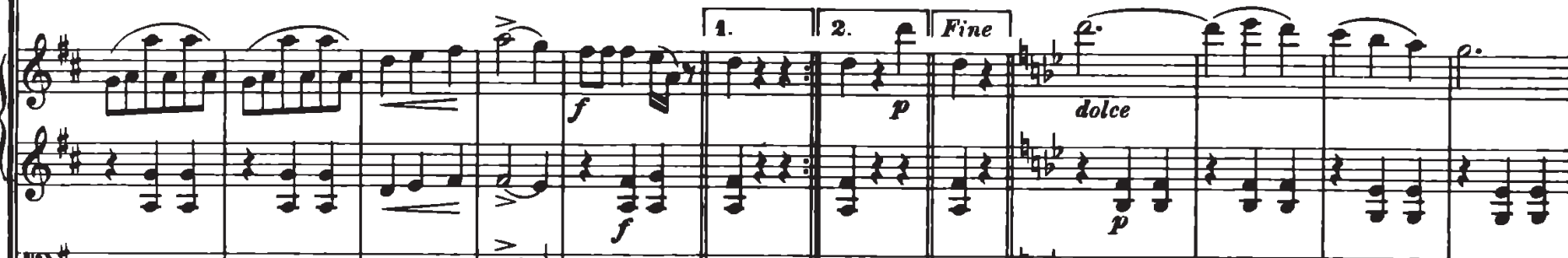

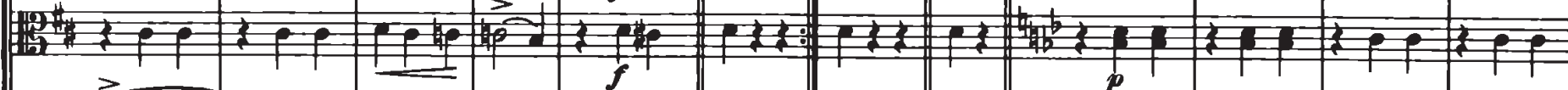

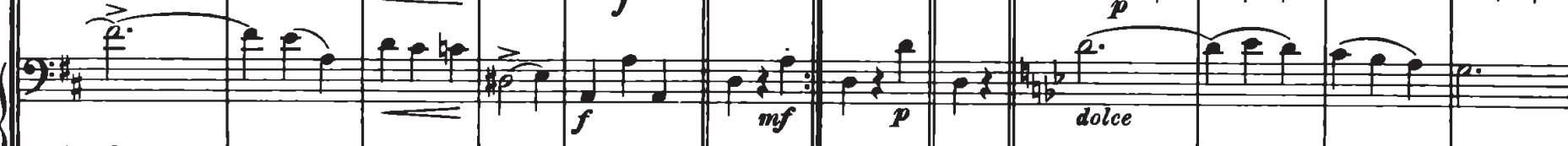

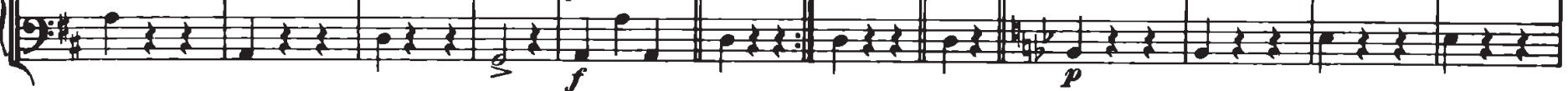




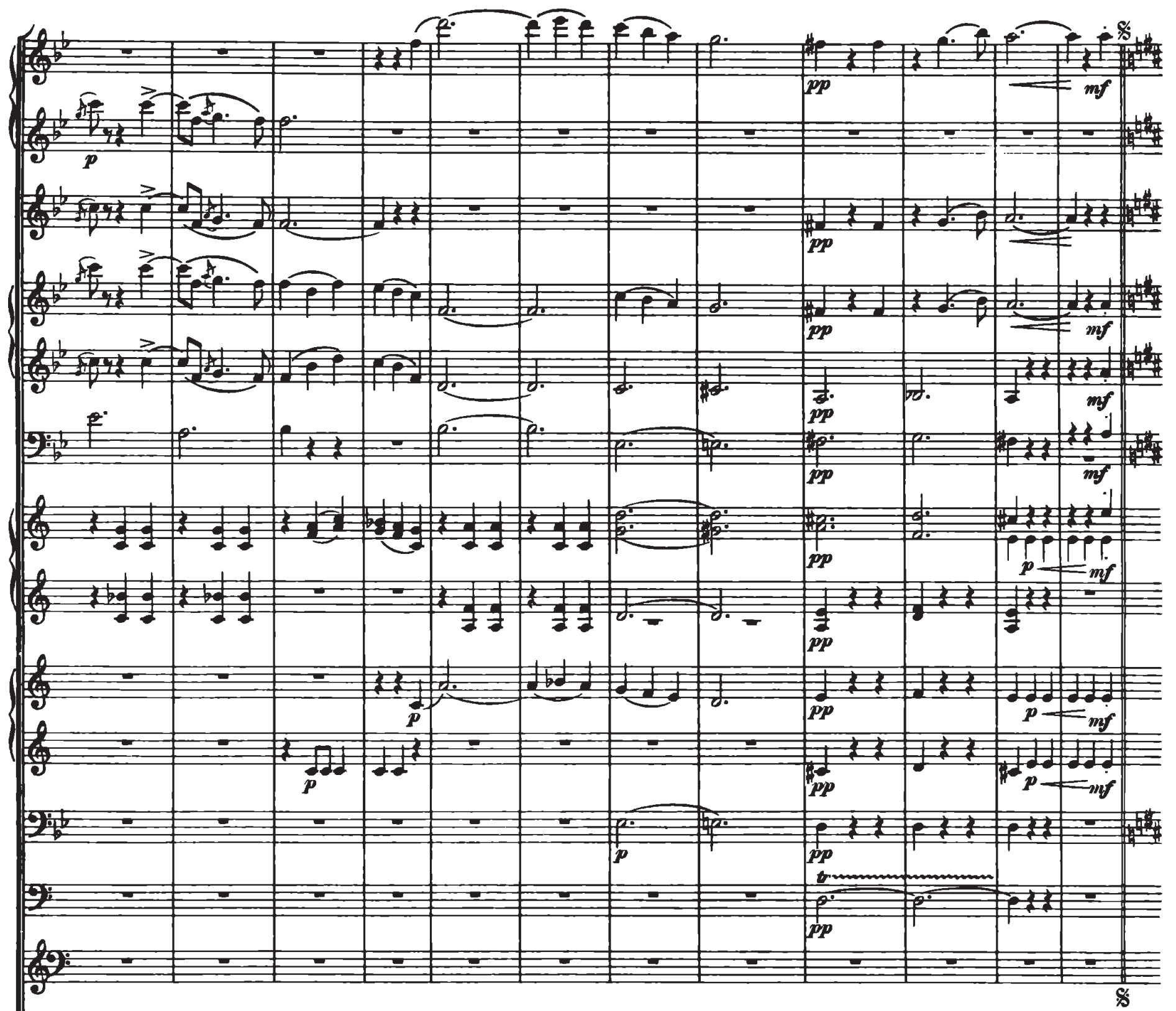

(2)

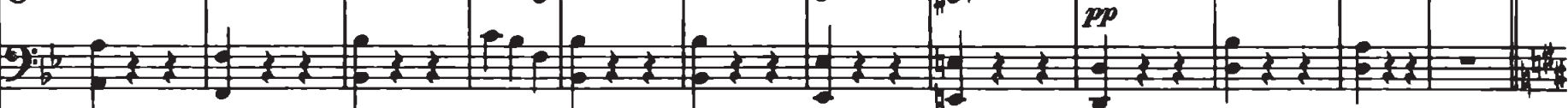

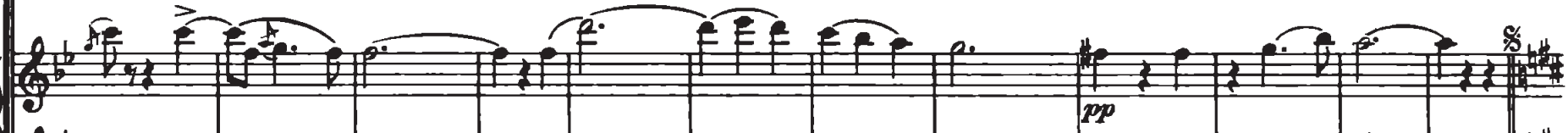

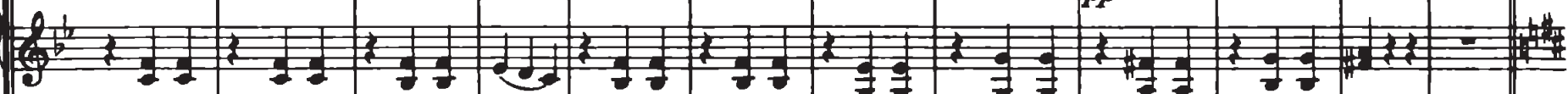

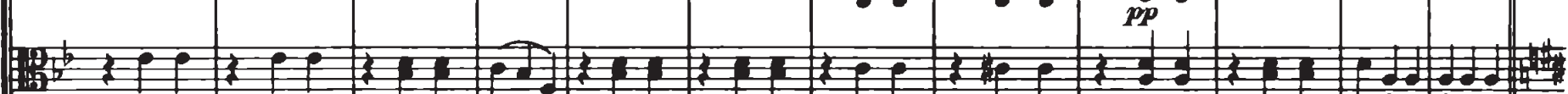

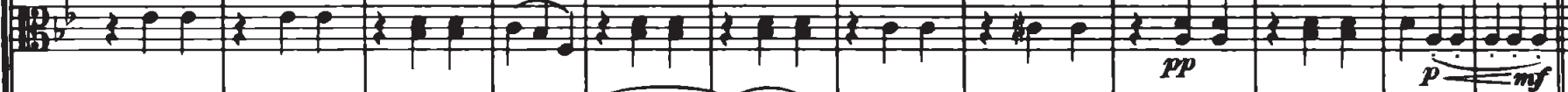

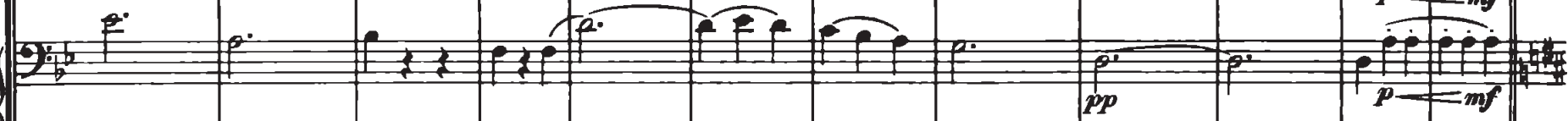

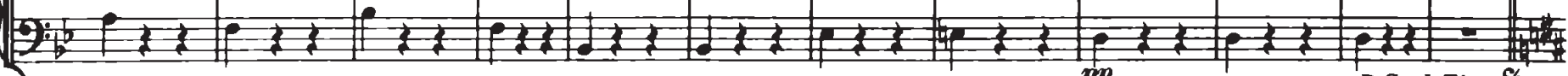
D.S. al Fine $\%$ 


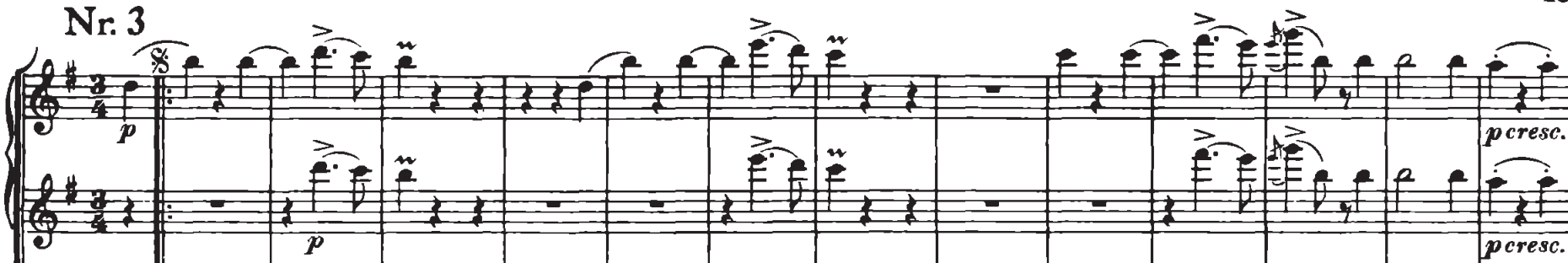

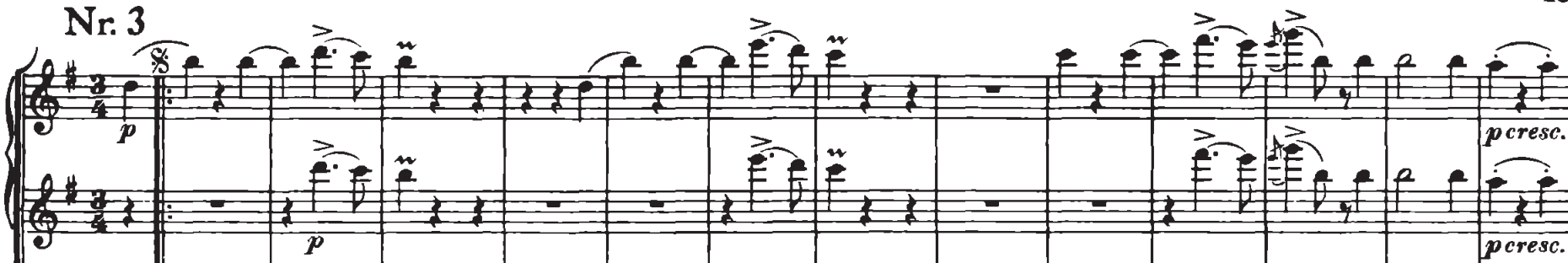

2.

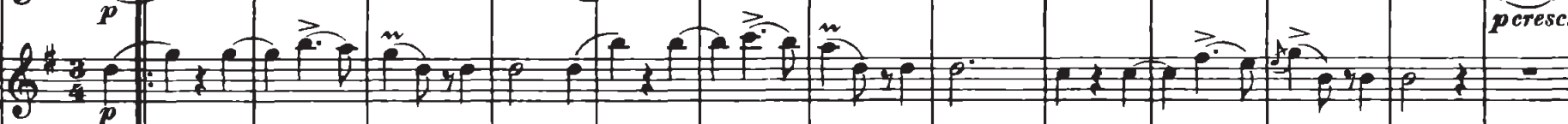

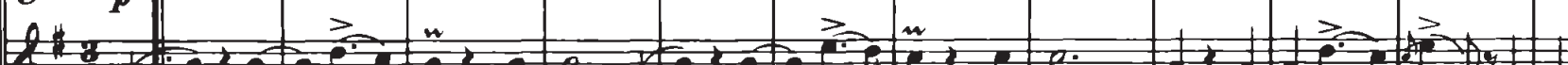
3.

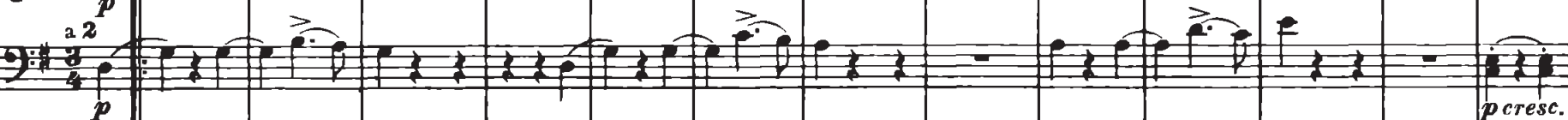
3.

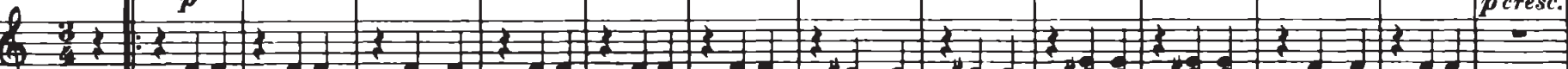
2

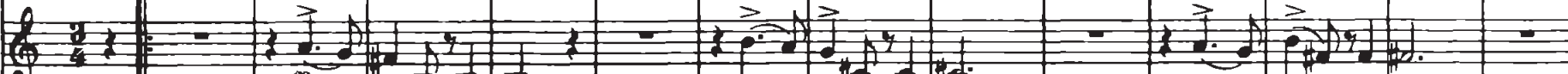

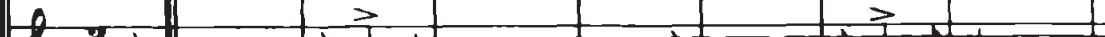

2.

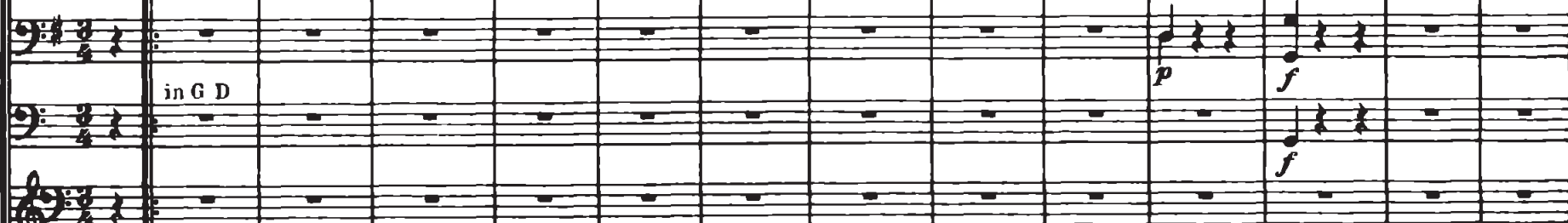
8

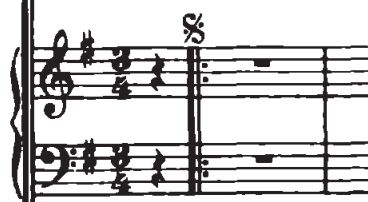

(2)

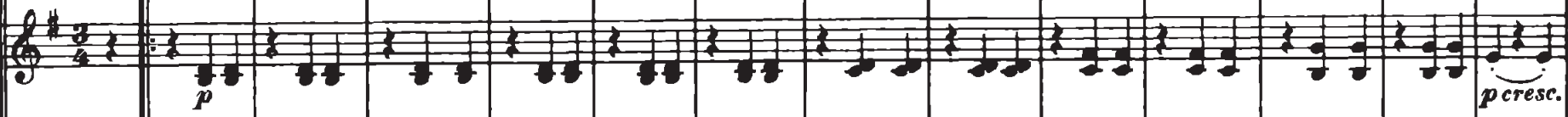

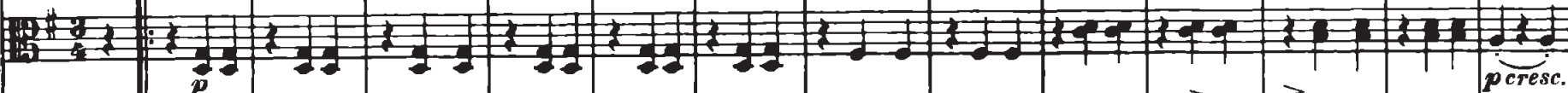
(2)

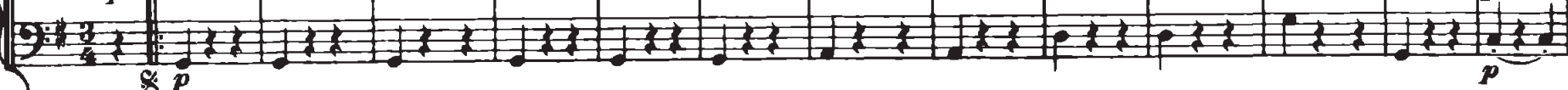


14
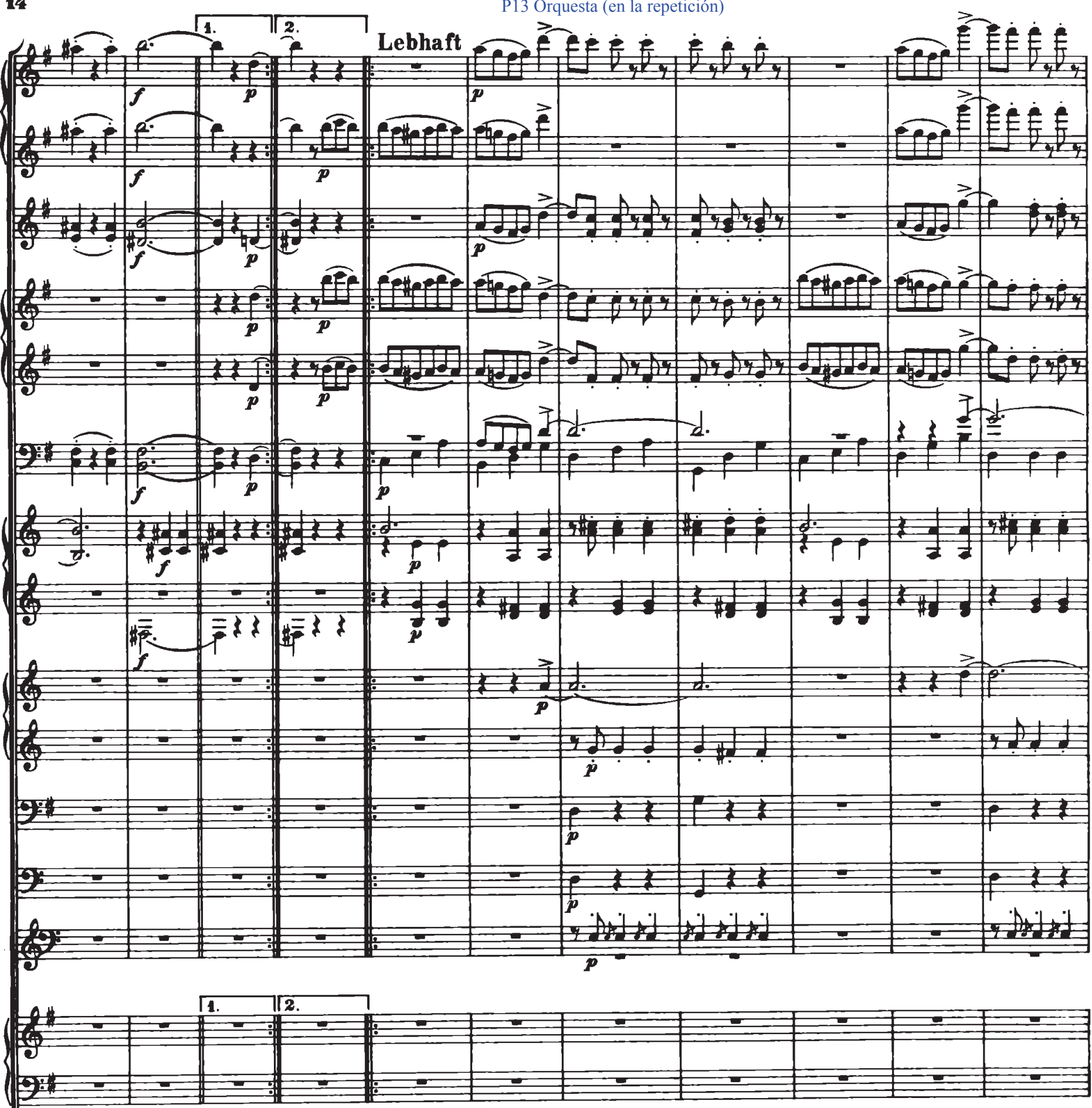

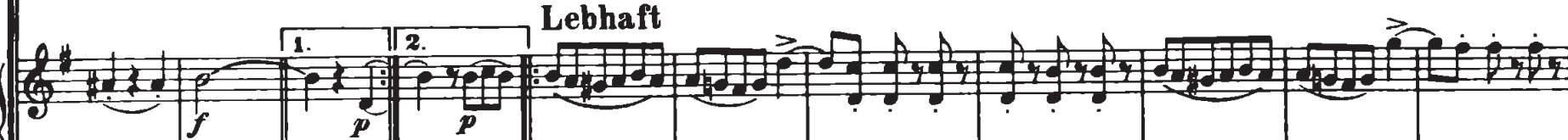

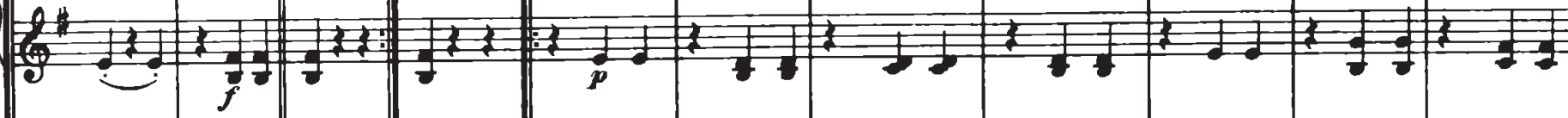

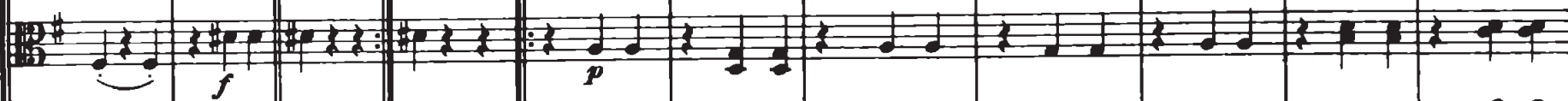

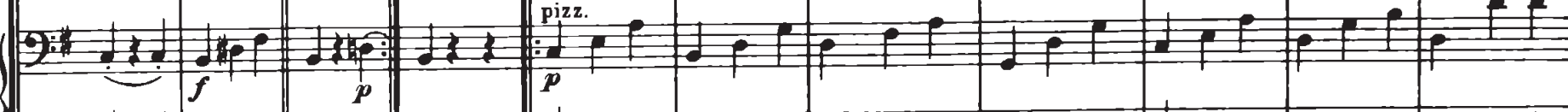

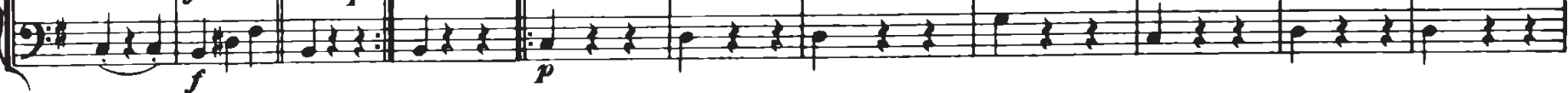



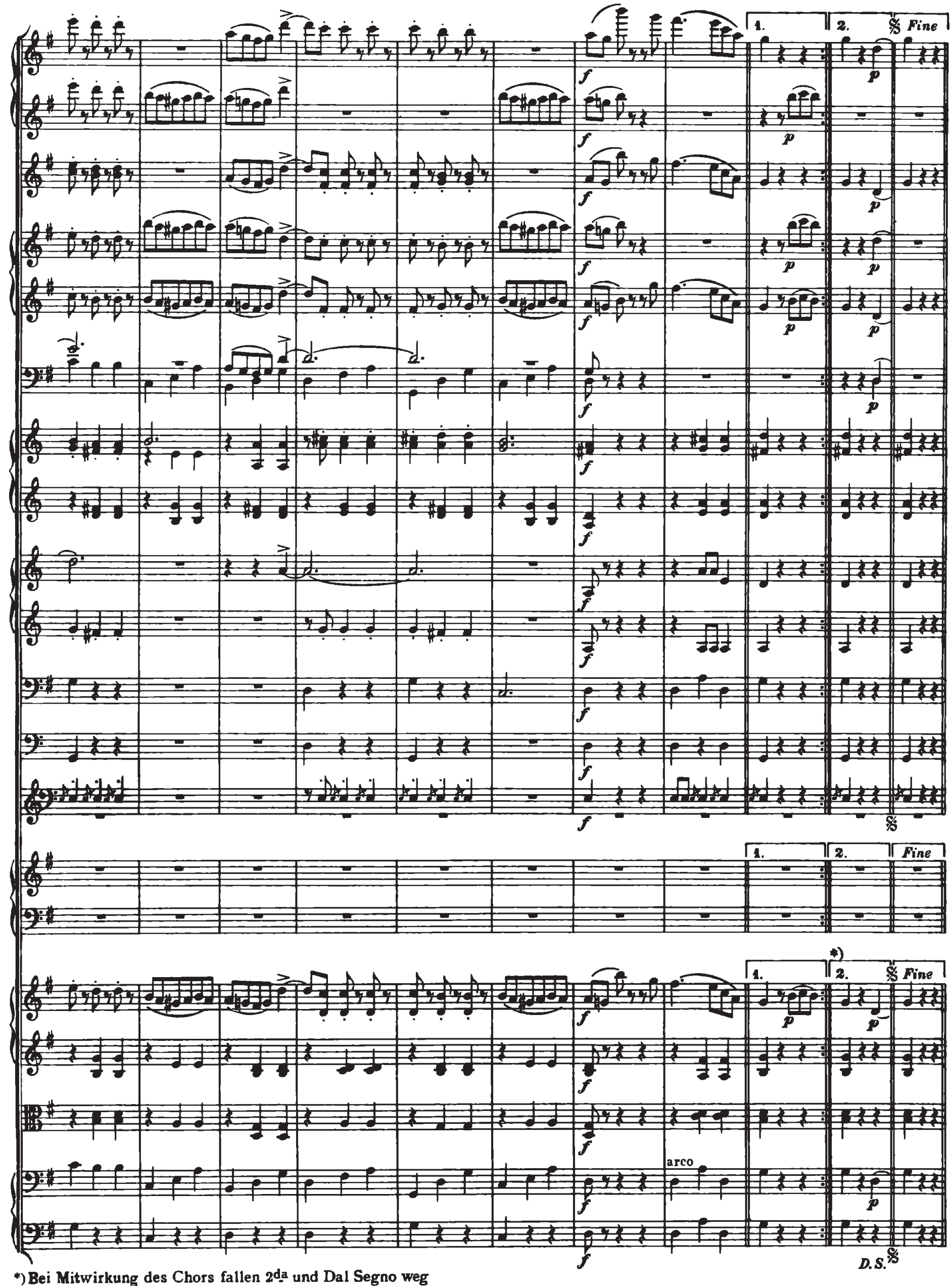


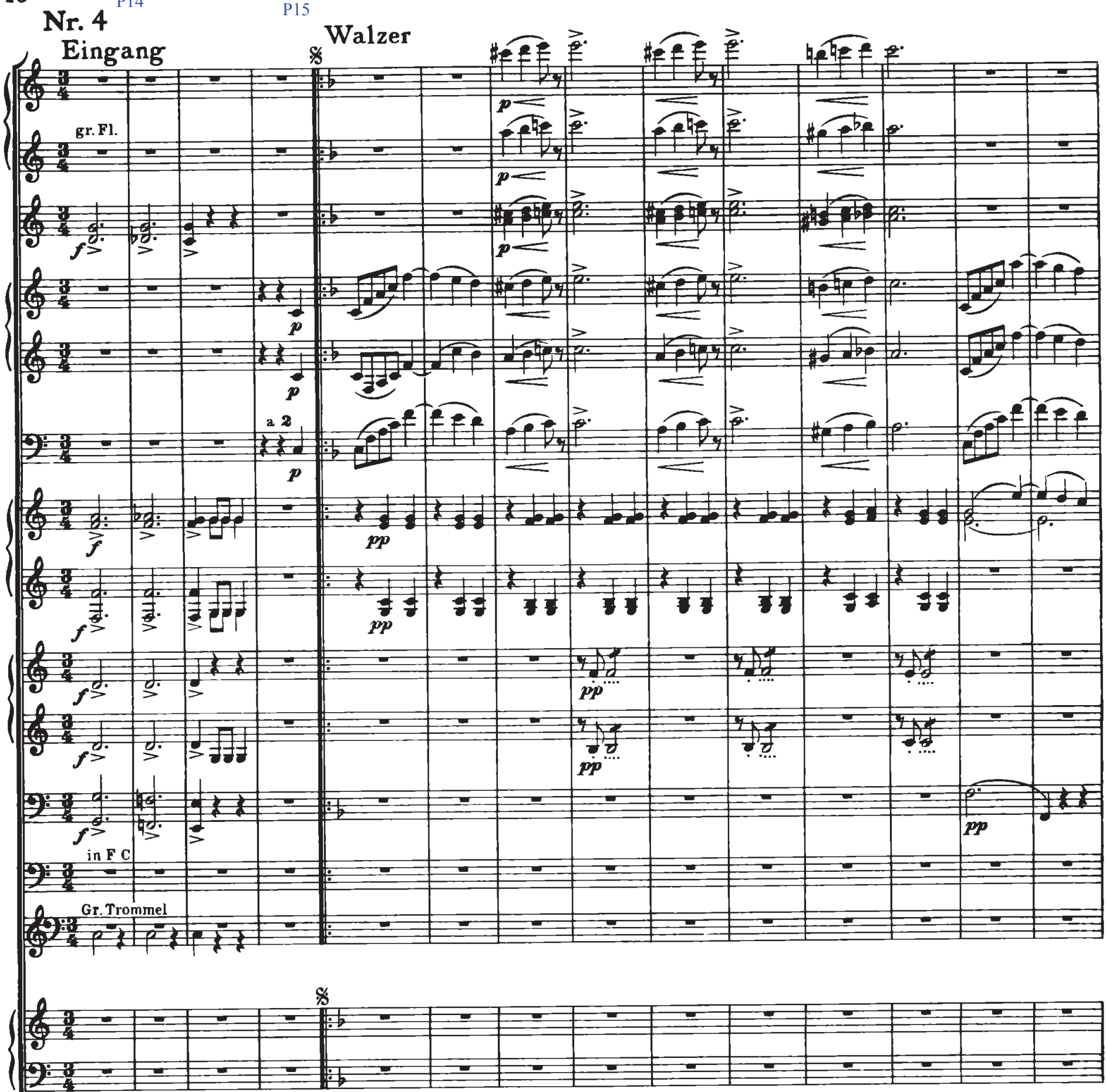

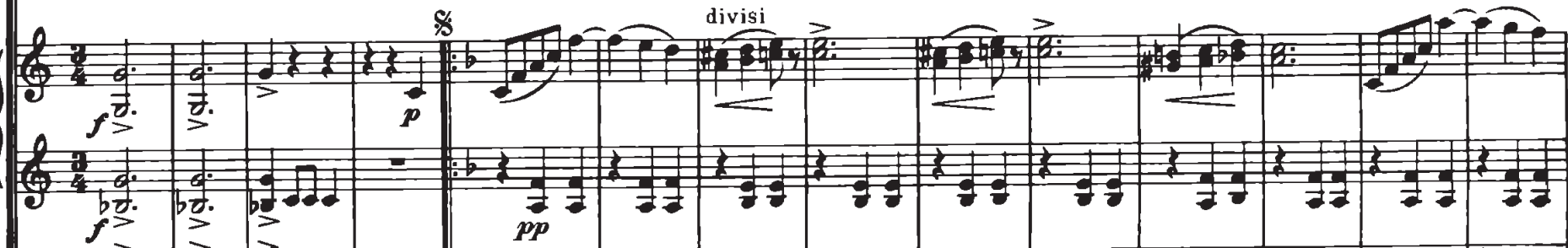

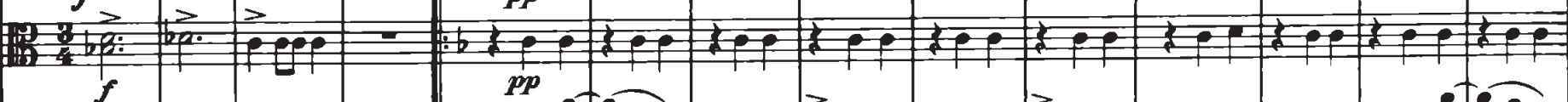

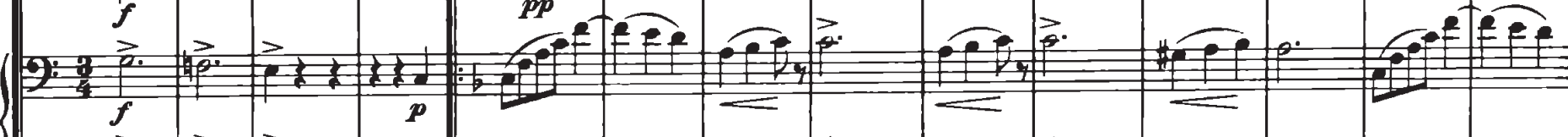

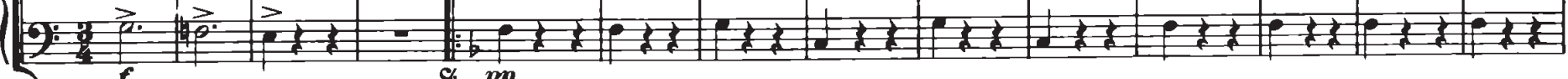



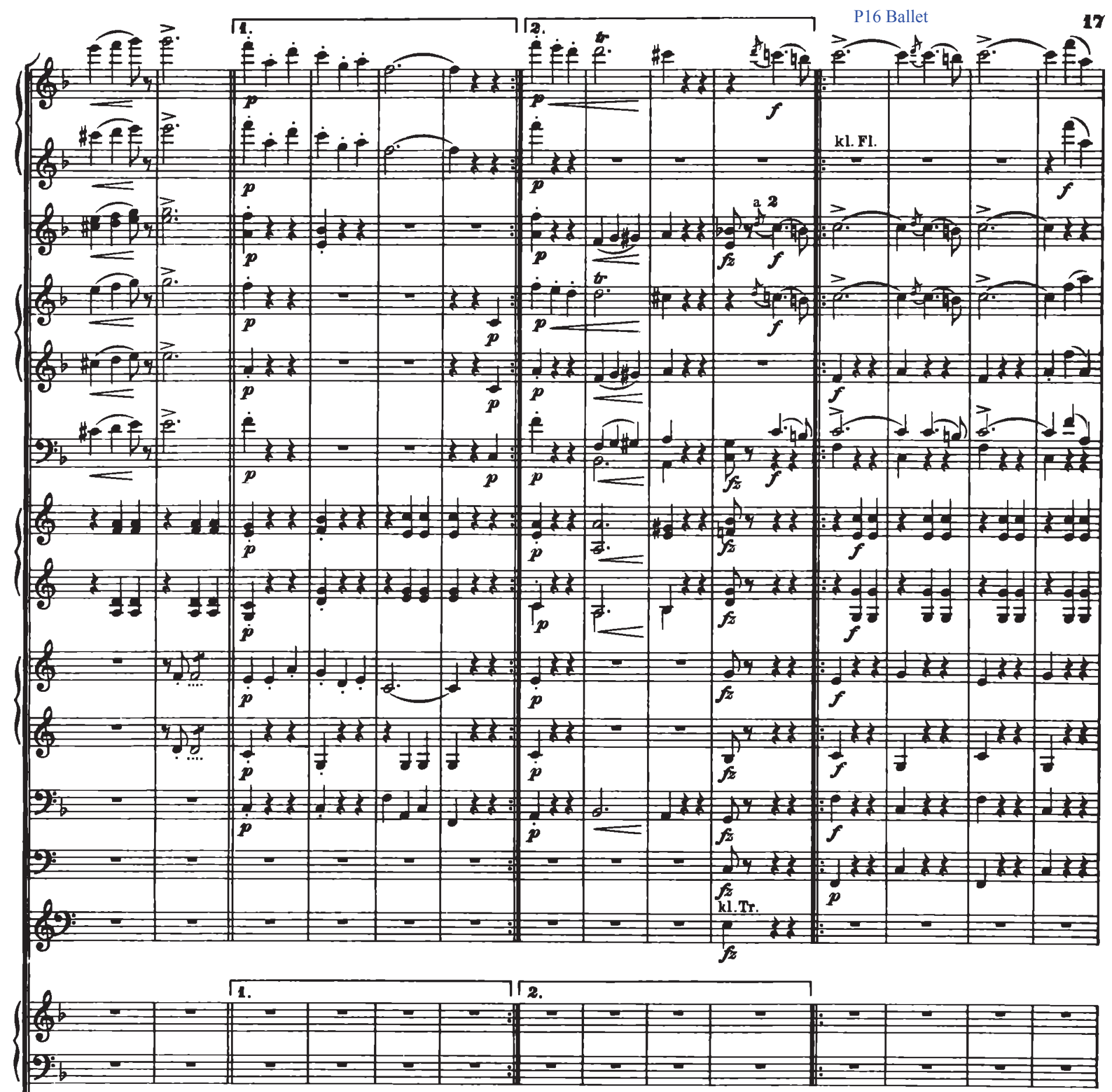

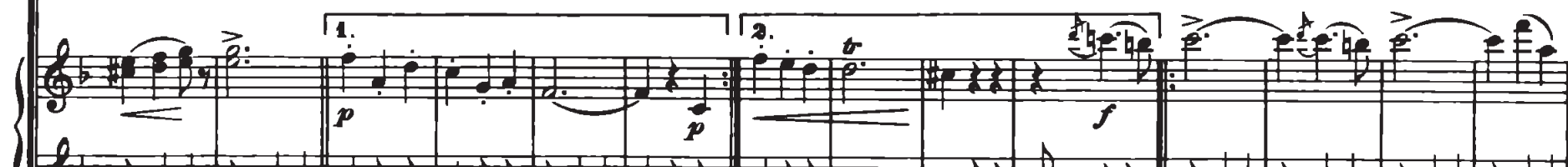

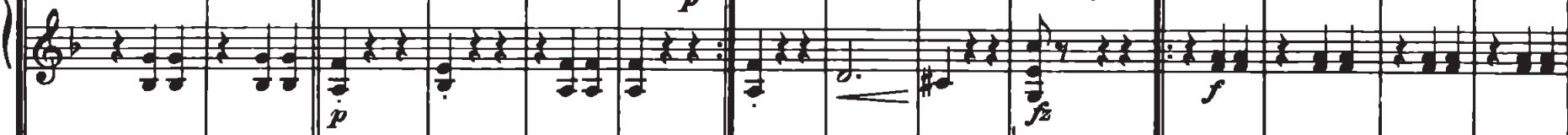

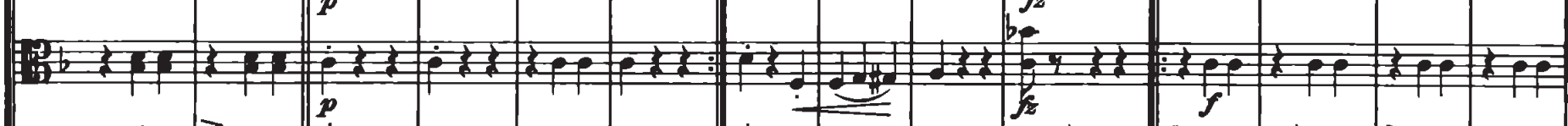

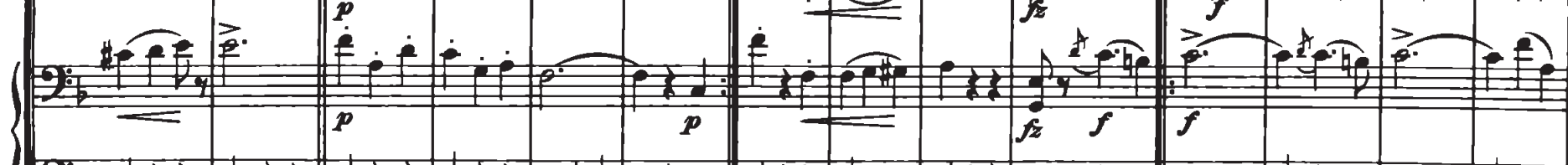

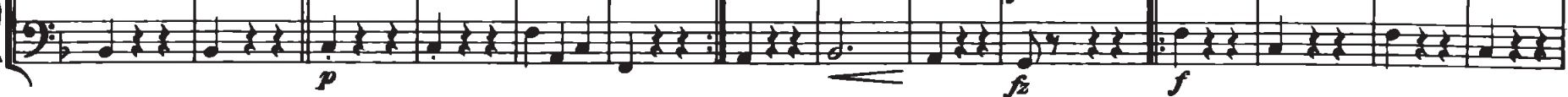


18

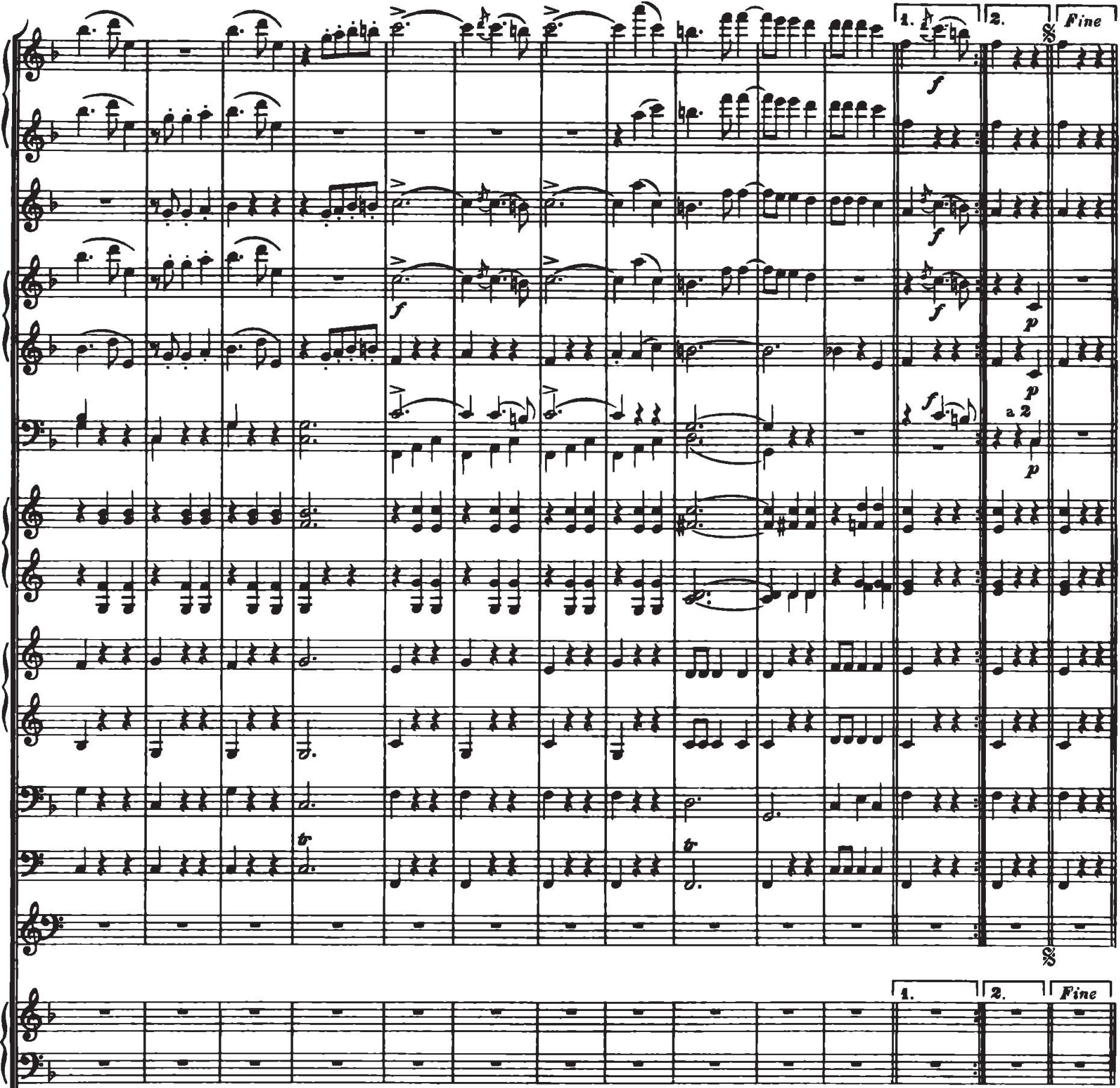

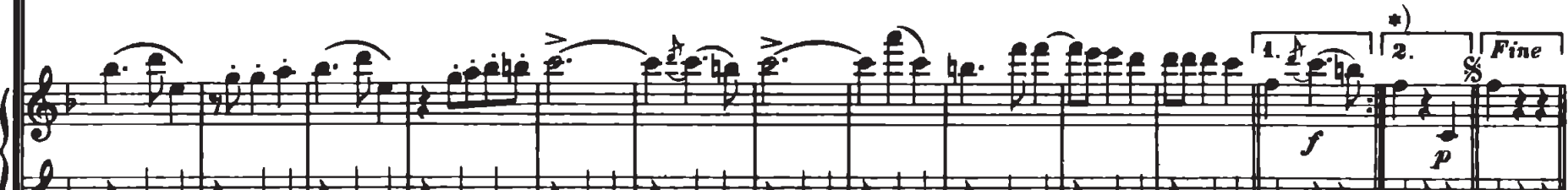

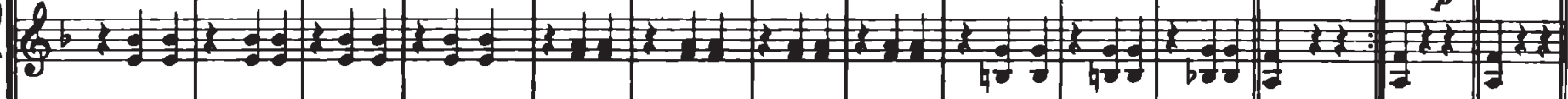

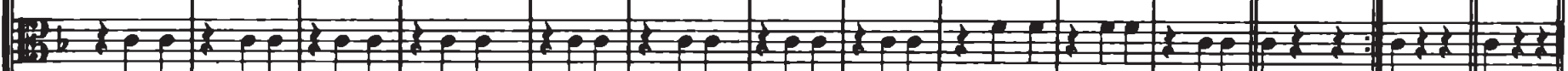

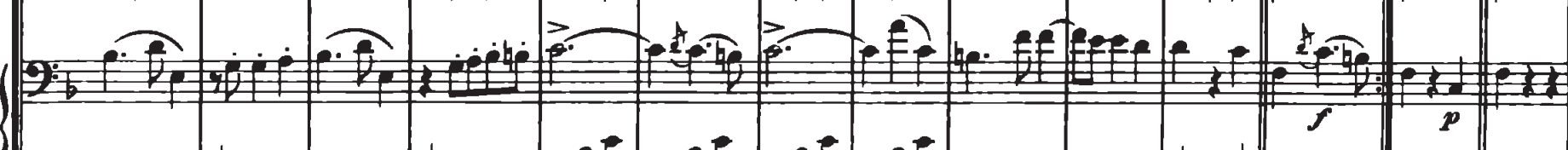

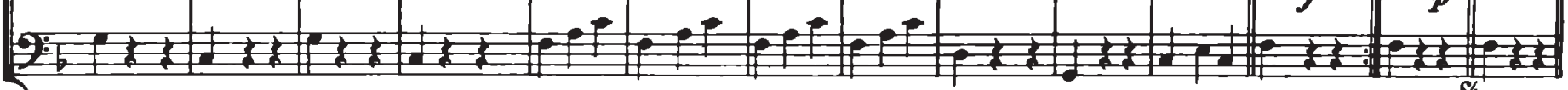

*) Bei Mitwirkung des Chors fallen 2da und Dal Segno weg 
Nr. 5

Lav Eingang

E

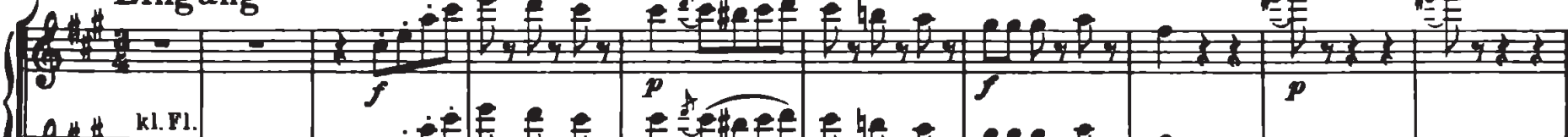

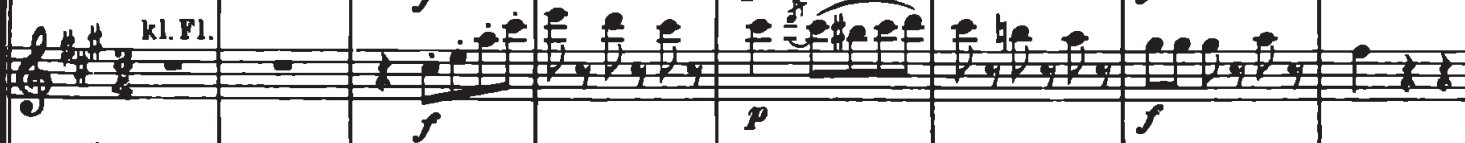

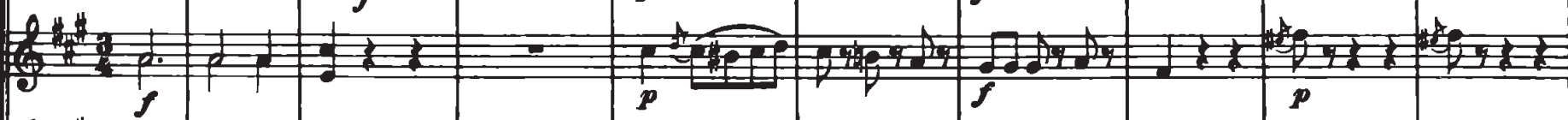

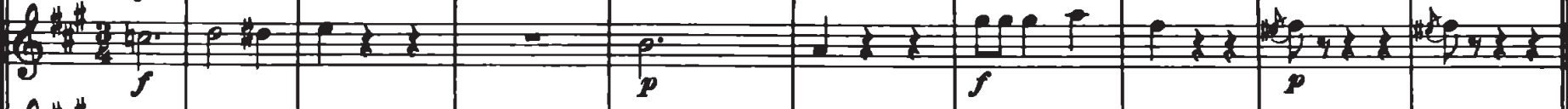

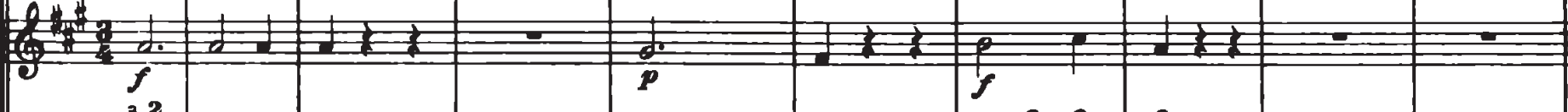

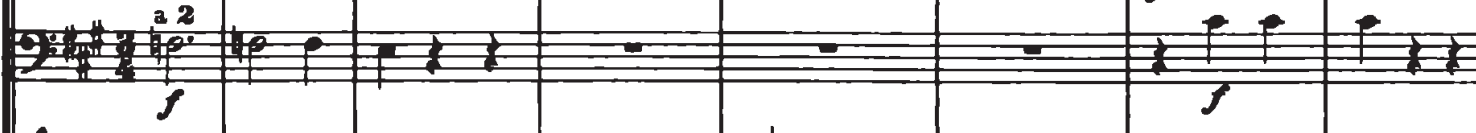

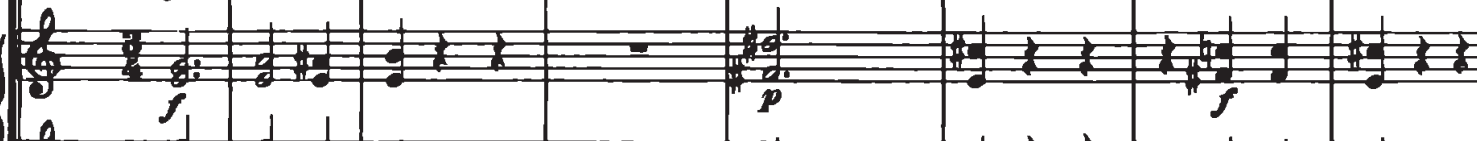

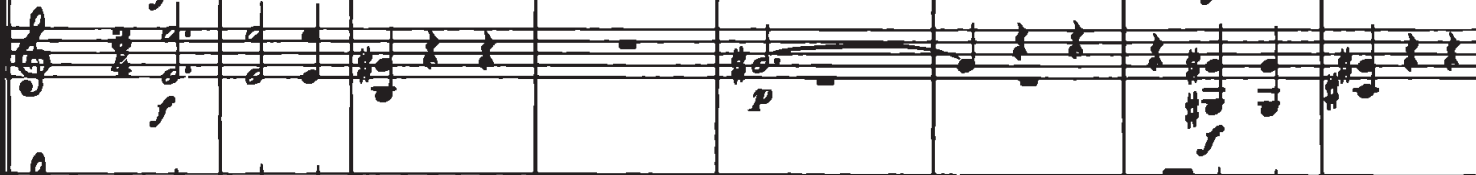

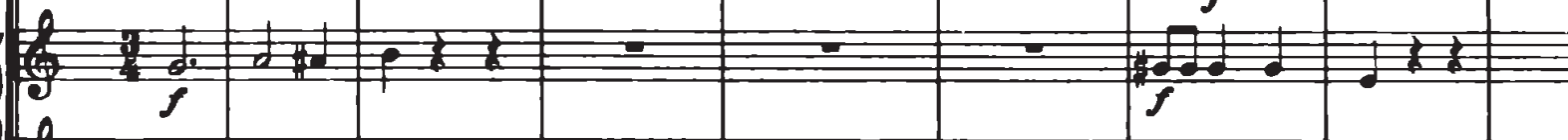

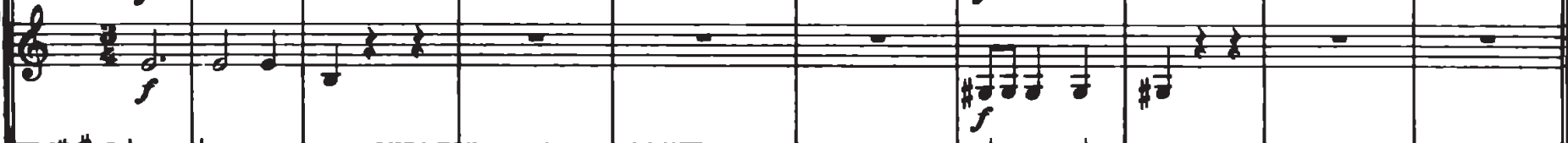

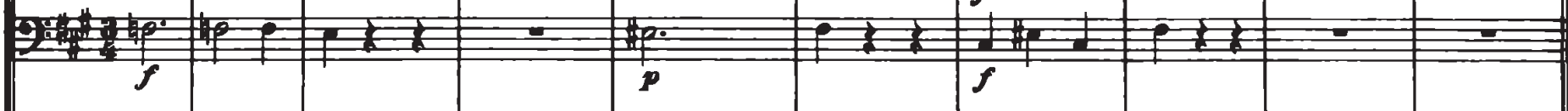
\begin{tabular}{|l|l|l|l|l|l|l|l|l|}
\hline 0 & & & & & & & & \\
\hline
\end{tabular}

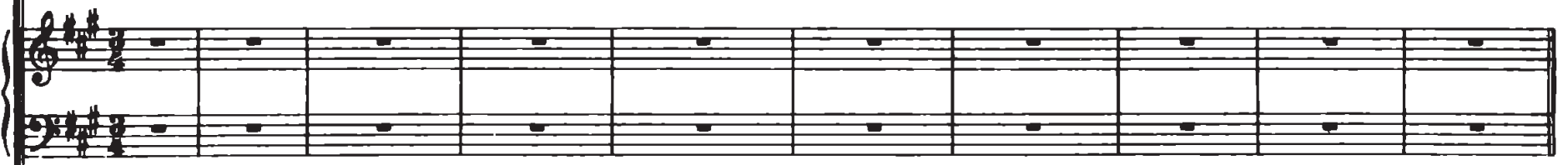

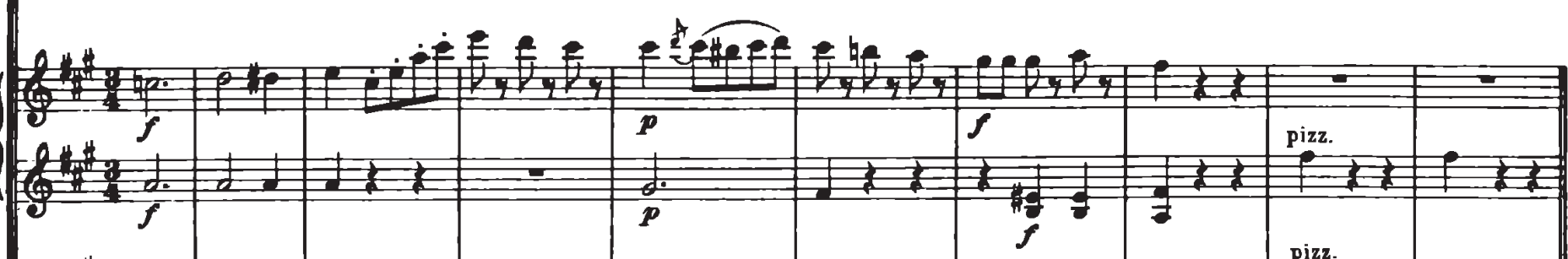

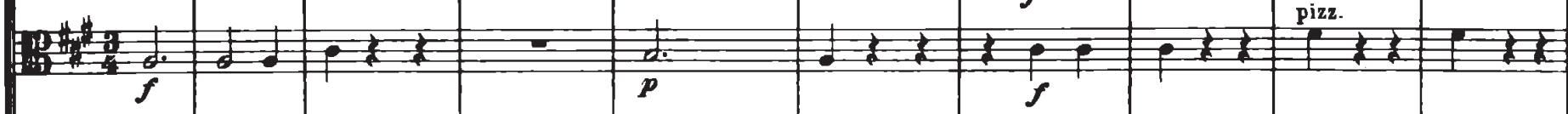

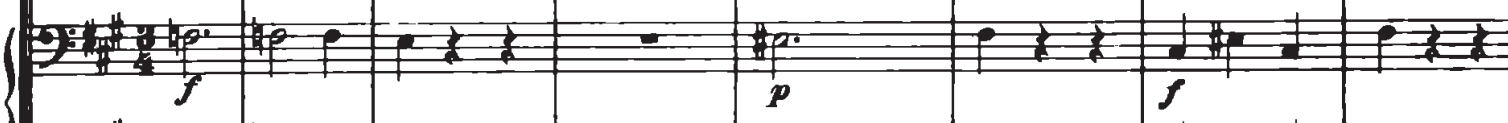

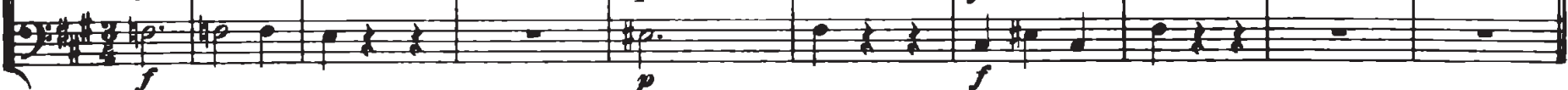


Walzer

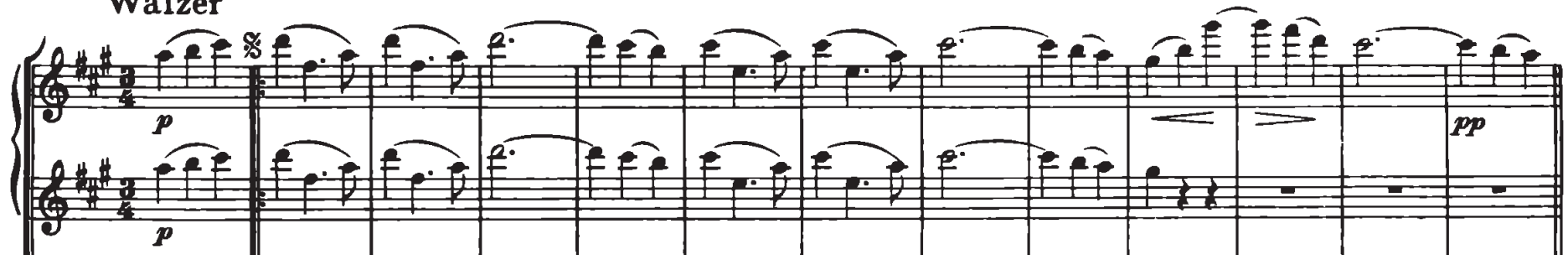

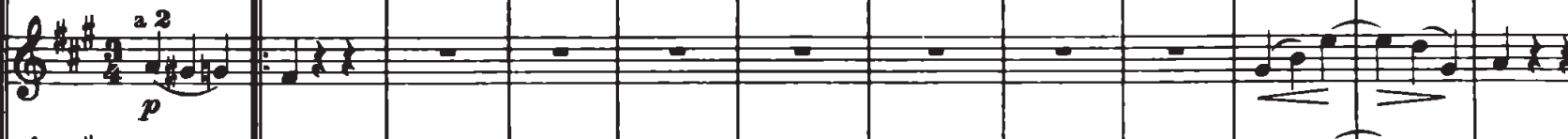

(2.4.7F 6. Sor

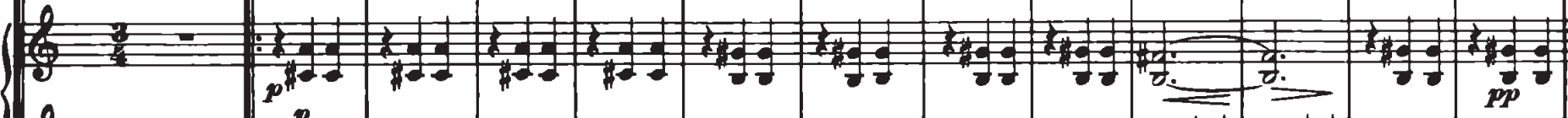

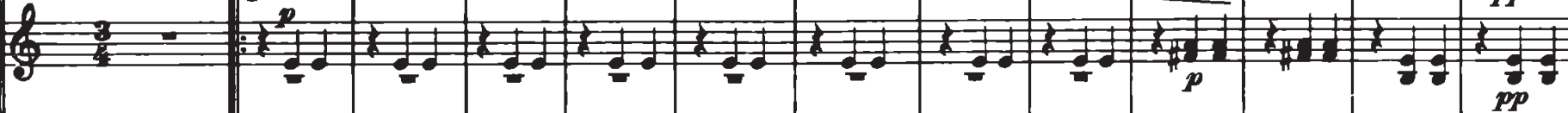

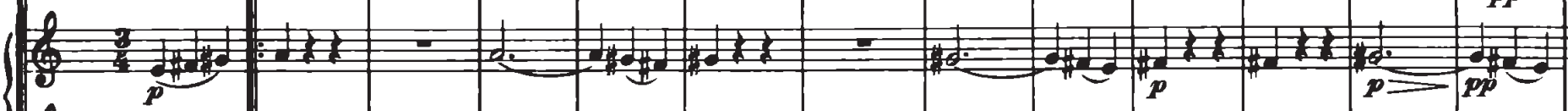

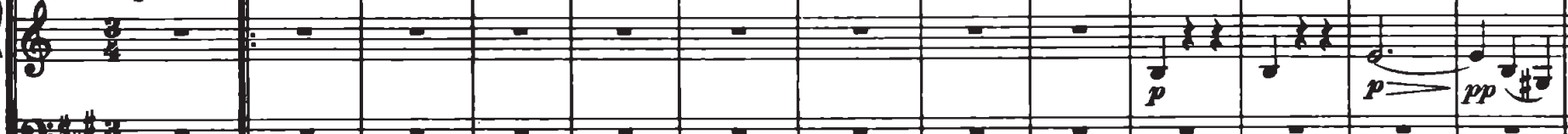

\begin{tabular}{|c|c|c|c|c|c|c|c|c|c|c|c|c|}
\hline 4 & $=$ & $\bar{\sigma}$ & $=$ & 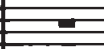 & $\sigma$ & $=$ & 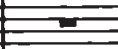 & EF & 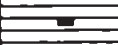 & $\overline{c=}$ & 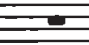 & 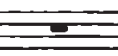 \\
\hline $\bar{E}$ & $=$ & $=$ & 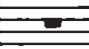 & $=$ & $=$ & $=$ & $=$ & $=$ & $\angle \sigma$ & 듬 & $\equiv$ & 프 \\
\hline & $=$ & $=$ & $=$ & 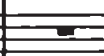 & 5 & 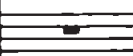 & 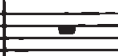 & $=$ & $=$ & $=$ & $=$ & $\underline{z}$ \\
\hline
\end{tabular}

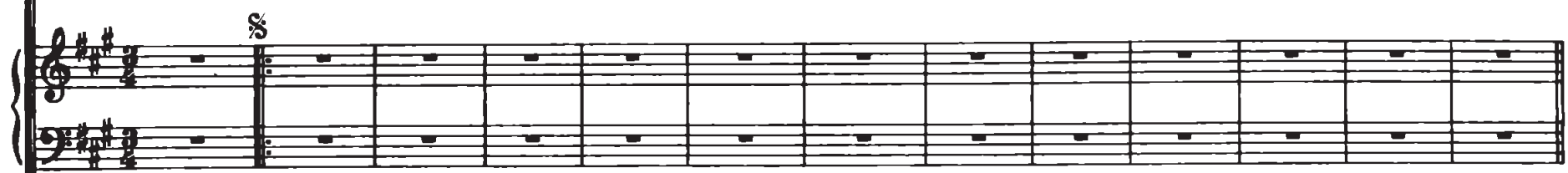

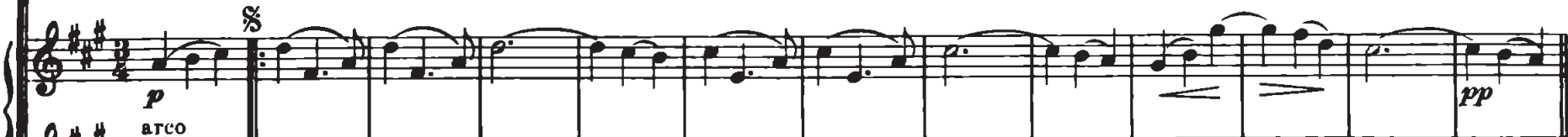

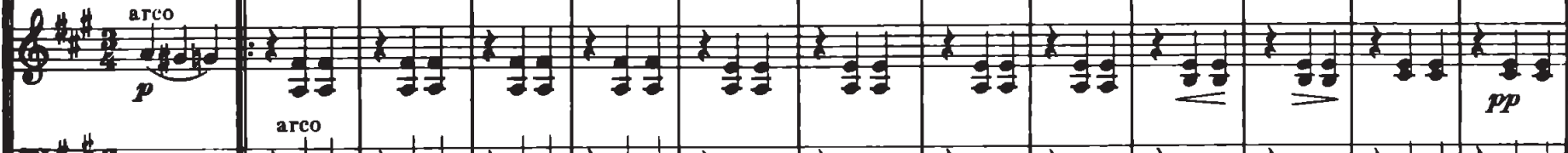
月.

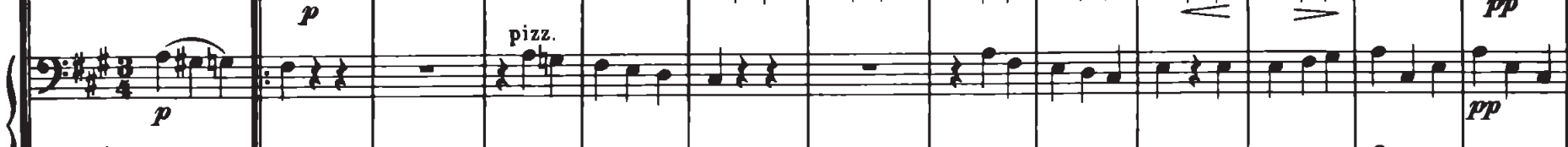

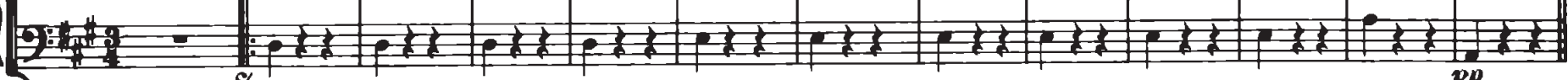
$\$ p$ 
1. शि?

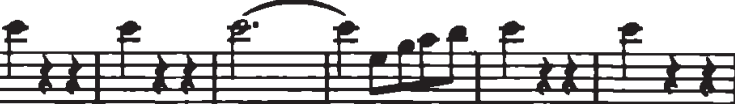

P

$f \longrightarrow$

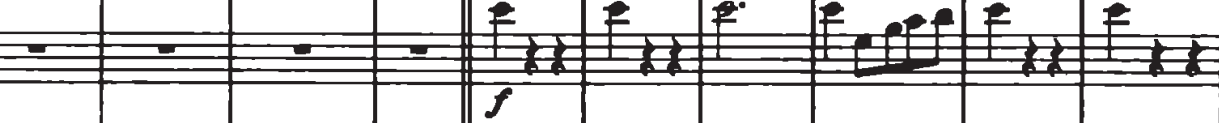

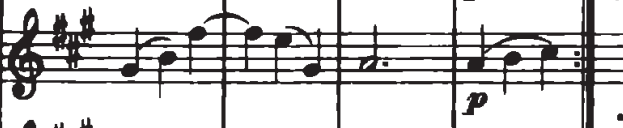

ref

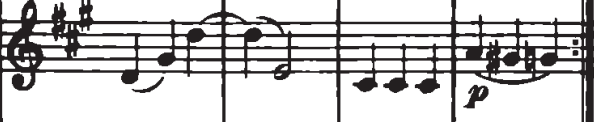

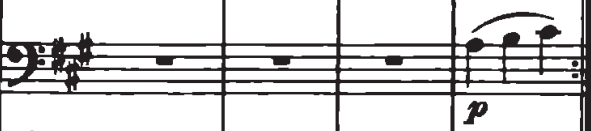

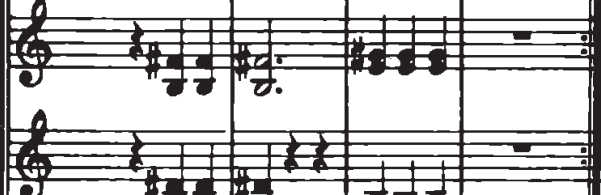

2=-1)

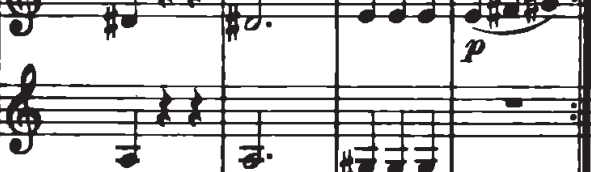

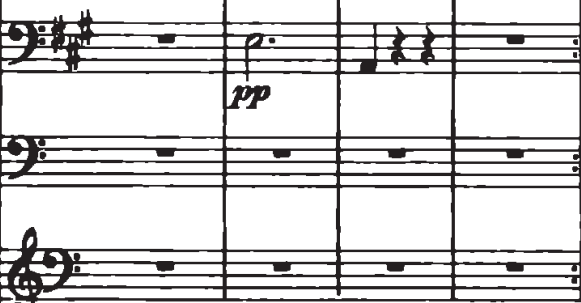

\begin{tabular}{l|l|l}
\hline+2 \\
\hline
\end{tabular}

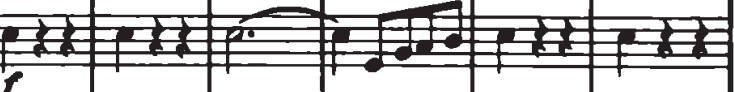

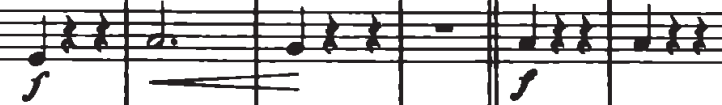

कटत्ट

fef

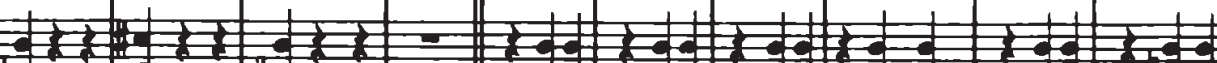

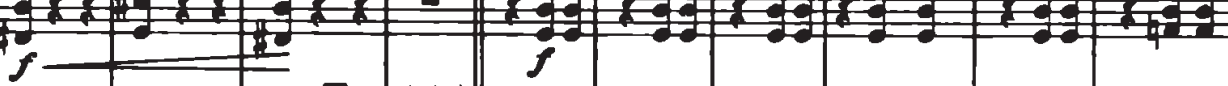

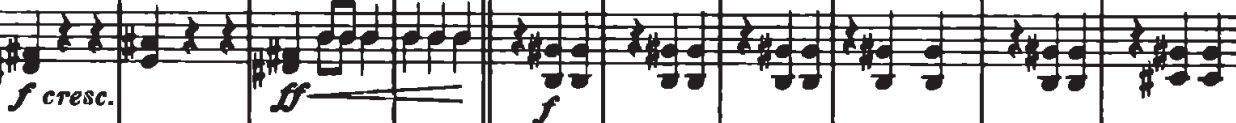
foresc.

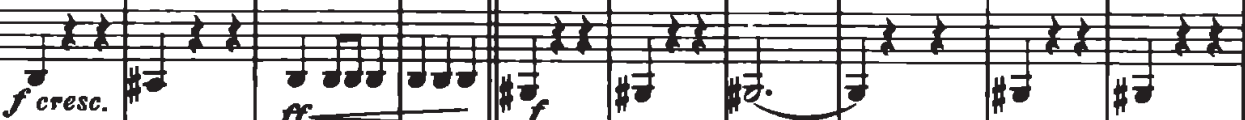

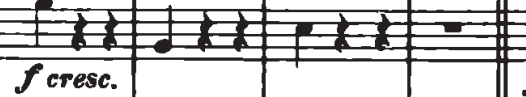
(leo\begin{tabular}{l|l|l} 
f cresc. & & \\
\hline
\end{tabular} $f$

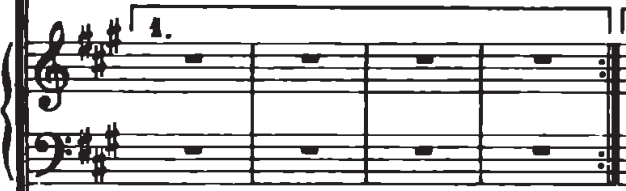

$7 \longdiv { 2 . }$

K1.Trommel Gr.Trommel $f$

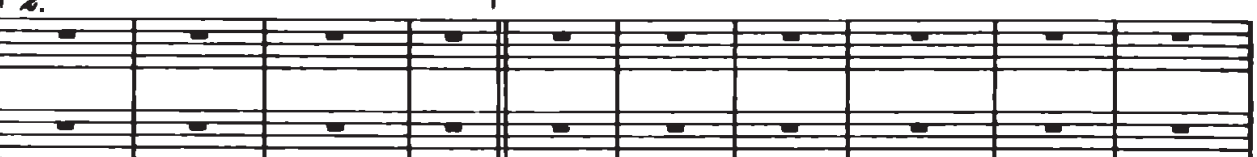

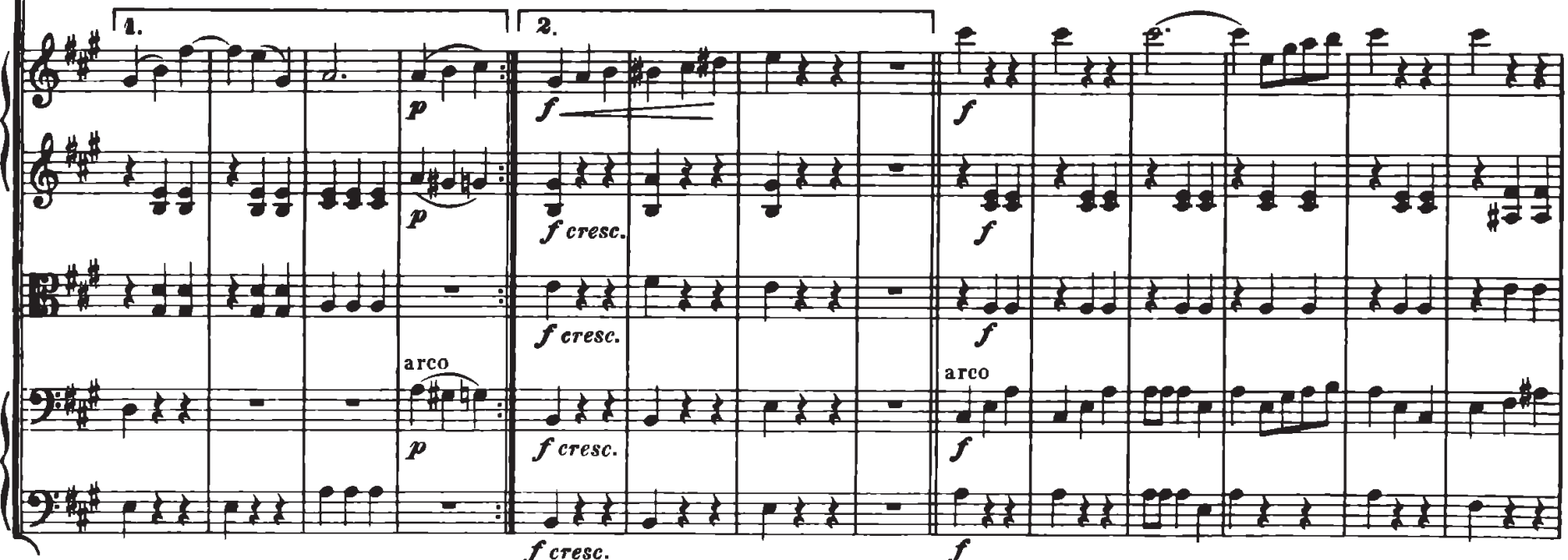




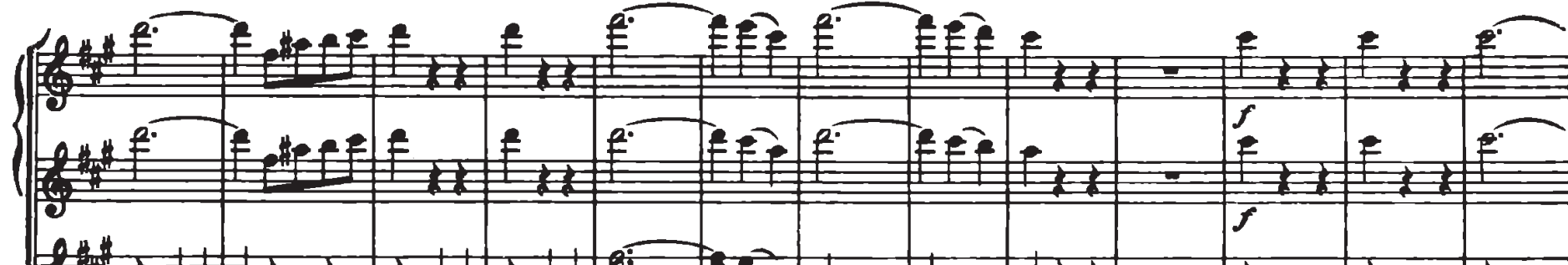
\%

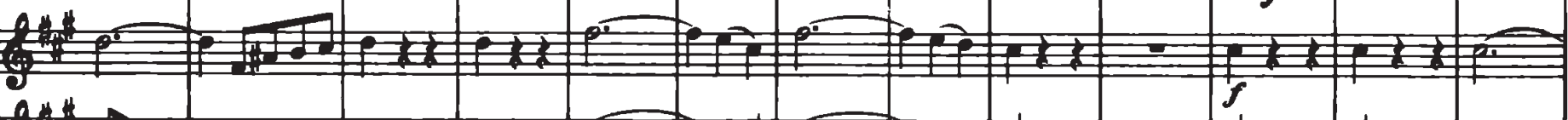

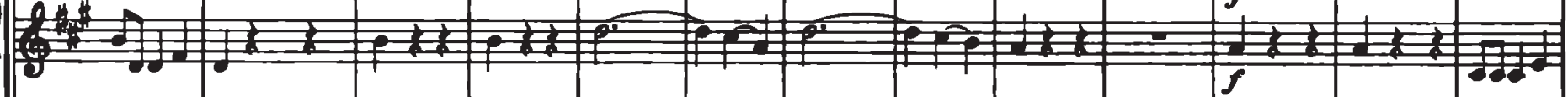

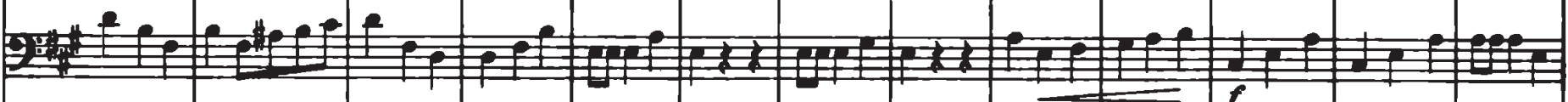

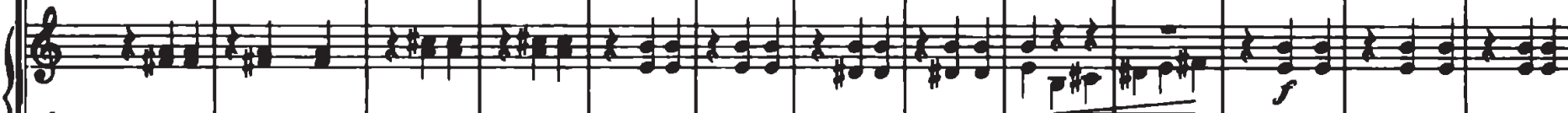

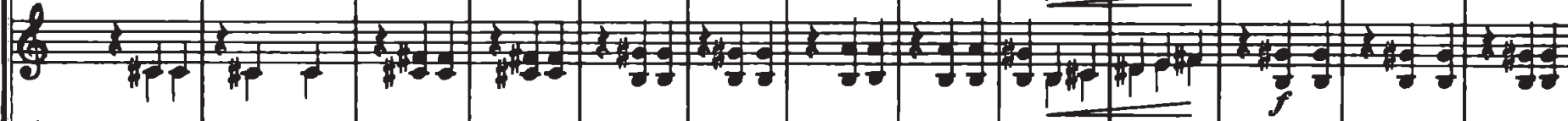

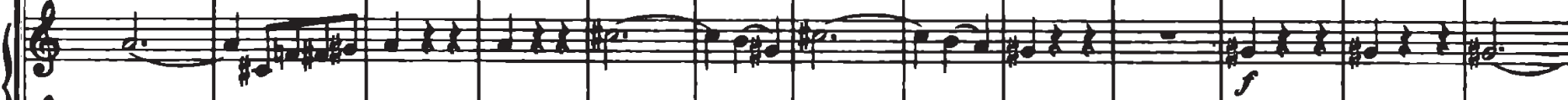

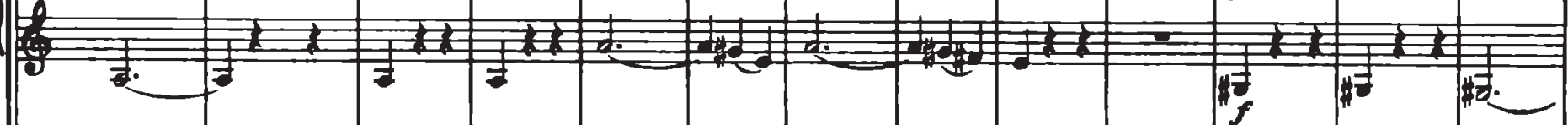

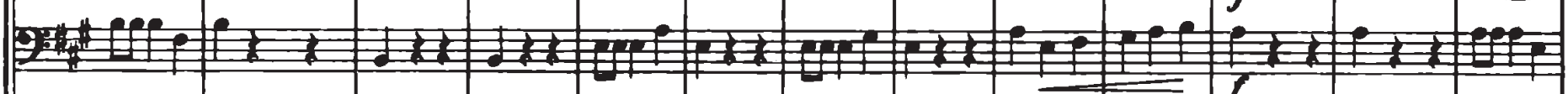

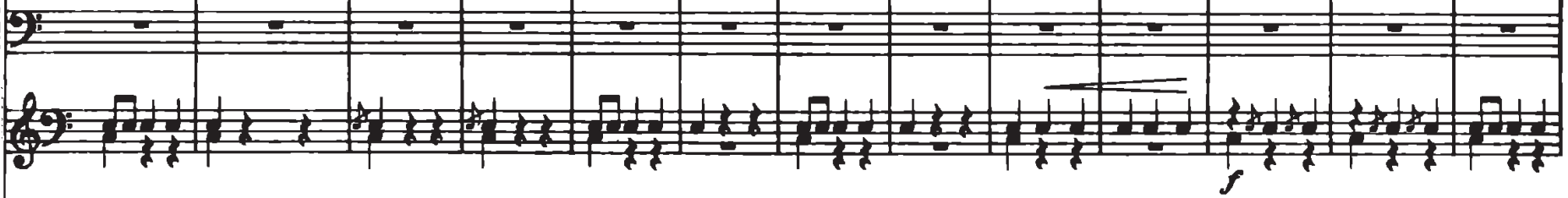

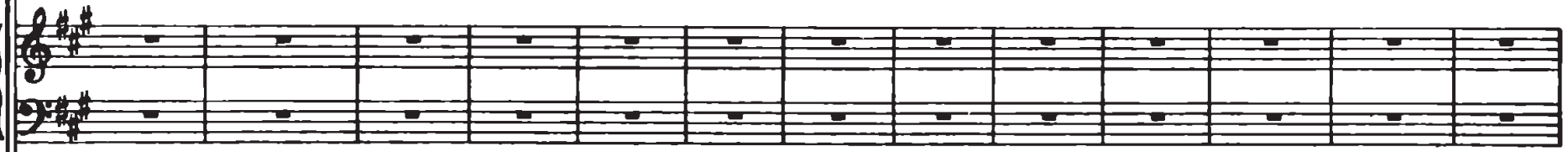

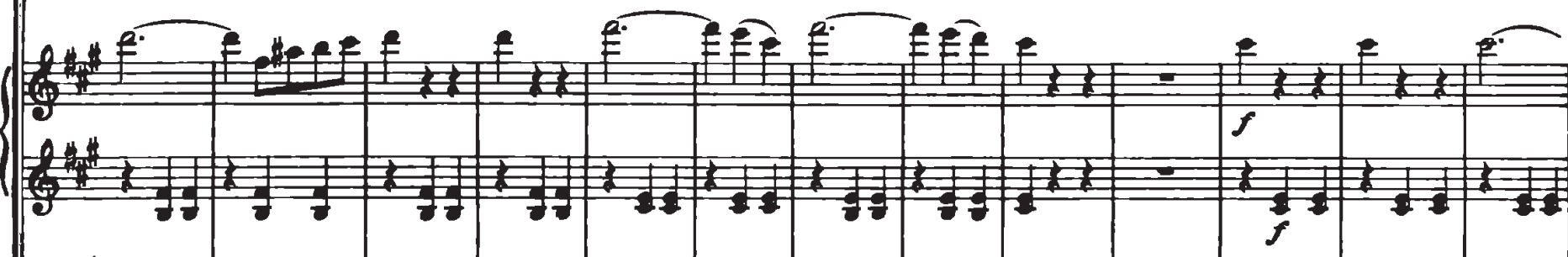

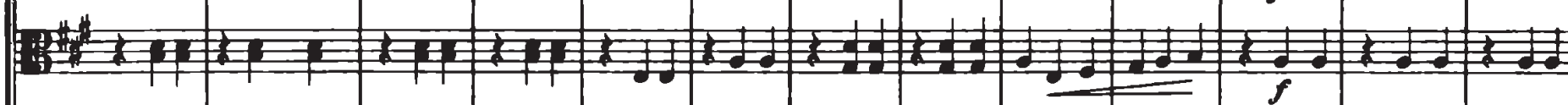

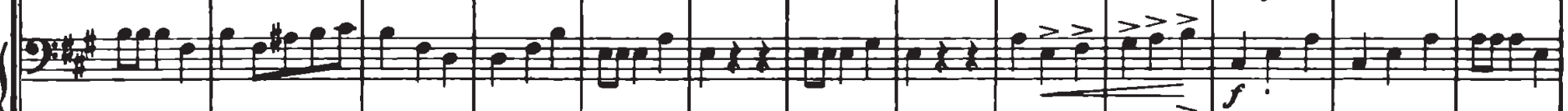

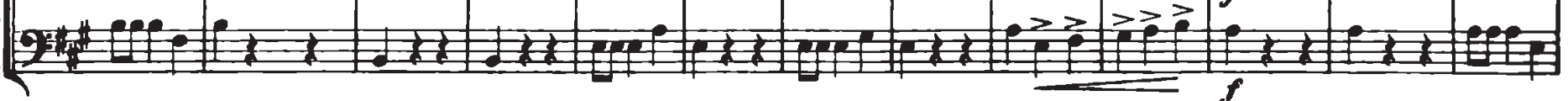



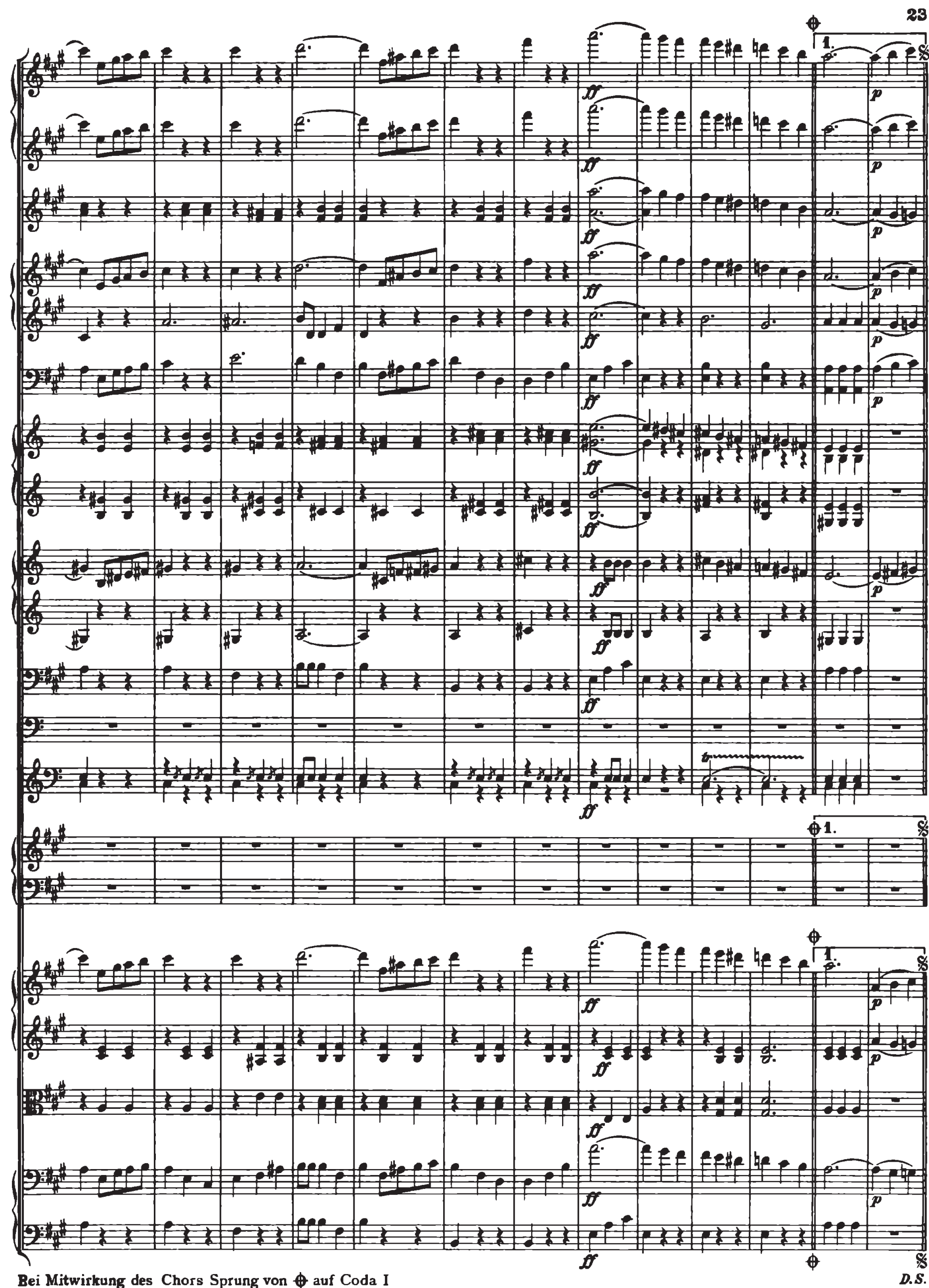
24
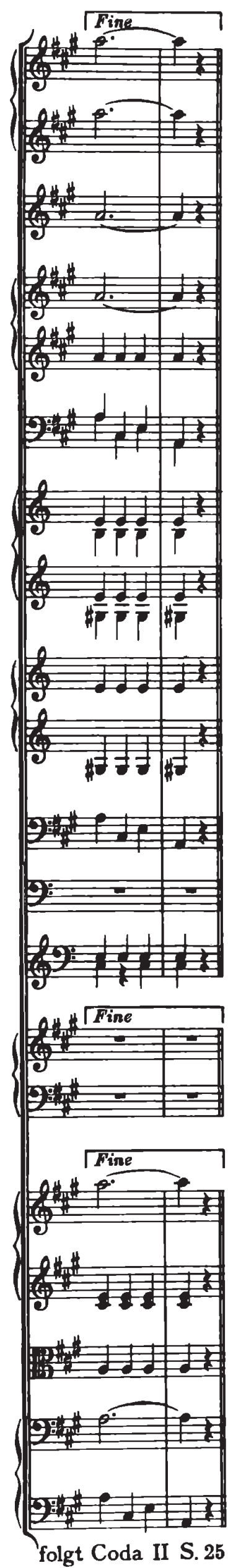

Coda I Nur bei Mitwirkung des Chors

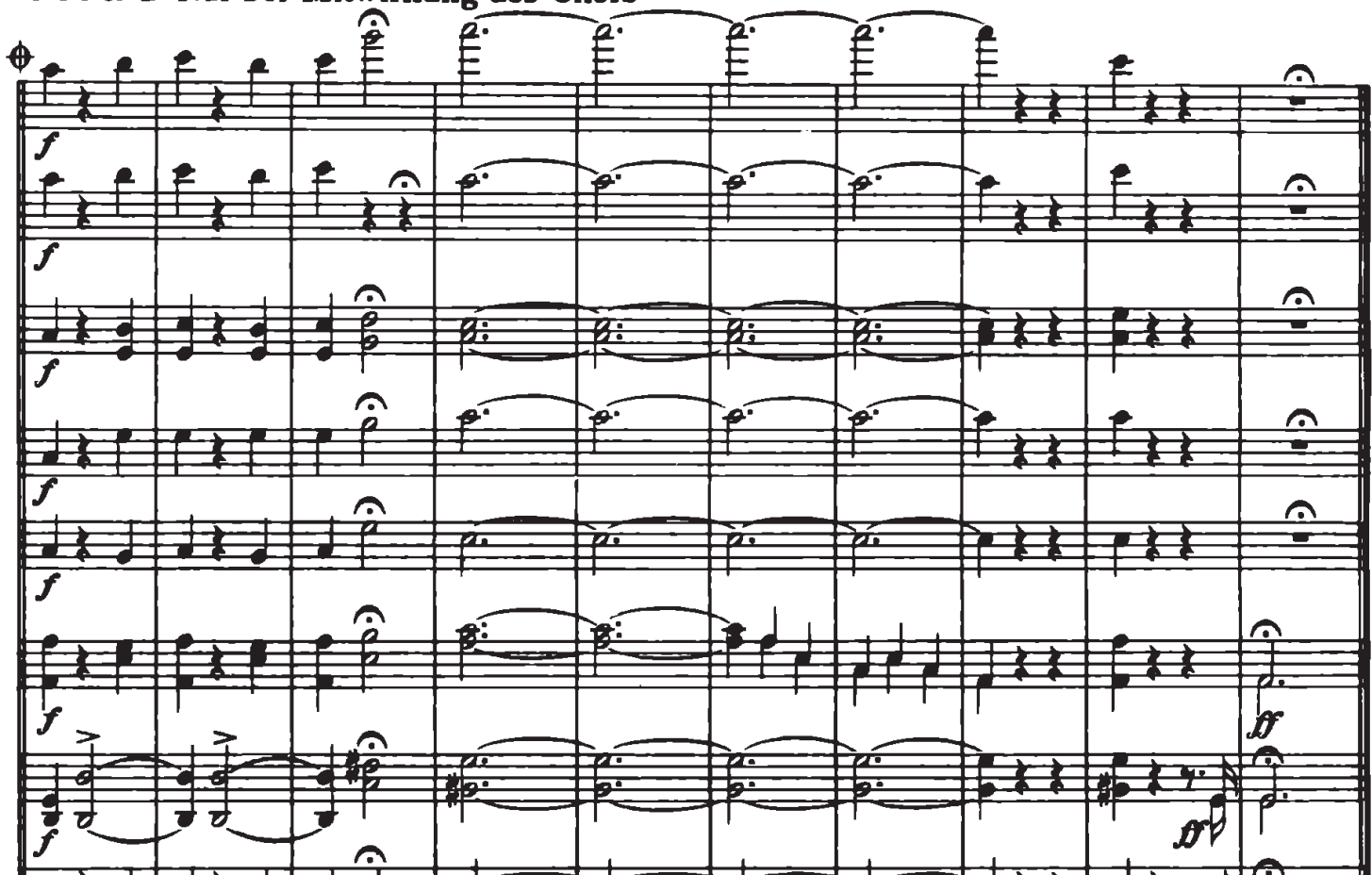

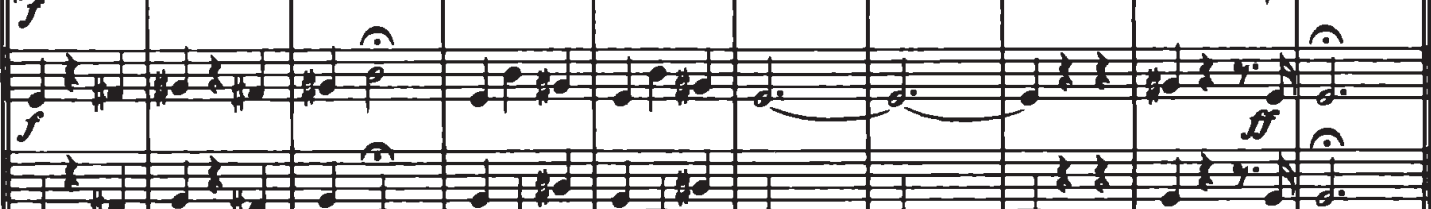

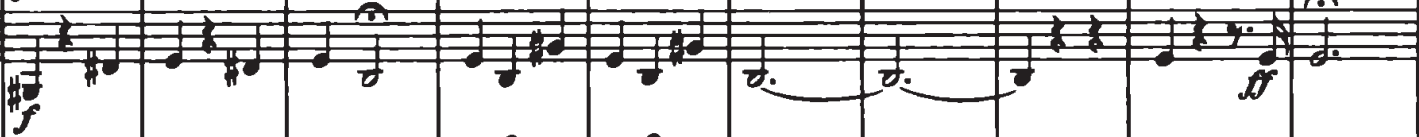

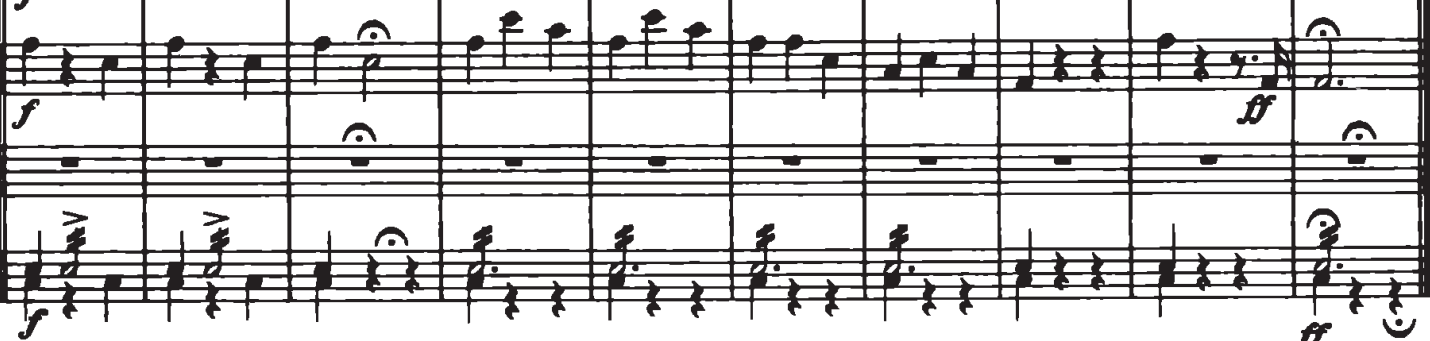

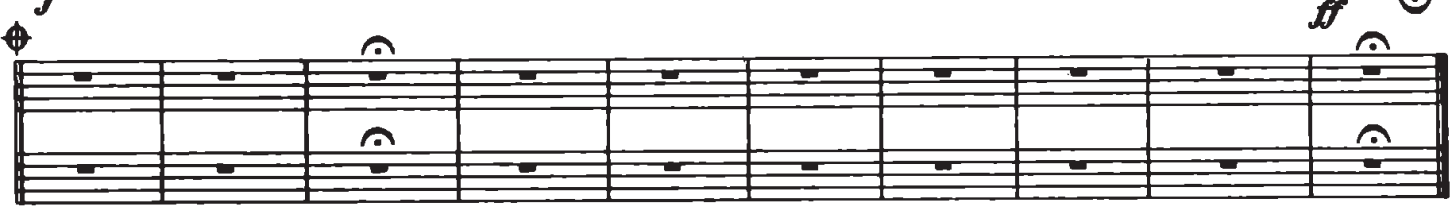

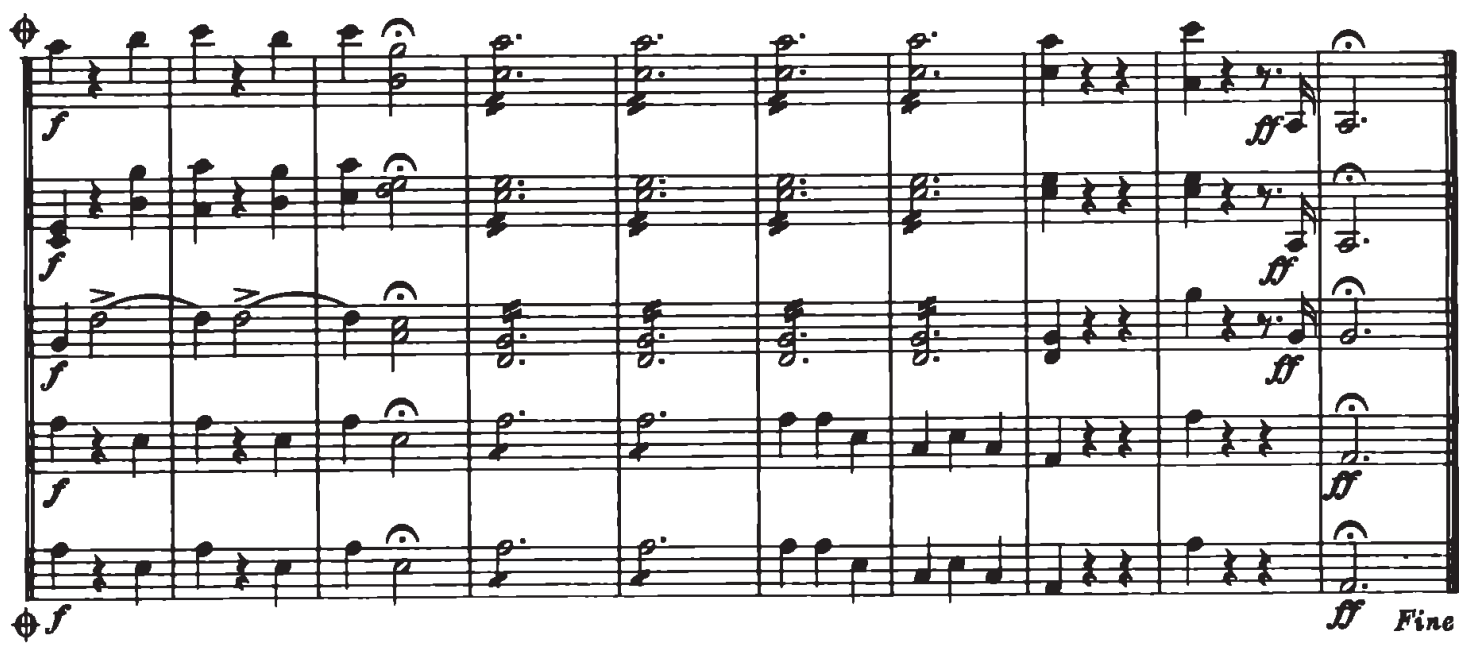


Coda II

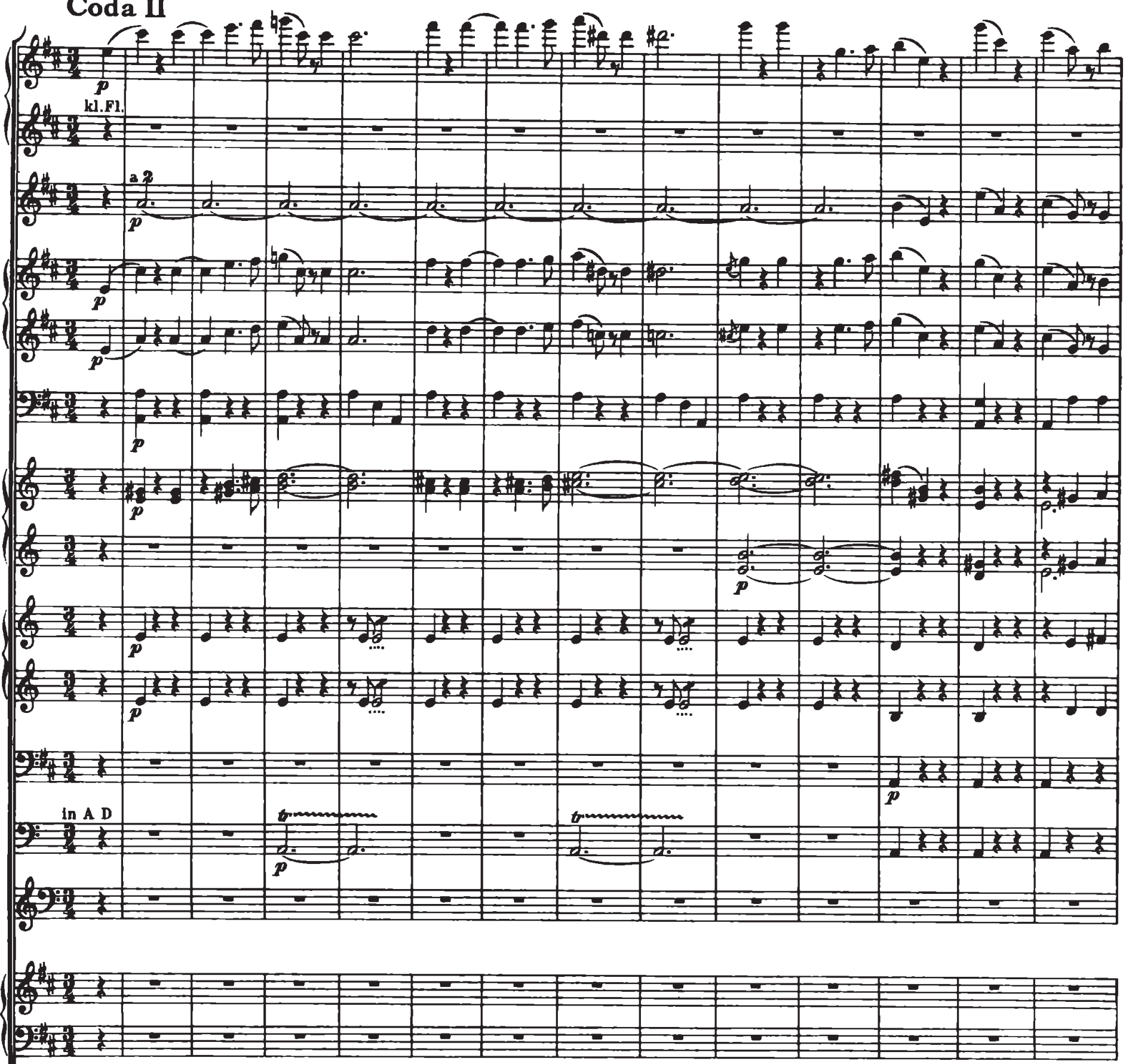

(2)

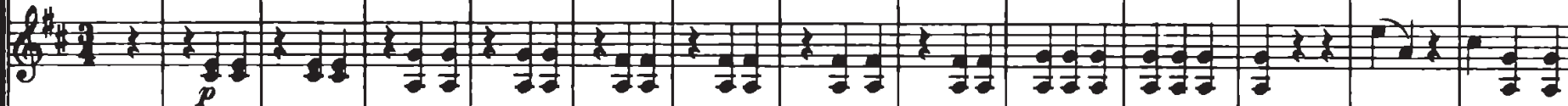

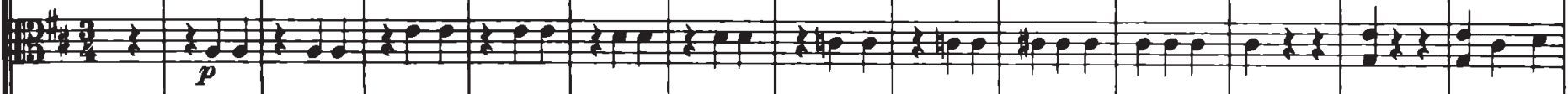

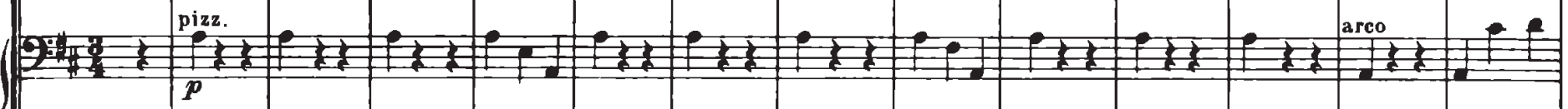

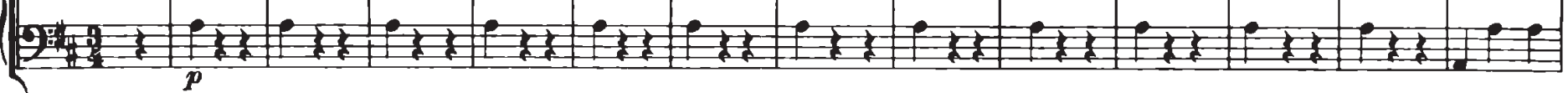




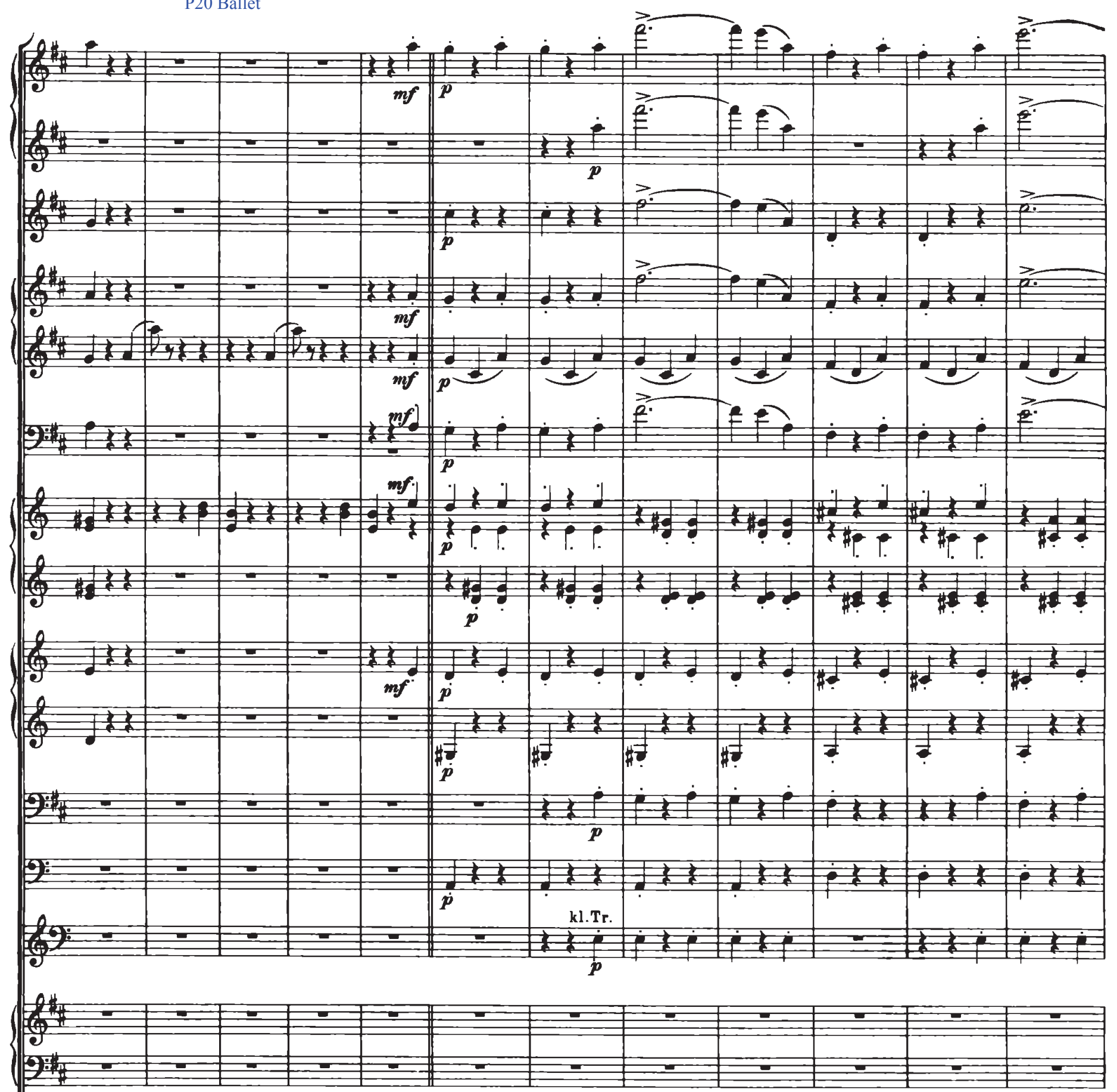

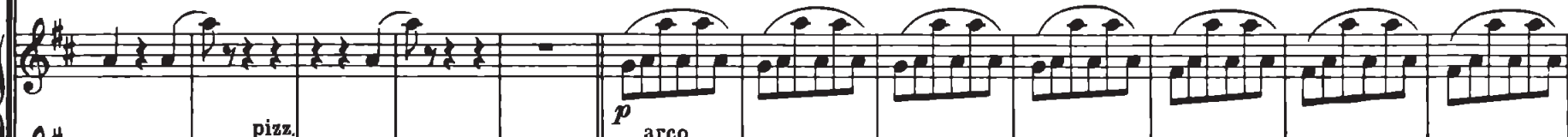

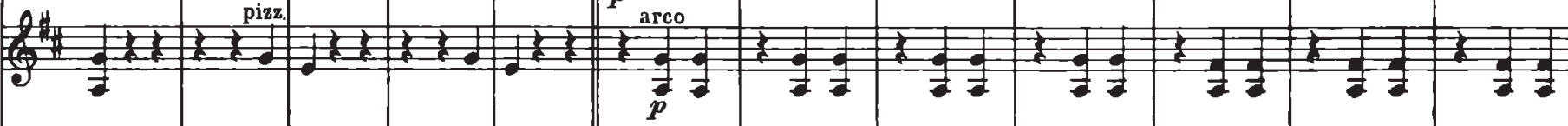
(1) 


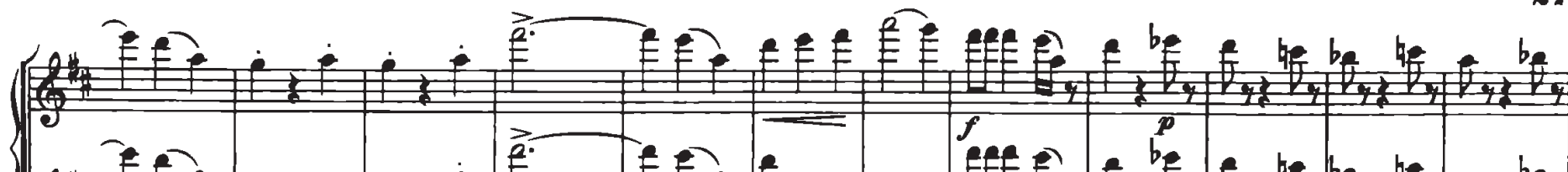

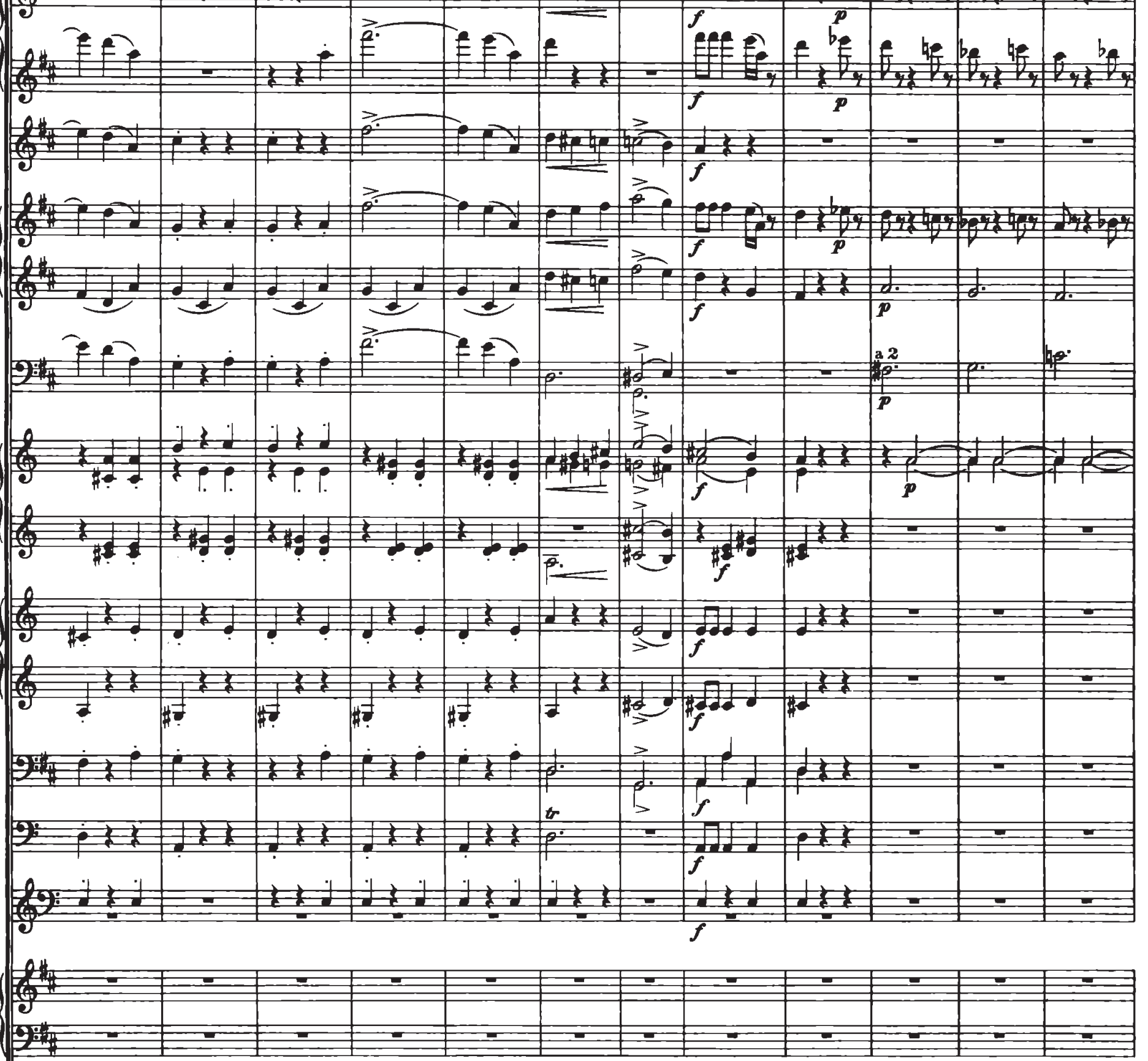

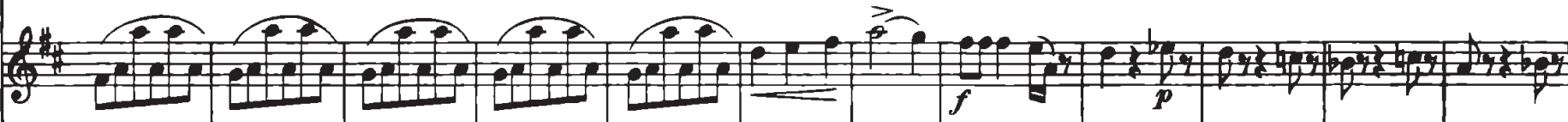

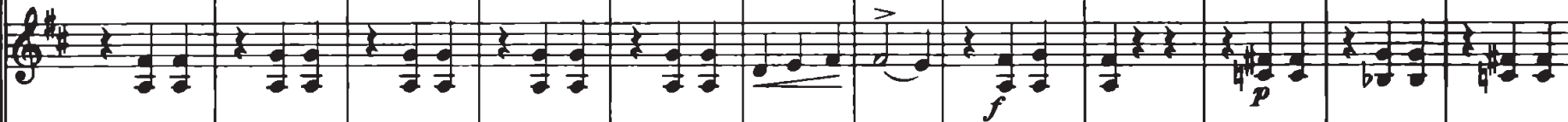

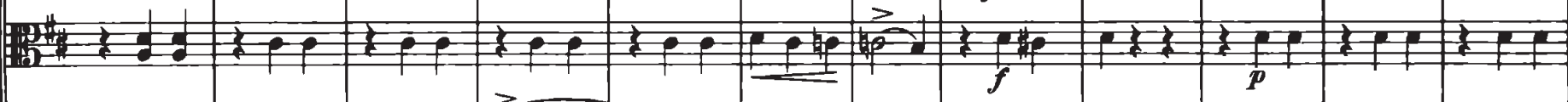

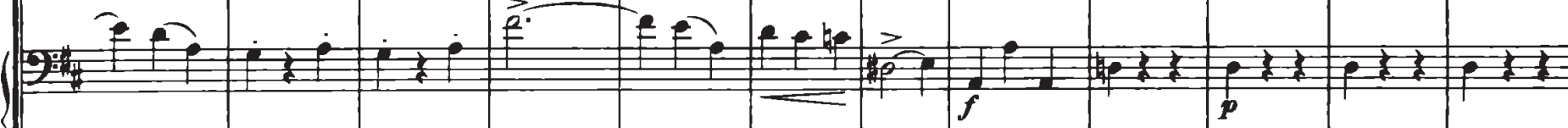

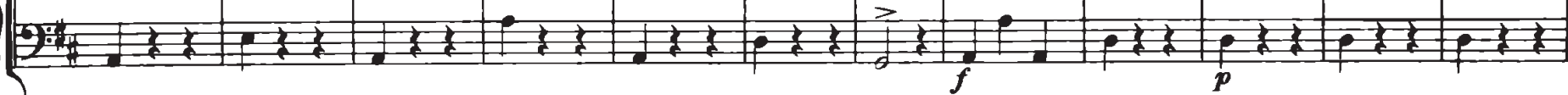




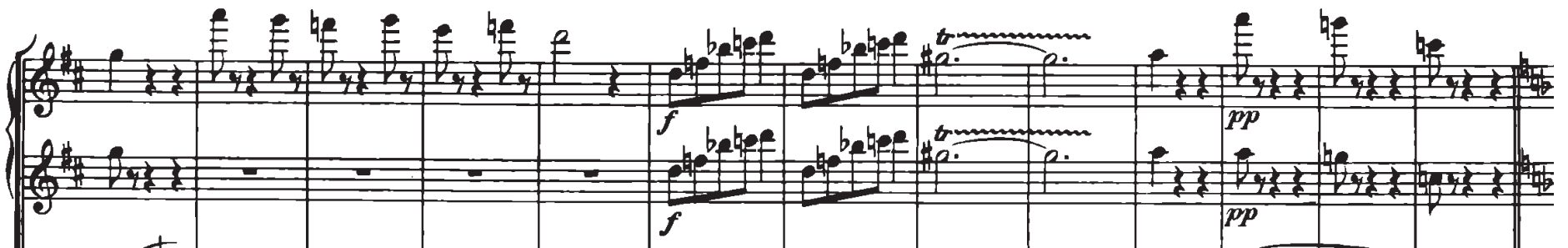
2.

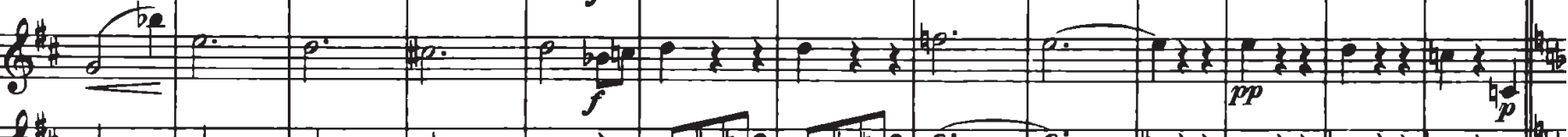

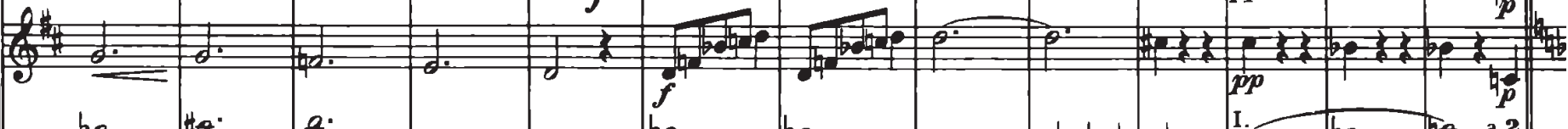
3. be.

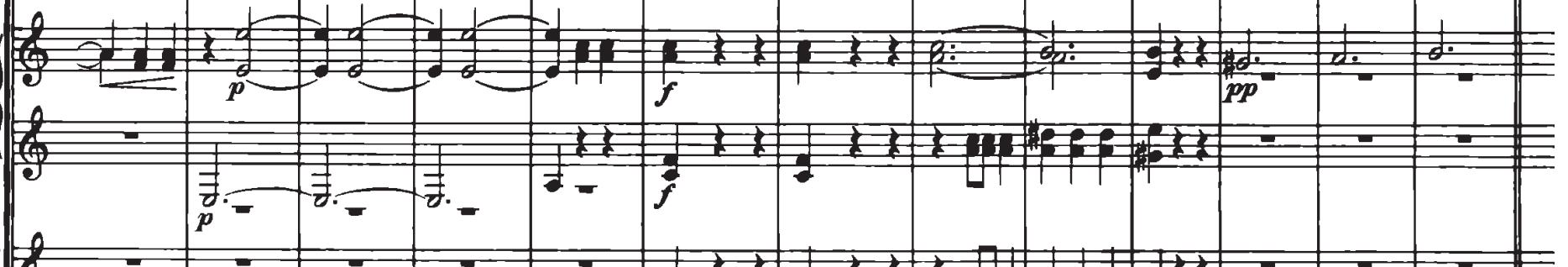

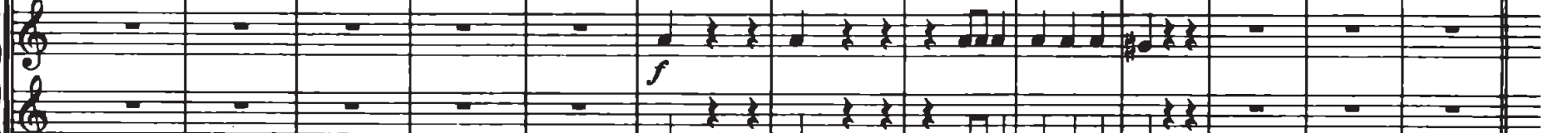

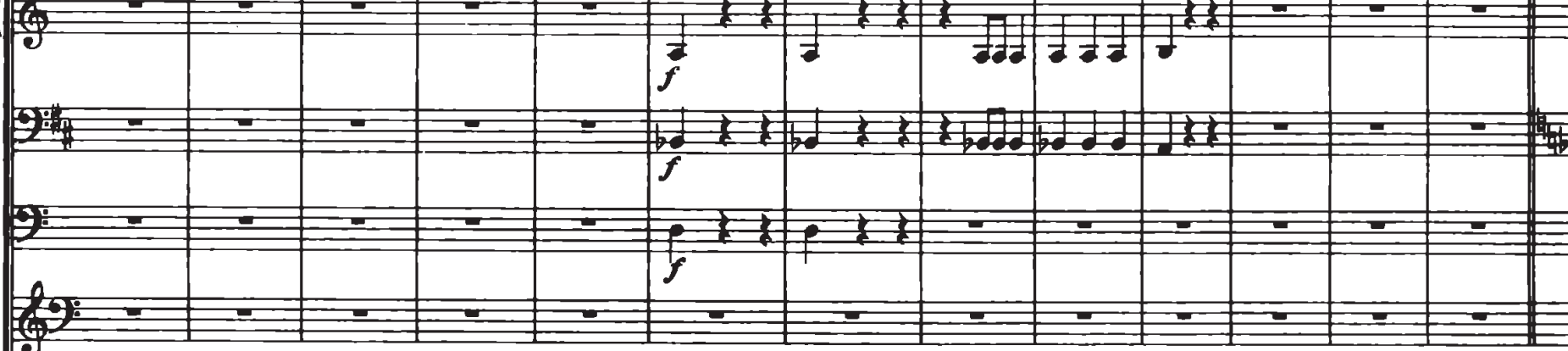

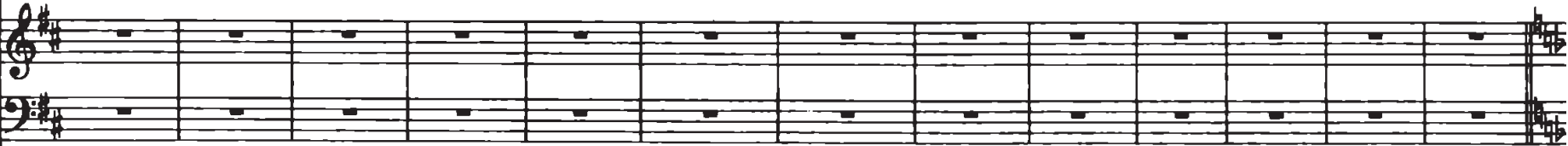

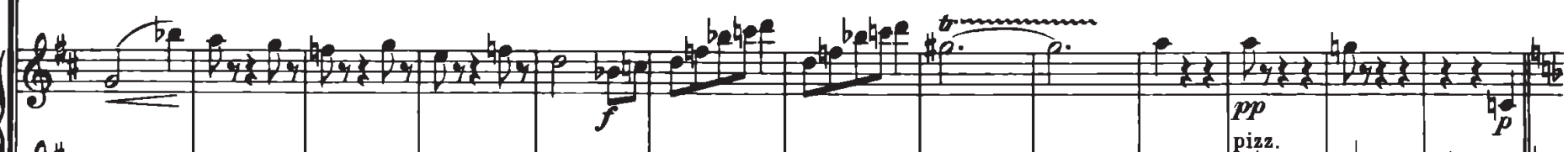

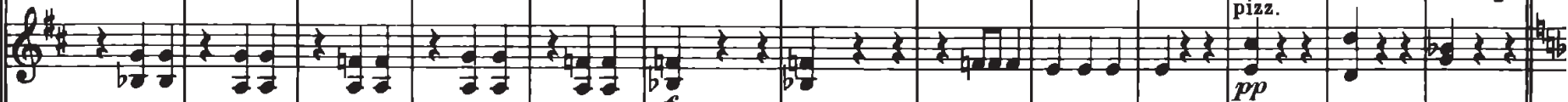
(1)

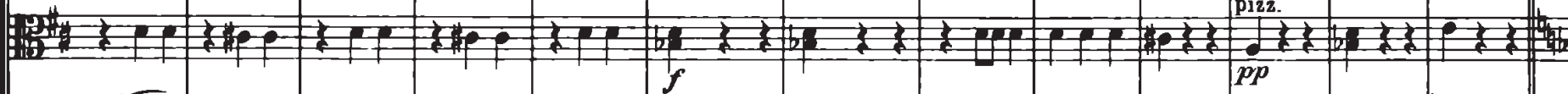

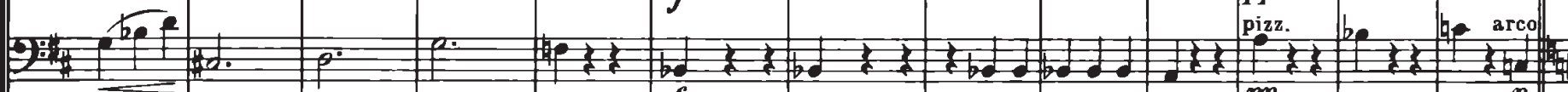

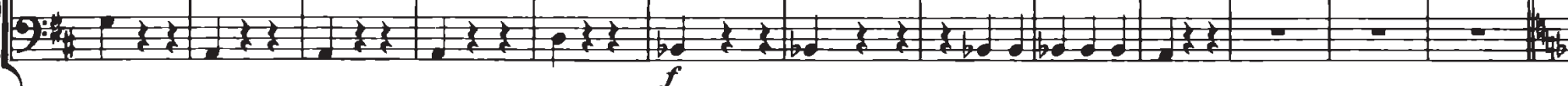




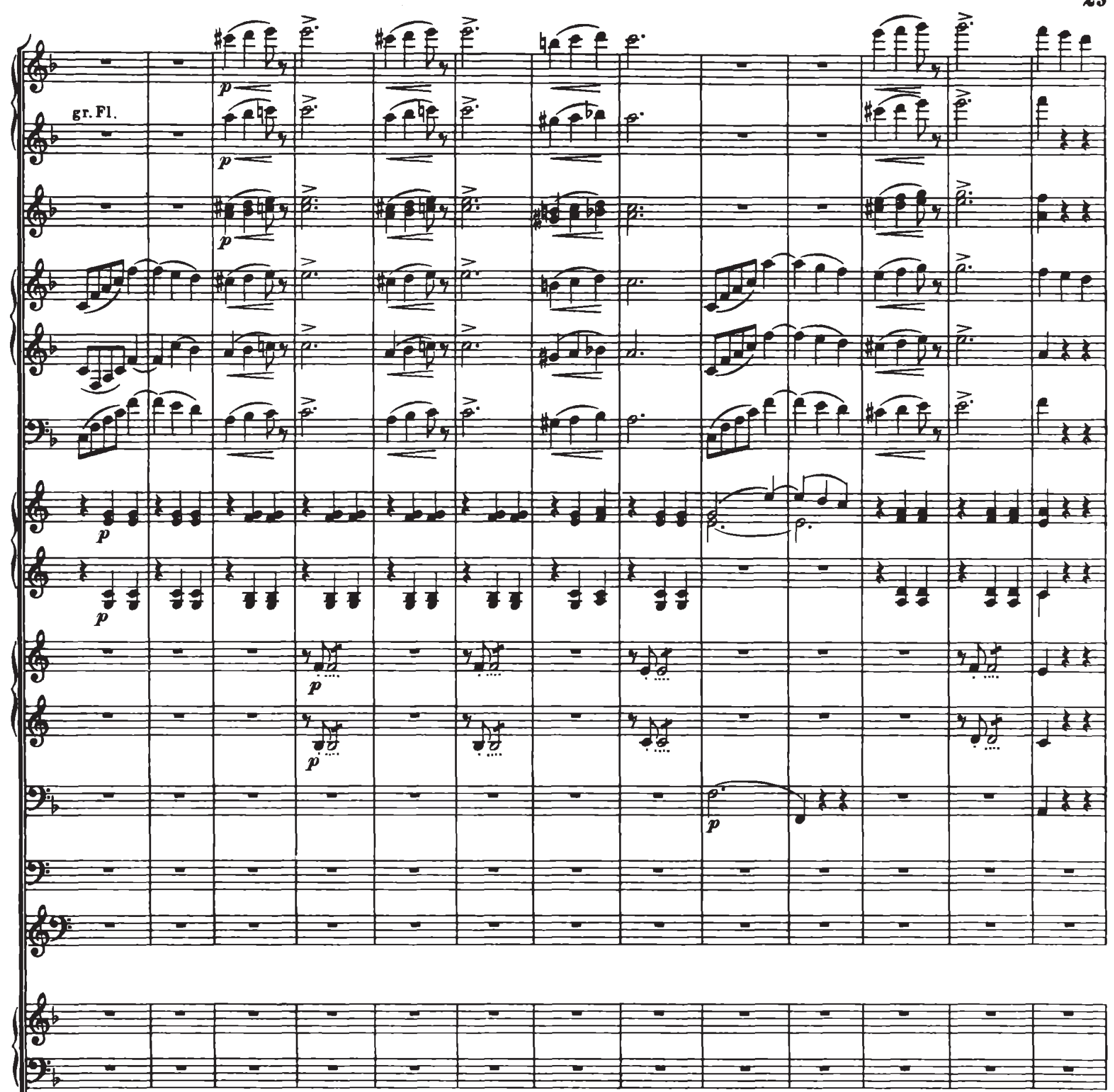

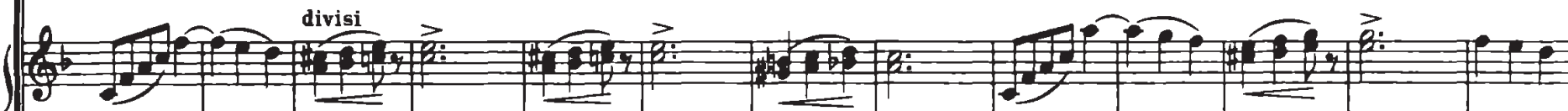

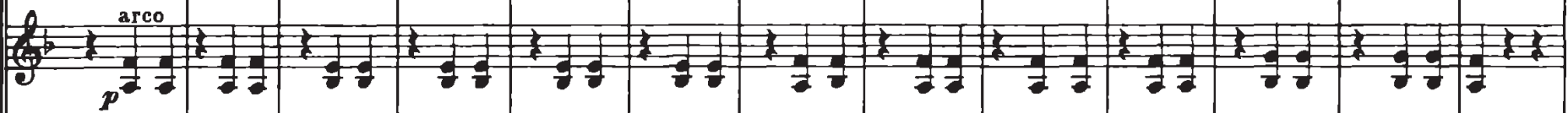

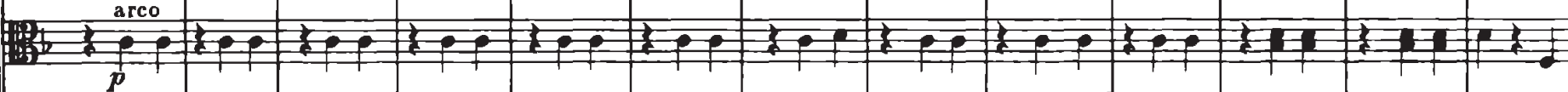

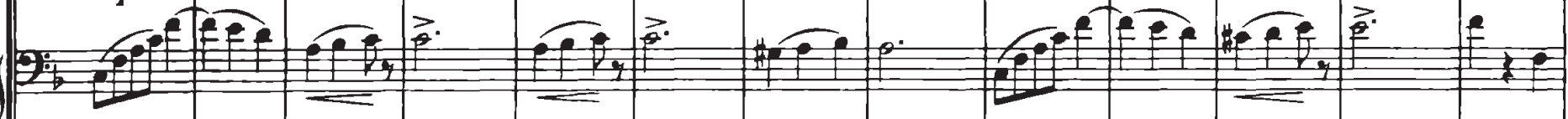

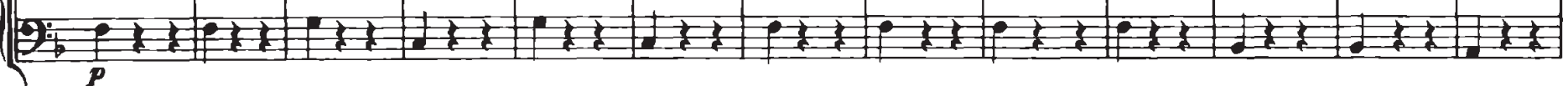



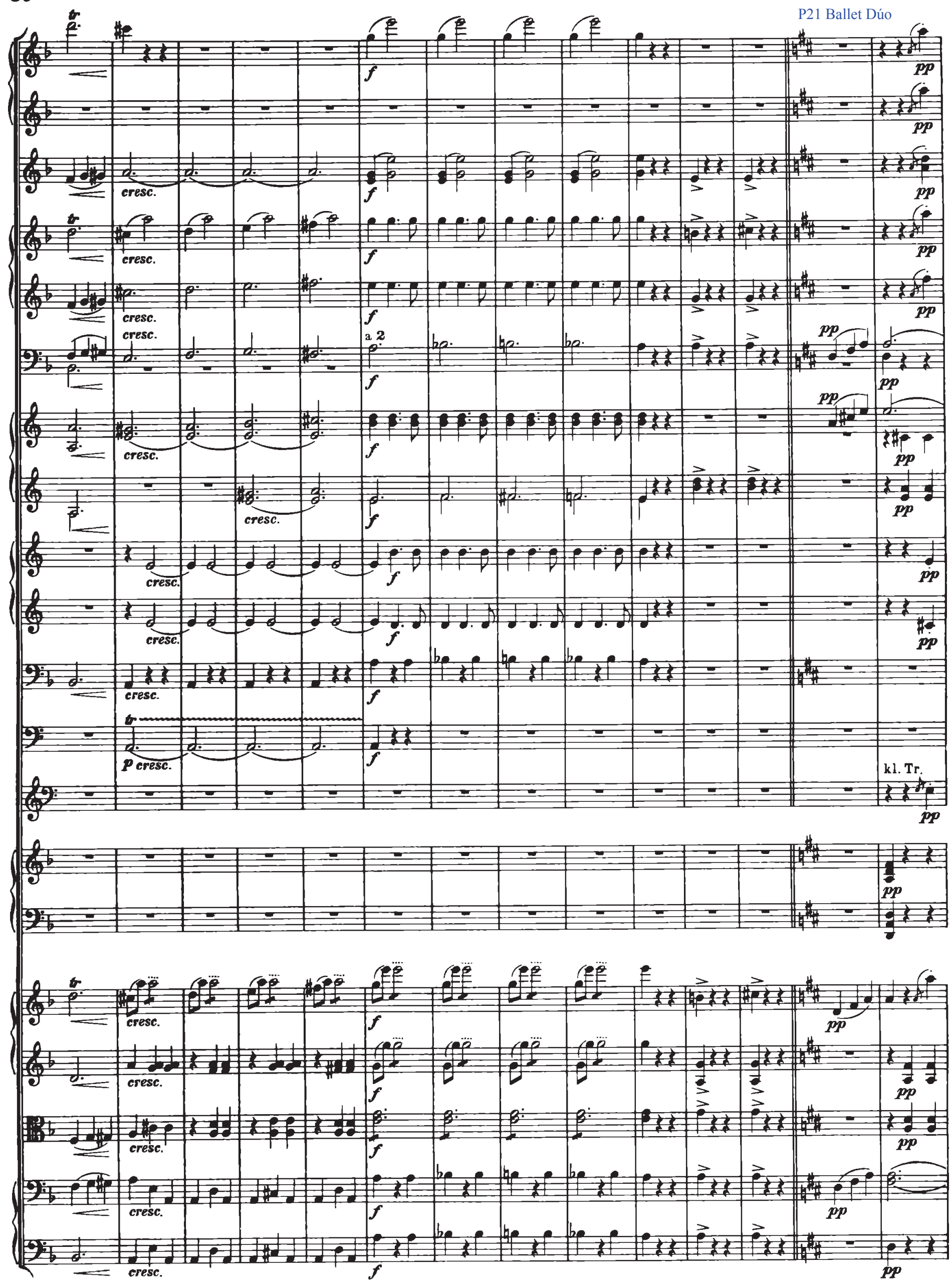


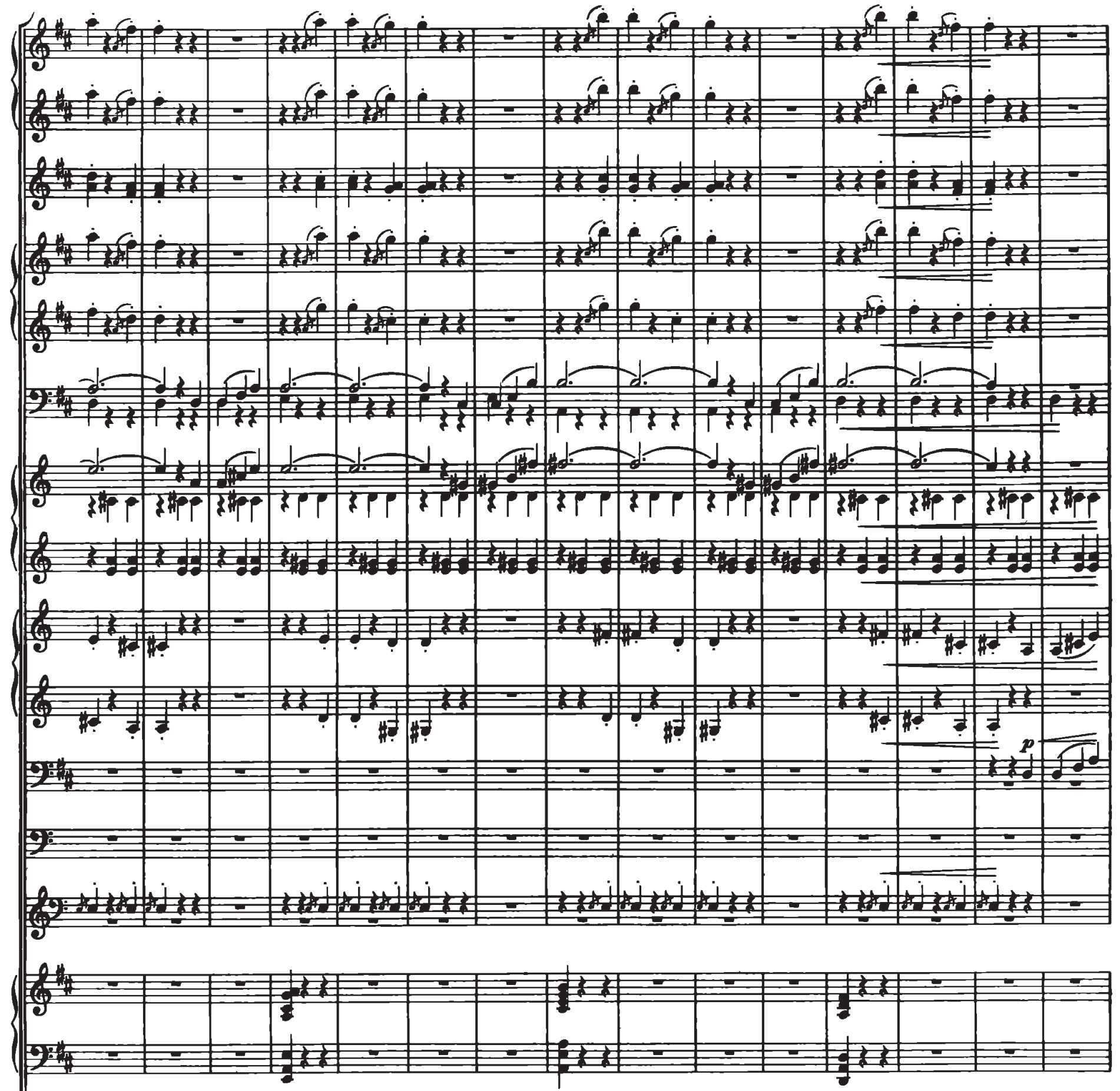

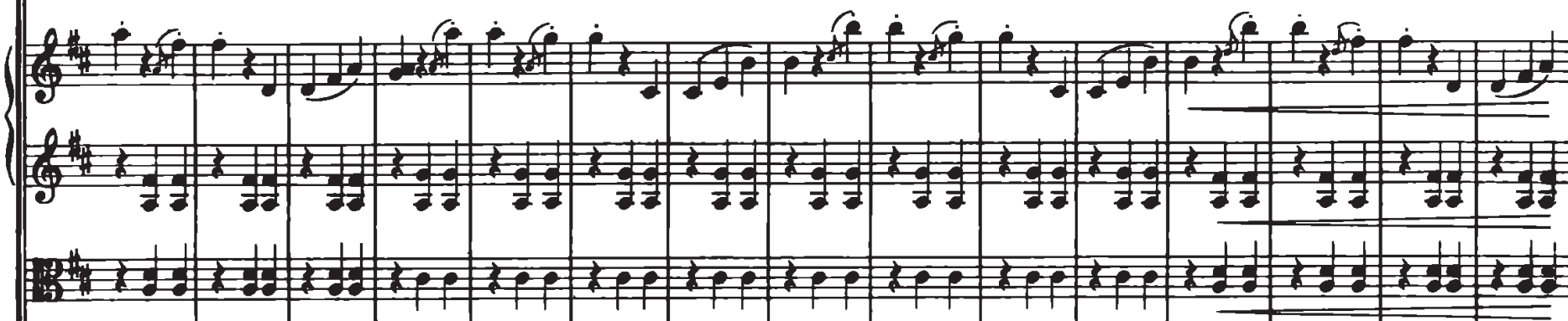
(2) 9 \%

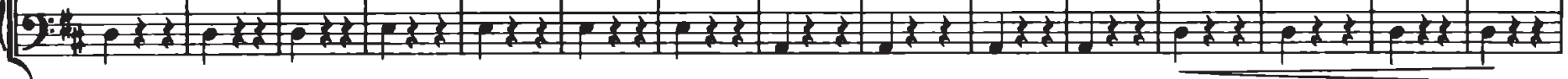


32

$\left(\int^{2}\right.$

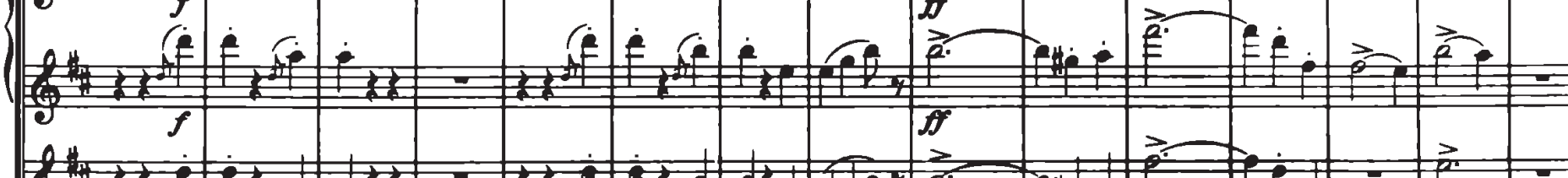
(1)

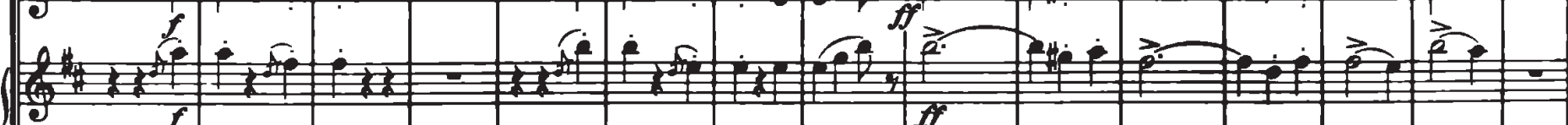

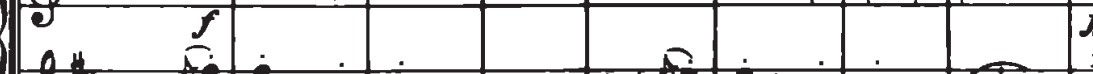

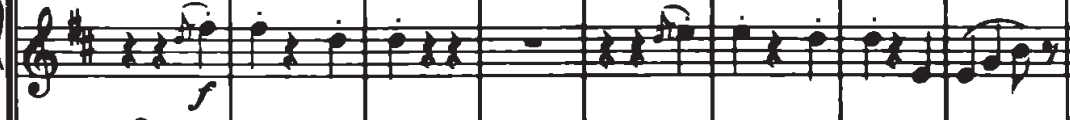

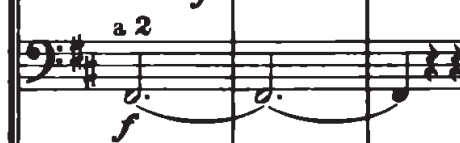

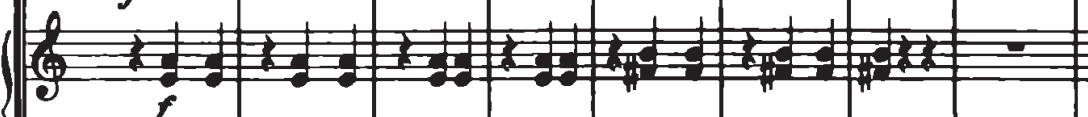
2 (1)

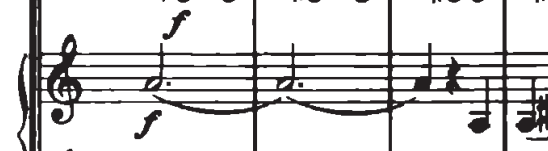

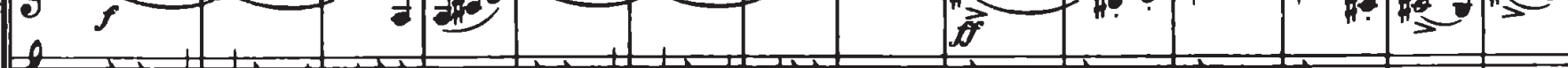

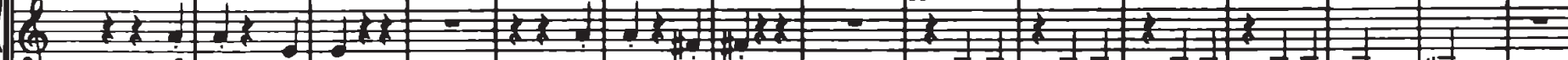
Pos. d.

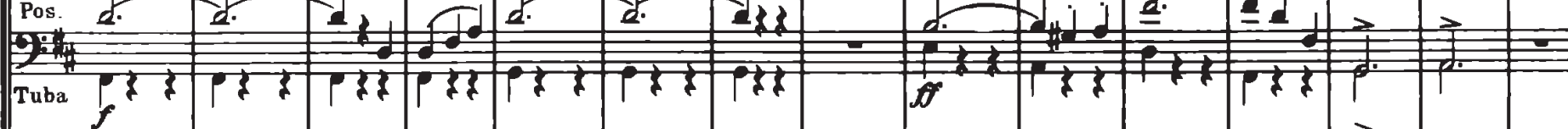

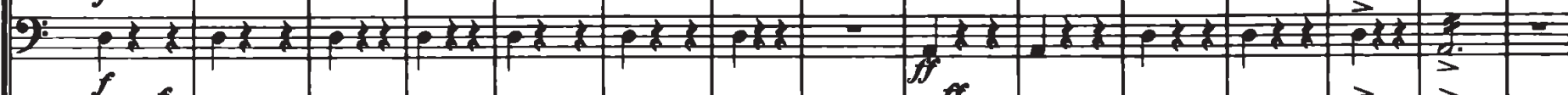

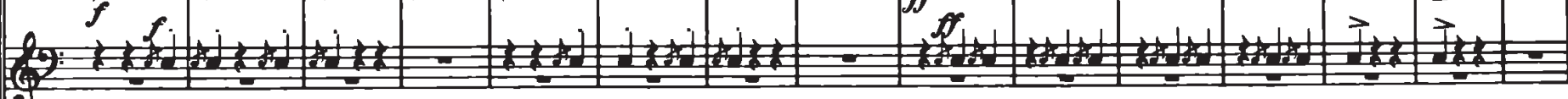
-

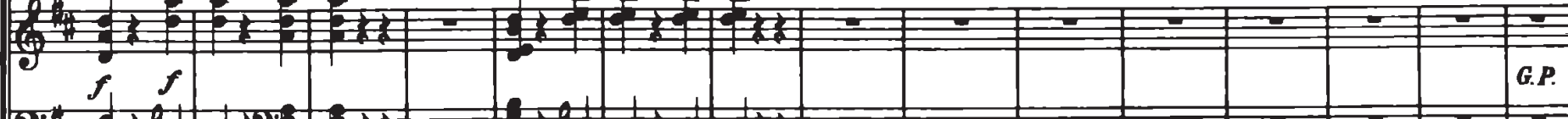

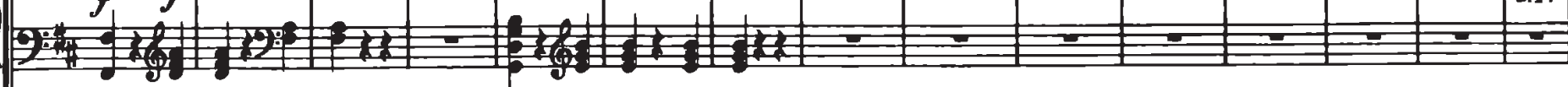

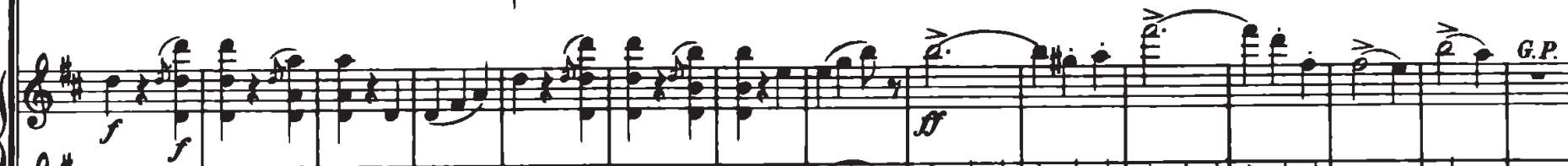

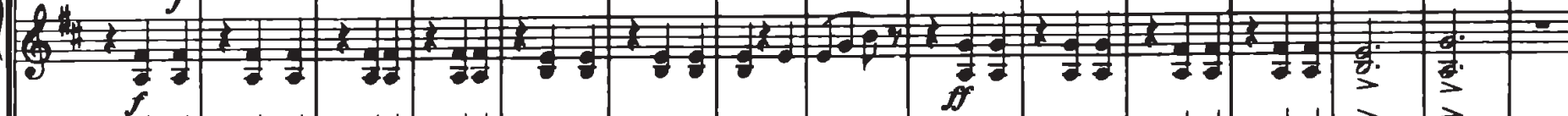
(1)

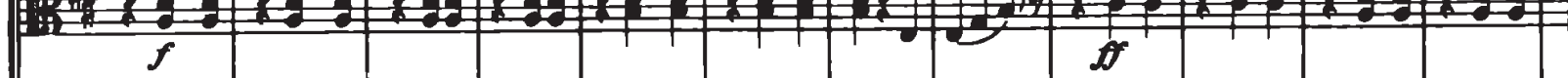

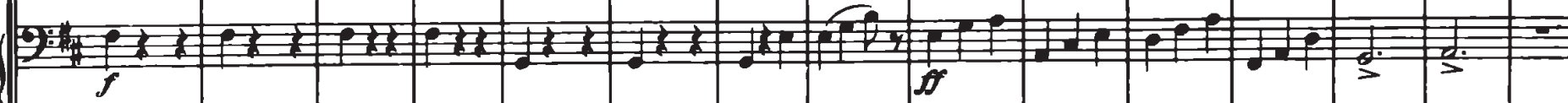

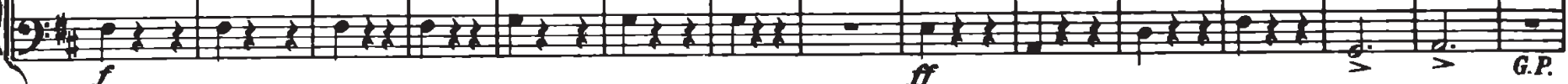



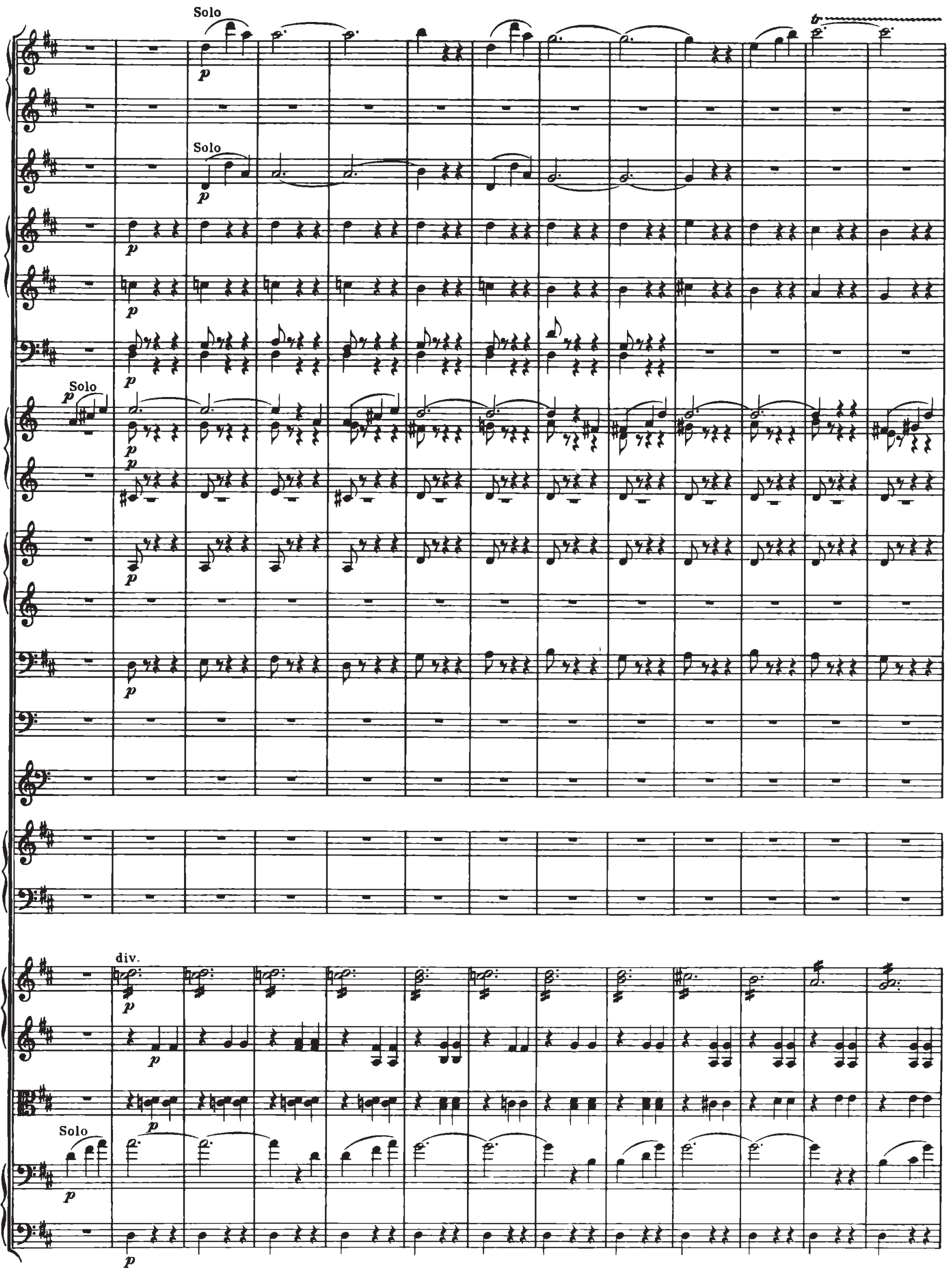

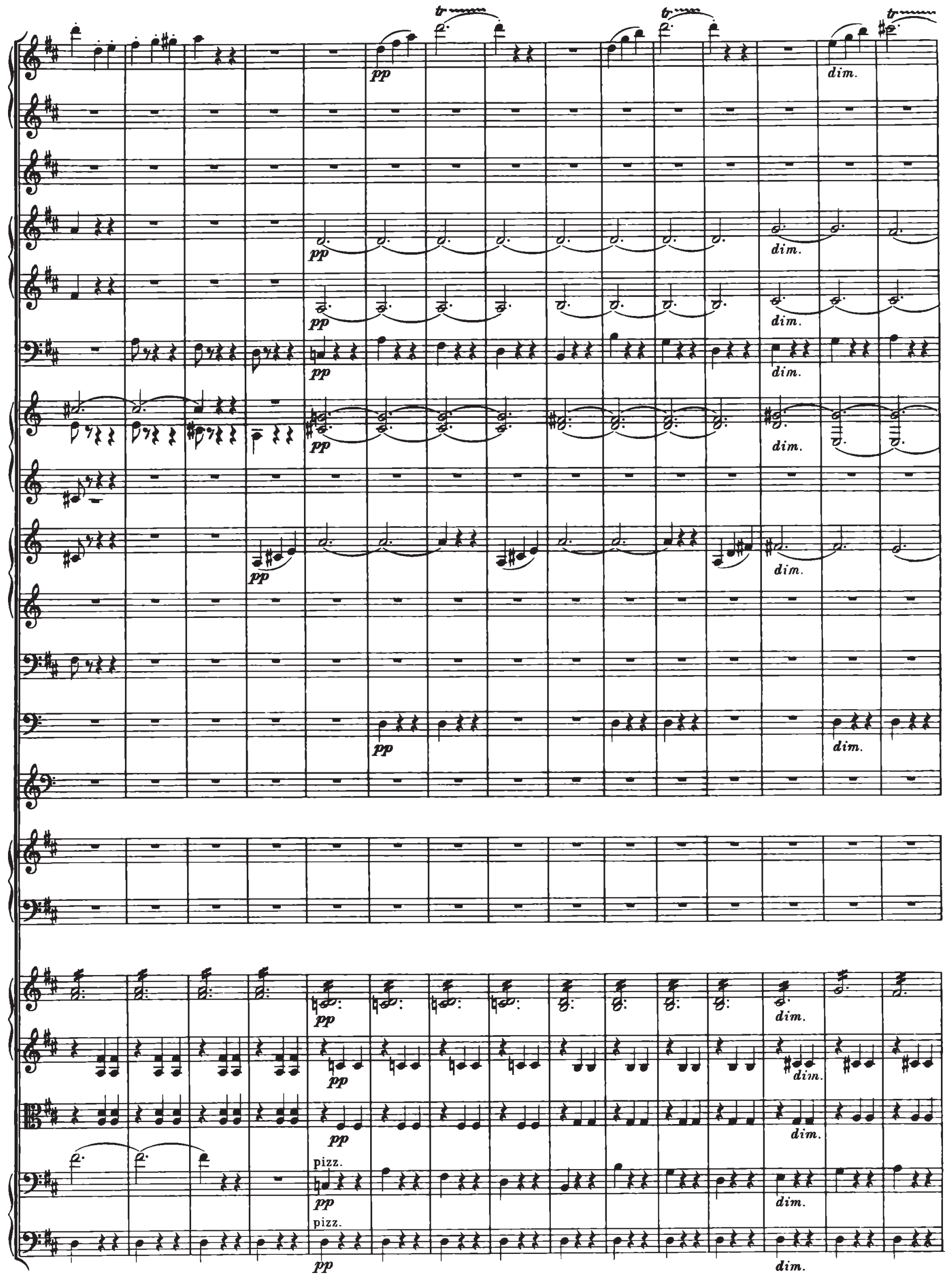


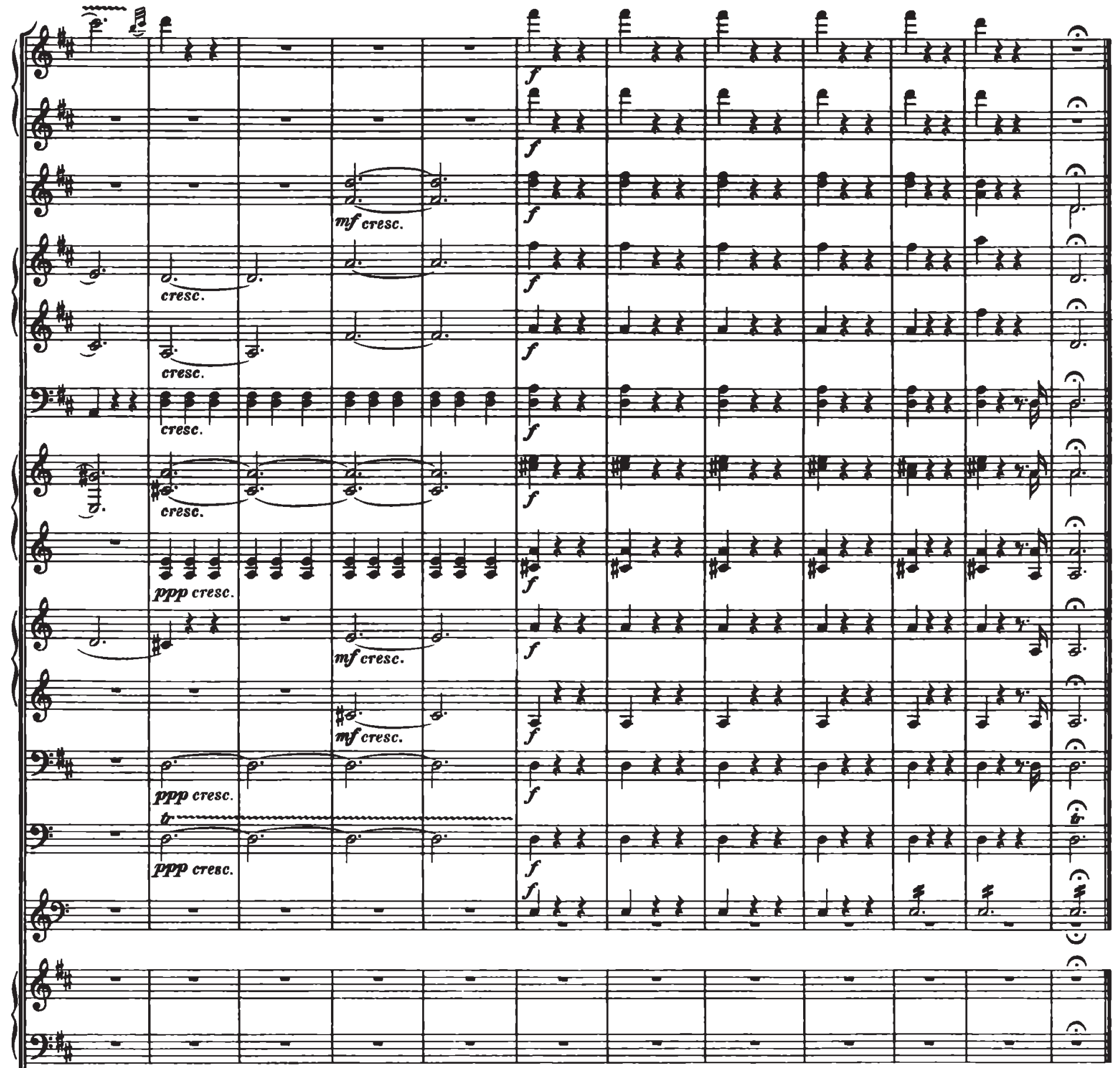

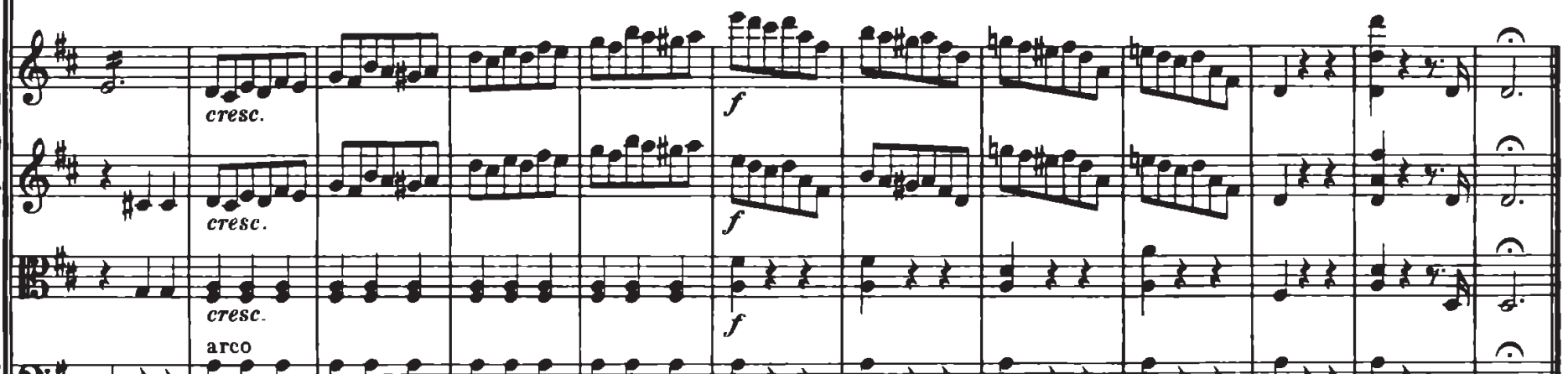

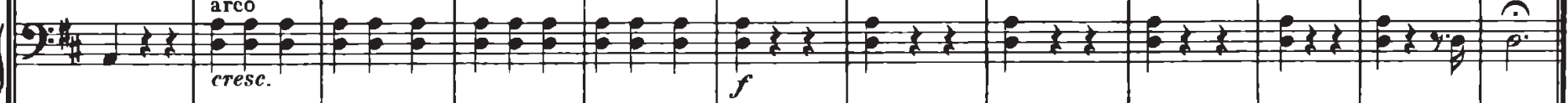
(|l: 
2

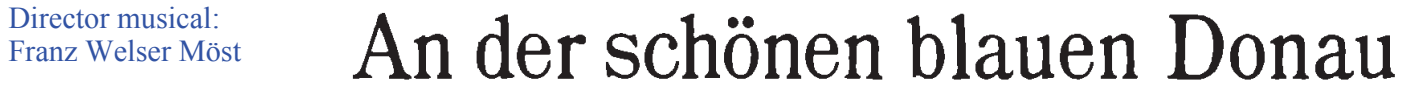

Director audiovisual:

Karina Fibich

P3 P4 Exterior

Walzer

P1 y P2 Introduktion

Johann StrauB, op. 314

Flöte I

Flöte II

Kleine Flöte

Oboen

Klarinetten in C

I

Fagotte

I II

Hörner in $\mathrm{F}$

III IV

Trompeten in $\mathrm{F}$

Baß-Posaune

Tuba

Pauken

Kleine Trommel

Triangel u.

große Trommel

Harfe

II
Andantino

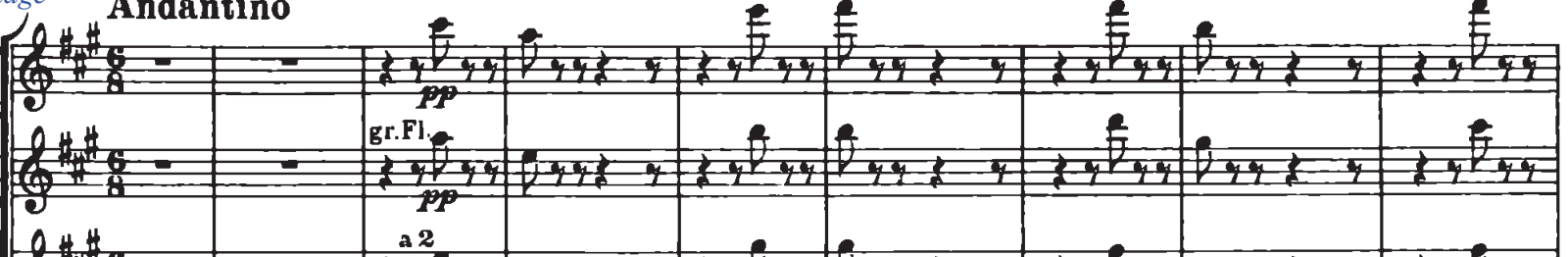

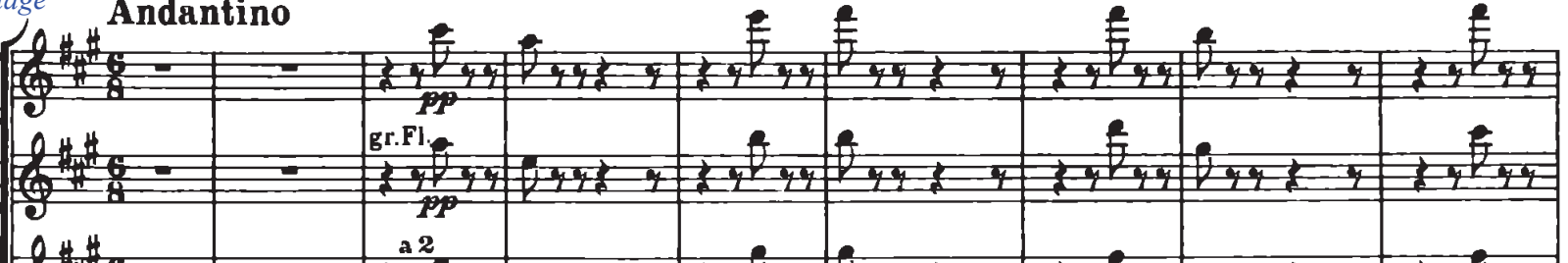

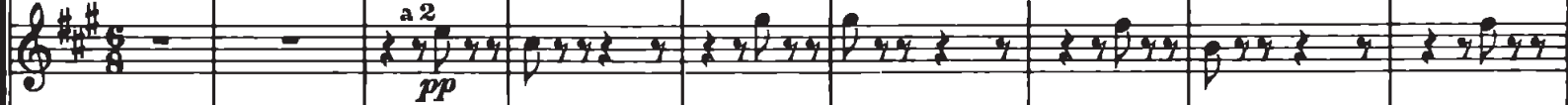
64:-

II

$2+6$
0

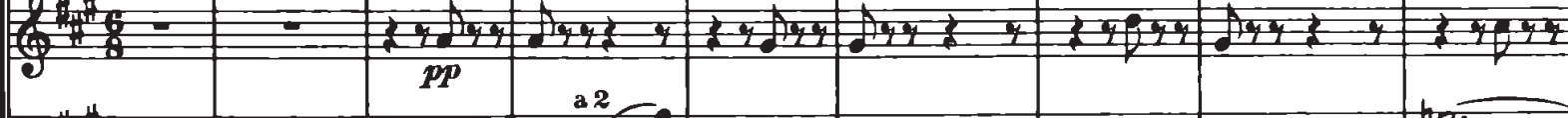
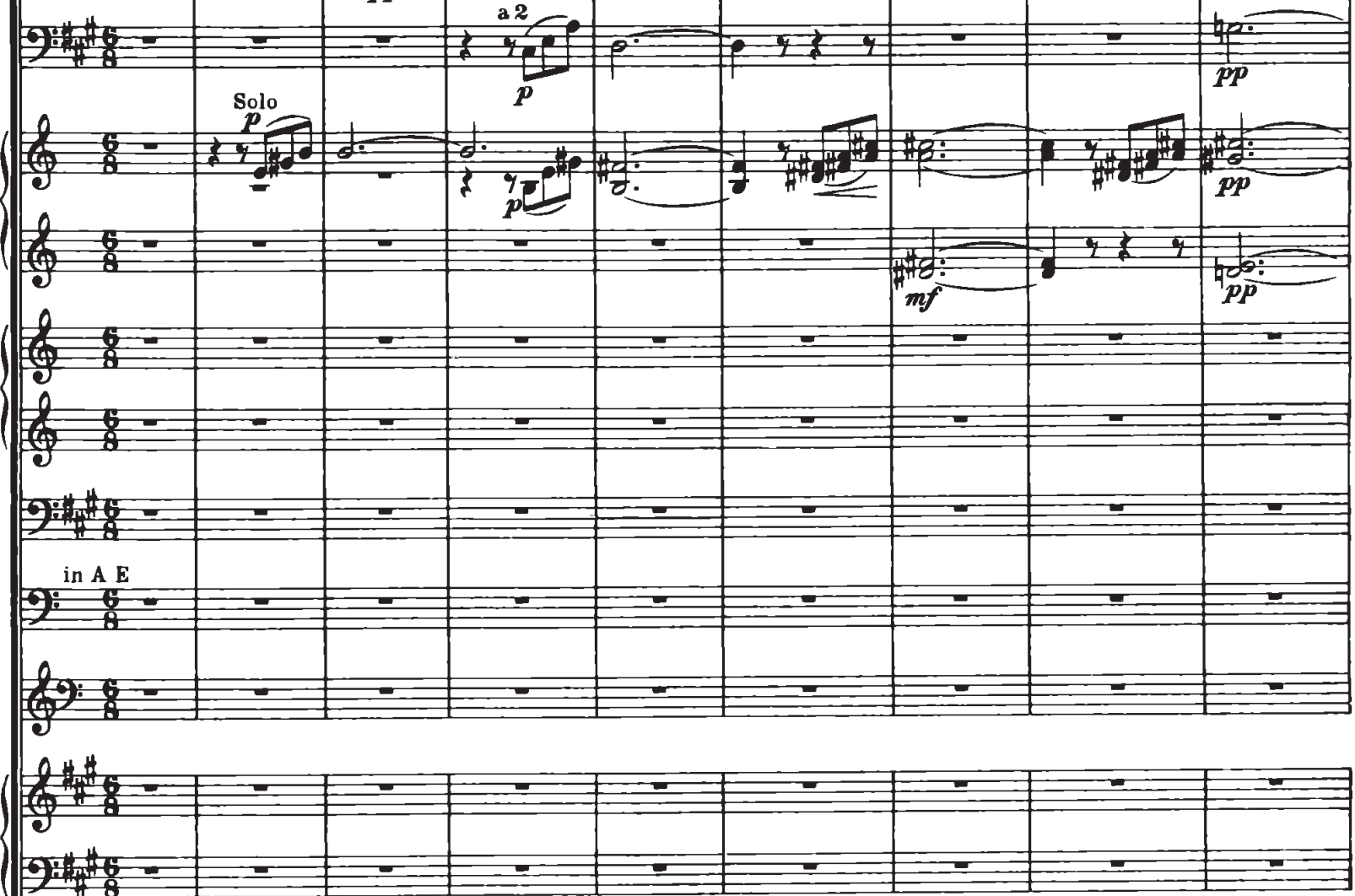

Andantino

Violine I

Violine II

Viola

Violoncello

Kontraba $\beta$

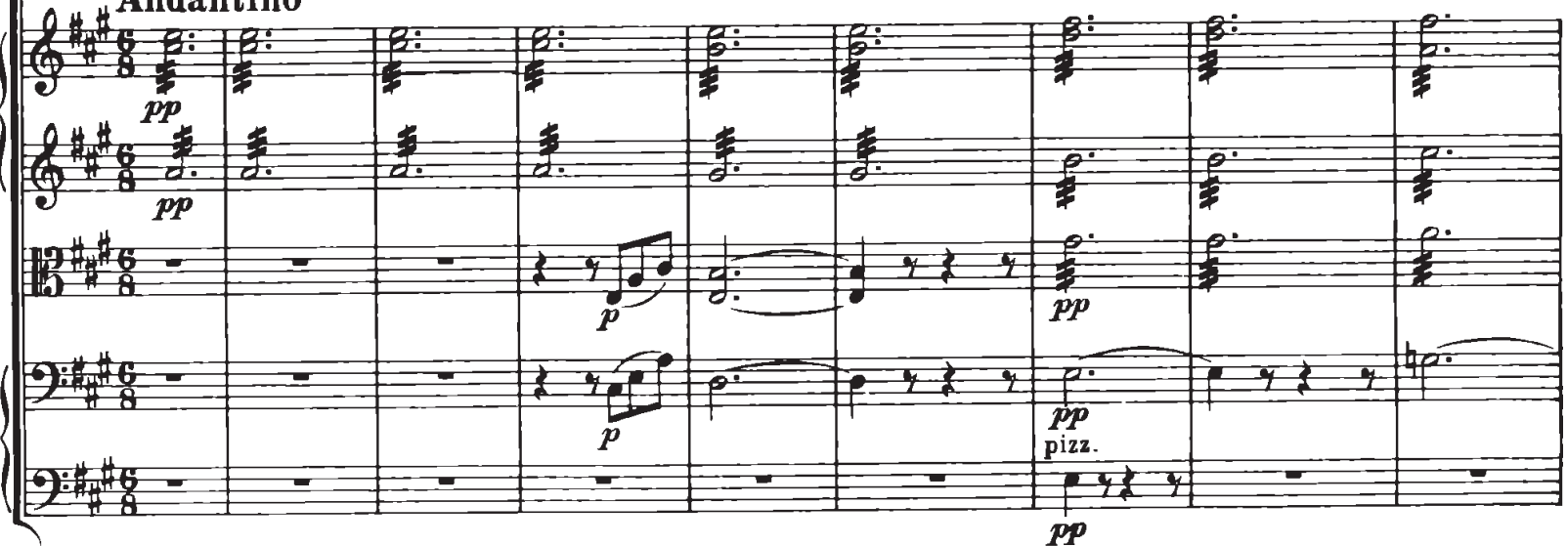


(4) (3) + 201.

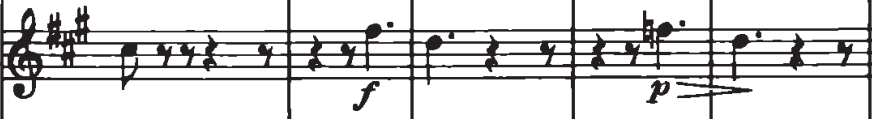

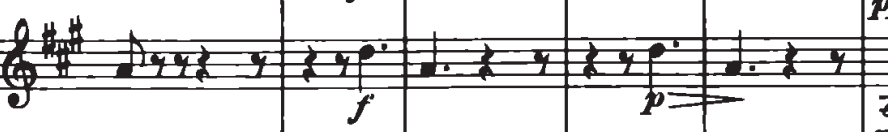

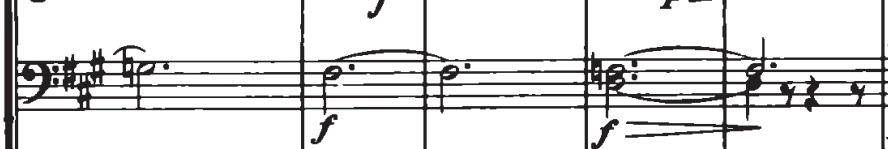
(2)

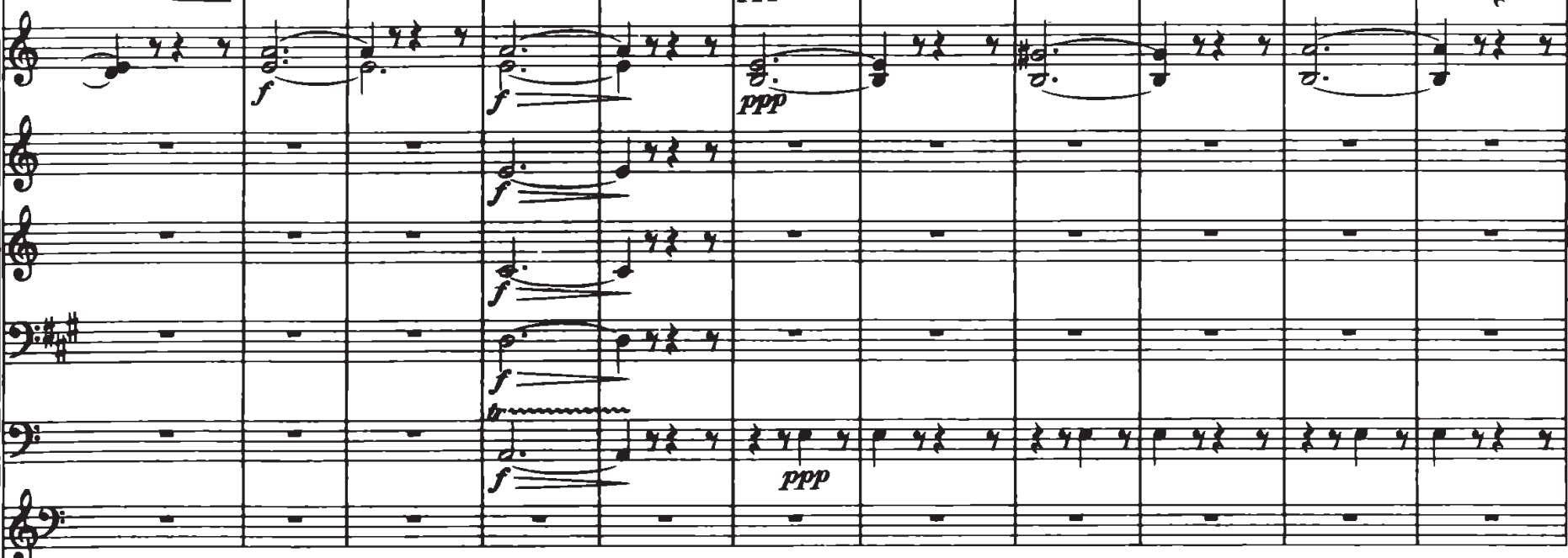
\begin{tabular}{|l|l|l|l|l|l|l|l|l|l|l|}
\hline & 0 \\
\hline
\end{tabular}

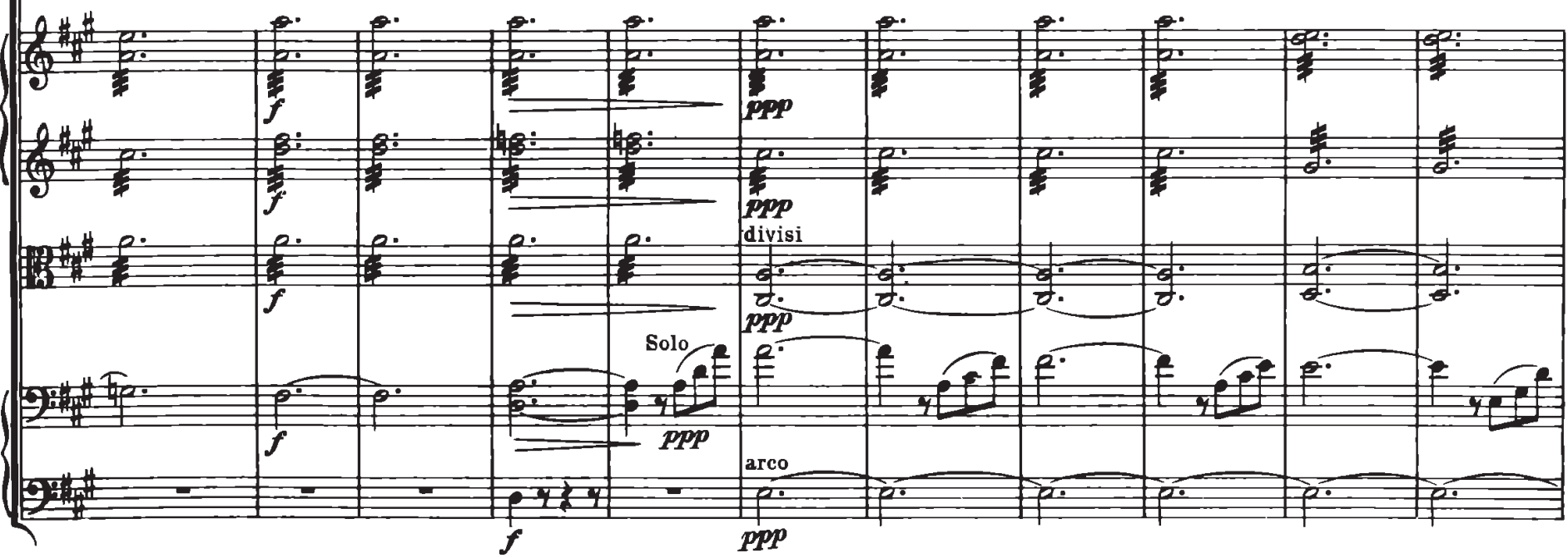


TempodiValse

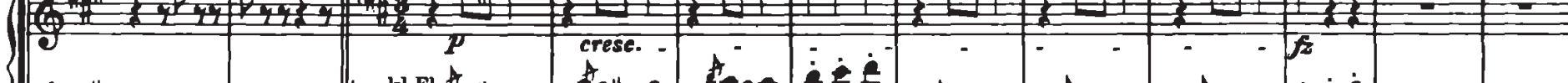

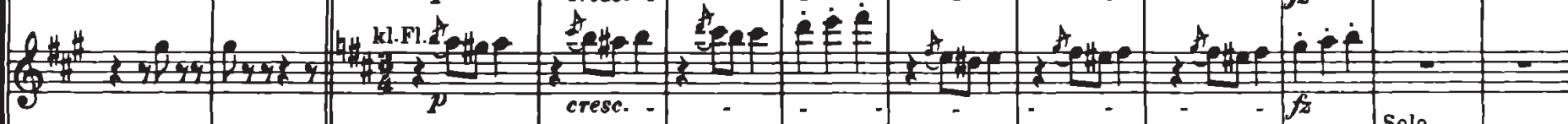

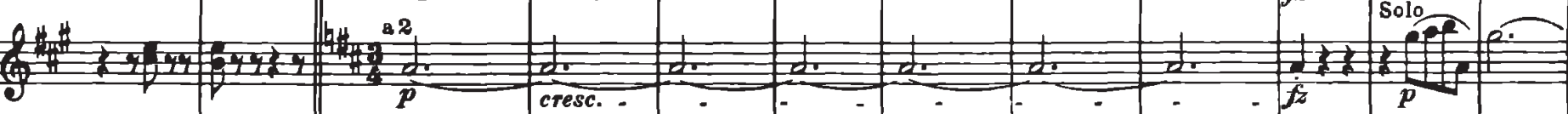

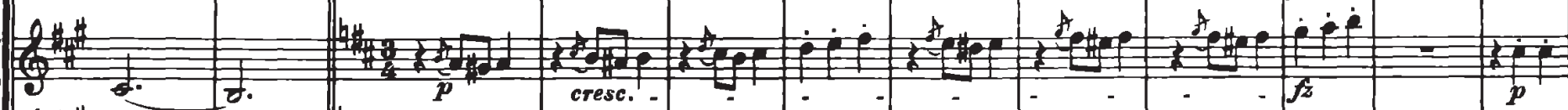

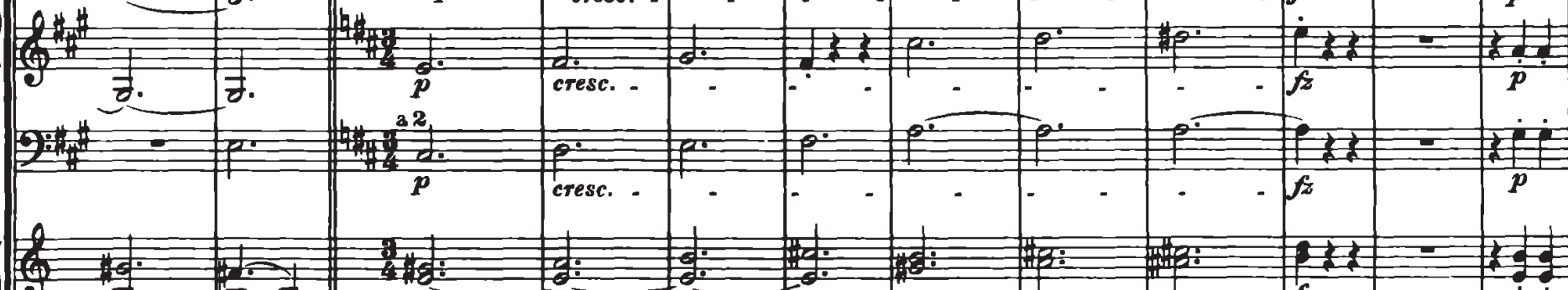

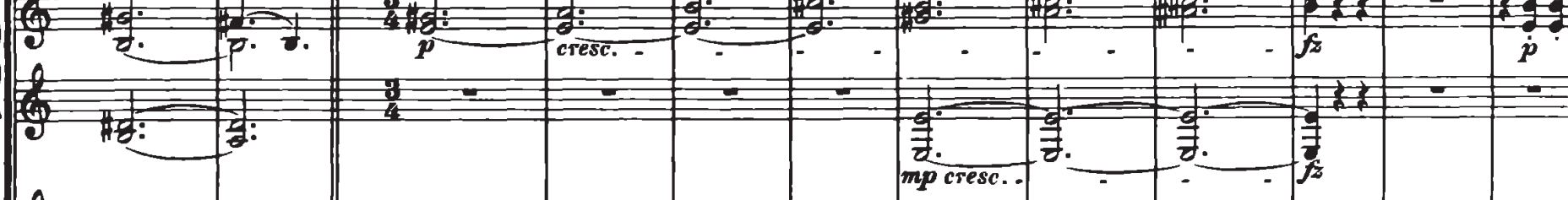

$\left\{\begin{array}{l|l}0 & 0\end{array}\right.$

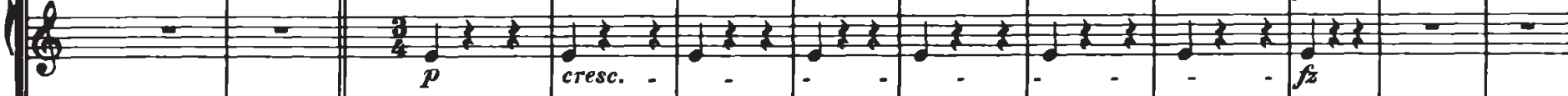
$3+2=0$

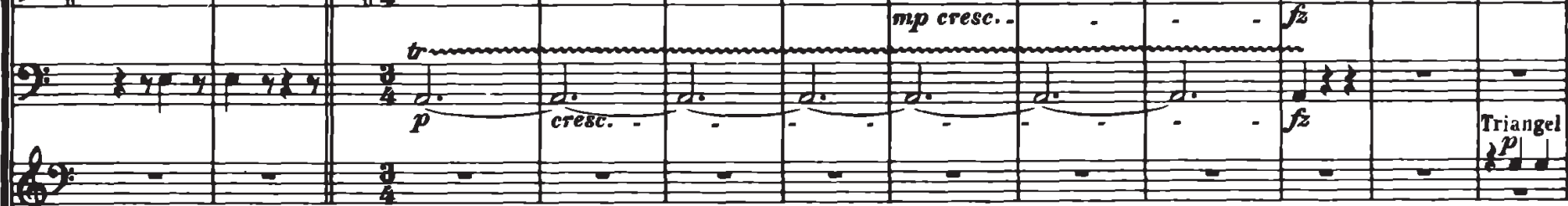

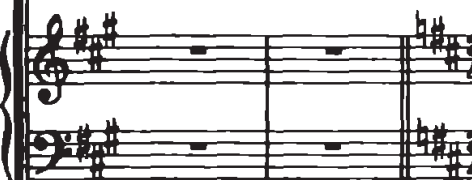

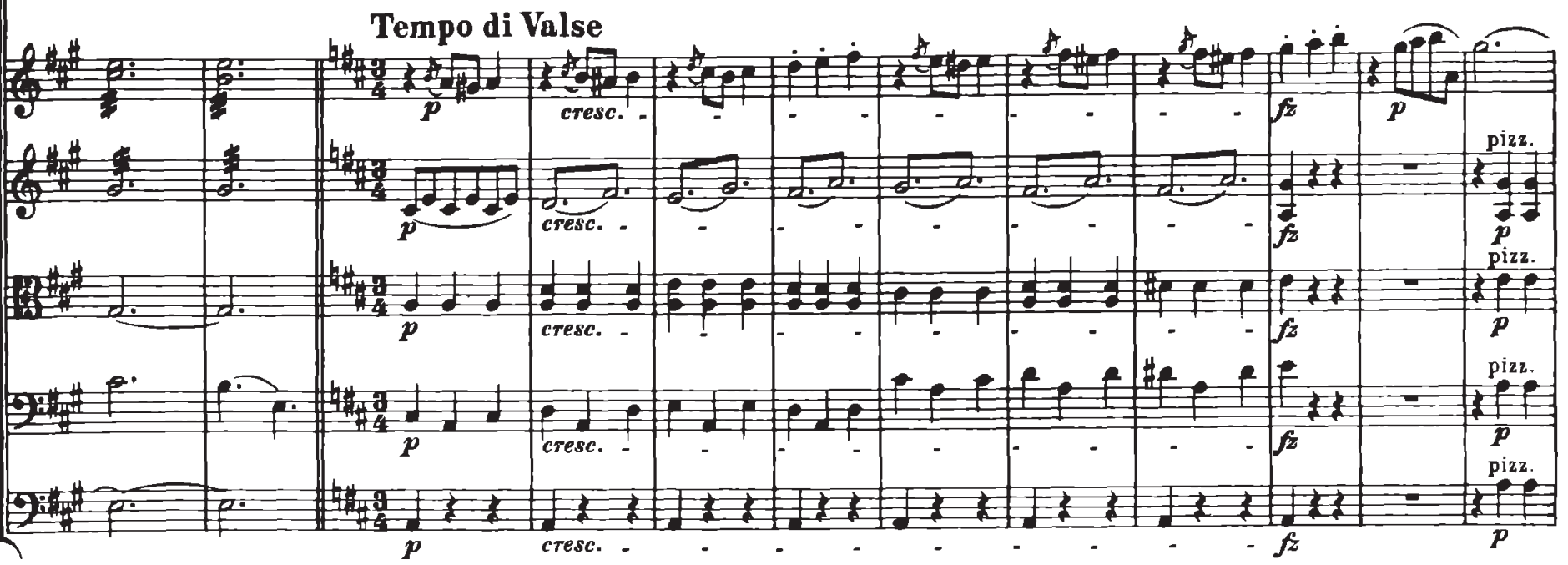




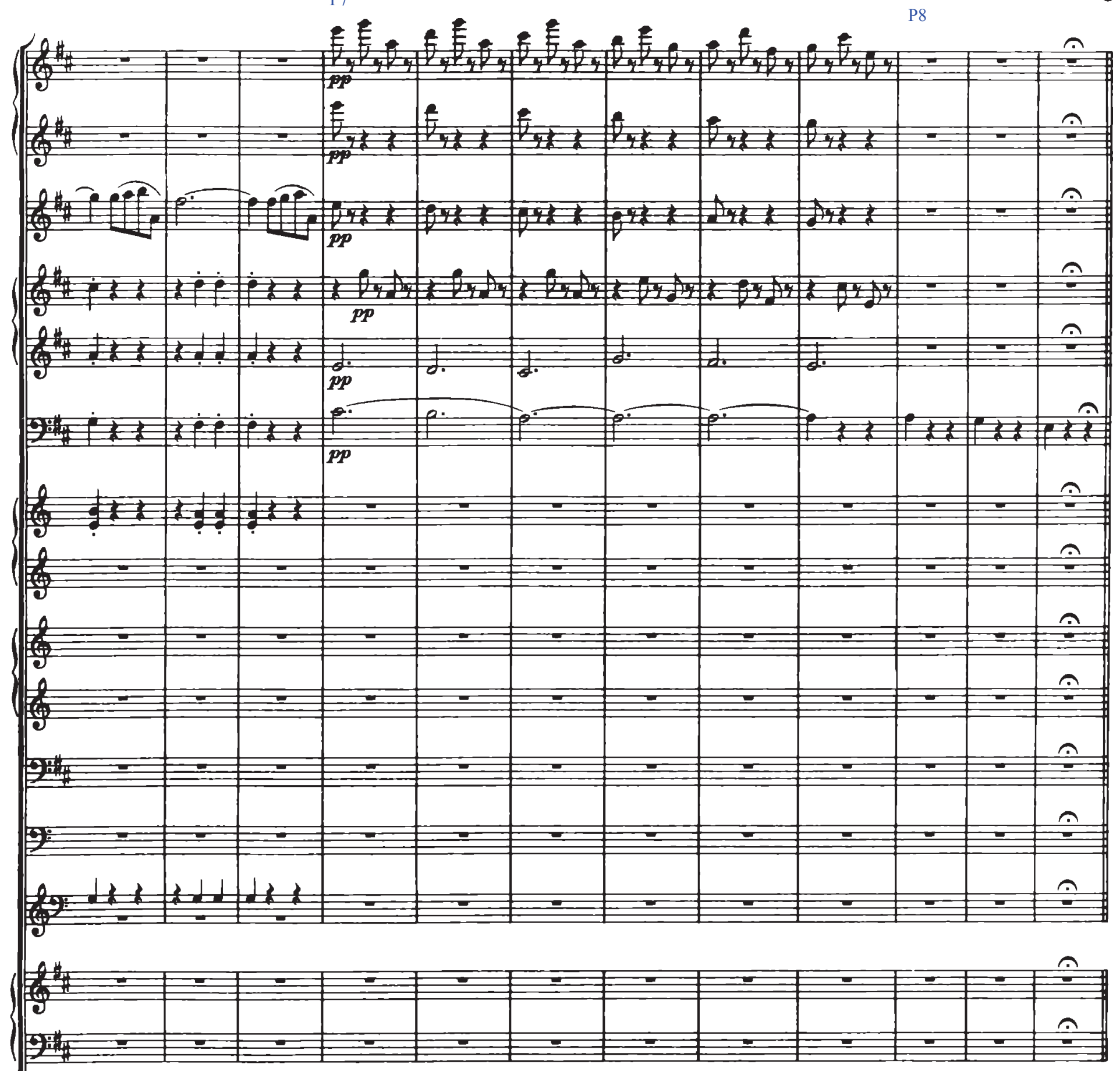

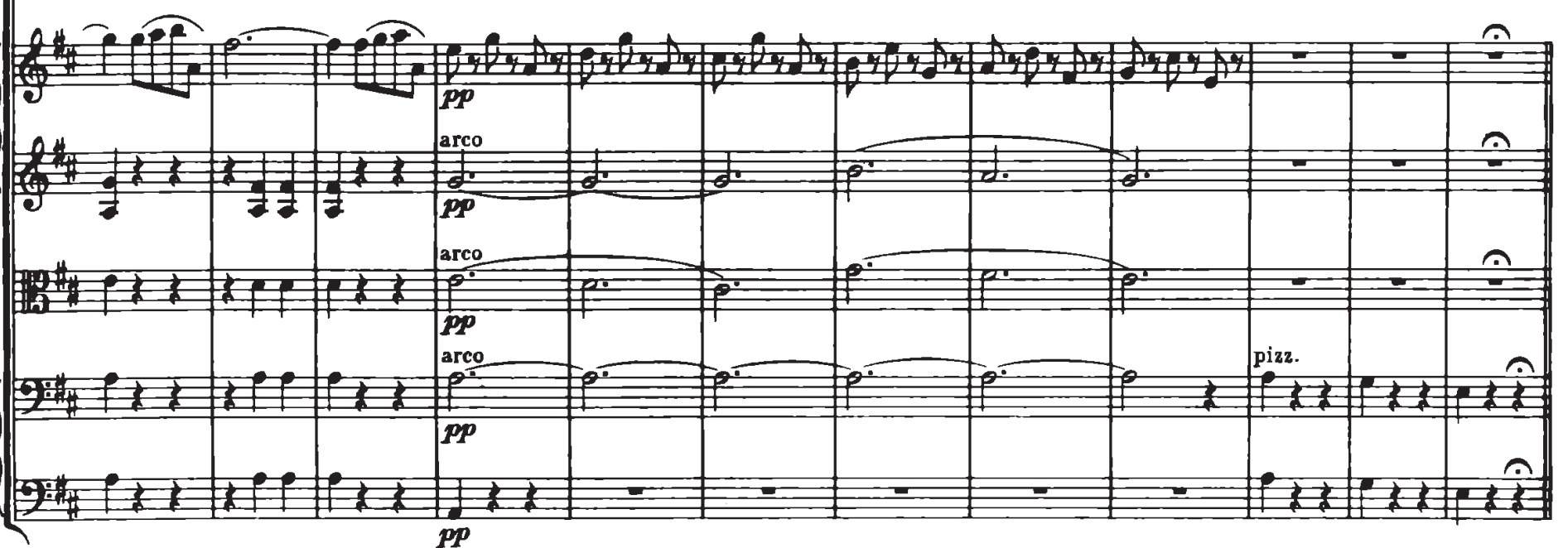


Nr.1 Walzer

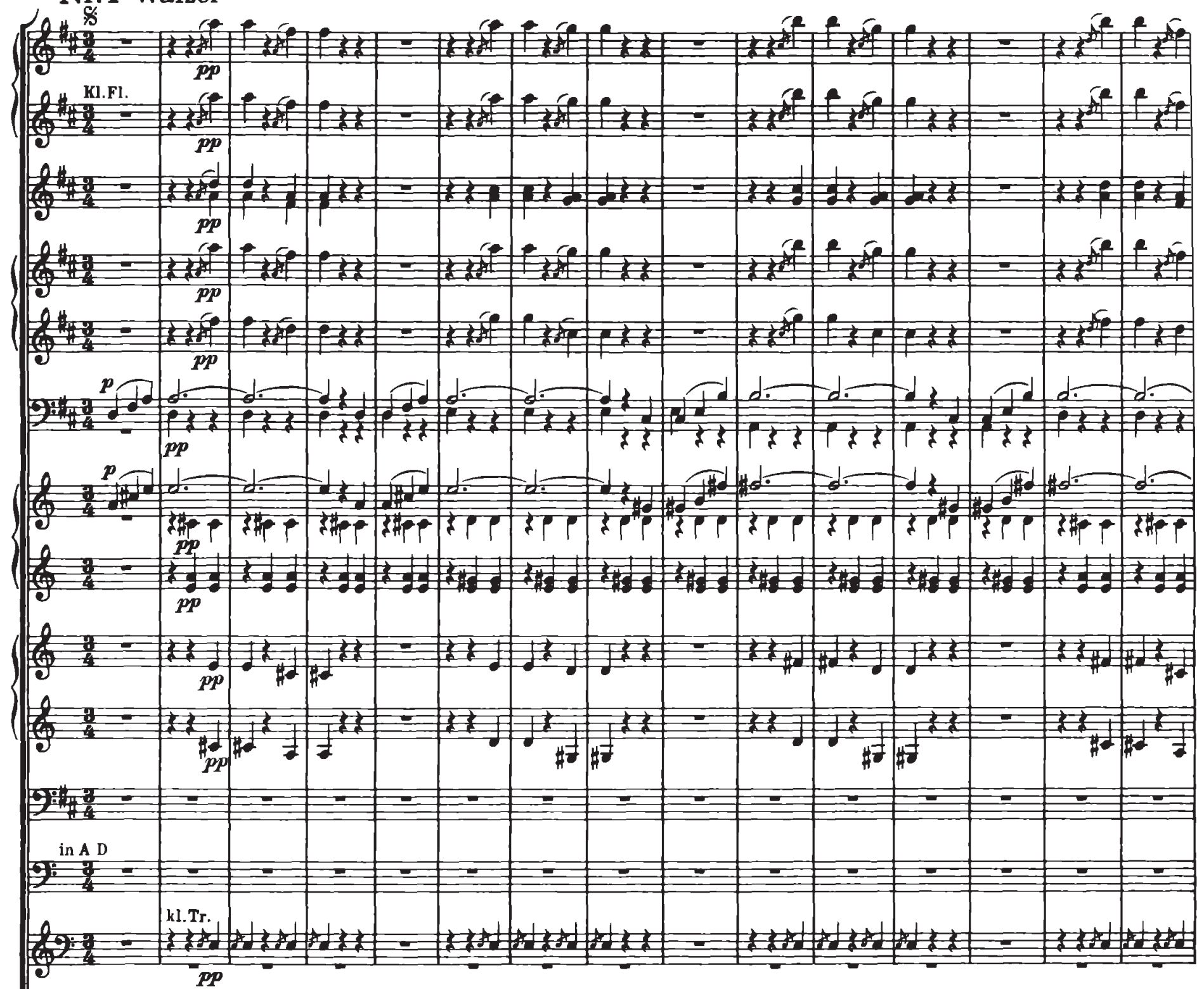

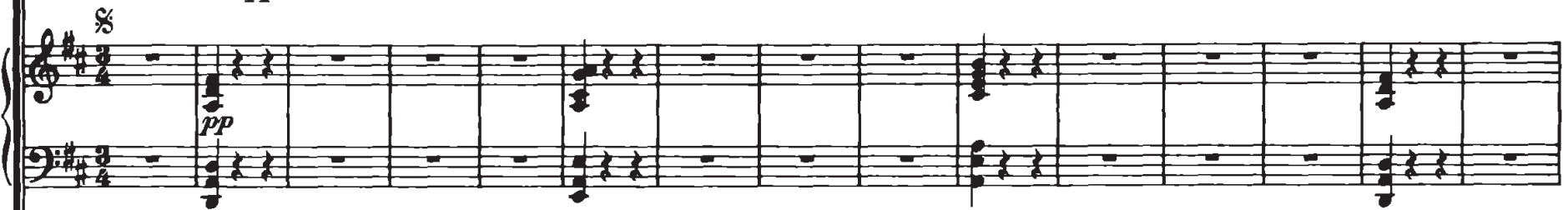

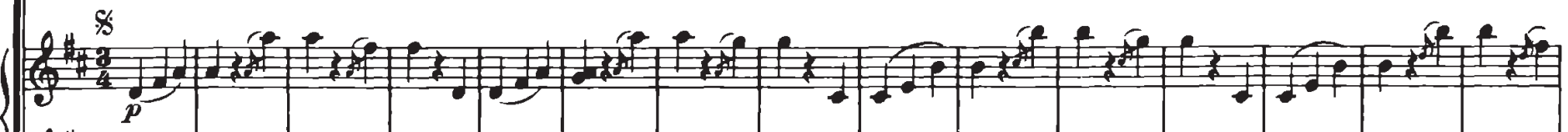

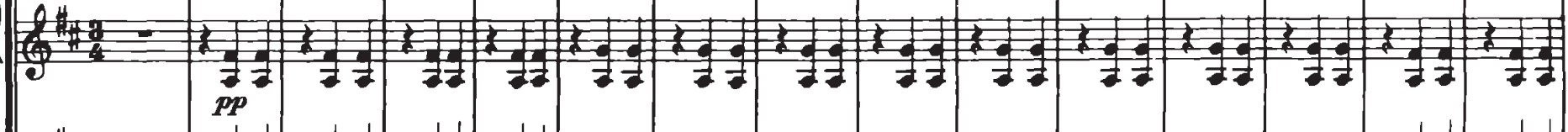

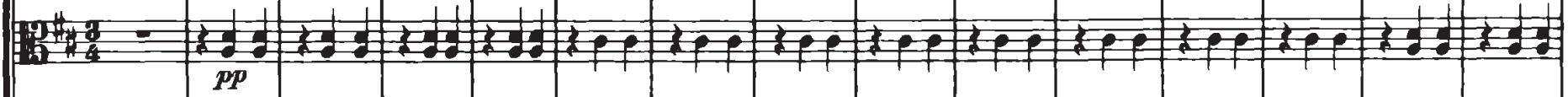

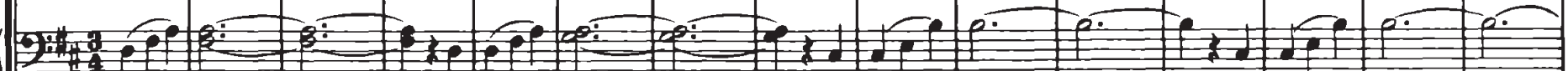

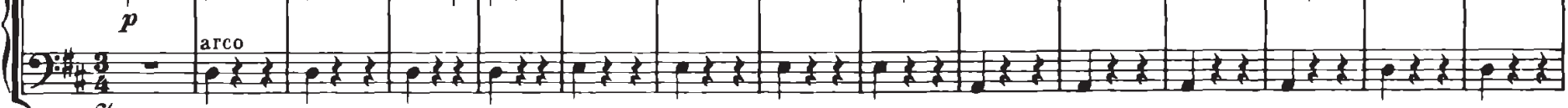




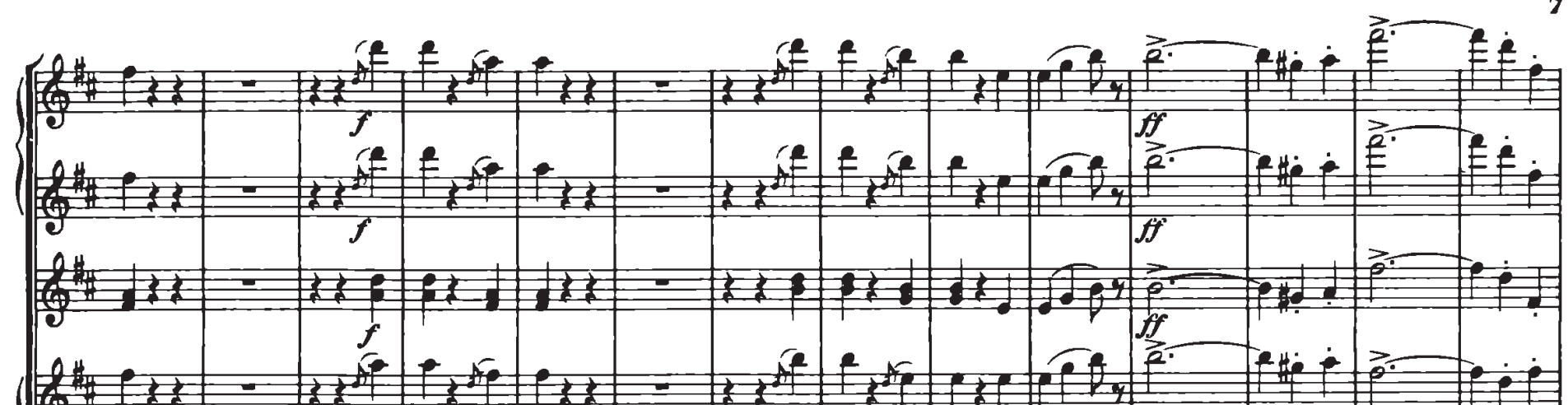
2.

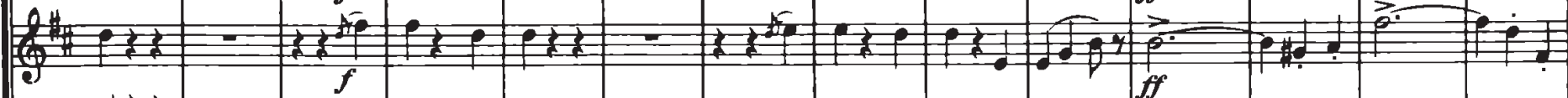

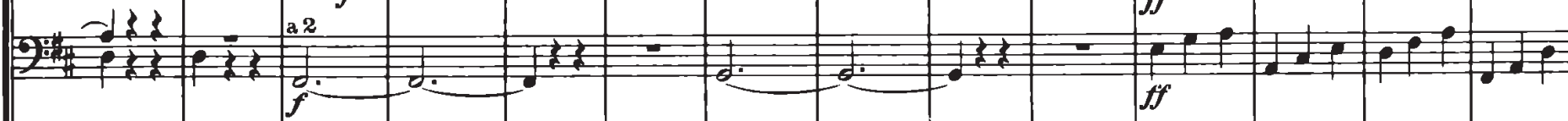

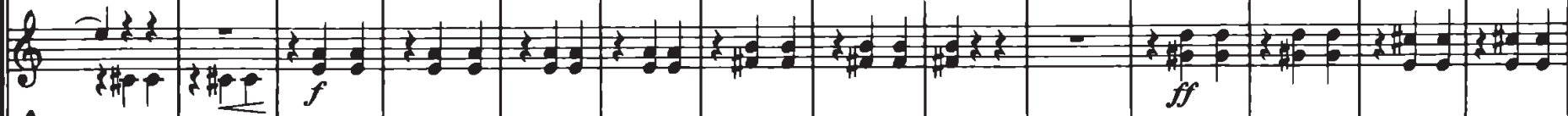

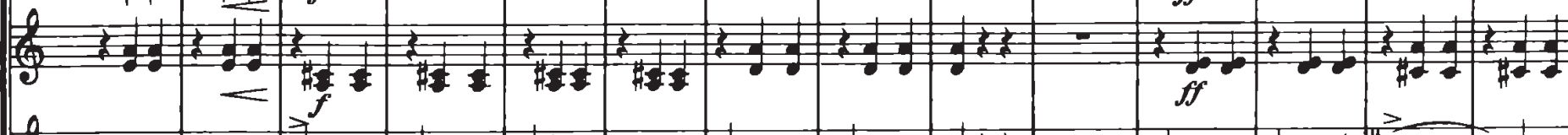
(2) Q

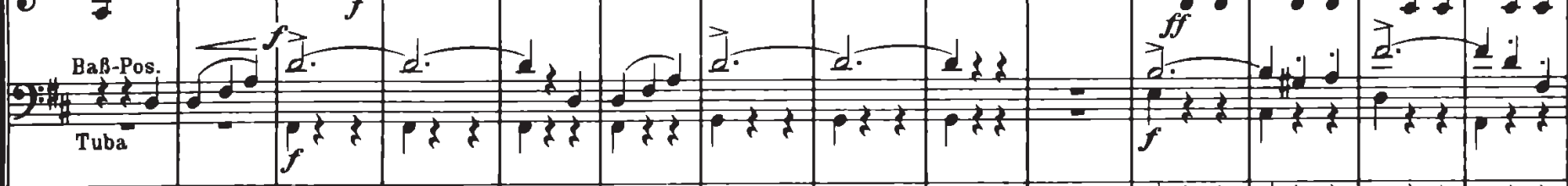

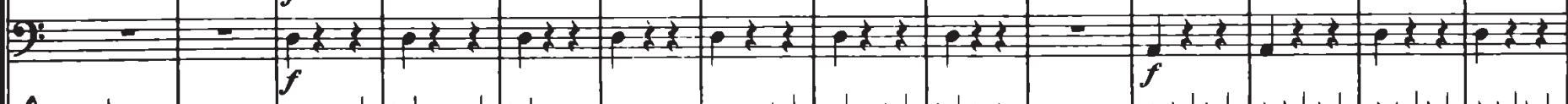

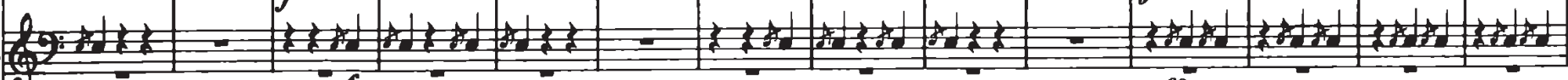

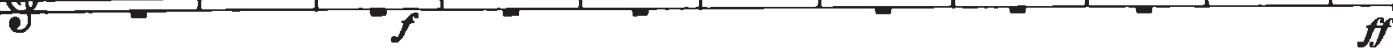

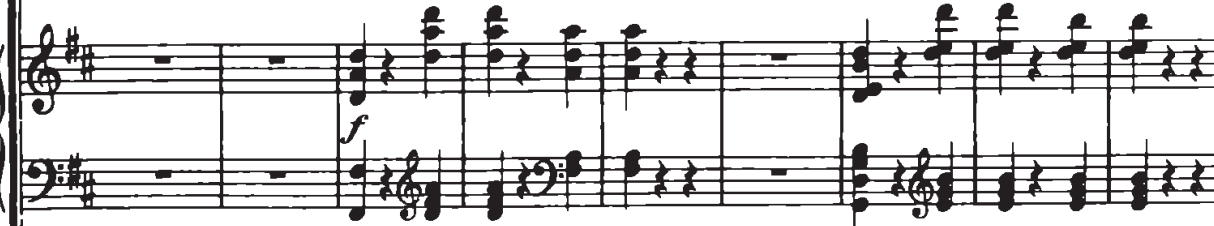

(10 (2)

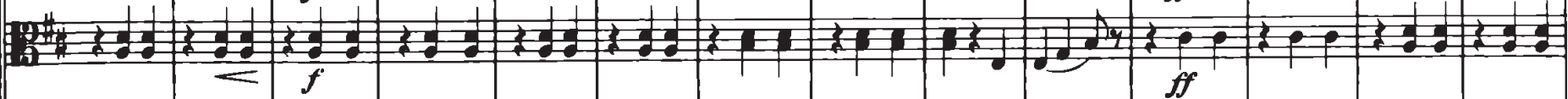

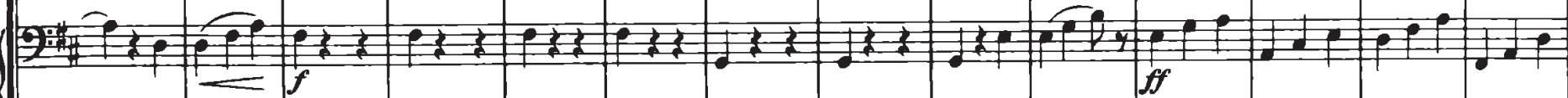

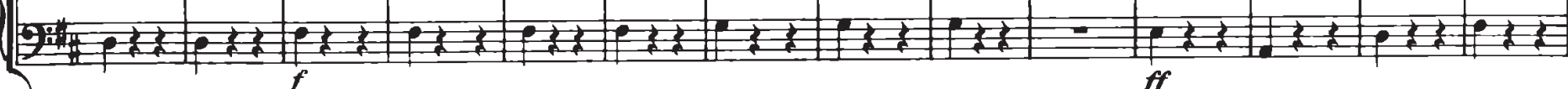




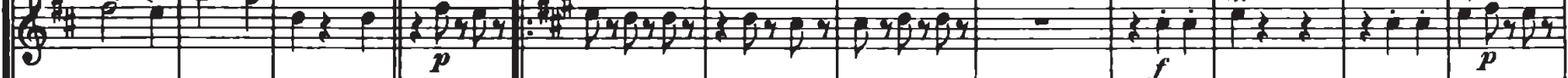

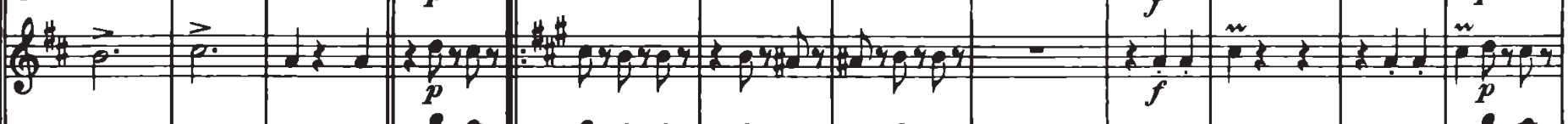

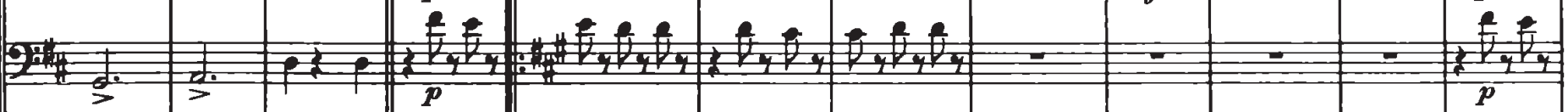

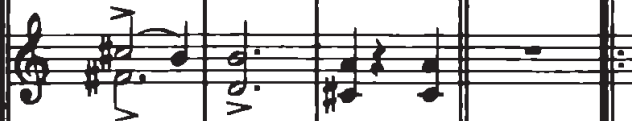
201: 楆 jos

(2) \begin{tabular}{|c||c|c|c|c|c|c|}
\hline \\
\hline 2
\end{tabular}

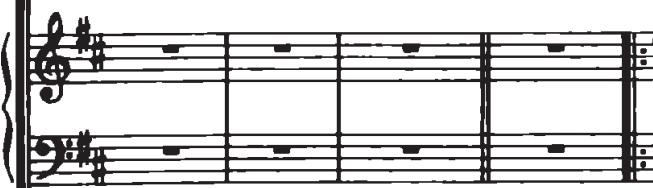

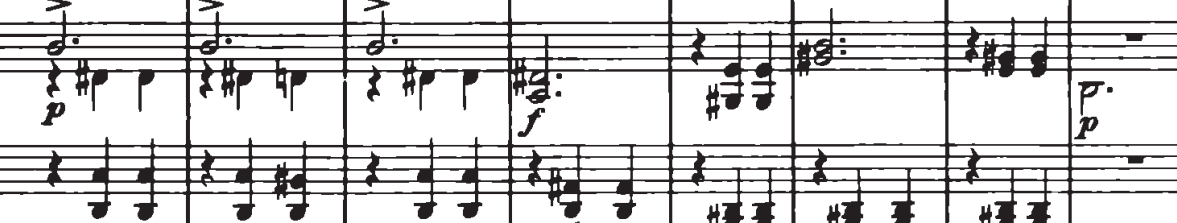




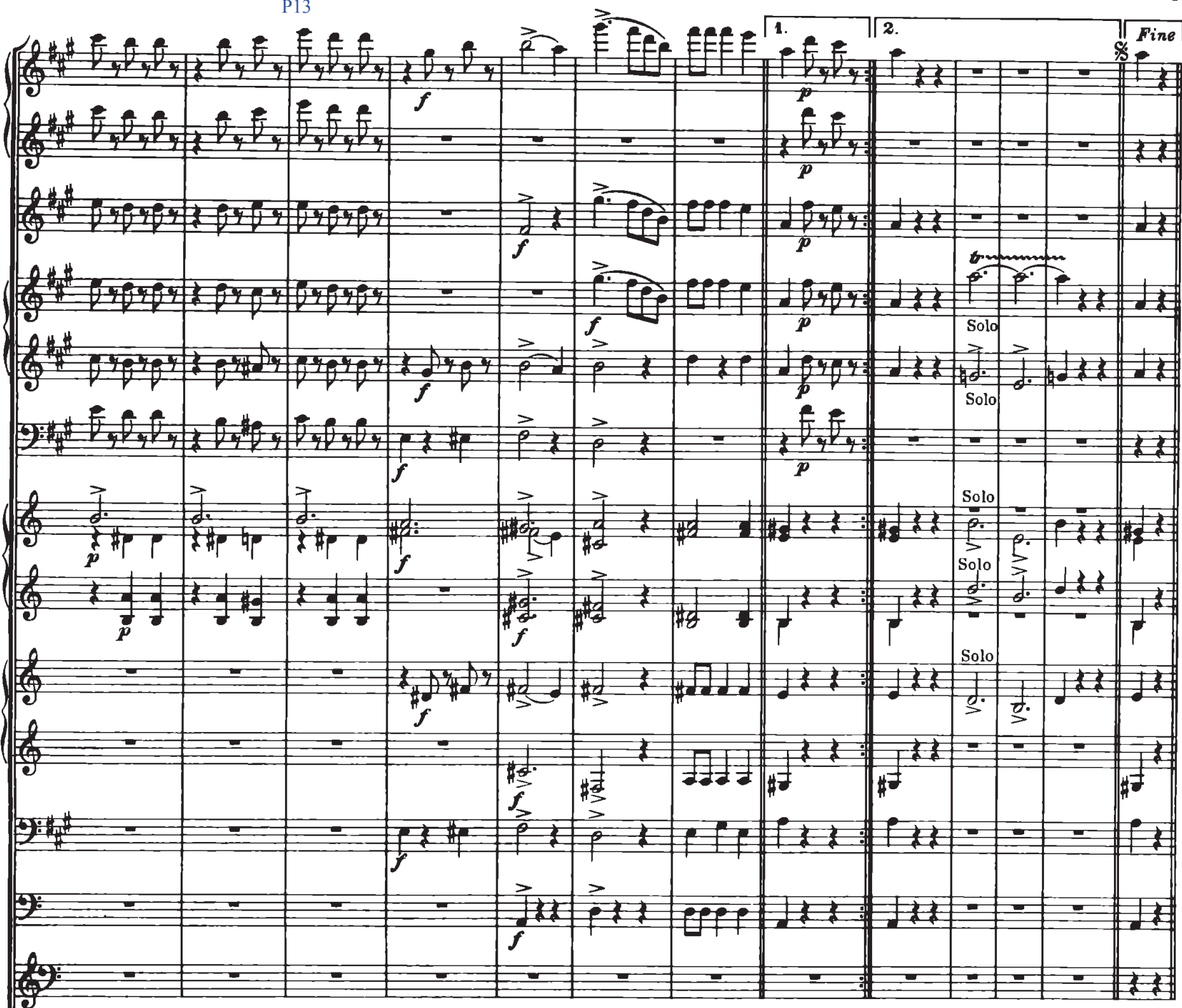

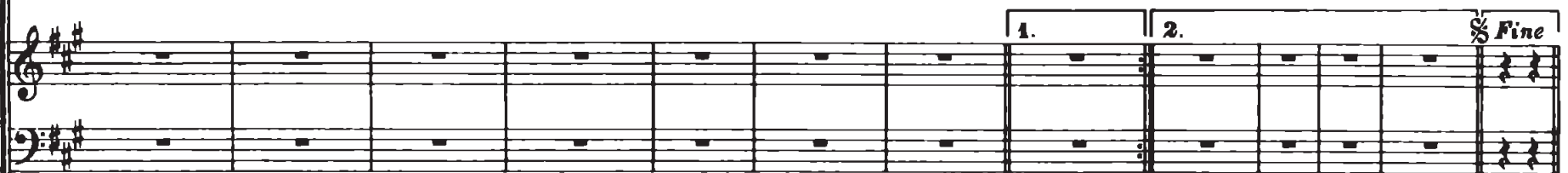

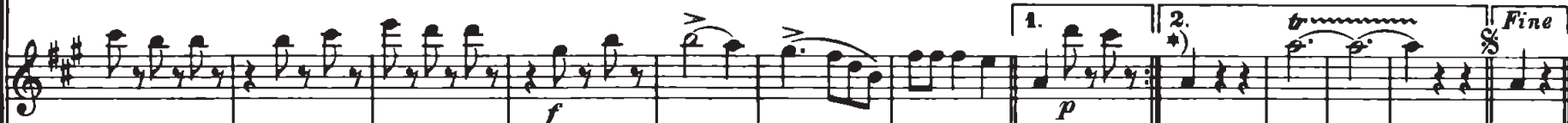

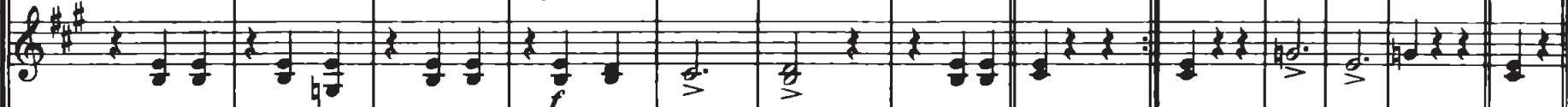
(1)

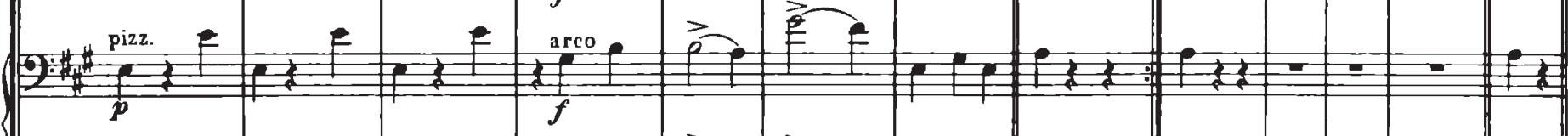

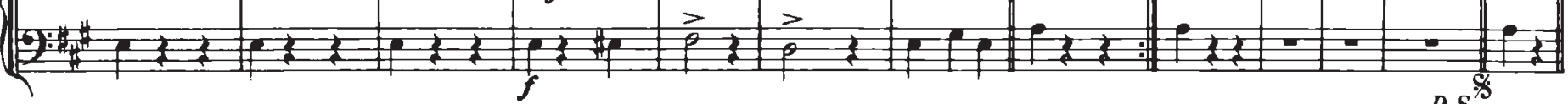
*) Bei Mitwirkung des Chors fallen 2da und Dal Segno weg 
10

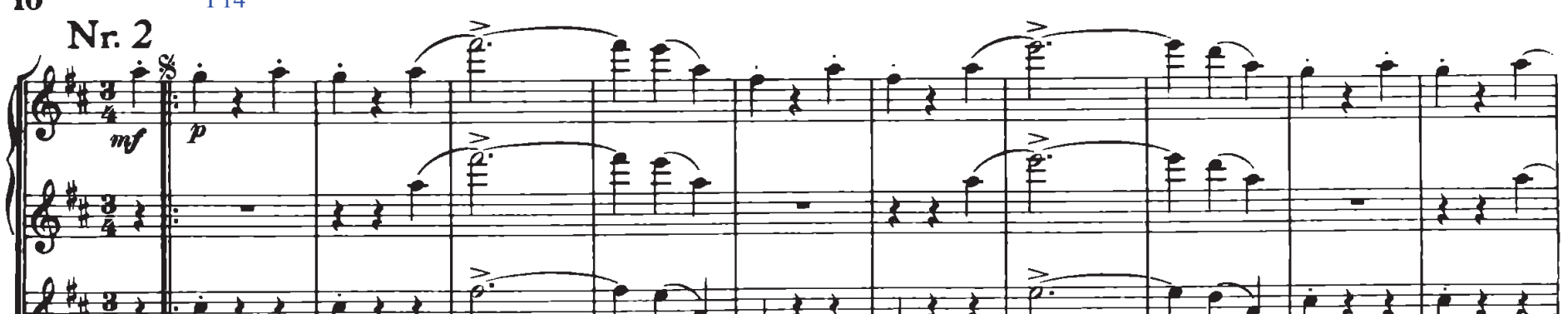

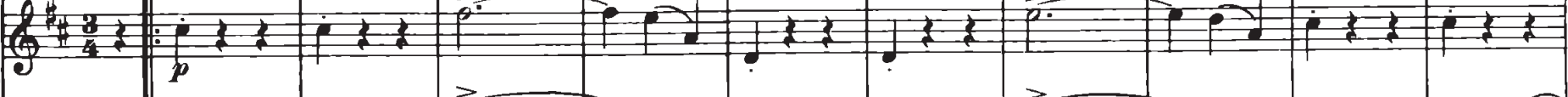
(9-8)

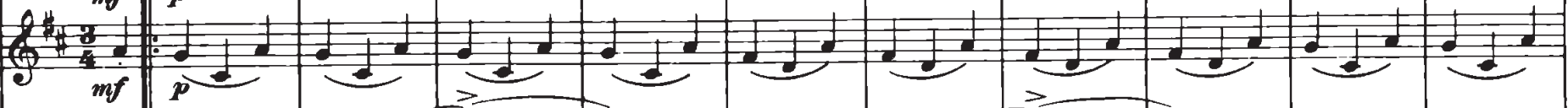

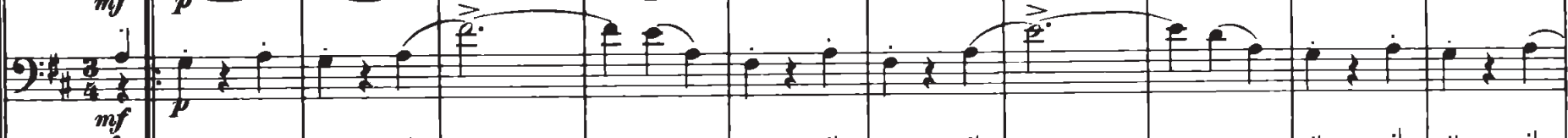

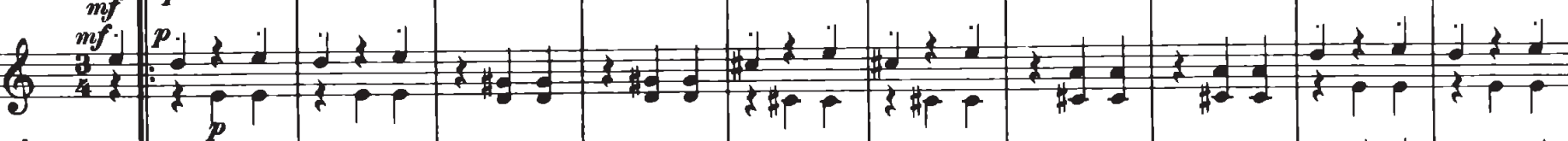

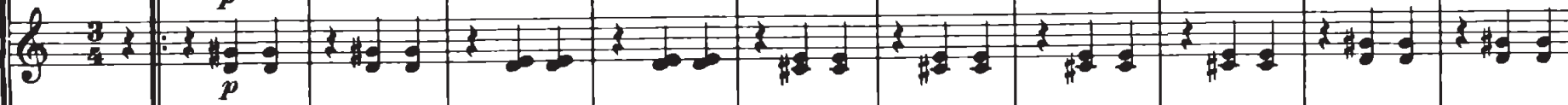

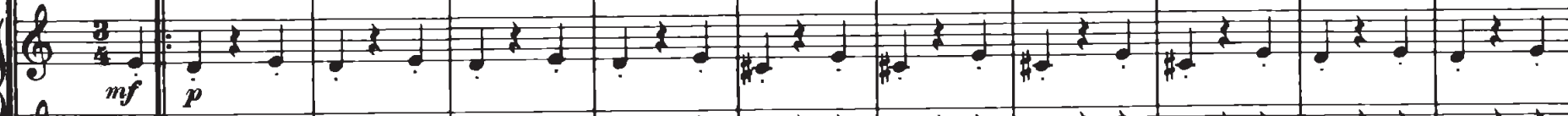

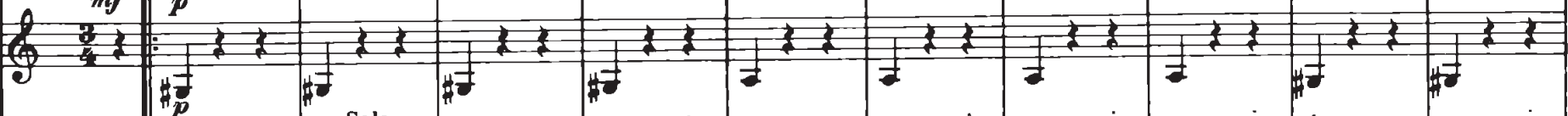
Q2.

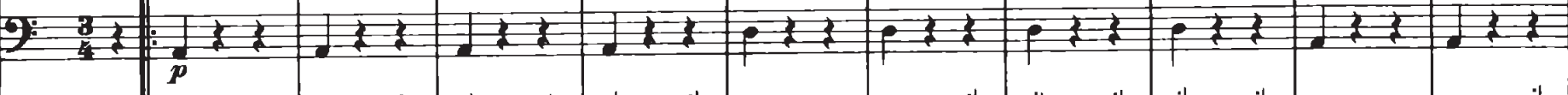

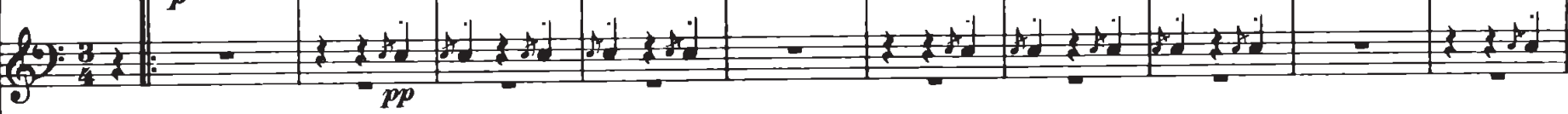

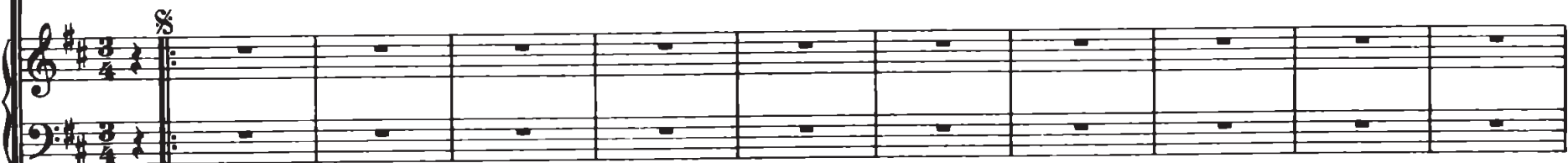
४3:

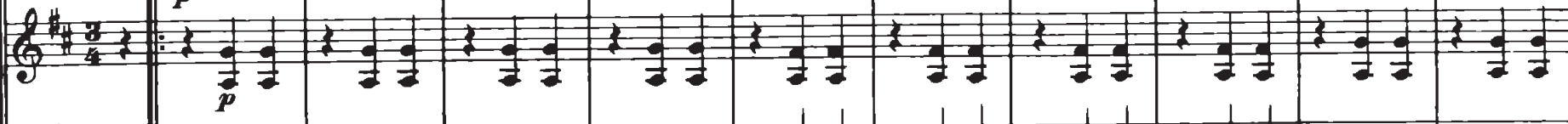
1.

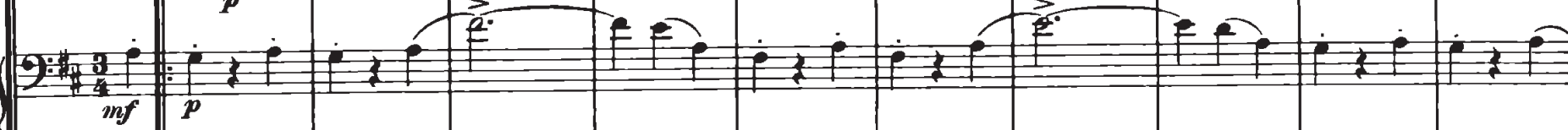

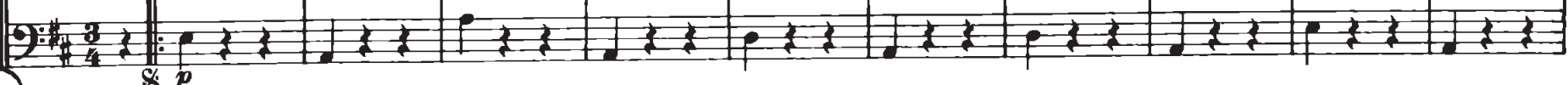




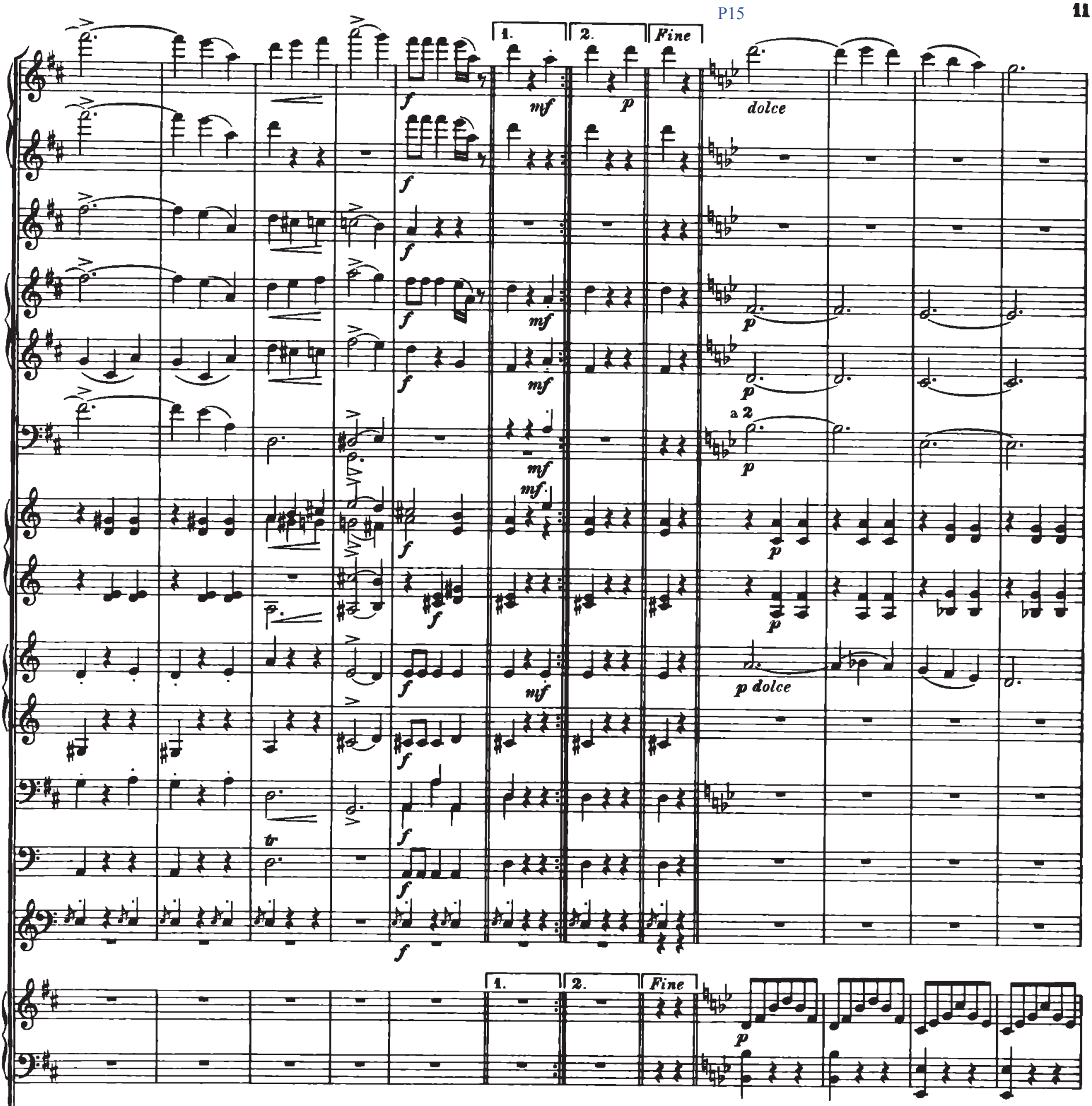

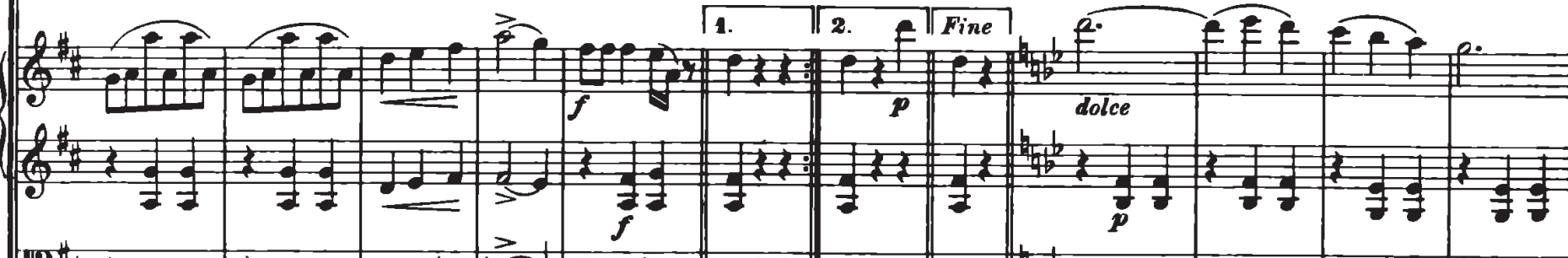

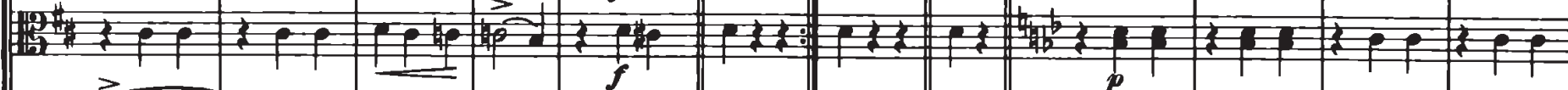

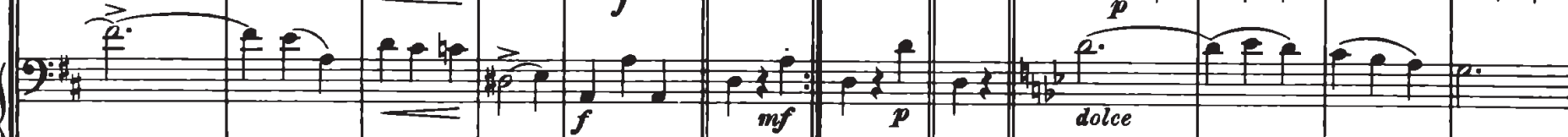

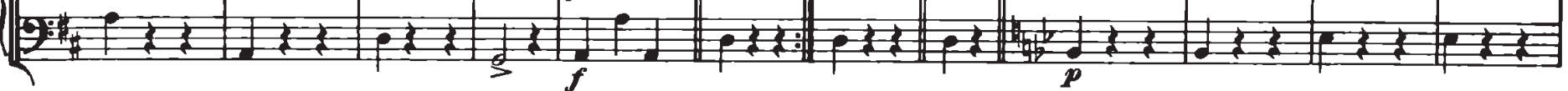


12

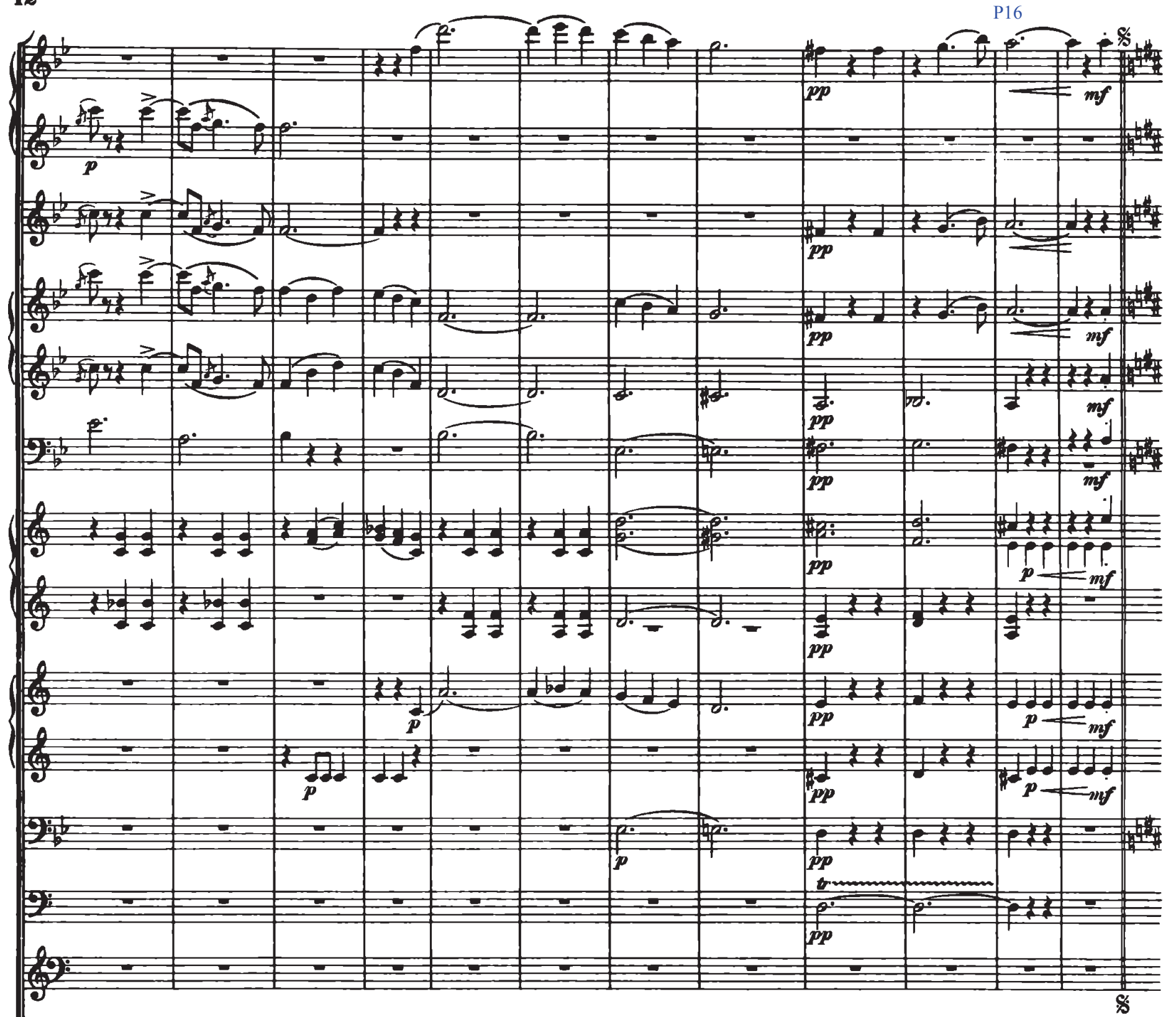

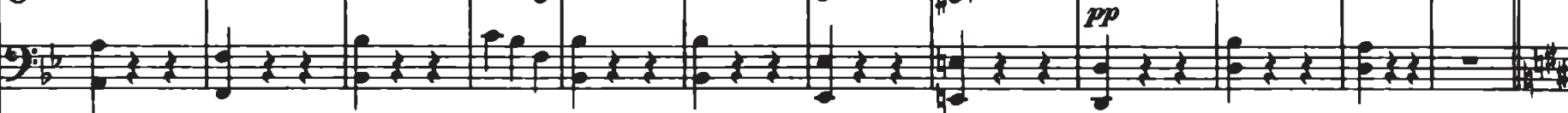

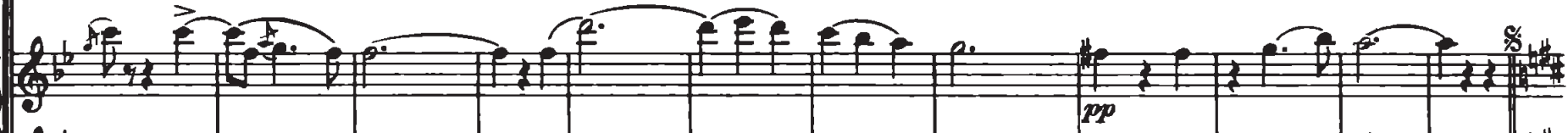

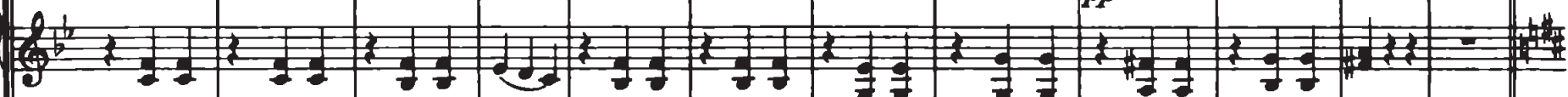

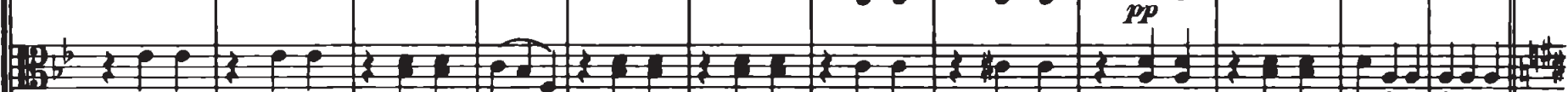

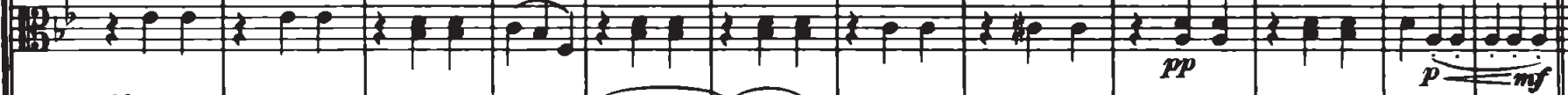

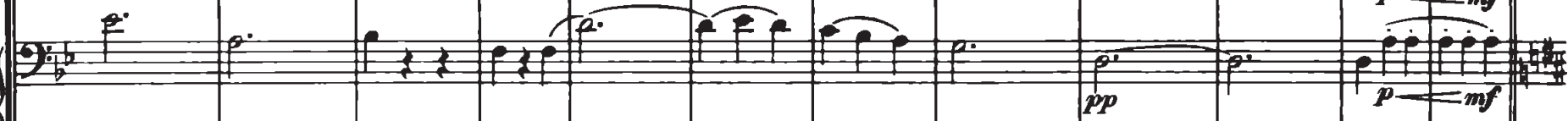

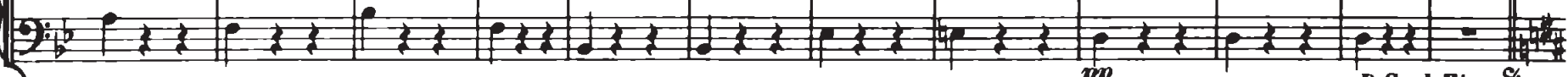
D.S. al Fine $\$$ 
Nr. 3 Exterior

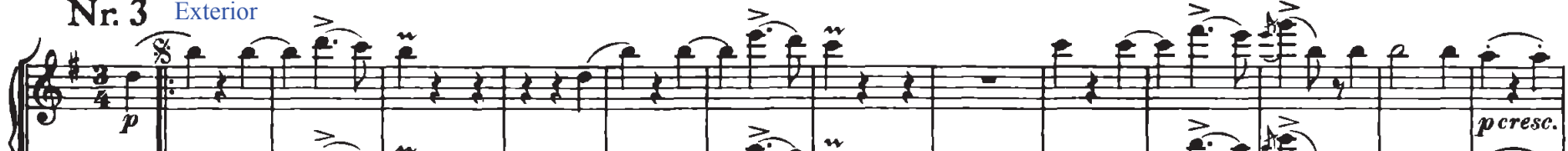

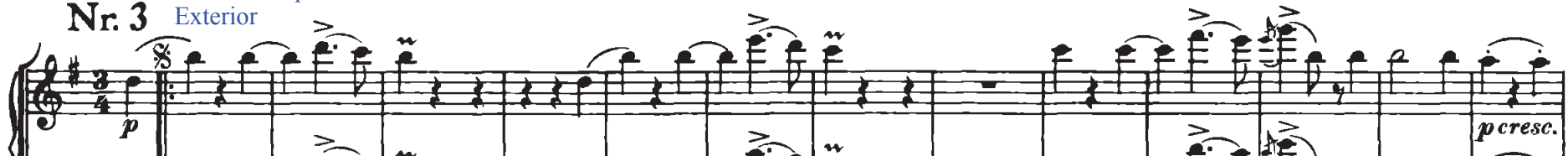

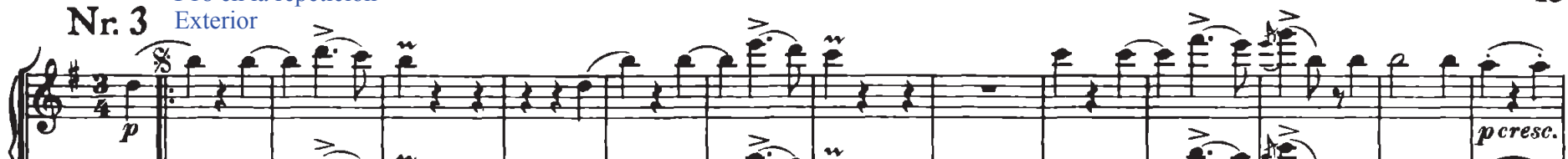
Q

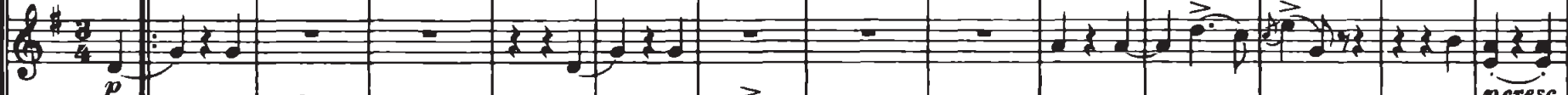

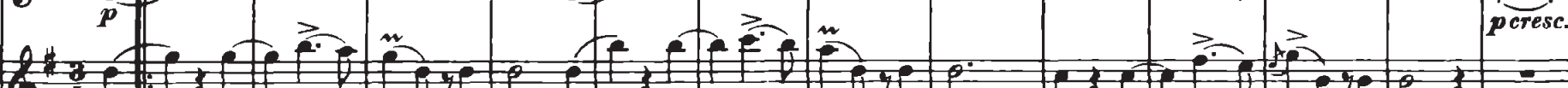

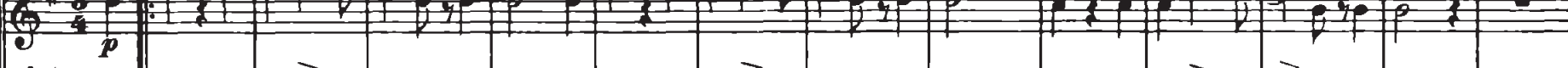

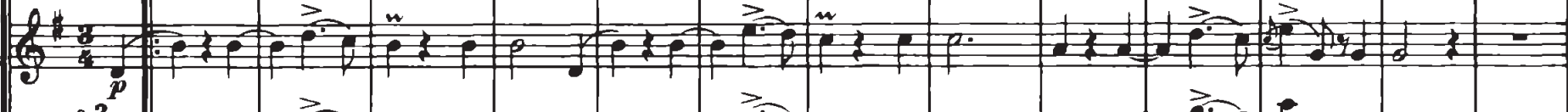

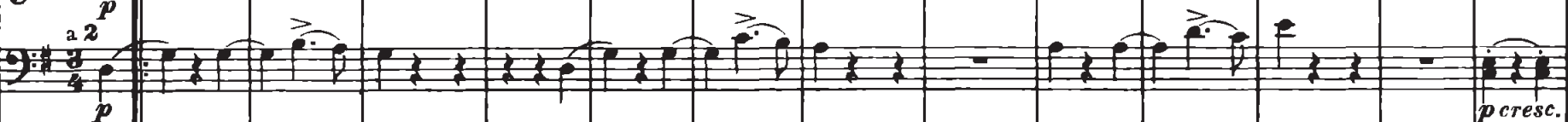
(2)

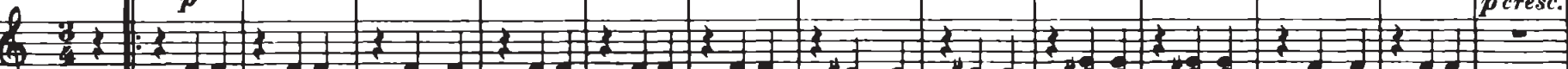

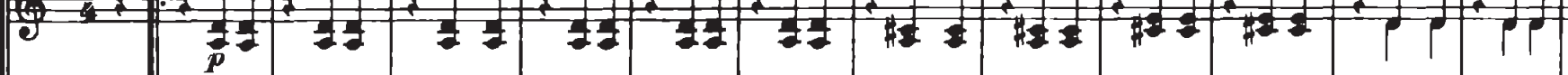

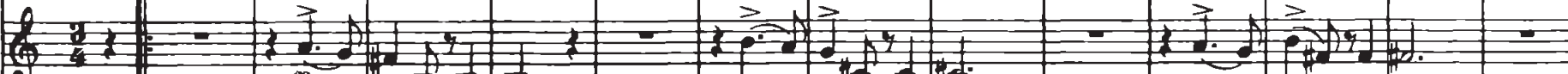
(1)

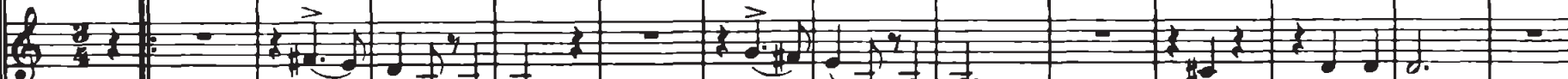
ए

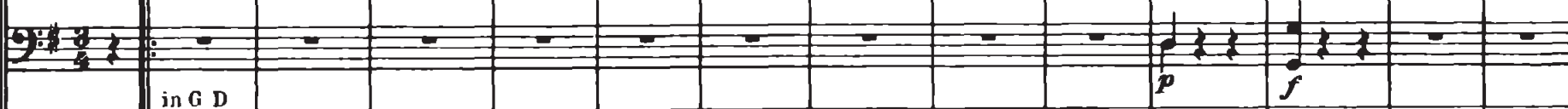

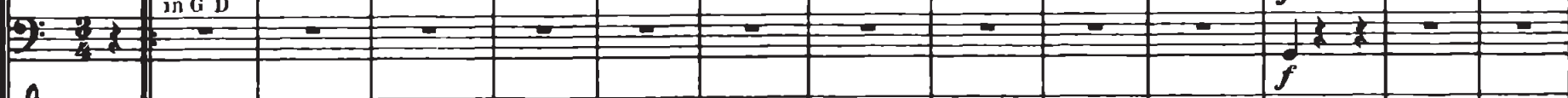

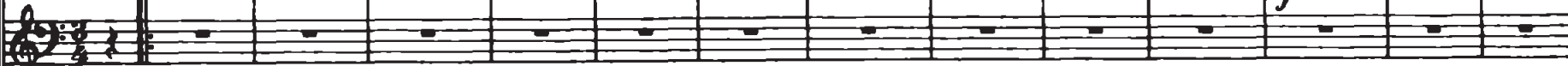

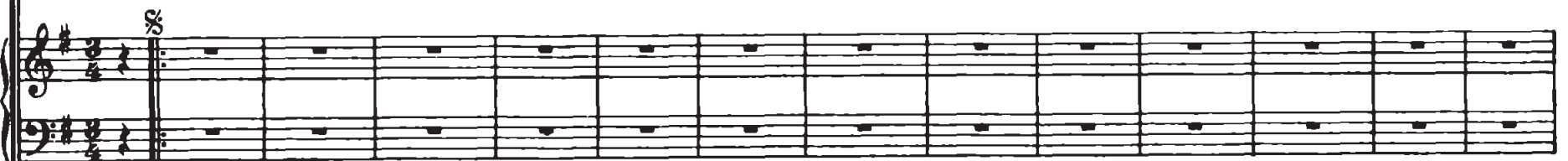

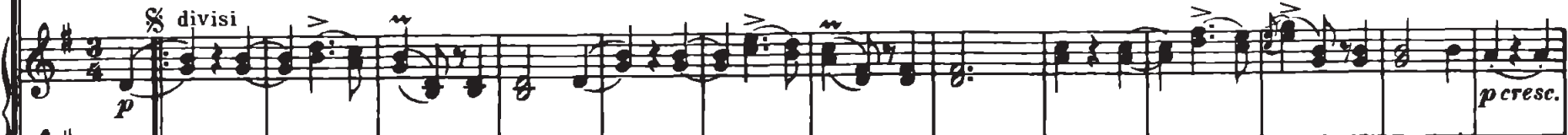

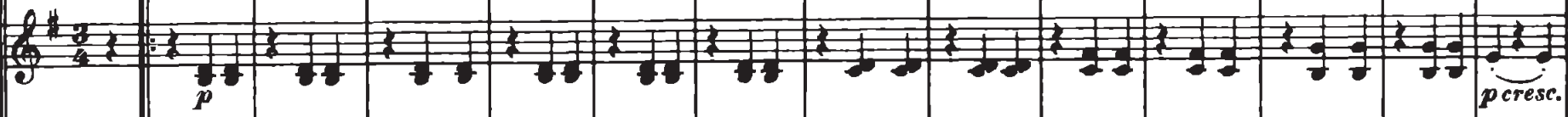

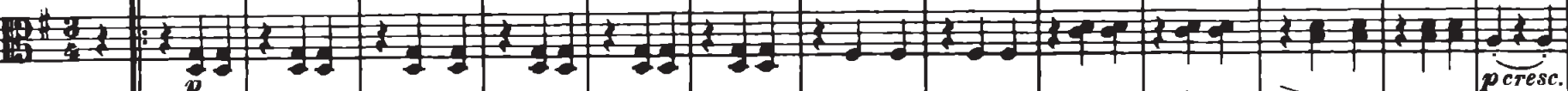

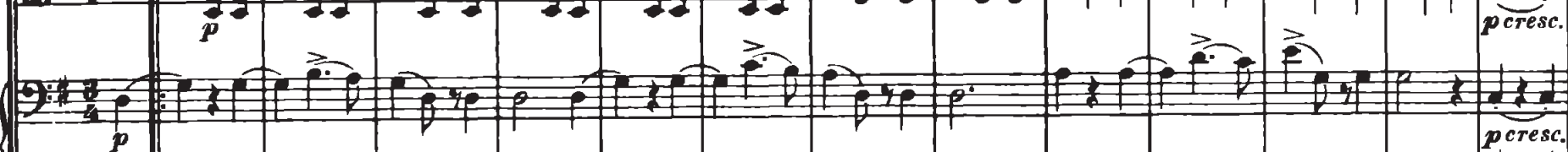
多3 
14
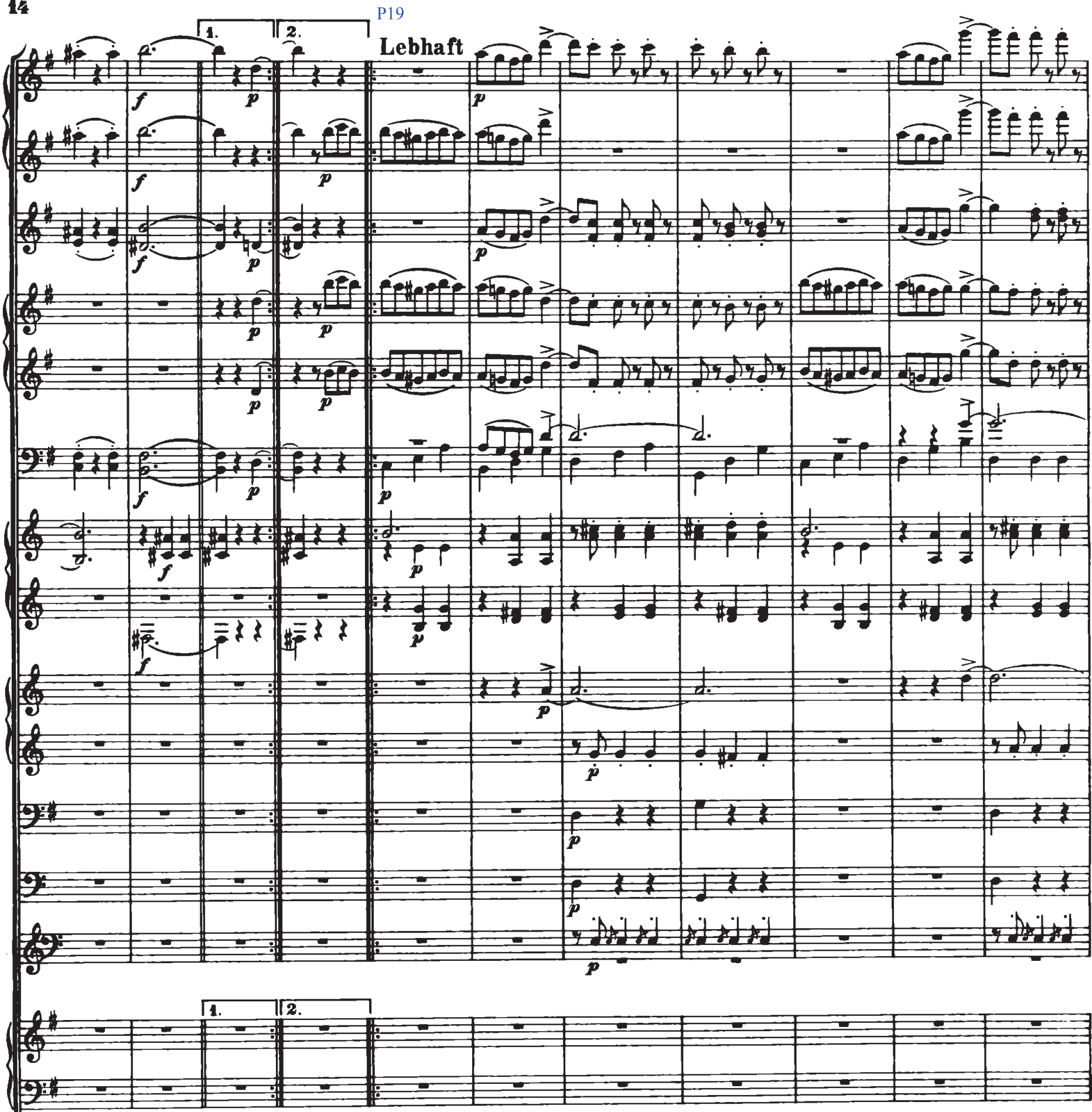

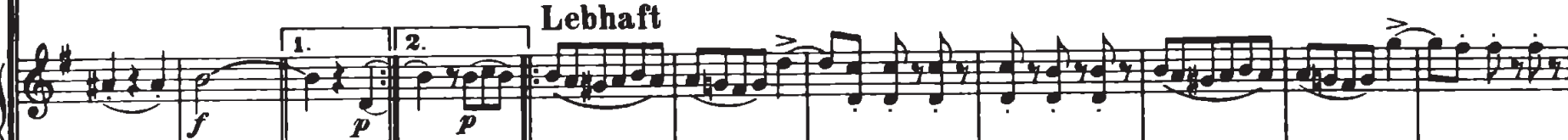
|c.

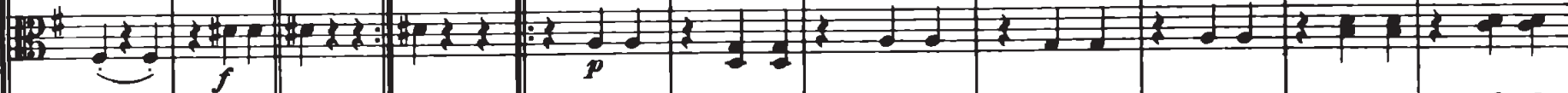

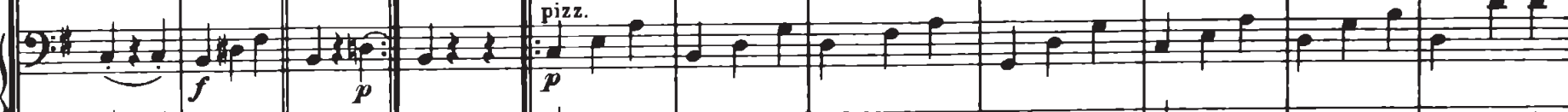

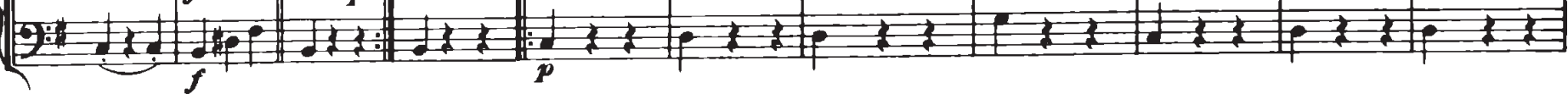



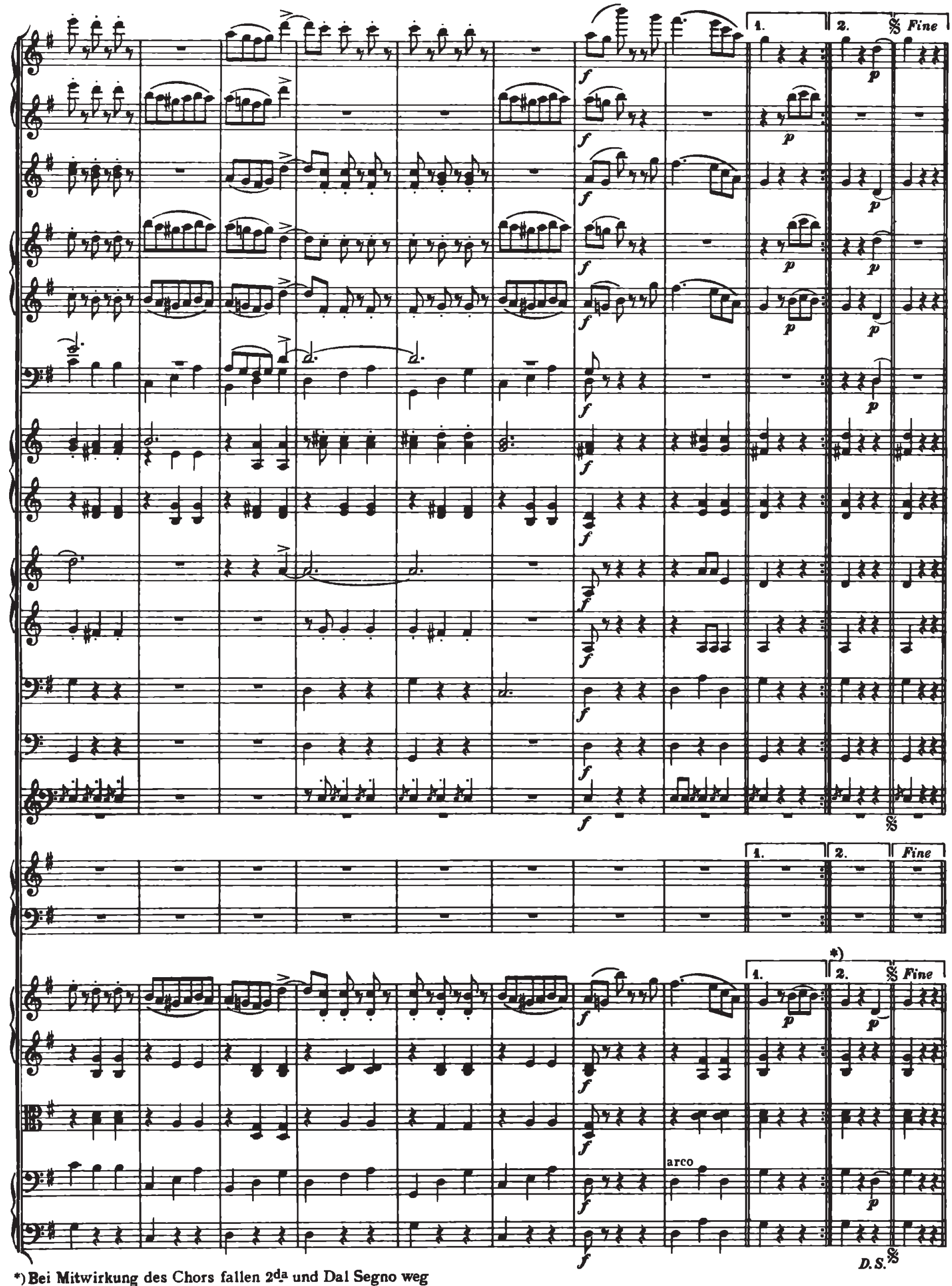
16

Nr. 4

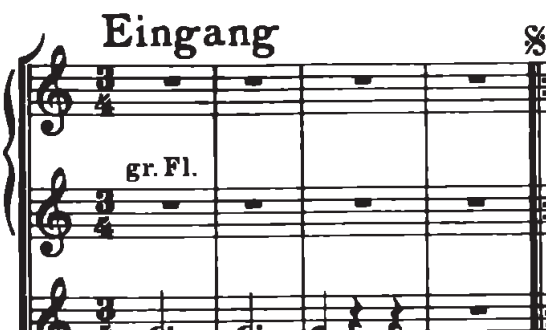

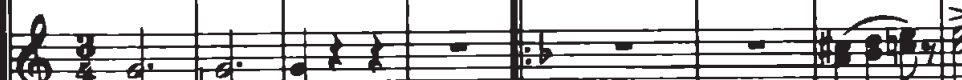

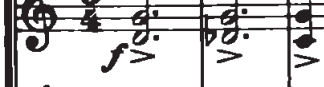

$\left\{\begin{array}{|l|l|l|l|}\hline g & & & \\ \hline e^{2} & & & p \\ \hline\end{array}\right.$

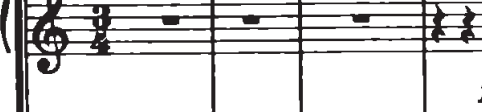

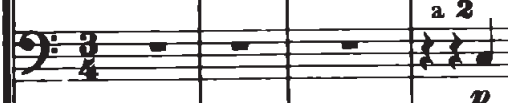

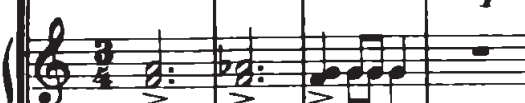

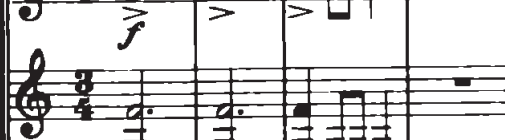

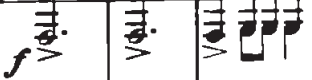

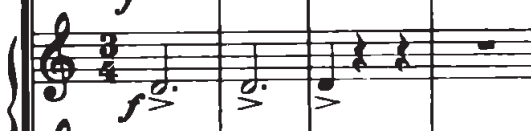

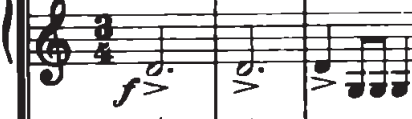

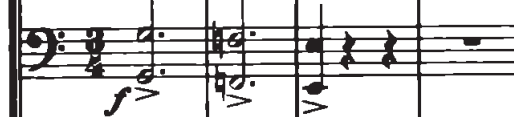

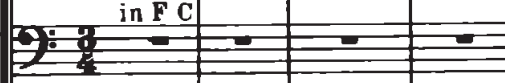

gor.Trommel

$\$$

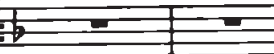
pp
P21

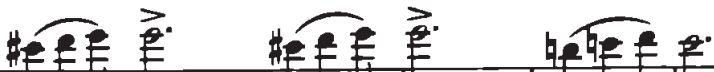

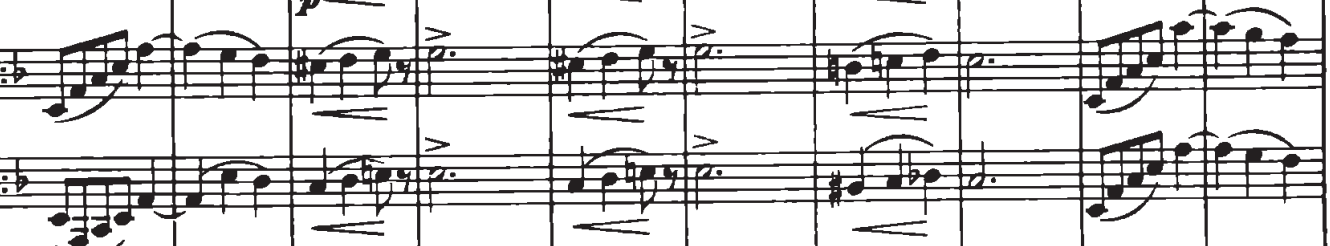

Tofefen

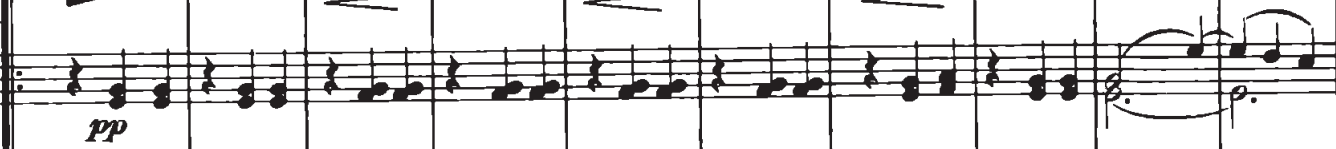

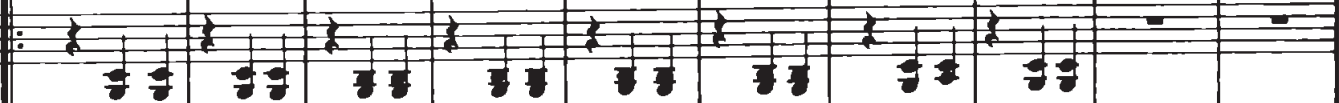

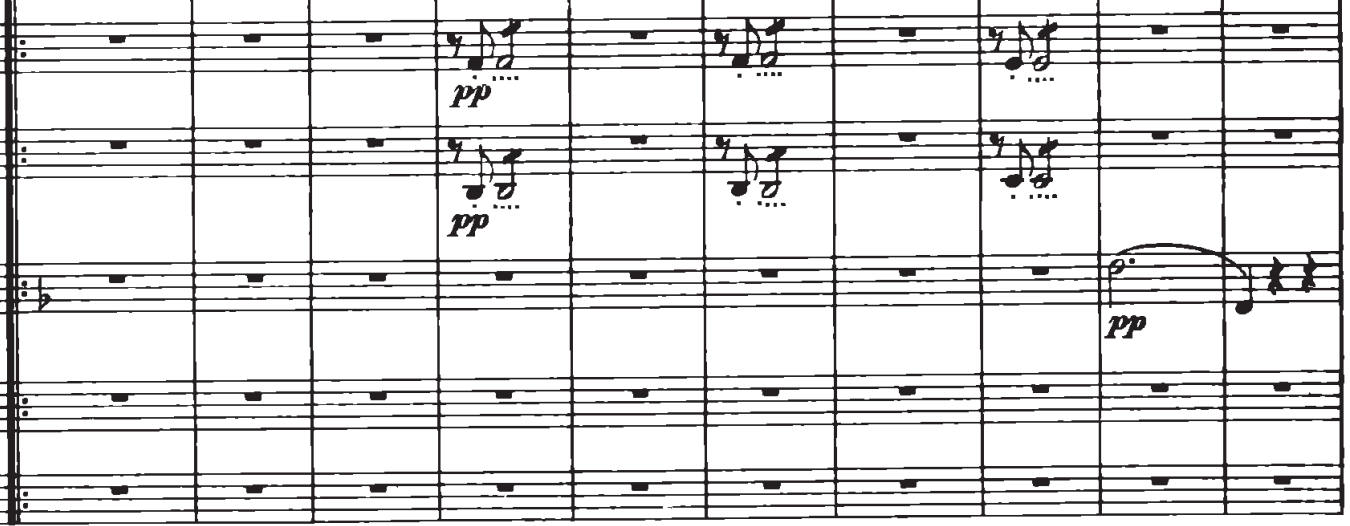

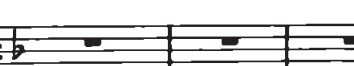

\begin{tabular}{|c|c|c|c|c|}
\hline 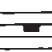 & $=$ & $\overline{\overline{\bar{C}}}$ & E & $=$ \\
\hline & & & & \\
\hline$=$ & $=$ & $=$ & 드 & $=$ \\
\hline
\end{tabular}

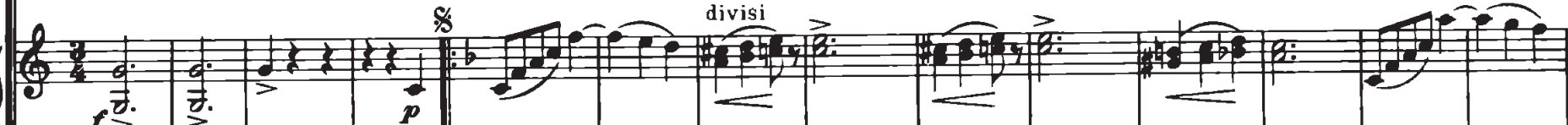

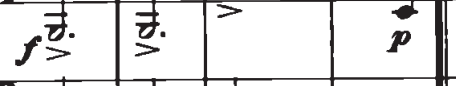

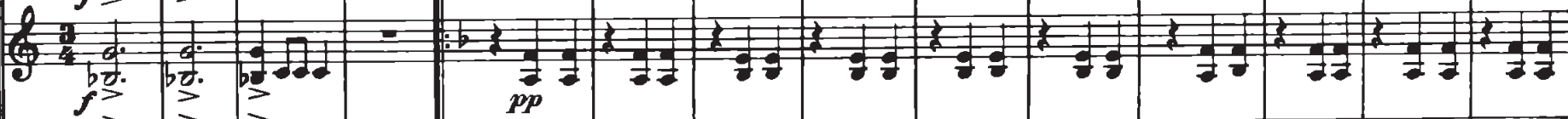

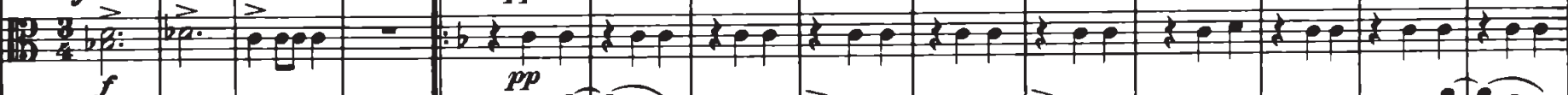

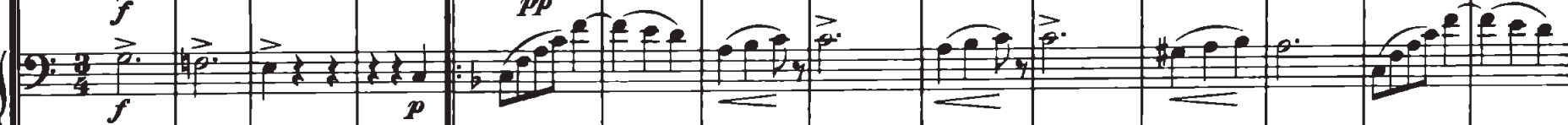

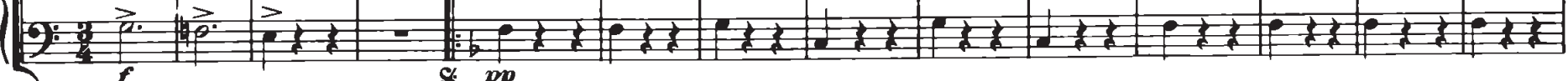



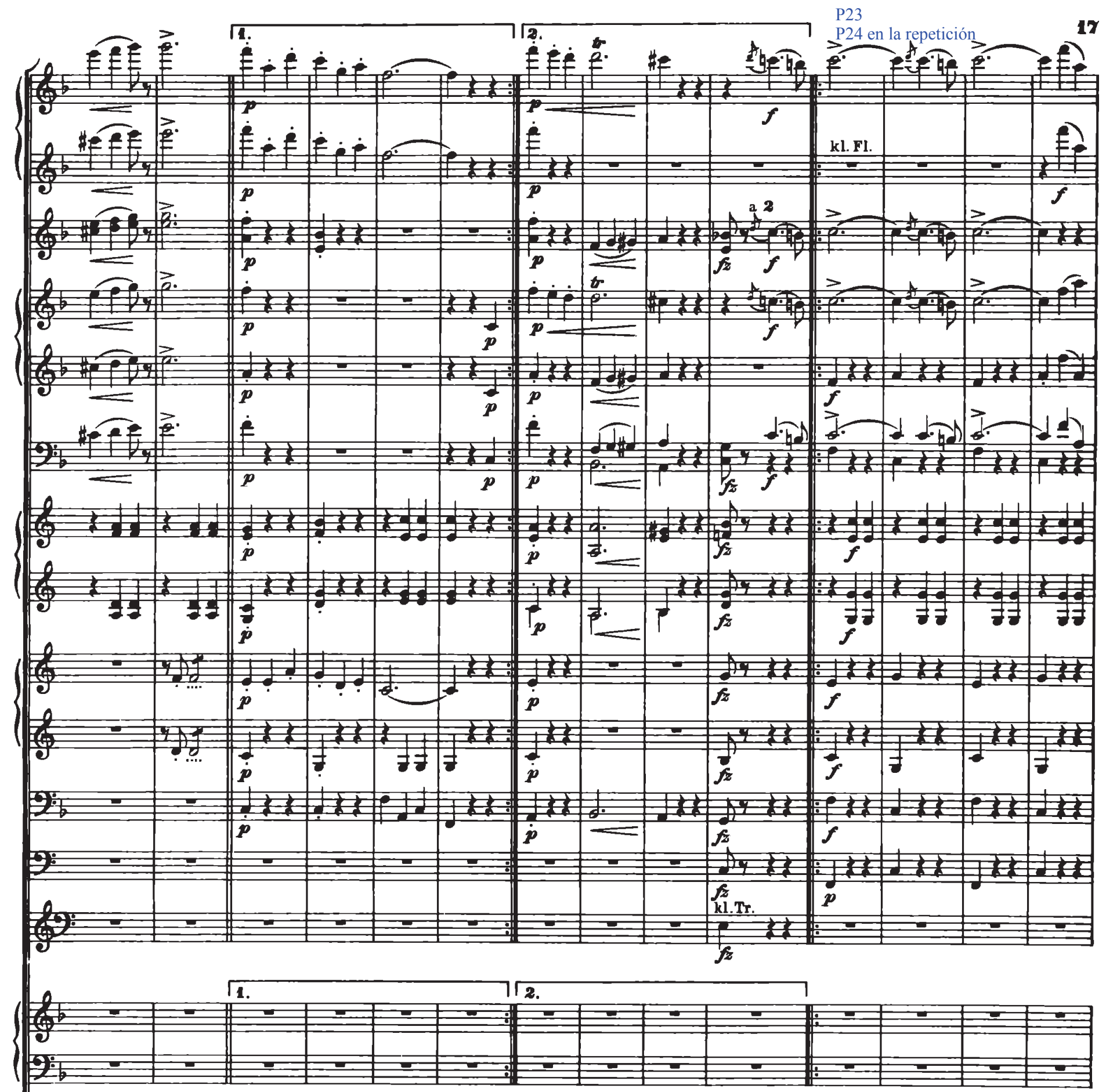

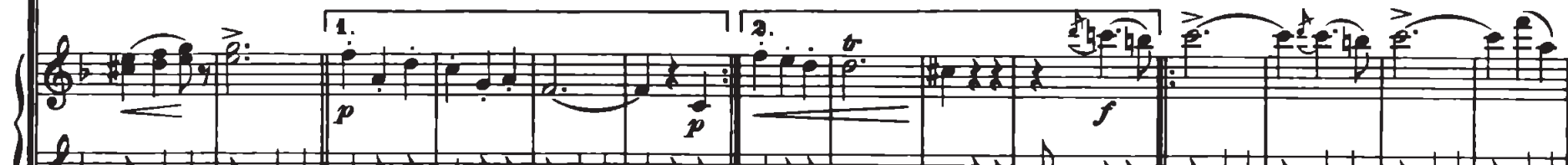

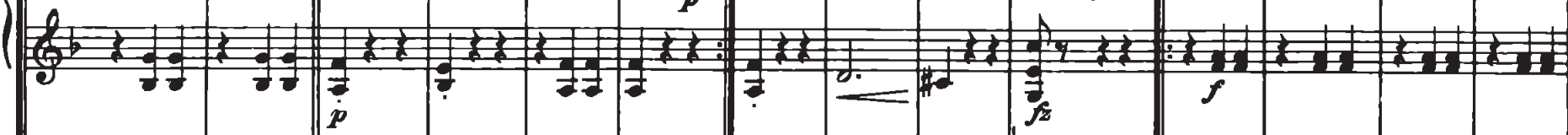

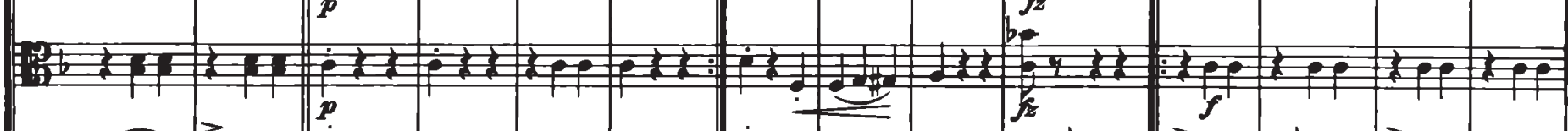

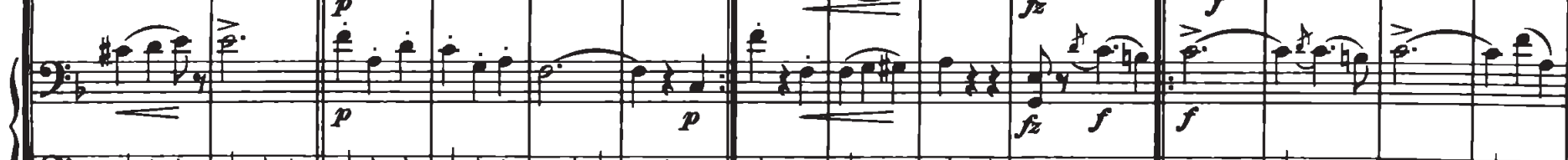

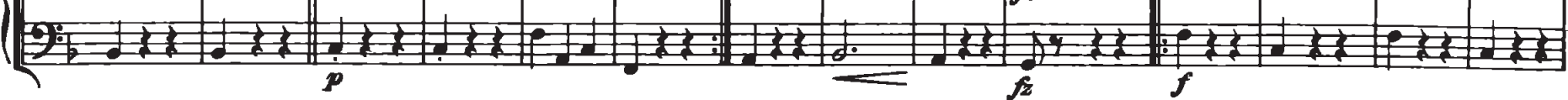


18

(⿸厃㔾)

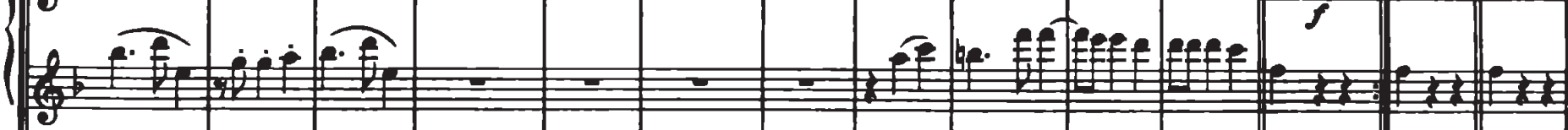
20 of (2)

(2)

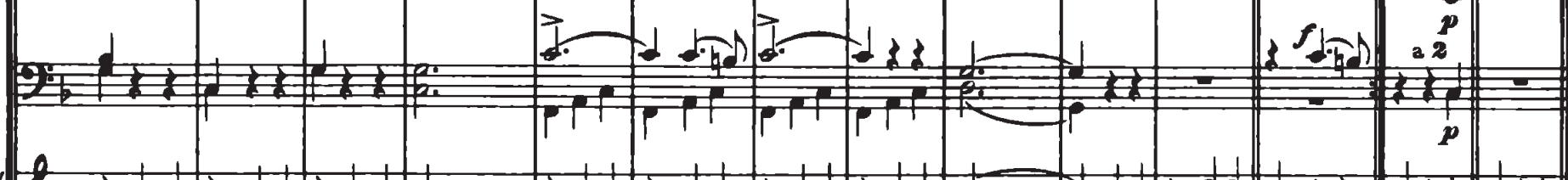

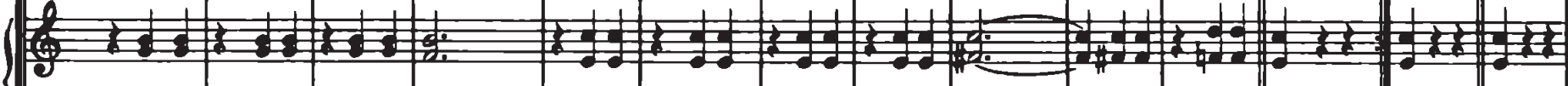
(2)

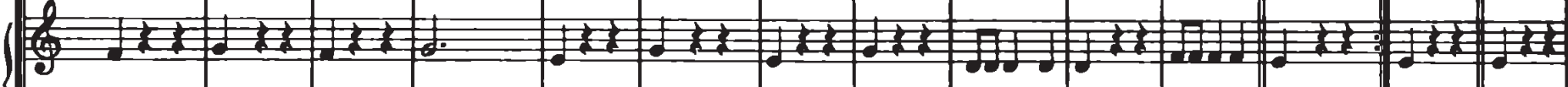

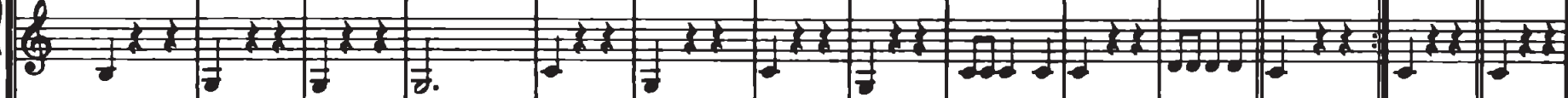

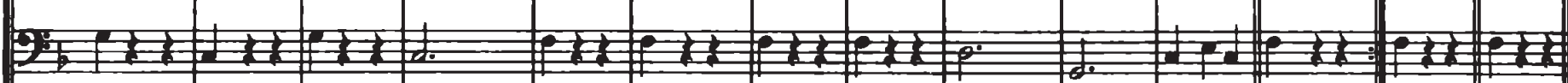

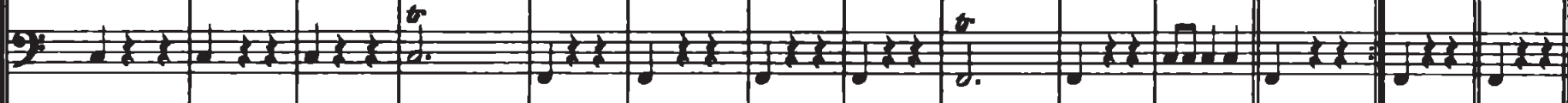

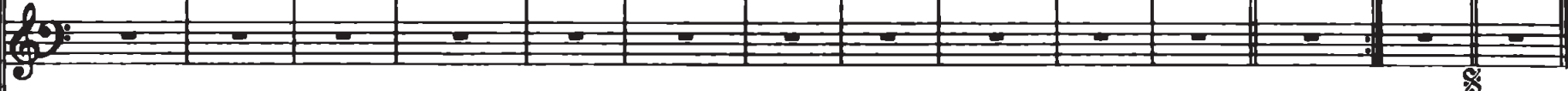

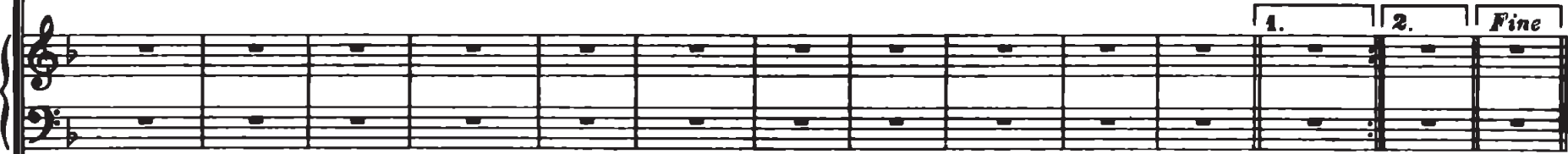

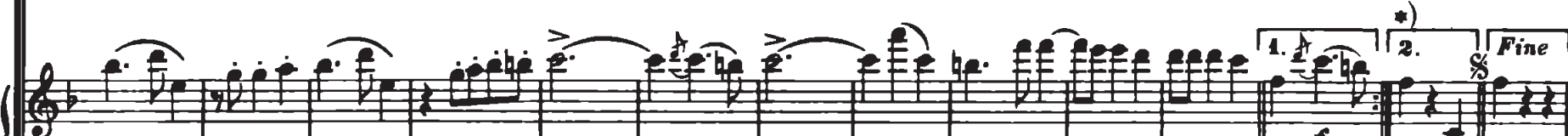

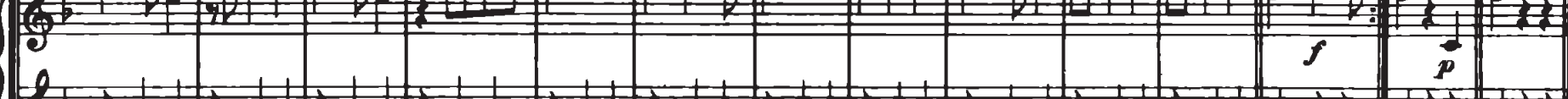

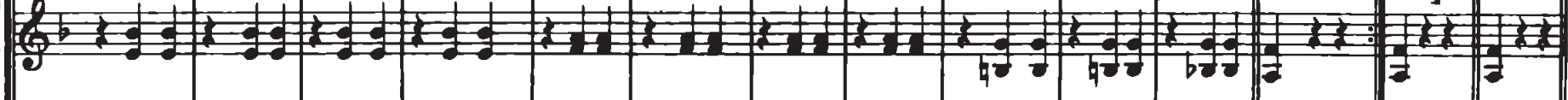

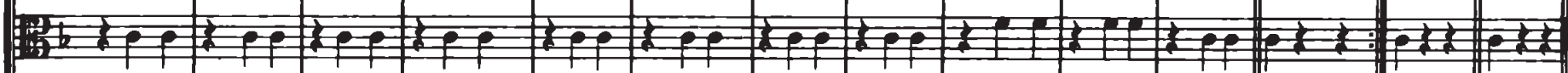

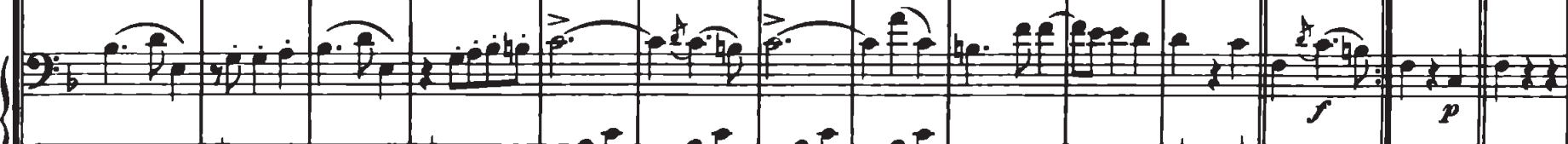

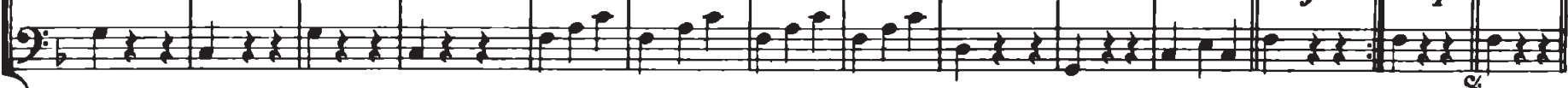

•) Bei Mitwirkung des Chors fallen $2^{\text {da }}$ und Dal Segno weg 
Nr. 5 Р28

P29

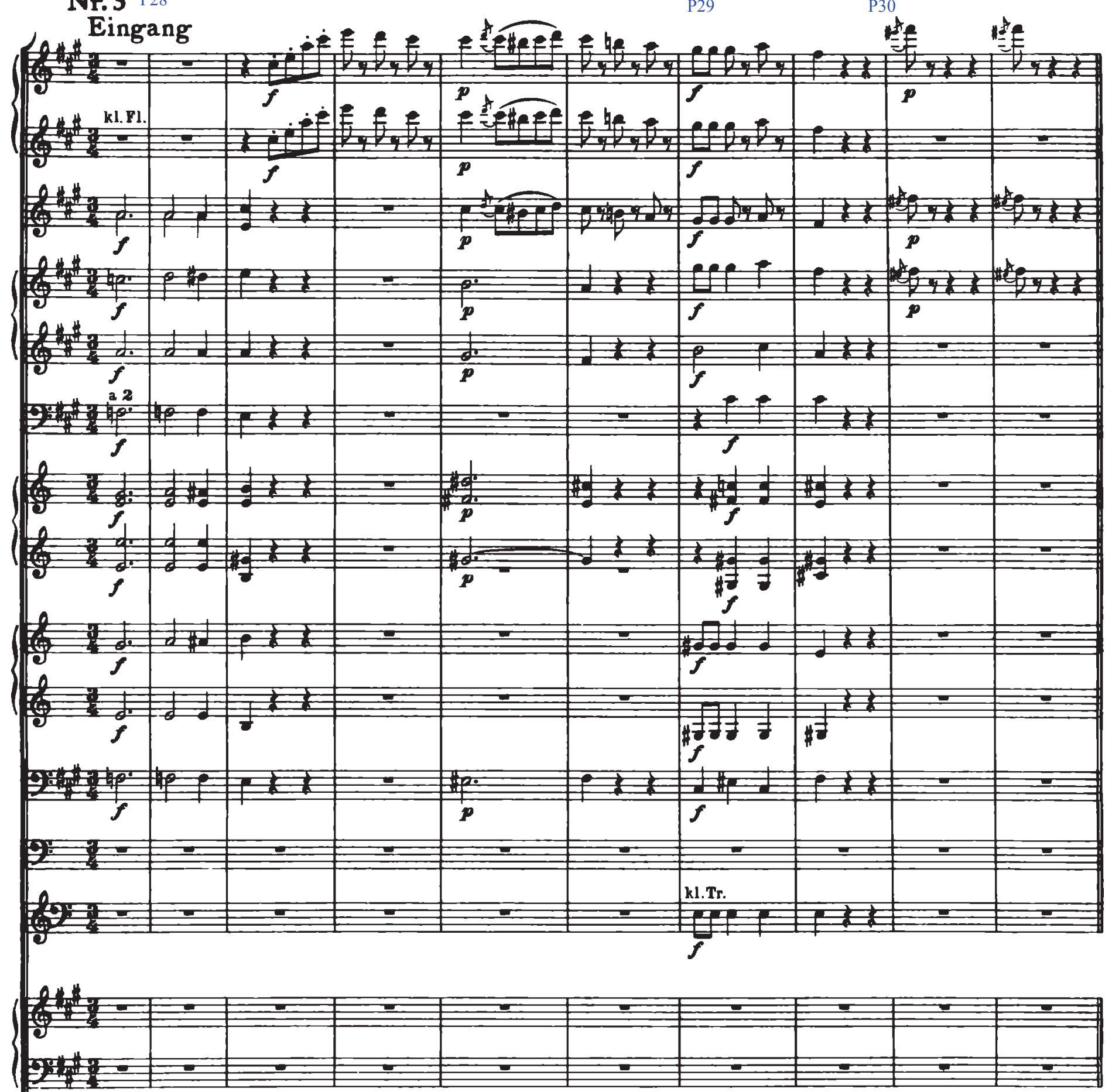

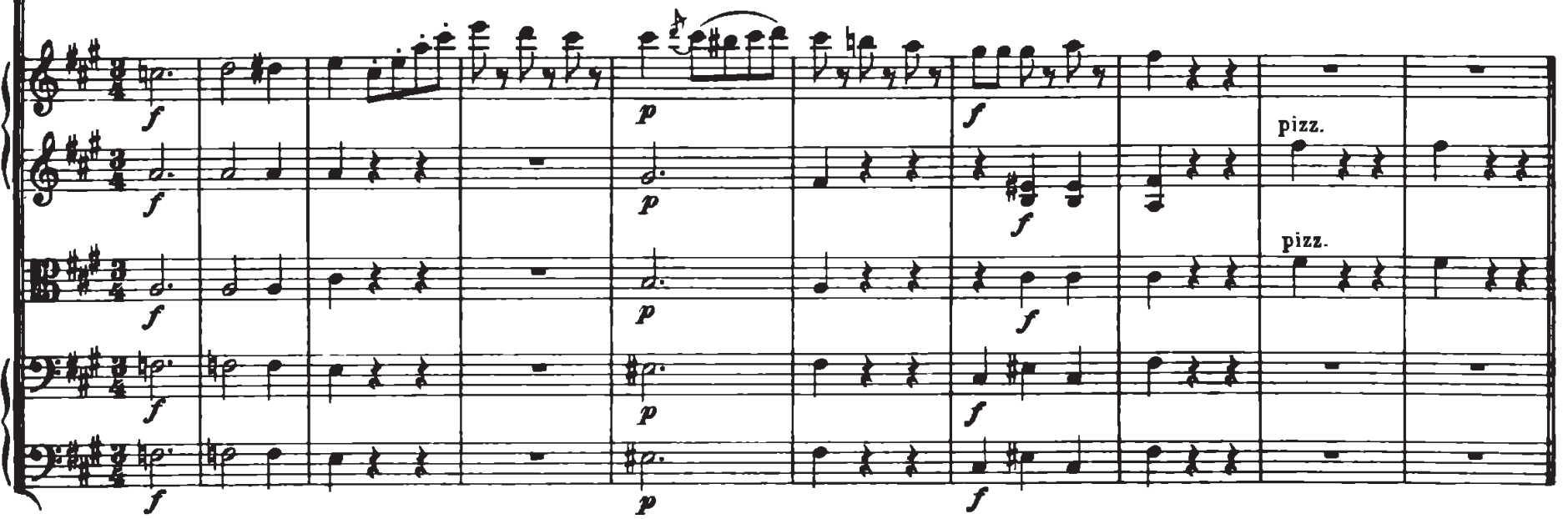


Walzer

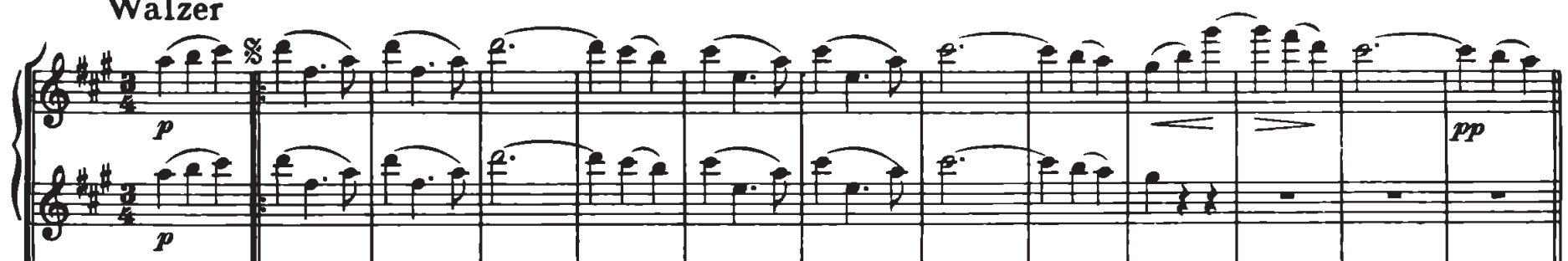

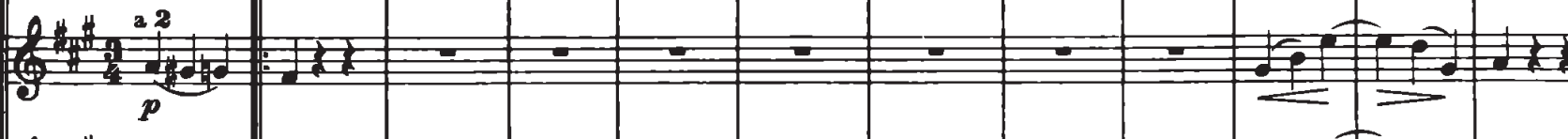

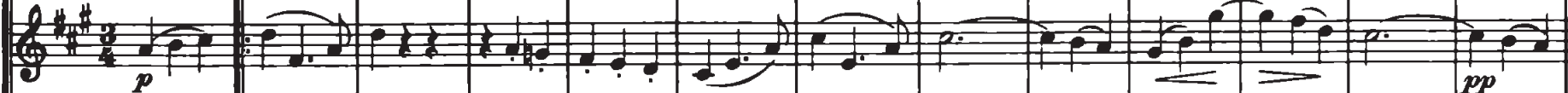
2.0. Yof

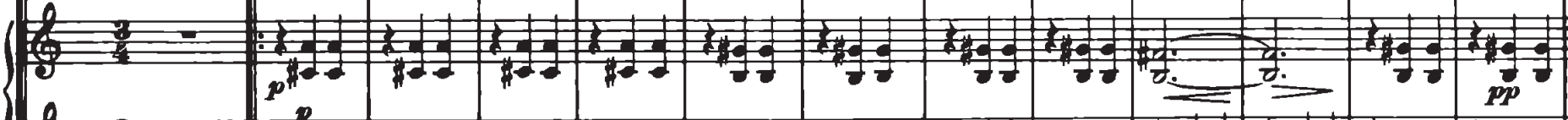

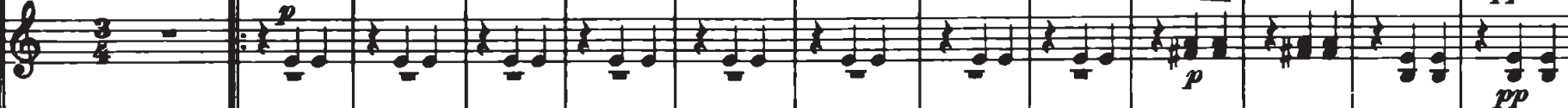

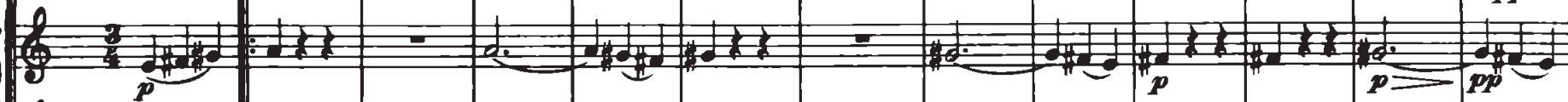

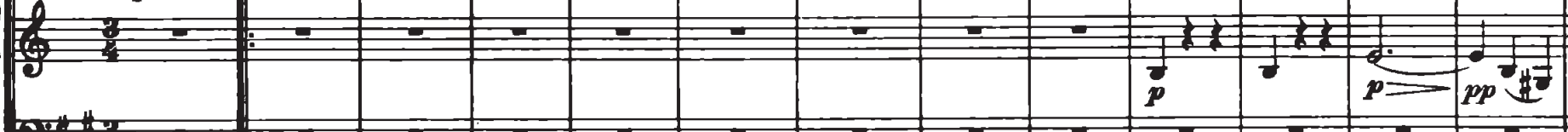

\begin{tabular}{|c|c|c|c|c|c|c|c|c|c|c|c|c|}
\hline 晋: & $=$ & $\overline{\bar{z}}$ & $=$ & 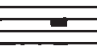 & $\sigma$ & $=$ & $\Longrightarrow$ & ב元 & $\angle$ & 드 & 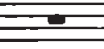 & 25 \\
\hline 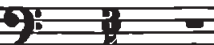 & $=$ & $\bar{~}$ & 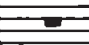 & $=$ & $=$ & 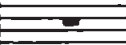 & $=$ & $=$ & $F$ & 드 & $\overline{\bar{z}}$ & $\overline{\bar{z}}$ \\
\hline & & $=$ & 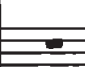 & & 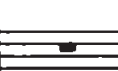 & 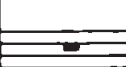 & $=$ & $=$ & & & & \\
\hline
\end{tabular}

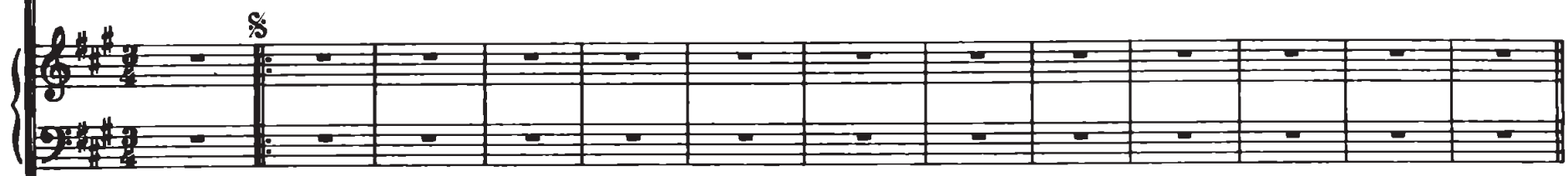

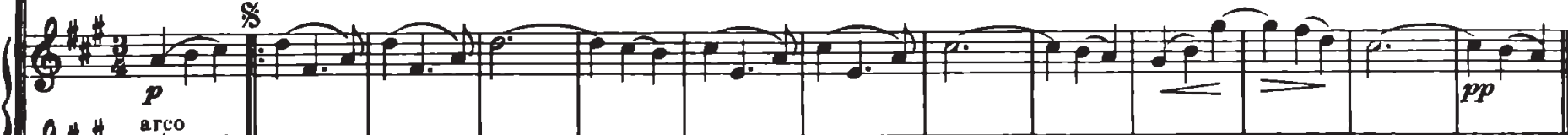
18. 月.

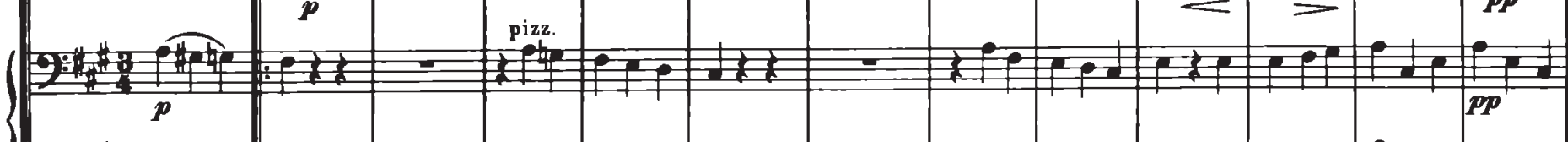

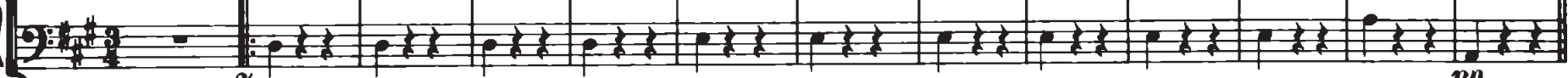
$\$ p$ 


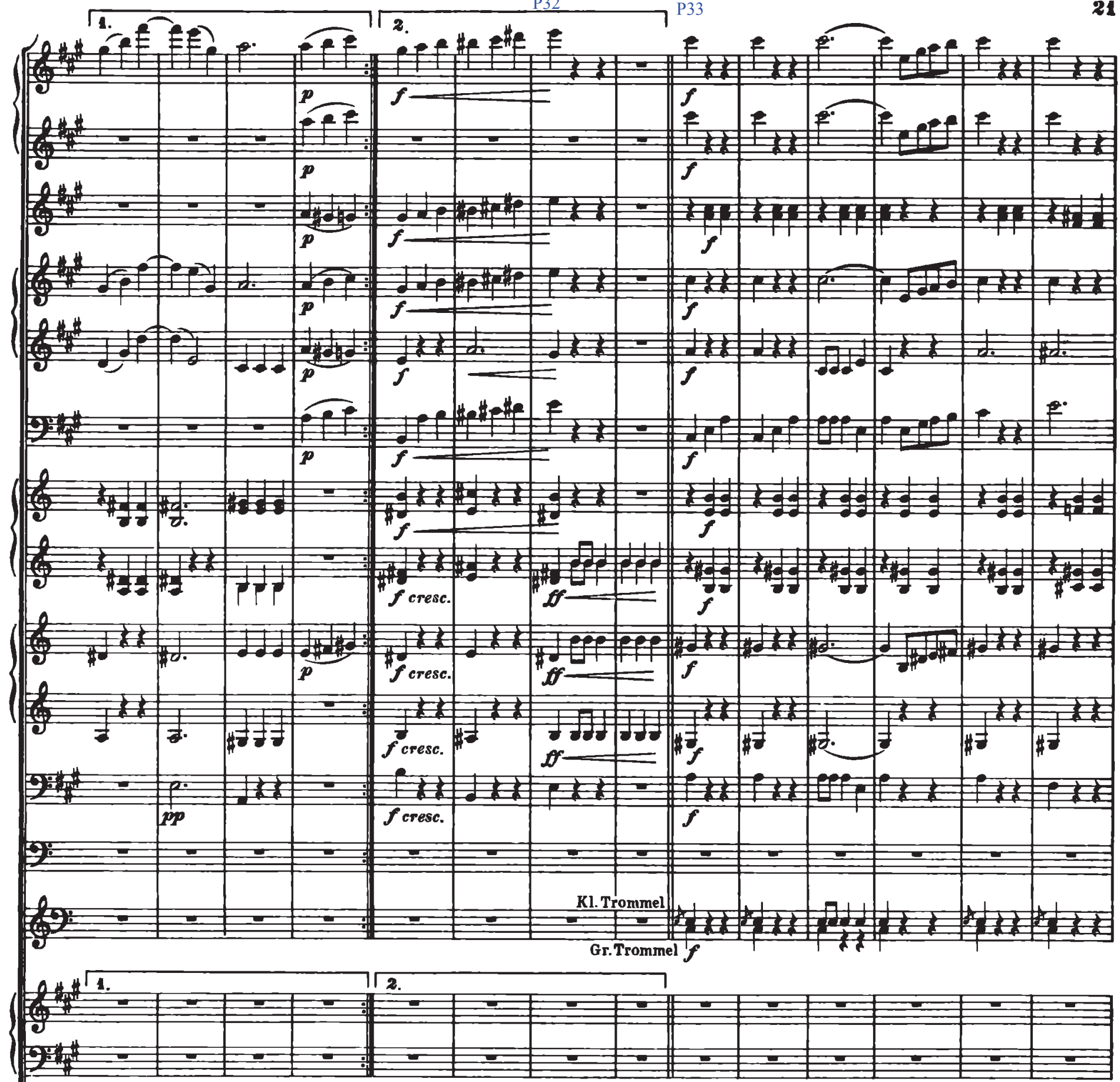

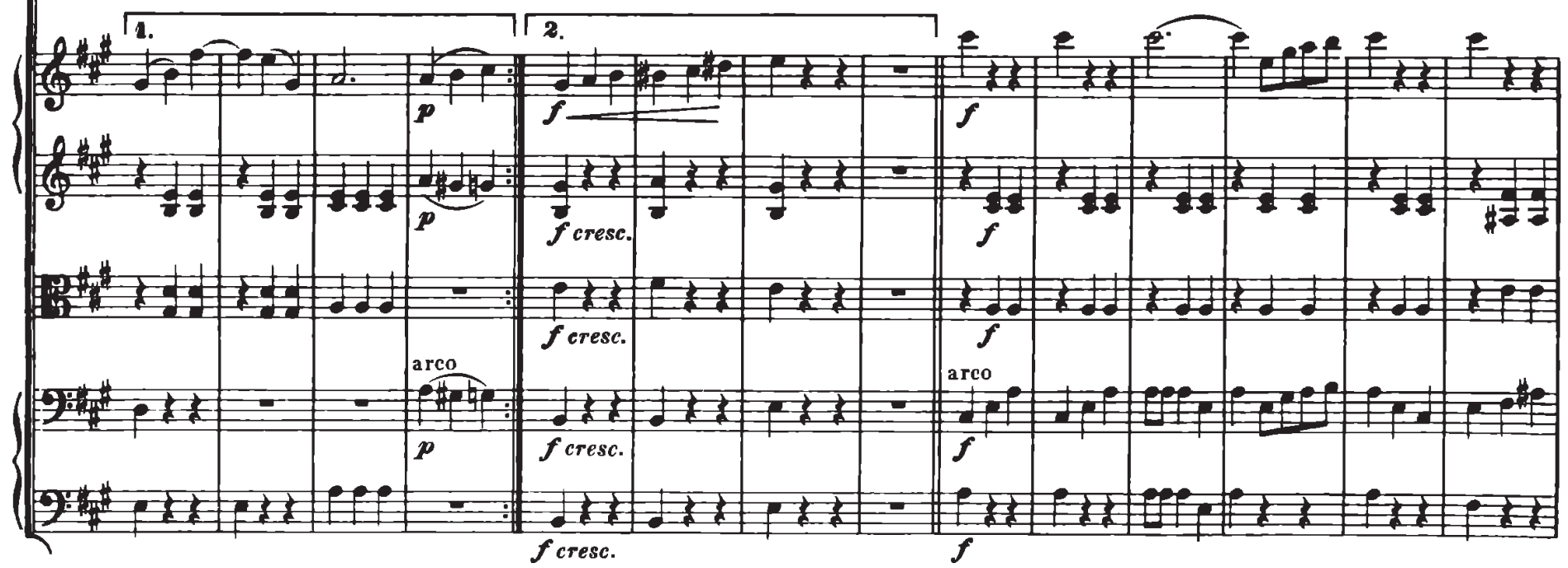


22

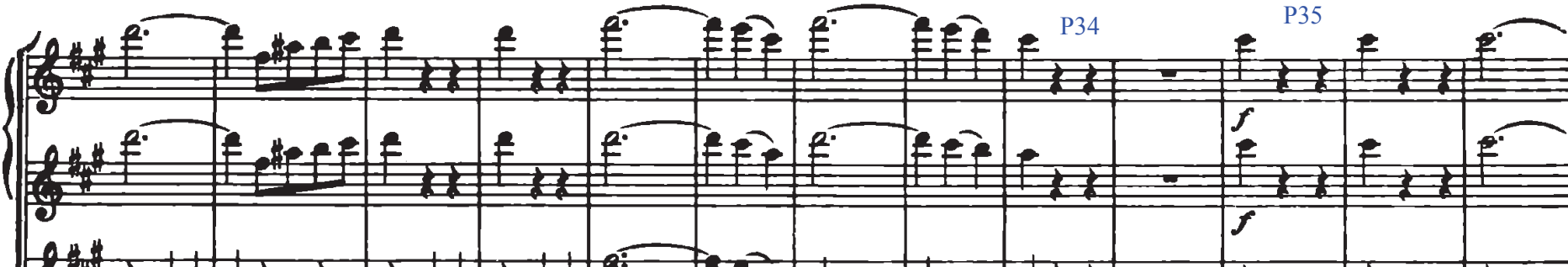

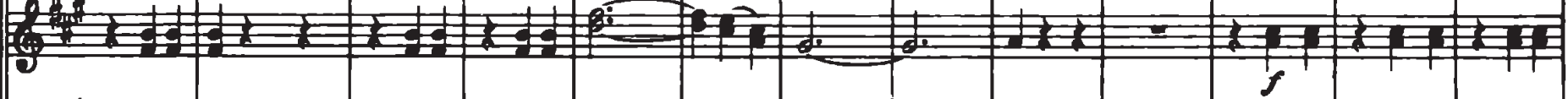

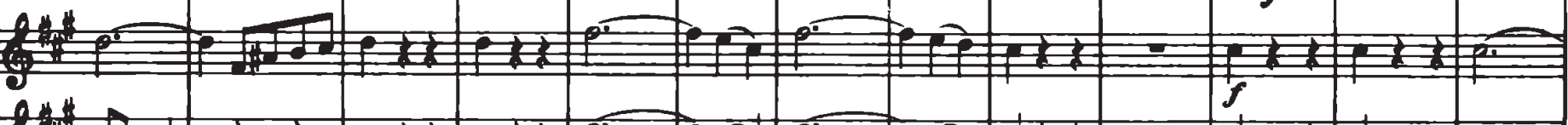

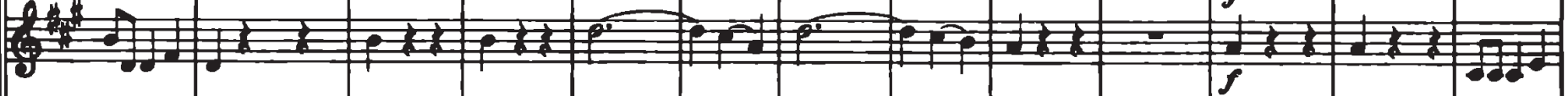

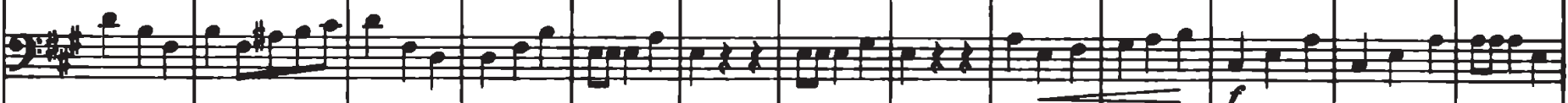

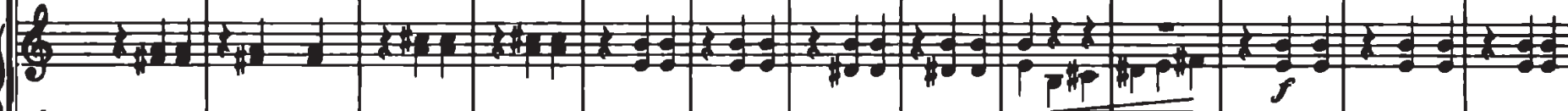

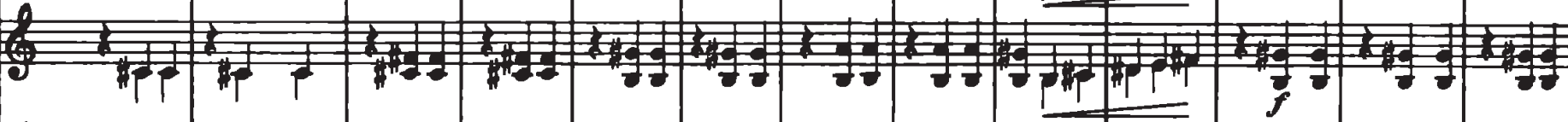

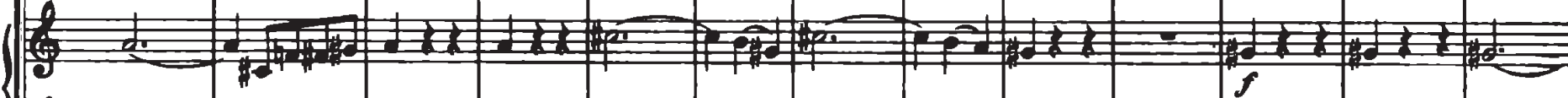

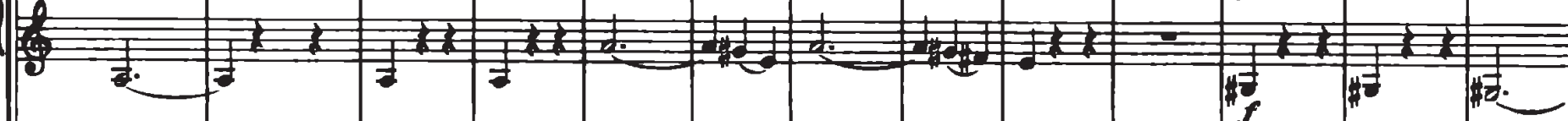

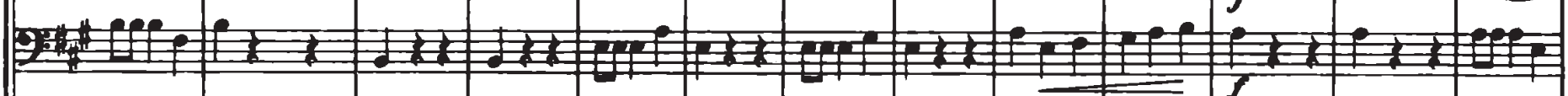

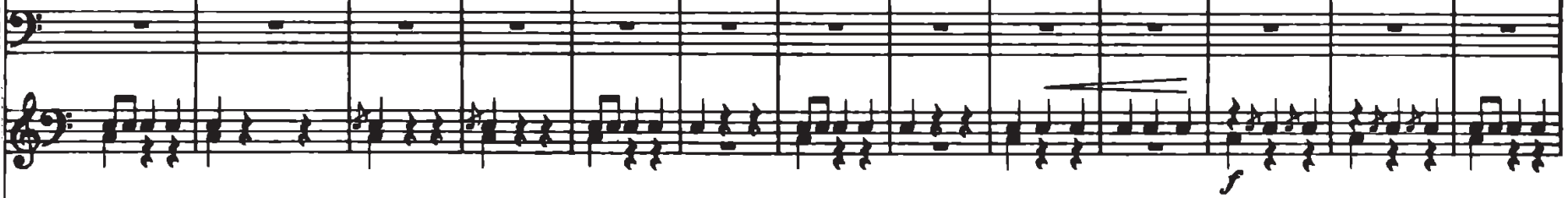

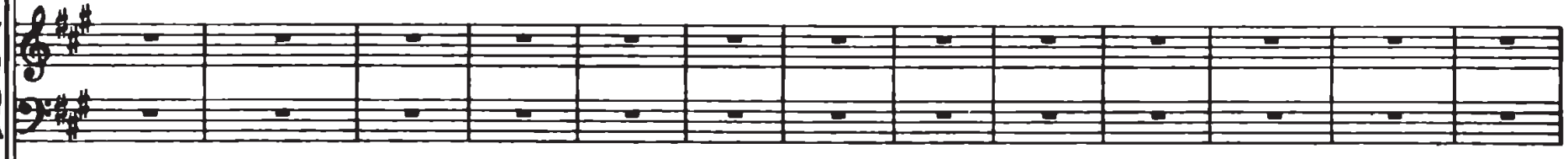

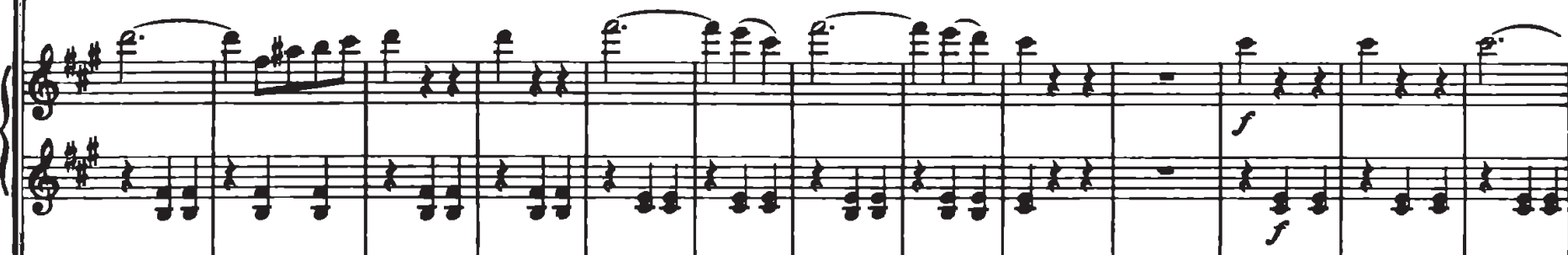

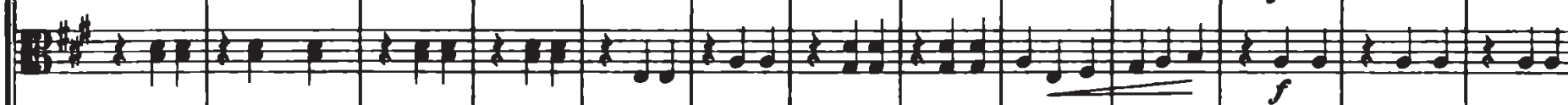

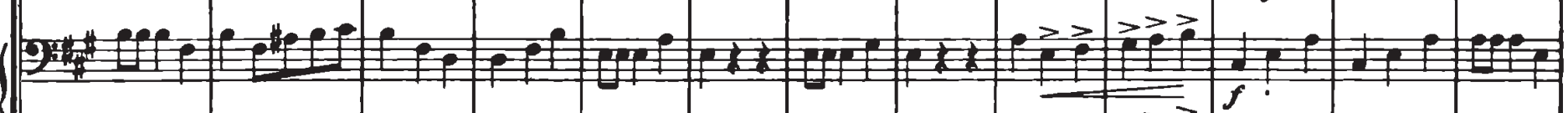

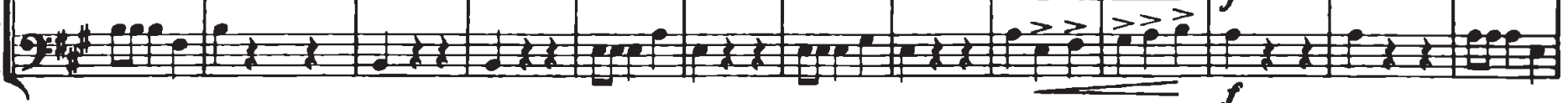



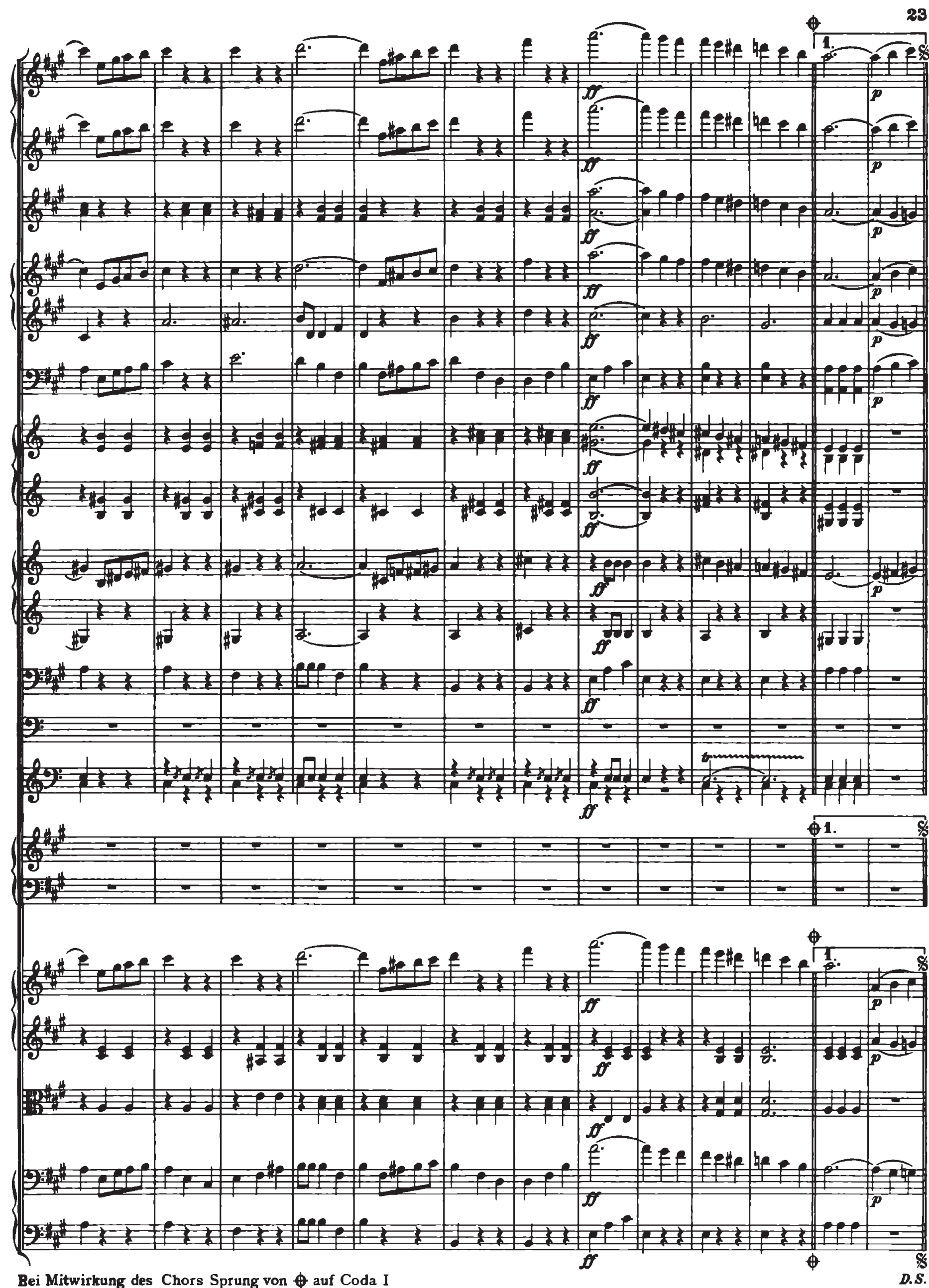
24
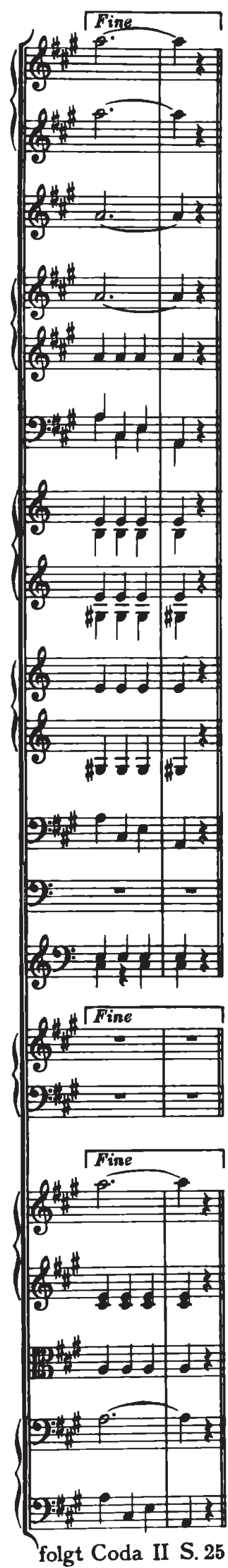

Coda I Nur bei Mitwirkung des Chors

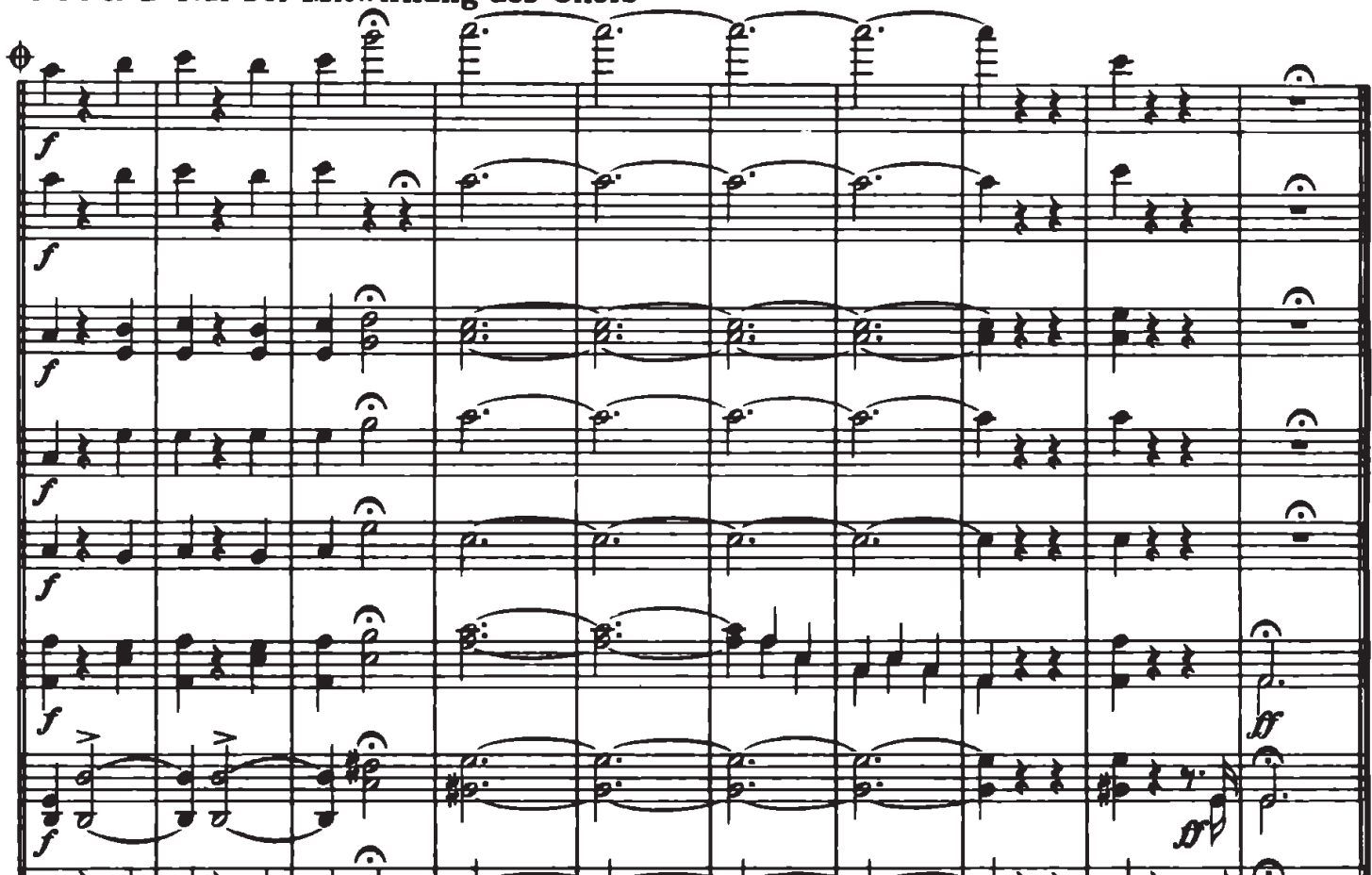

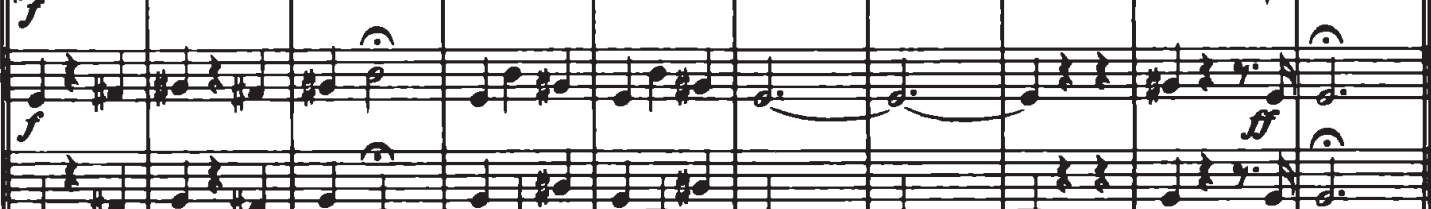

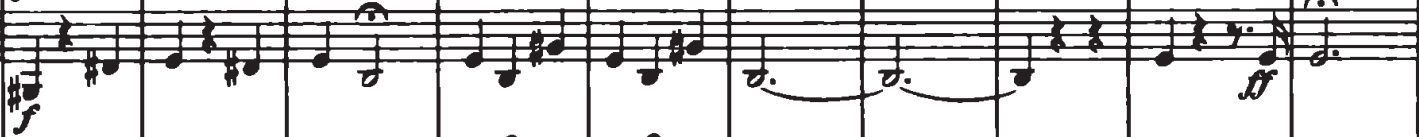

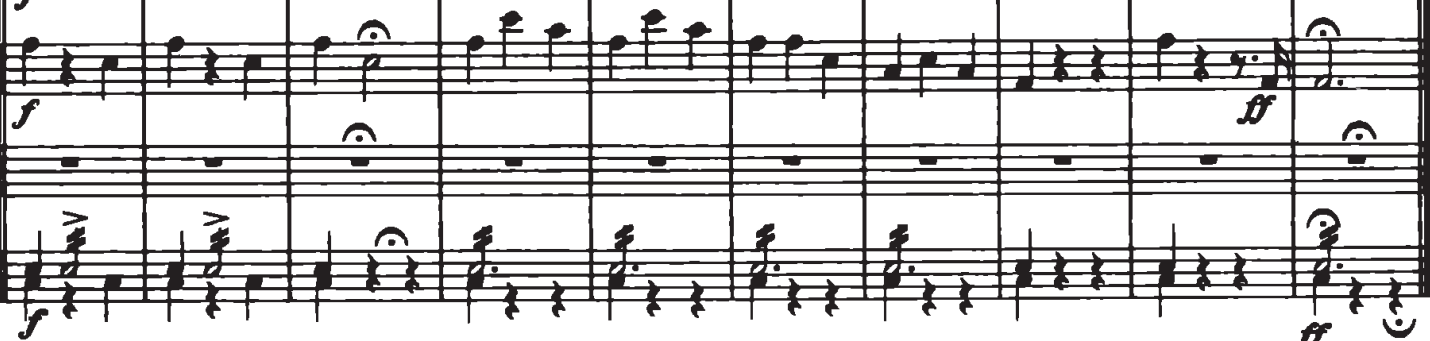

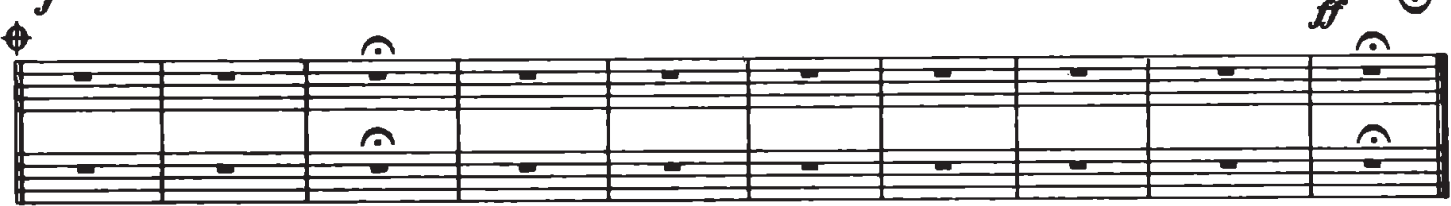

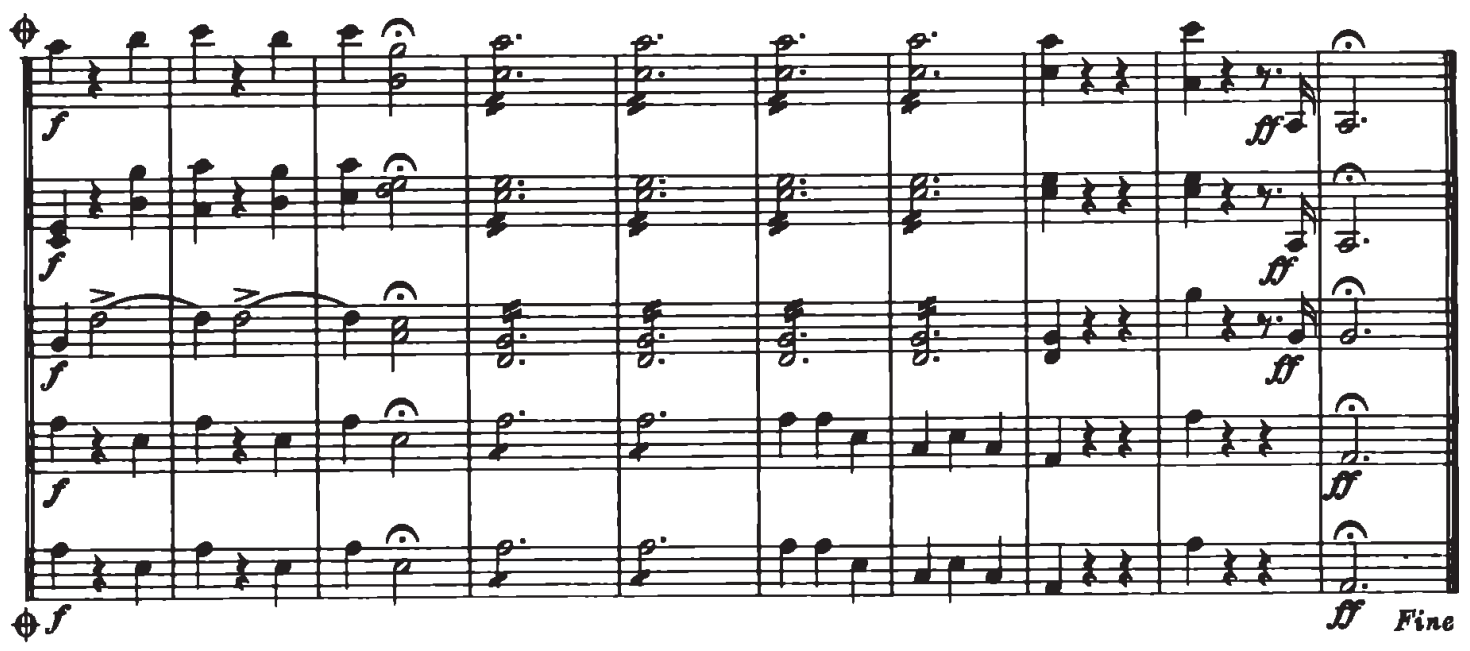


Coda II

P36

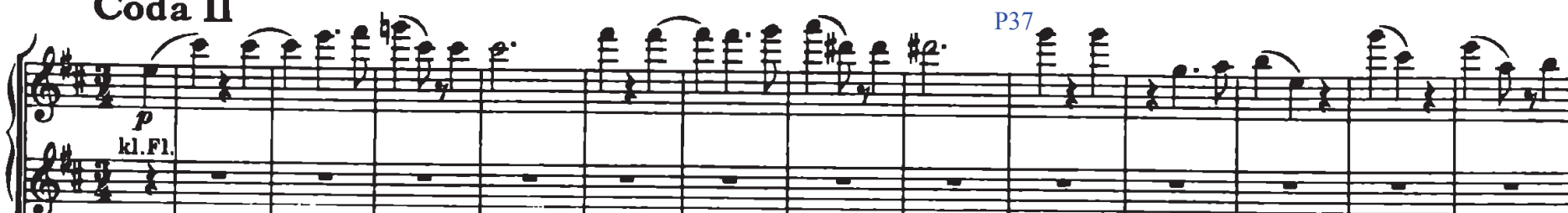

Q

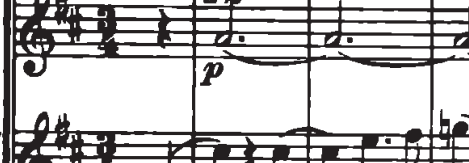

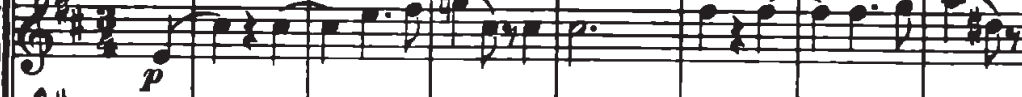

6.

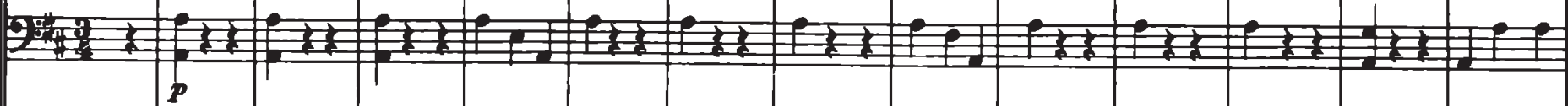
60.

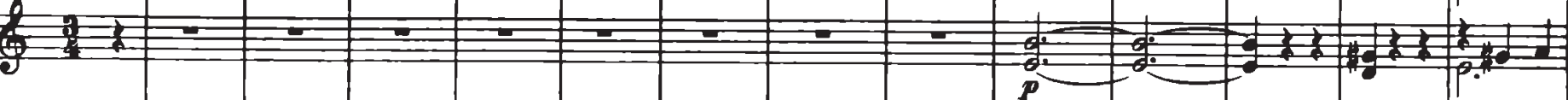
(3)

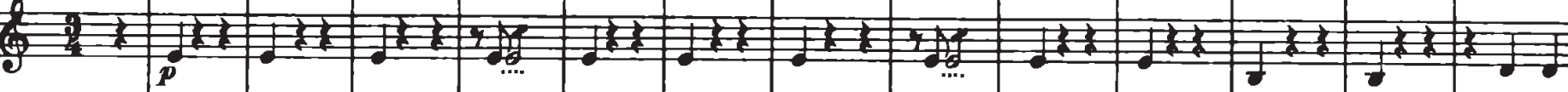

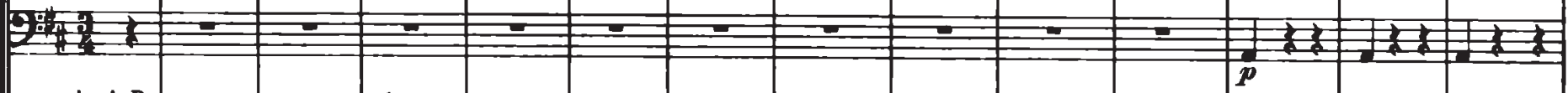

in A D

\begin{tabular}{|c|c|c|c|c|c|c|c|c|c|c|c|c|c|}
\hline E & $=$ & $E=$ & $F$ & $F$ & 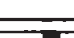 & $\bar{\square}$ & $\operatorname{trm}$ & 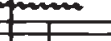 & 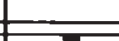 & 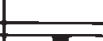 & $\rightarrow \rightarrow$ & & \\
\hline & 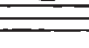 & 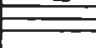 & & e. & 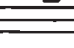 & $=$ & & & 䎴 & 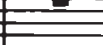 & 78 & 8 tat & 72 \\
\hline & & & & & & & & & & & & & \\
\hline$\Rightarrow$ & - & 2 & $=$ & $\underline{\underline{ }}$ & $=$ & 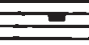 & $\underline{\underline{ }}=$ & $\underline{\underline{E}}$ & $\underline{\underline{2}}$ & $=$ & $=$ & $=$ & 든 \\
\hline
\end{tabular}

于

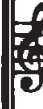

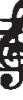

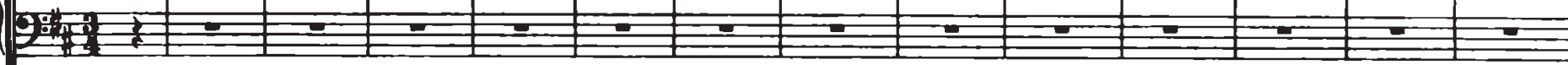

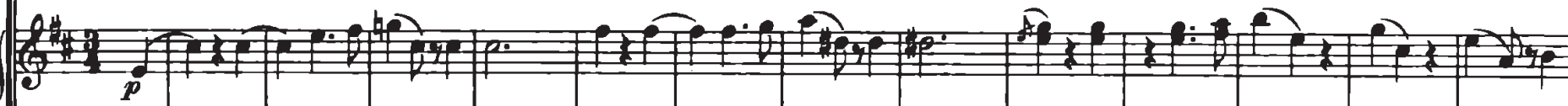
(2) m

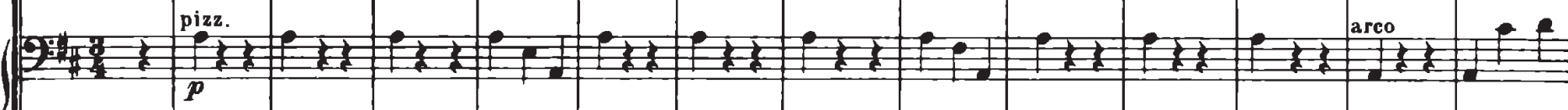

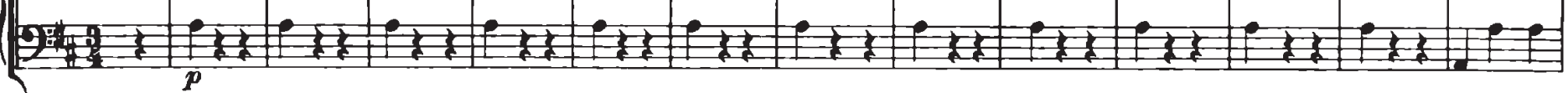




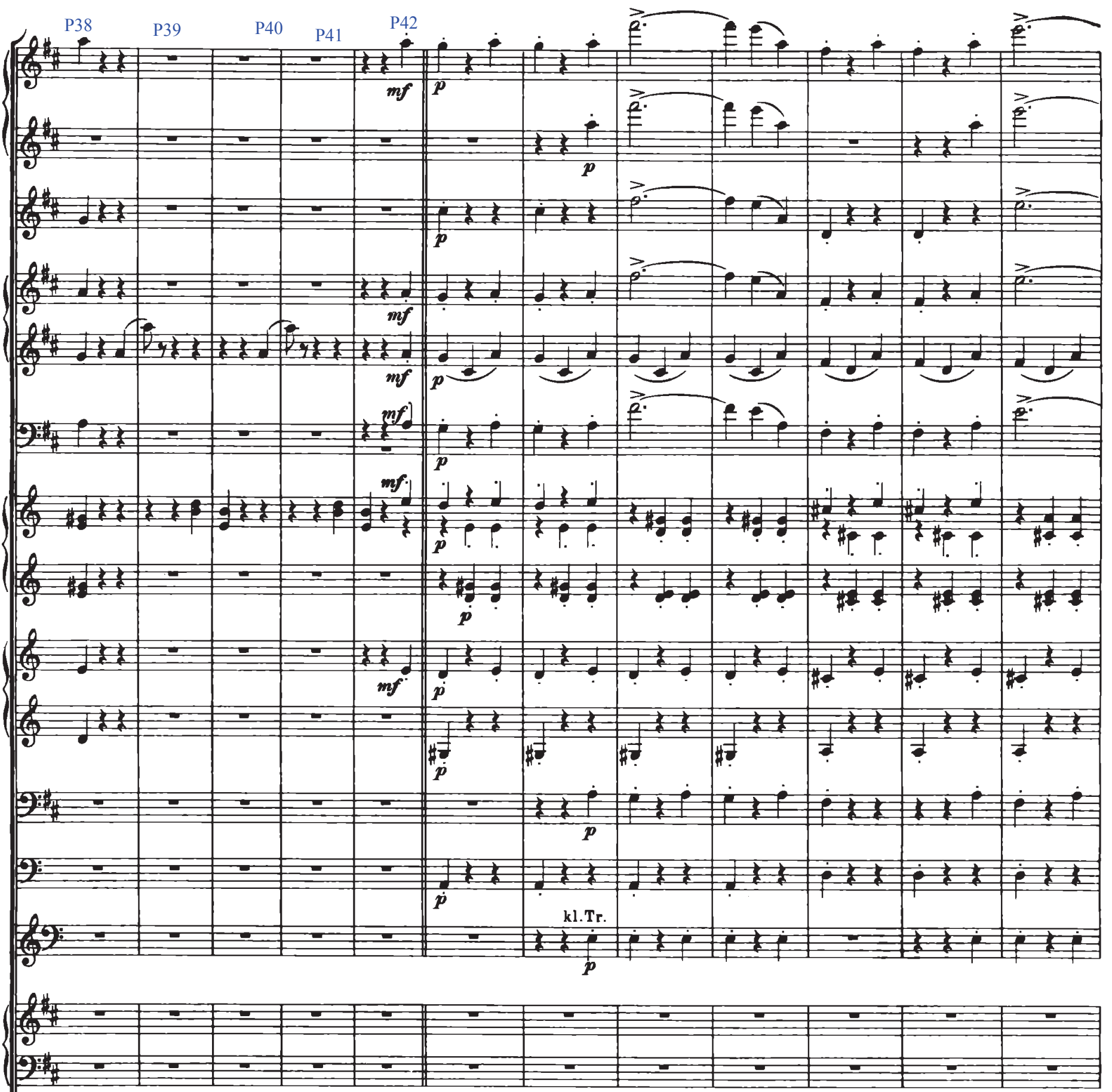

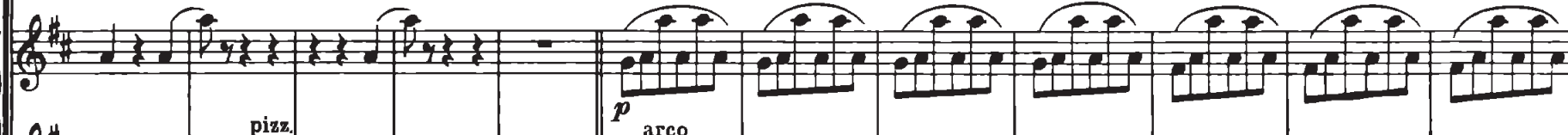

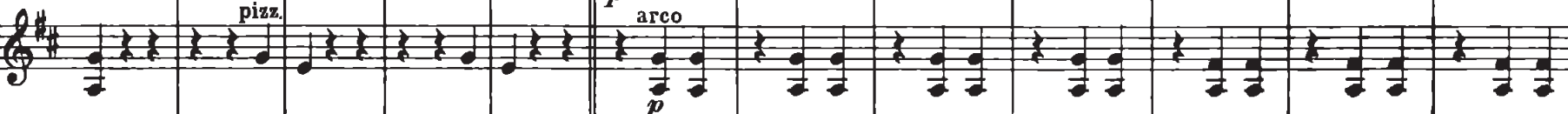

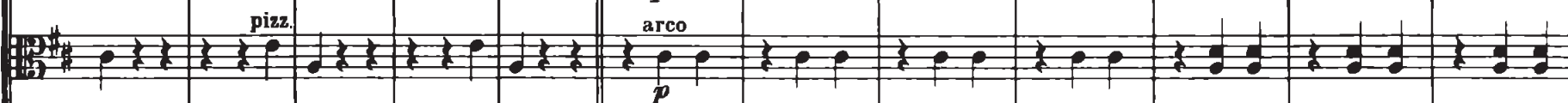




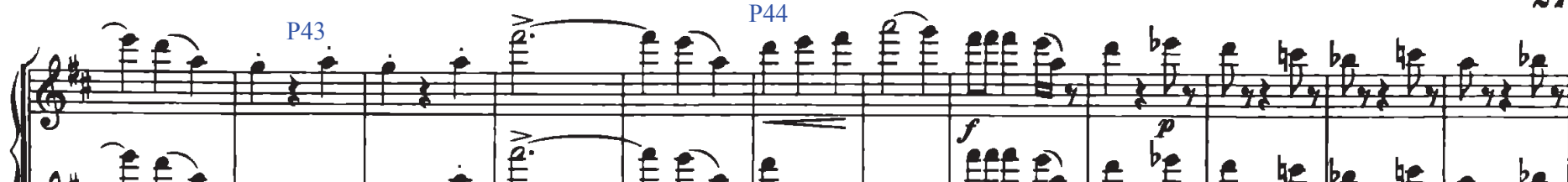

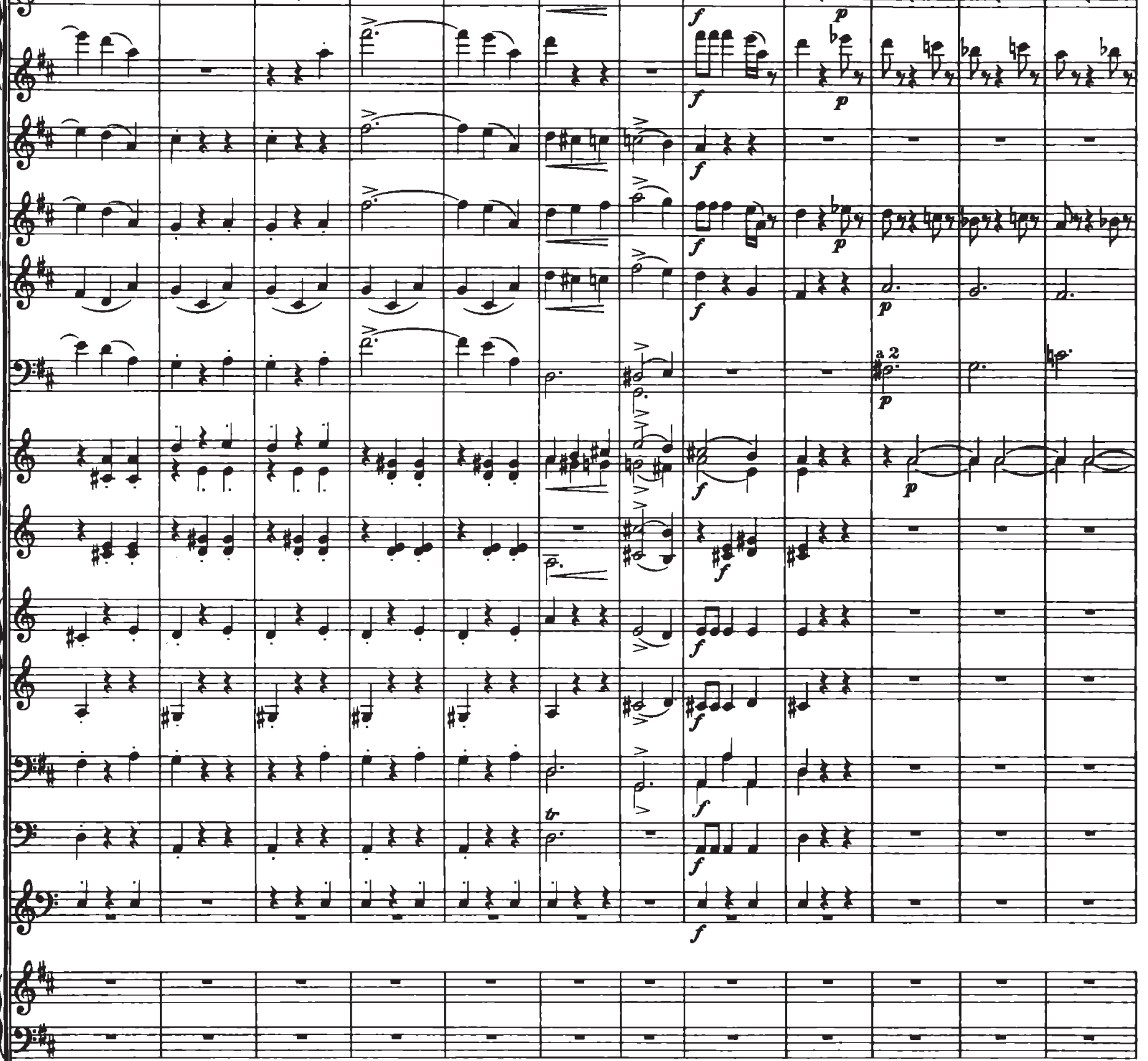

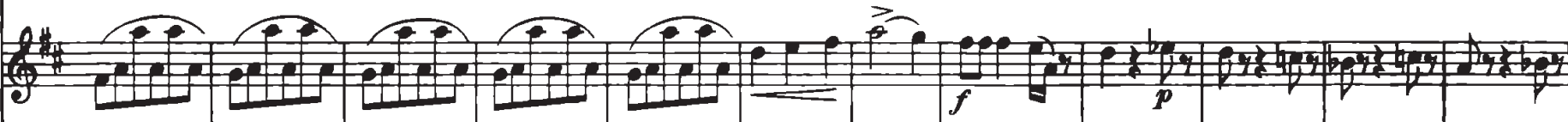

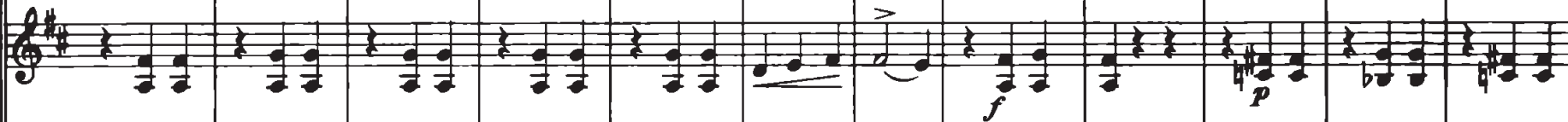

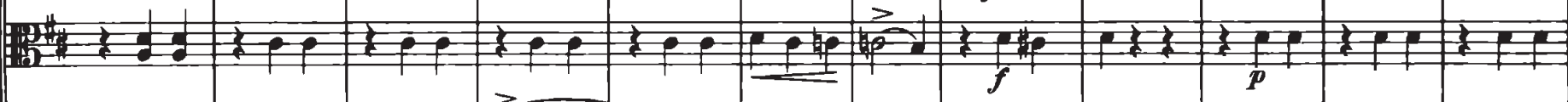

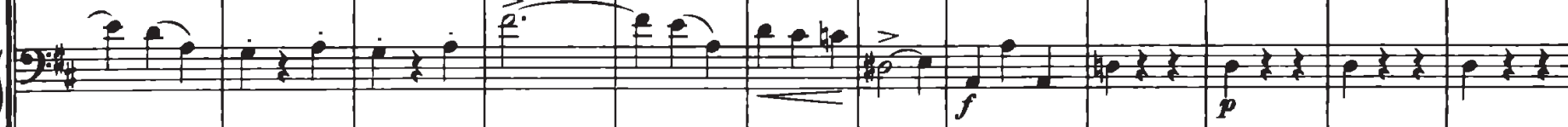

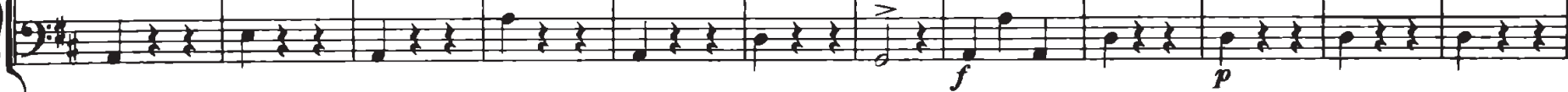




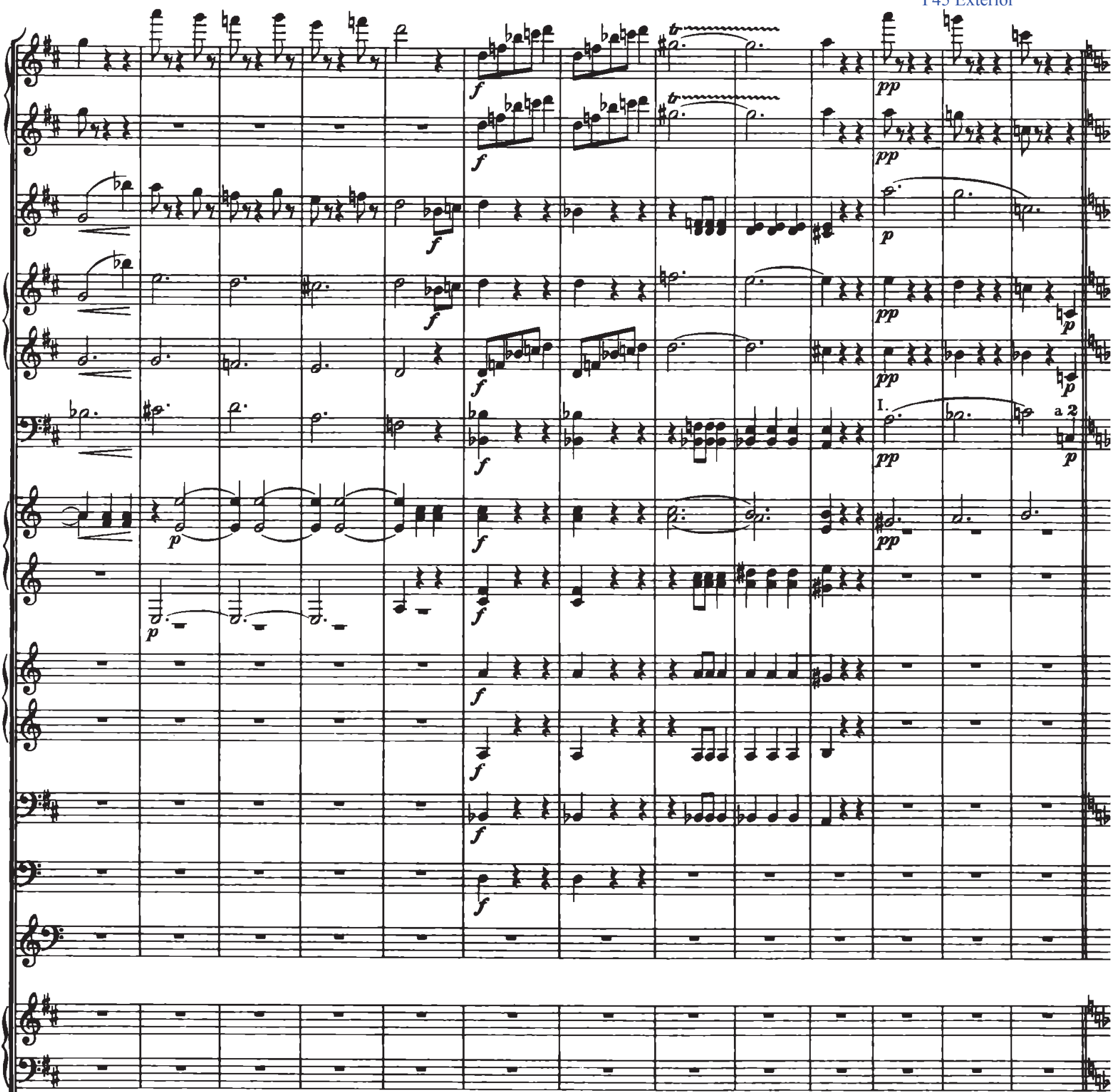

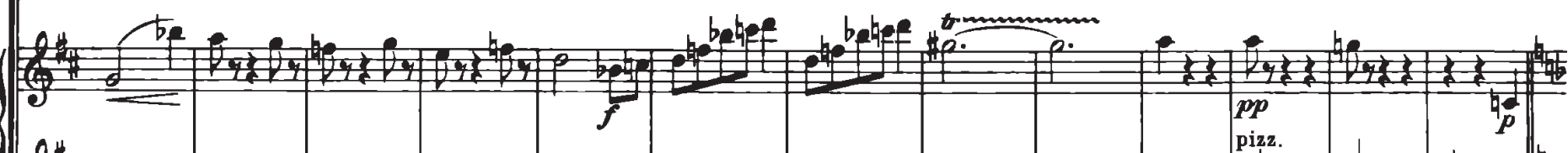
(2)

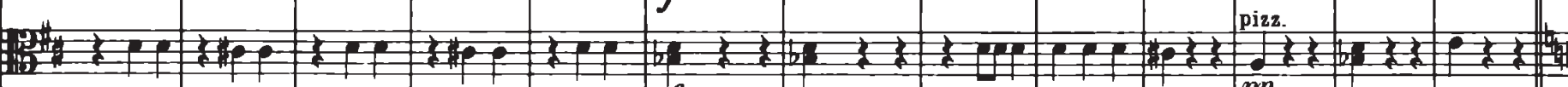

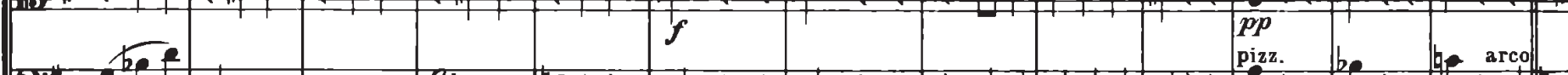

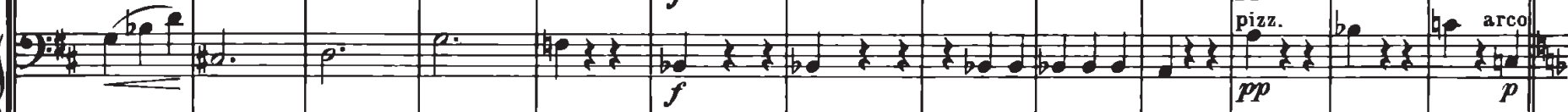
(20) 


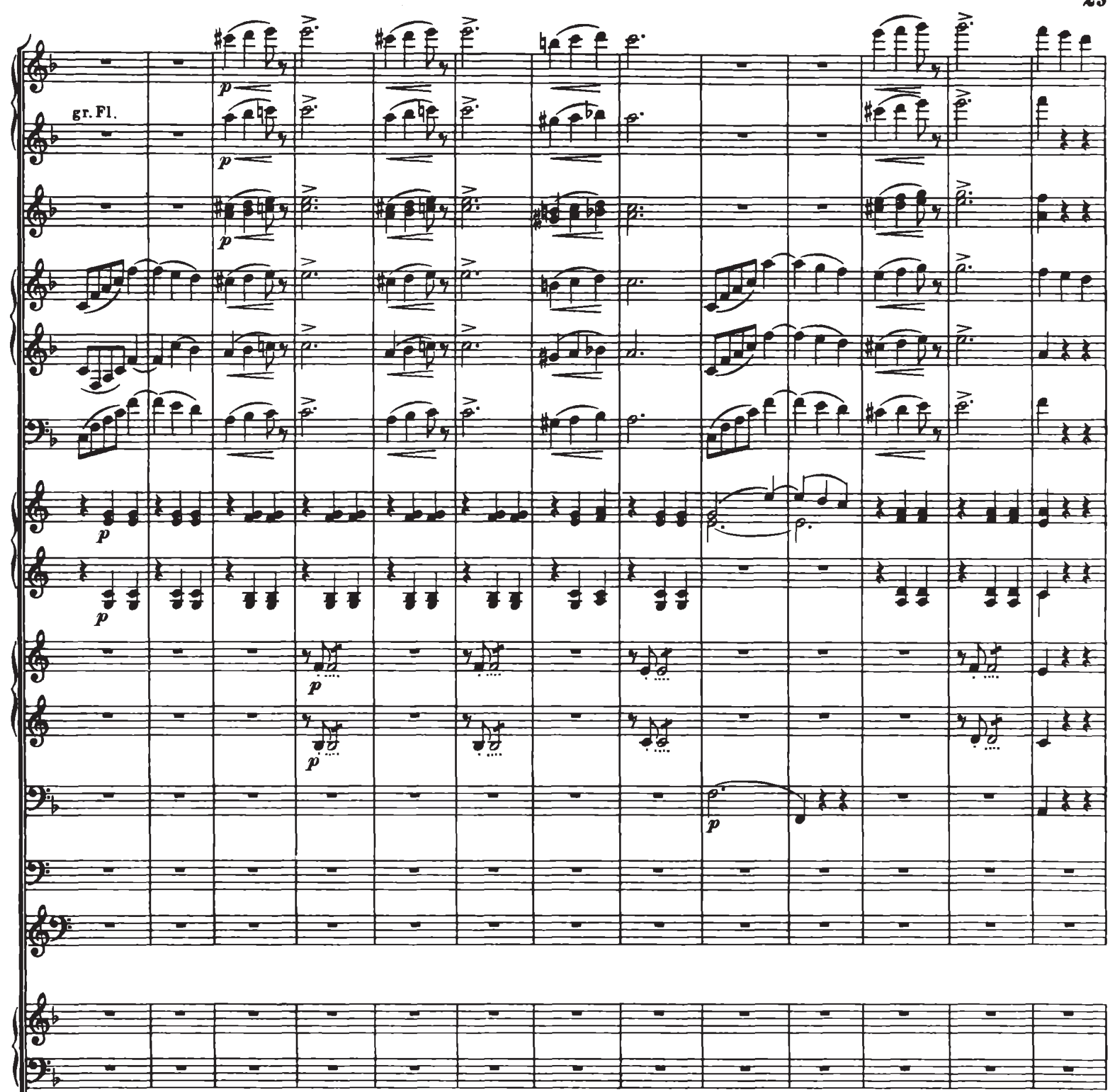

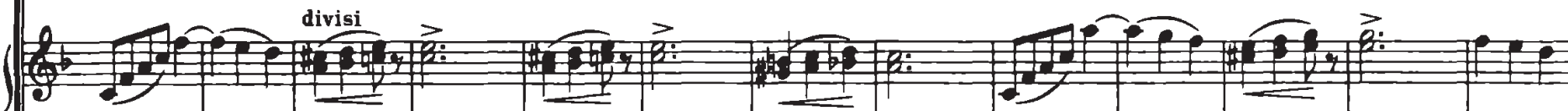

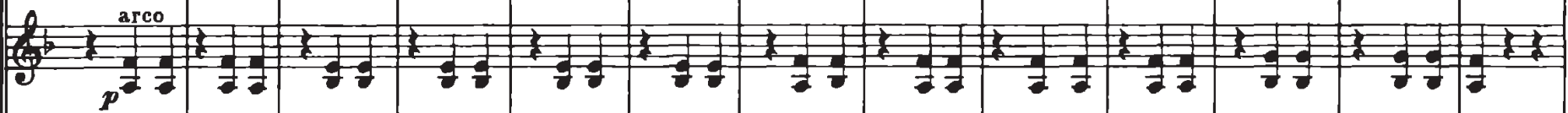

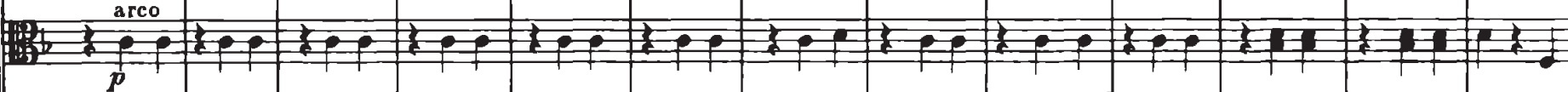

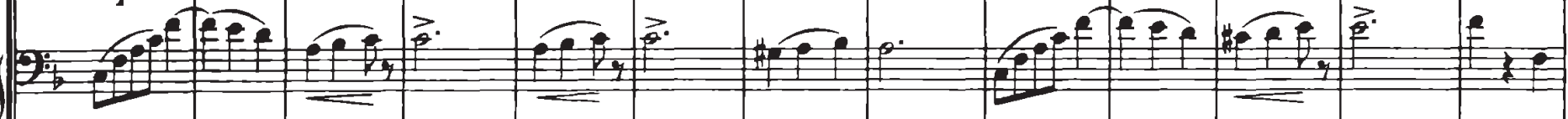

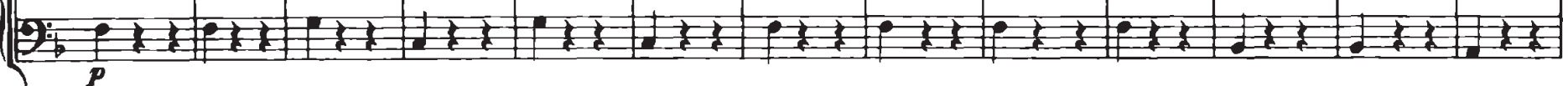



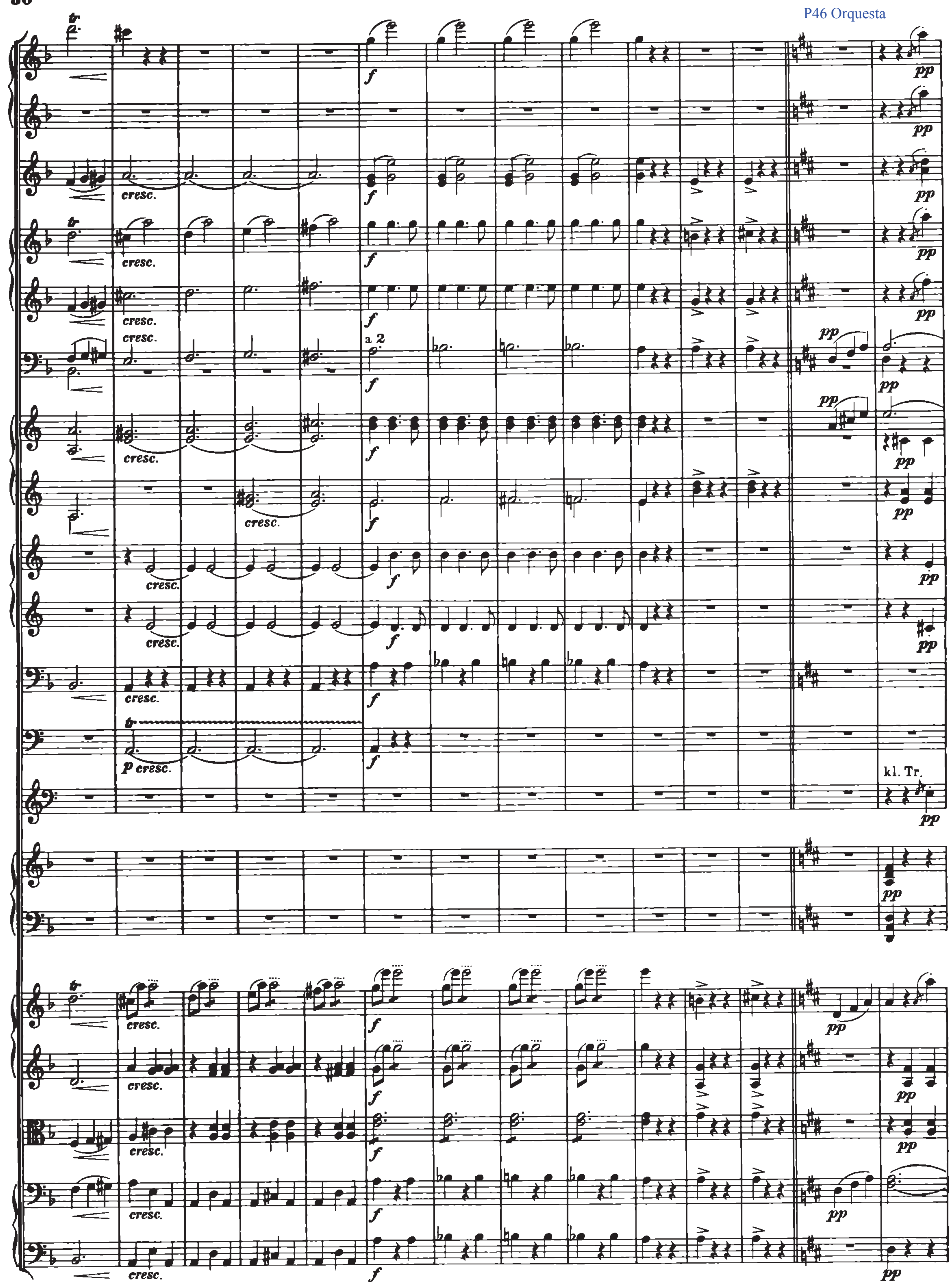


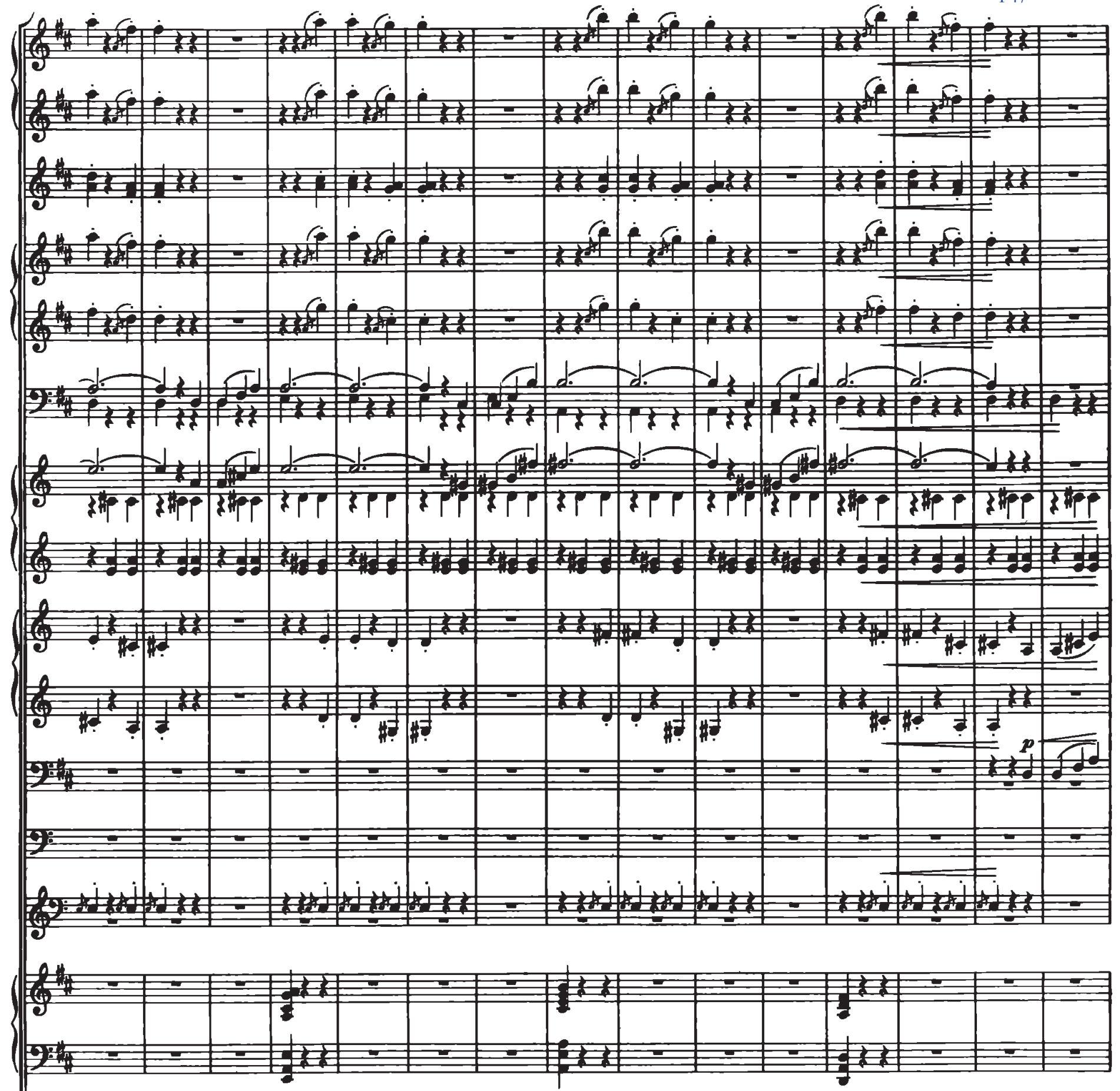

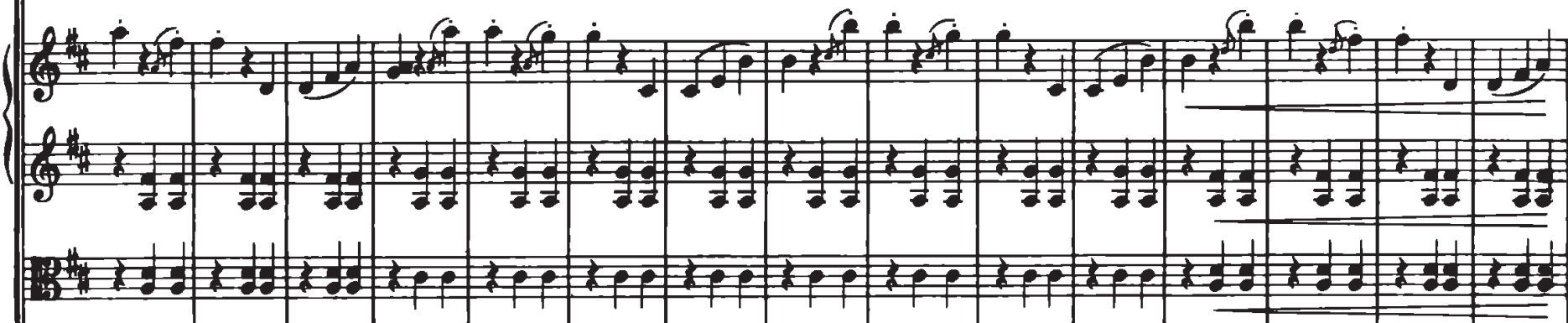

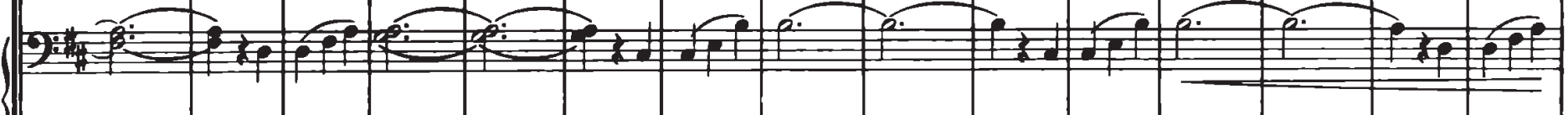

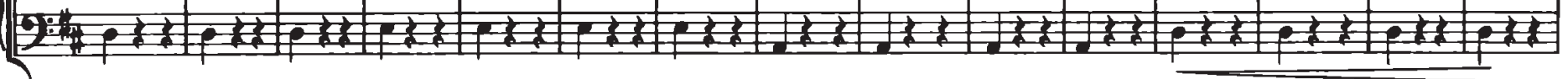


(4) 3.1.

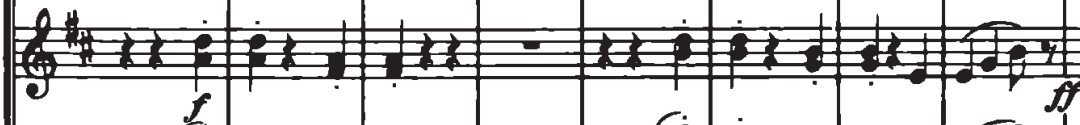
+ 12110

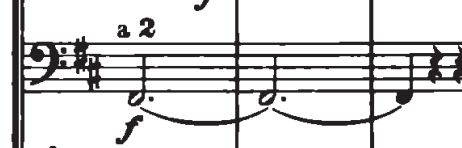

6. 10.

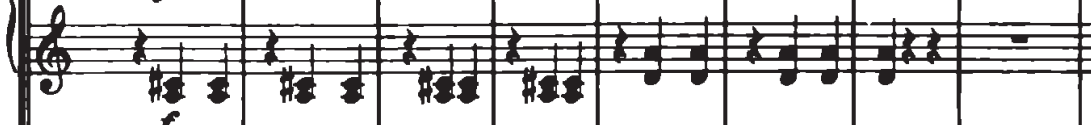
; is

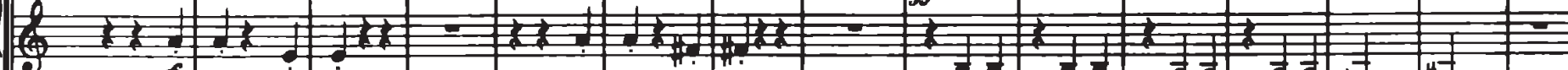

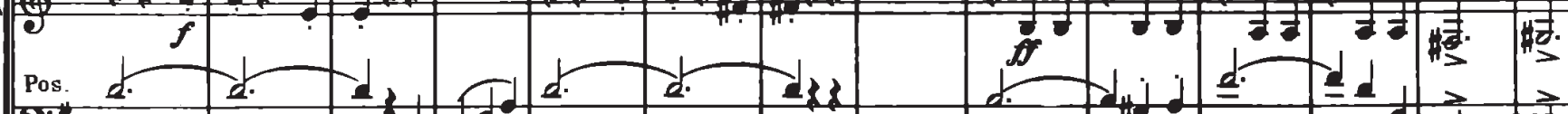

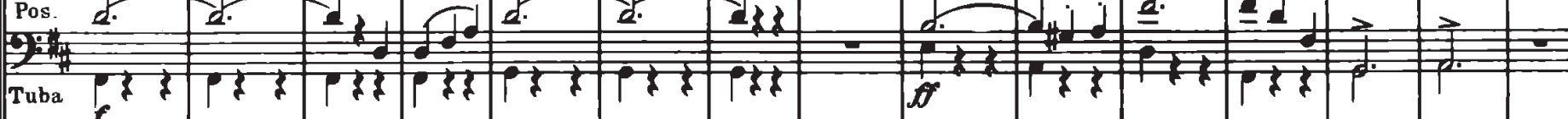
,

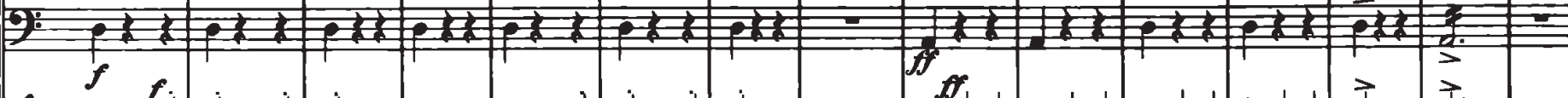

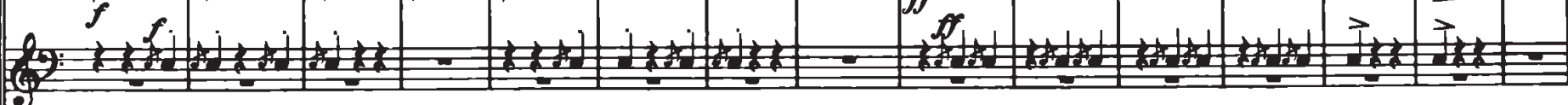

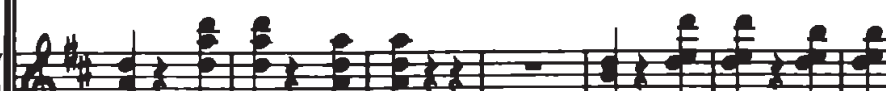
3)

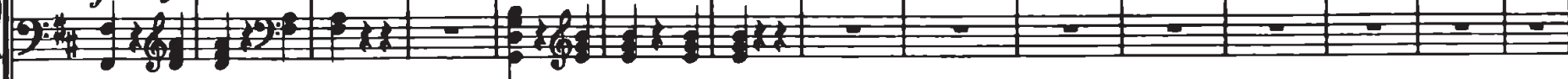
24

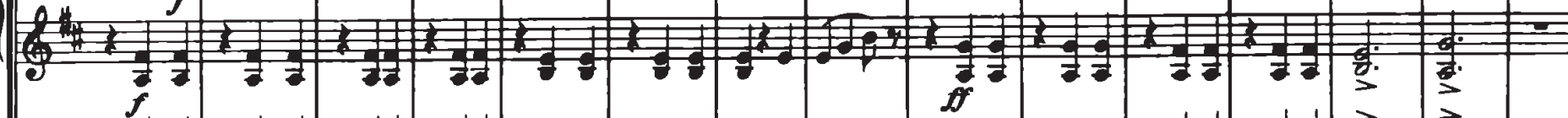

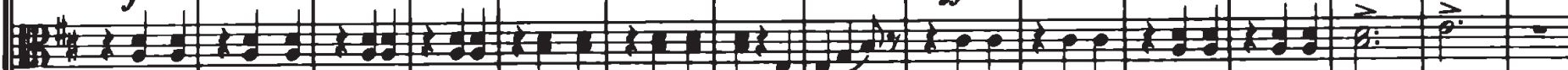
(2) 
P49

Solo

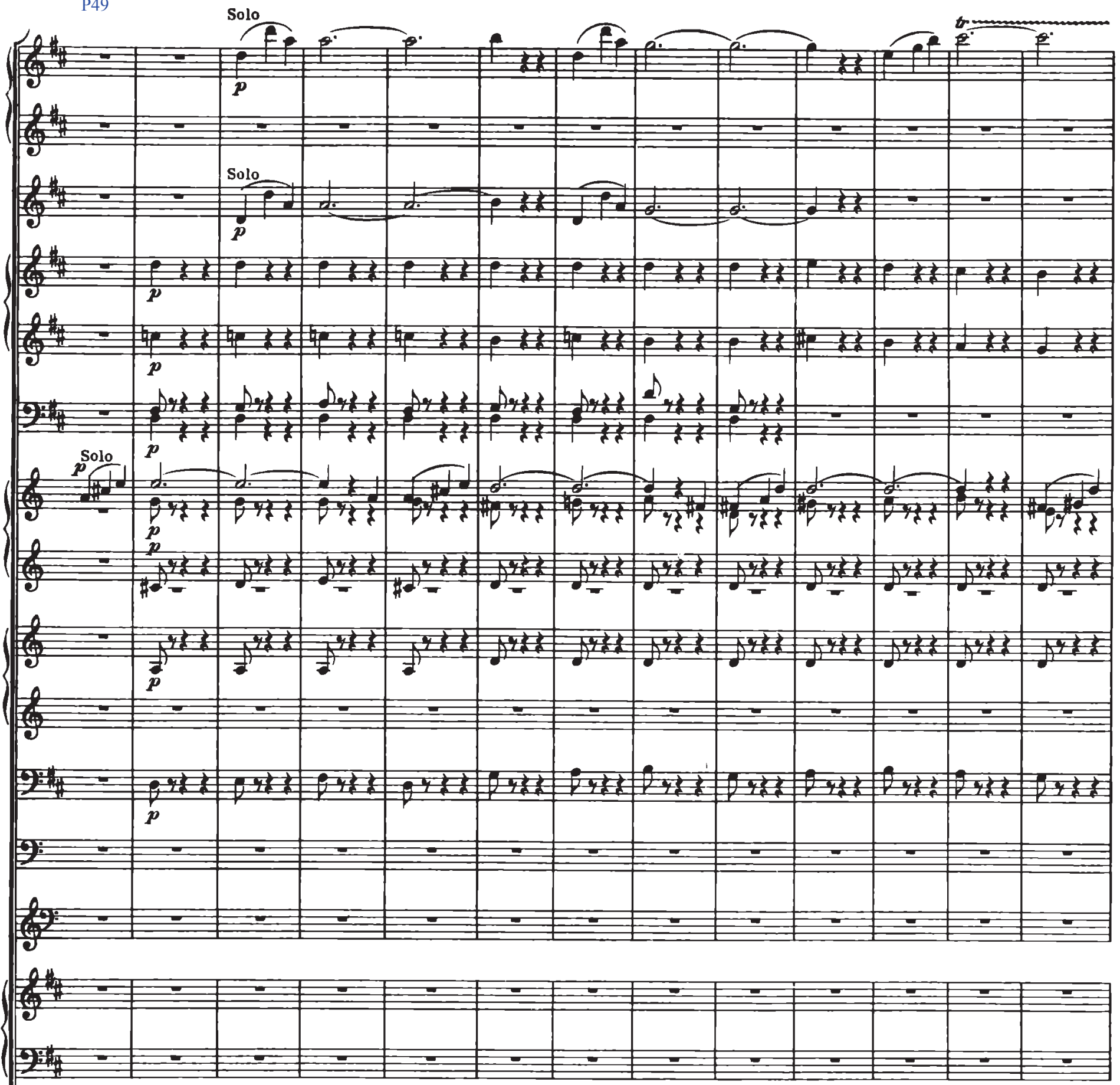

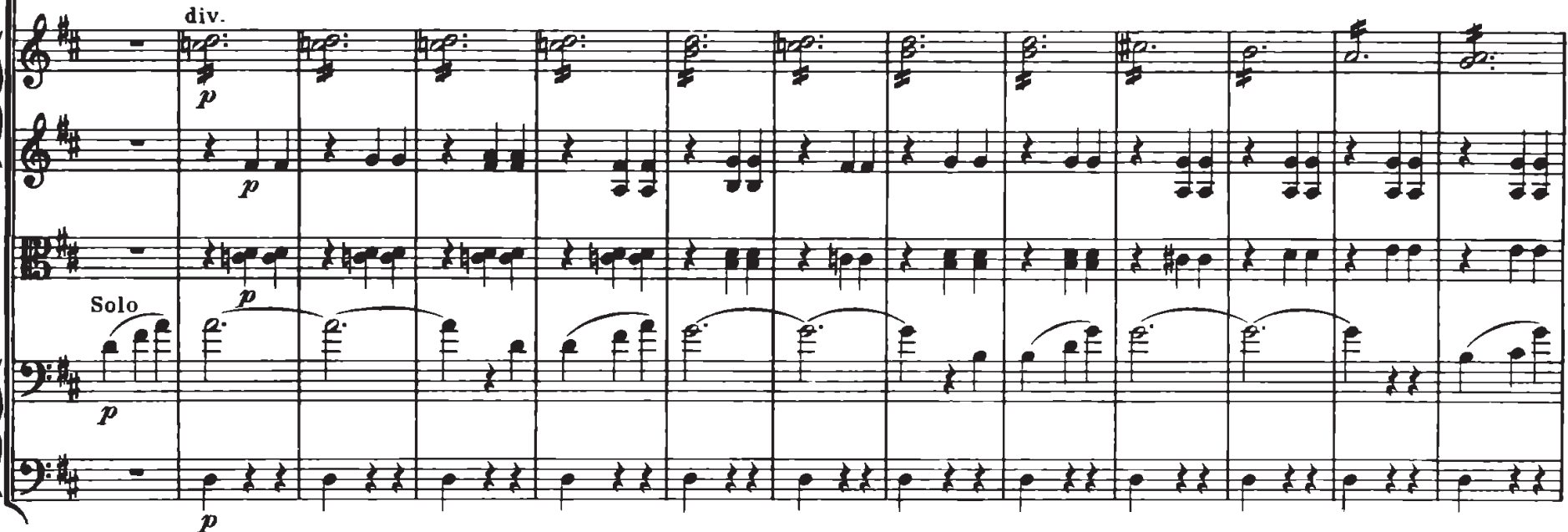



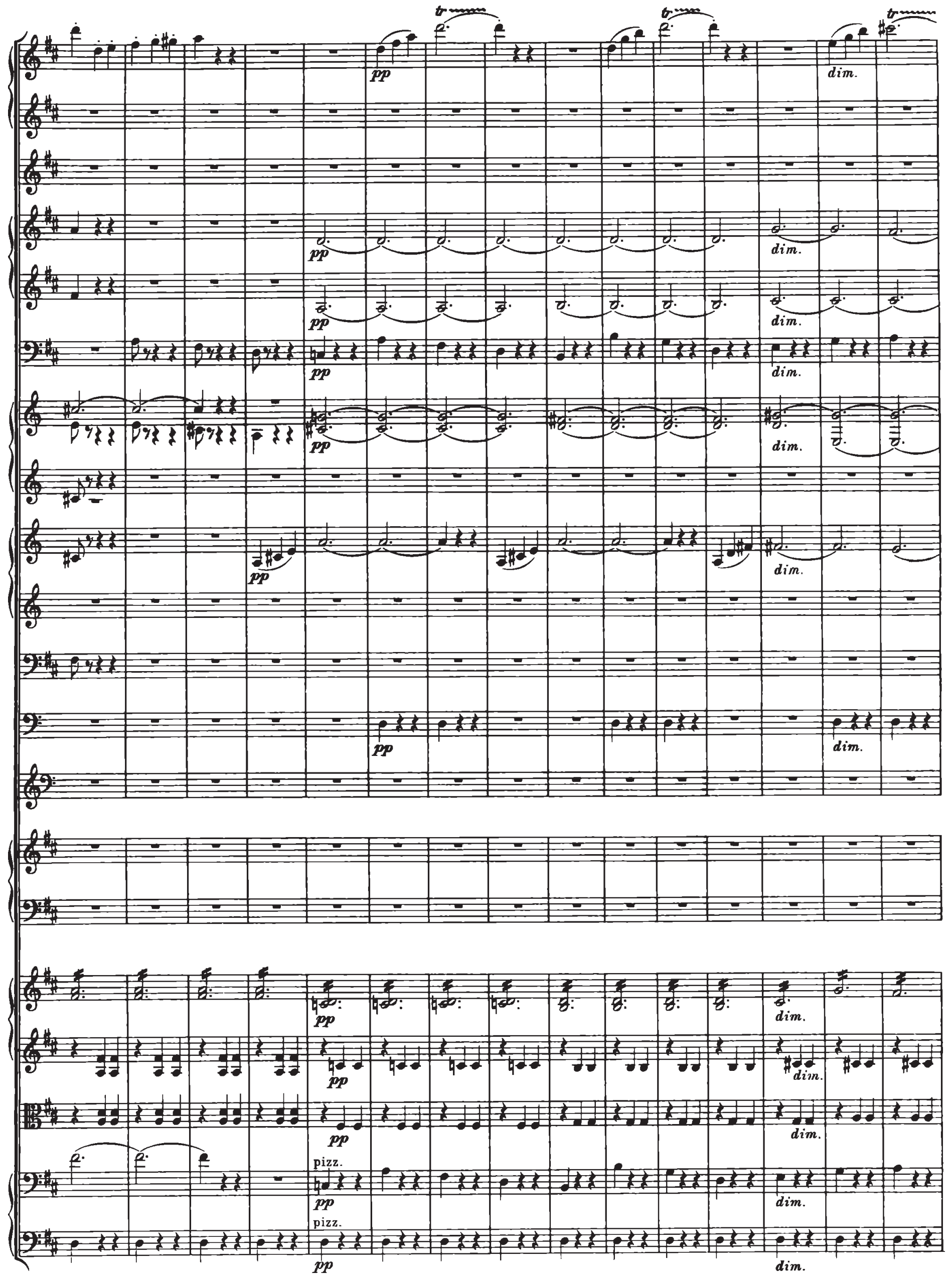


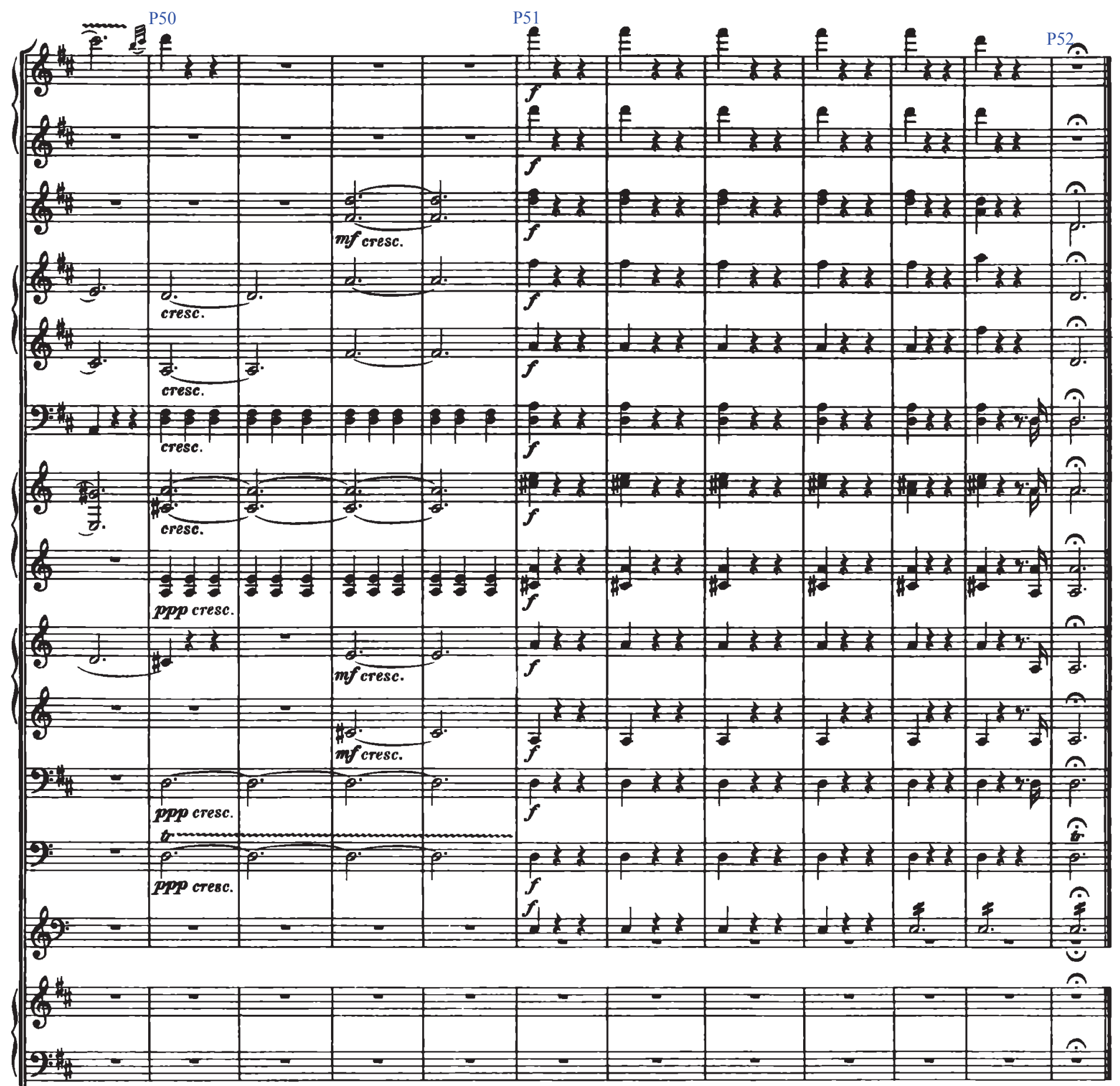

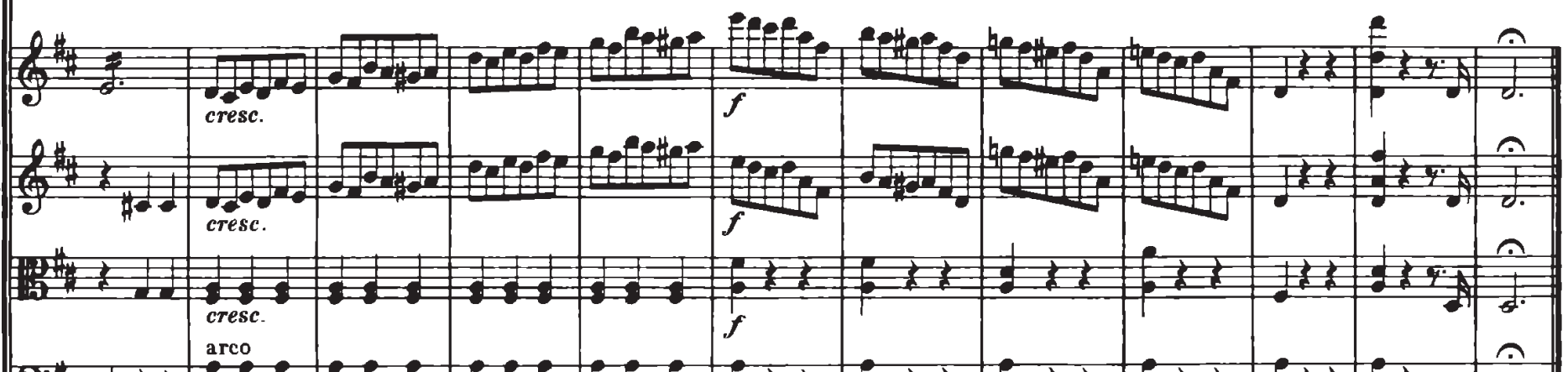

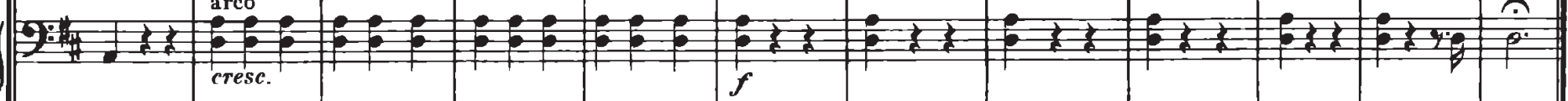

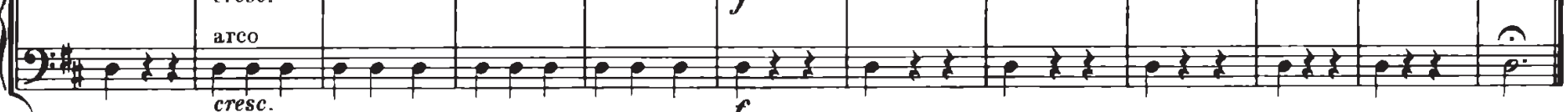


Director audiovisual:

Michael Beyer

\section{Walzer}

P1 P2 Introduktion

Johann Strauß, op. 314

Andantino

Flöte I

Flöte II

Kleine Flöte

Oboen

Klarinetten in $\mathrm{C}$

II

Fagotte

Hörner in $F$

I II

Trompeten in $\mathrm{F}$

Baß-Posaune

Tuba

III IV

Pauken

Kleine Trommel

Triangel u.

große Trommel

Harfe

II
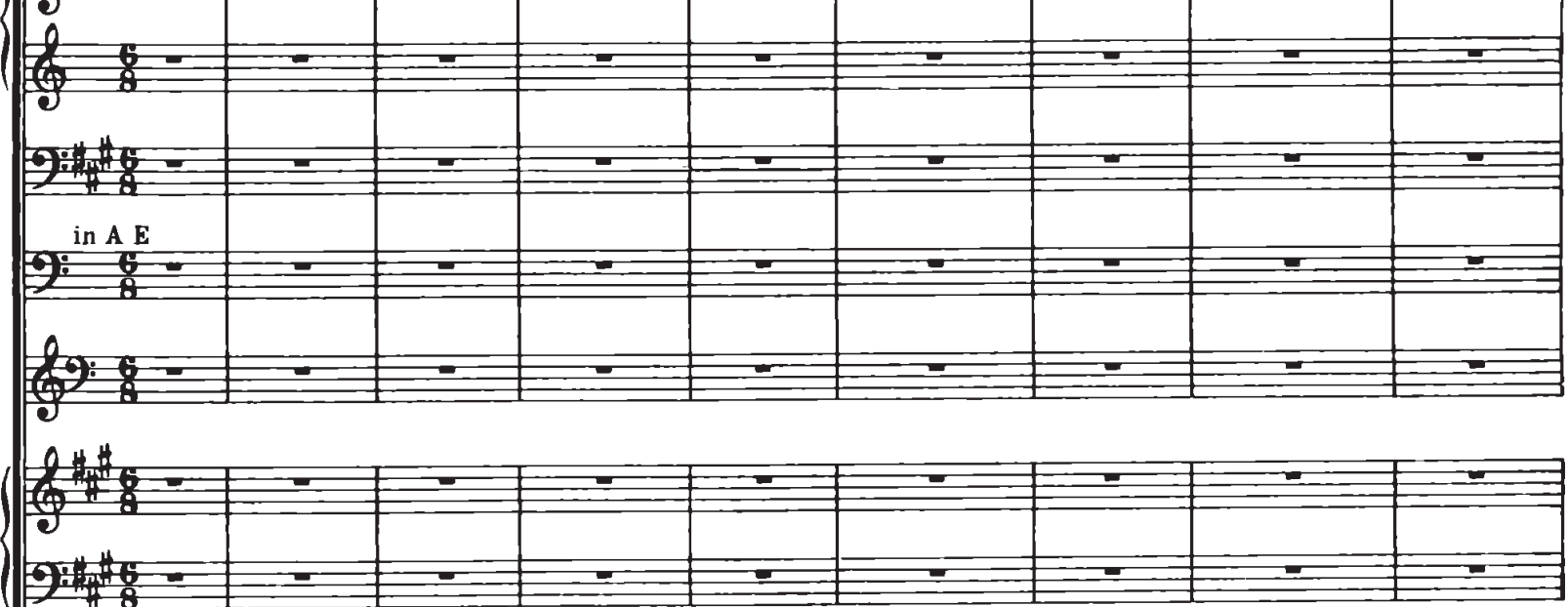

Andantino

Violine I

Violine II

Viola

Violoncello

Kontrabaß
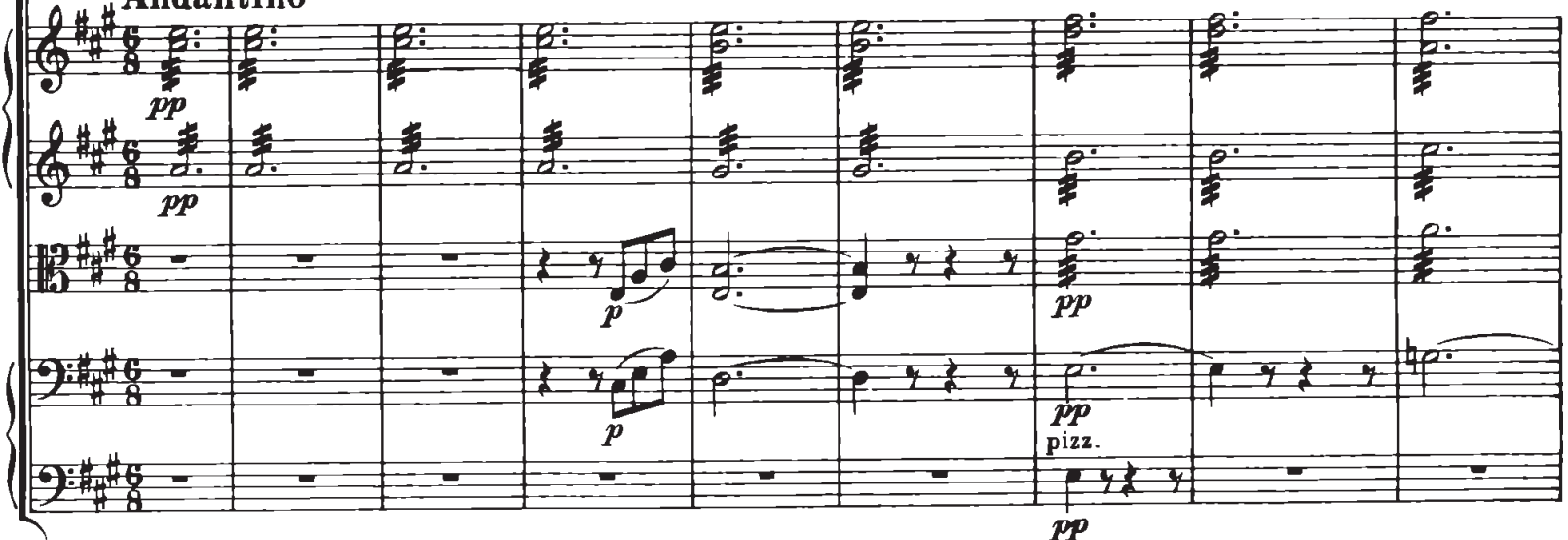
(4) (3) + 201.

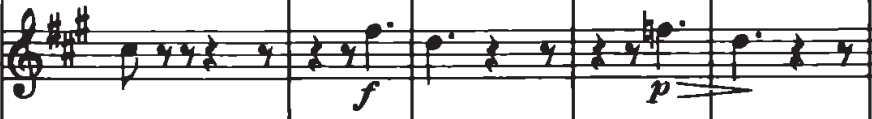

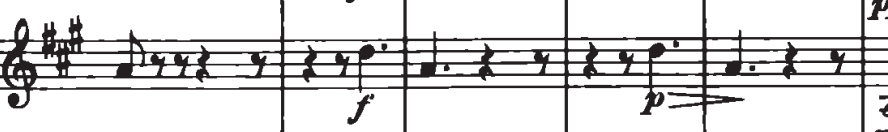

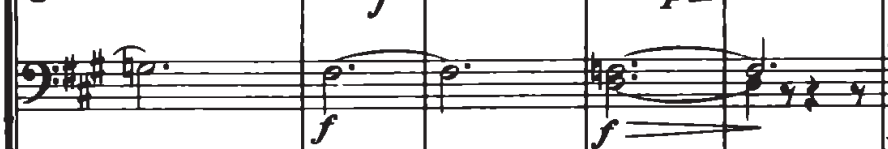
(2)

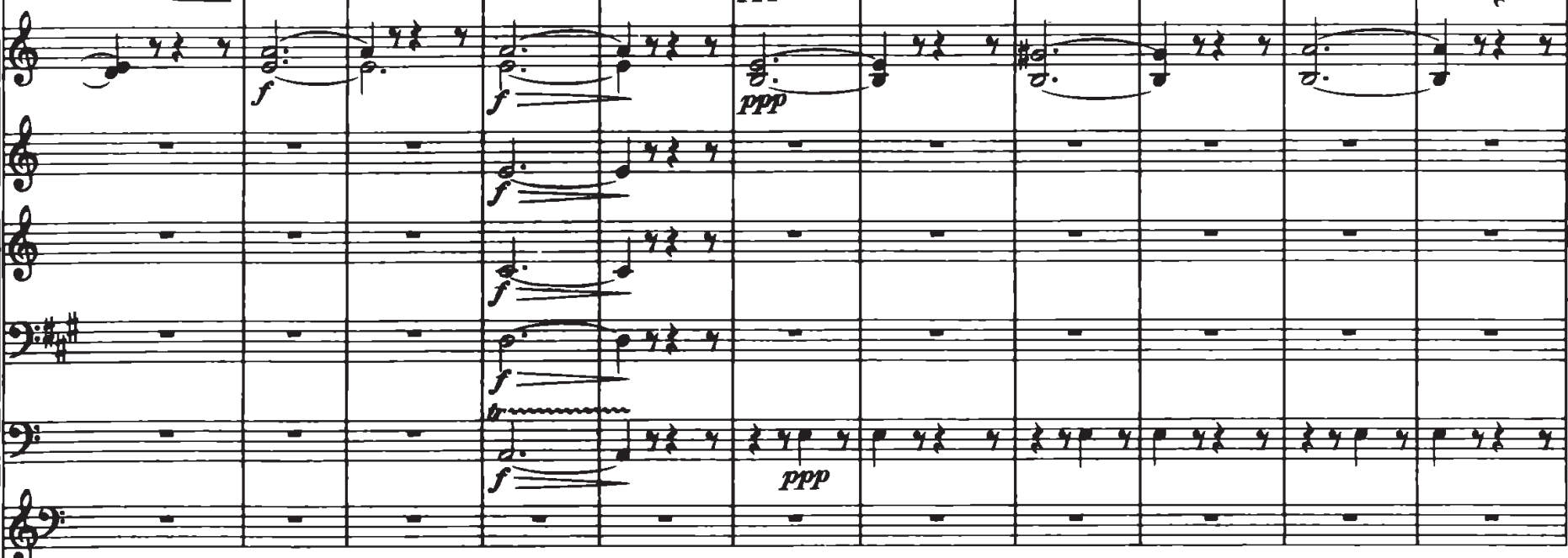
\begin{tabular}{|l|l|l|l|l|l|l|l|l|l|l|}
\hline & 0 \\
\hline
\end{tabular}

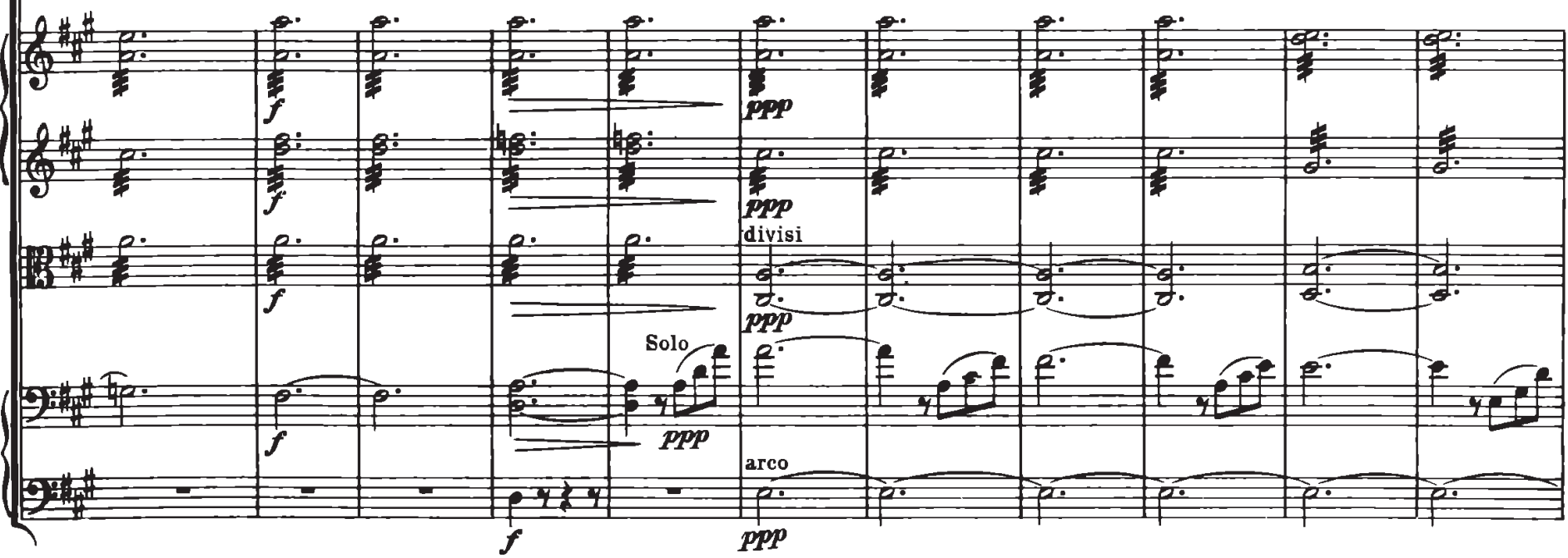


Movimiento circular de cámara Tempo di Valse

Movimiento circular de cámara Tempo di Valse

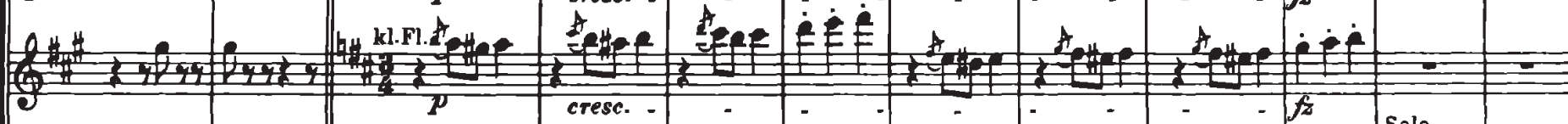

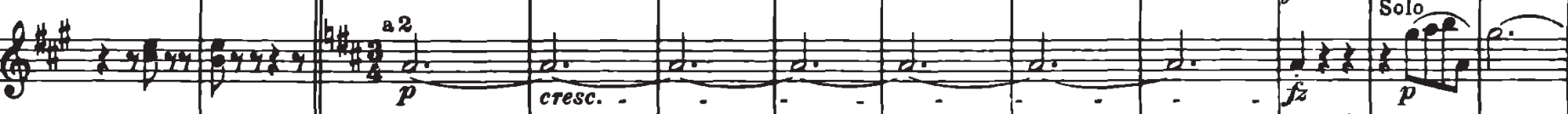
Q

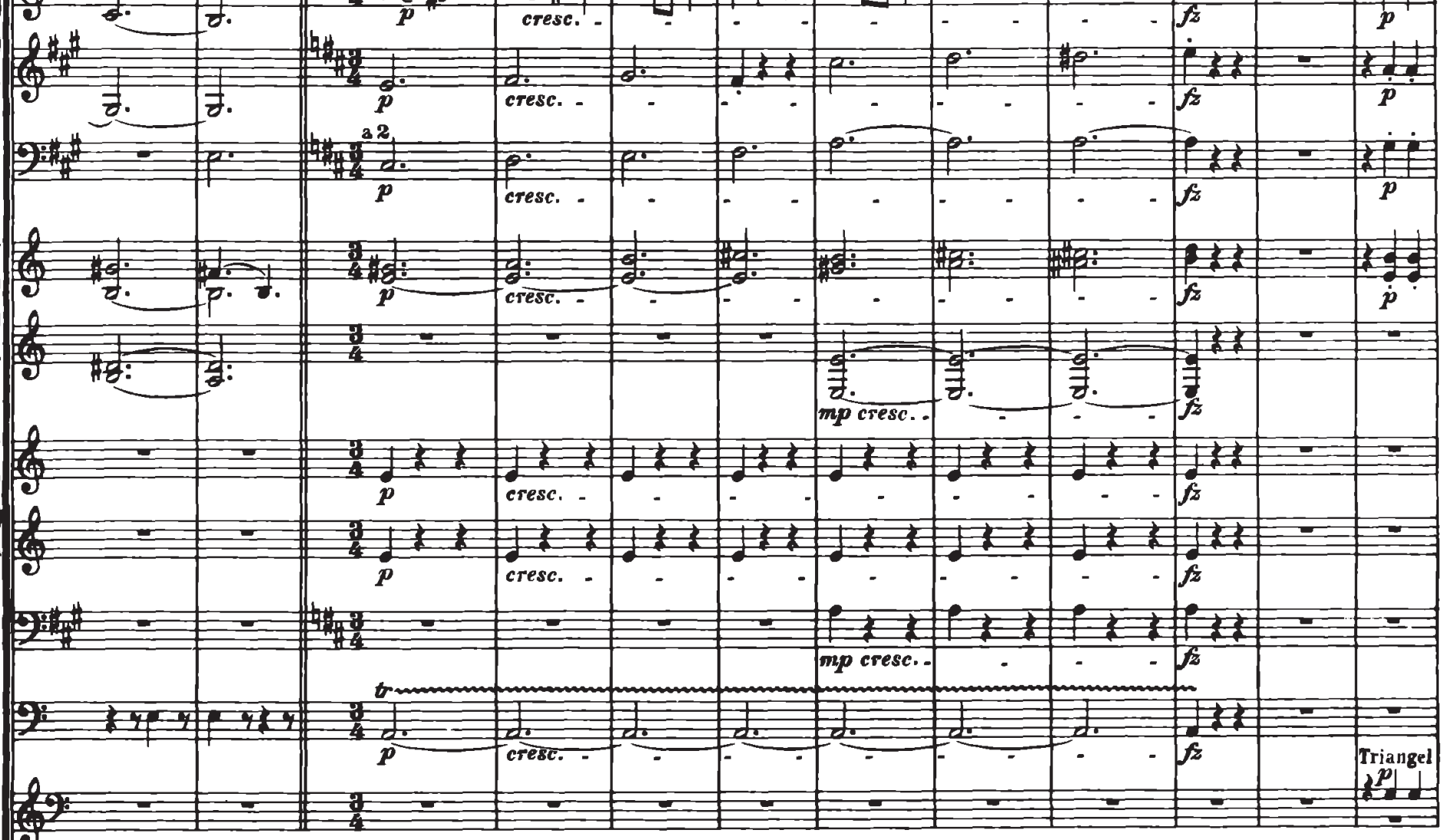

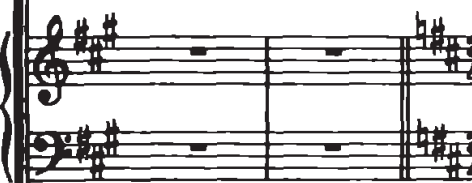

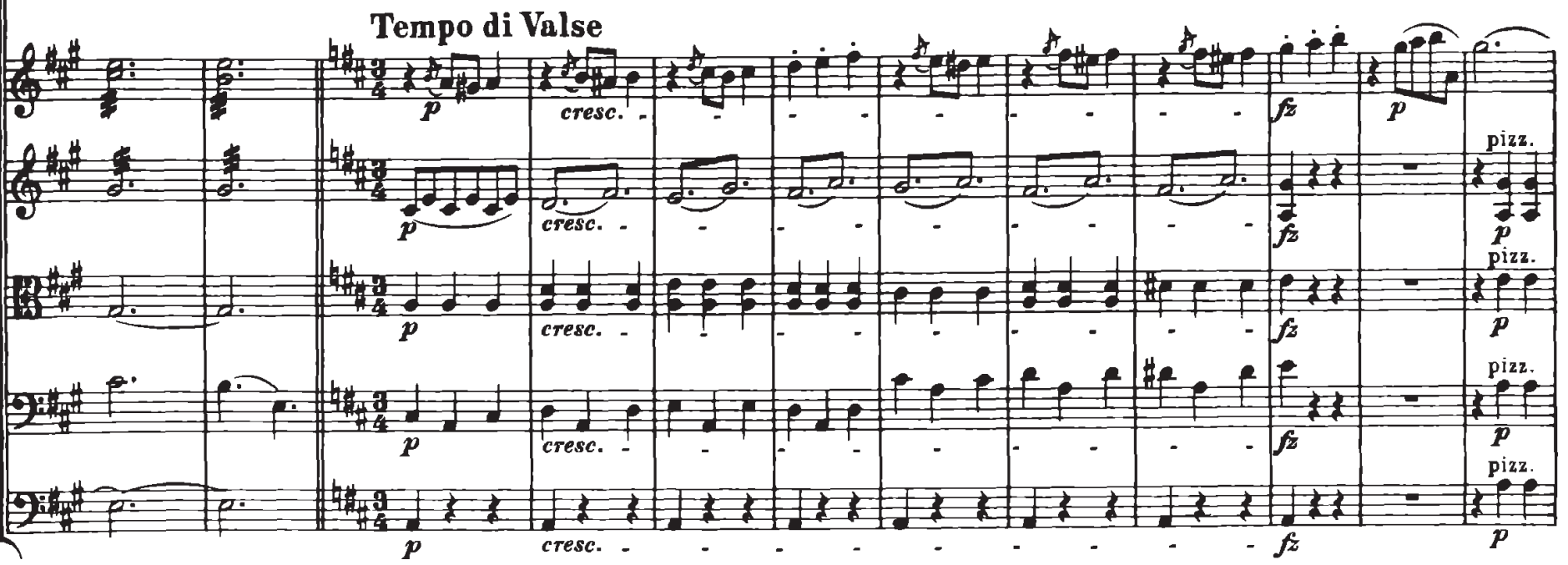




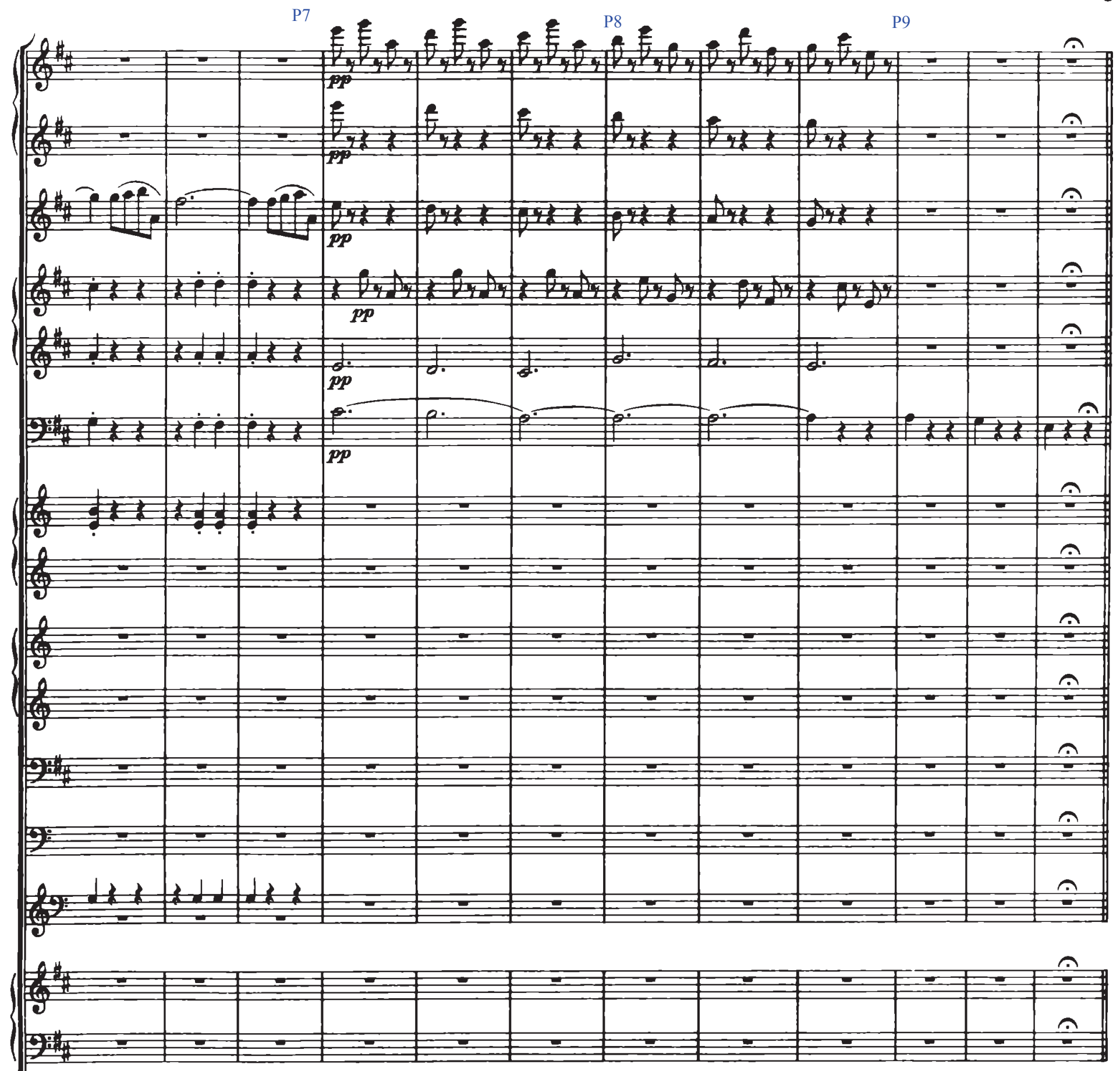

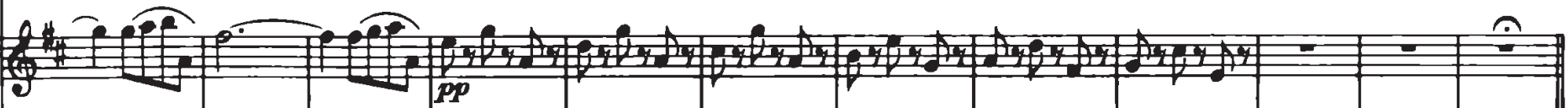

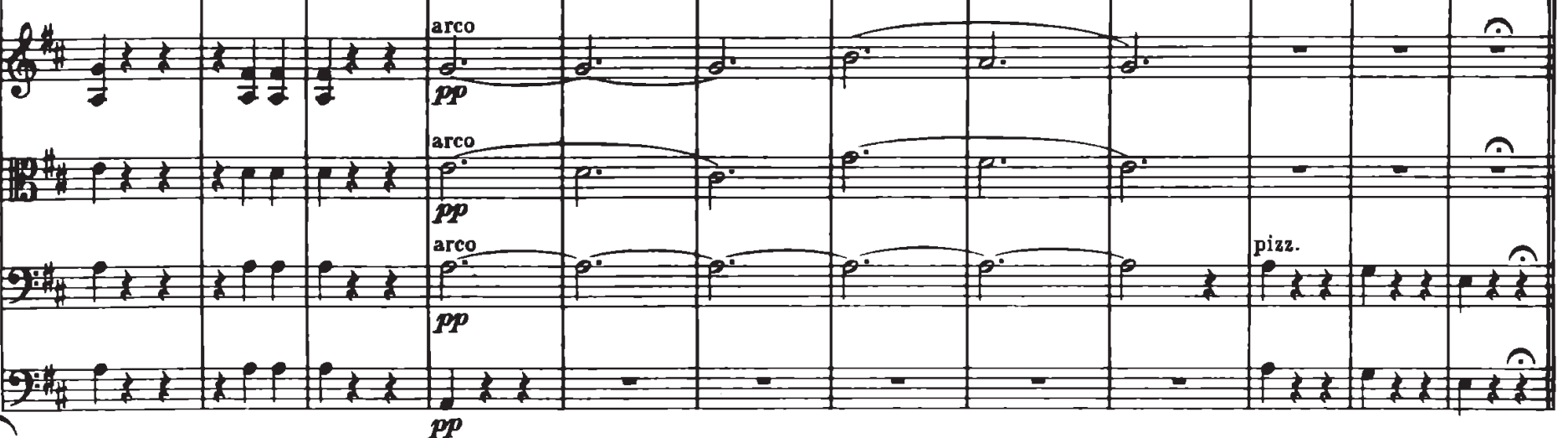


Nr. 1 Walzer

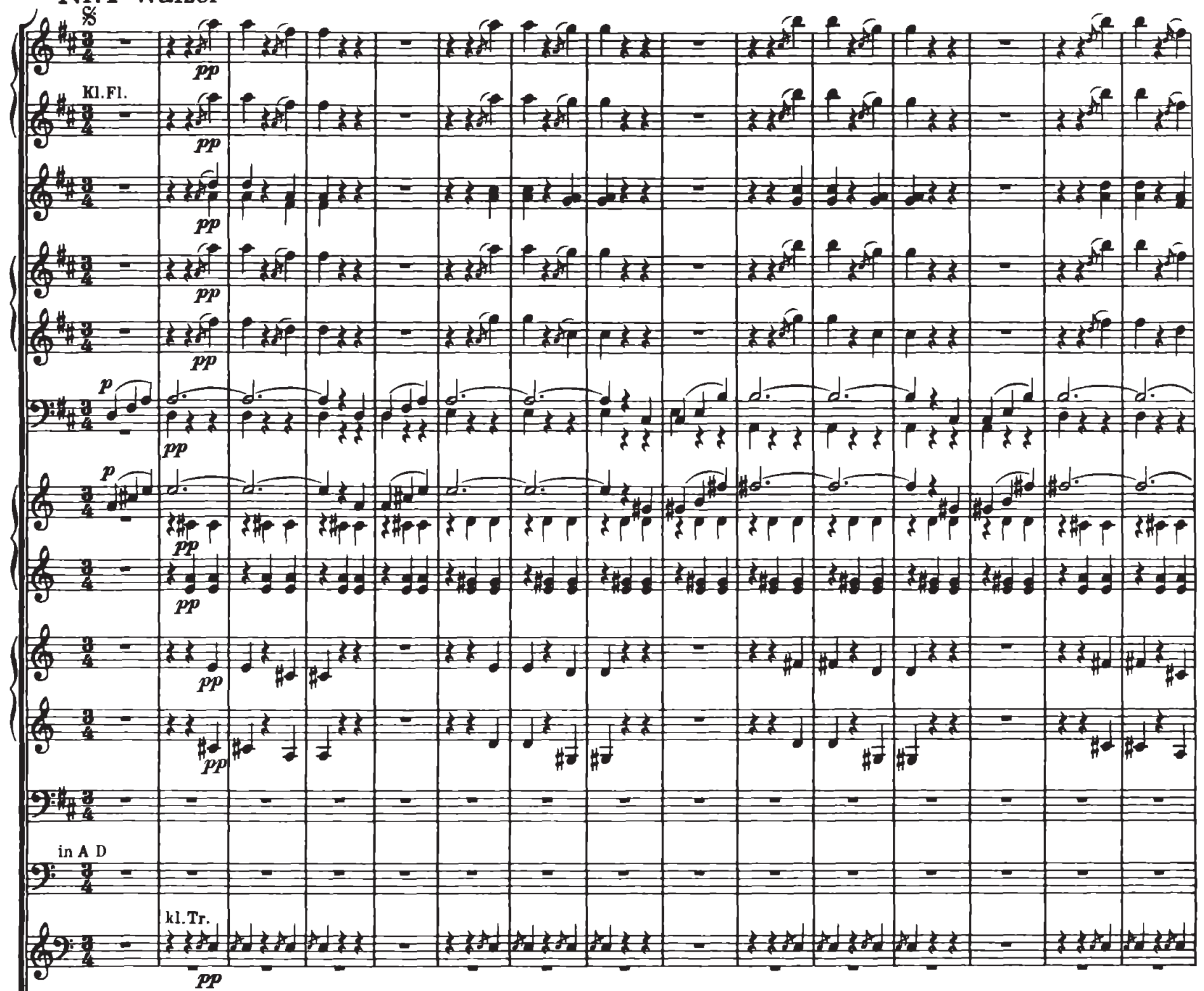

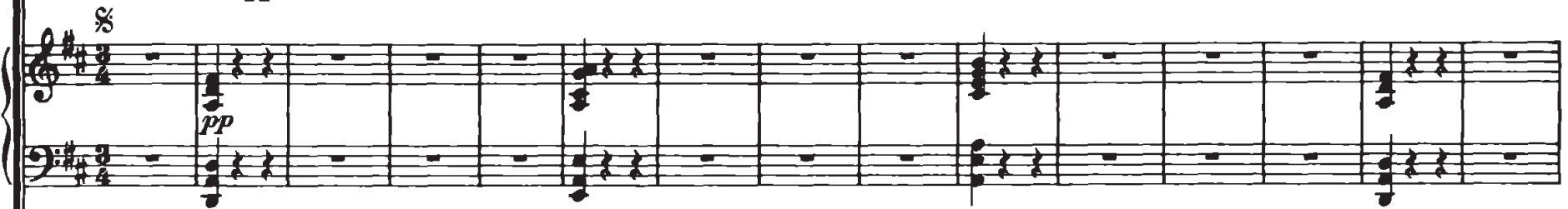

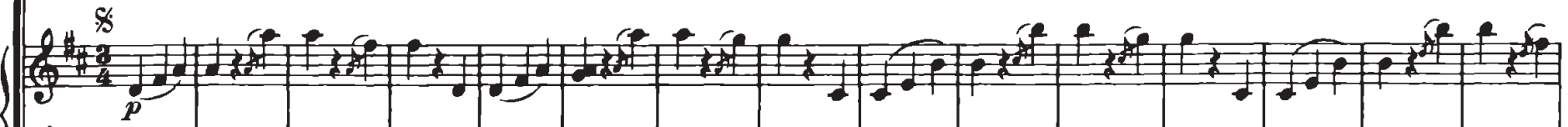
(2)

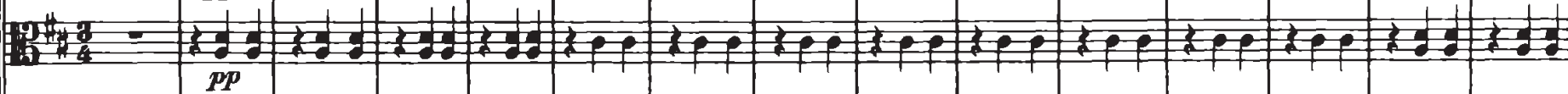

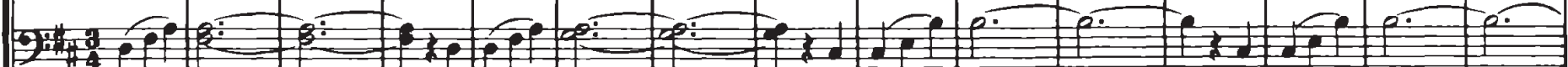

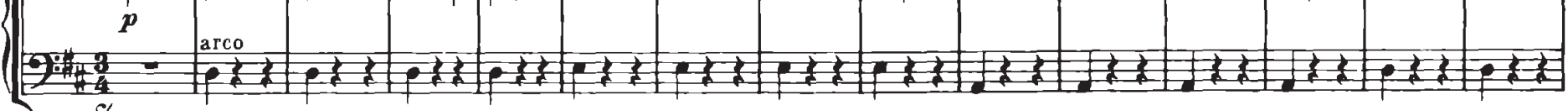


$\mathrm{P} 12$

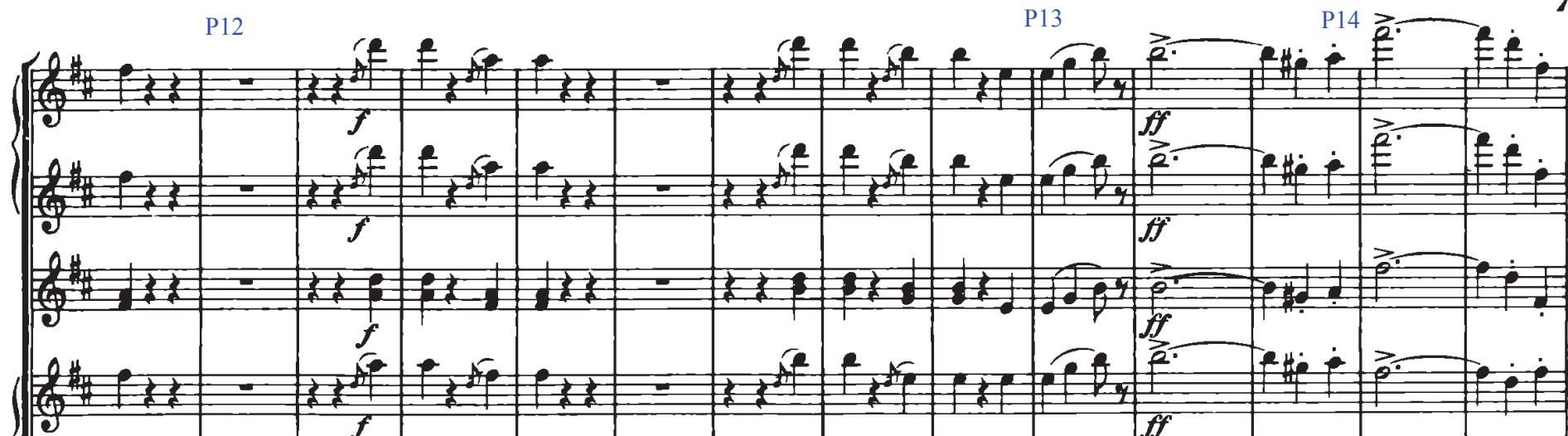

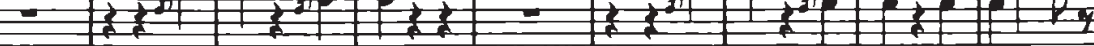

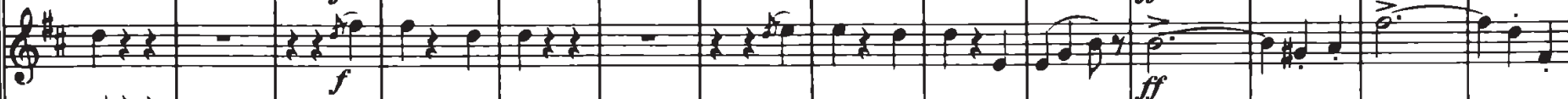

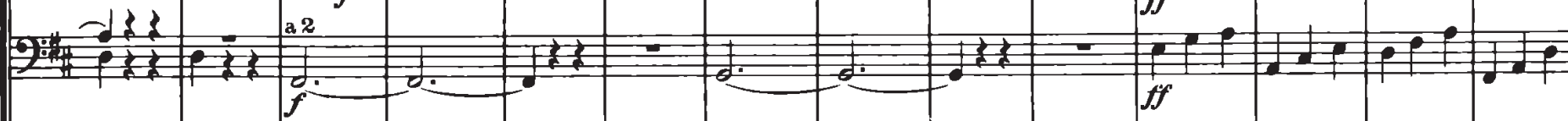

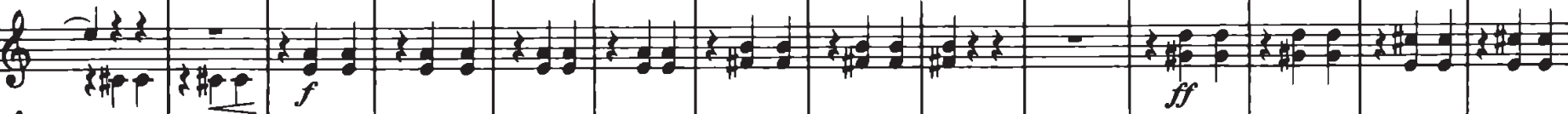

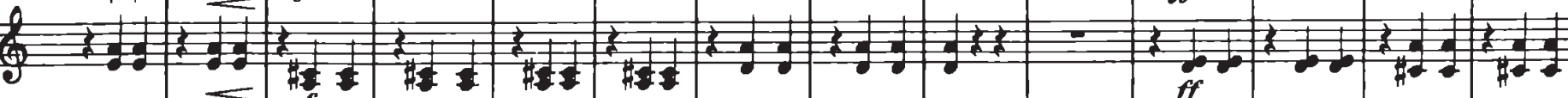
20

\%

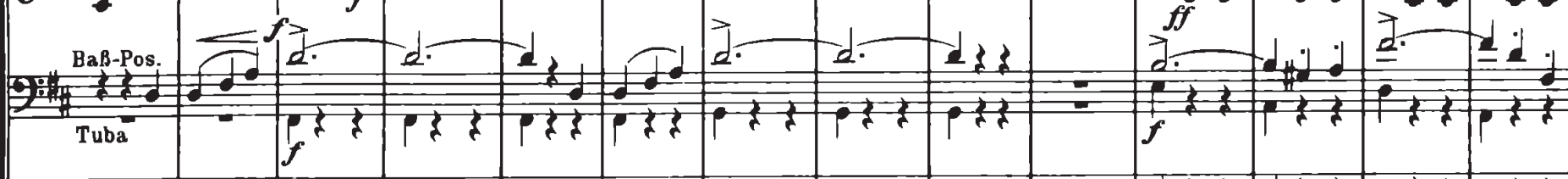

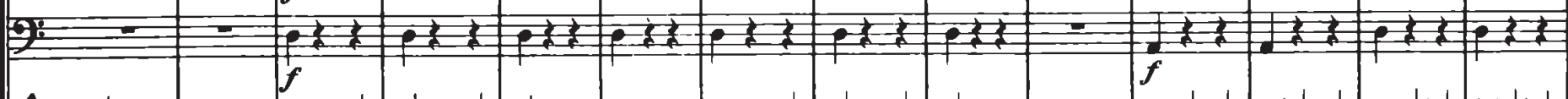

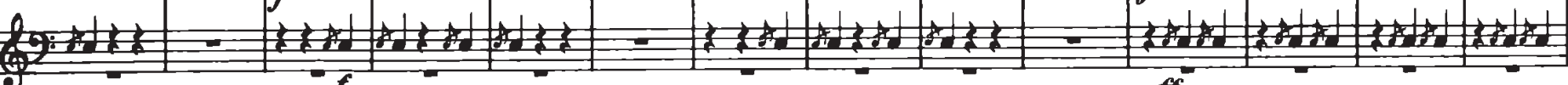
- $f$ r

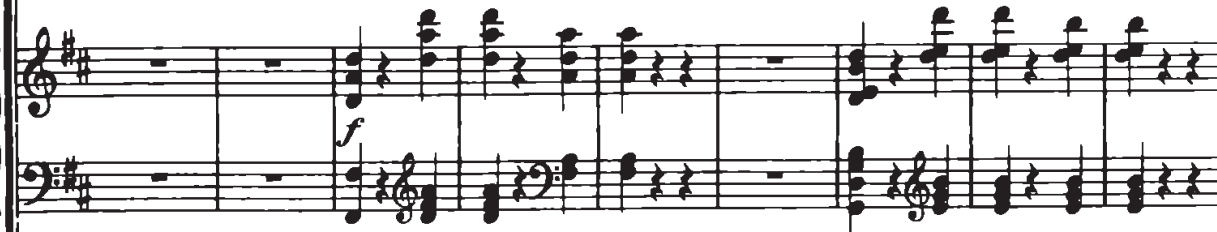

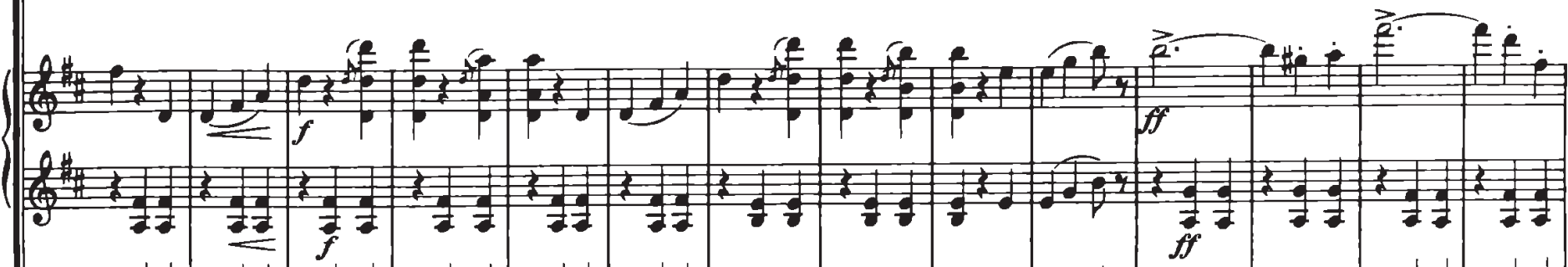

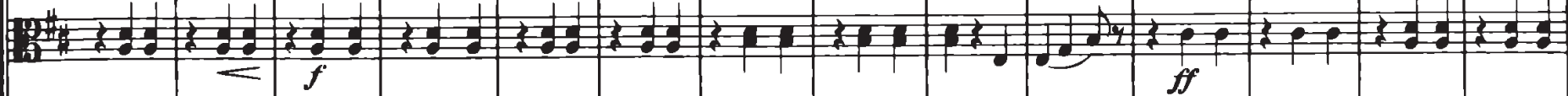
एव

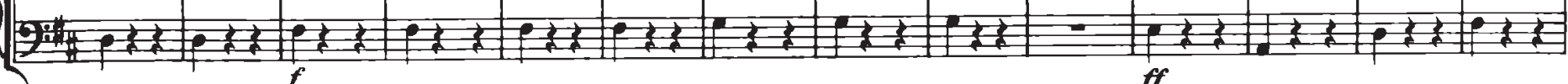




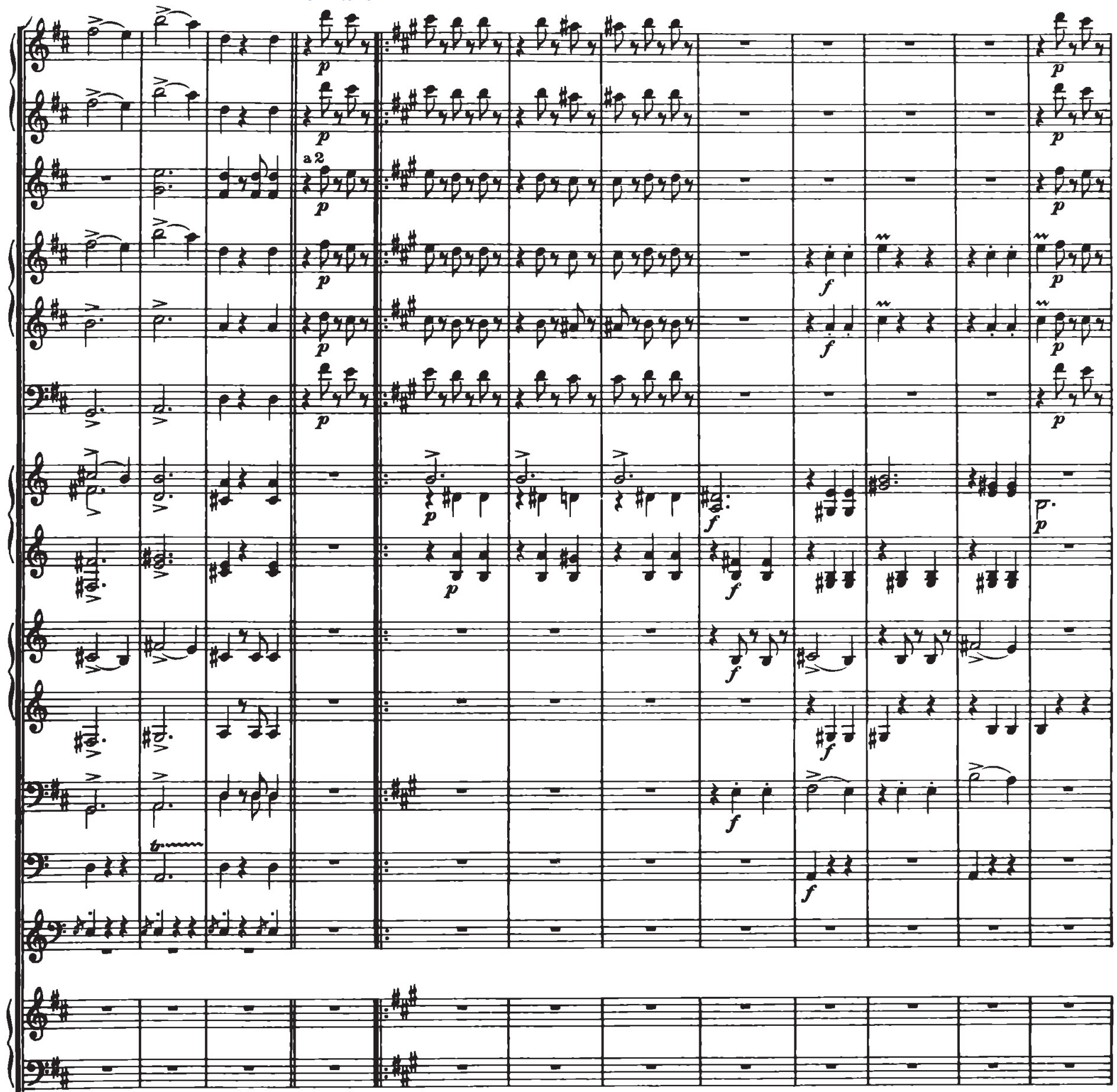

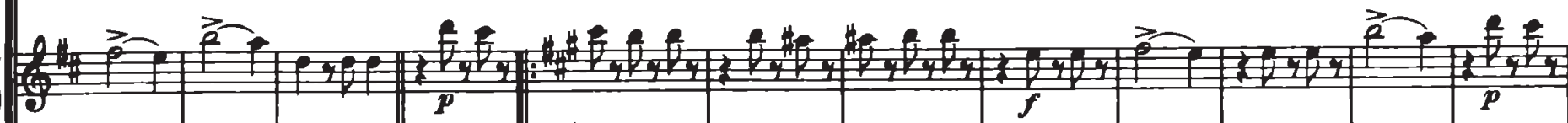

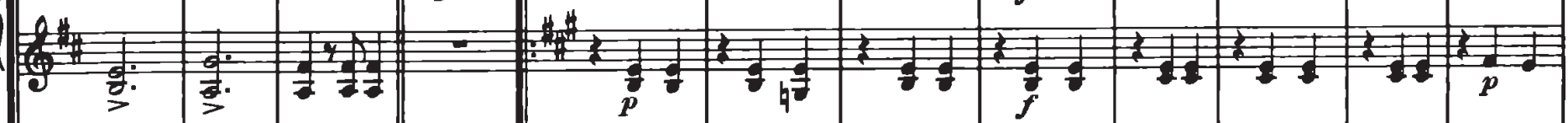

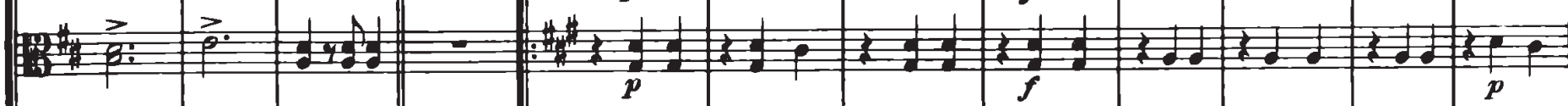




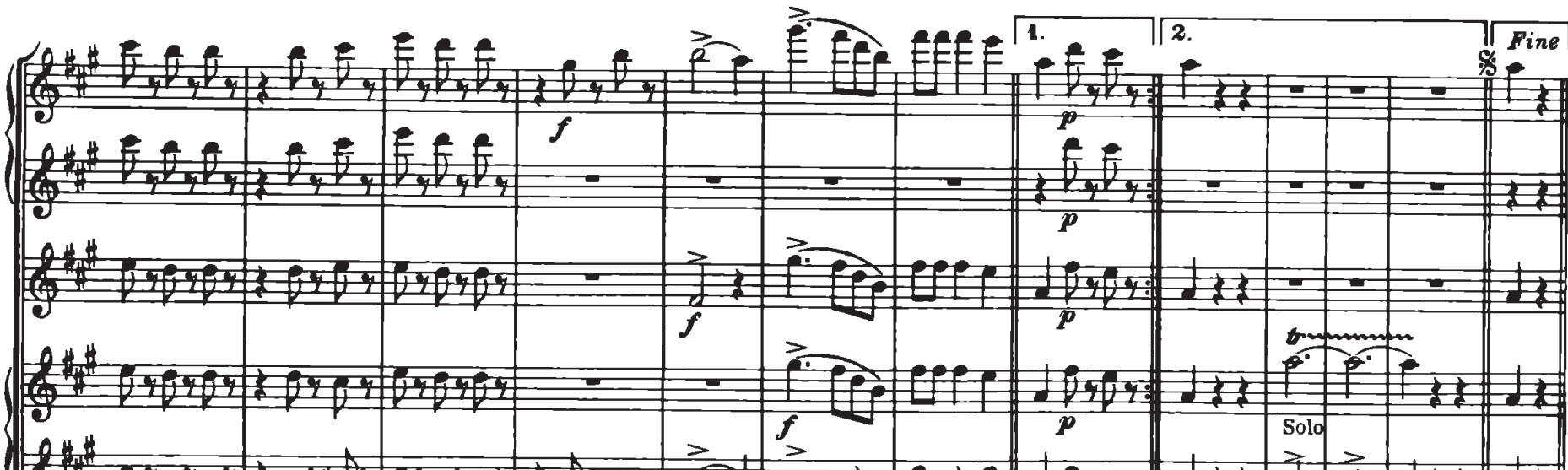

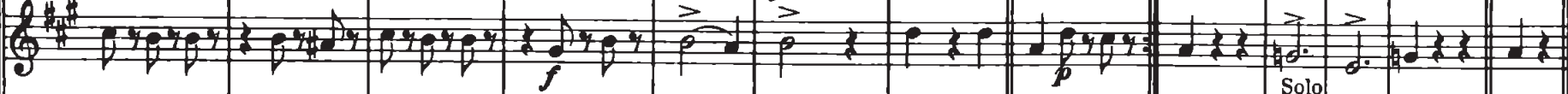

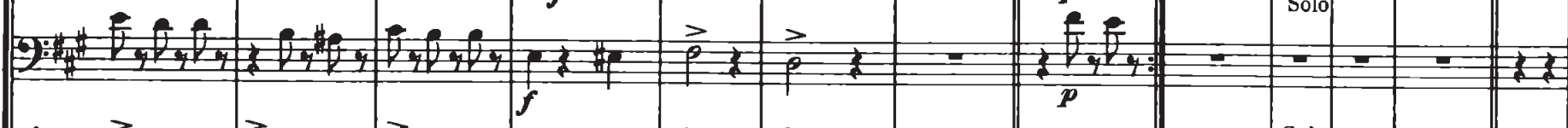

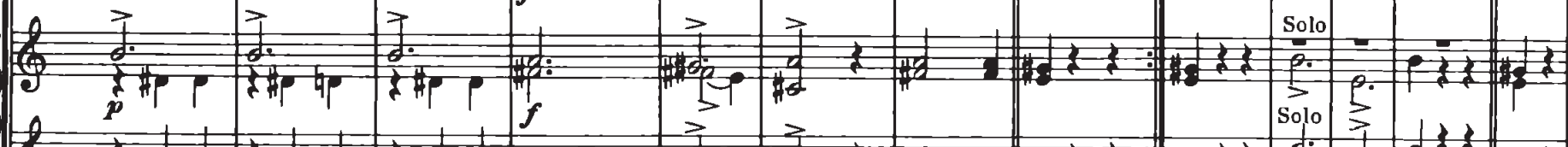

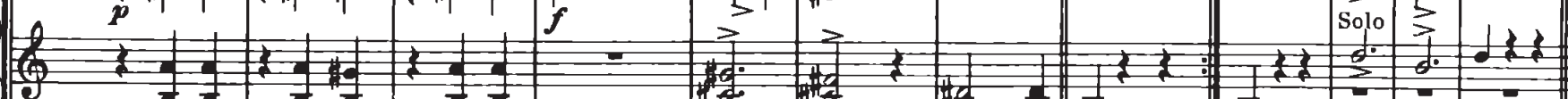

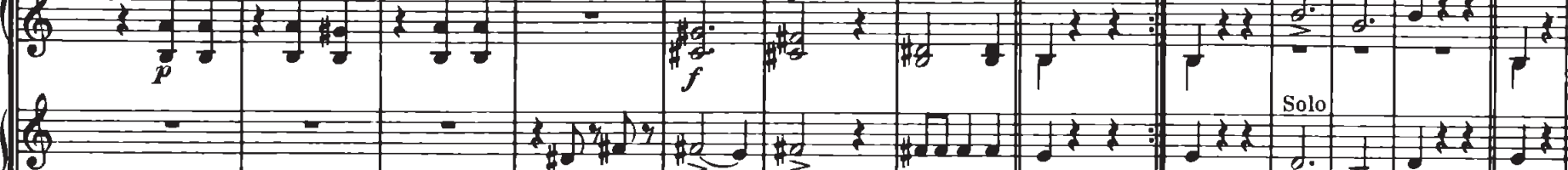
3

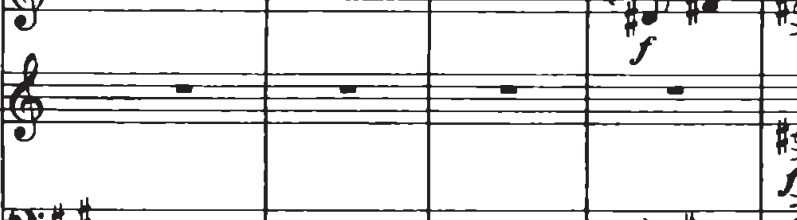

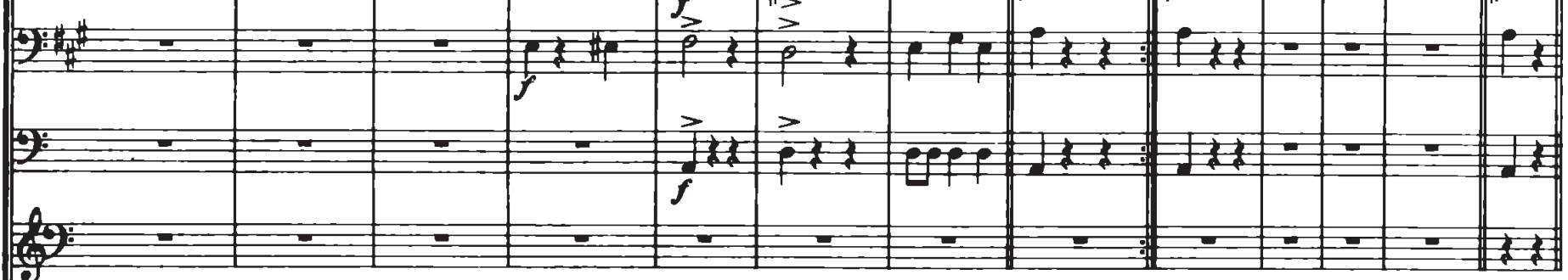

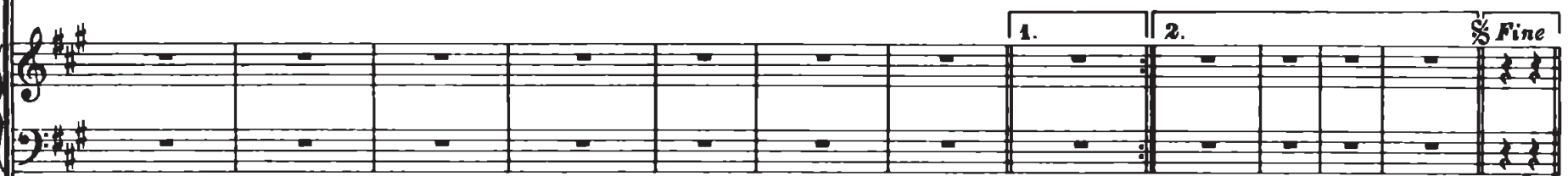

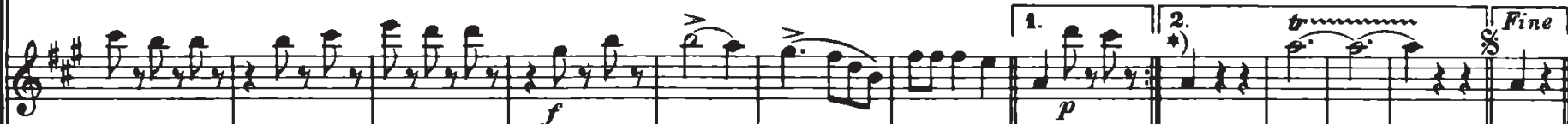

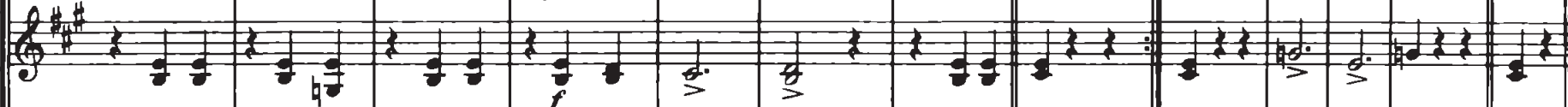

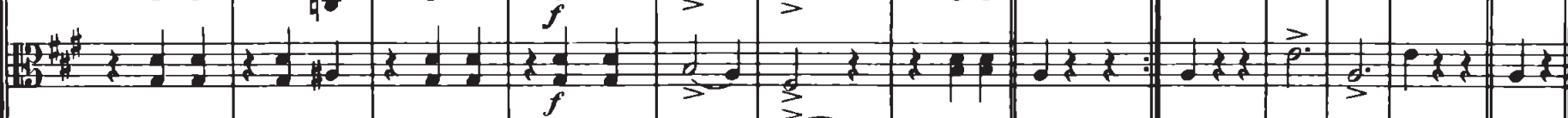

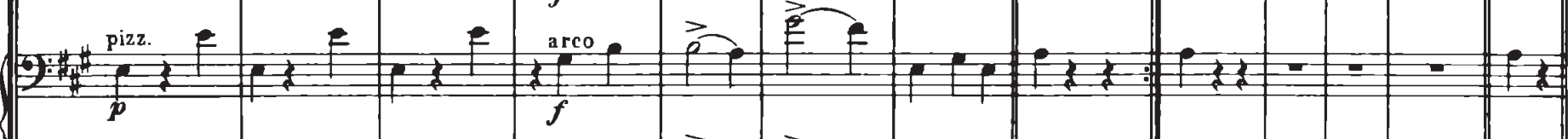

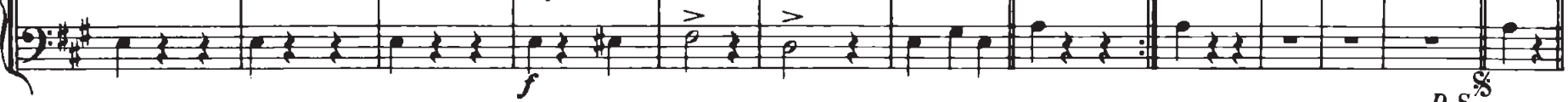
*) Bei Mitwirkung des Chors fallen 2da und Dal Segno weg 
10

P20 en la repetición

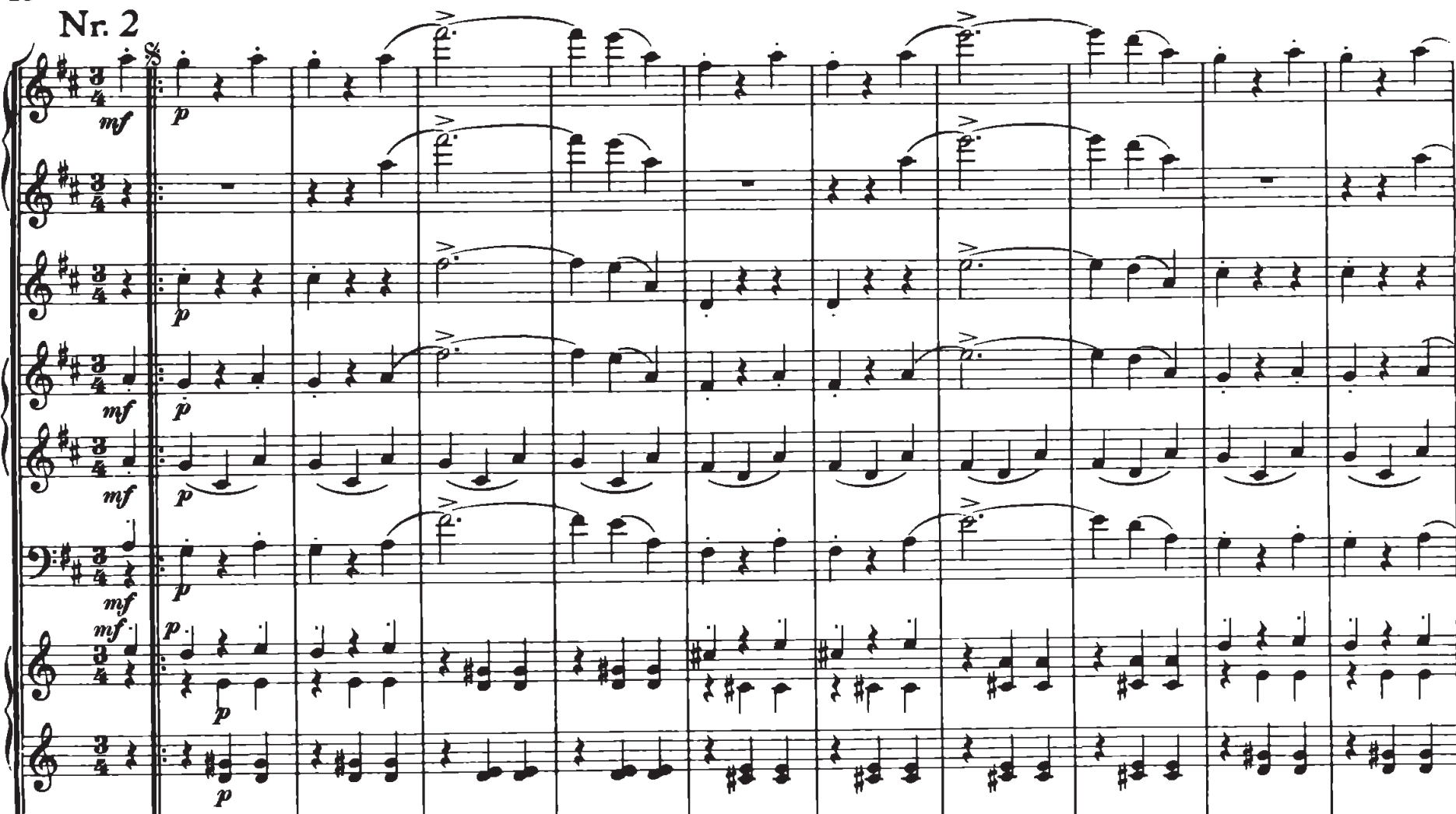

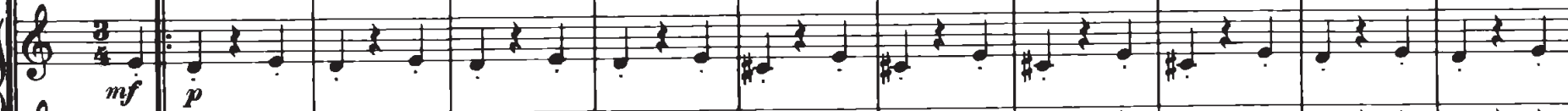

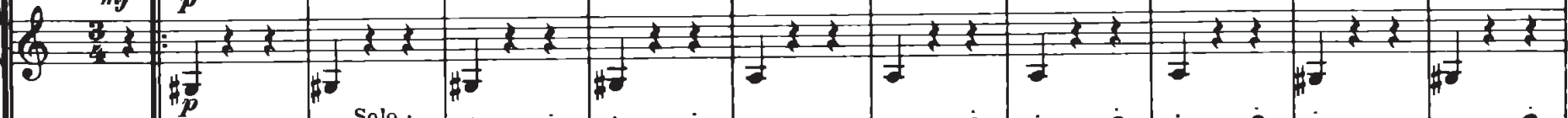
Q2. Q.

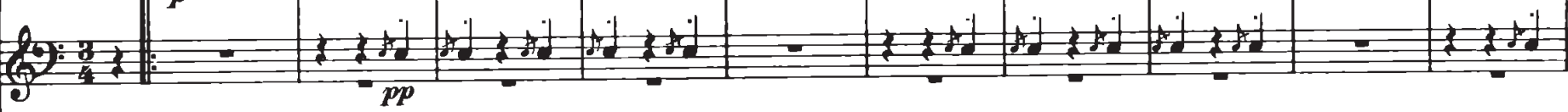

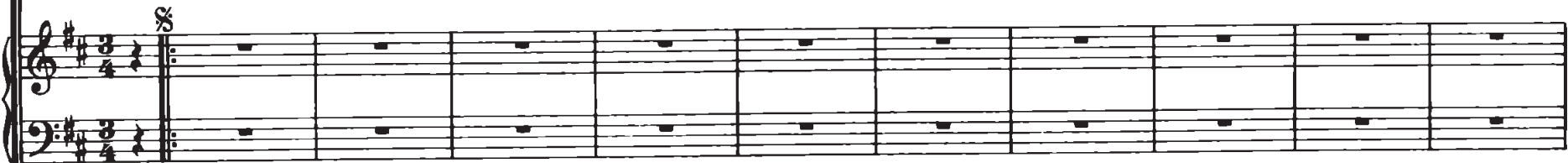
(5)

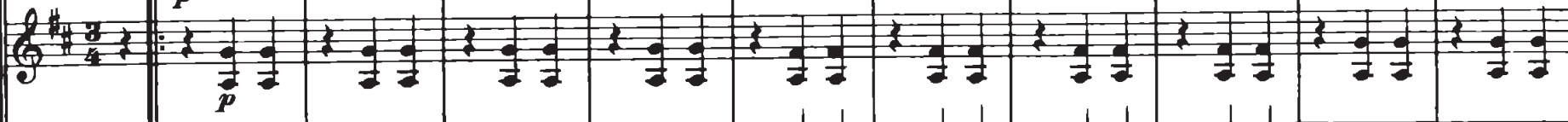

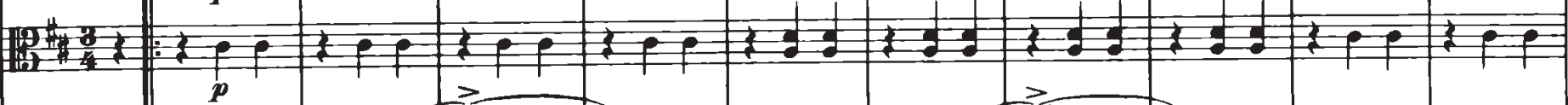

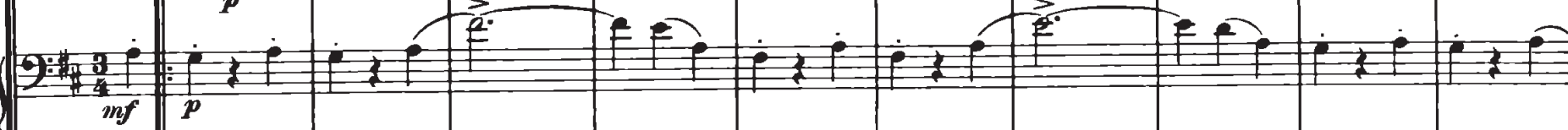

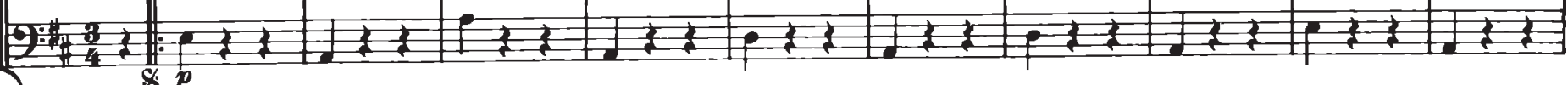




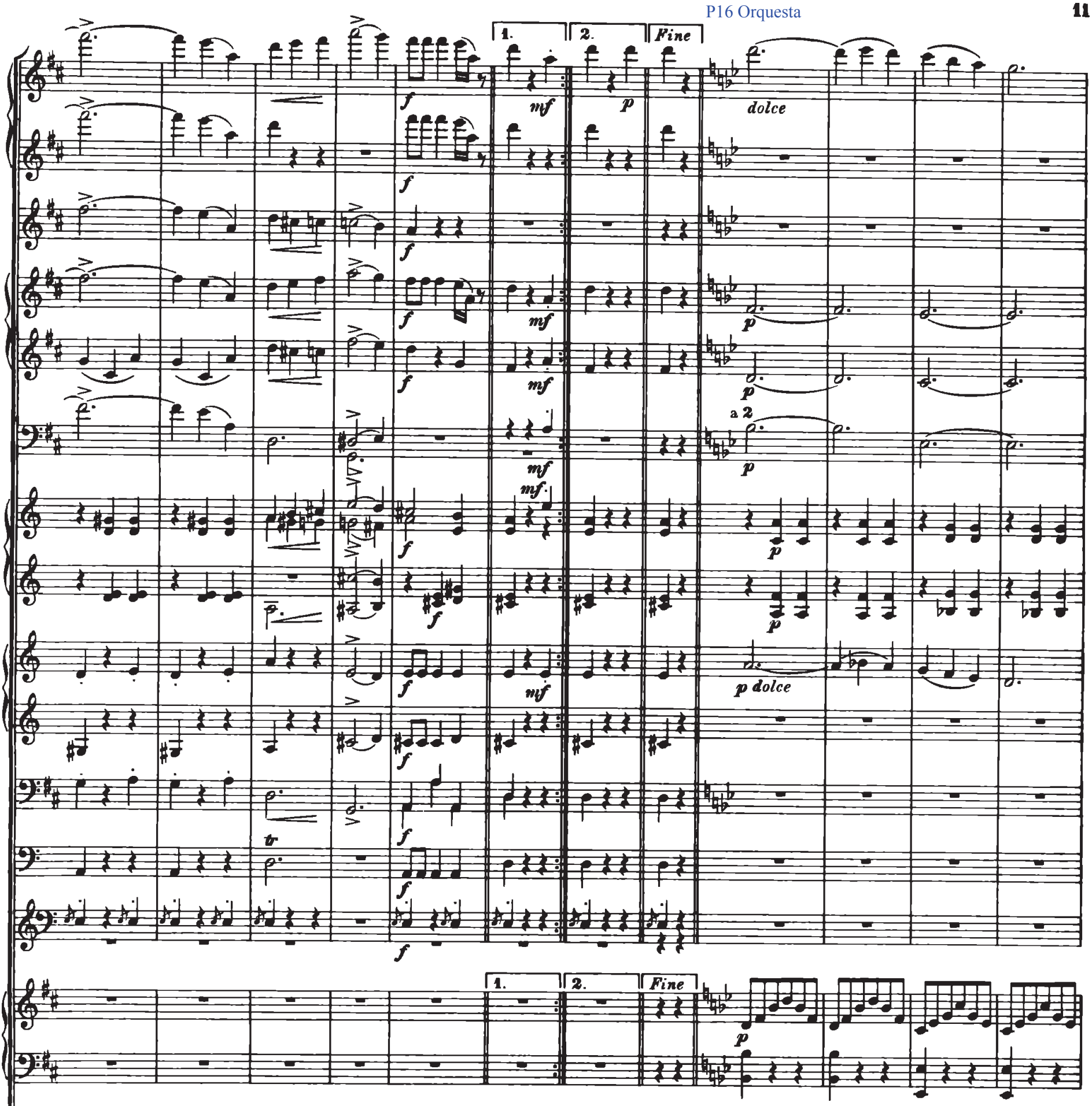

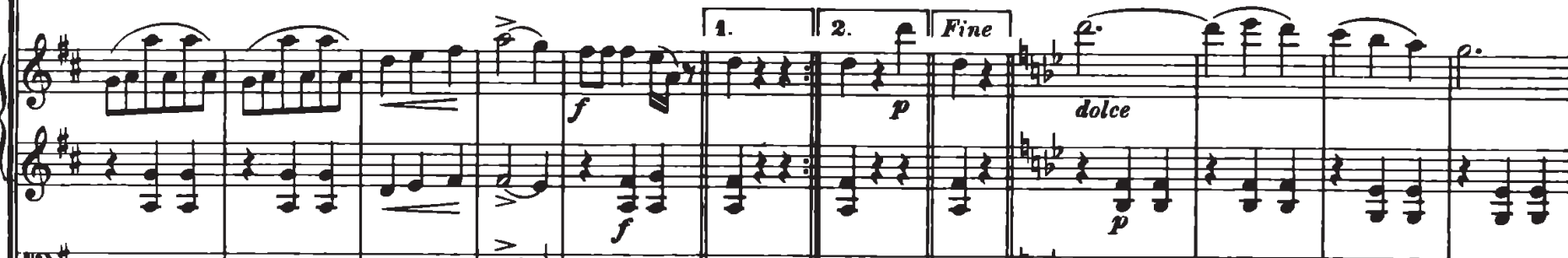

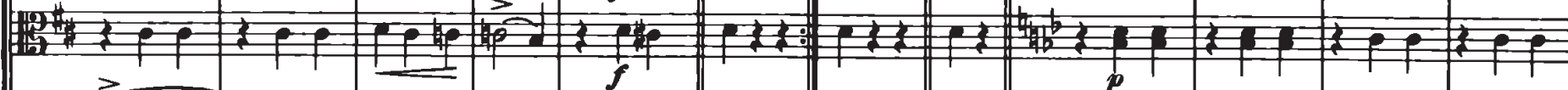

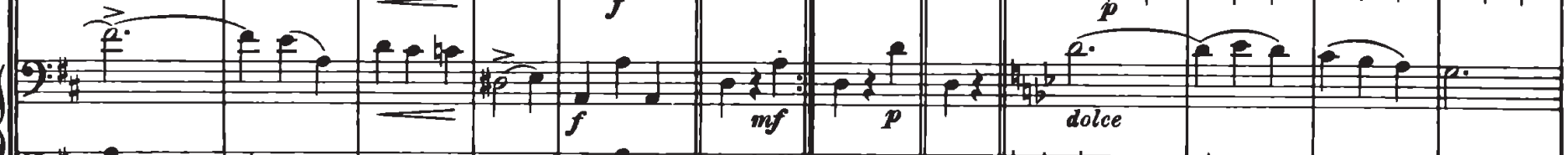

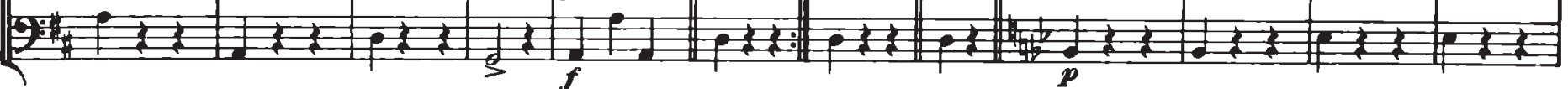


P19

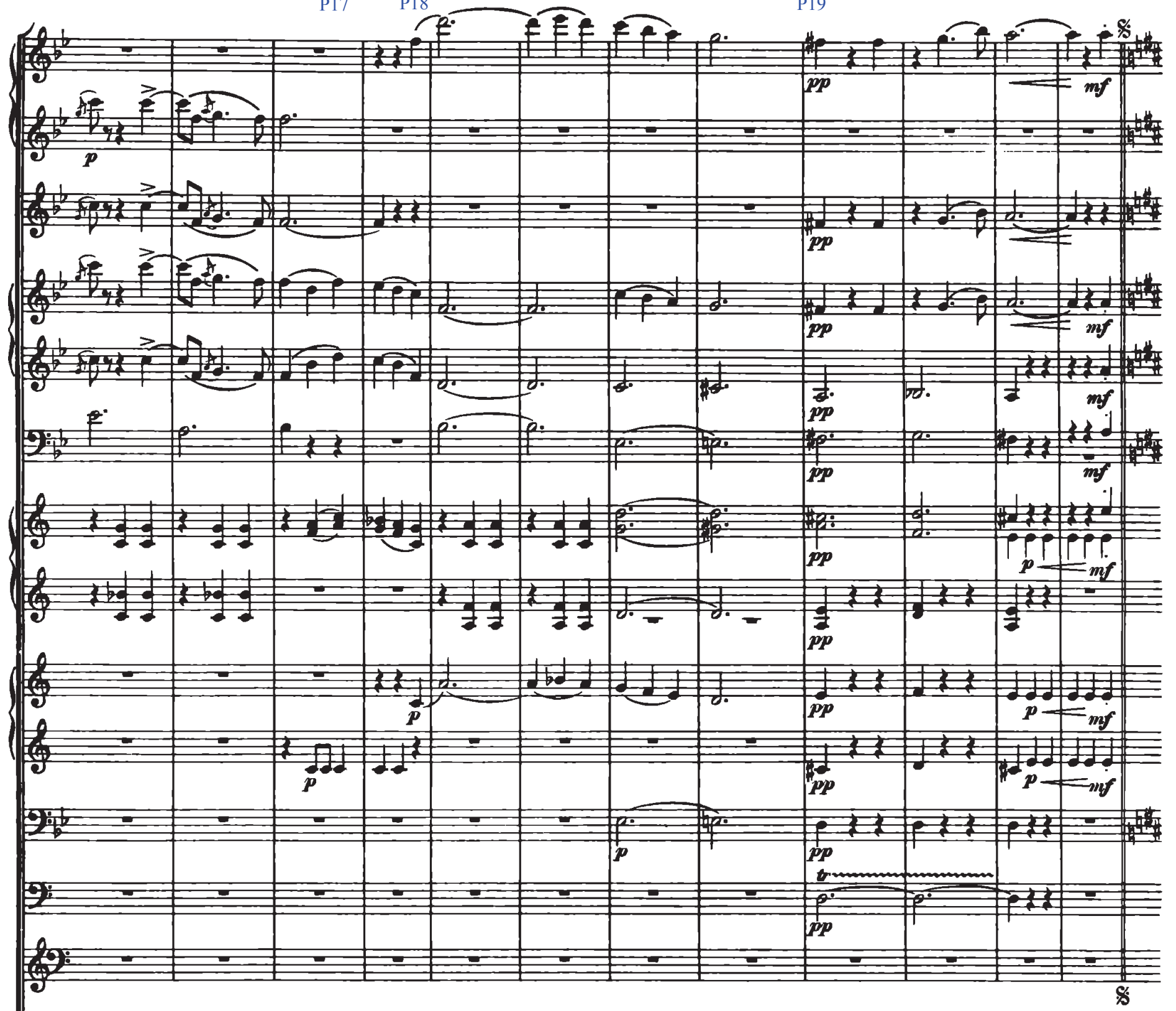

(2)

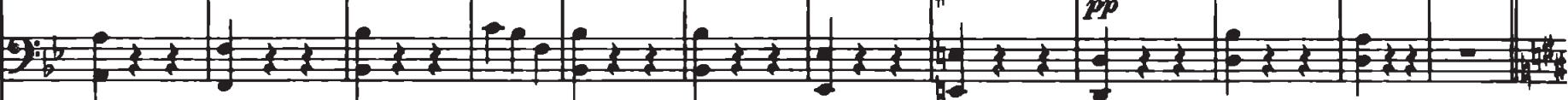

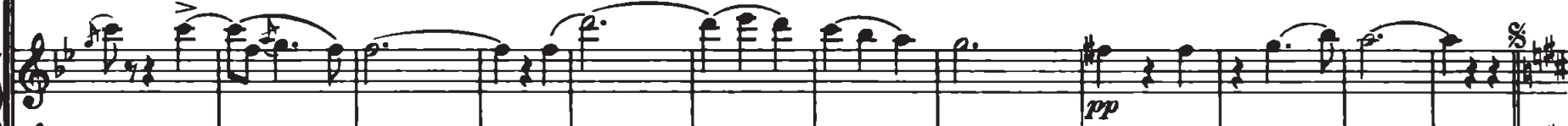

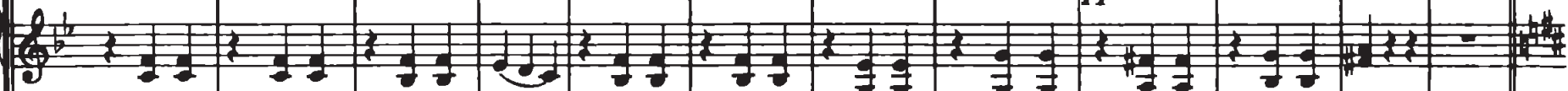

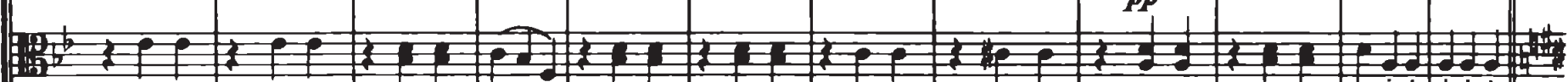

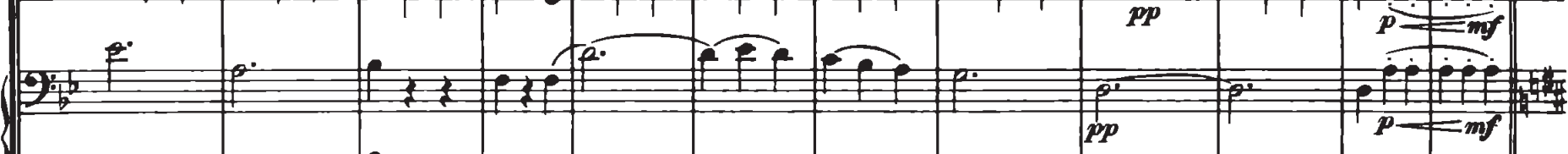

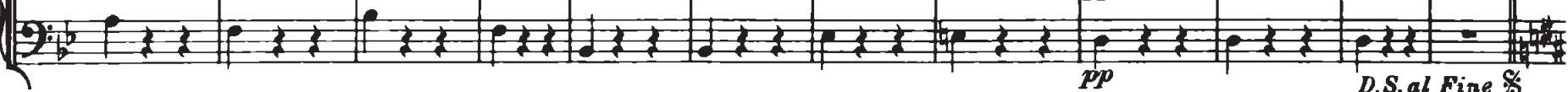




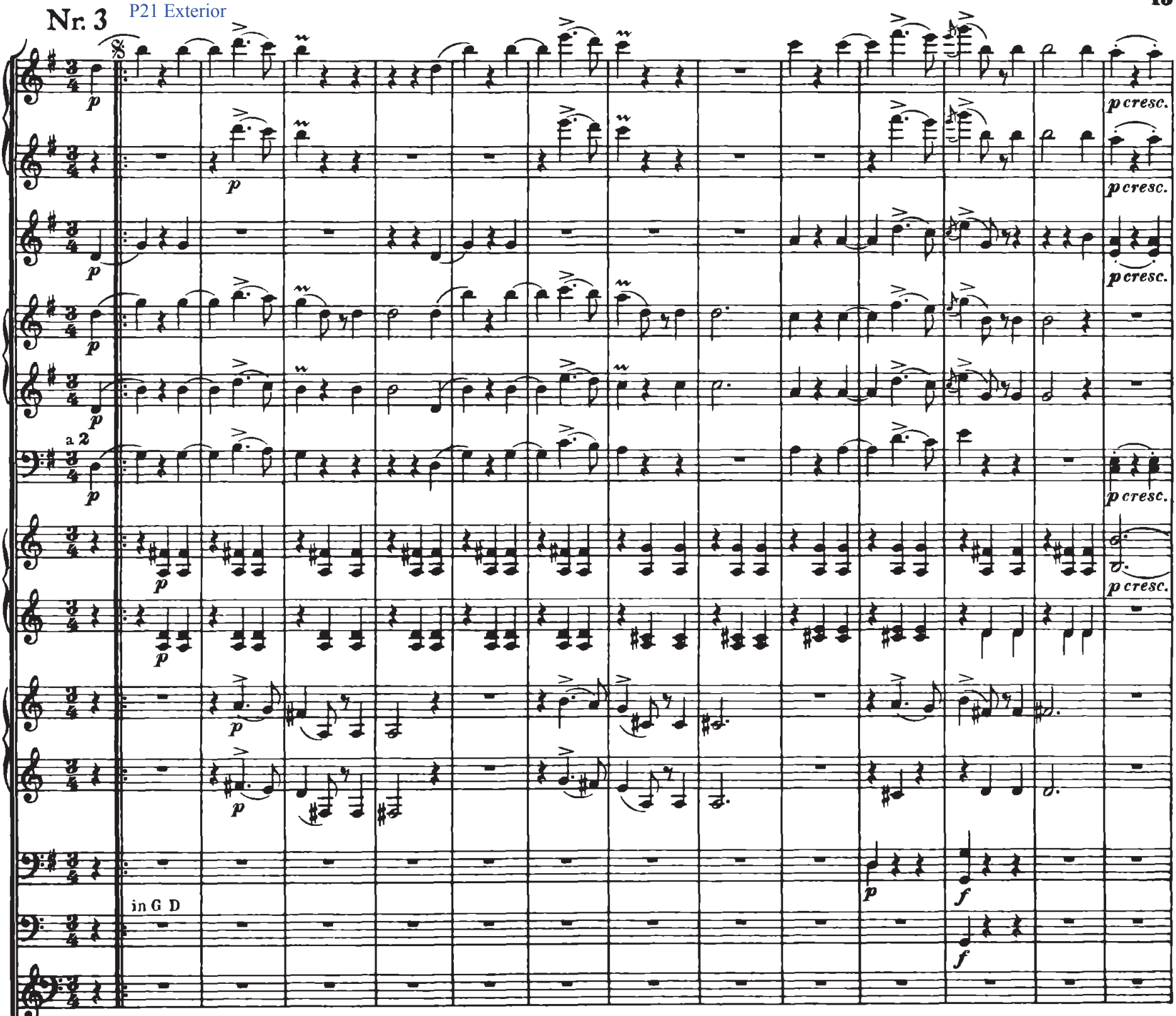

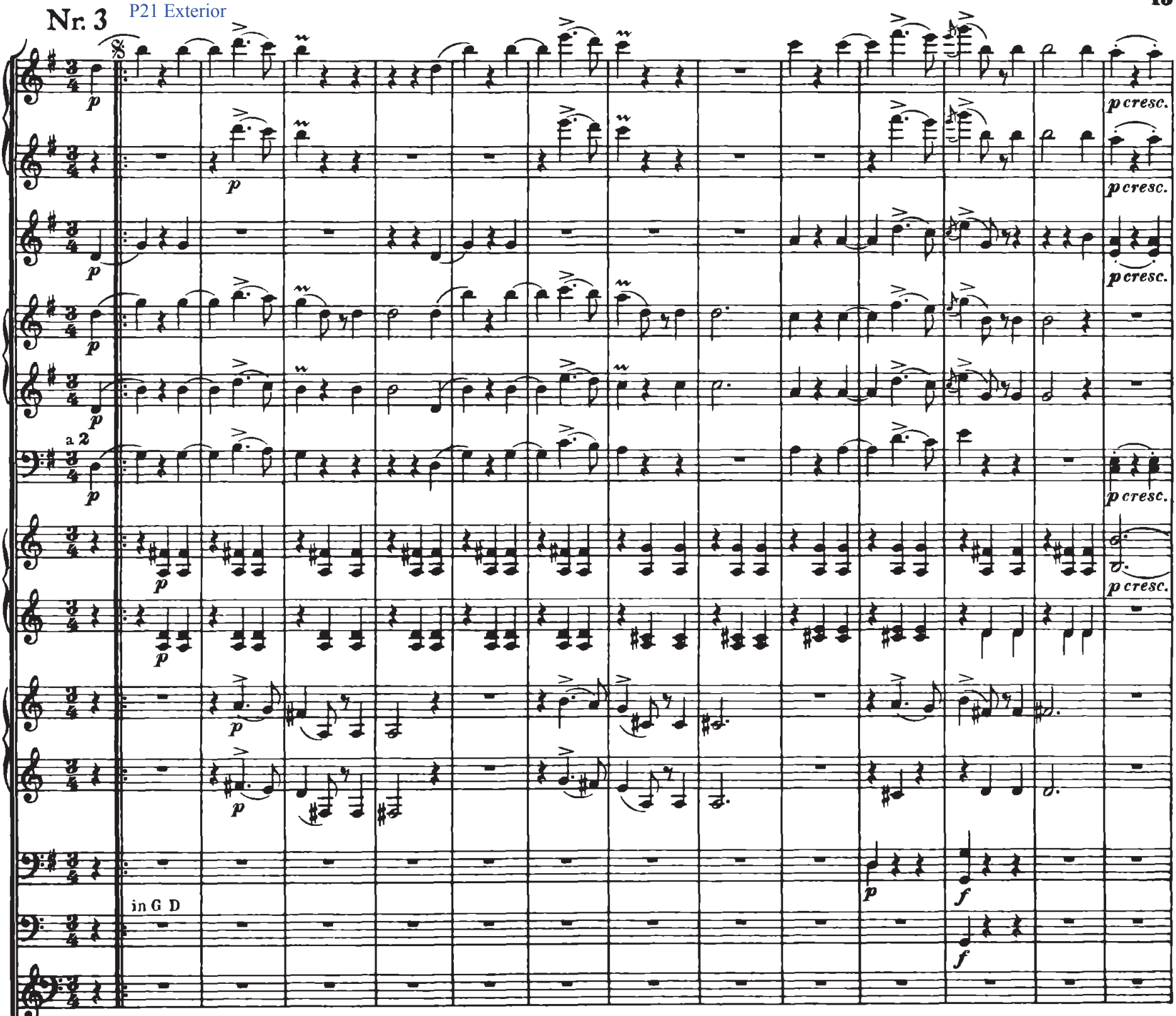

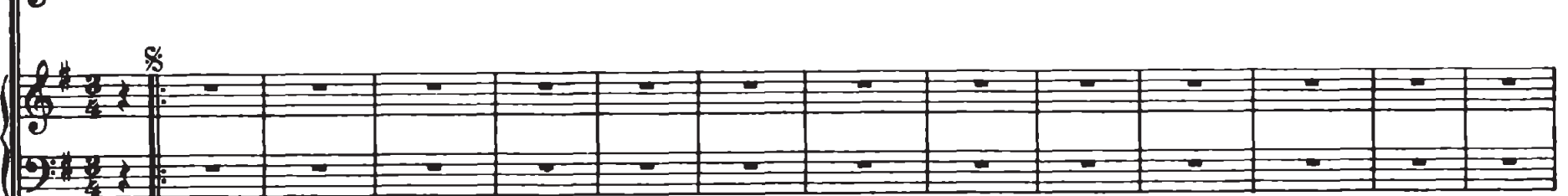

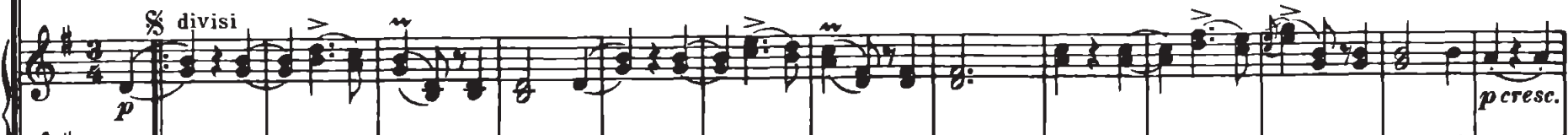

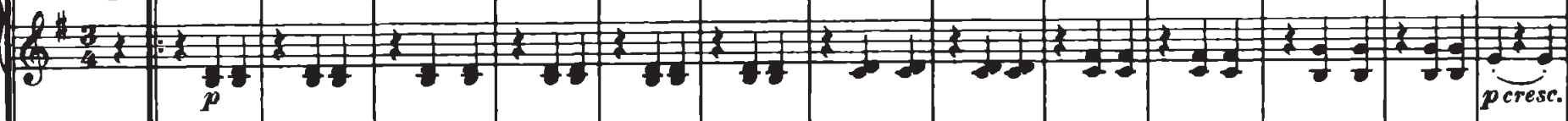

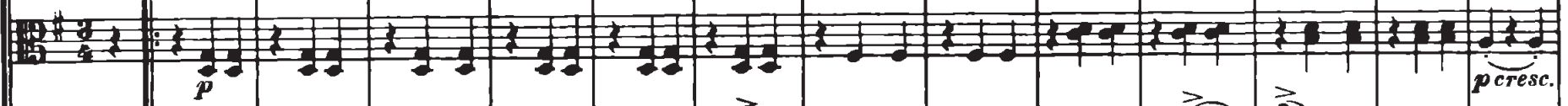

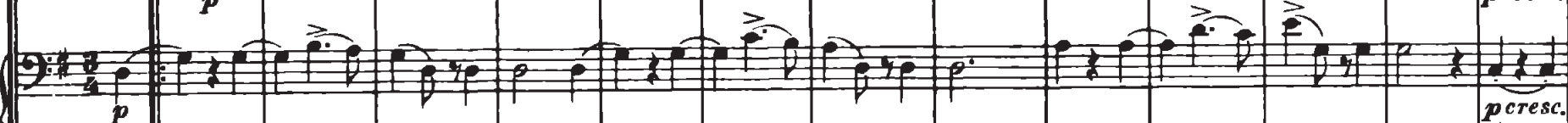
洋 
14
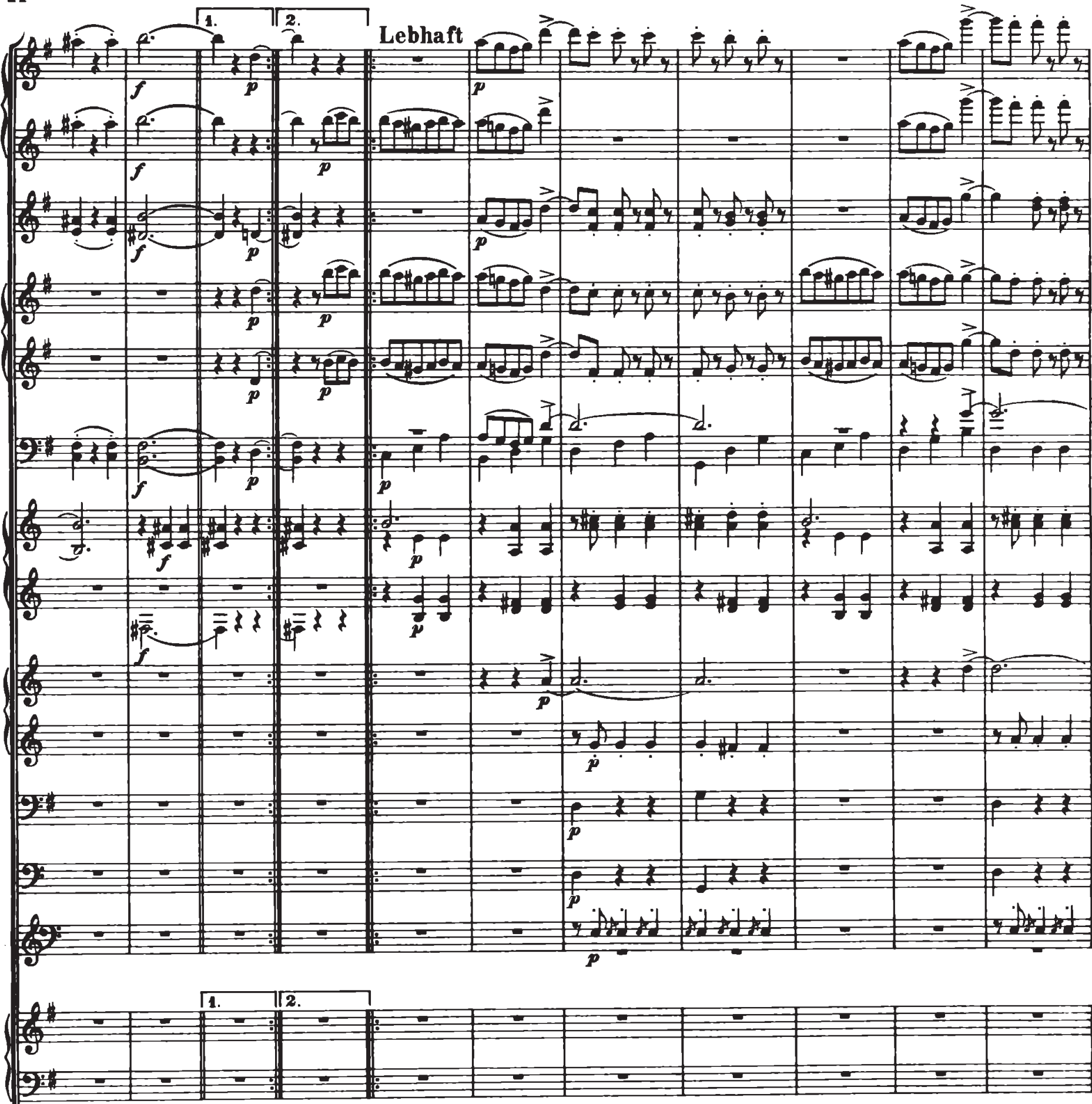

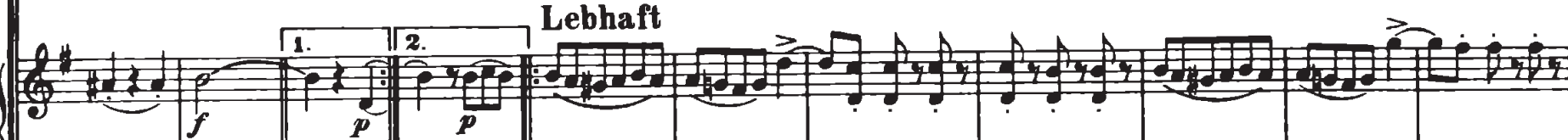

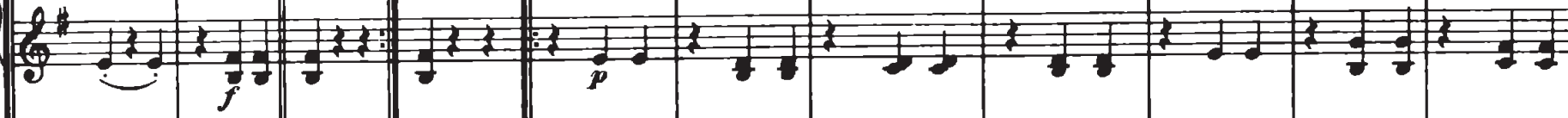

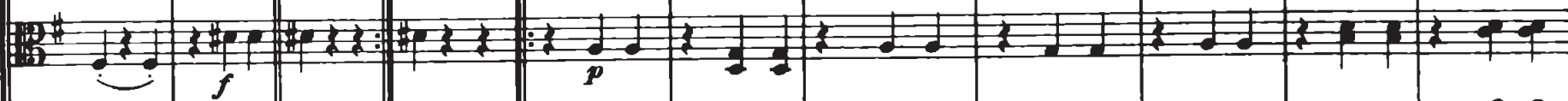

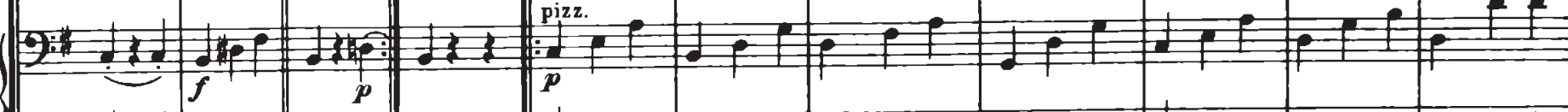

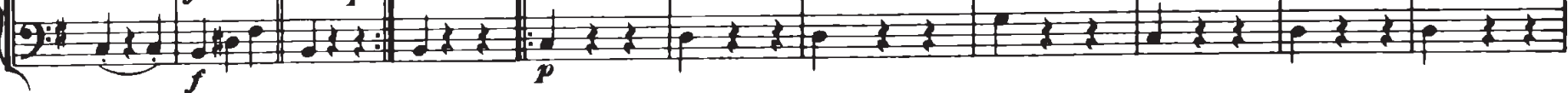



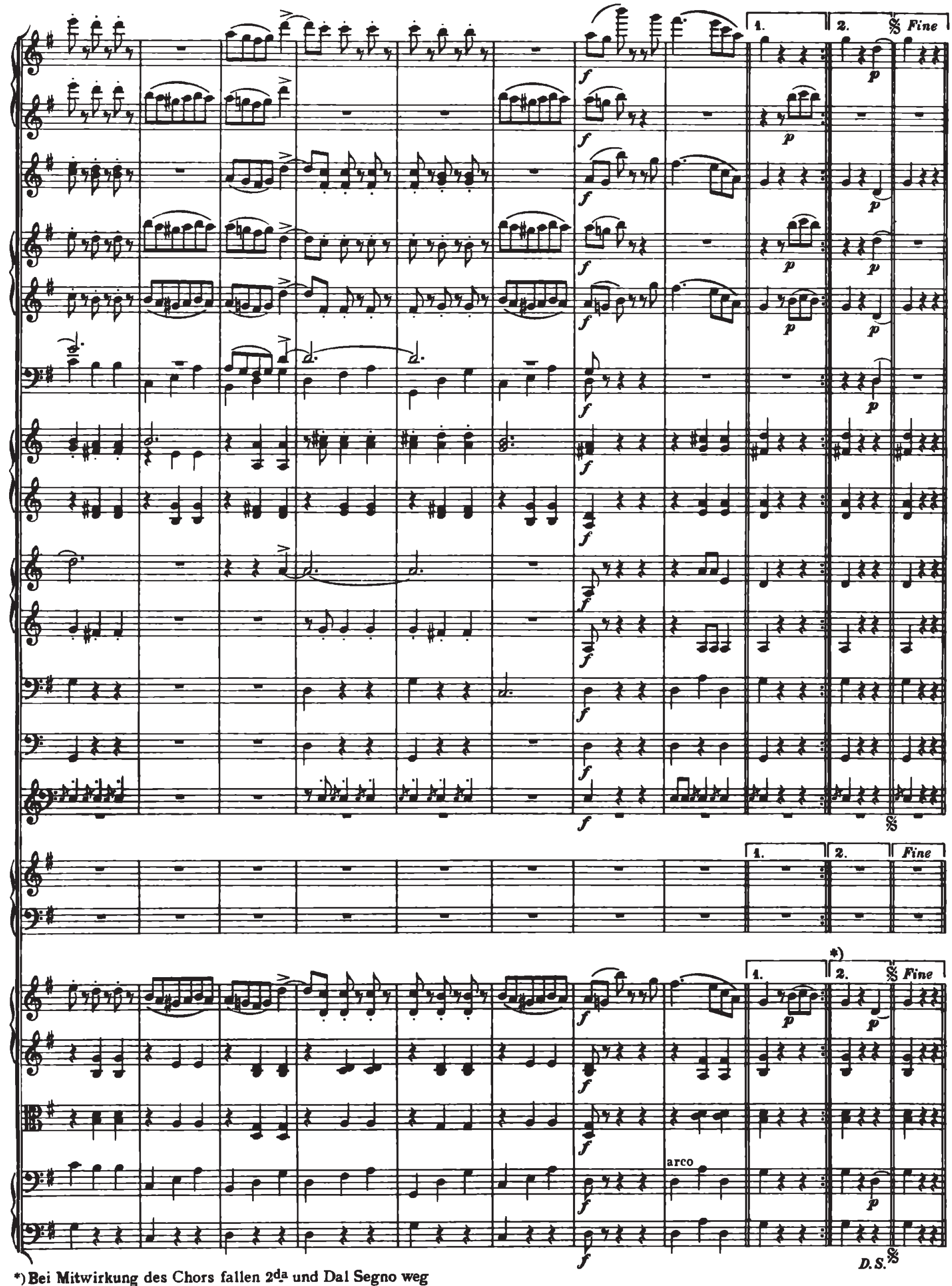
$16 \quad \mathrm{P} 23$

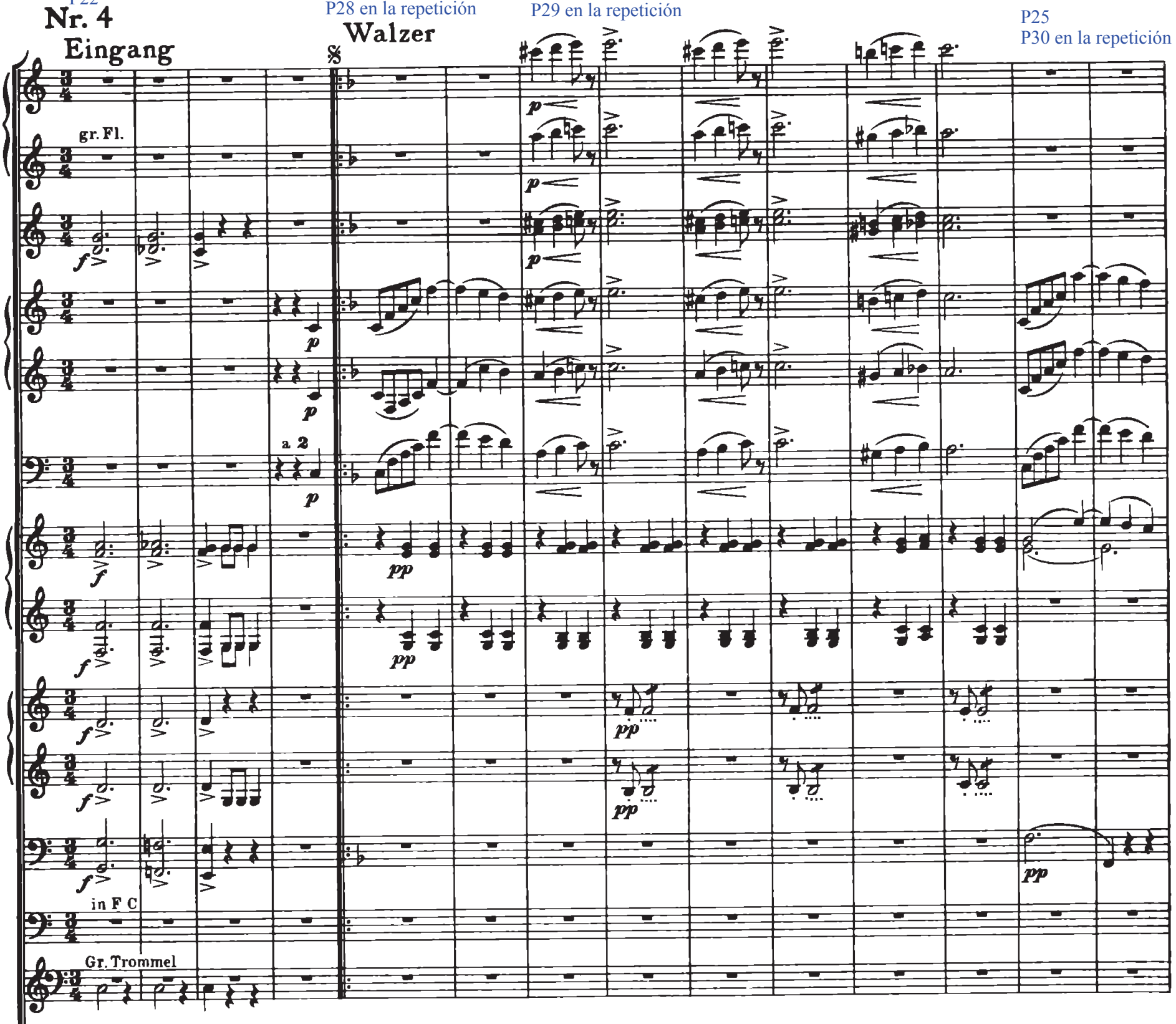

P28 en la repetición

P24

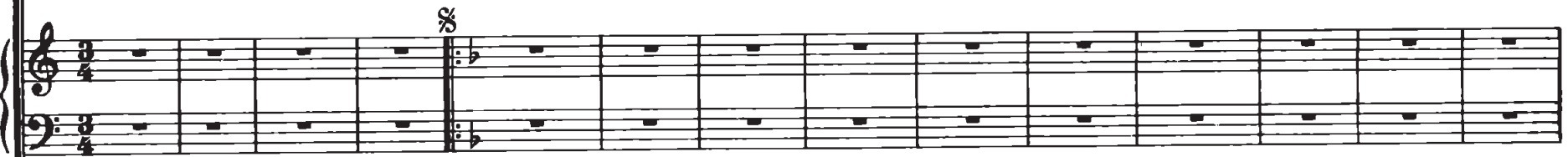

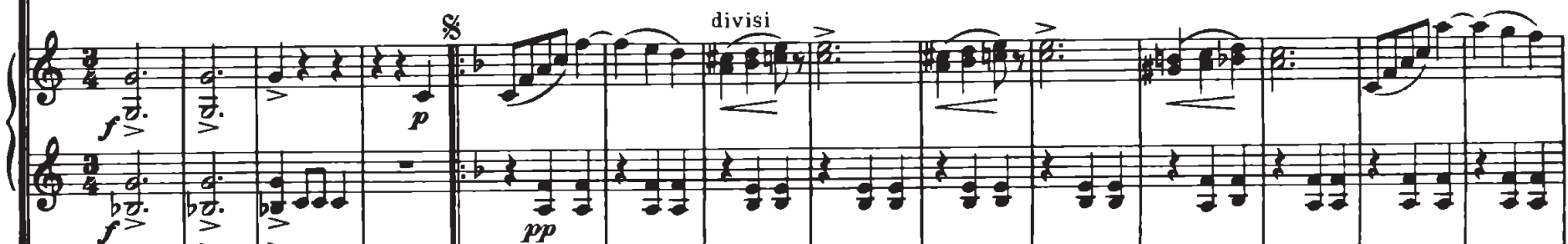

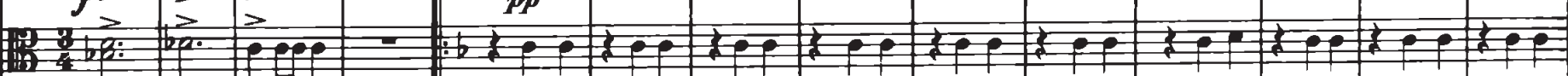

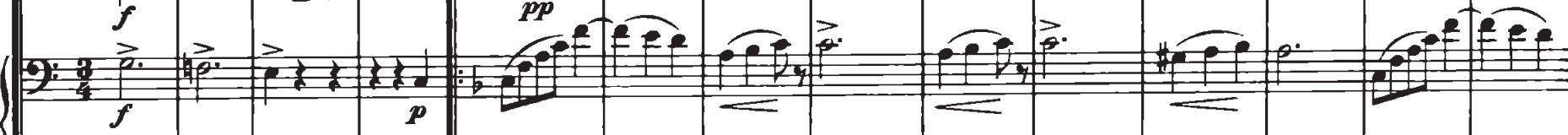

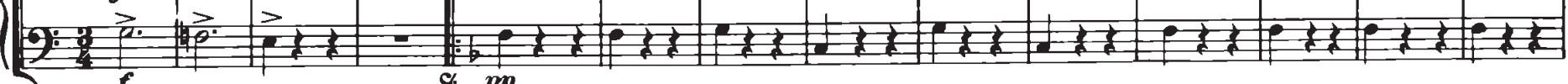



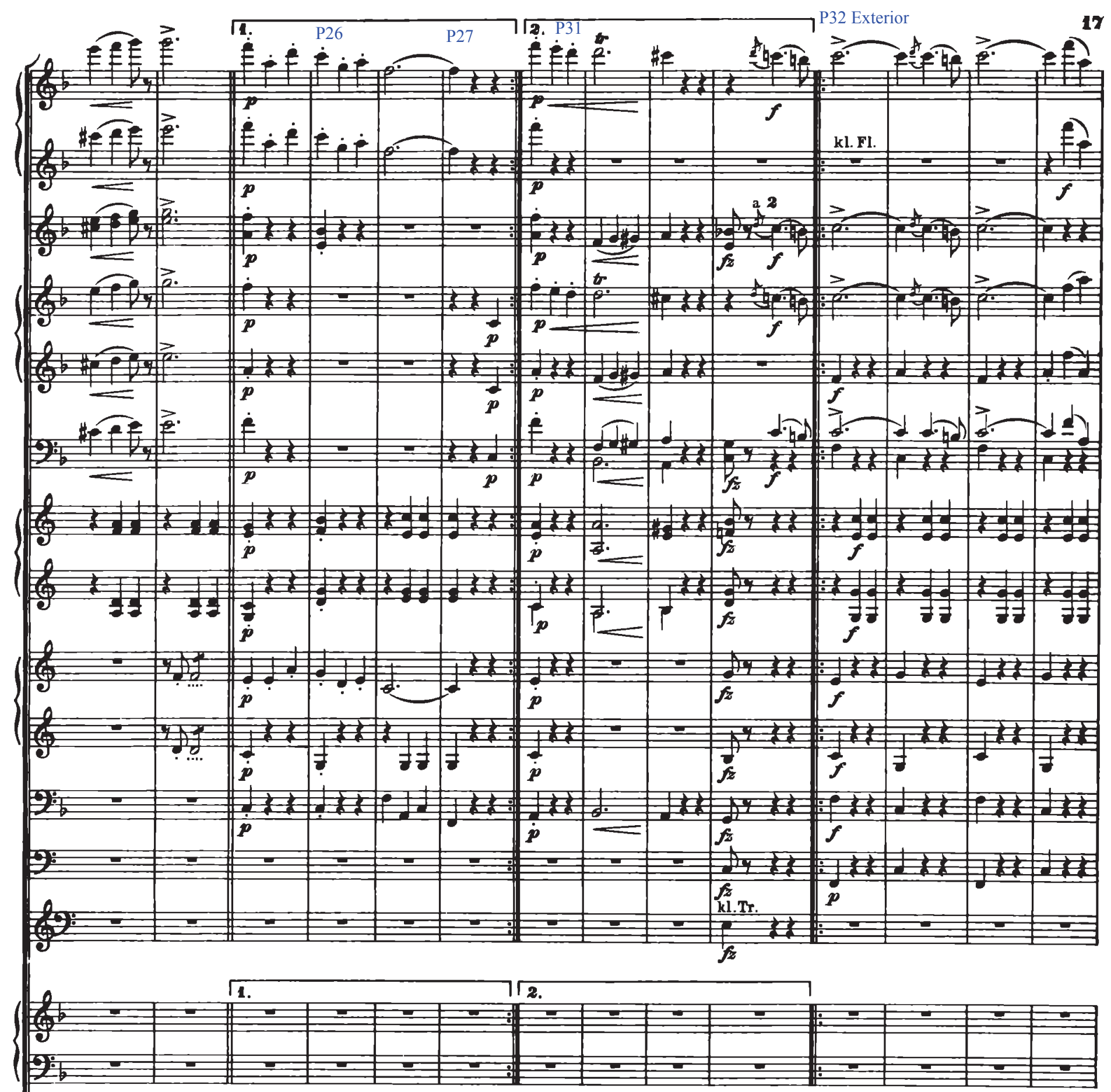

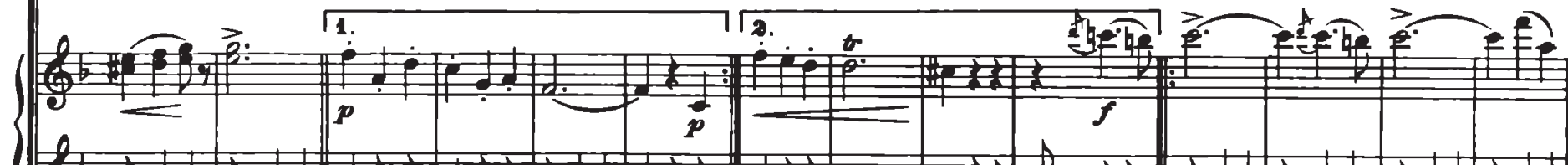

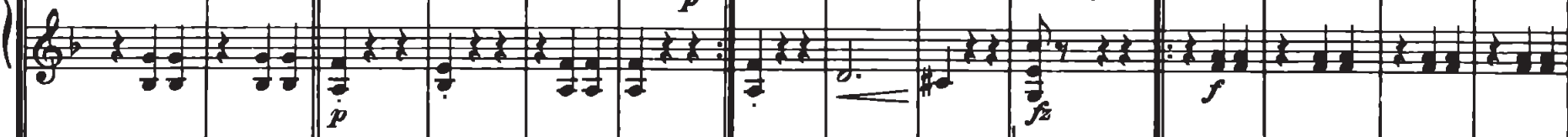

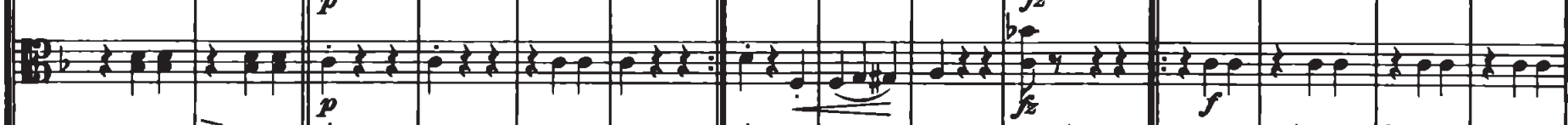

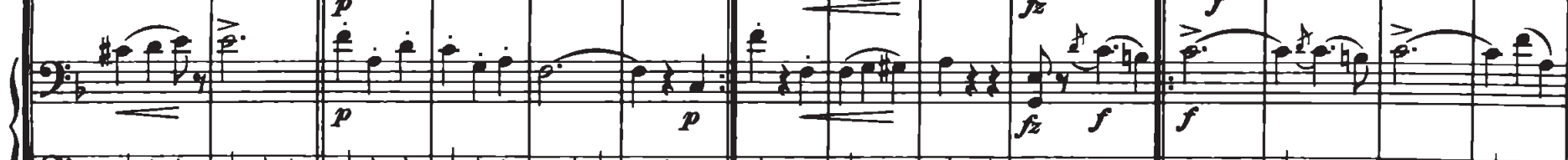

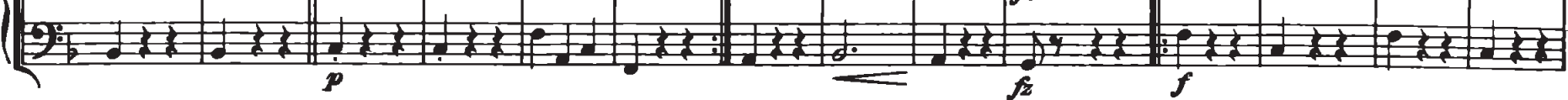


18

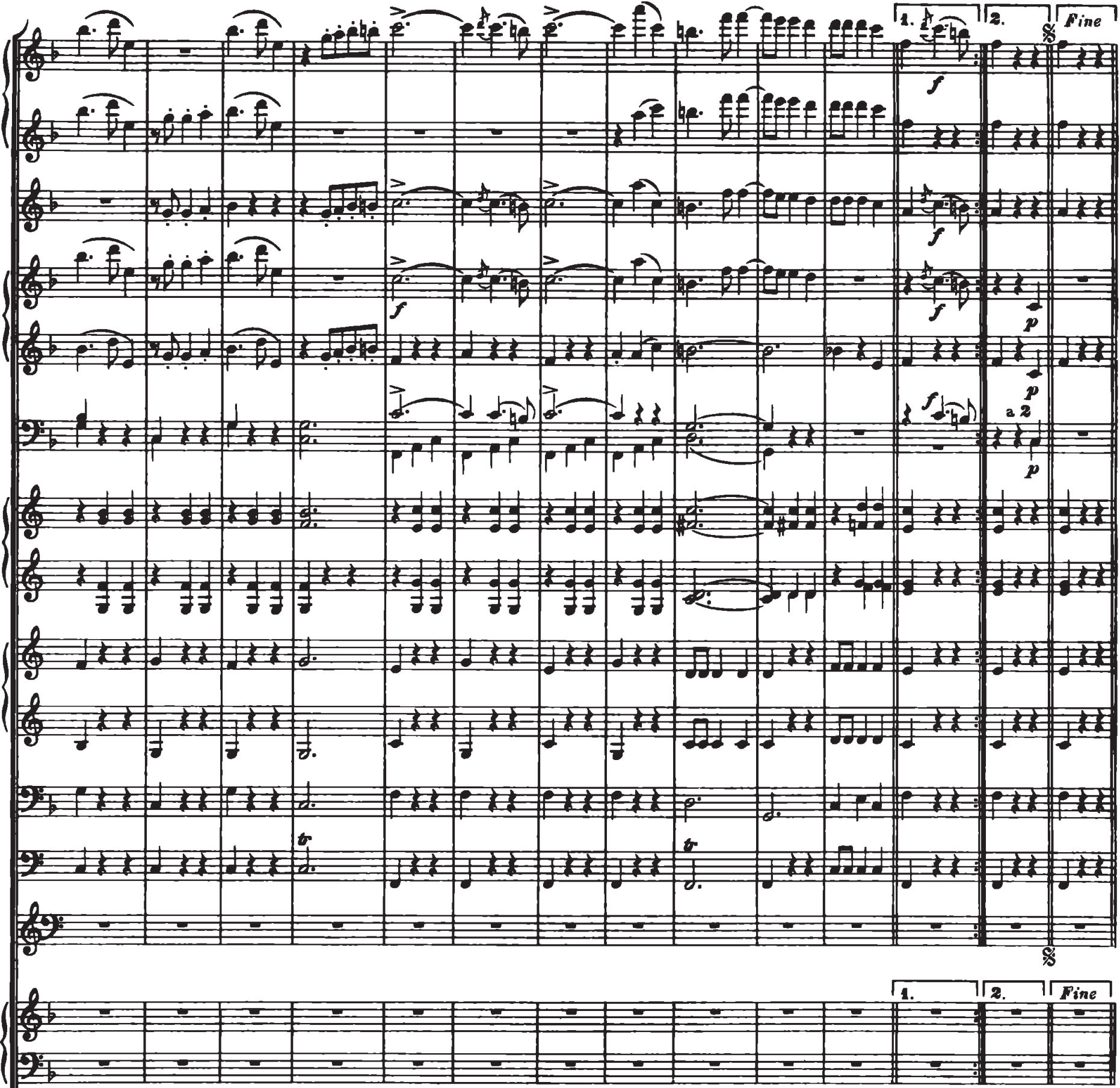

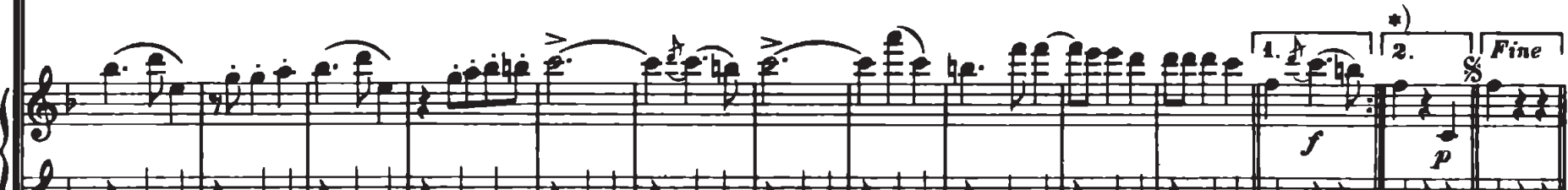

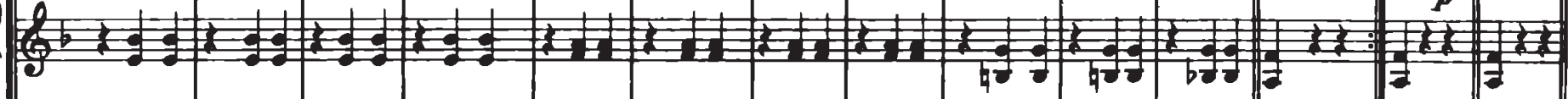

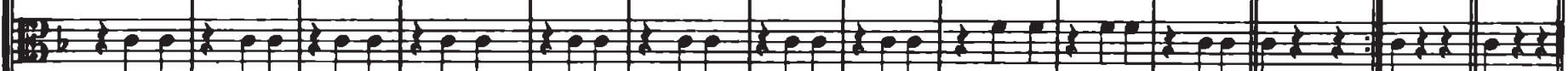

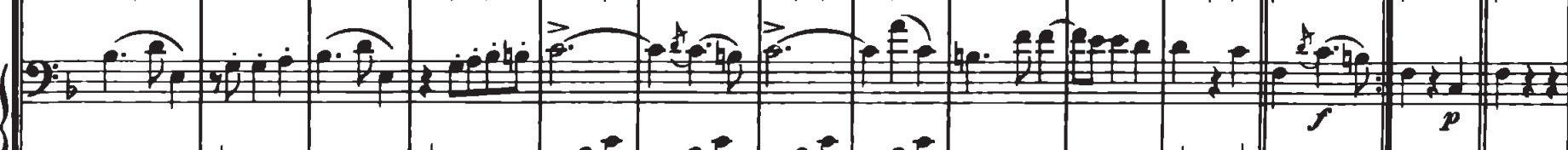

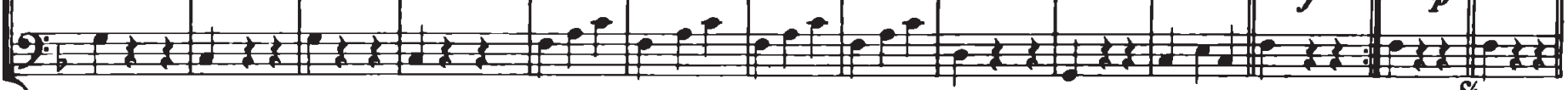

*) Bei Mitwirkung des Chors fallen 2da und Dal Segno weg 
Nr. 5

Lav Eingang

E

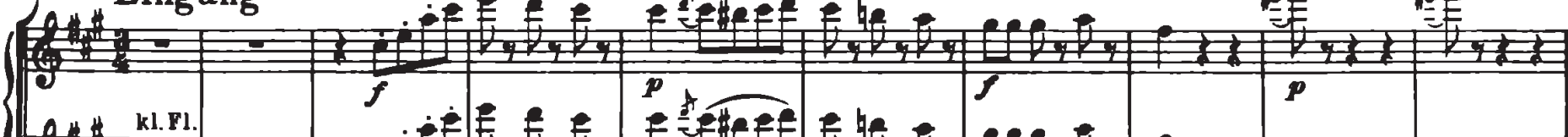

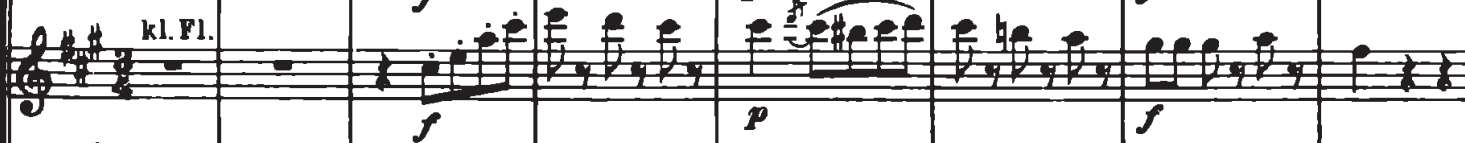

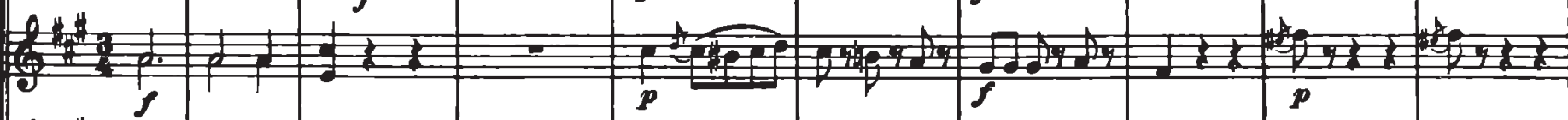

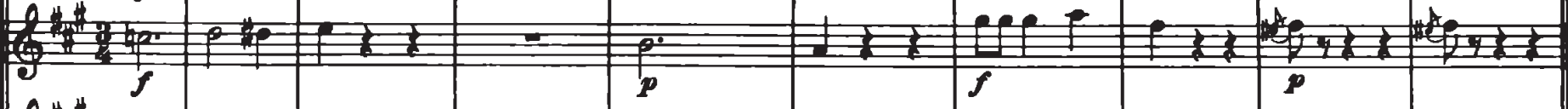

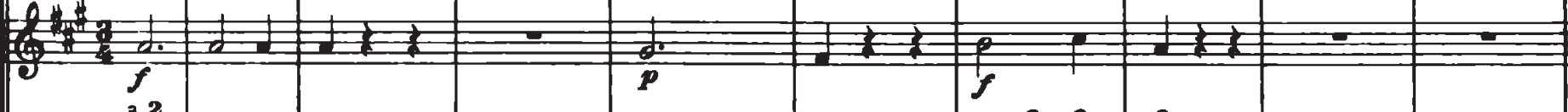

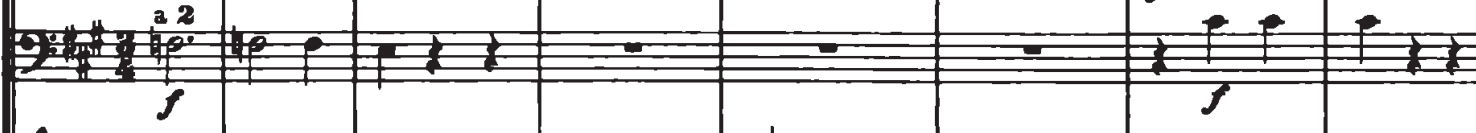

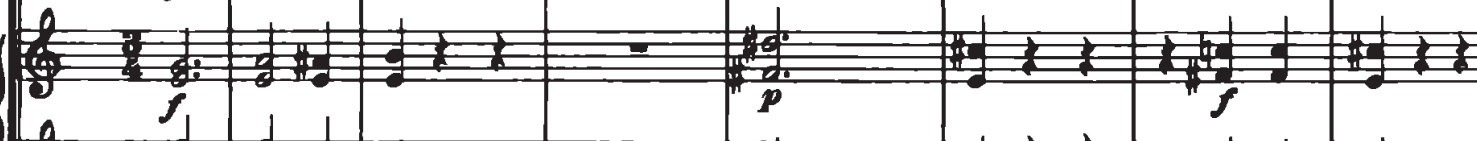

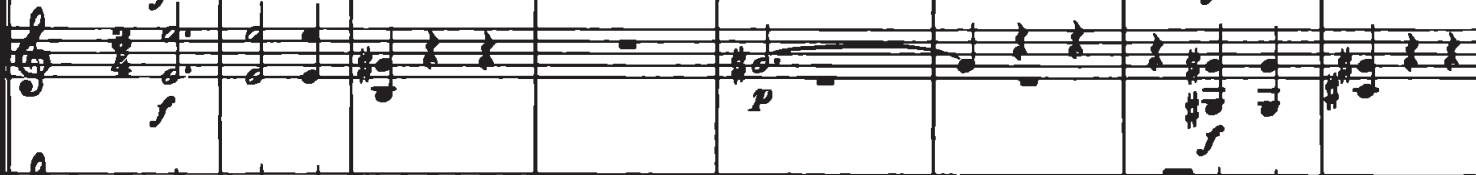

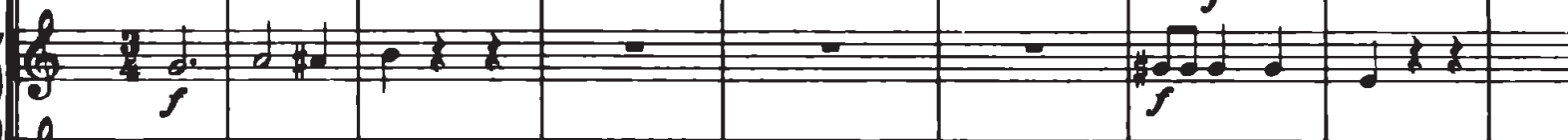

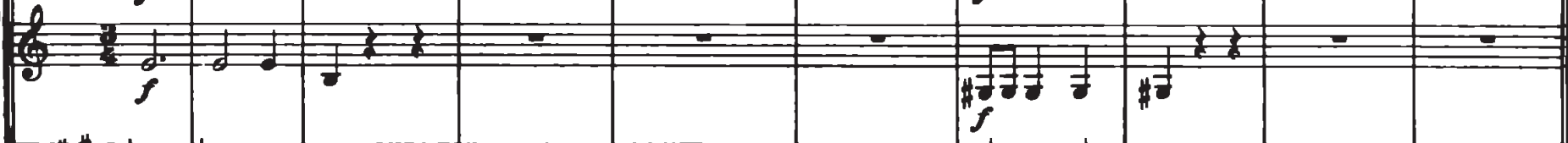

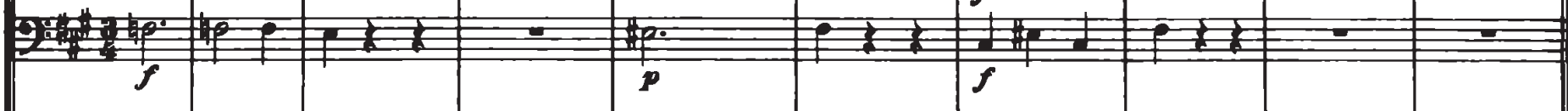
\begin{tabular}{|l|l|l|l|l|l|l|l|l|}
\hline 0 & & & & & & & & \\
\hline
\end{tabular}

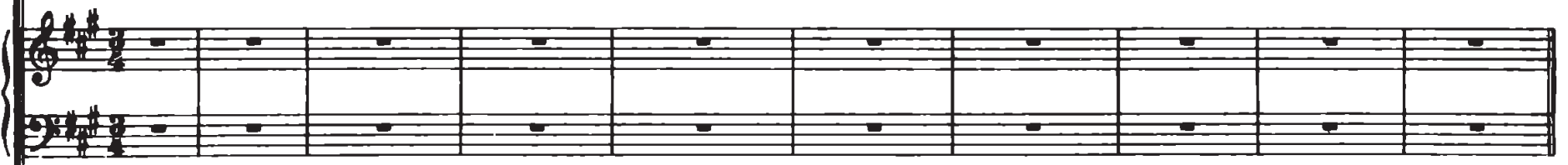

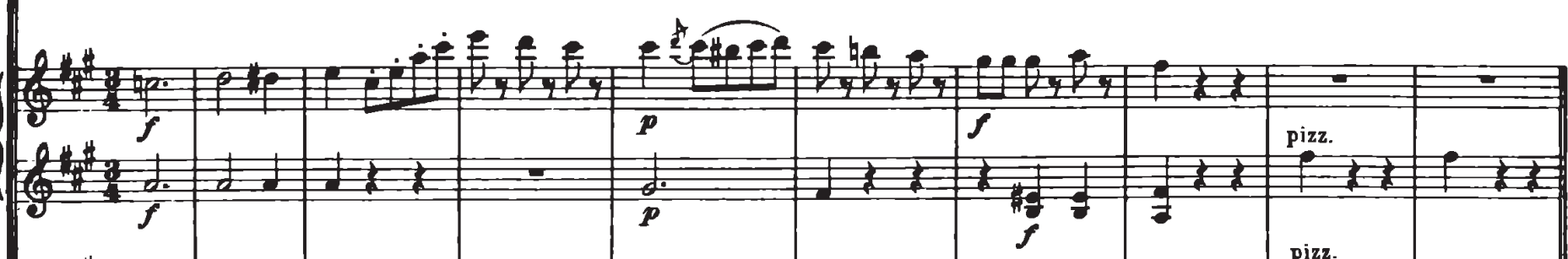

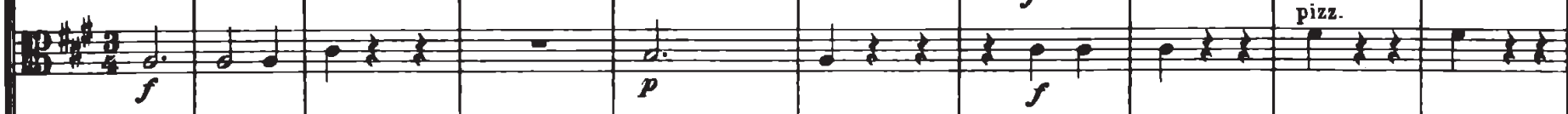

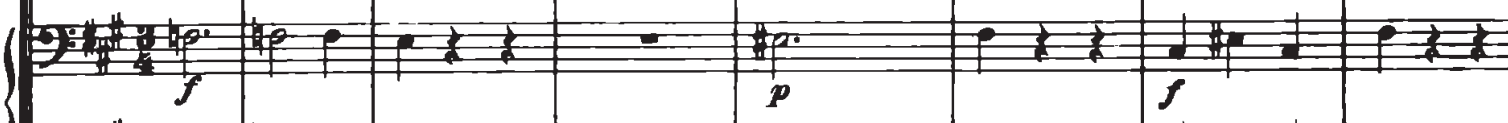

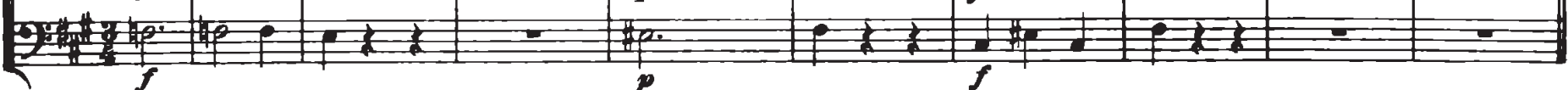


Walzer

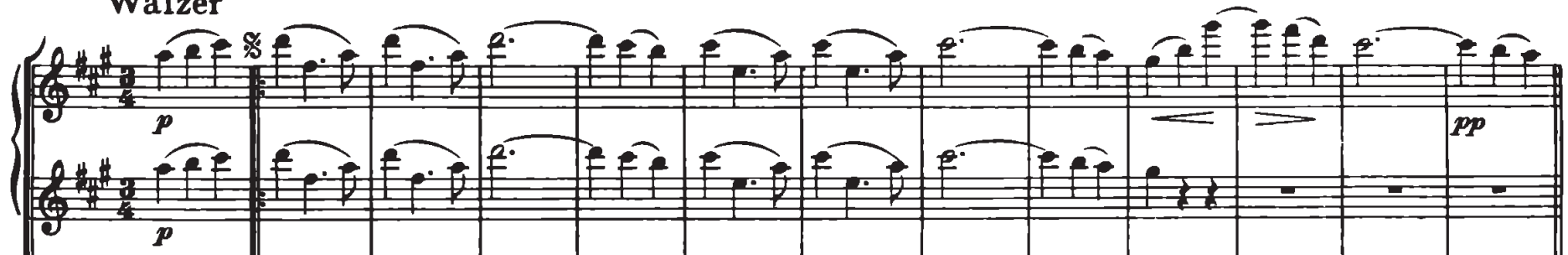

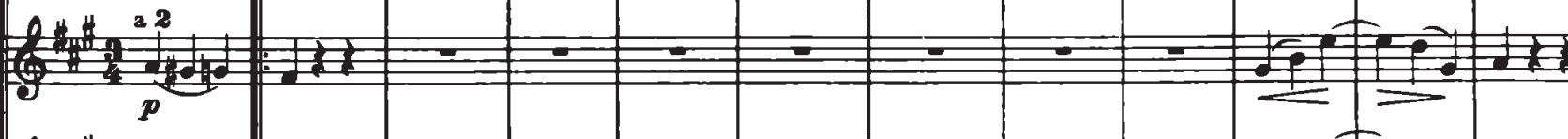

(2.4.7F 6. Sor

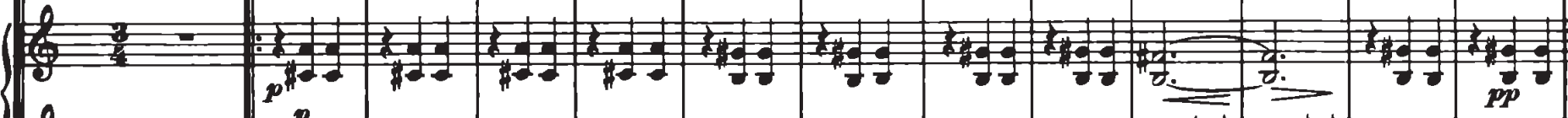

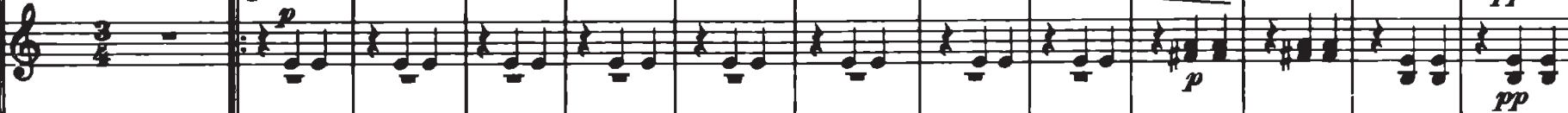

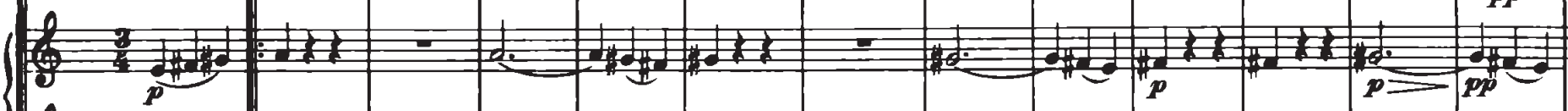

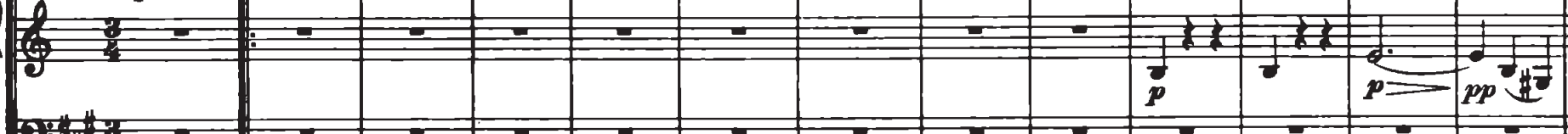

\begin{tabular}{|c|c|c|c|c|c|c|c|c|c|c|c|c|}
\hline 4 & $=$ & $\bar{\sigma}$ & $=$ & 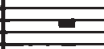 & $\sigma$ & $=$ & 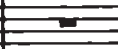 & EF & 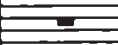 & $\overline{c=}$ & 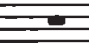 & 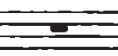 \\
\hline $\bar{E}$ & $=$ & $=$ & 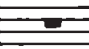 & $=$ & $=$ & $=$ & $=$ & $=$ & $\angle \sigma$ & 듬 & $\equiv$ & 프 \\
\hline & $=$ & $=$ & $=$ & 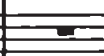 & 5 & 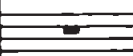 & 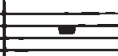 & $=$ & $=$ & $=$ & $=$ & $\underline{z}$ \\
\hline
\end{tabular}

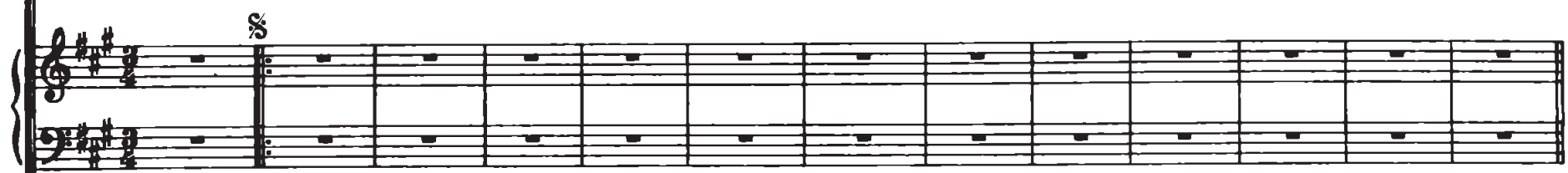

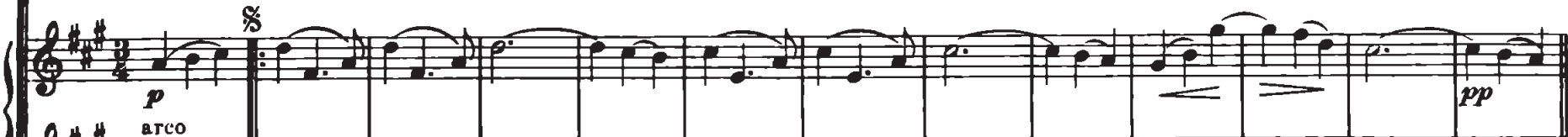

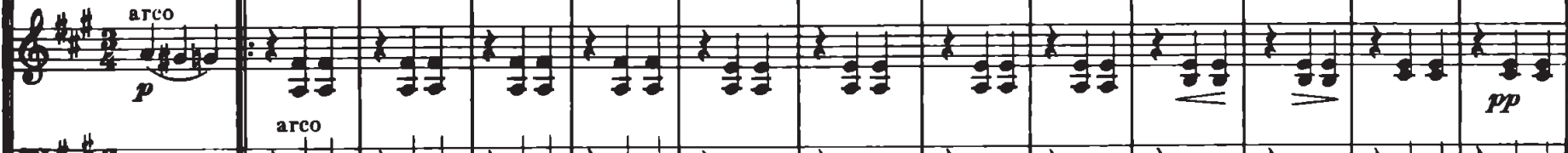
月.

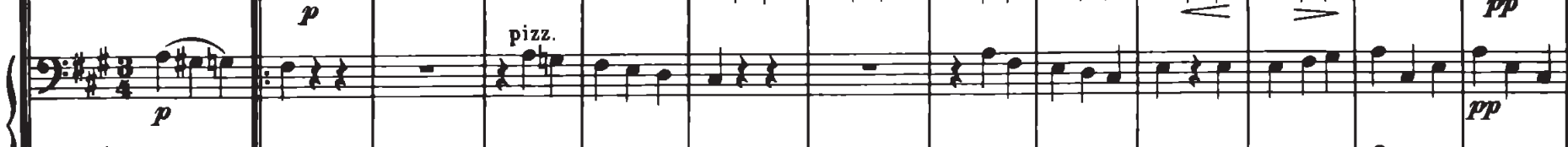

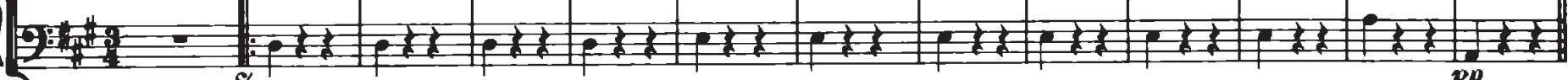
$\$ p$ 


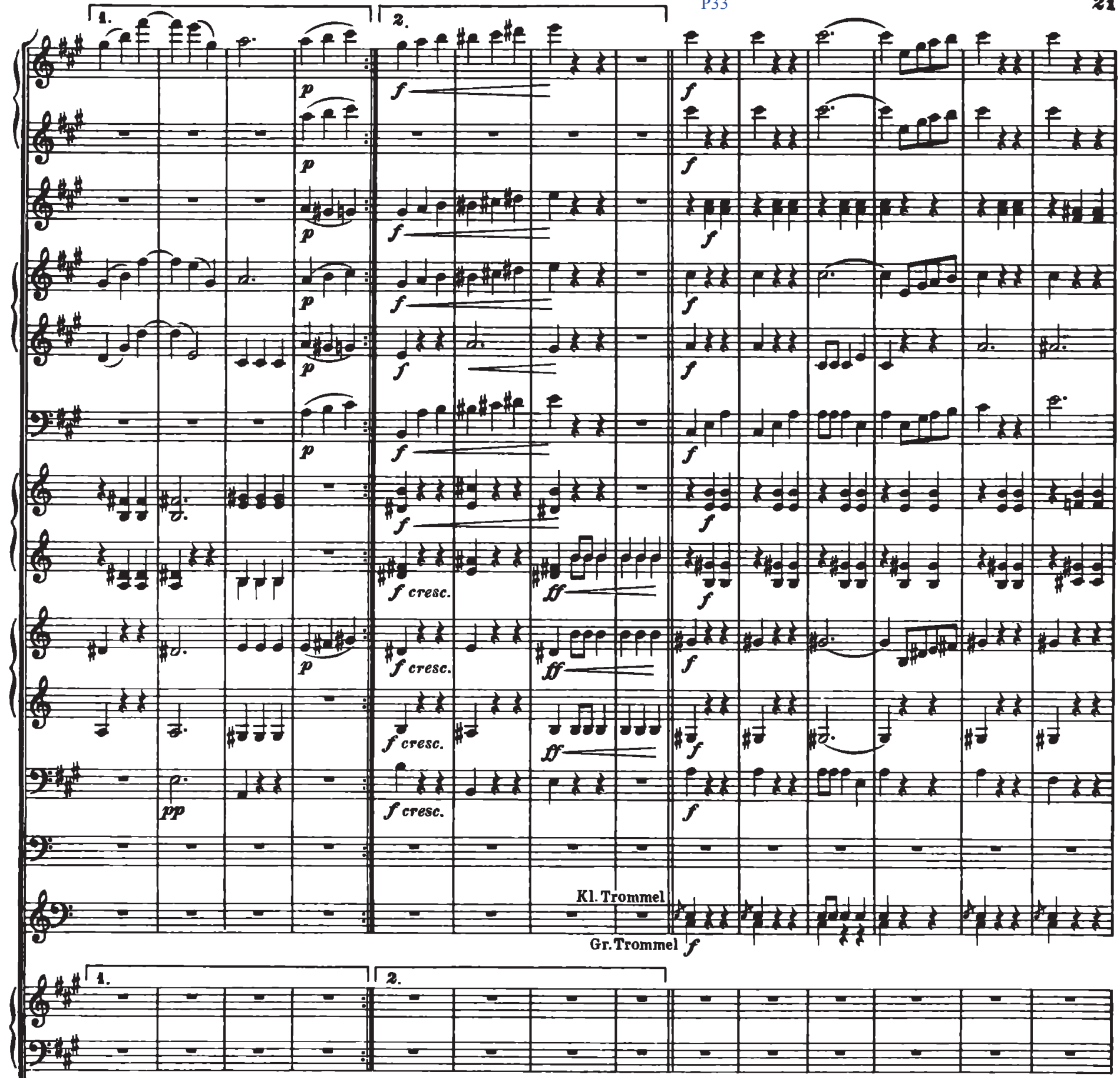

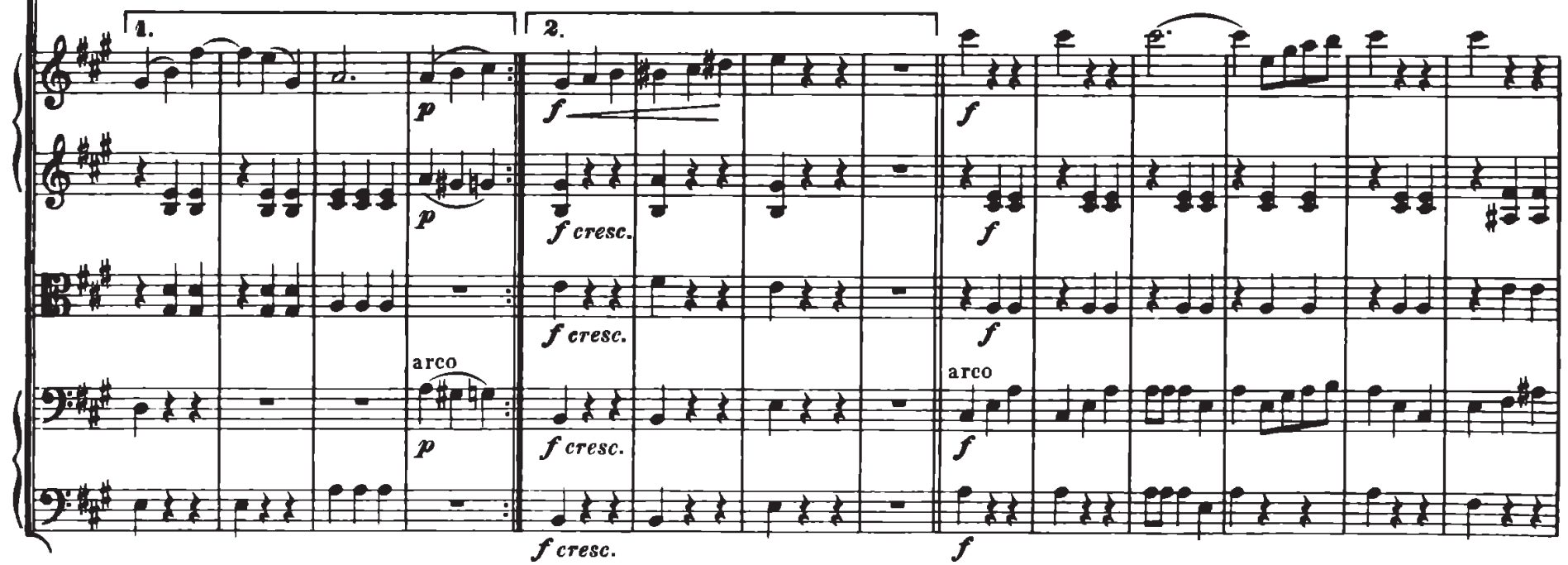


$22 \mathrm{P} 34$

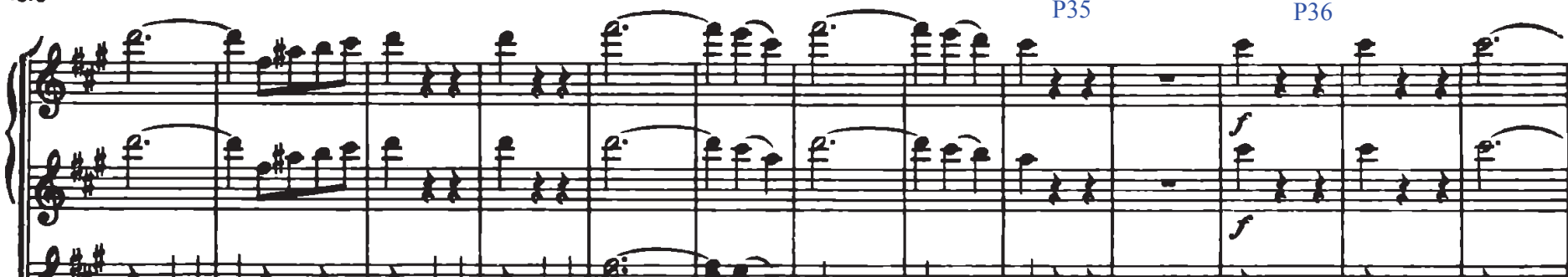
\%

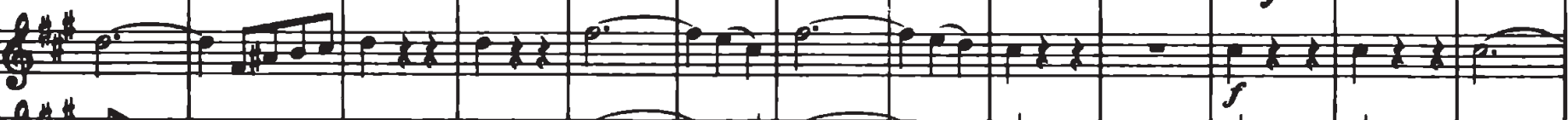

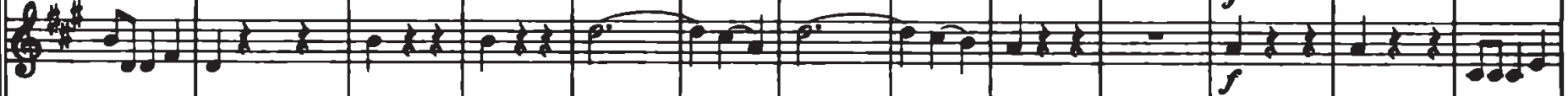

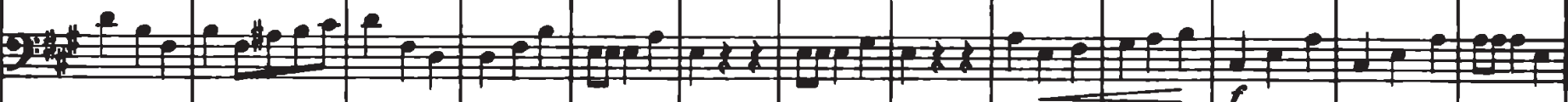

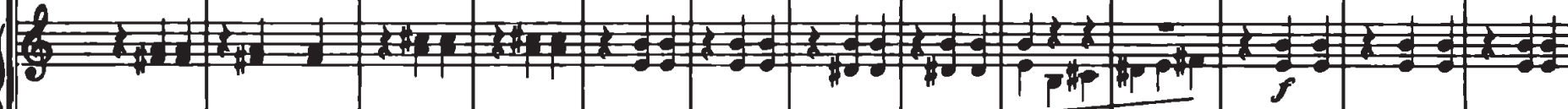

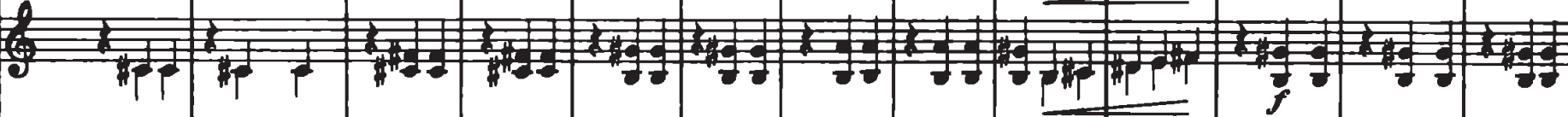

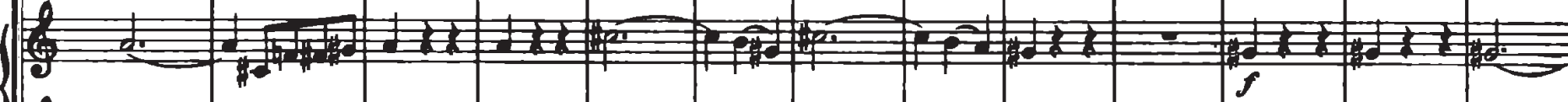

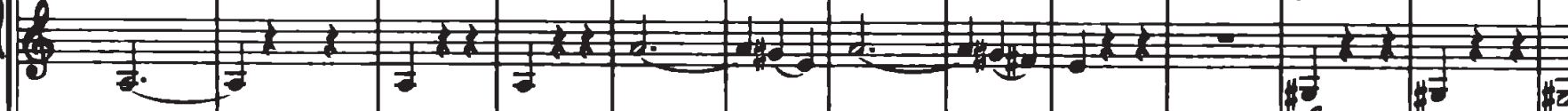
$\begin{array}{lll}2 & 1\end{array}$

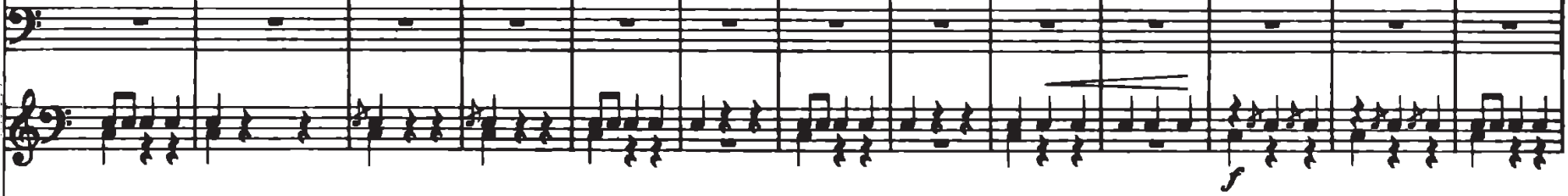

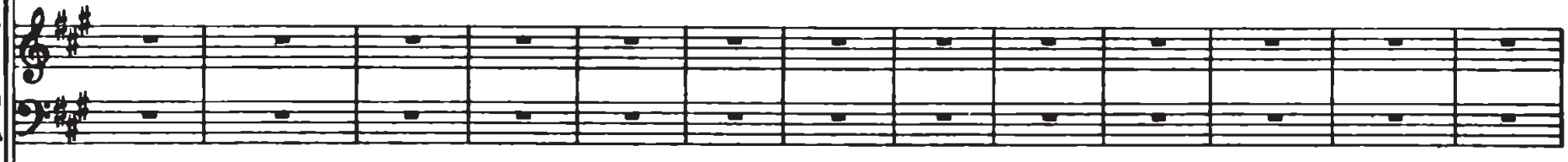

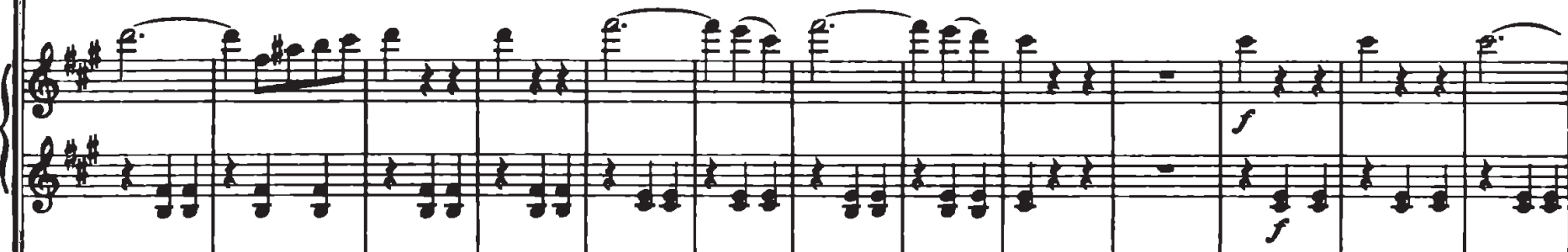

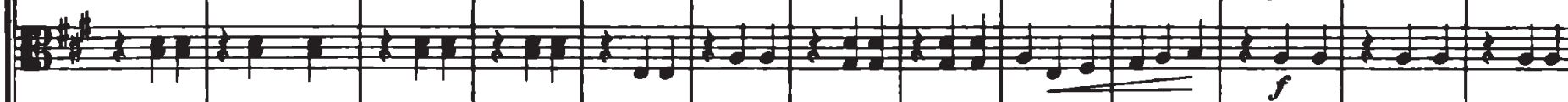

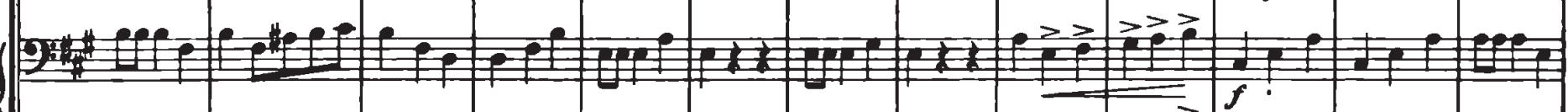

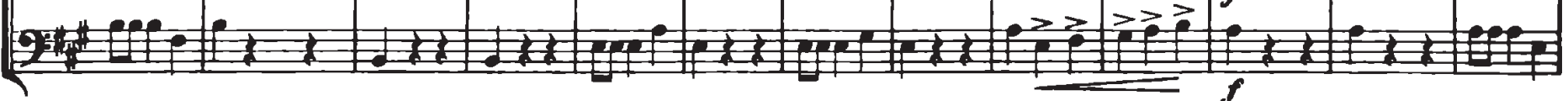



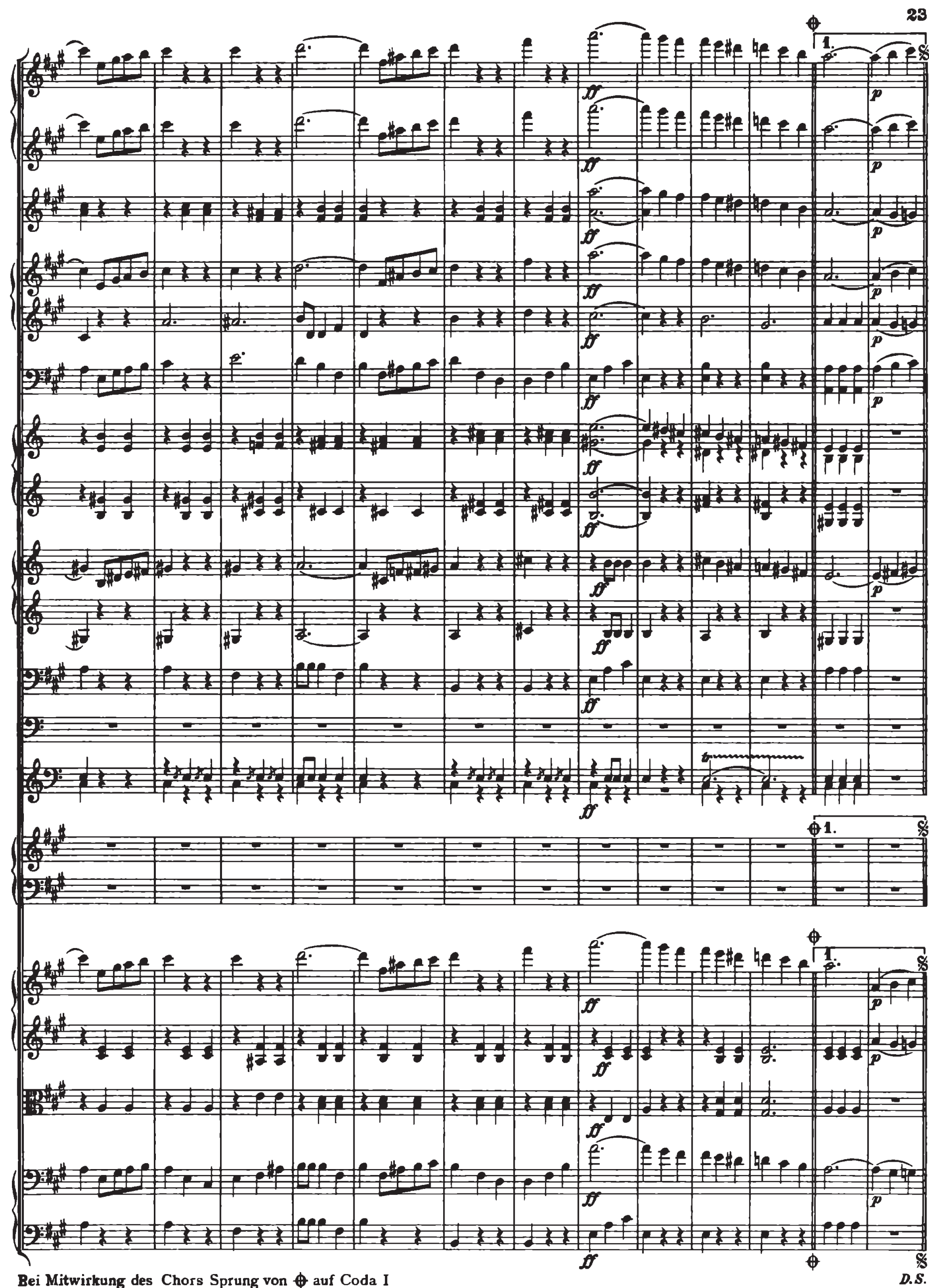
24
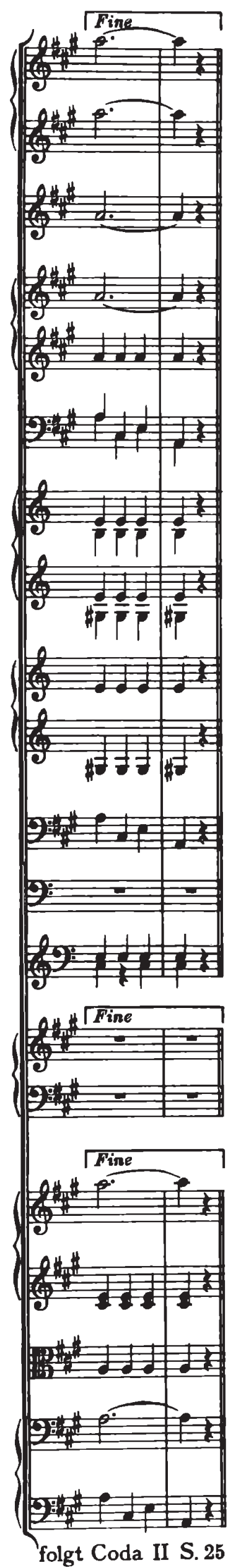

Coda I Nur bei Mitwirkung des Chors

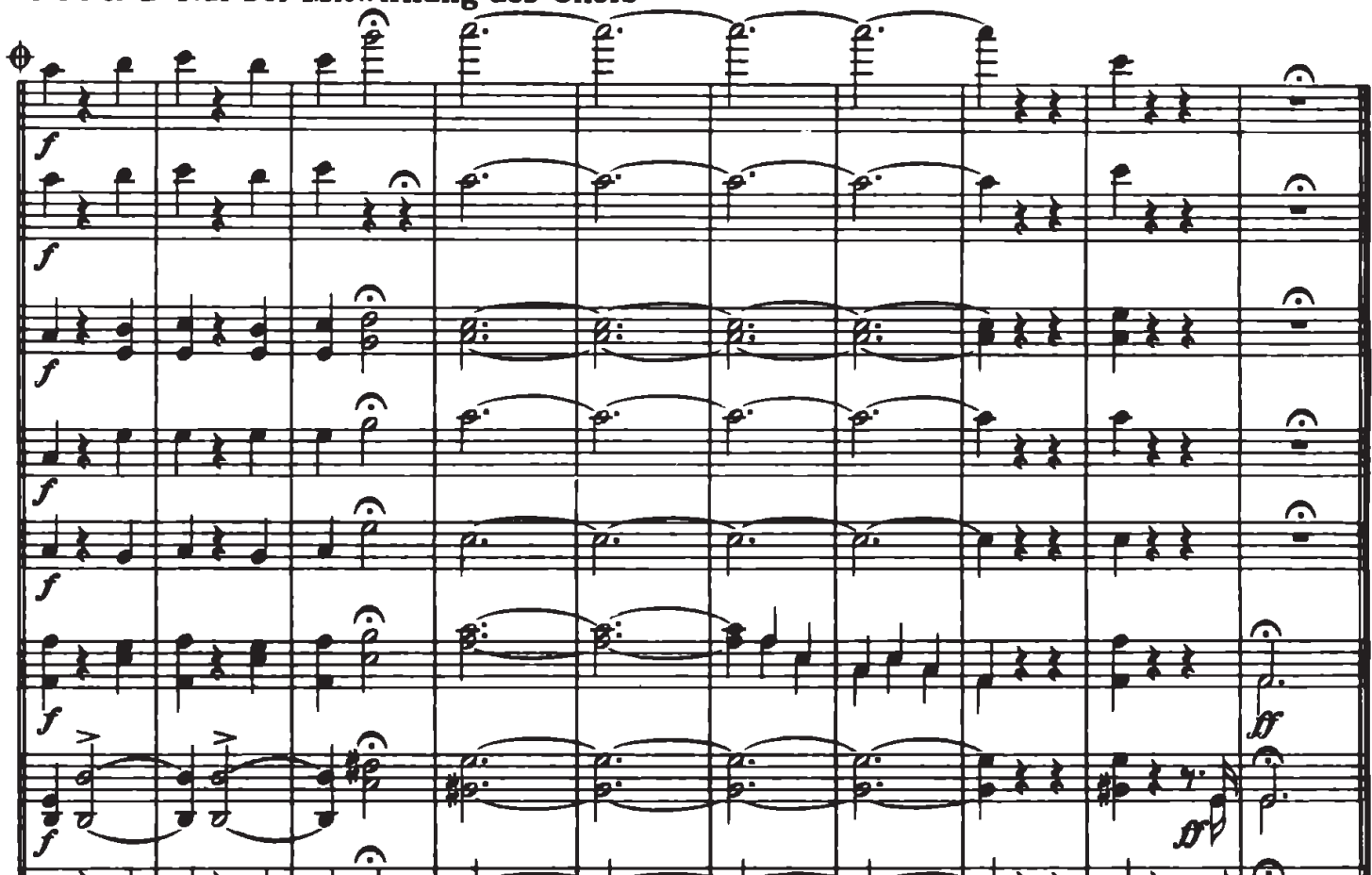

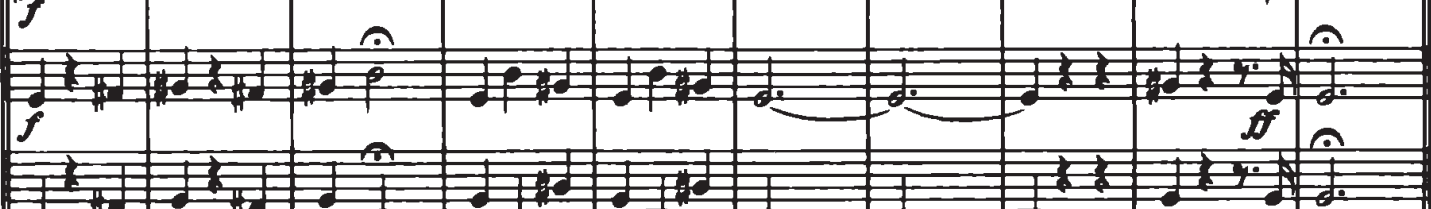

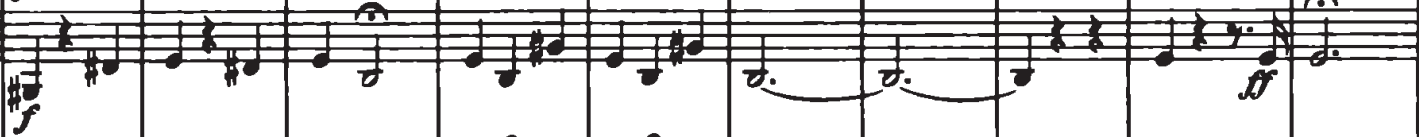

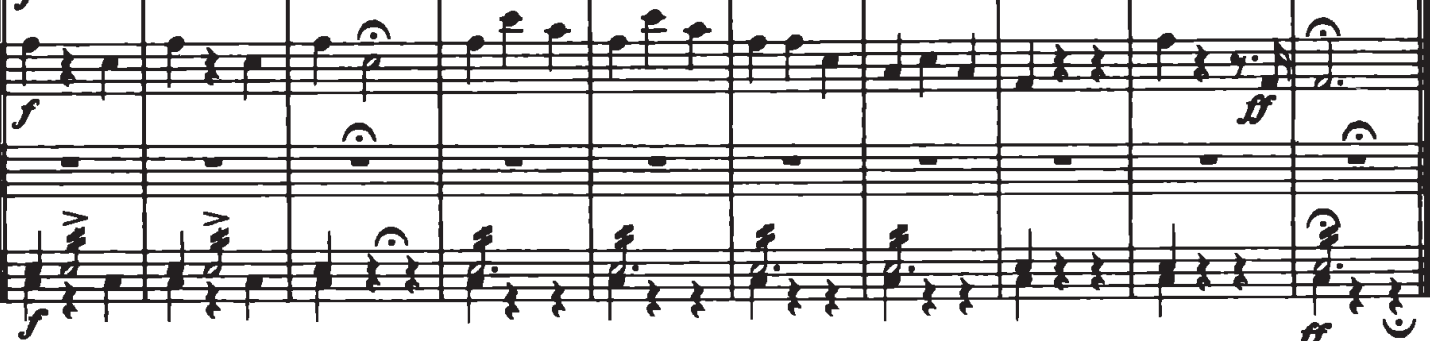

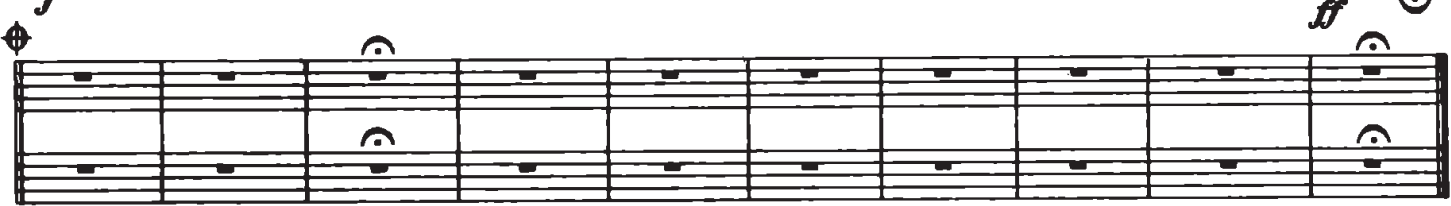

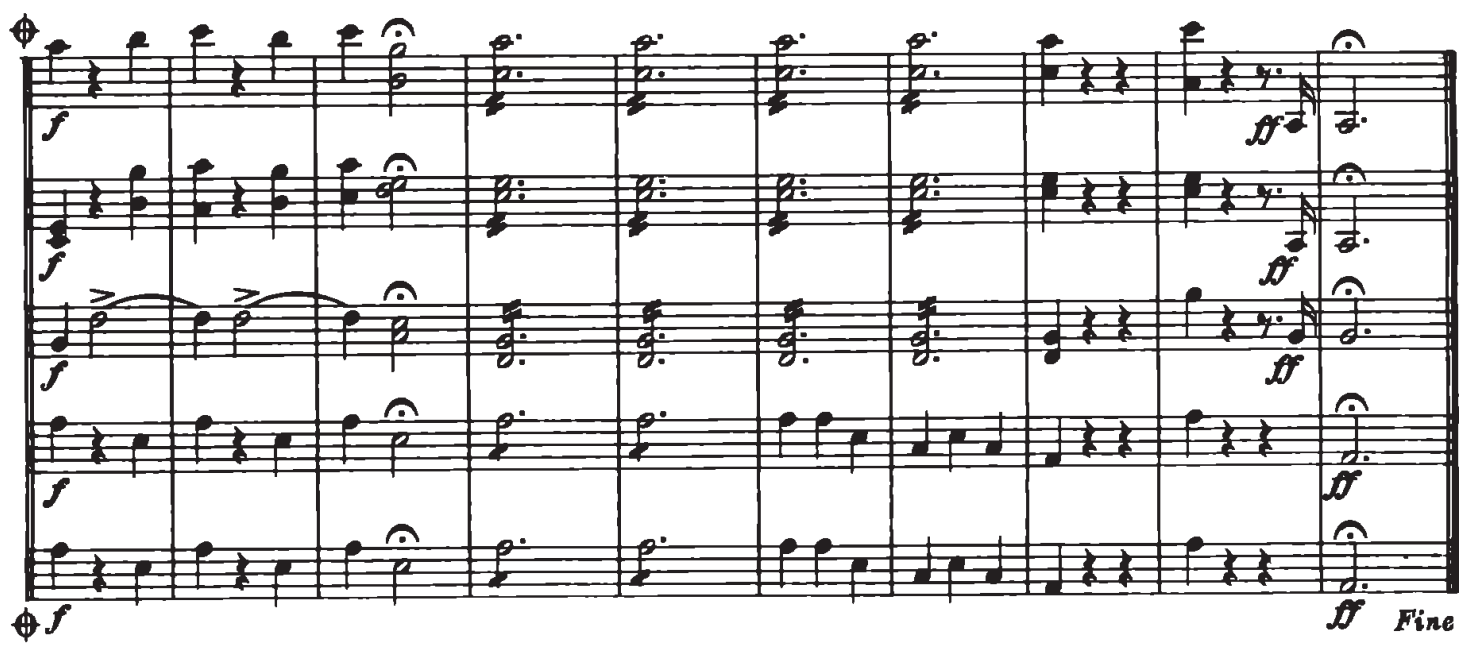


Coda II

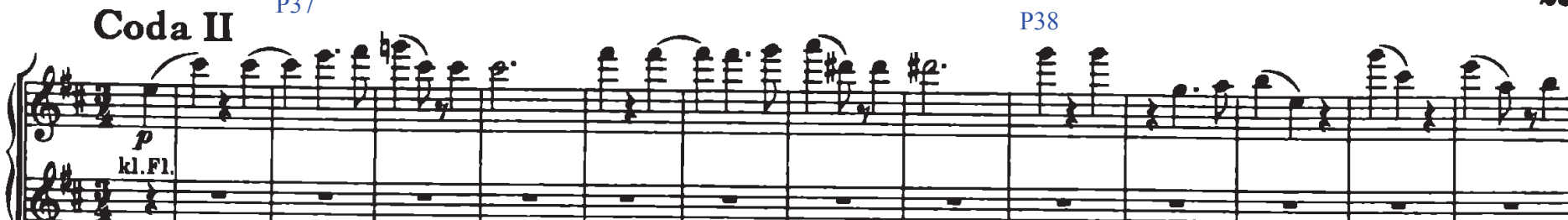

(1) $\%$

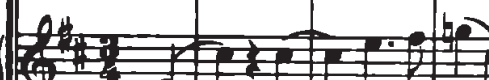

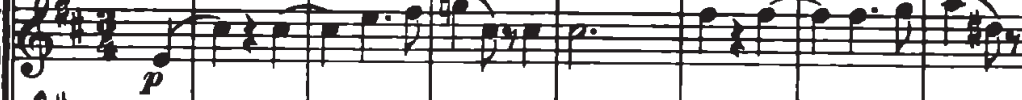

9.

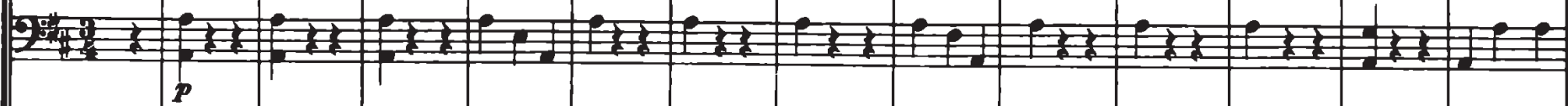
6 6.

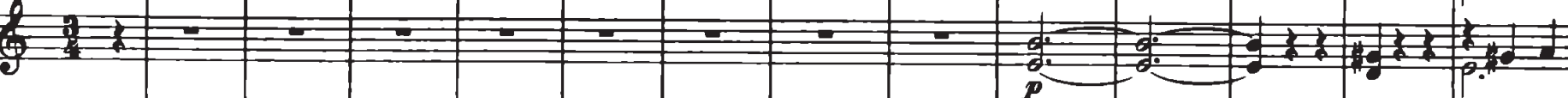
(3)

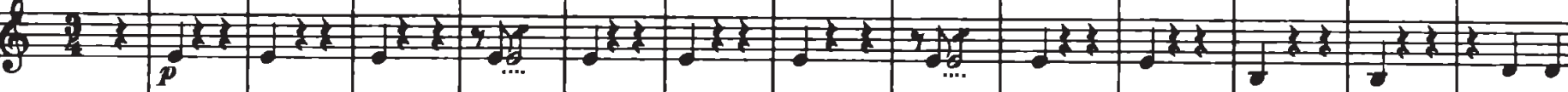

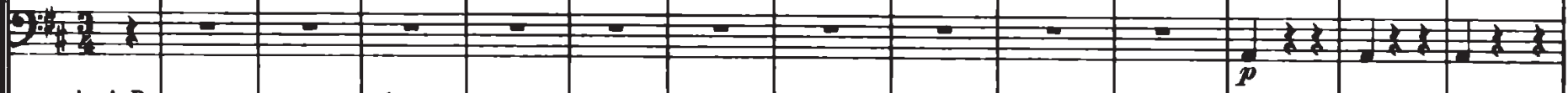

in A D

\begin{tabular}{|c|c|c|c|c|c|c|c|c|c|c|c|c|c|}
\hline${ }^{\ln A D}$ & $\overline{\bar{z}}$ & $E$ & toman & $F$ & $=$ & $\bar{\sigma}$ & & 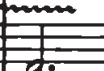 & 26 & $E$ & 12 & 72 & $\Rightarrow$ \\
\hline & & & $p$ & & & & & & & & & & \\
\hline 7 & $\overline{\underline{\underline{y}}}$ & $2=$ & $\overline{\bar{z}}$ & $=$ & $=$ & 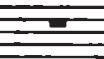 & $=$ & $=$ & $\angle$ & $=$ & $E$ & $=$ & 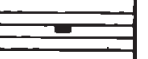 \\
\hline
\end{tabular}
学
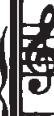

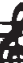

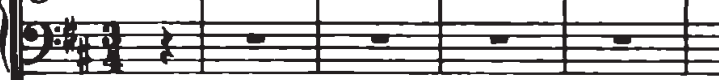

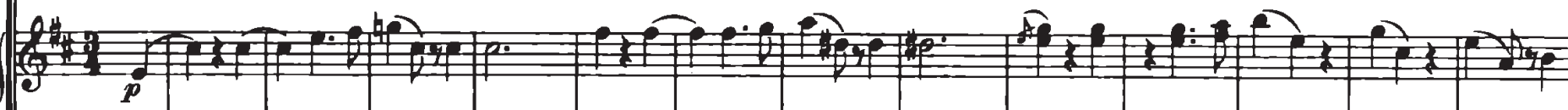
(2)

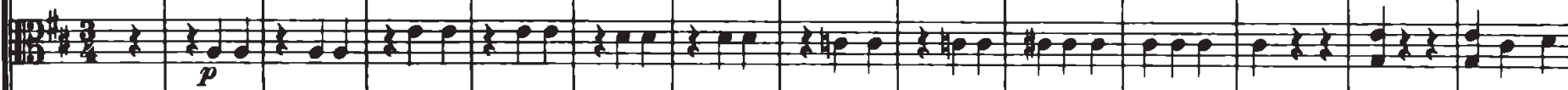

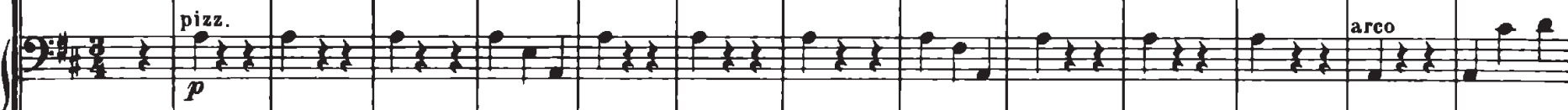

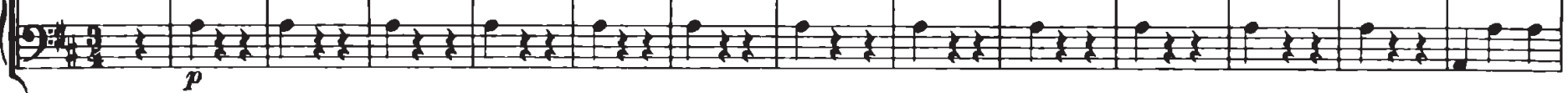




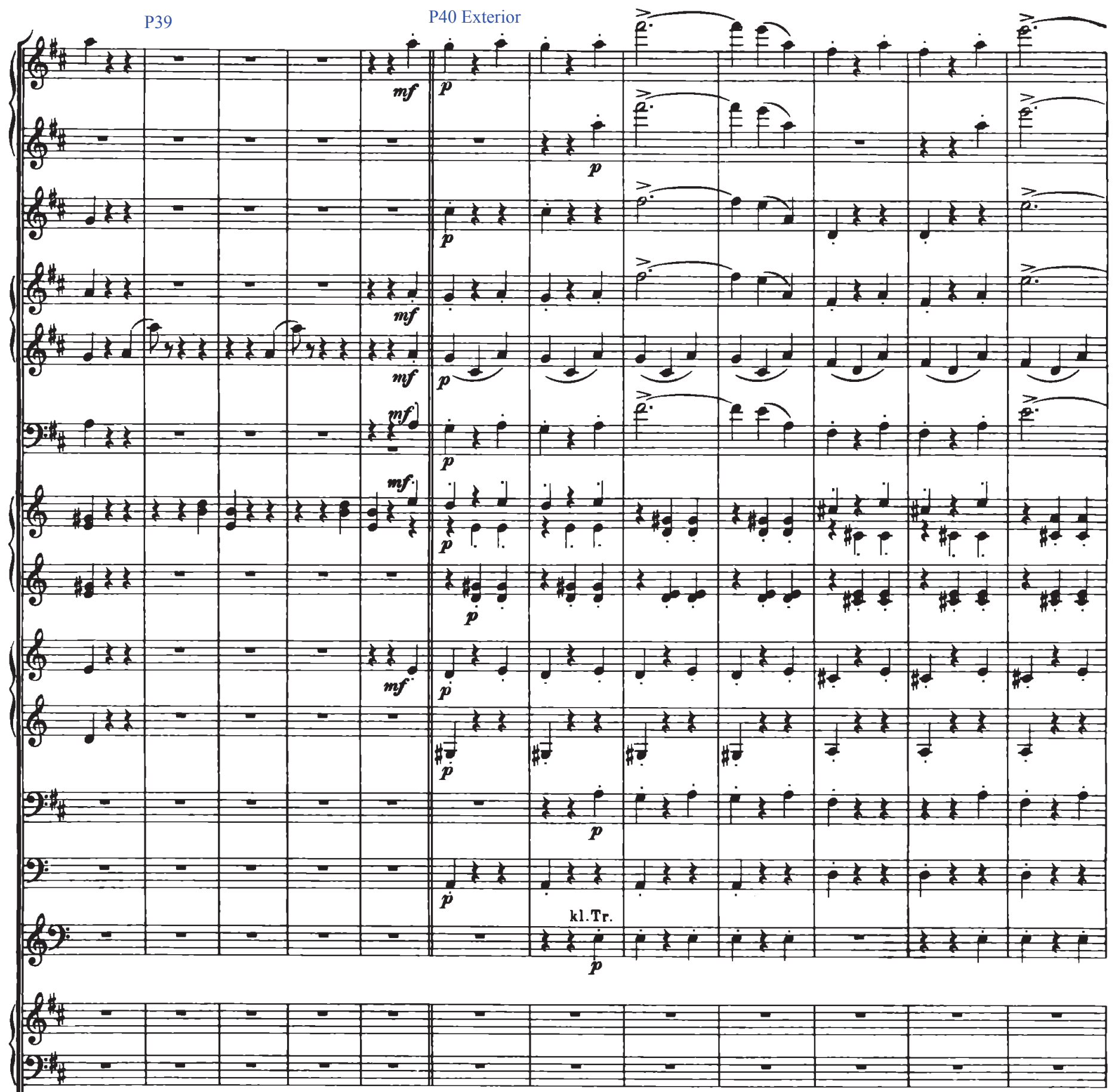

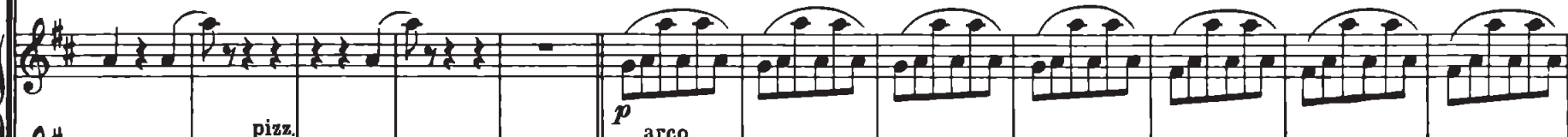

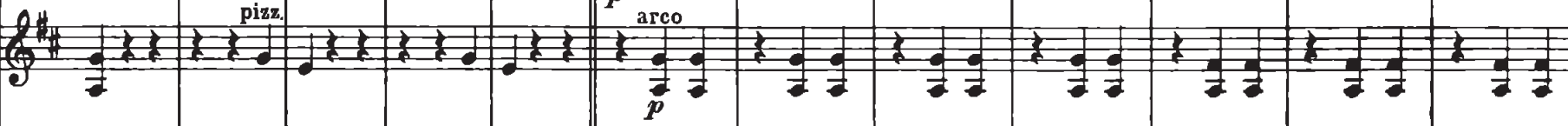
(1) 


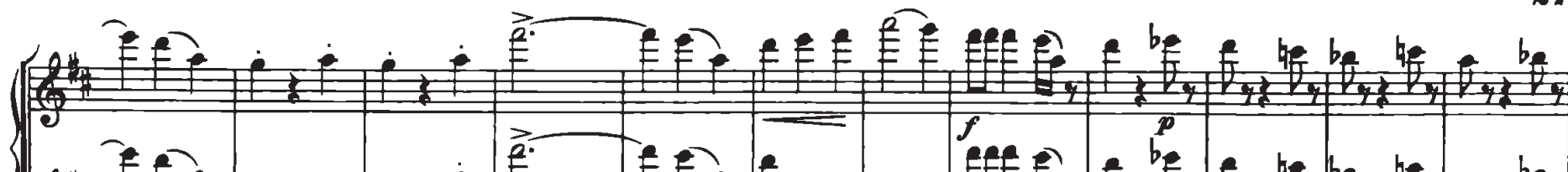

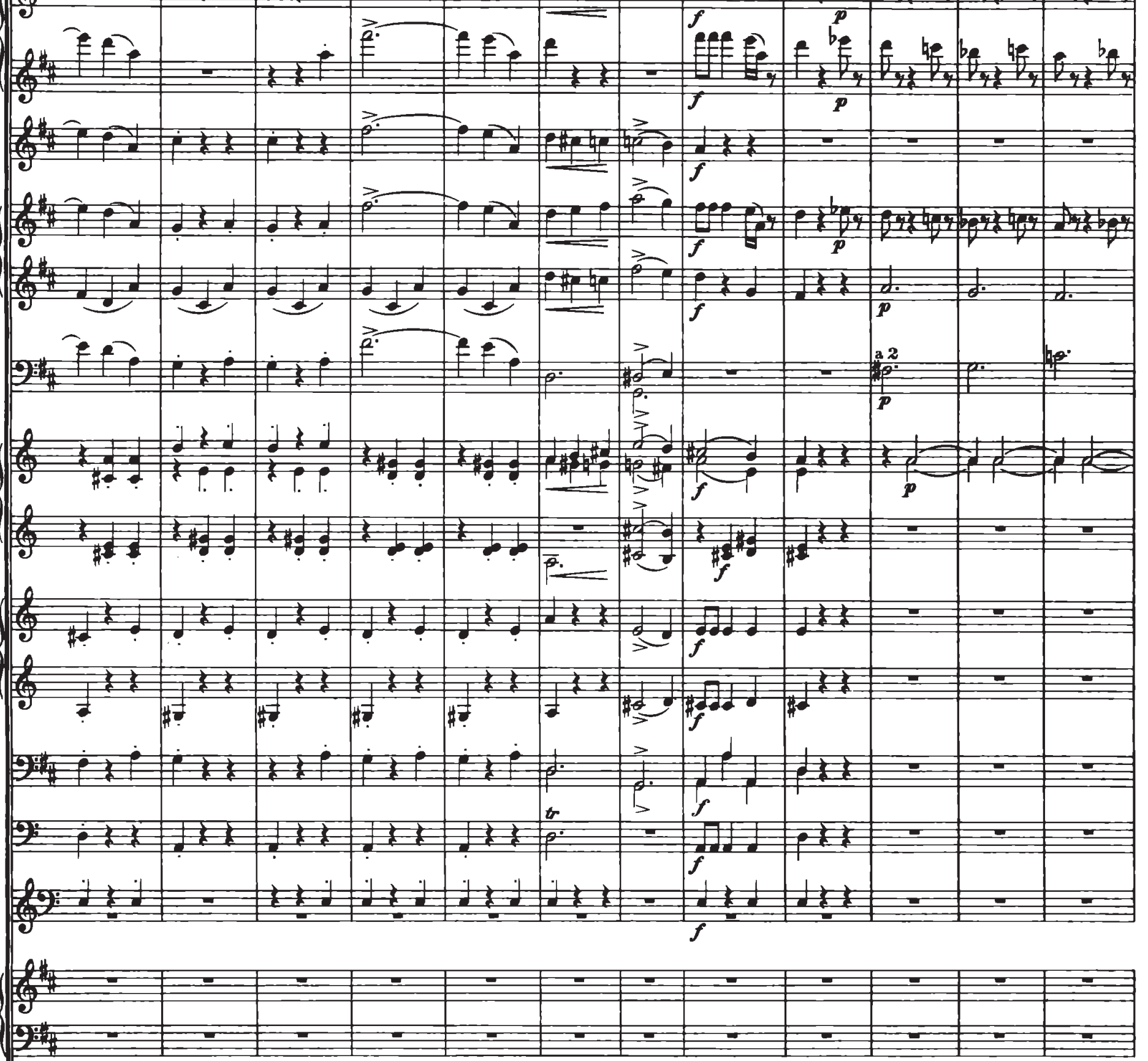

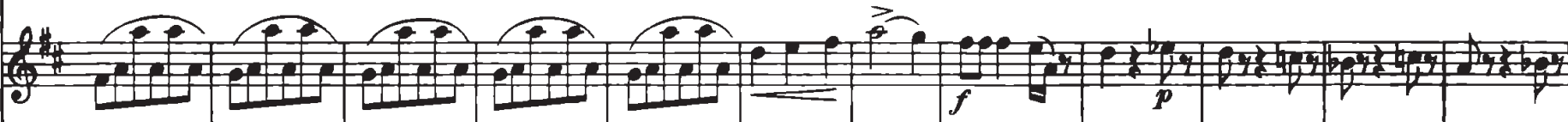

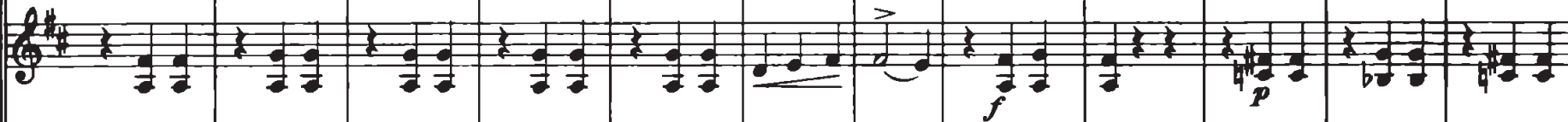

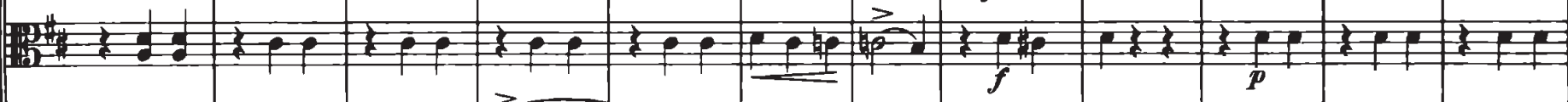

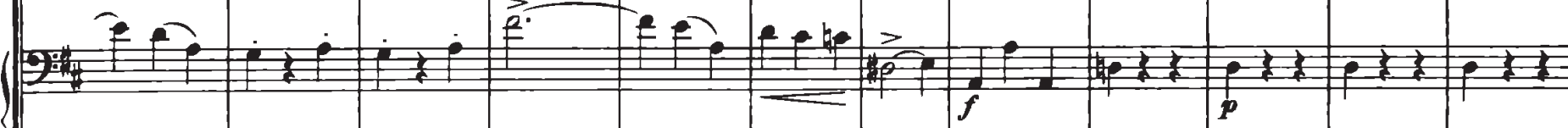

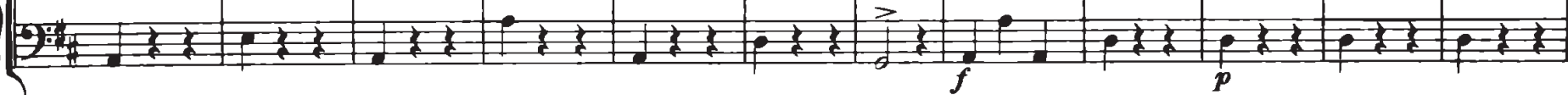




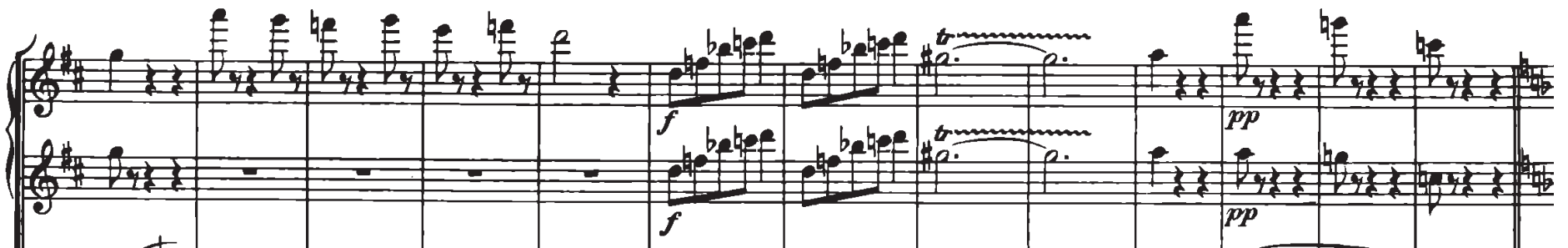
2.

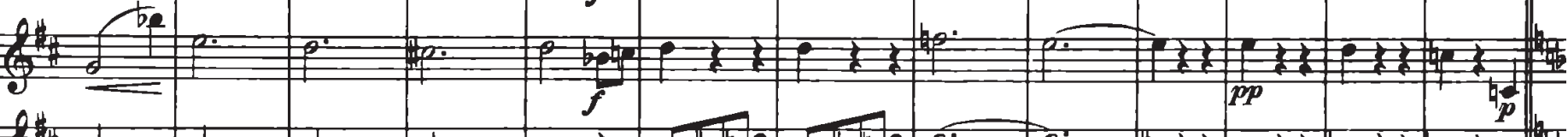

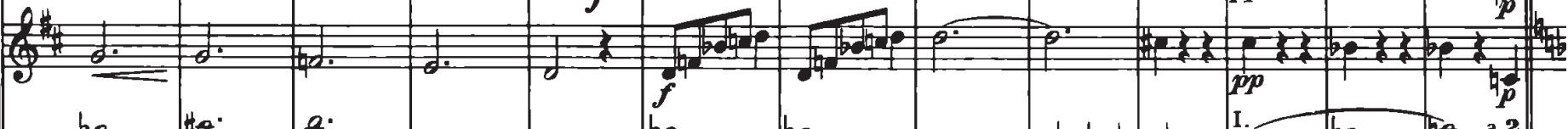
3. be.

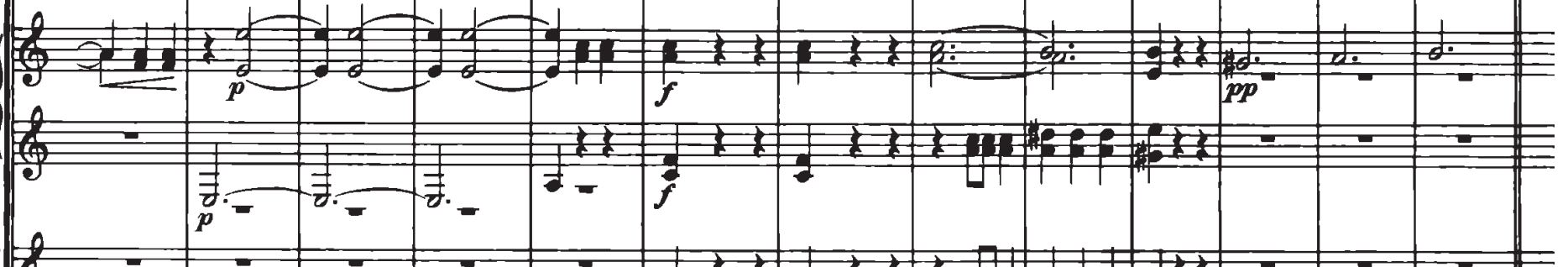

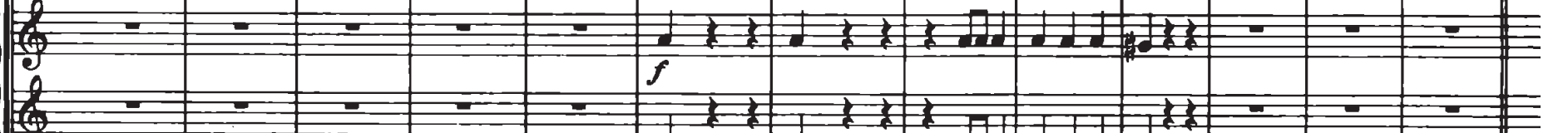

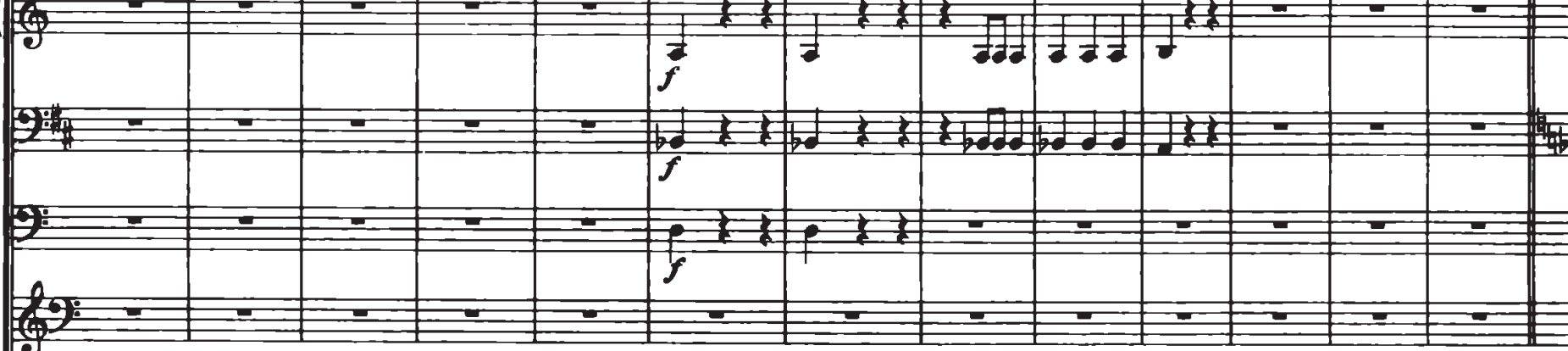

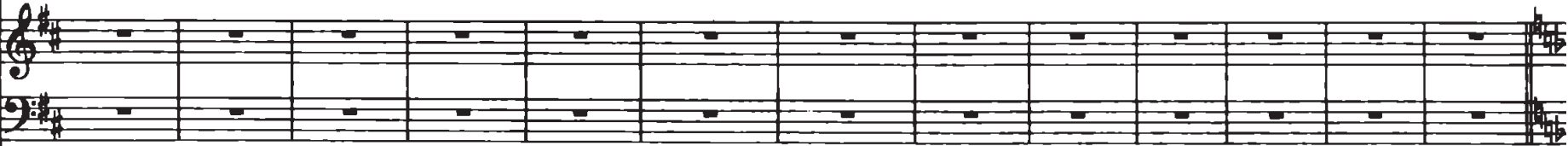

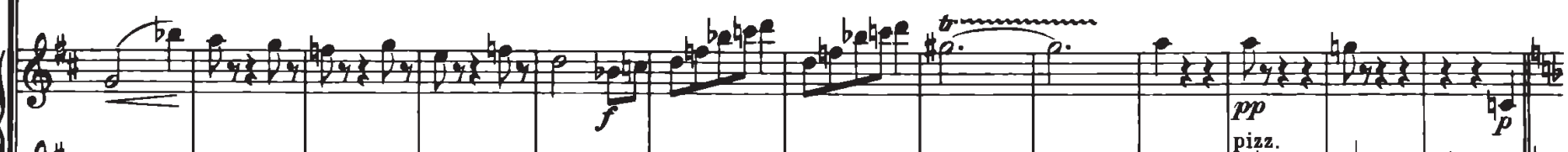

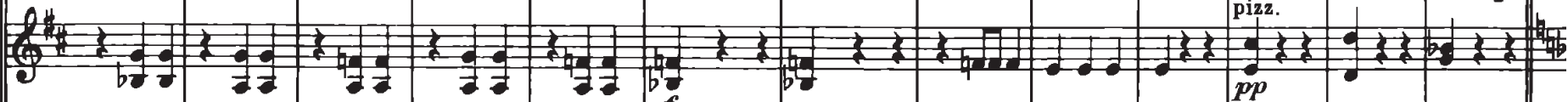
(1)

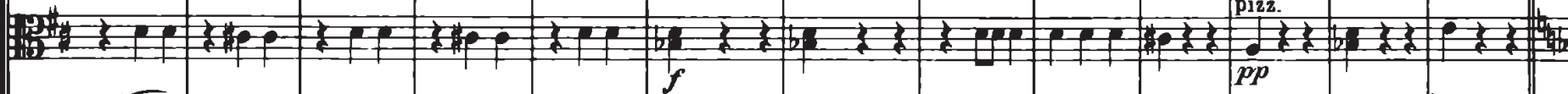

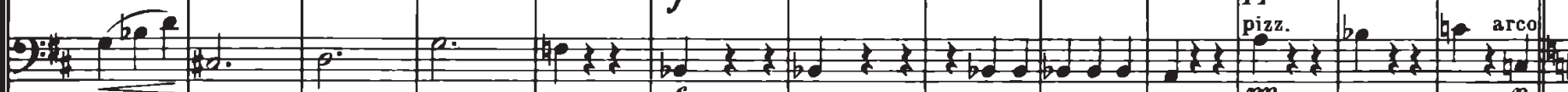

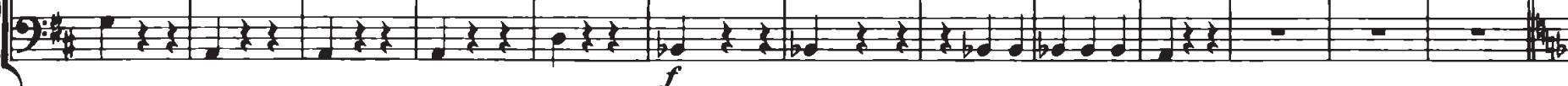




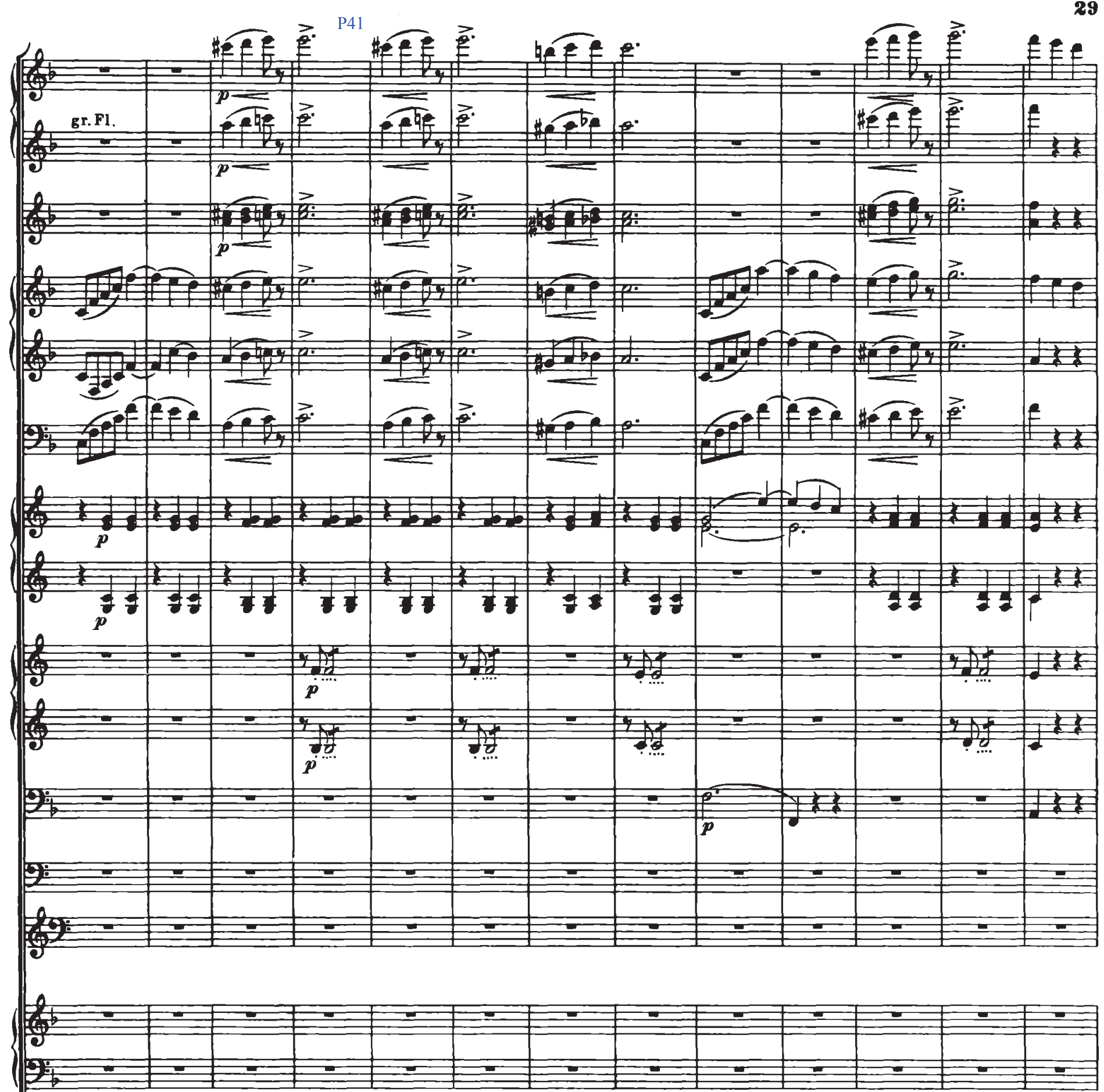

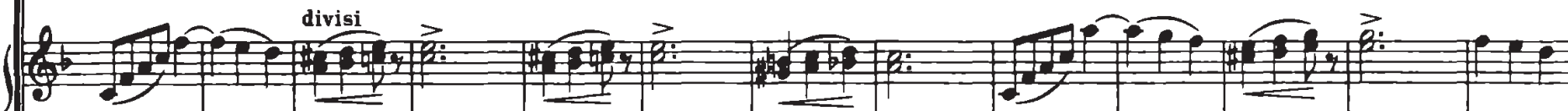

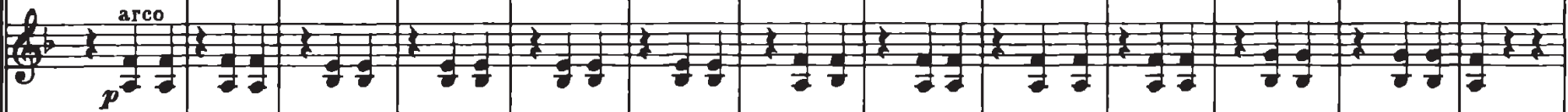

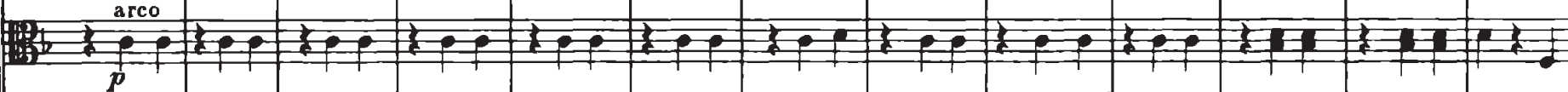

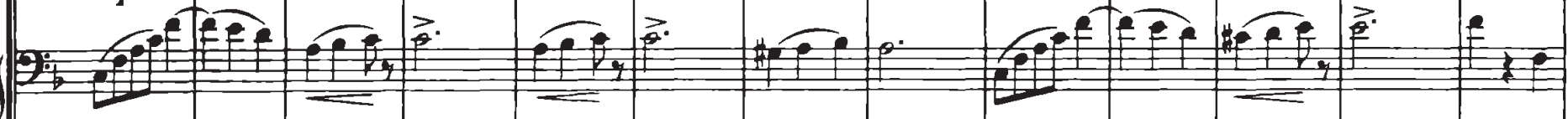

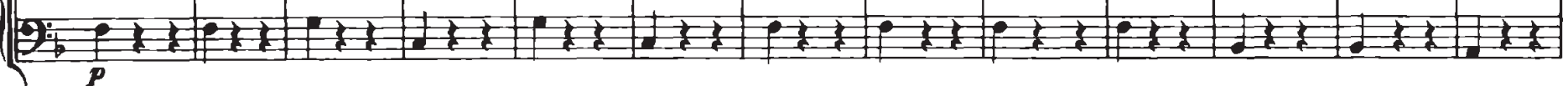



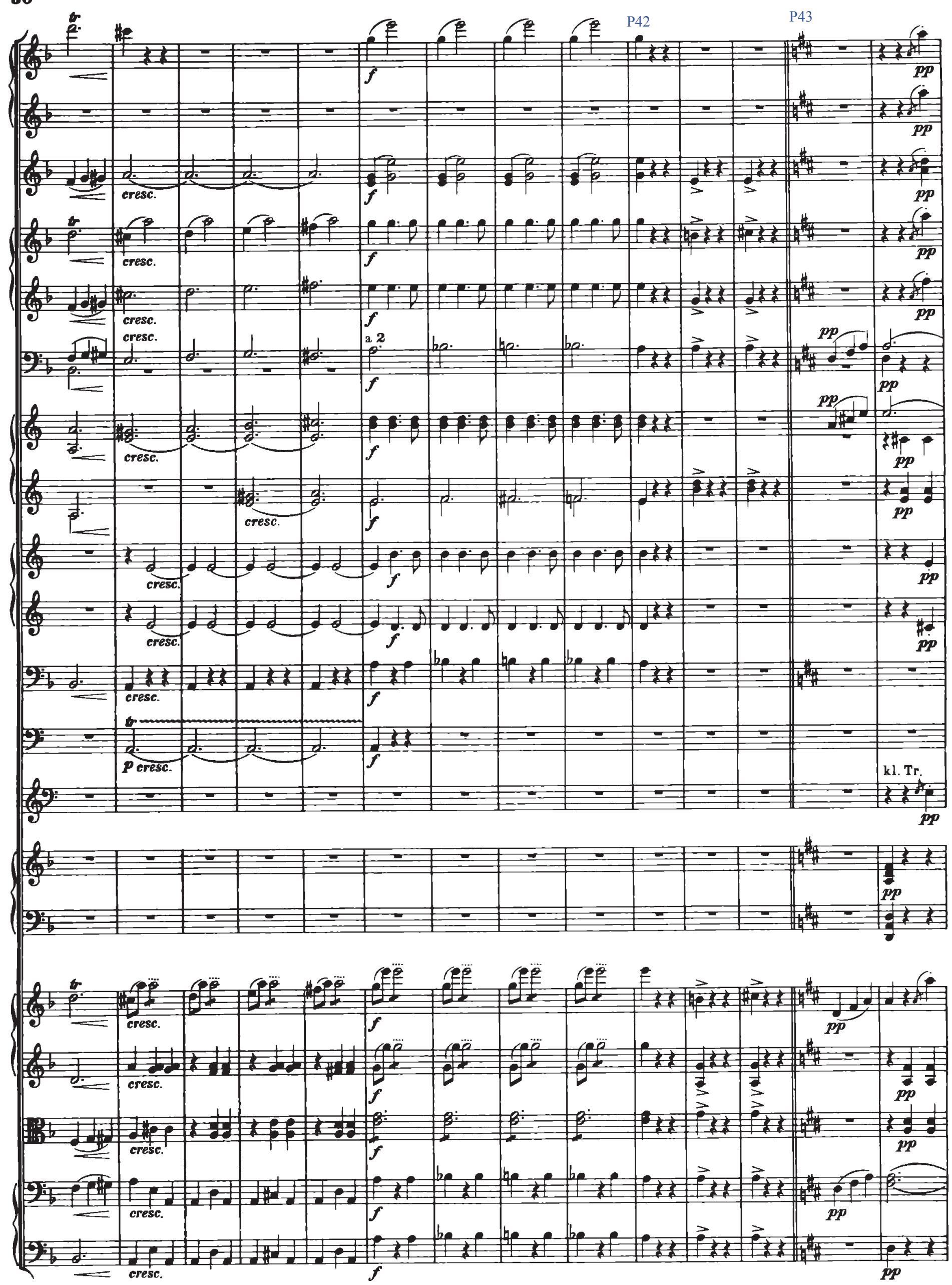


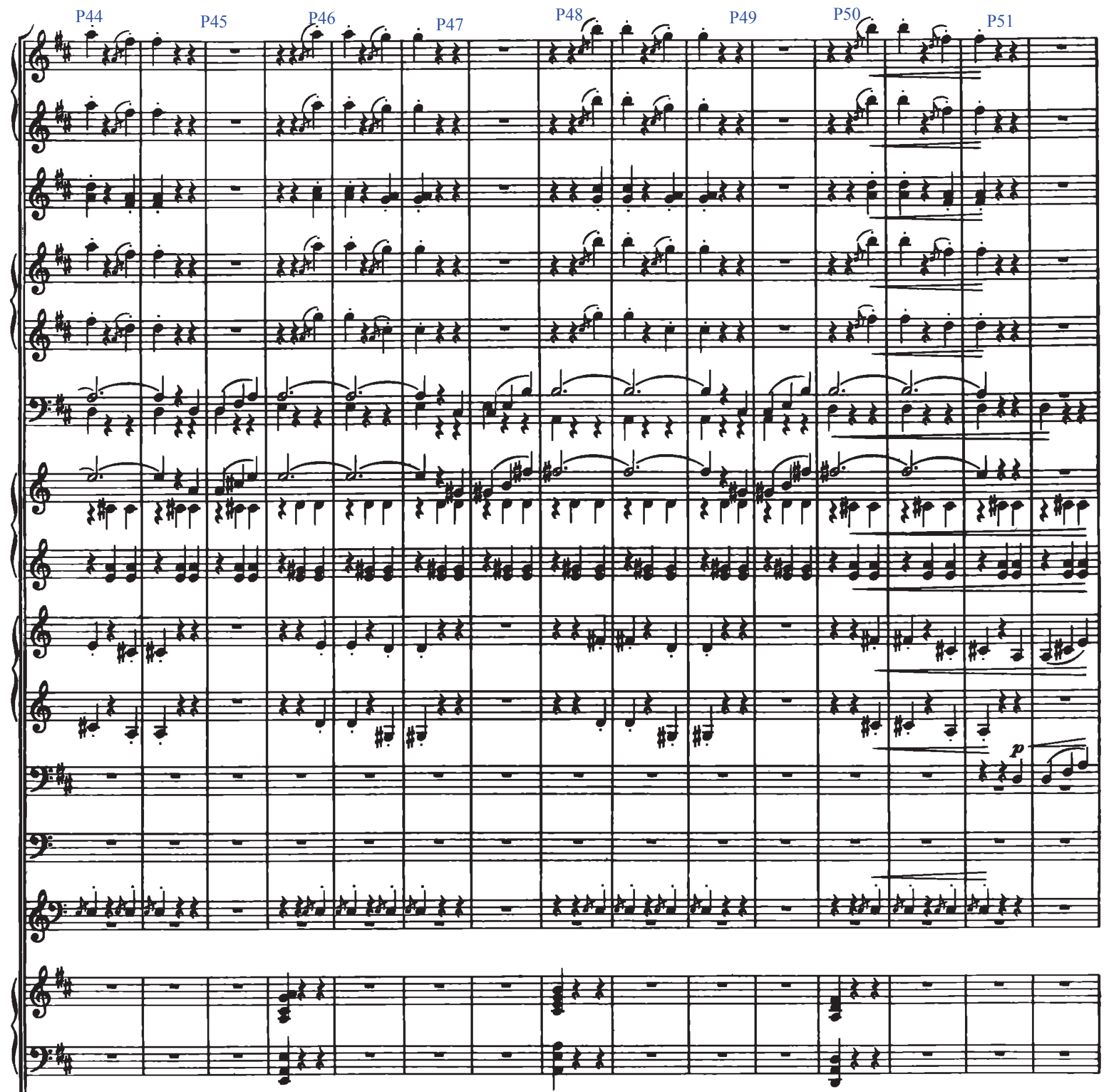

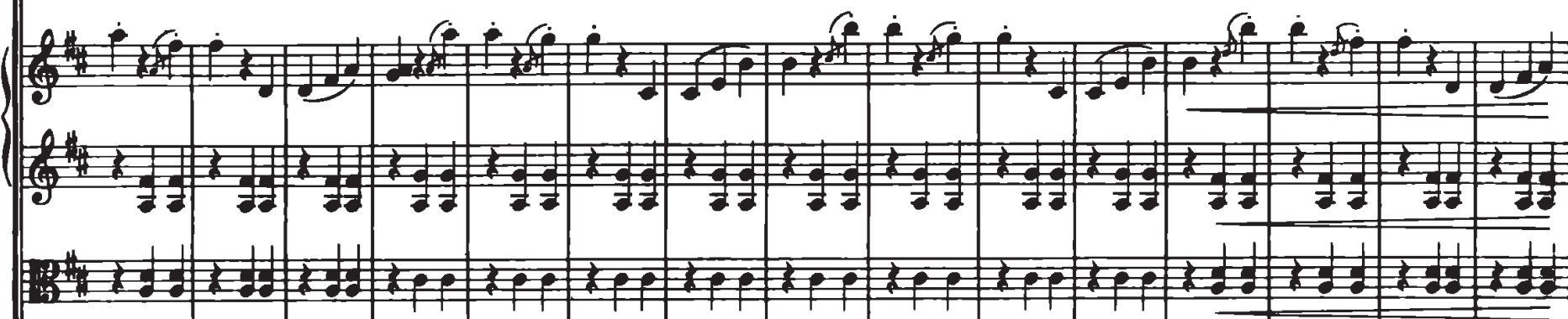
(2) 9 \%

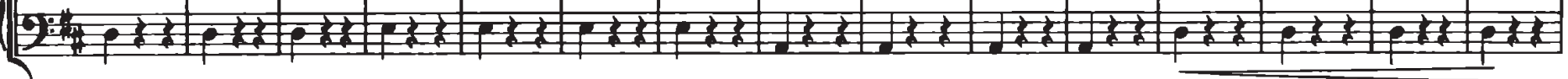


32

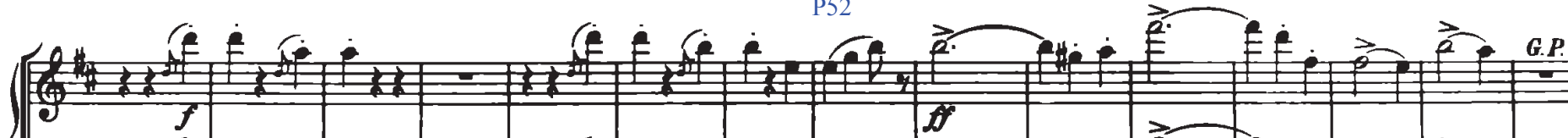

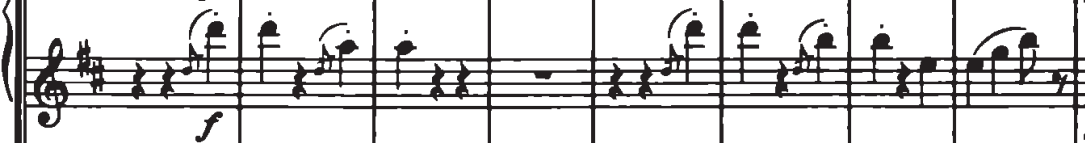

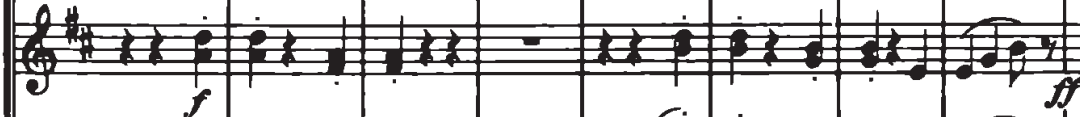

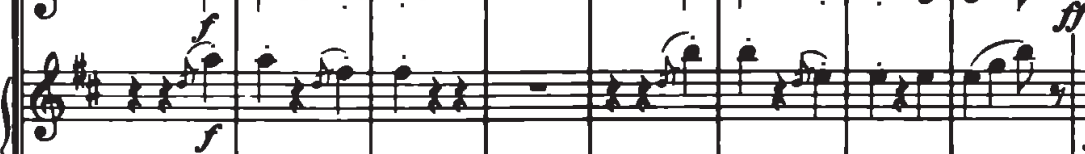

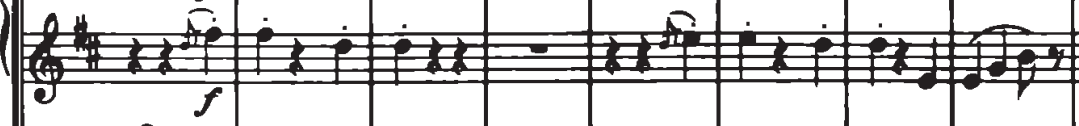

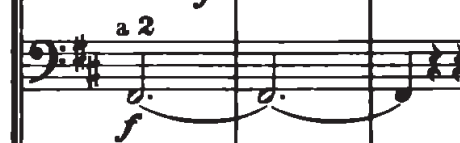

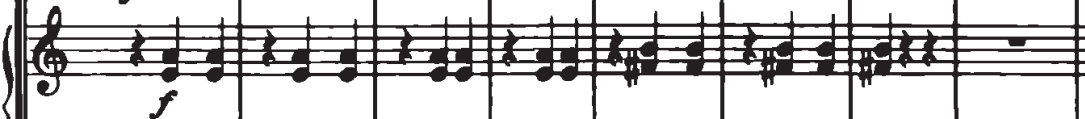

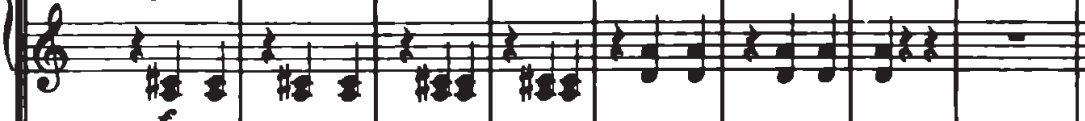

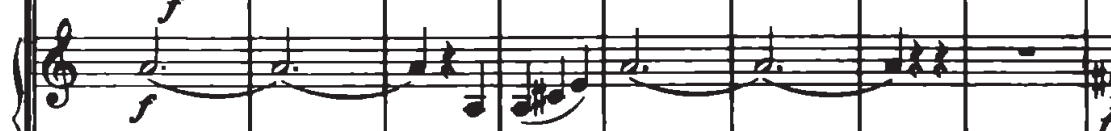

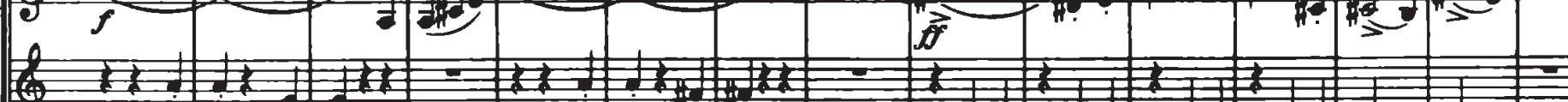
Pos.

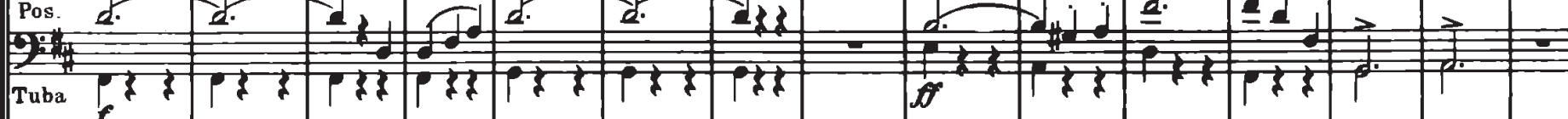

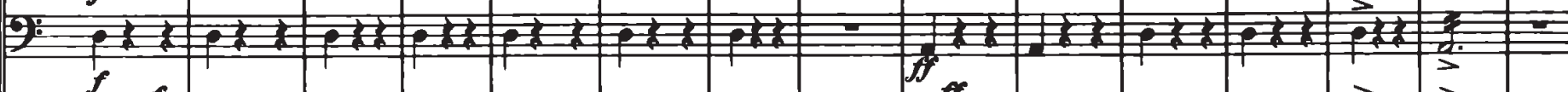

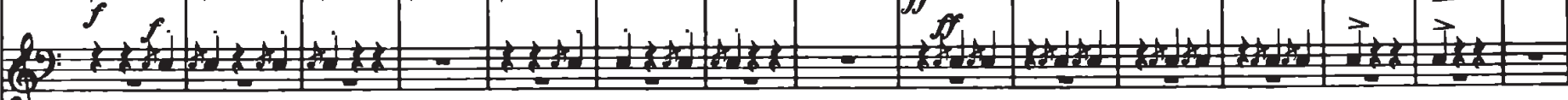
2

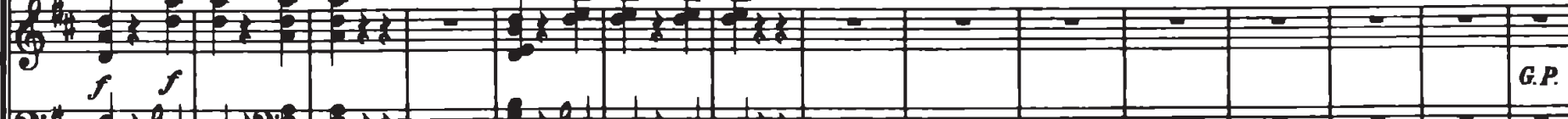

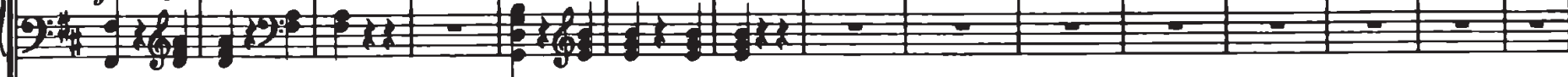

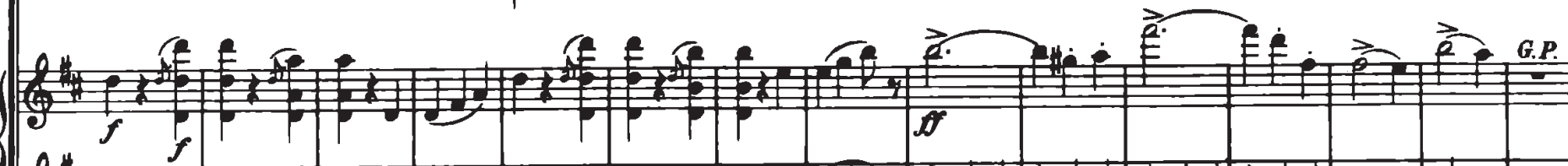

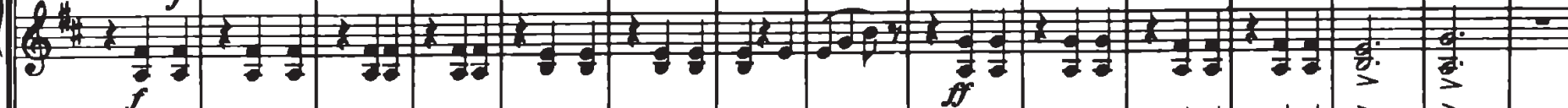

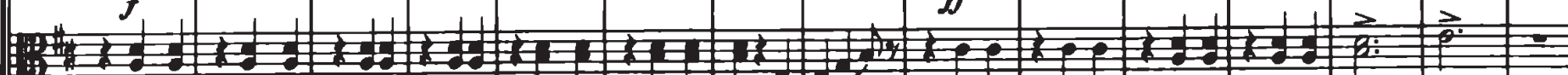

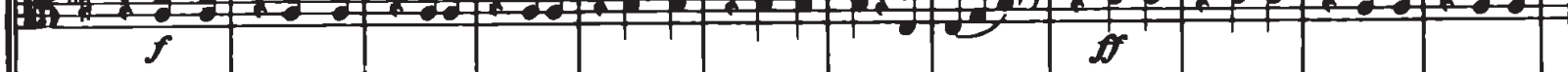

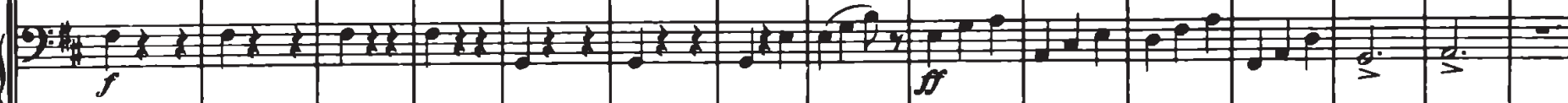
造: 
P53

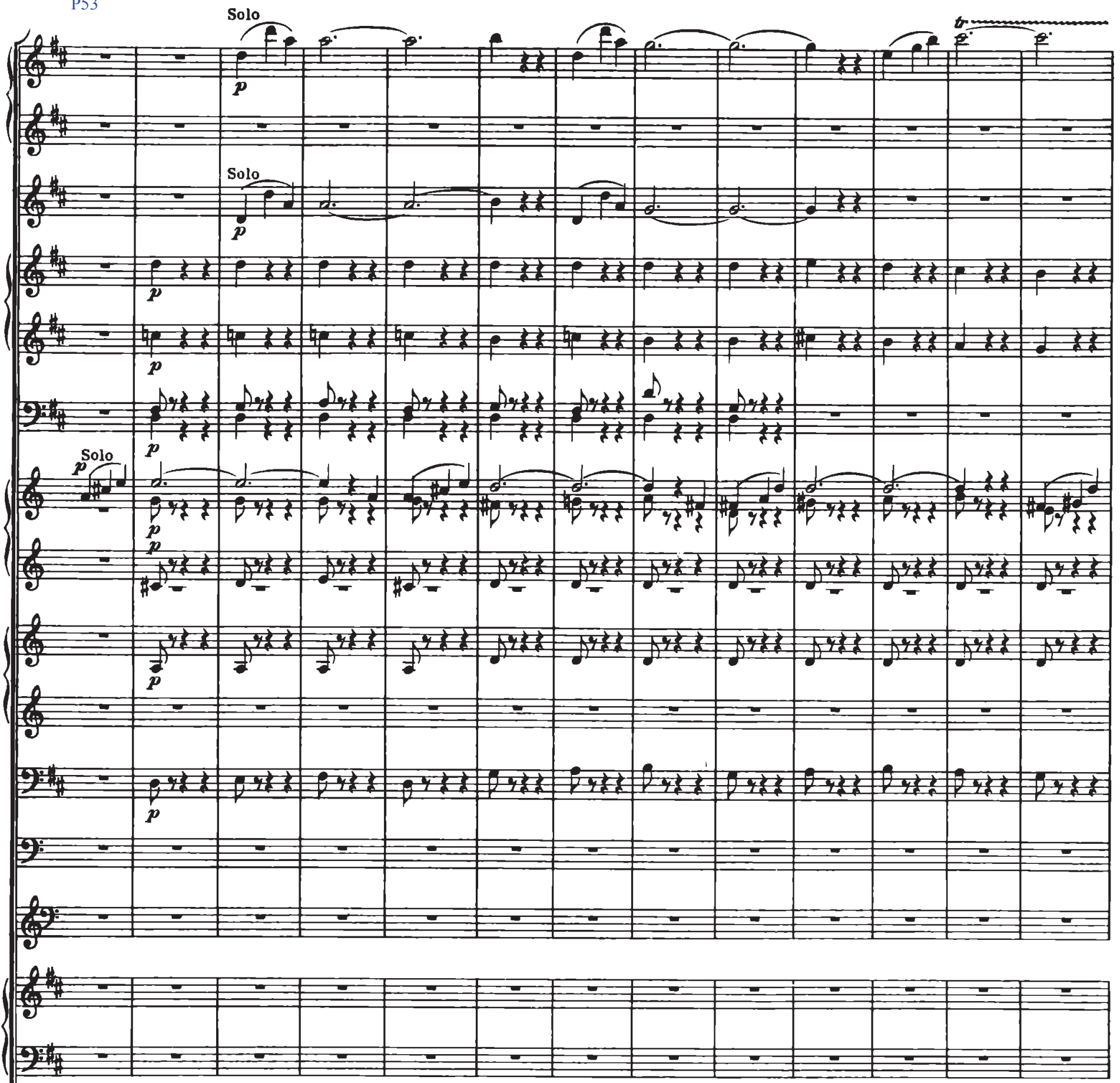

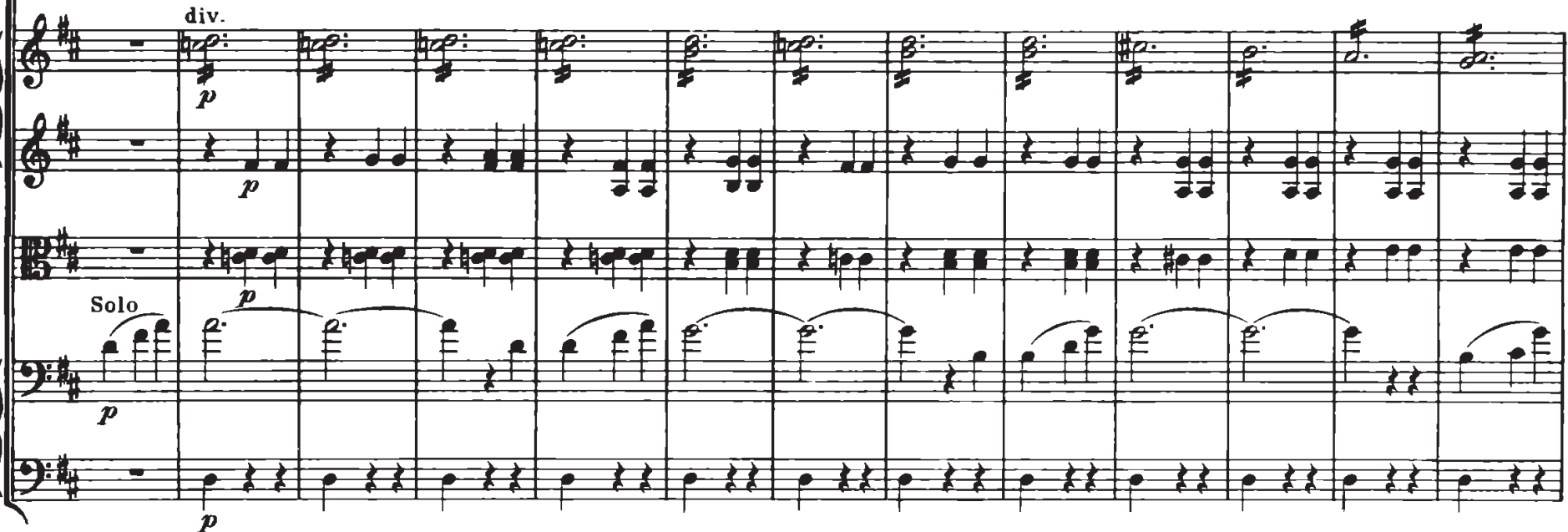



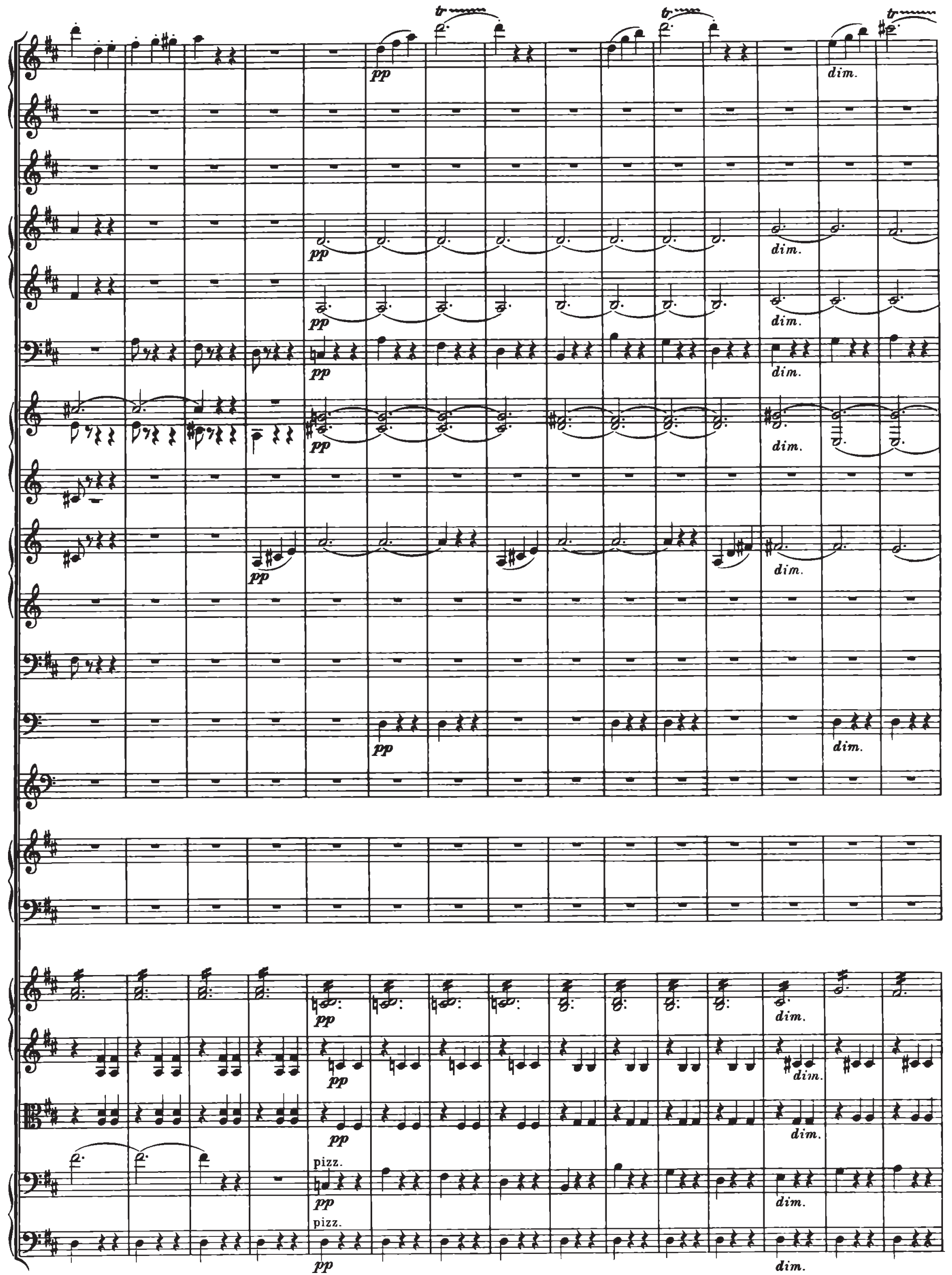


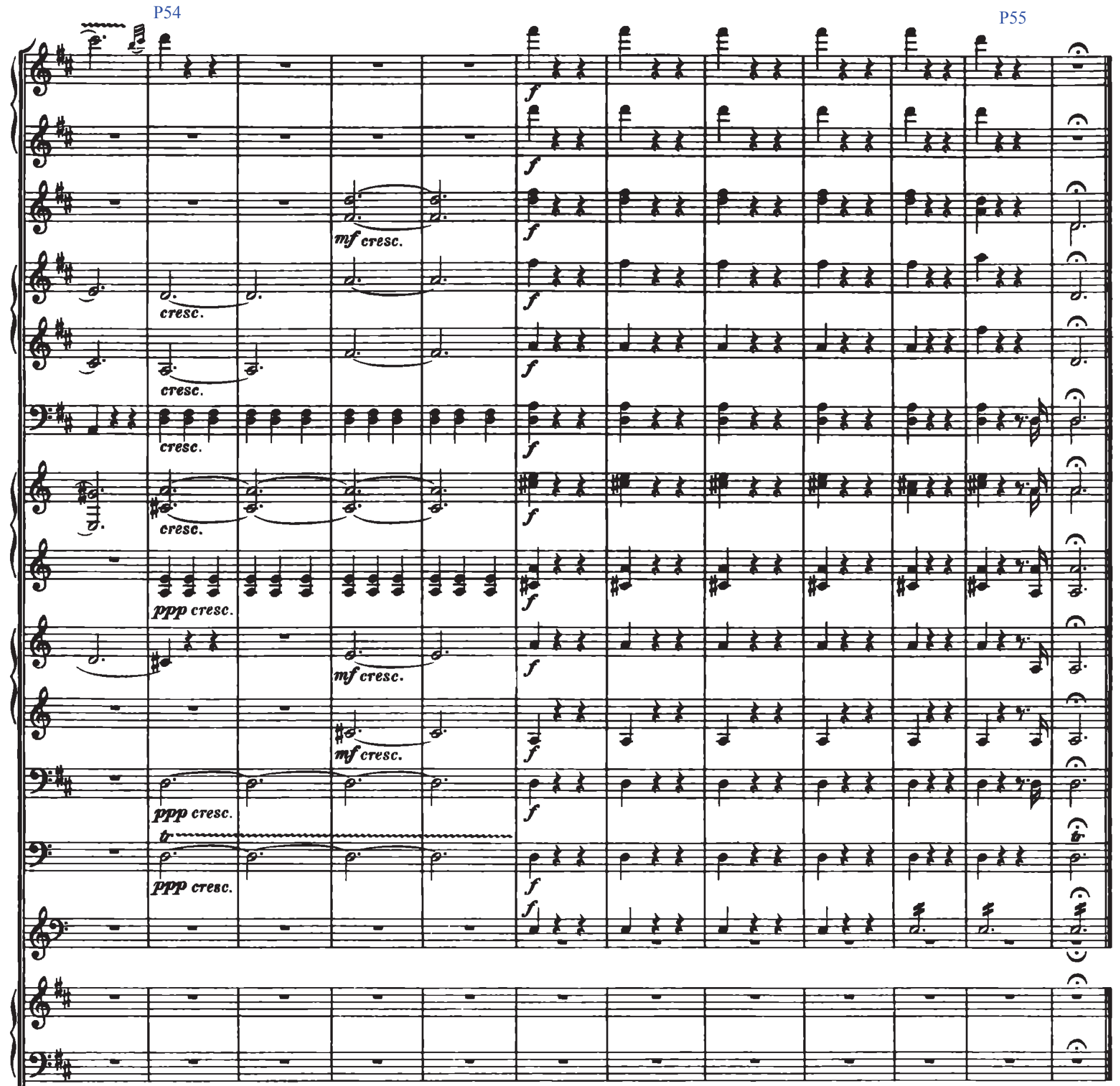

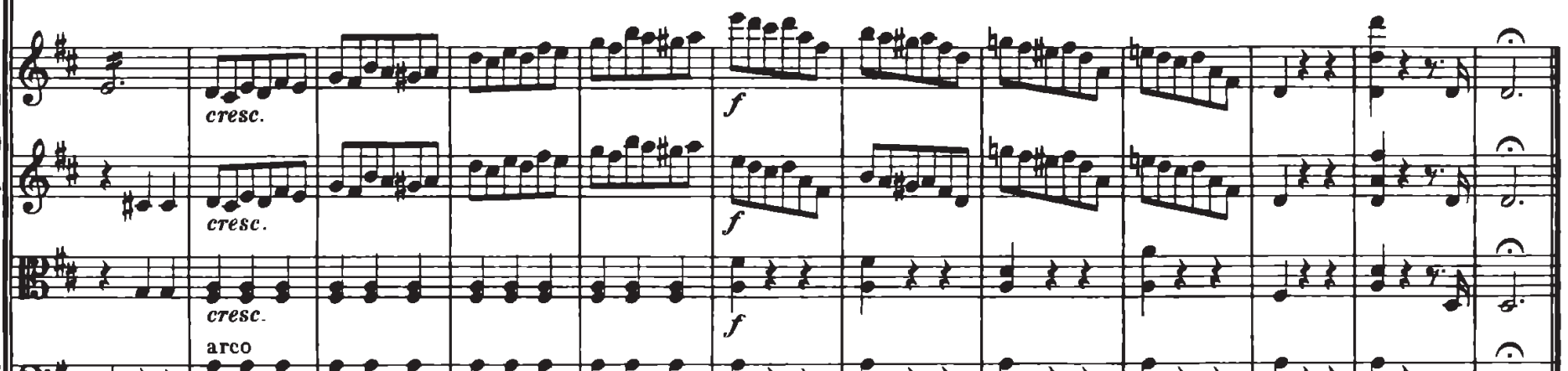

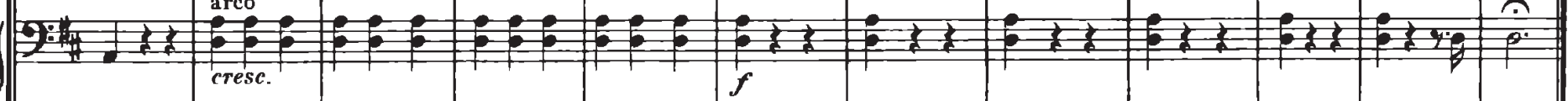

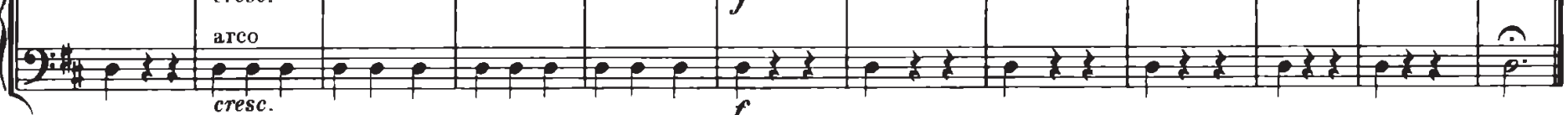


APÉNDICE II: Fuentes orales en directo y en diferido: personas entrevistadas y transcripción de las entrevistas 
De la partitura a la pantalla: plano y contraplano de una misma realidad- 342 


\section{Entrevista a José Nieto}

\section{(9 de Octubre del 2016, Hotel Liceu, Barcelona)}

Marta Millà (MM): Como compositor, no sólo de música incidental, sino también de música Sinfónica, como El castillo interior (2015) entre otras obras, me gustaría preguntarle, a modo genérico, qué esperaría de una obra suya ante la propuesta de ser grabada. De alguna manera, qué le gustaría que recibiera el espectador a través de la pantalla de todo aquello que usted ha dejado escrito en una partitura.

José Nieto (JN): Lo que espero en el caso de una retransmisión, no estamos hablando de un videoclip, no estamos hablando de hacer videoarte a partir de una música sino que entiendo que estás hablando de retransmitir el concierto al espectador que no está allí. Pues, en el fondo, lo que yo esperaría es que fuerais capaces de retransmitir y, efectivamente, trasmitir al espectador lo que el espectador querría haber visto si hubiese estado allí. Es decir, yo creo que la realización, para mí, debe ser un medio para hacer llegar al espectador lo que está pasando, en este caso, en la sala de conciertos y no un fin en sí mismo. Es decir, no voy a hacer arte con la retransmisión. Eso es otra cosa, eso es un trabajo más, digamos, de videoclip que otra cosa pero, en cuanto a la palabra estricta de retransmitir, pues yo lo que esperaría es eso, que el espectador viese lo que él hubiese querido ver si hubiera estado presente. Tengo un ejemplo... hace poco, me compré un blue-ray de un ballet británico Matthew Bourne y tenía una realización buena, excepto que en muchos momentos lo que tú querías ver no estaba. Yo quiero ver si está bailando, quiero ver la figura del bailarín, no quiero que cambie 27 veces de plano y que el protagonista de lo que veo sea la cámara, sea el realizador . El protagonista es el bailarín y quiero ver lo que hace.

MM: También podemos entrar en la parte de videoclip -no videoclip entendido como talpuesto que no sólo quiero investigar el momento de la retransmisión en directo, sino que, si después hay una post-producción, hasta dónde se puede llegar. Que sea una retransmisión, como usted dice, fiel a la partitura o que sea lo que el espectador quiere ver o en qué momento se cruza la frontera ya de videoarte...Así, ¿valora más una realización tipo performance, eso de los 27 cambios de plano que me nombraba, o una realización literal? Usted, en sus composiciones, ¿preferirá un seguimiento literal de la melodía o cree que hay muchos elementos en la partitura para escapar a este seguimiento? 
JN: No...yo no hablo de un seguimiento de la partitura. Es que yo creo que no es la partitura lo que hay que seguir. Yo creo que lo que hay que seguir es la música. Y, con criterio cinematogràfico. ¿A qué me refiero con criterio cinematográfico? Pues alguno de los clips que me has enviado en la encuesta, a mí, ya no como músico sino como cineasta, me llama mucho la atención porque, por ejemplo, encuentro que no hay correspondencia entre el tamaño de la música y el tamaño del plano. Eso es algo que, precisamente ayer estaba enseñando en el Máster del liceu a los compositores y les demostraba ejemplos. Sobre este plano de detalle yo no puedo componer un tutti de orquesta porque se produce una dicotomía grande y eso no es efecivo. Pues muchas veces pasa y en algunas de las cosas que me has enviado hay un tutti de orquesta y estoy vie ndo las manos del violín primero o del violín tercero porque la imagen, de repente, parece muy bonita o parece interesante pero cuando decía "lo que el espectador quiere ver" me refiero a eso, me refiero, echo de menos un tratamiento más cinematográfico del concierto, no tanto musical, sino cinematográfico.Es decir que haya una correspondencia entre tamaños de plano, densidades musicales, naturalmente cuando hay un instrumento protagonista, quiero ver el instrumento protagonista. Cuando el director está haciendo algo interesante quiero ver al director, pero echo de menos siempre el criterio este de cineasta. El ejemplo que te he contado antes, si hay un tutti de orquesta no quiero ver el plano en detalle de las manos del violín tercero...o la cara del violín tercero.

MM: Una vez leído el libro que presentará en el Liceu de Barcelona "José Nieto: un encuentro imprescindible", veo que su background no sólo tiene su origen en la música popular y la radio como elemento mediador, sino que asistía de bien pequeño a los conciertos de música clásica de la ONE. Me gustaría conocer la mirada de una orquesta a través de los ojos de “José Nieto, niño”. ¿Podría recordar qué era lo que le atraía a partir del momento en que el director daba la entrada con la batuta? ¿Cómo miraba la música? ¿Qué mira actualmente en un concierto?

JN: Ya no tan niño... estamos hablando de 14-15 años, estaba en el instituto cuando empecé a ir a los conciertos del Monumental. La orquesta tocaba los viernes por la tarde en el Palacio de la Música y los sábados por la mañana hacía un concierto en el Teatro Monumental de Madrid que es un teatro grande que es ahora la sede de la orquesta de radio y televisión. Entonces, claro que tengo un recuerdo. Tengo un recuerdo visual muy curioso y muy interesante porque yo iba a las entradas más baratas del teatro. Me costaban, me acuerdo, 8 ptas. Y era el último piso. Si no conseguía las tres primeras filas ya no tenía 
visión de toda la orquesta. A partir de la quinta fila no veía el director y empezabas según ibas cada vez menos, cada vez menos. Entonces era un poco angustioso porque afortunadamente casi siempre conseguía más entradas más cercanas pero el hecho de estar presente en un concierto y por ejemplo no ver el director me parecía como que faltaba algo. Entonces ese es un poco el recuerdo que tengo. Yo eso naturalmente lo veía en plano general te puedes imaginar que desde el piso de arriba lo que veías era un plano general de la orquesta claro tú haces de cámara tú dirigías tu atención si en un momento determinado pues había algo especial de trompeta pues mirabas al trompeta, si había algo de timbal, pues mirabas al timbal. Es decir que, tú hacías digamos tu propia selección de lo que veías pero en función de eso de qué era interesante en cada momento.

MM: actualmente, con la formación que tiene usted, cree que hay una distancia entre cómo veía los conciertos sin tanta formación musical o lo mira tal y como ahora le exigiría a un realizador, por ejemplo.

JN: No, no, no, no...cuando yo voy a un concierto es igual que cuando voy al cine en principio trato de ser espectador. Un oyente. ¿Cuándo me salgo de esto? Cuando no me interesa lo que veo o lo que oigo. Entonces, en ese momento, empieza a entrar otro tipo de...

MM: como de análisis...

JN: análisis y entonces empiezas a ver pues esto no está bien, puesto no sé qué...pero si el concierto está bien o la película está bien sencillamente la capacidad de análisis inmediata desaparece y en todo caso es a posteriori cuando analizas lo que has visto, lo que has oído. Pero, no...como oyente lo que sí ha cambiado es la distancia porque ahora puedo entradas mejores y tal...

Es igual, es decir que si realmente hay una intervención importante de la sección de metal, evidentemente la atención te va a la sección de metal pero claro, teniendo en cuenta que el ojo aunque es parecido, el funcionamiento del ojo es parecido al de la cámara o el de la cámara es parecido al del ojo la cámara realmente cuando encuadra, excluye de forma más contundente todo lo demás y el ojo no excluye, tú concentras la atención en la sección de metal o en la percusión o en el concertino y de alguna manera no estás excluyendo el resto de la orquesta. Esa es la diferencia fundamental que claro cuando alguien hace un plano de detalle como te decía antes, del primer violín, está excluyendo todo lo demás. Entonces, si ese plano primero no está justificado pues porque el violinista está haciendo un solo en ese 
momento una intervención importante digamos que ahí es donde se produce unaespecie de cruce extraño entre lo que oyes y lo que ves.

MM: ¿El realizador debe tenir formación musical para poder captar aquello que quiere el compositor o para saber transmitir la partitura a un público quizás ajeno al mundo musical? ¿o piensa que es un simple gestor de imágenes con una estética particular para cada creación?

JN: ¡Qué va...! Absolutamente necesario. Vamos a ver, cuando estabas hablando de la necesidad do no de saber música cuando yo, he trabajado mucho en el ballet, ¿Quién es el que realmente le dice al técnico de luz, cuándo entra un determinado pasaje musical? ¿Cuándo tiene que hacer un cambio de luz?

Pues tiene que hacer un cambio de luz cuando en la partitura toca esto y hace esto. Entonces, el técnico de luz nunca sabe música, pero claro que hay una persona siempre en el ballet y supongo que en la ópera también dónde alguien está siguiendo la partitura y en la partitura es donde están marcados los cambios de luz o los cambios de escenografía. Es decir que, realmente, es imprescindible que haya alguien que sepa música que sea capaz de leer una partitura para que el espectáculo sea posible. Pues, cuánto más, cuando el objeto de del espectáculo es una orquesta que está tocando. ¿Cómo sabes cuándo van a entrar las trompas o los metales?.

Muchas veces se nota que el realizador no sabe y entonces muchas veces dices...¿por qué me está enseñando esto?

MM: yo le llamo un gestor de imágenes...

$\mathbf{J N}$ : un gestor de imágenes pero como sordas. Un gestor de imágenes sordas. Esto aquí, esto aquí, esto aquí....ahora corto, esto me aburre y pongo esto. Realmente lo que está sonando y lo que está viendo no tiene una relación clara.

MM: Totalmente de acuerdo y en cuanto la concepción global de la obra ¿no?

JN: Por supuesto

MM: porque sabiendo música, creo que puedes también, no sólo saber cuándo entra el solo este sino qué color le vas a dar a esa retransmisión, qué ritmo,

JN: Claro, en uno de los clips que me has enviado había un momento que me pareció excelente. No recuerdo en cuál...era uno de ...una sección de metal e iban interviniendo y era 
como un crescendo y efectivamente, la cámara arrancaba de un solo individuo, de las trompas o no recuerdo bien y la cámara iba haciendo un zoom retro, abriendo a medida que la sonoridad...y yo decía: "Esto es, esto es".

Eso no se puede hacer si no sabes música.

\section{MM:}

Me ha gustado el concepto de música implícita. Me parece muy gráfico. Nunca...vaya si lo ha dicho en algún libro más, no lo recordaba.

JN: No

MM: Sí que he leído sobre música diegética, no diegética, todo esto...pero lo de música implícita me ha gustado mucho.

JN: Lo de implícita es un término que yo utilizaba en las clases pero que realmente el que lo ha sistematizado ha sido Vicente Ruiz Antón en este libro y antes en su tesis doctoral que es, precisamente, sobre la música en el documental. El documental como campo de experimentación y ha recogido el tema de la música implícita que curiosamente ahora al venir este año con los alumnos del master pues al repasar el guión de la clase efectivamente he visto que ahí estaba. Música explícita o música implícita.

MM: Yo, por eso lo he relacionado con la realización. Sí puede existir una realización implícita, que creo que es lo que un poco me ha estado contando. Si haces una realización explícita...sales totalmente de lo que es.

JN: el plano corto excluye.

MM: Del mismo modo que, para un ballet, hacer una síntesis de un guión como el de "El corazón de piedra verde", implica "una buena dosis de renuncia", también en la realización audiovisual de un concierto de música clásica nos encontramos con la mirada discriminatoria de un realizador. ¿A qué renunciaría usted en una partitura suya? $\mathrm{O}$, al contrario, ¿qué no dejaría que se perdiera el espectador audiovisual de su música? Puede poner un ejemplo concreto.

JN: Enlazamos con la primera pregunta. Lo que me gustaría es que, puesto que el lenguaje audiovisual es el que es, el lenguaje de la imagen es el que es, pues yo sé que tú no puedes estar mostrando todo el tiempo todo ni puedes retransmitir un concierto en plano general y 
entonces lo que no se trataría de renunciar, en todo caso renunciar a lo superfluo...o a lo secundario, más que a lo superfluo, se supone que en una partitura no debe haber nada superfluo, pero sí a lo secundario. Entonces, pues claro, si hay una melodía de flauta y hay un contrapunto de otro instrumento pues no puedes estar enfocando a los dos...o sí, hay recursos de dividir la pantalla o de sobreimpresiones, etc, etc, pero yo me iría siempre, pediría que estuviéramos viendo exactamente lo que te he dicho antes... si yo estuviera en un concierto a dónde miraría.

MM: Por ejemplo, un ejemplo concreto, en "Castillo interior" qué le gustaría si pudiéramos tener la oportunidad de filmar?

JN: El Castillo interior está pensado como una obra no de concierto tradicional. Yo creo que el concierto. No sé si viene a cuento o no pero me encantará comentarlo contigo... yo creo que el concierto como se ven todavía los conciertos en $99 \%$ de los casos... yo creo que es un espectáculo obsoleto. Yp creo que el ritual del concierto distanciador decimonónico no tiene cabida en este momento y se está probando porque la Edad Media de los asistentes a los conciertos cada vez es más alta.

No estoy hablando de España que ya sabemos el nivel que hay pero yo paso mucho tiempo en Londres voy allí a los conciertos y voy al teatro y el nivel, perdón, la media de edad de la gente que va aver una obra de Shakespeare es mucho más baja que la media de edad que va a oir un concierto de Beethoven o de shost. Y esos es un hecho. Vas y lo ves. Como a mi me gusta y soy curioso pues llegas al auditorio y echas un vistazo y no es que no haya gente joven pero menos. Es decir, el hecho teatral sigue atrayendo a gente joven porque se renueva y el concierto no como contenido sino formalmente el concierto no se renueva y sigue siendo en la mayor parte de los casos una especie de ritual siempre distanciador donde el director no habla el director es como una especie de Dios que sale,q ue saluda...ceremoniosos, es como una especie de ceremonia. Yo creo que eso tene que cambiar. Hay gente que ya está haciendo otro tipo de planteamiento en los conciertos pero yo creo que sino no hacemos nada. Es decir, hace poco estaba en Granada, precisamente cuando estaba en la obra esta de Teresa de Jesús y decían que la media de edad de espectadores para la orquesta de Granada estaba en 60 y tantos años. Entre otras csas porque ahí hay otros problemas no pueden contratar aumentos, eso está pasando en muchos sitios, no pueden contratar solistas, no pueden contratar aumentos y entonces el repertorio que toman es el de la orquesta que se reduce al primer 
Barroco y al período clásico y un poquito de Romanticismo, pero poco y encima pues eso es cada vez menos atractivo. Entonces todo esto, venía a que la suite de Teresa de Jesús, está pensada como un concierto teatralizado que yo creo que es lo que hay que hacer, hay que empezar a teatralizar el concierto. No a poner bailarines en el concierto y a poner lucecitas pero sí a teatralizar un poco. ¿En qué sentido? Pues, lo de Teresa de Jesús fue muy sencillo. A parte de que hay un narrador, en este caso una narradora no es un narrador sino es personaje. Entonces, alguien que dice, recita textos de Teesa de Jesús. Pero desde el principio eso está pensado que esa actriz, es una actriz que habla, no tiene porqué cantar y está pensado que tiene que estar aquí que tiene que haber un foco, que la orquesta tiene que tener atriles de ópera para poder oscurecer la orquesta, para poder...el día del estreno fue muy sencillo, además lo hicimos en media hora con las luces que había en el teatro, un ciclorama blanco detrás de la orquesta y unas luces azules, rojas, blancas frías y luz cálida...es decir 3 o 4 tonos de luz que había indicaciones... es decir, en este movimiento el fondo es rojo, en este movimiento. No sé qué...cuando está la actriz foco a la actriz, naturalmente el director siempre. Si no está la actirz la orquesta tiene otro protagonismo...es decir, teatralizar un poco el concierto que se podría hacer incluso en el caso de que no haya una actriz o de que no haya...por ejemplo, el cello solista, el solista se sienta en una silla, cuando le toca se pone de pie y está todo iluminado y entonces todo eso es una distracción. El hecho de que el solista que está sentado, cuando hay 4 no te digo nada, se ponga de pie, abra el papel y todo esto, eso distrae la atención, no es teatral. Porqué el solista no está en la oscuridad y se enciende una luz cuando va actuar? A eso me refiero, es decir, darle ese giro al concierto y bueno, como me has hablado de Teresa de Jesús, pues así estaba planteada Teresa de Jesús. Hace muchos años, muchos, muchos años....vi en Los Ángeles un concierto, fui a un concierto donde había un oratorio de Stravinsky y ahí estaba ya esto que te estoy diciendo y hace muchos, muchos años...el coro no estaba vestido desmoking ni las señoras estaban vestidas...estaban con gabardinas, perfectamente escogidas de una gama de colores, todas diferentes pero todas entonadas, había un narrador que era un actor conocido de allí, ahora mismo no me acuerdo, pero uno de los grandes actores conocidos de allí y el escenario era un escenario de teatro; es decir, que yp creo que el concierto tiene que empezar a ir por ahí, que de alguna manera, muchos realizadores es lo que buscais cuando retransmitís. Es decir, buscar que aquello no sea una cosa tan fría, tan distanciadora, y yo creo que el problema no está en que lo retransmitáis de una manera o de otra sino que lo que hay allí para enseñar no es bonito. En el siglo XXI, el mundo de la imagen.... 
MM: ...hay que buscarse la vida para hacer atrayente lo que ya es decimonónico.

JN: absolutamente... ha permanecido... si lo piensas, el ritual del concierto...

MM: totalmente, no sé si ha leído el libro de James Rhodes, Instrumental, bueno está superbién, yp era un poco reacia por ciertos temas y así, digo no sé cómo será, pero es que hace un retrato de lo que es un concierto que es que está muy bien y habla en una parte también de lo que es la retransmisión, los programas de televisión y beno es que lo retrata superbién, los directores, las salas de concierto...la verdad es que estça obsoleto.

JN: absolutamente

MM: entonces claro, buscar la fórmula de realización para que esto se haga atrayente en televisión con la cantidad de programas que hay hoy en día que bueno, las audienias son las que son...es muy difícil, ¿no?

JN: luego, dices, las salas de concierto. Hay salas y salas. Por ejemplo el Monumental de Madrid a mi me parece un sitio imposible porque no he visto nunca un sitio tan frío de aspecto para asistir a un concierto. Lo comparas con el Barbican de Londres y dices, hombre es verdad que el ritual es el mismo pero la luz es otra. Por ejemplo, la madera del auditorio es madera cálida, madera un poco más oscura, con calidez. La luz es luz así...pero es un poco tamizada, un poco cálida, hay otras salas como esta...madera clara, luz ni cálida ni nada, luz.

MM: totalmente plana ¿no?

JN: totalmente plano y entonces pues ahí todavía...incluso cuando estamos diciendo que decimonónico, yo supongo que en el XIX era desde el punto de vista de la luz era más interesante un concierto, que no podías poner focos.

MM: Cuando estuve en Berlín, es que me ha gustado mucho esto que ha salido aquí...establecí relación con el director de allá y se portaron muy bien, me enseñaron todo y él me pidió que...bueno, Barcelona resulta atrayente, le gustaría ver el Palau de la Música o l'Auditori...yo die, bueno cuando hagamos uno yo te lo diré y si quieres, puedes venir. Lo pedí en TV3, me dijeron que ningún problema y él vino. Entonces él cuando estuvo viendo la retransmisiónme encantó porquehabló de la fluidezque él le llamaba flow, porque estaba ya viendo como hacíamos el trabajo nuestro equipo y decía,luego me lo dijo a mí aparte, los cámaras trabajan superbién, todo el mundo trabaja superben, pero la crítica que hago es que no existe esta fluidez, el pulso...que no es una sincronía exacta que es lo que a mi me 
gustaría investigar por ahí: el cómo conseguir esta pulsación a través de la imagen. Porque él me decía, entras y sales continuamente y no hay esta fluidez que entras en el vídeo, en la visualización de plano tras plano y te quedas ahí, sino que lo que me ha pasado es que no existe esta fluidez. Me gustó mucho lo que me dijo porque yo ahora cuando trabajo en algún concierto con algún compañero pienso cómo conseguir esa fluidez en esa partitura, cómo seguir el pulso de la música con la imagen?

JN: Pues fíjate, es curioso porque una de las cosas que insisto mucho con los compositores pero no solamente con los compositores yo doy clase también en la escuela de cine, por ejemplo, en noviembre yo vengo a un máster de montaje y lo que más insisto con ellos es en que el montaje tiene que tener pulso musical, el montaje tiene que respirar musicalmente y que tiene que haber cómo se consigue eso? Pues con una relación entre el movimiento que hay en la imagen que estás tomando o que hay en la película, en el caso de la película es la que está, la relación entre el movimiento que hay en el plano y el corte del plano. Cuando la relación entre el moviento y el corte tiene musicalidad entonces el montaje respira y el montaje fluye y les pomgo unos ejemplos muy sorprendentes de montajes hechos de esta manera a los cuales tú lo ves, captas cuál es el pulso del montaje y resulta que tú le añades una música que no está pensada para eso pero que tiene ese pulso y sorprendentemente funciona. Entonces, yo creo que cuando retransmitís es al revés, hacer eso pero en directo. Es decir ¿Cuál es el pulso de la música? Pues ahora los cambios, cortes de plano y cómo paso de esto a esto tiene que tener respiración musical. Entonces, por ejemplo, si estás en un adagio, cuidado con los planos por corte; porque los planos por corte te van a dar algo que no está en el espíritu de la música. Por ejemplo, no coincidir un cambio de plano sincrónico con un ataque de orquesta porque eso le da dureza. Entonces, la fluidez viene precisamente en que la música no esté matemáticamente sincronizada, que no se perciba la sincronía- Tiene que estar, yo prefiero utilizar en clase el término articulada. Entonces, el grado de articulación puede ser sincronía dura, cuando quieres retransmitir algo con sensación de violencia y cuando no, la sincronía tiene que no ser perceptible. El espectador no se tiene que dar cuenta que estás siguiendo...

MM: que estás siguiendo frase A, frase B...

JN: claro, por ejemplo muchas veces...ya sabes cuando se trabaja para cine se mide exactamente el fragmento musical aquí pasa esto aquí lo otro y tú compones una música, al cambio de este plano pasa esto, al cambio de este plano pasa esto...cuando no es una 
secuencia de acción, cuando no buscas una sincronía realmente dura, evidente y violenta, siempre llegábamos con el bloque, en principio lo montas donde estaba previsto y ves que todo va bien. Entonces, lo normal era decirle al montador: bien, pues ahora retrasa toda la música cuatro fotogramas...desplazas música, todavía aguanta tres fotogramas más, dos fotogramas más y al final de donde estaba prevista la música desde el punto de vista matemático retrasas la música con respecto la imagen seis fotogramas, siete fotogramas y cambia absolutamente; es decir, la música sigue estando articulada, pero la articulación ya no es perceptible, ya no es visible. Eso es fluir, eso es el fluido.

MM: no...me ha encantado porque la coincidencia en música articulada y la música en retransmisión me ha recordado....al revés...

JN: es lo que hacéis en directo, cuando es retransmisión en directo y si estais en postproducción estáis haciendo lo mismo. No poniendo una música en la imagen, sino poniendo una imagen en la música. El criterio sería el mismo. ¿Dónde corto el plano? ¿Dónde pongo este plano? Y sobre todo ¿cómo lo pongo? Lo pongo exactamente cuando ataca pues, en ciertas obras sí, pero en ciertas obras no. Lo tendré que poner un poquito antes, lo tendré que poner un poquito después, no cortaré en un plano...es decir, muchas veces no quiere decir que ir por encadenado, si tú haces un encadenado de 12 fotogramas es como si fuera corte pero suave. Es decir, jugar con esas sutilezas. No es o corte o encadenado...encadenado, ¿de cuánto? Encadenado de 48 fotogramas no es igual que un encadenado de 24 . Incluso un encadenado de 24 , de un segundo equivale a que prácticamente no se percibe que hay un encadenado pero no está la dureza del corte. Fíjate que estamos hablando de criterios cinematográficos.

MM: totalmente

JN: de montaje, de montador

MM: y por último, también me ha encantado lo de la percepción ¿no? Que cuando define música aplicada dice que es aquella que tiene que ser analizada fundamentalmente desde el punto de vista de la percepción, no?

JN: claro. Qué produce la música

MM: qué efecto producen el oyente...aquí me parece que se ha parado demasiado allá la entrevista, porque me parecía muy interesante y enseguida Vicente ha ido hacia otros 
derroteros y me gustaría más profundizar porque llevado a la visualización en conciertos cómo conseguir la percepción pretendida por el compositor

JN: pues realmente, mediante todas estas cosas que estamos hablando. Por ejemplo antes has mencionado así como de "pasadilla" el tema del color. Claro, eso es lo que me ha llevado a mí a hablarte de la teatralización del concierto porque...qué vas a hacer con el color, el color es el que hay, la luz es la que hay. Entonces, incluso, ahora no tanto pero yo recuerdo que en las primeras transmisiones de conciertos o de obras de teatro, lo primero que hacía el equipo de tv era iijuah!!! Soltar unos chorros de luz porque las cámaras...

MM: Bueno, ahí tuvimos un problema nosotros con un director que vino al Palau de la Música hace unos años....no grabábamos eh? Por la luz que poníamos la tv; dijo que no grababa y no grababa...y los músicos no podían ni leer la partitura y él decía que con esa luz no grababa y tuvimos...

JN: claro, claro...pero además, la luz que echaban entonces, más bien recuerdo de obras de teatro en las que yo intervine. De repente decía, viene tv a grabar. Bueno colocaban unos focos de aquellos, unos sirios...toda la escenografía aplastada, y entonces, verdaderamente era peor cuando realmente de lo que estamos hablando es de retransmitir un poco teatralizando y el teatro es fundamentalmente juego de luz y entonces claro lo que pasa es que si no está, no está...qué le vas a hacer. Claro, el tema del color, como decíamos, pues sería importante ¡qué obra estoy tocando? Estoy tocando una obra del siglo XX, de los 90, de estos que son especulación intelectual, Xenakis...o estoy transmitiendo Brahms? El color que me da, pues no es lo mismo, porque además hay una relación entre el color visual y el color musical. Eso es una cosa que enseño yo ahí todos los días. A ver...nosotros muchas veces decimos, el color de la orquesta...y el color de la orquesta nos estamos refiriendo al timbre de la orquesta. Y podemos hablar de brillo, mate, es oscuro, es claroy todas estas referencias que hacemos a la música son referencias que hacemos también al color. Entonces el tratar de buscar esas relaciones, evidentemente, ayuda a transmitir lo que eestá no tanto en la partitura sino en la música que suena.

MM: Pues nada, ya estaríamos porque luego comentar, bueno en el libro salen muchas cosas que a mí me han pasado también como montadora musical ...me parece tremendo eso de haber dado música compuesta por usted y que el montador musical no se lo haya escuchado todo para ponerlo , me parece increíble, y bueno estas cosas pasan... 
JN: sí, eso fue...no era exactamente montador musical eran los montadores de imagen...

MM: iiiahhh, de acuerdo!!! Pensaba que era el montador musical que tenía que poner su música que le había dado y luego tenía....vale, vale

JN: no...no...era un documental con muchísimos capítulos que se llamaba El arca de Noé...

(Dejamos por unos momentos la grabación puesto que la conversación deriva hacia lo que es propiamente la ambientación musical. Sin embargo, la tenemos que reemprender puesto que surgen temas interesantes para la filmación del concierto)

JN: La visión un poco del músico o del profesional que a través de la televisión tiene la posibilidad de ver cómo toca un maestro. Ver cómo toca un gran solista o un gran instrumentista $\mathrm{y}$, entonces, la frustración que supone ese punto de vista que tienes la oportunidad de ver a un maestro tocando y el realizador no te deja verlo. Una vez por lo que decíamos antes, porque él se convierte en el protagonista y no te deja ver lo que hace el verdadero protagonista que es el que está tocando. Entonces, has querido grabar porque decía yo que cuando empezaba yo, que estaba estudiando la batería... además era una éoca en que en España no se encontraban discos de jazz, no había conciertos de jazz...la única forma era pues si pasaba por aquí alguien y actuaba en televisión y te lo retransmitían...entonces, la frustración tremenda de que dices: "Hombre, va a tocar fulanito, ha pasado por aquí y va a salir en televisión y te ponías a verlo...era frustrante no poder ver lo que estaba haciendo por lo que te decía al principio. Quiero ver lo que hace el bailarín.

MM: claro...yo aquí, en el Liceu he grabado ballets y una de las personas me dijo, por favor no hagáis como otras veces que es que no se ven los pies del bailarín.

JN: Claro, claro..

MM: y entonces es que dices si estamos viendo un vídeo de ballet y no vemos los pies, o la expresión de los brazos...

JN: y volvemos otra vez a criterios cinematográficos. Si yo no enseño de entrada por ejemplo, cómo está colocado el ballet, me voy directamente a planos cortos, planos de aquí, planos de allí, llega un momento que pierdo la perspectiva del ballet. Por ejemplo, a mí, el 
ballet, prefiero verlo desde el piso de arriba que desde el piso de abajo. ¿Por qué? Pues porque desde el piso de arriba tengo la perspectiva, el plano general de arriba donde me da la posición, la coreografía, cosa que desde abajo, sobre todo desde muy cerca, todo eso se pierde. Con eso te explico todo. Estos vídeos que te hablaba antes, arranca una pieza dentro del ballet y ni siquiera te das cuenta cómo evolucionan porque estamos todos en plano medio, plano corto, plano de detalle, primeros planos y dices, no es eso lo que yo miraría

MM: como me dijo Robert...aquí sí que se ve la flauta, pero estos planos que se ven los morros del músico y un trocito así de instrumento que él lo encuentra horrible. Y me dijo..."yo no lo entiendo".

JN: lo que te decía del violín. Es que en algunos de los clips que me has mandado está un tutti de orquesta y ni siquiera es un plano del violinista tocando sino un plano cortísimo con el puente, las manos, el arco...

MM: Sí, sí...totalmente de acuerdo.

JN: esto no tiene sentido (plano corto de contrabajo) si no va a algún lado.

Por cierto...volviendo a lo que decías tu de saber o no saber música, yo tengo alguna grabación de conciertos dirigidos por mí y cuando no se sabe música...hombre, el ataque de una cuerda a la hora de montar, más o menos todo el mundo lo pone, pero el gesto del director, no. Y es molestísimo, extraordinariamente molesto ver que el gesto del director no está realmente donde tiene que estar. ¿Que no lo capta más que un profesional? Pues sí o no...pero en cualquier caso, un concierto, la retransmisión de un concierto es un testimonio y no puede quedar un testimonio en el que el director realmente está marcando un poco antes un poco después de lo que suena, no corresponde exactamente al sitio, entonces, buscar la sincronía del plano del director es, si no sabes música, si no sabes realmente lo que está haciendo...

MM: no...y yo pienso que, además del testimonio, ¿qué más da que la gente no lo sepa? Hay que enseñárselo...

$\mathbf{J N}$ : no..pero es un testimonio, es un documento...entonces, yo, hay alguno en que veo ahora y no está en su sitio el plano del director no está en su sitio. Hay un concierto que por otra parte sonó muy bien, un concierto con la Joven Orquesta de Madrid que era excelente...ese 
año la orquesta era excelente y los planos del director a mí me ponen de los nervios porque no están en su sitio y eso es porque el que está detrás...no sabe...

MM: entonces....ahora se me ha ocurrido...del Concierto de Año Nuevo, ¿qué me diría?

JN: Eso es otra cosa porque eso ya se ha convertido en un espectáculo en donde...

MM: pero tiene los elementos que usted me está diciendo, ¿no? Saben lo que están haciendo...evidentemente.

JN: saben lo que están haciendo porque ya el planteamiento del concierto es otro. Desde el momento en que te sales de la sala de conciertos porque hay un ballet, el planteamiento de ese concierto ya no es la retransmisión de un concierto. Es un concierto más otras cosas y entonces se acepta que el espectador que está en la sala ve una cosa y el espectador del mundo que ve eso, está viendo otra $\mathrm{y}$, entonces, estamos jugando con otros elementos, con otras cosas y el planteamiento es diferente, ya no es la retransmisión de un concierto normal, dónde se trata de retransmitir lo que pasa. No retransmites lo que pasa, retransmites parte de lo que pasa y parte de cosas que no pasan o que pasan en otro lado

MM: Pero a pesar de mucha gente, por ejemplo, compañeros míos dicen que es lo típico, que es lo tradicional y tal, no deja de ser cuestionable su calidad y su manera de hacer...

JN: es que hay una confusión...

MM: lo de antiguo y lo...

JN: Sí...hay una pregunta que estaba, que leí y que ahora no ha salido que me decías algo donde hablabas de la modernidad...

MM: sí, sí..

JN: Y yo decía... ¿y qué es la modernidad?

MM: Bueno, es un poco lo que explica en su libro, ¿no? Que confundimos lo antiguo con lo clásico...

JN: y lo viejo...

MM: lo viejo, lo viejo... 
JN: claro. El concepto de modernidad... ¿qué es el concepto de modernidad? ¿qué es moderno? Resulta que, ¿el Bosco no es moderno? Precisamente, antes de ayer hablaba con un amigo mío, un arquitecto que había estado en Madrid viendo la exposición de El Bosco y decía: “es increíble, iqué moderno es! “ Y dices... ¡claro! Y Un cello, vas a ver unos cuadros de un cello que son increíblemente modernos. Entonces, ¿la modernidad qué es? Es algo, normalmente, lo que se entiende por modernidad, es algo que pasa...eso sí que se queda viejo... lo que muchas veces la gente considera modernidad, es lo que se queda viejo.

MM: Bueno es como cuando pone el ejemplo de poner una música rock en un documental cuando dices si dentro de 50 años esa música sí que es vieja... ¿no? si no lo haces con la música implícita, si no lo trabajas...

JN: claro, si no tiene un sentido. Por ejemplo, si esa música está puesta porque sí y no hay ningún elemento en la imagen en que enganche con ese planteamiento musical, pues cuando pasa el tiempo esa música queda ridícula...es decir, no tiene sentido. Porque eso, el concepto de la modernidad, a ver si te paso una cosa que saqué de un libro de Albert Boadella que se llamaba Memorias de un payaso y hace una reflexión tan lúcida de vanguardia, moderno y contemporáneo, de una lucidez extraordinaria.

MM: Pues me encantaría y me vendría muy bien.

JN: te lo voy a pasar. Creo que lo tengo aquí y ahora te lo paso por correo.

MM: Pues nada, muchas gracias. Me parece muy interesante... 


\section{ENTREVISTA ALBERT NIETO}

\section{(Entrevista en diferido por correo electrónico, 29-Julio-2017)}

Marta Millà (MM): En su libro El gesto expresivo del músico o cómo disfrutar de un concierto, manifiesta su interés en la gestualidad del músico desde hace muchos años. Me gustaría que me explicara en qué momento considera que, además del "gesto técnico" del músico para proyectar su sonido, hay también un "gesto expresivo" que suponga una verdadera comunicación con el espectador, "el flujo de emociones y sensaciones", tal como lo define usted.

Albert Nieto (AB): Es difícil dar una respuesta precisa pues hablamos de conceptos extraordinariamente sutiles. El "gesto técnico" es un gesto necesario, básico, y se pasa al "gesto expresivo" cuando el intérprete se involucra de una manera notoria en el trasfondo del carácter musical, para sugerirnos que la música que está proyectando tiene un determinado carácter. Pero reconocerlos es sumamente subjetivo, y es el espectador quien debe apreciarlo en base a su intuición perceptiva y, quizás también, a su experiencia observadora sobre este aspecto.

MM: ¿Cuál es la línea que separa un gesto expresivo de una gesticulación gratuita que convierte la interpretación en un "teatro" más que en una interpretación que surge de lo que la música quiere comunicar?

AN: También es una cuestión muy sutil, y de nuevo es el espectador quien debe percibir o no esa gestualidad excesiva. Por ejemplo, Lang Lang declara que siente una necesidad corporal para comunicar y que sus gestos no son gratuitos; pero hay un público a quien le parece excesiva su extraversión y cree que "hace teatro". Por tanto, para mí se traduce en definitiva en una elección del público de asistir o no a un concierto de un determinado intérprete o verlo o no en vídeo según sea su sensibilidad y afinidad por él. Pero recomendaría a ese público más "estricto" que se libere de prejuicios más propios de otra época y que se deje llevar por el carácter comunicativo de la música a través del gesto del intérprete. No estamos escuchando un disco, sino que estamos ante una "imagen musical", lo que es un fenómeno más completo que vale la pena aprovechar y disfrutar. Creo que es lo que también piensa Alfred Brendel cuando habla de su profesor Edwin Fischer: «Verle era algo extraordinario y no hacía teatro 
alguno. Y si lo hacía, se trataba del teatro más maravilloso que he visto nunca. Simplemente manaba de él, se ajustaba a la música y ayudaba sobremanera a que sus interpretaciones resultasen absolutamente memorables». Referente al pianista chino, comenta el crítico musical Xavier Chavarria, « (...) porque Lang Lang es un fenómeno puramente visual: es preciso verle, no sólo escucharle, porque buena parte de su magnetismo y atractivo reside en la imagen que transmite, tanto de la obra de arte musical como de él mismo». En el ámbito pedagógico tuvo un cierto arraigo incorporar la gesticulación como última etapa del proceso de estudio de una obra, tras "aprenderse las notas" y aplicar los demás elementos musicales (fraseo, dinámica, pedal, sonido...), como si de una prótesis ortopédica se tratara. Esta gestualidad impostada es ridiculizada por el escritor uruguayo Mario Benedetti en su cuento titulado La expresión, perteneciente a La muerte y otras sorpresas, en donde relata el suceso acaecido a un pianista.

MM: En la encuesta que he realizado, muchas de las personas se han fijado y valorado positivamente en cómo los intérpretes gesticulan, ya sea el director de orquesta, ya sean, por ejemplo, los intérpretes del quinteto de viento. ¿Son los músicos conscientes de ello? ¿Puede tener incidencia si saben que se les está grabando?

AN: No puedo estar en la mente de todos los músicos, pero no hay duda de que hay cada vez hay más intérpretes, sobre todo cuando actúan como solistas, que se dan cuenta de la importancia que tiene la comunicación corporal para influir más en la percepción global del espectador y que la comunicación, y por tanto el disfrute del espectador, e incluso el del propio intérprete, sea mayor. Por ejemplo, las pianistas optan por no tapar su rostro con su melena para que podamos apreciar su expresión facial.

Lo esencial consiste en que el músico sienta siempre esa necesidad de comunicación expresiva corporal, tanto si actúa en un estudio de grabación o bien ante un auditorio repleto de público, independientemente de si sabe que le están filmando. Otra cuestión es que, si se trata de un videoclip o grabación en estudio, se utilicen medios técnicos auxiliares para potenciar la comunicación, por ejemplo, por medio de coreografías.

MM: Recuerdo un viaje que hice a los lugares donde vivió Johann Sebastian Bach. Pude asistir a la interpretación de los Conciertos de Brandenburgo en la Iglesia de Santo Tomás de Leipzig. Realmente, fue la capacidad de comunicación de los músicos lo que me subyugó. Su gestualidad fue excepcional...todo lo contrario de lo que vi en una orquesta española 
interpretando los mismos conciertos. ¿Qué persona o personas deben ser los responsables de que esta gestualidad llegue a los espectadores?

AN: Evidentemente, depende de cada músico sentir esa necesidad expresiva que acabo de comentar. Lo que pasa es que si está aletargada por la tradición de una enseñanza restrictiva, el director de la orquesta puede potenciarla con sus consejos. Lo podemos ver claramente en la "Verbier Festival Music Camp Orchestra" dirigida por Alondra de la Parra, donde los jóvenes intérpretes manifiestan su entusiasmo tocando a menudo de pie y bailando ante una música tan alegre como es el Danzón $n^{\circ} 2$ de Márquez; o con la Orquesta BandArt dirigida desde el puesto de concertino por Gordan Nikolic, pues actúan de pie precisamente para potenciar al máximo la gestualidad. Y cada vez son más los cuartetos que actúan de pie, como el Emerson Strings Quartet, el Brodsky Quartet o el Apollon Musagete Quartet, pues son conscientes de que su mayor movilidad va en beneficio del carácter extravertido de la obra. Por otro lado, empiezan a haber orquestas que contratan los servicios de un actor o de un director de escena para trabajar aspectos relacionados con la actitud escénica de los músicos, desde que pisan el escenario hasta que lo abandonan.

En relación a la vivencia que usted comenta en Alemania, independientemente de la actitud de los intérpretes, el lugar del concierto puede influir para que se cree una magia especial. Disponemos de un emocionante testimonio, en forma de vídeo, de un recital del pianista András Schiff celebrado en la Iglesia Protestante de Leipzig, ciudad donde precisamente se compuso la colección de las Suites francesas de Johann Sebastian Bach, que era el programa del concierto. Antes de iniciar el recital, permaneció unos momentos pensativo con sus manos entrelazadas como si se tratara de una plegaria, de lo que podemos deducir una actitud de reverencia al compositor en un lugar tan emblemático. Yo viví una experiencia cautivadora en la Basílica de Santa María del Pi en Barcelona, en un concierto dedicado a obras de Arvo Pärt y Bernat Vivancos, pues el coro de la Radio de Letonia creó tal magia en un lugar tan singular que al final del concierto me ocurrió lo que suele suceder a los espectadores de los países germánicos después de permanecer extasiado con obras de larga duración: la imposibilidad de aplaudir inmediatamente después de finalizar. Este es un aspecto interesante del concierto, y que yo denomino "el espíritu del directo". Hay filmaciones que recogen ese estado especial de los espectadores, como Claudio Abbado dirigiendo obras como el Requiem Alemán de Brahms o el Requiem de Mozart. 
Pero no hay duda de que la actitud de los intérpretes es vital. Una experiencia impactante para mí, y que fue uno de los desencadenantes de mi estudio sobre la gestualidad, fue observar los rostros serios de los músicos de una orquesta de cuerda profesional interpretando la alegre y vitalista Vistas al mar de Eduard Toldrà: nada más paradójico, contradictorio e inverosímil.

MM: La pregunta anterior, quiere hacer referencia a una determinada "dirección de actores". Esto pasa en el teatro... ¿cree que en los conciertos, sobre todo los que se van a filmar, es importante que exista este papel? ¿Ve importante un diálogo entre el director de orquesta y el realizador, por ejemplo, para afrontar la filmación?

AN: En principio no tiene que haber diferencias entre una interpretación sin o con filmación, pues la necesidad gestual expresiva debe ser siempre inherente al intérprete como condición sine qua non y, por tanto, sin necesidad de que haya un "director de actores". No obstante, siempre es interesante que el director de orquesta pueda dar pistas al realizador de aquellos momentos musicales especialmente interesantes que pueden ser debidos a un instrumentista en particular o al propio director, dando por descontado la conveniencia de que la filmación siga a los instrumentos por el discurrir de la partitura.

MM: Está claro que para nosotros, los profesionales de la imagen, independientemente de la importancia del "gesto técnico", es el "gesto expresivo" el que nos ayudará a obtener una filmación más atrayente. Pero, ¿cómo trabaja usted o qué elementos son importantes para dicha comunicación?

AN: Tanto como pianista como profesor, considero que el aspecto fundamental consiste en captar el carácter de la música o, en todo caso -pues no siempre es tan evidente-, asignarle el que nosotros pensemos que puede tener; a partir de ahí, se trata de vivirlo interiormente para que salga también a relucir al exterior. Tenemos infinidad de caracteres extravertidos o introvertidos por los que optar; pero además, también hay que dar su importancia a elementos del discurso musical, como son la vivencia de los silencios, el poner en evidencia los ritmos sincopados o los puntos culminantes, o ser sensible a los enlaces entre los movimientos de las obras, entre otros elementos. 


\title{
MM: ¿Podría hacerme una valoración general de cómo ve las filmaciones de conciertos de música clásica? Es decir, cuando usted se dispone a visionar un concierto filmado o retransmitido en directo, ¿qué valora tanto desde el punto de vista de músico como de especialista en la gestualidad del intérprete?
}

\begin{abstract}
AN: Valoro, sobre todo, que se vea la imagen frontal del intérprete que está actuando en cada momento, pues así puedo apreciar su expresión corporal y facial. Y si se trata de una agrupación, lo ideal es que el intérprete escogido por el realizador no tenga la vista en la partitura sino en el director o en sus compañeros; así, podremos apreciar mejor su gestualidad facial y, musicalmente, tiene más coherencia como diálogo musical. Por descontado, también valoro que la filmación, cuando se trata de una orquesta, vaya siguiendo a los instrumentistas que intervienen en cada momento. También es interesante filmar a un solista que, aunque no esté tocando en ese momento, le vemos inmerso totalmente en la música, en lo que yo denomino "vivencia de espera", como ocurre con los pianistas Mitsuko Uchida, Krystian Zimerman, Kathia Buniatishvili, las violinistas Sara Chang y Patricia Kopatchinskaja, la violonchelista Sol Gabetta, o la trompetista Alison Balsom, por citar algunos de los instrumentistas que se caracterizan por valorar esta actitud.
\end{abstract}

Otro momento interesante para el realizador es captar la gestualidad del intérprete cuando llega un silencio repentino, pues el carácter que contiene, proveniente de la música precedente (dramatismo, interrogación, sorpresa, humor, duda, solemnidad, meditación...), puede ser potenciada con el tipo de inmovilidad y de actitud del músico.

Pero por desgracia, en la mayoría de filmaciones de pianistas y de instrumentistas de cuerda y de viento, los realizadores abusan del enfoque de las manos, privándonos lamentablemente del mayor goce que produce la observación de los movimientos expresivos del cuerpo y del rostro en particular. A mi modo de ver, este enfoque de la cámara sería comparable a mirar las pequeñas pinceladas del pintor en un cuadro, y sólo estaría justificado si se hiciera con la finalidad de realizar un estudio de tipo técnico. Voy a citar varios ejemplos que claman al cielo: un realizador, sabedor de la gran facilidad técnica del pianista György Cziffra, se concentra en un plano único de las manos revoloteando sobre el teclado mientras que interpreta el Grand Galop Chromatique de Liszt. En el vídeo que contiene los Estudios de Debussy interpretados por Mitsuko Uchida no hay ni un solo enfoque frontal, precisamente siendo una pianista de gran expresividad facial; y en contadas ocasiones lo tenemos en el vídeo del pianista Krystian Zimerman interpretando obras de Chopin. En el conocido vídeo del concierto del pianista Grigory Sokolov en París, el enfoque desde su espalda apenas 
recoge a vislumbrar las manos y su perfil. Y un caso mucho más incongruente lo encontramos en el vídeo titulado Alfred Brendel On Music. Three Lectures, donde Brendel comenta la connotación gestual del carácter gracioso en el segundo movimiento de la Sonata op.31 $n^{\circ} 1$ (Andante grazioso) de Beethoven, pues justo cuando lo interpreta al piano, la filmación se queda incomprensiblemente con el plano de sus manos.

El realizador debe estar atento, cuando filma a una agrupación camerística, de que los músicos no se tapen unos a otros. Especialmente, en el caso de un dúo con piano, me parece una descortesía que se tape sistemáticamente al pianista, pues tenemos el derecho a disfrutar de su gestualidad.

Se puede dar el caso de que el intérprete cause una gran fascinación en el público-como ocurría con el pianista Van Cliburn- por lo que aceptaría de buen grado que la cámara se apartase del intérprete por unos instantes para recrearse con alguna persona extasiada y reflejar así el ambiente tan especial.

Como conclusión, soy muy crítico con las filmaciones en que se apartan enseguida de la imagen facial del intérprete, pues me priva del placer que produce su comunicación visual, relegándome al placer parcial que ocasiona la música fonográfica.

MM: ¿Usted considera los primeros planos de los músicos como planos básicamente pedagógicos?

AN: Los planos frontales y cercanos de un músico, que raramente los podemos encontrar en una sala de conciertos, pueden llevarnos a concentrar demasiado la atención en las expresiones faciales, distrayéndonos del resultado global, por lo que conviene considerarlos sobre todo desde un punto de vista pedagógico. Dicho esto, podemos disfrutar mucho con ellos: me encanta la toma frontal de los pianistas, y cuando voy a un concierto intento situarme buscando el contacto visual con él: observar las manos moviéndose por el teclado apenas me interesa. 


\section{Entrevista Xavier Garasa, realizador Televisió de Catalunya}

(Sant Joan Despí, septiembre de 2017)

Marta Millà (MM): Para situar un poco tu mundo profesional...hace años, cuando aún no te conocía, ya oía hablar de ti como el realizador experto en multicámara, incluso con alguna que otra entrevista en algún medio de comunicación. ¿Cómo empezaste a trabajar en multicámara en el medio audiovisual? ¿Cuál fue tu primera producción?

Xavier Garasa (XG): Bueno, yo empecé en realidad a los 17 años en TVE (Televisión Española), donde estuve durante 3 años y, ahí, empezó mi primer contacto con el mundo de la multicámara por mi afición al fútbol. Allí, como mero observador porque, de hecho, mi trabajo era como de tercer o cuarto ayudante de una retransmisión. En televisión había meritorios y, entonces, la escalera era bastante larga para subir; pero sí que aproveché un poco para empezar a contaminarme de fútbol, en concreto, y, sobretodo, la multicámara, como especialidad de televisión.

(MM): Mi trabajo de investigación, parte, de hecho, del mundo del fútbol. He dividido la tarea del realizador en dos tipos de trabajo previo: la táctica y la estrategia. Evidentemente, sabrás a qué me refiero; la táctica como posicionamiento y la estrategia como el juego entre los jugadores. Yo me refiero a la táctica como posicionamiento de cámaras y a la estrategia como la manera de crear juego. Para ti, qué es primero cuándo te proponen una realización, ¿la táctica o la estrategia?

(evidentemente, dejo de lado partidos de la Champions donde todo es normativo o partidos que se realicen en el Camp Nou, supongo que conocidísimo por ti y, por tanto, con poca táctica que pensar)

Xavier Garasa: Primero...táctica y estrategia es similar. Antes de empezar una producción, aunque se pueda pensar que es repetitiva y, en el caso del fútbol, que cada partido puede ser igual...yo creo que no. Antes de hacer una táctica o una estrategia hay que documentarse y esto es aplicable a cualquier producción. Entonces, para documentarse hay que ver, en el caso de un partido de fútbol, qué elementos tiene este partido de fútbol que lo hace diferente a los demás o qué lectura quiero hacer yo de este partido de fútbol y qué táctica voy a hacer yo luego para explicar este partido de fútbol y que, con la táctica que yo haga, se entienda de la manera que yo quería que se representase. Esto es aplicable a cualquier producción y, también, a un concierto. Para retratar bien un concierto o para grabar bien un concierto pues, 
efectivamente, si tienes los conocimientos suficientes, pues mirar las partituras, los instrumentos o el rider que hay; pensar detenidamente en función de los medios que tienes, cómo vas a utilizar o qué cámaras o qué sitios vas a priorizar en el escenario. Esto no se puede aplicar sistemáticamente porque ya lo has hecho en otro concierto, sino que yo creo que es diferente hacer un concierto de un grupo de folk que hacer un concierto, con un pianista o con una orquesta sinfónica. Entonces, cada sitio, cada evento tiene una disposición diferente que si conoces, te has documentado y has estudiado, pues luego puedes aplicar la táctica con los conocimientos que tengas.

(MM): Siguiendo con el símil del mundo del fútbol, en un partido, el ritmo lo marca el mismo partido -seguramente muchos espectadores sabrían diagnosticar un partido como aburrido y falta de ritmo o, al contrario, un partido cuyo dinamismo hace que el espectador siga en la pantalla-; sin embargo, ¿puedes, como realizador, modificar el ritmo visual sea como sea el "juego"?

(XG): El caso del fútbol es un mundo un poco particular porque todo el mundo sabe mucho de fútbol. Antes que hablábamos un poco de la táctica y de la documentación, yo creo que, en función del partido, tú tienes que inventarte un ritmo diferente. Es más en función del partido que no del tipo de juego que hagan. Un Barça-Madrid se tiene que realizar de una manera concreta, no puedes darle un ritmo que tú quieras sino que tienes que seguir el ritmo que te marcan los jugadores. Quiero decir: si en un Barça-Madrid tú haces "boniquismos", das más información de la necesaria o si lo quieres adornar con excesivas repeticiones o planos cortos, por muy bonitos que sean, la gente en un Barça-Madrid lo que quiere ver es el plano general y dónde está el balón. Esto, uno. Y, por otra parte, quiere ver toda la polémica, que con repeticiones tú satisfagas lo suficiente como para que quede esclarecido. En un Barça-Madrid tienes que hacer esto y en un partido en general importante, esto sería el número uno.

Yo me acuerdo una vez que tuve la oportunidad de ir a Estados Unidos que los realizadores del básquet decían: "si yo tengo un director- para ellos realizador es lo mismo- que se pierde algún momento del juego cuando el balón está en movimiento, lo cambio”. Esto sería la mentalidad para un partido de fútbol importante. Luego, hay otros partidos de fútbol que por el ritmo que tengan, por la calidad diferente, por la trascendencia, que sí que puedes tú forzar un poquito, si el partido está aburrido: vamos a hacer más repeticiones, vamos a hacer más

\footnotetext{
${ }^{1}$ Con este substantivo se denominan aquellos planos no tan descriptivos sino estéticos.
} 
detalles o vamos a seguir el juego más desde abajo para tener otro ángulo más vistoso. Por supuesto que se puede alterar un poco el ritmo.

(MM): Y, en un concierto, ¿en qué medios piensas para dar el ritmo que tú deseas a un concierto?

(XG): En un concierto, si pudiera pedir y si estuviésemos en televisiones ricas, pediría que todas las cámaras tuviesen movimiento: spydercam, travelling, grúas... a mí me cuesta mucho ver una producción musical con planos estáticos; y luego, también evitar planos muy frontales que aplastan mucho. Pero, en general, el tema movimiento, tanto mecánico, por ejes o por zoom, porque a veces, sin movimiento de pedestal también se puede buscar movimiento: teleobjetivos, zoom, movimiento de cámara.

(MM): ¿Crees que ritmo musical es igual que ritmo audiovisual? ¿deben ir a la par? Me refiero a imágenes lentas, movimientos lentos...¿Estaría bien romper e ir un poco más allá? ¿Cómo lo ves?

(XG): A mí me gusta siempre dar los contrapuntos en todo. En una tertulia me gusta muchas veces más ver el que está escuchando que el que está hablando; prefiero ver la reacción que tiene el que está escuchando porque está escuchando alguna cosa que lo alude a él en directo que no, ver el que está hablando sobre el otro. En un concierto de música puede ser lo mismo. Está bien en momentos más puntuales quizás ver cómo se está preparando la trompeta que ver tocar la trompeta y combinar un poco los recursos que tengas y adaptándolos al lenguaje televisivo que quieras dar en cada momento.

(MM): ¿En una realización de cualquier producto audiovisual existe "una buena dosis de renuncia", también en la realización audiovisual de un concierto de música clásica nos encontramos con la mirada discriminatoria de un realizador. ¿Qué es lo que te determina como realizador para descartar planos? O, al contrario, ¿qué es lo que no dejarías que se perdiera el espectador audiovisual en la realización de un concierto? Puedes poner un ejemplo concreto.

(XG): Se tiene que renunciar siempre a algo y, a veces, no es nada muy preparado. Siguiendo en ese momento la intuición y siguiendo que la cámara te está mirando a tí de manera particular, por atracción o por simbiosis o por lo que sea, pues acabas yendo a esa càmara. Muchas veces también por precedentes o porque tienes un déja vu que, de repente dices, me va a funcionar mejor eso.

(MM): Bueno, la experiencia profesional y la intuición, ¿no? 
(XG): Sí.

(MM): Una vez un técnico de sonido, gran profesional que graba conciertos de música, me comentó que "menos es más". Es decir, una buena grabación no significa poner muchos micrófonos, sino pocos y bien colocados. ¿Piensas lo mismo de las cámaras?

(XG): Bueno, yo creo que es diferente el sonido que la imagen. En el sonido, aparte de la posición en que pongas los "micros", es la calidad del "micro". Si tú, en un concierto de clásica pones un buen "micro", bien puesto, te capta más que 12 "micros" malos. En las cámaras no es tanto, yo creo que cuantas más cámaras, mejor.

(MM): Después de haber trabajado con distintos realizadores...¿me puedes decir cuál es la estrategia que usas tú para ver todas las cámaras en la Unidad Móvil? Según Robert...normalmente, los realizadores ven las 3 cámaras centrales, eso dificulta la realización. Con otra pregunta...¿cómo puedes mantener el flow de la realización?

(XG): Bueno, el truco es primero la experiencia de muchos años de haberlo hecho; luego, hay un truco claro que es prepararse muy bien la retransmisión y saber muy bien lo que quieres hacer porque luego, como has dicho antes, pues muchas veces no hay tiempo y, el concierto, el evento pasa volando y muchas veces acabas haciendo cosas que no habías planificado y, al revés, quieres hacer muchas cosas y se te quedan en un saco roto porque no puedes ejecutarlas. Yo me organizo intentando estar en medio del escenario del sitio en concreto tanto en la unidad móvil como en mi cabeza sitúo las cámaras a la derecha o a la izquierda de ese eje central y entonces así me organizo mejor y sé qué cámaras voy a pinchar en función de donde esté la jugada o la situación o el foco de atención del evento en concreto. Esta es una organización básica de cámaras. Es básico el conocimiento de dónde están las cámaras. Hay gente que cuando mira los monitores no sabe qué cámara está dando ese plano. Si tú no le pones el número que pone el monitor y le preguntas: ¿qué cámara es ese plano? Seguro que no lo sabrán. Yo sé, cuando planifico un concierto, qué cámara está dando el plano. Eso es una ventaja, una ventaja de experiencia, tampoco no es que sea...yo lo he hecho muchos años y también es trabajo de planificación y de pensar. Antes del concierto hacer la táctica; antes, cuando hablábamos de la táctica, esa es mi táctica para que luego pueda dar una rápida ejecución de lo que quiero transmitir.

(MM): Según lo que me has comentado de Estados Unidos, ¿para ti cuál sería el balón en un concierto de música clásica?

(XG): El concertino. 
(MM): Ya, pero... aquello que no te querrías perder; o sea el concertino es fundamental pero me refiero a aquello que crees que un espectador no te perdonaría que en este momento no enseñaras. ¿O crees que hay una parte artística...?

(XG): Yo creo que no hay nada indispensable y que todo es necesario. Entonces, que cada momento se puede dar algo clave...pero, no hay nada que sea clave absolutamente.

(MM): Pues ya estamos. Muchas gracias. 


\section{EVALUACIÓN ROBERT GUMMLICH}

\section{Realizador Digital Konzert Hall}

\section{(Evaluación y comentarios recibidos por correo electrónico, 1-Julio-2013)}

He querido incluir, con el permiso de Robert Gummlich, esta evaluación y comentarios sobre el trabajo realizado en la filmación de un concierto de Jordi Savall en julio del 2013 porque pienso que es un análisis muy valioso por parte de uno de los realizadores que forman parte del equipo de la Digital Konzert Hall.

\section{Hi Marta,}

thank you once again for this great opportunity you offered us with this visit in Barcelona. We enjoyed it very much and I do hope that we will stay in touch, personally as well as professionally.

I was really impressed about the quality and size of TV3 as I told you before: In Germany regional stations sometimes exist only in some small blue-box-studios. So: Wow! Very impressing. All: The bandwidth of your programms, the technical standard and the great staff that seem to work very professionally.

I think that all of you work very well together as a team. For me this is the most important aspect that there is no aggression or anger during the recordings. Of course sometimes someone starts to speak louder, but I liked to see that especially Toni, Pep and you seem to know quite well how to interact and work together. And you laughed and spoke together afterwards.

Of course it was a very difficult production situation for you, but I remember when I worked as Assistant Director, I always wished to have one more day to prepare everything better. You never have enough time to be perfectly prepared, I think that is part of our job ;-D Speaking of that I liked very much the way you dealt with this situation, because you didn't panic, but concentrated very hard to make the best out of it! Very good! And you even found time to take care of Anja \& me, even better! I don't think I could have done that.

I think there are two kinds of people: One group looses their nerves in stress-situations and do not reach their potential. These people also fail in examinations etc. The other group has the 
ability to concentrate harder in stressful situations and can activate higher creativity than in normal situations. The second group is typically born for the stage or tv-live-work, but also surgeons or pilots need this ability (but often fail in "normal" life, because they miss the adrenaline during housework or tax-work ;-D). I belong clearly to the second group (even as a child I only play the piano concentrated in front of the audience and never at home). And I think that you belong to the second group as well.

So much about your person and work.

About the production in general: It was better than I expected and I am sure that after some postproduction the result will be honestly ok. That is because you have a very good cameracrew the found good pictures when you told them to. But the live mix was not following the music all the time, especially in the complex musical situations. After three or four shots "in the music" there followed a longer wide shot (during which Toni prepared the next shots). This does not produce the flow of pictures I try to create, when all the pictures during a production are exactly on the music. It is more like "in and out of the music", like waking up in between, loosing the flow.

And because of the improvisation Toni did not always use the best pictures but often only the ones from the middle (K5 / 6). I know the problem: You might loose the cameras, that are not directly in front of you, out of the focus when you are improvising. And I think especially the choir looked better from the sides in profiles.

And then there is a general thought: For me it is absolutely Director's work to choose the instruments, the angles and the shots. It is most important not only to have the right instrument. I also try to think if the music calls for a detail / close-up of an instrument or wide shots, pans or even a crane-movement. Or if I have to see only some faces of the choir or a large group. I try to hear this in the music when I do the preparations. So on the one hand Toni gives a lot of creative responsibility to Pep.

And if you improvise you can not think about these categories anyway but you have to take what you can get because you do not have the time to concentrate on the music and change camerapictures. So for me as a director I think I loose a great part of my creative tools if I only improvise.

But: I sometimes work with your system as well when we have to. For example when we broadcasted the "Magical flute" in March from the Berliner Philharmonie without rehearsal. 
Nanna did your you, Hannah arranged the cameras (we had a very simple but foolproof system) and I mixed the pictures. But I prefer to be prepared.

And this is the last thought: Preparations. You told me that you never use scripts in any productions situation. The result is that all of you together have to give the camera crew a lot of information in the right moment. And because in every mobile all over the world there are communication problems and the music is sometimes very loud and sometimes three persons talk at the same time, this creates a situation where misunderstandings and faults a to be expected. So I would think of doing a little paperwork (perhaps not a whole plan, but a small list for every cameraperson for every piece so she / he can concentrate on the tasks and prepare). For example:

\section{K 6 Jubilate}

1.) Violins

after cue from Marta (you only say: K 6 change to choir)

2.) Sopranos Choir

after cue

3.) Solo Sopran

etc.

Even if the cameraperson did not understand everything she / he knows where to go and the moment for a change.

It is the same system you use, so Toni does not need to learn anything new, but the advantage would be that you only have to check if the cameraperson is on the right picture and you have to talk less. And the cameraperson can "pre-think" about the next picture.

But of course: To write this down, you need all the information at least one day before production.

Robert Gummlich 


\section{Entrevista a José Nieto}

\section{(9 de Octubre del 2016, Hotel Liceu, Barcelona)}

Marta Millà (MM): Como compositor, no sólo de música incidental, sino también de música Sinfónica, como El castillo interior (2015) entre otras obras, me gustaría preguntarle, a modo genérico, qué esperaría de una obra suya ante la propuesta de ser grabada. De alguna manera, qué le gustaría que recibiera el espectador a través de la pantalla de todo aquello que usted ha dejado escrito en una partitura.

José Nieto (JN): Lo que espero en el caso de una retransmisión, no estamos hablando de un videoclip, no estamos hablando de hacer videoarte a partir de una música sino que entiendo que estás hablando de retransmitir el concierto al espectador que no está allí. Pues, en el fondo, lo que yo esperaría es que fuerais capaces de retransmitir y, efectivamente, trasmitir al espectador lo que el espectador querría haber visto si hubiese estado allí. Es decir, yo creo que la realización, para mí, debe ser un medio para hacer llegar al espectador lo que está pasando, en este caso, en la sala de conciertos y no un fin en sí mismo. Es decir, no voy a hacer arte con la retransmisión. Eso es otra cosa, eso es un trabajo más, digamos, de videoclip que otra cosa pero, en cuanto a la palabra estricta de retransmitir, pues yo lo que esperaría es eso, que el espectador viese lo que él hubiese querido ver si hubiera estado presente. Tengo un ejemplo... hace poco, me compré un blue-ray de un ballet británico Matthew Bourne y tenía una realización buena, excepto que en muchos momentos lo que tú querías ver no estaba. Yo quiero ver si está bailando, quiero ver la figura del bailarín, no quiero que cambie 27 veces de plano y que el protagonista de lo que veo sea la cámara, sea el realizador . El protagonista es el bailarín y quiero ver lo que hace.

MM: También podemos entrar en la parte de videoclip -no videoclip entendido como talpuesto que no sólo quiero investigar el momento de la retransmisión en directo, sino que, si después hay una post-producción, hasta dónde se puede llegar. Que sea una retransmisión, como usted dice, fiel a la partitura o que sea lo que el espectador quiere ver o en qué momento se cruza la frontera ya de videoarte...Así, ¿valora más una realización tipo performance, eso de los 27 cambios de plano que me nombraba, o una realización literal? Usted, en sus composiciones, ¿preferirá un seguimiento literal de la melodía o cree que hay muchos elementos en la partitura para escapar a este seguimiento? 
JN: No...yo no hablo de un seguimiento de la partitura. Es que yo creo que no es la partitura lo que hay que seguir. Yo creo que lo que hay que seguir es la música. Y, con criterio cinematogràfico. ¿A qué me refiero con criterio cinematográfico? Pues alguno de los clips que me has enviado en la encuesta, a mí, ya no como músico sino como cineasta, me llama mucho la atención porque, por ejemplo, encuentro que no hay correspondencia entre el tamaño de la música y el tamaño del plano. Eso es algo que, precisamente ayer estaba enseñando en el Máster del liceu a los compositores y les demostraba ejemplos. Sobre este plano de detalle yo no puedo componer un tutti de orquesta porque se produce una dicotomía grande y eso no es efecivo. Pues muchas veces pasa y en algunas de las cosas que me has enviado hay un tutti de orquesta y estoy vie ndo las manos del violín primero o del violín tercero porque la imagen, de repente, parece muy bonita o parece interesante pero cuando decía "lo que el espectador quiere ver" me refiero a eso, me refiero, echo de menos un tratamiento más cinematográfico del concierto, no tanto musical, sino cinematográfico.Es decir que haya una correspondencia entre tamaños de plano, densidades musicales, naturalmente cuando hay un instrumento protagonista, quiero ver el instrumento protagonista. Cuando el director está haciendo algo interesante quiero ver al director, pero echo de menos siempre el criterio este de cineasta. El ejemplo que te he contado antes, si hay un tutti de orquesta no quiero ver el plano en detalle de las manos del violín tercero...o la cara del violín tercero.

MM: Una vez leído el libro que presentará en el Liceu de Barcelona "José Nieto: un encuentro imprescindible", veo que su background no sólo tiene su origen en la música popular y la radio como elemento mediador, sino que asistía de bien pequeño a los conciertos de música clásica de la ONE. Me gustaría conocer la mirada de una orquesta a través de los ojos de “José Nieto, niño”. ¿Podría recordar qué era lo que le atraía a partir del momento en que el director daba la entrada con la batuta? ¿Cómo miraba la música? ¿Qué mira actualmente en un concierto?

JN: Ya no tan niño... estamos hablando de 14-15 años, estaba en el instituto cuando empecé a ir a los conciertos del Monumental. La orquesta tocaba los viernes por la tarde en el Palacio de la Música y los sábados por la mañana hacía un concierto en el Teatro Monumental de Madrid que es un teatro grande que es ahora la sede de la orquesta de radio y televisión. Entonces, claro que tengo un recuerdo. Tengo un recuerdo visual muy curioso y muy interesante porque yo iba a las entradas más baratas del teatro. Me costaban, me acuerdo, 8 ptas. Y era el último piso. Si no conseguía las tres primeras filas ya no tenía 
visión de toda la orquesta. A partir de la quinta fila no veía el director y empezabas según ibas cada vez menos, cada vez menos. Entonces era un poco angustioso porque afortunadamente casi siempre conseguía más entradas más cercanas pero el hecho de estar presente en un concierto y por ejemplo no ver el director me parecía como que faltaba algo. Entonces ese es un poco el recuerdo que tengo. Yo eso naturalmente lo veía en plano general te puedes imaginar que desde el piso de arriba lo que veías era un plano general de la orquesta claro tú haces de cámara tú dirigías tu atención si en un momento determinado pues había algo especial de trompeta pues mirabas al trompeta, si había algo de timbal, pues mirabas al timbal. Es decir que, tú hacías digamos tu propia selección de lo que veías pero en función de eso de qué era interesante en cada momento.

MM: actualmente, con la formación que tiene usted, cree que hay una distancia entre cómo veía los conciertos sin tanta formación musical o lo mira tal y como ahora le exigiría a un realizador, por ejemplo.

JN: No, no, no, no...cuando yo voy a un concierto es igual que cuando voy al cine en principio trato de ser espectador. Un oyente. ¿Cuándo me salgo de esto? Cuando no me interesa lo que veo o lo que oigo. Entonces, en ese momento, empieza a entrar otro tipo de...

MM: como de análisis...

JN: análisis y entonces empiezas a ver pues esto no está bien, puesto no sé qué...pero si el concierto está bien o la película está bien sencillamente la capacidad de análisis inmediata desaparece y en todo caso es a posteriori cuando analizas lo que has visto, lo que has oído. Pero, no...como oyente lo que sí ha cambiado es la distancia porque ahora puedo entradas mejores y tal...

Es igual, es decir que si realmente hay una intervención importante de la sección de metal, evidentemente la atención te va a la sección de metal pero claro, teniendo en cuenta que el ojo aunque es parecido, el funcionamiento del ojo es parecido al de la cámara o el de la cámara es parecido al del ojo la cámara realmente cuando encuadra, excluye de forma más contundente todo lo demás y el ojo no excluye, tú concentras la atención en la sección de metal o en la percusión o en el concertino y de alguna manera no estás excluyendo el resto de la orquesta. Esa es la diferencia fundamental que claro cuando alguien hace un plano de detalle como te decía antes, del primer violín, está excluyendo todo lo demás. Entonces, si ese plano primero no está justificado pues porque el violinista está haciendo un solo en ese 
momento una intervención importante digamos que ahí es donde se produce unaespecie de cruce extraño entre lo que oyes y lo que ves.

MM: ¿El realizador debe tenir formación musical para poder captar aquello que quiere el compositor o para saber transmitir la partitura a un público quizás ajeno al mundo musical? ¿o piensa que es un simple gestor de imágenes con una estética particular para cada creación?

JN: ¡Qué va...! Absolutamente necesario. Vamos a ver, cuando estabas hablando de la necesidad do no de saber música cuando yo, he trabajado mucho en el ballet, ¿Quién es el que realmente le dice al técnico de luz, cuándo entra un determinado pasaje musical? ¿Cuándo tiene que hacer un cambio de luz?

Pues tiene que hacer un cambio de luz cuando en la partitura toca esto y hace esto. Entonces, el técnico de luz nunca sabe música, pero claro que hay una persona siempre en el ballet y supongo que en la ópera también dónde alguien está siguiendo la partitura y en la partitura es donde están marcados los cambios de luz o los cambios de escenografía. Es decir que, realmente, es imprescindible que haya alguien que sepa música que sea capaz de leer una partitura para que el espectáculo sea posible. Pues, cuánto más, cuando el objeto de del espectáculo es una orquesta que está tocando. ¿Cómo sabes cuándo van a entrar las trompas o los metales?.

Muchas veces se nota que el realizador no sabe y entonces muchas veces dices...¿por qué me está enseñando esto?

MM: yo le llamo un gestor de imágenes...

$\mathbf{J N}$ : un gestor de imágenes pero como sordas. Un gestor de imágenes sordas. Esto aquí, esto aquí, esto aquí....ahora corto, esto me aburre y pongo esto. Realmente lo que está sonando y lo que está viendo no tiene una relación clara.

MM: Totalmente de acuerdo y en cuanto la concepción global de la obra ¿no?

JN: Por supuesto

MM: porque sabiendo música, creo que puedes también, no sólo saber cuándo entra el solo este sino qué color le vas a dar a esa retransmisión, qué ritmo,

JN: Claro, en uno de los clips que me has enviado había un momento que me pareció excelente. No recuerdo en cuál...era uno de ...una sección de metal e iban interviniendo y era 
como un crescendo y efectivamente, la cámara arrancaba de un solo individuo, de las trompas o no recuerdo bien y la cámara iba haciendo un zoom retro, abriendo a medida que la sonoridad...y yo decía: "Esto es, esto es".

Eso no se puede hacer si no sabes música.

\section{MM:}

Me ha gustado el concepto de música implícita. Me parece muy gráfico. Nunca...vaya si lo ha dicho en algún libro más, no lo recordaba.

JN: No

MM: Sí que he leído sobre música diegética, no diegética, todo esto...pero lo de música implícita me ha gustado mucho.

JN: Lo de implícita es un término que yo utilizaba en las clases pero que realmente el que lo ha sistematizado ha sido Vicente Ruiz Antón en este libro y antes en su tesis doctoral que es, precisamente, sobre la música en el documental. El documental como campo de experimentación y ha recogido el tema de la música implícita que curiosamente ahora al venir este año con los alumnos del master pues al repasar el guión de la clase efectivamente he visto que ahí estaba. Música explícita o música implícita.

MM: Yo, por eso lo he relacionado con la realización. Sí puede existir una realización implícita, que creo que es lo que un poco me ha estado contando. Si haces una realización explícita...sales totalmente de lo que es.

JN: el plano corto excluye.

MM: Del mismo modo que, para un ballet, hacer una síntesis de un guión como el de "El corazón de piedra verde", implica "una buena dosis de renuncia", también en la realización audiovisual de un concierto de música clásica nos encontramos con la mirada discriminatoria de un realizador. ¿A qué renunciaría usted en una partitura suya? $\mathrm{O}$, al contrario, ¿qué no dejaría que se perdiera el espectador audiovisual de su música? Puede poner un ejemplo concreto.

JN: Enlazamos con la primera pregunta. Lo que me gustaría es que, puesto que el lenguaje audiovisual es el que es, el lenguaje de la imagen es el que es, pues yo sé que tú no puedes estar mostrando todo el tiempo todo ni puedes retransmitir un concierto en plano general y 
entonces lo que no se trataría de renunciar, en todo caso renunciar a lo superfluo...o a lo secundario, más que a lo superfluo, se supone que en una partitura no debe haber nada superfluo, pero sí a lo secundario. Entonces, pues claro, si hay una melodía de flauta y hay un contrapunto de otro instrumento pues no puedes estar enfocando a los dos...o sí, hay recursos de dividir la pantalla o de sobreimpresiones, etc, etc, pero yo me iría siempre, pediría que estuviéramos viendo exactamente lo que te he dicho antes... si yo estuviera en un concierto a dónde miraría.

MM: Por ejemplo, un ejemplo concreto, en "Castillo interior" qué le gustaría si pudiéramos tener la oportunidad de filmar?

JN: El Castillo interior está pensado como una obra no de concierto tradicional. Yo creo que el concierto. No sé si viene a cuento o no pero me encantará comentarlo contigo... yo creo que el concierto como se ven todavía los conciertos en $99 \%$ de los casos... yo creo que es un espectáculo obsoleto. Yp creo que el ritual del concierto distanciador decimonónico no tiene cabida en este momento y se está probando porque la Edad Media de los asistentes a los conciertos cada vez es más alta.

No estoy hablando de España que ya sabemos el nivel que hay pero yo paso mucho tiempo en Londres voy allí a los conciertos y voy al teatro y el nivel, perdón, la media de edad de la gente que va aver una obra de Shakespeare es mucho más baja que la media de edad que va a oir un concierto de Beethoven o de shost. Y esos es un hecho. Vas y lo ves. Como a mi me gusta y soy curioso pues llegas al auditorio y echas un vistazo y no es que no haya gente joven pero menos. Es decir, el hecho teatral sigue atrayendo a gente joven porque se renueva y el concierto no como contenido sino formalmente el concierto no se renueva y sigue siendo en la mayor parte de los casos una especie de ritual siempre distanciador donde el director no habla el director es como una especie de Dios que sale,q ue saluda...ceremoniosos, es como una especie de ceremonia. Yo creo que eso tene que cambiar. Hay gente que ya está haciendo otro tipo de planteamiento en los conciertos pero yo creo que sino no hacemos nada. Es decir, hace poco estaba en Granada, precisamente cuando estaba en la obra esta de Teresa de Jesús y decían que la media de edad de espectadores para la orquesta de Granada estaba en 60 y tantos años. Entre otras csas porque ahí hay otros problemas no pueden contratar aumentos, eso está pasando en muchos sitios, no pueden contratar solistas, no pueden contratar aumentos y entonces el repertorio que toman es el de la orquesta que se reduce al primer 
Barroco y al período clásico y un poquito de Romanticismo, pero poco y encima pues eso es cada vez menos atractivo. Entonces todo esto, venía a que la suite de Teresa de Jesús, está pensada como un concierto teatralizado que yo creo que es lo que hay que hacer, hay que empezar a teatralizar el concierto. No a poner bailarines en el concierto y a poner lucecitas pero sí a teatralizar un poco. ¿En qué sentido? Pues, lo de Teresa de Jesús fue muy sencillo. A parte de que hay un narrador, en este caso una narradora no es un narrador sino es personaje. Entonces, alguien que dice, recita textos de Teesa de Jesús. Pero desde el principio eso está pensado que esa actriz, es una actriz que habla, no tiene porqué cantar y está pensado que tiene que estar aquí que tiene que haber un foco, que la orquesta tiene que tener atriles de ópera para poder oscurecer la orquesta, para poder...el día del estreno fue muy sencillo, además lo hicimos en media hora con las luces que había en el teatro, un ciclorama blanco detrás de la orquesta y unas luces azules, rojas, blancas frías y luz cálida...es decir 3 o 4 tonos de luz que había indicaciones... es decir, en este movimiento el fondo es rojo, en este movimiento. No sé qué...cuando está la actriz foco a la actriz, naturalmente el director siempre. Si no está la actirz la orquesta tiene otro protagonismo...es decir, teatralizar un poco el concierto que se podría hacer incluso en el caso de que no haya una actriz o de que no haya...por ejemplo, el cello solista, el solista se sienta en una silla, cuando le toca se pone de pie y está todo iluminado y entonces todo eso es una distracción. El hecho de que el solista que está sentado, cuando hay 4 no te digo nada, se ponga de pie, abra el papel y todo esto, eso distrae la atención, no es teatral. Porqué el solista no está en la oscuridad y se enciende una luz cuando va actuar? A eso me refiero, es decir, darle ese giro al concierto y bueno, como me has hablado de Teresa de Jesús, pues así estaba planteada Teresa de Jesús. Hace muchos años, muchos, muchos años....vi en Los Ángeles un concierto, fui a un concierto donde había un oratorio de Stravinsky y ahí estaba ya esto que te estoy diciendo y hace muchos, muchos años...el coro no estaba vestido desmoking ni las señoras estaban vestidas...estaban con gabardinas, perfectamente escogidas de una gama de colores, todas diferentes pero todas entonadas, había un narrador que era un actor conocido de allí, ahora mismo no me acuerdo, pero uno de los grandes actores conocidos de allí y el escenario era un escenario de teatro; es decir, que yp creo que el concierto tiene que empezar a ir por ahí, que de alguna manera, muchos realizadores es lo que buscais cuando retransmitís. Es decir, buscar que aquello no sea una cosa tan fría, tan distanciadora, y yo creo que el problema no está en que lo retransmitáis de una manera o de otra sino que lo que hay allí para enseñar no es bonito. En el siglo XXI, el mundo de la imagen.... 
MM: ...hay que buscarse la vida para hacer atrayente lo que ya es decimonónico.

JN: absolutamente... ha permanecido... si lo piensas, el ritual del concierto...

MM: totalmente, no sé si ha leído el libro de James Rhodes, Instrumental, bueno está superbién, yp era un poco reacia por ciertos temas y así, digo no sé cómo será, pero es que hace un retrato de lo que es un concierto que es que está muy bien y habla en una parte también de lo que es la retransmisión, los programas de televisión y beno es que lo retrata superbién, los directores, las salas de concierto...la verdad es que estça obsoleto.

JN: absolutamente

MM: entonces claro, buscar la fórmula de realización para que esto se haga atrayente en televisión con la cantidad de programas que hay hoy en día que bueno, las audienias son las que son...es muy difícil, ¿no?

JN: luego, dices, las salas de concierto. Hay salas y salas. Por ejemplo el Monumental de Madrid a mi me parece un sitio imposible porque no he visto nunca un sitio tan frío de aspecto para asistir a un concierto. Lo comparas con el Barbican de Londres y dices, hombre es verdad que el ritual es el mismo pero la luz es otra. Por ejemplo, la madera del auditorio es madera cálida, madera un poco más oscura, con calidez. La luz es luz así...pero es un poco tamizada, un poco cálida, hay otras salas como esta...madera clara, luz ni cálida ni nada, luz.

MM: totalmente plana ¿no?

JN: totalmente plano y entonces pues ahí todavía...incluso cuando estamos diciendo que decimonónico, yo supongo que en el XIX era desde el punto de vista de la luz era más interesante un concierto, que no podías poner focos.

MM: Cuando estuve en Berlín, es que me ha gustado mucho esto que ha salido aquí...establecí relación con el director de allá y se portaron muy bien, me enseñaron todo y él me pidió que...bueno, Barcelona resulta atrayente, le gustaría ver el Palau de la Música o l'Auditori...yo die, bueno cuando hagamos uno yo te lo diré y si quieres, puedes venir. Lo pedí en TV3, me dijeron que ningún problema y él vino. Entonces él cuando estuvo viendo la retransmisiónme encantó porquehabló de la fluidezque él le llamaba flow, porque estaba ya viendo como hacíamos el trabajo nuestro equipo y decía,luego me lo dijo a mí aparte, los cámaras trabajan superbién, todo el mundo trabaja superben, pero la crítica que hago es que no existe esta fluidez, el pulso...que no es una sincronía exacta que es lo que a mi me 
gustaría investigar por ahí: el cómo conseguir esta pulsación a través de la imagen. Porque él me decía, entras y sales continuamente y no hay esta fluidez que entras en el vídeo, en la visualización de plano tras plano y te quedas ahí, sino que lo que me ha pasado es que no existe esta fluidez. Me gustó mucho lo que me dijo porque yo ahora cuando trabajo en algún concierto con algún compañero pienso cómo conseguir esa fluidez en esa partitura, cómo seguir el pulso de la música con la imagen?

JN: Pues fíjate, es curioso porque una de las cosas que insisto mucho con los compositores pero no solamente con los compositores yo doy clase también en la escuela de cine, por ejemplo, en noviembre yo vengo a un máster de montaje y lo que más insisto con ellos es en que el montaje tiene que tener pulso musical, el montaje tiene que respirar musicalmente y que tiene que haber cómo se consigue eso? Pues con una relación entre el movimiento que hay en la imagen que estás tomando o que hay en la película, en el caso de la película es la que está, la relación entre el movimiento que hay en el plano y el corte del plano. Cuando la relación entre el moviento y el corte tiene musicalidad entonces el montaje respira y el montaje fluye y les pomgo unos ejemplos muy sorprendentes de montajes hechos de esta manera a los cuales tú lo ves, captas cuál es el pulso del montaje y resulta que tú le añades una música que no está pensada para eso pero que tiene ese pulso y sorprendentemente funciona. Entonces, yo creo que cuando retransmitís es al revés, hacer eso pero en directo. Es decir ¿Cuál es el pulso de la música? Pues ahora los cambios, cortes de plano y cómo paso de esto a esto tiene que tener respiración musical. Entonces, por ejemplo, si estás en un adagio, cuidado con los planos por corte; porque los planos por corte te van a dar algo que no está en el espíritu de la música. Por ejemplo, no coincidir un cambio de plano sincrónico con un ataque de orquesta porque eso le da dureza. Entonces, la fluidez viene precisamente en que la música no esté matemáticamente sincronizada, que no se perciba la sincronía- Tiene que estar, yo prefiero utilizar en clase el término articulada. Entonces, el grado de articulación puede ser sincronía dura, cuando quieres retransmitir algo con sensación de violencia y cuando no, la sincronía tiene que no ser perceptible. El espectador no se tiene que dar cuenta que estás siguiendo...

MM: que estás siguiendo frase A, frase B...

JN: claro, por ejemplo muchas veces...ya sabes cuando se trabaja para cine se mide exactamente el fragmento musical aquí pasa esto aquí lo otro y tú compones una música, al cambio de este plano pasa esto, al cambio de este plano pasa esto...cuando no es una 
secuencia de acción, cuando no buscas una sincronía realmente dura, evidente y violenta, siempre llegábamos con el bloque, en principio lo montas donde estaba previsto y ves que todo va bien. Entonces, lo normal era decirle al montador: bien, pues ahora retrasa toda la música cuatro fotogramas...desplazas música, todavía aguanta tres fotogramas más, dos fotogramas más y al final de donde estaba prevista la música desde el punto de vista matemático retrasas la música con respecto la imagen seis fotogramas, siete fotogramas y cambia absolutamente; es decir, la música sigue estando articulada, pero la articulación ya no es perceptible, ya no es visible. Eso es fluir, eso es el fluido.

MM: no...me ha encantado porque la coincidencia en música articulada y la música en retransmisión me ha recordado....al revés...

JN: es lo que hacéis en directo, cuando es retransmisión en directo y si estais en postproducción estáis haciendo lo mismo. No poniendo una música en la imagen, sino poniendo una imagen en la música. El criterio sería el mismo. ¿Dónde corto el plano? ¿Dónde pongo este plano? Y sobre todo ¿cómo lo pongo? Lo pongo exactamente cuando ataca pues, en ciertas obras sí, pero en ciertas obras no. Lo tendré que poner un poquito antes, lo tendré que poner un poquito después, no cortaré en un plano...es decir, muchas veces no quiere decir que ir por encadenado, si tú haces un encadenado de 12 fotogramas es como si fuera corte pero suave. Es decir, jugar con esas sutilezas. No es o corte o encadenado...encadenado, ¿de cuánto? Encadenado de 48 fotogramas no es igual que un encadenado de 24 . Incluso un encadenado de 24 , de un segundo equivale a que prácticamente no se percibe que hay un encadenado pero no está la dureza del corte. Fíjate que estamos hablando de criterios cinematográficos.

MM: totalmente

JN: de montaje, de montador

MM: y por último, también me ha encantado lo de la percepción ¿no? Que cuando define música aplicada dice que es aquella que tiene que ser analizada fundamentalmente desde el punto de vista de la percepción, no?

JN: claro. Qué produce la música

MM: qué efecto producen el oyente...aquí me parece que se ha parado demasiado allá la entrevista, porque me parecía muy interesante y enseguida Vicente ha ido hacia otros 
derroteros y me gustaría más profundizar porque llevado a la visualización en conciertos cómo conseguir la percepción pretendida por el compositor

JN: pues realmente, mediante todas estas cosas que estamos hablando. Por ejemplo antes has mencionado así como de "pasadilla" el tema del color. Claro, eso es lo que me ha llevado a mí a hablarte de la teatralización del concierto porque...qué vas a hacer con el color, el color es el que hay, la luz es la que hay. Entonces, incluso, ahora no tanto pero yo recuerdo que en las primeras transmisiones de conciertos o de obras de teatro, lo primero que hacía el equipo de tv era iijuah!!! Soltar unos chorros de luz porque las cámaras...

MM: Bueno, ahí tuvimos un problema nosotros con un director que vino al Palau de la Música hace unos años....no grabábamos eh? Por la luz que poníamos la tv; dijo que no grababa y no grababa...y los músicos no podían ni leer la partitura y él decía que con esa luz no grababa y tuvimos...

JN: claro, claro...pero además, la luz que echaban entonces, más bien recuerdo de obras de teatro en las que yo intervine. De repente decía, viene tv a grabar. Bueno colocaban unos focos de aquellos, unos sirios...toda la escenografía aplastada, y entonces, verdaderamente era peor cuando realmente de lo que estamos hablando es de retransmitir un poco teatralizando y el teatro es fundamentalmente juego de luz y entonces claro lo que pasa es que si no está, no está...qué le vas a hacer. Claro, el tema del color, como decíamos, pues sería importante ¡qué obra estoy tocando? Estoy tocando una obra del siglo XX, de los 90, de estos que son especulación intelectual, Xenakis...o estoy transmitiendo Brahms? El color que me da, pues no es lo mismo, porque además hay una relación entre el color visual y el color musical. Eso es una cosa que enseño yo ahí todos los días. A ver...nosotros muchas veces decimos, el color de la orquesta...y el color de la orquesta nos estamos refiriendo al timbre de la orquesta. Y podemos hablar de brillo, mate, es oscuro, es claroy todas estas referencias que hacemos a la música son referencias que hacemos también al color. Entonces el tratar de buscar esas relaciones, evidentemente, ayuda a transmitir lo que eestá no tanto en la partitura sino en la música que suena.

MM: Pues nada, ya estaríamos porque luego comentar, bueno en el libro salen muchas cosas que a mí me han pasado también como montadora musical ...me parece tremendo eso de haber dado música compuesta por usted y que el montador musical no se lo haya escuchado todo para ponerlo , me parece increíble, y bueno estas cosas pasan... 
JN: sí, eso fue...no era exactamente montador musical eran los montadores de imagen...

MM: iiiahhh, de acuerdo!!! Pensaba que era el montador musical que tenía que poner su música que le había dado y luego tenía....vale, vale

JN: no...no...era un documental con muchísimos capítulos que se llamaba El arca de Noé...

(Dejamos por unos momentos la grabación puesto que la conversación deriva hacia lo que es propiamente la ambientación musical. Sin embargo, la tenemos que reemprender puesto que surgen temas interesantes para la filmación del concierto)

JN: La visión un poco del músico o del profesional que a través de la televisión tiene la posibilidad de ver cómo toca un maestro. Ver cómo toca un gran solista o un gran instrumentista $\mathrm{y}$, entonces, la frustración que supone ese punto de vista que tienes la oportunidad de ver a un maestro tocando y el realizador no te deja verlo. Una vez por lo que decíamos antes, porque él se convierte en el protagonista y no te deja ver lo que hace el verdadero protagonista que es el que está tocando. Entonces, has querido grabar porque decía yo que cuando empezaba yo, que estaba estudiando la batería... además era una éoca en que en España no se encontraban discos de jazz, no había conciertos de jazz...la única forma era pues si pasaba por aquí alguien y actuaba en televisión y te lo retransmitían...entonces, la frustración tremenda de que dices: "Hombre, va a tocar fulanito, ha pasado por aquí y va a salir en televisión y te ponías a verlo...era frustrante no poder ver lo que estaba haciendo por lo que te decía al principio. Quiero ver lo que hace el bailarín.

MM: claro...yo aquí, en el Liceu he grabado ballets y una de las personas me dijo, por favor no hagáis como otras veces que es que no se ven los pies del bailarín.

JN: Claro, claro..

MM: y entonces es que dices si estamos viendo un vídeo de ballet y no vemos los pies, o la expresión de los brazos...

JN: y volvemos otra vez a criterios cinematográficos. Si yo no enseño de entrada por ejemplo, cómo está colocado el ballet, me voy directamente a planos cortos, planos de aquí, planos de allí, llega un momento que pierdo la perspectiva del ballet. Por ejemplo, a mí, el 
ballet, prefiero verlo desde el piso de arriba que desde el piso de abajo. ¿Por qué? Pues porque desde el piso de arriba tengo la perspectiva, el plano general de arriba donde me da la posición, la coreografía, cosa que desde abajo, sobre todo desde muy cerca, todo eso se pierde. Con eso te explico todo. Estos vídeos que te hablaba antes, arranca una pieza dentro del ballet y ni siquiera te das cuenta cómo evolucionan porque estamos todos en plano medio, plano corto, plano de detalle, primeros planos y dices, no es eso lo que yo miraría

MM: como me dijo Robert...aquí sí que se ve la flauta, pero estos planos que se ven los morros del músico y un trocito así de instrumento que él lo encuentra horrible. Y me dijo..."yo no lo entiendo".

JN: lo que te decía del violín. Es que en algunos de los clips que me has mandado está un tutti de orquesta y ni siquiera es un plano del violinista tocando sino un plano cortísimo con el puente, las manos, el arco...

MM: Sí, sí...totalmente de acuerdo.

JN: esto no tiene sentido (plano corto de contrabajo) si no va a algún lado.

Por cierto...volviendo a lo que decías tu de saber o no saber música, yo tengo alguna grabación de conciertos dirigidos por mí y cuando no se sabe música...hombre, el ataque de una cuerda a la hora de montar, más o menos todo el mundo lo pone, pero el gesto del director, no. Y es molestísimo, extraordinariamente molesto ver que el gesto del director no está realmente donde tiene que estar. ¿Que no lo capta más que un profesional? Pues sí o no...pero en cualquier caso, un concierto, la retransmisión de un concierto es un testimonio y no puede quedar un testimonio en el que el director realmente está marcando un poco antes un poco después de lo que suena, no corresponde exactamente al sitio, entonces, buscar la sincronía del plano del director es, si no sabes música, si no sabes realmente lo que está haciendo...

MM: no...y yo pienso que, además del testimonio, ¿qué más da que la gente no lo sepa? Hay que enseñárselo...

$\mathbf{J N}$ : no..pero es un testimonio, es un documento...entonces, yo, hay alguno en que veo ahora y no está en su sitio el plano del director no está en su sitio. Hay un concierto que por otra parte sonó muy bien, un concierto con la Joven Orquesta de Madrid que era excelente...ese 
año la orquesta era excelente y los planos del director a mí me ponen de los nervios porque no están en su sitio y eso es porque el que está detrás...no sabe...

MM: entonces....ahora se me ha ocurrido...del Concierto de Año Nuevo, ¿qué me diría?

JN: Eso es otra cosa porque eso ya se ha convertido en un espectáculo en donde...

MM: pero tiene los elementos que usted me está diciendo, ¿no? Saben lo que están haciendo...evidentemente.

JN: saben lo que están haciendo porque ya el planteamiento del concierto es otro. Desde el momento en que te sales de la sala de conciertos porque hay un ballet, el planteamiento de ese concierto ya no es la retransmisión de un concierto. Es un concierto más otras cosas y entonces se acepta que el espectador que está en la sala ve una cosa y el espectador del mundo que ve eso, está viendo otra $\mathrm{y}$, entonces, estamos jugando con otros elementos, con otras cosas y el planteamiento es diferente, ya no es la retransmisión de un concierto normal, dónde se trata de retransmitir lo que pasa. No retransmites lo que pasa, retransmites parte de lo que pasa y parte de cosas que no pasan o que pasan en otro lado

MM: Pero a pesar de mucha gente, por ejemplo, compañeros míos dicen que es lo típico, que es lo tradicional y tal, no deja de ser cuestionable su calidad y su manera de hacer...

JN: es que hay una confusión...

MM: lo de antiguo y lo...

JN: Sí...hay una pregunta que estaba, que leí y que ahora no ha salido que me decías algo donde hablabas de la modernidad...

MM: sí, sí..

JN: Y yo decía... ¿y qué es la modernidad?

MM: Bueno, es un poco lo que explica en su libro, ¿no? Que confundimos lo antiguo con lo clásico...

JN: y lo viejo...

MM: lo viejo, lo viejo... 
JN: claro. El concepto de modernidad... ¿qué es el concepto de modernidad? ¿qué es moderno? Resulta que, ¿el Bosco no es moderno? Precisamente, antes de ayer hablaba con un amigo mío, un arquitecto que había estado en Madrid viendo la exposición de El Bosco y decía: “es increíble, iqué moderno es! “ Y dices... ¡claro! Y Un cello, vas a ver unos cuadros de un cello que son increíblemente modernos. Entonces, ¿la modernidad qué es? Es algo, normalmente, lo que se entiende por modernidad, es algo que pasa...eso sí que se queda viejo... lo que muchas veces la gente considera modernidad, es lo que se queda viejo.

MM: Bueno es como cuando pone el ejemplo de poner una música rock en un documental cuando dices si dentro de 50 años esa música sí que es vieja... ¿no? si no lo haces con la música implícita, si no lo trabajas...

JN: claro, si no tiene un sentido. Por ejemplo, si esa música está puesta porque sí y no hay ningún elemento en la imagen en que enganche con ese planteamiento musical, pues cuando pasa el tiempo esa música queda ridícula...es decir, no tiene sentido. Porque eso, el concepto de la modernidad, a ver si te paso una cosa que saqué de un libro de Albert Boadella que se llamaba Memorias de un payaso y hace una reflexión tan lúcida de vanguardia, moderno y contemporáneo, de una lucidez extraordinaria.

MM: Pues me encantaría y me vendría muy bien.

JN: te lo voy a pasar. Creo que lo tengo aquí y ahora te lo paso por correo.

MM: Pues nada, muchas gracias. Me parece muy interesante... 


\section{ENTREVISTA ALBERT NIETO}

\section{(Entrevista en diferido por correo electrónico, 29-Julio-2017)}

Marta Millà (MM): En su libro El gesto expresivo del músico o cómo disfrutar de un concierto, manifiesta su interés en la gestualidad del músico desde hace muchos años. Me gustaría que me explicara en qué momento considera que, además del "gesto técnico" del músico para proyectar su sonido, hay también un "gesto expresivo" que suponga una verdadera comunicación con el espectador, "el flujo de emociones y sensaciones", tal como lo define usted.

Albert Nieto (AB): Es difícil dar una respuesta precisa pues hablamos de conceptos extraordinariamente sutiles. El "gesto técnico" es un gesto necesario, básico, y se pasa al "gesto expresivo" cuando el intérprete se involucra de una manera notoria en el trasfondo del carácter musical, para sugerirnos que la música que está proyectando tiene un determinado carácter. Pero reconocerlos es sumamente subjetivo, y es el espectador quien debe apreciarlo en base a su intuición perceptiva y, quizás también, a su experiencia observadora sobre este aspecto.

MM: ¿Cuál es la línea que separa un gesto expresivo de una gesticulación gratuita que convierte la interpretación en un "teatro" más que en una interpretación que surge de lo que la música quiere comunicar?

AN: También es una cuestión muy sutil, y de nuevo es el espectador quien debe percibir o no esa gestualidad excesiva. Por ejemplo, Lang Lang declara que siente una necesidad corporal para comunicar y que sus gestos no son gratuitos; pero hay un público a quien le parece excesiva su extraversión y cree que "hace teatro". Por tanto, para mí se traduce en definitiva en una elección del público de asistir o no a un concierto de un determinado intérprete o verlo o no en vídeo según sea su sensibilidad y afinidad por él. Pero recomendaría a ese público más "estricto" que se libere de prejuicios más propios de otra época y que se deje llevar por el carácter comunicativo de la música a través del gesto del intérprete. No estamos escuchando un disco, sino que estamos ante una "imagen musical", lo que es un fenómeno más completo que vale la pena aprovechar y disfrutar. Creo que es lo que también piensa Alfred Brendel cuando habla de su profesor Edwin Fischer: «Verle era algo extraordinario y no hacía teatro 
alguno. Y si lo hacía, se trataba del teatro más maravilloso que he visto nunca. Simplemente manaba de él, se ajustaba a la música y ayudaba sobremanera a que sus interpretaciones resultasen absolutamente memorables». Referente al pianista chino, comenta el crítico musical Xavier Chavarria, « (...) porque Lang Lang es un fenómeno puramente visual: es preciso verle, no sólo escucharle, porque buena parte de su magnetismo y atractivo reside en la imagen que transmite, tanto de la obra de arte musical como de él mismo». En el ámbito pedagógico tuvo un cierto arraigo incorporar la gesticulación como última etapa del proceso de estudio de una obra, tras "aprenderse las notas" y aplicar los demás elementos musicales (fraseo, dinámica, pedal, sonido...), como si de una prótesis ortopédica se tratara. Esta gestualidad impostada es ridiculizada por el escritor uruguayo Mario Benedetti en su cuento titulado La expresión, perteneciente a La muerte y otras sorpresas, en donde relata el suceso acaecido a un pianista.

MM: En la encuesta que he realizado, muchas de las personas se han fijado y valorado positivamente en cómo los intérpretes gesticulan, ya sea el director de orquesta, ya sean, por ejemplo, los intérpretes del quinteto de viento. ¿Son los músicos conscientes de ello? ¿Puede tener incidencia si saben que se les está grabando?

AN: No puedo estar en la mente de todos los músicos, pero no hay duda de que hay cada vez hay más intérpretes, sobre todo cuando actúan como solistas, que se dan cuenta de la importancia que tiene la comunicación corporal para influir más en la percepción global del espectador y que la comunicación, y por tanto el disfrute del espectador, e incluso el del propio intérprete, sea mayor. Por ejemplo, las pianistas optan por no tapar su rostro con su melena para que podamos apreciar su expresión facial.

Lo esencial consiste en que el músico sienta siempre esa necesidad de comunicación expresiva corporal, tanto si actúa en un estudio de grabación o bien ante un auditorio repleto de público, independientemente de si sabe que le están filmando. Otra cuestión es que, si se trata de un videoclip o grabación en estudio, se utilicen medios técnicos auxiliares para potenciar la comunicación, por ejemplo, por medio de coreografías.

MM: Recuerdo un viaje que hice a los lugares donde vivió Johann Sebastian Bach. Pude asistir a la interpretación de los Conciertos de Brandenburgo en la Iglesia de Santo Tomás de Leipzig. Realmente, fue la capacidad de comunicación de los músicos lo que me subyugó. Su gestualidad fue excepcional...todo lo contrario de lo que vi en una orquesta española 
interpretando los mismos conciertos. ¿Qué persona o personas deben ser los responsables de que esta gestualidad llegue a los espectadores?

AN: Evidentemente, depende de cada músico sentir esa necesidad expresiva que acabo de comentar. Lo que pasa es que si está aletargada por la tradición de una enseñanza restrictiva, el director de la orquesta puede potenciarla con sus consejos. Lo podemos ver claramente en la "Verbier Festival Music Camp Orchestra" dirigida por Alondra de la Parra, donde los jóvenes intérpretes manifiestan su entusiasmo tocando a menudo de pie y bailando ante una música tan alegre como es el Danzón $n^{\circ} 2$ de Márquez; o con la Orquesta BandArt dirigida desde el puesto de concertino por Gordan Nikolic, pues actúan de pie precisamente para potenciar al máximo la gestualidad. Y cada vez son más los cuartetos que actúan de pie, como el Emerson Strings Quartet, el Brodsky Quartet o el Apollon Musagete Quartet, pues son conscientes de que su mayor movilidad va en beneficio del carácter extravertido de la obra. Por otro lado, empiezan a haber orquestas que contratan los servicios de un actor o de un director de escena para trabajar aspectos relacionados con la actitud escénica de los músicos, desde que pisan el escenario hasta que lo abandonan.

En relación a la vivencia que usted comenta en Alemania, independientemente de la actitud de los intérpretes, el lugar del concierto puede influir para que se cree una magia especial. Disponemos de un emocionante testimonio, en forma de vídeo, de un recital del pianista András Schiff celebrado en la Iglesia Protestante de Leipzig, ciudad donde precisamente se compuso la colección de las Suites francesas de Johann Sebastian Bach, que era el programa del concierto. Antes de iniciar el recital, permaneció unos momentos pensativo con sus manos entrelazadas como si se tratara de una plegaria, de lo que podemos deducir una actitud de reverencia al compositor en un lugar tan emblemático. Yo viví una experiencia cautivadora en la Basílica de Santa María del Pi en Barcelona, en un concierto dedicado a obras de Arvo Pärt y Bernat Vivancos, pues el coro de la Radio de Letonia creó tal magia en un lugar tan singular que al final del concierto me ocurrió lo que suele suceder a los espectadores de los países germánicos después de permanecer extasiado con obras de larga duración: la imposibilidad de aplaudir inmediatamente después de finalizar. Este es un aspecto interesante del concierto, y que yo denomino "el espíritu del directo". Hay filmaciones que recogen ese estado especial de los espectadores, como Claudio Abbado dirigiendo obras como el Requiem Alemán de Brahms o el Requiem de Mozart. 
Pero no hay duda de que la actitud de los intérpretes es vital. Una experiencia impactante para mí, y que fue uno de los desencadenantes de mi estudio sobre la gestualidad, fue observar los rostros serios de los músicos de una orquesta de cuerda profesional interpretando la alegre y vitalista Vistas al mar de Eduard Toldrà: nada más paradójico, contradictorio e inverosímil.

MM: La pregunta anterior, quiere hacer referencia a una determinada "dirección de actores". Esto pasa en el teatro... ¿cree que en los conciertos, sobre todo los que se van a filmar, es importante que exista este papel? ¿Ve importante un diálogo entre el director de orquesta y el realizador, por ejemplo, para afrontar la filmación?

AN: En principio no tiene que haber diferencias entre una interpretación sin o con filmación, pues la necesidad gestual expresiva debe ser siempre inherente al intérprete como condición sine qua non y, por tanto, sin necesidad de que haya un "director de actores". No obstante, siempre es interesante que el director de orquesta pueda dar pistas al realizador de aquellos momentos musicales especialmente interesantes que pueden ser debidos a un instrumentista en particular o al propio director, dando por descontado la conveniencia de que la filmación siga a los instrumentos por el discurrir de la partitura.

MM: Está claro que para nosotros, los profesionales de la imagen, independientemente de la importancia del "gesto técnico", es el "gesto expresivo" el que nos ayudará a obtener una filmación más atrayente. Pero, ¿cómo trabaja usted o qué elementos son importantes para dicha comunicación?

AN: Tanto como pianista como profesor, considero que el aspecto fundamental consiste en captar el carácter de la música o, en todo caso -pues no siempre es tan evidente-, asignarle el que nosotros pensemos que puede tener; a partir de ahí, se trata de vivirlo interiormente para que salga también a relucir al exterior. Tenemos infinidad de caracteres extravertidos o introvertidos por los que optar; pero además, también hay que dar su importancia a elementos del discurso musical, como son la vivencia de los silencios, el poner en evidencia los ritmos sincopados o los puntos culminantes, o ser sensible a los enlaces entre los movimientos de las obras, entre otros elementos. 


\title{
MM: ¿Podría hacerme una valoración general de cómo ve las filmaciones de conciertos de música clásica? Es decir, cuando usted se dispone a visionar un concierto filmado o retransmitido en directo, ¿qué valora tanto desde el punto de vista de músico como de especialista en la gestualidad del intérprete?
}

\begin{abstract}
AN: Valoro, sobre todo, que se vea la imagen frontal del intérprete que está actuando en cada momento, pues así puedo apreciar su expresión corporal y facial. Y si se trata de una agrupación, lo ideal es que el intérprete escogido por el realizador no tenga la vista en la partitura sino en el director o en sus compañeros; así, podremos apreciar mejor su gestualidad facial y, musicalmente, tiene más coherencia como diálogo musical. Por descontado, también valoro que la filmación, cuando se trata de una orquesta, vaya siguiendo a los instrumentistas que intervienen en cada momento. También es interesante filmar a un solista que, aunque no esté tocando en ese momento, le vemos inmerso totalmente en la música, en lo que yo denomino "vivencia de espera", como ocurre con los pianistas Mitsuko Uchida, Krystian Zimerman, Kathia Buniatishvili, las violinistas Sara Chang y Patricia Kopatchinskaja, la violonchelista Sol Gabetta, o la trompetista Alison Balsom, por citar algunos de los instrumentistas que se caracterizan por valorar esta actitud.
\end{abstract}

Otro momento interesante para el realizador es captar la gestualidad del intérprete cuando llega un silencio repentino, pues el carácter que contiene, proveniente de la música precedente (dramatismo, interrogación, sorpresa, humor, duda, solemnidad, meditación...), puede ser potenciada con el tipo de inmovilidad y de actitud del músico.

Pero por desgracia, en la mayoría de filmaciones de pianistas y de instrumentistas de cuerda y de viento, los realizadores abusan del enfoque de las manos, privándonos lamentablemente del mayor goce que produce la observación de los movimientos expresivos del cuerpo y del rostro en particular. A mi modo de ver, este enfoque de la cámara sería comparable a mirar las pequeñas pinceladas del pintor en un cuadro, y sólo estaría justificado si se hiciera con la finalidad de realizar un estudio de tipo técnico. Voy a citar varios ejemplos que claman al cielo: un realizador, sabedor de la gran facilidad técnica del pianista György Cziffra, se concentra en un plano único de las manos revoloteando sobre el teclado mientras que interpreta el Grand Galop Chromatique de Liszt. En el vídeo que contiene los Estudios de Debussy interpretados por Mitsuko Uchida no hay ni un solo enfoque frontal, precisamente siendo una pianista de gran expresividad facial; y en contadas ocasiones lo tenemos en el vídeo del pianista Krystian Zimerman interpretando obras de Chopin. En el conocido vídeo del concierto del pianista Grigory Sokolov en París, el enfoque desde su espalda apenas 
recoge a vislumbrar las manos y su perfil. Y un caso mucho más incongruente lo encontramos en el vídeo titulado Alfred Brendel On Music. Three Lectures, donde Brendel comenta la connotación gestual del carácter gracioso en el segundo movimiento de la Sonata op.31 $n^{\circ} 1$ (Andante grazioso) de Beethoven, pues justo cuando lo interpreta al piano, la filmación se queda incomprensiblemente con el plano de sus manos.

El realizador debe estar atento, cuando filma a una agrupación camerística, de que los músicos no se tapen unos a otros. Especialmente, en el caso de un dúo con piano, me parece una descortesía que se tape sistemáticamente al pianista, pues tenemos el derecho a disfrutar de su gestualidad.

Se puede dar el caso de que el intérprete cause una gran fascinación en el público-como ocurría con el pianista Van Cliburn- por lo que aceptaría de buen grado que la cámara se apartase del intérprete por unos instantes para recrearse con alguna persona extasiada y reflejar así el ambiente tan especial.

Como conclusión, soy muy crítico con las filmaciones en que se apartan enseguida de la imagen facial del intérprete, pues me priva del placer que produce su comunicación visual, relegándome al placer parcial que ocasiona la música fonográfica.

MM: ¿Usted considera los primeros planos de los músicos como planos básicamente pedagógicos?

AN: Los planos frontales y cercanos de un músico, que raramente los podemos encontrar en una sala de conciertos, pueden llevarnos a concentrar demasiado la atención en las expresiones faciales, distrayéndonos del resultado global, por lo que conviene considerarlos sobre todo desde un punto de vista pedagógico. Dicho esto, podemos disfrutar mucho con ellos: me encanta la toma frontal de los pianistas, y cuando voy a un concierto intento situarme buscando el contacto visual con él: observar las manos moviéndose por el teclado apenas me interesa. 


\section{Entrevista Xavier Garasa, realizador Televisió de Catalunya}

(Sant Joan Despí, septiembre de 2017)

Marta Millà (MM): Para situar un poco tu mundo profesional...hace años, cuando aún no te conocía, ya oía hablar de ti como el realizador experto en multicámara, incluso con alguna que otra entrevista en algún medio de comunicación. ¿Cómo empezaste a trabajar en multicámara en el medio audiovisual? ¿Cuál fue tu primera producción?

Xavier Garasa (XG): Bueno, yo empecé en realidad a los 17 años en TVE (Televisión Española), donde estuve durante 3 años y, ahí, empezó mi primer contacto con el mundo de la multicámara por mi afición al fútbol. Allí, como mero observador porque, de hecho, mi trabajo era como de tercer o cuarto ayudante de una retransmisión. En televisión había meritorios y, entonces, la escalera era bastante larga para subir; pero sí que aproveché un poco para empezar a contaminarme de fútbol, en concreto, y, sobretodo, la multicámara, como especialidad de televisión.

(MM): Mi trabajo de investigación, parte, de hecho, del mundo del fútbol. He dividido la tarea del realizador en dos tipos de trabajo previo: la táctica y la estrategia. Evidentemente, sabrás a qué me refiero; la táctica como posicionamiento y la estrategia como el juego entre los jugadores. Yo me refiero a la táctica como posicionamiento de cámaras y a la estrategia como la manera de crear juego. Para ti, qué es primero cuándo te proponen una realización, ¿la táctica o la estrategia?

(evidentemente, dejo de lado partidos de la Champions donde todo es normativo o partidos que se realicen en el Camp Nou, supongo que conocidísimo por ti y, por tanto, con poca táctica que pensar)

Xavier Garasa: Primero...táctica y estrategia es similar. Antes de empezar una producción, aunque se pueda pensar que es repetitiva y, en el caso del fútbol, que cada partido puede ser igual...yo creo que no. Antes de hacer una táctica o una estrategia hay que documentarse y esto es aplicable a cualquier producción. Entonces, para documentarse hay que ver, en el caso de un partido de fútbol, qué elementos tiene este partido de fútbol que lo hace diferente a los demás o qué lectura quiero hacer yo de este partido de fútbol y qué táctica voy a hacer yo luego para explicar este partido de fútbol y que, con la táctica que yo haga, se entienda de la manera que yo quería que se representase. Esto es aplicable a cualquier producción y, también, a un concierto. Para retratar bien un concierto o para grabar bien un concierto pues, 
efectivamente, si tienes los conocimientos suficientes, pues mirar las partituras, los instrumentos o el rider que hay; pensar detenidamente en función de los medios que tienes, cómo vas a utilizar o qué cámaras o qué sitios vas a priorizar en el escenario. Esto no se puede aplicar sistemáticamente porque ya lo has hecho en otro concierto, sino que yo creo que es diferente hacer un concierto de un grupo de folk que hacer un concierto, con un pianista o con una orquesta sinfónica. Entonces, cada sitio, cada evento tiene una disposición diferente que si conoces, te has documentado y has estudiado, pues luego puedes aplicar la táctica con los conocimientos que tengas.

(MM): Siguiendo con el símil del mundo del fútbol, en un partido, el ritmo lo marca el mismo partido -seguramente muchos espectadores sabrían diagnosticar un partido como aburrido y falta de ritmo o, al contrario, un partido cuyo dinamismo hace que el espectador siga en la pantalla-; sin embargo, ¿puedes, como realizador, modificar el ritmo visual sea como sea el "juego"?

(XG): El caso del fútbol es un mundo un poco particular porque todo el mundo sabe mucho de fútbol. Antes que hablábamos un poco de la táctica y de la documentación, yo creo que, en función del partido, tú tienes que inventarte un ritmo diferente. Es más en función del partido que no del tipo de juego que hagan. Un Barça-Madrid se tiene que realizar de una manera concreta, no puedes darle un ritmo que tú quieras sino que tienes que seguir el ritmo que te marcan los jugadores. Quiero decir: si en un Barça-Madrid tú haces "boniquismos", das más información de la necesaria o si lo quieres adornar con excesivas repeticiones o planos cortos, por muy bonitos que sean, la gente en un Barça-Madrid lo que quiere ver es el plano general y dónde está el balón. Esto, uno. Y, por otra parte, quiere ver toda la polémica, que con repeticiones tú satisfagas lo suficiente como para que quede esclarecido. En un Barça-Madrid tienes que hacer esto y en un partido en general importante, esto sería el número uno.

Yo me acuerdo una vez que tuve la oportunidad de ir a Estados Unidos que los realizadores del básquet decían: "si yo tengo un director- para ellos realizador es lo mismo- que se pierde algún momento del juego cuando el balón está en movimiento, lo cambio”. Esto sería la mentalidad para un partido de fútbol importante. Luego, hay otros partidos de fútbol que por el ritmo que tengan, por la calidad diferente, por la trascendencia, que sí que puedes tú forzar un poquito, si el partido está aburrido: vamos a hacer más repeticiones, vamos a hacer más

\footnotetext{
${ }^{1}$ Con este substantivo se denominan aquellos planos no tan descriptivos sino estéticos.
} 
detalles o vamos a seguir el juego más desde abajo para tener otro ángulo más vistoso. Por supuesto que se puede alterar un poco el ritmo.

(MM): Y, en un concierto, ¿en qué medios piensas para dar el ritmo que tú deseas a un concierto?

(XG): En un concierto, si pudiera pedir y si estuviésemos en televisiones ricas, pediría que todas las cámaras tuviesen movimiento: spydercam, travelling, grúas... a mí me cuesta mucho ver una producción musical con planos estáticos; y luego, también evitar planos muy frontales que aplastan mucho. Pero, en general, el tema movimiento, tanto mecánico, por ejes o por zoom, porque a veces, sin movimiento de pedestal también se puede buscar movimiento: teleobjetivos, zoom, movimiento de cámara.

(MM): ¿Crees que ritmo musical es igual que ritmo audiovisual? ¿deben ir a la par? Me refiero a imágenes lentas, movimientos lentos...¿Estaría bien romper e ir un poco más allá? ¿Cómo lo ves?

(XG): A mí me gusta siempre dar los contrapuntos en todo. En una tertulia me gusta muchas veces más ver el que está escuchando que el que está hablando; prefiero ver la reacción que tiene el que está escuchando porque está escuchando alguna cosa que lo alude a él en directo que no, ver el que está hablando sobre el otro. En un concierto de música puede ser lo mismo. Está bien en momentos más puntuales quizás ver cómo se está preparando la trompeta que ver tocar la trompeta y combinar un poco los recursos que tengas y adaptándolos al lenguaje televisivo que quieras dar en cada momento.

(MM): ¿En una realización de cualquier producto audiovisual existe "una buena dosis de renuncia", también en la realización audiovisual de un concierto de música clásica nos encontramos con la mirada discriminatoria de un realizador. ¿Qué es lo que te determina como realizador para descartar planos? O, al contrario, ¿qué es lo que no dejarías que se perdiera el espectador audiovisual en la realización de un concierto? Puedes poner un ejemplo concreto.

(XG): Se tiene que renunciar siempre a algo y, a veces, no es nada muy preparado. Siguiendo en ese momento la intuición y siguiendo que la cámara te está mirando a tí de manera particular, por atracción o por simbiosis o por lo que sea, pues acabas yendo a esa càmara. Muchas veces también por precedentes o porque tienes un déja vu que, de repente dices, me va a funcionar mejor eso.

(MM): Bueno, la experiencia profesional y la intuición, ¿no? 
(XG): Sí.

(MM): Una vez un técnico de sonido, gran profesional que graba conciertos de música, me comentó que "menos es más". Es decir, una buena grabación no significa poner muchos micrófonos, sino pocos y bien colocados. ¿Piensas lo mismo de las cámaras?

(XG): Bueno, yo creo que es diferente el sonido que la imagen. En el sonido, aparte de la posición en que pongas los "micros", es la calidad del "micro". Si tú, en un concierto de clásica pones un buen "micro", bien puesto, te capta más que 12 "micros" malos. En las cámaras no es tanto, yo creo que cuantas más cámaras, mejor.

(MM): Después de haber trabajado con distintos realizadores...¿me puedes decir cuál es la estrategia que usas tú para ver todas las cámaras en la Unidad Móvil? Según Robert...normalmente, los realizadores ven las 3 cámaras centrales, eso dificulta la realización. Con otra pregunta...¿cómo puedes mantener el flow de la realización?

(XG): Bueno, el truco es primero la experiencia de muchos años de haberlo hecho; luego, hay un truco claro que es prepararse muy bien la retransmisión y saber muy bien lo que quieres hacer porque luego, como has dicho antes, pues muchas veces no hay tiempo y, el concierto, el evento pasa volando y muchas veces acabas haciendo cosas que no habías planificado y, al revés, quieres hacer muchas cosas y se te quedan en un saco roto porque no puedes ejecutarlas. Yo me organizo intentando estar en medio del escenario del sitio en concreto tanto en la unidad móvil como en mi cabeza sitúo las cámaras a la derecha o a la izquierda de ese eje central y entonces así me organizo mejor y sé qué cámaras voy a pinchar en función de donde esté la jugada o la situación o el foco de atención del evento en concreto. Esta es una organización básica de cámaras. Es básico el conocimiento de dónde están las cámaras. Hay gente que cuando mira los monitores no sabe qué cámara está dando ese plano. Si tú no le pones el número que pone el monitor y le preguntas: ¿qué cámara es ese plano? Seguro que no lo sabrán. Yo sé, cuando planifico un concierto, qué cámara está dando el plano. Eso es una ventaja, una ventaja de experiencia, tampoco no es que sea...yo lo he hecho muchos años y también es trabajo de planificación y de pensar. Antes del concierto hacer la táctica; antes, cuando hablábamos de la táctica, esa es mi táctica para que luego pueda dar una rápida ejecución de lo que quiero transmitir.

(MM): Según lo que me has comentado de Estados Unidos, ¿para ti cuál sería el balón en un concierto de música clásica?

(XG): El concertino. 
(MM): Ya, pero... aquello que no te querrías perder; o sea el concertino es fundamental pero me refiero a aquello que crees que un espectador no te perdonaría que en este momento no enseñaras. ¿O crees que hay una parte artística...?

(XG): Yo creo que no hay nada indispensable y que todo es necesario. Entonces, que cada momento se puede dar algo clave...pero, no hay nada que sea clave absolutamente.

(MM): Pues ya estamos. Muchas gracias. 


\section{EVALUACIÓN ROBERT GUMMLICH}

\section{Realizador Digital Konzert Hall}

\section{(Evaluación y comentarios recibidos por correo electrónico, 1-Julio-2013)}

He querido incluir, con el permiso de Robert Gummlich, esta evaluación y comentarios sobre el trabajo realizado en la filmación de un concierto de Jordi Savall en julio del 2013 porque pienso que es un análisis muy valioso por parte de uno de los realizadores que forman parte del equipo de la Digital Konzert Hall.

\section{Hi Marta,}

thank you once again for this great opportunity you offered us with this visit in Barcelona. We enjoyed it very much and I do hope that we will stay in touch, personally as well as professionally.

I was really impressed about the quality and size of TV3 as I told you before: In Germany regional stations sometimes exist only in some small blue-box-studios. So: Wow! Very impressing. All: The bandwidth of your programms, the technical standard and the great staff that seem to work very professionally.

I think that all of you work very well together as a team. For me this is the most important aspect that there is no aggression or anger during the recordings. Of course sometimes someone starts to speak louder, but I liked to see that especially Toni, Pep and you seem to know quite well how to interact and work together. And you laughed and spoke together afterwards.

Of course it was a very difficult production situation for you, but I remember when I worked as Assistant Director, I always wished to have one more day to prepare everything better. You never have enough time to be perfectly prepared, I think that is part of our job ;-D Speaking of that I liked very much the way you dealt with this situation, because you didn't panic, but concentrated very hard to make the best out of it! Very good! And you even found time to take care of Anja \& me, even better! I don't think I could have done that.

I think there are two kinds of people: One group looses their nerves in stress-situations and do not reach their potential. These people also fail in examinations etc. The other group has the 
ability to concentrate harder in stressful situations and can activate higher creativity than in normal situations. The second group is typically born for the stage or tv-live-work, but also surgeons or pilots need this ability (but often fail in "normal" life, because they miss the adrenaline during housework or tax-work ;-D). I belong clearly to the second group (even as a child I only play the piano concentrated in front of the audience and never at home). And I think that you belong to the second group as well.

So much about your person and work.

About the production in general: It was better than I expected and I am sure that after some postproduction the result will be honestly ok. That is because you have a very good cameracrew the found good pictures when you told them to. But the live mix was not following the music all the time, especially in the complex musical situations. After three or four shots "in the music" there followed a longer wide shot (during which Toni prepared the next shots). This does not produce the flow of pictures I try to create, when all the pictures during a production are exactly on the music. It is more like "in and out of the music", like waking up in between, loosing the flow.

And because of the improvisation Toni did not always use the best pictures but often only the ones from the middle (K5 / 6). I know the problem: You might loose the cameras, that are not directly in front of you, out of the focus when you are improvising. And I think especially the choir looked better from the sides in profiles.

And then there is a general thought: For me it is absolutely Director's work to choose the instruments, the angles and the shots. It is most important not only to have the right instrument. I also try to think if the music calls for a detail / close-up of an instrument or wide shots, pans or even a crane-movement. Or if I have to see only some faces of the choir or a large group. I try to hear this in the music when I do the preparations. So on the one hand Toni gives a lot of creative responsibility to Pep.

And if you improvise you can not think about these categories anyway but you have to take what you can get because you do not have the time to concentrate on the music and change camerapictures. So for me as a director I think I loose a great part of my creative tools if I only improvise.

But: I sometimes work with your system as well when we have to. For example when we broadcasted the "Magical flute" in March from the Berliner Philharmonie without rehearsal. 
Nanna did your you, Hannah arranged the cameras (we had a very simple but foolproof system) and I mixed the pictures. But I prefer to be prepared.

And this is the last thought: Preparations. You told me that you never use scripts in any productions situation. The result is that all of you together have to give the camera crew a lot of information in the right moment. And because in every mobile all over the world there are communication problems and the music is sometimes very loud and sometimes three persons talk at the same time, this creates a situation where misunderstandings and faults a to be expected. So I would think of doing a little paperwork (perhaps not a whole plan, but a small list for every cameraperson for every piece so she / he can concentrate on the tasks and prepare). For example:

\section{K 6 Jubilate}

1.) Violins

after cue from Marta (you only say: K 6 change to choir)

2.) Sopranos Choir

after cue

3.) Solo Sopran

etc.

Even if the cameraperson did not understand everything she / he knows where to go and the moment for a change.

It is the same system you use, so Toni does not need to learn anything new, but the advantage would be that you only have to check if the cameraperson is on the right picture and you have to talk less. And the cameraperson can "pre-think" about the next picture.

But of course: To write this down, you need all the information at least one day before production.

Robert Gummlich 
APÉNDICE III: Resultados encuestas 
De la partitura a la pantalla: plano y contraplano de una misma realidad - 344 


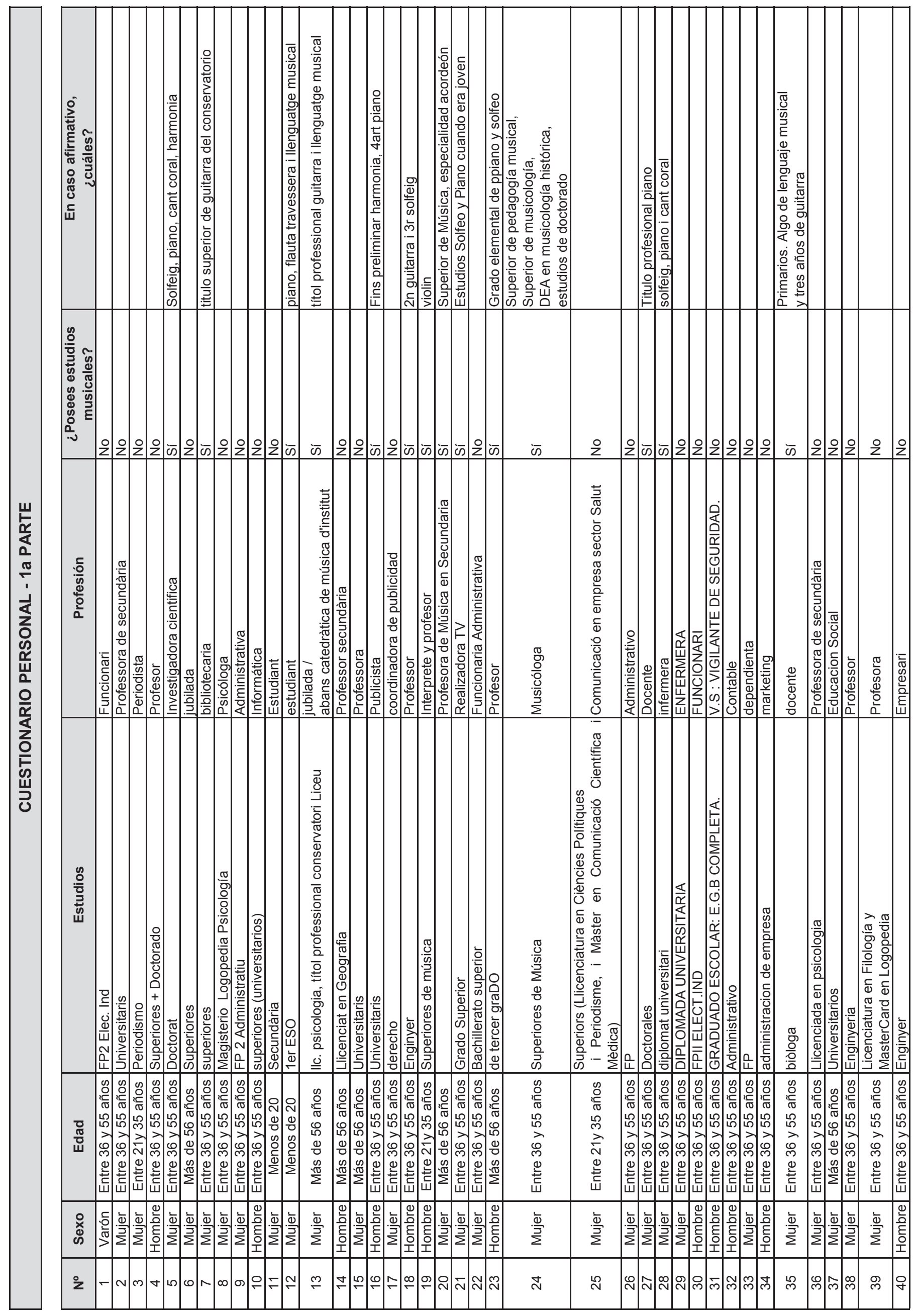




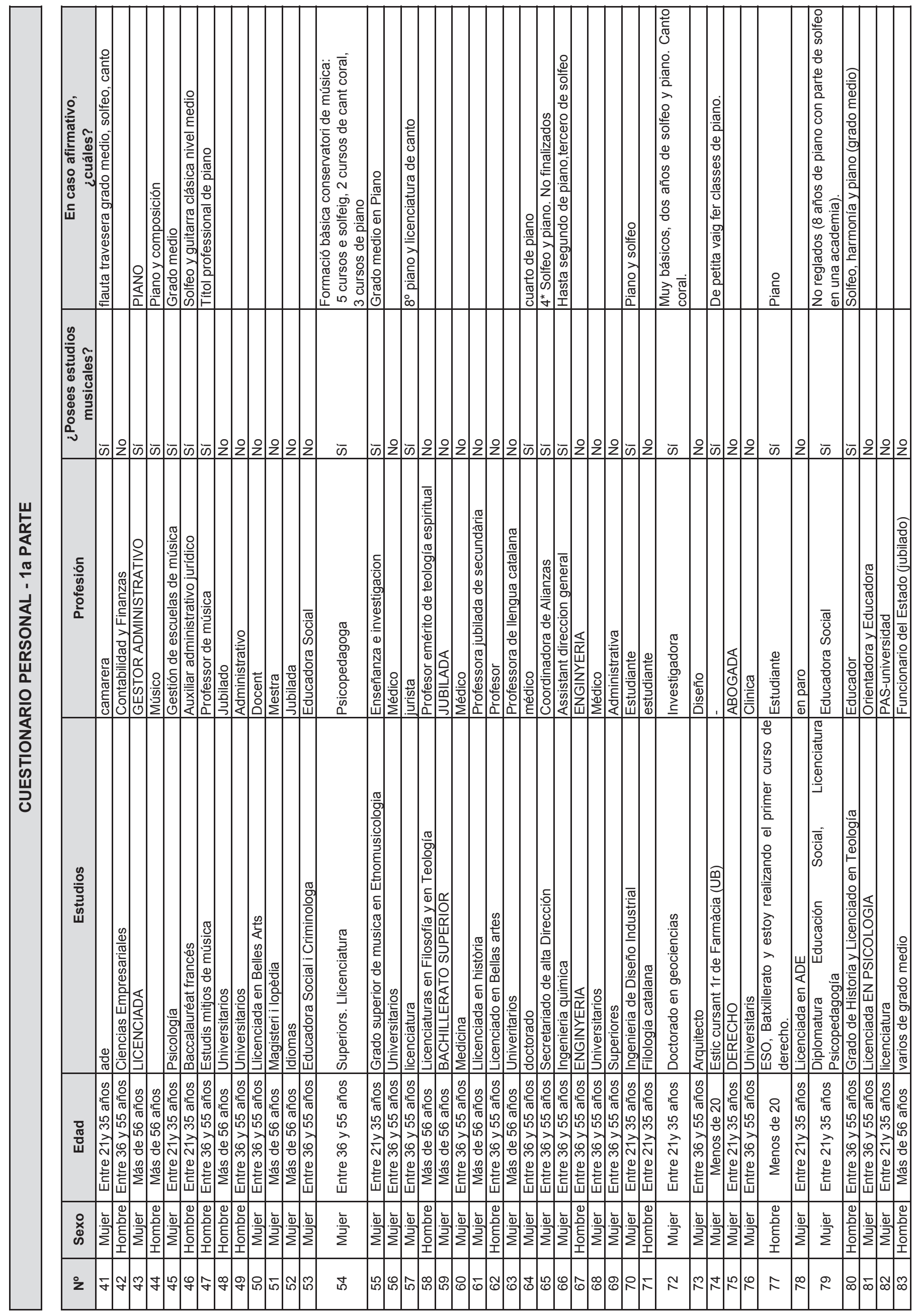




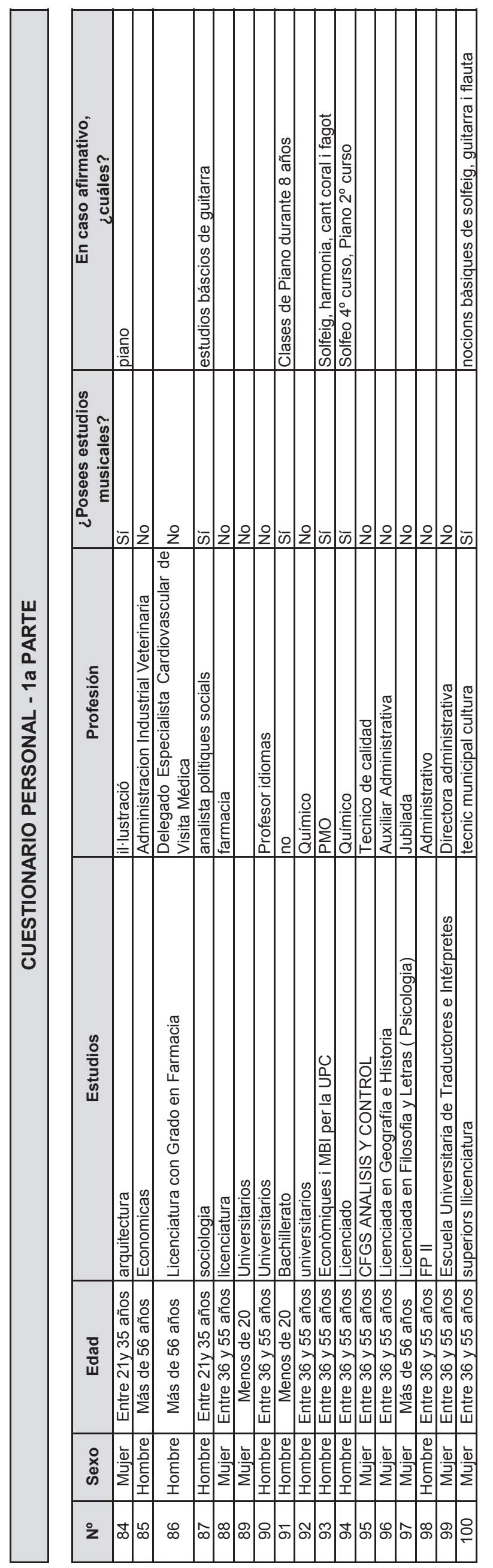

0
0
0
0
0
0
-5
$-\pi$
0 


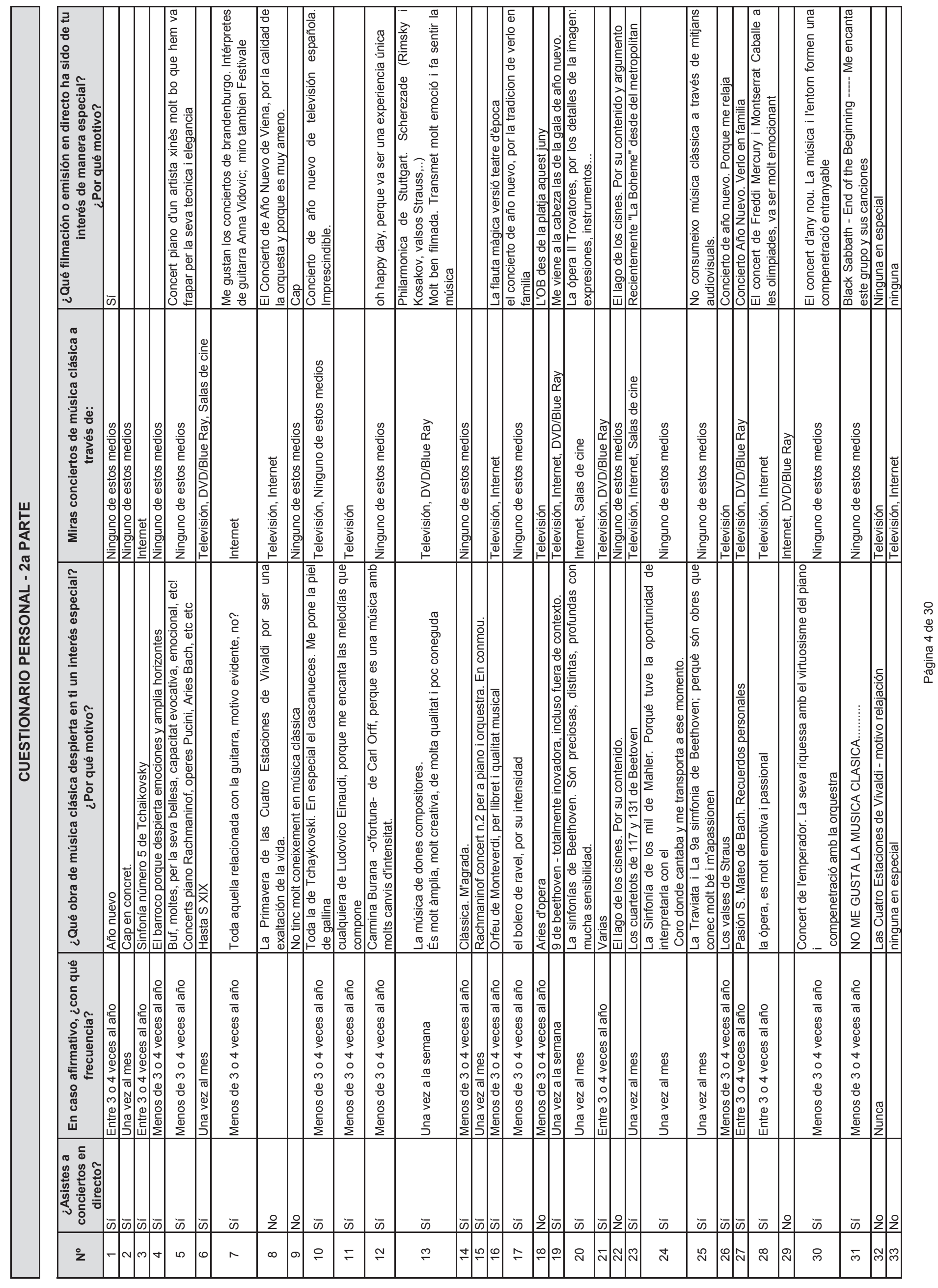




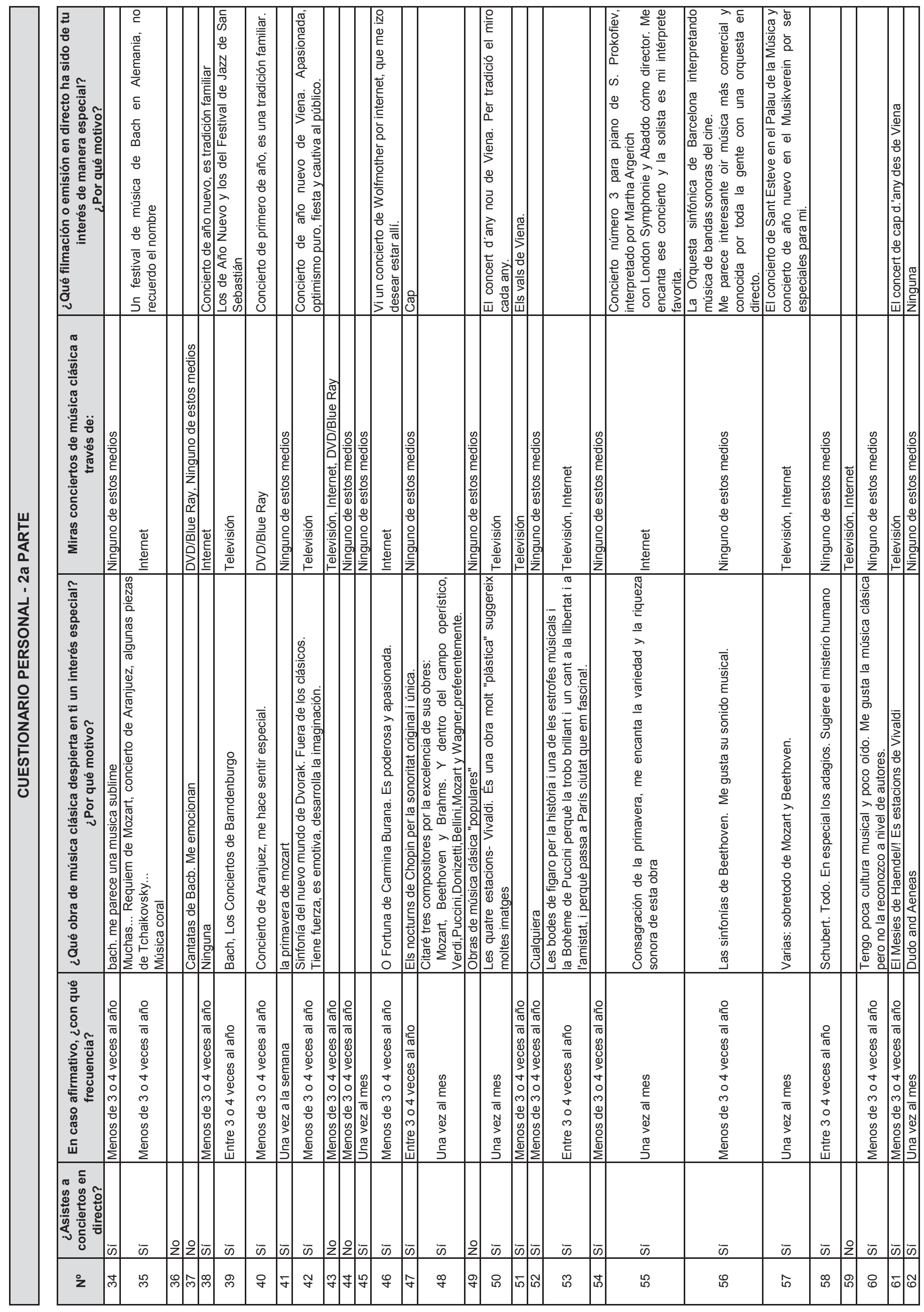




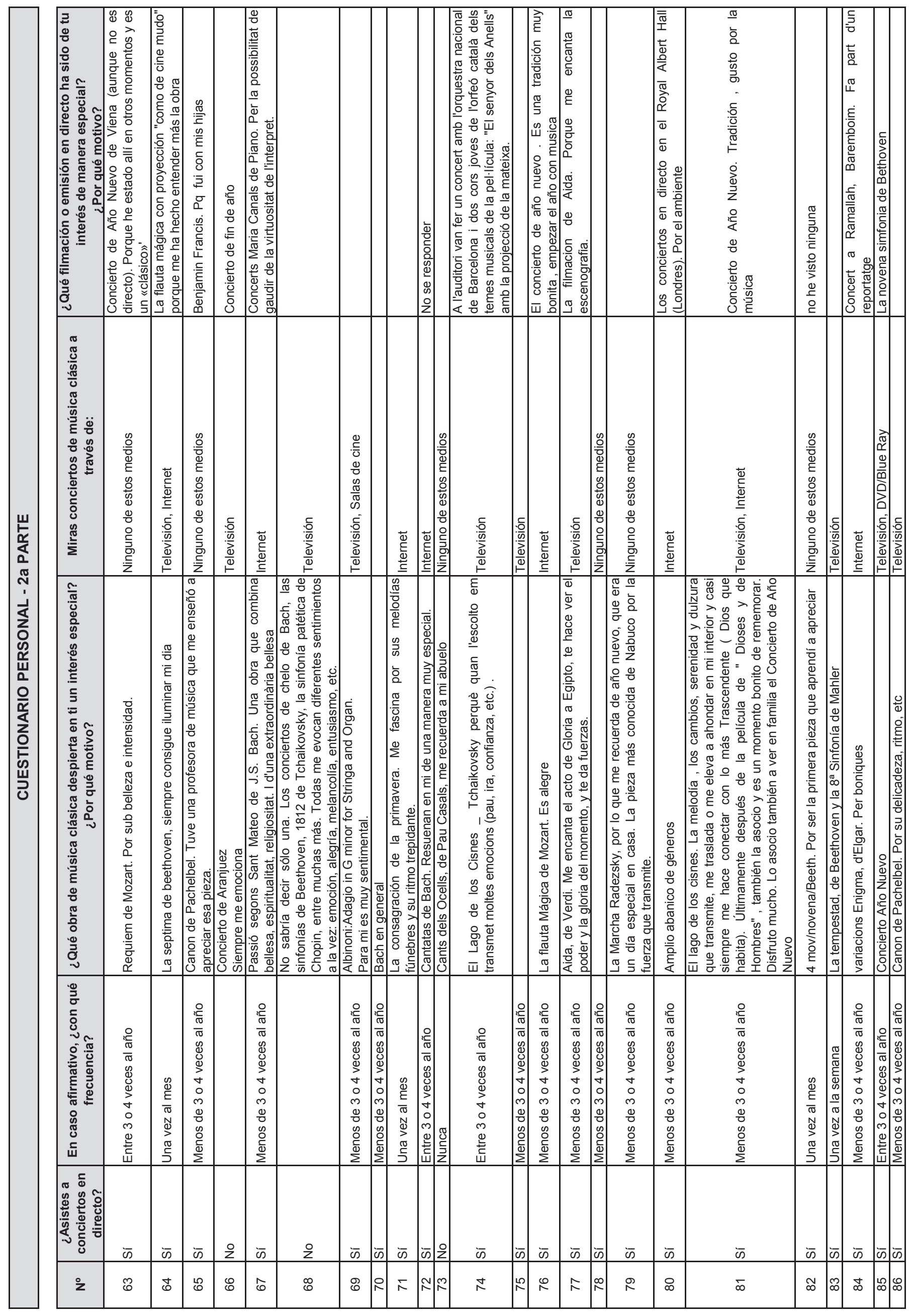




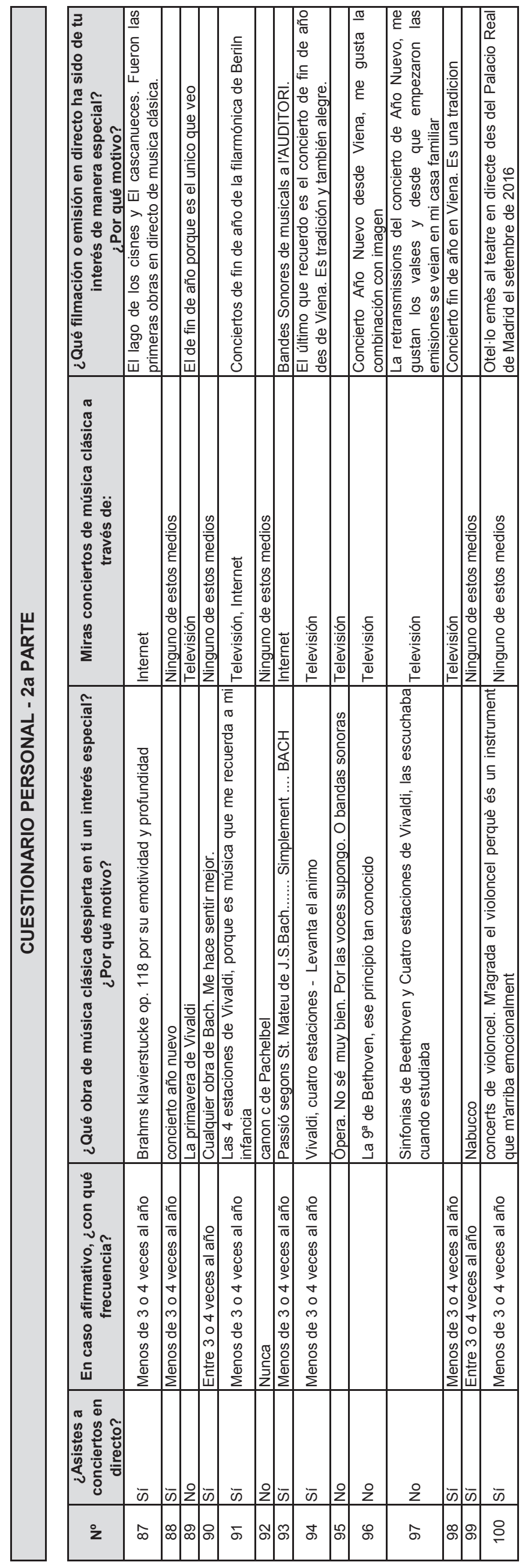

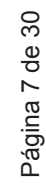




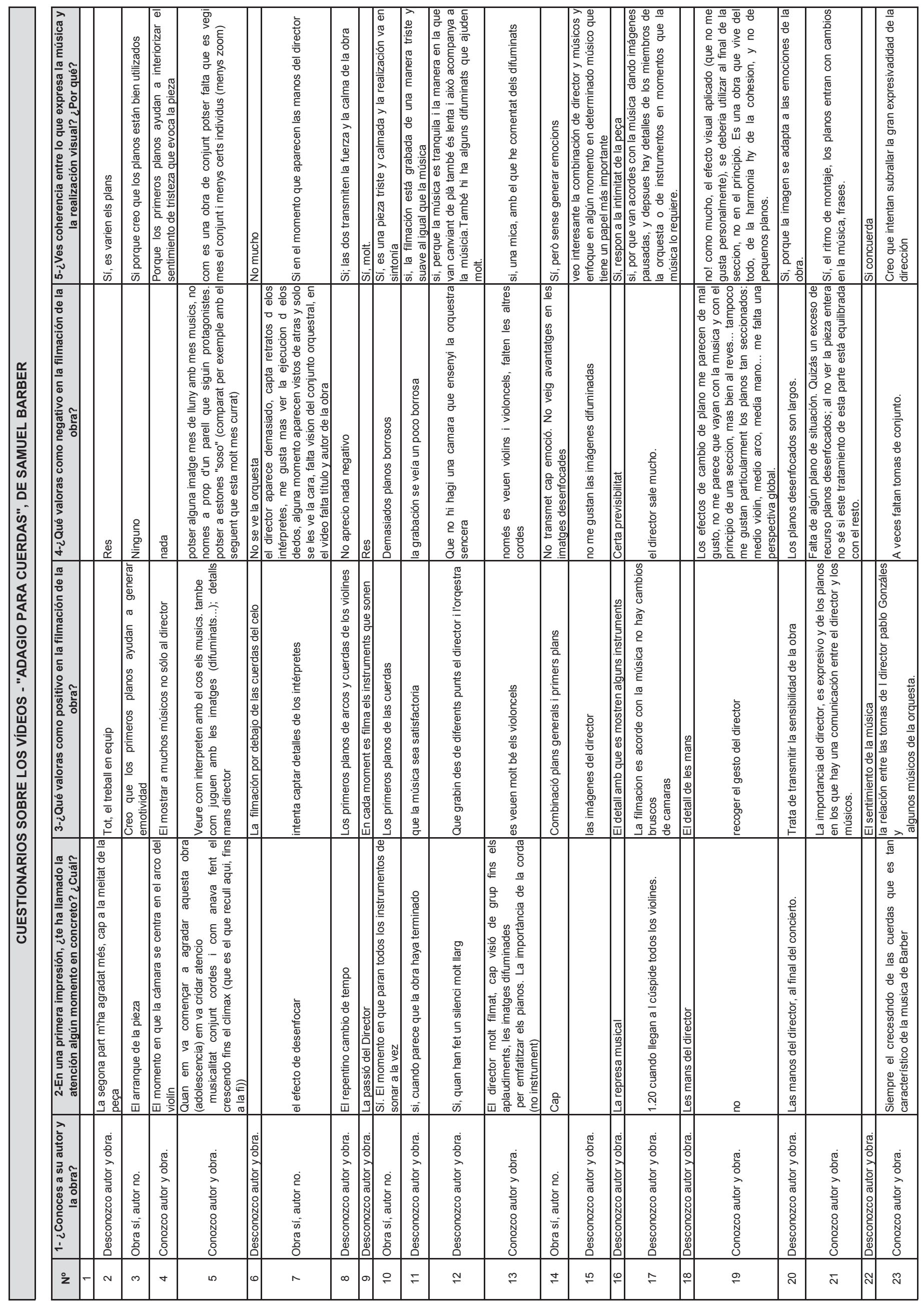




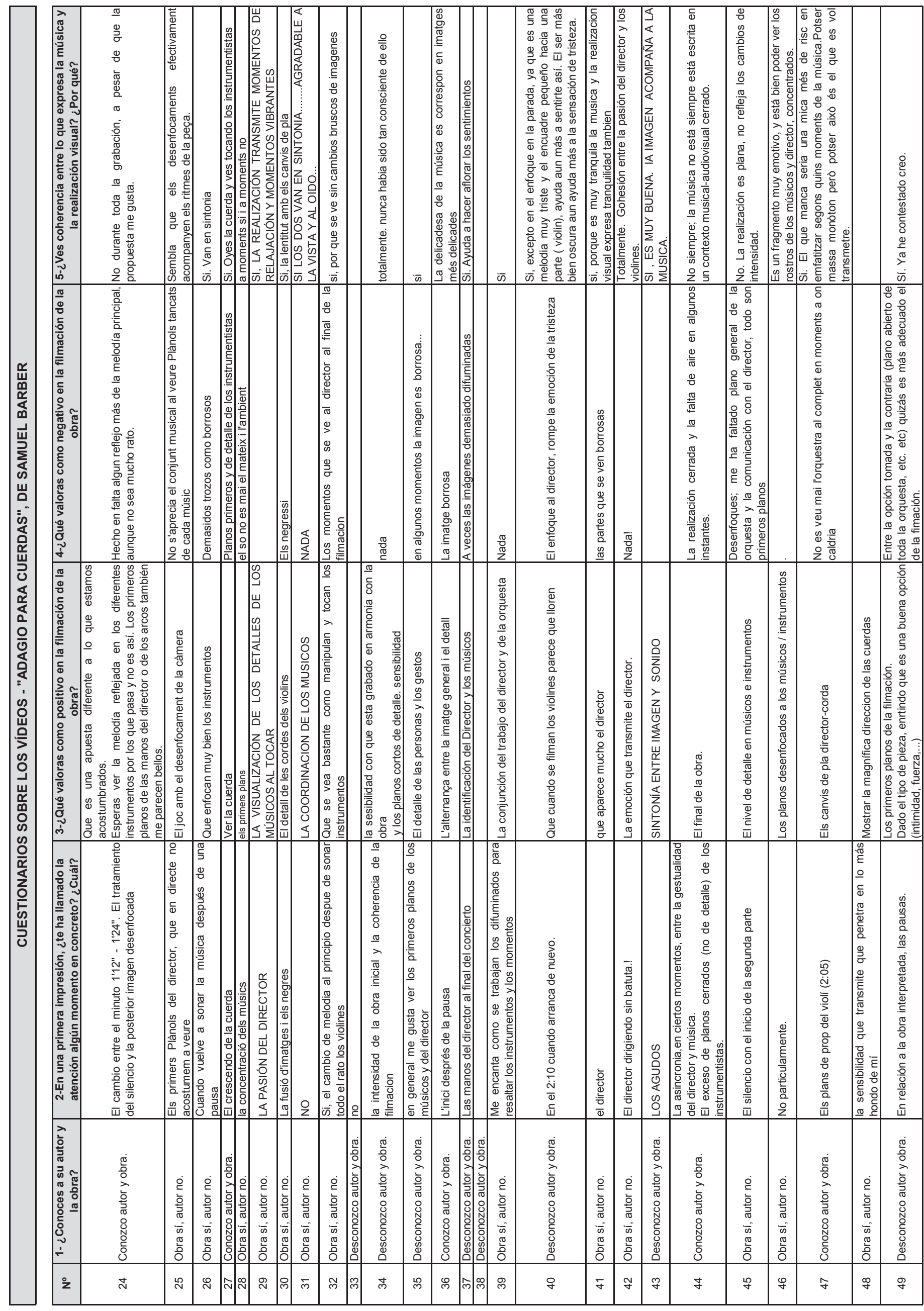




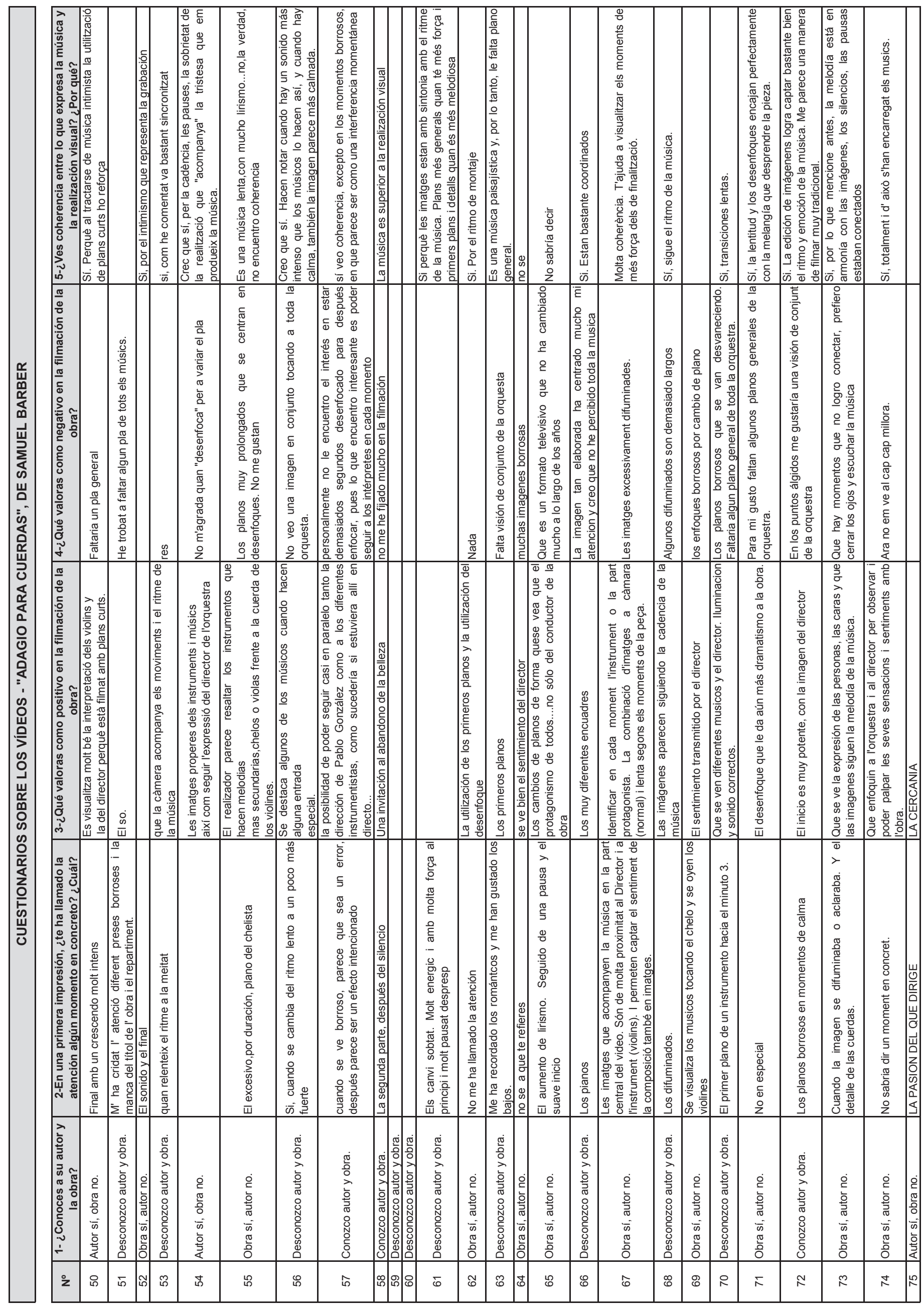




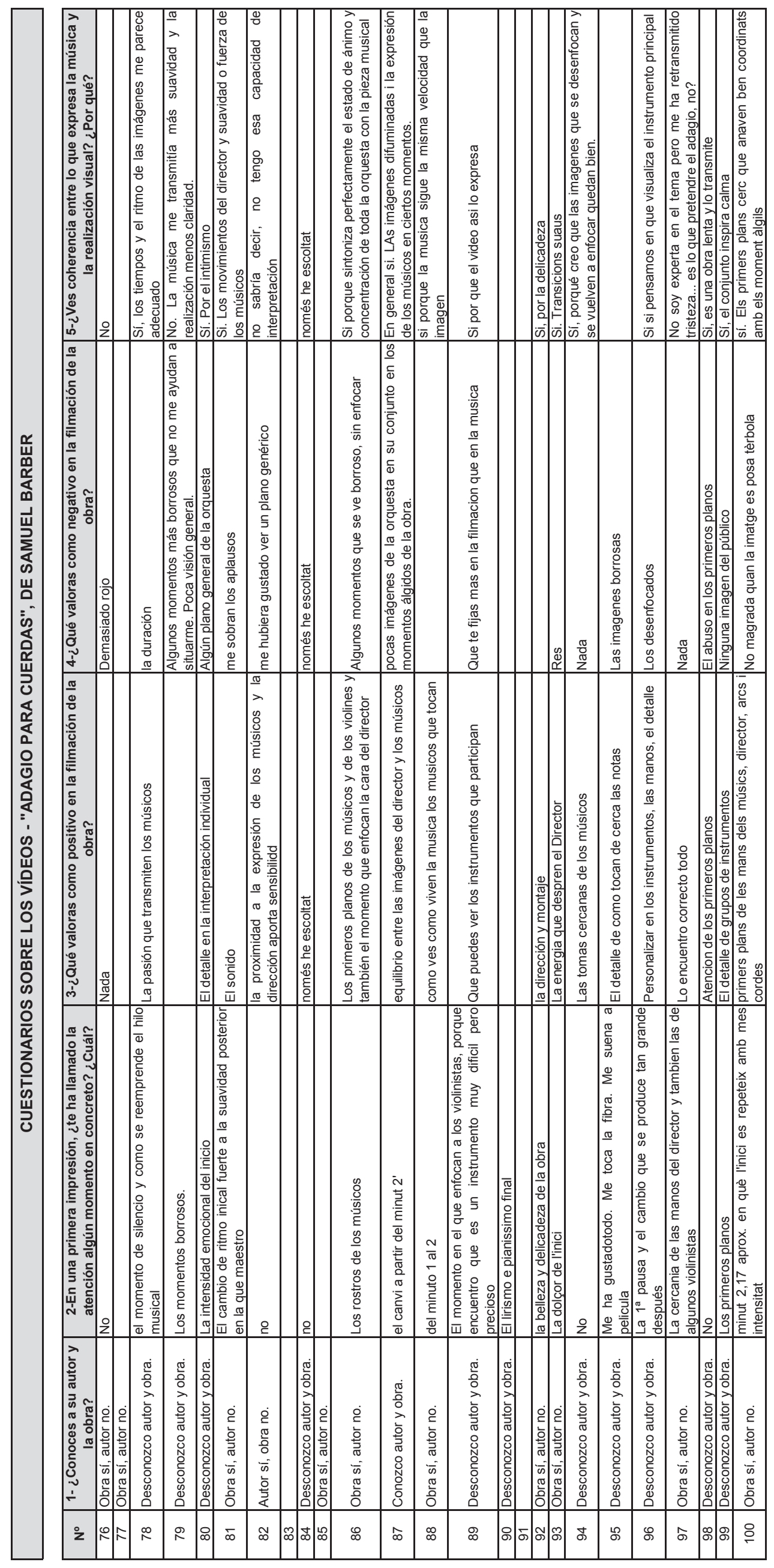




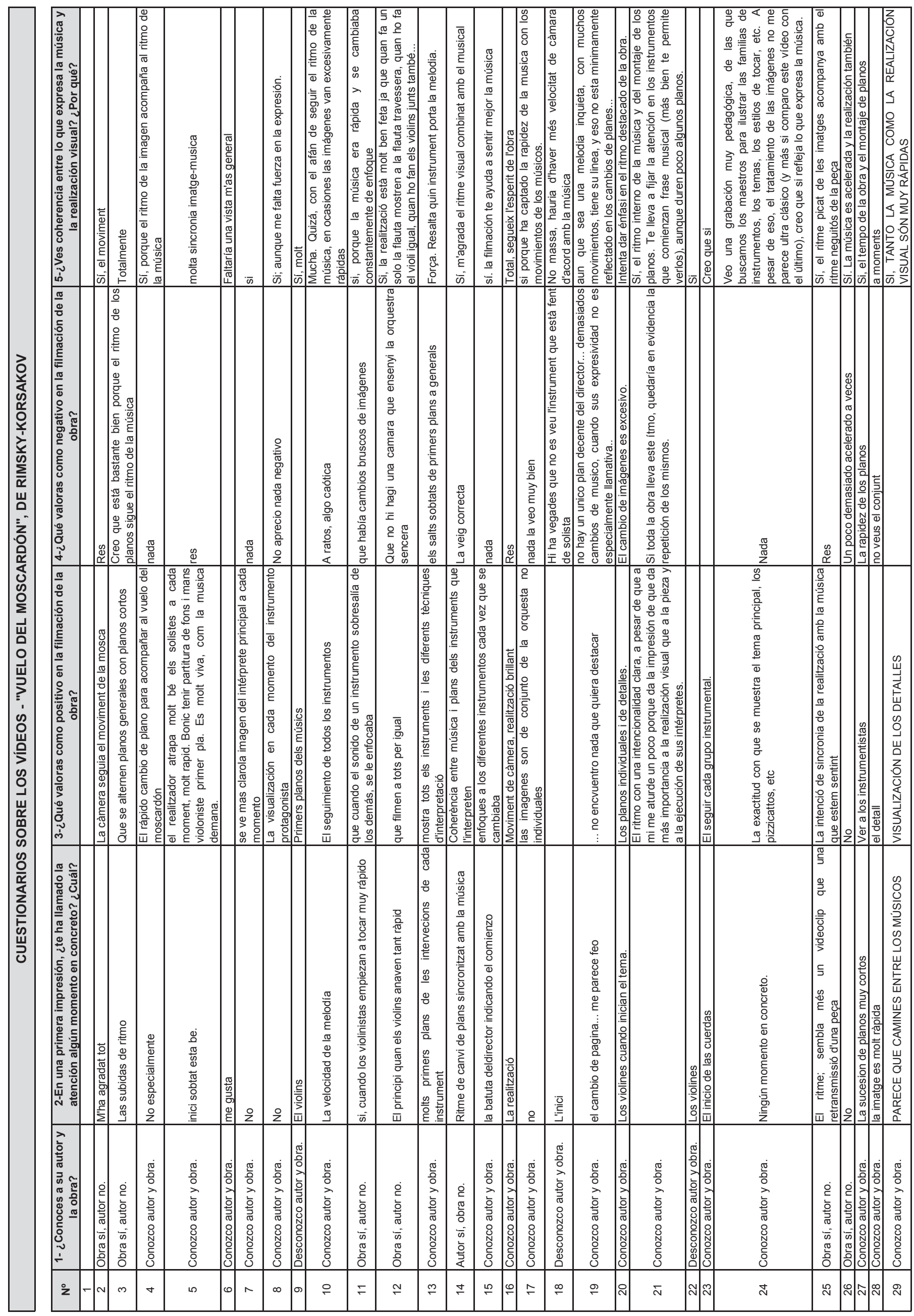




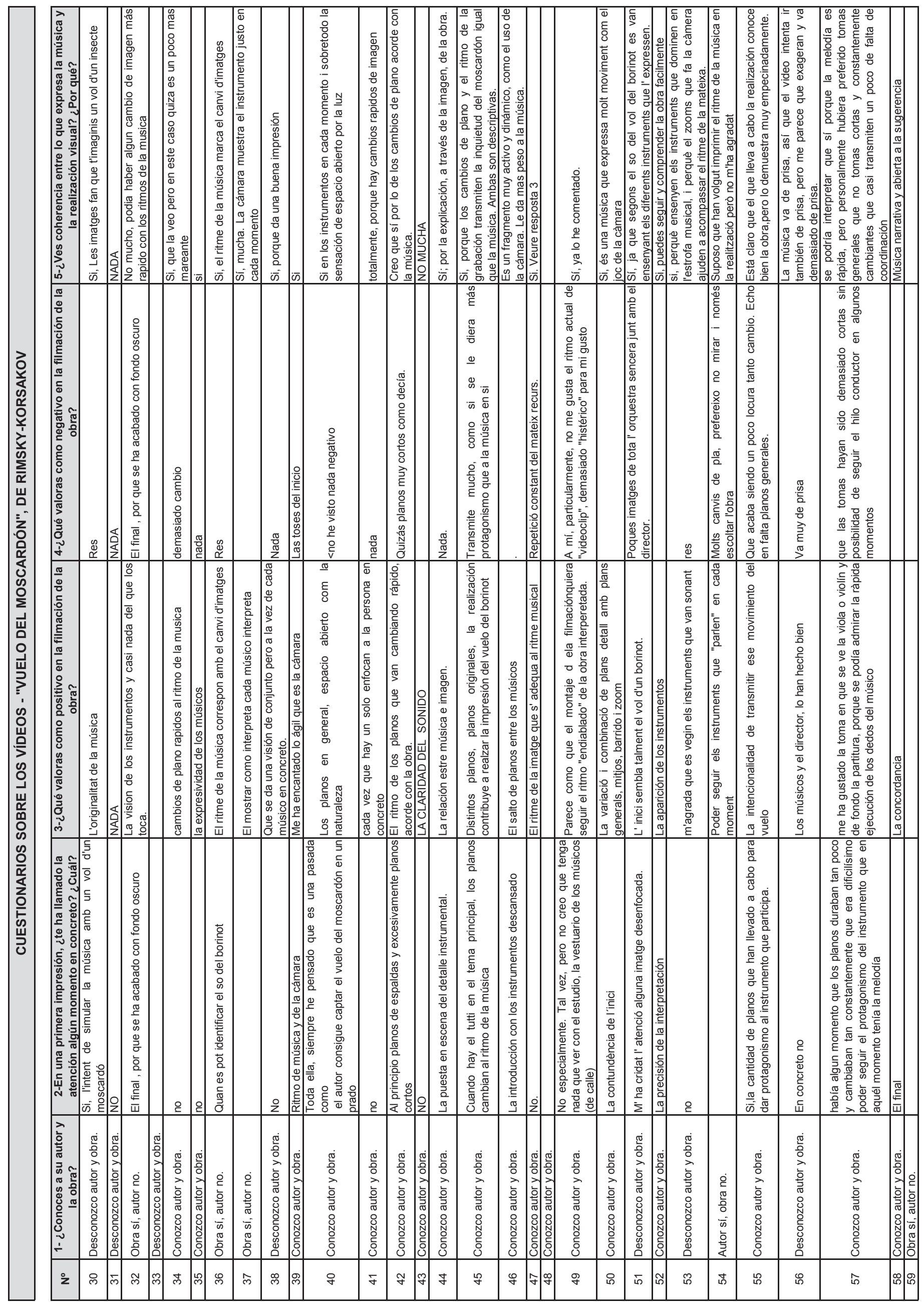




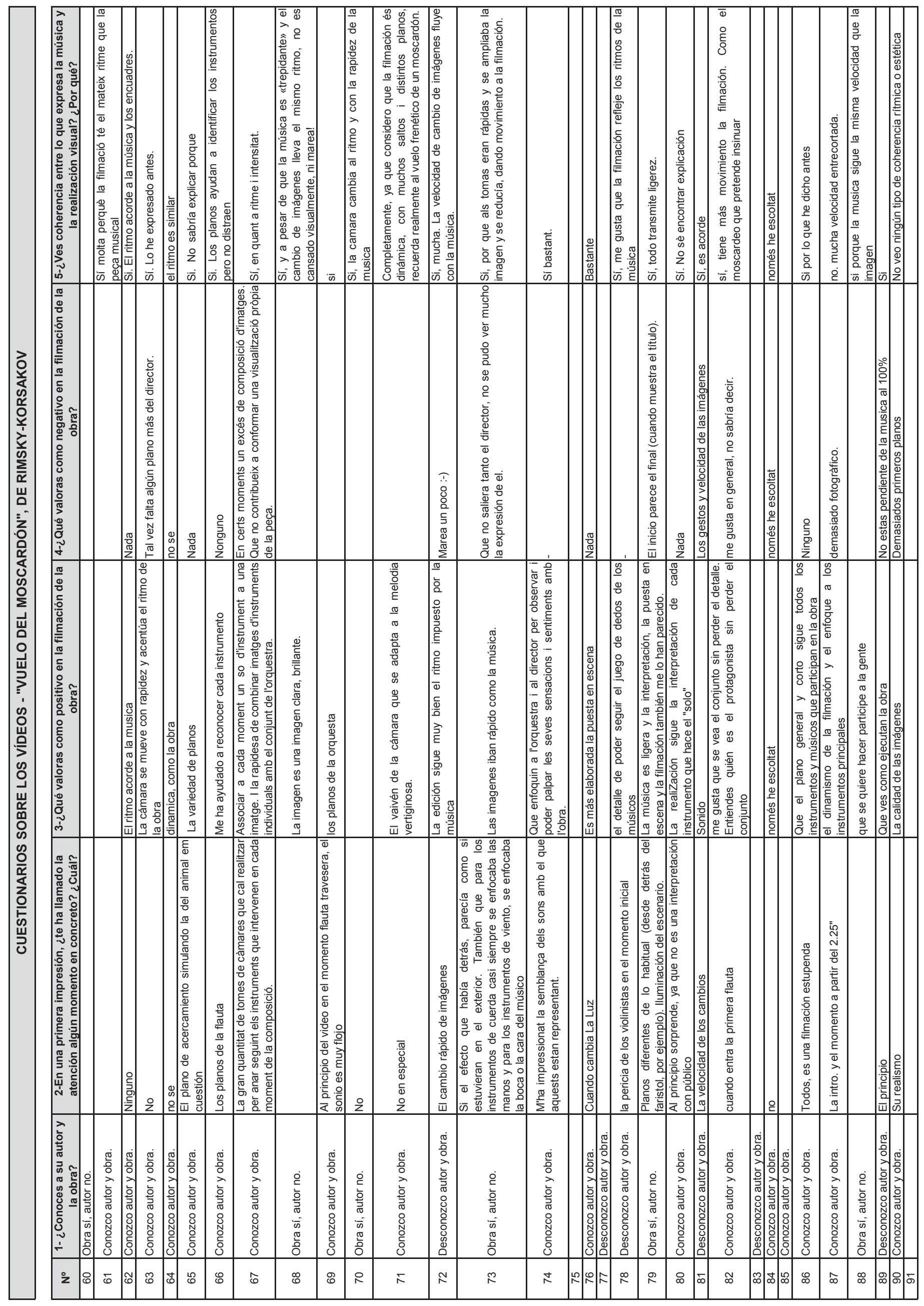




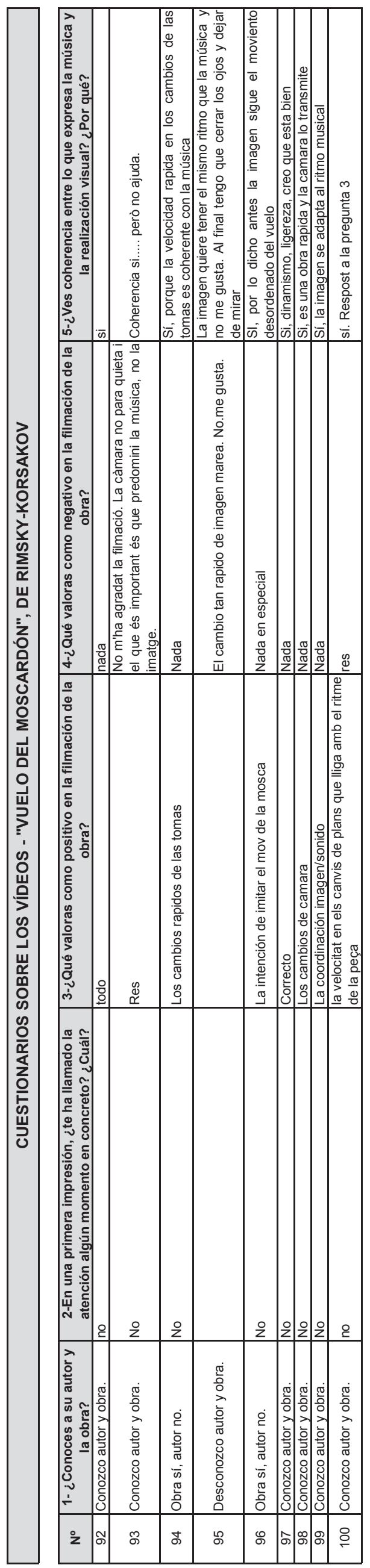




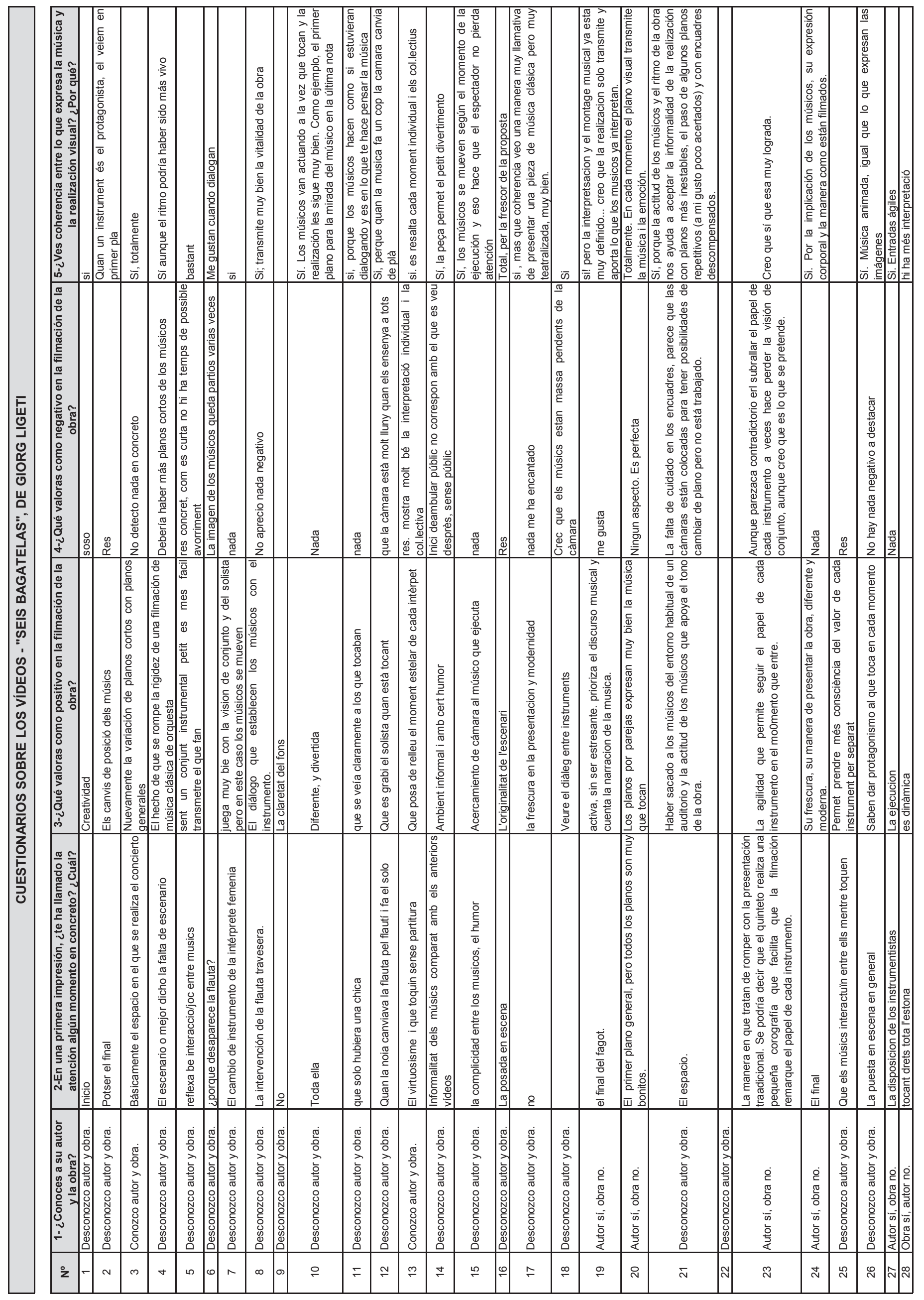




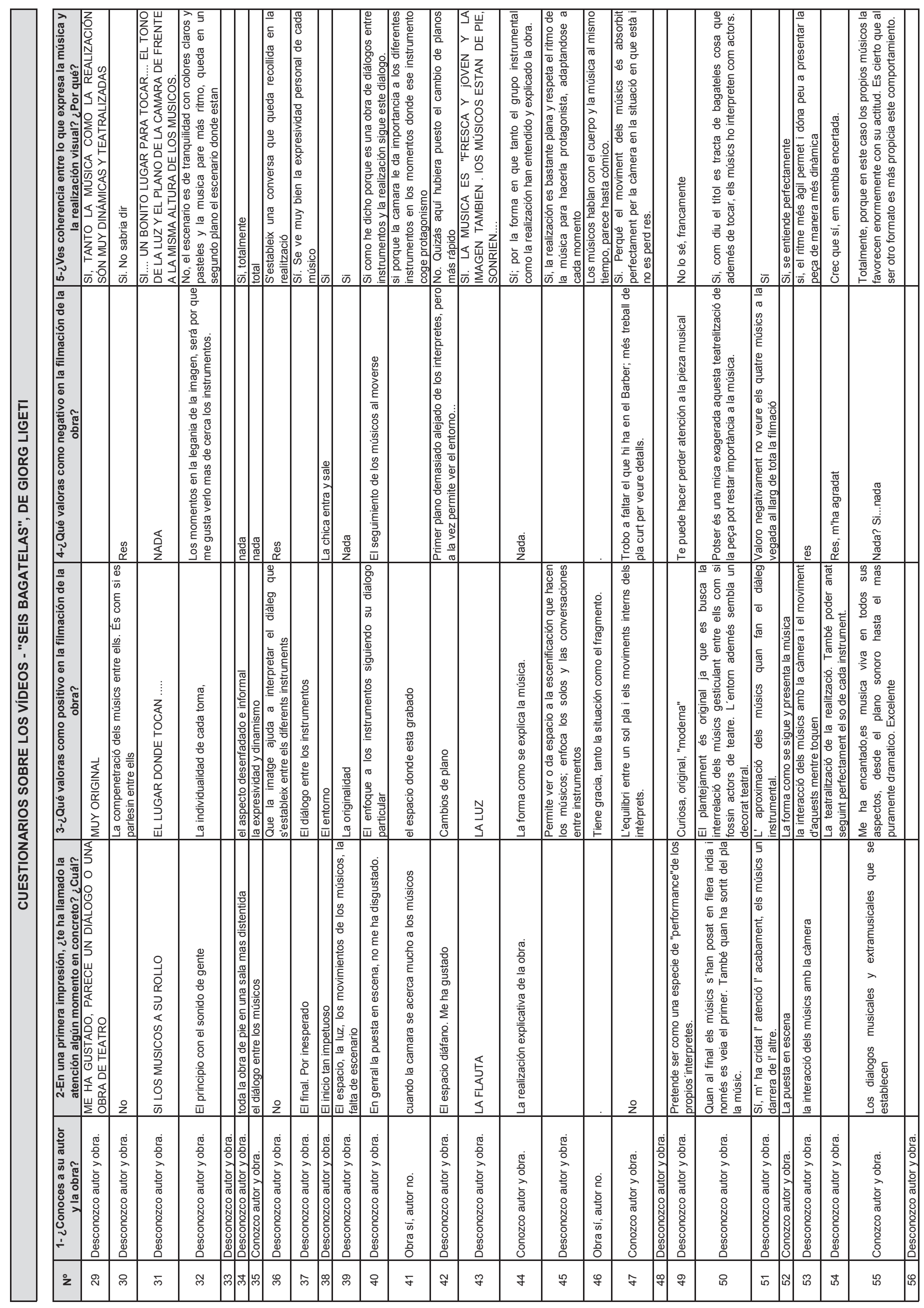




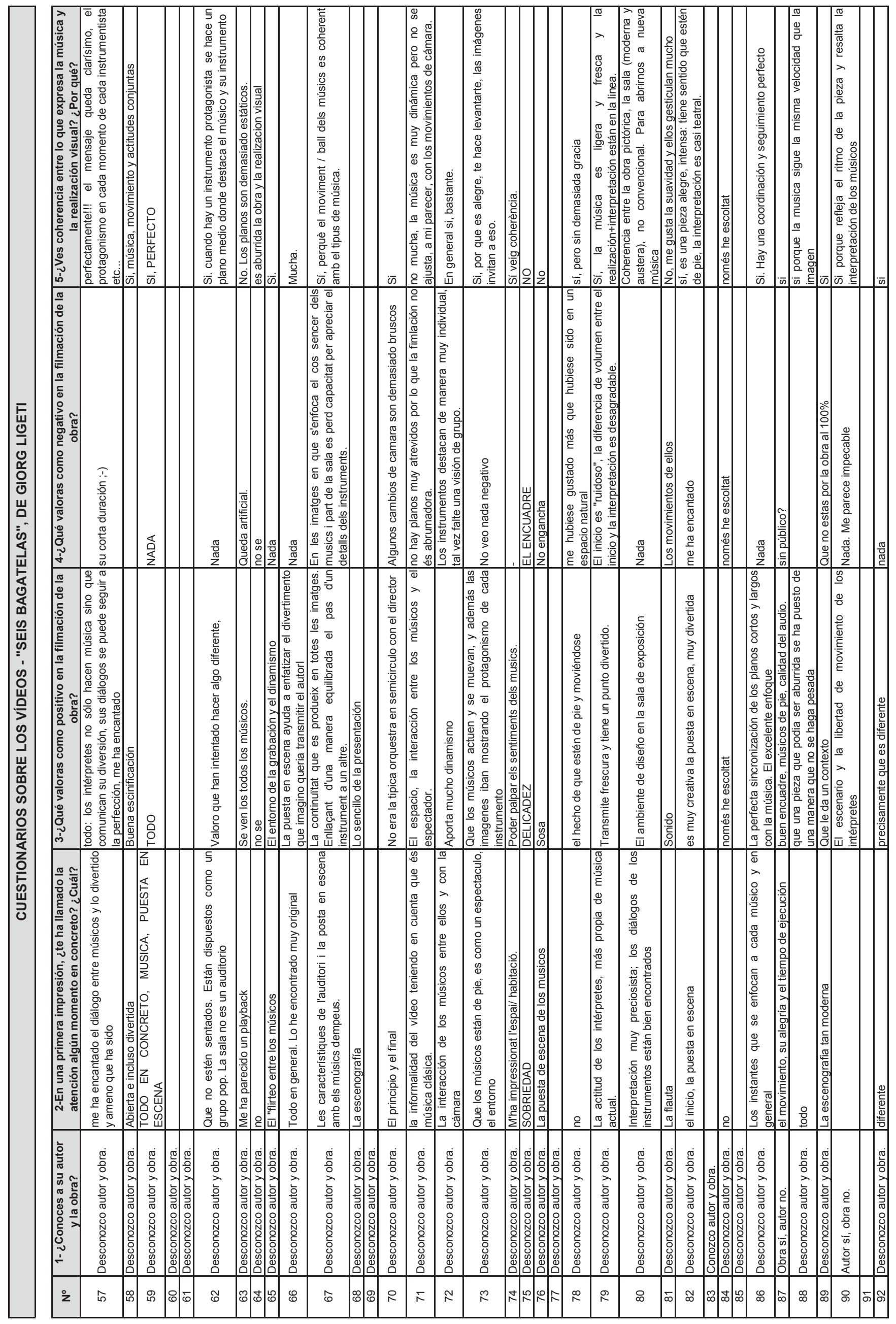




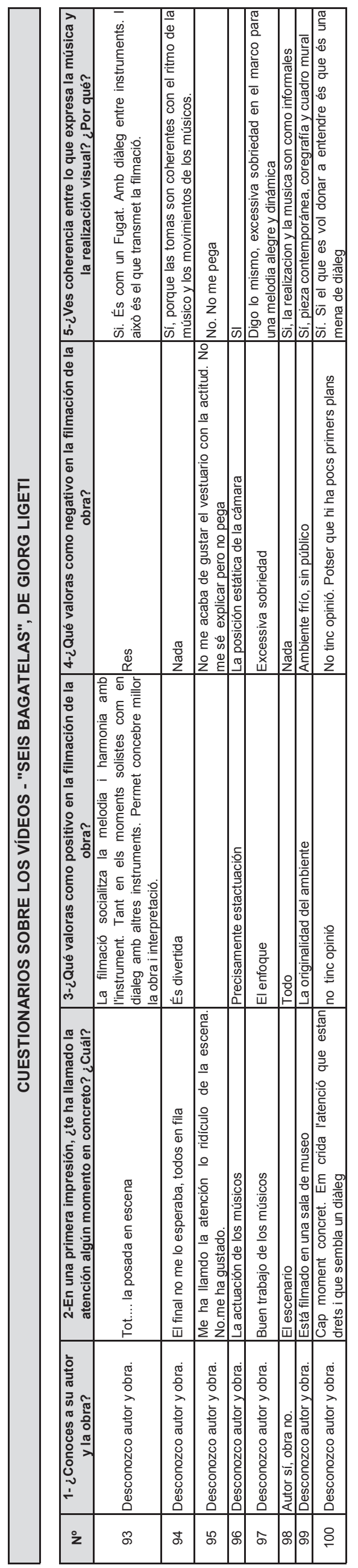




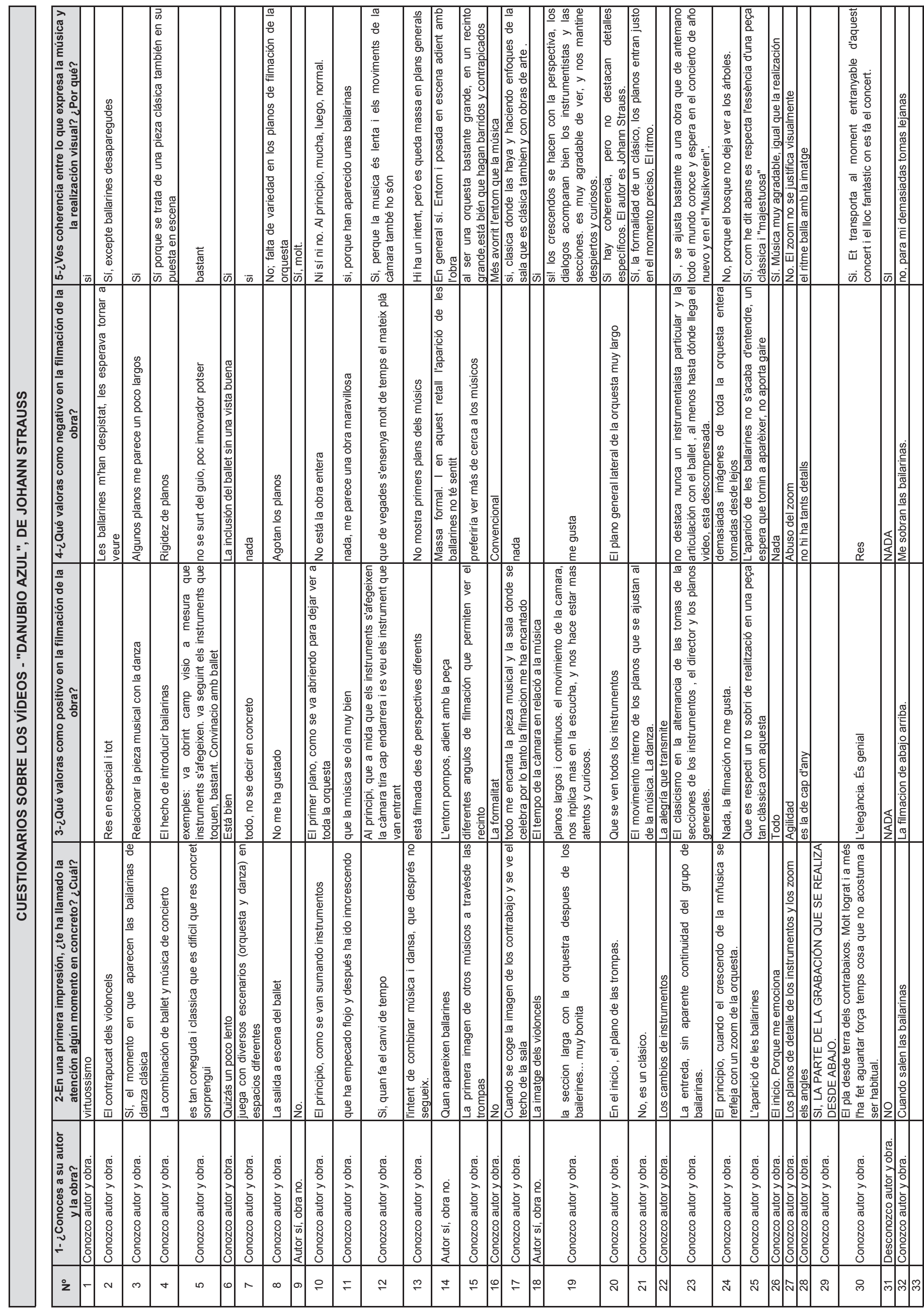




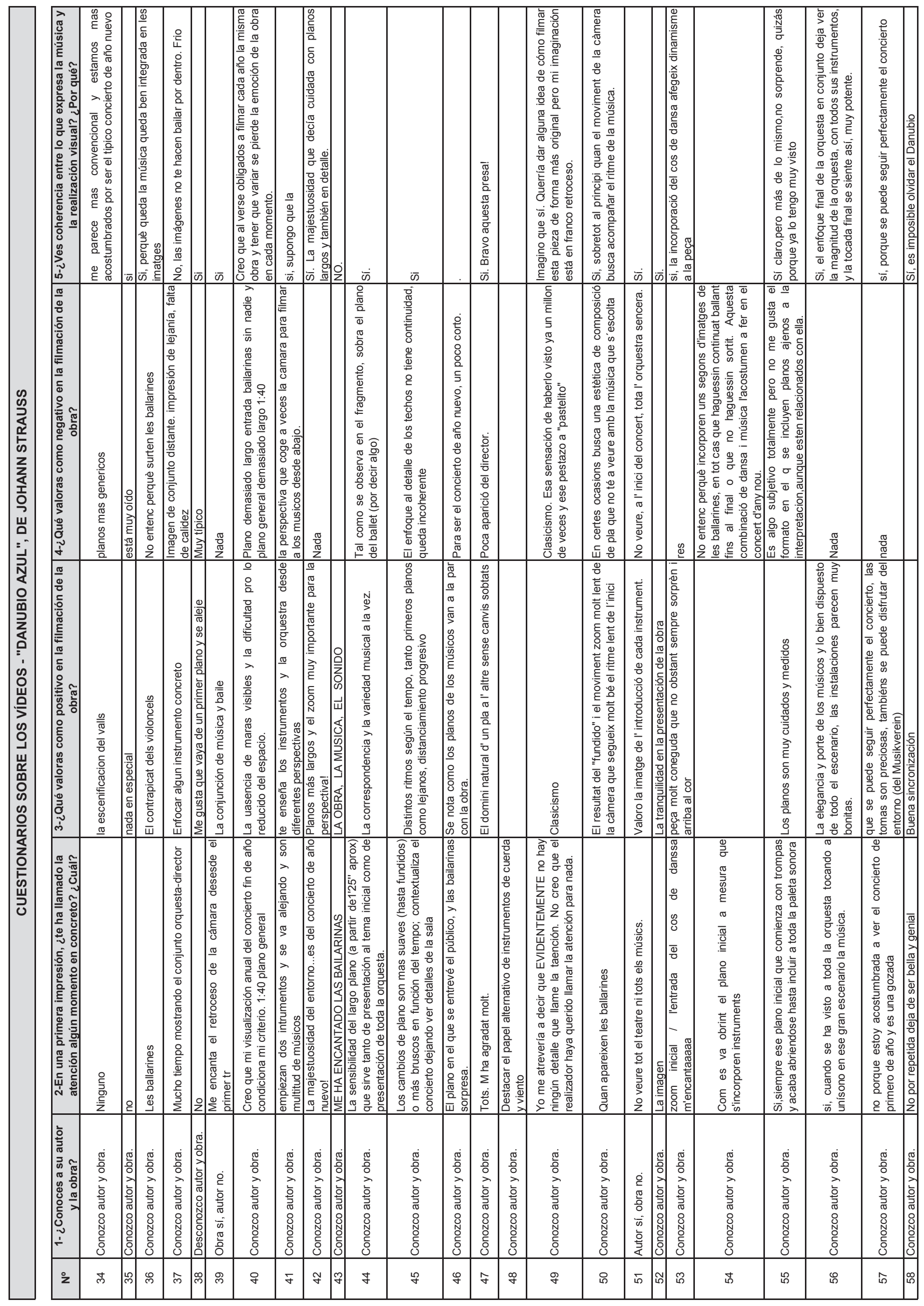




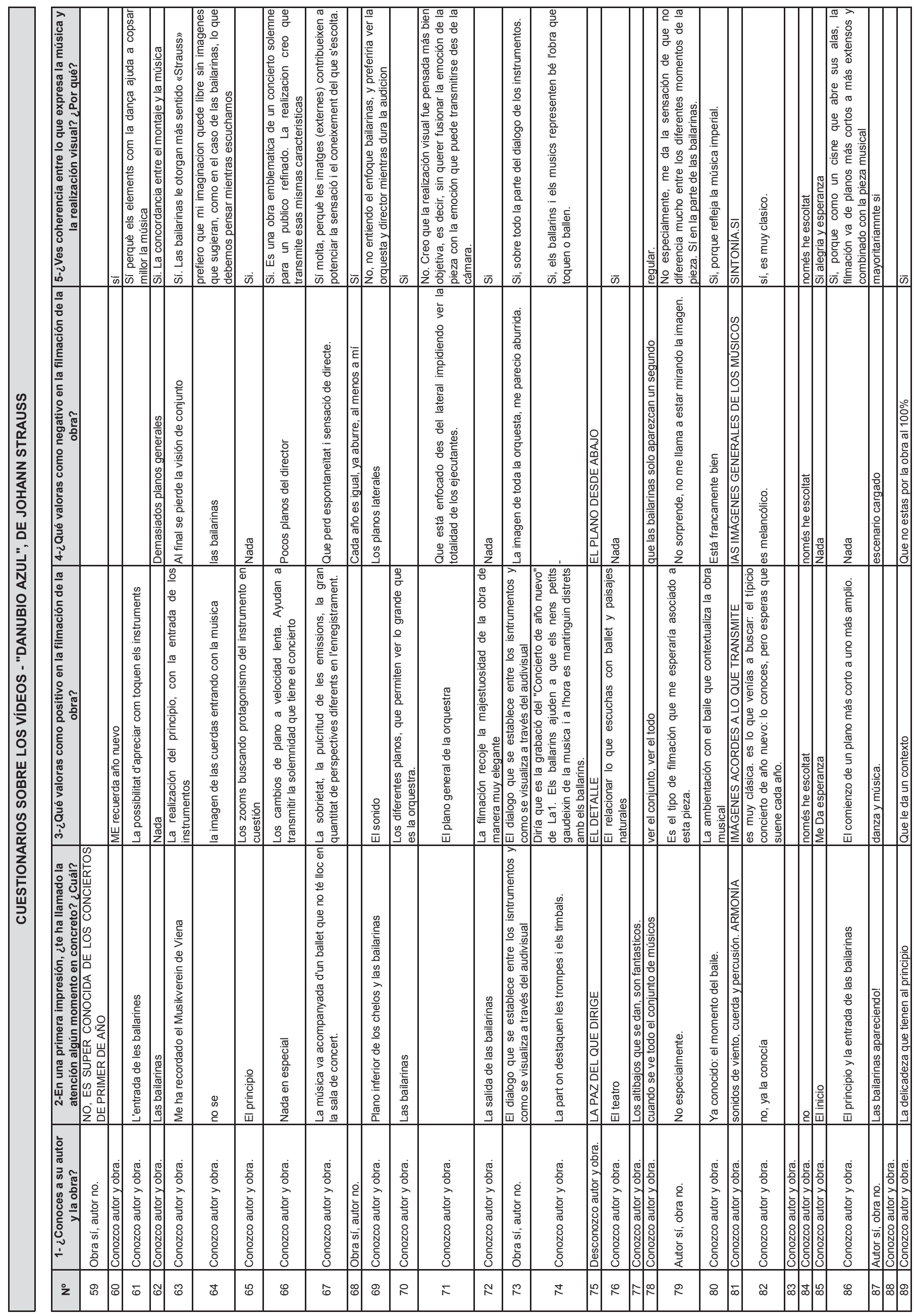




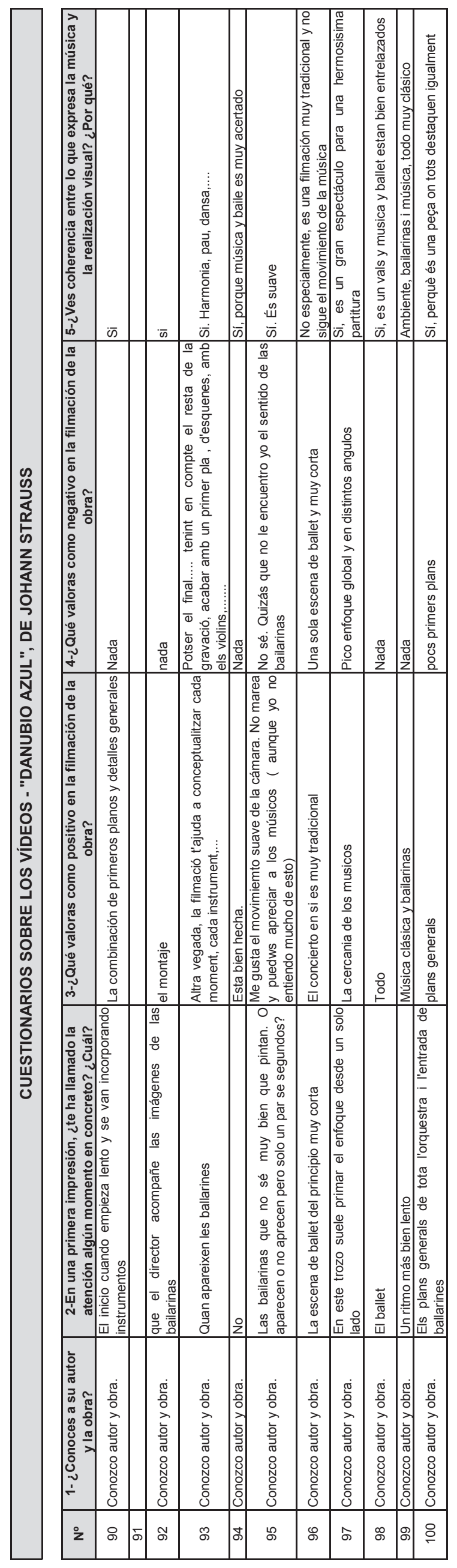




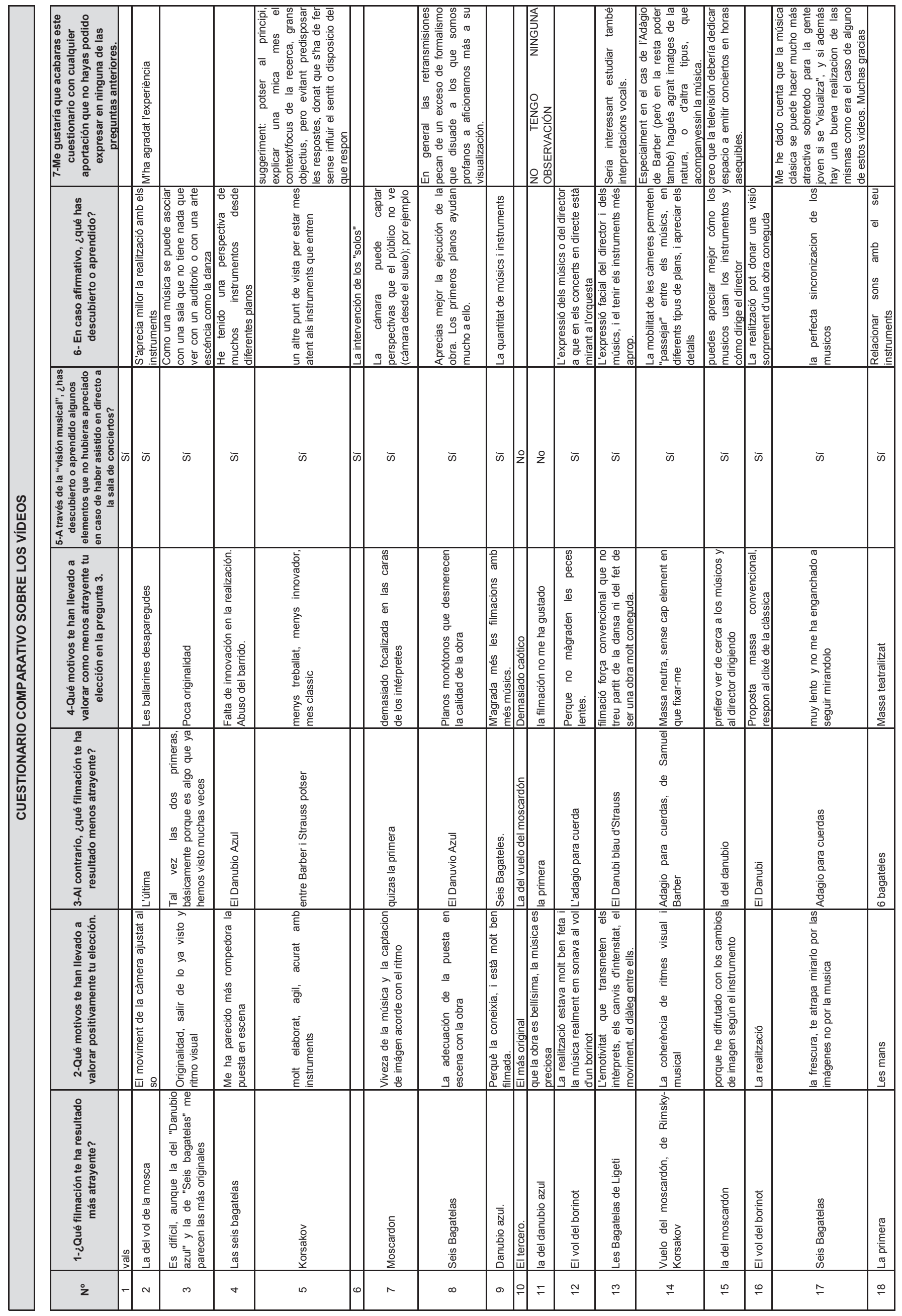




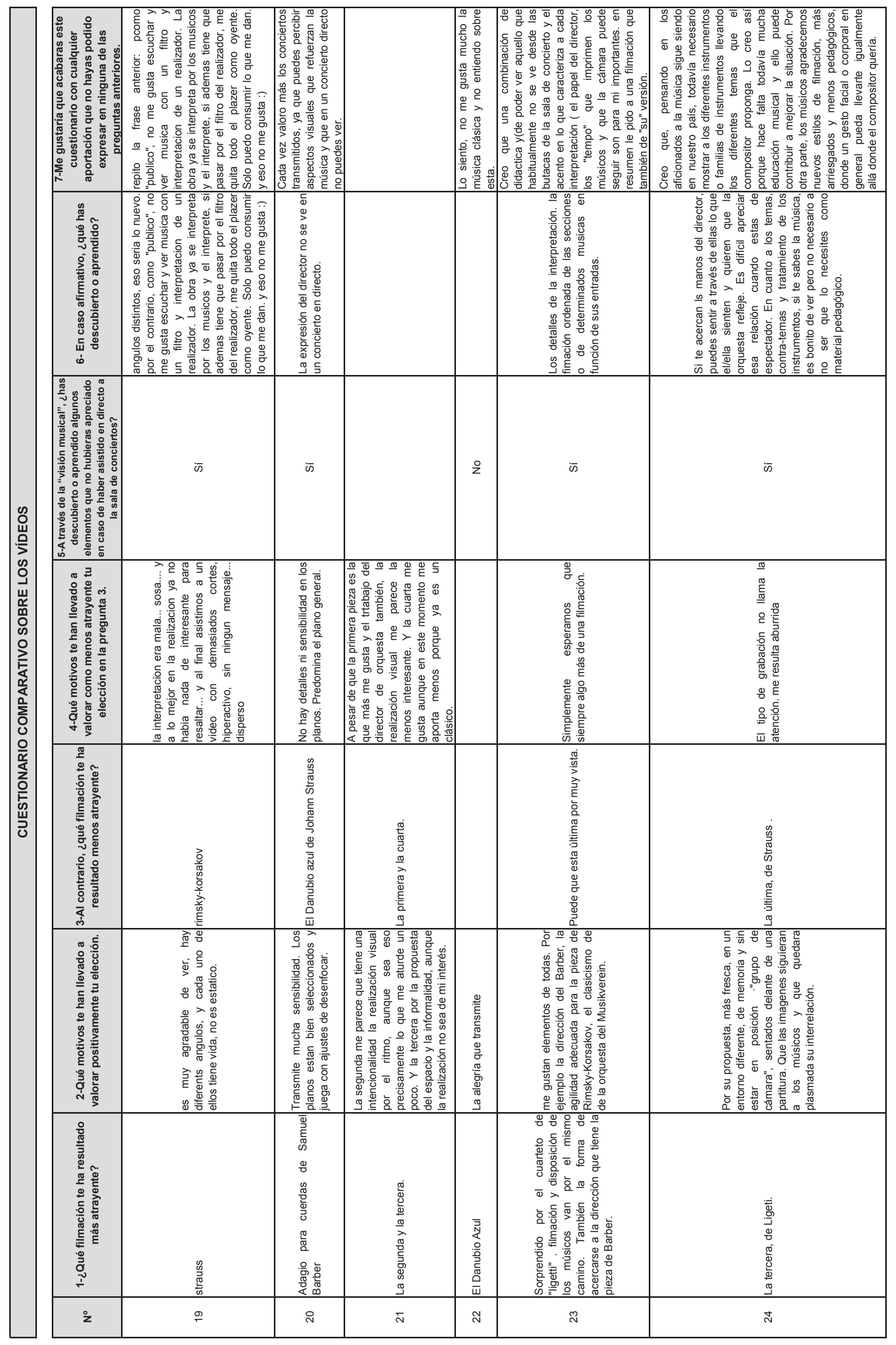




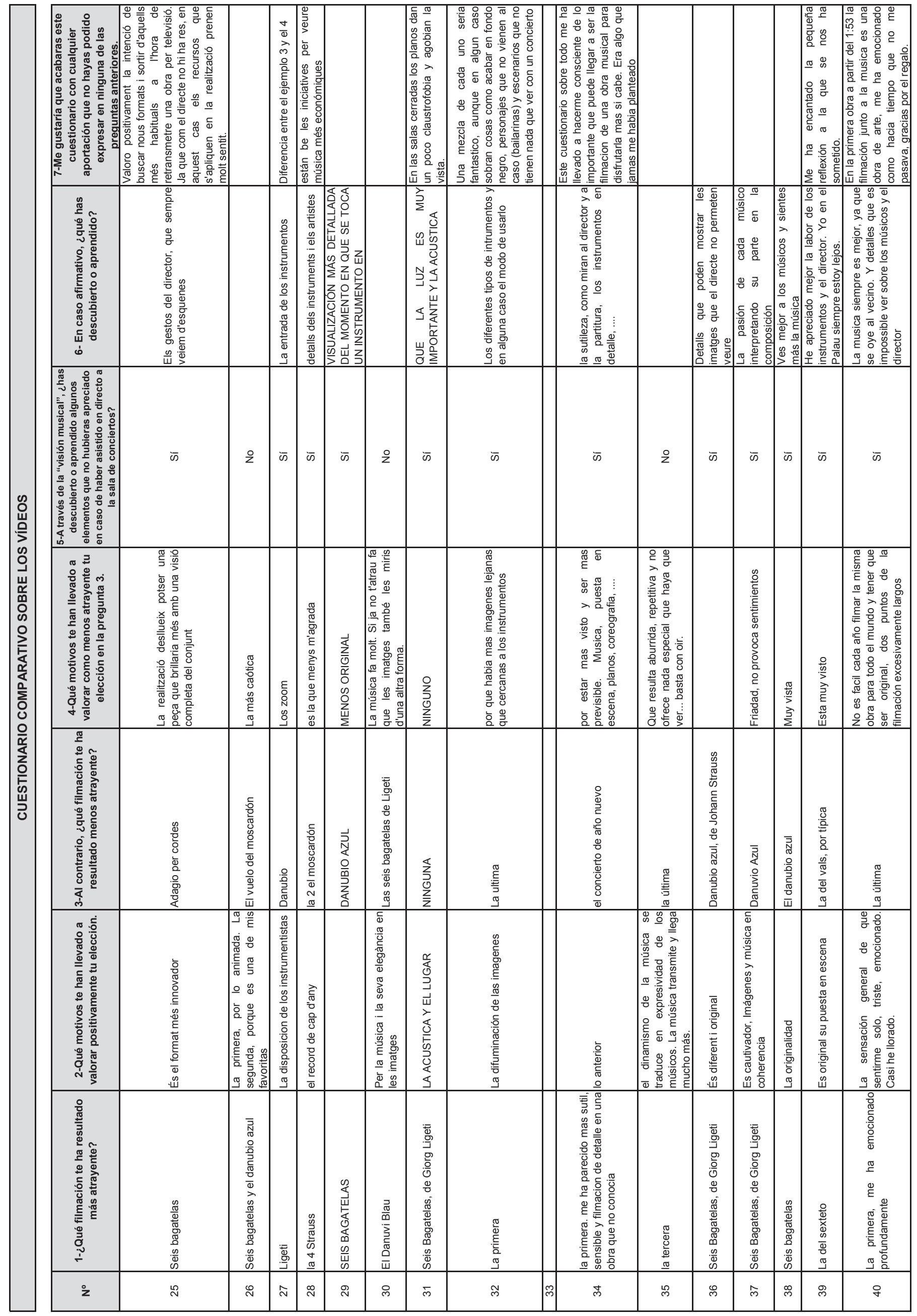




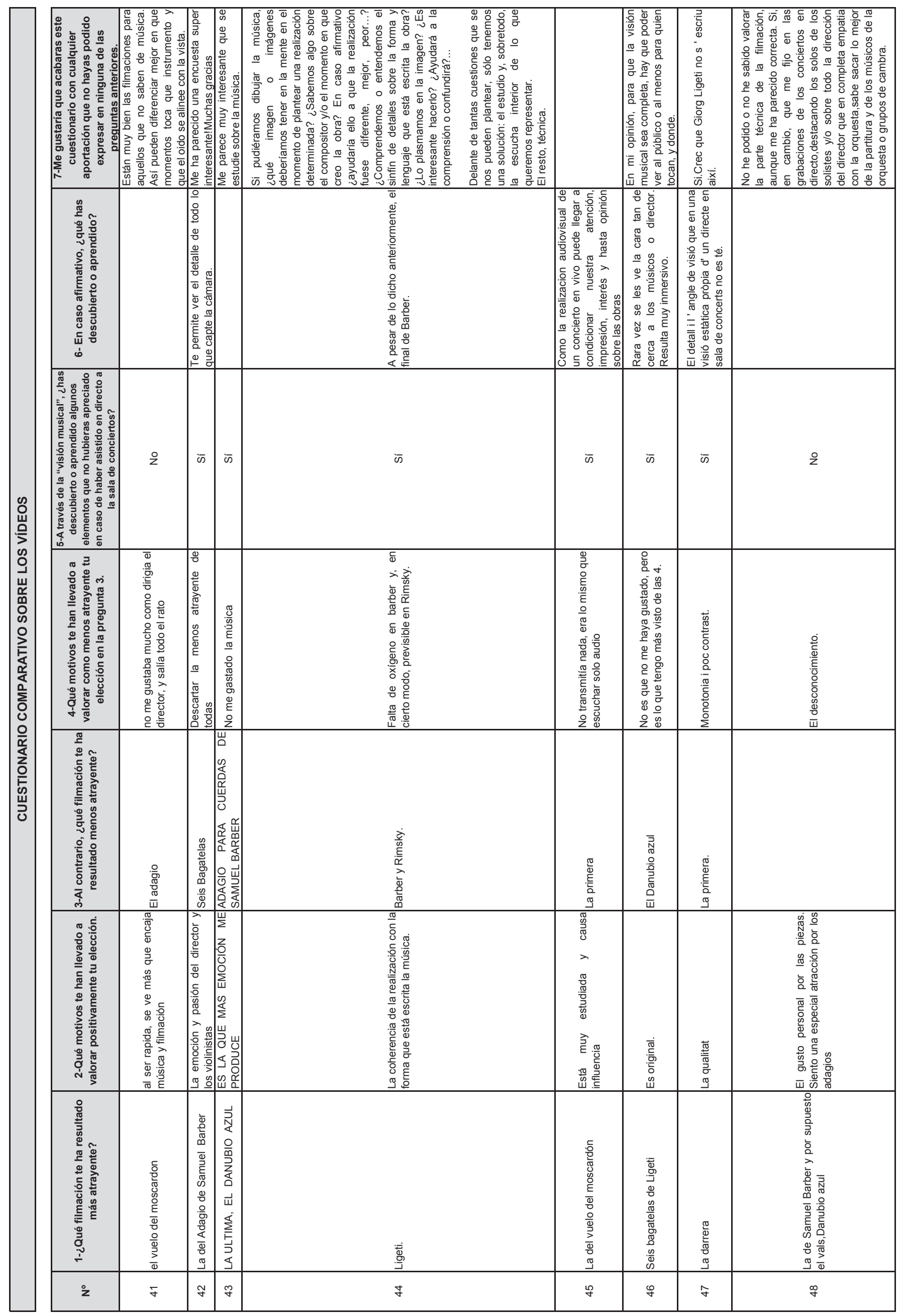




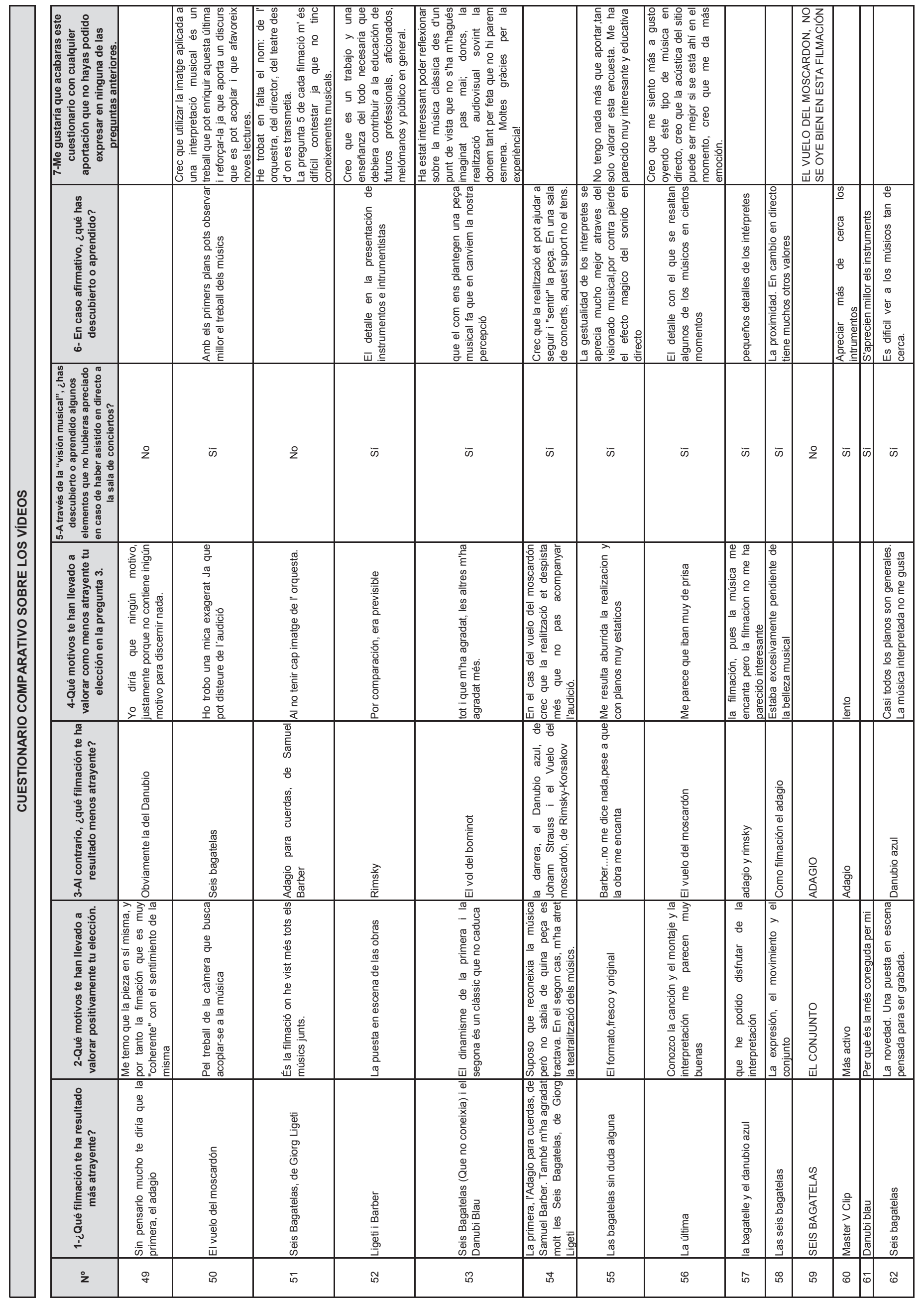




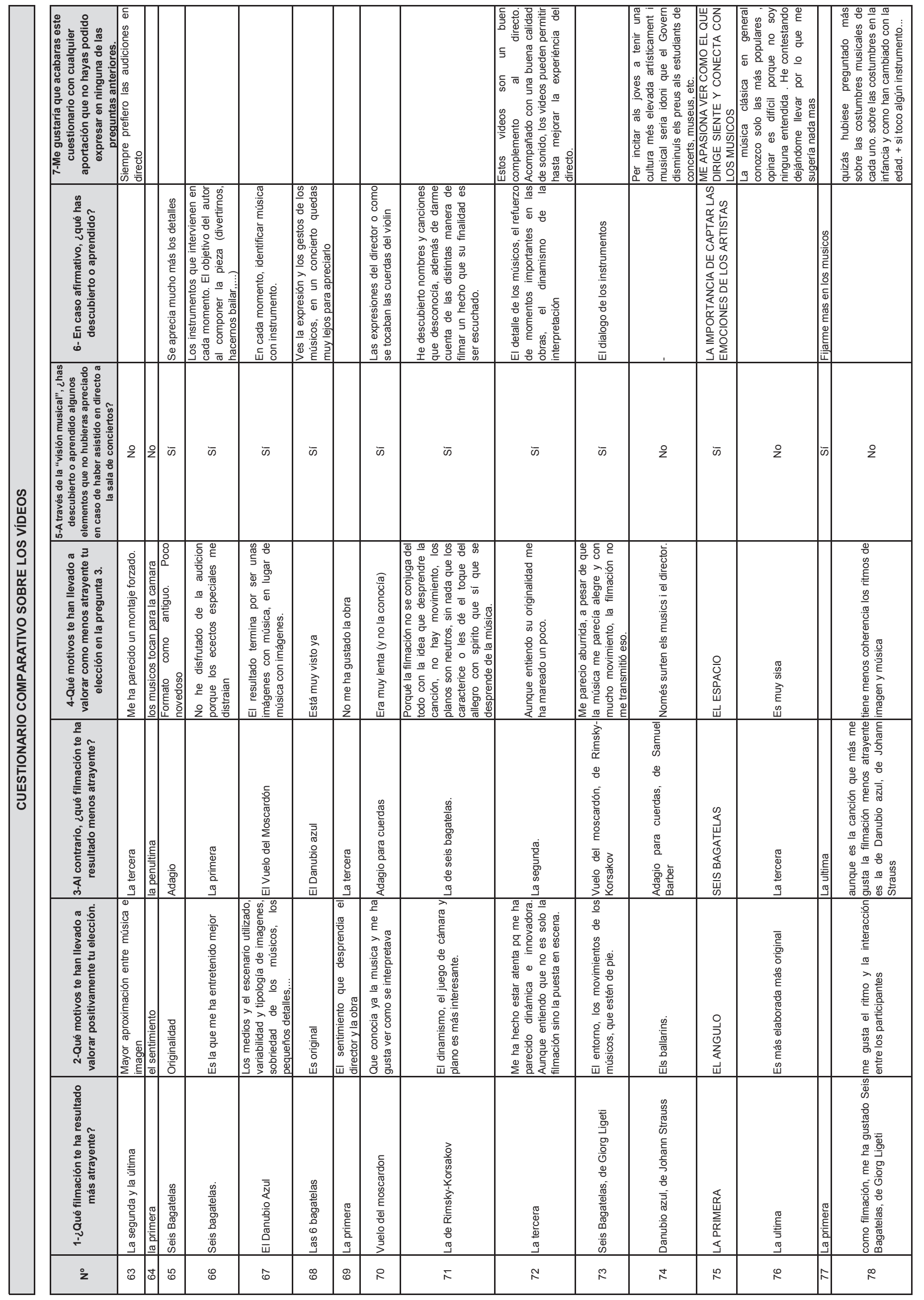




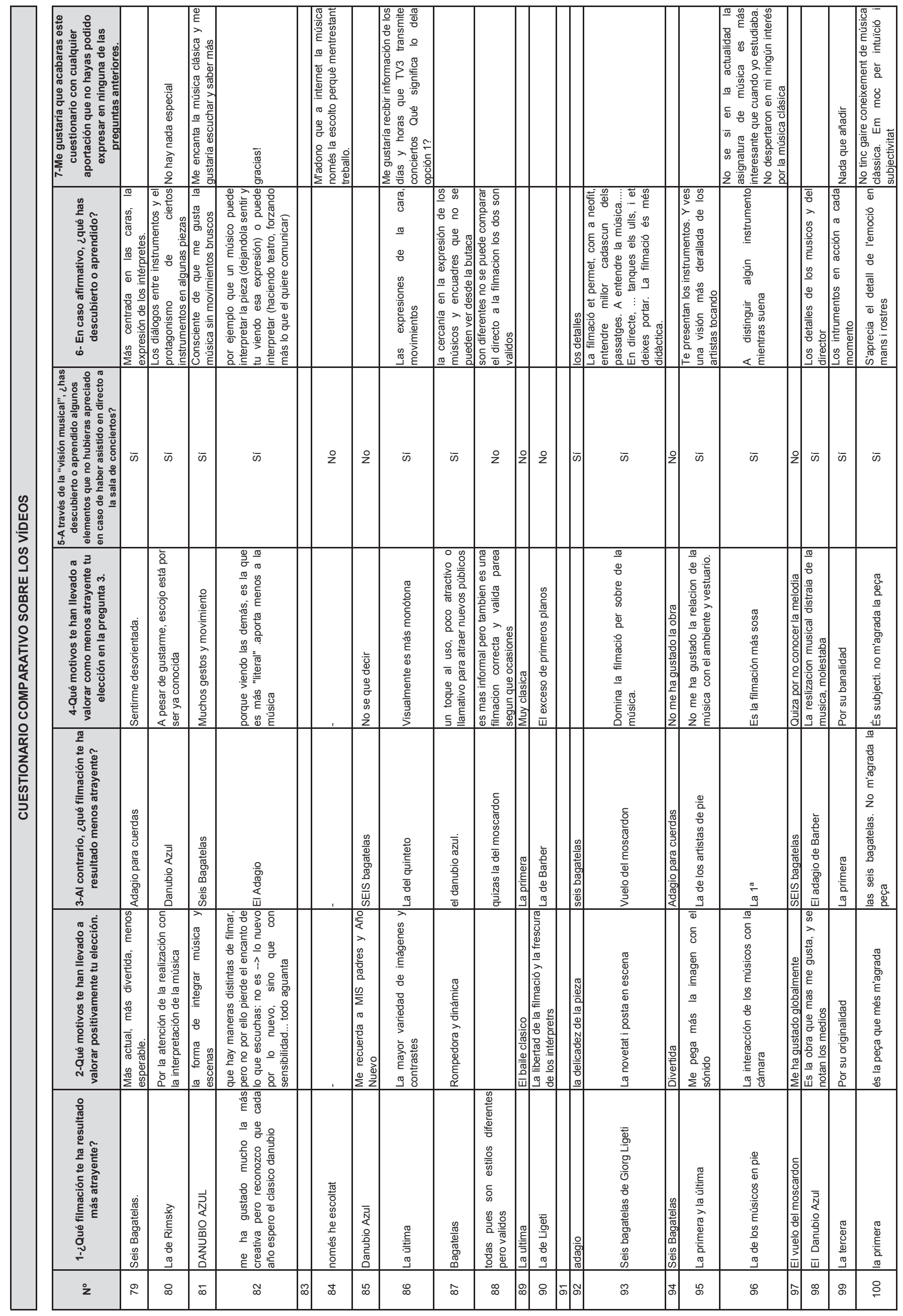


APÉNDICE IV: Audios de las entrevista originales (se entrega DVD) 